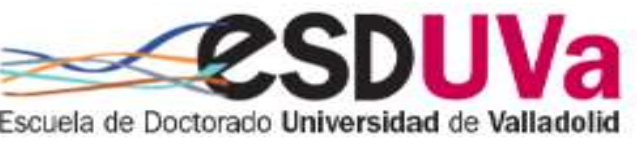

Universidad deValladolid

PROGRAMA DE DOCTORADO EN ARTES Y HUMANIDADES

PROG. INTERUNIVERSITARIO "EUROPA Y EL MUNDO

ATLÁNTICO: PODER, CULTURA Y SOCIEDAD"

(Univ. Valladolid y Univ. País Vasco).

TESIS DOCTORAL:

\title{
"SOCIOLOGÍA DE LAS RELACIONES SOCIOCULTURALES NORTATLÁNTICAS Y SU INFLUJO EN ESTADOS UNIDOS DE AMÉRICA: ORIGEN, DESARROLLO Y DECLIVE DE AMERICAN CIVIL RELIGION"
}

Presentada por Antonio Sánchez-Bayón para optar al grado de

Doctor por la Universidad de Valladolid

Dirigida por:

Prof. Dr. D. Jesús A. Valero Matas.

Tutor:

Prof. Dr. D. Pablo García Colmenares 
Sociología de las Relaciones Socioculturales Nortatlánticas (...) American civil religion - A. Sánchez-Bayón 


\section{SUMARIO:}

Resumen y palabras clave (p. 11).

Abstract \& key-words (p. 13).

Acrónimos, siglas y abreviaturas (p. 15).

Índice de figuras (p. 21).

INTRODUCTION (p. 27)

\section{PARTE INICIAL: ACERCA DEL ESTUDIO Y SU PROPEDÉUTICA}

(crisis idiosincrásica posglobalizatoria y su investigación sociocultural, p. 31)

1.- Justificación del estudio sociocultural realizado (p. 35).

1.1.- Problemas revelados: crisis idiosincrásica posglobalizatoria (p. 39).

1.1.1.- Visión de conjunto y diagnóstico coyuntural (p. 43).

1.1.2.- Velos de confusión posmodernos y la deconstrucción fundacional: más allá de la pérdida de consenso e identidad (p. 58)

1.2.- Interés social y científico-académico de la investigación (p. 87).

2.- Objetivos y contenidos socioculturales sistematizados (p. 99).

2.1.- Sentido y alcance de la investigación (p. 99)

2.2.- Hipótesis y plan de trabajo (p. 107) 
3.- Metodología empleada: abordaje combinado sociocultural (p. 113).

3.1.- Enfoques, técnicas y recursos (p. 114).

3.2.- Estado de la cuestión (p. 119).

\section{PARTe De Desarrollo General:}

FUNDAMENTOS SOCIOCULTURALES DE LA RELIGIÓN CIVIL

(su recepción trasatlántica y su Americaness, p. 143)

\section{4.- Religious factor in USA and its idiosyncratic impact and normalization:} rules $\mathcal{E}$ institutions of American social order (p. 147).

4.1.- A critical review: revelations on fake beliefs (p. 148).

4.2.- Historical \& sociological approaches: Blue Laws \& Colonial Order (p. 152).

4.3.- Fundamentals of the official Order (p. 165).

4.3.1.- Constitutional level (p. 165).

4.3.2.- Statutory and Executive Law development (p. 169).

4.3.3.- Jurisprudence: between Case Law and Legal Theory (p. 173).

4.4.- Topic in the early globalization: religion in domestic Politics $\mathcal{E}$ Law (p. 181).

4.4.1.- Case study: an overview (p. 181).

4.4.2.- Single cases: from correctness to neoconservative issues (p. 186).

4.4.2.1.- Faith-based and Community Organizations (p. 186).

4.4.2.2.- The First Freedom Project (p. 190). 
4.5.- Balance beyond the globalization and its crisis (p. 194).

\section{5.- Religiosidad civil estadounidense:}

claves sobre su configuración idiosincrásica

(mitopoiésis, legado y Americaness) (p. 197).

5.1.- Consideraciones preliminares:

estadounidización religiosa y religiosificación estadounidense (p. 199).

5.2.- Religión \& Americaness:

hitos de la matriz mitopoiética y su motor idiosincrásico (p. 203).

5.3.- Hoja de ruta de American civil religion (ACR):

annuit coeptis, novus ordo seclorum, e pluribus unum \& in God we trust (p. 234).

\section{6.- Fundamentos ontológicos socio-religiosos a reevaluar}

ante la posglobalización (p. 237).

6.1.- Consideraciones preliminares:

crisis social y sociológica de la Modernidad estadounidense (p. 239).

6.1.1.- Revisión sociológica aplicada a la Modernidad occidental estadounidense (p. 241)

6.1.2.- Retos: escenario posglobalizatorio, cambio paradigmático y velos (p. 254).

6.1.3.- Balance del pionero modelo sociocultural estadounidense (p. 260). 
6.2.- ACR a juicio: cuestionamiento del sentido

y alcance del metámero (p. 282).

6.3.- ACR \& American Covenant Theology I:

origen, desarrollo y resultado federal y nacional (p. 292).

6.4.- ACR \& American Covenant Theology II:

pactismo estadounidense y relaciones internacionales (p. 358).

\section{7.- Balance pragmático socio-religioso hasta la globalización:}

influjo de ACR en la emergencia hegemónica de EE.UU. (p. 367).

7.1.- ACR \& American manifest destiny (AMD):

auge de un pueblo elegido y bendecido (p. 370).

7.2.- ACR \& American crusades:

cruzadas socio-religiosas que han transfigurado EE.UU. (p. 393).

7.3.- ACR \& American heritage \& Western leadership:

geopolítica estadounidense de la globalización según su religión civil (de IRFA a clash of civilizations) (p. 421). 
Parte de Desarrollo Especial:

ESTUDIO DE CASO DEL LEGADO SOCIOCULTURAL

DE LA RELIGIÓN CIVIL ESTADOUNIDENSE

(retroalimentaciones trasatlánticas y proyecciones occidentales, p. 471)

\section{8.- Dimensión sistémica:}

estudio científico-académico y desarrollo universitario (p. 481).

8.1.- Complejidad sociocultural y de planteamientos:

materias interdisciplinarias y el hilo conector religioso (p. 492).

8.2.- Papel de los Estudios culturales: consensos y conflictos (p. 498).

8.3.- ¿Qué ha quedado del melting pot tras las guerras culturales? (p. 577).

\section{9.- Dimensión subjetiva:}

papel de los founding fathers en la constitución y legado de ACR (p. 607).

9.1.- Revelaciones sobre los padres fundadores:

más allá de la vida ejemplar de santos (p. 615).

9.2.- Legado patrístico: de pilgrims a statemen (p. 642).

10.- Dimensión objetiva:

casuística relevante de ACR y su legado sociocultural (p. 675).

10.1.- Consideraciones preliminares:

criterios de selección y exposición (p. 677).

10.2.- Principales advocaciones del legado (p. 689). 
10.2.1.- Símbolos y ritos (p. 690).

10.2.2.- Creencias y valores (p. 723).

10.2.3.- Normas e instituciones (p. 739).

10.2.4.- Arte, monumentos y folclore (p. 808).

10.3.- Evolución y evaluación de su gestión y estado actual:

ciclos de despertares y revitalizaciones (según relaciones atlánticas) (p. 820).

CONCLUSIONS (p. 835)

PARTE FinAL: BALANCE

(DECLIVE DE ACR, REALIZACIÓN DE APP-SET

Y FIN DE LAS RELACIONES ATLÁNTICAS Y DE OCCIDENTE, p. 839)

\section{1.- Resultados del estudio y su discusión (p. 841).}

11.1.- Balance general (p. 842).

11.2.- Teorema sobre el influjo identitario de ACR, su vulneración y declive, y los riesgos de realización de APP-set (p. 846).

\section{2.- Corolarios y otras líneas de investigación relacionadas (p. 861).}

12.1.- Fin de la Modernidad, de las relaciones atlánticas y de Occidente: más allá del estudio sociológico y el riesgo de transoccidentalización (p. 861). 
12.2.- Aristas sobrevenidas de APP-set: persecución del inmigrante religioso y el acogimiento a sagrado en la posglobalización (p. 863).

\section{REFERENCE SOURCES (p. 879)}

\section{3.- Bibliography (p. 879).}

14.- Multimedia sources (p. 923). 
Sociología de las Relaciones Socioculturales Nortatlánticas (...) American civil religion - A. Sánchez-Bayón 


\section{RESUMEN:}

Esta tesis doctoral es un estudio interdisciplinario, de base sociológica y cultural (en la línea de los Estudios culturales estadounidenses), que versa sobre el origen y desarrollo de la configuración estadounidense, mediante su religión civil (American civil religion-ACR). Se trata de un moderno metámero sociocultural de integración (anterior a la polémica decimonónica europea sobre la nación/nacionalismo), elaborado por los padres fundadores (desde las colonias atlánticas y durante su expansión continental hacia el Oeste -como mesianismo para extender Occidente-), siendo actualizado periódicamente en ciclos de despertares $y$ revitalizaciones (dando lugar a su estadounidización o Americaness). En el seno de Estados Unidos de América (EE.UU.), gracias a su pionera secularización y teología política de Modernidad combinada, se recibe y transforma de manera singular la tradición sagrada y profana occidental (llegada por vía atlántica), generándose un rico sistema propio de símbolos y ritos, creencias y valores, normas e instituciones, arte y monumentos, etc., constituyentes de un legado vehiculizador de la idiosincrasia estadounidense (su condensación de su identidad y mentalidad colectiva, su imaginario social y capital simbólico, sus relaciones entre estructuras y superestructuras y sus códigos comunicativos, etc.). Todo ello es analizado, evidenciado y sistematizado, además de ilustrarse su realidad mediante el estudio de casos del citado legado de la religión civil estadounidense. Se acomete esta investigación según la propia lectura que de ello han venido realizando los estadounidenses, sobre todo, desde sus Estudios culturales, responsables de clarificar su idiosincrasia y reformular periódicamente la misma, para actualizarla y mejorarla. Sin embargo, hoy en día, se hallan fragmentados y enfrentados, con 
dificultades para abordar su misión tradicional, además de poner su ACR en tela de juicio (dando lugar al conjunto de la paradoja posmoderna estadounidense o American posmodern paradox set-APP-set, conducente a Americaless y transoccidentalización). Tal circunstancia, no sólo afecta a la idiosincrasia estadounidense, sino que, igualmente, condiciona sus relaciones socioculturales y sus relaciones internacionales (alejándose más del mundo atlántico, acercándose al pacífico y desdibujándose Occidente).

\section{Palabras clave:}

Sociología, Estudios culturales, Estados Unidos de América (EE.UU.), estadounidización, desestadounidización, religión civil estadounidense (ACR), legado, padres fundadores, idiosincrasia, poder, cultura, sociedad, relaciones noratlánticas, conjunto de la paradoja posmoderna estadounidense (APP-set). 


\section{ABSTRACT:}

This $\mathrm{PhD}$ dissertation is an interdisciplinary study, based on sociological and cultural approaches (according to American cultural studies way), which deals with the origin and development of the American configuration, by the civil religion (American civil religion-ACR). It is a modern socio-cultural methamer of integration (previus to the nineteenth-century European controversy on nation/nationalism), made by the founding fathers (from the Atlantic colonies periord and during the continental expansion to the West -in a mesianic mission to extend the Western-), and periodically updated in cycles of awakenings and revitalizations (by the Americaness). Inside of the United States of America (USA), thanks to its pioner secularization and political theology of mixed Modernity, the sacred and profane Western tradition is received (from Atlantic route) and it is transformed in a singular way; the result is a rich system of symbols and rituals, beliefs and values, norms and institutions, art and memorials, etc. By this way is conformed the heritage to become the American idiosyncrasy (it contains the collective identity \& mentality, the social imagination \& symbolic capital, the structures-superstructures relations and its communicational codes, etc.). The mentioned issues, they are analyzed, evidenced and systematized; also, there is an illustration of topics by case studies of ACR heritage. This research is undertaken according to the own reading that the Americans have made (by theirselves), above all, from their Cultural Studies. American cultural studies have assumed the responsibility to clarify the idiosyncracy and to reformulate periodically the issue, to update and to improve it. However, currently, they are fragmented and confronted, without a chance to fix the identity trouble, and ACR is in the nuddle (thanks to them and improving the 
American posmodern paradox-set or APP-set, which drives to Americaless and transWesternelless). Such circumstance affects the American idiosyncrasy; also, it has an impact in the socio-cultural relations and international affairs (moving from Atlantic area to the Pacific land, and transforming the West in a fuzzy way).

\section{KEY-WORDS:}

Socilology, Cultural Studies, United States of America (USA/US), Americaness, Americaless, American civil religion (ACR), heritage, founding fathers, idiosyncrasy, power, culture, society, North-Atlantic relations, American posmodern paradox-set (APP-set). 


\section{ACRÓNIMOS, SIGLAS Y ABREVIATURAS}

aC.: antes de Cristo (cronología occidental, según su tradición sagrada); vid. supra $\mathrm{dC}$.

AC: vocación/profesionalización estadounidense (US/American calling).

ACCL: Derecho Eclesiástico del Estado -aprox.- (American Civil Church Law).

ACT: teología pactista estadounidense (US/American covenant theology, vid. APT y ARC).

ACLU: Asociación/sindicato de libertades civiles estadounidense (American Civil Liberties Union).

ACP: ética estadounidense (US/American civil piety).

ACR: religión civil estadounidense (US/American civil religion).

ACS: sentido civilizatorio estadounidense (US/American civilazing sense).

AD: sueño estadounidense (US/American dream).

ADs: (pluri)confesionalismo estadounidense (US/American denominalism).

AMD: destino manifiesto estadounidense (US/American manifest destiny).

AG/ASG: evangelismo social estadounidense -incluso, espíritu nacional(US/American (social) gospel).

ALCA: Área de Libre Comercio de las Américas.

APP-set: conjunto de la paradoja posmoderna estadounidense (US/American posmodern paradox-set). 
APT: Teología política estadounidense (US/American political theology).

art.: artículo/precepto.

ASR: autopercepción estadounidense con sobreestima -conducente a una superioridad moral, de mesianismo- (US/American self-righteousness).

AWL: estilo o modo de vida estadounidense (US/American way of life). cap.: capítulo.

CE: Constitución española de 1978.

CEU: Constitución estadounidense de 1787 (US/American Constitution). comp.: compilador.

complement.: complementariamente.

CCS: Estudios (inter)culturales ((Cross)Cultural Studies).

CSS: Estudios de Iglesia-Estado (Church State Studies).

dC.: después de Cristo (cronología occidental, según su tradición sagrada), vid. infra $\mathrm{aC}$.

DIE: Declaración de Independencia de 1776 (Declaration of Independence).

EE.UU.: Estados Unidos de América (The United States of America: USA, US or America).

ed.: editor.

E.O.: Órdenes / Decretos Ejecutivos Presidenciales (Executive Orders). epígr.: epígrafe.

et al.: y otros (et alii). 
FAS: Estudios sobre la Primera Enmienda (First Freedom Studies).

FBOs: organizaciones basadas en la comunidad y la fe (Faith-based E Community Organizations/Iniciatives).

HSC: Historia socio-cultural/sociocultural (separado: estudio sociológico y antropológico; junto: sistema complejo de conexiones evidentes y ocultas entre el estudio de la sociedad moderna en conjunto, con su producción cultural, y cómo la misma influye en la socialización que influye en el devenir social).

ICE: ius circa sagra (ordenación de las esferas sagradas o derecho eclesiástico * vid. Blue Laws, American Civil Church-State Law, etc.).

id./idem: lo mismo, también, igualmente. intro.: introducción.

KKK/Klan: Ku-Klux-Klan (clan del círculo -neologísmo hibrido entre griego, latín y germano: kuklos clan-; organización paraguas para las agrupaciones antisistema del Sur de los EE.UU. -xenóbofas, racistas, antisemitas, antisocialistas, antirrepublicanos: persiguiendo a carpetbaggers o norteños buscavidas, scalawags o sureños tránsfugas, slavers o negros ex esclavos, etc.-, alcanzando su apogeo en el período de Reconstrucción de los EE.UU. -tras la Guerra civil-; fue disuelto por el Presidente GRANT -Republicano-, reapareciendo con la Depresión).

OEA: Organización de Estados Americanos.

ONG: organización no gubernamental.

ONU: Organización de las Naciones Unidas.

op. cit.: obra citada (opus citatum). 
p./pág.: página.

PWF: pensamiento liberal-conservador (Whig) y librepensamiento masón (Free-manson/masonry).

pto.: punto.

RD: Real Decreto.

relig.: religiosa.

s.: siglo.

secc.: sección.

ss.: siguiente(s).

subepíg.: Subepígrafe.

TDR: teoría de despertares y revitalizaciones (awakings and revivals theory).

TIC: tecnologías de la información y la comunicación.

TRACS: Asociación transnacional de Universidades y Facultades Cristianas (Transnational Association of Christian Colleges and Schools).

TSEU: Tribunal Supremo estadounidense (US/American Supreme Court).

UAM: Universidad Autónoma de Madrid.

UCM: Universidad Complutense de Madrid.

UMU: Universidad de Murcia.

UVA: Universidad de Valladolid.

UE: Unión Europea.

UPSA: Universidad Pontificia de Salamanca. 
UK/RU: Reino Unido de la Gran Bretaña (United Kingdom of the Great Britain: UK). Univ.: Universidad.

v.g.: verbi gratia (por ejemplo).

vid.: vide (véase).

vol.: volúmen

v./vs.: versus (contra/frente a).

WASP: blanco anglosajón protestante -alude a un modelo cultural, supuestamente dominante en los EE.UU., acuñado por disidentes, de ahí que su acrónimo signifique avispa, pues es la comparación que se hace de las personas forjadas según dicho modelo- (white anglo-saxon protestant)-. 
Sociología de las Relaciones Socioculturales Nortatlánticas (...) American civil religion - A. Sánchez-Bayón 


\section{ÍNDICE DE FIGURAS}

Figura 1.- Claves sobre la globalización y sus efectos (p. 46 ss.).

Figura 2.- Historia estadounidense o de lo nuestro (History of US) (p. 64 ss.).

Figura 3.- Síntesis de velos extendidos por Estudios culturales sobrevenidos (p. 69 ss.).

Figura 4.- Conjunto de velos sobre la religión (p. 71 ss.).

Figura 5.- Tendencias y repuntes de la secularización en los EE.UU. (p. 93).

Figura 6.- Sistema de plurilealtades estadounidenses o ACR (p. 94).

Figura 7.- Conjunto de técnicas de investigación empleadas (p. 116 ss.).

Figura 8.- Formación especializada sobre la materia (p. 139 ss.).

Figure 9.- Source of Law \& Order in America (p. 150 ss.).

Figure 10.- Interdisciplinary areas of American Civil Church Law (ACCL) (p. 151 ss).

Figure 11.- Colonial socio-cultural \& political-legal typology (p. 152 ss).

Figure 12.- Colonial settlement development (p. 153).

Figure 13.- Constitutional socio-religious rules (p. 167 ss.).

Figure 14.- Main principles of the USA relational model (p. 168).

Figure 15.- Main cases about religion in public life (p. 174 ss.).

Figura 16.- Doctrina estadounidense de religión y secularización (p. 225 ss.).

Figura 17.- Relaciones religiosas (más allá del materialismo-histórico) (p. 228).

Figura 18.- Secularización en los EE.UU. y sus ciclos (p. 229 ss.).

Figura 19.- De la teología tradicional a la moderna o Teología política (p. 269 ss.). 
Figura 20.- Disquisiciones deístas franklinianas (p. 274).

Figura 21.- Performatividad de la religión civil estadounidense (p. 274 ss.).

Figura 22.- Apuntes sobre el pensamiento whig \& freemason-PWF (p. 280).

Figura 23.- Impronta judeocristiana en la toponimia y gentilicios estadounidenses (p. $297 \mathrm{ss})$.

Figura 24.- Configuración de las colonias y sus modelos (por agenda de supremacía y juramento) (p. 313).

Figura 25.- Llamada a la Unión de las Trece Colonias (p. 313).

Figura 26.- Modelos relacionales Iglesia-Estado (derecho-política-religión) en Occidente (p. 315).

Figura 27.- De las Cartas otorgadas coloniales a las Constituciones estatales (p. 316).

Figura 28.- Fallas del ensayo-error en modelos relacionales (p. 318 ss.).

Figura 29.- Dimensiones de la libertad religiosa (p. 321).

Figura 30.- Principios rectores (hipostasia) del modelo relacional estadounidense (p. 329).

Figura 31.- Referencias articuladoras de ACT: "God's manifestó \& dispensations" (p. 336 ss.).

Figura 32.- Federalismo plasmado en el Preámbulo de CEU (p. 344).

Figura 33.- Integración federal por el bien común (p. 346).

Figura 34.- Referentes gráficos de The Federalist Papers (p. 348). 
Figura 35.- Etapas de la implementación del federalismo (p. 350).

Figura 36.- Tipos formales de federalismo (p. 352).

Figura 37.- Disonancias del discurso federalista y sus detractores (p. 353).

Figura 38.- Escalada de la geopolítica (federal) estadounidense (p. 355).

Figura 39.- Salvar la libertad de culto (p. 357).

Figura 40.- Preceptos sobre religión en tratados estadounidenses (p. 361 ss.).

Figura 41.- Art. XI del Tratado de Paz y Amistad con Trípoli de 1797 (p. 364 ss.).

Figura 42.- Mesianismo estadounidense "duro" en Latinoamérica (p. 383).

Figura 43.- Fundamentos propagandísticos de la misión en Latinoamérica (p. 371 Ss.).

Figura 44.- Notas básicas sobre movimientos socio-religiosos estadounidenses ( $\mathrm{p}$. 394 ss.).

Figura 45.- Síntesis de los supuestos más ilustrativos de bioética y sus tensiones (p. 407 ss.).

Figura 46.- Primeros periódicos parroquiales estadounidenses (p. 421).

Figura 47.- Estructura y contenidos de IRFA (p. 448 ss).

Figura 48.- Organigrama operativo de la IRFA y su sistema (1998-01) (p. 452).

Figura 49.- Indicios de neocesaropapismo por liderazgo de confesiones (p. 461).

Figura 50.- Unidad doctrinal, dualidad estratégica y pluralidad operacional (p. $462)$.

Figura 51.- El bagaje del AEI en discurso democrático y iushumanista (p. 463). 
Figura 52.- Fuentes y ramas del Ordenamiento estadounidense (p. 478 ss.).

Figura 53.- Preceptos del IRC sobre clero e iglesia (p. 522).

Figura 54.- Disputas civiles y/o penales sobre religión más relevantes (p. 527).

Figura 55.- Otra clasificación de generaciones de elites estadounidenses (p. $623)$.

Figura 56.- Profesión religiosa de los Presidentes estadounidenses (p. 653 ss).

Figura 57.- Religiosidad de Magistrados de TSEU en la década de 2000 (p. 656).

Figura 58.- Cesaropapismo: comparación entre Roma y EE.UU. (p. 658 ss.).

Figura 59.- Devenir y peso confesional entre Presidentes (p. 665).

Figura 60.- Discursos presidenciales sobre el factor religioso (p. 668 ss.).

Figura 61.- Billete de dólar y los símbolos nacionales (p. 691).

Figura 62.- Caras del Gran Sello nacional (p. 695).

Figura 63.- La campana de la libertad y su inscripción (p. 699).

Figura 64.- La Bandera de Estrellas Centelleantes (p. 701).

Figura 65.- Sagradas escrituras de ACR (p. 702).

Figura 66.- Actual texto del recital "pledge of allegiance" y sus comentarios (p. $705 \mathrm{ss})$.

Figura 67.- Cambio en la ejecución del pledge of allegiance (p. 707).

Figura 68.- Símbolo de Halloween (p. 717).

Figura 69.- Celebraciones de la misa roja y la azul (p. 719). 
Figura 70.- Toma de posesión del Presidente JOHNSON (p. 720).

Figura 71.- Oración de apertura de sesión del Senado de EE.UU. (1939) (p. 722).

Figura 72.- Deísmo de los padres fundadores (p. 726).

Figura 73.- Representación del destino manifiesto estadounidense - GAST, 1872 (p. 729)

Figura 74.- Juego geopolítico estadounidense: escenarios y jugadores (p. 732).

Figura 75.- Juego geopolítico estadounidense (de influjo neocon): niveles o fases (p. 732).

Figura 76.- Valores del American civic piety según los jóvenes (p. 733).

Figura 77.- Denominalismo y tipo de vida según religión tradicional (p. 734).

Figura 78.- Estimaciones históricas sobre denominaciones cristianas en EE.UU. (p. 735).

Figura 79.- Denominaciones protestantes en los EE.UU. (1967-1987) (p. 735 ss).

Figura 80.- Religiones tradicionales en los EE.UU. de 1947-1987 (p. 736).

Figura 81.- Religiones tradicionales en los EE.UU. hasta la globalización (p. 736).

Figura 82.- PAGE y su redacción original de American's creed (p. 739).

Figura 83.- Los otros valores estadounidenses (Liberty bounds) (p. 739).

Figura 84.- Referencias reguladoras de la "gestión" de la religión en los EE.UU. (p. 746 ss.).

Figura 85.- Fragmentos de la Declaración de Independencia-DIE (p. 748).

Figura 86.- Primera Enmienda de la Constitución de los EE.UU. (CEU) (p. 748). 
Figura 87.- Ratificaciones estatales de la Constitución (CEU) (p. 778 ss.).

Figura 88.- Sistema estadounidense de libertades civiles (p. 786).

Figura 89.- Enmiendas (estatales) Blaine (p. 791).

Figura 90.- Técnicas de diagnóstico jurisprudencial (p. 792 ss.).

Figura 91.- Del tradicional arte sacro occidental al pop (p. 809).

Figura 92.- Representaciones de los diez mandamientos en edificios oficiales (p. 818).

Figura 93.- Capitol \& Congressional Prayer Room (p. 818).

Figura 94.- Jacob's Dream statue en ACU campus (Gn. 28:10-22) o Ozark Christ College

(Lc. 8: 5-11) (p. 818).

Figura 95.- National mall \& West Potomac Park (p. 818).

Figura 96.- Inmigrantes deportados desde la globalización (p. 868).

Figura 97.- Sanctuary movement (iglesias y centros socio-religiosos) (p. 870).

Figura 98: District of Columbia (p. 873). 


\section{INTRODUCTION}

The Sociology of North-Atlantic Socio-Cultural Relations and its influence in the United States of America: origin, development and decline of American civil religion. This is an interdisciplinary study, based on sociological and cultural approaches (according to American cultural studies way), which deals with the origin and development of the American configuration, by the civil religion (American civil religion-ACR). It is a modern socio-cultural methamer of integration (previus to the nineteenth-century European controversy on nation/nationalism), made by the founding fathers (from the Atlantic colonies periord and during the continental expansion to the West -in a mesianic mission to extend the Western-), and periodically updated in cycles of awakenings and revitalizations (by the Americaness). Inside of the United States of America (USA), thanks to its pioner secularization and political theology of mixed Modernity, the sacred and profane Western tradition is received (from Atlantic route) and it is transformed in a singular way; the result is a rich system of symbols and rituals, beliefs and values, norms and institutions, art and memorials, etc. By this way is conformed the heritage to become the American idiosyncrasy (it contains the collective identity \& mentality, the social imagination \& symbolic capital, the structures-superstructures relations and its communicational codes, etc.). The mentioned issues, they are analyzed, evidenced and systematized; also, there is an illustration of topics by case studies of ACR heritage. This research is undertaken according to the own reading that the Americans have made (by theirselves), above all, from their Cultural Studies. American cultural studies have assumed the responsibility to clarify the 
idiosyncracy and to reformulate periodically the issue, to update and to improve it. However, currently, they are fragmented and confronted, without a chance to fix the identity trouble, and ACR is in the nuddle (thanks to them and improving the American posmodern paradox-set or APP-set, which drives to Americaless and transWesternelless). Such circumstance affects the American idiosyncrasy; also, it has an impact in the socio-cultural relations and international affairs (moving from Atlantic area to the Pacific land, and transforming the West in a fuzzy way).

Preliminarily, a brief contextual note is offered in this epigraph, to indicate where this study starts from (the explanation of its evolution and evaluation is made in chapter 4). As well as known, unde the globalization and its crisis, the identity issue is back. The Western identity category of nation (linked to the State, which was dominant until the Cold War), right now it is done. There is not a new replacement proposal, so it is using revivals of communitarian identity ways, as ethnics and gender or religious identity (rethinking social process and its institutions). The identity trouble is becoming more complex and confusing for the crisis, it is taking advantage the pathetic -it means, from pathos- post-modern veils (e.g. relativism, political correctness, weak thought). Such veils are affecting the entire West, especially to relevant countries like the USA. The American national identity is a prototypical production (pioneer in the transition to the New Regimen, by a modern secularization and theology. The American formulation is previous to the national identity debate in continental Europe during the $19^{\text {th }}$ century (liberal patriotic model v. ethno-cultural model), and previous to the empowerment of the nation-State (with an overdevelopment beyond the whole social spheres). US identity construction (the vision and mission of an American has to be), it comes from the modern theology or political theology approach: traditional theology is related to 
God understanding and the eternal life, but political theology is concerned to religious thought and the organization of God's people in this life, so it is the inquire about the role of religion in public life (without the nation-State monopoly). Political theology is adapted in the American colonies (joining Catholic Mediterranean evangelism and Nordic-Saxon Protestant evangelism), and its result is a kind of pragmatic and humanistic Jewish-Christian model (based in federal covenant issues): it is a functional model to integrate people with diverse origins and traditions, by a pluralistic system of religious and civil loyalties established on religious liberty and autonomy, which allowed the emergence of native mixed formulas. US model is a reference too, because it helped to promote this country as one of the international powers (also, as Western leader after the Second World War, according to its own perception). The mismanagement of American identity problem (including the inaction) it could suppose, in international terms, the end of its hegemonic status (and the possible conflict for that); and in domestic terms, as result of its pluralistic integrated communities system (more than other European nation-State), it is progress the risk of entropy (social dysfunction until the collapse or total disorder) or the Armageddon (final conflict). To explain all these issues, as well as offering an evolution and evaluation of matter, it uses an interdisciplinary study of sociological and cultural approaches, with several social scientific bases. This approach includes, as a complement of American civil religion, like American gospel, American manifest destiny, American self-righteousness, etc. This approach permits also the study of the most relevant hierophanies (i.e. place names, signs \& symbols) and hierocracies (i.e. Church-State relations, Blue Laws), the heritage of the founding fathers (including hagiographies and its messianic sense: symbols, rituals, values, beliefs, institutions, etc.), the impact of religious movements (the 
awakenings and social crusades, and the influence in public opinion and political revivals), etc. By this way, it expects to offer a diagnosis and prognosis about the vulnerabilities of the US idiosyncratic matrix, before to transit to the postglobalization World. 


\section{PARTE INICIAL:}

\section{ACERCA DEL ESTUDIO Y SU PROPEDÉUTICA}

(crisis idiosincrásica posglobalizatoria y su investigación sociocultural)

Para iniciar la presentación de este estudio, se sigue la tradicional fórmula universitaria de memoria académical: se ha de exponer y explicar los conceptos básicos, los objetivos y contenidos a tratar, la metodología empleada y un esbozo de fuentes de partida (además de aclararse la idoneidad del candidato para la investigación presentada). Por tanto, en las siguientes páginas se formulan las grandes cuestiones canónicas, como son el qué, el porqué, el para qué y el cómo. De ahí que, partiendo de una constatación como es la incertidumbre y confusión ante el novedoso periodo que es la posglobalización -máxime al confirmarse y generalizarse la posmodernidad, vid. supra-, se requiera de un ejercicio panorámico de balance, especialmente de su potencia de referencia en los últimos tiempos. Así, se justifica la oportunidad y valía de esta investigación (tanto para la comunidad universitaria como para la sociedad en su conjunto, pudiendo interesar a su vez

${ }^{1}$ Con la fijación de la red de universidades estatales (para el afianzamiento del Estado-nación decimonónico), en buena parte de Europa continental se estableció un sistema de oposición a cátedra (la dirección de la disciplina y reconocimiento de dominio sobre las asignaturas correspondientes). Entre sus primeros ejercicios, además de la presentación del candidato y la defensa de su idoneidad, estaba la exposición de su visión de la disciplina. Tal ejercicio se realizaba mediante la llamada memoria académica: una presentación a modo de lección magistral del concepto, método, contenidos y fuentes que el candidato consideraba esenciales para enseñar y proporcionar así un nivel mínimo conocimiento de la materia. Posteriormente, dichas memorias eran revisadas, tras la práctica docente y se publicaban como manuales. Incluso, los catedráticos se las facilitaban a sus discípulos en sus oposiciones, forjándose así las escuelas contemporáneas de pensamiento universitario (entre otras fórmulas de poder académico). Vid. SÁNCHEZ-BAYÓN, A.: Estudios de cultura política-jurídica, Madrid: Delta Publicaciones, 2010. 
tanto a los propios estadounidenses, como al resto de occidentales y cualquier pueblo que mantenga relaciones con los estadounidenses). También se especifica la telología del estudio, indicándose su fin a alcanzar (como es la inteligibilidad del devenir de las relaciones socio-culturales estadounidenses, como resultado de las interacciones nortatlánticas, vehiculizándose a través de su religión civil, y cuál es su estado actual, dadas las crisis y paradojas detectadas); sin olvidar su mesología o medios de investigación (tal como se aborda, junto con la metodología y estado de la cuestión, en el cap. 2 y 3), así como la axiología, presente en todo el estudio, especialmente en la discusión de resultados. Se completa todo ello (combinándose telología, mesología y axiología), conforme a un sistema complejo (en cuanto objetos de estudio sociales y culturales entrelazados, o sea, socioculturales) ${ }^{2}$, tal como los contenidos del índice de la tesis presenta (v.g. qué es, cómo opera y cuál es el estudio de Americaness o estadounidización; ídem para American civil religion o religión civil estadounidense, en conexión directa con American (social) gospel o evangelismo social estadounidense -incluso, podría entenderse como su espíritu nacional-, que a su vez conducen a American manifest destiny o destino manifiesto estadounidense, American dream o sueño estadounidense, American way of life o modo/estilo de vida

\footnotetext{
${ }^{2}$ La complejidad no es dificultad, sino holisticidad -más bien, se pretende desde este estudio lo contrario a lo difícil y oscuro: se aspira a facilitar el acceso a la reflexión de los múltiples objetos de estudio entrelazados, y cómo aumentan así sus significados al estudiarse conjuntamente-. La complejidad es un atributo de la realidad, que es variada y voluble, además de estar interconectada. Por tanto, se alude con la complejidad sociocultural a la gran diversidad de conexiones evidentes y ocultas existentes (más la retirada de velos que se requiere tras las guerras culturales), máxime en un sistema evolutivo como el estudiado (relativo a la idiosincrasia estadounidense), que es tanto social como cultural, en relación signalagmática (una dimensión influye en la otra en igual medida en su devenir: lo social afecta a la percepción y gestión cultural, como lo cultural condiciona dicha percepción y gestión de lo social, pues tal como se conoce la realidad social, así se trata, y se es socializado en tal sentido y alcance). De ahí que el estudio también sea de entrelazamientos en la Sociología y la Antropología, tal como los Estudios culturales estadounidenses han venido haciendo (al menos hasta su división y polarización, vid. supra).
} 
estadounidense, American civilazing sense o sentido civilizatorio estadounidense, American self-righteousness o autopercepción estadounidense con sobreestima tendente a una superioridad moral, de mesianismo-, et al.). Finalmente, se da a conocer la metodología empleada, con su combinación de enfoques, técnicas y recursos, más un esbozo del estado de la cuestión (que ha servido de partida para esta investigación). 
Sociología de las Relaciones Socioculturales Nortatlánticas (...) American civil religion - A. Sánchez-Bayón 


\section{1.- JUSTIFICACIÓN DEL ESTUDIO SOCIOCULTURAL REALIZADO}

Esta investigación sociocultural (de la sociedad, su cultura y sus conexiones en su devenir conjunto), que se halla entre las Humanidades y las Ciencias Sociales (especialmente la Sociología, la Antropología y los Estudios culturales), es principalmente de corte analítico (al basarse en el examen racional de argumentos y evidencias, haciéndolo sobre todo de manera crítica y refutatoria), a la vez que de corte empírico (apoyándose en los acontecimientos de la experiencia y aplicándose comparación y contraste); se combinan además ambos enfoques para un análisis de autenticidad (contrastándose su lógica y su acontecer real, detectándose falsificaciones, ocultaciones, etc.), y de revelaciones (de retirada de velos de confusión y revisión hasta su desviación). En consecuencia, el formato expositivo y explicativo más adecuado de esta investigación analítico-empírica es el de un estudio: una indagación en la búsqueda y sistematización de conocimiento (y no tanto en la aplicación del mismo, como supondría el corte experimental). Ahora bien, no se trata de un estudio monográfico de especialización al uso (como han venido siendo habitual en las tesis doctorales en euro-mediterráneas), ni de síntesis (como en el mundo anglosajón), sino más bien panorámico: aquel que permite explorar una realidad social compleja según unas coordenadas espacio-temporales y materiales amplias, buscándose patrones y conexiones de largo alcance y mayor calado, permitiéndose ofrecer así un sistema holístico (en el que el quepa el estudio de las partes, pero la unión de las mismas ofrezca un mayor y mejor conocimiento). En definitiva, se pretende realizar una indagación sociocultural, que favorezca el conocimiento de una realidad compleja presentada de manera sistémica, sin caer en preferencialismos, reduccionismos, anacronismos, etc. El resultado esperado es un 
estudio de evolución y evaluación de unas relaciones tan complejas como volubles, tanto de amistad como de rivalidad, como han venido siendo las relaciones noratlánticas entre Europa occidental y los Estados Unidos de América (EE.UU.), durante los últimos tres siglos largos de la Contemporaneidad (o Baja Modernidad), y cómo dichas relaciones han servido para la forja de la idiosincrasia estadounidense (al saber recibir influjos y adaptarlos a su realidad, para luego reenviarlos). Y es que, pese a la fraternal relación esperable de pueblos occidentales (con los mismos ancestros y su tradición: tanto sagrada/judeocristiana y profana/grecorromana), con sus flujos migratorios constantes y puentes socioculturales (de gentes, tradiciones, folclore, etc.), además de haber cohabitado el mismo hemisferio (como ha sido el entorno atlántico -resultando por ello el epicentro de la geopolítica de la Contemporaneidad aludida-), en cambio, las diferencias van aflorando de manera progresiva y programática (v.g. guerras de independencia y expansión al Oeste, doctrina MONROE y corolario ROOSEVELT, reinterpretación del hemisferio occidental). De tal suerte, se va dando lugar a evoluciones divergentes y visiones de Occidente dispares. Finalmente, con la posglobalización (inaugurada tras la crisis de 2008), parece que las relaciones noratlánticas se han enfriado hasta el punto de provocar un distanciamiento (casi aislacionista -como el finisecular y novecentista acaecido entre Latinoamérica y España, donde comenzar el fin de la Modernidad y se extendieran los velos posmodernos-): EE.UU. se ha vuelto hoy hacia el Pacífico (reafirmándose en su idea de ser el hemisferio occidental-aunque, paradójicamente, alejándose del Occidente histórico, vid. supra Parte de desarrollo general-), mientras que Europa cree regresar al Mediterráneo (en sus posmodernas relaciones con África y Asia, vid. supra idem). Por tanto, antes de entrar a conocer la formación de las 
nuevas tendencias, urge realizar un balance de las relaciones habidas, por si pudieran retenderse los puentes de antaño (o mejores).

El hilo conductor del presente estudio, sobre las citadas complejas y nutridas relaciones socioculturales noratlánticas (de amistad, competición, conflicto, mutuo auxilio, etc.), resulta una suerte de antinomia para las élites europeas (conforme a su tardía secularización contemporánea), o un tipo de oxímoron (con disonancia cognitiva) para los estadounidenses (según su pionera secularización moderna) ${ }^{3}$. Se alude la religión civil: una propuesta formulada en Europa (v.g. ROUSSEAU y su Contrato social) y diagnosticada por europeos viajeros en América (v.g. TOCQUEVILLE y su Democracia en América), es reinterpretada y transformada por los founding fathers o padres fundadores (mediante su Americaness o estadounidización), dando lugar a un mecanismo de integración de multitud de comunidades llamadas a ser un mismo pueblo (o en palabras de CHESTERTON otro europeo visitante- un pueblo con alma de iglesia). Así se articula el Estado en América, sin monopolios, sino mediante una matriz mitopoiética condensadora de un minimo común denominador (o sea, aquello común a todas las confesiones) y con un sistema de plurilealtades compatible (vid. supra). Ahora bien, dicha construcción estatal mediante la religión civil, no eximió de guerras civiles ni exclusiones y/o segregaciones sociales, pero sí permitió su canalización y sostenibilidad hasta la segunda mitad del s. XX. Es entonces, con las guerras culturales

\footnotetext{
${ }^{3}$ Todo ello estudiado a fondo en la tesis doctoral SÁNCHEZ-BAYÓN, A.: “Secularización moderna y teología política estadounidense: estudio panorámico del sentido y alcance de la religión en su configuración idiosincrásica", Tesis doctoral en Humanidades (especialidad: Teología) por Universidad de Murcia (Facultad de Letras-UM e Instituto Teológico de Murcia OFM-Facultad de Teología de Pontificia Universidad Antonianum de Roma); defendida: 21/10/2016; calificación: sobresaliente, cum laude, mención internacional y premio extraordinario de doctorado (Digitum-UMU, URL: https://digitum.um.es/jspui/.../1/Tesis\%20UMU\%20ASB\%20PhD\%20dissertation.pdf ;

Teseo-MEC: https://www.educacion.gob.es/teseo/mostrarSeleccion.do).
} 
acaecidas durante la Guerra fría, cuando empiezan los Estudios culturales sobrevenidos (de origen ideológico europeo y nutridos de su fuga de cerebros, vid. supra cap. 8) a extender sus velos de confusión posmodernos (vid. supra epíg. 1.1.2), provocando fallos en el sistema (v.g. American posmodern paradox-set o APP-set, vid. supra cap. 2), agravándose todo con las crisis abiertas por la globalización, y provocándose el riegos de Americaness y transoccidentalización (la desnaturalización estadounidense y la reformulación de Occidente, en términos meramente geográficos, no socioculturales, luego, sin la tradición sagrada y profana, sin Europa, sin el peso de liderar el viejo Occidente). 


\section{1.- PROBLEMAS REVELADOS: CRISIS IDIOSINCRÁSICA POSGLOBALIZATORIA}

A finales de la Administración OBAMA (2016), si se abría un periódico en EE.UU., podía leerse con habitualidad, entre las noticias domésticas más destacadas, aquellas relativas a los delitos de odio (racismo, machismo, homofobia, supremacismo WASP, etc.). Parecía que era uno de los graves problemas de la nación: más aún, daba la impresión de que, tras la globalización, la nación estaba rota y agotada; ya no había una ciudadanía común, sino facciones enfrentadas entre sí. Profundizándose algo más, podía observarse sin dificultad que, en realidad, existía una polémica interna por la superioridad moral sobre el pueblo estadounidense, su redefinición y su destino: de un lado, la izquierda-liberal, apoyada por los Estudios culturales sobrevenidos, preocupada por la defensa del hecho diferencial de las minorías existentes en EE.UU. y su apoyo, aún a costa de la paz social; de otro lado, la derecha-cristiana, soportada por los Estudios culturales tradicionales, hoy $\sin$ argumentos de consenso (al haber sido deconstruidos por la otra facción), y únicamente centrados en oponerse a nuevas divisiones y tensiones (aunque desde

posiciones reduccionistas y también ya posmodernas). Sendos bandos, a su vez, estaban fragmentados en su seno de manera calidoscópica (v.g. los afroamericanos compitiendo con los latinoamericanos, así como con los asiaticoamericanos y nativoamericanos, y todos ellos cuestionados con por el género, además de culpar a los WASP, aunque los evangélicos critiquen a los eclesiásticos, y todos ellos persigan a los inmigrantes religiosos...). Ante tal situación, cualquier foráneo creía estar en los Estados (des)Unidos (no quedando claro si por entropía de un sistema o un guerracivilismo en ciernes). Y todo ello, dada la severa crisis identitaria estadounidense (agravada por las políticas identitarias resultantes de las guerras 
culturales, e intensificadas con la globalización): los bandos enfrentados, se atacaban entre sí y sin pudor alguno, luchando por hacerse con el control de la nación y su república (no desde bases reales y racionales, sino discursivas y emocionales). Así surgió este estudio, aunque se remonta al final de los felices años 90, con los últimos años de la Adm. CLINTON y los primeros de la Adm. W.BUSH (cuando la corrección política se volvió neopuritanismo). Fue entonces cuando se iniciaron las estancias de investigación en universidades estadounidenses de diversas regiones: las liberales de la costa atlántica, las tradicionales sureñas, las progresistas del medio-oeste, etc. (vid. supra). Tras lustros de investigación (y varias tesis previas en otras áreas -para comprender las ideas-fuertes y circulares-)4, se está en disposición de empezar a aclarar el problema y las revelaciones que afectan al devenir estadounidense y su continuidad o no tras la globalización, vinculado al declive de American civil religion o ACR (religión civil estadounidense).

Previamente, se invita a reflexionar sobre el rótulo del epígrafe (que inspirara el inicio de esta tesis): ¿existe una idiosincrasia estadounidense y se halla la misma en crisis? ¿Qué problemas tiene? ¿Son generales y compartidos con otros pueblos o resultan propios y singulares? Para empezar a responder, permítase un mínima digresión: en la Alta Modernidad, influida por el humanismo hispánico (con su

\footnotetext{
${ }^{4}$ Así se ha abordado en profundidad, beneficiándose de ello esta investigación, cuestiones como relaciones Iglesia-Estado, secularización, Teología política, etc. Vid. SÁNCHEZ-BAYÓN, A.: “Estado y religión de acuerdo con los Estados Unidos de América: análisis y sistematización del modelo relacional", tesis doctoral de Derecho (especialidad: Derecho Eclesiástico del Estado y Derecho Canónico) por la Universidad Complutense de Madrid, 2007 (Cisne-UCM: http://cisne.sim.ucm.es/record=b2416179; Teseo-Ministerio de Educación y Cultura: https://www.educacion.gob.es/teseo/mostrarRef.do?ref=422466). Más "Secularización moderna y teología política estadounidense", tesis doctoral de Humanidades (especialidad: Teología) por la Universidad de Murcia, 2016 (vid. infra nota anterior).
} 
denominado largo siglo de oro, 1492-1681)5, como herencia de su recepción de la tradición occidental profana (o grecorromana), "problema" se usaba con su significado etimológico de preocupación o adelantamiento de cuestiones, favoreciéndose su comprensión y propuesta de gestión antes de su manifestación plena (una vez se diera esta, ell dificultaría su abordaje, al primar entonces la urgencia y necesidad, en vez de la racionalidad auténtica). Se trataba de un ejercicio intelectual de relación potencia-acto (sin tropezar con falacias naturales: confusión del ser con el deber ser, vid. supra). Sin embargo, con la Baja Modernidad (o Contemporaneidad), dirigida por las potencias anglosajonas y nórdicas (desde la perspectiva mediterránea, incluyéndose así a centroeuropeos), la voz "problema" es transformada, para pasar a reducirla a detección de un conflicto (tal como generalizan las ideologías surgidas por entonces y el citado entorno, como son el nacionalismo y el socialismo). Resulta que, de dichas acepciones de "problema", los Estudios culturales sobrevenidos (del último tercio del s. XX, vid. supra cap. 8), se han centrado en la de conflicto social, aunque con una nueva variación de significado: si antes el conflicto era por desviaciones o anomalías contrarias a la mayoría (que se pretendía construir ideológicamente), ahora se entiende "problema" como el conflicto subversivo de autodeterminación y paridad de las (autocalificadas) minorías marginadas, cuyo hecho diferencial ha sido reprimido y ocultado. Pues bien, partiendo de tal denuncia de conflicto por ocultación, se ha llegado a detectar otras cuestiones, como resultan los velos de confusión posmodernos (velos, vid. supra epígr. 1.1.2). Dichos velos anuncian las postrimerías de la prototípica Modernidad estadounidense (fruto del sincretismo

\footnotetext{
5 Vid. SÁNCHEZ-BAYÓN, A.: La Modernidad sin prejuicios (3 vols.), Madrid: Delta Publicaciones, 2008-13. - Estudios de cultura político-jurídica, Madrid: Delta Publicaciones, 2010. - Humanismo Iberoamericano. Una guía para transitar la globalización, Guatemala: Cara Parens, 2012. - Renovación de la Filosofía Social Iberoamericana, Valencia: Tirant lo Blanch, 2013.
} 
entre el racionalismo humanista hispánico y el racionalismo técnico-profesional anglo-nórdico), que sirviera para la matriz mitopoiética estadounidense y su legado idiosincrásico. Pues bien, dichos velos fueron extendidos de manera masiva durante las guerras culturales (en la Guerra fría, vid. supra), tejiéndose mediante unos discursos problemáticos (en la última acepción expuesta): se buscan excepciones para atacar epistemologías previas y subvertirlas, pasando a generalizar sus respectivos hechos diferenciales (siendo una de las múltiples paradojas, únicamente superables mediante disonancias cognitivas del pathos, vid. supra). La plataforma para extender tales velos ha sido, sobre todo, la académica: los Estudios culturales sobrevenidos. De tal manera, se ha preparado la crisis identitaria que, finalmente, ha eclosionado tras la globalización, dejando a los EE.UU., ante un grave problema (en su acepción originaria) de integración y operatividad.

En consecuencia, en este estudio sociocultural sobre la idiosincrasia estadounidense y su crisis vigente (afectando a cuestiones tales como su propia visión, misión y valores, así como a otras conexas, como su relación con el mundo atlántico y el resto de Occidente), se van a manejar todas las acepciones mencionadas de problema (más otras que aflorarán); empero, para esta parte propedéutica o de nociones preliminares de inmersión en la investigación, se va a potenciar el uso de la primera (preocupación), como parte del diagnóstico y pronóstico mediante la crítica a acometer (relativa a los fallos religantes o relaciones vinculantes de conciencia sobre la idiosincrasia estadounidense ante la posglobalización, dado el declive de su ACR, vid. supra cap. 2, 4, 7 y 10). 


\subsection{1.- VISIÓN DE CONJUNTO Y DIAGNÓSTICO COYUNTURAL}

Tal como se ha avanzado, este es un estudio interdisciplinario, además de panorámico, sobre la complejidad sociocultural estadounidense y su crisis idiosincrásica, pues ante la incertidumbre del futuro (la posglobalización, el riesgo de Americaness $\mathcal{E}$ transoccidentalización, más el posible TecnoEvo consiguiente) ${ }^{6}$, y la confusión del presente (tras la globalización, sus crisis y los velos extendidos, vid. supra cap. 2, 6 y 8), se vuelve imperativo el hacer balance y discernir sobre qué se conoce y su autenticidad. Para ello, es necesario retirar velos de confusión y retrotraerse a aquel hito y/o momento de ocultación, falsificación y desviación, para acometer un giro copernicano de subsanación. A tal respecto, la doctrina de los Estudios culturales estadounidenses ${ }^{7}$, pese a su gran diversidad y fuerte tensión vigente

${ }^{6}$ Vid. VALERO-MATAS, J., SÁNCHEZ-BAYÓN, A.: Balance de la globalización y teoría social de la posglobalización, Madrid: Dykinson, 2018.

${ }^{7}$ Como avance y clarificación preliminar (vid. supra cap. 8): se alude así al variopinto conjunto de programas académicos en los que se han combinados disciplinas de Humanidades y Ciencias Sociales, para indagar sobre la idiosincrasia estadounidense. Los Estudios culturales se van consolidando con la normalización de los programas académicos de las universidades a finales del s. XIX, desarrollándose en el seno de las Facultades de Humanidades o Liberal Arts, Teología y CC. Religiones o Divinities, y Derecho y CC. Jurídicas o Laws, en las elitistas universidades del club de la hiedra o Ivy League. Entre los primeros Estudios culturales en consagrase destaca el área de conocimiento de American Studies (también llamada en su origen American Civilization, v.g. Programa de doctorado de la Univ. Harvard desde los años 20: History and American Civilization), es el resultado del estudio combinado de Historia, sociedad y cultura estadounidense, mediante el recurso de Historia, Literatura y una incipiente Antropología, dominada entonces por dos corrientes, como eran los Estudios religiosos y folklóricos (influyentes en los Estudios culturales tradicionales, v.g. American Culture, American Social Thought, Church-State Studies, Religion E, First Amendment Studies), más la Teoría crítica (clave para los Estudios culturales sobrevenidos, v.g. African American Studies, Asian American Studies, Latin American Studies, American feminist and gender -todos ellos impulsados a raíz de Ethnic Heritage Studies Program Act of 1972-), añadiéndose poco después aportes de otras Ciencias Sociales y Humanidades, v.g. Economía, Política, Comunicación y Psicología Social. Para conocer la historiografía y devenir universitario de esta área de estudios, suele citarse la voluminosa y premiada obra de Parrington (1871-1929), uno de los integrantes de la generación de historiadores progresistas (junto con Turner, los Beard, et al., vid. supra). PARRINGTON, V.L.: Main Currents in American 
hasta la fecha (hallándose polarizada y en conflicto, vid. supra cap. 8), sin embargo, se acepta como último gran consenso que, tras la II Guerra Mundial, a la vez que los EE.UU. se autoproclamaron potencia hegemónica y líder occidental, también comenzó el fin de su inocencia, y el adentramiento en la posmodernidad. El hito al que hay que remontarse es el de la fuga de cerebros de posguerra y su versión de la Guerra fría que fueron las guerras culturales (cuyo boom tiene lugar en la década de 1960), atacándose desde distintos flancos el modo de ser estadounidense y su estilo de vida o American way of life-AWF (manifestación relacionada con ACR, vid. supra cap. 5 y 6$)$.

Como avance del diagnóstico coyuntural, acerca de las mencionadas desviaciones detectadas, cabe fechar como periodo más reciente de crisis la denominada globalización: a finales de los años 80 (del s. XX), con la guerra de las galaxias y la perestroika (apertura, gracias a la previa trasparencia o glasnot empezándose a retirar velos tras el telón de acero-), se produjo el debilitamiento y desarticulación de la Unión de Repúblicas Socialistas Soviéticas (URSS), y con ello el fin de la Guerra fría (pasándose de un mundo bipolar a otro multipolar, aunque con una potencia hegemónica: EE.UU.). De tal manera, se dieron las condiciones para el trasvase y popularización de las tecnologías de la información y la comunicación-TIC (vid. supra figura 1). Se abrió así un nuevo ciclo histórico, pasándose de una época rígida dominada por el Estado-nación, a otra flexible de la aldea global (como se previera en la Carta de la Organización de Naciones Unidas, cuyo espíritu de San Francisco había quedado suspendido durante la Guerra fría): tal proceso de tránsito

Thought (3 vols.), Norman: Univ. Oklahoma Press, 1927 (premiada en 1928: Pulitzer Prize for History). Para profundizar, vid. SÁNCHEZ-BAYÓN, A.: Universidad, ciencia y religión en los Estados Unidos de América, Porto: Ed. Sindéresis, 2015. 
entre épocas y modelos socio-culturales es la globalización ${ }^{8}$. La misma, trajo consigo una serie de cambios socio-culturales importantes (sobre todo, de normas e instituciones, quedando caducas en su mayoría, pero sin relevo aún), dando lugar a expresiones descriptivas de la situación actual del tipo sociedad de riesgo, líquida, frágil, corrosiva y flexible, digital y en red, difusa, glocal y de interconexión, holográfica, de retos $^{9}$. Igualmente, la globalización (por medio de las TIC), al poner en contacto a pueblos y culturas de todo el mundo, ello provocó la reactivación del debate sobre la identidad (más la solidaridad, y demás cuestiones idiosincrásicas). En tal sentido,

${ }^{8}$ La globalización no es una mera internacionalización de mercados (como postulaban los franceses, con su expresión "mundialización"), sino que es un proceso de apertura planetaria, en el que la humanidad puede conectarse y operar en tiempo real en cualquier parte, gracias a las tecnologías de la información y la comunicación (TIC, trasvasadas de lo militar a lo civil, con el fin de la Guerra Fría). Como se indica, no se trata de un conglomerado (algo uniforme y acabado -y menos aún, la versión de unas pocas potencias al resto de pueblos-), sino un proceso de transición de diversas etapas (globalización 1.0, para conectarse mundialmente; globalización 2.0, para las redes sociales y la participación procomún; globalización 3.0, para la gobernanza de la humanidad, etc.), y múltiples dimensiones (v.g. política, jurídica y económica mediante organizaciones internacionales, foros sociales, empresas multinacionales, movimientos religiosos, etc.), transitándose así de un periodo en desaparición, dominado por los Estados-nación, a otro emergente, como es la aldea-global. Vid. SÁNCHEZ-BAYÓN, A.: Filosofía Político-Jurídica Glocal, Saarbrücken: EAE, 2012. - Humanismo Iberoamericano... op. cit. - Renovación de la Filosofía Social Iberoamericana... op. cit. - Problemas y retos para alcanzar la sociedad del conocimiento, Madrid: Delta Publicaciones, 2016. - "Prisma holístico para una teoría social posglobalizatoria", Cauriensia Vol. XI (2016). VALERO-MATAS, J.A., SÁNCHEZBAYÓN, A.: Balance de la globalización y teoría social de la posglobalización... op. cit.

${ }^{9}$ Son metáforas sobre el tránsito de un mundo estable (con normas e instituciones claras) a otro voluble. Entre los grandes pensadores de la globalización (amén de los antecedentes de ECO y BOBBIO en Italia, BELL y BERGER en EE.UU., et al.), y bautizadores con los calificativos formulados, vid. BAUMAN, Z.: Modernidad líquida (trad.), México: Fondo de Cultura Económica, 2003. BECK, U.: La sociedad del riesgo (trad.), Barcelona: Paidos, 1998. CASTELLS, M.: La Era de la información (3 vols.), México: Siglo XXI, 2001-02. KOSKO, B.: El futuro borroso o el cielo en un chip (trad.), Madrid: Crítica, 2006. LUHMANN, N.: Sociología del riesgo (trad.), México: Universidad Iberoamericana, 1998. MANZANERO, D., et al.: Philosophical challenges of plurality in a global World, Cambridge: Cambridge Scholars Publishing, 2014. SÁNCHEZ-BAYÓN, A.: Estudios de cultura político-jurídica... op. cit. Filosofía Político-Jurídica Glocal, Saarbrücken: EAE, 2012. - Humanismo Iberoamericano... op. cit. Renovación de la Filosofía Social Iberoamericana... op. cit. SENNETT, R.: La corrosión del carácter (trad.), Barcelona: Anagrama, 1998. TALEB, N.N.: Antifrágil (trad.). Barcelona: Paidos, 2013. WILBER, K.: El paradigma holográfico (trad.), Barcelona: Kairos, 1987. Complement., VALERO-MATAS y SÁNCHEZBAYÓN: Balance de la globalización... op. cit. 
parece que ha quedado caduca la categoría occidental contemporánea de identidad (dominante hasta la Guerra fría), como era la nación vinculada al Estado. Al no terminar de consolidarse alguna novedosa propuesta sustitutiva, en su lugar se están reformulando y revitalizando otras pretéritas, como la comunitaria religiosa (reinterpretándose los procesos de socialización primaria y su institucionalización).

Figura 1.- Claves sobre la globalización y sus crisis

a) Crisis del Estado-nación: desmembramiento de países y despertar de las minorías nacionales y los regionalismos (v.g. disolución de Checoslovaquia, fragmentación de la URSS en Federación Rusa, Estados Bálticos, Repúblicas del Este, etc.; devastación de Yugoslavia); pérdida de soberanía económica (se cede a las organizaciones internacionales y se crean áreas de libre comercio, uniones aduaneras y monetarias; multinacionales con red de sedes y presupuestos mayores a muchos gobiernos); imposibilidad de seguridad y defensa individual, sino que ha de ser colectiva, por el coste de la ciberguerra; política exterior basada en la interconexión solidaria; deslocalización empresarial (producción toyotista y paraísos fiscales); crimen transnacional (mafia y células en diversos países); crisis del estado de bienestar (inversión de pirámide de población, más necesidades que recursos); amenazas globales al medioambiente (capa de ozono, calentamiento mundial, cambio climático); despertar de la sociedad civil mediante organizaciones no gubernamentales o ONG y foros sociales mundiales (movimientos invitados en las cumbres y conferencias mundiales organizadas por la Organización de las Naciones Unidas-ONU).

b) Eclosión de la globalización: fin de Guerra fría (caída del muro de Berlín 1989, reunificación de Alemania 1990-94, aparición de nuevas repúblicas 1991), y avance de las TIC (v.g. satélites para uso civil y despegue de TV privada y telefonía móvil; chips aplicados a la domótica; incorporación masiva de ordenadores e internet en los hogares; apertura del espacio aéreo y vuelos charters y lowcost; incremento de instrumentos y mercados financieros -quintuplicando las operaciones de la economía real: en número y volumen de dinero manejado-; nueva economía basada en las TIC: empresas.com, e-operaciones 24h, etc.) y Organizaciones Internacionales (reactivación de la ONU y OTAN en derecho humanitario, v.g. guerras en Oriente Próximo y África Subsahariana, misiones de paz por todo el planeta; educación en derechos humanos; arranque de NAFTA y Mercosur en 1991, adopción del Tratado de la UE en 1992, aparición de la OMC desde 1996, etc.).

c) Consecuencias: desdibujamiento de fronteras y demás límites estatales, pues lo doméstico hoy se fusiona con lo exterior en cuanto alcance a los intereses propios (v.g. la política exterior estadounidense llega allá donde lo hagan los intereses de sus ciudadanos, quienes tienen una presencia mundial). Ya no hay que pensar el mundo en rígidos cuadrados, sino en círculos difusos e interconectados

* Otras consideraciones: Con la globalización también vuelve a sonar la noción de aldea global (de los textos iushumanistas), pero también coexisten expresiones cínicas del tipo fábrica global 
(una economía real a escala planetaria dirigida por OMC, OCDE, UE, Mercosur, Alca, Tlc(s), etc.); Las Vegas mundiales (un mundo financiero de agentes de bolsa y supervisado por los Bancos Centrales y el Grupo Banco Mundial, con el FMI); la polis global (un amago de gobernabilidad mundial sin gobierno concentrado, sino por medio de una red de organizaciones internacionales y foros mundiales); una apartheid global (pues la tríada AsiaPacífico, Europa-Occidental y América del Norte, sustentan el poder y el resto del mundo es dependiente-incluso, dentro de estos entornos las desigualdades son grandes y variadas-), etc. En definitiva, tal variedad de denominaciones evidencia que aún no hay una concepción dominante ni una visión compartida de conjunto, por lo que no cabe hablar de una única globalización, sino varias, que requieren de un cierto consenso. Y es que el proceso en marcha de globalización no tiene por qué conducir a un futuro positivo de armonización y solidaridad, sino que bien puede terminar en una asimetría brutal -en vez de acercar posiciones, las polariza-, así como, una fragmentación injusta -sin redistribución de la riqueza y de sectorialización toyotista, donde no se trabaja para el bien de la humanidad, sino los beneficios de las corporaciones-. Ahora bien, se insiste en que el proceso está en marcha, y el devenir del mismo dependerá en buena medida de las reglas de juego que se establezcan y respeten, o sea, del tipo de Derecho Global que se consolide: al vivir un tiempo de transición, entre una época que agoniza, que es la monopolista del Estado-nación, con su paradigma del positivismo formalista estatal, y otra que está naciendo, que es la pluralista de la comunidad o aldea global, con su paradigma del positivismo sistémico holístico y difuso (...), que promueve, además, la interconexión solidaria -en vez del actual intercambio desigual, que acerca el Derecho más a la fuerza (de las grandes potencias y su imposición de las reglas de juego) que a la razón-, entonces, se comprenderá así la importancia de acometer un estudio serio del Derecho Global, tal como aquí se invita (...).

Fuente: elaboración propia (SÁNCHEZ-BAYÓN, 2012 y 16).

En cuanto a la revitalización del factor religioso, téngase en cuenta que la religión ${ }^{10}$, no sólo articula las relaciones entre el poder y lo sagrado, sino que además constituye una de las grandes esferas sociales (al igual que la política, el derecho, la economía, etc.), donde se resuelve la cuestión de la salvación y trascendencia -o sea, el sentido vital (visión y misión) en relación con todo lo demás-. Por tanto, la religión

\footnotetext{
${ }^{10}$ Por religión se entiende (tal como se rendirá debida cuenta más adelante), toda relación estrecha y reiterada (re-ligar) con aquello que obliga a salir de uno mismo, pudiendo ser la divinidad, la tradición, la comunidad, el legado, etc. Cierto es que en este estudio, para acotar dicha noción difusa, se centra la atención de la investigación en la tradición judeocristiana, en concreto, en sus movimientos religiosos, en lo tocante al influjo socio-cultural del país. Vid. SÁNCHEZ-BAYÓN, A.: La Modernidad sin prejuicios. La religión en la vida pública estadounidense (3 vols.), Madrid: Delta Publicaciones, 2008-13. - Estado y religión de acuerdo con los Estados Unidos de América, Saarbrücken: EAE, 2012.
} 
también comprende cuestiones de conciencia compartida y conectividad (v.g. identidad, solidaridad, mentalidad, imaginario, vid. supra), ergo afectando al diseño idiosincrásico. En definitiva, la religión impacta severamente en la configuración idiosincrásica de un pueblo, o sea, en su sigularización -que desde el s. XIX fue la nacional, pero antes fue la Cristiandad, y en la Antigüedad fue la ecúmene (mundo civilizado), y hoy puede resultar Occidente o la humanidad de la sociedad del conocimiento-. Y es que, según opere el factor religioso, el mismo puede servir de promotor o censor cultural (tal como estudia la Antropología cultural y los Estudios Culturales), así como de cemento o disolvente social (tal como viene estudiando, sobre todo, la Sociología de la religión). Igualmente, la religión juega un papel crucial como motor social, al acelerar, ralentizar o frenar la acción social, sus cambios y crisis $^{11}$. En consecuencia, siendo un factor tan valioso para descubrir el devenir social y cultural, actualmente, con la globalización, parece que lo es aún más. Sin embargo, ¿se tiene claro en qué consiste el factor religioso y cómo opera en la configuración idiosincrásica? El problema planteado sobre la globalización y sus crisis, afectándose a las identidades y solidaridades, y en el que reemerge el factor religioso, resulta más complejo y confuso por los velos posmodernos (v.g. relativismo, cientificismo, corrección política, posverdad). Estas "telillas cognitivas", que distorsionan el reconocimiento y gestión de la realidad social subyacente en curso, son el resultado de la hibridación de retazos ideológicos, basados en la réplica discursiva y la falacia naturalista (o wishful-thinking: confundir el ser o realidad, con el deber ser o deseo). Tales velos están afectando a todo Occidente, especialmente a un país referencial como es EE.UU., dificultándose así su revisión identitaria y solidaria (visión y misión).

\footnotetext{
${ }^{11}$ Vid. SÁNCHEZ-BAYÓN, A.: La Modernidad sin prejuicios... op. cit. - Estado y religión de acuerdo con los Estados Unidos de América... op. cit.
} 
Téngase en cuenta que la configuración idiosincrásica estadounidense (quién es, cómo se es y para qué se es estadounidense) resulta prototípica, por las múltiples comunidades de diversos orígenes a integrar. También por ser anterior al ideológico debate nacional decimonónico europeo (modelo liberal-patriótico vs. étnico-cultural), y al fortalecimiento del Estado-nación (con su hiperdesarrollo, extendiéndose por todas las esferas sociales). La configuración idiosincrásica estadounidense (o sea, su singularización, al comprender las cuestiones indicadas de identidad y solidaridad, mentalidad y códigos comunicativos, capital simbólico e imaginario social, etc.), es resultado del tránsito a la Modernidad y su correspondiente articulación del Nuevo Régimen (o como reza el lema nacional del Gran Sello de los EE.UU.: novus ordo seclorum, vid. supra cap. 5 y 10) ${ }^{12}$. Se parte así de la circunstancia de la secularización moderna, facilitadora de los planteamientos de la teología moderna o Teología política. Frente a la teología tradicional, la moderna no se ocupa tanto de Dios y del más allá, sino de la religión y la organización del pueblo de Dios en el más acá, o sea,

\footnotetext{
12 Desafortunadamente, es muy habitual confundir el sustantivo Modernidad (que es un periodo histórico, fijado etnocéntricamente por los occidentales: del s. XV al XVIII, de nuestro sistema de tiempo - por cierto, de la era cristiana: d.C.-), con su adjetivo moderno (lo último en tendencia). Se deja fuera otra voz, muchas veces mal empleada como sinónimo, como es el modernismo: corriente artística finisecular entre los europeo-continentales y novecentista entre los anglosajones). Para este estudio, Modernidad se emplea de manera laxa, para referirse no sólo al periodo histórico occidental, sino al nuevo paradigma que sigue al Medievo y su mundo feudal espiritual, y sin embargo rígido (por su oficialidad), dando paso a un paradigma basado en propuestas realistas y materialistas -con las prevenciones necesarias frente al concepto, por tanto reconducido hacia la noción ilustrada de riqueza y bienestar (v.g. Ilustración escocesa -heredera de la Escuela de Salamanca-: de HUME a SMITH, llegando a LOCKE, y de ahí a los padres fundadores). Por tanto, la prototípica Modernidad habida en los EE.UU. resulta real, al transitarse de la tolerancia a la libertad (consagrándose el ámbito de autonomía interna del individuo), con una secularización favorecedora de la separación acomodaticia de Iglesia-Estado, y con ello, consolidándose la pluralidad social de comunidades integradas en la vida pública. Se da paso así al Nuevo Régimen, cuyas expresiones oficiales estadounidenses (en el Gran Sello nacional) son: novus ordo seclorum y e pluribus unum. Mientras que en Europa continental, la Modernidad efectiva se retrasa siglos, pero no por la religión, sino por los Absolutismos regios (además de otras instituciones tradicionales, como los gremios, los señoríos, etc.). Vid. SÁNCHEZ-BAYÓN, A.: La Modernidad sin prejuicios... op. cit.
} 
del impacto de la religión en la vida pública (sin el pretendido monopolio estatal). La Teología política es adaptada en las colonias americanas (combinándose el evangelismo mediterráneo católico y el evangelismo protestante nórdico-anglosajón), dando lugar a un modelo pragmático judeocristiano humanista (de corte pactista federal), o sea funcional integrador de gentes de procedencias y tradiciones diversas (gracias a un sistema de plurilealtades religiosas y civiles, respetuoso con la libertad y autonomía religiosa), además de permitir la emergencia de fórmulas de mestizaje autóctonas. Tal modelo resulta además referencial, al posicionar dicho país entre las potencias mundiales (incluso -tal como se ha adelantado ya y a explicar mejor más adelantecomo adalid de Occidente, según su autopercepción posterior a la II Guerra Mundial). Adviértase de que la incorrecta gestión del problema identitario estadounidense (incluida la inacción), supondría internacionalmente su pérdida de condición hegemónica (así como un vacío de poder, con el consiguiente conflicto en el orden mundial); y domésticamente, dada su alta diversidad comunitaria integrada en su seno (mayor que la de cualquier Estado-nación europeo-continental), se intensificaría el riesgo de colapso (entropía) v. conflicto (armagedón).

Por tanto, aplicándose las premisas anteriores, se entenderá mejor el diagnóstico que se acometiera al respecto con la globalización desde parte de los Estudios culturales estadounidenses. Como se viene advirtiendo, con la globalización, al facilitarse el contacto en tiempo real de los pueblos del mundo, parece que se ha reavivado la cuestión identitaria, para saber quién es quién, y con dicho debate se ha recuperado el interés por factores sociales (como la religión), que permitan conocer y gestionar al respecto. Uno de los autores más conocidos y relevantes (como académico y asesor político), además de animador de la polémica planteada, fue el profesor Samuel P. HUNTINGTON, de la Universidad de Harvard 
(politólogo, historiador especializado e integrante del movimiento Liberal Consensus, vid. supra cap. 8), con la publicación en 1993 de su artículo "The Clash of Civilizations?" en la revista Foreing Affairs. Dado el interés del texto, lo amplió como libro, presentándolo en 1996 -ya en sentido afirmativo- como The Clash of Civilizations and the Remaking of the World Order. Una de sus tesis era que la religión servía para delimitar unas civilizaciones de otras. Partía de las veintiuna civilizaciones detectadas por TOYNBEE, y afirmaba que sólo seis seguían vigentes en la actualidad, de las cuales, en riesgo de colisión estaban las variantes fundamentalistas de cristianos, judíos y musulmanes, sobre todo. Igualmente, se aventuraba a atribuir a EE.UU. el papel estratégico de director del nuevo orden mundial. Ahora bien, en el año 2001, con los ataques terroristas yihadistas a los símbolos de poder estadounidense (el comercial del World Trade Center de New York, el militar del Pentágono, y el político de la Casa Blanca-abortado en el último momento-), se inició una guerra del terror (así declarada por la Administración George W.BUSH): de un lado los EE.UU., autoproclamados adalides de Occidente y dirigidos por una Administración de corte neoconservador, y respaldada por la Christian Right y Moral Majority; y de otro lado, el yihadismo proveniente de Oriente Próximo (identificándose como enemigo o eje del mal: Afganistán, Irak, Irán, Pakistán, etc.). De tal suerte, se intensificó el debate y la obra de HUNTINGTON cobró especial interés. Para aclarar su punto de vista, profundizando en la cuestión y aterrizándolo en la realidad estadounidense, HUNTINGTON publicó en 2004 su libro Who Are We: The Challenges to America's National Identity. En dicho libro llevaba el debate civilizatorio y estratégico, junto con la cuestión identitaria y religiosa, al seno mismo de los EE.UU.: defendía que su configuración nacional era el resultado 
de la cultura WASP, acrónimo de white anglo-saxon protestant ${ }^{13}$. Se contraponía así dicha cultura dominante a otras minoritarias -según el autor- como la católica latina. Lo cierto es que sus planteamientos, pese a intentar recuperar los postulados de WEBER y su El espíritu del capitalismo y la ética protestante ${ }^{14}$, en realidad fueron interpretados por su detractores como próximos a las creencias de la supuesta extrema derecha cristiana del Ku-Klux-Klan (y su WASP power). Tal ejercicio apologético terminó generando una tensión y marcada polarización entre universidades, sus disciplinas y sus académicos. Donde más se notó fue en los Estudios culturales estadounidenses ${ }^{15}$ : en vez de tenderse puentes de colaboración en la indagación de planteamientos (revisionistas y de profundización), acerca del papel de la religión (o cualquier otro factor social relevante) en la Historia y la cultura estadounidense, se minó el consenso alcanzado a inicios del siglo XX vía el constructo intelectual del melting pot y las explicaciones del excepcionalismo, causando un enfrentamiento directo entre escuelas y la manera de impartir las asignaturas (vid. supra cap. 8).

En cuanto se empieza a indagar mínimamente, el justificado interés por el influjo religioso en la configuración idiosincrásica estadounidense no resulta algo nuevo y propio de la globalización, sino que se trata de algo inherente al devenir

\footnotetext{
${ }^{13}$ WASP, no sólo es el acrónimo de blanco protestante anglosajón, sino que curiosamente significa también avispa -que no la abeja, más trabajadora y pacífica-. SÁNCHEZ-BAYÓN, A.: La Modernidad sin prejuicios... op. cit. - Estado y religión de acuerdo con los Estados Unidos de América... op. cit.

${ }_{14}$ Protestantische Ethik und der 'Geist' des Kapitalismus fue publicado en 1905, fruto de una estancia de investigación del autor en los EE.UU. Sin embargo, la base del estudio es la tesina de un alumno suyo, y sus postulados claramente son una apología del protestantismo que profesaba, pues defendía que sólo los países protestantes eran los más ricos, frente a los católicos -algo incorrecto, pues la Bélgica de entonces era católica y figuraba entre los más pujantes; además, en lo tocante a los EE.UU., al ser el resultado de un mestizaje, el catolicismo y el judaísmo tenían una fuerte presencia en Estados muy ricos, v.g. California-.

${ }^{15} \mathrm{Vid}$. nota a pie 7.
} 
mismo estadounidense -más aún, varios de sus Presidentes han llegado a proclamar que la religión ha influido en los EE.UU. hasta convertirla en la potencia que es, vid. supra cap. 6 y 9-. El interés religioso en los EE.UU., y su impacto cultural e idiosincrásico, se remonta a su fundación y ha perdurado desde entonces. En términos cuantitativos, EE.UU., desde sus orígenes ha sido uno de los países occidentales que mayor diversidad religiosa ha acogido en su seno: desde variantes cristianas, con diversas llamadas a la evangelización, al reconocimiento progresivo de otras expresiones abrahámicas (además de cristianos católicos, ortodoxos y protestantes, también judíos, musulmanes, bahais, ahmadíes, etc.); también orientales (v.g. budistas, taoístas, hindúes), indígenas (v.g. cada nación india continental, más esquimales, hawaianos, etc.), pasando por manifestaciones sincréticas (v.g. santería, vudú), hasta aquellas otras autóctonas de cariz posjudeocristiano (v.g. mormones, testigos de Jehová, cienciólogos), et al. En términos cualitativos, la convivencia de tanta diversidad religiosa ha sido posible, entre otras razones, gracias al frontier factor o factor fronterizo (vid. supra), que permitiera al disidente buscar dónde ensayar propuestas, y si las mismas alcanzaban éxito y beneficio, entonces quedaban integradas en el all that jazz o sincretismo general, articulado a modo de American civil religion o religión civil estadounidense (un recurso para la construcción nacional anterior al debate decimonónico del nacionalismo, sólo que dirigido desde la propia sociedad civil) ${ }^{16}$. Y es que la religión,

\footnotetext{
16 Vid. SÁNCHEZ-BAYÓN, A.: Religión civil estadounidense, Porto: Ed. Sindéresis, 2016; complement., vid. SÁNCHEZ-BAYÓN, A.: "Estudio de la idiosincrasia estadounidense desde su Teología política y Ciencias Eclesiásticas", Estudios Eclesiásticos, v. 93, nº 364, 2018. p. 165-204. - "La religión civil estadounidense: análisis de la configuración de la realidad socio-cultural y su identidad social", en Revista General de Derecho Canónico y Derecho Eclesiástico del Estado-Iustel (no 10), 2006, p. 1-36. "Idiosincrasia de la identidad nacional y del modelo socio-cultural estadounidense según el influjo de sus elites político-jurídicas (a vueltas con la religión civil)", en Actas del VII Congreso Español de Ciencia Política y de la Administración: Democracia y Buen Gobierno (Grupo 26: Elites de poder), 2005, p. 265-281. Vid. supra nota al pie 24.
} 
como factor y esfera social, ha contribuido a la forja de los EE.UU., al servir de cemento social frente a las adversidades (v.g. la naturaleza, los enemigos), y de estímulo para el progreso ante los retos (v.g. las cruzadas sociales, el destino manifiesto), además de facilitar un sistema identitario y solidario, así como propiciador de una mentalidad e imaginario colectivo al que adherirse. Ahora bien, si la religión en los EE.UU. (en términos generales) ha jugado dicho papel, ha sido porque su expresión llegada a las colonias se hallaba ya en un proceso de secularización moderna (de apertura a los cambios de los tiempos), habilitándose así la puesta en marcha de una teología política impulsora de un tránsito efectivo a la Modernidad y su Nuevo Régimen ${ }^{17}$, o como fórmula desde 1782 uno de los lemas del Gran Sello nacional: novus ordo seclorum (nuevo orden de los tiempos).

Se insiste en que la religión, en los EE.UU., no puede concebirse como un conglomerado monolítico (pues sus manifestaciones son diversas y aún siguen evolucionando), ni ha jugado un papel lineal y unívoco (ha habido avances y retrocesos en los que las confesiones han competido en bandos distintos), y muchos menos se halla establecida (no hay religión oficial -ni confesionalismo, ni Iglesia de Estado-, ya no sólo por la prohibición constitucional en su Primera enmienda de 1791, sino por el renovado espíritu con el que reemergen periódicamente los movimientos

\footnotetext{
${ }^{17}$ Suele confundirse el sustantivo Modernidad (que es un periodo histórico, fijado etnocéntricamente por los occidentales: aprox., del s. XV al XVIII de nuestro sistema de tiempo -por cierto, de la era cristiana: d.C.-), con su adjetivo moderno (lo último en tendencia). Incluso, hay quien usa como sinónimo la voz modernismo (corriente artística finisecular entre los europeo-continentales y novecentista entre los anglosajones). Para este estudio, Modernidad se emplea de manera laxa (comprendiendo la Alta Modernidad de mediterráneos y la Baja Modernidad de nórdicos y anglosajones, vid. supra), para referirse no sólo al periodo histórico occidental, sino al paradigma del Nuevo Régimen (opuesto al Viejo, del Medievo y su mundo feudal), con su orden secular basado en una sociedad abierta de comunidades e individuos libres, iguales y en busca de su felicidad (como se afirma desde la Declaración de Independencia de 1776, vid. supra). Para mayor detalle, vid. SÁNCHEZBAYÓN, A.: La Modernidad sin prejuicios... op. cit.
} 
religiosos en su vida social) ${ }^{18}$. Ahora bien, sí cabe generalizar al respecto su importancia en el impulso de la vida socio-cultural estadounidense, marcando sus tiempos y objetivos coyunturales, así como un plan a largo plazo de progreso y mesianismo, además de influir en su configuración idiosincrásica o singularización estadounidense (aportándose una visión y misión). Los EE.UU. no resulta excepcional, en cuanto a radicalmente distinto al resto de los países occidentales (igualmente, sus gentes han transitado del campo a la ciudad, de la artesanía a la industria, produciéndose una separación entre Iglesia y Estado, o ejército y sociedad civil, etc.). Quizá, la razón de su singularidad radica en su condición pionera (en los tránsitos mencionados), así como en el tipo de religión recibida y el papel jugado en su seno -más aún, los EE.UU. ha logrado despuntar como potencia occidental, sin el lastre de la religión, sino más bien gracias a ella, como se aclarará-. En los EE.UU. se ha contado activamente con la religión ( $\sin$ las restricciones europeas coetáneas de

18 El factor religioso puede manifestarse de diversa manera: desde elementos básicos individualizables (v.g. creencias, ritos, símbolos), hasta otros más complejos y colectivos, como son los movimientos religiosos (que a su vez incluyen a los anteriores). Dichos movimientos pueden institucionalizarse en forma de confesión (grupo religioso organizado y arraigado, cuya máxima expresión es iglesia), o ser meras iniciativas puntuales (vigilias, proyectos, cruzadas, misiones, etc.). Sobre los movimientos religiosos en la Historia estadounidense a tratar en este estudio, sirvan como avance las siguientes notas introductorias: a) tipos de movimientos: de conversos, transformistas, de introversión, utópicos, cientificistas, de manipulación, taumatúrgicos, et al.; reformistas, revolucionarios, aislacionistas, salvíficos, etc.; b) corrientes: congregationalism [congregacionalismo], propagationism [propagandismo], perfectionism [perfeccionismo], millennialism [mileniarismo], restorationism [restauracionismo], communitarianism [comunitarismo], sabbatarianism [dominicalismo], evangelicalism [evangelismo], harmonialism [armonialismo], pentecostalism [pentecostalismo], fundamentalism [fundamentalismo], neortodoxa [neortodoxia conservadurista], ecumenicalism [ecumenismo], judeochristianism [judeocristianismo], et al.; c) hitos: New Plymouth (peregrinos y puritanos, 1620); Philadelphia (deístas, 1776-87); Cane Ridge (metodistas, 1801); Salt Lake City (mormones, 1847); Oneida Community (perfeccionistas y comunitaristas, década de 1840); Gettysburg (religión civil, 1863); New Orleans \& Harlem (santería y vudú, década de 1920); Woodstock (orientalismo y New age, 1969); New York-Washington (judeocristianos, 2001), etc. Vid. supra cap. 9. Vid. infra bibliografía citada (notas a pie: 5, 11 y 16), más SÁNCHEZ-BAYÓN, A.: "Historia de la Comunicación Social Estadounidense a través de sus Movimientos Religiosos", en Historia y Comunicación Social (vol. 13), 2008, p. 199-223. 
oficialidad religiosa o cualquier intento de injerencia estatal). Y es que ha sido la sociedad civil la que ha hecho uso del recurso religioso para lograr, entre otros objetivos, el dinamizar la acción social, orientándose así el carácter moral y pionero en cada época, eligiéndose las misiones y cruzadas influyentes en la agenda institucional (con sus políticas públicas y regulación), proporcionándose la renovación de las élites de poder, y con ello el cuidado e impulso de cuestiones como el legado o matriz mitopoiética estadounidense, etc. En definitiva, tal ha sido el interés que suscita y ha suscitado la religión en los EE.UU., que bien merece su estudio histórico, como un foco más de iluminación en la trayectoria estadounidense.

Queda por señalar, en cuanto al interés religioso de los estadounidenses, que dado su peso social e influjo cultural, no es de extrañar que ya en sus primeras universidades se prestara una rica atención a la materia. De entre las variadas disciplinas encargadas de su estudio, en esta investigación se ha seguido de cerca las aportaciones de un área de conocimiento multidisciplinar, como son los Estudios culturales, en concreto sus disciplinas de vertiente tradicional (v.g. American Studies y sus especializaciones del tipo Church-State Studies, Religion E, First Amendment Studies o American civil religion), cuya historiología e historiografía ha sido tenida en consideración para la realización de este estudio.

En definitiva, tras el diagnóstico coyuntural preliminar planteado, parece claro que las crisis de la globalización no son el origen del problema actual (de incertidumbre y confusión ante la posglobalización por el fallo idiosincrásico estadounidense), sino que se trata del resultado de un proceso de erosión previo también aludido-, como fueron las guerras culturales y sus velos extendidos recuérdese la cita de LENIN: la mentira es un arma revolucionaria (...) y mueve el mundo. Los ataques producidos durante las mismas, no se limitaron a su periodo, sino que 
se remontaron incluso a la época fundacional (vid. supra epígr. 1.1.2), afectándose a la matriz mitopoiética estadounidense y su legado (canalizado a través de su ACR, vid. supra cap. 10). Se entenderá entonces que la urgente necesidad de un estudio panorámico crítico como este (vid. supra cap. 2) $)^{19}$.

A continuación, se aclara algo más qué son los velos, pues abarcan desde las falsificaciones artísticas -como afán de destruir cualquier canon- de los movimientos vanguardistas precursores de la posmodernidad, hasta los bulos de la Guerra fría: se llamaban veils o velos a la contrainteligencia extendida por los soviéticos en EE.UU., con el respaldo de la intelligentsia universitaria y comunicativa estadounidense de entonces.

\footnotetext{
19 Sirva como adelanto (vid. supra cap. 2): para tratar todo lo planteado, además de ofrecer una evolución y evaluación de la materia, se recurre a un estudio interdisciplinario (de base sociológica, antropológica y estudio-cultural, además de iuseclesiasticista y teológico-política, prestándose especial atención a la expresión autóctona de American Covenant Theology o ACT (teología pactista estadounidense). Esta expresión requiere el abordaje de otras cuestiones inherentes, tales como American/US civil religion o ACR (religión civil estadounidense) y American/US (social) gospel o ASG (evangelismo social estadounidense), que a su vez conducen a American/US self-righteousness o ASR (autopercepción estadounidense con sobreestima, tendente a una superioridad moral, de mesianismo), American/US manifest destiny o AMD (destino manifiesto estadounidense), American/US way of life o AWL (estilo de vida estadounidense), American/US dream o AD (sueño estadounidense), American/US calling (vocación estadounidense), et al. A la postre, tras el abordaje de las más destacadas hierofanías (v.g. toponímia, simbología) y hierocracias (v.g. relaciones Iglesia-Estado, Blue Laws o Derecho dominical), se espera poder ofrecer también un diagnóstico, y pronóstico acerca de las vulnerabilidades de la matriz idiosincrásica estadounidense (el legado de los padres fundadores estadounidenses o su Founding fathers' heritage). Vid. SÁNCHEZ-BAYÓN, A.: "Revelaciones sobre los padres fundadores estadounidenses y su legado en materia de relaciones Iglesia-Estado, libertad religiosa y asistencia socio-religiosa", Anuario de Derecho Eclesiástico del Estado-Ministerio de Justicia (no33), 2017, p. 383-438. - "Raíces de la teología política estadounidense, su reconocimiento iuseclesiástico y su impacto idiosincrásico: estudio de caso de la religión civil", Anuario de Derecho Eclesiástico del Estado-Ministerio de Justicia (nº33), 2017, p. 599-652.
} 


\title{
1.1.2.- VELOS DE CONFUSIÓN POSMODERNA Y DECONSTRUCCIÓN FUNDACIONAL:
}

\author{
MÁS ALLÁDE LA PÉRDIDA DE CONSENSO E IDENTIDAD ${ }^{20}$
}

Se introduce aquí la cuestión de la posmodernidad ${ }^{21}$, como agotamiento de la Modernidad $^{22}$, y por tanto el efecto pendular a la misma: del tiempo del ethos

${ }^{20}$ Vid. SÁNCHEZ-BAYÓN, A.: “Revelaciones conceptuales y lingüísticas de la posglobalización: Retos de construcción moral de la sociedad del conocimiento y aportes del humanismo hispánico", en Carthaginensia. Revista de Estudios e Investigación (vol. XXXIII, no. 64), 2017, p. 411-458. - "Prisma holístico para una teoría social posglobalizatoria: papel de la religión y su relación con el resto de esferas sociales", en Cauriensia - Revista Anual de Ciencias Eclesiásticas-Ftad. Teología de Cáceres (vol. XI), 2016, p. 675-96; complement., vid. supra nota a pie 23 y 24.

${ }^{21}$ Existen diversas posmodernidades, pudiendo distinguir -como avance- grosso modo: a) una primera posmodernidad, con el fin de la Alta Modernidad en el mundo mediterráneo-latinoamericano (a raíz del desastre americano de 1898 y el declive hegemónico hispánico), impulsada por las vanguardias artísticas y literarias (vid. supra), dando lugar a la renuncia del capital cultural hispánico y su identidad aparejada (pasándose de potencia hegemónica de civilizados al guerracivilismo y dictaduras de neobárbaros); b) un siguiente posmodernidad, con el fin de la Baja Modernidad en el mundo anglosajón (con el desastre indochino, entre la década de 1950 hasta la de 1970), en este caso, impulsada por etnoculturalismo traido por la fuga de cerebros y el auge de la contracultura, amplificándose desde los Estudios culturales sobrevenidos. Vid. infra bibliografía citada (nota a pie: 5, 11 y 16), más SÁNCHEZ-BAYÓN, A.: “Comunicación y Geopolítica estadounidense actual: de IRFA al Choque de Civilizaciones", en Historia y Comunicación Social (vol. 11), 2006, p. 173-198. "Revitalizaciones religiosas postmodernas en América y sus riesgos para la democracia y los derechos humanos", en Revista General de Derecho Canónico y Derecho Eclesiástico del Estado-Iustel (n⿳o 11), 2006, p. 1-23. - "La International Religious Freedom Act of 1998 y la geopolítica estadounidense actual", en CAIRO, H., PASTOR, J. (comp.): Geopolítica, guerras y resistencias, Madrid: Trama Editorial, 2006, p. 121-140. - "International Religious Freedom Act of 1998 y la evolución de la geopolítica estadounidense reciente (tras el discurso religioso neoconservador)", en Actas del VII Congreso Español de Ciencia Política y de la Administración: Democracia y Buen Gobierno (Grupo 27: Geopolítica, guerras y democracias), 2005, p. 152-176.

22 Tal como se viene aclarando (entre las nociones circulares de esta tesis), se recuerda aquí que, suele confundirse el sustantivo Modernidad (que es un periodo histórico, fijado etnocéntricamente por los occidentales, en especial los europeos: aprox., del s. XV al XVIII de nuestro sistema de tiempo -por cierto, de la era cristiana: d.C.-), con su adjetivo moderno (lo último en tendencia). Incluso, hay quien usa como sinónimo la voz modernismo (corriente artística finisecular entre los europeo-continentales y novecentista entre los anglosajones) -vid. papel de las vanguardias-. Para este estudio, Modernidad se emplea de manera laxa, para referirse no sólo al periodo histórico occidental, sino al paradigma del Nuevo Régimen (opuesto al Viejo, del Medievo y su mundo feudal), con su orden secular basado en una sociedad abierta de comunidades e individuos libres, iguales y en busca de su felicidad (como 
(racional, normalizado y de progreso, cuya producción socio-cultural está basada en la realidad y lo tangible), se ha pasado al tiempo del pathos (uno difuso, de emocionalidad y exaltación de lo diferencial, donde predomina lo discursivo y la virtualidad). En términos comparados, más que el paso de un periodo a otro, o de una corriente intelectual y artística a otras (v.g. como el tránsito de la Ilustración y el Neoclasicismo al Romanticismo y la Primavera de las naciones), pues la Modernidad se considera como el estadio superior de progreso en Occidente, ergo se trata de una crisis civilizatoria en forma de fuerza centrífuga (vid. supra cap. 2). Para los estadounidenses, la posmodernidad, se extiende con las guerras culturales (1960-80), confirmándose con la globalización (1990-00). No obstante, para otros pueblos, como los ingleses y franceses, su posmodernidad les sobreviene tras la II Guerra Mundial (pese a los intentos de frenarla con la constitución de Ministerios de cultura y demás proyectos para revitalizar identidades). Por su parte, para los prusianos y rusos, acontece algo antes, con el fin de la I Guerra Mundial (con su desmoronamiento imperial, el triunfo del nihilismo y la rendición final al nacionalsocialismo y al comunismo respectivamente). Ahora bien, los más precoces en el tránsito posmoderno fueron los actuales iberoamericanos, arrancando con la crisis final de la Corona española (el denominado desastre de 1898, que devino en guerras civiles y dictaduras consecutivas) ${ }^{23}$. Todas las experiencias citadas de

se afirma desde la Declaración de Independencia de 1776 de EE.UU. y se plasma como uno de los lemas nacionales en el Gran sello nacional en 1782: "novus ordo seclorum", vid. supra cap. 5 y 10).

${ }^{23}$ La posmodernidad hispanoamericana -como ya se ha señalado- parte de círculos artíticos y literarios, expresándose con las vanguardias (en especial, por poetas como F. de ONÍS, R. DARÍO, N. PARRA, G. MISTRAL, et al., o pintores como P. RUÍZ "Picasso"), y finalmente se extiende al resto de la cultura, así como a las principales esferas sociales (v.g. la política, la religión, el derecho, la economía). Entre los velos posmodernos, que ocultaran el humanismo hispánico, cabe destacar: adanismo y tabula rasa, buen salvaje y revolucionario, arielistas-calabanistas, bucle melancólico, (des)medida holón, etc. Vid. SÁNCHEZ-BAYÓN, A.: “El manifiesto de los odiseos iberoamericanos (tribulaciones intergeneracionales)", en PENA, M.A. (coord.): El mundo iberoamericano antes y después de las 
posmodernidad, han empezado con la extensión de velos de confusión (discursos emocionales de exaltación diferencial y contrarios al ethos oficializados), siguiéndose de una labor de desmontaje de la Modernidad y sus sistemas socio-culturales (deconstrucción según DERRIDA, destrucción según HEIDEGGER, invertebración según ORTEGA Y GASSET, etc. $)^{24}$. Igualmente, todo ello pone de manifiesto el gran peligro de dejar de ser una potencia hegemónica de la Modernidad (por la crisis identitaria doméstica y la imperiofobia exterior), corriéndose el riesgo de renunciar al bagaje cultural común, cuyo vacío es llenado por roles, status y clichés fijados por otros, lo que no sólo dificulta la propia comprensión, sino también la relación con los demás y con el medio, con el pasado y con el futuro. Por ejemplo, así se entiende que el mundo hispánico pasara de ser el formado por los civilizados de la Alta Modernidad al de los neobárbaros de la Baja Modernidad o Contemporaneidad, invirtiéndose su rol, status y cliché $^{25}$ con los anglosajones y nórdicos, que vienen transitando su posmodernidad).

En cuanto a los velos (como se viene señalando y se profundizará más adelante, vid. supra cap. 2,7 y 8$)^{26}$, metafóricamente, suponen una telilla interpuesta

\footnotetext{
independencias, Salamanca: Universidad Pontificia de Salamanca, 2011, p. 729-752. - Humanismo iberoamericano... op. cit. - Renovación de la Filosofía Social Iberoamericana... op. cit. - Problemas y retos para alcanzar la sociedad del conocimiento... op. cit. VALERO, J., SÁNCHEZ-BAYÓN, A.: Balance de la globalización... op. cit.

${ }^{24}$ Vid. infra bibliografía citada (notas a pie: 5, 11, 16 y 23), et supra (nota 28).

25 Sirva como ejemplo (de la citada inversión), cómo los españoles y portugueses, de ser los impulsores de la Alta Modernidad, en la actualidad han sido ninguneados a la condición de PIGS (juego de palabras con la inicial de los países sureños para significar "cerdos") de la Unión Europea; o cómo los latinoamericanos, que ya fueran Repúblicas soberanas en el s. XIX, sin embargo, asumen el anacronismo de tercermundistas (como si fueran parte de los países africanos y asiáticos recién descolonizados en 1950-60). Vid. infra nota a pie 23.

${ }^{26}$ Dichos velos son la normalización e institucionalización de la falsificación (la mentira necesaria para asegurar la crisis y transición entre paradigmas y ciclos), fruto de la combinación estética (de los artistas trasgresores de los cánones) e ideológica (de la intelligentsia en universidades y medios de comunicación). Ya no se miente para evitar vergüenza, conflicto o castigo, ni para lograr ventaja, éxito
} 
(tejida de discursos y réplicas de los mismos entretejidos -a modo the patchwork-), que oculta la realidad y la racionalidad, dificultando su reconocimiento y gestión. Su tipología es diversa, según su intencionalidad y difusión (v.g. prejuicios e inferencias, imposturas, falacias, disonancias, reverberaciones); también se pueden clasificar según su nivel de elaboración e hibridación (v.g. leyendas doradas, rosas o negras, género epidíctico o testimonial) ${ }^{27}$, etc. Téngase en cuenta que, con la globalización y sus crisis, se ha favorecido una temporada fértil (la posmodernidad),

y beneficio, sino para provocar y escandalizar (para evitar el esfuerzo racional del emisor, se vuelve performance, y para el receptor, se apela a emociones, v.g. miedo, asco, envidia), al considerarse la mentira como arma revolucionaria de transformación social (alterándose así la realidad incómoda, insatisfactoria y/o tediosa, además de lograr el pathos de superioridad moral y cultural). Se trata de mentiras de formulación en las aulas y medios, relacionada con el socialismo cultural durante las guerras culturales, pero su auge y extensión a las políticas públicas se produce con la globalización y en forma de neopuritanismo censor. Vid. supra cap. 8.

${ }_{27}$ En el mundo iberoamericano (heredero del hispanoamericano), donde arranca la posmodernidad (al ser el primero en agotar su Alta Modernidad, vid. siguiente nota), cabe señalar al respecto que, tras el realismo mágico de principios del s. XX (heredero del esperpento y las nivolas), surge una antiliteratura: el género testimonial -precursor del cientificismo literario de los estudios culturales (sobre todo en los latinoamericanos posteriores a la globalización)-. Sus antecedentes los encontramos en la memoria del exilio, como el español M. AUB, con sus descripciones de los campos de concentración de la II Guerra Mundial, o el ecuatoriano B. CARRIÓN y su García Moreno, el santo del patíbulo (1959). Sin embargo, no eclosiona dicho género hasta la cobertura proporcionada por la colección Casa de las Américas (La Habana), tomando fuerza como corriente de hibridación -confundiendo interesadamente literatura y memoria histórica, con historia, filosofía y ciencias sociales-. Como trabajos ilustrativos de tendencias, cabe señalar: Biografía de un cimarrón (1966) y Canción de Raquel (1970), de M. BARNET (Cuba); Hasta no verte Jesús mío (1969) y La noche de Tlatelolco (1971), de E. PONIATOWSKA (México); Operación masacre (1969) y El caso Satanowski (1973), de R. WALSH (Argentina); La montaña es algo más que una inmensa estepa verde (1980), de O. CABEZAS (Nicaragua); Tejas verdes: diario de un campo de concentración chileno (1974), de H. VALDÉS (Chile); Secuestro y capucha (1979), de C. CARPIO (El Salvador); Miguel Mármol. Los sucesos de 1932 en El Salvador (1972), de R. DALTON (El Salvador); Las cárceles clandestinas en El Salvador (1978), de A.G. MARTÍNEZ (El Salvador)... así hasta las mayores imposturas testimoniales: Si me permiten hablar: testimonio de Domitila, una mujer de las minas de Bolivia (Historia inédita) (1977), de M. VIEZZER (Brasil); junto con Me llamo Rigoberta Menchú y así me nació la conciencia (1983/1991), de E. BURGOS (Francia/Guatemala) -se supone que hay una edición anterior a la mexicana de Siglo XXI, que es la cubana de Casa de las Américas, 1982-83-, de E. BURGOS-DEBRAY (Venezuela -aunque refiera vivencias guatemaltecas, eso sí, narradas en París, y jamás ocurridas personalmente a la supuesta protagonista, y aún así, ganando a la postre el Premio Nobel de la Paz-). Vid. SÁNCHEZ-BAYÓN, A.: Humanismo iberoamericano... op. cit. - Renovación de la Filosofía Social Iberoamericana... op. cit. 
multiplicándose este tipo de confusiones (fomentadas durante las guerras culturales): con el fin del bloqueo de la Guerra fría y las conexiones de las TIC, tiene lugar al contacto de las culturas del mundo, incluyéndose sus resabios ideológicos, por lo que a la postre termina brotando un pensamiento débil (de hibridación y paradójicamente unívoco -un pensamiento único de consumo pulsional-): desde la corrección política y políticas discriminatorias y de cuotas, pasando por el relativismo, posverdad, cientificismo, ecopacismo, realismo mágico y testimonial, memoria histórica, sin olvidar el poscolonialismo y el posmarxismo (v.g. discurso de género, etnicidad), et al. Todo ello no deja de ser un ejercicio estético antisistémico de posicionamiento en contra de Occidente y sin banderas propias (la crítica se limita a la contestación y subversión -sino directamente la descalificación emocional-, pero sin sentido y alcance auténtico, vid. supra cap. 2). Se trata de replicas discuarsivas efímeras y emotivas de polarización, elaboradas para su consumo de y en masa.

En consecuencia, los velos posmodernos (extendidos durante las guerras culturales), no se han limitado a ocultar la realidad, suplantando su percepción y gestión racional y auténtica por discursos emocionales de exaltación de hechos diferenciales y narrativas épicas de resistencia de supuestas minorías marginadas, sino que además atacaron directamente el periodo fundacional, intentado su deconstrucción, a la vez que se reconstruía la Historia estadounidense y su producción sociocultural aparejada. Para comprender mejor la cuestión, permítase un breve excursus ilustrativo: de cómo se intentó ocultar la Historia oficial, desmontándose el hito fundacional del descubrimiento, reivindicándose otras versiones oficiosas, institucionalizadas por la academia de los Estudios culturales.

Suele considerarse que la Historia de los EE.UU., o mejor dicho, la Historia de los estadounidenses (como prefieren llamarla los afectados, vid. siguiente figura), es 
una historia breve, de un pueblo joven, nacido con la Modernidad (con las primeras colonias de la primera mitad del s. XVII -aunque exactamente no sea así, vid. supra), consolidándose en la Contemporaneidad (tras su Guerra civil y conquista del Oeste). Sin embargo, que sea breve (en cuanto al número de siglos en su haber) no quiere decir que sea simple, ni nimia, pero es que tampoco resulta tal cosa: se trata de un caso prototípico (pionero -rasgo que mejor define a sus generaciones fundacionales, por cierto-, que no excepcional, vid. supra cap. 8) de tránsito a la Modernidad y su Nuevo Régimen (tal como reza su ya citado lema nacional novus ordo seclorum, vid. supra cap. 5 y 10). Es la historia de una sociedad abierta (plural y móvil): sin estamentos, sino clases; sin súbditos, sino ciudadanos; sin Absolutismo regio o monopolio estatal alguno, sino con una sociedad civil dinámica y variada, et al. Y es que, muy posiblemente, los estadounidenses dispongan de una rica historia moderna (lato sensu), con amplia experiencia en la convivencia de multitudes, la gestión de olas migratorias, la implantación de la cultura democrática, etc. Incluso, a la hora de abordar el estudio histórico -como también se ha apuntado ya-, los estadounidenses parecen mostrar una mayor disponibilidad y sensibilidad a la atención de otros factores sociales y culturales, como en este caso es la religión. 


\section{Figura 2.- Historia estadounidense o de lo nuestro (History of US) ${ }^{28}$}

La Historia estadounidense, que al ser estudiada por los propios estadounidenses, los mismos
prefieren un enfoque más popular y participativo (para que sus conciudadanos se
identifiquen y hagan suya la narrativa de tal pasado) -y no tan academicista y distante,
como cabe esperar de los europeo-continentales-. De ahí que en los rótulos de sus estudios
se opte por títulos como "History of US" (con el juego de palabras: "us" nuestro, "U.S."
que es el acrónimo de EE.UU.)29; "History of American People" (Historia de los
estadounidenses); "History of American republic" (Historia de la república
estadounidense); "History of our nation" (Historia de nuestra nación), "Our History / Past"
(Nuestra Historia/Pasado); "American civilization" (civilización estadounidense),
"American experience / life" (vida / experiencia estadounidense); "American tradition"
(tradición estadounidense); "America: a History" (América/EE.UU.: una historia) ${ }^{30}$, et al.

${ }^{28}$ Cuestión desarrollada en publicaciones como las ya citadas (La Modernidad sin prejuicios, et al.), más otras específicas, vid. SÁNCHEZ-BAYÓN, A.: "Historia, Historiología e Historiografía de los Estudios Interculturales en EE.UU.", en Revista Banda de Moebius, Univ. Chile (no 48), 2014, p. 147-57. - "Religión, Cultura y Comunicación Social en la Historia de la universidad estadounidense: de Church-State \& American Studies a Cross-Cultural Studies", en Compé, Revista Científica de Comunicación, Protocolo y Eventos, UCJC (no 2), 2013, p. 6-28. - "Historia de la Comunicación Social Estadounidense a través de sus Movimientos Religiosos", en Historia y Comunicación Social (vol. 13), 2008, p. 199-223. SÁNCHEZ-BAYÓN, A., et al.: "Historia cultural estadounidense desde el factor religioso: fallos de Americaness y sus velos", en Cauriensia - Revista Anual de Ciencias Eclesiásticas-Ftad. Teología de Cáceres (vol. XII), 2017, p. 627-59. - "Vindicatio Historia Philosophiae: estudio de caso de los programas culturales estadounidenses", en Bajo Palabra (II Época), no 17, 2017, p. 457-76. - "A History of American Religious Factor according to the US Cultural Studies: a sociological \& cultural approach from colonies to globalization", en Journal of Sociology and Theory of Religion-JSTR Loyola Univ. E Univ. Valladolid (vol. 6), 2017, p. 84-117.

29 Sirva como ilustración (de obras con dicho recurso en sus títulos), publicadas únicamente en la pasada década (más de una docena), v.g. BREWER, S.: Borders and bridges. A History of US, Westport: Preager, 2006. HAKIM, J.: Freedom. A History of US, New York: Oxford University Press, 2003. KAUFMAN, J.P.: A concise History of US, New York: Rowman \& Littlefield Publishers, 2010, et al. Y el número de rótulos con dicho recurso se multiplica en cuanto se especializa la historia, v.g. FREDRIKSEN, J.C.: Fighting elites: A History of US Special Forces, Santa Barbara: ABC-CLIO, 2012. DICKER, R.: A History of US Feminism, Berkeley: Seal Press, 2008. GASMAN, M. (edit.): The History of US Higher Education, New York: Routledge, 2013, et al. Para concluir este apunte, se recuerdan las obras más usadas en las escuelas al inicio de la globalización (por recomendación de la Secretaría de Estado de Educación y el peso de la editorial): en cuanto a teoría, vid. HAKIM, J.: A History of US (10 vols.: The First Americans: Prehistory-1600; Making Thirteen Colonies: 1600-1740; From Colonies to Country: 1735-1791; The New Nation: 1789-1850; Liberty for All? 1820-1860; War, Terrible War: 18551865; Reconstructing America: 1865-1890; An Age of Extremes: 1880-1917; War, Peace, And All That Jazz: 1918-1945; All the People: Since 1945), New York: Oxford University Press, 1995; en cuanto a práctica, vid. MINTZ, S. (edit.): A History of US, New York: Oxford University Press, 1999, et al.

30 Se considera América (según su versión ilustrada de la tradición profana, reformulada por el pensamiento Free-mason $\mathcal{E}$ Whig, vid. supra), como divinidad materna protectora y legitimadora de su expansionismo continental; de ahí su gentilicio American o estadounidense. 
Otras expresiones manejadas en los títulos, que expresan la vocación socio-cultural (popular y participativa), y que más se reiteran, son: "The birth of / The rise of / The growth of (America/the Americans/the Republic)" [el nacimiento/el crecimiento de América/EE.UU.]; “A short / concise History of (ídem)” [Una breve Historia de (...)]; "Roots of / Patterns of / Shaping / Making (ídem)" [Rutas / Raíces / Hitos / cuestiones (...)]; "The foundations / origins of (ídem)" [La fundación/el origen de (ídem)], "The mind of / The spirit / The soul of (ídem)" [La mentalidad/el espíritu de (ídem)], etc. La razón de ser de un estudio y divulgación de la Historia en los EE.UU. de modo tan popular y participativo se sustenta en su propio pragmatismo ${ }^{31}$ (vid. supra Parte de desarrollo especial).

Fuente: elaboración propia (SÁNCHEZ-BAYÓN, 2016 y 17).

Recuperando la atención por la religión ${ }^{32}$, téngase en cuenta que no sólo articula las relaciones entre el poder y lo sagrado, sino que además constituye una de las grandes esferas sociales (al igual que la política, el derecho, la economía, etc.),

${ }^{31}$ Se trata de la gran corriente de pensamiento autóctono estadounidense. Los Estudios culturales sobrevenidos y la reciente Filosofía estadounidense (v.g. RORTY, WALLERSTEIN) han pretendido reducir el pragmatismo a una suerte de aplicación de la teoría de la evolución a las ideas: sólo prevalecen aquellas teorías plausibles y pedagógicas, o sea, fáciles de comprender y de comunicar, siendo asequibles a cualquiera. Su padre -al menos, uno de sus referentes más notorio- fue R.W. EMERSON (1803-1882) desde Harvard (en su Divinity School), y sus principales discípulos en otras áreas fueron los sociólogos W. G. SUMMER (1840-1910) y A. SMALL (1854-1926), así como los científicos sociales C. S. PEIRCE (1839-1914), W. JAMES (1842-1910) -en realidad, todos los hermanos JAMES-, y J. DEWEY (1859-1952), junto con las aportaciones del Club Metafísico de la Univ. Harvard y de la Escuela de Chicago (dando lugar a teorías tan interesantes como útiles, del tipo del interaccionismo simbólico de G. H. MEAD, 1863-1931), hasta producciones más recientes, como la democracia simbólica y de liderazgo, basándose en las consideraciones de los herederos estadounidenses de L. STRAUSS (1899-1973), cuyas ideas e hipótesis sobre la materia han servido a analistas y gestores -de corte neoconservador e influyente en la Administración W. BUSH- para la formulación e implementación de políticas públicas orientadas al reconocimiento, protección y promoción de la identidad nacional, así como del modelo socio-cultural estadounidense. MENAND, L.: The metaphysical club: a store of ideas in America, New York: Straus and Giroux, 2001. WIENER, P.: Evolution and the Founders of Pragmatism, Cambridge: Harvard Univ. Press, 1949. Vid. supra nota 509.

32 Por religión se entiende (tal como se rendirá debida cuenta más adelante), toda relación estrecha y reiterada (re-ligar) con aquello que obliga a salir de uno mismo, pudiendo ser la divinidad, la tradición, la comunidad, el legado, etc. Cierto es que en este estudio, para acotar dicha noción difusa, se centra la atención de la investigación en la tradición judeocristiana y su institucionalización primaria, como son los movimientos religiosos, y su influjo socio-cultural en la marcha del país. Vid. SÁNCHEZ-BAYÓN, A.: Estado y religión... op. cit. - Derecho Eclesiástico Global, Madrid: Delta Publicaciones, 2012. 
donde se resuelve la cuestión de la salvación y trascendencia -o sea, el sentido vital (visión y misión) en relación con todo lo demás-. Por tanto, la religión también comprende cuestiones de conciencia compartida y conectividad, como la identidad, solidaridad, mentalidad, imaginario, capital simbólico y producción cultural, códigos comunicativos y psicosociales, mitopoiesis, et al. En definitiva, la religión impacta severamente en la configuración idiosincrásica de un pueblo, o sea, en su singularización. Y es que, según opere el factor religioso, el mismo puede servir de promotor o censor cultural (tal como estudia la Antropología cultural y los Estudios culturales), así como de cemento o disolvente social (tal como viene estudiando, sobre todo, la Sociología de la religión). Igualmente, la religión juega un papel crucial como motor social, al acelerar, ralentizar o frenar la acción social, sus cambios y crisis. En consecuencia, siendo un factor tan valioso para descubrir e interpretar las conexiones sociales y su devenir, afectándose a la configuración idiosincrásica del país, se entenderá entonces que los propios estadounidenses hayan recurrido a la religión para su propia investigación y divulgación histórica, con una rica producción científico-académica al respecto (vid. supra Parte de desarrollo especial).

Ahora bien, se recuerda que, si la esencia de la Historia es la indagación acerca del pasado y su sentido, entonces cualquiera que desee (re)descubrir el origen y evolución del Americanness o ser estadounidenselestadounidización ${ }^{33}$ (desde cualquiera de los Estudios culturales tradicionales), bien habrá de requerirse de la ayuda del factor religioso para comprender mejor al respecto. Como se viene señalando, la construcción identitaria nacional estadounidense nunca fue ideológica ni monopolio de Gobierno o Administración de Estado-nación alguno (como sí pasara en buena

\footnotetext{
${ }^{33}$ Se alude a la herramienta principal de adaptación socio-cultural que se dispone en EE.UU., para recibir y transformar cualquier influjo, que más tarde se presenta al resto del mundo como algo idiosincrásico (revestido de éxito y beneficio), vid. supra cap. 4-7.
} 
parte de la Europa posterior a la Ilustración), sino que ha estado en manos de un pueblo -que se cree- unido y amparado por Dios (fundamento de su religión civil pasando de predestinación a autodeterminación, vid. supra-, que a su vez es el sustento de su Americanness). Así se oficializó la primera vez que se presentaron los estadounidenses a los demás pueblos del mundo -hasta entonces sólo querían ser británicos de pleno derecho-:

"Cuando en el curso de los acontecimientos humanos se hace necesario que un pueblo disuelva los vínculos políticos que lo han ligado a otro y tome entre las naciones de la Tierra el puesto separado e igual al que las leyes de la naturaleza y del Dios de esa naturaleza le dan derecho (...) Así que, para sostener esta declaración con una firme confianza en la protección divina, nosotros empeñamos mutuamente nuestras vidas, nuestras fortunas y nuestro sagrado honor" (Declaration of Independence o Declaración de Independencia, aprobada en Filadelfia, durante el Segundo Congreso Continental, el 4 de julio de 1776).

Del modo retratado, la Declaración de Independencia codifica parte de los dogmas de la religión civil estadounidense, cifrándose como verdades evidentes e inalienables las siguientes:

“(...) Sostenemos como evidentes por sí mismas dichas verdades: que todos los hombres son creados iguales; que son dotados por su Creador de ciertos derechos inalienables; que entre estos están la vida, la libertad y la búsqueda de la felicidad; que para garantizar estos derechos se instituyen entre los hombres los gobiernos, que derivan sus poderes legítimos del consentimiento de los gobernados; que cuando quiera que una forma de gobierno se vuelva destructora de estos principios, el pueblo tiene derecho a reformarla o abolirla, e instituir un nuevo gobierno que base sus cimientos en dichos principios, y que organice sus poderes en forma tal que a ellos les parezca más probable que genere su seguridad y felicidad" (idem).

De modo tan moderno (como ciudadanos y no súbditos), se configuraron los estadounidenses (recordándose periódicamente en sus crisis posteriores, v.g. discursos presidenciales de JEFFERSON durante las tensiones diplomáticas con los europeos a resultas de la expedición de Lewis-Clark de 1804-06, de MADISON con la 
Guerra Anglo-americana de 1812, de LINCOLN durante la Guerra civil de 1861-64), apoyándose en una doctrina planteada por los teólogos-juristas universitarios españoles de la Escuela de Salamanca en el S. XVI, como es la del tiranicidio (aprendido luego por la Ilustración escocesa y holandesa, publicitado por LOCKE, e influyéndose a la postre en los founding fathers o padres fundadores estadounidenses: la patrística de la religión civil estadounidense, vid. supra cap. 9). Así se ha percibido y gestionado su Americaness (con ayuda de la religión) hasta buena parte del s. XX. Sirva como ejemplo el breve catecismo estadounidense enseñado a los niños en las escuelas a recitar el Pledge of allegiance o saludo a la bandera (escrito en 1892, por el Rev. bautista F. BELLAMY, con motivo del IV Centenario del descubrimiento de América): "juro lealtad (...) a una nación ante Dios, indivisible, con libertad y justicia para todos", añadiéndose en su posterior versión extensa "para liderar al resto de naciones del mundo" (versión actual, propuesta por el Rev. presbiteriano G. DOCHERTY, y aprobada por la Administración EISENHOWER en 1954). De tal comprensión procede el sentido civilizatorio y mesiánico de los estadounidenses (American manifest destiny), con su polémica superioridad moral identitaria (American selfrigtheousness), y demás manifestaciones a considerar (vid. supra Parte de desarrollo general).

En consecuencia, se espera haber facilitado una mínima visualización (de lo que se desarrolla con detalle más adelante) acerca de la riqueza que aporta el recurso de la religión, en especial su ACR, para aclarar la evolución estadounidense y su configuración nacional (junto con el riesgo de su desaparición, no sólo para la integridad de los EE.UU., sino de Occidente mismo, vid. supra cap. 2). Por ello, resulta clave el conocer las aportaciones epistemológicas ofrecidas por la historiografía estadounidense (tanto general como de Estudios culturales), desde 
sus explicaciones fundacionales (con teorías como la disidencia religiosa, las llamadas evangelizadoras o la religiosidad fronteriza) hasta las relativas a su configuración idiosincrásica (v.g. city upon a hill, melting pot, excepcionalism). Todo este acervo ha sido manejado -en mayor o menor medida-, para explicar su propio devenir, por los historiadores estadounidenses (v.g. la generación dorada, los críticos, los excepcionalistas), ahondándose en los argumentos y evidencias al respecto en la Parte de desarrollo especial de este estudio.

Sobre lo que se desea llamar la atención ahora, es acerca del problema detectado en forma de paradoja (American posmodern paradox-APP): resulta que, a la vez que se revitaliza el interés religioso con la globalización (por el debate identiario), en cambio, en EE.UU., donde históricamente siempre hubo interés por la religión y estuvo muy viva socio-culturalmente, sensu contrario, hoy permanece oculta por velos de confusión posmoderna (vid. siguiente figura), además de sufrir una fuerte desconstrucción, incluso de su periodo fundacional (cuando se fijó su matriz mitopoiética y su legado).

Figura 3.- Síntesis de velos extendidos por Estudios culturales sobrevenidos

\begin{tabular}{|l|}
\hline Noción: \\
\hline a) definitoria: simulacros discursivos, basados en hibridaciones ideológicas, preñados de \\
disonancias cognitivas, superadas gracias al peso del pathos (la emoción colectiva), \\
conducentes a una suerte de pensamiento débil único de confusión social (propiciador de \\
la sociedad-masa de consumo y sus riesgos de entropía y/o armagedón). * Paradoja: \\
aunque muchos guarden relación con el socialismo cultural y el etnoculturalismo de las \\
guerras culturales (cuando los velos eran considerados armas revolucionarias -más que \\
mentiras, licencias artísticas de denuncia-), su cénit se produce con la globalización, \\
momento en que pasan de las aulas y medios a las políticas públicas, en forma de \\
neopuritanismo (un intento de control y censura de lo que se puede decir y/o hacer según \\
los nuevos gestores culturales y sus parámetros desiderativos de superioridad moral). \\
\hline b) enunciativa (de enumeraciones y rasgos): conjunto de ocultaciones de autenticidad (de \\
la realidad, la racionalidad, la subjetividad, la objetividad, etc.), bajo discursos \\
distorsionadores y fragmentarios de pensamiento mágico (vía inferencias, imposturas, \\
falacias y disonancias de suplantación del deseo, reiterados de manera contínua y
\end{tabular}


abundante -no importa que se contradigan entre sí, ni que carezcan de sentido y alcance más allá de la influencia inmediata, de ahí la calificación de pensamiento débil-); deconstruccionistas (desarticuladores de normas e instituciones, suprimiéndose cualquier referente de generalidad y normalidad), de corte relativista y cientificista (estimulando vía TIC modas de consumo de opiniones clónicas, sin fundamento de autoridad, ni reflexión y tendiéndose al pensamiento débil único, vid. supra); de carácter compensatorio (supuestamente son contestatarios y correctores de abusos y/o exclusiones previas -en realidad, buscan su legitimación maniquea por contraste, basándose en la victimización-), reivindicándose en consecuencia un resentimiento de marginalidad, contracultura y antipolítica (la lucha contra lo establecido, pretendiendo hacer públicas causas privadas, v.g. la orientación sexual, el género, la objeción de conciencia -aunque más bien suelen ser casos de escrúpulo y/o arrogancia moral, y no tanto de oposición a la regulación vigente-); se busca la fragmentación social (acceso de poder por cuotas representativas de grupos de interés) y la imposición de planteamientos antisistema (para gobernar el sistema).

\section{Manifestaciones:}

corrección política: circunloquios de pensamiento mágico/wishful thinking, para cambiar la realidad -y finalmente negarla (vid. supra delito de odio)-;

política discriminatoria y de cuotas: promoción de minorías por su mera condición aducida -no probada-, en contra de la mayoría y de los criterios de concurso y mérito;

pensamiento débil: retazos ideológicos hibridados, v.g. ecopacifismo, feminismo y género, poscolonialismo, memoria histórica (con posverdad y delitos de odio), orgullo sexual/LGTB -cualquier manifestación no heterosexual, más bien contraria a dicha condición-;

relativismo: préstamo de las ciencias naturales (de la Física), que permite cuestionar de cualquier referente general y normalizado, poniendo todo a un mismo nivel, y elevándose la opinión personal a categoría aceptable de opinión pública -suele vincularse su eclosión con la falta autocrítica de la intelectualidad socialista, pues tras la caída de la URSS, prefiriendo optar por esta vía laxa, negadora del materialismo histórico y dialéctico, antes que reconocer error alguno-;

cientificismo: se confunde ideología y tecnología, para suplantar la ciencia; se trata de una exaltación del dato y su medición, siguiendo modas y tendencias, sin sustento en teoría firme ni autoridad científico-académica;

posverdad (y relato o storytelling): es la interpretación de interpretaciones (con narraciones posmanieristas, vid. supra), sin criterio objetivo (sin ethos), sino emocional (sólo pathos) -a la postre es una infantilización social (de justificación y excusas constantes, con generalización del autoengaño)-;

posmanierismo y propaganda patética (relativa al pathos): se trata de fórmulas discursivas altisonantes y polarizantes (se buscan adhesiones), diseñadas para generar y modelar la opinión pública, pues los hechos objetivos tienen menos influencia que las apelaciones a las emociones y las creencias (recurriéndose a falacias de victimización y compensación, generalización de la excepción, etc.);

delitos de odio: tipificación de velos e imposibilitación de su refutación al castigarse (bajo acusación de negacionismo y/o discriminación); et al.

Fuente: elaboración propia (SÁNCHEZ-BAYÓN, 2015 y 16). 
Figura 4.- Conjunto de velos sobre la religión ${ }^{34}$

a) Falacia 1: la religión no permite el tránsito a la Modernidad, pues es un ancla con el Antiguo Régimen -refutación: la religión inspira la difusión de la imprenta, v.g. Biblia como libro más vendido; así como la expansión americana, v.g. competición entre coronas protestantes y católicas; en EE.UU., además ilumina la configuración nacional y la conquista del Oeste, v.g. ACR y lemas nacionales: annuit coeptis, In God We Trust.

b) Falacia 2: la religión es el opio del pueblo -refutación: confiere trascendencia y salvación, cosa que las ideologías sólo alienación (como falsa conciencia)-.

c) Falacia 3: la secularización ha de ser total (laicidad), para asegurar la independencia de esferas sociales y reubicar así la religión en el ámbito de lo privado -refutación: vienen dándose oleadas de secularización (resecularización, desecularización, etc.); la secularización moderna estadounidense favoreció la separación Iglesia-Estado, al mismo tiempo que facilitó un mayor papel de la religión en la vida pública, v.g. cruzadas sociales, apoyo asistencial de las confesiones.

d) Falacia 4: el estudio jurídico del factor religioso se restringe a la libertad religiosa -lo cual limitaría las reglas de juego a la regulación estatal (legislatio libertatis), restando

${ }^{34}$ La mayor parte de estas falacias se popularizan y se consagran con la Administración CLINTON, que acerca posiciones a los discursos posmodernos de la Europa continental de entonces -hasta el punto de participar en la noción de multilateralismo e interculturalidad, por la que se reconoce fuerza a una Europa débil, a la que se ayuda con problemas internos como el de la ex Yugoslavia, a cambio de ventajas económicas-. El problema no se soluciona, sino que se agrava con la Administración W.BUSH, pues se presenta como oposición a la de CLINTON, cuando en realidad procede del mismo modo o peor (frente a la corrección política, la discriminación positiva y el relativismo se produce una revitalización del neoconservadurismo y su discurso del miedo, redención, etc., con movimientos que ya han incorporado los velos de confusión a su argumentario, v.g. Moral majority). Se llega así a alienar a la ciudadanía, a la que se sumerge en la era del terror (o Guerra contra el terrorismo global), para que dependa del Estado (vulnerándose una vez más el espíritu de San Francisco y su proyecto de la aldea global). Para desmontar los velos de la figura, habría bastado con afirmar -de manera coherente y continuada-, lo contrario de lo que se niega (vid. refutaciones entre guiones), además de conectarse todo ello entre sí y con la realidad subyacente. Por ejemplo, las premisas son falsas (conforme a la Historia estadounidense previa a las guerras culturales), pues gracias a la prototípica secularización moderna de los EE.UU., que permitiera la recuperación originaria de religión (sin su institucionalización identificasora con una iglesia concreta y sus juegos de poder), permitiéndose además la separación real entre esferas sociales (pero sin independizarlas); así, la religión operó, no bajo un nombre propio (e.g. confesionalismo, Iglesia de Estado), sino como una suerte de cemento social, integrador de expresiones tradicionales y otras nuevas, como la religión civil. Esta última, nunca se encontró en manos únicas de los poderes públicos -no fue una nacionalización de la religión, como acometiera Francia con su laicidad-, sino que su evolución ha dependido del juego de despertares y revitalizaciones entre las bases sociales y las elites estadounidenses. Es por ello que la religión puede y debe operar en la vida pública (en cuanto vele por el interés general y el bien común), pues ni la religión ni la arena pública son monopolio del Estado, ni se consideran cuestiones privadas. Más chocante en la lógica clásica de distinción entre público y privado, es convertir al Estado en un operador económico, en vez de serlo sólo político -de ahí los esfuerzos cientificistas y los ingentes velos de confusión para justificar el sometimiento de la política al Estado en Europa continental-. 
autonomía a las confesiones (libertas ecclesiae) y los ciudadanos en general (humana iura), desapareciendo además áreas de trabajo como las asistenciales (religio ex machina), lo que aumentaría exponencialmente el coste del mal llamado Estado de bienestar.

Fuente: elaboración propia (SÁNCHEZ-BAYÓN, 2015 y 16).

Como último apunte sobre los velos (para irse familiarizando con ellos), se llama la atención acerca de sus herramientas de confusión, empleadas para su extensión, como han sido -al menos- el neolenguaje, el doblepensar y el criptopoder ${ }^{35}$. Sirvan como ejemplos sencillos de su aplicabilidad la siguiente inversión de planteamientos -imaginándose luego lo que supone su implementación en nociones más complejas, volviéndolas contraintuitivas e inauténticas, al impermeabilizarlas frente a la razón, la realidad, etc.-: pasión, revolución, crítica y problema. Sólo se trata de una nímia muestra de conceptos interrelacionados, que favorecieron la emergencia de la posmodernidad y la inversión de relaciones culturales y generacionales, máxime en los roles entre civilizados y bárbaros (vid. infra): para los viejos civilizados hispánicos (hoy neo-bárbaros iberoamericanos, tras renunciar a su

35 Todas estas herramientas fueron ya denunciadas por Eric BLAIR (conocido bajo el pseudónimo de George ORWELL), especialmente en su obra 1984 (1949). Téngase en cuenta que Blair era de familia acomodada (su padre fue responsable del departamento del opio en India y su madre, de ascendencia anglo-francesa, pertenecía a una familia pudiente en la Birmania de entonces -por cierto, ambos BLAIR, dada la endogamia colonial-), y por ende recibió una educación de calidad (v.g. Eton). Comenzó a trabajar para la Policía Imperial India en Birmania, volviéndose anti-imperialista y entrando en contacto con el socialismo (de la II Internacional), lo que le llevó a ser brigadista en España: tal es el horror que descubre en Cataluña (con la cruel práctica del desollamiento de los comunistas del Frente Popular, aplicada a enemigos y supuestos aliados -sobre todo a otras corrientes de izquierdas, como los anarquistas y trotskistas del Partit Obrer d'Unificació Marxista-POUM, por vulnerar su pretendido monopolio revolucionario-; plasmó parte de aquellas vivencias en su Homage to Catalonia, 1938, y algún editorial de Tribune -revista de izquierdas no-socialista oficial-). Tras su regreso a Gran Bretaña (UK), se ganó la vida como maestro, periodista y editor literario, mientras escribía para dar a conocer el horror de los totalitarismos. Poco después ingresó en la Home Guard o Dad's Army (cuerpo de voluntarios, ya mayores, quienes debían defender UK ante el inminente desembarco del Eje). Lo interesante del personaje es lo opuesto que resulta a la tendencia generalizada que se denuncia más adelante. 
acervo humanista de la Alta Modernidad), la pasión era la contención del espíritu (v.g. pasión de Cristo), mientras que desde el Romanticismo de los neo-civilizados (anglosajones y nórdicos) pasa a ser la alienación sentimental (hasta el desorden de los afectos), que termina pendulando a la exaltación y exhibición pública. Así, la revolución, que antes era fruto de la crítica, permitiendo volver al momento previo a la desviación del camino (v.g. revolución ptolemaica, copernicana), se convierte para las ideologías decimonónicas en el camino mismo de la utopía, vía la excitación de los sentimientos populares (pasa de ser un problema racional -en términos humanistas y/o ilustrados- a uno irracional-vitalista: de vínculo, identificación del poder y del conflicto). En cuanto a la crítica, deja de ser la revisión racional de lo que se conoce (por si hubiera habido alguna desviación), para convertirse en una contestación frente al poder establecido $y$, finalmente, un furibundo ataque a planteamientos contrarios al propio -como exaltación narcisista-). Y la idea de problema -tal como se adelantara ya-, que originalmente refería a una preocupación especulativa sobre posibles crisis en ciernes a superar, pasa a convertirse en conflicto (v.g. lucha patrónobrero, hombre-mujer, heterosexual-homosexual, blanco-negro, rico-pobre -dichos conflictos son explotados por los Estudios culturales sobrevenidos-).

Una vez lograda cierta familiariedad con dichas técnicas propagandísticas, resulta bastante sencillo el detectar y desmontar velos, pues se evidencian por haber algo que no encaja racionalmente, sólo de manera pulsional (en inglés su indicador se llama red-light).

Para comprender mejor todo lo planteado sobre los velos y la deconstrucción, y cómo los Estudios culturales han introducido a los EE.UU. en la posmodernidad, se procede a continuación a esbozar-como mero adelanto- un breve apunte sobre la vigente crisis histórica, historiológica e historiográfica estadounidense, dada la 
multiplicidad de relatos fundacionales basados en la exaltación del hecho diferencial de cada comunidad (amparada por cada variante de los Estudios culturales sobrevenidos).

A modo de premisa, sírvase a considerar que, para estudiar la Historia estadounidense, resulta lícito -además de muy conveniente- el cuestionarse por qué y cómo comienzan los asentamientos coloniales en los actuales EE.UU. A tal respecto, pese a que se tiene en consideración para esta tesis, no se toma partido aquí por alguna de las reformulaciones epistemológicas relativas al polémico debate sobre el descubrimiento de América, ya que cada variante de Estudios culturales sobrevenidos defiende la suya propia -de manera casi exclusiva y excluyente-: los Estudios Americanos (más nativistas), defienden la tesis del descubrimiento por los vikingos, basándose en las Vidland Sagas y los viajes de Erick el Rojo. Por su parte, los Estudios Asiático-americanos lo hacen desde la llegada de los primeros orientales, tanto por Bering como por la Costa Pacífica. Los Estudios Afro-americanos prestan atención a los primeros esclavos dinamizadores de la economía, ya que así se garantizó la sostenibilidad de las colonias. Los Estudios feministas y de género enfatizan la importancia de las madres de los primeros nacidos en América. Los Estudios nativo-americanos, se centran en las culturas indias precolombinas, et al. Incluso, ahora hay también Estudios religioso-americanos (en ciertas universidades confesionales del TRACS) ${ }^{36}$, que defienden que en realidad los americanos son

\footnotetext{
36 Transnational Association of Christian Colleges and Schools [Asociación Transnacional de Universidades y Facultades Cristianas] o TRACS, es la organización que integra a los centros cristianos de educación aquellos que cumplen las exigencias de la Secretaria de Educación de los EE.UU. (el equivalente al Ministerio/Departamento de Educación en Europa continental). No es hasta el cuarto despertar, cuando se inicia el auge de dichos centros, que pasan de centrarse en la formación de líderes religiosos, a comprender otras áreas científico-académicas (v.g. Derecho, Política, Economía, Educación, Comunicación, Medicina, Biología). Así surgen universidades de nuevo cuño -de marcado proselitismo- como Bob Jones University, Oral Roberts University, Liberty University, etc.
} 
descendientes de una de las tribus desaparecidas de Israel (de los hijos de José: Manasés y Efraín) ${ }^{37}$. Luego, tal disparidad de planteamientos dificulta la articulación de un pasado común -difuminándose el periodo fundacional y su impronta mitopoiética (en especial, la raíz sacro-occidental judeocristiana)-, además de dejar al descubierto un sinfín de lagunas y disonancias cognitivas -sólo superables por el pathos del pensamiento débil, vid. supra-. Frente a tal cúmulo de microhistorias por comunidades y sensibilidades -sin hilo conector, pues hasta la religión se ha distorsionado y vuelto motivo de conflicto-, ahora bien, sin dejar de atender a dichas microhistorias, y como se viene señalando, en la presente tesis se aboga por la recuperación de un factor de integración e hilo conductor de longue durée/long term ${ }^{38}$, como es la religión. Eso sí, antes es necesario el retirar una serie de velos de confusión al respecto, extendidos por el también aludido ya Americaness (vid. supra).

Este estudio pretende retrotraerse al consenso general de los Estudios culturales tradicionales, aceptadores de la tradición sagrada occidental o judeocristiana (que conecta directamente América y Europa, sacando a esta última

\footnotetext{
${ }_{37}$ Tal planteamiento usa como evidencia la polémica piedra tallada de Los Lunas (Hidden Mountain, Nuevo México). Comenzó a tratarse el asunto en entornos académicos en 1933, cuando F. Hibben, Profesor de Arqueología de la Universidad de Nuevo México, dio a conocer la roca y su supuesto grabado paleo-hebreo de los Diez Mandamientos -el problema es que ya falsificó otras fuentes y en la Torá es distinto el número de mandamientos que en la Biblia-. Por su parte, el arqueólogo y lingüista C. Gordon postulaba que se trataba de una mezuzá samaritana, traída por los marineros fenicios. Y el geólogo G.E. Morehouse, estimó que la inscripción de la roca podría tener entre 500 y 2.000 años de antigüedad. Todas estas tesis fueron soportadas desde la década de 1970, por la Epigraphic Society, fundada por profesores de Harvard, Bentley, etc. Vid. FELL, B.: "Ancient punctuation and the Los Lunas text”, Epigraphic Society Occasional Papers (no13), 1985. FEDER, K.L.: Encyclopedia of Dubious Archaeology: from Atlantis to the Walam Olum, Greenwood: ABC-Clio, 2011. GORDON, C.: "Diffusion of Near East Culture in Antiquity and in Byzantine Times", Orient (n⿳o. 30-31), 1995. HIBBEN, F.: A chronological problem presented by Sandia Cave, Albuquerque: American Antiquity, 1940. MOREHOUSE, G.E.: "The Los Lunas inscriptions, a geological study", Epigraphic Society Occasional Papers (nำ13), 1985.

38 Vid. GULDI, J., ARMITAGE, D.: The History manifesto, Cambridge: Cambridge University Press, 2014.
} 
de la Cristiandad y abriándola a ser Occidente propiamente). Para ello, se requiere de la recuperación del descubrimiento oficial atribuido a COLÓN, en su servicio a la Corona castellana (española después -también conocida como Monarquía hispánica, de impronta católica-). Cierto es que dicha tesis adolece de un error de partida, pues COLÓN buscaba las Indias, dando con las que llamaría Indias Occidentales -para mantener la legalidad de entonces-, y que finalmente sería América -de modo que el resto de potencias pudieran participar en la colonización-. Y es que tal error ha de ser revisado desde el foco del factor religioso, purgándose el Americaness de los Estudios culturales tradicionales. ¿Qué se quiere decir al respecto? En este trabajo -como se viene señalando-, se arranca de la premisa descubridora de América por parte de los europeos en general (del mundo atlántico), en cuanto que resulta así incorporada al mundo civilizado de entonces o Cristiandad -como etnocentrismo de la época-, centrándose la atención en la configuración de los primeros asentamientos coloniales de la Costa Atlántica del Norte (cuna de las Trece colonias originales, firmantes de la Declaración de Independencia). En consecuencia, es de destacar el papel que juega la religión en la carrera de establecimiento de los europeos en América, y cómo se van articulando sus variados modelos socioculturales: pese a resultar común entre todas las potencias la fórmula de toma de posesión de los territorios, plantándose un estandarte junto con una cruz, seguido del oficio de una ceremonia religiosa de agradecimiento, sin embargo difiere y mucho su modelo de dominio y organización socio-cultural. Suele aceptarse aún la inferencia extendida por el Americaness acerca de que los asentamientos nortatlánticos son el resultado de la rivalidad entre la Corona española (de corte católico-confesional) y la Corona inglesa (protestante de Iglesia de Estado), en cuya carrera fundacional implementan dos grandes modelos evangelizadores: de un lado, 
se habla de la evangelización católica de conquista (acaecida al sur del río Mississippi, en la que se separa la figura del soldado y del religioso, con instituciones como el patronato y la encomienda -a modo de misión-, más el mestizaje socio-cultural), y de otro lado, la evangelización protestante de colonización (hacia el norte de la bahía de Chesapeake, en la que se concentra en el colono las figuras del soldado y del religioso, con instituciones como adventure y company -a modo de empresa-, más el modelo WASP -vid. infra- es el del dominalismo ${ }^{39}$ ). Sin embargo, esto no es del todo correcto, pues son más los pueblos en competición y diversos los descubridores a su servicio (tanto católicos como protestantes). Se recuerda en tal sentido el papel de dos navegantes europeos católicos -de origen italiano: genoveses ambos, parece coincidir la doctrina- ${ }^{40}$, como fueron Cristoforo COLOMBUS (c. 1450- c. 1500) y Giovanni CABOTO (c. 1450- c. 1499). COLOMBUS (conocido por los hispanoparlantes como Cristóbal COLÓN, al naturalizarse castellano y prestar servicio a Isabel la Católica, quien le nombrara Almirante de Castilla), resultó clave para la evangelización de España y Portugal, desde 1492, en el Caribe, Centro América y Sudamérica. Por su parte, CABOTO (conocido por los angloparlantes como John CABOT/CABOTT, al naturalizarse inglés y prestar servicio a Enrique VIII, quien a su vez le nombró Almirante de Inglaterra), lo fue para ingleses y franceses,

\footnotetext{
${ }^{39}$ Vid. Gen. 1: y Dios indicó al hombre que dominara la creación -ergo, el hombre ha de someterlo todo, incluidos los indígenas si se resisten al proceso colonizador-. BROWN, D.: Bury My Heart at Wounded Knee: An Indian History of the American West. New York: Rinehart and Winston, 1971. HORSMAN, R.: Race and Manifest Destiny. The origins of American racial Anglo-Saxonism. Cambridge: Harvard University Press, 1981. ORTEGA, J.A.: La evangelización puritana en Norteamérica, México DF: Fondo de Cultura Económica, 1976. PRUCHA, F.P.: The Great Father. The United State Government and the American Indians (vols. 1-2). Lincoln: University of Nebraska Press, 1984.

${ }^{40}$ Incluso desde los Estudios culturales sobrevenidos, en especial los Latinoamericanos y la Red modernidad y colonialidad (v.g. DUSSEL, QUIJANO, MIGNOLO, GROSFOGUEL), que atribuyen tal coincidencia al conocimiento oculto del Vaticano, tomado de los chinos -todo ello resulta anacrónico e insostenible, tal como se probará más adelante-.
} 
desde 1497, para la evangelización de la costa noratlántica. Pero es que tampoco hay que olvidar a otro católico itálico, como el cartógrafo -aunque autopresentado como cosmógrafo de entonces-, de origen florentino y nacionalizado español (de las Españas centroeuropeas del Imperio de Carlos V de las Alemanias y I de las Españas), Amerigo VESPUCCI (conocido por los españoles como Américo VESPUCIO), quien bautizara con su nombre al nuevo mundo (en su edición revisada de 1507 de la Comographie de PTOLOMEO) ${ }^{41}$, siendo así respaldado y difundido por el Gymnasium Vosgianum y un sinfín de editores centroeuropeos e itálicos (con el apoyo de personajes destacados como el cartógrafo WALDSEEMÜLLER, el poeta RINGMANN, el editor OTMAR, et al.). En definitiva, si otros católicos y protestantes apoyaron las aspiraciones de VESPUCIO fue porque así se abría la oportunidad de descubrir las Costas noratlánticas o América.

Ahora bien, si se indaga más, podrá descubrirse la mayor complejidad subyacente, pues frente a la inferencia de que la Costa noratlática fue descubierta mayoritariamente por WASP (tal como sostienen los historiadores críticos y excepcionalistas, vid. supra), tal planteamiento se desmonta con las siguientes evidencias:

- Cuando CABOT, en nombre la Corona inglesa, realiza su ruta de exploración siguiendo los vientos del norte y llega a las costas de la actual Canadá, en realidad da con una tierra deshabitada -a sus ojos-, a la que bautiza como Terra de prima vista. Quien fija el nombre posterior y motivo de conflicto entre ingleses

\footnotetext{
${ }^{41}$ Dado que acompañó a COLÓN en alguno de sus viajes, gozó del crédito suficiente para dividir el Novus Orbe, según el influjo de los vientos y sus rutas de navegación, en las Indias Occidentales de aquel (amparadas jurídicamente por las cuatro Bulas de Alejandro VI de 1493 y el Tratado de Tordesillas de 1494), y calificando el Mundus Novus como tal o América (conforme a la regla de las tierras ignotas: novum mundum appelare licet).
} 
y franceses es el explorador portugués Gaspar DE CORTE REAL, quien fija la denominación de Tierra del Labrador, tal como se plasma en el mapa de 1529 de RIBERO (nacido como Diogo RIBEIRO, entra al servicio de la Corona española en 1518, y en 1523 es nombrado Cosmógrafo Real).

- El propio COLÓN, en su primer viaje, el 12 de octubre llegó a Guanahani (parte del archipiélago de las Bahamas -manteniéndose españolas hasta mediados del s. XVII, con las incursiones de compañías inglesas-). De ahí siguió con su periplo por el Caribe hasta arribar a Cuba en octubre, y a La Española en diciembre. Como dato curioso relativo al influjo del factor religioso, sólo señalar que debido al encallamiento de la carabela la Santa María, con sus restos se construyó la primera gran edificación americana: el Fuerte Navidad (el 24 de diciembre de 1492).

- Desde La Española y Cuba se mandaron expediciones de exploración hacia las Costas noratlánticas (los llamados adelantados), donde se descubrieron territorios tales como: Las Bermudas (reclamadas por Juan BERMÚDEZ en 1505); Las Floridas (por Juan PONCE DE LEÓN, quien fuera Gobernador de la Isla de San Juan -actual Puerto Rico-, y desde allí alcanzara las costas continentales en 1513, seguido de otros adelantados como NARVÁEZ, SOTO, et al.); las tierras de Nueva España (actual México, por Francisco HERNÁNDEZ DE CÓRDOBA en 1517 -en Yucatán-, Hernán CORTÉS, desde 1519, etc.); la actual Carolina del Norte por Francisco GORDILLO en 1522; las Tierras de Ayllón (comprendiendo las actuales Carolinas y Virginia encomendadas a Lucas VÁZQUEZ DE AYLLÓN desde 1523); la llamada Expedición de Narváez (Pánfilo NARVÁEZ, 1528-36) por todo el Golfo de México, adentrándose en la actual Texas, además de ser los primeros europeos en avistar el río Mississippi; las tierras de la actual 
Georgia, Carolinas y Tennessee por Hernando DE SOTO en 1540, etc.

- Una mención destacada se merece Estêvão GOMES, nacido portugués y nacionalizado español (Esteban GÓMEZ), pasando a ser piloto de la Casa de Contratación en Sevilla desde 1513. Colaboró con otros portugueses nacionalizados españoles, como MAGALLANES (quien tuviera la misión de dar la vuelta al mundo, junto con ELCANO, lográndose en 1522), o el ya citado cartógrafo RIBERO (quien pudo completar su valiosísimo mapa de 1529 -que fuera versionado un siglo después por franceses como S. CHAMPLAIN, ingleses como J. SMITH, u holandeses como J. BLAEU, vid. supra-). Gracias a la labor de descubrimientos de GÓMEZ (1524-25), se cartografió desde Nueva Escocia a Florida (adentrándose en los actuales Estados de Maine y New Hampshire).

- $\quad$ Et all2.

Igualmente, cabe desmontar la inferencia tan reduccionista (estimulada durante las guerras culturales por los Estudios culturales sobrevenidos), por la que se hacía creer que en las Américas españolas sólo y exclusivamente había españoles católicos ("cristianos viejos probados", como criterio de selección para lograr el permiso del viaje de ultramar -cosa que no ocurría en el mundo WASP, donde se imponían "contratos de servidumbre" y "salarios de libertad", incluso se mandó a marginados y condenados, como fuera el origen fundacional de Georgia-43), vigilado

\footnotetext{
${ }^{42}$ Vid. AVERY, E.Mc.: History of the United States and its people (vol. 1), Cleveland: The Burrows Bro. Co., 1904. Otras evidencias, de fuentes primarias, son compiladas en TIJERAS, E.: Crónica de la frontera. Antología de primitivos historiadores de Indias, Madrid: Ed. Jucar, 1974.

${ }^{43}$ Vid. VV.AA.: Reseña de la Historia de los Estados Unidos, Washington DC: Agencia de Comunicación Internacional-Secretaria de Estado, 1986. Se trata de una obra de revisión y difusión de la versión oficial de la Historia estadounidense, para dar a conocer en el mundo de habla hispana, realizada por OLSON (Prof. Historia de los EE.UU. en la Univ. Maryland), con el apoyo de GRAY (también
} 
todo ello por la Inquisición:

- En primer lugar, hubo comerciantes protestantes centroeuropeos con licencias de explotación en compensación por el apoyo económico prestado al emperador Carlos V de las Alemanias y I de las Españas, v.g. las familias alemanas de los FUGGER y los WELSER, quienes recibieran la explotación por un cuarto de siglo de las tierras de la actual Panamá y Venezuela (Capitulaciones de Burgos en 1528).

- En segundo lugar, hubo misiones de órdenes con religiosos extranjeros. Sirva de ilustración el caso de los jesuitas: el padre Diego de TORRES BOLLO, como procurador del Perú, logró el permiso del Consejo de Indias para la entrada en América de misioneros extranjeros, en especial, de jesuitas alemanes, como el padre FELDMANN en Paraguay, los padres RUES y REIMANN en Perú; tal fue su prestigio, que finalmente, la Real Cédula de 1674 permitía a cualquier jesuita ir de misiones a América.

- En tercer lugar, los neerlandeses calvinistas iniciaron su independencia de la Corona española, originando la Guerra de los Ochenta Años (1568-1648), formando con la Unión de Utrecht (1579) la República de los Siete Países Bajos Unidos. Mientras, consiguieron tratados de paz con Francia (1598) y con Inglaterra (1604), más la Tregua de los doce años o de Amberes (1609). Todo ello fue aprovechado para fundar las Compañías de Indias (en especial la Compañia Holandesa de las Indias Occidentales) y para contratar exploradores alemanes (v.g. CHRISTIANSEN, MINUIT -quien también trabajó para los Suecos, apoyando a la constitución de Nueva Suecia) e ingleses (v.g. HUDSON): aprovechándose de los conocimientos

profesor de Historia estadounidense, pero en la Univ. George Washington), y supervisada por el líder de la generación de historiadores críticos y profesor de Historia estadounidense en la Univ. California, HOFSTADTER (vid. supra cap. 8). 
de América, mientras se formó parte las Españas, se inició la fundación de Nova Belgica et Anglia Nova según el mapa de Blaeu (1635), que sirviera para fijar los asentamientos desde 1619 y que a la postre darían lugar a la colonia de NieuwNederland o Nuevos Países Bajos, que comprendiera los actuales Estados de New York, New Jersey, Delaware y Connecticut, más pequeños puestos fronterizos en Pensilvania y Rhode Island (su capital fue New Amsterdam: la actual New York City); todo ello, tras las guerras anglo-holandesas, pasaron a manos de la Corona inglesa en 1664 (Capitulación de Fort Amsterdam, ratificado con el Tratado de Westminster de 1674).

- En cuanto a la Inquisición española o moderna -nada que ver con la medieval conocida en el mundo WASP y que tanto influyera en líderes protestantes como CALVINO y sus Instituciones, vid. supra-, la misma fue llevada y sostenida por las mismas órdenes (sobre todo dominicos y franciscanos) a las que se les reconoce la promoción de los derechos naturales (actuales derechos humanos) entre la población indígena. Tanto fue así que los indios, como nuevos cristianos, no estaban sometidos a la Inquisición española -que separaba la jurisdicción civil y religiosa, además de seguir un proceso en el que se respetaba el habeas corpus y otras garantías, que se cuestionaban u obviaban en el mundo WASP-, sino que se encontraban bajo el amparo del Procurador o protector universal de todos los indios de las Indias (figura constituida en 1516, por el regente Cardenal CISNEROS para Fray Bartolomé DE LAS CASAS, quien fuera así comisionado consejero de los frailes jerónimos enviados a La Española).

- Et al. 
Cierto es que el factor religioso, no sólo confiere un sentido legitimador de carácter misionero a la exploración e incorporación de nuevos territorios, sino que también aviva los espíritus para las grandes hazañas, mediante una fe en lo desconocido, además de proporcionar fortaleza frente a las adversidades. Ahora bien, la carrera europea por la conquista y/o colonización de Norteamérica, resultó una mezcla político-religiosa, pues los poderes civiles hicieron uso del factor religioso para sus fines: consolidar los nuevos Estados-dinásticos y sus áreas de influencia, bajo el lema cuius regio, eius religio (de quien [es] la región, de él [es] la religión). De ahí que se tardara más de un siglo en empezar a consolidar los asentamientos en Norteamérica (desde los avistamientos de 1497 hasta los poblados estables de la década de 1620). Previamente, fue necesario revocar la legalidad de la época (tanto tradicional, mediante bulas, como moderna, de causas justas de la Escuela de Salamanca), que confería el derecho de asiento (exclusividad de la explotación de la ruta) a la Corona española. No obstante, tras el desastre de la Gran Armada (o Armada invencible, 1588), la Corona española se quedaba sin recursos ni prestigio para proteger su ruta, animándose así los nuevos Estados protestantes a trazar sus rutas, ya no hacia las Indias occidentales, sino América -y por ende, fuera de la legalidad previa-. El cambio es progresivo y programático, pues pese a que se defiende el cambio de denominación (de Indias occidentales por América), para legitimar las nuevas rutas de navegación, sin embargo las compañías inglesas y holandesas que asumen los riesgos de tales aventuras comerciales se siguen llamando Compañías de las Indias Occidentales. Se llama la atención al respecto, que dichas compañías y sus asentamientos no empiezan a tener éxito y sostenibilidad, hasta la regularización de los capellanes en sus buques y la apertura a familias de 
colonos movidos por la fe (según la Reforma, en una salvación a través del éxito en el mundo).

En definitiva, el influjo del factor religioso en los descubrimientos de Norteamérica opera a tres niveles:

a) Macro: se trata de un potente recurso legitimador de los nuevos Estadosdinásticos (frente al Papa y al Emperador), sirviendo además para la justificación de la expansión mesiánica como potencias emergentes de dichos nuevos Estados (necesitando para ello nuevas rutas comerciales, colonias de abastecimiento y posicionamiento geopolítico, etc.). Sin embargos, desmontándose parte del Americaness, el presente motivo también será causa de las mal llamadas guerras de religiones en Europa, con consecuencias en el mapa americano, y el pasar de unas dinastías a otras los territorios.

b) Meso: para animar a la población a viajar a América, se recurre propagandísticamente a presentar los nuevos territorios como la tierra prometida o Nuevo Sion/Jerusalén. Tal reclamo (y otros más relacionados, v.g. paraíso terrenal, Salem $)^{44}$, sirve de estímulo para las migraciones de comunidades religiosas

\footnotetext{
${ }^{44}$ El legado de los padres fundadores está repleto de analogías conectoras del nuevo pueblo de Dios (estadounidenses) con el viejo (israelitas). Para ello se realizan constantes alusiones, del tipo -ya aludido- New Zion/New Jerusalem -incluso, sólo su terminación: Salem (una de las primeras colonias de Nueva Inglaterra, y de presencia recurrente en posteriores fundaciones)-, así como paradise/garden in wilderness [paraíso terrenal], a city upon the hill [una ciudad en lo alto de la colina], son un conjunto de expresiones bíblicas sobre la redención terrenal (v.g. Gn 3 y 12, Is 54 y 60, Mt 5, Lc 6), de tal fortuna recogidas en la literatura religiosa fundacional (de corte predicamental o Preaching Style), considerada como el comienzo de la implantación de American covenant theology [ACT: teología político-jurídica estadounidense (pactista)]. Uno de sus ejemplos más famosos es el sermón "A model of Christian Charity" (1630) de J. WÍNTHROP (recuperado con posterioridad por el Presidente Reagan en su Discurso de despedida de 1989), junto con los igualmente ilustres casos de J. COTTON, J. ELIOT, I. MATHER, C. MATHER, T. TATCHER o J. EDWARDS. Pues bien, tal recurso identitario, con un pueblo elegido, redimido y redentor (de otros pueblos), reaparece periódicamente en los EE.UU., tanto para legitimar su destino manifiesto, como su discurso de sobreestima moral y liberador de minorías, o la
} 
minoritarias (v.g. Pilgrims o peregrinos, anabautistas, menonitas). Igualmente, desmontándose parte del Americaness, y como adelanto de lo que se aclara más adelante, se pone de manifiesto que la tolerancia no fue fácil (tuvo sus avances y retrocesos), pues las citadas minorías colonizadoras, que tanto respeto buscaban en su tierra prometida, sin embargo, al sentirse como mayoría, tendían a la intolerancia con las minorías emergentes. Otro dato a aclarar (más bien a desmontar) es que dichas minorías no sólo eran protestantes, sino también católicos (como pasara con los católicos ingleses en Maryland), judíos (hacia Rhode Island), etc.

c) Micro: el factor religioso, no sólo sirve para la eclosión de pueblos y comunidades, sino también de individuos, pioneros (cada uno a su manera), con anhelos de reconocimiento y enriquecimiento (salvándose a través del éxito y beneficio terrenal).

En tal sentido, en los Estudios culturales tradicionales se han usado una serie de recursos expositivos para explicar la emergencia y fundación de los EE.UU. Entre dichos recursos han destacado, y aquí se han seleccionado (por su relación con el

misma reconciliación y reconstrucción del Sur tras la Guerra civil, incluso las propuestas de reformulación identitaria estadounidense habidas durante las recientes guerras culturales, del tipo del Originalismo y la Teonomía. Vid. BOORSTIN, D.J. (comp.): An American Primer, Chicago: The University of Chicago Press, 1966. GAUSTAD, E.S.: Faith of the Founders. Religion and the New Nation 1776-1826, Waco: Baylor University Press, 1993. - A documentary History of Religion in America. To the Civil War, Grand Rapids: William B. Eerdmans Publishing Co., 1993. MARSDEN, G.M.: Religious and American Culture, San Diego: Harcourt Brace, 2000. NOONAN, J.T., NOONAN, E.Mc.: Religious Freedom. History, cases, and other materials on the interaction of religion and Government, New York: Foundation Press, 2001. POWER, M. S.: Before the Convention. Religion and the Founders, Lanham: University Press of America, 1984. SONTANG, F., ROTH, J.K.: God and America's future, Wilmington: Consortium Books, 1977. STOWELL, D.W.: Rebuilding Zion. The religious reconstruction of the South, 1863-1877, New York: Oxford University Press, 1998. 
factor religioso), los siguientes: a) el mesianismo y el excepcionalismo (relacionados con dimensión macro, vid. infra); b) la frontera y la misión (idem, dimensión meso); c) factor llamada y la condición pionera (ibídem, dimensión micro).

Todo ello no sólo se abordará con mayor detalle en la Parte de desarrollo especial del estudio (profundizándose en el influjo del factor religioso en la configuración idiosincrásica estadounidense), sino que además se atenderá a los ejercicios más populares de deconstrucción realizada, con sus velos de confusión, acometido todo ello por los Estudios culturales sobrevenidos. 


\section{2.- INTERÉS SOCIAL Y CIENTÍFICO-ACADÉMICO DE LA INVESTIGACIÓN}

¿Cuál puede ser la justificiación de un estudio como este? ¿En qué puede interesar a la comunidad científico-académica, a la vez que a la sociedad estadounidense y a cualquier otro pueblo que guarde relación con los EE.UU.?

Como se viene indicando, una de las consecuencias de la globalización (con sus conexiones, dando lugar a un "pequeño-mundo", y sus crisis, de la Contemporaneidad y del predominio del Estado-nación), ha sido la reactivación del problema identitario (a qué comunidad se pertenece y de qué cultura se participa, cuál es su misión, visión y valores, etc.). De tal suerte, se ha vuelto a prestar atención al factor religioso (qué vincula con los demás, la tradición, lo sagrado, etc., y qué aporta trascendencias y sentido vital). Se ha ido abandonando fórmulas identitarias como la de nación (ligada al Estado y en caducidad), para recuperar otras previas, como la religión; sin embargo, ¿qué religión? Ya para el nacimiento de los EE.UU., la religión mutó, pasando a un nuevo estadio secular, dando lugar a fórmulas posjudeocristianas (v.g. mormones, cienciólogos), incluso de religión civil o ACR. En Europa, en cambio, aún tardaría en dar el salto secular, haciendo de manera acelerada e hibridada con las ideologías (desde la laicidad nacionalista a la teología de la liberación) ${ }^{45}$, extendiéndose tal confusión por sus áreas de influencia, aunque en proceso de descolonización (sobre todo, África y Asia, dando lugar al nuevo Islam, por ejemplo). De tal manera, se pasa la religión por el tamiz posmoderno y

\footnotetext{
45 Vid. SÁNCHEZ-BAYÓN, A.: “Secularización moderna y teología política estadounidense: estudio panorámico del sentido y alcance de la religión en su configuración idiosincrásica". Tesis defendida en la Universidad de Murcia (2016), con mención internacional y obteniendo Premio extraordinario (URL: https://digitum.um.es/jspui/.../1/Tesis\%20UMU\%20ASB\%20PhD\%20dissertation.pdf ;

Teseo MEC: https://www.educacion.gob.es/teseo/mostrarSeleccion.do).
} 
sus velos de confusión (pensamiento débil -aunque de vocación única- formado de relativismo, corrección política, cientificismo, posverdad, etc., vid. supra). Dichos velos están afectando a todo Occidente, transfiriéndose de Europa a EE.UU., lo que ha agravado las crisis de la globalización, al dificultarse su revisión identitaria y solidaria (visión y misión). Téngase en cuenta que la configuración idiosincrásica estadounidense resulta prototípica, por las múltiples comunidades de diversos orígenes a integrar. También por ser anterior al ideológico debate nacional decimonónico europeo (modelo liberal-patriótico vs. étnico-cultural), y al fortalecimiento del Estado-nación (con su hiperdesarrollo, extendiéndose por todas las esferas sociales). La configuración idiosincrásica estadounidense parte de los planteamientos de la teología moderna o Teología política, que frente a la tradicional, no se ocupa tanto de Dios y del más allá, sino de la religión y la organización del pueblo de Dios en el más acá, o sea, del impacto de la religión en la vida pública (sin el pretendido monopolio estatal). Para tratar todo lo planteado, además de ofrecer una evolución y evaluación de la materia, se recurre a un estudio interdisciplinario de base sociológica y cultura (además de iuseclesiasticista y teológico-política, psicosocial, etc.), prestándose especial atención a la expresión autóctona de American civil religion (religión civil estadounidense), en conexión directa con American gospel (evangelismo social estadounidense o espíritu nacional), que a su vez conducen a American manifest destiny (destino manifiesto estadounidense) o American selfrighteousness (autopercepción estadounidense con sobreestima, tendente a una superioridad moral, de mesianismo), et al. A la postre, tras el abordaje de las más destacadas hierofanías (v.g. toponímia, simbología, ritualística) y hierocracias (v.g. relaciones Iglesia-Estado, Blue Laws o Derecho dominical), se espera poder ofrecer 
también un diagnóstico, y pronóstico acerca de las vulnerabilidades de la matriz idiosincrásica estadounidense, previo al tránsito de la posglobalización.

Como se viene indicando, con la globalización, los estadounidenses se ven abocados a su recurrente reto de redefinición identitaria (como ya lo hicieran durante su revolución de independencia, sus guerras indias, su guerra civil, su conquista del Oeste, su gran depresión, etc.): ¿qué es ser estadounidense y cómo se socializa? Se trata de ahondar de nuevo en su Americanness o estadounidización (expresión impulsada por los Estudios Culturales estadounidenses, máxime por American Studies [Estudios estadounidenses] ${ }^{46}$. Ahora bien, lo peculiar esta vez es que coincide la urgencia y necesidad de revisión idiosincrásica con el resto de pueblos del mundo (dadas las crisis de la globalización), además de sufrirse igualmente los contagios posmodernos (por la serie de velos de confusión que dificultan reconocer la realidad social subyacente en curso, vid. infra figuras 3 y 4). La extensión de dichos velos no sólo es atribuible a los Estudios Culturales sobrevenidos (a raíz de su formalización académica con la Ley homónima de 1972, dándoles carta de naturaleza en el currículo escolar, v.g. Estudios étnico-culturales o etnoculturales -afroamericanos, asiáticoamericanos, latinoamericanos, etc.-, Estudios feministas y de género -que vienen a sustituir los Estudios de la mujer-), igualmente es imputable a la respuesta

\footnotetext{
${ }^{46}$ El gentilicio American es de vocación expansiva (continental), como lo es su forma de organización política (el federalismo, vid. supra cap. 6 y 10); sin embargo, no ha de traducirse por americano -sería un false-friend o error de traducción por aparente similitud fonética y/o gráfica entre lenguas, pero no así de contenidos-, sino que lo correcto es "estadounidense". Por lo que su recepción, adaptación y socialización es la "estadounidización" o Americanness. Tal proceso requiere de elementos conversores, como la paradoxología, el pragmatismo y el humanismo judeocristiano o posjudeocristianismo. Dichos elementos de estadounidización permiten a los EE.UU. el recibir influencias de cualquier parte del mundo, darle apariencia propia (al revestir de éxito y beneficio), y exportarlo nuevamente. De este modo, en los EE.UU. se ha recibido y transformado la tradición occidental sagrada o judeocristiana y la profana o grecorromana, combinándola con otras aportaciones, teniendo como resultado un modelo moderno socio-cultural. Vid. SÁNCHEZ-BAYÓN, A.: La Modernidad sin prejuicios... op. cit. - Estado y religión... op. cit.
} 
polarizada y también tergiversada de los neocon [neoconservadores], anger male $\mathcal{E}$ redneck movements [movimiento de hombres molestos y de paletos], Christian Right [derecha cristiana] ${ }^{47}$, etc., durante las guerras culturales iniciadas en la década de 1960.

Se recuerda que, el ser estadounidense, es un tipo de identidad moderna (pionera de la Baja Modernidad), que requiere del factor religioso para entenderse: su construcción nacional nunca fue ideológica ni monopolio de Gobierno o Estadonación alguno (como sí pasara en la Europa posterior a la Ilustración), sino de un pueblo -que se cree- unido y amparado por Dios. Así se oficializa, cuando se presenta a los pueblos del mundo en su Declaración de Independencia-DIE ("se hace necesario que un pueblo disuelva los vínculos políticos que lo han ligado a otro y tome entre las naciones de la Tierra el puesto separado e igual al que las leyes de la naturaleza y del Dios de esa naturaleza le dan derecho"), ratificándose luego en su Constitución de 1787 (“Nosotros, el pueblo de los EE.UU.”). De modo tan moderno, como ciudadanos y pueblo libre (no súbditos), se configuraron los estadounidenses; sin embargo, con los velos extendidos por los Estudios culturales sobrevenidos, para introducir a los EE.UU. en la posmodernidad, parece que se desea conducir al país a una suerte de Medievo, donde primen las comunidades sobre los individuos, los privilegios sobre los derechos, etc.

\footnotetext{
${ }^{47}$ Sirva como ejemplo la constante denuncia FRITZE, Decano y Profesor de Historia de la Universidad de Athens, además de reconocido especialista en América colonial. Es famoso por sus libros donde denuncia y desmonta la pseudohistoria: "El aludido conocimiento inventado -o anticienciacomprende la ufología y colonizadores extraterrestres, pasando por la pseudohistoria del descubrimiento y colonización de América, las cosmogonías racistas (v.g. los hombres del fango, la Nación del Islam), las fabulaciones de Atlántida y Atenea Negra, etc." (trad. propia). Y sobre las últimas confusiones afirma: "(...) qué mejor momento que esta era post-Bush para arrojar un poco de luz sobre el tenebroso mundo de las invenciones desvergonzadas" (idem); vid. FRITZE, R.H.: Invented Knowledge. False History, Fake Science and Pseudo-Religions, London: Reaktion Books, 2009.
} 
En definitiva, el problema estadounidense actual, no se halla tanto en la clarificación de qué se entiende por ser estadounidense y su misión, pues ese es un reto cíclico al que se enfrentan sus gentes. Lo singular de la presente coyuntura radica en la urgente necesidad en la retirada de los posmodernos velos de confusión, y en la reintegración del factor religioso para la correcta comprensión y gestión de su idiosincrasia: hasta la fecha, el factor religioso ha sido clave para comprender el devenir estadounidense. No obstante, por contagios posmodernos (en su mayoría de origen europeo-continental y latinoamericano), parece que se pretende sacar a la religión de la ecuación identitaria, llegando a confundir su propia Historia reduciéndola a un cúmulo de historias, v.g. historia de los afroamericanos, de los asiáticoamericanos, de los latinoamericanos, de las mujeres y de género-, desde propuestas tropológicas (de narrativas ideológicas patéticas -de agitación del espíritu, de manera melancólica y revanchistas-, desde la corrección política, la discriminación positiva, el pensamiento débil y el relativismo, hasta la memoria histórica y la literatura testimonial, vid. infra).

Paradójicamente, pese a tener el mismo origen de planteamientos modernos los modelos sociales europeo-continental y estadounidense (de tránsito del Viejo al Nuevo Régimen), y pese a ser el caso estadounidense el primero en secularizarse (conforme a la secularización moderna: de manera mixta -entre la evangelización católica y protestante- e inacabada -fluctuante por ciclos-), haciéndolo mucho más tarde los europeos-continentales (desde el s. XIX), de modo acelerado y completo (adentrándose en la posmodernidad, con los teóricos de la sospecha, v.g. NIETZSCHE, MARX, FREUD, y sobre todo, con sus reintérpretes neomarxistas, v.g. Escuela de Frankfurt, Normale-Annales, Birmingham), todo ello ha tenido como resultado una bifurcación de caminos y modelos sociales. En Europa continental, con su variante 
de secularización extrema (llegando incluso a la laicidad o intento de monopolio de lo neo-sagrado por el Estado-nación), se ha tergiversado el significado y papel de la religión, en especial en lo tocante a la Modernidad. Sirva como ejemplo la reinterpretación posterior de la Modernidad, llegándose a afirmar que fue la religión freno de la misma, cuando se trató justo de todo lo contrario: el celo evangelizador sirvió de incentivo para los descubrimientos, conquistas y colonizaciones desde el s. $\mathrm{XV}$. Otra cosa fue el uso político que se realizara del factor religioso, dando lugar a las mal llamadas Guerras de religión del s. XVI y XVII, causantes de la migración de protestantes y católicos a América: en realidad se trató de un conflicto por la soberanía, pues el lema de los Príncipes alemanes conversos protestantes y enfrentados al Emperador católico del Sacro Imperio Romano Germano fue cuius regno eius religio [de quien es el reino es la religión -dominándose así la identidad y mentalidad de su pueblo-], culminando todo ello en la Paz de Westfalia de 1648 (consagrándose así el moderno Derecho Internacional, que acaba con la Cristianda e inaugura Occidente). El caso es que la relectura histórica de aquella época resulta bien distinta en América, con una prototípica Modernidad real (transitándose de la tolerancia a la libertad, con una secularización favorecedora de la separación IglesiaEstado, y con ello, consolidándose la pluralidad social de comunidades integradas en la vida pública), mientras que en Europa, la Modernidad efectiva se retrasa siglos, pero no por la religión, sino por los Absolutismos regios -de ahí que la Baja Modernidad, dominada por anglosajones y nórdicos tiene lugar con las revoluciones industriales que favorecen cambios sociales-. Tal es la tergiversación histórica, en especial, en lo relativo al papel del factor religioso, y los contagios posmodernos posteriores (máxime los de procedencia europea -de manera directa o a través de Latinoamérica también-), que hoy en día se cuestiona, incluso, se desconoce el 
significado y alcance del factor religioso en la articulación del AWL y su Americanness [estadounidización]. De ahí la urgencia y necesidad de un estudio como el presente, tal como se aclara -algo más- a continuación.

Figura 5.- Tendencias y repuntes de la secularización en EE.UU.

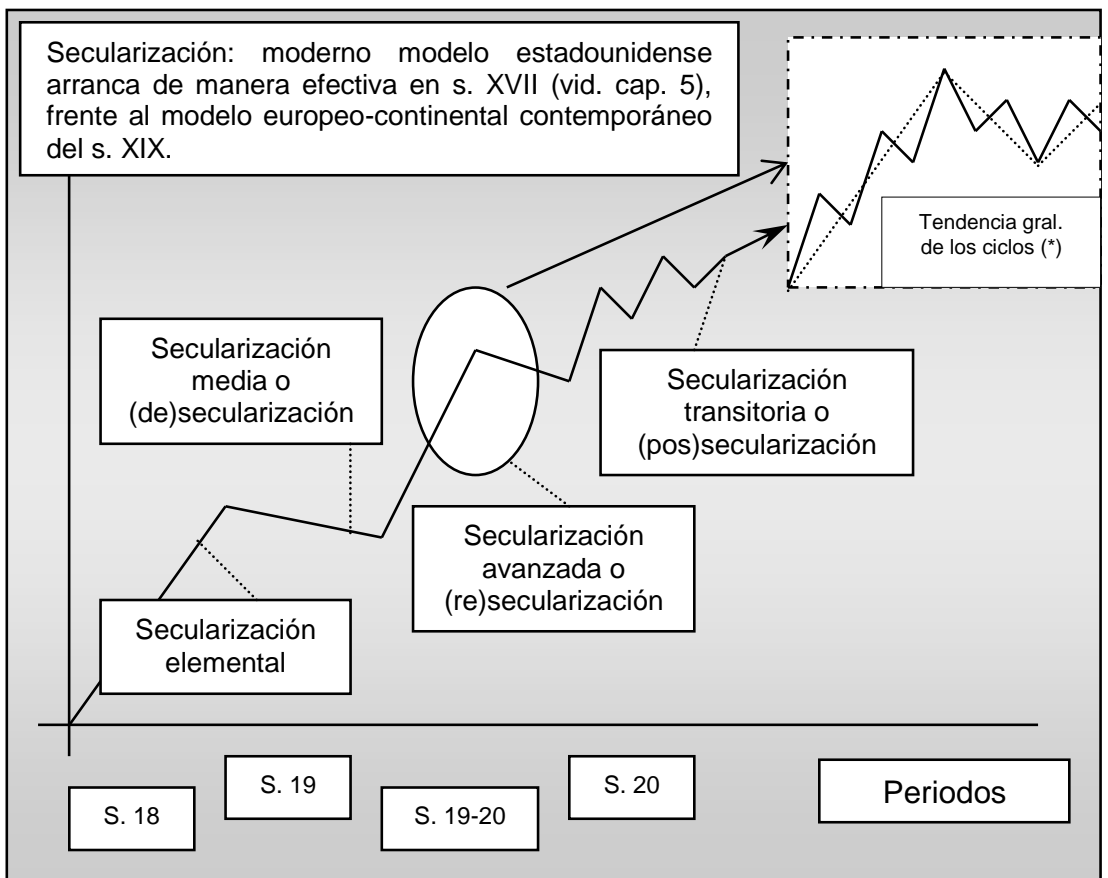

(*) Tendencia general: ciclos de crecimiento en tríadas con sus repuntes, seguidos de dos periodos de recesión limitada, para dar continuidad a un nuevo ciclo (vid. supra Parte de desarrollo general y cap. 10).

Fuente: elaboración propia (SÁNCHEZ-BAYÓN, 2007 y 16). 
Figura 6.- Sistema de plurilealtades estadounidenses o ACR $^{48}$

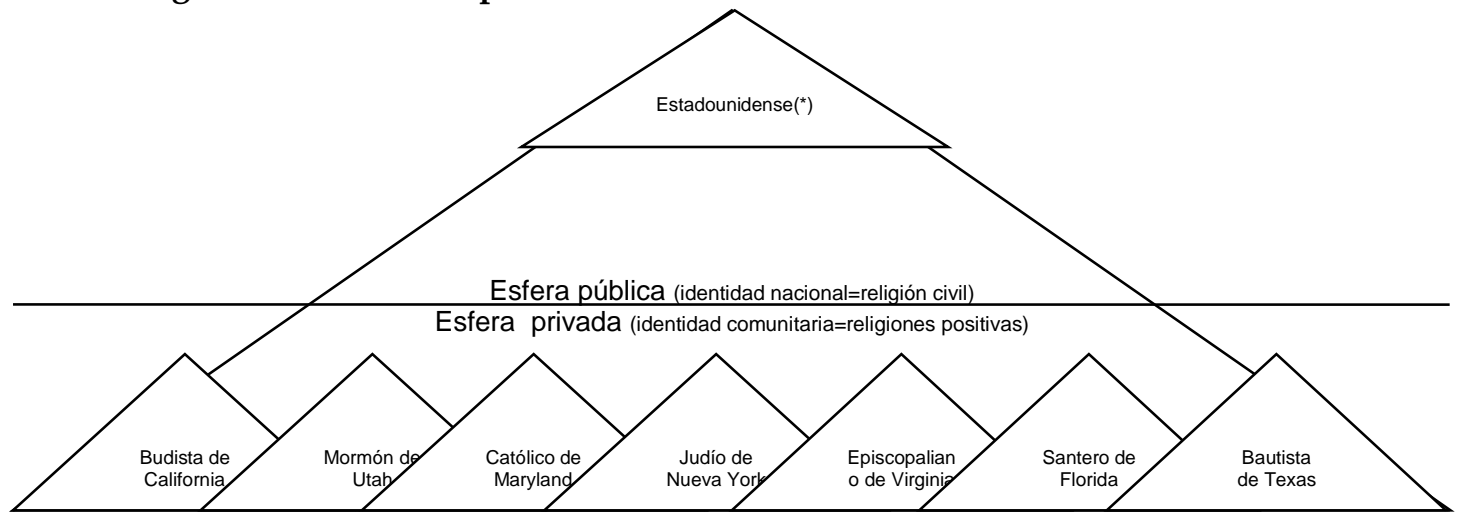

${ }^{*}$ En inglés es aún más expresivo, ya que su gentilicio es American, por tanto, extensible a todo el continente -muestra de su vocación de pueblo elegido con un destino manifiesto-.

Fuente: elaboración propia (SÁNCHEZ-BAYÓN, 2006, 07 y 16).

Ahondándose en las consideraciones previas, si se atiende a la Historia de los EE.UU., desde la propia perspectiva estadounidense -que no es la científica-formal decimonónica europeo-continental (llamada positivista)-, la misma resulta más popular, preocupada por la formación de su idiosincrasia nacional (recuérdense los ejemplos ya planteados de abordaje, v.g. History of American People [Historia del pueblo estadounidense], History of US -con el juego alusivo al nosotros (us) y el acrónimo inglés de EE.UU. (US)- [Historia nuestra/de EE.UU.]). En consecuencia, antes de las guerras culturales (1960-80), desde los Estudios culturales, se venía exponiendo y explicando el devenir estadounidense en términos de excepcionalismo, máxime desde la generación de historiadores escépticos (v.g. generación 1a. HOFSTADTER, HIGHAM, CONKIN, WRIGHT MILLS, JENSEN, CROWL, POOL, et al.; generación 2º. KELLEY -y sus discípulos en el extranjero-, SCHLESINGER

\footnotetext{
48 Vid. SÁNCHEZ-BAYÓN, A.: "Revitalizaciones religiosas postmodernas en América y sus riesgos para la democracia y los derechos humanos", en la Revista General de Derecho Canónico y Derecho Eclesiástico del Estado-Iustel (no 11), 2006.
} 
JR., LIPSET, etc. $)^{49}$, como fórmula de ruptura, especialmente frente a las vías y maneras del Antiguo Régimen europeo-continental. Sin embargo, si se observa bien y desde la lectura crítica de revelaciones que aquí se propone-, en los EE.UU. también ha habido Ilustración, republicanismo, movimientos sociales, obreros, etc. Entonces, ¿dónde radica la gran diferencia? El quid de la cuestión está en aquello que con la globalización viene revitalizándose, como es el problema identitario y el juego de las esferas sociales (sobre todo, entre política y religión), y que resulta tan difícil de comprender para quienes renunciaran a ello tiempo atrás (máxime, los países europeo-continentales), creyendo que ese era su camino de progreso (un sentido histórico tardo-moderno o contemporáneo, basado en la independencia entre esferas, llegando incluso a suprimir la religión, al sustituirse por ideologías e hipertrofiar la política, y dando paso más tarde a la posmodernidad, con su relativismo y demás velos de confusión). En definitiva, lo que sí se ha mantenido en los EE.UU., contribuyendo a su consolidación como referente del Nuevo Régimen y Occidente (como coordenadas espacio-temporales y culturales), ha sido la religión, que ha tenido un papel crucial de contrapeso en los procesos de nacionalización de múltiples colectivos de orígenes diversos (v.g. bautistas de Texas, judíos de Rhode

\footnotetext{
${ }^{49}$ Vid. HOFSTADTER, R., et al.: The structure of American History, Pretice-Hall: Englewood Cliffs, 1946. - The American political tradition and the men who made it, London: Jonathan Cape, 1967. - The progressive historians, New York: Vintage Books, 1970 (tesis respaldada por sus coetáneos, vid. HIGHAM, J., CONKIN, P.K. (eds.): New directions in American intellectual History, Baltimore: The John Hopkins University Press, 1979. KELLEY, R.: The cultural pattern in American politics. The first century, New York: Alfred A. Knopf, 1979. WRIGHT MILLS, C.: The New Men of Power: America's Labor Leaders, New York: Harcourt, Brace \& co, 1948. - White Collar: The American Middle Classes, New York: Oxford University Press, 1951. HIGHAM, C.: New directions in American intellectual History, Baltimore: The John Hopkins University Press, 1979. SCHLESINGER JR., A.: The cycles of American History. New York: Houghton Mifflin Co., 1986. LIPSET, M.S.: Political Man: The Social Bases of Politics, New York: Doubleday, 1960. - The First New Nation: The United States in Historical and Comparative Perspective, New York: W.W.Norton, 1979. - Revolution and Counterrevolution: Change and Persistence in Social Structures, New York: Basic Books, 1968. - The Politics of Unreason: Right Wing Extremism in America, 1790-1970, New York: Harper \& Row, 1970.
} 
Island, católicos de Maryland, budistas de California, vid. infra figura 6), a través de una fórmula protonacional -previa al debate de los nacionalismos decimonónicos en Europa-, como es la ACR. Con dicha fórmula se combina la tradición occidental sagrada (judeocristiana), de pueblo elegido con destino manifiesto, y la profana (grecorromana), de moderna empresa nacional talasocrática, pasando por el filtro del pensamiento whig [liberal-conservador] y freemason [libre-pensador] o PWF (vid. supra cap. 5 y 6), y siempre adaptándose a las experiencias estadounidenses y la noción de legado (de los padres fundadores).

Ahora bien, este estudio no sólo presenta cuestiones claves para entender la idiosincrasia estadounidense, como la citada ACR, procurando hacer legible todo ello al lector no-estadounidense, sino que además se presta atención a los problemas que hoy la afectan, y que sólo se pueden resolver desde una perspectiva históricocrítica, que purgue de inferencias, imposturas y falacias habidas en las últimas décadas: con la globalización, están teniendo lugar una serie de cambios en la realidad social y el paradigma que se maneja para su comprensión -recuérdese lo dicho al inicio-. Durante el s. XX, se vivía bajo un modelo de sociedad internacional de Estados-naciones de producción, con comunicaciones analógicas, donde destacaba un país autoproclamado adalid de Occidente, con un gran poder duro (militar) y blando (económico y cultural), como es el caso de los EE.UU. Hoy en día, en pleno tránsito hacia una comunidad mundial de consumo y comunicaciones digitales, ha entrado en crisis la hegemonía de los EE.UU., por lo que los propios estadounidenses han de revisar cuestiones relativas a su imaginario social (tales como su mentalidad e identidad, su sistema de atribuciones e influencias, su misión y acción social, etc.), para asegurar una legítima, válida y eficaz generación y transmisión de dicho imaginario en sus interacciones ad intra y ad extra. La dificultad 
añadida radica en los extendidos durante la Guerra fría, cuando imperó el reduccionismo por el cual el ser estadounidense y su misión se entendía como la lucha contra el comunismo y la defensa del mundo libre. Con la caída de la URSS (1989-91), la cuestión se complicó, pues pasaron a extenderse los velos cientificistas de la corrección política primero, y del neoconservadurismo después. Si hoy se desea descubrir por qué y cómo los estadounidenses han llegado a ser como son y si aún lo siguen siendo, no es posible acudir a los Estudios culturales -que parecería la opción más lógica, pues académicamente son los encargados de estudiar las relaciones entre cultura y poder, pero debido a su cientificismo proclive a la fragmentación social, quedan por tanto descartados en su empleo para procurar comprender al conjunto de los estadounidenses ${ }^{50}$. La intuición de este trabajo consiste en el estudio revolucionario (en sentido copernicano), entendido modernamente (como retroceso hasta el punto previo al inicio de la desviación), por lo que se vuelve a los orígenes fundacionales (desde las primeras colonias hasta la Guerra civil), y se recurre al tratamiento que se hacía entonces de la cuestión: se regresa al pragmatismo y al interaccionismo simbólico (entre otras corrientes historiológicas e historiográficas autóctonas), sólo que con un mayor espíritu crítico y con una intencionalidad clara de proyectarlo hasta el momento presente, de modo que sirva para el diagnóstico y pronóstico que hoy se demanda. En tal ejercicio sistémico propuesto (holístico y difuso, analítico y empírico, etc.), se pretende desvelar -entre otras cuestiones- el ASG. Se trata de uno de los principales motores de la cultura popular y el control social estadounidense, ordenador del juego entre las elites y las bases sociales, la

\footnotetext{
50 Vid SOKAL, A.: Beyon the hoax: Science, Philosophy and Culture, New York: Oxford University Press, 2008. - "Transgressing the boundaries: towards a transformative hermeneutics of quantum gravity", en Social Text, no 46-47, 1996, pp. 217-52. SOKAL, A., BRICMONT, J.: Fashionable nonsense: postmodern intellectuals'abuse of science, New York: Picador, 1998.
} 
esfera religiosa y la política, etc., puesto que ha aportado constantes soluciones para integrar y superar las disonancias cognitivas de la compleja idiosincrasia estadounidense (v.g. ¿es un pueblo elegido y bendecido con un destino manifiesto o se trata de una moderna empresa nacional?). 


\section{2.- OBJETIVOS Y CONTENIDOS SOCIOCULTURALES SISTEMATIZADOS}

En este apartado se presenta con algo más de detalle los objetivos a lograr (con este estudio), conforme a la finalidad de la investigación (su telología, al menos en cuento a su sentido y alcance). De tal manera, es posible incluso el diseño de hipótesis, teorías de rango medio y teoremas correspondientes y a probar. Además, se adelanta un esbozo de la estructura expositiva del estudio (como ruta a seguir para alcanzar resultados a discutir).

\section{1.- SENTIDO Y ALCANCE DE LA INVESTIGACIÓN}

Este trabajo surge de una serie de intuiciones, que ha sido investigadas y articuladas en forma de hipótesis, tesis y teoremas, durante décadas de estudio e inmersión socio-cultural estadounidense, a lo largo de sus grandes regiones: la costa atlántica, el medio oeste y el sur-fronterizo (vid. supra) ${ }^{51}$. Dado el gran volumen de información obtenida, para su presentación en esta tesis, se ha llevado a cabo una síntesis y sistemática, avalada previamente por la comunidad científico-académica (con conferencias, publicaciones, etc., vid. supra cap. 3). Luego, el disponerse de un objetivo a alcanzar al inicio de la investigación (vid. infra), ello no resulta un fallo de

\footnotetext{
${ }^{51}$ Sirva como avance: costa atlántica (académico visitante en Harvard University, 2002-2003; voluntario en programas de asistencia social, v.g. SABES; colaborador en medios de comunicación, v.g. D\&D, Zalacaín); el medio oeste (académico visitante en DePaul University en 2005 y senior-fellow desde 2006; voluntario en programas de asistencia social, v.g. OIDE); el sur-fronterizo (académico visitante en MHBU y Baylor University: Church-State Studies 2006, Latin American Studies 2010, etc.).
} 
subjetividad (que reste cientificidad), más bien lo contrario: si se sabe identificar qué se pretende conocer, la investigación tendrá más visos de éxito (v.g. antes de navegar, ha de fijarse un rumbo, o en otro caso cabe la posibilidad de perderse por el camino). Por tanto, fijar un sentido y alcance de investigación (o sea, prever un objeto de estudio a definir y verificar, así como determinar sus coordinadas delimitadoras), resulta una práctica escolástica instaurada desde el inicio de la universidad (desde el tardo-medievo hasta la Alta Modernidad). Es lo propio de la ciencia analítica y empírica; incluso, de la ciencia experimental (ha de fijarse previamente las condiciones de cualquier experimento para su validación posterior). En consecuencia, se ofrece a continuación una serie de consideraciones preliminares sobre la telología del estudio y sus coordenadas de investigación.

En cuanto a la telología de esta investigación (sus fines y objetivos), la misma, se corresponde con los siguientes planteamientos:

a) Objetivos principales: la articulación de un análisis revisor crítico y de autenticidad, sobre el devenir de la ACR y su influencia en la configuración idiosincrasia estadounidense (tras recibir y adaptar la tradición occidental, singularizándola vía Americaness, y convertirse a la postre en líder occidental). En dicho análisis, además de profundizar en su dimensión sociocultural, se acomete en perspectiva comparada (no sólo diacrónica, sino también sincrónica en las relaciones noratlánticas). De tal suerte, se espera:

- Conocer cuáles son las esencias y manifestación de ACR (como metámero socio-cultural de integración anterior a la categoría decimonónica de nación), además de indagar en su evolución (sus avances y derivas, con sus ciclos y transiciones), según su influjo en la articulación 
estadounidense de su identidad y mentalidad colectiva, su imaginario social y su capital simbólico, etc.

- Prestar atención a las relaciones noratlánticas en el devenir de ACR, para averiguar cómo se produjeron y qué calado tuvieron las retroalimentaciones entre sendas costas. Téngase en cuenta que el despertar nacional de los EE.UU. se realizó con la integración de gentes de toda Europa, dando lugar a un país moderno, que llegaría a liderar a Occidente. Sin embargo, también dichas relaciones, con la fuga de cerebros, han traído consigo contagios posmodernos, que han puesto en peligro la ACR y su correspondiente configuración idiosincrásica. Hoy en día las relaciones noratlánticas se hallan en una situación muy delicada, afectándose no sólo a cada una de las costas, sino también al conjunto de Occidente.

- Acometer un balance de la situación actual de ACR, su crisis y traslación al trance vigente de idiosincrásica estadounidense, no sólo desde las crisis de la globalización (por la caducidad de normas e instituciones vinculadas al Estado-nación), sino por las previas, durante las guerras culturales (en el transcurso de la Guerra fría), que se han proyectado sobre épocas pasadas, remontándose incluso al periodo fundacional y su matriz mitopoiética y su legado consiguiente (causándose una corrupción de set-up-como se diría en términos posmodernos-).

- Descubrir otros constructos complementarios a ACR (con sus correspondientes teorías de rango medio), como son American (social) gospel-AG/ASG (evangelismo social estadounidense), American manifest destiny-AMC (destino manifiesto estadounidense), American dream-AD 
(sueño/progreso estadounidense), American way of life-AWL (modo de vida estadounidense), American calling-AC (vocación/profesionalización estadounidense), American civilazing sense-ACS (sentido civilizatorio estadounidenses), American self-righteousness-ASR ((sobre)autoestima estadounidense), American excepcionalism \& melting pot (excepcionalismo estadounidense y su crisol cultural), et al.

b) Objetivos complementarios: se plantea e intenta aclarar un conjunto de paradojas y problemas relativos al ser estadounidense y su relación con los demás (en especial, con los europeos). Dicho conjunto, pese a su variedad, todas sus cuestiones guardan relación entre sí, tal como aquí se presentan bajo la denominación común de American post-modern paradox-set o APP-set. Sirva como muestra anticipada los siguientes ejemplos a abordar:

- Paradoja posmoderna estadounidense o American post-modern paradox $(\mathrm{APP})^{52}$ : con las TIC, ha quedado interconectado el mundo, pudiendo entrar en contacto cualquier cultura con otra, de ahí que con la globalización se haya reabierto el debate identitario, recuperándose para ello el recurso de la religión. Al mismo tiempo que esto pasa en todo el planeta (la revitalización religiosa), llama la atención que en EE.UU., donde la religión siempre ha tenido una gran presencia sociocultural, en cambio, se encuentra en declive, por los velos posmodernos de confusión extendidos sobre ella, dejando de servir para religar o unir estrechamente

\footnotetext{
${ }^{52} \mathrm{APP}$, como abreviatura, resulta un juego de palabras, pues en inglés significa también aplicación informática para móviles, tabletas, ordenadores, etc. Se alude así intento de convertir, mediante velos posmodernos, a la religión en un instrumento de ingeniería social, según el empleo de cada comunidad.
} 
con la divinidad, la comunidad, la tradición, etc., sino para convertirse en instrumento de diferenciación y conflicto entre comunidades. El impacto de APP no sólo alcanza al periodo actual de transición (entre la época dominada por el Estado-nación y la supuesta emergencia de la aldea global y la sociedad del conocimiento), sino que desde las guerras culturales (1960-80), viene sirviendo para deconstruir la ACR y su articulación del a idiosincrasia estadounidense, remontándose incluso al periodo fundacional, y atacando directamente a la matriz mitopoiética y su legado.

- Paradoja identitaria de los Estudios culturales: si los Estudios culturales encuentran su lugar en la universidad estadounidense (en el periodo de entreguerras), es para dotar de entidad científica y académica a su articulación idiosincrática nacional. Tales estudios sirvieron para alcanzar los consensos de integración doméstica y la entidad para que el país tuviera una condición de potencia hegemónica mundial. Ahora bien, todo ello se distorsionó durante las guerras culturales, pues frente a los Estudios culturales tradicionales (basados en el citado consenso) surgieron los sobrevenidos (de corte etnocultural y socialista), focalizados en el conflicto y la exaltación del hecho diferencial. El resultado ha sido una polarización entre los Estudios culturales, enfrentados entre sí, e imposibilitados para reformular el ACR y la idiosincrasia estadounidense para el nuevo periodo en curso (por lo que la amenaza de entropía y/o armagedón nacional va tomando carta de naturaleza).

- Paradoja dogmática de los velos posmodernos: pese a nacer de la supuesta crítica y resultar de lo más diversos entre sí, los velos 
encuentran su unión en su finalidad de desunión, atacando el consenso previo. Resulta que niegan cualquier posible noción universal o intento generalizador, salvo sus propios postulados e intereses, los cuales no se articulan desde la realidad y la racionalidad del ethos, sino desde la narrativa y la emocionalidad del pathos. De tal suerte, los velos, que supuestamente venían a aportar pluralidad, pretendiendo atacar los dogmatismos anteriores (con su etnocentrismo y moralismo), se han convertido en aquello a combatir, imponiendo un pensamiento débil único, con espirales de silencio, incluso con condenas de delito de odio (frente a las posibles críticas de aquello que debería serlo).

- Paradoja regresiva y desnaturalizadora de los Estudios culturales y sus velos (o la corrupción del set-up): si desde los EE.UU. se estimuló la recepción de fuga de cerebros (sobre todo europeos), para ayudar a impulsar sus Estudios culturales, responsables de la articulación de su idiosincrasia, sin necesidad de depender de avales exteriores (apartándose así la sombra fundacional europea y su supuesta superioridad socio-cultural -o sea, para que dejara de ser la madre y, en todo caso, quedara como una relación de hermanos-), hasta llegar incluso a liderar el mundo occidental (tras la II Guerra Mundial). Sin embargo, la labor de deconstrucción occidental acometida (durante las guerras culturales), no sólo desmarcó a EE.UU. de Europa (y su tradición occidental sagrada y profana), sino que además causó la desnaturalización estadounidense, al vulnerarse su matriz mitopoiética y su legado (corrompiéndose su set-up), al renunciarse a su condición moderna y perderse su realismo y racionalidad (propio de su 
pragmatismo). De tal suerte, con su transición posmoderna (de carácter regresivo), los EE.UU. han dejado de ser inmunes a las ideologías, volviéndose con ello un país anti-moderno y anti-occidental (abandonando así EE.UU. la órbita atlántica para orientarse hacia la pacífica, presentándose como una intensificación hacia el Oeste y el fortalecimiento del hemisferio occidental -que en realidad es sería un giro oriental asiático-pacífico-, pero ya sin la tradición occidental como sustento).

En cuanto a las coordenadas (o delimitación del objeto de investigación en cuanto a su alcance), baste indicar:

a) Coordenadas temporales: estudio panorámico, que parte del balance actual (ante los problemas y retos de la posglobalización y el riesgo de Tecno-Evo), para retrotraerse hasta el periodo fundacional (en las colonias atlánticas del s. XVII: las plantaciones sureñas, Nueva Inglaterra y las provincias centrales). Durante dicha revisión crítica de autenticidad, en este estudio, se van retirando velos de confusión extendidos (contrarios a su ACR y su idiosincrasia correspondiente).

b) Coordenadas espaciales: se focaliza el estudio en los EE.UU. (desde su nacimiento noratlántico hasta su expansión continental al Oeste y por el hemisferio occidental). Eso sí, se presta especial atención a las relaciones noratlánticas y su influjo en el resto de Occidente, pues tanto la Modernidad y posmodernidad del país se han producido por dicha vía. 
c) Coordenadas materiales: sintéticamente (se remite a lo señalado en los objetivos, vid. infra), la investigación gira entorno a ACR y su influjo en la configuración idiosincrasia estadounidense (y su religazón), abordándose la compleja y diversa tópica desde el rico enfoque y producción científicoacadémica de los Estudios culturales estadounidenses.

La realización de las aclaraciones previas, aunque puedan parecer redundantes, sólo pretende dar a conocer mejor el trasfondo del estudio a presentar. Téngase en cuenta que, hace más de una década (durante los años felices de la globalización), se realizó un estudio sociológico sobre la materia: Manual de Sociología Jurídica Estadounidense. Del poder, lo sagrado y la libertad en Occidente (vid. supra Estado de la cuestión). Era un trabajo de corte hegeliano: cómo el influjo de todo Occidente, con su síntesis en los EE.UU., dio lugar a la realización del espíritu de la humanidad en forma de libertad, alzándose así por encima del resto de pueblos y guiándolos en dicho camino. De ahí el epítome de autores estadounidenses como BELL (ya en los años 60) o FUKUYAMA (en los 90), que con el fin de la Guerra fría y el inicio de la globalización, veían acabada la historia, pues el resto de Occidente habría de seguir a los EE.UU. por la senda la libertad. Eso podría ser en lo tocante a la economía, pero no así en lo socio-cultural, pues lo que no se había considerado era el efecto de las guerras culturales y los velos extendidos por los Estudios culturales sobrevenidos, cuyo socialismo cultural iba a tomar forma de etnoculturalismo, provocando una fragmentación social interna cada vez mayor. De ahí que diagnósticos de otros sociólogos y estudiosos culturales, como BELLAH (desde los años 70), quienes auguraban un revival de ACR, tuvieran que enmendarse posteriormente, como 
también lo hicieran comparativistas y geopolíticos como LIPSET (en los 90) y HUNTINGTON (en la década del 2000). Por tanto, urge estudiar socioculturalmente, conforme a la telología y coordenadas marcadas, de modo que no quepa perderse por el camino, como sí le ha pasado a prestiosos autores, incluso a escuelas de pensamiento y disciplinas, como se verá al abordar la trayectoria científico-académica de los Estudios culturales estadounidenses (vid. supra cap. 8). 


\section{2.- HIPÓTESIS Y PLAN DE TRABAJO}

Las ideas guía de esta investigación son las planteadas en el epígrafe anterior, pero ¿cómo se ha llegado a detectar las paradojas y problemas como los formulados (APP-set)? ¿Guardan relación los mismos con el Americaness o capacidad adaptativa estadounidense? Esa es la hipótesis formal de partida, pues poco tienen que ver las paradojas actuales con las pretéritas: mientras que las paradojas tradicionales del Americaness eran de tipo moderno (realistas, racionales, etc.) y centrípetas (movían a una convergencia social: para configurar un espíritu nacional y su ciudadanía), pues partían de la experimentación en la frontera (noción manejada por la generación de TURNER, vid. supra cap. 8 y 9), para pasar a integrarse a la postre en el legado y su consenso identitario; en cambio, las paradojas presentes (v.g. APP, paradoja identitaria y la dogmática), son posmodernas (discursivas, emocionales, etc.) y centrífugas (tienden a la dispersión en pro de una multiplicidad de comunidades en conflicto).

Para comprender un poco mejor de qué se está hablando, permítase un breve adelanto: resulta que, entre las herramientas propias del Americaness (o estadounidización de cualquier influjo exterior en los EE.UU., integrándolo en su sistema doméstico y socializándolo luego como algo propio, revestido de éxito y beneficio), destacan la paradoxología, junto con el pragmatismo y el posjudeocristianismo ${ }^{53}$. La combinación de dichas herramientas otorga a los

\footnotetext{
${ }^{53}$ Vid. SÁNCHEZ-BAYÓN, A.: “Comunicación y Geopolítica estadounidense actual: de IRFA al Choque de Civilizaciones", en Historia y Comunicación Social (vol. 11), 2006, p. 173-198. - "La International Religious Freedom Act of 1998 y la geopolítica estadounidense actual", en CAIRO, H., PASTOR, J. (comp.): Geopolítica, guerras y resistencias, Madrid: Trama Editorial, 2006, p. 121-140. "Idiosincrasia de la identidad nacional y del modelo socio-cultural estadounidense según el influjo
} 
estadounidenses la capacidad de poner en práctica aquello que en otras partes del mundo resulta marginal, recibiéndolo y transformándolo (conforme a sus criterios de Modernidad: éxito y beneficio), para presentarlo luego como algo propio a exportar al resto del planeta (así pasó con cuestiones surgidas en Europa, tales como la democracia y el federalismo, incluso la misma noción incipiente de ACR, fallidas todas ellas en su implementación, hasta su experimentación en los EE.UU., con su posterior irradiación como fórmulas de referencia mundial). Dicha capacidad del Americaness de realizar con éxito y beneficio lo aparentemente contradictorio e ilógico (conforme a la tradición y al contexto dominante -que en el caso europeo era el peso de las instituciones del Antiguo Régimen, así como las normas ideológicas posteriores-), en realidad consiste en un ejercicio de preferencia por la praxis antes que por la doxa, algo habilitado por la moderna Teología política que inspira el periodo fundacional: así se entiende que los peregrinos o pilgrims, marginados y excluidos de Gran Bretaña y Países Bajos, sin embargo, terminen siendo parte de los padres fundadores estadounidenses of founding fathers. Pues bien, se aclara todo esto, pues mientras que en la Europa decimonónica el tipo de pensamiento dominante es el deductivo de corte dialéctico (por HEGEL y sus discípulos, entre los que hay que destacar a MARX), en los EE.UU. va a ser el pensamiento inductivo, de corte empírico-natural, impulsado por el pragmatismo (desde el Club Metafísico de Harvard, irradiado al resto de universidades del Ivy League $)^{54}$. Ahora bien, con el

\footnotetext{
de sus elites político-jurídicas (a vueltas con la religión civil)", en Actas del VII Congreso Español de Ciencia Política y de la Administración: Democracia y Buen Gobierno (Grupo 26: Elites de poder), 2005, pp. 265-281. Complementariamente, vid. nota a pie 11 y 16.

${ }_{54}$ De los millares de centros universitarios reconocidos en los EE.UU., existe un reducido y exclusivo grupo denominado Ivy League o Liga de la hiedra. Se trata de una metáfora muy plástica, pues la exclusividad de dicho club se basa en: a) la reivindicación de la supuesta antigüedad de sus universidades - pretendidas herederas de las más venerables europeas (v.g. Oxford, Cambridge), donde hay hiedra en sus muros-; b) la calidad de su educación y la selección intensiva de sus alumnos y profesores -que como la hiedra, se entremezcla para ser más fuerte y elevarse-; c) la referencia
} 
tránsito a la posmodernidad en Europa con los post-estructuralistas y postcoloniales, dadas las relaciones atlánticas, con la fuga de cerebros tras las Guerras mundiales (incluida la Guerra fría y las guerras culturales), finalmente se produce la transición posmoderna en los EE.UU., por lo que las paradojas del Americaness (que sirvieran para superar las disonancias cognitivas y conformar consensos), en cambio, las paradojas impulsadas por los Estudios culturales sobrevenidos (nutridos de la fuga de cerebros aludida), van a extender velos de confusión orientados a la deconstrucción de ACR y la idiosincrasia estadounidense generada, avivando toda clase de conflictos socio-culturales. Esta es la hipótesis sustancial de la investigación: cómo la deconstrucción fragmentaria de ACR y su idiosincrasia lograda, vía los Estudios culturales sobrevenidos y sus velos (al haberse remontado incluso el periodo fundacional, vulnerándose la matriz mitopoiética y su legado $-\mathrm{o}$ si se prefiere, en términos posmodernos: la corrupción del set-up, vid. infra-), se ha provocado un efecto domino, pues la crisis estadounidense trasciende a Occidente y al resto del mundo. Si EE.UU. renuncia a su condición de último bastión de Modernidad occidental, quizá no pierda su condición hegemónica (al forjar novedosas alianzas asiático-pacíficas).

En cuanto al plan de trabajo, se remite a la hoja de ruta trazada en el índice, que sigue un modelo clásico científico-académico, de división en partes, capítulos y epígrafes (de estructura y contenidos lo más simétrico posible):

social, tanto por ser parte de su comunidad como por acogerla, pues todo ello proporciona respetabilidad y posibilidad de promoción social -como la hiedra, proporciona solera y distinción a la edificación-, etc. La mayor parte de estas universidades se fundaron como centros educativos confesionales para asegurar el relevo generacional de profesiones liberales, especialmente los ministros de culto (v.g. Princeton College y los presbiterianos, Yale y los congregacionalistas, Harvard y los unitarianistas, Brown y los bautistas); vid. supra cap. 8 . 
a) Introduction, Conclusion \& References: those parts in English, and a long overview in chapter 4, because this thesis pretends the international mention (art. 14, RD 99/2011).

b) Una parte inicial (o propedéutica) ${ }^{55}$ : para presentar el estudio, con sus capítulos respectivos (del 1 al 3), relativos al interés social y científicoacadémico de la investigación, sus fines y objetivos, con su plan de trabajo, más su metodología empleada.

c) Una parte de desarrollo general (o de fundamentos) ${ }^{56}$ : para ampliar el conocimiento sobre las variables principales de investigación (cap. 4-7); en este caso, sobre la ACR y su influjo en la configuración idiosincrásica estadounidense. Se ofrece una perspectiva histórica y comparada, revisándose su ontología, epistemología y axiología correspondiente en el devenir de la materia.

d) Una parte de desarrollo especial (o de tópica) ${ }^{57}$ : de profundización en la casuística seleccionada para comprender mejor la materia (cap. 8-10). Se aborda su dimensión sistémica (o estudio científico-académico, a través de la disciplina interdisciplinaria de los Estudios culturales estadounidenses);

\footnotetext{
${ }^{55}$ Parte articulada con apoyo, revisión y mejora de ponencias y publicaciones previas (avaladoras de la investigación, tal como exige el RD 99/2011): Estudios de cultura político-jurídica... op. cit. La Modernidad sin prejuicios... op. cit. Estado y religión de acuerdo con los Estados Unidos de América... op. cit. Manual de Sociología Jurídica Estadounidense... op. cit. Humanismo Iberoamericano... op. cit. Renovación de la Filosofía Social Iberoamericana... op. cit. Problemas y retos para alcanzar la sociedad del conocimiento... op. cit. Universidad, ciencia y religión en los Estados Unidos de América... op. cit. La religión civil estadounidense... op. cit.; más las tesis previas (con sus avances correspondientes) y el resto de bibliografía citada en Estado de la cuestión, así como las especificaciones (de artículos en revistas indexadas de impacto científico-académico: Scopus, SJR, SciELO, etc.) al inicio de cada capítulo (más las notas aclaratorias). Complement., vid. infra notas 3-6.

56 Vid. infra nota previa (ídem).

57 Vid. infra ibidem.
} 
también su dimensión subjetiva (relativa a la renovación de sus elites de poder y su recepción, mejora y transmisión del legado idiosincrásico); así como su dimensión objetiva (con todas sus manifestaciones de ACR: símbolos y ritos, valores y creencia, normas e instituciones, arte y monumentos, etc.).

e) Una parte final ${ }^{58}$ : donde acometer un balance, partiendo de una recapitulación de los principales argumentos y evidencias, para sistematizar y sintetizar la discusión de resultados, mediante un pentálogo de tesis de rango medio y un posible teorema de cierre (cap. 11-12). Igualmente, se presenta algunos corolarios complementarios (v.g. por los velos y su deconstrucción, se ha producido una desnaturalización, conducente a la vulneración de principios fundaciones estadounidenses, causándose en la posglobalización la persecución religiosa y migratoria, y la manifestación de anacronismos como el acogimiento a sagrado en centros religiosos).

${ }^{58}$ Vid. infra ib. ibídem. 


\section{3.- MetOdOLOGÍA EMPLEADA: ABORDAJE COMBINADO SOCIOCULTURAL ${ }^{59}$}

Recuérdese que, la metodología es, etimológicamente hablando (del griego clásico), el camino a trazar para la indagación y difusión del estudio realizado, por lo que dicho camino lógico y prefijado depende en gran medida del diseño y aplicación de las técnicas de investigación empleadas y los enfoques inspiradores. Aquí se han usado de manera combinada una rica batería de recursos, tal como se viene realizando por los Estudios culturales estadounidenses al abordar la materia.

Se recuerda también que, este estudio, con su propuesta de renovación metodológica (tomada prestada de los EE.UU. y conectándose con otras disciplinas), pretende contribuir al debate actual sobre la situación de la Sociología: se trata de la puesta en práctica del análisis realizado en la obra Balance de la globalización y teoría social de la posglobalización (vid. supra Estado de la cuestión).

Por tanto, este es en esencia un estudio cultural así como sociológico, pero tal como se requiere y acomete tras las crisis de la globalización: se observa lo cuantitativo, pero se prioriza lo cualitativo, en busca de teorías sociales válidas. Dado que la Sociología surgió para entender los cambios en las novedosas relaciones sociales desde la Baja Modernidad y su tránsito al Nuevo Régimen: del campo a la ciudad, de los talleres a las fábricas y oficinas, etc., pero también del estancamiento y la servidumbre feudal a la movilidad y libertad de sociedades abiertas, con sus maneras de producir y consumir la cultura... entonces, ¿qué pasaría si EE.UU. renunciara a su pionero modelo socio-cultural de Modernidad occiental? ¿Qué tipo de estudio se necesitaría para comprender dicha nueva realidad? Se entenderá por

\footnotetext{
${ }^{59}$ Vid. infra notas 3-6 y 55.
} 
tanto que la cuestión metodológica no es baladí, aunque hoy urgen más la revisión crítica ontológica, epistemológica y axiológica (tal como aquí se pretende).

\section{1.- ENFOQUES, TÉCNICAS Y RECURSOS}

La originalidad de este estudio radica no sólo en su temática, sino también en su tratamiento otorgado (sus enfoques, técnicas, etc.), al acometerse una evaluación de la evolución de ACR y su influjo en la idiosincrasia estadounidense -por tanto, no se trata de una investigación experimental, sino analítica y empírica, vid. infra-. Para ello se ha recurrido al enfoque mixto (científico-social y humanista), característicio de los Estudios culturales, que constituyen la base de este estudio. De ahí que se haya combinado recursos sociológicos, con políticos y jurídicos (sobre todo iuseclesiasticistas, iusfilosóficos, filosófico-político y moral, más teológico político); sin olvidar los planteamientos antropológicos, comunicativos y psicosociales; además de manejar aportes trasversales de los Estudios históricos, comparados, filosóficos y religiosos.

En cuanto a las técnicas de investigación empleadas, aquí se han usado de manera combinada -una vez más, tal como lo realizan los Estudios culturales estadounidenses-, las propias de la Teología y del Derecho -por cierto, las ciencias universitarias de las Facultades Mayores, y de las más extendidas en la universidad decimonónica estadounidense (como en el resto de Occidente)-: la exégesis, la hermenéutica y la heurística; la crítica (v.g. interna y externa, mayor y menor) de

fuentes e instituciones (combinándose con la epojé, la mayéutica, el materialismo, etc.); 
la síntesis y sistemática, etc. Claramente, durante la fase de trabajo de campo, las técnicas empleadas han sido predominantemente cuantitativas (para el acopio de información tratable), como el rastreo de ítems en grandes bases bibliográficas y de datos (mediante análisis de fuerza bruta, con su posterior refinamiento y filtrado, vía minería de datos, según variables y vectores), más encuestas y entrevistas in loco (principalmente, se ha recurrido a la entrevista en profundidad a profesores universitarios estadounidenses: MANSFIELD, CARRASCO, et al., en Harvard; BLACKMAN, MOUSIN, etc., en DePaul; PAYNE, MARSH, MCDANIEL y otros en Baylor; DAVIS en MHBU, et al., vid. supra). En la fase de despacho, han tenido mayor peso las técnicas cualitativas, como el análisis de discurso y contenido, más su variante casi emancipada de story-telling analysis (análisis narrativo, v.g. narrativa motivacional, literatura testimonial), o los estudios singulares de la clínica, (vid. supra); sin olvidar la técnica de semblanzas y perfiles para personajes relevantes; más otras tantas técnicas combinadas, que se irán aclarando en su momento. Igualmente, se han incluido técnicas de investigación propias, como es el análisis prospectico C4 o APC-4 (ídem).

A continuación, se esbozan algunas de las técnicas empleadas en esta investigación, tal como se usan en los Estudios culturales estadounidenses, tras su incorporación de otras ramas de las Humanidades y Ciencias Sociales: 
Figura 7.- Conjunto de técnicas de investigación empleadas ${ }^{60}$.

a) Técnicas clásicas.

\begin{tabular}{|l|l|}
\hline Técnicas & \multicolumn{1}{|c|}{ Propósitos } \\
\hline Exégesis & Interpretación de fuentes primarias (introspección) \\
\hline Hermenéutica & Interpretación de fuentes secundarias (proyección) \\
\hline$\left(^{*}\right)$ Bibliografía & Articulación de fuentes convencionales \\
\hline$\left(^{*}\right)$ Epigrafía & Descifrado de fuentes iconografías \\
\hline Heurística & Determinación de fuentes (jerarquización y criba) \\
\hline Criticismo & $\begin{array}{l}\text { Búsqueda de la duda razonable (causalidad e } \\
\text { intencionalidad) }\end{array}$ \\
\hline Dialéctica & $\begin{array}{l}\text { Confrontación de normas e instituciones para su } \\
\text { autentificación. }\end{array}$ \\
\hline Especulación & $\begin{array}{l}\text { Búsqueda de hipótesis alternativas y analogías } \\
\text { (v.g. cábala judía, especulación cristiana) }\end{array}$ \\
\hline Instituciones & Síntesis de ideas y formas para la práctica y la docencia \\
\hline
\end{tabular}

$\left.{ }^{*}\right)$ Derivados de la hermenéutica.

Fuente: elaboración propia (SÁNCHEZ-BAYÓN, 2007 y 16).

\section{b) Dimensiones del análisis comparado y clínico}

\begin{tabular}{|l|l|}
\hline Técnicas & \multicolumn{1}{|c|}{ Propósitos } \\
\hline Interpretación & Buscar significados \\
\hline a) Interpretac. & $\begin{array}{l}\text { Análisis del significado subjetivo } \\
\text { (clarificar intenciones) }\end{array}$ \\
\hline b) Construcc. & Análisis del significado objetivo (clarificar definiciones) \\
\hline c) Traducción & Análisis del significado formal (clarificar lenguaje) \\
\hline Analogía & Buscar supuestos (casos similares o trasplantes) \\
\hline
\end{tabular}

Fuente: elaboración propia (SÁNCHEZ-BAYÓN, 2007 y 16).

${ }^{60}$ Vid. tesis previas del autor, más SÁNCHEZ-BAYÓN, A.: La Modernidad sin prejuicios... op. cit. Estudios de cultura político-jurídica... op. cit. 
c) Metodología del Análisis Prospectivo C-4 (APC-4)

\begin{tabular}{|l|l|}
\hline Análisis & \multicolumn{1}{|c|}{ Pretensiones } \\
\hline Crítico & $\begin{array}{l}\text { Estudio para la depuración, fundamentación } \\
\text { y concreción del conocimiento (evitándose el dogmatismo } \\
\text { y la endogamia) }\end{array}$ \\
\hline Creativo & Estudio basado en la intuición, inquietud y construcción (ídem) \\
\hline Científico & $\begin{array}{l}\text { Estudio metódico y riguroso, por el que se fijan leyes, teoremas, } \\
\text { etc., y se recurre a un lenguaje artificial especializado } \\
\text { (evitándose las confusiones polisémicas coloquiales) }\end{array}$ \\
\hline Clínico & $\begin{array}{l}\text { Estudio para la identificación y gestión de peculiaridades } \\
\text { definitorias y anomalías transitorias (evitándose la falta de } \\
\text { aplicación cotidiana del conocimiento) }\end{array}$ \\
\hline
\end{tabular}

${ }^{*}$ ) No existe tensión real entre las pretensiones, pues en su puesta en práctica, el APC-4 logra una acomodación equilibrada según las necesidades del análisis acometido.

Fuente: elaboración propia (SÁNCHEZ-BAYÓN, 2007 y 16).

d) Protocolos de actuación del análisis clínico y estratégico social.

\begin{tabular}{|l|}
\hline \multicolumn{1}{|c|}{ Análisis clínico } \\
\hline $\begin{array}{l}\text { A/ Examen: obtención de la historia clínica (documentación) y exploración } \\
\text { (trabajo de campo). }\end{array}$ \\
\hline $\begin{array}{l}\text { B/ Diagnóstico: dilucidación del origen y naturaleza de las peculiaridades y } \\
\text { anomalías (rastreo top-down \& botton-up). }\end{array}$ \\
\hline $\begin{array}{l}\text { C/ Pronóstico: inferencia de las posibles consecuencias del trastorno } \\
\text { (delimitando los factores de riesgo) y predicción sobre su manifestación. }\end{array}$ \\
\hline $\begin{array}{l}\text { D/ Prescripción: resolución o mitigación del problema mediante tratamiento } \\
\text { (políticas públicas). }\end{array}$ \\
\hline $\begin{array}{l}\text { E/ Evaluación: seguimiento de la evolución y epicrisis (confirmando el análisis } \\
\text { clínico y revisando los estadios de la anomalía y su prevención: susceptibilidad, } \\
\text { presintomática, recaída, recuperación, secuela). }\end{array}$ \\
\hline \multicolumn{1}{c|}{ Análisis estratégico } \\
\hline $\begin{array}{l}\text { A/ Operatividad: sistematización (compiladora, codificadora), predicción } \\
\text { (proyección, previsión, conjetura), comparación (sincrónica, diacrónica, } \\
\text { similitudes, diferencias). }\end{array}$ \\
\hline $\begin{array}{l}\text { B/ Dimensionalidad: macroanálisis, microanálisis, mesoanálisis, metanálisis, } \\
\text { etc. }\end{array}$ \\
\hline $\begin{array}{l}\text { C/ Temporalidad: cronométrica (corto plazo, medio plazo, largo plazo), } \\
\text { cronoscopia (sine die, illo tempore, ipso facto). }\end{array}$ \\
\hline $\begin{array}{l}\text { D/ Sectorialidad: Geopolítica y Relaciones Internacionales, Seguridad y } \\
\text { Defensa, Derechos Humanos y Ética aplicada. }\end{array}$ \\
Fuente: elaboración propia (SÁNCHEZ-BAYÓN, 2007 y 16). \\
\hline
\end{tabular}


En definitiva, la metodología empleada sólo pretende ser reflejo de las prácticas científico-académicas estadounidenses, que a su vez responden a su vocación idiosincrásica de melting pot o crisol cultural ${ }^{61}-$ al menos así oficializada tal narración, y cuestionada por los Estudios culturales sobrevenidos (vid. supra cap. 8)-. A diferencia de Europa continental, en los EE.UU., las disciplinas no están tan delimitadas, ni su metodología tan tasada y cerrada, sino que conviven diversas disciplinas interrelacionadas y de sus investigaciones brotan nuevas combinaciones de enfoques y técnicas de investigación y docencia (de ahí que existan unos Estudios culturales tradicionales y otros sobrevenidos). Conforme a dicho espíritu científicoacadémico, se entenderá mejor la selección acometida en el Estado de la cuestión (vid. supra).

\footnotetext{
${ }^{61}$ Melting pot es una expresión muy popular, acuñada como metáfora de lo que supone el estudio de la Historia estadounidense, lo que en realidad supone el estudio de la Historia de la inmigración, y con ella la(s) historia(s) de sus contribuciones culturales. Desde sus orígenes, los EE.UU., ha sido un país que ha recibido dos tipos de ciudadanos potenciales, que pese a su inspiración por el mismo sueño $-y / 0$ fe- de oportunidades (AD), unos buscaban el enriquecimiento (colonias del sur y territorios del oeste) y otros el reconocimiento (colonias del norte y grandes metrópolis). Para que tal amalgama social resultara viable y comprometida con el proyecto estadounidense, desde el inicio fue necesaria una propensión hacia la tolerancia -en su emergente sentido moderno (pensamiento whig $\mathcal{E}$ freemason-PWF)-, que con el tiempo ha ido puliendo su significado, llegando a expresar la fórmula para la pluralidad integrada de una sociedad abierta (e pluribus unum, Sello nacional, 1789, vid. supra). Por tanto, aterrizándose en la expresión melting pot, con la misma se alude al caldero donde se prepara una especie de potaje, por lo que cuanto mayor es la diversidad de sus componentes, más sabroso se estima el plato cocinado. Pues bien, así se ven así mismos los estadounidenses, como crisol cultural, donde todos pueden traer componentes de sus culturas de procedencia, pero ello sólo es para mejorar el sabor civilizatorio occidental que en los EE.UU. se cuece (vid. supra Parte de desarrollo general, más cap. 8 y 10).
} 


\section{2.- ESTADO DE LA CUESTIÓN}

Dado que este es un estudio revisor crítico, focalizado en la producción científico-académica de los Estudios culturales estadounidenses acerca de su ACR y su idiosincrasia (todo ello en crisis tras la globalización), se entenderá entonces que no se acometa un estado de la cuestión al uso (indagándose sobre la frontera del conocimiento, o sea, sobre las publicaciones de último lustro), sino que se centre la atención en la producción estadounidense de la materia, aquella más relevante (por su impacto y citas recibidas), generada durante las guerras culturales y el inicio de la globalización.

Antes de proceder con la sistematización historiográfica anunciada, se desea introducir una breve aclaración acerca de la procedencia original de dicha producción. Resulta que entre los primeros estudios de ACR (combinados con AG y Teología política estadounidense), cabe destacar las aportaciones de la patrística estadounidense o sus founding father (vid. supra cap. 8), que lato sensu comprende a: los peregrinos o pilgrims y los puritanos o puritans, más los líderes coloniales o leaders (s. XVII-XVIII), que postulan ser un pueblo elegido, en Nueva Jerusalén, tal como hicieran WINTHROP y los MATHER, y como dejara constancia MORTON en sus Anales; en la generación de los constituyentes o framers (s. XVIII), como HAMILTON, MADISON y JAY y sus escritos federalistas (The Federalist papers), quienes definen su país como la república comercial de los hombres libres, responsables de dar ejemplo ante el resto de naciones. Incluso, cabe recordar lecturas sociales de gran trascendencia como las realizadas por viajeros extranjeros como TOCQUEVILLE, en sus volúmenes de Democracia en América (obra en la que expone y explica la religión civil

en América), o WEBER, en su Ética protestante y espíritu del capitalismo (ídem). En 
cuanto a la Teología política, procediendo del mismo tronco común, como es el cambio de mentalidad que va desde la Reforma a la Ilustración (tal como reciben todo ello en América los padres fundadores), sin embargo termina dando lugar a dos ramas autóctonas estadounidenses: una mayoritaria, cultivada por liberales-conservadores y libre-pensadores (con raíces en el pensamiento whig $\mathcal{E}$ free-manson) en los Seminarios Teológicos y Divinity Schools (Facultades de Divinidad/CC. Divinas o Religiosas), con autores tan sobresalientes en los ciclos de despertares religiosos como S. STODDARD y los MATHER (en seminarios teológicos de Nueva Inglaterra del s. XVII), W. AMES y S. DAVIES (en Princeton University -Provincias medias-, en el s. XVIII), G. WHITEFIELD, W. TENNENT y J. EDWARDS (en la proto-Ilustración de las trece colonias), et al.; y otra minoritaria, impulsada por democristianos populistas y cristianos-socialistas, con polarizantes planteamientos patéticos recuérdese: relativos a pathos- (v.g. tradicionalismo, comunitarismo, milenarismo). Esta última rama, comienza a aglutinarse, gracias a la acción de autores como NIEBUHR (con títulos de referencia, como Moral Man and Inmoral Society: a study of ethics and Politics, 1932), hasta la gran revitalización e inversión de planteamientos y posición numérica que tiene lugar con el auge neoconservador (desde la década de 1980). Es entonces cuando los ex-marxistas -vista la lección del socialismo real de la URSS- se vuelven supuestos liberales y apoyan al movimiento fundamentalista, produciéndose una distorsionada de la Teología política, en la que dominan los planteamientos heredados de C. SCHMITT y su obra homónima (Teología política, 1922), transmitidos por L. STRAUSS (en la Universidad de Chicago y en centros universitarios de New York). El resultado es una teología posmoderna (de acción social antisistema en un supuesto mundo post-secular), divergente de la tradicional teología moderna estadounidense (vid. supra cap. 5 y 6). Entre las lecturas confusas 
actuales, cabe destacar: CLAYTON, C.: Radical political theology, New York: Columbia University Press, 2011. KAHN, P.W.: Political Theology. Four new chapters on the concept of sovergignty, New York: Columbia University Press, 2011. PERRY, J.: The pretenses of Loyalty: Locke, liberal theory, and American political theology, New York: Oxford University Press, 2011. PHILLIPS, E.: Political theology. A guide for the perplexed, New York: T\&T Clark, 2012. ROBBINS, J.W.: Radical democracy and political theology, New York: Oxford University Press, 2011. YONG, A.: In the days of Caesar. Pentecostalism and political theology, Grand Rapids: William B. Eerdmas Publishing Co., 2009.

En lo tocante al constructo científico-académico de ACR, el mismo se venía estudiando (entre otras disciplinas) desde la Teología política (más aquellas otras autóctonas), relanzándose en la universidad desde la década de 1960, gracias a la Sociología de la Religión (más tarde, también, las CC. Religiosas), hasta llegar a dar como fruto su disciplina homónima (v.g. Baylor Univ.). Entre los reactualizadores de la ACR cabe destacar las aportaciones significativas de BELLAH (Beyond beliefs, New York: Harper \& Row., 1970. - The broken covenant: American Civil Religion in the Time of Trial, New York: The Seabury Press, 1975), BERGER (vid. infra pto. a), CASANOVA (Public religions in the Modern World, Chicago: The University of Chicago, 1994), REICHLEY (Religion in American Public Life, Washington DC: The Brookings Institution, 1985), SEWARD (Religion in American Culture. A sociological interpretation, Homewood: The Dorsey Press, 1964), et al.

Ahora sí, conforme a la sistemática realizada, se procede a rendir cuenta de las fontes cogniscendi empleadas para iniciar la investigación ${ }^{62}$ :

\footnotetext{
62 Se insiste en que son fuentes de conocimiento generalmente aceptadas y citadas en los programas, disciplinas y asignaturas de las materias afectadas; eso sí, se trata de bibliografía que llega hasta la
} 
a) Teología política e Historia, Filosofía y Sociología de la Religión en EE.UU.: AHLSTROM, S.E.: A religious History of the American people, New Haven: Yale University Press, 1972. BAIRD, R.: Religion in the United States of America, New York: The New York Times, 1969. BECKER, H.: Through values to social interpretation, Durham: Duke University Press, 1950. BELL, D.: “The return of the sacred", en British Journal of Sociology (XXVIII, 4), 1977. BERGER, P: The Sacred Canopy: Elements of a Sociological Theory of Religion, New York: Garden City, 1967. - A rumor of angels: Modern Society and the rediscovery of the Supernatural, New York: Garden City, 1970. - The social reality of religion, London: Penguin Books, 1973. BOLT, J.: A free church, a holy nation. Abraham Kuyper's American Public Theology, Grand Rapids: Eerdmans Publishing Co., 2001. CAVANAUGH, W.: Theopolitical Imagination, New York: T\&T Clark Ltd., 2002. CLARK, H.: The irony of American Morality, New Haven: College \& University Press, 1971. CONKIN, P.K.: Puritans and Pragmatist: Eight Eminent American Thinkers, Waco: Baylor University Press, 2006. COX, H.: The Secular City: Secularization and Urbanization in Theological Perspective, New Haven, Yale Univ. Press, 1965. - The Feast of Fools: A Theological Essay on Festivity and Fantasy, Cambridge: Harvard Univ. Press, 1969. DEMERATH, N.J.: Social class in American Protestantism, Chicago: Rand McNally, 1965. EVERETT, W.J.: God's Federal Republic. Reconstructing our Governing Symbol, New York: Paulist Press, 1988. FRISCH, M.J., STEVENS, R.G.: American political thought. The Philosophic dimension of American statesmanship, New York: Charles Scribner's Sons, 1971. GALLUP, G., et al.: The people's religion.

\footnotetext{
globalización y sus crisis, previa al triunfo de los velos posmodernos de confusión de los Estudios
} culturales sobrevenidos, sobrefinanciados por la Adm. CLINTON, Fundación ROCKEFELLER, etc, 
American Faith in the 90's, New York: MacMillan, 1989. GARMAN, G.: America's real religion, Pittsburg: ARRP, 1989. GREELY, A.M.: The Denominational society. A sociological approach to Religion in America, Glenview: Scott Foresman \& Co., 1972. HARRIS, M.: American Now: the Anthropology of a Changing Culture, New York: Simon \& Schuster, 1984. HUDSON, W.S.: Religion in America. An historical account of the development of American religious life, New York: Charles Scribner's Sons, 1973. JAMES, W.: The Varieties of Religious Experience. A study in Human Natures, New York: The Modern Library, 1902. KEILLOR, S.L.: This Rebellious House. American History $\mathcal{E}$ the Truth of Christianity, Downers: InterVarsity Press, 1996. KOHUT, A., et al.: The diminishing divide. Religion's changing role in American politics, Washington: Brookings Institution Press, 2000. MARANELL, G.: Responses to Religion. Studies in the social psychology of religious belief, Lawrence: University Press of Kansas, 1974. MARTY, M.: The Public Church, New York: Crossroad, 1989. MAZUR, E.: The Americanization of Religious Minorities. Confronting the Constitutional Order, Baltimore: The Johns Hopkins University Press, 1990. MEACHAM, J.: American Gospel: God, the Founding Fathers and the Making of a Nation, New York: Random House, 2006. MEAD, F.S., et al.: Handbook of Denominations in the United States, Nashville: Abingdon Press, 1985. MERK, F.: Manifest Destiny and Mission in American History, Cambridge: Harvard University Press, 1995. MARTIN, D.: The religious and the secular, New York: Routledge, 1969. NOLL, M.A.: A History of Christianity in the United States and Canada, Grand Rapids: William B. Eerdmans Publishing Co., 1992. NORTH, G.: Political Polytheism. The myth of pluralism, Tyler: Institute for Christian Economics, 1989. OLMSTEAD, C.E.: History of Religion in the United States, Englewood: PrenticeHall, 1960. PERSONS, S.: Free religion: an American faith, New Haven: Yale 
University Press, 1947. PFEFFER, L.: Creeds in competition: A creative force in American culture, New York: Harper \& Row., 1958. POWEL DAVIS, A.: American Destiny. A faith for America, Boston: Beacon Press, 1942. ROBERTSON, R. (comp.): Sociology of religion, London: Penguin Books, 1969. SANDOZ, E.: A Government of Laws. Political Theory, Religion, and the American Founding, Sabon: Louisiana State University Press, 1990. SHELDON, G.W.: Religion and Politics. New York: Peter Lang Publishing Inc., 1990. SINGER, C.G.: A theological interpretation of American History, Nutley: The Craig Press, 1964. SMITH, G.S.: God and politics, Philipsburg: Prebyterian and Reformed Publishing Co., 1987. SMITH, J.W., JAMISON, A.L. (ed.): Religion in American Life (vol. I-IV, con especial atención a la bibliografía seleccionada por BURR para el vol. IV), Princeton: Princeton University Press, 1961. SONTAG, F., ROTH, J.K.: God and America's future, Wilmington: Consortium Books, 1977. STARK, R., GLOCK, C.: American piety: the nature of religious commitment, Berkeley: University of California Press, 1970. TYLER, A.F.: Freedom's Ferment. Phases of American Social History to 1860, Minneapolis: The University of Minnesota Press, 1944. SWEET, W.W.: Religion in the development of American culture, New York: Charles Scribner's Sons, 1952. - Religion in Colonial America, Charles Scribner's Sons, New York, 1942. TAYLER, M.L.: Religion, Politics and the Christian Right, Minneapolis: Forterpress Press, 2005. TYLER, A.: Freedom's Ferment. Phases of American social History to 1860, Minneapolis: University of Minnesota Press, 1944. VV.AA.: Religious and Secular Reform in America. Ideas, beliefs, and social change, New York: New York University Press, 1999. WEINBERG, A.K.: Manifest Destiny. A study of nationalist expansionism in American History, Baltimore: The Johns Hopkins Press, 1935. WILLIAMS, W.A.: Empire as a way of life. An essay on the causes and character of America's present 
predicament along with few thoughts about an alternative, New York: Oxford University Press, 1980. WOOD, R.C. (ed.): Civil Religion and transcendent experience, Macon: Mercer University Press, 1988. WRIGHT, C. (edit): Religion in American life. Selected readings, New York: Houghton Mifflin Co, 1972. YARNOLD, B (ed.). The role of religious organizations in social movements, New York: Praeger, 1991.

b) Estudios de Derecho-política-religión, relaciones Iglesia-Estado y iuseclesiasticistas $^{63}$ : BATES, M.S.: Religious Liberty. An inquiry, New York: International Missionary Council, 1945. BETH, L.P.: The American Theory of Church and State, Gainesville: University of Florida Press, 1958. BLAKELY, W.A. (comp.): American State papers and related documents on Freedom in Religion, Washington DC: The Religious Liberty Association, 1949. BROWN, W.A.: Church and State in contemporary America, New York: Charles Scribner's Sons, 1936. COBB, S.H.: The rise of religious liberty in America, New York: MacMillan, 1902. CORNELISON, I.A.: The relation of religion to Civil Government in the United States of America. A State without a Church, but not without a Religion, New York: Da Capo Press, 1970. CURRY, T.J.: The First Freedoms. Church and State in America to the passage of the First Amendment, New York: Oxford University Press, 1986. DAWSON, J.M.: America's Way of Church, State, and Society, New York:

\footnotetext{
${ }^{63}$ Amén de sus publicaciones periódicas más acreditadas y de mayor índice de impacto: a) las revistas, del tipo de Journal of Church \& State, del J.M. Dawson Institute of Church-State Studies-Baylor University, o Religion and the Public Order. An annual review of Church and State and of Religion, Law, and Society, del Institute of Church and State Villanova University School of Law, publicado por The University of Chicago Press (1963-67), luego por Cornell University Press (desde 1968), etc.; b) los informes, como los Annual Reports on International Religious Freedom, del U.S. Bureau of Democracy, Human Rights and Labor (con apoyo de la CIRF y la OIRF).
} 
MacMillan, 1953. GREENE, E.B.: Religion and the State: the making and testing of an American tradition, Ithaca: Cornell University Press, 1959. HAMMAR, R.R.: Pastor, Church \& Law, Springfield: Christian Ministry Resources, 1983. HUTCHESON, R.G.: Church, State and Chaplaincy: essays and statements on the American Chaplaincy System, Washington DC: General Commission on Chaplains and Armed Forces Personnel, 1969. KLINEBERG, F.A.: A free Church in a free State, Gainesville Indianapolis: National Foundation Press, 1947. LEGLER, J.: The Two Sovereignties. A study of the relationship between Church and State, New York: Gainesville Philosophical Library, 1952. LINDGREN, A.J.: Foundations for purposeful Church Administration, Nashville: Abingdon Press, 1981. MANNING, L.F.: The Law of Church-State Relations in a Nutshell, West Publishing Co., St. Paul, 1981. MOONEY, C.: Religion and the American dream. The search for Freedom under God, Philadelphia: The Westminster Press, 1977. - Public Virtue. Law and the Social Character of Religion, Notre Dame: University of Notre Dame Press, 1986. MORGAN, R.E.: The Politics of religious conflict: Church and State in America, Washington DC: University Press of America, 1980. OLDHAM, J.H.: Church, Community, and State, New York: Harper \& Row., 1935. PFEFFER, L.: Church, State and Freedom, Boston: The Beacon Press, 1967. POWER, M.S.: Before the Convention. Religion and the Founders, Lanham: University Press of America, 1984. ROBBINS, T., ROBERTSON, R.: Church-State Relations. Tensions and transitions, New Brunswick: Transaction Books, 1987. SCHAFF, P.: Church and State in the United States or the American idea of religious liberty and its practical effects with official documents, New York: American Historical Association, 1888. STOKES, A.P.: Church and State in the United States (vol. I-III), New York: Harper \& Row., 1950. THORPNING, J.F.: Religious liberty in transition, Washington DC: The 
Catholic University of America Press, 1931. VOLOKH, E.: The First Amedment. Problems, cases and policy arguments, New York: Foundation Press, 2001. WOOD, J., et al (edits).: Church and State in Scripture. History and Constitutional Law, Waco: Baylor University Press, 1958. - Church and State, Waco: Baylor University Press, 1961. - Religion and the State. Essays in Honor of Leo Pfeffer, Waco: Baylor University Press, 1985. ZOLLMANN, C.: American Church Law, St. Paul: West Publishing Co., 1933.

Es de destacar otra vertiente (de la misma corriente), como es la de Derecho Político y Constitucional, que en los EE.UU. ha sido prolija al tratar dos temas recurrentes, como son el devenir de la libertad religiosa y de la moral pública. Ambas cuestiones, se han recogido en las especialidades académicas de First Amendment Studies [Estudios sobre la Primera Enmienda], más Political \& Social Thougth [Pensamiento Político y Social]. De este modo, se confiere una especial atención a las ideas, formas y movimientos, que mejor han contribuido al avance sostenible y armónico de las relaciones entre el poder, lo sagrado y la libertad, en el novus ordo seclorum [nuevo orden secular/de los tiempos (también se puede traducir como Nuevo Régimen)] de los EE.UU. (codificado en su ACR, vid. cap. 5). De entre los trabajos producidos en el seno de los Estudios sobre la Primera Enmienda, acerca de la libertad religiosa (en relación con el resto de derechos y libertades) y su aplicación por los tribunales, es preciso destacar las contribuciones de ADAMS, EMMERICH, BUZZARD, BRANDON, TORPEY y VAN ALSTYNE ${ }^{64}$. Sobre el factor religioso en la Constitución de los EE.UU. (CEU),

${ }^{64}$ Vid. ADAMS, A.M., EMMERICH, C.J.: A Nation dedicated to Religious Liberty. The Constitutional Heritage of Religión Clauses, Philadelphia: University of Pennsylvania Press, 1990. BUZZARD, L.R., BRANDON, T.S.: Church Discipline and the Courts, Tyndale: Carol Stream, 1987. TORPEY, W.G.: Judicial doctrines of religious rights in America, Chapel Hill: The University of North Carolina Press, 1948. VAN ALSTYNE, W.W.: First Amendment. Cases and Materials, New York: Foundation Press, 
más su impacto en las elites de poder y las políticas públicas posteriores, tal y como se estudia desde la disciplina de Pensamiento Político y Social, cabe reseñarse las aportaciones de BERNSTEIN, RICE, COUSINS, EIDSMOE, EVERETT, GREENAWALT, KAUPER, LIPSET, MALBIN, MAY, OAKS, PIERARD, LINDER, REICHLEY, SANDOZ y TUVESON ${ }^{65}$.

c) Compilaciones de documentos históricos y obras enciclopédicas (evidencias socio-culturales relativas al impacto del factor religioso): BLAU, J.(ed.): Cornerstones of Religious Freedom in America. Selected Basic Documents, Courts Decisions, and Public Statements, Boston: The Beacon Press, 1949. BOORSTIN, D.J. (comp.): An American Primer, Chicago: The University of Chicago Press, 1966.

1990. Más recientes en el tiempo, y como excepción a la afirmación de partida sobre las lecturas escogidas, cabe citarse por méritos de casación de planteamientos, por ejemplo, los trabajos de ARIENS, M.S., DESTRO, R.A.: Religious Liberty in a Pluralistic Society, Durham: Carolina Academic Press, 1996. KRAMNICK, I., MOORE, R.L.: The Godless Constitution. A moral defense of the secular State, New York: W.W. Norton \& Co., 2005. NOONAN, J.T., GAFNEY, E.Mc.: Religious Freedom. History, cases, and other materials on the interaction of religion and Government, New York: Foundation Press, 2001.

${ }^{65}$ Vid. BERNSTEIN, R.B., RICE, K.S.: Are we to be a Nation? The making of the Constitution, Cambridge: Harvard University Press, 1987. COUSINS, N. (ed.): The Republic of Reason. The philosophies of the Founding Fathers, New York: Harper \& Row., 1988. EIDSMOE, J.: Christianity and the Constitution. The Faith of our Founding Fathers, Grand Rapids: Baker Book House, 1987. EVERETT, W.J.: God's Federal Republic. Reconstructing our governing symbol, New York: Paulist Press, 1988. GREENAWALT, K.: Religious convictions and political choice, New York: Oxford University Press, 1988. KAUPER, P.G.: Religion and the Constitution, Baton Rouge: Louisiana State University Press, 1964. LIPSET, S.M.: Religion and American Values in the First New Nation, New York: Basic Books, 1964. MALBIN, M.J.: Religion and politics: the intentions of the authors of the First Amendment, Washington DC: American Enterprise Institute, 1978. MAY, H.: Ideas, Faith, and Feelings. Essays on American Intellectual and Religious History 1952-1982, New York: Oxford University Press, 1983. OAKS, D.H.: Trust Doctrines in Church Controversies, Macon: Mercer University Press, 1984. PIERARD, R.V., LINDER, R.D.: Civil religion and the Presidency, Grand Rapids: Academia Books, 1988. REICHLEY, A.J.: Religion in American Public Life, Washington DC: The Brookings Institution, 1985. SANDOZ, E.: Government of Laws. Political Theory, Religion, and the American Founding, Baton Rouge: Louisiana State University Press, 1990. TUVESON, E.L.: Redeemer Nation. The Idea of America's Millennial Role, Chicago: University of Chicago Press, 1968. 
BRUNKOW, R.V. (ed.): Religion and society in North America. An annotated bibliography, Santa Bárbara: ABC-Clio Press, 1983. BURR, N.R.: Religion in American Life, New York: Meredith Corp., 1971. DIXON, R.G., et al.: American Government: basic documents and materials, New York: D. van Nostrand Co., 1950. DORSEY, S.P.: Early English Churches in America 1607-1807, New York: Oxford University Press, 1952. GLAZIER, M., SHELLEY, T.J.: The Encyclopedia of American Catholic History, Collegeville: The Liturgical Press, 1983. HILLERBRAND, H.J. (ed.): The Encyclopedia of Protestantism (vol. 1-4), New York: Routledge, 2004. HURD, A.E. (ed.): Religion and Church and State: a bibliography selected from the ATLA religion database, Chicago: American Theological Library Association, 1986. KURLAND, P.B., LERNER, R.(ed.): The Founders' Constitution (vols. I-V), Indianapolis: Liberty Fund, 1987. LEVY, L.W. (ed.): Encyclopedia of the American Constitution (vol. 1-4), New York: MacMillan, 1986. LIPPY, C.H., WILLIAMS, P.W. (edits.): Encyclopedia of the American Religion. Studies of traditions and movements (vol. I-III), New York: Charles Scribner's Sons, 1988. MacDONALD, W.: Select Charters and other documents illustrative of American History, 1606-1775, New York: MacMillan Co., 1899. MELTON, J.G.: The Encyclopedia of American Religions, Detroit: Gale Research Inc., 1989. MENÉNDEZ, A.J.: Church-State Relations: an annotated bibliography, New York: Garland, 1976. - Religious conflict in America: a Bibliography, Garland, New York, 1985. QUEEN, E.L., et al.: The encyclopedia of American Religious History (vol. 1-2), New York: Facts of File, 1996. SCHULTZ, J.D., et al. (edits.): Encyclopedia of Religion in American Politics, Phoenix: Oryx Press, 1999. SWATOS, W.H. (ed.): Encyclopedia of Religion and Society, Walnut Creeck: Altamira Press, 1998. WILSON, C.R., FERRIS, W. (edits.): Encyclopedia of Southern Culture, Chapel Hill: 
The University of North Carolina Press, 1989. WOOD, J.E.: Church and State in Historical Perspective: A Critical Assessment and Annotated Bibliography (Bibliographies and Indexes in Religious Studies), Westport: Praeger Publishers, 2005. Así como, se recomienda la consulta de la reciente colección de temario más específico -y controvertido- de Routledge Encyclopedias of Religion and Society: The Encyclopedia of Millennialism \& Millennial Movements. The Encyclopedia of African $\mathcal{E}$ African-American Religions, The Encyclopedia of Fundamentalism, The Encyclopedia of Religious Freedom.

En cuanto a la legitimación científico-académica de las propuestas de este doctorando sobre la materia (amén de la nota de idoneidad y preparación del candidato, vid. supra), cabe destacar el siguiente conjunto de publicaciones idexadas relacionadas y sustentadoras de la investigación (como aval de la comunidad científico-académica internacional al respecto) ${ }^{66}$ :

a) Monografías y manuales: Religión civil estadounidense, Porto: Sindéresis, 2016. Universidad, Ciencia y Religión en los Estados Unidos de América: ¿separación,

66 A diferencia de programas previos de doctorado (v.g. RD 778/1998, en el que originalidad significaba inédito), el vigente (vía RD 99/2011, en el que la originalidad se vincula con la madurez de criterio, previas publicaciones que lo avalen), exige para la selección de idoneidad de candidatos, que accedan con cierto bagaje ya científico-académico: artículos, ponencias, participación en proyectos de investigación, etc. Igualmente, se pide a los doctorandos, como requisito previo al depósito, que logren la publicación de parte de la tesis como artículos en revistas ISI (Scopus, SJR, SciELO, etc. -como se ha procedido en este caso-), así como alguna ponencia en congreso internacional -como las impartidas durante la estancia de investigación en IPB-Portugal-. Todo ello se ha satisfecho (tal como se ha ido dejando constancia en la memoria del curso 2017-18 y 2018-19); incluso, se ha ido más allá, y se ha realizado una estancia de investigación en el extranjero (de tres meses), un centro académico de prestigio y de habla no española (IPB-Portugal), impartiéndose cursos y charlas, además de publicar en la revista de la Escuela de Estudios Sociales (Eduser). De tal suerte, se espera lograr el reconocimiento de mención internacional, al haber redactado parte de la tesis en otro idioma de valía científico-académica: en este caso, en inglés. 
colaboración o confusión?, Porto: Sindéresis, 2015. - La Modernidad sin prejuicios. La religión en la vida pública estadounidense (3 vols., Madrid: Delta, 2008-13). - Estado y religión de acuerdo con los Estados Unidos de América (Saarbrücken: EAE, 2012). Derecho Eclesiástico Global. Cuestiones y materiales de trabajo para Derecho Eclesiástico y Canónico, Madrid: Biblioteca Universitaria de CC. Jurídicas, Económicas y Sociales - UCJC/Delta, 2012. - Estudios de cultura político-jurídica, Madrid: Delta, 2010. - Manual de Sociología Jurídica Estadounidense, Madrid: Delta, 2009 ( $2^{\underline{0}}$ edic.), etc.

Entre las coautorías, cabe destacar la producción con el Prof. GONZÁLEZ, M., SÁNCHEZ-BAYÓN, A.: RIDE. Regulación Iberoamericana de Derecho Eclesiástico (pp. 393), Madrid: Delta Publicaciones, 2011. - Derecho Eclesiástico de las Américas: Fundamentos Socio-Jurídicos y Notas Comparadas (Prólogo del Prof. Dr. I. MARTÍN, Director del Área de Derecho Eclesiástico - UAM, pp. 190), Madrid: Delta Publicaciones, 2009, et al., más la edición y coautoría de PELÁEZ, M.J. (dir.): Diccionario de Canonistas y Eclesiasticistas Europeos y Americanos. Tomo I (ed. y coautoría de A. Sánchez-Bayón: "Maldonado Fernández del Torco, José" (p. 27176); “Martín Martínez, Isidoro" (p. 290-93); “Stokes, Anson Phels" (p. 451-53), etc., pp. 547), Saarbrücken: LAP LAMBERT Academic Publishing GmbH \& Co./EAE, 2012. Sin olvidar, la monografía en coautoría con el director de la tesis, VALERO-MATAS, J., SÁNCHEZ-BAYÓN, A.: Balance de la globalización y teoría social de la posglobalización: cómo percibir y gestionar la diversa, compleja y voluble realidad social en curso del TecnoEvo, Madrid: Dykinson, 2018.

b) Capítulos y artículos: entre las aportaciones en libros colectivos publicados por editoriales indexadas en SPI, cabe destacar SÁNCHEZ-BAYÓN, A.: “Religión y globalización desde la perspectiva judeo-cristiana" (pp. 69-92), en GARCÍA, S. 
(coord.): Gobernanza y religión (Serie Gobernanza, no2), Madrid: Delta Publicaciones (Grupo Ediberum), 2017. - “Gobernanza glocal: claves sobre el orden y administración en la globalización" (p. 107-133), en GARCÍA, S. (coord.): La Gobernanza y sus enfoques (Serie Gobernanza nº1), Madrid: Delta Publicaciones (Grupo Ediberun), 2016. -“Enseñanzas del Prof. Navarro-Valls para comprender el "aggiornamento" del Ordenamiento global: aplicación a las Américas" (vol. 1 Religión y Derecho, secc. 5 Derecho Comparado p. 1719-53), en MARTÍNEZ-TORRÓN, et al.: Religión, Matrimonio y Derecho ante el siglo XXI. Estudios en homenaje al Profesor Rafael Navarro-Valls (2 vols.), Madrid: Iustel, 2013. “La International Religious Freedom Act of 1998 y la geopolítica estadounidense actual" (pp. 121-140), en CAIRO, H., PASTOR, J. (comp.): Geopolítica, guerras y resistencias, Madrid: Trama Editorial, 2006. - "Idiosincrasia de la identidad nacional y del modelo socio-cultural estadounidense según el influjo de sus elites político-jurídicas (a vueltas con la religión civil)" (pp. 265-281), en Actas del VII Congreso Español de Ciencia Política y de la Administración: Democracia y Buen Gobierno (Grupo 26: Elites de poder), 2005. - "International Religious Freedom Act of 1998 y la evolución de la geopolítica estadounidense reciente (tras el discurso religioso neoconservador)" (pp. 152-176), en Actas del VII Congreso Español de Ciencia Política y de la Administración: Democracia y Buen Gobierno (Grupo 27: Geopolítica, guerras y democracias), 2005.

Entre los capítulos en coautoría, cabe destacar SÁNCHEZ-BAYÓN, A., FUENTE, C.: “Del Poder y lo Sagrado en Occidente: Velos y Falsificaciones (arte crítico y comparado aplicado a sus principales textos político-jurídicos y protocolarios" (p. 265-312), en DÍAZ, J., ESCANERO, P.: El texto de arte. Instrucciones de uso, Porto: Ed. Sindéresis, 2017. SÁNCHEZ-BAYÓN, A., 
SÁNCHEZ, S.: “Glocal Politics and Law: why scholars do not understand each other and what are the veils of confusion" (Chapter 2 p. 25-53), en MANZANERO, D., et al. (edits.): Philosophical Changes of Plurality in a Global World, Cambridge: Cambridge Scholars Publishing, 2014, et al.

Entre los artículos en revistas ISI (Scopus, SJR, SciELO, etc.), se citan los siguientes: SÁNCHEZ-BAYÓN, A.: “Estudio de la idiosincrasia estadounidense desde su Teología política y Ciencias Eclesiásticas" (p. 165-204), Estudios Eclesiásticos, v. 93, nº 364, 2018. - “Revelaciones conceptuales y lingüísticas de la posglobalización: Retos de construcción moral de la sociedad del conocimiento y aportes del humanismo hispánico" (pp. 411-458), en Carthaginensia. Revista de Estudios e Investigación (vol. XXXIII, nº. 64), 2017. - "Prisma holístico para una teoría social posglobalizatoria: papel de la religión y su relación con el resto de esferas sociales" (pp. 675-96), en Cauriensia - Revista Anual de Ciencias Eclesiásticas-Ftad. Teología de Cáceres (vol. XI), 2016. - "Régimen jurídico del factor religioso en EE.UU.: teoría y praxis relativa a los ministros de culto y las confesiones" (pp. 313-340), en Cauriensia. Revista Anual de Ciencias Eclesiásticas Instituto Teológico de Cáceres (UPSA) - Universidad de Extremadura (vol. IX), 2014. - "Freedom of religion at large in American Common Law: a critical review and new topics" (pp. 35-72), en Journal for the Study of Religions and Ideologies, Univ. Babes-Bolyai-Rumanía (vol. 13, issue 37), Spring 2014. - “Historia, Historiología e Historiografía de los Estudios Interculturales en EE.UU." (pp. 147-57), en Revista Banda de Moebius, Univ. Chile (nº 48), ene. 2014. - "Examen de las principales fuentes e instituciones originarias de Derecho canónico pluriconfesional: Una historia crítica para la revelación de falacias y fundamentos" (pp. 605-637), en Revista de Derecho-Valparaiso/Revista de Derecho 
de la Pontificia Universidad Católica de Valparaiso (nº XLI), 2ํㅗㄴ Semestre 2013. “Innovación docente en Ciencias Eclesiásticas y Jurídico-Sociales: estudio crítico y comparado" (pp. 317-349), en Cauriensia - Revista Anual de Ciencias Eclesiásticas (vol. 8), 2013. - “Cómo se aprende Derecho Eclesiástico del Estado en los Estados Unidos de América y su jurisprudencia: los otros estudios de casos menos conocidos" (pp. 1-43), en Revista Jurídica de la Universidad Bernardo O'Higgins Ars Boni et Aequi (vol. 9, no 2), nov. 2013. - "Regulación sobre ministros de culto y organizaciones religiosas en los Estados Unidos: estado de la cuestión y evaluación de las últimas décadas" (pp. 103-141), en Revista Jurídica de la Universidad Bernardo O'Higgins Ars Boni et Aequi (vol. 9, no 1), junio 2013. “Religión, Política y Derecho en las Américas del nuevo milenio" (pp. 39-104), en Revista Jurídica de la Universidad Bernardo O'Higgins Ars Boni et Aequi (vol. 8, no 1), enero 2012. - “Historia de la Comunicación Social Estadounidense a través de sus Movimientos Religiosos" (pp. 199-223), en Historia y Comunicación Social (vol. 13), junio 2008. - "Comunicación y Geopolítica estadounidense actual: de IRFA al Choque de Civilizaciones" (pp. 173-198), en Historia y Comunicación Social (vol. 11), junio 2006. - "Revitalizaciones religiosas postmodernas en América y sus riesgos para la democracia y los derechos humanos" (pp. 1-23), en Revista General de Derecho Canónico y Derecho Eclesiástico del Estado-Iustel (n ${ }^{\circ}$ 11), mayo 2006. - “La religión civil estadounidense: análisis de la configuración de la realidad socio-cultural y su identidad social" (pp. 1-36), en Revista General de Derecho Canónico y Derecho Eclesiástico del Estado-Iustel (nº 10), febrero 2006. "La libertad religiosa en el Sistema Interamericano de Derechos Humanos" (pp. 1-62), en Revista General de Derecho Canónico y Derecho Eclesiástico del Estado-Iustel (n⿳⺈ 6), octubre 2004. 
En coautoría, sírvase a consultar SÁNCHEZ-BAYÓN, A., et al.: “Una historia filosófica de la identidad estadounidense: Balance de propuestas y su crisis actual", en Bajo Palabra (II Época), no 18, 2018, p. 209-36. - "Historia cultural estadounidense desde el factor religioso: fallos de Americaness y sus velos" (pp. 627-59), en Cauriensia - Revista Anual de Ciencias Eclesiásticas-Ftad. Teología de Cáceres (vol. XII), 2017. - “Vindicatio Historia Philosophiae: estudio de caso de los programas culturales estadounidenses", en Bajo Palabra (II Época), no 17, 2017, p. 457-76, et al. Con el director, vid. SÁNCHEZ-BAYÓN, A., VALERO, J.: “Comunidad ahmadía del Islam: ¿interlocutor en el diálogo OrienteOccidente?" (pp. 767-78), en Cauriensia - Revista Anual de Ciencias EclesiásticasFtad. Teología de Cáceres (vol. XII), 2017.

Otros artículos de relevancia, sólo que publicados en revistas de menor indexación (v.g. Latidex, indiceH Google Scholars, MIAR, CARHUS) son: SÁNCHEZ-BAYÓN, A.: "Revelaciones sobre los padres fundadores estadounidenses y su legado en materia de relaciones Iglesia-Estado, libertad religiosa y asistencia socio-religiosa" (p. 383-438), Anuario de Derecho Eclesiástico del Estado-Ministerio de Justicia (nº33), 2017. - “Raíces de la teología política estadounidense, su reconocimiento iuseclesiástico y su impacto idiosincrásico: estudio de caso de la religión civil" (p. 599-652), Anuario de Derecho Eclesiástico del Estado-Ministerio de Justicia (nº33), 2017. - “Evolución y evaluación de la ciencia iuseclesiasticista en los EE.UU." (p. 637-729), en Anuario de Derecho Eclesiástico del Estado - Ministerio de Justicia (vol. XXXI), 2015. - “Régimen jurídico estadounidense de las organizaciones religiosas y sus miembros" (pp. 221-51), en ICADE-Revista Cuatrimestral de las Facultades de Derecho y Ciencias Económicas y Empresariales (n⿳089), sept. 2013. - “Religión, Cultura y 
Comunicación Social en la Historia de la universidad estadounidense: de Church-State \& American Studies a Cross-Cultural Studies" (pp. 6-28), en Compé, Revista Científica de Comunicación, Protocolo y Eventos, UCJC (nº 2), dic. 2013. - "El Derecho Eclesiástico en las universidades estadounidenses" (pp. 229-265), en Revista Española de Derecho Canónico (vol. 70, nำ171), junio 2013. - “Conocer y gestionar las esferas sociales en la globalización: de las religión, la política y el derecho en las Américas del nuevo milenio" (pp. 103-146), en ICADE-Revista Cuatrimestral de las Facultades de Derecho y Ciencias Económicas y Empresariales ( $\mathrm{n}^{\mathrm{0}}$ 81), sept.-dic. 2010. - “Universalizing the Human Right to marry" (pp. 3-4 y 26), en Diversity and Distinction Harvard's Common Ground (vol. 8, nº 3), Spring 2003. - "Derecho y Religión en Estados Unidos de Norteamérica: Análisis de su relación desde diversos enfoques" (pp. 32-36), en Zalacaín Harvard Journal of Ibero-America (vol. I, no 5), Fall 2002. - “La viabilidad de la enseñanza del Derecho Eclesiástico del Estado en la Universidad de Harvard" (pp. 13-18), en Zalacaín, Harvard Journal of Ibero-America (vol. I, no 5, copyright@2002zalacain), Fall 2002; (pp. 1-7) en Documentos y Doctrina (monografía no. 28), septiembre 2002, et al.

En coautoría, se destaca especialmente COLL, A., SÁNCHEZ-BAYÓN, A.: “The Federal Legal Framework for Religion: freedom of religion and church-state relations in the United States" (pp. 253-280), en Derecho y Religión (vol. VIII), septiembre 2013. FUENTE, C., CAMPOS, G., CORTINA, C., SÁNCHEZBAYÓN, A.: “De l'localisme a la universalitat via Protocol i maridatge de conceptes soci-religiosos" (pp. 31-54), en Journal of Sociology and Theory of Religion-JSTR Loyola Univ. E Univ. Valladolid (vol. 6), 2017. GONZALEZ, M., SÁNCHEZ-BAYÓN, A.: “Libertades fundamentales en las Américas: devenir de la libertad religiosa en América Latina, los Estados Unidos de América y el 
Sistema Interamericano" (pp. 107-126), en Revista Jurídica-Universidad Autónoma de Madrid (no 14), 2006. SÁNCHEZ-BAYÓN, A., et al.: “Revelaciones sobre la religión civil estadounidense: influjo en su configuración nacional y crisis postglobalizatoria" (pp. 1-29), en Journal of Sociology and Theory of Religion-JSTR Loyola Univ. E Univ. Valladolid (vol. 6), 2017. - “¿Revitalización o inhabilitación religiosa en la realidad social posglobalizada? El caso estadounidense y sus problemas" (pp. 1-27), en Journal of Sociology and Theory of Religion-JSTR Loyola Univ. \& Univ. Valladolid (vol. 7), 2018, et al.

En coautoría con el director, vid. SÁNCHEZ-BAYÓN, A., VALERO MATA, J., LEÓN FLORIDO, F.: "A History of American Religious Factor according to the US Cultural Studies: a sociological \& cultural approach from colonies to globalization" (pp. 84-117), en Journal of Sociology and Theory of Religion-JSTR Loyola Univ. \& Univ. Valladolid (vol. 6), 2017, et al.

c) Otras aportaciones: edición del vol. VI de la Revista Derecho y Religión (DeltaIMDEE, UAM) "Civil religión in the United States of America" (con las intervenciones de profesores estadounidenses como CANIPE, DAVIS, FLOWERS, LINDER, LIPPY, PIERAD, SMITH, etc.). Edición y coautoría (junto con el Prof. PELÁEZ) del Diccionario de Canonistas y Eclesiasticistas Europeos y Americanos. Tomo I, Saarbrücken: LAP LAMBERT Academic Publishing GmbH \& Co./EAE, 2012. "Idiosincrasia de la identidad nacional y del modelo sociocultural estadounidense según el influjo de sus elites político-jurídicas (a vueltas con la religión civil)" (pp. 265-281), en Actas del VII Congreso Español de Ciencia Política y de la Administración: Democracia y Buen Gobierno (Grupo 26: Elites de poder), 2005. "International Religious Freedom Act of 1998 y la evolución de la geopolítica estadounidense reciente (tras el discurso religioso neoconservador)" 
(pp. 152-176), en Actas del VII Congreso Español de Ciencia Política y de la Administración: Democracia y Buen Gobierno (Grupo 27: Geopolítica, guerras y democracias), 2005.

\section{Nota de idoneidad del candidato}

Para acometer el presente proyecto de investigación (iniciado en la década de 2000), este doctorando ha recibido diversas ayudas (v.g. becas MEC y UCM), siendo crucial el respaldo de las siguientes instituciones: a) International School of Events and Communication Management (ISEMCO-URJC y Universidad del Atántico MedioUNIDAM); b) Instituto Superior de Comunicación y Eventos (ISCE); c) Instituto Superior de Protocolo y Eventos (IsPE).

En cuanto a la preparación, para afrontar este estudio, cabe destacar la siguiente relación de apoyos a la formación y la investigación: a) cursos especializados (cursos de doctorado en la Univ. Complutense de Madrid-UCM, más Oxford Univ.; posgrado en Harvard, DePaul, Baylor, et al., vid. supra figura 8); b) acceso a grandes bases de datos y documentación (v.g. WestLaw, ISOC, Proj. Gutenberg, Avalon Proj.); c) estancias en universidades estadounidenses con centros punteros (v.g. J.M. Dawson Institute of Church-State Studies-Baylor Univ., Center for Church-State Studies-DePaul Univ., Center for Religious Liberty-MHBU); d) entrevistas en profundidad a prestigiosos especialistas (v.g. en Harvard a los profesores MANSFIELD, DONAHUE, etc.; en DePaul a SHAMAN, MOUSIN, et al.; en Baylor a PAYNE, DANIEL, MARSH, y otros; en MHBU a Davis); e) manuales y códigos (v.g. Manual de Sociología Jurídica Estadounidense: del poder, lo sagrado y la libertad en 
Occidente, Madrid: Delta, 2008; Derecho Eclesiástico del Estado en las Américas, Madrid: Delta, 2009) y publicaciones científico-académicas de impacto (v.g. La Modernidad sin prejuicios: la religión en la vida pública estadounidense -3 vols.-, Madrid: Delta, 2008-13; “Historia de la Comunicación Social Estadounidense a través de sus Movimientos Religiosos", en Historia y Comunicación Social, vol. 13, junio 2008), vid. Fuentes de consulta; f) docencia en Historia y Filosofía Social (v.g. Historia del Derecho y las Instituciones en Univ. Europea de Madrid-UEM, Univ. Camilo José Cela-UCJC; Filosofía Política en ICADE-UPCO); et al.

Figura 8.- Formación especializada sobre la materia

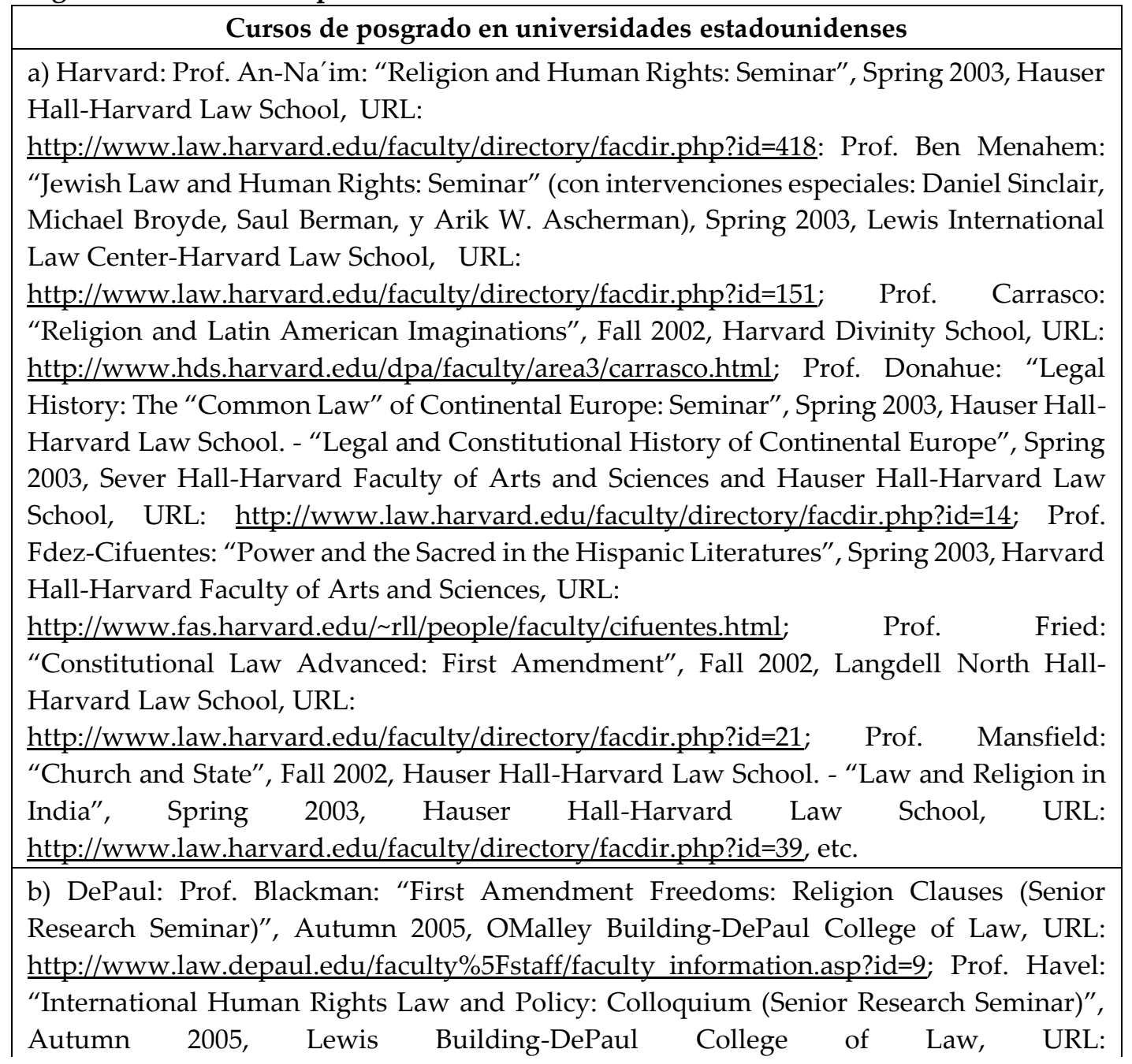


http://www.law.depaul.edu/faculty\%5Fstaff/faculty information.asp?id=28; Prof. Shaman: "First Amendment Freedoms: Freedom of Speech/Press (Senior Research Seminar)", Autumn 2005, OMalley Building-DePaul College of Law, URL: http://www.law.depaul.edu/faculty\%5Fstaff/faculty information.asp?id=48, etc.

c) Baylor: Prof. Payne: "American Civil Religion", Fall 2006, Carroll Library-CHS Baylor University, URL: http://www.baylor.edu/church state/index.php?id=34818; Prof. Marsh: "Seminar in Religion, Politics, and Society", Fall 2006, Carroll Library-CHS Baylor University, ídem; Prof. McDaniel: "Church-State in the U.S.", Fall 2006, Carroll LibraryCHS Baylor University, ídem; Prof. Daniel: "Seminar on Church-State Relations in the Modern World", Fall 2006, Carroll Library-CHS Baylor University, ídem.

\section{Cursos de doctorado en universidades españolas}

Dpto. Derecho Eclesiástico e Instituto de Derecho Comparado de UCM (2000-02); Cátedra Hispano-Británica UCM-Oxford University "A Theory of Law (by Prof. J. Raz)" por Instituto de Derechos Humanos-UCM (enero-junio 07).

Otros cursos de especialización en diversas universidades

Prof. González Cruz (Profesor y Director de Relaciones Internacionales de la Universidad de Huelva): "Religión y conflictos bélicos en Iberoamérica (S. XV-XIX)", agosto 2007, en Univ. Internacional de Andalucía-Sede La Rábida; Prof. Subirats (Profesor de Filosofía y Literatura en New York Univ.): "Teoría crítica y las crisis de la era industrial”, jun-jul. 2006, en Univ. Internacional Menéndez Pelayo, VVAA. (Catedráticos de Sociología y CC. Política, UCM): “Religiosidad y política en la sociedad contemporánea", jun. 2005, en El Escorial-UCM; Prof. Fontana (Profesor Emérito, Universidad Ponpeu Fabra): "Las promesas frustradas: el mundo entre 1945 y 2001", agosto 2003, en Univ. Internacional Menéndez Pelayo; Prof. Carrillo Salcedo (Catedrático de Derecho, Universidad de Sevilla): "Violencia, orden internacional y construcción de la paz en un mundo convulso", agosto 2002, en Univ. Internacional Menéndez Pelayo; Prof. Fusi (Catedrático de Historia Contemporánea, UCM): "Claves históricas del mundo contemporáneo", nov. 2001-ene. 2002, en el Colegio Mayor Universitario Isabel de España-UCM, etc.

Fuente: elaboración propia (SÁNCHEZ-BAYÓN, 2007 y 16).

Para completar la investigación (en especial, en la parte idintitaria, de Relaciones Atlánticas y de Sociología aplicada), procurando además, la consecución para esta tesis de la mención de doctorado internacional (art. 14 RD 99/2011), no sólo se ha continuado con las estancias de investigación en DePaul y en Baylor, sino que también se han realizado una estancia prolongada en la Escuela de Estudios Sociales del Instituto Politécnico de Braganza (Portugal) -agradeciéndose la amabilidad y 
colaboración permanente brindada por todos, especialmente, por los integrantes del Departamento de Ciencias Sociales, a cargo de la Prof. Dra. M.N. MATEUS-.

Igualmente, ha sido clave el apoyo brindado por la Facultad de Educación en Palencia-UVA y de la Escuela Internacional de Doctorado en Valladolid-UVA. Y sobre todo, la magnífica labor de dirección del Prof. Dr. J.A. VALERO-MATAS y del Prof. Dr. P. GARCÍA COLMENARES. 
Sociología de las Relaciones Socioculturales Nortatlánticas (...) American civil religion - A. Sánchez-Bayón 


\title{
Parte de Desarrollo General:
}

\section{FUNDAMENTOS SOCIOCULTURALES DE LA RELIGIÓN CIVIL}

\author{
(su recepción trasatlántica y su Americaness) ${ }^{67}$
}

La religión civil, puede parecer a simple vista una contradictio in terminis, que en realidad ha dado lugar a un oxímoron: no se trata de la mera unión de conceptos contrapuestos, sino que su combinación ha dado lugar a una figura plena de sentido y alcance. Gracias a la secularización moderna (que libera a la religión de la Iglesia) y su Teología política (que organiza de manera participativa las relaciones entre los fieles), se logra así una religión práctica (liberada del monopolio de élites y dogmas, además de orientada a la asistencia social: a resolver los problemas terrenales). Tal novedosa religión práctica, resulta operante conforme a unas reglas de libre competencia (cada cuál decide cuánto involucrarse, según el nivel de salvación que desee, y con respeto a los demás). De tal suerte, comienzan a convivir las religiones tradicionales establecidas (hierocráticas y relacionadas con el poder civil) y recibidas (v.g. judíos, católicos, protestantes, ortodoxos), con la recién conformada ACR (basada en un panteísmo colector, para la integración social): en un sistema de plurilealtades o multi-identidades, se puede ser un judío de Rhode Island, un católico de Maryland, un budista de California, un mormón de Utah, etc., pero en última instancia, todos convergen en la misma creencia: I'm American (soy estadounidense).

\footnotetext{
${ }^{67}$ Vid. infra notas 3 a 5, 11, 16, 24 y 55, más p. 126 ss.
} 
Para comprender mejor, es necesario revisar el origen y desarrollo de dicha figura (ACR), que en la actualidad incluso ha alcanzado la condición de metámero (por ser un poderoso conector de factores y esferas sociales, además de condensador de capital socio-cultural, logrando reproducir de manera muy fidedigna la compleja y voluble realidad social, sin incurrir en un alto coste al hacerlo). Téngase en cuenta que, para acometer dicho ejercicio de profundidad comprensiva, además de requerir la retirada de velos de confusión extendidos (durante las guerras culturales), urge remontarse al hito que cambió el devenir de europeos y americanos: pese a contar con la misma tradición occidental sagrada y profana, en las colonias americanas se combinará el racionalismo humanista de la Alta Modernidad hispánica (que de la libertas christiana pone el énfasis en la libertad) y el racionalismo protestante o profesional de la Baja Modernidad nórdico-anglosajona (que de la libertas christiana pone el acento en el modo de vida mesiánico), dándose lugar así al panteísmo de ACR. Ahora bien, para alcanzar a entender más, resulta conveniente el abordar cuestiones preliminares como qué se entiende por religiosidad en los EE.UU. (ya que la religión se ha desarrollado en un novedoso estadio de secularización moderna, facilitador de la aparición de novedosas manifestaciones -tal como explicara James (uno de los padres del pragmatismo)-), y cuál ha sido su Teología política de partida (centrada en la organización social de un pueblo predestinado y/o mesiánico), lo que ha permitido la formulación e implementación de una categoría de integración social de multitudes como es ACR (generando con ello una idiosincrasia: el ser propio estadounidense -relacionado con los europeos, pero diferente de ellos-).

En consecuencia, a continuación, se va a ofrecer una visión sintética del influjo del factor religioso en la normalización estadounidense (en su aparente all that jazz o miscelánea de $\mathrm{ACR}$ ), prestándose especial atención a las bases político- 
jurídicas, desde el periodo fundacional hasta la globalización (vid. supra cap. 4). Seguidamente, se aborda cómo la religión, recibida e implementada conforme a su novedoso estadio secular (más centrado en la praxis de asistencia socio-religiosa, que en el dogma divino), permitió que EE.UU. naciera y se erigiera como gran potencia hegemónica occidental (vid. supra cap. 5 y 7). Dicha cuestión habilita además para aclarar el origen mismo del Americaness (la estadounidización o el hacer estadounidense algo). Por último, se acomete una revisión de cuestiones fundamentales de ACR (vid. supra cap. 6 y 7), antes de proceder al estudio de su tópica en la Parte de desarrollo especial. 
Sociología de las Relaciones Socioculturales Nortatlánticas (...) American civil religion - A. Sánchez-Bayón 


\title{
4.- RELIGIOUS FACTOR IN USA AND ITS IDIOSYNCRATIC IMPACT AND NORMALIZATION:
}

\author{
ROLES, RULES E INSTITUTIONS OF AMERICAN ORDER ${ }^{68}$
}

This paper offers a sociological and cultural global vision (fixing Cultural Studies, Sociology of Religion, Legal Sociology, etc.) about the American religious factor and its dimensions in various frameworks (i.e. religious liberty, Church-State relations, welfare state \& solidarity). With this aim in mind, it begins with a brief notion of the evolution of religious issues, from colonial Sunday regulation or the Blue Laws, up to current regulation on freedom of religion and non-discrimination. Also, this paper offers a systematic set of diverse legal sources (i.e. Executive orders and rulings, Legislative statutes, Judicial cases and resolutions). This paper also evaluates the allegedly paradoxical policies and regulations referring to this issue during two previous presidential Administrations, those of CLINTON and G.W. BUSH.

\footnotetext{
68 Vid. SÁNCHEZ-BAYÓN, A.: "Freedom of religion at large in American Common Law: a critical review and new topics" (pp. 35-72), en Journal for the Study of Religions and Ideologies, Univ. BabesBolyai-Rumanía (vol. 13, issue 37), Spring 2014. - "Global System in a Changing Social Reality: How to Rethink and to study it" (p. 196-209), en Beijing Law Review (no 5), 2014. SÁNCHEZ-BAYÓN, A., et al.: "A History of American Religious Factor according to the US Cultural Studies: a sociological \& cultural approach from colonies to globalization" (pp. 84-117), en Journal of Sociology and Theory of Religion-JSTR Loyola Univ. \& Univ. Valladolid (vol. 6), 2017. "The Federal Legal Framework for Religion: freedom of religion and church-state relations in the United States" (pp. 253-280), en Derecho y Religión (vol. VIII), septiembre 2013. - "Glocal Politics and Law: why scholars do not understand each other and what are the veils of confusion" (Chapter 2 p. 25-53), en MANZANERO, D., et al. (edits.): Philosophical Changes of Plurality in a Global World, Cambridge: Cambridge Scholars Publishing, 2014. Así como Chapter 11. A critical review of American religion \& its influence in the U.S. development: from tolerance to novus ordo seclorum of liberty, en tesis Secularización moderna y Teología política estadounidense... op. cit. Also, see notes 3 a 5, 11, 16, 24 y 55, \& p. 126 ss.
} 


\section{1.- A CRITICAL REVIEW: REVELATIONS ON FAKE BELIEFS}

There are many foreign studies based on several wrong premises about the USA in the field of Political and Constitutional Law, or the area of Ecclesiastical Law/Church-State Studies, and about its culture (lato sensu -including political and legal institutions-). They are written for the most part by Continental European authors), and they make it difficult to properly conduct an analysis and obtain a model. The most common mistakes committed by Continental authors are the following:

a) Prejudice 1: wrongly assuming that most American people are Protestant and, consequently, guide their lives by a professional logic. WEBER was the author who spread this explanation in Continental Europe in his popular book The Protestant Ethic and the Spirit of Capitalism. According to this premise, education in the USA should mainly be professionally oriented right from the beginning in order to develop specific work skills. Nevertheless, this is not the case; this is more likely to be an ethnocentric mistake on the part of Continental Europe people, who do indeed educate their future generations in this way. In the USA a personalized education (a broad scope of selection) is predominant (in the academic world). In addition, this system is based on mature knowledge (not memorization), and on critical reflection in order to learn to be resolute and diligent in any social aspect, not only in the professional sense. This evaluation was established due to Pragmatism ${ }^{69}$. This pragmatism has favored the broadening of the educative method in the case method, of which some examples

\footnotetext{
${ }^{69}$ Pragmatism is the most relevant native philosophical current in the USA; see note $31 \& 509$.
} 
will be given in this paper in order to understand how an American Jurist reasons.

b) Prejudice 2: There is a mystifying presumption that the American model is a model of complete independence between Church and State regarding a total freedom of religion, which is an over-simplification of a complex reality. Thanks to this prototypical secularization, in the USA there is a space between religion and policy, in two different social spheres. This, however, does not imply independence, only separation (a definition of competences). Also, this model could be described as an implementation of a multifaceted system of accommodation, based on certain principles, and each generation has to reinterpret those principles and this model to adjust the Legal System to its circumstances. In the same way, the freedom of religion is still not total, because public powers have the constitutional commitment to protect and to promote the free exercise of religious liberty and non-discrimination, and other associated rights, and this is a continuous mission. Also, in the last two (Presidential) Administrations (CLINTON and G.W. BUSH), there are many examples of violations of this freedom and its associated rights and certain positive discrimination measures have been taken at both extremes (vid. supra case study).

c) Prejudice 3: Another kind of legal misunderstanding is the extreme oversimplification of American Common Law, which is reduced to the (federal) Constitution and some Case Law, despite the many sources that exist in the US Legal System. Consequently, another mistake (associated with the previous one) is ignorance about the special branch of the Legal System and its academic 
disciplines that are both focused on the legal dimension of the religious factor (see next point).

Figure 9.- Sources of Law \& Order in America ${ }^{70}$

\begin{tabular}{|c|}
\hline Primary or direct Sources of Law \\
\hline \\
\hline $\begin{array}{l}\text { Constitutions: } 1 \text { US Constitution, } 50 \text { Constitutions (Alabama, Alaska, Arizona, } \\
\text { Arkansas, California, Colorado, Connecticut, Delaware, Florida, Georgia, Hawaii, } \\
\text { Idaho, Illinois, Indiana, Iowa, Kansas, Kentucky, Louisiana, Maine, Maryland, } \\
\text { Massachusetts, Michigan, Minnesota, Mississippi, Missouri, Montana, Nebraska, } \\
\text { Nevada, New Hampshire, New Jersey, New Mexico, New York, North Carolina, North } \\
\text { Dakota, Ohio, Oklahoma, Oregon, Pennsylvania, Rhode Island, South Carolina, South } \\
\text { Dakota, Tennessee, Texas, Utah, Vermont, Virginia, Washington, West Virginia, } \\
\text { Wisconsin, Wyoming); and special jurisdictions (e.g. Puerto Rico). }\end{array}$ \\
\hline $\begin{array}{l}\text { Jurisprudence/Case Law ("Cases", "Reports"): a) US Federal Courts (judicial circuit: } \\
\text { United States district courts -one in each of the } 94 \text { federal judicial districts-, United } \\
\text { States court of appeals, Supreme Court of the United States), b) State Courts (judicial } \\
\text { circuit: it depends on each State, but in any case, it is similar to the Federal system. } \\
\text { Regarding several legal matters, such as Rights and Freedoms, the final Court of } \\
\text { appellation is the Supreme Court of the United States of America) }\left(^{*}\right) \text { By this means, the } \\
\text { Customary Law and General Principles are introduced, apart from the International } \\
\text { Law/Law of Nations, Religious Regulations; the paramount importance of the } \\
\text { interpretation can be observed, but this construction is suspicious . }\end{array}$ \\
\hline Regulation of the development \\
\hline $\begin{array}{l}\text { Statutory Law ("Statutes": "Public Law", "Private Law", "Act", "Bill”, "Amendment"): } \\
\text { a) Federal Laws (passed by the Congress), b) State Laws (passed by the Legislative } \\
\text { Power of each State: similar). It is compiled in the Official Codes (with or without }\end{array}$ \\
\hline
\end{tabular}

${ }^{70}$ Vid. FINE, T.: American Legal Systems: A resource and reference guide, Cincinnati: Anderson Publishing Co, 1997. HODES, W.: Legal research: A self-teaching guide, found in the Law library, Minneapolis: The National Institute for Trial Advocacy, 1998. KELSO, J.C.: Studying Law: An introduction to legal research, New York: Matthew Bender, 1990. KLEIN, D.: Legal research materials, Dubuque: Kendall/Hunt Publishing Co, 1989. KUKLIN, B., STEMPEL, J.W.: Foundations of the Law. An Interdisciplinary and Jurisprudential Primer, St. Paul, West Publishing Co., 1994. OLSON, K.: Legal information. How to find it, how to use it, Phoenix: Oryx Press, 1999. VV.AA.: Legal research illustrated. An abridgment of fundamentals of legal research, New York: Foundation Press, 1998. VV.AA.: Practical approaches to Legal research, New York: The Haworth Press, 1988. VV.AA.: Searching the Law, Arlsley: Transnational Publishers, 1999. VV.AA.: Winning research skills, New York: West Group, 1999. WREN, C.G., WREN, J.R.: The Legal research manual. A game plan for Legal research and Analysis, Rice Lake: Adams \& Ambrose Publishing, 1986. 
Executive Law ("Orders", "Rules", "Proclamations", "Regulations"): a) Federal regulation (it comes from the President of the United States and Federal agencies), b) State regulation (It comes from the Governor of each State and State agencies), c) Local regulation (Counties, Mayors' offices).

\section{Secondary or indirect sources}

Doctrine/Scholars: Handbooks/Manuals, Treatises, Restatement, etc., developed by jurists, with the sponsorship of Bar Associations; Law Reviews: edited by the Schools of Law, i.e. "Harvard Law Review"; Legal Encyclopedias, American Law Reports, etc.

Other less common: "Commercial Loose-leaf Services", "Practice guides", "Form books", "Memorandum opinion", "Amicus curia", et al.

Source: SÁNCHEZ-BAYÓN (2007 \& 16).

Hence, having observed so many erroneous prejudices, this research aims to discover the authentic relationship between Church and State, the type of protection given to freedom of religion, and how it affects in Public policies, obtaining a clear and systematic vision of the American Legal System regarding the issue at hand.

Figure 10.- Interdisciplinary areas of American Civil Church Law (ACCL) $)^{71}$

a) Constitutional Studies: This branch of the study has mainly been developed in Schools of Law, following a positive-formalist approach (First Amendment and its judicial interpretation).

b) Church-State Studies: This area has been developed in Schools of Theology and Humanities, from a philosophical-historical point of view, different from political and sociological approaches

c) Religion ands/E: This is the most recent and eclectic vision (origin of Critical \& Cultural Studies), consolidated, above all, in Schools of Humanities and Communications, and it includes new approaches, such as Geostrategic and Biopolitical ones.

d) Church-State patterns (part of Cultural Studies, above all of Latin American Studies): one of its main proponents was Prof. MECHAM (Church and State in Latin America, Chapel

${ }^{71}$ In the development of this area of study, not only Ivy League Universities are noteworthy (like Harvard, Yale or Stanford, which continue innovating in this respect), but also Universities with a confessional stamp, which aided in the research on this issue, such as the Baptist Baylor University (J.M. Dawson Institute of the Church-State Studies), the Catholic DePaul University (Center for the ChurchState Studies), the Mormon Brigham Young University (International Center for Law and Religion Studies); even think tanks have been relevant as opinion-makers and interest groups. 
Hill: University of North Carolina Press, 1934), creating a well-known school in southern USA (above all in Texas).

Source: SÁNCHEZ-BAYÓN (2007 \& 16).

\section{2.- HistORICAL \& SOCIO-CULTURAL APPROACHES:}

\section{BLUE LAWS \& COLONIAL ORDER}

Blue Laws or Sunday Laws were a kind of regulation of religious aspects during the colonial period (1604-1776) and the beginning of the national period, from the first settlements until the Civil War. It was also necessary to pass the Fourteenth Amendment. It is a diverse System, which includes different regulations (e.g. ordinances, covenants, chapters) and it covers from confessionalism (Church-State union) to preferentialism (a Church accepted by the majority and tolerant of other denominations). The Fourteenth Amendment standardized the guarantee of religious liberty and the separation of Church and State within the Union, and the Supreme Court became the highest organ of supervision.

Figure 11.- Colonial socio-cultural \& political-legal typology

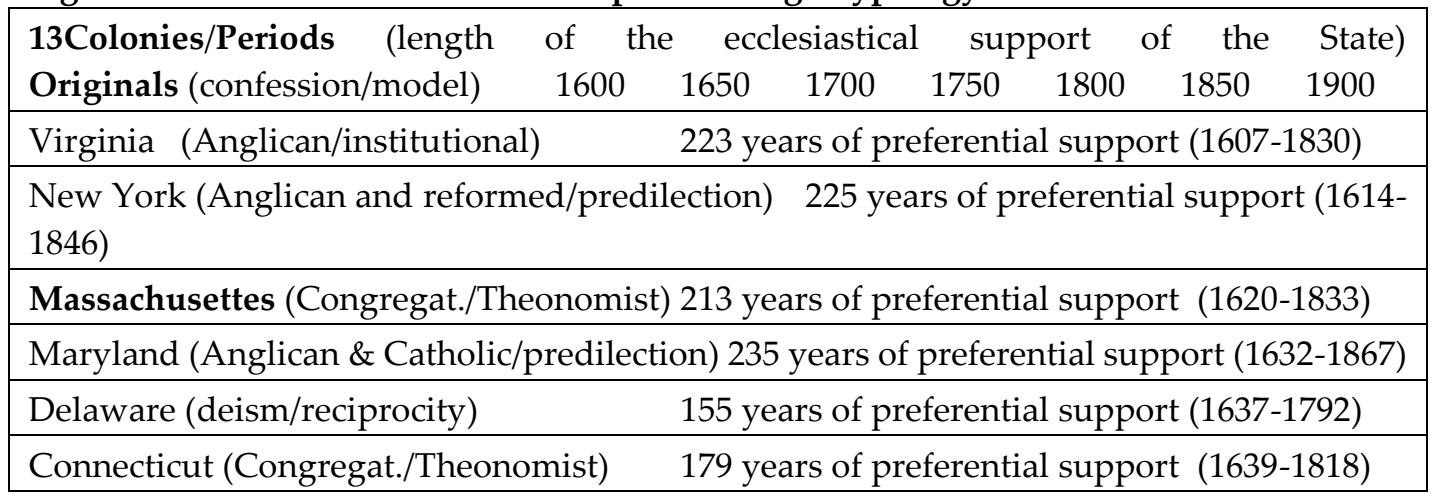




\begin{tabular}{|c|c|}
\hline Rhode Island (deism/tolerance) & 199 years of preferential support (1643-1842) \\
\hline Georgia (Anglican/institutional) & 135 years of preferential support (1663-1798) \\
\hline (Anglican/institutional) & 212 years of preferential support (1663-1875) \\
\hline (Anglican/institutional) & 205 years of preferential support (1663-1868) \\
\hline Pennsylvania (deism/tolerance) & 109 years of preferential support (1681-1790) \\
\hline New Jersey (deism/predilection) & 142 years of preferential support (1702-1844) \\
\hline
\end{tabular}

Key dates to the change: 1776(Declaration of Independence)-1787(USA Constitution)1791( $1^{\text {st }}$ Amend $)-1868$ (14 $4^{\text {th }}$ Amend.)

* The shading highlights the most polarized cases regarding models and length. Source: SÁNCHEZ-BAYÓN (2007 \& 16).

An elementary explanation of Blue Laws will be presented below with respect to the main foundational settlements in the USA. The experience of previous settlements has been useful in reaching the current Legal System (as presented in the following section). The areas mentioned are: a) Southern plantations, b) New England, c) the Middle Provinces, and d) social laboratories where the effective transition to freedom of religion will be tested.

Figure 12.- Colonial settlements development

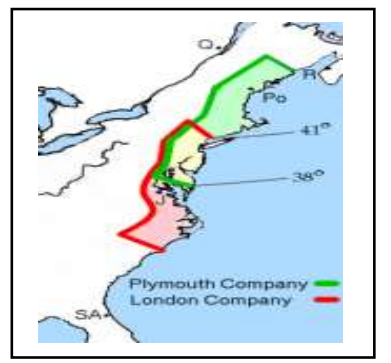

Source: SÁNCHEZ-BAYÓN (2007 \& 16). 


\section{A) Southern plantations and the stamp of Anglicanism}

\section{(official ecclesiastic recognition)}

This first area consists of four great administrative groups: the Colony and Dominion of Virginia -nowadays, Virginia, West Virginia and Kentucky; the Province of North Carolina -currently, North Caroline and Tennessee-; the Province of South Carolina and the Province of Georgia. These colonies are directly dependent on the British Crown, and therefore have an institutional model of Anglican as the state religion. An attempt at this, for example, is the admission of the Episcopalian and Presbyterian-variants as part of the power elites. Within this core foundation, the reference point is the colony of Virginia, where the first settlement was located (Jamestown, 1607), which branches into the adjoining settlements (North Carolina, 1663, South Carolina, 1670; Georgia, 1732), where changes to the model of freedom are ratified (i.e. art. 16 of Virginia Declaration of Rights, 1776). Virginia:

a) Its fundamental/constitutional rules (Grants, Charters, Statutes $\mathcal{E}$ Constitutions) ${ }^{72}$, as the first (Royal) Charter of 1606, included the mission of Christianizing and evangelizing the Indians; the second Charter of 1609 included a religious requirement (the Oath of Supremacy) ${ }^{73}$ in order to be admitted into the colony. The third Charter of 1611 maintained the Oath of Supremacy, although Catholics were exempted from taking it. Eventually, the Declaration of Rights (art. 16), proclaimed Freedom of conscience.

\footnotetext{
72 See The First Charter of Virginia (April 10, 1606), The Second Charter of Virginia (May 23, 1609), The Third Charter of Virginia (March 12, 1611), Ordinances for Virginia (July 24, 1621), Virginia Declaration of Rights (June 12, 1776), The Constitution of Virginia (June 29, 1776).

${ }^{73}$ The Oath of Supremacy is the requirement to pledge subservience to the Anglican Church, recognizing the British Monarch as its visible head.
} 
b) Among the precepts regarding religion, it is necessary to highlight the Death Penalty for Blasphemy of 1610; the Sunday Law of 1610; the Law requiring religious attendance of 1623; the Law about Sunday travel and church attendance of 1661; the Law requiring the christening of children of 1662; the Law against Quakers of 1663, the Law in order to expedite the elimination of blasphemy, the Oath (in vain), substance abuse and no compliance with Sabbath (dominical rest) of 169974; the Law of Lashes for working, travel or non-attendance of Church on Sunday of 1705; etc.

- North Carolina:

a) Amongst the fundamental Laws ${ }^{75}$, in the Charters of 1663 and 1665, North Carolina is recognized as an Anglican colony (with the maintenance of the confessional religion), though no such officinal denomination is adopted until 1711; finally came the Declaration of Rights of 1776, including Freedom of Conscience;

b) Among the above precepts regarding religion, the most salient is the Law of the observance of the Lord's sacred name, commonly known as Sunday of 174, which started a crusade against vice.

- South Carolina:

\footnotetext{
${ }^{74}$ The Sabbath is the day of rest established by the Bible and it must be dedicated to the praise of God. The problem is the controversy generated with the First Great Awakening (1740's). Even though it had come from ancient times. Because the American paradoxology, protestant confessions suffered a certain grade of Jewishism in their pursuit of Orthodoxy, which makes them transfer the traditional day of rest to Saturday. For the purposes of this paper, Sunday \& Sabbath Laws will be considered as a whole, since the important fact is that eventually a greater secularization was promoted for fundamentalist reasons, given that the calendar was divided into working days and holidays. Vid. SÁNCHEZBAYÓN, A.: La Modernidad sin prejuicios (3 vols.), Madrid: Deltal, 2008-12.

75 See Charter of Carolina (March 24, 1663), A Declaration and Proposals of the Lord Proprietor of Carolina (Aug. 25, 1663), Concessions and Agreements of the Lords Proprietors of the Province of Carolina (1665), Charter of Carolina (June 30, 1665), The Fundamental Constitutions of Carolina (March 1, 1669), The Mecklenburgh Resolutions (May 20, 1775), Constitution of North Carolina (Dec. 18, 1776).
} 
a) Among its Fundamental Laws ${ }^{76}$, once independent of the other Carolina (1729), after the Border Agreement of 1735, the Anglican Church was formally established.; finally, the Constitution of 1778 declared that Christianity as the official religion.

b) In the interim of the segregation of the Carolinas, already enjoying a certain amount of autonomy, its assembly passed the Sunday Laws of 1692 and 1712.

- Georgia:

a) Among its fundamental Laws ${ }^{77}$, the Charter of 1732, declared the Anglican Church to be the official one; in the Constitution of 1777, it is disestablished.

b) Among its mandates on religion, the most outstanding is the Law to punish vice, profanations, immorality and to observe the Sacred Name of the Lord, commonly known as Sunday of 1762, similar to North Carolina.

\section{B) New England and traces of Puritanism}

\section{(The Covenant of Grace)}

This second area is the regional group, which consists of four main territorial divisions, the Province of Massachusetts Bay (afterwards Massachusetts), the Province of New Hampshire (New Hampshire, plus Maine and Vermont), the Colony of Connecticut (Connecticut), and the Colony of Rhode Island and Providence Plantations (Rhode Island). In this environment, a Congregationalist Theonomic model of

\footnotetext{
76 See State Boundery Agreement (April 1, 1735), Constitution of South Carolina (March 26, 1776), Constitution of South Carolina (March 19, 1778).

77 See Royal Charter of Georgia (Jun 9, 1732), Constitution of Georgia (Feb. 5, 1777), Constitution of the State of Georgia (May 6, 1789).
} 
puritan confessions was originally predominant, until its total incorporation into the British Crown, when it then became a semi-institutional model. Although the first migrations are motivated by the search for recognition and tolerance, the genomic excesses (e.g. witch hunts, strict morality) generated a decline in the settlements due to explicit or tacit ostracism, which created the urgent necessity to found new settlements that were more flexible and permeable for local minorities (e.g. Baptists, Quakers ${ }^{78}$. Massachusetts is the great colonial reference for the region, since it is the place where the first settlements were established (the Pilgrims in New Plymouth in 1620 and the Puritans in Massachusetts Bay in 1629-30 -later combining in 1691). In addition, this colony established the subsequent foundational initiatives, because the purging of WINTHROP ${ }^{79}$, allowing the formation of Connecticut (Rev. T. HOOKER in 1635-36), Rhode Island (Rev. R. WILLIAMS on 1636); New Hampshire (North-Irish Presbyterians as permanent settlers in the 1630's); Maine (Nova Scotia, 1696-1713).

- Massachusetts ${ }^{80}$ :

a) In New Plymouth, the Charter of 1620 established a Theonomic model, the mandate including the conversion of the Indians, and the requirement of the Oath

\footnotetext{
${ }^{78}$ In New England, severe punishment was inflicted on Catholics, Baptists, Jews and Quakers (e.g. seizing assets, imprisonments, forced labours, hidings, and hangings). In the Boston area, after prescriptive reminders (up to three), several families were exiled, and four Quakers that did not comply with exile were eventually hanged. Cfr. WOOD, J.E., et al: Church and State in Scripture History and Constitutional Law, Baylor University Press, Waco, 1958, pp. 80 ss. PFEFFER, L.: Church, State and Freedom, Beacon Press, Boston, 1953, pgs. 65 ss.

${ }^{79} \mathrm{He}$ was elected governor up to twelve consecutive times, between 1631 and 1648, dying several months after his last election. His strict policy is a consequence of the social demands at that moment, since the population was terrified by previous experiences in other less integrated settlements that did not survive. His zeal, however, was so great that his own son had to move to New Hampshire, where he become Governor.

${ }^{80}$ See Massachusetts Constitution (March 2, 1780).
} 
of Supremacy in order to be admitted into the Colony; among its religious regulation, it is necessary to highlight severe punishment for Desecration of the Lord's Day of 1650 and 1699, The Lack of attendance to Church of 1651, the Death Penalty for idolatry, Marital Infidelity and Witchcraft of 1671, The Death Penalty for presumption of desecrating the Lord's Day of 1671, The requirement of orthodoxy for the free man of 1672, The punishment for travelling on the Lord's Day of 1682.

b) In Massachusetts Bay, the Charter of 1629 recognized natural rights, but was subject to the Oath of Supremacy; the Charter of 1691, recognized as a general principle that people were free from the Oath of Supremacy, except when holding public office. However, the Christians still discriminated against were those labeled as Papists.

c) In religious regulation, it is important to note: The regulation of Sabbath of 1629, The prosecution on religious grounds of 1630 (BAKER was punished), The exclusive right to vote for members of the Church of 1631, Court Orders to attend Church on Sunday of 1635, the Declaration of the Civil administration subject to the Divine Administration of 1636, the Death Penalty on religious grounds of 1641, the Decree of Church Attendance in 1646, the Edict of exile for heresy of 1646, the Edict of exile or Death Penalty for Catholic Priests of 1647, Edict of exile or Death Penalty for disowning the Bible of 1651, Edict of exile or Death Penalty for the Homeless Quakers of 1658, Mandate recognizing the right to vote for members of the Church of 1660, Edict of death against Quakers, only as a last resort, of 1661, etc.

- Connecticut: 
a) Among its constitutional acts ${ }^{81}$, such as the Fundamental Orders of Connecticut of 1638-39 and the Government Act of the Colony of New Haven of 1643, the Oath of Supremacy is imposed (for political representatives and free owners, respectively);

b) The most significant mandates about religion are: the Law to prevent and punish the profanation of the Sabbath or the Lord's day of 1721, and the Law for the implementation of the due observance of the Sabbath or Lord's day of 1750.

- New Hampshire:

a) Among its foundational laws ${ }^{82}$, such as the Concessions of 1629 and 1635, it is not uncommon to observe the requirement of the Oath of Supremacy and Sunday Laws, although they were more flexible than Massachusetts laws in those days.

b) Among the rules regarding religion, it is possible to identify: the Law for the better implementation and enforcement of the Lord's day of 1700, as well as the Prohibition of blasphemy of 1718 .

\footnotetext{
${ }^{81}$ See Fundamental Orders (Jan. 14, 1639), Fundamental Agreement, or Original Constitution of the Colony of New Haven (June 4, 1639), Government of New Haven Colony (1643), Charter of Connecticut (1662), Constitution of Connecticut (Oct. 5, 1818).

82 See Grant of Hampshire to Capt. John Mason (Nov. 7, 1629), Grant of Laconia to Sir Ferdinand Gorges and Captain John Mason by the Council for New England (Nov. 17, 1629), Grant of the Province of New Hampshire to John Wollaston Esq. (1635), Grant of the Province of New Hampshire to Mr. Mason (April 22, 1635), Grant of his interest in New Hampshire by Sir Ferdinand Gorges to Captain John Mason (Sept. 17, 1635), Agreement of the Settlers at Exeter in New Hampshire (1639), The Combinations of the Inhabitants upon the Piscataqua River for Government (1641), Commission of John Cott (1680), Constitution of New Hampshire (Jan 5, 1776; June 13, 1784).
} 


\section{C) Middle Provinces and the influence of reformism (social communitarianism)}

This third area is the regional bloc which consists of five original territories, the Province of New York (previously New Netherlands and, afterwards, New York and Vermont), the Province of New Jersey (New Jersey), the Province of Pennsylvania (Pennsylvania), Delaware Colony (originally, The Lower Counties on the Delaware River, today being Delaware), the Province of Maryland (Maryland). Among the abovementioned colonies, the prevailing model was of deist reciprocity, open to various denominations like the Anglican and its derivatives. The continental European Reformed and Catholics, while not being persecuted, were minorities in their home countries and went to America seeking both recognition and enrichment. The cardinal colonies in the area are, on one hand, Maryland (1634-36), and on the other, New York (founded as New Netherlands, by the Dutch Reformed Church, from 1614 to 1664 , transforming to Anglicanism by annexation after the mid-century DutchBritish Wars). From this last colony, New Jersey broke away (West New Jersey in 1676 and East New Jersey in 1683, united and autonomous in 1702) and then Delaware (founded by the Swedes in 1665, then assimilated by the Dutch and later by the British, and achieving autonomy in 1701).

- New York:

a) Among its fundamental laws ${ }^{83}$, the Real Concessions of 1664 and 1674 established the Anglican Church as the official religion until it was abolished in the Constitution of 1777 .

\footnotetext{
83 See Notification of the Purchase of Manhattan by the Dutch (Nov. 5, 1626), The Constitution of New York
} (April 20, 1777). 
b) Among its mandates about religion, the most outstanding are Laws against the desecration of the Sabbath and other immoralities of 1673 and 1695.

- New Jersey:

a) Its fundamental laws ${ }^{84}$ from the very beginning follow a model characterized by tolerance, although with certain preferences (e.g. requirement of the Oath of Supremacy for public officials) ${ }^{85}$, as is reflected by the Concession and Agreement of 1664, the Fundamental Constitution for the province of East New Jersey of 1683.

b) The regulation of religion included the Sunday Laws or Against the desecration of the Lord's day of 1683 and 1693, The law for the suppression of immorality of 1700, etc.

- Delaware:

a) Its primordial laws ${ }^{86}$ are very similar to those of New Jersey, with a tolerant approach and certain preferences (although the Oath of Supremacy is compulsory for every citizen), which may be inferred from the Charter of Delaware of 1701 and

84 See The Duke of York's Release to John Ford Berkeley, and Sir George Carteret (June 24, 1664), The
Concession and Agreement of the Lords Proprietors of the Province of New Caesarea, or New Jersey, to and
with all and every the Adventurers and such as shall settle or plant there (1664), A Declaration of the True
Intent and Meaning of us the Lords Proprietors, and Explanation of these concessions made to the Adventurers
and Planters of New Caesarea or New Jersey (1672), His Royal Highness' Grant to the Lords Proprietors, Sir
George Carteret (July 29, 1674), The Charter of Fundamental Laws, of West New Jersey, Agreed upon (1676),
Quintipartite deed of revision, between E. and W. Jersey (July 1, 1676), Duke of York's Second Grant to
William Penn, Gawn Lawry, Nicholas Lucas, John Eldridge, Edmund Warner, and Edward Byllynge, for the
soil and Government of West New Jersey (Aug. 6, 1680), Duke of York's Confirmation to the twenty four
proprietors (March 14, 1682), The Fundamental Constitutions for the Province of East New Jersey in America
(1683), The King's Letter recognizing the Proprietors' Rights to the soil and Government (1683), Surrender
from the Proprietors of East and West New Jersey, of their pretended right of Government to her Majesty
(1702), The Queen's acceptance of the surrender of Government (April 17, 1709), Constitution of New Jersey
(July 2,1776).
85 There are hundreds of examples of incipient tolerance, but the most meaningful is the Yale apostasy,
movement headed by the Presbyterian Reverend and a senior Academic at Yale, T.B. CHANDLER.
See CURRY, T.J.: The First Freedoms. Church and State in America to the passage of the First Amendment,
New York: Oxford University Press, 1986.
86 See Charter of Delaware (1701), Constitution of Delaware (Aug. 22, 1776), Constitution of Delaware (1792). 
the Law on the organization of the testimony of government employees and ministers for church affairs of 1701;

b) Among its most relevant articles, it is possible to highlight the Decree against Blasphemy of 1739 and the Law to prevent the breach of the Lord's day, commonly known as Sunday of 1739 -the clarification is owing to the boom in religious awakening and the controversial issue of Sabbatarianism.

\section{D) Social Laboratories and the emergence of deism}

\section{(the vox populi/publicist)}

What differs from the previous cases is that these colonies do not have a clear physical convergence ${ }^{87}$, but are in harmony with a certain state of mind, given that here are found the milestones in the emersion of the modern conception of Tolerance, and together with this, in the subsequent goal of freedom. In the first place, Maryland is a colony founded through a real commitment ${ }^{88}$ by an Irish Catholic aristocrat, C. CALVERT (Lord Baltimore) circa 1629-34, in the east of Virginia, to make room for persecuted Christians. Secondly, Rhode Island is a colony south of Massachusetts established between 1634 and 1636 by the Congregationalist and allegedly Baptist reverend-, ${ }^{89}$, R. WILLIAMS, in his escape from the

\footnotetext{
${ }^{87}$ It is true that there is a convergence in latitude, but geographically, Rhode Island is considered part of the Northeast, Pennsylvania in the center and Maryland in the South.

${ }^{88}$ Charles I, being Secretary of State (in 1625), grants to G. CALVERT, Irish House of Lords, the exploitation of lands in America. But it will be his son who will receive the Charter in 1632 that consolidates the first settlement in 1634.

89 WILLIAMS and JEFFERSON (the former a Congregationalist, and the latter an Episcopalian) introduced the metaphor of the wall of separation as part of their separatist Church-State speech, which
} 
WINTHROP "purges" (the tolerance pot). Thirdly, Pennsylvania, because a noble $\operatorname{debt}^{90}$, is founded to the west of Delaware by Quaker leader, W. PENN, who wanted to house all persecuted Quakers. Overall, the three aforementioned groups show the same firm will of their founders to house those people persecuted for the dictates of their conscience (the holly experiment). This started a process of emancipation of those persecuted people obliged to flee with respect to majority groups, and of Civil law with respect to religious law (the above-mentioned major religions no longer maintain these public stances). Nevertheless, it is necessary to specify that in the case of Maryland, this step is the consolidation of the idea of modern tolerancepredominating the negative burden of resignation. Subsequent situations in Rhode Island and Pennsylvania are an example of a trial and error method of transit to modern tolerance, in its positive sense and characterized by greater respect for others, close to the modern concept of freedom.

- Maryland:

a) Among the basic rules ${ }^{91}$ clearly passed to fix a system of coexistence and assure social tolerance, what stands out is the Charter of Maryland in 1632 and the Instructions to settlers by Lord Baltimore in 1633 (in which Lord Baltimore suggests to Catholics that they should not cause offence to their Protestant neighbors);

b) Among the most popular mandates, projected by the Law on religion, the Act of Tolerance (1649), could be highlighted (which only takes into account tolerance

\footnotetext{
became the basis of current Baptist doctrine. Actually, it seems to be a confusion of interests to legitimize their positions.

${ }^{90}$ Because the Duke of York's debts to Admiral/Commander PENN, Charles II granted a Charter to W. PENN (the Admiral's son and one of the most relevant Quaker leaders) in 1681.

91 Vid. Charter of Maryland (1632), An Act Concerning Religion/Maryland Tolerance Act (1649), Constitution of Maryland (Nov. 11, 1776), Amendments to the Maryland Constitution (1776).
} 
among Christians and which includes severe punishments for blasphemy and the lack of compliance with religious holidays), along with the Law for the observance and sanctification of the Lord's Day, also known as Sunday in 1696, and the Law to punish blaspheming, perjury, alcoholics and those not observant of the Sabbath in 1723, etc.92.

-Rhode Island:

a) Its fundamental laws ${ }^{93}$ are oriented toward social tolerance and the protection of freedom of conscious (the oath of Supremacy is not required of the citizens), as can be observed in the Covenant of Providence in 1636, the Agreement of the Plantation of Providence in 1640, the Agreement of government of Rhode Island in 1641 and the Charter of Rhode Island and Plantations of Providence in 1663.

-Pennsylvania:

a) Among its fundamental laws ${ }^{94}$, such as the Charter of Pennsylvania in 1681 and the Agreement of government of Pennsylvania in 1682, and despite philosophical tolerance similar to that of Rhode Island, Pennsylvania is stricter regarding formalities and religion, demanding the conversion of all Indians, the oath of supremacy to hold public office and to be a citizen and the observance of the Sabbath; this was probably as a consequence of trying to avoid external controls and trying to guarantee free development for the persecuted Quakers.

b) Among its more outstanding precepts, there are two that are especially

\footnotetext{
${ }_{92}$ It is also important to underline the special status attributed to the Jesuits- Maryland was the operating center of their subsequent work in the USA, above all in the academic world-, thanks to the letters between the Jesuit Priest T. COPLEY and Lord Baltimore Vid. CURRY, T.J.: The First Freedoms. Church and State in America to the passage of the First Amendment, Oxford University Press, New York, 1986.

${ }_{93} \mathrm{Vid}$. Constitution of Rhode Island (Nov. 5, 1843).

${ }^{44} \mathrm{Vid}$. Constitution of Pennsylvania (Sept. 28, 1776).
} 
representative of the model, the Great Law or the Charter of Penn and the Laws of Pennsylvania in 1682 (where freedom of conscience is allowed, although an oath of supremacy and the consecration of Sunday are obligatory), and the Law of restriction of work the first day of the week in 1705. Taking into consideration the First Awakening and the problematic Sabbatarianism for most Protestants, it made the week start on Sunday.

To sum up, the three cases are examples of the trial and error method in the long evolution toward modern religious tolerance. The special feature was that, in the case of Maryland, the emphasis was on the achievement of coexistence, while on the other hand, it was freedom of conscience that was of primary importance in Rhode Island and Pennsylvania. In any case, these three cases have been very useful in driving forward the political process of emancipation of the individual with respect to a group, and of the political and civil community versus the religious and cultural one. 


\section{3.- FUNDAMENTALS OF THE OFFICIAL ORDER}

\subsection{1.- CONSTITUTIONAL LEVEL}

In what sense is the US model peculiar? How could we explain it? In Continental Europe, religion was used as an instrument by the public powers to create national identities and expel dissidents. In contrast, in the new-born USA, it is very clear from the very beginning that it is not a question of preserving the State from religion, as has been argued of late by socialism. To the contrary, religion is popular patrimony and, because of this, religious allegiance cannot be obligatory to hold public office. Thus, art. VI of the U.S. Constitution breaks with the colonial tradition of demanding the Oath of Supremacy ${ }^{95}$. What is more, to make things even clearer, one year after the Constitution was passed, its writers started to work on a Declaration of Rights with the form of ten constitutional amendments (elaborated in 1789 and passed in 1791). The First Amendment starts with the recognition, protection and promotion of the freedom and Autonomy of religion. This point is so important that it is endowed with a double clause in its regulation: a) the establishment clause, which promotes non-religious "officialisation", thus guaranteeing the autonomy, plurality and popularity of religion; b) free exercise clause, by which, the public powers agree to protect the observance and promotion of religious practice as a way of strengthening interpersonal relations which insure social integration. In a nutshell, there are a wide range of acts, in which the lowest

95 It is a gesture to demonstrate the overturning of the discriminatory British vestiges of submissiveness in the colonies, due to the Act of Supremacy of Henry VIII (1534) and Isabella I (1559), with their colonial versions of the Blue Laws. 
limit is the disestablishment process and the highest, the guarantee of freedom of worship, thus giving each State great discretion in the regulation of this issue (e.g. if some favor is conceded to any religious confession, it is compulsory to extend it to the rest of the confessions to maintain the condition of Legal Equality. In order to consolidate this model and avoid excessive dispersion, in 1866 The Fourteenth Amendment was passed (entering into effect in 1868), which put an end to ecclesiastic preferentialism. In addition, it established federal supervision of the issue, as a guarantee that all citizens in the USA would enjoy the same rights and freedoms in all the States of the Union.

Thus, at federal level, The Supreme Court of the USA becomes the great supervisor, not only because it has to ensure a proper interpretation of the Constitution (arts. 3 and 6), but because in addition, it has to clarify significant numbers of rulings on this matter (according to the First and the Fourteenth Amendments), there being already over three hundred consolidated rulings, although with a mercurial ratio decidendi. Nonetheless, this is not the only federal organism with competence to deal with the development of legislative and regulatory framework in this area, as we will see below.

Figure 13.- Constitutional socio-religious rules

Explicit Rules: we have to consider two precepts that expressly and substantially regulate religion, such as art. VI (religious test $\mathcal{E}$ oath) and the First Amendment (free exercise clause \& establishment clause), plus the procedural rules, which are set out in the Fourteenth Amendment (equal clause).

Implicit Rules: they could be defined as those rules that use formulas and figures of sacred western traditions (under the filter of secularization), making room for valuable transfers of legitimacy to the institutions of civil government (e.g. the Constitution becomes the sacred book of the American people). Other rules come from imitations of religious inspiration (e.g. Eighteenth Amendment). The Mentioned precepts that may be interpreted in a neofetishist way are: Preamble (People, Union-secular covenant- $\mathcal{E}$ blessings' of liberty). Art. I (impeachment-oath, Sundays excepted, Law of Nation \& contracts). 
Art. II (oath, pardon, faithfully/worship clause \& impeachment). Art. III (good behavior, witnesses $\&$ corruption of blood). Art. IV (faithfully/worship clause). Art. VII (unanimous consent $\mathcal{E}$ year of our Lord). Fourth Amendment (oath). Fifth Amendment (limb, witness against himself, property). Eighteenth Amendment (intoxicating liquors prohibited).

Tacit Rules: they are the inspirational rules of the system as a whole (vid. infra).

Source: SÁNCHEZ-BAYÓN (2007 \& 16).

Figure 14.- Main principles of the USA relational model

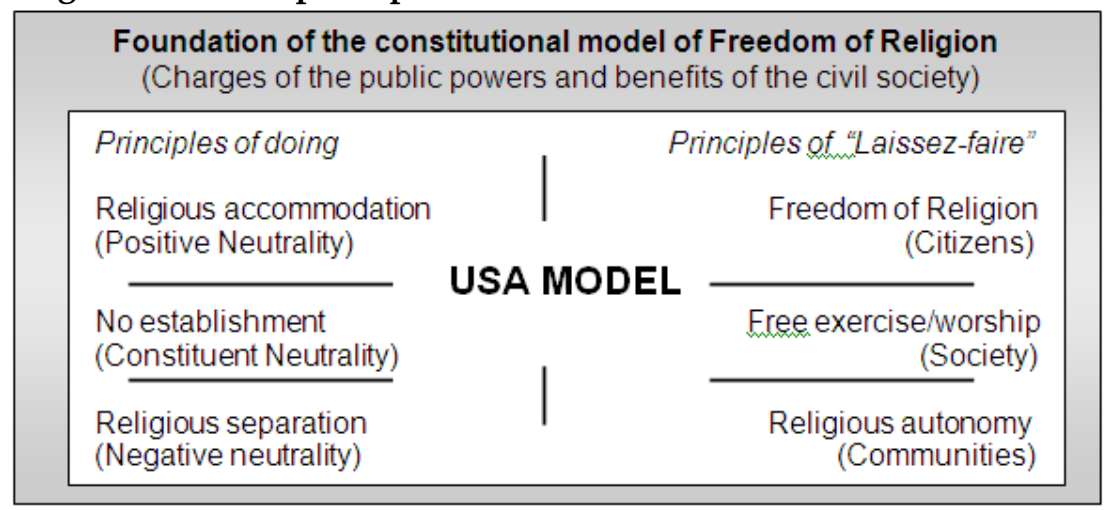

Source: SÁNCHEZ-BAYÓN (2007 \& 16). 


\subsection{2.- STATUTORY AND EXECUTIVE LAW DEVELOPMENT}

In summary, any legislative or regulatory development of the abovementioned constitutional precepts has to be in accordance with the following rules:

a) Substantially: a1) Establishment clause: it is the formulation of the disestablishment process, thus the existence of any official religion is forbidden. After the Fourteenth amendment was passed, the existence of a group of official religions was not possible, as was typical in Preferentialism. a2) Free exercise clause: public powers are obliged to remove any obstacles that prevent freedom of worship, and also have the duty to look for formulas to accommodate a sustainable separation. a3) Equal clause: It is essential to guarantee the freedom, equality and autonomy of religion in the whole country, which is a task pertaining to Federal powers. Nonetheless, in their supervision, they will have to respect the rest of the principles, so they may not develop a legislative and regulatory framework that defines religion, the internal operating rules of any denominations and/or try to equate religious organizations with other types of associations, given that this decision can only be made by the American people. a4) Ecclesiastical corporation sole: It recognizes the right of the American People to decide whether they want to inscribe their group as a religious entity or not, and it is simply with respect to the Labor and Taxation Law; in the same way, public powers are compelled to evaluate civil efficacy with regard to the internal rules of confessions, except in the case of fraud, arbitrariness or attack against public order. a5) Checks \& balances policy: It consists of a system of limitation of power through the mutual vigilance of public institutions and the requirement of citizen accountability. This way, Federal powers have to supervise the policies 
of the rest of powers (both State and Municipal) but, at the same time, Federal powers have to be vigilant of each other.

b) Procedurally: b1) Outdated regulation: They are precepts of a limited temporal nature, given their relation to public policies being enforced. They really depend on the holder of office and his/her institutional agenda, as well as the duration of the legislature and/or administration in office. b2) Dependant regulation: They are precepts that require the support of other bodies. In the case of the Acts and Bills, they only enter into force completely when they are quoted in a judicial proceeding. On the other hand, the Proclamations and Regulations are administrative acts and are not of a regulatory nature completely until Congress $^{96}$ endorses them; once this occurs, specific precepts become general rules and are applicable in similar cases. In the same way, the intention of the Courts is revealed. b3) Regulation of welfare: Most of the rules passed regarding religions are a consequence of the Social Gospel, and thus are pragmatically conceived in a secularized way as a Public and health welfare issue ( $42^{\text {nd }}$ Title of U.S. Code), and are subject to tax control $\left(26^{\text {th }}\right.$ Title, regarding Internal Revenue Code).

So far, it has been the common features of governing principles and legislative and regulatory development that have been highlighted, but there are also many differences among them. Needless to say, these are evident in sources, formalities and goals and are clearly affected by diverse areas of activity that guide the regulation:

\footnotetext{
${ }_{96}$ Remember that "Act" comes from the saying "act before the monarch", and in the USA it means "act before the Congress", and this is the correct way to introduce the Institutional agenda, giving it legal force, and converting it into Statutory Law.
} 
a) Domestic management: It has been a rich source of legislative output regarding the religious factor in the last few years: Church Arson Prevention Act of 199697; The Defense of Marriage of 199698; Bankruptcy-Religious Liberty and Charitable Donation Protection Act of 199899; Religious Land Use and Institutionalized Persons Act of 2000'00; Religious Workers Act of $2000^{101}$. However, among all these Acts, undoubtedly the most outstanding is the Religious Freedom Restoration Act of 1993. It was passed by the Clinton Administration and many of its articles were derogated by the Supreme Court in 1997.

b) Foreign management: The same as domestic management, it is generous in normative production: Extension of Immigration Deadlines for Religious Workers, Charitable Service Workers, and Paperwork Changes in Employer Sanctions of 1997102; International Religious Freedom Act of 1998103; International Religious

\footnotetext{
${ }^{77}$ Vid. PL [Public Law] 104-155, July 3, 1996, 110 Stat. 1392 UNITED STATES PUBLIC LAWS 104th Congress - Second Session Convening January 3, 1996 PL 104-155 (HR 3525) CHURCH ARSON PREVENTION ACT OF 1996.

98 Vid. PL 104-199, Sept. 21, 1996, 100 Stat. 2419 UNITED STATES PUBLIC LAWS 104th Congress Second Session Convening January 3, 1996 PL 104-199 (HR 3396) THE DEFENSE OF MARRIAGE ACT OF 1996

99 Vid. PL 105-183, June 19, 1998, 112 Stat 517 UNITED STATES PUBLIC LAWS 105th Congress Second Session Convening January 27, 1998 PL 105-183 (S 1244) BANKRUPTCY-RELIGIOUS LIBERTY AND CHARITABLE DONATION PROTECTION ACT OF 1998.

100 PL 106-274, September 22, 2000, 114 Stat 803 UNITED STATES PUBLIC LAWS 106th Congress Second Session Convening January 24, 2000 PL 106-274 (S 2869) RELIGIOUS LAND USE AND INSTITUTIONALIZED PERSONS ACT OF 2000.

${ }^{101}$ PL 106-409, November 1, 2000, 114 Stat 1787 UNITED STATES PUBLIC LAWS 106th Congress Second Session Convening January 24, 2000 PL 106-409 (HR 4068) RELIGIOUS WORKERS ACT OF 2000).

102 PL 105-54, October 6, 1997, 111 Stat 1175 UNITED STATES PUBLIC LAWS 105th Congress - First Session Convening January 7, 1997 PL 105-54 (S 1198) EXTENSION OF IMMIGRATION DEADLINES FOR RELIGIOUS WORKERS, CHARITABLE SERVICE WORKERS, AND PAPERWORK CHANGES IN EMPLOYER SANCTIONS OF 1997.

103 PL 105-292, October 27, 1998, 112 Stat 2787 UNITED STATES PUBLIC LAWS 105th Congress Second Session Convening January 27, 1998 PL 105-292 (HR 2431) INTERNATIONAL RELIGIOUS FREEDOM ACT OF 1998.
} 
Freedom Act Amendments of 1999104; Global Anti-Semitism Review Act of 2004105, which is surprising, especially taking into account that the Clinton Administration was its driving force, while at the same time promoting a greater participation of the USA in International Organizations. How is it possible to ratify the International Covenant on Civil and Political Rights (ICCPR), with its report mechanism (i.e. Report of freedom of Religion), and at the same time, constitute your own service, like the one established with the International Religious Freedom Act of 1998, which justified International interventions?

The key to understanding this atypical situation, and its apparent infringement of the above-mentioned governing principles and common features, lies in the 90's and the public policies of the CLINTON Administration. These were absolutely dichotomous -paradoxical speeches and garbage-can policy- and where there is a notable change before and after the sexual sandal. The culmination of the confusion comes with the subsequent interpretation of these previous policies by the G.W.BUSH Administration which reformulated them according to their neoconservative approach and their own interests. Again, the "rules of the game" are not respected.

104 PL 106-55, August 17, 1999, 113 Stat 401 UNITED STATES PUBLIC LAWS 106th Congress - First Session Convening January 27, 1999 PL 106-55 (S 1546) INTERNATIONAL RELIGIOUS FREEDOM ACT AMENDMENTS, 1999.

105 PL 108-332, October 16, 118 Stat 1282 UNITED STATES PUBLIC LAWS 108th Congress - Second Session Convening January 20 (S 2292) PL GLOBAL ANTI-SEMITISM REVIEW ACT OF 2004. 


\subsection{3.- JURISPRUDENCE: BETWEEN CASE LAW AND LEGAL THEORY}

It is a common error to identify American Common Law with Case Law, but the latter is only one source and branch of Law. There are others equally important, such as Executive Law (with its regulations) or Statutory Law (and its laws). Such exaltation comes from the LANGDELL method and casebooks (vid. supra). Nevertheless, there is a very deep relationship between these concepts. It is commonly noted that in order for Executive law to reach true fruition, for example, it needs to be quoted in several judicial proceedings; thus Case Law is used to foster and spread a great part of Executive Law (vid. infra).

In honor of the aforementioned American pragmatism, there is below a synthesized and systematic list of the most outstanding cases that have created the interpretative tendency on issues related to religious factors in the USA, such as: the implementation of freedom of religion and religious autonomy (of natural and juridical persons, as well as of denominations), and also the tutelage of nondiscrimination on religious grounds (idem), and other related issues. Everything is related to legal grounds and the comparative analysis is carried out while studying the following judicial decisions (nearly three hundred case studies of Case Law, systematized by date and issue) $)^{106}$. The main cases are:

\footnotetext{
106 Purportedly, the first regional cases were Van Hornes Lessee v. Dorranze (2 Dallas 304, 1795) and Calder v. Bull (2 Dallas 386, 1798); and especially People v. Phillips (New York City of General Sessions, 1813), where religious autonomy and religious communications were judged, when instructing the jury about the Seal of Confession of a Catholic priest. SÁNCHEZ-BAYÓN, A.: Estado y religión... op. cit. - La Modernidad sin prejuicios... op. cit.
} 
Figure 15.- Main cases about religion in public life

1.- Terrett v. Taylor (13 U.S. 43, 1815), Ecclesiastical property; 2.- Town of Pawlet v. Clark (13 U.S. 292, 1815), Ecclesiastical property; 3.- Trs. of Dartmouth Coll v. Woodward (17 U.S. 518, 1819), Educational religious centers; 4.- Trs. of Philadelphia Baptist Assoc. v. Hart's Ex. (17 U.S. 1, 1819), Legacies for charity; 5.- Society for Propagation of the Gospel v. Town of New Haven (21 U.S. 464, 1823), Ecclesiastical property; 6.- Beatty v. Kurtz (27 U.S. 566, 1829), Ecclesiastical property; 7.- Worcester v. Georgia (31 U.S. 515, 1832), Missionaries and Indians; 8.- Vidal v. Mayor of Philadelphia (43 U.S. 127, 1844), Legacies for charity; 9.- Permoli v. Municipality no 1 (44 U.S. 589, 1845), Freedom of religion (FR) and Federalism; 10.- Hallett v. Collins (51 U.S. 174, 1850), FR and Family Law; 11.- Gaines v. Relf (53 U.S. 472, 1852), FR and Family Law; 12.Goesele v. Bimeler (55 U.S. 589, 1852), Ecclesiastical property; 13.- Smith v. Swormstedt (57 U.S. 288, 1853), Ecclesiastical property; 14.- Baker v. Nachtrieb (60 U.S. 126, 1856), Ecclesiastical property; 15.- Philadelphia, Wilmington and Baltimore R.R. Co. v. Philadelphia \& Havre de Grace Steam Towboat Co. (64 U.S. 209, 1859), Sunday Laws; 16.- Richardson v. Goodard (64 U.S. 28, 1859), Sunday Laws; 17.- Christ Church Hospital v. Philadelphia (65 U.S. 300, 1861), Tax derogations; 18.- Gaines v. Hennen (65 U.S. 553, 1861), FR and Family Law; 19.- Attorney Gral. v. Federal Street Meeting-House (66 U.S. 262, 1862), Ecclesiastical property; 20.- Cummings v. Missouri (71 U.S. 277, 1866), Oaths and religious tests; 21.- Insurance Co. v. Chase (72 U.S. 509, 1867), Religious autonomy; 22.- Watson v. Jones (80 U.S. 679, 1871), Religious autonomy; 23.- Bouldin v. Alexander (82 U.S. 131, 1872), Religious autonomy; 24.- Young v. Godbe (82 U.S. 562, 1873), Ecclesiastical Liability; 25.- Reynolds v. U.S. (98 U.S. 145, 1878), Polygamy; 26.Christian Union v. Yount (101 U.S. 352, 1879), Ecclesiastical property; 27.- Kain v. Gibboney (101 U.S. 362, 1879), Legacies for charity; 28.- Miles v. U.S. (103 U.S. 304, 1880), Polygamy; 29.- Missionary Society of M.E. Church v. Dallas City (107 U.S. 336, 1883), Ecclesiastical property; 30.- Cannon v. U.S. (116 U.S. 55, 1885), Polygamy and Canon Law; 31.- Soon Hing v. Crowley (113 U.S. 703, 1885), Sunday Laws; 32.- Murphy v. Ramsey (114 U.S. 15, 1885), Polygamy; 33.- Clawson v. U.S. (114 U.S. 477, 1885), Polygamy and religious test; 34.- Cannon v. U.S. (118 U.S. 355, 1886), Polygamy and Canon Law; 35.- Gibbons v. District of Columbia (116 U.S. 404, 1886),Tax derogations; 36.- Snow v. U.S. (118 U.S. 346, 1886), Polygamy; 37.- Gilmer v. Stone (120 U.S. 586, 1887), Ecclesiastical property; 38.- In re Snow (120 U.S. 274, 1887) *vid. 37, Polygamy; 39.- Speidel v. Henrici (120 U.S. 377, 1887), Ecclesiastical property; 40.- Bucher v. Cheshire RR. Co. (125 U.S. 555, 1888), Sunday Laws; 41.- Ex Parte Hans Nielsen (131 U.S. 176, 1889), Polygamy and adultery; 42.- Bassett v. U.S. (137 U.S. 496, 1890), Polygamy and testimony; 43.- Davis v. Beason (133 U.S. 333, 1890), Polygamy and oath; 44.- Late Corp. of the Church of Jesus Christ of Latter-day Saints v. U.S. (136 U.S. 1, 1890), Ecclesiastical property and Polygamy; 45.- Ball v. U.S. (140 U.S. 118, 1891), Sunday Laws; 46.- Late Corp. of the Church of Jesus Christ of Latter-day Saints v. U.S. (140 U.S. 665, 1891) *vid. 45, Ecclesiastical property and Polygamy; 47.- Rector of Holy Trinity Church v. U.S. (143 U.S. 457, 1892), Clerical exceptions and work; 48.- Catholic Bishop of Nesqually v. Gibbon (158 U.S. 155, 1895), Ecclesiastical property; 49.- 
Hennington v. Georgia (163 U.S. 299, 1896), Sunday Laws; 50.- Stone v. U.S. (167 U.S. 178, 1897), Sunday Laws; 51.- Bradfield v. Roberts (175 U.S. 291, 1899), Benefits to Religious Organizations and hospitals; 52.- Petit v. Minnesota (177 U.S. 164, 1900), Sunday Laws; 53.- Schwartz v. Duss (187 U.S. 8, 1902), Ecclesiastical property; 54.Chicago Theological Seminary v. Illinois (188 U.S. 662, 1903), Tax derogations; 55.- Bd. of Educ. of Methodist Episcopal Church v. Tax derogations Illinois (203 U.S. 553, 1906); 56.- Montana Catholic Missions Taxes v. Missoula County (200 U.S. 118, 1906), Jesuits and Indians; 57.- Speer v. Colbert (200 U.S. 130, 1906), Legacies for charity; 58.- Lowrey v. Hawaii (206 U.S. 206, 1907), Ecclesiastical property; 59.- Berea College v. Kentucky (211 U.S. 45, 1908), Educational religious centres; 60.- Ponce v. Roman Catholic Apostolic Church (210 U.S. 296, 1908), Ecclesiastical property; 61.- Quick Bear v. Leupp (210 U.S. 50, 1908), Legacies for charity, Indians, Catholics; 62.- Santos v. Holy Roman Catholic and Apostolic Church (212 U.S. 463, 1909), Ecclesiastical property; 63.- Lowrey v. Hawaii (215 U.S. 554, 1910), Ecclesiastical property; 64.- Helm v. Zarecor (222 U.S. 32, 1911), Ecclesiastical property; 65.- Sharpe v. Bonham (224 U.S. 241, 1912), Ecclesiastical property; 66.- Order of St. Benedit v. Steinhauser (234 U.S. 640, 1914), Religious committees and public contracts; 67.- Crane v. Johnson (242 U.S. 339, 1917), Legal exceptions for religious organizations and people; 68.- Arver v. U.S. (245 U.S. 366, 1918), FR and military service; 69.- Shepard v. Barkley (247 U.S. 1, 1918), Religious autonomy and Ecclesiastical property; 70.- Bartels v. Iowa (262 U.S. 404, 1923), Educational religious centers; 71.- Meyer v. Nebraska (262 U.S. 390, 1923), Educational religious centers, father rights, languages; 72.- Hygrade Provision Co. v. Sherman (266 U.S. 497, 1925), Religious fraud; 73.- Pierce v. Society of Sisters of the Holy Names of Jesus \& Mary (268 U.S. 510, 1925), Educational religious centres parent rights; 74.- Farrington v. Tokushige (273 U.S. 284, 1927), Educational religious centres; 75.- González v. Roman Catholic Archbishop (280 U.S. 1, 1929), Legacies for charity and Religious autonomy; 76.- U.S. v. Schwimmer (279 U.S. 644, 1929), FR, pacifism and granting of citizenship; 77.- Cochran v. Louisiana State Bd. of Educ. (281 U.S. 370, 1930), Benefits to religious organizations and Educational religious centers; 78.- U.S. v. Macintosh (283 U.S. 605, 1931), FR, oath and granting of citizenship; 79.- U.S. v. Bland (283 U.S. 636, 1931), FR and guns; 80.- Hamilton v. Regents of Univ. of California (293 U.S. 245, 1934), FR and military service; 81.- Coleman v. City of Griffin (302 U.S. 636, 1937), Distribution of religious literature and Jehovah's Witnesses; 82.- Lovell v. City of Griffin (303 U.S. 444, 1938), Distribution of religious literature and press; 83.- Schneider v. State of New Jersey, Town of Irvington (308 U.S. 147, 1939), Distribution of religious literature; 84.Cantwell v. Connecticut (310 U.S. 296, 1940), FR, Religious communications and Fourteenth Amendment; 85.- Minersville Sch. Dist. v. Gobitis (310 U.S. 586, 1940), FR, Religious communications and salute to the flag; 86.- Cox v. New Hampshire (312 U.S. 569, 1941), FR, Religious communications y Public gatherings; 87.- Chaplinsky v. New Hampshire (315 U.S. 568, 1942), FR, Religious communication; 88.- Jones v. Opelika (316 U.S. 584, 1942), Distribution of Religious literature, commercial activity; 89.- Busey v. Dist. of Columbia (319 U.S. 579, 1943), Distribution of Religious literature; 90.- Douglas v. City of Jeannette (319 U.S. 157, 1943), Distribution of Religious literature, Taxes; 91.Jamison v. Texas (318 U.S. 413, 1943), Distribution of Religious literature; 92.- Jones v. Opelika (319 U.S. 103, 1943) * vid. 87, Distribution of Religious literature; 93.- Largent v. Texas (318 U.S. 418, 1943), Distribution of Religious literature; 94.- Murdock v. 
Pennsylvania (319 U.S. 105, 1943), Distribution of Religious literature; 95.- Martin v. City of Struthers (319 U.S. 141, 1943), Distribution of Religious literature; 96.- Taylor v. Mississippi (319 U.S. 583, 1943), FR, salute to the flag; 97.- West Virginia State Bd. of Educ. v. Barnette (319 U.S. 624, 1943), FR, salute to the flag, Religious communication; 98.- Falbo v. U.S. (320 U.S. 549, 1944), FR, military service; 99.- Prince v. Massachussetts (321 U.S. 158, 1944), Distribution of Religious literature, parental rights; 100.- Follett v. Town of McCormick (321 U.S. 573, 1944), Distribution of Religious literature, Taxes; 101.- U.S. v. Ballard (322 U.S. 78, 1944), Religious autonomy, jury, Religious communication, fraud; 102.- In re Summers (325 U.S. 561, 1945), FR, oath, military service; 103.- Chatwin v. U.S. (326 U.S. 455, 1946); Polygamy, kidnapping; 104.- Marsh v. Alabama (326 U.S. 501, 1946), Distribution of Religious literature; 105.- Tucker v. Texas (326 U.S. 517, 1946), Distribution of Religious literature; 106.- Estep v. U.S. (327 U.S. 114, 1946), FR, military service; 107.- Girouard v. U.S. (328 U.S. 61, 1946), FR, granting of citizenship; 108.- Gibson v. U.S. (329 U.S. 338, 1946), FR, military service; 109.- Cleveland v. U.S. (329 U.S. 14, 1946), Polygamy, kidnapping; 110.- Everson v. Bd. of Educ. (330 U.S. 1, 1947), Benefits to a religious organization and Educational religious centers; 111.- Cox v. U.S. (332 U.S. 442, 1947), FR, military service; 112.- Musser v. Utah (333 U.S. 95, 1948), Polygamy, Religious communication; 113.- McCollum v. Bd. of Educ. (333 U.S. 203, 1948), Worship in public schools; 114.- Sata v. New York (334 U.S. 558, 1948); FR, Religious communication; 115.- Bunn v. North Carolina (336 U.S. 942, 1949), FR, discriminations; 116.- Corp. of Presiding Bishop of Church of Latter-Day Saints v. City of Poterville (338 U.S. 805, 1949); Regulation of the soil use and religious specialty; 117.- Cohnstaedt v. INS (339 U.S. 901) * vid. 10, FR, granting of citizenship; 118.Niemotko v. Maryland (340 U.S. 268, 1951), FR, Use of public spaces and licenses; 119.Kunz v. New York (340 U.S. 290, 1951), FR, Use of public spaces and licenses; 120.- Gara v. U.S. (340 U.S. 857, 1950), FR, military service; 121.- Friedman v. New York (341 U.S. 907, 1951), Sunday Laws; 122.- Donner v. New York (342 U.S. 884, 1951), Educational religious centres; 124.- McKnight v. Bd. of Pub. Educ. (341 U.S. 913, 1951), FR, discrimination; 125.- Doremus v. Bd. of Educ. (342 U.S. 429, 1952), FR, Taxes, Biblical Reading, schools; 126.- Zorach v. Clauson (343 U.S. 306, 1952), Worship in public Schools; 127.- Joseph Burstyn, Inc. v. Wilson (343 U.S. 495, 1952), FR, censorship; 128.Heisler v. Bd. of Review (343 U.S. 939, 1952), FR, Sunday Laws and work; 129.- Kedroff v. St. Nicholas Cathedral (344 U.S. 94, 1952), Religious autonomy and ecclesiastical disputes; 130.- Fowler v. Rhode Island (345 U.S. 67, 1953), FR, discrimination, Religious communication; 131.- Poulos v. New Hampshire (345 U.S. 395, 1953), FR, Use of public spaces and licenses; 132.- U.S. v. Nugent (346 U.S. 1, 1953), FR, military service; 133.Witmer v. U.S. (348 U.S. 375, 1955), FR, military service; 134.- Sicurella v. U.S. (348 U.S. 385, 1955), FR, military service; 135.- Dickinson v. U.S. (346 U.S. 389, 1953), FR,

military service; 136.- Simmons v. U.S. (348 U.S.397, 1955), FR, military service; 137.Gonzales v. U.S. (348 U.S. 407, 1955), FR, military service; 138.- Heisey v. County of Alameda (352 U.S. 921, 1956), FR, Tax derogations; 139.- First Unitarian Church v. County of L.A. (357 U.S. 545, 1958), FR, oaths, Tax derogations; 140.- Kreshik v. St. Nicholas of Russian of Orthodox Church North America (363 U.S. 190, 1960), Religious autonomy, of internal ecclesiastical disputes; 150.- McGowan v. Maryland (366 U.S. 420, 1961), Sunday Laws; 151.- Torcaso v. Watkins (367 U.S. 488, 1961), FR, oaths, religious test for public office; 152.- Two Guy from Harrison-Allentown, Inc. v. McGinley (366 
U.S. 582, 1961) * vid. 150, Sunday Laws; 153.- Broaunfeld v. Brown (366 U.S. 599, 1961); Sunday Laws, FR and Jewish; 154.- Gallagher v. Crown Kosher Super Mkt. (366 U.S. 617, 1961), Sunday Laws, FR and Jewish; 155.- Gen. Fin. Corp. v. Archetto (369 U.S. 423, 1962), FR, religious tax derogations; 156.- Engel v. Vitale (370 U.S. 421, 1962), Worship in public schools; 157.- Arlan's Dep. Store of Louisville v. Kentucky (371 U.S. 218, 1962), Sunday Laws; 158.- Sch. Dist. of Abington Township v. Schempp (374 U.S. 203, 1963), Worship in public schools; 159.- Sherbert v. Verner (374 U.S. 398, 1963), FR, no compensation for job; 160.- Chamberlin v. Bd. of Pub. Instruction (377 U.S. 40, 1964), Worship in public schools; 161.- Cooper v. Pate (378 U.S. 546, 1964), FR, prisoners, Muslims; 162.- U.S. v. Seeger (380 U.S. 163, 1965), FR, military service; 163.- Bd. of Educ. v. Allen (392 U.S. 236, 1968), Benefits to religious organizations and Educational religious centers; 164.- Jehovah's Witnesses v. King County Hosp. (390 U.S. 59, 1968) FR, Medical care. 165.- Flast v. Cohen (392 U.S. 83, 1968), FR, Taxes, religious schools, judicial activism. 166.- Epperson v. Arkansas (393 U.S. 97, 1968), FR, evolution, public schools. 167.- Oestereich v. Selective Service System (393 U.S. 233, 1968), FR, military service. 168.- Presbytarian Church in the U.S. v. Mary Elizabeth Blue Hull Memorial Presbyterian Church (393 U.S. 440, 1969), Religious autonomy, internal religious disputes. 169.- Maryland \& Virginia Eldership of Churches of God v. Church of God at Sharpsburg (396 U.S. 367, 1970), Religious autonomy, internal religious disputes. 170.Walz v. Tax Comm. (397 U.S. 664, 1970), FR, Tax derogations. 171.- Welsh v. U.S. (398 U.S. 333, 1970), FR, military service. 172.- Mulloy v. U.S. (398 U.S. 410, 1970), FR, military service. 171.- U.S. v. Sisson (399 U.S. 267, 1970), FR, military service. 172.- Gillette v. U.S. (401 U.S. 437, 1971), FR, military service. 173.- Dewey v. Reynolds (402 U.S. 689, 1971), Sunday Laws and work. 174.- Clay v. U.S. (403 U.S. 698, 1971), FR, military service. 175.Lemon v. Kurtzman (403 U.S. 602, 1971), Benefits to religious organizations., Private Schools., wages. 176.- Tilton v. Richardson (403 U.S. 672, 1971), Benefits to religious organizations, Educational religious centers. 177.- Coit v. Green (404 U.S. 997, 1971), FR, Tax derogations, race. 178.- Diffenderfer v. Central Baptist Church (404 U.S. 41, 1972), FR, Tax derogations. 177.- U.S. v. Christian Echoes National Ministry, Inc. (404 U.S. 561, 1972), FR, Tax derogations. 178.- Cruz v. Beto (405 U.S. 319, 1972), FR and jails. 179.Brusca v. Bd. of Educ. (405 U.S. 1050, 1972), Religious autonomy, benefits to religious organizations. 180.- Wisconsin v. Yoder (406 U.S. 205, 1972), FR, compulsory education, parent rights. 181.- Essex v. Colman (409 U.S. 808, 1972), Benefits to religious organizations., Educational religious centers. 182.- McClure v. Salvation Army (460 U.S. 896, 1972), Religious autonomy, clerical exceptions. 183.- Lemon v. Kurtzman (411 U.S. $192,1973) *$ vid. 175, Benefits to religious organizations. Educational religious centers. 184.- Norwood v. Harrison (413 U.S. 455, 1973), Benefits to religious organizations, Educational religious centers, race. 185.- Levitt v. Committee for Pub. Educ. (413 U.S. $472,1973)$, Benefits to religious organizations. Educational religious centers. 186.- Hunt v. McNair (413 U.S. 734, 1973), Benefits to religious organizations., Educational religious centers, Tax derogations. 187.- Committee for Pub. Educ. v. Nyquist (413 U.S. 756, 1973),

Benefits to religious organizations. Educational religious centers, tax deductions. 188.Sloan v. Lemon (413 U.S. 825, 1973), Benefits to religious organizations., Educational religious centers. 189.- Grit v. Colman (413 U.S. 901, 1973), Educational religious centers, tax deductions. 190.- Durhan v. McLeod (413 U.S. 902, 1973), FR, universities. 191.Johnson v. Robison (415 U.S. 361, 1974), Religious discrimination, military service. 192.- 
Hernandez v. Veterans' Administration (415 U.S. 391, 1974), Religious discrimination, military service. 193.- Wheeler v. Barrera (417 U.S. 7, 1974), Benefits to religious organizations, Educational religious centers. 194.- Griggs v. Pub. Funds for Pub. Schs. (417 U.S. 961, 1974), Benefits to religious organizations. Educational religious centers. 195.- U.S. v. American Friends Serv. Comm. (419 U.S. 7, 1974), Taxes, pacifism, conscientious objection. 196.- Luetkemeyer v. Kaufmann (419 U.S. 888, 1974), Benefits to religious organizations, Educational religious centers. 197.- Franchise Tax Bd. v. Americans for Pub. Schs. (419 U.S. 890, 1974), Benefits to religious United organizations. Educational religious centres. 198.- Meek v. Pittenger (421 U.S. 349, 1975), Benefits to religious organizations. 199.- Serbian Eastern Orthodox Diocese for the U.S. \& Canada Milivojevich (426 U.S. 696, 1976), Religious autonomy, internal religious disputes. 200.Roemer v. Bd. of Pub. Works (426 U.S. 736, 1976), Benefits to religious organizations, Educational religious centers. 201.- Parker Seal Co. v. Cummings (429 U.S. 65, 1976), Sunday rest and work. 202.- United Jewish Orgs. of Willamsburgh, Inc. v. Carey (430 U.S. 144, 1977), Religious committee and votes. 203.- Wooley v. Maynard (430 U.S. 705, 1977), FR and national symbols. 204.- Trans World Airlines, Inc. v. Hardison (432 U.S. 63, 1977), Sunday rest and work. 205.- Wolman v. Walter (433 U.S. 229, 1977), Benefits to religious organizations., Educational religious centers. 206.- Parker Seal Co. v. Cummings (433 U.S. 903, 1977) * vid. 201, Sunday rest and work. 207.- New York v. Cathedral Academy (434 U.S. 125, 1977) Benefits to religious organizations., Educational religious centers. 208.- Americans United for Sep. of Church \& State v. Blanton (434 U.S. 803, 1977), Benefits to religious organizations, Educational religious centers. 209.- Pacific Union Conf. of Seventh-day Adventist v. Marshall (434 U.S. 1305, 1977), FR and wages. 210.- McDaniel v. Paty (435 U.S. 618, 1978), Clergy and public officials. 211.- Gen. Council on Fin. \& Admin. of United Methodist Church v. Superior Court (439 U.S. 1369, 1978), Religious autonomy. 212.- National Labour Relations Bd. v. Catholic Bishop (440 U.S. 490, 1979), Religious schools and workers. 213.- Byrne v. Pub. Funds for Pub. Schs. (442 U.S. 907, 1979), Benefits to religious organizations. Educational religious centers, Taxes. 214.- Sch. Dist. v. Pennsylvania Dept. of Educ. (443 U.S. 90, 1979), Benefits to religious organizations., Educational religious centers. 215.Jones v. Wolf (443 U.S. 595, 1979), Religious autonomy, ecclesiastical internal disputes. 216.- Committee for Pub. Educ. \& Religious Liberty v. Reagan (444 U.S. 646, 1980), Benefits to religious organizations, Educational religious centers. 217.- Trammel v. U.S. (445 U.S. 40, 1980), clergy privileges. 218.- Harris v. McRae (448 U.S. 297, 1980), Abortion and Judicial activism. 219.- Stone v. Graham (449 U.S. 39, 1980), Worship in public schools. 220.- Thomas v. Review Bd. (450 U.S. 707, 1981), Conscientious objection, weapons, wages. 221.- St. Martin Evangelical Lutheran Church v. South Dakota (451 U.S. 772, 1981), Educational religious centers, workers. 222. - Heffron v. International Soc. for Krishna Consciousness, Inc. (452 U.S. 640, 1981), Distribution of religious literature. 223.- Widmar v. Vincent (454 U.S. 263, 1981), Meetings in religious groups and public universities. 224.- Valley Forge Christian College v. Americans United (454 U.S. 464, 1982), FR, Taxes \& Judicial activism. 225.- U.S. v. Lee (455 U.S. 252, 1982), FR, Social Security, Amish. 226.- Treen v. Karen B. (455 U.S. 913, 1982), Worship in public schools. 227.- Rusk v. Espinosa (456 U.S. 951, 1982), Religious autonomy, religious discrimination. 228.- Larkin v. Gredenl. Den., Inc. (459 U.S. 116, 1982), Ecclesiastical Privileges. 229.- Bob Jones Univ. v. U.S. (461 U.S. 574, 1983), Religious university 
Religious discrimination and racism. 230.- Mueller v. Allen (463 U.S. 388, 1983), Benefits to religious organizations., Educational religious centers. 231.- Marsh v. Chambers (463 U.S. 783, 1983), Chapels and worship in the state parliament. 232.- Grove City Coll. v. Bell (465 U.S. 555, 1984), Religious Universities and federal aids. 233.- Lynch v. Donnelly (465 U.S. 668, 1984), Religious symbols and public spaces. 234.- Board of T.V. of Scarsdale v. McCreary (471 U.S. 83, 1985), Religious symbols and public spaces. 235.Tony \& Susan Alamo Foundation v. Secretary of Labour (471 U.S. 290, 1985), Fair Labour Standards and religious foundations. 236.- Wallace v. Jaffree (472 U.S. 38, 1985), Worship and Public schools. 237.- Jensen v. Quaring (472 U.S. 478, 1985), FR and driving license. 238.- Estate of Thornton v. Caldor, Inc. (472 U.S. 703, 1985), Work and religious rest. 239.- Grand Rapids School District v. Ball (473 U.S. 373, 1985), Benefits to religious organizations, Educational religious centres. 240.- Aguilar v. Felton (473 U.S. 402, 1985), Benefits to religious organizations., Educational religious centers. 241.- Witters v. Washington Department of Servs. for the Blind (474 U.S. 481, 1986), Benefits to religious organizations. Educational religious centers. 242.- Goldman v. Weinberger (475 U.S. 503, 1986), FR and military service. 243.- Bender v. Williamsport School District (475 U.S. 534, 1986), FR, education and judicial activism. 244.- Bowen v. Roy (476 U.S. 693, 1986), FR and Social Security. 245.- U.S. v. Dion (476 U.S. 734, 1986), FR and Indians. 246.- Ohio Civil Rights Comm. v. Dayton Christian Schools (477 U.S. 619, 1986), FR, Administration and refraining from jurisdiction. 247.- Hobbie v. Unemployment Appeals Comm. (480 U.S. 136, 1987), Work and religious rest. 248.- Cooper v. Eugene School District (480 U.S. 942, 1987) Religious symbols, work, public schools. 249.- Shaare Tefila Congregation v. Cobb. (481 U.S. 615, 1987), Religious discrimination. Jewish. 250.O'Lone v. Estate of Shabazz (482 U.S. 342, 1987), FR, Jails. 251.- Board of Airport Comm. v. Jews for Jesus, Inc (482 U.S. 569, 1987), Religious communication public spaces. 252.Edwards v. Aguillard (482 U.S. 578, 1987), Creationism v. Evolutionism. 253.Corporation of Presiding Bishop of the Church of Jesus Christ of Latter-day Saints v. Amos (483 U.S. 327, 1987), Religious discrimination. 254.- Karcher v. May (484 U.S. 72, 1987), FR and judicial constructionism. 255.- Lyng.v. Northwest Indian Cemetery Protective (485 U.S. 439, 1988), FR and Indians. 256.- Employment Div. v. Smith (485 U.S. 660, 1988), FR, work, Indians. 257.- U.S. Catholic Conference v. Mobilization, Inc. (487 U.S. 72, 1988), FR, Catholics and Abortion Rights, judicial activism /constructionism. 258.- Bowen v. Kendrick (487 U.S. 589, 1988), Benefits to religious organizations, religious and judicial constructionism. 259.- Texas Monthly, Inc. v. Bullock (489 U.S. 1, 1989), Religious publications, Tax derogations. 260.- Frazee v. Illinois Department of Empl. Security (489 U.S. 829, 1989), Religious work and rest. 261.Hernández v. Commissioner of Internal Revenue (490 U.S. 680, 1989), FR, donations, Tax derogations. 262.- County of Allegheny v. ACLU (492 U.S. 573, 1989), Religious symbols. Public spaces. 263.- Jimmy Swaggart Ministries v. Bd. of Equalization (493 U.S. 378, 1990), Religious Organizations, Tax derogations. 264.- Employment Div. v. Smith (494 U.S. 872, 1990), FR and Indians. 265.- Davis. V. U.S. (495 U.S. 472, 1990), FR, donations, Taxes. 266.- Westside Bd. of Educ. v. Mergens (496 U.S. 226, 1990), Worship, Public Schools. 267.- EEOC v. Arabian American Oil Co. (499 U.S. 244, 1991), Religious Discrimination, work. 268.- Lee v. Weisman (505 U.S. 577, 1992), Worship, Public Schools. 269.- International Soc. for Krishna Consciousness, Inc. v. Lee (505 U.S. 672, 1992), Religious literature in public spaces. 270.- Church of Scientology v. U.S. (506 U.S. 
9, 1992), FR, Judicial activism. 271.- Lamb. Chapel v. Ctr. Moriches Union Free School Dist. (508 U.S. 384, 1993), FR, religious discrimination \& Schools. 272.- Church of Lukumi Babalu Aye, Inc. v. City of Hialeah (508 U.S. 520, 1993), FR, witchcraft, sacrifices. 273.- Zobrest v. Catalina Foothills School Dist. (509 U.S. 1, 1993), Benefits to religious organizations., Educational religious centers. 274.- Bd. of Educ. v. Grumet (512 U.S. 687, 1994), FR, Public schools, religious organizations. 275.- Hurley v. IrishAmerican Gay, Lesbian \& Bisexual Group (515 U.S. 557, 1995), Freedom of conscience, sexuality and public order and public morals. 276.- Capitol Sq. Review 6 Advisory Bd. v. Pinette (515 U.S. 753, 1995), Religious Symbols, Public schools. 277.- Rosenberger v. Rector \& Visitors (515 U.S. 819, 1995), Religious discrimination. Publicschools. 278.Agostini v. Felton (521 U.S. 203, 1997), Benefits to religious organizations, Public schools. 279.- City of Boeme v. Flores (521 U.S. 507, 1997), FR, RFRA. 280.- Boy Scouts of America v. Dale (530 U.S. 640, 2000), Freedom of conscience and moral. 281.- Troxel v. Granville (530 U.S. 57, 2000), FR, parent rights. 282.- Santa Fe Ind. School Dist. v. Doe (530 U.S. 290, 2000), Worship, Religious educative centers. 283.- Mitchell v. Helms (530 U.S. 1296, 2000), Benefits to religious organizations, Religious educative centers. 284.Good News Club v. Milford Cent. School (533 U.S. 98, 2001), Religious discrimination, Religious educative centres. 285.- Zelman v. Simmons-Harris (536 U.S. 639, 2002), Benefits to religious organizations, Religious educative centers. 286.- Watchtower Bible and Tract Society of New York, Inc. v. Village of Stratton (536 U.S. 150, 2002), Religious literature, proselytism. 287.- Elk Grove Unified School Dist. v. Newdow (542 U.S. 1, 2004), Worship, public schools, salute to the flag. 288.- Hibbs v. Winn. (542 U.S. 88, 2004), NGOs, Taxes. 289.- Locke v. Davey (540 U.S. 712, 2004), Religious Discrimination, Education, aids. 290.- Brown v. Payton (544 U.S. 133, 2005), FR, rights of The detainees. 291.- Cutre v. Wilkinson (544 U.S. 709, 2005), FR, interned persons.

Source: SÁNCHEZ-BAYÓN (2007 \& 16).

The headings of the cases from 2005 have been omitted (those after the reelection of G.W. BUSH), since explanations about the new topics and tendencies are developed in the following case study below because there are currently more than three hundred and fifty cases involved. 


\section{4.- TOPIC IN THE EARLY GLOBALIZATION: RELIGION IN DOMESTIC POLITICS \& LAW}

\subsection{1.- CASE STUDY: AN OVERVIEW}

The USA is a country considered as the New World or New Regime, as it is specified in one of its national mottos ("novus ordo seclorum"). But this does not mean that there is a lack of knowledge with respect to Western tradition, both sacred (Judean-Christian) and profane (Greek-Roman), as is evident in its national motto which is translated into Latin. The Framers of the constitution were well acquainted with the Greco-Roman culture, as well as the importance of the art of questioning through different methods, such as the epoché or the maieutic. Thus, the Socratic Method was introduced in university studies which began to be standardized nearly one century afterwards, using as a reference the native adaptation of Dean LANGDELL, as explained below.

The foregoing Socratic method consisted in the combination of the epoché or suspension of judgment (which means taking nothing for granted), and the maieutic or questioning of the reason why (in order to analyze in more depth, until reaching the primary reason). Nonetheless, we could wonder: how did this method become universally accepted in US Schools of Law? It occurred in the late 1870s, when Europe implanted its public universities (i.e. Spain and the background of the GAMAZO Plan) $)^{107}$, and when the standardization of studies came about. All these changes provoked the transformation of traditional faculties, as the School of Cannons and Laws, into the Law Schools were called (afterwards) Jurisprudence

\footnotetext{
107 See SÁNCHEZ-BAYÓN, A.: Estudios de cultura político-jurídica... op. cit.
} 
Schools, where all the efforts of professors were concentrated on teaching the new Public Law, mainly characterized by its codified nature. So, although US Law was comparable to Common Law in its roots, it became something extraordinary, because USA Law is the most open to the influences of Civil or Continental Law. So much so, that amongst the flourishing universities of New England -the foundation of the Ivy League (or club of universities, which imitate the European style) Harvard University begins to stand out in its attempt to become a reference in the standardization of Law studies. It is important to take into account that the influence of English Law, where the prevailing method was the Inn Court where only the mere rudiments were learned. This meant that the most important learning experience was actually acquired afterwards by working as an articled clerk in Law firms or with judges. However, the Dean of the Faculty of Law, Prof. LANGDELL, started to put into practice a method of Socratic inspiration, though very formalist (related to the exegetical and analytical studies which had been previously undertaken in such referential works as the BLACKSTONE commentaries or Austin's Jurisprudence). It was a three- pronged study: a) read the cases b) distill the rule; c) apply the rule to future cases. It is curious that the method did not achieve its goals, not because of a lack of quality, but because of the publicity generated by the personal competition between the two greatest jurists of the time: LANGDELL v. HOLMES- a rivalry comparable to that had existed one century before between HAMILTON and JEFFERSON-. Since LANGDELL was the Dean of the Harvard Law School, HOLMES also attempted to reach the same position, but he only achieved professor status; for this reason, he opted for the legal practice, acquiring the category of Judge of the Supreme Court. While LANGDELL promoted legal formalism, HOLMES sponsored the appearance of Legal Realism (it would be 
necessary to wait until after World War I); etc. The fact is that HOLMES provoked an effect that was just the opposite of what he intended through the Law Review he edited (American Law Review) and it's well known book The Common Law (1881). At the end, he afforded undue attention to LANGDELL; HOLMES criticized him so harshly, that LANGDELL become famous thanks to HOLMES. This great rivalry also originated the competition between the Schools of Law, such as Harvard (which would continue to maintain LANGDELL on a pedestal for several years) and Yale (who's incontrovertible reference was HOLMES). The fact is that, in the same way that new legal operators are trained, so is Law transformed in its theory and practice. Needless to say, the influence that these two universities have held and continue to hold in the USA today is tremendous; among their students there are a great number of senior government officials (e.g. Presidents, Supreme Court Judges, Secretaries of State, Senators, Congressmen), as well as extremely important business men.

Although the law and its study have changed, the LANGDELL stamp has survived to the present, since he was the first to offer a native version of the Socratic Method, presenting an example to improve, change, criticize and propose alternatives in his method. Other proposals and materials have emerged from the this method, such as the casebook (it is a type of textbook used mainly by students Which, rather than simply laying out the legal doctrine, contains excerpts from legal cases in which the law is applied). The latest successful version of this method was the Problem method, because the opposition to the LANGDELL method and the casebooks, which were said to be a mere excuse for trivializing Classes. Courses became competitions where students had to learn by heart-preordained answers. Afterwards, in order to revitalize the study of Law, the Problem method was chosen, in which a fictitious or real case is set up, with several legal implications that 
students have to resolve, usually in groups, and simulating a judicial proceeding supervised by their professors.

Therefore, although the LANGDELL method and casebooks have been useful to standardize US Law, they are also the origin of a reductionist method that attempted to teach the law through the Case Law or rulings, when there are other sources and branches of the Legal System, as we will clarify below.

The topics chosen, the network of interlaced questions, have an interdisciplinary character and a great complexity, which is the reason behind the use of the holistic way of studying cases. It consists of combining the epoché and maieutic, together with political analysis and critical culture, until it reaches the problem method, without ignoring the legal priority approach (according to the legal grounds that guide the rest of the argumentation of a specific case).

Finally, it deals with the role of religion in the USA because it's more secular conception. It is the key to achieve salvation in the world, which definitely contributes to boost a Welfare State with a specialfoundation or social gospel -where social assistance is mainly provided by local religious associations. This is how a great deal of information was collected in Title 42 of the U.S. Code, which is headed by the Public Health and Welfare Department. Thus it is possible to understand the list of more than one hundred activities that are being developed by the clergy, religious organizations and the churches and their agencies. Among these activities, it would be necessary to highlight: a) activities and services (adoption services, orphans, children's shelters, assistance to single mothers, programs to support retired people, youth recreation centers, senior recreation centers, spiritual retreat centers, health clinics, services to assist immigrants, charitable funds, sanctuaries, programs of rehabilitation, programs of psychological support, programs of feeding 
the homeless); b) organizations and sponsored activities (nursery schools, elementary schools, high schools, Bible schools, theological seminaries, universities, educational foundations, convention centers, home study courses, public seminars, meditation centers, book stores, archives, libraries, publishing companies (religious and educative books); c) goods and products offered by churches (books, magazines, documentaries, radio shows, TV shows); d) leisure and social activities (theatre groups, men's clubs, women's clubs, youth centers, senior centers, summer camps, picnic areas, playgrounds, bazaars, social clubs, single clubs); e) affiliated organizations (farms, religious stores, convents, monasteries, cemeteries, inspection services and food stamp certification (kosher), programs of mutual societies); etc.

Thus, the great weight of the denominations in the local implementation of social policies, it can be understood why the next two examples have been chosen, though both come from the Federal Executive. They seem to carry out a reverse interpretation of the classic clauses of the first Amendment regarding the Freedom of religion (free exercise and (non)establishment), thus provoking some degree of discrimination, as well as a growing gap in the much-publicized "wall of separation". 


\subsection{2.- SINGLE CASES: FROM CORRECTNESS TO NEOCONSERVATIVE ISSUES}

\subsubsection{1.- FAITH-BASED AND COMMUNITY ORGANIZATIONS}

a) Preliminary considerations: The social policy of the G.W. BUSH Administration - as will be explained below- inherits the federal interventionist boom of programs designed by the CLINTON Administration (e.g. Charitable choice, International Religious Freedom Monitoring, No child left behind, etc. ${ }^{108}$, but characterized by a neoconservative bias. More specifically, this fact explains the clear paradoxology involved in the public policies of G.W. BUSH Administration; he is a republican and converse evangelist while his federal programs of communitarian intervention, in fact, are ways of financing Faith-based $\mathcal{E}$ Community Organization/Initiatives (FBOs). This euphemistic denomination refers to organizations and religious initiatives, and specifically those types developed under the Last Great Awakening (before well-established) ${ }^{109}$, and whose devotees made up a great part of the electoral base of G.W. BUSH. Now that

\footnotetext{
108 As has been mentioned previously, the origin of the programs of faith-based organizations of G.W. BUSH lies in the Welfare Reform of the CLINTON Administration, through Charitable Choice (introduced by Acts as The Personal Responsibility and Work Opportunity Reconciliation Act of 1996 and programs such as Temporary Assistance to Needy Families, Community Services Block Grant, etc.) The difference is that the initial goal of the first stage of Clinton's public policies of was to give public funds to NGOs -in exclusive competition with churches-, whereas G.W. Bush removes the traditional restrictions to faith-based organizations that carry out community promotion activities, allowing them access to public funds. See DAVIS, D., HANKINS, B. (edits.): Welfare reform \& Faith-based organizations, Baylor University Press, Waco, 1999. EDWARDS, G.C.: Governing by campaigning. The politics of the Bush Presidency, New York: Pearson, 2007.

${ }^{109}$ Faith groups are those most recent and informal varieties of religious groups, which emerged in the Last Great Awakening during the 1960's. The aforementioned terminology is adopted, as opposed to the well-established religious denominations, the rest of the religious organizations.
} 
some relevant clarifications have been made, we will continue to summarily describe the FBOs, focusing mainly on two questions: a) what are they and how are they related to the White House? b) What are their norms? c) Controversial Issues and aporeias)

b) Meaning and scope: FBOs constitute a group of social intervention programs, described by the President himself as "one of my most important initiatives (...) to extol great American compassion, through the USA with heart, soul, and conscious at the same time"110. Starting with the reform of the Welfare State, initiated by CLINTON with the group of charitable choice programs, G.W. BUSH redirected the planned aids, incrementing the funds and donating to local organizations based on the faith and the municipal service, with the excuse of drawing the Administration closer to the citizenship, without any intermediaries, avoiding excessive "red tape" and the lack of immediate financing. In order to organize the system, president G.W. BUSH, in 2001, designated J. TOWEY the Director of the White House office for FBOs (substituted in 2006 by J.F. HEIN, who, in addition, held the post of Deputy Secretary of the President) to act as a link with one hundred and fifty programs underway in other departments (i.e. Agriculture, Trade, Education, Health and Social Services, Housing and Land development, Justice, Work, Veterans affairs, Small business management), and to manage the designation of more than one thousand programs of grants and scholarships (with a one hundred million dollar budget). All these aids are open to any organization carrying out activities of social promotion and general welfare (e.g. charity, education, health, and help

\footnotetext{
110 Cfr. VV.AA.: Guidance to Faith-based and Community Organizations on Partnering with the Federal Government, Washington: White House, 2001, pg. 2
} 
for handicapped people). There are no exclusive funds for organizations based on the faith. With the exception of small and specific programs, such as Compassion Capital Fund, all the aids are open to any organization and/or initiatives with a calling for helping others and to serve the common good. The monitoring of all the aids granted is carried out through a five-step process: (1) Step 1: Financial records: the completion of Standard Form 269 is required, which assures that these organizations are up-to-date in their tax payments and have an appropriate financial situation. (2) Step 2, Co-sponsorship: it is not a mandatory requirement for all aids, but it is quite common. It consists of asking for information about the other organizations that contribute to the project. (3) Step 3, Storage of documents: the recipient of the aid is asked to keep the documents submitted, as well as receipts and bills of expenses, during an approximate period of three years (e.g. if the help is granted from 2003 to 2006, it will be necessary to keep all the documentation until 2009) (4) Step 4, Periodic notification: while the organization is benefitting from the grant, it is obliged to report information with details on the project's evolution, expenses, outcomes, etc. in the prescribed periods for each notification, (5) Step 5, Audit: because of the reception of public funds, the Administration reserves the right to audit. Usually, in the case of funds under USD 500,000, a system of self-auditing is possible for the organizations that receive the aid; if funds are over USD 500,000, organizations are usually required to hire an external auditor; in case of greater amounts, the administration itself audits the organization.

c) Regulation: this is a regulation at various levels, since it is comprised of Executive Orders passed by the President, Public Acts/Bills enacted by Parliament and Final Rules passed by the Departments, and even Orders of 
autonomous agencies: (1) Executive Orders (E.O.): E.O. 13397, to create a new center for FBOs in US department homeland Security (March $7^{\text {th }}$ 2006); E.O. 13280 , to require equal protection for FBOs (December 12 ${ }^{\text {th }} 2002$ ); E.O. 13199, to create the White House office for FBOs (January 29th 2001); E.O. 13198, to create five centers for FBOs (January $2^{\text {th }}$ 2001) ; etc. (2) Public Acts/Bills: Charity Aid, Recovery, and Empowerment Act of 2002, Savings for Working Families Act of 2002; etc. (3) Final Rules (F.R.): a) F.R. of Department of Education: Participation in Education Department Programs by Religious Organizations; Providing for Equal Treatment of All Education Program Participants (June $\left.4^{\text {th }} 2004\right)$; b) F.R. Department of Veteran Affairs: Homeless Providers Grant and Per Diem Program; religious organizations ( June $8^{\text {th }}$ 2004); c) F.R. Department of Agriculture: Equal opportunity for religious organizations (July $9^{\text {th }} 2004$ ); etc.

d) Controversial Issues: the constitutionality of the use of the granted funds could be called into question: activities are close to proselytism (e.g. campaigns for salvation of souls and sexual abstention); there is a religious establishment (e.g. worship for general welfare); etc. These funds have even been used to finance the contracting of civil liability insurances for ministers and church worship. How do these things affect the interpretation of the aforementioned clauses of the First Amendment about Freedom of Religion? Does a conflict exist in the study of the second case? 


\subsubsection{2.- THE First FreEdom ProJeCt}

a) Preliminary considerations: In February $20^{\text {th }}, 2007$, the US Attorney General, A. R. Gonzales revealed to the media one of the key initiatives in his term of office, The First Freedom Project. In his own words, he called it "an initiative to preserve the freedom of religion, which requires a great commitment in order to protect the most basic freedom of people of all faiths".

b) Meaning and scope: among the initial measures to include in the framework of this project, the Attorney General drew attention to the following: a) the submission of a report about the increased support, to favor the compliance of the Acts protecting the freedom of religion (activity of the public prosecutor, between 2001 and 2006), in which it is established that, in spite of the strong commitment demonstrated, it is necessary to provide more resources; $b$ ) the establishment of a dependent Department is proposed, whose director would be the assistant to the Attorney General for the Division on Civil Rights; c) several initial complementary actions to foment awareness are formulated, such as: regional seminars, establishment of a consulting service about religious discrimination, etc.; d) the goals: the main topics to enhance freedom of religion and fight against discrimination through synergies are: 1) educational discrimination; 2) labor discrimination, 3) intra-household discrimination; 4) credit discrimination; 5) public assistance discrimination; 6) religious discrimination in the educational sector (in the Division on Civil rights, the Educational Opportunities section, pursuant to Titles IV and IX of the Civil Rights Act of 1964, is in charge of filing court cases in order to avoid discrimination in public classes on the grounds of race, color, religion, sex or 
national origin). The most typical disputes and their most recent examples (there are no notes of registry as of yet as for the rest of the cases included) are:

(1) Harassment: cases of religious harassment are supervised, especially harassment of students by professors (e.g. In Delaware School District, in March 2005, it was necessary to protect Muslim students in the fourth grade).

(2) Student Religious Expression: Discrimination as a consequence of the initiative of students themselves is also supervised (a group of students in a high school in Massachusetts were suspended for distributing candy with religious messages); and those discriminatory acts sponsored by the educational centers themselves (e.g. in a competition of young musical talents in a School in New Jersey, one song was censored for being Christian).

(3) Religious dress: any discrimination is forbidden, for example, the use of Muslim headscarves (e.g. Muskogee Public School District was sued because it did not allow a Muslim student to attend classes with a headscarf).

(4) Equal access: Public centers must allow religious groups to develop extracurricular activities with equal-opportunities (e.g. Good News Clubs are student associations that develop charitable activities to improve society, but their work is not taken into consideration because of their religious background and thus they have no space to hold their meetings, and they receive no funding, etc.).

(5) Exclusion from Higher Educational Opportunities Based on Belief: idem (e.g. Texas Tech University, a biology professor refused to write letters of recommendation for medical schools if students had not previously sworn that they firmly believed in the theory of evolution). 
(6) Religious Holidays: holidays must be observed, especially in cases with parental authorization (e.g. in Indiana, a boy was suspended from school because he did not attend class several times as a consequence of religious celebrations, and his mother was sued for negligence by local authorities).

(7) Religious discrimination in employment: By the same token, in the Civil Rights Division, there is a Commission promoting equal employment opportunities, pursuant to title VII of the Civil Rights Act of 1964, which is in charge of filing lawsuits against the discrimination of employees in public institutions or in religious centers. Among the most recent disputes in which the commission has intervened (financial year 2005-06 finds many of them already in the courts), we could point out two cases: a) U.S. v. Los Angeles County Metropolitan Transit Authority, because the Transit Authority demanded full-time availability in the employment application form, without allowing for the Sabbath rest of Jewish People and the Sunday rest of Christians, etc.; b) U.S. v. State of Ohio, where the agency of environmental protection refused to recruit workers based on religious motivation, alleging conscientious objection so as to not to pay mandatory fees to trade unions (because the trade unions were in favor of abortion, homosexual marriage, etc.).

(8) Religious discrimination in housing: Another entity in the Civil Rights Division, the Housing and Civil Promotion Section (in compliance with the Fair Housing Act- a competence shared with the Housing and Urban Development Department) is in charge of filing lawsuits against religious discrimination in the purchase of a house. In the same way, among the most recent disputes which have quoted this section, we could highlight three cases where the people affected did not manage to buy houses, or their houses were attacked 
because of their faith, or race: a) U.S. v. Hillman Housing Corporation, in New York; b) U.S. v. Altmayer, in Chicago; c) U.S. v. San Francisco Housing Authority, in San Francisco.

(9) Religious discrimination in granting credits: the Housing and Civil Promotion section is also in charge of enforcing the Equal Credit Opportunity Act, a shared competence with other agencies such as the Internal Revenue Service, that files lawsuits to prevent religious discrimination in the granting or return of credits (e.g. common circumstances in practice are: the refusal to grant credit, incorporation of unfair terms, etc. $)^{111}$.

(10) Religious discrimination in Public services: Again, it is a duty pertaining to the Housing and Civil Promotion Section, pursuant to Title II of the Civil Rights Act of 1964, whose main task is enforcing the observance of religious respect in public places, like restaurants, cinemas, etc. One of the latest cases to employ this section was the discrimination suffered by a Sikh in a restaurant in Virginia, where he was obliged to remove his turban to gain admission to a restaurant.

(11) Religious discrimination in public assistance: Without a specific unit, the Civil Rights Division, pursuant to Title III of the Civil Rights Act of 1964, may deal with all the cases related to a lack of equality in obtaining access to government benefits. An illustrative case in this matter is Blanch Springs (Texas), where a municipal ordinance prohibited all religious activities in Senior Leisure Centers, which meant that the elderly could no longer bless the table, sing bible hymns etc.

${ }^{111}$ After the mortgage crisis, this measure has become somewhat blurred. 
c) Regulation: vid. Legal grounds summoned in paragraph b).

d) Controversial issues: It is true that Public Authority has the duty of promoting free exercise, while not admitting a proselytizing attitude in religious issues. Is there any evidence of discretion and/or judicial activism?

\section{5.- BALANCE BEYOND THE GLOBALIZATION AND ITS CRISIS}

In the USA, freedom of religion is widely enjoyed, not only as a foundational milestone, but as a colonial freedom for those who were prosecuted for their religion, and also during the great wars and mass exterminations of the $\mathrm{XX}$ century (e.g. Jewish People, Armenians, Baha'is). This is such a key issue that it is the very first of the liberties recognized, and even in a double doubly fashion (with two protective clauses). What is more, a great part of US doctrine considers that it is the cornerstone through which the rest of Civil freedoms have been construed, as has been observed in the cases studied. Therefore, Freedom of religion is deeply acknowledged, protected and furthered in the USA, and in its relations with other countries (idem). Nonetheless, the last administrations (CLINTON and G.W.BUSH) have prompted a crisis due to post-modern contagion. There has been a manipulation of meanings in the traditional scope of words, and language has been used politically and selfishly in order to legitimize public policies. What then has happened to the much-quoted "wall of separation"?

It is crucial to draw a clear separation between Church and State: the Church is an institution pertaining to the religious sphere, and the State is the political 
sphere, so each one has its own competences. Although both have an impact on society, they are not mutually exclusive. It is so important to highlight this notion because otherwise the result could be: a) identification, like in Middle East regimes (confessionalism), or b) exclusion, like in continental European countries (secularism/laicite). Politics and religion have their own social spheres, but they overlap in areas like social assistance. That is the reason why it is so urgent in the West to recover an accommodating separation model to lead to a rational system of checks and balances.

Regarding the final assessment of the U.S. legal system and its treatment of the religious factor, such regulation ranges from basic rules (Constitution and jurisprudence), to auxiliary ones (Executive Law, Statutory and International Treaties, especially in human rights). Traditionally, in the first third of the XX century, the weight of organization was in the hands of the law, but statutory law took on more prominence beginning in the interwar period, and it has been the instrument chosen to implement the welfare state. However, with the onset of globalization, Executive Law has become particularly relevant, although its short expiration and rather discursive load are serious problems. The question now is how to articulate the Ordinance, which is the current major factor to regulate this issue.

The religious factor in the U.S. is crucial, because as mentioned before, it has been considered a cornerstone of identity, cultural background, social power, and solidarity. The U.S. model is still a reference point for other Western countries. 
Sociología de las Relaciones Socioculturales Nortatlánticas (...) American civil religion - A. Sánchez-Bayón 


\title{
5.- RELIGIOSIDAD CIVIL ESTADOUNIDENSE:
}

\section{CLAVES SOBRE SU CONFIGURACIÓN IDIOSINCRÁSICA}

\author{
(MITOPOIÉSIS, LEGADO Y AMERICANESS) ${ }^{112}$
}

Ya se ha mencionado el oxímoron que supone la religión civil -máxime para los europeos (quienes tardaran en entrar en el proceso secularizador moderno, haciéndolo a la postre de manera acelerada y casi completa, v.g. laïcité, vid. infra figura 5)-. Ahora bien, con respecto a la realidad social estadounidense, no resulta tanto; más bien, responde a una lógica empírica, relativa a la marcha de sus acontecimientos y la construcción de sentido socio-cultural. Basta con atender a los momentos históricos y sus tendencias, e interpretarlos conforme a una serie de claves propias o idiosincrásicas: EE.UU., nace como país, en un intento de ensayo de Nuevo Régimen (v.g. sin estamentos y con movilidad social), aplicándose un modelo socio-cultural prototípico de una Modernidad occidental mestiza. En su seno, no sólo se combina la tradicción occidental sagrada y profana, sino que se hace desde la mixtura del racionalismo humanista hispánico y el racionalismo profesional/protestante de anglosajones y nórdicos. De tal manera, el proceso de secularización moderna (que permite la separación de esferas social, de modo que puedan crecer más) y su Teología política (centrada en la organización y salvación del pueblo de Dios), tan predicados y deseados por las élites europeas, se empieza a

\footnotetext{
112 Con el respaldo de pasadas publicaciones (citadas en el cap. 3, especialmente, La Modernidad sin prejuicios, Universidad, ciencia y religión en los Estados Unidos de América y La religión civil estadounidense), el presente capítulo está sustentado por recientes artículos (publicados durante la matrícula de doctorado en la UVA y aprobados en las memorias tramitadas); complement., vid. infra notas 3 a 5 , 11, 16, 24, 55 y 68, más p. 126 ss.
} 
realizar en América de manera social (generalizándose a todo el pueblo de Dios). Comienza así a extenderse a casi todas las facetas de la vida social, alcanzando a las diversas comunidades, que progresiva y programáticamente se van integrando en forma de una sociedad abierta (al convivir las religiones tradicionales con la moderna o ACR). El cemento social del periodo fundacional pasa a ser la religión, pues la misma se concibe y gestiona conforme al nuevo paradigma, el de la citada secularización moderna y su Teología política (dotar de pactos y compromiso social al pueblo). Por tanto, la religión deja de ser un elemento de control social (en manos de unas elites, v.g. Papa, emperador, monarca), para pasar a ser un recurso civilizador de lo desconocido (v.g. la conquista del Oeste, la naturaleza en su esplendor), además de dinamizar la vida social, con su agenda institucional (v.g. cruzadas anti-duelo, anti-alcohol o anti-juego; cruzadas pro-vida, pro-abolición o pro-sufragistas). Por tanto, aún siendo Europa y América parte de la Cristiandad (hasta la primavera de las naciones -que en EE.UU. se adelanta, gracias a ACR, como más tarde se aclarará-), en el Nuevo Mundo se vive de distinta manera. Eso es así, no sólo porque se parta con menos cargas y haya más facilidad para el ensayo de nuevas fórmulas, sino que tal es la manera propia de entender las relaciones socioculturales (su Americaness): la religión se entiende y opera de manera distinta por las claves que se van a revelar a continuación. 


\section{1.- CONSIDERACIONES PRELIMINARES:}

\section{ESTADOUNIDIZACIÓN RELIGIOSA Y RELIGIOSIFICACIÓN ESTADOUNIDENSE}

¿EE.UU. es distinto al resto de Occidente por su comprensión y gestión propia de la religión o ha sido dicha comprensión y gestión prototípica la que ha hecho de EE.UU. un país hegemónico de Occidente? Dicho de otro (tal como avanza el rótulo del epígrafe): ¿prima la estadounidización religiosa (la reformulación del cristianismo, desde la puesta en práctica de la libertas christiana, dando lugar a su democratización con los evangélicos, incluso las comunidades poscristianas, v.g. mormones, cienciólogos) o más bien la religiosificación estadounidense (como cemento y/o levadura social del país, dotándolo de una visión, misión y valores compartidos y trascendentes)? ¿Fue necesario que el Americaness adaptara la religión o gracias a la religión surgió el Americaness? Tal dualismo, conducente a la dialéctica, resulta la manera de pensar dominante en la Europa de la Modernidad, que en América se reconvierte en pragmatismo (en conocimiento empírico de lo real): un pensamiento vivo, sobre realidades tangibles y experimentadas, y aplicado a demandas sociales (v.g. no preocupa la concepción acabada del universal de justicia, sino la formulación y aplicación de un sistema de justicia). Por tanto, no se trata de anteponer la estadounidización religiosa sobre la religiosificación estadounidense, ni al revés; más bien, conviene entender que se trata de una relación sinalagmática, en la que el influjo de una parte afecta a la otra y viceversa, pues hay interacción constante y copulativa (tal como se anuncia en el rótulo del epígrafe): cada reacción tiene su respuesta, que provoca otras; así se explica en la teoría de ciclos de despertares y revitalizaciones socio-religiosas (vid. supra epígr. 6.3 y 9.3), que aclara cómo se han ido dando las relaciones entre las bases sociales (con sus demandas) y las élites (con 
su renovación y realización de políticas públicas), y en las que la religión ha jugado un papel clave en la vida pública estadounidense. Luego, tan importante ha sido la recepción de la religión y las propuestas de la secularización moderna y su Teología política, como adaptación de las mismas mediante el Americaness, y la puesta en marcha de demandas sociales transformadoras de la realidad social, que a su vez se ha transmitido en el tiempo gracias a la religión y su capacidad condensadora y de trascendencia.

Otros aspectos a tener en consideración, e ilustradores de la sinalagmática relación planteada (entre la religión y la forja del carácter propio estadounidense en contraste con los europeos coetáneos-), son los siguientes:

- La religión queda liberada del constreñimiento dogmático, y por ende del control hierocrático. Los ministros de culto pasan a ser uno más de la comunidad (como Marx advirtiera -más la hija, por influjo de su marido Lafargue, que el padre al estudiar las tesis de Feuberbach-: cada hombre puede ser ministro de culto de su propia iglesia). Tal libertad, genera un estímulo evangelizador y de competencia social, que dinamiza constantemente al país (construido así por las bases sociales, vid. supra).

- La religión no es monopolio de las élites de poder, sino que está en manos de las bases sociales (en concreto, de cada comunidad, en la que todos participan). Tal situación provoca un desarrollo similar de otras instituciones, como el Estado: desde el periodo colonial se tiene claro que su soberanía es de carácter popular. De tal suerte, no es que se alcance la separación de Iglesia-Estado, sino que las esferas sociales de religión y política quedan liberadas para su mayor y mejor desarrollo (sin la restricción faccionalista de determinadas instituciones 
impuestas -que era algo que preocupaba a los Federalistas durante los congresos continentales constituyentes-).

- En consecuencia, la religión no queda relegada a la esfera privada (como pretenden las élites europeas desde la Ilustración), sino que participa activamente en la vida pública, ayudando en la asistencia socio-religiosa (v.g. educación, salud, beneficencia), así como a la regeneración de la agenda institucional (aclarando que problemas preocupan a los ciudadanos: cruzadas anti-alcohol, anti-apuestas, anti-duelos, pro-vida, pro-abolición, etc.).

- Al concebirse y operar la religión de manera autónoma (como esfera social separada -que no independiente- de la política), ello evita un exceso de propaganda política (como sí ocurre con el debate decimonónico del nacionalismo en Europa). Al ser contrarrestada la propaganda política por la religiosa, ello provoca la consolidación de un contrapoder civil, como son las confesiones (frente a los poderes públicos), además de evitar el auge de las ideologías (de ahí la contención del nacionalismo y del socialismo hasta el triunfo de la posmodernidad y los contagios etnoculturales, vid. supra cap. 7).

- Et al.

En definiva, tan importante ha sido la estadounidización de la religión (dando lugar a nuevas variedades religiosas -como expresara James-, incluida una como la ACR, que facilitara la convivencia de todas las demás), como lo ha sido la religiosificación estadounidense (confiriendo elementos como una sobrestima moral o ASR, un destino manifiesto o AMD, etc.). Téngase en cuenta que gracias a la simbiosis, fruto de la relación sinalagmática planteada, los estadounidenses no sólo 
quieren a Dios, sino que se sienten queridos por Él (con una relación muy personal, de proyección social), inspirándose así su credo de ser un pueblo elegido, con un destino manifiesto, para guiar al resto de gentes del mundo (tal creencia es parte de su matriz mitopoiética). Para comprender tal cosa (y conectarla con el resto de elementos configuradores de la matriz mitopoiética estadounidense), se ofrecen seguidamente unas nociones sobre secularización moderna y su Teología política, más la hoja de ruta para la articulación de ACR, dándose así lugar a la idiosincrasia estadounidense, y su transmisión a través de un legado (a estudiar pormenorizadamente en la Parte de desarrollo especial). 


\section{2.- RELIGIÓN \& AMERICANESS:}

\section{HITOS DE LA MATRIZ MITOPOIÉTICA Y SU MOTOR IDIOSINCRÁSICO}

Como aclaración, de las acciones a acometer en esta Parte de desarrollo general de la tesis, al tratarse de un estudio de revisión crítica y de autenticidad, se entenderá que se proceda al (re)examen de conceptos clave como religión, secularización y Teología política, por ser algunas de las unidades de medida más importantes del sistema aquí planteado. Además, resultan de lo más confusas hoy en día (al haberse ocultado por diversos velos), y su interpretación occidental, pese a partir de un mismo origen, en cambio, su desarrollo ha sido de lo más divergente entre el modelo europeo-continental y el estadounidense. Dicha divergencia de modelos se entiende (como breve adelanto, vid. supra) del siguiente modo: cuando una sociedad se moderniza, desarrollándose y volviéndose más compleja, no por ello ha de desaparecer de escena la religión -haciéndose creer que se trata de un vestigio del pasado-, como se ha pretendido desde el modelo europeo-continental (tanto positivista como vitalista que finalmente condujo al triunfo de las ideologías y sus guerras posteriores). La alternativa del modelo estadounidense es un recurso de la religión como valioso cemento y levadura social, al crear vínculos solidarios e identitarios, códigos comunicativos y simbología, condensar capital imaginario, resolver conflictos, fijar parámetros ético-morales, etc. Incluso, se percibe la religión como levadura social, al promover las acciones de transformación para un bien común (con campañas o cruzadas de toda índole). Para comprender tal divergencia (entre europeos y estadounidenses), es necesario el remontarse al error de lectura europeo-continental de la secularización moderna -amen de haberse producido su 
implantación con cierto retraso y de manera violenta-113. Dicha lectura postulaba que la religión, en vez de adaptarse al Nuevo Régimen, se extinguiría (por ser un lastre histórico), siendo sustituida en la práctica por las transformadoras ideologías, renovadoras de la sacralidad moderna -aunque probaron ser lo contrario: factores sociales necrotizantes, al fundamentarse en la consecución de frustrantes utopías ${ }^{114}$, que requirieron del fin de lo existente, para alcanzar lo deseable-. En cambio, la

${ }^{113}$ El diagnóstico y pronóstico de los autores europeo-continentales, desde COMTE a HABERMAS, es fallido porque no se basa en la experiencia real, sino en el ejercicio de falsificación de la misma, para promover una ideología socialista suplantadora (como mínimo, se trata de un caso de falacia naturalista: confusión interesada del ser con el deber ser).

${ }^{114}$ Las utopías, son cultismos usados por la patrística cristiana (v.g. San Agustín y su La ciudad de Dios, adaptando el mensaje de Jesús sobre el Reino de los Cielos), con un desarrollo medieval orientado a la consecución del comunitarismo dominante de aquel periodo -distorsionador del dualismo cristiano. Mediante las utopías se recupera la dialéctica de lo terrenal imperfecto y temporal frente a lo celestial perfecto y eterno, mostrándose así el camino entre el ser (lo cotidiano corrupto) y el deber ser (el modelo a seguir). Quien consagra el término es Tomás MORO con su obra Utopía (De optimo reipublicae statu, deque nova insula Vtopiae, 1516), pudiendo referir tanto a un no-lugar (ou-topos), como a un feliz-lugar (eu-topos). Sin embargo, desde ideologías decimonónicas como el socialismo, el concepto de utopía se ha deformado -ignorándose los planteamientos del dualismo cristiano-, llegando a confundir el fin con el medio, además de predicarse una tanatofilia o deseo de destrucción de lo presente (del hombre, la sociedad, la cultura, etc.), articulándose desde el resentimiento (malinterpretándose la metafísica y los enunciados del materialismo dialéctico e histórico), para exigir a la postre a las bases sociales la renuncia de la realidad y seguir los dictados mesiánicos de los líderes (vid. artículos de MARX en DFJ, de LENIN en Iskra, o de CASTRO en Granma). En consecuencia, la utopía ya no es el modelo a seguir y alcanzar, sino los dictados convenientes de quienes pretenden llegar y mantenerse en el poder. Ideológicamente, se articula nutriendo un malestar social, y alentando un victimismo revanchista. De este modo, una vez ha calado la utopía ideológica, se impide el libre desarrollo de la autonomía individual, en pro de una seguridad e igualdad colectiva (primando el supuesto bienestar dado frente a felicidad personal buscada). Este autor acometió tiempo atrás otro planteamiento actual de utopía, como los no-lugares (clónicos y de tránsito), donde no se desea estar y que, sin embargo, son requeridos para llegar al destino pretendido (más bien, impuesto por el sistema), como son los ascensores, las estaciones de autobús o tren, los aeropuertos, etc. Además de las utopías, existen las distopías, dorotopías, et. al.; y frente a todas estas expresiones, desde el humanismo (máxime el hispánico) se aboga por la realidad con ilusión: sin perder contacto con el mundo y la cultura, se trata de buscar la felicidad, a través de una luz guía de las vocaciones (cada uno la suya e interconectadas todas), para lograr la mejor versión posible de la imagen referente de la perfección. Vid. SÁNCHEZ-BAYÓN, A.: Renovación de la Filosofía Social Iberoamericana... op. cit. - Filosofía Político-Jurídica Glocal... op. cit. - Humanismo Iberoamericano... op. cit. 
religión, en el marco de la secularización moderna y el impulso de la Teología política, ha probado su valía para inspirar ilusión y progreso social, especialmente en América (gracias a la combinación -no exenta de tensiones, en los ensayos y errores acometidos- del racionalismo humanista hispánico y el racionalismo profesional anglo-nórdico).

Pues bien, se recuerda que con la globalización se reactiva el debate identiario, en el que recupera un importante papel la religión y, sin embargo, en los EE.UU. se da el problema de APP. Por tanto, antes de avanzar, se sugiere la revisión de la noción identitaria (por conformar la idiosincrasia y a la luz de las otras categorías, como secularización moderna, Teología política, etc.), de modo que pueda comprender mejor qué ha caracterizado a los estadounidenses, y por qué ha de funcionar (de cara a la posglobalización). Entonces, si los EE.UU. nacen con la Modernidad (con el triunfo de la racionalidad individual y la sociedad abierta), ¿cómo se articula la identidad moderna? En la Modernidad (tanto la Alta Modernidad hispánica, como la Baja Modernidad anglo-nórdica o Contemporaneidad), se han usado diversos metámeros para la gestión de identidades colectivas, tales como la religión, la nación o el partido. Téngase en cuenta que, la identidad es una producción o constructo social -que no natural-, necesario para asegurar la convivencia. Según la lectura occidental, basada en una expectativa constante de progreso (frente a interpretaciones orientales que postulan ciclos, retornos continuos, etc.), para dar el salto a la Modernidad ${ }^{115}$, que representa

\footnotetext{
115 Desafortunadamente, es muy habitual confundir el sustantivo Modernidad (que es un periodo histórico -fijado etnocéntricamente por los occidentales: del s. XV al XVIII, de nuestro sistema de tiempo), con su adjetivo moderno (lo último en tendencia) -se deja fuera otra voz, muchas veces mal empleada como sinónimo, como es el modernismo: corriente artística finisecular entre los europeocontinentales y novecentista entre los anglosajones). Para este estudio, Modernidad se emplea de manera laxa, para referirse no sólo al periodo histórico occidental, sino al nuevo paradigma que sigue
} 
el Nuevo Régimen (o sea, una sociedad abierta: no estamental, sino de clases; no absolutista, sino democrática; no comunitarista, sino individualista; no antieconomicista, sino capitalista, etc.), todo ello demanda un cambio de identidad y mentalidad: de ahí que, pese a que se prepara desde el Renacimiento, no germina hasta la Reforma protestante y el asentamiento en América (como laboratorio social, sin el peso de las instituciones históricas), resultando urgente y necesario el romper como la oficialidad, para que la diversidad compita. El problema que aquí atañe es el de contradicción: pese a tener un origen común (los fundamentos del tránsito a la Modernidad), en cambio, se manifiestan de manera distinta, con lecturas casi contradictorias, dando lugar al modelo moderno estadounidense (prototípico e inacabado), frente al posterior europeo-continental, que más bien resulta contemporáneo (acelerado, violento y agotado - de ahí la condición posmoderna actual-). Para entender mejor el problema, es prioritario el reconocer y diagnosticar las categorías y modelos vigentes, para proceder así al contraste de los mismos. Como unidades de medida y diagnóstico se van a usar la religión y la secularización -como hoy en día cabría usar las tecnologías de la información y comunicación (TIC) y la globalización: las TIC no son buenas ni malas, sino cómo se usen; y la globalización sólo es un proceso de trasformación y apertura... mutatis mutandis, cabe predicarse de la religión, la secularización moderna y la Teología política, que sí son categorías ontológicas de gran calado (frente a las mencionadas secundarias, de subproducto, como las TIC y la globalización, vid. infra cap. 1)-.

\footnotetext{
al Medievo y su mundo feudal espiritual, y sin embargo rígido (por su oficialidad), dando paso a un paradigma basado en propuestas realistas y materialistas -con las prevenciones necesarias frente al concepto, por tanto reconducido hacia la noción ilustrada de riqueza y bienestar (v.g. Ilustración escocesa -heredera de la Escuela de Salamanca, vid. supra-: de HUME a SMITH).
} 
Se insiste en que, filosófica y sociológicamente, tanto la identidad (en este punto) como la religión civil (más adelante), resultan dos constructos socio-culturales -como se viene señalando-, siendo necesarios para la gestión de sociedades, especialmente aquellas de multitudes diversas y cada vez más sofisticadas en sus interacciones e instituciones socializadoras. Resulta difícil probar una identidad social natural, pues cada comunidad tiene sus singularidades y va evolucionando ergo, la comunidad genera la identidad (los vínculos solidarios, el capital sociocultural, etc.), que luego se recrea para los siguientes miembros de dicha comunidad, socializados en consecuencia-. Y es que, además, la identidad comunitaria cambia al igual que lo hacen sus integrantes. Ni siquiera un ser humano es idéntico a sí mismo con el paso del tiempo: poco tiene que ver el niño del que se parte, con el adulto que se llega a ser, o con el anciano que finalmente resulta. Sin embargo, existen y son muy relevantes las identidades sociales para asegurar la convivencia. La identidad, además, permite fijar unos límites definitorios: dónde termina el "yo" y/o el "nosotros", y dónde comienza el "otro(os)" -el problema de confusión se da cuando se intenta hacer pasar dicha identidad (integradora para dentro y diferenciadora para fuera), como algo innato e inmutable, justificador de jerarquías y discriminaciones-. En consecuencia, para facilitar las relaciones sociales, además de las herramientas racionales (v.g. la justicia del derecho, el bien común de la política, el bienestar de la economía), también se requieren otras emocionales como la identidad para la solidaridad: ¿cómo vincular a diversos seres humanos en un mismo proyecto social que garantice la pacífica y próspera convivencia? ¿Cómo se compensan los esfuerzos a favor de dicha convivencia? Se requiere de un sistema de lazos empáticos favorecedores de las interacciones (basados en la presunción de similitud y confianza), que según su nivel de complejidad en su desarrollo, bien se 
terminará dando lugar a propuestas cada vez más sofisticadas de imaginarios sociales compartidos (cuestión a la que llamó “interaccionismo simbólico" la Escuela de Chicago, desde la década de 1920), con otros elementos relacionados con la identidad, como es la mentalidad, los símbolos y ritos, los códigos comunicativos, etc. Todo ello genera lealtades grupales que, en contraste con otras gentes, cabe denominar lato sensu idiosincrasia o singularidad identitaria. Pero se insiste en que, tanto lo que aparentemente une a una sociedad y la distingue de otras, es fruto de producción cultural: cómo se ha ido percibiendo y gestionando los elementos naturales influyentes, transformándolos y transmitiéndolos entre generaciones. Para tal proceder, un constructo cultural aún más complejo que el de identidad, es el específico de religión civil. Baste adelantar por ahora (pues tiene su propio apartado de desarrollo, vid. supra cap. 6 y 10), que si bien la religión $n^{116}$ se halla entre lo natural

116 Únicamente, para dejar constancia de la problemática definitoria de la religión (en general), obsérvense las siguientes indicaciones: 1) Las atribuciones verbales originarias: a) según CICERON -o mejor dicho, atribuyéndosele el mérito a él-, el vocablo latino "religio-onis" guarda relación con las fórmulas verbales "relegere/religere" [acción de tratar con cuidado o escrúpulo]; b) según SAN AGUSTÍN, con "religere" [acción de ligarse a Dios]; c) según LACTANCIO, con "religare" [acción de volver a elegir a Dios]; etc. 2) Las interpretaciones y construcciones etimológicas: a) "relegere" cabe ser traducida como recoger o agrupar, pues hace referencia al conjunto de ritos que constituyen la esencia sagrada de las instituciones sociales y su observación escrupulosa, porque equivale a estar de acuerdo con la prescripción ritual y escrutar en su conducta lo que sucede a su lado, más allá o más acá de allá; b) "religare", como reunir, o dicho de otro modo, es aquello que une al hombre con dios; etc. Atendiendo a tales reflexiones, la noción atribuida a "relegere", parece ajustarse a la fase de religión natural, y de un mundo no secularizado, mientras que religare, por su parte, da la impresión de referirse a la fase de religión positiva, donde las religiones verdaderas reclaman su autonomía. En cualquier caso, ambas acepciones son tenidas en consideración por los Padres fundadores, para establecer la que es la definición tradicional de religión en los EE.UU. Por su parte, entre los eclesiasticistas españoles y completando las referencias etimológicas, MARTINEZ conecta la voz "religio" con los verbos y significados siguientes: a) "religari" [volver a ligarse]; b) "relegere" [volverse constantemente a]; c) "reeligere" [volver a elegir]; etc. En definitiva, su propuesta la termina definiendo como lo hiciera TOMAS DE AQUINO, quien consideraba la religión como "la ordenación a dios". Cfr. FERRATER, J.: Diccionario de Filosofía (tomo IV), Ariel, Barcelona, 1994, pp. 3062 ss. GARIN, P.Ma.: Temas de Derecho Eclesiástico del Estado. La "religión" en la comunidad política desde la libertad, Universidad de Deusto, Bilbao, 2000. pp. 27. GUERRA, M.: Historia de las religiones (tomo 1), Eunsa, Pamplona, 1980, pp. 2021. GRIGORIEFF, V.: El gran libro de las religiones del mundo, Ediciones Robinbooks, Barcelona, 1995, 
-incluso, tendente a lo sobrenatural- (como atributo humano, v.g. pius homo, religatio, salutatis), y lo cultural (esfera social, con sus instituciones), sin embargo, la variante de religión civil, es una expresión aparentemente paradójica de la Ilustración -máxime en contraste con el devenir europeo-continental decimonónico-, que en los EE.UU. ha servido para forjar su idiosincrasia: su manera de recibir imaginarios sociales diversos (actuales e inveterados, públicos y privados, sagrados y profanos, etc.), armonizándolos, y gestionándolos con éxito y beneficio (vid. supra). Pues bien, a intentar exponer y explicar los elementos planteados se dedican los siguientes puntos de estudio.

Sólo apuntar en este avance un par de cuestiones a desarrollar luego:

- Identidad, secularización y religión: la religión articula los vínculos, que permiten trascender, salvando así al ser humano de su miseria (su condición finita). Sin embargo, cuando la religión se institucionaliza, entra en conexión íntima con la política (con los juegos de poder), como pasara con el cristianismo medieval en Europa, que tras su institucionalización eclesiástica y su oficialización católica (Edicto de Tesalónica, 380), comienza a desnaturalizarse (dando lugar a la Reforma ortodoxa u oriental, y más tarde a la Reforma protestante). Sin embargo, cuando la religión llega a América, lo hace en pleno proceso de secularización moderna (de apertura al Nuevo Régimen), mediante dos modelos de evangelización en competición (con estadios dispares de secularización), como

pp. 13 ss. MARTINEZ, A.: Derecho Eclesiástico del Estado, Tecnos, Madrid, 1994, pp. 27 ss. MORENO, M (dir.): Diccionario de Pensamiento Contemporáneo, San Pablo, Madrid, 1997, pp. 1033 ss. VVAA.: Diccionario Enciclopédico Albor (tomo IX), Olimpo Ediciones, Barcelona, 1993, pp. 3571 ss. Vid. SÁNCHEZ-BAYÓN, A.: La Modernidad sin prejuicios (vol. 1)... op. cit. - Estado y religión de acuerdo con los Estados Unidos de América... op. cit. Sobre religión civil en particular, vid. cap. 3 y 5. 
es el colonial-protestante de nórdicos y anglosajones, y el de conquista-romano de mediterráneos (manifestaciones originarias de identidad en América, y no las posmodernas de las Américas WASP y Latina, vid. supra). Gracias a sus interacciones en el periodo fundacional (y el influjo de la Teología política), la religión en los EE.UU. se adapta y combina dando paso a un prototípico sistema de relaciones entre las religiones comunitarias tradicionales y la religión civil nacional (vid. infra figura 6). De tal suerte se conforma un tipo de plurilealtades propio de la idiosincrasia estadounidense (en el que, de base se puede ser católico de Maryland, judío de Rhode Island, budista de California, etc., todos quedan integradas en la cúspide, al autopercibirse como American o estadounidense, vid. ídem). Ahora bien, tal logro identitario moderno de plurilealtades entrelazadas y funcionales, que ha sido revisado y actualizado cíclicamente, ha quedado muy tocado y oculto por velos de confusión posmoderna (dando lugar al problema mitopoiético e idisincrásico presente): la corrección política lo ha difuminado; el relativismo lo ha negado; los planteamientos neomarxistas y posmarxistas (al exaltar la diferenciación y los particularismos) lo están haciendo desaparecer, etc.

- Identidad y Teología política: la Teología política es un tipo de teología moderna, preocupada por el papel del creyente en el mundo. Ayuda en materia de identidad, pues permite formular las tres grandes cuestiones al respecto (en consecuencia con lo planteado en el punto previo): qué es ser estadounidense (ACR, ASR, etc.), para qué y cómo se es estadounidense (AMD, ASR, ASG, etc.).

Hechas las aclaraciones, se procede ahora a examinar el papel de la religión como motor social y vehículo idiosincrásico en América. Y es que, se manejan hoy categorías muy discutibles, no sólo porque no se ajustan a la realidad, sino porque 
vulneran el paradigma de la Modernidad, contribuyendo a su deterioro y resultado fallido. De ahí que uno de los primeros entornos más expuestos al fallo paradigmático sea Europa continental, por no entender y gestionar adecuadamente el factor religioso, máxime en su expresión moderna, como es la acaecida en las Américas (concepto a clarificar más adelante). Dicho sea de paso, tal categoría (Américas), tampoco se entiende -especialmente por los europeo-continentales, quienes tienen una relación compleja con los americanos- ${ }^{117}$, de ahí que se acepte cualquier definición ofrecida, aunque carezca de sustento analítico y empírico auténtico.

Se procede ahora, de manera sintética, a practicar un ejercicio de revelaciones (de retirada de velos de confusión posmodernos), sobre las Américas (America WASP v. Latina) -dichos velos ocultan la inteligibilidad de la combinación fundacional de la racionalidad humanística hispánica y la racionalidad profesional/protestante anglo-nórdica, tal como se constata en la Declaración de independencia-DIE, la Constitución estadounidense-CEU, o su Declaración de derechos (Bill of rigths)-BR-.

En los EE.UU. de la década de 1990, con el inicio de la globalización, y punto álgido de la corrección política y el relativismo (bajo la Administración CLINTON), tuvo gran fortuna la expresión the Americas [las Américas]: ya no había una diferenciación geográfica de América (América del norte y del sur), sino supuestamente- cultural (América anglosajona y latina). Tal constructo permitía

\footnotetext{
117 Por un lado, desde un error etnocentrista, los europeo-continentales consideran que son la cuna civilizatoria de los americanos (sin considerar los aportes indios, africanos, asiáticos, etc.), sintiéndose heridos por su expulsión del continente (v.g. Doctrina MONROE, Corolario ROOSEVELT), rompiéndose así la relación metrópoli-colonia, para dar paso a una inversión de roles, con la necesidad de la ayuda americana para resolver las dos guerras mundiales del s. XX (además de tener que dar acogida a grandes flujos migratorios -en condición inferior a los nativos-), y cuyo resultado fue la autoproclamación de los EE.UU. como adalid de Occidente.
} 
seguir pensando -sin decirlo abiertamente- en una América del norte anglosajona, por ende rica y desarrollada, frente a otra del sur latina, ergo pobre y en vías de desarrollo -por no decir tercermundista (categoría propia del Guerra fría para los países recién descolonizados)-. Resulta sorprendente que buena parte de los países latinoamericanos hayan aceptado tales categorías falaces, pues ya a finales del s. XIX buena parte de los Estados americanos eran repúblicas soberanas, con un equivalente nivel de prosperidad. Con la categoría anacrónica de Américas, se pretende dar carta de naturaleza y cobertura al cúmulo de una América culturalmente WASP (White Anglo-Saxon Protestant [blancos protestantes anglosajones -su acrónimo coincide con la palabra avispa, no quedando claro si se pretendía fijar paralelismo alguno-]), junto con una América culturalmente latina noción aún más polémica, pues ya no se alude a la herencia de los Imperios católicos español y portugués, sino al mestizaje racial y religioso indigenista y africanista-118. Tal fue el éxito de Américas, que obtuvo un satisfactorio reconocimiento internacional, desde la Organización de las Naciones Unidas (ONU) -reajustando su distribución regional-, hasta iniciativas y organizaciones americanas (v.g. Organización de Estados Americanos-OEA, Área de Libre Comercio de las Américas-

\footnotetext{
${ }^{118}$ La noción de América Latina la extiende Francia (con Napoleón III), para legitimar su presencia en América, pretendiendo su fundamentación en que aglutinaba a los pueblos de origen latino. Algo incorrecto históricamente, pero sustentando en el influjo del Imperio romano en las metrópoli conquistadoras. Con las construcciones nacionales decimonónicas, las élites criollas comenzaron a rechazar su herencia cultural, para generar una novedosa identidad panamericana (con conferencias internacionales, proyectos políticos como la Gran Colombia, etc.), de la que los EE.UU. se desvinculó (por tener ya su proyecto continental de Americanness). Finalmente, con la renuncia del capital cultural a lo largo del s. XX -fomentado por las ideologías, v.g. socialismo, nacionalismo-, se terminó aceptando la superioridad de los viejos bárbaros, devenidos en nuevos referentes civilizados, admitiéndose las categorías de éstos: el latinoamericano ya no era un dandy, sino un espalda mojada. Todo ello se expone y explica con detalle (y amplias evidencias y fuentes) en SÁNCHEZ-BAYÓN, A.: Humanismo Iberoamericano... op. cit. - Renovación de la Filosofía Social Iberoamericana... op. cit. Complement., vid. GONZÁLEZ, M., SÁNCHEZ-BAYÓN, A.: Derecho Eclesiástico de las Américas, Madrid: Delta, 2009. - RIDE, Madrid: Delta, 2011.
} 
ALCA $)^{119}$. Resulto tal el calado de Américas, que finalmente se logró diferenciar entre el exitoso modelo socio-cultural WASP, restringiéndolo a los EE.UU. y Canadá, frente al fallido latino, al que se le adhirió el caribeño (aquellas experiencias de origen WASP, como Jamaica, Trinidad y Tobago, Belice, etc., de las que ha habido un desembarazamiento, identificándolas con el mestizaje fallido latino). De tal manera, en la década del 2.000 se consolidó la categoría internacional Latinoamérica y Caribe -sin objeción de los afectados-.

La reinvención idiosincrásica mencionada sirvió, durante un tiempo, para la reafirmación estadounidense tras la Guerra fría: durante dicho periodo (de la segunda mitad del s. XX), la autodefinición dada por los propios estadounidenses era la de líderes del mundo libre y opositores del comunismo. El problema es que Latinoamérica y Caribe no es un conglomerado de identidad clara -más bien dada por otros-, ni se puede definir una identidad de manera sostenible por la mera oposición a otros, ya que se requiere de un nexo común interno y rasgos propios compartidos. Tal debilidad idiosincrásica ha favorecido la proliferación de contagios posmodernos (que han encontrado su nicho en los difusos Estudios culturales, vid. supra cap. 8), haciendo urgente y necesario un revisionismo de fundamentos: las esencias constitutivas que permanecen y cómo ha operado su factor o motor evolutivo (frente a discursos de conflicto como los poscoloniales y descoloniales de los Latin American Studies, al aceptar las Américas y la condición colonial, cuando los Estados latinoamericanos eran ya repúblicas soberanas en el s. XIX).

En definitiva, si se asume que las identitades son constructos culturales, que se van generando en un entorno y por un pueblo, se comprenderá entonces el gran

119 Otras organizaciones, vid. GONZÁLEZ, M., SÁNCHEZ-BAYÓN, A.: Derecho Eclesiástico de las Américas... - RIDE... op. cit. 
riesgo que supone la pérdida de la identidad propia, para pasar a asumir otra diseñada por terceros (con intereses ajenos a la solidaridad de la comunidad influida). Frente a tal confusión y reinvención de identidades posmodernas (v.g. América WASP, América Latina), desde este estudio se aboga por la atención a aquel factor que resulta clave en la configuración de modelos culturales en América con sus consiguientes identidades e idiosincrasias. Se procede así al estudio del factor religioso como artífice de identidades en las Américas: evangelización católica de conquista v. protestante colonial

Como ya se ha planteado, desde esta tesis, no sólo se propone una síntesis histórica del influjo religioso en el descubrimiento y colonización de América (v.g. las rivalidades entre potencias católicas y protestantes, los llamamientos evangelizadores), sino que además se presta atención a su prototípica secularización moderna y sus expresiones hierocráticas (v.g. la diversidad de modelos históricos habidos de Iglesia-Estado: confesionalismo de las plantaciones sureñas, denominalismo de Nueva Inglaterra, deísmo de las provincias medias, vid. supra). También se atiende a la historiología socio-cultural y comparada del factor religioso, desde propuestas comprensivas -a la vez que comprehensivas- como US/American (social) gospel o ASG (evangelismo social estadounidense) hasta US/American civil religion o ACR (religión civil estadounidense), procurándose el completar con otras teorías y modelos idiosincrásicos de rango medio, como US/American calling o AC (vocación estadounidense), US/American dream o AD (sueño estadounidense), US/American way of life o AWL (modo/estilo de vida estadounidense), US/American manifest destiny o AMD (destino manifiesto estadounidense), US/American civilazing sense o ACS (sentido civilizatorio estadounidense), US/American self-righteousness o ASR ((sobre)autoestima estadounidense), et al. Por tanto, para aclarar todo ello, 
sirviendo además de verificación fundacional frente a los ulteriores postulados de finales de s. XX, como el anacronismo ya planteado de las Américas, y su -supuestatensión de modelos socio-culturales (América WASP y latina), se ofrece a continuación una serie de apuntes acerca del real influjo del factor religioso en la emergencia americana y sus dos grandes modelos socio-culturales históricos, como fueron la evangelización católica de conquista (de la Reconquista Ibérica a la Conquista Americana para llevar buena nueva), y la evangelización protestante colonizadora (con su dominalismo ${ }^{120}$ de los ungidos en tierra prometida, también llamada nuevo paraíso, Sion, Jerusalén o Salem) -tal contraste permite a su vez, no sólo el redescubrir los orígenes fundacionales reales, sino también el desmontar el anacronismo de las Américas y la supuesta superioridad de un modelo socio-cultural sobre otro (máxime por los sincretismos acaecidos, vid. supra)-.

Como apunte de partida, se reitera la urgencia y necesidad de retirar una serie de velos de confusión extendidos de manera interesada: los primeros velos se corresponden con los apuntalados por la generación dorada de historiadores estadounidenses (vid. supra cap. 8), quienes consolidaran la leyenda dorada de la forja estadounidense desde el dominio WASP y frente a la leyenda negra española. Los segundos velos fueron impulsados por la generación de historiadores críticos de American Studies (ídem), exacerbados a la postre por su vertiente étnico-cultural. Se alude así a la negación histórica del descubrimiento de América por los españoles -

\footnotetext{
${ }^{120}$ Vid. Gen. 1: y Dios indicó al hombre que dominara la creación -ergo, el hombre ha de someterlo todo-. Vid. BROWN, D.: Bury My Heart at Wounded Knee: An Indian History of the American West, New York: Rinehart and Winston, 1971. HORSMAN, R.: Race and Manifest Destiny. The origins of American racial Anglo-Saxonism, Cambridge: Harvard University Press, 1981. ORTEGA Y MEDINA, J.A.: La evangelización puritana en Norteamérica, México DF: Fondo de Cultura Económica, 1976. PRUCHA, F.P.: The Great Father. The United State Government and the American Indians (vols. 1-2), Lincoln: University of Nebraska Press, 1984.
} 
dado su pecado de la sangre (al mezclarse con los indios)-, buscándose otros orígenes -supuestamente superiores- como el escandinavo y su mito de Erik el rojo y la Saga de Vinland [tierra de viñas]). Sin embargo, tal relativismo se ha vuelto en contra, al multiplicarse y abrirse a otros orígenes, como el descubrimiento asiático (con las expediciones chinas a la costa pacífica). Toda esta hibridación ${ }^{121}$ viene acometida por el revisionismo tropológico de la memoria histórica ${ }^{122}$, que viene acometiéndose desde los heterodoxos Estudios culturales (vid. supra cap. 8), en especial aquellos de orientación post-marxista (v.g. estudios post-coloniales, de género, étnicoculturales), cada una de sus corrientes defienden un descubrimiento de América según sus intereses: los estudios de género desde el desembarco de la primera mujer, y su papel en la colonización; los estudios etnoculturales varían según la comunidad en la que se focalicen, pues para los afroamericanos lo relevante es el factor "negro" -muestra de la hibridación ya señalada (vid. infra)-, mientras que los asiáticos se ocupan de los desembarcos en la costa pacífica -así cada comunidad, según la llegada de sus primeros integrantes-; etc. Ante tal deriva y dispersión, se ofrece aquí la recuperación de una propuesta de larga trayectoria en la universidad

${ }^{121}$ Cuando los dioses (tanto el judeocristiano como los grecorromanos) pretendían castigar a humanos soberbios, entonces, les confundían el juicio, que es el síndrome de Babel (v.g. pueblos ante-diluvianos, Nabucodonosor, Zacarías) o la hybris (v.g. Edipo, Orfeo, Prometeo), de modo que el resto de humanos les excluyeran. Luego, se alude a la confusión, por la que se intenta sustituir la realidad por modelos soberbios, que sólo devienen en fracaso -más agudizado cuanto más utópico-; vid. SÁNCHEZBAYON, A.: Filosofía Político-Jurídica Glocal... op. cit. - Renovación de la Filosofía Social Iberoamericana... op. cit.

122 Partiendo de la premisa de que se trata de conceptos antagónicos, pues la memoria es una lectura fragmentada, voluble y personal del pasado, mientras que la Historia es la racionalización integradora del pasado lejano, relevante y común, influyente en la configuración idiosincrásica de un pueblo (y en relación con los demás pueblos vecinos); se entenderá entonces la sospecha que suscita el triunfo de dicha corriente de confusión en la Historia contemporánea, al tratarse de su propia negación, pues se confunden fuentes e instituciones, de origen privado y/o ficticio (v.g. voluntarista, ideológico, falaz naturalista), haciéndolas pasar por públicas y oficiales, dando lugar al triunfo de las historias o narrativas victimistas -y revanchistas, de supuestas comunidades reprimidas-, imposibilitadoras de una ciencia histórica. 
estadounidenses, como es la de Church-State Studies (CSS: estudios de Iglesia-Estado, vid. supra cap. 8), basada en la atención al factor religioso (como variable intra y extra-comunitaria), como configurador de modelos socio-culturales. En este caso, de manera sucinta, se plantea lo que supuso en el periodo colonial la rivalidad de dos variantes del cristianismo, con modelos socio-culturales dispares (la conquista hispánica de evangelización v. la colonización anglosajona de dominalismo), cuya liza aceleró el proceso de occidentalización de América.

Téngase en cuenta que, desde el enfoque de Church-State Studies, no se atiende exclusivamente al factor religioso -restringiéndolo a planteamientos teológicos o catequéticos-, sino a cómo éste influye en los modelos socio-culturales, pues se estudia la evolución de la relación entre las diversas variables y esferas sociales (derecho, política, economía... y religión). Así se entiende que, pese a haber católicos en el modelo socio-cultural dominado por la colonización anglosajona (v.g. comunidades en Maryland u Ohio), al ser minoría no responden entonces al modelo de conquista hispánica, y viceversa. A su vez, la cuestión se complica, pues surgen además las variantes: en el modelo de conquista hispánico, hay que distinguir al menos entre la vía española y la portuguesa; en el modelo de colonización anglosajona, es necesario diferenciar entre la variante dominada por las main-line churches o iglesias establecidas y jerárquicas (v.g. anglicanos, presbiterianos, episcopalianos), y las evangelical churches o iglesias emergentes y comunitarias (v.g. congregacionalistas, metodistas, carismáticos). Con estas prevenciones es posible ahora contrastar dichos modelos socio-culturales. Pues bien, el modelo de conquista hispánica se basa en el descubrimiento y anexión como una parte más del mundo conocido, sirviéndose para ello de dos figuras, el soldado (quien conquista, representando la espada y el poder civil) y el religioso (quien evangeliza, 
representando la cruz y el poder religioso) -tal dualidad favorece el diálogo cuando aparece un tercero, o sea, el indio-. Mientras, el colonialismo anglosajón concentra la labor en un solo sujeto: el colono es al mismo tiempo soldado (espada y poder civil) y religioso (cruz y poder religioso), de ahí que se sirva del dominalismo interpretación bíblica del sometimiento humano de la creación, vid. supra- para su subsistencia (su avance es más lento, pues ha de someter lo que coloniza). De estos dos modelos socio-culturales, el primero en llegar y extenderse por América es el de conquista hispánica (a finales del s. XV), por el Caribe y el Continente, en una diagonal ascendente, de la actual Florida a Oregón, y todo lo que queda por debajo. Poco más de un siglo después (a principios del s. XVII), es cuando empieza a extenderse el modelo colonial anglosajón, de Virginia hacia el norte, disputándose más tarde el Caribe. El aliciente inicial para la colonización de América por parte de la Corona británica (de corte protestante y con Iglesia de Estado) es el de frenar la expansión de la Corona española (de corte católico/romano y confesional). Sin embargo, pronto pesa la parte comercial, debido a la distinta lectura de los Evangelios: la conquista hispánica oscila entre el comunitarismo medieval y la nueva crematística de la Escuela de Salamanca, frente al colonialismo anglosajón, que prima el individualismo profesional. Así, las guerras dinásticas europeas, disfrazadas de guerras de religiones, afectan al mapa americano, haciendo oscilar los avances y retrocesos de los modelos socio-culturales, siempre primándose uno en detrimento del otro. Todo ello se plantea, para que se advierta de la gran complejidad de la cuestión y su volubilidad, de ahí que, sin la atención debida al factor religioso en cada coyuntura y en relación con el resto de factores y esferas sociales, difícilmente se pueden disponer de claves adecuadas acerca del devenir americano, más concretamente del estadounidense. Los EE.UU., desde su fundación, ha sido un país 
que ha albergado en su seno sendos modelos socio-culturales (con sus variantes evangelizadoras), incluso fusionándolos a veces (vid. supra), por lo que no cabe la prédica actual de que se corresponde exclusivamente con el conglomerado anglosajón (WASP), siendo su abanderado además.

Se centra ahora la atención en la secularización moderna que dará origen a los EE.UU. Y tal como acometen los propios estadounidenses con su pragmatismo, se estudia más exactamente las secularizaciones made in USA. Se alude así a las múltiples manifestaciones de la secularización moderna estadounidense. Vaya por delante la prevención sobre la complejidad de la secularización ${ }^{123}$, pero lo que más interesa destacar, antes de proceder a enunciar las manifestaciones estadounidenses, es la divergencia de significados entre europeos y estadounidenses hasta la globalización: buena parte de los autores europeo-continentales, tras la década de 1960 van preparando el tránsito (que se hace efectivo con la globalización) a la posmodernidad, por lo que ya no es necesario atender a la realidad, sino a la pluralidad de discursos que sobre la misma se manejan ${ }^{124}$. Tras el influjo ideológico

${ }^{123}$ Vid. SÁNCHEZ-BAYÓN, A.: “Secularización moderna y teología política estadounidense: estudio panorámico del sentido y alcance de la religión en su configuración idiosincrásica", Tesis doctoral en Humanidades (especialidad Teología) por Universidad de Murcia (Facultad de Letras-UM e Instituto Teológico de Murcia OFM-Facultad de Teología de Pontificia Universidad Antonianum de Roma; defendida: 21/10/2016; calificación: sobresaliente, cum laude, mención internacional y premio extraordinario de doctorado).

124 Pese al origen común en Occidente, actualmente, existen tantas divergencias comprensivas en torno a la religión -justo cuando más se requiere su operatividad, con la revitalización brindada por la globalización (vid. cap. 1), al tratarse de un vigoroso mecanismo de generación y "almacenamiento" de creencias y valores identitarios, relativos a la experiencia vital y la última referencia-; sin embargo, las dos modalidades principales en su abordaje son: a) la europeacontinental: se parte de la premisa de la declinación aparente de la relevancia socio-cultural de la religión, relegándose su estudio al de las iglesias establecidas y nuevas sectas (cults); b) la estadounidense: se parte de la premisa de los despertares y revitalizaciones periódicos de la religión (vid. supra cap. 10), entendiéndose de forma amplia y central a todos los estudios de Ciencias Sociales (vid. supra cap. 8). 
(tanto nacionalista como socialista), la secularización es entendida de distinta manera ${ }^{125}$ : los franceses abogan por su laicidad y religión civil republicana (vid. supra), los italianos y españoles por sus lecturas de teología de la liberación -y todo ello hibridado se extiende posteriormente por Latinoamérica (o el conglomerado que se predica desde el mundo WASP, vid. infra) $)^{126}$.

Como última aclaración, antes de proceder con la idiosincrásica lectura estadounidense de la secularización, se esboza -mediante trazos rápidos y a mano alzada-, una aclaración fundamental (desmontadora de una falacia muy extendida), diferenciadora de dos compresiones próximas en su origen y divergentes desde el s. XIX, como ocurre entre la visión secular estadounidense y laica europeo-continental. Y es que resulta falaz el pretender usar como sinónimos secularización y laicidad: nada más lejos de la realidad y de su estudio científico-académico -insistiéndose en que es una de las grandes diferencias actuales entre estadounidenses, aún modernos (lato

125 FERRAROTI, por ejemplo, habla de los riesgos de juntar marxismo y ciencia, dando lugar a una religión laica y una teología para ateos, como vago deísmo de salón de los filisteos de la cultura, dispuestos a venderse al mejor postor; vid. FERRAROTI, F.: Una fede senza dogmi, Roma: Guis, 1990.

${ }^{126}$ La religión civil republicana o republicanismo francés, es un constructo falaz, pues desde la fusión de propuestas originalmente dialécticas (el nacionalismo está llamado a ser localista, y el socialismo, a ser internacionalista), se promueve así una gestión identitaria monopolizada por el Estado, desde un discurso republicano que nunca existió, reinventando la Historia para ello (v.g. argumentando que la Revolución francesa de 1789 fue nacionalista y socialista, incluso antes de existir dichas ideologías; que el republicanismo no es una forma de gobierno, sino una ideología, pese a que van por el quinto intento, con dictaduras intermedias). En cuanto a la teología de la liberación mediterránea y latinoamericana, sólo decir que ni es heterodoxa ni disidente, únicamente resulta un contrasentido antirreligioso: no vincula con nada, sino que promueve la destrucción (tanto humano como del resto de la creación) en pro de utopías (no-lugares: un supuesto edén mejor que el anteadánico); no permite trascender, pues la relación con lo demás es de violencia inmanente (hay resentimiento contra el sistema vigente, por lo que en todo momento hay que destruirlo); y sobre todo, se califica de "liberación", pero descalifica en todo momento la libertad o autonomía de la voluntad individual o AAII: su aspiración es la revolución, o mejor dicho, la involución a un comunitarismo dominante (de ahí que sirva tanto para nacionalistas como para socialistas) -hay críticos que la describen como la apología de la santa pobreza, basada en una relación casi idolátrica con el dinero y la riqueza, por fijarlas como referencia del sistema-. 
sensu, o sea modernos y contemporáneos), y europeo-continentales, claramente posmodernos-.

Mientras que, ontológicamente la secularización se corresponde con un proceso fluctuante o de devenir (en las relaciones entre lo sagrado y lo profano), de diversas fases (v.g. secularización, desecularización, resecularización, vid. supra), en cambio, la laicidad es un resultado, presentándose como el último estadio de la secularización, que además, se circunscribe al ámbito de la religión, en una lectura materialista-histórica (o sea, de su supuesta (r)evolución de sus estructuras y superestructuras) $)^{127}$. Adviértase de que la laicidad es una noción localista y protoposmoderna, de origen francés y vinculada a planteamientos ideológicos, extendida después con diversa fortuna entre los países mediterráneos y latinoamericanos (sobre todo en los que ha llegado el socialismo al poder). Su origen está en el laicismo, que es un movimiento anticlerical y antisistema finisecular (de manifestaciones violentas, como la quema de conventos e iglesias, asesinato de religioso y sacerdotes, violaciones de monjas, etc.). Tal es el temor social que genera (en el sur de Francia e Italia, España, etc.) que finalmente desaparece, resurgiendo a finales del s. XX, tras un maquillaje discursivo, por lo que ya no se habla de laicismo (proceso para

\footnotetext{
${ }^{127}$ Se trata de un reduccionismo marxista, según el cual, la religión sigue un desarrollo por estadios, positivizándose e institucionalizándose de diversa manera, hasta su desaparición, pues cada hombre será una iglesia -el fin último es sustituir la religión por la ideología, ninguneando la primera y fomentando socialmente la segunda-. Tal lectura, falla porque no alcanza a cuestiones clave como las creencias, ritos o símbolos (vid. supra cap. 10); tampoco comprende la lógica de una institución, restringiéndola a su lectura política, en cuanto lucha de poder por su gobierno (tesis desmontada por JAMES en su obra Variedades de la experiencia religiosa, vid. supra); igualmente, su lógica es lineal, irreversible y excluyente, cuando la realidad es compleja y oscilante (v.g. en EE.UU. conviven diversos estadios -vid. supra-, que según la lectura materialista-histórica no pueden coincidir, pues unos llevan a otros); et al. Sintéticamente, los estadios de la lectura materialista-histórica de la religión son: a) proto-religiones o religiones naturales; b) religiones positivas primarias (animistas y totemistas); b) religiones positivas secundarias (antropomórficas y míticas); c) religiones terciarias, en especial las monoteístas (v.g. las Abrahámicas: judíos, cristianos, musulmanes y bahais).
} 
suprimir la religión -en su sentido tradicional, vinculada a iglesias-), sino de laicidad (realidad alcanzada -al menos discursivamente-) ${ }^{128}$.

Analíticamente, la laicidad parte de una contradictio in terminis, pues

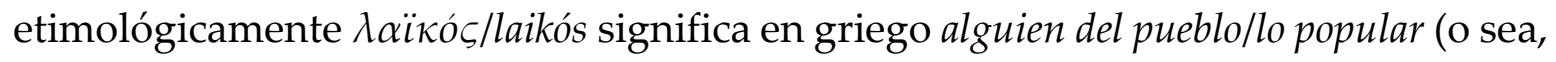
el contra-poder civil o popular no establecido), por lo que un Estado no puede ser laico, ya que no existe un poder más oficial y establecido que él mismo. En añadidura, el intento de rescate de la laicidad incurre en el problema de su obligatoria adjetivización: laicidad positiva y negativa, neutral, etc. -cuando es necesario completar conceptos con adjetivos y adverbios, es que dichas nociones no están claras y pueden ser foco de conflicto social, además de quedar al arbitrio interpretativo del poder de turno-.

Frente a confusiones ideológicas, es preferible atender a soluciones históricamente experimentadas con éxito y de manera sostenible, como es la aconfesionalidad (literalmente, sin religión oficial), ensayada y recogida constitucionalmente por primera vez en los EE.UU.: la Primera enmienda (aprobada en 1791), tipifica la cuestión como primer derecho de los estadounidenses, haciéndolo mediante dos cláusulas (establishment clause $\mathcal{E}$ free exercise clause), de modo que la aconfesionalidad comprende tanto la no oficialidad de religión alguna,

\footnotetext{
${ }^{128}$ Así pasa en Francia, como resultado de las acciones del novedoso Ministerio de Cultura, constituido tras la II Guerra Mundial, para recuperar el "orgullo nacional"; de modo que, al llegar los socialistas al poder, comienzan a fomentar el giro hermenéutico de la laicidad. Una vez más, las influencias francesas (re)calan en España: mientras que el socialista PECES-BARBA, siendo uno de los constituyentes, no incluyó en la ponencia de la Constitución española de 1978 (CE) mención alguna al término, fue ya como diputado en 1982, cuando procuró la modificación indirecta de la CE, y para ello recurrió a un recurso de inconstitucionalidad (RI 68/82, frente a la Ley 48/81 de ascensos militares, ya que reconocía la figura tradicional del capellán castrense). Finalmente, el Tribunal Constitucional deniega el recurso, pero al hacerse eco de la terminología en la sentencia, desde entonces es aprovechado para definir dogmáticamente España como un Estado laico.
} 
como la obligación de los poderes públicos de velar por el libre ejercicio de derechos de sus ciudadanos, removiendo obstáculos (algo parecido a lo que tipifica el art. 9 y 16 de la Constitución española de 1978 o CE). Tal es la discrepancia entre modelos, que la puesta en práctica de la supuesta laicidad del Estado en Europa continental conduce a la violación de la libertad y autonomía religiosa, pues se obliga a declarar las creencias religiosas para determinar si reconoce o no a una confesión (para determinar así si hay notorio arraigo, por ejemplo), y cuál va a ser su régimen jurídico (rayándose la discriminación religiosa, al reconocerse distinto trato según la calificación estatal). En cambio, en el modelo de aconfesionalidad, el Estado deja en manos de la ciudadanía la propia calificación jurídica: en los EE.UU. se realiza a través de IRS (Hacienda), y se conceden ayudas económicas a cualquier confesión que ayude a la prestación de servicios socio-religiosos que sustenten el Estado de bienestar (luego, no se entra en lo interno, sino que se ordena lo externo, y en su aplicación y relación con otras esferas sociales) ${ }^{129}$.

Como se viene aclarando, la cuestión es harto compleja, por lo que se procede mejor a exponer y explicar la singularidad estadounidense, procurando en todo momento el aportar suficientes argumentos y evidencias clarificadoras (vid. figuras próximas).

En los EE.UU. la secularización se ha entendido como el proceso conducente a la Modernidad y su Nuevo Régimen ${ }^{130}$, de autonomía de la voluntad (AAII), libertad,

\footnotetext{
129 Vid. SÁNCHEZ-BAYÓN, A.: La Modernidad sin prejuicios (vol. 2)... op. cit. - Estado y religión de acuerdo con los Estados Unidos de América... op. cit.

${ }_{130}$ Como se viene aclarando -y se insistirá a lo largo del trabajo-, es crucial entender el sentido laxo de Modernidad aquí manejado: se tiene clara la diferencia entre el sustantivo, Modernidad, que alude a un periodo histórico (fijado etnocéntricamente por los occidentales entre finales del s. XV y el XVIII), y el adjetivo o lo moderno, relativo a lo último (a las tendencias en curso). Sin embargo, en este estudio se usa para aludir el tránsito al Nuevo Régimen, o sea, el devenir de una sociedad abierta (no estamental), democrática (no absolutista), de derechos (no sólo de Derecho), capitalista (no gremial y
} 
democracia, etc. De ahí que los padres fundadores (vid. cap. 8) adoptaran el concepto, tras una modificación lingüística, como uno de los lemas nacionales (presente en el Gran Sello nacional, y entre otros elementos cotidianos, en las monedas y billetes de curso legal, vid. supra cap. 10): novus ordo seclorum -debería decir "saeculorum"-. El concepto es realmente rico en contenidos, tal como se aclara a continuación (cuando ontológicamente se expliquen sus teorías y formas estadounidenses), dado lo mucho que se ha transformado a lo largo del tiempo. Ahora bien, aún sigue manteniendo un significado moderno, relativo al proceso de transformación, y no al estadio alcanzado (como diferencia con el significado y uso dado por los europeocontinentales, ya situados en la posmodernidad, vid. infra) $)^{131}$. Entre las últimas y más relevantes aportaciones epistemológicas sobre la cuestión (partiendo de renovadores como ELIADE en la Univ. Chicago, STOKES en la Univ. Yale, o WOOD en la Univ. Baylor, vid. cap. 8) $)^{132}$, destacan las de los sociólogos de la religión, tales

ni de trueque), etc., y sobre todo, con un modelo socio-cultural fluctuante en una secularización moderna, que permite en todo momento el ir transformando las relaciones entre el poder, lo sagrado y la libertad.

${ }^{131}$ Muchos conceptos, por el influjo de los decimonónicos teóricos de la sospecha (v.g. MARX, FREUD), y sus reinterpretes neomarxistas del s. XX (v.g. Escuela de Frankfurt, de Annales, de Birmingham), ponen todos ellos en jaque a la racionalidad ilustrada, provocando así una mutación de significados (incluso, su pendulación): de este modo, pasión, que implicó contención y sufrimiento, pasa significar exaltación emocional; la felicidad, que era la realización por reconocimiento como sujeto pleno y por ende partícipe en los asuntos públicos, pasa a entenderse como autorrealización de la esfera de lo privado (la satisfacción de las pulsiones, que es lo más infantil); asombro, como capacidad para descubrir la realidad y conocerla así, pasa a relacionarse con el miedo a lo desconocido; los sobrenatural, que estaba relacionado con la escatología de la teología judeocristiana, pasa a entenderse como algo relativo a los superhéroes paganos y demás personajes de ficción; et al. Todos estos conceptos alimentan en sus matices la noción de secularización, por lo que no ha de sorprender las divergencias entre los modernos estadounidenses y los posmodernos europeo-continentales.

132 Vid. ELIADE, M., et al.: The sacred and profane: the nature of religion, New York: Harvest Book, 1959. - Images and symbols: Studies in religious symbolism, London: Harvill Press, 1961. - Myth and reality, New York: Harper \& Row., 1963. - The Quest: History and meaning in religion, Chicago: The University of Chicago Press, 1969. - A History of Religious Ideas (vol I-III), Chicago: The University of Chicago Press, 1978-85. STOKES, A.P.: Church and State in the United States (vol I-III), New York: Harper \& 
como BECKER, BELL, BERGER, COX o MARTIN (vid. figura siguiente) ${ }^{133}$. Todos ellos revitalizaron la materia, y su tratamiento científico-académico, proyectándolo al resto de la Sociología y sus nuevas áreas de conocimiento, además de llegar a otras CC.SS., y los interdisciplinarios Estudios culturales (vid. ídem). Gracias a su influjo surgen tendencias importantes para esta investigación, como es la religión civil de BELLAH, o la Teología política estadounidense neoconservadora de los discípulos de STRAUSS (más KRISTOL, NOVAK, et al.).

Figura 16.- Doctrina estadounidense de religión y secularización TEOLOGÍA, FILOSOFIA, SOCIOLOGÍA RELIGIOSA y CC. RELIGION (hasta s. XX)

a) Supernaturalismo (sobrenatural)

- Supernaturalismo tradicional: G. MACHEN, E.Y. MULLINS, F.L. PATTON

- Neosupernaturalismo: J. OMAN, P.Y. TILLICH, G.W. RICHARDS, R. NIEBUHR, H.R. NIEBUHR, W. PAUCK, E. LEWIS, G.C. CELL

Row., 1950. WOOD, J., et al.: Church and State in Scripture History and Constitutional Law, Waco: Baylor University Press, 1958.

133 Según BECKER, hay sociedades sagradas (hostiles al cambio y su prioridad es la seguridad), y sociedades seculares (sociedades fragmentadas y amorfas, v.g. sociedades de consumo); dado que los EE.UU., no encaja en su teoría, termina concluyendo que en realidad, casi todas las sociedades están en vía de secularización. Según BELL, la secularización depende de cambios culturales y no de estructuras sociales, lo que es rebatido por BERGER, para quien el factor religioso no está en aislamiento respecto de otros factores, sino en una relación dialéctica con infraestructuras prácticas de la vida social, por eso hay encantamientos, desencantamientos y reencantamientos. COX, por su parte, analiza la ciudad secular (alertando de que la secularización no ha de considerarse como un proceso negativo, sino de purificación de la religión). Y según MARTIN, no son tanto los cambios culturales, ni las dialécticas, sino "los transformismos intelectuales" (los estudiosos alineados en frentes opuestos cambian de banderas: unos lo hacen de manera elegante, otros de forma sibilina, y algunos lo hacen abruptamente). Vid. BECKER, H.: Through values to social interpretation, Durham: Duke University Press, 1950. BELL, D.: "The return of the sacred", en British Journal of Sociology (XXVIII, 4), 1977. BERGER, P: The Sacred Canopy: Elements of a Sociological Theory of Religion, New York: Garden City, 1967. - A rumor of angels: Modern Society and the rediscovery of the Supernatural, New York: Garden City, 1970. - The social reality of religion, Londres: Penguin Books, 1973. COX, H.: The Secular City: Secularization and Urbanization in Theological Perspective, New Haven: Yale Univ. Press, 1965. The Feast of Fools: A Theological Essay on Festivity and Fantasy, Cambridge: Harvard Univ. Press, 1969. MARTIN, D.: The religious and the secular, New York: Routledge, 1969. 
b) Idealismo

- Idealismo absolutista: J. ROYCE, W.E. HOCKING, W.M. URBAN, J.A. LEIGHTON, G.W. CUNNINGHAM, G.P. ADAMS

- Misticismo moderno: R.M. JONES, C.A. BENNETT

- Idealismo personalista: B.P. BOWNE, E.S. BRIGHTMAN, A.C. KNUDSON, R.T. FLEWELLING, J.W. BUCKHAM, F.J. MCCONNELL, G.A. WILSON

c) Romanticismo

- Intuicionismo ético (Grupo filosófico): D.C. MACINTOSH, E.W. LYMAN, C.A. BECKWITH

- Intuicionismo ético (Grupo teológico): W.A. BROWN, W.M. HORTON, H.P. VAN DUSEN, J.C. BENNETT

- Naturalismo ascético: G. SANTAYANA, J.C. RANSOM, B. BROWNELL, H.B. ALEXANDER

d) Naturalismo

- Teísmo evolutivo: J.E. BOODIN, W.P. MONTAGUE, R.L. CALHOUN, H.W. WRIGHT, W.K. WRIGHT

- Teísmo cósmico: A.N. WHITEHEAD, F.S.C. NORTHROP, G.P. CONGER, EDMUND NOBLE, H.A. OVERSTREET

- Humanismo religioso: M.C. OTTO, R.W. SELLARS, A.E. HAYDON, W. LIPPMANN

- Teísmo empírico: E.S. AMES, J. DEWEY, S. MATHEWS, G.B. SMITH, B.E. McLAND, H.N. WIEMAN

d) Pragmatismo (trascendentalismo-pragmatismo): EMERSON, WHITMAN, JAMES CIENCIAS DE LAS RELIGIONES (desde S. XX)

a) Sociología y Antropología de la Religión

- Interaccionismo (y conexos): MEAD, MERTON, LIPSET, PARSONS $\left(^{*}\right)$

- Evolucionismo (y conexos): EISENSTADT, GEERTZ, LIENHARDT

- Constructivismo y Cognición: BERGER, LUCKMANN, STARK

- Discursivismo (y sociologicismo): BELLAH, COX, HUNTINGTON, WORSLEY

- Empirismo fenomenológico: DEMERATH, GLOCK, HUDSON

- Excepcionalismo (variantes neomarxistas débiles): WRIGHT MILLS, LIPSET -más tarde, neoconservador-.

b) Historia (comparada) de las religiones

- Hermenéutica: ELIADE y discípulos

- Ecumenismo: STACKHOUSE, WOOD

- Americanismo: GAUSTAD, MALBIN, MARTY, NOVAK

c) Estudios jurídico-religiosos

- Estudios Iglesia-Estado: DAWSON, ESBECK, HAMMAR, MOUSIN, PFEFFER, STOKES, WITTE

- Estudios de la Primera Enmienda: BERG, BLACKMAN, DAVIS, DURHAM, GAFFNEY, GUNN, MANSFIELD, THOMAS, TRIBE 
d) Estudios geopolíticos: STRAUSS, BERGER, LIPSET, HUNTINGTON.

$\left({ }^{*}\right)$ Categoría más discutible, debido al gran personalismo académico de todos ellos, por lo que la enunciación no es alfabética, sino por grado de alusión.

Fuente: elaboración propia (SÁNCHEZ-BAYÓN, 2007 y 16).

Por tanto, la condición compleja y prototípica de la secularización moderna en los EE.UU. (al empezar a implementarse en el s. XVII, siendo la primera sociedad de multitudes o pluri-comunidades integradas), más allá de su restricción a la religión (pues afecta también a las relaciones entre el poder, lo sagrado y la liberad, entre otras nociones), y menos aún a su identificación etnocéntrica occidental de mínimos, como es su institucionalización de tendencia eclesiástica (ya que en EE.UU., también existen otras instituciones como los palos, reglas, tribus, etc., y sobre todo, credos personales) ${ }^{134}$. Todo ello concede carta de naturaleza y hace merecedora de atención las propuestas autóctonas al respecto (vid. figuras previa y

${ }^{134}$ Se recuerda lo dicho sobre la lectura materialista-histórica, que no aborda la religión, sino la institucionalización de sus manifestaciones, y por ende los juegos de poder que se dan en su seno y se proyectan hacia otras comunidades; aún así, pese a tal reducción simplista, los EE.UU. es uno de los países con mayor diversidad religiosa del mundo (vid. censo de 2010: U.S. Census Bureau, URL: http://factfinder.census.gov/home/saff/main.html? lang=en) -máxime, en contraste con los países europeo-continentales-. Para comprender la cuestión resultan más acertadas las propuestas autóctonas (vid. figuras), no por ser domésticas, sino por su mayor capacidad expositiva y explicativa, ajustada y soportada por la realidad. Sirva como ejemplo las tesis de JAMES, quien en su obra Las variedades de la experiencia religiosa (1902), profundizaba de manera plausible en la religiosidad popular, la personal, etc. Desmonta el materialismo-histórico en los siguientes términos: La palabra religión, tal como se usa ordinariamente, es equívoca. Un repaso a la Historia revela que, por lo general, los genios religiosos atraen a discípulos y generan grupos de simpatizantes. Cuando dichos grupos llegan a ser lo bastante fuertes como para organizarselestablecerse, se convierten en instituciones eclesiásticas con sus propias ambiciones corporativas. Aparecen entonces el espíritu de la política y el afán de dominio dogmático y contaminan la inocencia original; de modo que cuando hoy en día oímos la palabra religión, pensamos inevitablemente en una u otra Iglesia; y para algunas personas la palabra religión sugiere tanta hipocresía y tiranía, mezquindad y pervivencia de la superstición que se enorgullecen de decir, de forma genérica $e$ indiscriminada, que pasan totalmente de la religión (traducción propia de The varieties of religious experience, New York: The Modern Library, 1902). 
próximas), puesto que dichas propuestas, cada una en su medida y sobre todo como un conjunto (de teorías de rango medio, aquí entretejidas), han servido para clarificar el moderno modelo socio-cultural estadounidense, volviéndolo apto para la realización efectiva del Nuevo Régimen.

Figura 17.- Relaciones religiosas (más allá del materialismo-histórico)

\begin{tabular}{|c|}
\hline Propuesta de partida: omnisacralidad \\
\hline $\begin{array}{l}\text { Protorreligión (religión natural primitiva): naturaleza encantada y religión es toda } \\
\text { explicación. }\end{array}$ \\
\hline Evolución/desarrollo de la propuesta: trasvases sacro-profano (de la secularización) \\
\hline $\begin{array}{l}\text { Religión positiva tradicional: proceso de autorreconocimiento en el entorno e } \\
\text { institucionalización/establecimiento del poder y lo sagrado. } \\
\text { - Politeísmo (fase primaria: del espiritualismo a la mitología): del animismo a la monolatría } \\
\text { (desacralización de la naturaleza por conocimiento y dominio del entorno) } \\
\text { - Monoteísmo (fase secundaria: de la mitología a la teología): del teísmo al deísmo } \\
\text { (divinidad con rasgos humanos que atiende al destino de la humanidad) } \\
\text { - Panteísmo (fase terciaria: de la teología a la metafísica): del deísmo a la religión civil (por } \\
\text { la razón -y su propia limitación-, el hombre se convence de la conveniencia de la religión } \\
\text {-más allá de las restricciones de su establecimiento) }\end{array}$ \\
\hline Reflujos de la propuesta: despertares y revitalizaciones \\
\hline $\begin{array}{l}\text { Sincretismos: reformulaciones coyunturales de las religiones tradicionales y } \\
\text { neofetichizaciones subversivas } \\
\text { - Sincretismo ecuménico: variantes de posjudeocristianismo (búsqueda de una identidad } \\
\text { integral en Occidente) } \\
\text { - Sincretismo marginal: variantes (más o menos toleradas) de fusión entre propuestas } \\
\text { posjudeocristianas y afro-indigenismo u orientalismo } \\
\text { - Neopaganismo: variantes subversivas contraparadigmáticas, frente al } \\
\text { posjudeocristianismo, bien de corte ocultista (v.g. brujería, satanismo, esoterismo, } \\
\text { fenómenos paranormales, etc.), ufológico o ecoactivista, et al. } \\
\text { - (pseudo)cultismo: variantes subversivas ultra-ortodoxas, generadoras de un sectarismo } \\
\text { intolerante y alienante. }\end{array}$ \\
\hline $\begin{array}{l}\text { *eocesaropapismo: cuestión híbrida (pretendido dominio del poder civil sobre el } \\
\text { religioso para su relegitimación y mesianismo). }\end{array}$ \\
\hline
\end{tabular}

Fuente: elaboración propia (SÁNCHEZ-BAYÓN, 2007 y 16). 
Sociología de las Relaciones Socioculturales Nortatlánticas (...) American civil religion - A. Sánchez-Bayón

Figura 18.- Secularización en EE.UU. y sus ciclos 135

Compendio marco (teorías de rango medio entretejidas)

135 Vid. ARGYLE, M.: Religious behavior, Glencoe: The Free Press, 1958. BERGER, P. (ed.): The secularization of the World. Resurgent religion and World politics, Grand Rapids: Williams B. Eerdmans Publishing Co., 1999. BLOOM, H.: The American religion. The emergence of the Post-Christian Nation, New York: Simon \& Schuster, 1992. CHEVALIER, J (dir.): Las religiones (trad.), Bilbao: Ediciones Mensajero, 1976. DEMERATH, N.J.: Social class in American Protestantism, Chicago: Rand McNally, 1965. DIEZ DE VELASCO, F.: La historia de las religiones: métodos y perspectivas, Madrid: Akal, 2005. DUCH, LL.: Religión y mundo moderno. Introducción al estudio de fenómenos religiosos, Madrid: PPC, 1995. - Antropología de la religión, Barcelona: Herder, 2001. DUE, A.: Atlas histórico del Cristianismo (trad.), Madrid: San Pablo, 1998. ESTRUCH, J.: La innovación religiosa. Ensayo teórico de Sociología de la Religión, Barcelona: Ariel, 1972. FERRAROTTI, F.: Una fede senza dogmi, Roma: Laterza \& Figli Spa, 1990. FEUERBACH, L.: La esencia del cristianismo (trad.), Salamanca: Ed. Sígueme, 1975. GARCIA, P.: Diccionario Filosófico. Manual de materialismo filosófico. Una introducción analítica (revisión de G. BUENO), Ovideo: Biblioteca Filosófica en Español, 1999. GELLNER, E.: Posmodernism, reason and religión, New York: Routledge, 1992. GOMEZ CAFFARENA, J., MARTIN VELASCO, J.: Filosofía de la Religión, Madrid: Revista Occidente, 1973. GRIGORIEFF, V.: El gran libro de las religiones del mundo (trad.), Barcelona: Ediciones Robinbooks, 1995. HOUTART, F. (coord.): Religiones: sus conceptos fundamentales (trad.), México DF: Siglo XXI, 2002. HUISMAN, D.: Diccionario de las mil obras clave del pensamiento (trad.), Madrid: Tecnos, 1997. JAMES, W.: The Varieties of Religious Experience. A study in Human Natures, New York: The Modern Library, 1902. MARROMAO, G.: Poder y secularización, Ediciones Península, Barcelona, 1989. MARDONES, J.Ma.: Capitalismo y religión, Santander: Sal Terrae, 1991. MARTIN, D.: A General Theory of Secularization. New York: Harper \& Brow, 1978. MARTIN VELASCO, J.: Introducción a la fenomenología de la religión, Madrid: Trotta, 2006. MATTHES, J.: Introducción a la Sociología de la Religión (vols. 1-3), Madrid: Alianza, 1971. MULLAN, D.G.(ed.): Religious Pluralism in the West: An Anthology. Oxford: Blackwell Publishers, 1998. O'BRIEN, J., PALMER, M.: Atlas Akal del estado de las Religiones, Madrid: Akal, 2000. OSER, F, GMÜNDER, P.: El hombre. Estadios de su desarrollo religioso (trad.), Barcelona: Ariel, 1998. PASTOR, G.: Sociología de la Religión, Salamanca: Universidad Pontificia de Salamanca, 1991. SANTIDRIAN, P.: Diccionario breve de pensadores cristianos, Estella: Editorial Verbo Divino, 1991. SERRITELLA, J.A. (ed.): Religious organizations in the United States. A study of identity, liberty and the law, Durham: Carolina Academic Press, 2006. TAYLOR, C.: Varieties of Religion Today, Cambridge: Harvard University Press, 2002. TURNER, B.S.: La religión y la Teoría social. Una perspectiva materialista (trad.), México DF: Fondo de Cultura Económica, 1985. VVAA.: ¿Qué pueden ofrecer las tradiciones religiosas a las sociedades del S. XXI?, Barcelona: CETR Editorial, 2005. VVAA.: Tratado de Antropología de lo Sagrado (vols. 1-3), Madrid: Trotta, 1995-97. WAAL, A.: Introducción a la Antropología de la Religión, Estella: Verbo Divino, 1975. WACQUANT, L (dir.): Repensar los Estados Unidos. Para una Sociología del Hiperpoder (trad.), Barcelona: Anthropos Editorial, 2005. WEBER, M.: Sociología de la Religión (trad.), Madrid: Istmo, 1997. WIEMAN, H.N., MELAND, B.E.: American Philosophies of Religion, Chicago: Willett, Clark \& Co., 1936. WRIGHT, C.: Religion in American life. Selected readings, Boston: Houghton Mifflin Co., 1972. YINGER, J.M.: The Scientific study of Religión, New York: McMillan, 1990. ZUBIRI, X.: El hombre y dios, Madrid: Alianza, 1984. Complement., vid. lecturas citadas de BELL, BERGER, ELIADE, STOKES, WOOD, et al. 
Teoría de la secularización (elemental): de naturalismo (religiones positivas primarias: animismo y totemismo de indios nativos) a teísmo (religiones positivas terciarias: monoteísmo abrahámico, v.g. judío, cristiano, musulmán, bahai)

Teoría de la (de)secularización (media): de monoteísmo (religiones positivas terciarias: cristianismo) a panteísmo (religiones positivas cuaternarias o sincréticas: deísmo, mormonismo)

Teoría de la (re)secularización (avanzada): de panteísmo (religiosidad popular: evangelismo) a religión civil (religiosidad ciudadana: civilismo)

Teoría de la (pos)secularización (transitoria): de los despertares y revitalizaciones coyunturales (sincretismo ecuménico: posjudeocristianismo, vid. cap. 5; sincretismo marginal: afro-indigenismos y orientalismos; neopaganismo: ocultismo y ufología; (pseudo)cultismo)

Propuestas sectoriales (perfilaciones idiosincrásicas)

Teoría de las variedades: del (pluri)confesionalismo y su riqueza representativa (dogmática y orgánica)

Teoría del denominalismo: de la afiliación religiosa y sus repercusiones en el status y rol social (v.g. movilidad social vertical -ascendente o descendente- y horizontal distribución territorial)

Teoría del libre mercado (religioso): de la oferta y demanda religiosa, en términos modernos de beneficio y éxito (v.g. fusión de teorías de libre competencia y de elección racional, introducción de la teoría del negocio religioso, etc.)

Teoría de la conversión (y el mesianismo): de la relación convencida y personal con la divinidad, las revelaciones y los renacimientos religiosos, dando lugar a síndromes mesiánicos, proféticos, milagrosos, etc.

Teoría de la gestión cognitiva: de la formación del juicio religioso (personal y social, para interpretar y construir la experiencia vital, más la ratio ulterioris), así como, de la participación de las organizaciones religiosas en los procesos de socialización (v.g. superación de disonancias, compromiso cívico-social, etc.) $\left(^{*}\right)$ Problema: violencia simbólica.

Teoría del ecumenismo: del diálogo interreligioso (judeocristiano) y el obstáculo oriental (v.g. geopolítica misionera, choque civilizatorio, etc.).

Fuente: elaboración propia (SÁNCHEZ-BAYÓN, 2007 y 16).

Téngase en cuenta que, todas estas lecturas entretejidas de la secularización estadounidense, vienen referidas a la variante de la secularización moderna lato sensu, posibilitadora del tránsito efectivo a la Modernidad y su Nuevo Régimen (pues han existido y existirán otros procesos de secularización -a diferencia de un velo 
posmoderno en boga, que postula un mundo postsecularizado, y por tanto agotado lo sagrado-. En consecuencia, en el caso estadounidense, conviven los estadios y ciclos de la Modernidad y Contemporaneidad, gracias a la secularización moderna acontecida en su seno, que da como resultado un tránsito al Nuevo Régimen mediante un sistema prototípico, no acabado y de largo recorrido -como se viene mencionando y se va a aclarar mejor a continuación-. Dichas lecturas entretejidas de la secularización moderna estadounidense, han venido orientadas desde una Teología política autóctona o APT (a su vez fruto del mestizaje entre pensamiento liberalconservador -de origen Whig- y librepensador-masón o Free-mason, vid. supra). Dicho APT y su lectura de la secularización, ha dado prueba de saber distinguir, para poder luego entremezclar convenientemente, lo religioso y lo civil, lo temporal y lo eterno, lo espiritual y lo corporal, etc. De tal suerte, se han producido expresiones (vid. supra cap. 6 y 10) del tipo ACR, AG, AMD, ius circa sacra, Sunday Laws, etc. Por tanto, los ciclos y fluctuaciones en el devenir de la secularización moderna estadounidense han permitido:

a) La emancipación de la religión del cristianismo medieval (fomentando la libertas christiana hacia un panteísmo), dando lugar a un cambio de mentalidad y época. Durante el final de la Antigüedad y todo el Medievo, dada su oficialización con la Constitución de Tesalónica en el año $380^{136}$, se han considerado como sinónimos sendos términos (cristianismo o religión auténtica y universal, y lo demás son herejías o expresiones de infieles). De ahí que su deslinde favorezca un cambio de mentalidad profundo, permitiendo la emancipación también de otras

136 Vid. SÁNCHEZ-BAYÓN, A.: “Examen de las principales fuentes e instituciones originarias de Derecho canónico pluriconfesional: Una historia crítica para la revelación de falacias y fundamentos" (pp. 605-637), en Revista de Derecho-Valparaiso/Revista de Derecho de la Pontificia Universidad Católica de Valparaiso (n⿳o XLI), 2o Semestre 2013. - Derecho Eclesiástico Global, Madrid: Delta, 2012. 
cuestiones como: el tiempo (el calendario pasa a marcarse por el trabajo y celebraciones civiles), los valores (van extinguiéndose las virtudes, sustituidas por criterios de medición social, en términos de éxito y beneficio), la identidad (se universaliza a todo Occidente -incluidos Estados originalmente no cristianos ni europeos), la educación (surgen los colegios públicos), la Política (prevalecen, en el gobierno del Estado, las instituciones civiles), el Derecho (la legitimación prioritaria es humana -siendo secundaria la natural y la divina-, debido a la confianza en su capacidad de progreso y perfeccionamiento), la Economía (se impone una ética de trabajo y con un espíritu capitalista), etc.

b) La distinción entre religión y secularización, pues la última trasciende a la primera (o sea, la religión no tiene el monopolio de lo sagrado y profano, sino que son elementos originarios que comparte con otras esferas sociales, v.g. potestas o poder de la política, auctoritas o autoridad del derecho). Eso sí, a la vez que se pluraliza la religión, tanto dentro del cristianismo (máxime, tras la Reforma protestante), como fuera (al reconocerse a los marginados hasta entonces, v.g. judíos y musulmanes, más otros emergentes, v.g. hindúes, taoístas), lo mismo ocurre con la secularización, descubriéndose así que es un proceso múltiple de largo recorrido: las distintas manifestaciones de la secularización han permitido ordenar periódicamente las relaciones entre lo sagrado y profano, el poder y el conocimiento, la libertad y la seguridad, etc., favoreciéndose así los proceso de apertura y tránsito a un nuevo estadio civilizatorio en Occidente (en este estudio se ha centrado la atención en la secularización moderna, contextualizándola mínimamente entre las otras acaecidas). 
c) El maridaje de conveniencia (gracias a los padres fundadores, vid. supra cap. 9) de un pueblo elegido (chosen/Godless people) con una moderna empresa nacional (national enterprise), dando lugar a la unción de un linaje predestinado al éxito y beneficio. Al proyectarse las creencias religiosas sobre lo profano, se ha transferido así la confianza que requiere un pueblo nuevo para llegar a liderar entre las tradicionales potencias mundiales (pasando de ser colonia a adalid occidental). De este modo han surgido expresiones como self-righteousness, civilizing sense, one nation under God, etc.

d) La liberalización de la religión lato sensu, pues se alcanza un régimen de libertad religiosa (como derecho humano -legislatio libertatis- y principio de autonomía en las relaciones entre Iglesia y Estado -libertas ecclesiae-), a la vez que la religión se desjerarquiza y se vuelve más comunitaria y social. En los EE.UU., se pasa del modelo de main-line church (hierocrática) a evangelical church (comunitaria). Ello supone que sean dominantemente las bases sociales quienes gestionan el factor religioso, impulsando las cruzadas que condicionan la opinión pública, y cuyas temáticas pasan a formar parte de la agenda institucional de las élites de poder, además de servir de plataforma para la renovación de dichas élites (vid. supra Parte de desarrollo especial).

e) La esfera religiosa entra en contacto con otras esferas sociales, como la económica, por lo que las organizaciones religiosas se contemplan como otro negocio más, en competencia por la captación de fieles y fondos, además de participar en el sustento del Estado de bienestar, con la prestación de servicios socio-religiosos (v.g. beneficencia, auspicio, acomodación, docencia, sanidad). 
Tras las aclaraciones realizadas, se espera haber sentado las bases para poder tratar cómo la secularización moderna facilitó el impulso de la Teología política, y con ella la ACR y la articulación de la idiosincrasia estadounidense.

\section{3.- HOJA DE RUTA DE AMERICAN CIVIL RELIGION (ACR):}

ANNUIT COEPTIS, NOVUS ORDO SECLORUM, E PLURIBUS UNUM \& IN GOD WE TRUST

¿Con qué mimbres se empieza a tejer la $\mathrm{ACR}$ y por ende la nueva nación o, mejor dicho, el pueblo estadounidense? Durante los Congresos Continentales (1774 y 1775-81), en los que se decidió si se independizaban y cuáles iban a ser las normas e instituciones básicas de gobierno, se adoptaron tres grandes lemas guía, a modo de principios idiosincrásicos inspiradores del sistema a formular e implementar. Dichos lemas, como era propio de la Ilustración, para dotar de mayor legitimidad (por autoridad y vínculos con la tradición occidental), se plasmaron en latín: “Novus ordo seclorum" (nuevo orden de los siglos/Nuevo Régimen), "Annuit coeptis" (Dios/la providencia- favorece (el) entendimiento/aprueba (nuestra) empresa algunos autores lo traducen como "favorece la causa estadounidense"-), y "E pluribus unum" (de muchos, uno/unidos en la diversidad). Se plasmaron todos ellos en el símbolo que había de representar a todos los estadounidenses como pueblo, tando doméstica como exteriormente, tal como ha venido siendo el Gran Sello nacional (adoptado en 1782). Sirva como adelanto de los múltiples significados aparejados a dichos lemas, como en el caso de los dos más ligados entre sí (e pluribus unum y annuit coeptis), que ambos constan de trece letras, por los tres Estados 
originales.

En la formulación de los lemas y el diseño del Gran Sello nacional compilador, participaron los principales padres fundadores de la época (WASHINGTON, FRANKLIN, ADAMS, et al., vid. supra cap. 9 y 10), concibiéndolo como parte de la matriz mitopoiética y su legado. Así, cuando se iniciaron las reformas estatales y de gobierno, durante las Convenciones de Annapolis (1786) y Philadelphia (1787), dando lugar al actual sistema federal, dichos lemas estuvieron más presentes que nunca, plasmándose en la vigente Constitución de los EE.UU. (CEU, 1787) y la Declaración de Derechos (BR, 1791): se trataba de consolidar una mayor unión (de una "declaración unánime" de Independencia, a la "Unión perpétua" de la Confederación, para lograr la "Unión más pertecta" de la Federación), para desarrollar un Nuevo Régimen (de cultura de los derechos, empezando por la libertad religiosa como Primera enmienda), amparado y guiado por el Ser Superior (como era comúnmente denominado entonces Dios -también el Creador, vid. DIE-), de modo que los EE.UU. alcanzaran su esplendor y liderazgo entre los pueblos (primero por predestinación/providencia o destino manifiesto por los pactos mayores-, y más tarde por autoderminación/autoconfianza o excepcionalismo -por los pactos menores-, vid. infra cap. 5, y supra cap. 8 y 10). Dadas las tribulaciones decimonónicas (v.g. Pánicos de 1837 y 1857, Guerra civil de 1861-65 y la Reconstrucción, la Gran depresión de 1877-96), sobre todo, resultado de problemas de confianza en el sistema (en especial, en su parte económica), se entiende así la adopción del último gran lema nacional, ya en inglés (para reafirmación idiosincrásica): "In God we trust" (en Dios confiamos). Empezó a usarse en monedas y billetes, hasta su oficialización definitiva en 1956. El sentido y alcance de todos estos lemas se abordará con detalle más adelante (vid. supra cap. 
10), pues lo que interesa realmente aquí es destacar los mimbres con los que se empezó a tejer el tiesto nacional, donde dar cabida todos los estadounidense, conforme al credo civil estadounidense (tipificado como "verdades evidentes" en los novedosos textos sagrados de la ACR, como son la Declaración de Independencia-DIE, Artículos de la Confederación-AC, Constititución de EE.UU.-CEU, Declaración de Derechos-BR): individualismo y libre asociación (unidad: gobierno democrático y economía capitalista), dando lugar a un pueblo singular (soberano y que sólo rinde cuentas a Dios); igualdad de libertades y derechos inalienables (incluida la búsqueda de la felicidad) de todos y cada uno de los estadounidenses (gracias a su Creador); separación de Iglesia-Estado (gracias a Dios, permitiendo un mayor desarrollo de esferas sociales acomodadas y un mayor disfrute de libertades y derechos); et al. (vid. supra epígr. 6.2 y cap. 10). 


\section{6.- FUNDAMENTOS ONTOLÓGICOS SOCIO-RELIGIOSOS}

\section{A ReEVAlUAR ANTe LA PosglOBALIZACIÓN ${ }^{137}$}

Se recuerda que esta es una tesis llamada a revisar las modernas relaciones socio-culturales estadounidenses (cómo se perciben y gestionan, y cómo las mismas son producidas por unos sujetos, que a su vez son condionados por el sistema que los socializa); tal labor revisora crítica, implica tener que examinar también su correspondiente Sociología (con su comprensión general de sociedad moderna occidental) y sus Estudios culturales (con su comprensión particular estadounidense, de ahí su focalización en la cuestión identitaria y su producción socio-cultural singular). En lo tocante a las ciencias y disciplinas afectadas en el ámbito universitario, tal cosa se expone y explica en la Parte del desarrollo especial (en especial, en el cap. 8). Ahora bien, lo que aquí se ofrece es una aproximación a los cambios acaecidos con las crisis de la globalización (desde la década de 1990) y el tránsito posglobalizatorio (tras la gran crisis de 2008); por ende, se trata también la urgente necesidad de una reformulación paradigmática: ha de revisarse todo, no sólo porque es un patrón habitual en el devenir estadounidense (conforme a su serie de ciclos de despertares y revitalizaciones, vid. supra cap. 10), sino por el cambio de ciclo en curso (de un periodo dominado por el Estado-nación a otro emergente de la aldea global -o no-). Además, otro motivo de revisión son los velos de confusión posmodernos (vid. infra cap. 1) extendidos por los Estudios culturales sobrevenidos

\footnotetext{
${ }^{137}$ Con el respaldo de pasadas publicaciones (citadas en el cap. 3, especialmente, La Modernidad sin prejuicios, Universidad, ciencia y religión en los Estados Unidos de América y La religión civil estadounidense), el presente capítulo está sustentado por recientes artículos (publicados durante la matrícula de doctorado en la UVA y aprobados en las memorias tramitadas); complement., vid. infra notas 3 a 5 , 11, 16, 24, 55 y 68, más p. 126 ss.
} 
(vid. supra cap. 8), los cuales se han retrotraído incluso al periodo fundacional, cuando se sentaran las bases de la Modernidad estadounidense. De tal suerte, hoy cabe constatar el agotamiento de dicha Modernidad (que conectaba claramente a los EE.UU. con sus vecinos atlánticos y el resto de Occidente), pues tras el asedio de la posmodernidad, la misma se ha generalizado (aprovechándose las crisis acentuadas con la globalización). Para comprender algo mejor, se esboza a continuación una síntesis realmente telegráfica de cómo se han percibido y gestionado las relaciones socio-culturales en EE.UU. (su Sociología sobre todo, pues los Estudios culturales se abordan con detalle más adelante), y cuáles han sido los instrumentos usados para ello (v.g. ACR, ASG, ACT). 


\section{1.- CONSIDERACIONES PRELIMINARES:}

\section{CRISIS SOCIAL Y SOCIOLÓGICA DE LA MODERNIDAD ESTADOUNIDENSE ${ }^{138}$}

Un adagio popular, afirma que "más que cosechar certezas, hoy hay que sembrar dudas". Esta máxima fue puesta en boga por los "profetas de la globalización" (BELL, BELLAH, BERGER, CAPRA, ECO, HARRIS, LUCKMANN, WATTS, WILBER, et al). Todo ellos fueron renovadores de la Sociología, la Antropología y los Estudios culturales (como pasara con los decimonónicos teóricos de la sospecha y el nacimiento de las ciencias citadas), allá por los años 60 del s. XX

\footnotetext{
${ }^{138}$ Además de las referencias bibliográficas de la nota anterior, vid. SÁNCHEZ-BAYÓN, A.: “Conocer y gestionar las esferas sociales en la globalización: de las religión, la política y el derecho en las Américas del nuevo milenio" (pp. 103-146), en ICADE-Revista Cuatrimestral de las Facultades de Derecho y Ciencias Económicas y Empresariales (no 81), sept.-dic. 2010. “Trasplantes jurídicos de la globalización” (pp. 1-21), en Revista General de Derecho Canónico y Derecho Eclesiástico del Estado-Iustel (nº 23), mayo 2010. "Normatividad Global: repensar las reglas de juego" (pp. 81-119), en Anales de la Facultad de Derecho-Universidad de La Laguna (n²8), diciembre 2011. “Acerca de la nada: de la naturalización de la nada a la nada de pensamiento" (pp. 85-95), en Bajo Palabra. Revista de Filosofía (no 7), 2012. “Religión, Política y Derecho en las Américas del nuevo milenio" (pp. 39-104), en Revista Jurídica de la Universidad Bernardo O'Higgins Ars Boni et Aequi (vol. 8, no 1), enero 2012. "Repensar la normatividad: ¿quiénes son los sujetos, los objetos y contenidos de las relaciones vinculantes en la globalización?" (pp. 181-217), en ICADE-Revista Cuatrimestral de las Facultades de Derecho y Ciencias Económicas y Empresariales (n85), ene.-abril 2012. "Religión, Cultura y Comunicación Social en la Historia de la universidad estadounidense: de Church-State $\mathcal{E}$ American Studies a Cross-Cultural Studies" (pp. 6-28), en Compé, Revista Científica de Comunicación, Protocolo y Eventos, UCJC (nº 2), dic. 2013. "Política, Derecho y Administración en la Globalización: ¿es posible un orden común? (una propuesta iberoamericana)" (pp. 125-145) en Rev. Pensamiento Americano-Coruniamericana (vol. 8, no 15), 2015. "Revelaciones conceptuales y lingüísticas de la posglobalización: Retos de construcción moral de la sociedad del conocimiento y aportes del humanismo hispánico" (pp. 411-458), en Carthaginensia. Revista de Estudios e Investigación (vol. XXXIII, no. 64), 2017. "Apuntes para una teoría crítica humanista y su praxis económico-empresarial en la posglobalización", Rev. Miscelania Comillas, vol. 75, n 147, 2017, p. 305-329. "Revelaciones conceptuales y lingüísticas de la posglobalización: Retos de construcción moral de la sociedad del conocimiento y aportes del humanismo hispánico" (pp. 411-458), en Carthaginensia. Revista de Estudios e Investigación (vol. XXXIII, no . 64), 2017. "Balance de la Sociología tras la globalización" (pp. 49-68), en Eduser-Revista de Educação, IPB (S.l., v. 10, n. 1), july 2018. SÁNCHEZ-BAYÓN, A., et al.: "Plan de acción frente al consumismo global de la Nueva Economía" (p. 69-93), Empresa y Humanismo, vol. XXI, n¹, 2018, et al.
} 
(durante las guerras culturales). Su visión partía de la premisa crítica de las escuelas neomarxistas de entonces (v.g. Frankfurt, Normal-Annales, Birmingham-llegadas a los EE.UU. con la fuga de cerebros de la II Guerra Mundial y Guerra fría-). Enseguida su crítica divergió, pues los citados autores no auguraban el conflicto ni la alienación social, sino que invitaban a repensar el mundo y su mejora (en términos de coherencia y solidaridad expansible a la humanidad en su conjunto). Mientras, los Estudios culturales sobrevenidos (o poscoloniales) sí se mantuvieron en la intensificación del "hecho diferencial" y su conflicto subyacente. Lamentablemente, el influjo de los anteriores en la universidad resultó menor (al tender más a la creatividad y libre pensamiento), pues no se preocuparon de su organización como grupo de presión en la política universitaria (tal como sí hicieron los neomarxistas, más tarde estructuralistas y finalmente posmodernos: los Estudios culturales sobrevenidos, poscoloniales y de la otredad, de sexo y género, étnico-culturales, tecnólogos, et al.). Más de medio siglo después, una vez materializada y completada la globalización, y para transitar al nuevo ciclo histórico, con sus cambios socioculturales, se recoge el legado de aquellos pioneros, que fueron hasta la frontera del conocimiento disponible e invitaron a otros a percibir y gestionar los primeros cambios de una realidad social en transformación. Ergo, este no es un estudio dogmático (ni de pensamiento acabado ni único), ni cuantitativista (no hay culto al número, y se tiene claro que antes de medir, hay que conocer -pues las matemáticas sólo proporcionan plausibilidad, no sustanciabilidad-), ni siquiera es revolucionaria (salvo en el sentido clásico, o sea, copernicano: de vuelta a los planteamientos anteriores a su desviación); se trata de una guía sociológica de ayuda, para tomar conciencia del mundo en el que se vive. Se espera así poder mostrar una acrisolada realidad social (tan diversa, compleja y voluble), que se interconecta globalmente, 
aunque opera localmente, tanto en un plano tangible como virtual. De tal manera, es posible reflexionar críticamente porqué los sociólogos de la globalización (BAUMAN, BECK, KOSKO, SENNETT, SOUZA, et al.) calificaron las sociedades occidentales de riesgo, líquidas, difusas, corrosivas, etc., antojándose ultramodernas Babeles, cuyas normas e instituciones coexisten, no sin cierto grado de confusión (unas en extinción, otras trasplantadas, algunas sincretizadas, bastantes hibridadas, y las restantes están emergiendo). Tal es el nivel de dinamismo de la realidad social en curso (cohabitando lo tradicional con lo moderno y lo utópico, más las fuerzas y factores sociales centrífugos con los centrípetos, etc.), que urge una revisión de guías y mapas disponibles tras la globalización y todas sus crisis aparejadas.

\subsection{1.- REVISIÓN SOCIOLÓGICA APLICADA}

\section{A LA MODERNIDAD OCCIDENTAL ESTADOUNIDENSE ${ }^{139}$}

Resulta que, paradójicamente, ahora que más se necesita la Sociología, para reflexionar críticamente las transformaciones socio-culturales en curso -aún enmarcada en una diferenciación disciplinaria un tanto artificial, vid. infra-, resulta que dicha ciencia social está viviendo una etapa difícil: casi murió de éxito a finales del s. XX (pues casi todo se explicaba en términos sociológicos y cualquiera se consideraba sociólogo), además de sucumbirse a modas, buscándose la emulación de las CC. Naturales e Ingenierías (por lo que se redujo al análisis de causalidad -

139 Vid. SÁNCHEZ-BAYÓN, A.: “Balance de la Sociología tras la globalización” (pp. 49-68), en EduserRevista de Educação, IPB (S.1., v. 10, n. 1), july 2018. 
sin intencionalidad-, y al citado cuantitativismo -sin apenas teoría social-). En consecuencia, se entenderá que desde esta obra se recupere la teoría social, entendida como un conjunto de propuestas guía para conducirse por la vasta realidad social en evolución. En consecuencia, se ofrece aquí una síntesis de la rica noción de Sociología y su conocimiento propio, aplicado a las sociedades modernas occidentales, bien determinadas hasta la fecha en el marco del Estado-nación, en crisis desde la globalización. Con tales mimbres se pretende afrontar los problemas y retos de las crisis globalizatorias y del tránsito posglobalizatorio (adentrándose en el TecnoEvo), articulándose para el caso una teoría social conectada a los Estudios culturales (y demás disciplinas y ciencias conexas) -como se viene acometiendo en los EE.UU. desde las guerras culturales-. Y es que, el nuevo ciclo histórico-social que se ha iniciado (con la posglobalización), requiere de alguna teoría social que lo haga inteligible, de modo que se favorezca la aproximación a la anhelada sociedad del conocimiento (SC); de otro modo (dada la falta de pensamiento -por mera cuantificación de datos, la extensión de velos de confusión, la fatuidad de los simulacros discursivos, etc.-), se agravaría así la deriva en ciernes de la sociedad masa global de consumo (con sus riesgos de entropía y/o armagedón). Ya se verá, pero se van realizando propuestas como la Tecnoevología ${ }^{140}$.

Dado que la Sociología, con la asunción del liderazgo occidental por parte de EE.UU. (tras la II Guerra Mundial), estuvo a punto de morir de éxito (pues todo lo comprendía y cualquiera se pronunciaba en dichos términos) ${ }^{141}$, lo primero que se

\footnotetext{
${ }^{140}$ Vid. VALERO-MATAS, J., SÁNCHEZ-BAYÓN, A.: Balance de la globalización y teoría social de la posglobalización... op. cit.

${ }^{141}$ En las postrimerías de la globalización -como se viene señalando- la Sociología estuvo a punto de morir de éxito, pues como si de una moda se tratase, cualquiera se consideraba sociólogo y/o se pronunciaba en dichos términos -eso sí, apostillándose con estadísticas de resultado dudoso, incluso inexistente-. Y es que ni la Sociología puede alcanzar a comprender todo, ni es monopolio de los
} 
afronta aquí (con el diagnóstico de su crisis), es su indagación científico-académica, para saber distinguir su conocimiento propio de otros afines (sobre todo de Estudios culturales, vid. supra cap. 8). En consecuencia, se revisa a continuación su memoria académica (se llamaba así al ejercicio para lograr la posición de profesor universitario $)^{142}$, procurando recuperar fundamentos, retirar velos de confusión, además de facilitar su adaptación a las necesidades actuales.

¿A dónde va la Sociología? Más aún, ¿qué queda hoy de la Sociología? ¿Cuáles son sus conceptos básicos y aún válidos en la actualidad? Dado el triunfo de velos cientificistas, como el cuantitativismo, que reduce todo a la mera medición (como si de un potente automóvil todoterreno y sin volante se tratase), ¿se recuerda acaso la complejidad teórica que subyace bajo la voz Sociología?

Se trata de un neologismo decimonónico, surgido de la combinación

sociólogos, y menos aún se sostiene únicamente mediante datos de comportamientos o apreciaciones colectivas. Se recurrió entonces a la Sociología para explicar los ricos y variados cambios en curso, de modo que transmitiera alguna seguridad entre tanta incertidumbre. En realidad, hubiera bastado con algo más sencillo -e intelectualmente más honrado-: volver a sorprenderse con el mundo en el que uno vive (redescubrirlo al suspender el juicio), cuestionándolo (al preguntarse por sus partes, sus relaciones y por el conjunto) y favorecer la toma de conciencia, tanto de sí mismo (reflexionando de manera auténtica y con un pensamiento propio) como del medio social en el que se desenvuelve (cuestionándose cómo funciona el sistema, cuál es su papel en el mismo, etc.). El ejercitar la capacidad de asombro es esencial, para no partir de condicionamientos ni dar por sentado nada, pues todo es cuestionable, y ha de ser revisado y reformulado, con respecto a los tiempos que corren y sus transformaciones. Se encontrarán trabas (para asombrarse, cuestionarse y reflexionarse por y para sí y los demás), como la negación actual de apoyos tan elementales como la noción de realidad, racionalidad, sociabilidad, etc., por lo que resulta preferible el fijar unas expectativas más básicas y realizables: antes de jugar a aprendiz de sociólogo (con un conocimiento y métodos que bien podrían ponerse en duda), baste por ahora con ser una persona en busca de una teoría social que le permita comprender su medio social y su papel en el mismo. Para ello no sólo se cuenta con herramientas como las ya citadas (v.g. epojé, mayéutica, crítica), sino también con la brújula de las virtudes cardinales (fortaleza, templanza, sabiduría y justicia), así como otros recursos, consejos y claves que se irán ofreciendo. Aquí se inicia el viaje para descubrir la realidad social posglobalizada y su teoría inteligible (...). Vid. VALERO-MATAS, J., SÁNCHEZ-BAYÓN, A.: Balance de la globalización y teoría social de la posglobalización... op. cit.

${ }^{142}$ Vid. SÁNCHEZ-BAYÓN, A.: Estudios de cultura político-jurídica... op. cit. 
impropia de una raíz latina (societas-societatis) y otra griega (logos-logoi), para expresar la necesidad de un nuevo conocimiento aplicado a las abundantes y significativas transformaciones sociales en curso en Occidente. Téngase en cuenta que el s. XIX, tanto europeos como estadounidenses están viviendo grandes revoluciones domésticas (v.g. una segunda revolución energética, industrial y urbana), además de afrontar una expansión colonial exterior (encontrándose con otros pueblos). De ahí la urgencia de un conocimiento que permita su propia comprensión (la Sociología), y la de los otros pueblos (la Antropología). Ahora bien, en tal proceso efervescente, coexisten diversas voces similares, como socialismo (filosofía política centro-europea, preocupada por el deber ser de la nueva organización social y que MARX y ENGELS redujeron a ideología del proletariado), socialidad (relativa a las experiencias de las nuevas reglas e instituciones sociales implantadoras del Nuevo Régimen), socionomía (leyes sociales que rigen el progreso de las modernas sociedades occidentales, como si de una ciencia natural se tratara), etc. Así se entienden las confusiones del periodo fundacional: Comte pretendiendo la fijación del neologismo socio-logia en su Curso de Filosofía Positiva (1838); MARX y ENGELS hablando del socialismo auténtico en su Manifiesto comunista (1848); Durkheim usando como sinónimos socialismo y sociología en su tesis sobre $L a$ división del trabajo social (1893) y su obra posterior Las reglas del método sociológico (1895); SOMBART y su militancia socialista, que no marxista, oponiéndose al comunismo y simpatizando con el nazional-socialismo, publicando mientras su clásico ¿Por qué no hay socialismo en los Estados Unidos? (1906); y WEBER (maestro de SCHMITT, amigo de SOMBART y de otros tantos llamados entonces "socialistas de cátedra"), resulta el más confuso de todos, tanto biográfica como intelectualmente (v.g. de raíces liberales, intenta combinar socialdemocracia y democristianismo, 
oponiéndose al comunismo, pero facilitando en su borrador de la Constitución de Weimar el acceso de los nazional-socialistas); llega a reconocer con resignación en el último año de su vida (1920), en una carta a LIEFMANN (un economista conocido suyo).

Un dato curioso sobre el cultivo de la Sociología es que, como se ha podido apreciar entre los apellidos de los autores citados, en su mayoría son anglosajones y nórdicos (incluidos los centroeuropeos, y entre estos los franceses -sólo declarados latinos para influir en América-, por haber sido normalizados -proceso de asimilación nacional- desde los parámetros de París y para aglutinar las disputadas regiones de Alsacia y Lorena -de donde era DURKHEIM-). Ello se debe a que son los más expuestos a los grandes cambios de la Modernidad tardía (de ahí su dominio de la Contemporaneidad), y las grandes transformaciones sociales del rígido e inamovible feudalismo agrario a las dinámicas sociedades modernas industrializadas y urbanas (tal como pretende WEBER en su falaz ensayo La ética protestante y el espíritu del capitalismo). En cambio, los mediterráneos y latinoamericanos no requieren tanto de la Sociología, pues disponen de la gran herencia del humanismo hispánico, cimiento del pensamiento moderno (el de los descubrimientos y la búsqueda de fama y fortuna, la crematística, el tiranicidio, etc.), estudiado hasta principios del s. XX en los Departamentos de Filosofía y Letras de las más prestigiosas universidades occidentales: ¿acaso el Quijote (CERVANTES, 1605 y 15) la mayor obra sociológica de la Alta Modernidad? (con descripciones sociales: hábitos, roles, status, estereotipos, etc.). Incluso, ¿no podría considerarse como una de las primeras obras del humanismo hispánico y su pensamiento proto-sociológico la obra La Celestina (DE ROJAS, 1499)? (sobre la corrupción social y preñada de refranes y correas). 
Téngase en cuenta que la concepción de la sociedad moderna occidental que se va a imponer va a ser la de los neocivilizados, de transición tardía, pero más acelerada y acabada, del campo y la agricultura a la ciudad y los servicios, de la artesanía y los gremios a la industria y el libre comercio, del economato local a la economía de mercado a escala, de la servidumbre a la ciudadanía, etc. En definitiva, el tránsito de sociedades feudales, rígidas, cerradas y mecánicas (que apenas han variado desde el Medievo) a las modernas, dúctiles, abiertas y orgánicas. Así se va a estudiar por la Sociología impulsada por los neocivilizados (máxime desde los flamantes Departamentos estadounidenses). Los antecedentes de cursos de Sociología se los disputan buena parte de las universidades del Ioy League (aunque en realidad aún se trataba de Filosofía social). El primer Departamento específico y estable de Sociología arranca en el curso 1891-92 en la Univ. Chicago (dado el interés por la ecología social en las emergentes megalópolis de entonces), a cargo de A.W. SMALL (1854-1926), quien tres cursos después funda la revista American Journal of Sociology. Continúan dicha trayectoria sociólogos tan destacados como G.H. MEAD y C.H. COOLEY, cultivando el interaccionismo simbólico, así como las bases de la Psicosociología (aunque ya hubiera antecedentes como el Club Metafísico de Harvard). Ahora bien, el boom de los Departamentos de Sociología no llega hasta después de la II Guerra Mundial, en los cuales se trasplantan los herederos de Escuela de Frankfurt, Normale-Annales, Birmingham, etc. (vid. supra), y aquellos que son altamente ideológicos (nacionalsocialistas, reinterpretados como etnoculturalistas), se desarrollan en los Estudios culturales sobrevenidos. Ahora bien, aclarada la emergencia de los estudios de Sociología en EE.UU., al declinar estos y su modelo sociocultural, también ha entrado en crisis la propia categoría de sociedad moderna occidental, criticándose demoledoramente desde dentro por su academia 
posmoderna, y desde fuera, postulándose modelos socioculturales no-occidentales como alternativas mejores -aunque no sean ni una cosa ni la otra: en realidad son anti-occidentales, al haber sido inoculados de nacionalsocialismo o etnoculturalismo (desdibujando los planteamientos tradicionales: no es lo mismo Islam que islamismo, ni pueblo indígena que indigenismo, etc.), ni son alternativa mejor, pues dependen de su oposición a Occidente-.

En cualquier caso (como se viene indicando y a desarrollar algo más), la dialéctica bárbaro-civilizado resulta clave para comprender -al menos- la legitimidad, la validez y la eficacia, para imponer un modelo sociocultural de progreso líder en Occidente. Ahora bien, se insiste en que si decae dicho liderazgo, también se tambalea su modelo sociocultural, con su producción dominante hasta entonces (como ha pasado con otras potencias e imperios a lo largo de la Historia occidental). La particularidad de esta época que agoniza -y que hacía tiempo no acontecía-, es la falta de imperios fuertes (si acaso el liderazgo y poder-blando estadounidense), así como la falta de existencia de un relevo (según el espíritu de San Francisco, deberían ser las organizaciones internacionales, pero aún no ha llegado su momento). Las alternativas no-occidentales, como se ha indicado, del tipo islamismo y/o indigenismo, tampoco son viables por haber sido tamizadas por velos de confusión en los procesos de descolonización durante las guerras culturales (están inoculadas de la tendencia conflictiva del nacionalsocialismo o etnoculturalismo promovido por los Estudios culturales sobrevenidos).

De vuelta al neologismo de la Sociología, entonces, qué se esconde tras ese confuso y multidimensional término (impulsado sobre todo por anglosajones y nórdicos para hacer inteligibles los cambios sociales de su acelerado tránsito a la Baja Modernidad o Contemporaneidad y su alta movilidad social): 
a) Dimensión objetiva: relativa a tres aspectos interrelacionados, como son la realidad social (con sus esferas y factores, o sus estructuras y dinámicas) y su producción correspondiente (su capital simbólico y cognitivo, su manera de ser, estar y tener en el mundo, etc.); la ciencia social (sus teorías, métodos y formas de percepción y gestión, tanto gnoseológicas -intuitivas- como epistemológicas sistematizadas-, más las disciplinas universitarias con sus asignaturas); y la literatura científico-académica (las investigaciones realizadas por sus especialistas, conforme a los aspectos anteriores, dando lugar a la doctrina).

b) Dimensión subjetiva: relativa a la facultad humana de sociabilidad, que desde los griegos clásicos y su zoon politikon zun logos, se sabe que comprende la racionalidad, la política y la comunicación. Esto es, la inteligencia es lo que favorece que los humanos se unan y creen comunidades, no para sobrevivir, sino para prosperar; y para que dicha convivencia sea sostenible se requiere de normas e instituciones, cuyas herramientas clave son la comunicación (la interacción con otros) y la política (la organización del poder). Igualmente, la dimensión subjetiva comprende la solidaridad o proyecto común, cuestión fomentada por la sociabilidad (según su percepción y gestión, para orientar la comunidad constituida).

c) Dimensión normativa: como sistema de producción socio-cultural, mediante el que socializa a sus integrantes, y se permite a los mismos la modificación del propio sistema, según gustos, urgencias y necesidades. Ergo no se trata de un sistema acabado y cerrado, sino en evolución, como el propio objeto de su estudio -de ahí que se prefiera poner en cuarentena cualquier doctrina sociológica actual, prefiriéndose una mera teoría al respecto-. 
En consecuencia, ¿cuáles son los conceptos sociológicos, conforme a la multidimensionalidad planteada y que podrían usarse para una teoría social de la posglobalización? Se alude a las nociones circulares, ya planteadas algunas (destacadas en cursiva y con algún acrónimo o sigla), a revisar y refinar a lo largo del texto (según los matices, aristas y contextos), y otras irán surgiendo a medida que se vayan necesitando para hacer inteligible la realidad social y su teoría expositiva y explicativa. Estos constructos son: Occidente y progreso, que implica relaciones culturales y generacionales, con especial atención a la dialéctica bárbaroscivilizados; también Modernidad y Nuevo Régimen, junto con humanismo hispánico e iberoamericano, más sociedades occidentales modernas; sin olvidar problema y paradigma, globalización, crisis y posmodernidad, velos de confusión posmodernos, guerras culturales y Estudios culturales, mundo posglobalizado, et al. Y ¿cómo encajan todas estas piezas y qué sentido social ofrecen?

Resulta que vivimos una época de crisis e incertidumbres, debidas al tránsito entre una época agonizante y otra emergente (del Estado-nación y sus rigideces a la aldea-global y su flexibilidad). Ahora bien, el vértigo se ha intensificado por los velos de confusión extendidos intencionalmente (durante las guerras culturales de finales del s. XX por los Estudios culturales sobrevenidos), poniéndose en jaque casi todo (dejándose sin paradigmas y problematizándolo todo), salvo la pulsión destructiva del sistema que es la nave social en la que viajamos. Tanto es así, que se ha deconstruido Occidente y su supuesto progreso. Luego, ¿qué es lo que queda? Baste recordar -por ahora-, que Occidente surge en oposición a Oriente: significa etimológicamente poniente $\mathrm{u}$ ocaso, pues si el despertar está en levante (con su comunitarismo y ciclicidad oriental), el desarrollo se halla en Occidente, donde se cree en un plan de progreso (una expectativa de mejora y bienestar para cada cual). 
Por tanto, es inherente a Occidente tanto las crisis como las transiciones (las globalizaciones del pasado, por ejemplo, han sido los descubrimientos de otros continentes), y las mismas, a la postre, han quedado integradas en el devenir occidental. Entonces, ¿qué ha sido diferente esta vez? Mientras que en el pasado se ha luchado por influir sobre el ser occidental (en su visión y misión de progreso, con su racionalidad y realismo para materializar sociedades modernas y de bienestar), lo que ha ocurrido esta vez es que se ha intentado negar el mismo Occidente, procurando además dejar sin herramientas para reconducir la deriva. Así se intentó con las ideologías decimonónicas y sus guerras mundiales durante el s. XX, intensificándose luego con las citadas guerras culturales, sus velos y el respaldo de los Estudios culturales sobrevenidos. En consecuencia, dada la confusión vigente, es prioritario el acometer una revolución copernicana, que permita volver a los planteamientos previos a la desviación. Para entender el origen de tal desviación, que en lo social ha supuesto negar las sociedades occidentales modernas (conforme a la Modernidad y su Nuevo Régimen), resulta crucial el reevaluar las relaciones culturales y generacionales conforme a la dialéctica bárbaro-civilizado. La clave al respecto está en el origen mismo de Occidente: su cuna es el Mediterráneo (Mare nostrum), donde surge su tradición profana (grecorromana) y sagrada (judeocristiana), dando lugar a la ecúmene o mundo conocido y civilizado (donde florece la cultura y las generaciones impulsan el progreso), frente a los extraños (incluso los foedi o pueblos federados, responsables de la fronteras -para impedir que otros más salvajes llegaran-, a los que la cultura sólo alcanzó superficialmente). Así surge la dialéctica de civilizados (mediterráneos) y bárbaros (anglosajones y nórdicos -incluidos los centro-europeos, vistos como nórdicos desde la perspectiva mediterránea-). Durante el Medievo (tras la oficialización del cristianismo con la 
Constitución de Tesalónica, 380), la ecúmene se transformó en la Cristiandad (Res Publica Gentium Christianorum), y ya en la Alta Modernidad, iniciada con el Renacimiento e inspirada por el humanismo hispánico, al extenderse a América, se transformó en Occidente (por su expansión hacia el ocaso). En las Indias occidentales, América hispánica o Nueva España, se implantaron las primeras universidades e imprentas del continente (convirtiéndose en la república de las letras): un siglo y medio antes de que comenzara el seminario teológico que la postre sería Harvard University y demás universidades del Ivy League. Ahora bien, tras la Baja Modernidad (también conocida como el tránsito a la Contemporaneidad), gracias a la Ilustración y sus revoluciones liberal-burguesas (v.g. políticas o de implantación del Nuevo Régimen, económicas o comerciales e industriales, sociales y demográficas de urbanización y alfabetización), poco a poco se abandona el humanismo (pues el hombre deja de ser el epicentro, pasando a serlo el sistema, y organizándose la vida social en torno al trabajo, el dinero, el Estado, etc.). Las élites de poder pretenden la renuncia del humanismo hispánico y su imaginario social a favor de las ideologías nórdicas (nacionalismo y socialismo sobre todo) -téngase en cuenta que el humanismo se basa en el respeto a la diversidad de la humanidad, y su relación con el cristianismo dificulta la realización de la revolución, mientras que la ideología es un sistema cerrado de creencias, fácilmente monopolizable y diseñado para producir el cambio social-. Se pasa así de una racionalidad pura (preocupada por el sentido y alcance del conocimiento y sus límites) y práctica (acerca de una moral universalizable), a una racionalidad instrumental (despreocupada de las Humanidades, para centrarse en las recién llegadas CC.NN. e Ingenierías -pura ambitio pecuniae, sin ambitio dignititatis). Dado el éxito y beneficio de los antiguos bárbaros (imponiéndose sus imperios, como el británico o prusiano 
-más el amago constante del francés-, e iniciándose el colonialismo en África y Asia), se autoproclaman neo-civilizados (al lograr que los viejos civilizados rechacen su condición y acepten la de neo-bárbaros: a) los mediterráneos aceptan ser el bloque de cerdos o PIGS (acrónimo de los países sureños en inglés -Portugal, Italy, Greek \& Spain-, con una intencionalidad despectiva clara); b) los latinoamericanos aceptando ser tercermundistas, como si alguna vez hubiesen sido colonias, pese a haber sido repúblicas soberanas desde el s. XIX (incluso antes que algunos de los Estados nórdicos $)^{143}$.

Paradójicamente, la relación bárbaro-civilizado (como se viene aclarando), siendo clave en Occidente para comprender la lógica de su progreso (quién se ha impuesto a los demás, procurando extender su visión y misión de desarrollo, con su modelo sociocultural de referencia), en cambio, ha quedado relegada por décadas en el análisis social, hasta la globalización (hasta el declinar de los neocivilizados). Y es que, la cuestión de ser considerado bárbaro o civilizado no es baladí (al conferir la autoridad -el conocimiento- y el poder -la fuerza- para transformar la realidad social), pues en pocas generaciones se invirtió la relación, y nos condujo al punto crucial actual. Resulta que, frente a la visión dominante de los neocivilizados (los nórdicos y anglosajones), se recupera aquí (como guía posglobalizatoria) parte de los planteamientos de los viejos civilizados (los mediterráneos y latinoamericanos hoy devenidos en neobárbaros-), por lo que la voz problema no se reduce a conflicto (como se ha pretendido desde las ideologías anglo-nórdicas), sino que hace referencia a la preocupación; y la crítica, tampoco es ataque o contestación (ídem ideologías), sino indagación en el sentido y alcance del conocimiento disponible. Y ¿cómo

\footnotetext{
143 Vid. SÁNCHEZ-BAYÓN, A.: Humanismo iberoamericano... op. cit. - Renovación de la Filosofía Social Iberoamericana... op. cit.
} 
aplicar los planteamientos anteriores al análisis de la realidad social? De manera telegráfica -pues se revisará en diversos momentos y maneras-: hace tiempo que la humanidad se adentró en la globalización, haciéndolo bravamente, incluso de manera algo temeraria e inconsciente, al menos en sus inicios (en los prósperos años 90, con el triunfo ilusorio de Wall-Street \& Hollywood). Incluso, fue polémica la globalización, no sólo por sus crisis, sino también por su gestión (v.g. la fábrica global, Las Vegas mundiales, vid. infra figura 1). De ahí que, tras décadas de tránsito hacia un nuevo milenio y una emergente civilización diferente (la anhelada SC, posibilitadora del estadio de civilización tipo I o $(I)$, con las crisis de un mundo que se deja atrás (dominado por el Estado-nación), y la deriva detectada de deshumanización y asocialización (dada la incertidumbre que se extiende en nuestras sociedades, calificadas de riesgo, líquidas, corrosivas, etc.), urge entonces una visión crítica y guía (reflexionar sobre lo auténtico, para avanzar sobre lo real). Para ello es recomendable el volver a graduarse la vista (en cuanto al paradigma manejado para percibir y gestionar nuestra realidad), además de reconocer el terreno que se pisa (no vaya a ser que sean arenas movedizas, de discursos y velos, y no la tierra firme esperada). Por tanto, ahora que la posglobalización o salida de la misma está en ciernes, nos hallamos en un punto crucial (de no retorno), lo que requiere de una revisión de las cartografías disponibles, junto con una retirada de velos (inferencias, imposturas y falacias fruto de la combinación del pensamiento débil con la corrección política, cientificismo, posverdad, et al.), así como un ejercicio de reflexión crítica de fundamentos: no sólo urge el redescubrir nuestra realidad (social y natural, más la virtual), sino también el paradigma a usar al respecto, con sus estudios correspondientes. En tal sentido, este trabajo ofrece un despertar y revitalización de principios, desde una combinación de enfoques y propuestas (con base en las CC. 
Económicas y Empresariales, conectadas con el resto de CC.SS. y Humanidades, tal como se acomete desde los Estudios de Gestión Cultural o Cross-Cultural Management$C C M)$, pensado todo ello para procurar alumbrar lo mejor posible el mencionado punto en el que moramos, y poder atisbar hacia dónde dirigirse y cómo se alcanza.

Son muchas más las nociones circulares (v.g. velos, guerras culturales, crisis identitaria), pero es preferible no fatigar ahora, dejando que se vayan descubriendo a lo largo de esta revisión ontológica las relaciones socio-culturales estadounidenses, ante el agotamiento de su Modernidad (y su tránsito a un nuevo estadio y/o ciclo posglobalizatorio), y con ello de sus disciplinas de Sociología y de Estudios culturales (vid. supra cap. 8).

\subsection{2.- RETOS: ESCENARIO POSGLOBALIZATORIO, CAMBIO PARADIGMÁTICO Y VELOS ${ }^{144}$}

Permítase una consideración acerca de cómo se percibe y gestiona el ser de nuestra realidad social -que no su deber ser o utopía-, la cual se halla transitando de una época y su paradigma a otro mundo aún por determinar: ¿será la anhelada SC o sólo del tecno-consumo global? ¿Estaremos evolucionando, involucionando, o

\footnotetext{
${ }^{144}$ SÁNCHEZ-BAYÓN, A.: “Revelaciones conceptuales y lingüísticas de la posglobalización: Retos de construcción moral de la sociedad del conocimiento y aportes del humanismo hispánico" (pp. 411458), en Carthaginensia. Revista de Estudios e Investigación (vol. XXXIII, no. 64), 2017. "Balance de la Sociología tras la globalización" (pp. 49-68), en Eduser-Revista de Educação, IPB (S.1., v. 10, n. 1), july 2018. Complementariamente, vid. SÁNCHEZ-BAYÓN, A.: Humanismo Iberoamericano, Guatemala: Cara Parens, 2012. Renovación de la Filosofía Social Iberoamericana, Valencia: Tirant Lo Blanch, 2013.
} 
simplemente mutando a no se sabe qué? ¿Se dispone de cartografías sociales de la posglobalización o, al menos, de algún parámetro de toma de decisiones que guíe en el transitar hacia el nuevo mundo? Este estudio pretende acometer un diagnóstico y pronóstico de nuestra voluble realidad social, ofreciendo una terapia desde el humanismo (en especial el hispánico) y sus planteamientos éticos -de modo que se retire algún velo (vid. infra cap. 1)-.

Desde los Clásicos, que el cuestionamiento permanente del mundo en el que se vive, es un sano ejercicio de humanidad: sólo los hombres están llamados a tal labor (a diferencia de bestias y dioses, que no requieren de tal (unas por no plantearse nada y otros por saberlo todo; según se desarrolle dicha labor, así se estará más cerca de las bestias o de los dioses). Si aún se conserva un mínimo de actitud crítica hacia el mundo, se podrá observar sin dificultad que se habita una época de cambios, cada vez más números y acelerados: ¿por qué? Y ¿por qué quienes deberían ayudar a explicar dichos cambios (los académicos e intelectuales) no cumplen dicha labor? Primeramente, son muchos velos posmodernos de confusión, entre ellos los cientificistas (v.g. reduccionismo cuantitativista), que han de retirarse para recuperar el contacto con la realidad, correspondiendo después un ejercicio de atención al aggiornamento o actualización (realista y holística) del estudio del entorno social glocal en curso. De la lluvia de cuestiones apuntadas, quizá las que más calen, sean las relativas a cómo opera el poder hoy, lo que conduce a lo glocal: al no haber ya barreras planetarias rígidas, gracias a las TIC, y al estar todo interconectado, a modo de red de redes, entonces es posible el desarrollo de una ordenación basada en un pensamiento global de acción local, capaz de integrar procesos e instituciones en los que lo mundial se ha localizado y viceversa. Antes de proceder a estudiar dicho sistema de ordenación (y si tiene parámetros éticos o no, y cómo afecta a los 
grandes cambios económico-sociales), se ofrecen unos apuntes elementales sobre cómo percibimos la realidad circundante.

La pregunta de arranque -partiendo del rótulo de este apartado-, ha de ser: ¿qué es un paradigma? Por así decirlo -y mediante una metáfora accesible a cualquiera-, se trata de las gafas intelectuales con las que vemos la realidad, lo que implica tener que reconocer de partida que: a) nuestra visión es deficitaria; b) requiere de graduación periódica, por si hubiera variado. $\mathrm{Y}$ así es, porque un paradigma sólo resulta válido en tanto en cuanto permita resolver los problemas acaecidos en nuestra realidad, pero si no cumple tal misión, ello significa que su tiempo ha pasado y ha de pensarse en corregir la graduación de las gafas o hacer unas nuevas, para ver mejor. Por tanto, partiendo de la presunción de que nuestra percepción y gestión de la realidad social va cambiando, y tal circunstancia modificativa no es mala, sino todo lo contrario -se trata de una evolución para la mejora de dicha percepción y gestión-, entonces, téngase en cuenta los siguientes factores acaecidos con la globalización: crisis del Estado-nación (desmembramiento de países y auge de minorías nacionales), transferencia de tecnología militar a civil (TIC para telefonía móvil, domótica, etc.), revitalización de organizaciones internacionales (máxime las económicas, v.g. OMC, UE), et al.

Para comprender el significado y alcance del tránsito paradigmático que aquí se plantea, téngase en cuenta el siguiente planteamiento preliminar de circunscripción (relativo a las relaciones entre paradigmas: el que se agota y el nuevo). Sintéticamente, sobre el paradigma en declive -sino caduco ya-, cabe destacarse que sus antecedentes son decimonónicos, remontándose a la eclosión del Estado-nación y el auge de las ideologías (v.g. socialismo, nacionalismo); sus rasgos definitorios son: su formalismo (medios y apariencias tasadas), su estatalismo (se 
centra en dichos sujetos y se gestiona por los mismos, de ahí su tendencia jerárquica y burocrática), su economicismo (todo está mesurado y trasladado a un valor y coste), y de racionalidad lógica binaria y técnico-profesional (las decisiones se toman conforme al criterio aliado-enemigo, aunque se disfrazan con argumentarios aparentemente complejos). En cuanto al emergente paradigma global, que viene a sustituir al caduco estatalista, se caracteriza por -al menos, esa es la expectativa, si se aplicara la terapia humanista aquí planteada-: su informalidad (se propician los nuevos cauces, pues vuelven a priorizarse los fines y el fondo -respetándose unos principios-), su civilidad (su motor es la sociedad civil, v.g. ONGs, foros), su humanismo (proporciona los parámetros para la toma de decisiones, que favorece la empatía, entre otras competencias), y su racionalidad es lógico-difusa y simbólica (las conexiones que se producen responden a parámetros propios de la naturaleza humana, trascendiéndose las limitaciones culturales). El paradigma global, arranca en los años 90 y tal cosa es posible gracias al acceso generalizado a las TIC, favoreciéndose las relaciones entre las personas, por todo el mundo, al margen de los límites fronterizos estatales. El emergente paradigma global, responde $-\mathrm{o}$ al menos tal habría de ser su vocación si se aplicara la ética humanista postulada en este trabajo- a una serie de principios, como son: optimización, que no maximización (consistente en sacar toda la ventaja a costa de otros), ni compensación (que pretende el mantenimiento de la predominancia a cambio de mínimas concesiones -supone un tipo de dependencia-); equilibrio, que no sostenibilidad (pues supone un énfasis en la prolongación temporal y no en la equidad esperable), ni ecologicismo (pues habría de primar el medio natural sobre el social, cuando lo que debe haber es una simbiosis entre ambos); progreso, cuya inspiración positiva y de confianza -tan presente en la Historia occidental- haga posible alcanzar la SC (en su estadio de CI), mediante 
círculos virtuosos; armonización, favorecedora de la pluralidad compatible y tendente a la integración de la humanidad.

Conforme a lo planteado, ¿en qué consiste el tránsito del paradigma estatal al global y cómo afecta a su gestión ética (si la hubiera)? Si el paradigma estatal era pro sistema, institucionalista y proteccionista, en cambio, el global es flexible y difuso, teniendo como reto rehumanizar y resocializar el mundo que habitamos: está llamado a ser un paradigma de apertura y encuentro, basado en la cooperación y bienestar generalizado, donde el hombre y su felicidad ocupen un lugar central. No es tanto un desideratum -o wishful thinking, como se aludiría ahora a la falacia naturalista-, sino más bien la confirmación del patrón occidental: Occidente -que significa ocaso, para renacer más vigoroso-, ha progresado de sus crisis (cíclicas), superando sus límites y mejorando su relación con los demás (v.g. de la ekumene mediterránea de la Antigüedad, al salto trasatlántico de las Américas de la Modernidad). La novedad del momento actual radica en que, gracias a las TIC, puede aspirarse realmente al objetivo de $\mathrm{CI}$; pues la alternativa es de lo más destructiva, en cualquiera de sus versiones posibles: entropía (colapso de lo social) o armagedón (conflicto social máximo). Sin embargo, para que la actual sea una crisis de crecimiento, y no civilizatoria, primero hay que reconocer el terreno que se pisa (para asegurarse de que no se avanza hacia arenas movedizas o la nada).

Queda pendiente el apuntar una serie de consideraciones preliminares sobre los velos de confusión (tal como reza el rótulo de este apartado). Dichos velos, metafóricamente, suponen una telilla interpuesta, que oculta la realidad, dificultando su reconocimiento y gestión. Su tipología es diversa, según su intencionalidad y difusión (v.g. prejuicios e inferencias, imposturas, falacias). También se pueden clasificar según su nivel de elaboración e hibridación (v.g. 
leyendas doradas, rosas o negras, género testimonial), etc. Téngase en cuenta que, con la globalización y sus crisis, se favorece una temporada fértil (la posmodernidad) para este tipo de confusiones, ya que el fin del bloqueo de la Guerra fría y las conexiones de las TIC dan lugar al contacto de las culturas del mundo, incluyéndose sus resabios ideológicos, por lo que a la postre termina brotando un pensamiento débil amorfo: desde la corrección política y el relativismo, junto con el cientificisimo, pasando por la memoria histórica y el ecopacifismo, sin olvidar el poscolonialismo y el posmarxismo (v.g. discurso de género, etnicidad), más la posverdad y el posmanierismo, et al. Todo ello no deja de ser un ejercicio estético antisistémico de posicionamiento en contra y sin banderas propias. Se trata de réplicas discursivas efímeras y emotivas de polarización, elaboradas para su consumo en masa, frente a lo cual, se reivindica el regreso del ethos frente al pathos (la vuelta a lo racional, solidario y público -frente a las modas pulsionales, de fragmentación y exaltación de lo privado, intentando suplantar lo anterior, v.g. las banderas políticas de conflicto sexual y de género, de laicismo-). Entre los velos menos conocidos, que han ocultado el humanismo hispánico y su ética, se adelantan ahora: adanismo y tabula rasa, buen salvaje y revolucionario, arielistas-calabanistas, bucle melancólico, (des)medida holón, etc. ${ }^{145}$ Todos ellos ponen de manifiesto el gran peligro que supone la renuncia del bagaje cultural común, cuyo vacío es llenado por roles y clichés fijados por terceros, lo que no sólo dificulta la propia comprensión, sino también la relación con los demás y con el medio, con el pasado y con el futuro; el problema de la no-ética o corrupción sistémica atribuida a los actuales iberoamericanos radica en la resolución del problema identitario.

145 Vid. SÁNCHEZ-BAYÓN, A.: Humanismo iberoamericano... op. cit. - Renovación de la Filosofía Social Iberoamericana... op. cit. 
De vuelta al punto crucial, y aterrizándolo en la globalización y su tránsito posglobalizatorio, el reto en curso está en saber dejar atrás la Modernidad (con su Nuevo Régimen y su modelo sociocultural, sintetizado en lo que la Sociología ha llamado la sociedad moderna occidental -que no sociedades modernizadas nooccidentales, como ocultan los velos de los Estudios culturales sobrevenidos-), y elegir un camino (a ser posible, conducente a la SC). El problema es que, hasta los EE.UU., pese a ser el autoproclamado adalid de Occidente (tras la II Guerra Mundial) y el último bastión de la Modernidad, finalmente ha sucumbido tras décadas de desgaste, con las guerras culturales (1960-80) y el caballo de Troya de los Estudios culturales sobrevenidos y sus velos (vid. infra cap. 1 y supra cap. 8).

\subsection{3.- BALANCE DEL PIONERO MODELO SOCIO-CULTURAL ESTADOUNIDENSE ${ }^{146}$}

La Modernidad estadounidense es el resultado de la transición entre la Alta Modernidad hispánica (con su racionalismo humanista -propenso a lo telologíco y axiológico) y la Baja Modernidad anglo-nórdica (con su racionalismo profesional tendente a lo mesológico e instrumental), combinándose ambas en su seno y dando lugar a un pionero modelo socio-cultural de mestizaje, que aspira a la realización de la libertad (tanto personal, de los ciudadanos, como colectiva, de las confesiones), como de la felicidad (igualmente, personal y colectiva, en forma de un mayor bien común, vía progreso y bienestar), además de atender a manifestaciones mesiánicas

\footnotetext{
146 Vid. infra notas 137 y 138, especialmente, La Modernidad sin prejuicios, Estado y religión, Manual de Sociología Jurídica Estadounidense y La religión civil estadounidense; complement., vid. infra notas 3 a 5, 11, 16, 24, 55 y 68, más p. 126 ss.
} 
(al sentirse elegidos para trascender, y favorecidos para la unión y el compromiso en la resolución con éxito y beneficio de los problemas terrenales). Así se entiende que los EE.UU. se vuelvan una potencia hegemónica occidental, incluso su adalid autoproclamado tras la II Guerra Mundial. Ahora bien, al triunfar el pensamiento débil posmoderno, no sólo se abandona la Modernidad (con su contacto con la realidad, la racionalidad, etc.), provocándose la crisis su modelo socio-cultural, sino que además se arrastra al resto de Occidente (por sus relaciones de liderazgo con EE.UU. y por pérdida de un renovado referente al respecto). Por tanto, el que EE.UU. deje de ser el último bastión de la Modernidad, no sólo afecta a este país, sino a los demás que se relacionan con el mismo, y al conjunto de Occidente, por quedarse sin un modelo referencial. Para comprender la situación, una vía de análisis puede ser la que se viene ofreciendo, como es la facilitada por la religión (en el sentido laxo de la secularización moderna, vid. infra).

¿Por qué se aterriza la cuestión en la religión para comprender la crisis de la Modernidad estadounidense y su pionero modelo socio-cultural? Como se viene señalando -desde distintos enfoques-, la religión es un tipo de conocimiento, con sus conceptos y teorías, como lo puede ser la ciencia, o la filosofía (sendos conocimientos se combinan en la Teología política). También se trata de una vigorosa esfera social, con sus normas e instituciones, como pasa con la política y el derecho (con expresiones como la religión civil, que es eminentemente práctica y está en manos de la sociedad civil -a diferencia de otras religiones políticas decimonónicas extendidas por Europa-). Incluso, cabe entenderla como un factor de transformación y/o estancamiento social, mediante movimientos y campañas, afectando al devenir de comunidades (con el evangelismo social). Tal es la complejidad que subyace bajo ese iceberg al que se llama religión -y sobre el que se han extendido tantos velos de 
confusión, especialmente, tras las guerras culturales, vid. infra-, que en los EE.UU., además, como prototípico país de la Modernidad y su Nuevo Régimen, resulta que por el influjo de la religión, no sólo se ha forjado su identidad y la agenda de la vida pública, sino que a su vez ha favorecido la sobreestima y sentido mesiánico para autoproclamarse adalid de Occidente. $\mathrm{Y}$ es que, como ya se probara en otros estudios $^{147}$ el factor religioso es capaz de condicionar el tránsito a la Modernidad de un país (bien acelerando, bien retrasando los acontecimientos). En aquel Estado donde su pasado ha pesado más que su presente, y su concepción religiosa ha quedado anclada en fórmulas tradicionales, entonces sí, la religión ha podido ser un lastre -de ahí el desprecio de los intelectuales ilustrados europeo-continentales-. En cambio, en países como los EE.UU., la religión ha trascendido a su siguiente estadio (más secularizado, pero no del todo, vid. infra figura 5 y 18), propiciándose así la convivencia de una pluralidad de cultos, con preocupaciones terrenales y humanas. La religión ha jugado un papel clave en la gestión de las problemáticas y las demandas sociales, procurándose su incorporación a la agenda institucional de los poderes públicos, para la consecución de un mayor y mejor progreso y bienestar general: ha sido la fe para la consecución de un progreso y advenimiento de un mundo mejor (tal como afirmaran los colonos del s. XVII, plasmándose a la postre en la concepción de AD). En consecuencia, prejuicios al margen -a desmontar cumplidamente en su momento-, la religión supone al mismo tiempo un conocimiento, un factor, una esfera y una institución de gran influjo social, pues contribuye no sólo a la articulación de la mentalidad colectiva y la orientación de la acción social, sino que además, resulta el constructo cognitivo adecuado para la

147 Vid. SÁNCHEZ-BAYÓN, A.: La Modernidad... op. cit. - Estado y religión... op. cit. - Universidad, ciencia y religión en los Estados Unidos de América, Porto: Sindéresis, 2015. Complement., vid. nota siguiente. 
condensación y transmisión del capital cultural y/o imaginario social, así como, la afectación de la opinión pública y las relaciones institucionales (v.g. Iglesia-Estado, geopolítica y biopolítica, asistencia socio-religiosa y misiones).

Para aclarar lo singular del factor religioso en los EE.UU., que a su vez ha conferido su idiosincrasia a los estadounidenses (o sea, cómo un pueblo crea la realidad social, que luego le recrea), se ha hecho gala de la secularización y su devenir: se ha abordado el significado y alcance de la secularización moderna, lo que a su vez ha traído consigo el cultivo e implementación del otro gran componente material, como es la teología moderna o Teología política. Su realización estadounidense ha traído consigo múltiples expresiones, pero en este estudio se prefiere prestar especial atención a la religión civil o ACR, pues pese a que algo se trata el evangelismo social o ASG, el mismo requeriría de otro trabajo monográfico ${ }^{148}$.

148 Sirva como avance un bosquejo que sintentizara alguna de las charlas impartidas en DePaul y Baylor, vid. SÁNCHEZ-BAYÓN, A.: Manual de Sociología Jurídica Estadounidense. Del poder, lo sagrado y la libertad en la Modernidad Occidental, Madrid: Delta, 2008. - "Historia de la comunicación social estadounidense a través de sus movimientos religiosos", en Historia y Comunicación Social (vol. 13), 2008, p. 199-223. - "La religión civil estadounidense: análisis de la configuración de la realidad sociocultural y su identidad social", en Revista General de Derecho Canónico y Derecho Eclesiástico del EstadoIustel ( $\mathrm{n}^{\mathrm{o}}$ 10), febrero 2006, p. 1-36. Complement., vid. SÁNCHEZ-BAYÓN, A.: “Historia, Historiología e Historiografía de los Estudios Interculturales en EE.UU.", en Revista Banda de Moebius, Univ. Chile (no 48), ene. 2014, p. 147-57. - "Innovación docente en Ciencias Eclesiásticas y JurídicoSociales: estudio crítico y comparado", en Cauriensia - Revista Anual de Ciencias Eclesiásticas (vol. 8), 2013, p. 317-349. - "Cómo se aprende Derecho Eclesiástico del Estado en los Estados Unidos de América y su jurisprudencia: los otros estudios de casos menos conocidos", en Revista Jurídica de la Universidad Bernardo O'Higgins Ars Boni et Aequi (vol. 9, no 2), nov. 2013, p. 1-43. - "Religión, Política y Derecho en las Américas del nuevo milenio", en Revista Jurídica de la Universidad Bernardo O'Higgins Ars Boni et Aequi (vol. 8, no 1), enero 2012, p. 39-104. - Derecho Eclesiástico Global. Cuestiones y materiales de trabajo para Derecho Eclesiástico y Canónico, Madrid: Biblioteca Universitaria de CC. Jurídicas, Económicas y Sociales - UCJC/Delta, 2012. - Filosofía Político-Jurídica Glocal, Saarbrücken: EAE, 2012. - Humanismo Iberoamericano, Guatemala: Cara Parens, 2012. - "Religión, Política y Derecho en las Américas del nuevo milenio", en Revista Jurídica de la Universidad Bernardo O'Higgins Ars Boni et Aequi (vol. 8, no 1), enero 2012, p. 39-104. - "Mejora del aprendizaje del Derecho mediante los estudios de caso: aplicación al Derecho Eclesiástico del Estado", en REPES: Revista Electrónica de Pensamiento, Economía y Sociedad-Instituto Virtual de Ciencias Humanas (vol. 16), sept.-oct. 2012, p. 49-80. - “La International Religious Freedom Act of 1998 y la geopolítica estadounidense actual", en CAIRO, H., 
Lo mismo pasa con otras expresiones como el destino manifiesto o AMD, así como $\mathrm{AWL}, \mathrm{AD}$, etc.

Como última consideración preliminar, sólo recordar al lector no estadounidense que, las tres categorías aquí planteadas (Teología política, religión civil y evangelismo social), posiblemente resulten de primeras una suerte de dialéctica antagónica, incluso un oxímoron (vid. infra). Para un europeo-continental actual (posmoderno), acostumbrado a mirar la realidad social bajo unos velos discursivos, probablemente, le parezca que se está presentando una serie de artificios con cierto interés analítico, pero sin sustento empírico -y justo por eso mismo, el europeo-continental es incapaz de percipir las religiones políticas que le rodean y socializan, v.g. ideologías, como el nacionalismo y/o el socialismo, incardinadas en el sustento del Estado y su sociedad tutelada-. Ahora bien, en el devenir estadounidense, no sólo ha existido el trinomio apuntado en el rótulo del epígrafe -y no de manera excepcional, sino generalizada-, es que además, su peso material y estructural ha sido tal, que ha determinado la marcha de la realidad social, su conocimiento y la producción científica al respecto. Luego, el trinomio mitopoiético que se estudia seguidamente, alude a las tres patas del taburete que sostiene la construcción de la realidad socio-cultural estadounidense (cómo se produce la misma, que a su vez reproduce a quienes la seguirán generando): la identidad estadounidense y su misión vienen dadas por el juego de interacción entre el tronco común, que es la Teología política (al conferir el referente del poder y lo sagrado, así como la identidad y misión del pueblo elegido), y sus extensiones acomodaticias (que

PASTOR, J. (comp.): Geopolitica, guerras y resistencias, Madrid: Trama Editorial, 2006, p. 121-140. "Comunicación y Geopolítica estadounidense actual: de IRFA al Choque de Civilizaciones", en Historia y Comunicación Social (vol. 11), junio 2006, p. 173-198. - "Revitalizaciones religiosas postmodernas en América y sus riesgos para la democracia y los derechos humanos", en Revista General de Derecho Canónico y Derecho Eclesiástico del Estado-Iustel (oํ 11), mayo 2006, p. 1-23. 
equilibran el peso del tronco común, según se van desarrollando los acontecimientos), como son la religión civil (con sus aportes para construir una identidad nacional -antes del debate decimonónico europeo-continental-, respetuosa con las religiones tradicionales, integrándolas en una superestructura común) y el evangelismo social (la concreción en cruzadas transformadoras de la realidad social conforme a su relación de equilibrio con las otras dos patas del taburete).

Por tanto, se clarifica seguidamente qué se entiende por Teología política (relativa a la vocación y misión del pueblo de Dios), completándose en los puntos siguientes dos de sus consiguientes manifestaciones principales (que ayudan a su comprensión), como son: a) la religión civil (sus creencias, valores, ritos, símbolos, normas e instituciones, et al. -vid. supra cap. 10- surgidos gracias a la secularización moderna y como resultado del influjo de su Americaness); y b) el evangelismo social (la heteropraxis, que guía la salvación del pueblo de Dios, a través de su creación: cómo alcanzar el más allá a través del más acá, prestando atención a cuestiones de justicia social -incluso, con un destino manifestó, vid. supra cap. 7-).

\section{A.- Teología política}

¿A qué se alude cuando se habla de Teología política? En este estudio se ha venido usando como sinónimo de teología moderna (como se aclara en breve, en contraposición con la tradicional y la posmoderna, vid. supra figura), relacionándola con la secularización moderna (entre cuyas expresiones destacadan, desde el s. XVI, las Reformas protestantes y/o la Escuela de Salamanca, aunque sus antecentes se 
remontan a iniciativas de reforma de órdenes, como la franciscana en el s. XIV, y previamente, los postulados universitarios del s. XIII). Se favorece así la realización del tránsito a la Modernidad y la emergencia y consolidación del Nuevo Régimen (novus ordo seclorum). Todos estos conceptos auxiliares son generalmente conocidos, por lo que resulta más conveniente el proceder directamente a ahondar en la noción bifronte que es la Teología política: ¿en qué consiste tan moderna ciencia, que se halla entre el conocimiento de Dios (Teología) y el gobierno de los hombres (Política)? Sírvase el partir de la siguiente premisa: con la denominación Teología política se alude al mismo tiempo a dos cuestiones conexas, como es, de un lado, aquel pensamiento que inspirara y posibilitara el citado tránsito a la Modernidad y su Nuevo Régimen; y de otro lado, la disciplina que aún se cultiva de manera desigual en las universidades, los seminarios teológicos y los centros de alto rendimiento o thinktanks.

La Teología política, nominalmente, se presenta como un aparente oxímoron como se viene advirtiendo-, al combinarse dos categorías en principio antitéticas, como son la ciencia de Dios y la del gobierno de los hombres. Sin embargo, no se debe a confusión alguna, más bien a la confianza del dominio de sendos conocimientos, lo que permite pasar a un estadio superior, en el que es posible aumentar y especializar el conocimiento, sin confundirlo (sirva como ejemplo, cómo se pasa de la propaganda tradicional o religiosa a generar la propaganda moderna o política, con resultados como las religiones políticas y civiles, vid. supra).

Gracias al despuntar universitario en el s. XIII, ya para el s. XIV, la Teología constituye la primera Facultad Mayor (seguida de Derecho -por entonces, Cánones y Leyes-, más Medicina). En cuanto a su conocimiento, se ha desarrollado plenamente, gracias a la Filosofía (conocida por entonces como ancilla theologiae o sierva de la 
Teología). En concreto, son cruciales las contribuciones de la Metafísica, aportando sustento ontológico y lógico de máxima solidez. Es por ello que los teólogos han de asumir nuevos retos e ir a la frontera del conocimiento: en el s. XIV, la gran demanda social es dar respuesta a la correcta organización social de la Iglesia, sin corrupciones. Igualmente, deben resolverse los problemas relativos a la propiedad, la esclavitud y/o servidumbre, etc. Así se entiende el nacimiento de la pre-reforma, con teólogos de máximo nivel, como J. WYCLIF (Profesor de Teología en la Universidad de Oxford y uno de los padres espirituales de los husitas, junto con su fundador J. HUS); J. COLET (también Profesor de Teología en Oxford y decano de la Catedral de San Pablo en Londres -uno de sus discípulos fue E. de ROTTERDAM); Erasmo de ROTTERDAM (Profesor de Teología en la Universidad de Cambridge, donde completó su traducción del Nuevo Testamento o Novum Instrumentum, que tanto influyera en LUTERO); Jan HUS (Profesor de Teología y Rector de la Universidad Carolina de Praga, además de líder de los husitas), et al. A la labor de todos ellos hay que sumar la herencia de las órdenes religiosas y su devotio moderna (no ha de traducirse como devoción moderna, sino como virtud de la religión según la neoescolástica, surgida tras la querella de la pobreza, y las aportaciones de franciscanos como J. DUNS SCOTO en las universidades de Oxford, París y Colonia, junto con G. OCKHAM en los centros de Oxford, Aviñón y Pisa) ${ }^{149}$. En realidad, la

\footnotetext{
149 Pese a ser franciscanos, preocupados por cuestiones político-jurídicas de la época (v.g. propiedad, causas justas, corrupción), también guardan proximidad con los planteamientos del agustinismo, sobre el pluralismo de las formas y la primacía de la voluntad sobre el entendimiento, o sea, el voluntarismo -no en su concepción europea-continental y pro-católica, sino anglo-germánica y proreformista, conciliándose así la predestinación y el libre albedrío o free will-: la voluntad no tiende necesariamente al bien (como postulara Tomás de AQUINO), sino que la esencia de la voluntad es la libertad (dada por Dios para que los hombres la deseen y la busquen, o no, produciéndose así la confirmación de ambas), de ahí que la voluntad sea más perfecta que el entendimiento y superior a él, pues el entendimiento no es libre para asentir o disentir de las verdades que capta; el entendimiento es una potencia natural, pero la voluntad no lo es -el problema es que tal lectura pre-
} 
pre-reforma y los autores citados, así como el despertar de la Teología política, no es más que la constatación de las crisis y el tránsito entre épocas -tal como acontece hoy en día, tras la globalización-. Se está pasando del Medievo y su Antiguo Régimen (feudalismo), con su paradigma escolástico (con autores como San Agustín de HIPONA, Santo Tomás de AQUINO, etc.), cuya principal ciencia es la teología tradicional (centrada en Dios y la salvación en el más allá), para dar paso a la Modernidad y su Nuevo Régimen (sociedades libres), con su paradigma neoescolástico (con autores como los citados, especialmente DUNS SCOTO y OCKHAM), dando paso a una teología moderna, abierta a otros conocimientos, como el Derecho y la Política, cuyo resultado en la Teología política. Entre las dos tradiciones que informan a la Teología política y que tienen un influjo clave en América (en teólogos fundacionales e impulsores de despertares y revitalizaciones, como STODDARD, MATHER, AMES, DAVIES, WHITEFIELD, EDWARDS, HODGE, et al.) ${ }^{150}$, cabe destacar, de un lado, la tradición mediterránea católica (y su evangelismo de conquista), con la Escuela de Salamanca (desde VITORIA a SUÁREZ, con su mysterium ecclesiae, de auxiliis, títulos justos, etc.), y de otro lado, la anglogermánica protestante (y su evangelismo de colonización, ídem), con personajes como los anteriormente citados, más LUTERO, CALVINO, ZWINGLIO, et al. (impulsores de theonomy, que los padres fundadores transforman en deísmo). Todo ello

reformista del pensamiento franciscano, no termina de resolver la cuestión-. Tal posicionamiento, junto con otros, hace que tanto DUNS SCOTO y OCKHAM resulten de lo más influyentes en el pensamiento de teólogo-políticos y filósofo-políticos clave como SPINOZA, HOBBES, LOCKE, etc., a su vez, muy citados por los padres fundadores estadounidenses. Ahora bien, se insiste que tal es la interpretación más o menos coincidente de los citados autores pre-reformistas, aunque más bien parece un producto historiográfico posterior. Vid. SÁNCHEZ-BAYÓN, A.: Secularización moderna... op. cit.

${ }^{150}$ S. STODDARD y los MATHER, en seminarios teológicos de Nueva Inglaterra del s. XVII; W. AMES y S. DAVIES en Princeton University -provincias medias-, en el s. XVIII; G. WHITEFIELD, W. TENNENT y J. EDWARDS en la proto-Ilustración de las trece colonias, et al. 
favorece un sistema comprensivo, lo suficientemente elástico y flexible, para una sociedad abierta en un nuevo orden secular. Se sintetiza el tránsito y mestizaje mencionado en la siguiente figura.

Figura 19.- De la teología tradicional a la moderna o Teología política ${ }^{151}$

Teología tradicional (coordenadas: Europa, Medievo, Dios): es una ciencia básica y/o propia, centrada en su articulación y procurando en consecuencia el responder a las preguntas de quién es Dios (sus atributos, su omnisciencia y su santidad), y para qué y cómo actúa (la salvación en el más allá). Se busca la ortodoxia (reprimiéndose la herejía), además de primarse sobre la ortopraxis y la ortopatía. Sus problemas son la secularización (el avance de lo temporal, profanando lo sagrado), y por ende el apocalipsis (la segunda venida, con su milenarismo y parusía -incluido el armagedón-).

Definición de Santo Tomás de AQUINO (Summa Theologica, parte I. secc. 1, cap. 7, 1274): "una ciencia unificada en la que se tratan todas las cosas bajo el aspecto de Dios porque son Dios mismo o porque se refieren a Dios".

Teología moderna (coord.: Europa-América, Modernidad, Cristiandad): es una ciencia aplicada y/o impropia (trata con interés temas como el pecado, la revelación y lo sobrenatural, vid. supra), centrada en dar respuesta al papel del cristiano en el mundo (qué es ser cristiano o cristología - pero centrada en un Jesús más personal y presente en el día a día, vid. infra Cristianía y posjudeocristianismo-, cómo ser cristiano y su organización o eclesiología -por ende, también las relaciones Iglesia-Estado-, y para qué

${ }^{151}$ La clasificación, evidentemente, puede ser más compleja, habiendo de distinguir primero entre la teología natural y la positiva. La teología natural es el conocimiento de Dios directamente revelado a través de su creación. Cabe distinguir entre la teología natural común y propia. La primera se denomina así por su corte general y ordinario, pues la naturaleza revela en cada instante el poder y el amor de Dios, además de resultar compartida con otras religiones. La teología natural propia es particular y extraordinaria, ya que versa sobre la encarnación de Dios, para salvar del pecado, dando luegar al Cristianismo. La teología positiva es el conocimiento de Dios mediado por el hombre, y centrada en el pueblo elegido para su salvación. Se puede distinguir también entre la común (focalizada en el estudio de los pactos, las dispensaciones y las Escrituras), y la particular (de cada una de las tradiciones teológicas, v.g. ortodoxos, católicos romanos o latinos y orientales, protestantes). A su vez, se puede diferenciar (como se hace en esta figura, adaptándose ya a la realidad socio-cultural estadounidense) entre la antigua o tradicional, la moderna o política y la posmoderna. Sobre su recorrido histórico universitario en los EE.UU., vid. SÁNCHEZ-BAYÓN, A.: "Evolución y evaluación de la ciencia iuseclesiasticista en los EE.UU.", en Anuario de Derecho Eclesiástico del Estado - Ministerio de Justicia (vol. XXXI), 2015, p. 637-729. - Universidad, ciencia y religion... op. cit. Complement., vid. MARSDEN, G.: The Soul of the American University: From Protestant Establishment to Established Nonbelief, New York: Oxford Univ. Press, 1994; en cuanto a los debates actuales al respecto, vid. BIRD, D.L., SMITH, S.G. (eds.): Theology and Religious Studies in Higher Education, London: Continuum, 2009. 
ser cristiano o salvación, pero a través del más acá, para llegar al más allá). Sigue habiendo cierto problema (de manera excepcional) con la secularización y el apocalipsis (vid. milenarismo decimonónico en EE.UU.), pues el gran problema es la revelación, sobre todo en lo tocante a la predestinación-redención (qué hacer para saberse salvado). El reto de esta teología es la convivencia de la heteropraxis (y su plasmación en la libertad y autonomía religiosa, así como la ordenación de la acción socio-religiosa, v.g. beneficencia, educación, sanidad, familia), lo que implica la heterodoxia y la heteropatía -una vía de solución es la ACR-.

Definición de AMES (Medulla Theologiae, 1630 aprox.): "la doctrina o enseñanza de vivir a Dios" (maestro de N. EATON, primer director de Harvard).

Definición de HODGE (Systematic Theology, vol. 1, Intro. 2.1, 1871): “La Teología es la ciencia de los hechos de revelación divina hasta ahora; cómo esos hechos conciernen a la naturaleza de Dios y nuestra relación con él" (De los primeros directores de Princeton, entre las décadas de 1850 y 1870, quien marcará una manera de estudiar Teología).

Fuente: elaboración propia (SÁNCHEZ-BAYÓN, 2007 y 16).

El resultado del tránsito aludido es una teología moderna, que en vez de centrar las preguntas en un conocimiento de sí misma (qué es la Teología y quién es Dios, y para qué la Teología y cómo opera), aplicándose a la realidad social (quiénes son los cristianos, cómo se organizan y salvan, y para qué ser cristiano), y ayudándose para ello de un cariz liberal y material (vid. supra PWF), fruto de la combinación de la tradición católica y de la protestante, que en América, tras su proceso de Americaness o estadounidización (vid. infra), genera: a) una modalidad propia de Teología política estadounidense, como es la American covenant theology o teología pactista (ACT), que al basarse en la creencia de alianzas entre Dios y su pueblo, mediante representantes elegidos (reyes, jueces, etc.), y la participación asamblearia (como iglesia -que es su etimología griega-), se favorece así el florecimiento del parlamentarismo, la democracia, el federalismo, incluso, el presidencialismo (vid. supra cap. 10); b) un sistema de tipificación político-jurídica, como es el ius circa sacra 
moderno o ICS ${ }^{152}$ [ordenación de las esferas sagradas o derecho eclesiástico], cuyas manifestaciones más destacadas son las Blue Laws o Derecho dominical, y su posterior American Civil Church-State Law o Derecho eclesiástico estadounidense (ACCL). Todo ello se aborda con mayor detalle en los siguientes epígrafes. Únicamente, a modo de prevención, sí se desea dejar constancia de que, a diferencia de la deriva europea, como en los EE.UU. tiene lugar una realización combinada de Modernidades (la hispánica y la anglo-nórdica), su Teología política opera con normalidad y abiertamente, con variedades de pensamiento y movimientos sociales al respecto (v.g. trascendentalismo, pragmatismo, excepcionalismo); en cambio, en el caso europeo, se va a ocultar todo ello bajo velos, como el materialismo, el marxismo, etc., que no dejan de ser pseudo-teologías políticas encubiertas (como denunciara uno de los autores clave de la Escuela de Frankfurt, W. BENJAMÍN, en sus tesis sobre la Historia, comparando el socialismo europeo con un autómata del ajedrez, en cuyo interior sólo había un enano deforme que era la vieja teología).

\footnotetext{
${ }^{152}$ Se alude a un mestizaje entre el Ius Circa Sacra [Derecho de las esferas sagradas] de las Monarquías confesionales católicas europeo-continentales (tras la Reforma), con el predominante Ius in Sacra británico (más los comunitarismos luterano, calvinista, zwinglianista, etc.), así los estadounidenses han desarrollado una elástica y flexible teología político-jurídica posjudeocristiana, que bebe de los pensamientos Whig y Freemason o PWF, así como, de sus suplementos Puritan, Naturalist, Mechanicist, etc., además de lograr integrar expresiones sectoriales dogmáticas (v.g. Theonomy, Mysterium ecclesae) o pragmáticas (v.g. Redemptive-Historical Preaching Style), llegando a dar carta de naturaleza a la ACR, vid. supra. Vid. HAMMER, D.: The Puritan Tradition in Revolutionary, Federalist, and Whig Political Theory. A rhetoric of origins, New York: Peter Lang, 1998. RICHARD, C.J.: The Founders and the Classics. Greece, Rome, and the American Enlightement, Cambridge: Harvard University Press, 1994. WILTSHIRE, W.: The Usefulness of Classical Learning in the Eighteenth Century, New York: American Philological Association, University Press, 1976. - Greece, Rome, and the Bill of Rights, Norman: University of Oklahoma Press, 1992.
} 


\section{B.- Religión civil}

Desde las relaciones atlánticas (sobre todo desde la perspectiva europeocontinental), quizá sea el oxímoron más llamativo de los tres. La denominación religión civil alude a un proceso de secularización popularizadora de la religión, como etapa siguiente al periodo hierocrático (s. XI-XIV) y preparatoria de la Reforma (s. XVI). Se revive una religiosidad popular que devuelve al pueblo su participación (con cofradías y hermandades, procesiones y peregrinaciones, etc.), pues en el periodo anterior había quedado reducido su papel a la condición espectadora. Dichos cambios son favorecidos por las órdenes reformadoras y los movimientos protestantes, además de la progresiva y programática inclusión de laicos en las universidades. Ello favorece el surgimiento de una concepción religiosa más allá de los poderes establecidos (la religión deja de ser un teatro hierocrático -en su manus de lo sanctus-, contemplado por el pueblo, para contar nuevamente con la participación de todos, incluso con la producción de nuevas liturgias). El problema es que dicha revitalización religiosa es llevada al campo político, usándose para impulsar los Estados-dinásticos modernos, produciéndose religiones políticas, que desembocan en las mal llamadas guerras de religiones del s. XVI y XVII.

En el entorno estadounidense, se alude a ACR como expresión del ya mencionado proceso de Americaness o estadounidización: los EE.UU., resulta un país con la capacidad de recibir influencias externas, adaptarlas y mejorarlas, para luego exportarlas con cierto éxito y beneficio (vid. supra parlamentarismo, federalismo, presidencialismo, democracia, etc.). En consecuencia, uno de los mejores ejemplos de dichas influencias recibidas y transformadas en su seno es la religión civil, sirviendo para solventar el problema identitario que acarreara el tránsito al Nuevo Régimen, 
al fomentar la integración de multitudes, sin caer en el problema posterior de la religión política del nacionalismo vinculado a un Estado. En tal sentido, de integración de multitudes, cabe recordar una vez más los lemas nacionales del Gran Sello: e pluribus unum y novus ordo seclorum -como se viene reiterando y se estudia con detalle posteriormente-. Y es que, el caso estadounidense es de los pioneros en formular e implementar una religión civil, que no religión política, pues no resulta monopolio de Estado algún, como sí pasara en Europa y su principio "cuius regio, eius religió" (causante le las mal llamadas guerras de religión, cuando en realidad fue su uso político, para consagrar los nuevos Estados).

De los primeros autores modernos de los que se tiene constancia sobre su teorización acerca de la religión civil destacan CALVINO y sus Instituciones (1536), VICO y su Principios de Ciencia Nueva (1725), así como ROUSEAU y su Contrato Social (1762). Todos ellos aluden al germen de una religión laica y una Teología política, posible gracias a la secularización moderna, cuyo fruto ha de ser una emergente sociedad civil, ya no de súbditos, sino de ciudadanos. Ahora bien, el más famoso de los europeos -al menos entre los estadounidenses- es TOQUEVILLE, en su Democracia en América (1835-40), quien reiteradamente hace uso de la expresión ACR, por ser un constructo cultural en boga, impulsado por los padres fundadores, en especial, por WASHINGTON y FRANKLIN. 
Figura 20.- Disquisiciones deístas franklinianas ${ }^{153}$.

Tal y como he pensado, los principios esenciales de toda religión conocida están en liberarse del vicio mediante la práctica y el hábito generales de la virtud (...), el temor de Dios (...), el interés y el desinterés (...). Soy alguien de extensa caridad y un gran perdonador de injurias privadas, un cordial amante del clero y todos los hombres buenos y un enemigo mortal del gobierno arbitrario y el poder ilimitado (...). Soy naturalmente muy celoso de los derechos y las libertades de mi país, y la más mínima apariencia de usurpación de esos privilegios invaluables es capaz de hacer que mi sangre se caliente en exceso.

Fuente: elaboración propia (SÁNCHEZ-BAYÓN, 2007 y 16).

Baste por ahora (vid. supra epígr. siguiente, más cap. 10) el ofrecer un esbozo de alguno de los elementos propios de la ACR (vid. figura inmediata).

Figura 21.- Performatividad de la religión civil estadounidense ${ }^{154}$.

\begin{tabular}{|c|}
\hline US CIVIL RELIGION PERFORMANCE \\
(de mayor a menor grado de evocación religiosa tradicional según el estadio de \\
secularización)
\end{tabular}

153 Traducción propia (contrastada). FRANKLIN, pretende la perfección moral, mediante principios universales, que doten del sentido común o brújula ética a la nación en formación -muchos son sus referentes, pero destacan sobre todo el bíblico Libro de Job, junto con Theory of moral sentiments de A. SMITH. Cfr. COMMANGER, H.S. (comp.): Benjamin Franklin. Autobiography and Selections from his other writings, New York: The Modern Library, 1944, pp. 106 ss.

${ }^{154}$ El babarismo "performatividad" es la adaptación del anglicismo performance, que se refiere a un evento cargado de significado del que participan los demás, como espectadores y/o partícipes. Así se ha incorporado e impulsado en las Ciencias Sociales (sobre todo, en Política y Antropología), por la vía latinoamericana, hasta volverse dominante -este autor preferiría realización-. Vid. SÁNCHEZBAYÓN, A.: La Modernidad sin prejuicios... op. cit. - Estado y religión de acuerdo con los Estados Unidos de América... op. cit. - "Comunicación y Geopolítica estadounidense actual: de IRFA al Choque de Civilizaciones", en Historia y Comunicación Social (vol. 11), 2006. - "La religión civil estadounidense $(\ldots)$ "... op. cit. - “U.S. Religious Liberty: One (secular) Nation under God. Paradox nature and explanatory hypothesis", tesina inédita de DEA (investigación realizada en Harvard University, 2002-03), Madrid: UCM, 2003. - “Derecho y Religión en Estados Unidos de Norteamérica: Análisis de su relación desde diversos enfoques", en Zalacaín Harvard Journal of Ibero-America (vol. I, no 5), Fall 2002, p. 32-36. - "La viabilidad de la enseñanza del Derecho Eclesiástico del Estado en la Universidad de Harvard", en Zalacaín, Harvard Journal of Ibero-America (vol. I, no 5), Fall 2002, p. 13-18. 
Billetes de dólar ("in god we trust \& seal"); Gran sello nacional ("mottos \& icons"); campana de la libertad (“Leviticus 25:10”); himno nacional ("The Star-Spangled Banner"); Declaración de Independencia y de Derechos, más Constitución de los EE.UU. (textos venerados y ufanos de referencias religiosas, custiodados en NARA); etc.

\section{B.- RITOS:}

Saludo a la bandera ("pledge of allegiance"); juramentos públicos ("public oath ceremonies"); festividades de carácter nacional ("National Holidays \& School District's Calendar: Christmas, Thanksgiving Day, St. Valentine's Day, St. Patrick's Day", etc.); oración del Congreso al comenzar las sesiones; Día de la Oración y demás invocaciones religiosas presidenciales (desde "Thanksgiving Proclamation of 1789" hasta "Jewish Heritage Week Proclamation of 2004"; "National Day of prayer"; "Presidential Christmas Messages"; "Inaugural \& Farewell Addresses"; etc.); redmass en la Catedral de Washington DC (para inaugurar año judicial); Día del Presidente (veneración del líder -de la nación elegida-, elementos de legitimidad teológica); discursos políticos con invocación a Dios ("God bless America", "God bless you", etc.) y citas bíblicas; tele-evangelismo; etc.

\section{C.- CREENCIAS}

Tierra prometida y pueblo elegido ("Promise Land or New Jerusalem"; "Pilgrims \& Founding Fathers"; "American's creed"; sentencias del Tribunal Supremo declarando los orígenes judéo-cristianos de los EE.UU.); Destino manifiesto y mesianismo ("Manifest Destiny \& Messianism"); Valores democristianos* ("American values" forman parte del "American way of life", bajo las tensiones interpretativas del "self-righteousness \& self-understanding"); Sistema no jurídico sino de justicia (v.g. pena de muerte, juramento sobre la biblia); Uso de la religión como justificante de intervenciones internacionales (v.g. IRFA, "clash of civilizations"); La vidas ejemplares de los padres fundadores ("founding fathers tales"); bendiciones (inicio o fin de discursos con expresiones como "God bless you" o "God bless America"), etc.

\section{D.- INSTITUCIONES}

Blue Laws o derecho dominical/eclesiástico (conducente de la tolerancia a la libertad religiosa); Church-State relations o relaciones Iglesia-Estado ("(non)establishment clause", "free exercise clause", "wall of separation"); pactismo y federalismo, más democracia y presidencialismo ("American covenantism" o ACT); patrística y su legado ("founding fathers \& heritage: pilgrims, puritans, leaders, rebels, framers, statemen"); influjo en parlamentarismo, constitucionalismo, federalismo, et al.

\section{E.- ARTE}

Obras y piezas del Museo Smithsonian; Cristo de los Ozarks; arte sacro en museos y centros públicos; templos nacionales ("Chaplains for the House and Senate"); etc.

\section{F.- MONUMENTOS}

Monumentos a padres fundadores (v.g. Washington Memorial, Jefferson Memorial, Lilcoln Memorial) en explanada nacional o National mall; Monumento Nacional Monte

Rushmore; NARA; monumentos de los diez mandamientos en Tribunales; Memorial de Guerra del Cuerpo de Marines de EE.UU. (Marine Corps War Memorial o Iwo Jima 
Memorial: en Arlington, Newington, Quantico, etc.); monumentos conforme a Antiquities Act of 1906 y Servicio de Parques Nacionales (más de 100 en 2010, v.g. Monumento nacional de la torre del diablo, Monumento nacional salina Pueblo Missions, Monumento nacional G. Washington Birthplace, Monumento nacional Islas San Juan), et al.

Fuente: elaboración propia (SÁNCHEZ-BAYÓN, 2007 y 16).

Únicamente, como apunte comparado de interés, se deja constancia de que la cuestión de la religión civil, pese al interés despertado durante las guerras culturales (y de la tópica que se va a tratar a continuación), en cambio, tras la globalización, han hibridado con los retazos de religiones políticas (las viejas ideologías), dando lugar a fórmulas de pensamiento débil, del que se han apropiado los poderes públicos bajo la apariencia de pseudo-variantes de neo-religiones políticas, v.g. ecologismo, género. De vuelta a las religiones civiles de posguerra en transición a religiones políticas, se llama la atención sobre constructos tales como:

a) La religión civil republicana o republicanismo francés (aparentemente proveniente de la sociedad civil, aunque en realidad es impulsada por intelectuales orgánicos autoproclamados regeneracionistas), consiste en un artificio falaz impulsado por el Ministerio de Cultura -creado por entonces y para tal fin-, pues desde la fusión de propuestas originalmente dialécticas (el nacionalismo, que está llamado a ser localista, y el socialismo, pretendidamente internacionalista). Se promueve así una gestión identitaria monopolizada por el Estado, desde un discurso republicano que nunca existió, reinventándose la Historia para ello (v.g. se argumenta que la Revolución francesa de 1789 fue nacionalista y socialista, incluso antes de existir dichas ideologías; que el republicanismo no es una forma de gobierno, sino una ideología, pese a que van por el quinto intento, con dictaduras intermedias). 
b) La teología de la liberación mediterránea y latinoamericana (y sus expresiones de la Iglesia obrera, Iglesia nacionalista, Iglesia tercermundista, etc.), igualmente, de dudosa laicidad, pues originalmente fue promovida por sacerdotes secularizados en su mayoría a la postre (quienes pasaran de vivir de la financiación de los concordatos a apoyar la revolución armada para tomar el poder estatal). Entre sus múltiples contradicciones, cabe señalar que ni es una fórmula heterodoxa ni disidente, únicamente resulta un contrasentido antirreligioso, pues no vincula con nada, sino que promueve la destrucción (tanto del ser humano como del resto de la creación) en pro de utopías (nolugares: un supuesto edén mejor que el ante-adánico). No se permite trascender, porque la relación con lo demás es de violencia inmanente (hay resentimiento contra el sistema vigente, por lo que en todo momento hay que destruirlo). Además, el complemento del nombre, "de la liberación", en realidad es una suerte de neolenguaje orweliano, pues descalifica en todo momento la libertad o ámbito de la autonomía de interna de la voluntad individual (su aspiración es la revolución, o mejor dicho, la involución a un comunitarismo dominante -de ahí que sirva tanto para nacionalistas como para socialistas-. Incluso, cabe destacar que hay críticos que la describen como la apología de la santa pobreza, basada en una relación casi idolátrica con el dinero y la riqueza, por fijarlas como referencia del sistema -y en contra de los mismos Evangelios-. 
c) Otras expresiones como el nacional catolicismo (v.g. tecnócratas del OPUS en la Dictadura de Franco, los democristianos en la Italia y Alemania de posguerra ocupadas), et al. ${ }^{155}$

\section{C.- Evangelismo social}

El Evangelismo social (estadounidense) o ASG constituye una doctrina autóctona estadounidense ${ }^{156}$, inspirada por todo lo anterior, y extendida con éxito sobre la realización de una fe en el progreso y el advenimiento de un mundo mejor -una suerte de adelanto del Reino de los Cielos-, reformulándose más tarde en términos de justicia social ${ }^{157}$-sin caer en el problema noético y de velos de confusión de la teología posmoderna, v.g. teología de la liberación-. Gracias a la secularización

\footnotetext{
155 Vid. SÁNCHEZ-BAYÓN, A.: Secularización moderna... op. cit.

156 Cierto es que tiene su origen en el mundo protestante, como reacción al mundo católico y su teología tradicional, más centrada en la doxa que en la praxis -y ni que decir tiene sobre la pathia, vid. infra figura-. Sirva como ejemplo: frente a la Propagatio Fide de la Iglesia Católica, la Iglesia Anglicana impulsa la Propagation of Gospel (desde universidades tan prestigiosas como Oxford y Cambridge), que en América, toma forma desde la proto-universidad de William and Mary College, donde se constituye la relevante Society for the propagation of the Gospel in foreign parts (SPG), foco de irradiación de la visión y misión de acción socio-religiosa para toda Virginia y demás Plantaciones sureñas. Vid. NOLL, M.A. (ed.): Religion and American Politics. From the Continental Period to the 1980s, New York: Oxford University Press, 1990. Complement., vid. NOLL, M.A.: A History of Christianity in the United States and Canada, Grand Rapids: William B. Eerdmans Publishing Co., 1992.

${ }^{157}$ Con el giro hermenéutico de la Teología política estadounidense, se recupera e incide en el elemento del bien común, combinado con el de justicia social, orientándose hacia la consecución terrenal de bienestar e igualdad social (atendiendo al respeto de la costumbre generada). Se trata de una fusión estadounidense, en su nuevo orden secular, de propuestas religiosas reformadas y políticas conservadoras modernas (v.g. common sense [sentido común], commitment [compromiso], welfare [bienestar], etc.). Su sustento parte de la confianza en la posible consecución material del adelanto (terrenal) del reino de los cielos, tal y como se ha recogido en la teología político-jurídica posjudeocristiana estadounidense (y su codificación ICS, vid. supra), desde sus múltiples alusiones tempranas por el Redemptive-Historical Preaching Style [estilo de predicación histórico-redentora], hasta los diversos estilos de American Social Gospel [evangelismo social estadounidense].
} 
moderna y la Teología política, así como el pragmatismo y posjudeocristianismo estadounidense, resulta posible el llevar a la realización cotidiana las enseñanzas del Evangelio. De ahí el impulso de los despertares y revitalizaciones socio-religiosas en los EE.UU., dando lugar a la emergencia de movimientos comprometidos con cruzadas de transformación social, tales como la lucha contra el alcohol, las apuestas, la prostitución, etc. ${ }^{158}$. Teológicamente hablando, el ASG es el resultado de la heteropraxis (reconducida luego hacia la ortopraxis de ACR, vid. supra), por la que las confesiones compiten por mejorar su comunidad, en el sentido milenarista de preparar la II Venida de Cristo. Políticamente, se trata del reflejo del liberalismo y del activismo de la sociedad civil. En los EE.UU., el liberalismo estuvo presente desde sus orígenes, gracias al pensamiento Whig y Freemanson o PWF (vid. supra figura 22), de ahí su aceptación natural y su fácil interacción religioso-civil. En cambio, en Europa continental, con los vaivenes en el tránsito del Antiguo al Nuevo Régimen, dicho reto de transformación social lo terminaron por monopolizar las ideologías (nacionalismo y socialismo). El ASG es el mestizaje y puesta en práctica de los modelos de evangelización mediterránea-católica y anglosajona-protestante ${ }^{159}$, más orientados hacia la heteropraxis y la ordenación de la cristiandad. Hasta el s. XIX, el

\footnotetext{
158 Sirvan como ejemplos concretos: Gospel Propagation, Holiness and Perfection, Millennialism and Adventism, Social Reforms and Crusades/Campaigns, Restorationism and the Stone-Campbell Tradition, Communitarianism, Sabbatarianism, Nineteenth-Century Evangelicalism, Christian Science and Harmonialism, Social Christianity, Pentecostalism, Fundamentalism, Conservative and Charismatic Developments of the Later Twentieth-Century, Ecumenical Movement, et al. Vid. LIPPY, C.H., WILLIAMS, P.W. (eds.): Encyclopedia of the American religious experience. Studies of traditions and movements (vols. III), New York: Charles Scribner's Sons, 1988. SMITH, J.W., JAMISON, A.L. (ed.): Religion in American Life (vol. I-IV, con especial atención a la bibliografía seleccionada por BURR para el vol. IV), Princeton: Princeton University Press, 1961. STOKES, A.P.: Church and State in the United States (vols. I-III), New York: Harper \& Row., 1950. TYLER, A.F.: Freedom's Ferment. Phases of American Social History to 1860, Minneapolis: The University of Minnesota Press, 1944. VAN ALSTYNE, W.W.: First Amendment. Cases and Materials, New York: Foundation Press, 1990.

159 Vid. SÁNCHEZ-BAYÓN, A.: Renovación de la Filosofía Social Iberoamericana, Valencia: Tirant lo Blanch, 2013.
} 
mestizaje de modelos y el ASG resultante es liderado por el protestantismo; sin embargo, con el cambio de siglo, pasa a tener un gran peso la doctrina social de la Iglesia católica: con el tractarianismo y la teología liberal de NEWMAN, FEBLE o PUSEY, más la teología social desde la corriente jesuita HOPKINS, o la dominica de DRANE, así como los movimientos socio-religiosos del tipo National Catholic War Council de 1919, League of Social Justice de 1932, etc. -antes de los contagios posmodernos posteriores de la teología de la liberación, vid. ídem-. En recientes revisiones de la materia, se conectan ACR y ASG, como la base del credo estadounidense, sobre el que se cimienta su identidad ${ }^{160}$.

Como se ha ido indicando, el trinomio presentado es el resultado del mestizaje de la tradición occidental (tanto sagrada o judeocristiana, como profana o grecorromana), aplicada al Nuevo Régimen de la Modernidad, como es el modelo estadounidense de novus ordo seclorum. Para la manifestación del mencionado modelo, a través de ensayo y error, ha sido clave la contribución adaptativa del pensamiento whig o liberal-conservador y freemason o librepensador (vid. supra figura 22), propio de la Ilustración estadounidense, que concretaran los padres fundadores en expresiones hierofánicas y hierocráticas, tal como se aclara más adelante.

\footnotetext{
160 Vid. MEACHAM, J.: American Gospel: God, the Founding Fathers and the Making of a Nation, New York: Random House, 2006.
} 
Figura 22.- Apuntes sobre el pensamiento whig $\mathcal{E}$ freemason-PWF 161

Whig proviene del gaélico escocés y norirlandés y puede traducirse por villano, pues aludía a los pequeños propietarios de los minifundios del Norte, en concreto a los covenanters o pactistas presbiterianos (futuros puritanos), quienes durante las guerras civiles británicas del s. XVII (marcharon sobre Edimburgo y luego hacia la capital para reclamar derechos (sobre todo, libertad religiosa, de asociación y de comercio), además de oponerse a la Monarquía absoluta. También se les conoció como los dissenters [disidentes] y Kirk party [partido eclesiástico], por oponerse a la oficialidad del anglicanismo (y cuando llegaron al poder, también se enfrentaron al catolicismo, vid. Exclusión bill, 1678). Darán lugar al partido liberal, tanto en UK como en los EE.UU., dominante durante el s. XIX.

Freemason es la adaptación de una expresión traída del continente, de los territorios británicos en la Bretaña francesa (causa de disputa en la Guerra de los cien años), y alude al constructor de casas, quien disponía de los pocos oficios libres del Medievo, pues no dependía de gremios ni talleres que le limitaran, sino de su conocimiento y se desplazaba allá donde hubiera trabajo (construcción de catedrales, palacios, etc.). En síntesis (sobre el cambio de concepción acaecido en los EE.UU., y por ende, qué se entiende desde entonces por freemason), hasta el S. XVII, la masonería era de corte operativo: relativa a los oficios liberales de la época, como el de constructor de catedrales, ya que disponían de autonomía de normas y movimiento, organizándose entorno a Collegia o colegios profesionales. A partir de entonces, la masonería empieza a ser de corte especulativo: abierta al librepensamiento, especialmente de filósofos naturales o experimentales (la Nueva Filosofía comprendía los campos de la medicina, la mecánica, la navegación, la geometría, etc.), juristas, literatos (políticos y económicos), et al., organizándose ahora en el seno de Reales Sociedades/Academias -en los EE.UU., otros focos que continúan la tradición son los Colleges y sus Fraternities.

Fuente: elaboración propia (SÁNCHEZ-BAYÓN, 2007 y 16).

161 Sobre Whig, vid. HAMMER, D.: The Puritan Tradition in Revolutionary, Federalist, and Whig Political Theory. A rhetoric of origins, New York: Peter Lang, 1998. RICHARD, C.J.: The Founders and the Classics. Greece, Rome, and the American Enlightement, Cambridge: Harvard University Press, 1994. WILTSHIRE, W.: The Usefulness of Classical Learning in the Eighteenth Century, New York: American Philological Association, University Press, 1976. - Greece, Rome, and the Bill of Rights, Norman: University of Oklahoma Press, 1992. Sobre Freemason, vid. BULLOCK, S.C.: Revolutionary brotherhood. Freemasonry and the transformation of the American Social Order, 1730-1840, Chapel Hill: The University of North Carolina Press, 1996. DUCHANE, S.: The Masonery, Köln: Book Laboratory, 2007. NEWTON, J.F.: The Builders, Lexington: The Supreme Council, 1973. ROBERTS, A.E.: Freemasonry in American History, Richmond: Macoy Publishing, 1985. 


\section{2.- ACR A JUICIO:}

\section{CUESTIONAMIENTO DEL SENTIDO Y ALCANCE DEL METÁMERO ${ }^{162}$}

Como se viene acometiendo, se pretende dar a conocer la US/American civil religion o $\mathrm{ACR}$, como protonoción moderna de nación (construida desde las interacciones entre religión y política, desde los planteamientos de la secularización moderna y su Teología política, vid. infra). Dicha noción es previa a la dialéctica contemporánea europeo-continental de nacionalismo liberal-patriótico (o nacionalismo incluyente) y el étnico-cultural (o nacionalismo excluyente), que derivara en múltiples conflictos -ello debido a la confusión interesada en forma de Estadonación y su correspondiente religión política (Dios es sustituido por el Estado, el credo por la ideología, etc.), cosa que en los EE.UU. se mantiene en su sentido original de pueblo (no concreto de gens o tribu, sino laxo de pueblo de Dios: integrándose las gentilitas, y organizándose como ecclesia o asamblea participada).

La ACR, hace posible el exponer y explicar cómo se pasa de la propaganda religiosa a la política, permitiendo gestionar identidades sociales, pero desde la sociedad civil, sin el monopolio estatal (como sí tiene lugar en Europa continental de entonces -de ahí que resulte una religión civil y no política, vid. supra-). Además, el estudio de la ACR, facilita el acometer una revisión crítica y comparada (tal como se viene haciendo en los EE.UU.), atendiéndose así al análisis históricohistoriológico-historiográfico, así como funcional, de la articulación de la noción y operatividad de la noción estadounidense de nación y sus elementos constitutivos

\footnotetext{
162 Vid. infra nota 137 y 138, especialmente, Universidad, ciencia y religión y La religión civil estadounidense; complement., vid. infra nota 3 a 5, 11, 16, 24, 55 y 68, más p. 126 ss.
} 
principales. Téngase en cuenta que, la relevancia de dicha proto-noción de nación, viene dada por su condición pionera entonces, revisada cíclicamente y en un punto crucial hoy: con la globalización y los contagios posmodernos europeo-continentales (v.g. la corrección política, la memoria histórica), los propios estadounidenses tienen la urgente necesidad de repensar su identidad, misión y capital simbólico nacional. Ante el suscitado problema, de cariz mitopoiético (de generación idiosincrática: de crisis del mito fundacional integrador, vid. supra), tal circunstancia pone de manifiesto el riesgo de la insostenibilidad de la convivencia (si quiebra el discurso nacional), dado el cúmulo de comunidades incluidas en la nación estadounidense. Aparentemente, la solución más plausible y revolucionaria -en sentido copernicano: de regreso al momento previo al inicio de la desviación y/o confusión-, parece ser la de volver a los orígenes fundacionales (de su idiosincrasia), desde las colonias hasta la superación de su Guerra civil. En consecuencia, al exponerse y explicarse aquí la ACR y sus elementos articuladores, se va a centrar la atención en su origen y desarrollo inicial, tal como los padres fundadores lo interpretaran, conforme a su contexto socio-cultural (v.g. incluso los deístas, siendo el resultado de la secularización moderna y grandes ilustrados de entonces, partían de planteamientos de Teología política para sus propuestas de ordenación social). Luego, lo que se indique a continuación ha de entenderse en la clave de su emergencia durante el periodo fundacional, y no tanto desde la actual, evitándose así el riesgo de anacronismo y falacia naturalista. Cierto es que, pese a que puedan sorprender determinados orígenes, no hay que olvidar la capacidad de adaptación estadounidense (sobre todo, su pragmatismo y posjudeocristianismo, vid. infra), y por tanto, la labor de adecuación del legado de los padres fundadores acometido por las siguientes generaciones, de modo que constructos como la ACR 
respondieran a las demandas coyunturales de cada momento, manteniendo una visión y visión de continuidad (como es la configuración idiosincrásica estadounidense).

La $\mathrm{ACR}^{163}$ es un constructo de la Modernidad occidental ${ }^{164}$, que permite culminar las teorías expuestas (además de llevarlas a la práctica), pues responde al ulterior estudio de la evolución religiosa (fase cuaternaria) ${ }^{165}$, y aclara los parámetros de la actual revitalización religiosa (en proceso desde la crisis socio-cultural de 1960 y las posteriores guerras culturales). En los EE.UU. -tal como se viene señalando-, la religión civil responde a una fórmula adaptativa propia (vía su Americaness), hábil para casar las disonancias del nuevo orden secular, del tipo de: a) integración v. autonomía; b) religiones tradicionales (privadas) v. religiosidad pública; c) éxito y beneficio (personal) v. bienestar común (con su plus social); etc. En definitiva, la religión civil es -como mínimo- aquel vínculo moral y sacro, común a todas las comunidades y predicable del conjunto de la sociedad, en el que el individuo, como ser sociable y trascendental, necesita para dar sentido a su entorno y su papel en el mismo. Se trata del cemento y levadura social de las sociedades modernas, donde hay madurez racional, pero falta paridad emocional y social -pues ese tipo de

\footnotetext{
163 Buena parte de los planteamientos y evidencias que aquí se sistematizan fueron avalados por la comunidad científico-académica hace más de un década, tanto en publicaciones como congresos. Sirva como ejemplo, y en español, vid. SÁNCHEZ-BAYÓN, A.: “La religión civil estadounidense: análisis de la configuración de la realidad socio-cultural y su identidad social", en Revista General de Derecho Canónico y Derecho Eclesiástico del Estado-Iustel (no 10), 2006.

164 Eso quiere decir que, pese a posibles inspiraciones sobrenaturales, la ACR es ante todo un producto cultural, de un entorno dominando por el cristianismo, llamado por entonces Cristiandad. De ahí que, pese a las procedencias diversas, las bases socio-culturales son muy similares, por lo que se aprovecha tal circunstancia para fomentar fórmulas de integración como la ACR: gracias a la secularización moderna, lo común de la religión es usado para facilitar el tránsito hacia un nuevo orden secular o Nuevo Régimen.

${ }^{165}$ Se alude a un sistema de clasificación evolutiva de la religión en su positivización. Vid. SÁNCHEZBAYÓN, A.: La Modernidad sin prejuicios... op. cit. - Estado y religón... op. cit. - Manual de Sociología... op. cit.
} 
inteligencia suele quedar menguada por la desproporción con el progreso científicotécnico-. La religión civil, aún con todas las aristas de su problemática denominación (al sintetizar dos constructos supuestamente antitéticos -al menos para los europeos contemporáneos-, como es lo religioso y lo civil-, sin olvidar las inconveniencias de su tratamiento -al no quedar claro si es causa y/o resultado del sincretismo moderno, especialmente el estadounidense-, en cambio, guarda una relación directa e influyente con otros constructos tales como AWL, AD, AMD, et al. (en cuanto que articula la fe y/o el modo de vida estadounidense, su sueño, su destino, etc.).

Con la religión civil, en cierto modo, se cierra el círculo evolutivo occidental, ya que en buena medida se retorna al clásico modelo greco-romano, empero, con importantes discrepancias: a) es universalista (por influjo cristiano), así que está abierta a todo hombre y/o mujer, joven y/o anciano, rico y/o pobre, etc.; b) es vocacional, lo que exige un convencimiento responsable; c) se basa en la libertad y la pluralidad (propia de una sociedad de hombres libres, con conciencia propia y, que sin embargo, sienten una llamada común, además de comprometerse con un pacto de prosperidad y salvación); d) es secular (hay distinción de órdenes), pues la religión interactúa con la política, pero no hay confusión (la política gestiona los bienes y servicios terrenales y la religión la convivencia y salvación de las almas); etc. La noción de religión civil de la que parten los autores ilustrados europeos -con influjo suficiente en los EE.UU.-, es la constantiniana (antes de la corrupción teodosiana), con ciertos toques comprensivos de autores previamente mencionados (v.g. CALVINO, VICO, TOCQUEVILLE). Así, de manera generalmente aceptada, se atribuye el bautizo de la idea moderna de religión civil a ROSSEAU (Libro IV de El contrato social, más ciertos matices apuntados en el Emilio). Más tarde, es otro francófono quién devuelve a los europeos la expresión apreciada en los EE.UU.: 
TOCQUEVILLE (La democracia en América). Durante el S. XIX y principios del XX, la semiología estadounidense de la religión civil se circunscribe al ámbito estrictamente político-jurídico ${ }^{166}$, concibiéndose como el instrumento para lograr la sublimación de la nación, la democracia y el Estado de Derecho (neofetichizándose así sus instituciones y adquiriendo, entonces, legitimidad moral y sacra). Empero, tras la crisis de los 1960 (y las guerras culturales), con la consiguiente reformulación del AWL, comienzan a barajarse diversas propuestas académicas para su estudio: desde la dominante de BELLAH y su signatura de 1966, la religión civil (que es heredera del funcionalismo de PARSONS y el interaccionismo de MEAD, con la religión republicana $)^{167}$, hasta las propuestas matizadas y tentadoras de LUCKMANN y su religión invisible (construccionista), NOVAK y su religión cívica (electivista), ROBERTSON y su religión americana (excepcionalista), LONG y su religión secular (comparativista), CASANOVA y su religión política (aunque esta es más predicable de europa), et al.

En realidad, si se quiere llegar al meollo de la cuestión, donde se produce la auténtica paradoxología de Americaness (la transformación exitosa de la propuesta para el nuevo orden secular), además de tener en cuenta las influencias (transformadoras igualmente) del pensamiento Whig y Freemason (PWF) en las elites político-jurídicas estadounidenses (con el pulimiento coyuntural por parte de sus grandes Estadistas), es imprescindible resaltar la significativa aportación de elites

\footnotetext{
${ }^{166}$ La europea, en cambio -y adelantándose sin éxito, una vez más-, es más psicosociologizante, como invitan a la reflexión DURKHEIM, WEBER, etc.

167 BELLAH fue un discípulo destacado de PARSONS, al igual que recibió ciertas influencias de MEAD. Indirectamente, también se vio influido por las propuestas previas de HERBERG y su "civic faith", en 1955. La publicación que dio fama a BELLAH fue su artículo en la revista Daedalus (no 96), 1967, pp. 1-21; más tarde vería la luz ampliada como libro (algo habitual como le pasara a LIPSET con el excepcionalismo estadounidense, a FUKUYAMA con el fin de la historia, a HUNTINGTON con el choque de civilizaciones, etc.).
} 
intelectuales, como los trascendentalistas: su promotor fue el ministro de culto unitarista CHANNING -padre, igualmente, de la pseudo-teodicea estadounidense, cuyos herederos naturales fueron, el también ministro unitarista y ya mencionado EMERSON (Naturaleza), ALCOTT (Reflexiones en torno al Evangelio), THOUREAU (Desobediencia civil), FULLER (directora del periódico “The Dial”), et al. Su lema fue "a cada uno su propio dios" (recuérdese lo dicho sobre un nivel de secularización tocante incluso a la denominación y tratamiento de la divinidad, vid. infra), o sea, una fe sin dogmas, una iglesia abierta, una religión cultural, una relación interna con Dios (y con la naturaleza, porque guarda una relación inmanente con la misma), etc.

En cuanto a sus manifestaciones cotidianas, se recuerda alguna de las ya apuntadas con anterioridad (vid. infra figura 21), y a desarrollar pormenorizadamente más adelante (vid. supra cap. 10):

a) Símbolos: monedas y billetes de dólar (con el Gran Sello y sus lemas nacionales, v.g. in God we trust, en monedas desde 1864 -para reactivar al confianza tras la Guerra civil- y en billetes desde 1935 -ídem, tras Crac y Gran depresión); Gran Sello nacional (mottos $\mathcal{E}$ icons); campana de la libertad (tallada en 1751 y papel en 1776, Levitico 25:10); himno nacional (The Star-Spangled Banner, letra de 1773 y oficializada por ley en 1987); etc.

b) Ritos: saludo a la bandera (pledge of allegiance, versión original de 1892 y última gran revisión en 1954); juramentos públicos (public oath ceremonias, tanto en tomas de posesión o declaraciones ante tribunales, con el recurso de la Biblia y/o la Constitución de EE.UU.); festividades de carácter nacional (National Holidays $\mathcal{E}$ School District's Calendar, ley de 1870 y modificaciones de 1968 y 71: Christmas, Thanksgiving Day, St. Valentine's Day, St. Patrick's Day, etc.); oración del Congreso 
al comenzar las sesiones; Día de la Oración y demás invocaciones religiosas presidenciales (desde Thanksgiving Proclamation of 1789 hasta Jewish Heritage Week Proclamation of 2004, National Day of prayer, Presidential Christmas Messages; Inaugural \& Farewell Addresses, etc.); red-mass en la Catedral de Washington DC (para inaugurar año judicial), blue-mass (ídem, para cuerpos y fuerzas de seguridad), etc.; Día del Presidente (veneración del líder -de la nación elegida-, elementos de legitimidad teológica); discursos políticos con invocación a Dios (v.g. God bless America, God bless you) y citas bíblicas; tele-evangelismo; etc.

c) Creencias: tierra prometida y pueblo elegido (promise land or New Jerusalem; pilgrims $\mathcal{E}$ founding fathers; American's creed; sentencias del Tribunal Supremo declarando los orígenes judéo-cristianos de los EE.UU.); Destino manifiesto y mesianismo (manifest destiny \& messianism); vidas ejemplares de los padres fundadores (founding fathers tales); etc.

d) Valores: valores democristianos (American values forman parte del American way of life, bajo las tensiones interpretativas del self-righteousness); sistema no jurídico sino de justicia (v.g. pena de muerte, juramento sobre la biblia); uso de la religión como justificante de intervenciones internacionales (v.g. IRFA, clash of civilizations); etc.

e) Normas: Declaración de Independencia (1776), Constitución de EE.UU. (1787) y Declaración de Derechos o Bill of Rights (1791), son textos ufanos de referencias religiosas, además de venerados como nuevas escrituras sagradas, custiodados en NARA; Blue Laws o derecho dominical/eclesiástico (conducente de la tolerancia a la libertad religiosa, y aún vigente alguna norma en los Ordenamientos locales); etc. 
f) Instituciones: Church-State relations o relaciones Iglesia-Estado ((non)establishment clause, free exercise clause, wall of separation); pactismo y federalismo, más democracia y presidencialismo (American covenantism-ACT); patrística y su legado (founding fathers $\mathcal{E}$ heritage: pilgrims, puritans, leaders, rebels, framers, statemen); influjo en parlamentarismo, constitucionalismo, federalismo, et al.

g) Arte: obras y piezas del Instituto Smithsonian (con sus exposiciones y colecciones); compilaciones de NARA; arte sacro en museos y centros públicos (v.g. diez mandamientos en los tribunales de justicia); capillas, pinturas y esculturas en edificios públicos (parlamentos, ayuntamientos, universidades, etc., v.g. Chaplains of the US Senate $\mathcal{E}$ House of Representatives); ídem, instituciones privadas (v.g. Jacob's Dream o escalera de Jacob en campus de Abilene Christian Univ.); medio centenar de catedrales católicas, protestantes y ortodoxas, y millares de templos, etc.

h) Monumentos: homenajes a padres fundadores (v.g. Washington Memorial, Jefferson Memorial, Lilcoln Memorial) en explanada nacional o National mall \& West Potomac Park; Monumento Nacional Monte Rushmore; Cristo de los Ozarks; monumentos de los diez mandamientos en Tribunales; Memorial de Guerra del Cuerpo de Marines de EE.UU. (Marine Corps War Memorial o Iwo Jima Memorial: en Arlington, Newington, Quantico, etc.); monumentos conforme a Antiquities Act of 1906 y Servicio de Parques Nacionales (más de 100 en 2010, v.g. Monumento nacional de la torre del diablo, salina Pueblo Missions, Washington Birthplace), et al.

i) Floclore: toponimia y gentilicios (v.g. Jerusalem/Salem y Hope son nombres frecuentes de poblaciones en casi la mitad de los Estados de la Unión); estilos 
musicales (v.g. góspel, soul, R\&B -incluso el subestilo Underground railroad: canciones con clave para fuga de esclavos y abolicionistas), canciones populares (v.g. God bless America, Jingle bells, Amazing grace, Hallelujah! -fusionando Handel, soul, etc.-, When the saints go marching in -usado en actos oficiales, v.g. funerales de Estado) y musicales (v.g. Jesus Christ Superstar, Sister Act), et al.

j) Y demás cuestiones (v.g. arte, literatura, música) a profundizar en la Parte de desarrollo especial (máxime en el cap. 10).

En lo relativo a su tratamiento académico actual, se destacan una serie de lecturas clave (para el asentamiento de la disciplina ACR -de ahí que sean textos producidos entre las guerras culturales y la globalización inicial-), según líneas de trabajo:

a) fundamentos de la religión civil (propedéutica): BALITZER, LINDER, RICHEY, SMITH o WEST ${ }^{168}$.

b) religión civil, estadistas y sociedad (principios y movimientos): DAVIS, JEWETT, LAWRENCE, LITTLE, et al. ${ }^{169}$.

\footnotetext{
168 Vid. BALITZER, A.: "Some thoughts about civil religion", en Journal of Church and State (n⿳⺈ 16), 1974, pp. 31-50. LINDER, R.: "Civil religion in historical perspective: the reality that underlies the concept", en Journal of Church and State (n⿳⺈ 17), 1975, pp. 399-422. RICHEY, R.E., JONES, D.G. (eds.): American Civil Religion, New York: Harper \& Row., 1974. SMITH, E.A.: "The civil religion: is it a viable concept?", en Journal of Ecumenical Studies (no 14), 1977, pp. 113-124. WEST, E.M.: “A proposed neutral definition of civil religion", en Journal of Church and State (n⿳⺈ 22), 1980, pp. 23-40.

169 Vid. DAVIS, D.: "Religious pluralism and the quest for unity in American life", en Journal of Church and State (no 36), 1994, pp. 245-259. - "Civil religion as a Judicial Doctrine", en Journal of Church and State (no 40), 1998, pp. 7-24. JEWETT, R., LAWRENCE, J.S.: Captain America and the Crusade against Evil: The Dilemma of Zealous Nationalism, Grand Rapids: Wm. B. Eerdmans, 2004. LITTLE, D.: "American civil religion and the rise of pluralism", en Union Seminary Quaterly Review (no 38), 1984, pp. 401-413. PIERARD, R.V., LINDER, R.D.: Civil religion and the Presidency, Grand Rapids: Zondervan Publishing House, 1988. SMITH, E.A. (ed.): The Religion of the Republic, Philadelphia: Fortress Press, 1971.
} 
c) diagnóstico y evaluación de la religión civil (críticas y previsiones): BALDWIN, BELLAH, BLOOM, HUGHES, LIPSET o HUNTINGTON ${ }^{170}$.

Como el tema de la religión civil resulta de lo más atractivo (para afrontar el problema de la gestión idiosincrática -de ahí que haya tenido su propia disciplina de Estudios culturales tradionales-), actualmente, corre el riesgo de volverse una cuestión difusa, llegándose a desnaturalizar (dados los embites de los Estudios culturales sobrevenidos y el creciente desdibujamiento identitario tras la globalización). Téngase en cuenta que, hasta ahora, era clara la conveniencia y gestión de la religión civil, ya que ha permitido construir un nuevo orden secular donde es posible compatibilizar cuestiones tales como: la esfera política y la religiosa; la integración comunitaria y la autonomía del sujeto; las religiones tradicionales, entre sí y con la religiosidad civil (de una nación líder); etc. -todas estas circunstancias, por ejemplo, han impedido que en los EE.UU. se sucumbiera al Fascismo y al Totalitarismo (como variantes de religiones políticas contemporáneas), cuando Europa-continental cayó en el periodo de entreguerras del s. XX-. En cambio, con la tendencia actual de la materia, donde predominan los excesos formales (v.g. discursos maniqueos y moralistas, políticas de gestos), se está hibridando y confundiendo la cuestión, en vez de abordarse la auténtica prioridad, o sea, la reformulación de los fundamentos, y con ello, la esencia misma de la idiosincrasia estadounidense y su cemento social -quedando una vez más en el aire la respuesta

\footnotetext{
${ }^{170}$ Vid. BALDWIN, J.: The fire next time, New York: Vintage, 1993. BELLAH, R.N.: The Broken Covenant: American Civil Religion in a Time of Trial, Chicago: The University of Chicago Press, 1992. BLOOM, H.: The American religion. The emergence of Post-Christian nation, New York: Simon \& Schuster, 1992. HUGHES, R.T.: Myths America Lives By, Urbana: University of Illinois Press, 2003. HUNTINGTON, S.: Who are we? The Challenges to America's National Identity, New York: Simon \& Schuster, 2004.
} 
a la pregunta clave sobre cuál ha sido, es y debe ser el papel de la religión en la configuración idiosincrásica estadounidense-.

\section{3.- ACR \& AMERICAN COVENANT THEOLOGY I:}

ORIGEN, DESARROLLO Y RESULTADO FEDERAL Y NACIONAL ${ }^{171}$

¿Qué relación guarda ACR con American Covenant Theology (ACT)? Para responder, permítase un breve excursus. Tal como se viene aclarando, la teología positiva es el conocimiento de Dios mediado por el hombre, y centrada en el pueblo elegido para su salvación. Entre sus clasificaciones, cabe distinguir entre una teología positiva común, focalizada en el estudio de los pactos y las Escrituras, y una teología positiva particular, de cada una de las tradiciones teológicas (v.g. ortodoxos, católicos romanos y orientales, protestantes). Pues bien, la ACT es la principal manifestación de Teología política estadounidense, combinando la teología positiva moderna, tanto común como particular, pues permite atender a los pactos (de salvación) de Dios con su pueblo, observándose las tradiciones recibidas y desarrolladas en su seno, incluso aquellas posjudeocristianas como las decimonónicas mormona y de los testigos de Jehová, o las del s. XX de los cienciólogos o los davidianos, et al.

Por tanto, vía ACT, se alude a la principal manifestación de Teología política estadounidense (combinándose pactos/alianzas, Escrituras y tradiciones), de modo

\footnotetext{
${ }^{171}$ Vid. infra nota 146.
} 
que, por analogía, los estadounidenses se sienten el pueblo elegido (ortopatía, vid. infra figura 19), con pactos de redención y salvación, que les conectan con Dios. Dichos planteamientos, herencia de la tradición sagrada occidental, son revisados y reformulados por los padres fundadores, bajo el influjo del pensamiento proto-liberal, tanto en su vertiente católica (v.g. Escuela de Salamanca, y sus aportes de los derechos naturales -base de los actuales derechos humanos-, el tiranicidio y desobediencia civil, etc., todo ello reflejado en DIE) como protestante (v.g. Whigs o liberal-conservadores y Freemasons o librepensadores, tal como se aclara con mayor detalle seguidamente). Pese al citado sincretismo, se destaca especialmente -como se ha hecho notar ya a lo largo de la tesis- el influjo de PWF en la secularización del judeocristianismo, pues en el marco estadounidense, finalmente, ha devenido en su idiosincrásica fórmula posjudeocristiana (vid. infra) y su codificación ICS (vid. supra). Ambos constructos han favorecido la emergencia de una religión civil, sustentadora a su vez de expresiones aún más seculares como el pactismo del Federalismo o el modelo relacional de Iglesia-Estado y libertad religiosa (sendas expresiones resultan clave para entender la ACT, vid. supra). Igualmente -como se viene indicando-, ha sido muy valiosa la habilidad de las corrientes de pensamiento para poner en conexión la tradición occidental sagrada (judeocristiana) y la profana (grecorromana), generándose una mayor interacción en el seno de los EE.UU.

¿Cuál se considera el origen de ACT y cómo ha sido su desarrollo? Resulta que el legado de los padres fundadores está repleto de analogías conectoras del nuevo pueblo de Dios (estadounidenses) con el viejo (israelitas). Para ello se realizan constantes alusiones, del tipo New Zion/New Jerusalem [Nuevo Sión/Nueva Jerusalén -incluso, sólo su terminación: Salem (una de las primeras colonias de Nueva Inglaterra)], así como paradise/garden in wilderness [paraíso terrenal], a city upon the 
hill [una ciudad en lo alto de la colina], son un conjunto de expresiones bíblicas sobre la redención terrenal (v.g. Gn 3 y 12, Is 54 y 60, Mt 5, Lc 6), de tal fortuna recogidas en la literatura religiosa fundacional (de corte predicamental o Preaching Style), considerada como el comienzo de la implantación de American covenant theology [ACT: teología político-jurídica estadounidense (pactista)]. Uno de sus ejemplos más famosos es el sermón "A model of Christian Charity" (1630) de J. WINTHROP (recuperado con posterioridad por el Presidente REAGAN en su Discurso de despedida de 1989), junto con los igualmente ilustres casos de J. COTTON, J. ELIOT, I. MATHER, C. MATHER, T. TATCHER o J. EDWARDS ${ }^{172}$. Pues bien, tal recurso identitario, con un pueblo elegido, redimido y redentor (de otros pueblos), reaparece periódicamente en los EE.UU., tanto para legitimar su destino manifiesto, como su discurso de sobreestima moral y liberador de minorías, o la misma reconciliación y reconstrucción del Sur tras la Guerra Civil, incluso las propuestas de reformulación identitaria estadounidense habidas durante las recientes guerras culturales, del tipo del Originalismo y la Teonomía ${ }^{173}$.

Para comprender mejor de qué se está hablando, se procede a proporcionar a continuación una muestra de hierofanías estadounidenses, como ejemplos del mestizaje de la tradición occidental recibida (vía ensayo-error, sobre todo) en la

172 Vid. BOORSTIN, D.J. (comp.): An American Primer, Chicago: The University of Chicago Press, 1966. GAUSTAD, E. S. (ed.): A documentary History of Religion in America. To the Civil War, Grand Rapids: William B. Eerdmans Publishing Co, 1993. MARSDEN, G.M.: Religion and American Culture, Fort Worth: Harcourt Brace Jovanovich College Publishers, 1990. NOONAN, J.T., GAFNEY, E.Mc.: Religious Freedom. History, cases, and other materials on the interaction of religion and Government, New York: Foundation Press, 2001. POWER, M.S.: Before the Convention. Religion and the Founders, Lanham: University Press of America, 1984.

173 Vid. SONTAG, F., ROTH, J.K.: God and America's future, Wilmington: Consortium Books, 1977. STOWELL, D.W.: Rebuilding Zion. The religious reconstruction of the South, 1863-1877, New York: Oxford University Press, 1998. 
configuración del modelo relacional estadounidense (vid. supra). Entre las hierofanías profanas, destacan:

\section{a) Tradición clásica (grecorromana):}

- Expresiones como Eureka, sirven de lema para California o de nombre para poblaciones de Illinois, Kansas, Missouri. Montana, Nevada o South Dakota.

- Nombres de ciudades de la Antigüedad, como Troy [Troya], existen en Illinois, Missouri, Montana, New York, North Carolina, Ohio, Oregon o Tennessee; Syracuse [Siracusa, en Sicilia], también es una población de Kansas, Missouri, Nebraska, New York o Utah; Augusta, en Kansas, Kentucky, Maine, Missouri, Montana o Wisconsin; Sparta, en Kentucky, Michigan, Missouri, North Carolina, Tennessee, Wisconsin; Athens en Illinois, Lousiana, Michigan, Ohio, Tennessee o Texas.

- Nombres de ilustres personajes clásicos, como Solon, bautizan ciudades en Iowa o Ohio; Horace en Kansas; Seneca, en Michigan, Oregon y South Carolina.

- et al.

\section{b) Tradición moderna (Freemasonry):}

- Denominaciones relacionadas con la masonería, como Mason, en Michigan, Ohio o Texas; Mason City, en Illinois o Iowa; Masonville en Iowa.

- Poblaciones relacionadas con la libertad (desde la perspectiva masona: "free"), como Freeland en Michigan; Freeman en Missouri. 
- Otras denominaciones relacionadas con mitología pagana y aspiraciones de librepensadores, como Avalon en New Jersey; Cosmopolis en Washington; Mentor en Ohio; i) Canton City en North Dakota; j) Europa en Mississippi; etc.

\section{c) Tradición moderna (Whig):}

- Poblaciones relacionadas con la libertad (desde la perspectiva liberal: "liberty"), como Liberal y/o Liberty en Kansas; Liberty en Kentucky o North Carolina; New Liberty y/o North Liberty en Iowa.

- Ciudades relacionadas con las aspiraciones liberales de unión y pactismo, como Union en South Carolina o Utah; Union y/o Unity en Oregon; Union y/o Unionville en Iowa, Michigan o Missouri; Unionville en North Carolina; Union y/o Uniontown en Kentucky; Union City en New Jersey o Tennessee; Uniontown en Pennsylvania; Independence en Kansas, Kentucky, Missouri, Ohio o Wisconsin; et al.

\section{d) Tradición moderna (fusión Whig-Freemason):}

Philadelphia en Mississippi y New York (neologismo entendido como amor fraternal, a diferencia de la de Pennsylvania, que se debe a los cuáqueros, también llamados friends o amigos, quienes tomaron el nombre de la ciudad bíblica de Asia Menor, Filadelfo, donde estaban las siete iglesias del Apocalípsis); New Philadelphia en Ohio; Concordia en Kansas; Concord en Kentucky o New Hampshire; Federal Way en Washington; etc. 
En cuanto a las hierofanías de la tradición sagrada occidental, determinantes para la transformación del judeocristianismo de herencia europea en el peculiar posjudeocristianismo estadounidense, a la vez que influyentes en la configuración nacional de los EE.UU., se sintetiza a continuación una muestra de las mismas:

Figura 23.- Impronta judeocristiana en la toponimia y gentilicios estadounidenses

\begin{tabular}{|c|c|}
\hline Capitales & $\begin{array}{l}\text { Ciudades Lemas } \\
\text { (por tamaño y antigüedad) }\end{array}$ \\
\hline Arizona & $\begin{array}{ll}\text { Paradise Valley, } & \text { Ditat Deus } \\
\text { St. Johns, San Manuel } & \end{array}$ \\
\hline Sacrament & $\begin{array}{l}\text { Los Angeles, } \\
\text { San Francisco, San Diego }\end{array}$ \\
\hline Colorado & $\begin{array}{l}\text { Las Animas, Alma Nil sine Numine } \\
\text { Sangre de Cristo Ranches, St. Mary's }\end{array}$ \\
\hline Connecticut & $\begin{array}{l}\text { New Haven Qui transtulit sustinet } \\
\text { (New Canaan, House of Hope) }\end{array}$ \\
\hline Florida & St. Agustine In God we trust católicos y judíos \\
\hline Idaho & $\begin{array}{l}\text { Eden, Genesee, Grace } \\
\text { Hope, Priest River, St. Anthony, St. Charles }\end{array}$ \\
\hline Illinois & $\begin{array}{l}\text { East St. Louis, Salem, St. Charles } \\
\text { St. Elmo, St. Francisville, Zion }\end{array}$ \\
\hline Iowa & $\begin{array}{l}\text { Arcadia, Holy Cross, Monticello, Mystic } \\
\text { St. Ansgar, St. Anthony, St. Charles, St. Marys, Salem }\end{array}$ \\
\hline Kansas & $\begin{array}{l}\text { Alma, Hope, Paradise, St. Francis, St. George } \\
\text { St. John, St. Marys, St. Paul }\end{array}$ \\
\hline Kentucky & $\begin{array}{l}\text { Hebron Estates Deo gratia habeamus }\left(^{* *}\right) \\
\text { Hollyvilla, Providence } \\
\text { Sacramento, St. Charles, St. Matthews, Salem }\end{array}$ \\
\hline Louisiana & St. Gabriel, St. Martinville, Arcadia, Church Point \\
\hline Maryland & St. Mary Scuto bonae voluntatis tuae corononasti nos católicos \\
\hline Massachussetts & católicos \\
\hline Michigan & $\begin{array}{l}\text { Cross Village, Grand Haven, Holly, Hope } \\
\text { Nazareth, Old Mission, Paradise, St. Charles, St. Clair }\end{array}$ \\
\hline Minnesota & \\
\hline Mississippi & Bay St. Louis, Holly Springs, Pass Christian \\
\hline Missouri & $\begin{array}{l}\text { Alma, Cross Timbers, Lake St. Louis, } \\
\text { New Haven, St. Ann, St. Charles, St. Clair, St. Louis, Salem }\end{array}$ \\
\hline Montana & St. Ignatius \\
\hline
\end{tabular}




\begin{tabular}{|c|c|}
\hline Nebraska & Alma, Hebron, St. Edwards, St. Paul \\
\hline Nevada & Paradise, Paradise Valley, \\
\hline New Jersey & Salem, Fair Haven, Hopewell, New Providence \\
\hline New Mexico Santa Fe & $\begin{array}{l}\text { Las Cruces, Santa Rosa, San John } \quad \text { católicos e indios } \\
\text { Santa Clara, San Isidro }\end{array}$ \\
\hline New York Albany & católicos y judíos \\
\hline North Carolina & $\begin{array}{l}\text { Eden, Hope Mills, Holly Springs, Mount Holly } \\
\text { Trinity, St. Helena, St. Pauls }\end{array}$ \\
\hline North Dakota & $\begin{array}{l}\text { Churchs Ferry, Hope, New Salem, St. John } \\
\text { St. Thomas }\end{array}$ \\
\hline Ohio & $\begin{array}{l}\text { Marysville, With God all things are possible } \\
\text { St. Bernard, St. Clairsville, St. Marys } \\
\text { Salem, St. Clairsville }\end{array}$ \\
\hline Oregon & $\begin{array}{l}\text { St. Benedict, St. Helens, St. Joseph, St. Louis } \\
\text { St. Paul, Salem }\end{array}$ \\
\hline Pennsylvania & $\begin{array}{l}\text { Philadelphia Virtue, Liberty \& Independence cuáqueros(friends) } \\
\text { St. Mary }\end{array}$ \\
\hline Rhode Island & nce $\quad$ East Providence $\quad$ Hope $\quad$ judíos \\
\hline South Dakota & $\begin{array}{l}\text { Salem, Chapel Hill Under God the people rule indios } \\
\text { Church Hill, Cross Plains, New Hope, St. Joseph }\end{array}$ \\
\hline Texas & $\begin{array}{c}\text { San Antonio, Cross Plaíns, Eden, Santa Fe católicos } \\
\text { San Angelo, San Benito, San Marcos, San Baba, Santa Anna }\end{array}$ \\
\hline Utah & Salem, Santa Clara, St. George, Virgin \\
\hline Vermont & St. Albans \\
\hline Virginia & $\begin{array}{l}\text { Viginia Beach, Deus nobis haec otia fecit }\left(^{*}\right) \\
\text { Falls Churchs }\end{array}$ \\
\hline Washington & Holly, Moses Lake, Port Angeles \\
\hline West Virginia & Salem, St. Albans, St. Marys \\
\hline Wisconsin & Alma, St. Croix Falls, St. Francis \\
\hline
\end{tabular}

(*) Sustituido por Sic semper tyrannis. $\left({ }^{* *}\right)$ Aprobado en 2002. Ciertas jurisdicciones especiales, igualmente, poseen dicha influencia, como Puerto Rico, cuya capital es San Juan y su lema es Joannes est nomen eius (refiriéndose a San Juan Bautista); Samoa, cuyo lema es Samoa, muamua le atua/Samoa, let God be first; etc.

Fuente: elaboración propia (SÁNCHEZ-BAYÓN, 2007 y 16).

Esta parte del trabajo se dedica a compilar alguna de las muestras de hierocracias estadounidenses. Se pretende dar a conocer cuál fue el origen y evolución del modelo sincrético teológico-político de relaciones Iglesia-Estado, o si se 
prefiere, de relaciones entre las esferas sociales derecho-política-religión, y por ende cuál fue su configuración como ICS ${ }^{174}$, partiendo de las ordenaciones coloniales de derecho dominical o Blue Laws ${ }^{175}$ (vid. infra cap. 4), hasta la vigente formulación constitucional de libertad y autonomía religiosa: se muestra así la oficialización de relaciones, saliendo de la privacidad de la moral, para adentrarse en la publicidad de la política y el derecho. En consecuencia, se presentan a continuación las experiencias repartidas por bloques (los modelos relacionales coloniales y estatales -centrándose sobre todo en los trece originales y las anexiones inmediatas-, hasta la armonización plena con la Decimocuarta enmienda constitucional -lo que supone la consegración del común modelo federal-), para terminar ofreciéndose las propuestas teoréticas al respecto (tal como se barajaran en su momento, así como han sido estudiadas por la principal historiografía) ${ }^{176}$.

De modo inductivo (para atender mejor a las expresiones hierocráticas coloniales, antes de analizar cualquier propuesta de modelización relacional y su armonización a la postre), se va a prestar atención seguidamente a los principales

${ }^{174}$ Como ya se ha aclarado, se alude al mestizaje entre el Ius Circa Sacra [Derecho de las esferas sagradas] de las Monarquías confesionales católicas europeo-continentales (tras la Reforma), con el predominante Ius in Sacra británico (más los comunitarismos luterano, calvinista, zwinglianista, etc.), desarrollándose así una elástica y flexible teología político-jurídica posjudeocristiana, que combina el pensamiento Whig y Freemason, con Puritan, Naturalist, Mechanicist, etc., además de lograr integrar expresiones sectoriales dogmáticas (v.g. Theonomy, Mysterium ecclesae) o pragmáticas (v.g. RedemptiveHistorical Preaching Style).

${ }^{175}$ Bajo la denominación coloquial de Blue Laws [normativa de rectitud] -se atribuye su bautizo al Rev. PETERS y su General History of Connecticut-, se hace referencia al proto-sistema de Derecho Eclesiástico del Estado (DEE) de los EE.UU., donde cada colonia, según el margen de actuación conferido por su modelo relacional Estado-religión, fija las leyes fundamentales y los mandatos aprobados por el Gobernador y/o la Asamblea local, con la intención de instrumentalizar la religión como herramienta de integración social (religio ex machina), garantizándose así la supervivencia del asentamiento. Los ítems más destacados y objeto de regulación de las Blue Laws suelen ser, de un lado, el Oath of Supremacy o juramento de supremacía, y las Sabbath/Sunday Laws o leyes dominicales.

176 Vid. SÁNCHEZ-BAYÓN, A.: Universidad, ciencia y religión... op. cit. - Evolución y evaluación... op. cit. 
focos de mestizaje estadounidense sobre la materia (vid. infra cap. 4) $)^{177}$ : a) Plantaciones sureñas (las colonias anglicanas y su oficialidad eclesiástica -aunque de tolerancia moderna: utilitaria, conducente al jurisdiccionalismo, vid. supra figura 24 y 26-), b) Nueva Inglaterra (las colonias puritanas y reformadas, con sus pactos de

177 Se trata de tres grandes categorías regionales originales, más una cuarta derivada de mestizaje (entre las tres originarias -que en realidad proceden de propuestas europeas modificadas, por lo que tal adjetivo ha de entenderse por su orden de llegada y establecimiento, sin tener en cuenta la evangelización católica-). Son aquellas generalmente aceptadas por la mayoría de la academia estadounidense -al menos, las llamadas categorías originarias-, aunque presentan ciertas discrepancias puntuales de clasificación, sobre todo relativas a fechas y alineaciones territoriales. Ello se debe a la complejidad de su configuración fundacional (v.g. con asentamientos de diversos motivos y procedencias, con una estabilidad incierta), así como, a la rápida distorsión en su desarrollo posterior (v.g. unas colonias dan lugar a otras, las absorven, cambian de nombre y dirigentes). Un problema común a todas ellas es la agenda de supremacía británica y su juramento -base del prejuicio WASP (acrónimo de blanco anglosajón protestante, que a su vez en inglés significa avispa, por su actitud cultural)-, cuyo sustento radica en la absorción de colonias de adventurers y planters desde mediados del S. XVII (v.g. New Netherlands, New Sweden), más las adquisiciones de territorios americanos de otras potencias europeas (v.g. Floridas, Terra Nova, Québec), sobre todo tras la Guerra de Sucesión Española (1702-13), la Guerra de los Siete Años (1756-63) y las Guerras Indias (Franco-Indias, 1754-63). Todo ello exigió una reordenación administrativa, que culmino con la Royal Proclamation Act de 1763 y la Declarative Act de 1766, con las que empezó el malestar colonial, que terminaría por agrabarse con las Intolerable Acts de 1774 -en especial, para este estudio, la Quebec Act-, desembocándose en la Independencia de los EE.UU. Por tanto, según la agenda de supremacía británica -cuyo discurso legitimador se remonta al plan de reparto territorial entre la London Company y la Plymouth Company, vid. supra-, primero se debían afianzar los territorios del sur (las Plantaciones sureñas), luego intensificar los lazos con el norte (Nueva Inglaterra y las pesquerías de Terra Nova), y haciendo una pinza, absorver los asentamientos de en medio (Provincias medias). Finalmente, la referida agenda de supremacía, originadora del mapa colonial del s. XVIII, termina siendo sustituido por el pactismo independentista (vid. figuras 34 y 35). Vid. JAMESON, J.F. (ed.): British Royal Proclamations relating to America, 1603-1783 (vols. 1-16), New York: American Historical Association, 1906-17. JONES, M.A.: The limits of Liberty. American History 1607-1992, New York: Oxford University Press, 1930. MORISON, S.E., et al.: A concise History of the American Republic, New York: Oxford University Press, 1983. En español, se destaca la monumental obra de MOYANO PAHISSA, A., VELASCO MARQUEZ, J.: EUA. Documentos de su Historia Política (tomo 1-9: Documentos de su historia política, 3 vols.; Documentos de su historia socioeconómica, 4 vols; Síntesis de su historia, 2 vols), México DF: Instituto de Investigaciones Dr. José Mª Luís Mora, 1988. 
Gracia), c) Provincias medias (las colonias posreformadas y su comunitarismo social) d) laboratorios sociales (las colonias deístas y su proto-libertad religiosa) ${ }^{178}$.

a) Plantaciones sureñas: bloque regional conformado por cuatro grandes agrupaciones administrativas (Colony and Dominion of Virginia -actualmente, Virginia, Virginia Occidental y Kentucky-, Province of North Carolina -hoy, Carolina del Norte y Tennessee-, Province of South Carolina -Carolina del Sur- y Province of Georgia-Georgia-). Estas colonias son directamente dependientes de la Corona británica, y por ello, con un modelo institucional anglicano de relaciones Estado-religión. Empero, dicho modelo -superados los episodios de $1642-{ }^{179}$, debido a que se trata de colonias con una motivación inicial relativa al enriquecimiento ${ }^{180}$, el modelo institucional anglicano resulta más flexible y

178 Vid. ADAMS, A.M., EMMERICH, C.J.: A Nation dedicated to Religious Liberty. The Constitutional Heritage of Religion Clauses... op. cit. ARIENS, M.S., DESTRO, R.A.: Religious Liberty in a Pluralistic Society, Durham: Carolina Academic Press, 1996. BLAKELY, W.A.: American State papers on Freedom in Religion, Washington DC: The Religious Liberty Association, 1949. CORNELISON, I.A.: The relation of religion to Civil Government in the United States of America. A State without a Church, but not without a Religion, New York: Da Capo Press, 1970. GAUSTAD, E.S.: Faith of the Founders. Religion and the New Nation 1776-1826, Waco: Baylor University Press, 1993. KURLAND, P.B., LERNER, R. (ed.): The Founders' Constitution (vols. I-V), Indianapolis: Liberty Fund, 1987. MACLEAR, J.F. (ed.): Church and State in the Modern Age. A documentary History, New York: Oxford University Press, 1995. NOONAN, J.T., et al.: Religious Freedom. History, cases, and other materials on the interaction of religion and Government, New York: Foundation Press, 2001. STOKES, A.P.: Church and State in the United States (vol. I-III)... op. cit. THORPE, F.N.: The Federal and State Constitutions, Colonial Charters, and other Organic Laws (vols. 1-7), Washington DC: Government Printing Office, 1909. Complement., vid. Avalon Project-Yale Law School (URL: http://www.yale.edu/lawweb/avalon/avalon.htm). From Revolution to Reconstruction Project-University of Groningen (URL: http://www.let.rug.nl/ usa/D/index.htm).

${ }^{179}$ Se hace referencia a la "Great Persecution" de 1642, donde se acorraló, golpeó y encarceló a los disidentes religiosos y se prohibió, con graves penas, la blasfemia, la profanación y la renegación de creencias, así como, la agresión a clerigos. Cfr. GREENE, E.B.: Religion and the State: The making and testing of an American tradition, Ithaca: Cornell University Press, 1959, pp. 47 ss. WOOD, J.E., et al: Church and State in Scripture History and Constitutional Law, Waco: Baylor University Press, 1958, pp. 83 ss.

180 Tanto es así, que su denominación conjunta es la referida de Southern Plantations, relativa a su explotación agrícola. Tal visión se mantuvo, incluso, hasta la fundación de la última colonia de este 
permeable para los disidentes que en UK -al imponerse de la exigencia material de requerimiento de mano de obra. Prueba de ello, por ejemplo, es la admisión de las variantes episcopalianas y presbiterianas -pasando a formar parte de las elites de poder. Dentro de este núcleo fundacional, la colonia referente es Virginia, que es donde se fija el primer asentamiento (Jamestown, 1607), del que se ramifica la colonización colindante (North Carolina, 1663; South Carolina, 1670; Georgia, 1732), y donde se ratifican los cambios hacia el modelo de libertad (v.g. art. 16 of the Virginia Declaration of Rights, 1776).

- Virginia: a) en sus leyes fundamentales (Grants, Charters, Statues $\mathcal{E}$ Constitutions) $)^{181}$, como la Primera Carta Otorgada de 1606, se proclama la misión de cristianización de los territorios y la conversión de los indios; en la Segunda Carta Otorgada de 1609, se tipifica el test religioso (el juramento de

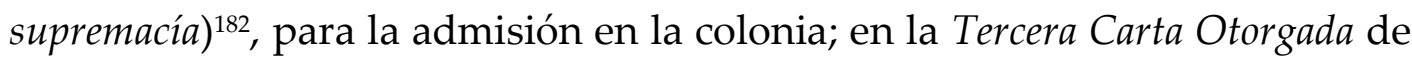
1611, se mantiene el juramento de supremacía, aunque excluyéndose del mismo a los católicos; etc. Finalmente, la Declaración de Derechos (en su art.16), proclama la libertad de conciencia. b) Entre los preceptos sobre la religión, destacan los mandatos de Pena de muerte por blasfemia de 1610; Leyes dominicales de 1610; Ley exigiendo la asistencia religiosa de 1623; Ley sobre los viajes dominicales y la asistencia a la iglesia de 1661; Ley exigiendo bautizo de los niños de 1662; Ley contra los cuáqueros de 1663; Ley para hacer más efectiva la

núcleo fundacional, Georgia, que por concesión real, se convierte en el refugio de debtors o deudores/impagadores.

${ }^{181}$ Vid. The First Charter of Virginia (April 10, 1606), The Second Charter of Virginia (May 23, 1609), The Third Charter of Virginia (March 12,1611), Ordinances for Virginia (July 24, 1621), Virginia Declaration of Rights (June 12, 1776), The Constitution of Virginia (June 29, 1776).

182 The Oath of Supremacy o juramento de supremacía, es la exigencia de sometimiento a la Iglesia Anglicana, reconociendo al monarca británico como cabeza visible de la misma. 
supresión de la blasfemia, el juramento (en vano), la drogadicción y la inobservancia del Sabbath (descanso dominical) de 1699183; Ley de latigazos por trabajo, viaje o no asistencia a la iglesia en domingo de 1705; etc.

- North Carolina: a) entre las leyes fundamentales ${ }^{184}$, en las Cartas Otorgadas de 1663 y 1665, se reconoce como colonia anglicana (manteniendo la confesión), aunque no adopta tal denominación oficial hasta 1711; etc. Por último, la Declaración de Derechos de 1776, reconoce la libertad de conciencia. b) Entre los preceptos sobre la religión, el más sobresaliente es la Ley para guardar el sagrado día del Señor, comúnmente llamado domingo de 1741, con la que se inicia una cruzada contra el vicio.

- South Carolina: a) de entre sus leyes fundamentales ${ }^{185}$, una vez independiente de la otra Carolina (1729), tras el Acuerdo de Fronteras de 1735, se establece formalmente la Iglesia Anglicana; etc. A la postre, la Constitución de 1778, declara la religión cristiana como la oficial. b) En el ínterin de separación de las Caralinas, empero, ya gozando de cierta autonomía, su Asamblea aprueba las leyes dominicales de 1692 y 1712.

183 El Sabbath, es el día de descanso reconocido por la Biblia y ha de dedicarse al culto a dios. El problema radica en la polémica suscitada con el Primer Despertar Religioso (década de 1740) -aunque se prepara tiempo atrás, como se observa-, pues las confesiones protestantes -como efecto de la paradoxología estadounidense-, sufren una cierta judeización en su búsqueda de ortodoxia, lo que les hace trasladar el tradicional descanso dominical al sábado. Para efectos de este trabajo, las Sunday $\mathcal{E}$ Sabbath Laws, se consideran en su conjunto, pues lo realmente destacable es el hecho de que por motivos originalmente fundamentalistas, finalmente, se promueve una mayor secularización, al fijarse el calendario entre días laborables y festivos (v.g. sabbatharianismo).

184 Vid. Charter of Carolina (March 24, 1663), A Declaration and Proposals of the Lord Proprietor of Carolina (Aug. 25, 1663), Concessions and Agreements of the Lords Propietors of the Province of Carolina (1665), Charter of Carolina (June 30, 1665), The Fundamental Constitutions of Carolina (March 1, 1669), The Mecklenburgh Resolutions (May 20, 1775), Constitution of North Carolina (Dec. 18, 1776).

185 Vid. State Boundery Agreement (April 1, 1735), Constitution of South Carolina (March 26, 1776), Constitution of South Carolina (March 19, 1778). 
- Georgia: a) entre sus leyes fundamentales ${ }^{186}$, la Carta Otorgada de 1732, fija la Iglesia Anglicana como oficial; en la Constitución de 1777, la desinstitucionaliza. b) Entre sus mandatos sobre religión, el más destacado es el de la Ley para castigar el vicio, las profanaciones, la inmoralidad y guardar el sagrado día del Señor, comúnmente llamado domingo de 1762, en la línea de North Carolina.

b) Nueva Inglaterra: bloque regional que consta de cuatro divisiones territoriales principales, Province of Massachusetts Bay (luego Massachusetts), Province of New Hampshire (New Hampshire, más Maine y Vermont), Colony Connecticut (Connecticut), Colony of Rhode Island and Provindence Plantations (Rhode Island). En este entorno, originalmente, predomina un modelo teonómico congregacionalista de confesiones puritanas, hasta su incorporación plena a la Corona Británica, siendo entonces el modelo de corte semi-institucional. Aunque las primeras migraciones están motivadas por la búsqueda de reconocimiento y tolerancia, los excesos geonómicos (v.g. caza de brujas, moralismo estricto), generan una merma tal que, bien por ostracismos explícitos y/o implícitos, se hace urgente y necesaria la fundación de nuevos asentamientos más flexibles y permeables a las minorías locales (v.g. bautistas, cuáqueros) ${ }^{187}$. Massachusetts es el gran referente colonial de la región, pues es donde se fijan los primeros asentamientos (los pilgrims o peregrinos en New Plymouth en 1620 y los puritans

\footnotetext{
186 Vid. Royal Charter of Georgia (Jun 9, 1732), Constitution of Georgia (Feb. 5, 1777), Constitution of the State of Georgia (May 6, 1789).

${ }^{187}$ En Nueva Inglaterra, se inflingieron severos castigos a católicos, bautistas, judíos y cuáqueros (v.g. confiscación de bienes, encarcelamientos, trabajos forzosos, palizas, ahorcamientos). En el área de Boston, tras los avisos pertinentes (hasta un máximo de tres), se desterraron varias familias, y cuatro cuáqueros que desoyeron el mandato de expulsión colonial y volvieron, fueron luego ahorcados.Cfr. WOOD, J.E., et al: Church and State in Scripture History and Constitutional Law... op. cit., pp. 80 ss. PFEFFER, L.: Church, State and Freedom, Boston: Beacon Press, 1953, pp. 65 ss.
} 
o puritanos en Massachusetts Bay en 1629-30 -adsorbiendo la última a la primera en 1691). Además, de esta colonia arrancan las iniciativas fundacionales posteriores -debido a las purgas de WINTHROP188-, dando lugar a Connecticut (por el Rev. T. HOOKER en 1635-36); Rhode Island (por el Rev. R. WILLIAMS en 1636); New Hampshire (por Norirlandeses presbiterianos -como colonos estables- en la década de 1630); Maine (primero Nova Scotia o Nueva Escocia, entre 1696-1713).

- Massachusetts ${ }^{189}$ : en New Plymouth, la Carta Otorgada de 1620 fija el modelo teonómico, el mandato de conversión de los indios y la necesidad del juramento de supremacía para ser admitido en el asentamiento; entre su regulación sobre la religión, destacan los severos castigos impuestos por las prohibiciones de la Profanación del día del Señor de 1650 y 1669, La (falta de) asistencia a la iglesia de 1651, Las Penas de muerte por idolatría, infidelidad y brujería de 1671, La Pena de muerte por presunción de profanación del domingo de 1671, La (exigencia de) ortodoxia requerida al hombre libre de 1672, La sanción por viaje en el día del Señor de 1682. En Massachusetts Bay, la Carta Otorgada de 1629, reconoce derechos naturales, pero sujetos a las restricciones del juramento de supremacía; la Carta Otorgada de 1691, exime del juramento de supremacía generalizado, salvo para ocupar cargos públicos -ahora bien, sigue discriminando a los católicos, a los que califica despectivamente como los papistas; de entre la regulación sobre la religión, cabe señalar los mandatos

\footnotetext{
188 Fue elegido Gobernador hasta doce veces, entre 1631-48, muriendo meses después. Su estricta política responde a las demandas sociales del momento, pues la población estaba atemorizada por las experiencias de otros asentamientos menos integrados y que no lograron sobrevivir -aunque su celo fue tal, que su propio hijo tuvo que desplazarse a New Hampshire, donde llegó a ser Gobernador.

189 Vid. Massachussets Constitution (March 2, 1780).
} 
de La regulación del Sabbath de 1629, La persecución por motivo religioso de 1630 -se castigó a BAKER-, La concesión (exclusiva) del derecho al voto a los miembros de la iglesia de 1631, Orden de los tribunales a asistir a la iglesia en domingo de 1635, Declaración del Gobierno Civil sometido al Gobierno divino de 1636, Penas de muerte (por motivo) religioso de 1641, Decreto de asistencia a la iglesia en 1646, Bando de exilio por herejía de 1646, Bando de exilio o pena de muerte a los curas católicos de 1647, Bando de exilio o pena de muerte por renegar de la Biblia de 1651, Bando de exilio o pena de muerte a los vagabundos cuáqueros de 1658, Mandato para el reconocimiento del derecho al voto a los miembros de la iglesia de 1660, Bando de muerte contra los cuáqueros, sólo y como último recurso, de 1661, etc.

- Connecticut: a) entre sus leyes constitucionales ${ }^{190}$, como las Ordenes Fundamentales de Connecticut de 1638-39 y la Ley de Gobierno de la Colonia de New Haven de 1643, se impone el juramento de supremacía (a los representantes políticos y los propietarios libres, respectivamente); b) de entre los mandatos sobre la religión, los más relevantes son, la Ley para prevenir y castigar la profanación del Sabbath o día del Señor de 1721, y la Ley para la observación debida del Sabbath o día del Señor de 1750.

- New Hampshire: a) entre sus leyes fundacionales ${ }^{191}$, como las Concesiones de 1629 y 1635, se va imponiendo la exigencia del juramento de supremacía y

\footnotetext{
190 Vid. Fundamental Orders (Jan. 14, 1639), Fundamental Agreement, or Original Constitution of the Colony of New Haven (June 4, 1639), Government of New Haven Colony (1643), Charter of Connecticut (1662), Constitution of Connecticut (Oct. 5, 1818).

${ }^{191}$ Vid. Grant of Hampshire to Capt. John Mason (Nov. 7, 1629), Grant of Laconia to Sir Ferdinando Gorges and Captain John Mason by the Council for New England (Nov. 17, 1629), Grant of the Province of New Hampshire to John Wollaston Esq. (1635), Grant of the Province of New Hampshire to Mr. Mason (April 22, 1635), Grant of his interest in New Hampshire by Sir Ferdinando Gorges to Captain John Mason (Sept. 17, 1635), Agreement of the Settlers at Exeter in New Hampshire (1639), The Combinations of the Inhabitants
} 
las leyes dominicales -aunque con más flexibilidad que en la Massachusetts de entonces; b) entre la normativa dedicada a la religión, destacan la Ley para la mejor observancia del día del Señor de 1700, más la Prohibición de la blasfemia de 1718 ,

c) Provincias medias: bloque regional que consta de cinco territorios matriz, Province of New York (previamente Nueva Holanda y, con posterioridad, Nueva York y Vermont), Province of New Jersey (Nueva Jersey), Province of Pennsylvania (Pensilvania), Delaware Colony (originalmente, Los Bajos Condados de Delaware, siendo hoy Delaware), Province of Maryland (Maryland). Entre las mencionadas colonias, predomina un modelo de reciprocidad deísta, abierto a diversas confesiones como la anglicana y sus derivadas, las reformadas europeocontinentales y la católica, que sin estar perseguidas, sí son minorías en sus países de origen y buscan en América, tanto reconocimiento como enriquecimiento. Las colonias cardinales de la zona son, de un lado, Maryland (1634-36), y del otro, New York (fundada como New Netherlands, por la Iglesia Reformada Holandesa, entre 1614-64, convirtiéndose al anglicanismo por anexión tras las Guerras Holandesas-Británicas de mitad de siglo); de esta última colonia, se desprenden luego New Jersey (West New Jersey en 1676 y East New Jersey en 1683, unidas y autónomas en 1702) y Delaware (fundada por los suecos en 1665, siendo asimilados por los holandeses, más tarde por los británicos, y con autonomía en 1701).

upon the Piscataqua River for Government (1641), Commission of John Cott (1680), Constitution of New Hampshire (Jan 5, 1776; June 13, 1784). 
- New York: a) entre sus leyes fundamentales ${ }^{192}$, las Concesiones Reales de 1664 y 1674, establecen la Iglesia Anglicana como oficial, hasta que en la Constitución de 1777 queda abolida; b) entre sus mandatos sobre religión, los más sobresalientes son las Leyes contra la profanación del domingo y otras inmoralidades de 1673 y 1695.

- New Jersey: a) entre sus leyes fundamentales ${ }^{193}$, ya desde un comienzo se apuesta por un modelo de tolerancia, aunque con cierto preferencialismo (v.g. exigencia del juramento de supremacía a los cargos públicos) ${ }^{194}$, tal y como reflejan la Concesión y Acuerdo de 1664, la Constitución Fundamental para la Provincia de Nueva Jersey Oriental de 1683, las Leyes Fundamentales de Nueva Jersey Occidental de 1676; b) entre la regulación sobre la religión, destacan las Leyes dominicales o frente a la profanación del día del Señor de 1683 y 1693, la Ley para la supresión de la inmoralidad de 1704, etc.

192 Vid. Notification of the Purchase of Manhattan bay the Duth (Nov. 5, 1626), The Constitution of New York (April 20, 1777).

${ }_{193}$ Vid. The Duke of York's Release to John Ford Berkeley, and Sir George Carteret (June 24, 1664), The Concession and Agreement of the Lords Proprietors of the Province of New Caesarea, or New Jersey, to and with all and every the Adventurers and such as shall settle or plant there (1664), A Declaration of the True Intent and Meaning of us the Lords Proprietors, and Explanation of there concessions made to the Adventurers and Planters of New Caesarea or New Jersey (1672), His Royal Highness' Grant to the Lords Proprietors, Sir George Carteret (July 29, 1674), The Charter of Fundamental Laws, of West New Jersey, Agreed upon (1676), Quintipartite deed of revision, between E. and W. Jersey (July 1, 1676), Duke of York's Second Grant to William Penn, Gawn Lawry, Nicholas Lucas, John Eldridge, Edmund Warner, and Edward Byllynge, for the soil and Government of West New Jersey (Aug. 6, 1680), Duke of York's Confirmation to the twenty four proprietors (March 14, 1682), The Fundamental Constitutions for the Province of East New Jersey in America (1683), The King's Letter recognizing the Proprietors'Rights to the soil and Government (1683), Surrender from the Proprietors of East and West New Jersey, of their pretended right of Government to her Majesty (1702), The Queen's acceptance of the surrender of Government (April 17, 1709), Constitution of New Jersey (July 2, 1776).

${ }^{194}$ Los ejemplos de apertura a la tolerancia son muchos, pero uno bien significativo y a recordar es el de la Apostasía de Yale, movimiento liderado por el que fuera Rev. Presbiteriano y alto cargo de la universidad, T.B. CHANDLER. Vid. CURRY, T.J.: The First Freedoms. Church and State in America to the passage of the First Amendment, New York: Oxford University Press, 1986. 
- Delaware: a) sus leyes primordiales ${ }^{195}$, resultan muy similares a las de New Jersey, con vocación de tolerancia y cierto preferencialismo (pero el juramento de supremacía se exige a todo ciudadano), así se desprende de la Carta Otorgada de Delaware de 1701 y de la Ley de ordenación del testimonio de funcionarios y ministros de culto de $1701 ; b)$ entre sus preceptos más relevantes, cabe citarse el Decreto contra la blasfemia de 1739 y la Ley para prevenir el incumplimiento del día del Señor, comúnmente llamado domingo de 1739 -la puntualización se debe al auge del Despertar Religioso y a la cuestión polémica del Sabbatharianismo (una rejudeización del protestantismo estadounidense, postulándose como día festivo, no el domingo, sino el Sabbath o sábado).

d) Laboratorios sociales: a diferencia de los casos anteriores, no se trata de colonias con una convergencia física clara ${ }^{196}$, sino que se corresponden con grados de un estadio mental, pues resultan hitos clave en el nacimiento de la tolerancia moderna, y con ella, en la consecución posterior de la libertad. En primer lugar, Maryland, es una colonia fundada por un compromiso real ${ }^{197}$, entre 1629-34, al este de Virginia, por un noble irlandés católico, C. CALVERT (Lord Baltimore), para dar cabida a los católicos perseguidos. En segundo lugar, Rhode Island, es una colonia constituida entre 1634-36, al sur de Massachusetts, por un reverendo congregacionalista -supuestamente, bautista- ${ }^{198}$, R. WILLIAMS, en su huida de

195 Vid. Charter of Delaware (1701), Constitution of Delaware (Aug. 22, 1776), Constitution of Delaware (1792).

196 Cierto es que convergen en latitud, pero geográficamente, Rhode Island se considera ubicada en el Noreste, Pennsylvania en el Centro y Maryland en Sur.

${ }^{197}$ Charles I, por el desepeño del puesto de Secretario de Estado (en 1625), concede a G. CALVERT, Primer Barón Baltimor (Irish House of Lords), la explotación de terrenos en América. Pero habrá de ser su hijo quien reciba la Carta Otorgada en 1632, consolidándose el primer asentamiento en 1634.

198 Tanto WILLIAMS como JEFFERSON, el uno congregacionalista y el otro episcopaliano, debido a su metáfora de wall of separation y su discurso separatista Iglesia-Estado, en los últimos años, han sido 
las "purgas" de WINTHROP. En tercer lugar, Pennsylvania, fruto de una deuda nobiliaria ${ }^{199}$, se establece al oeste de Delaware, por un líder cuáquero, W. PENN, deseoso de dar cabida a los cuáqueros huidos de otras partes (recuérdese que se trata de una confesión gnóstica, que pretende regresar al cristianismo primitivo, y su práctica en la colonia le vale el sobrenombre del "santo experimento"). En definitiva, los tres supuestos mencionados coinciden en la firme voluntad de sus fundadores de dar refugio a los hostigados por razón de conciencia. Se inicia así el proceso de emancipación del individuo (los perseguidos) frente al grupo (las confesiones mayoritarias), y de lo civil frente a lo religioso (dichas confesiones mayoritarias dejan de copar los cargos públicos). Ahora bien, como precisión, es conveniente distinguir que, mientras el caso de Maryland se corresponde con la consolidación de la noción de tolerancia moderna -predominando la carga negativa de la resignación-200, los supuestos posteriores de Rhode Island y Pennsylvania, suponen el artificio (en la aplicación del método de ensayo y error) del tránsito a la moderna tolerancia, en su sentido positivo y abierto de respeto, además de mínimo irrenunciable de la libertad actual.

- Maryland: a) entre la normativa elemental ${ }^{201}$, claramente aprobada para fijar las reglas de convivencia y asegurar la tolerancia social, destacan la Carta

convertidos en bastiones doctrinales de los bautistas (y su ya comentado argumentario) -aunque en realidad, más bien, parece ser una confusión de intereses, para legitimar posturas.

199 Debido a la deuda del Duque de York con el Almirante Penn, Charles II concede a W. PENN (hijo del Almirante y lider cuáquero más relevante que el padre), una Carta Otorgada en 1681.

${ }^{200}$ Recuérdese que se está ante una concepción vinculada al aguante del mal ajeno, por tratarse de una solución para los católicos, en épocas de restauración, en previsión de convulsiones posteriores. Luego no existe un claro y auténtico espíritu de convencimiento de la necesidad de la tolerancia, como ejercicio de respeto y apertura a la alteridad, sino que, más bien, se está ante un episodio de resignación prolongada.

201 Vid. Charter of Maryland (1632), An Act Concerning Religion/Maryland Tolerance Act (1649), Constitution of Maryland (Nov. 11, 1776), Amendments to the Maryland Constitution (1776). 
Otorgada de Maryland de 1632 y las Instrucciones a los colonos por Lord Baltimore de 1633 (donde Lord Baltimore recomienda a los católicos no ofender a los protestantes vecinos); b) entre sus mandatos más populares, sobresalen la Ley relativa a la religión -o popularmente conocida como Acta de Tolerancia- de 1649 (donde se reconoce la tolerancia sólo entre cristianos y con severos castigos por blasfemia y el incumplimiento de las festividades religiosas), la Ley para la observación y santificación del día del Señor, comúnmente llamado domingo de 1696, la Ley para castigar a blasfemos, perjurios, alcohólicos y no observantes del Sabbath de 1723, etc. ${ }^{202}$.

- Rhode Island: a) sus leyes fundamentales ${ }^{203}$, están orientadas a la consecución de la tolerancia social y la protección de la libertad de conciencia (no se exige el juramento de supremacía a los ciudadanos), tal y como se desprende del Pacto de Providence de 1636, el Acuerdo de la plantación de Providence de 1640, Acuerdo de Gobierno de Rhode Island de 1641 y la Carta Otorgada de Rhode Island y Plantaciones de Providence de 1663.

- Pennsylvania: a) entre las leyes fundamentales ${ }^{204}$, como Carta Otorgada de la Provincia de Pennsylvania de 1681 y el Acuerdo de Gobierno de Pennsylvania de 1682, pese a reconocer una filosofía de tolerancia muy similar a la de Rhode Island, en cambio, en las formas si resulta más estricta y taxativa con la religión, exigiéndose la conversión de los indios, el juramento de supremacía a los cargos públicos y ciudadanos, la observación del domingo -

\footnotetext{
202 También es de reseñar, el especial status reconocido a los Jesuitas -sirviéndo Maryland de centro de operaciones para su posterior labor en los EE.UU., máxime, en la docencia universitaria-, gracias a las cartas entre el Padre T. COPLEY y Lord Baltimore. Vid. CURRY, T.J.: The First Freedoms. Church and State in America to the passage of the First Amendment, New York: Oxford University Press, 1986. 203 Vid. Constitution of Rhode Island (Nov. 5, 1843).

204 Vid. Constitution of Pennsylvania (Sept. 28, 1776).
} 
seguramente, se debiera al deseo de mantener alejados los controles exteriores y garantizar un libre desarrollo a los perseguidos cuáqueros; b) entre sus preceptos más destacados, cabe señalarse dos muy representativos del modelo, la Gran Ley o Carta Otorgada a Penn y Leyes de la Provincia de Pennsylvania de 1682 (donde se reconoce la libertad de conciencia, aunque se exige el juramento de supremacía y la consagración del domingo), y la Ley de restricción del trabajo en el primer día de la semana de 1705 -en la línea del Primer Despertar Religioso y el problemático Sabbatharianismo, para la gran mayoría de los protestantes, la semana comienza en domingo.

En suma, los tres bloques originarios y el derivado son claros ejemplos del método de ensayo-error en el largo camino de la tolerancia moderna a la libertad (bajo la fórmula singular estadounidense, vía su Americaness), con la especialidad de que, en el caso de Maryland, el énfasis radica en la consecución de la convivencia, en cambio, en Rhode Island y Pennsylvania, lo más importante es la libertad de conciencia. En cualquier caso, los bloques estudiados han servido -y mucho- para ir avanzando en el proceso colonial emancipatorio en curso, del individuo frente al grupo, y de la comunidad político-civil frente a la religioso-cultural.

Por último (en lo tocante a las experiencias de hierofanías y hierocracias), recuérdese lo mencionado sobre la agenda de supremacía británica y su juramento (mediante lo cual los británicos articularon sus trece colonias resultantes): aunque tal agenda y el juramento fueron condicionando la evolución de los bloques (vid. supra figura 24 y 28), también resultaron revulsivos determinantes de la independencia, al sustituirse la citada fórmula de integración (basada en el juramento de supremacía -resabio que aún perdura en el pledge of allegiance, vid. supra 
cap. 10-), para dar lugar a la unión y el pactismo autóctono estadounidense (vid. supra figura 31).

Figura 24.- Configuración de colonias y modelos (por agenda de supremacía y juramento) ${ }^{205}$.

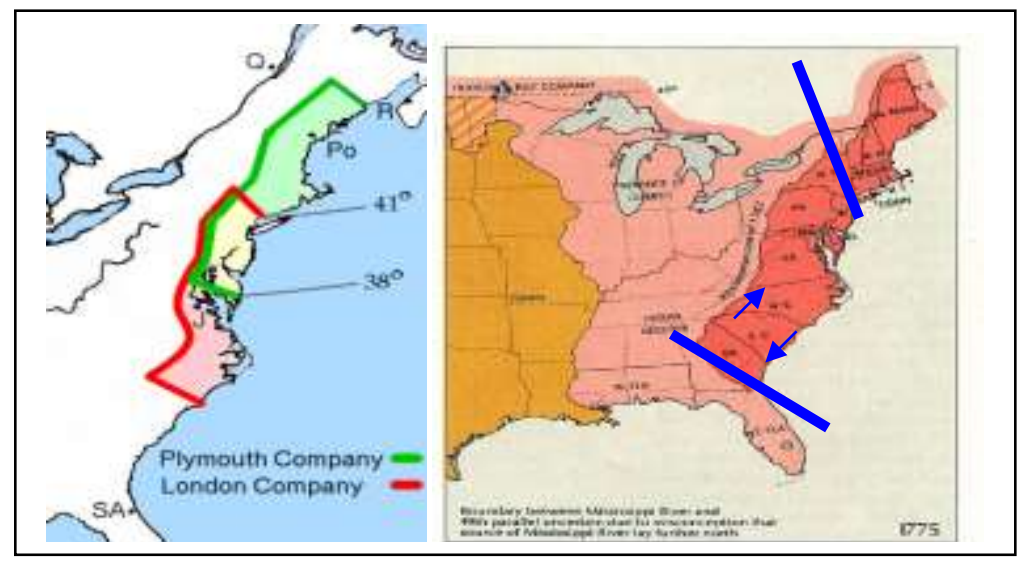

Fuente: elaboración propia (SÁNCHEZ-BAYÓN, 2007 y 16).

Figura 25.- Llamada a la Unión de las Trece Colonias ${ }^{206}$.

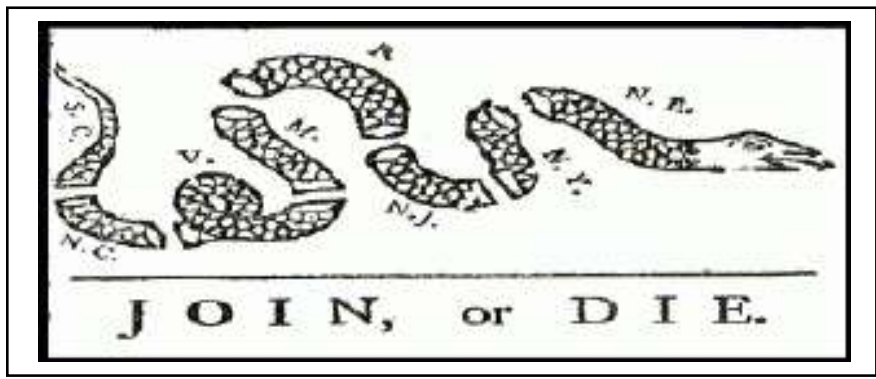

Fuente: elaboración propia (SÁNCHEZ-BAYÓN, 2007 y 16).

${ }^{205}$ La zona roja representa los territorios bajo control británico (y su sometimiento al juramento de supremacía); la zona rosa, los sometidos a integración tras la Royal Proclamation Act; la zona naranja, es la correspondiente a los territorios españoles. Vid. The National Atlas of the United States of America, un servicio del U.S. Department of the Interior (URL: http://nationalatlas.gov/).

206 El dibujo Join, or Die [unite, o muere], de FRANKLIN, fue publicado por primera vez en Pennsylvania Gazette, el 9 de mayo de 1754. De izquierda a derecha, refiere a: South Carolina, North Carolina, Vermont, Maryland, Pennsylvania, New Jersey, New York y New England. En realidad alude a un leviatán o monstruo marino bíblico, vid. supra. 
A continuación se ofrecen unos breves apuntes sobre la codificación de los modelos teológico-políticos de relaciones Iglesia-Estado (o relaciones de derechopolítica-religión). Para aligerar la exposición y explicación al respecto, se ha recurrido a una serie de figuras (26 ss.). La primera figura, recoge la síntesis del devenir occidental de las relaciones Estado-religión: del monismo entre el orden político-material y el religioso-ideal, hasta pluralismo habilitador de una diferenciación efectiva y garante de la autonomía del individuo frente a la comunidad, y de lo político-civil frente a lo religioso-cultural. La segunda figura, se ajusta a las expresiones habidas a inicios de los EE.UU., hasta que se implantó generalizadamente el modelo de libertad religiosa: los modelos ensayados -con sus errores- fueron el institucional (confesional moderno), el teonómico, el de reciprocidad, y el de tolerancia. La tercera figura, pone de manifiesto la crudeza de los resultados del método de ensayo-error en la consecución de la libertad religiosa: los casos más destacados - por sangrantes- se produjeron en Nueva Inglaterra ${ }^{207}$, donde dominaba el modelo teonómico. La cuarta figura, permite plasmar la significación dinámico-estructural de la libertad religiosa (de la mera tolerancia a la autonomía plena), como modelo logrado tras una serie de etapas, no todas ellas exitosas y beneficiosas (tal y como se desprende de las fallas de la figura precedente).

\footnotetext{
${ }^{207}$ El nombre de la región se consolidó a raíz de los experimentos proto-federales, como el ya citado de New England Confederation (1643), o su revisión ampliada (a colonias e intereses conjuntos) de Dominion of New England (1686-89), que incluía originalmente asentamientos tan relevantes como the Colony of Massachusetts Bay, the Colony of New Plymouth, the Province of New Hampshire, the Province of Maine, the Narraganset Country or King's Province. Posteriormente, se incorporaron The Colony of Rhode Island and Providence Plantations y the Colony of Connecticut (el 9 de septiembre de 1686), the Province of New York, the Province of East Jersey, y the Province of West Jersey (el 7 de mayo de 1688).
} 
Figura 26.- Modelos relacionales Iglesia-Estado (derecho-política-religión) en Occidente ${ }^{208}$

\begin{tabular}{|c|c|c|}
\hline Paradigmas & Sistemas & Modelos \\
\hline $\begin{array}{l}\text { Monismo } \\
\text { (Mundo Clásico) }\end{array}$ & $\begin{array}{l}\text { Identificación } \\
\text { Exclusión } \\
\text { (único poder) }\end{array}$ & $\begin{array}{l}\text { Teocracia (rey-sacerdote) } \\
\text { Persecucionismo } \\
\text { (eliminación minorías) }\end{array}$ \\
\hline $\begin{array}{l}\text { Dualismo } \\
\text { (Mundo Medieval } \\
\text { Moderno) }\end{array}$ & $\begin{array}{l}\text { Utilidad/Servicio } \\
\text { (poder directo } \\
\text { e indirecto) }\end{array}$ & $\begin{array}{l}\text { Cesaropapismo } \\
\text { Hierocratismo/Eclesiocracia y } \\
\text { Jurisdictionalismo Monárq. }\end{array}$ \\
\hline $\begin{array}{l}\text { Pluralismo } \\
\text { (Mundo Contemp.) }\end{array}$ & $\begin{array}{l}\text { Reciprocidad } \\
\text { (poder directivo) a) Eje } \\
\text { b) Le }\end{array}$ & $\begin{array}{l}\text { Jurisdictionalismo Republ. } \\
\text { cutivo (legitimidad recíproca) } \\
\text { gislativo (tolerancia con minorías relig.) }\end{array}$ \\
\hline- & $\begin{array}{l}\text { Oposición } \\
\text { (poder de resistencia) }\end{array}$ & $\begin{array}{l}-\overline{-} \quad- \\
\text { Estadolatría }- \\
\text { (Fascismo/Totalitarismo) } \\
\text { * deriva radical de Laïcité }\end{array}$ \\
\hline- & $\begin{array}{l}-\bar{N} \quad- \\
\text { Neutralidad } \\
\text { (poder equilibrado: } \\
\text { checks \& balances) C }\end{array}$ & $\begin{array}{l}-\bar{S} \\
\text { Separatismo (colaboración restringida) } \\
\text { Coordinac. (colab. diferentes niveles) } \\
\text { onfesionalismo (colabo. en mismo nivel) }\end{array}$ \\
\hline
\end{tabular}

${ }^{208}$ Cfr. SÁNCHEZ-BAYÓN, A.: “La religión civil estadounidense: análisis de la configuración de la realidad socio-cultural y su identidad social", en Revista General de Derecho Canónico y Derecho Eclesiástico del Estado-Iustel (n⿳0 10), 2006, pp. 32 (más tarde, revisada y mejorada en Derecho Eclesiástico Global, Madrid: Delta, 2012). Propuestas originales tomadas de WOLF (Ordnung der Kirche. Ein Lehrund Handbuch des Kirchenrechts auf ökumenischer Basis, Frankfurt: Frankfurt Univ., 1961), de FERNANDEZ DE LANDA (Las relaciones entre la Iglesia y el Estado, Madrid: Studium, 1968) y de los documentos del Concilio Vaticano II. Complement., bibliografía eclesiasticista española propedéutica, vid. GARÍN, P.M‥: Temas de Derecho Eclesiástico del Estado. La "Religión" en la comunidad política desde la libertad, Bilbao: Universidad de Deusto, 2000. GONZALEZ DEL VALLE, J.M.: Derecho Eclesiástico español, Ovideo: Universidad de Oviedo, 1997. GOTI, J.: Sistema de Derecho Eclesiástico del Estado (Parte general), Donostia: Kursaal, 1991. IBAN, I.C.: Manual de Derecho Eclesiástico del Estado, Madrid: McGraw-Hill, 1997. LlAMAZARES, D.: Derecho Eclesiástico del Estado. Derecho de la Libertad de Conciencia, Madrid: Univ. Complutense de Madrid, 1991. MARTIN, I (coord.): Curso de Derecho Eclesiástico del Estado, Valencia: Tirant lo Blanch, 1997. MARTINEZ BLANCO, A.: Derecho Eclesiástico del Estado (vol. I), Madrid: Tecnos, 1994. VERA, F.P.: Derecho Eclesiástico I. Cuestiones fundamentales de Derecho Canónico, relaciones Estado-Iglesias y Derecho Eclesiástico del Estado, Madrid: Tecnos, 1990. VV.AA.: Tratado de Derecho Eclesiástico, Pamplona: Eunsa, 1994. Otras lecturas favorecedoras de la compresión, vid. BATES, M.S.: Religious liberty. An inquiry, New York: International Missionary Council, 1945. HENSEL, J.B. (ed.): Church, State, and Politics, Washington DC: The Roscoe Pound, 1981. MURRAY, A.V.: The State and the Church in a Free Society, Cambridge: Cambridge University Press, 1958. STOKES, A.P.: Church and State in the United States (vol. I-III)... op. cit. WOOD, J., et al. (ed.).: Church and State in Scripture. History and Constitutional Law, Waco: Baylor University Press, 1958. - Church and State, Waco: Baylor University Press, 1961. 
Fuente: elaboración propia (SÁNCHEZ-BAYÓN, 2007 y 16).

Se observa de este modo que, el pluralismo es conditio sine qua non para lograr el tránsito al Nuevo régimen, propiamente, porque así es posible apreciar la consistencia del avance de la autonomía del individuo frente a la comunidad, y en el ámbito de ésta, entre lo político-civil y lo religioso-cultural.

Figura 27.- De las Cartas otorgadas coloniales a las Constituciones estatales

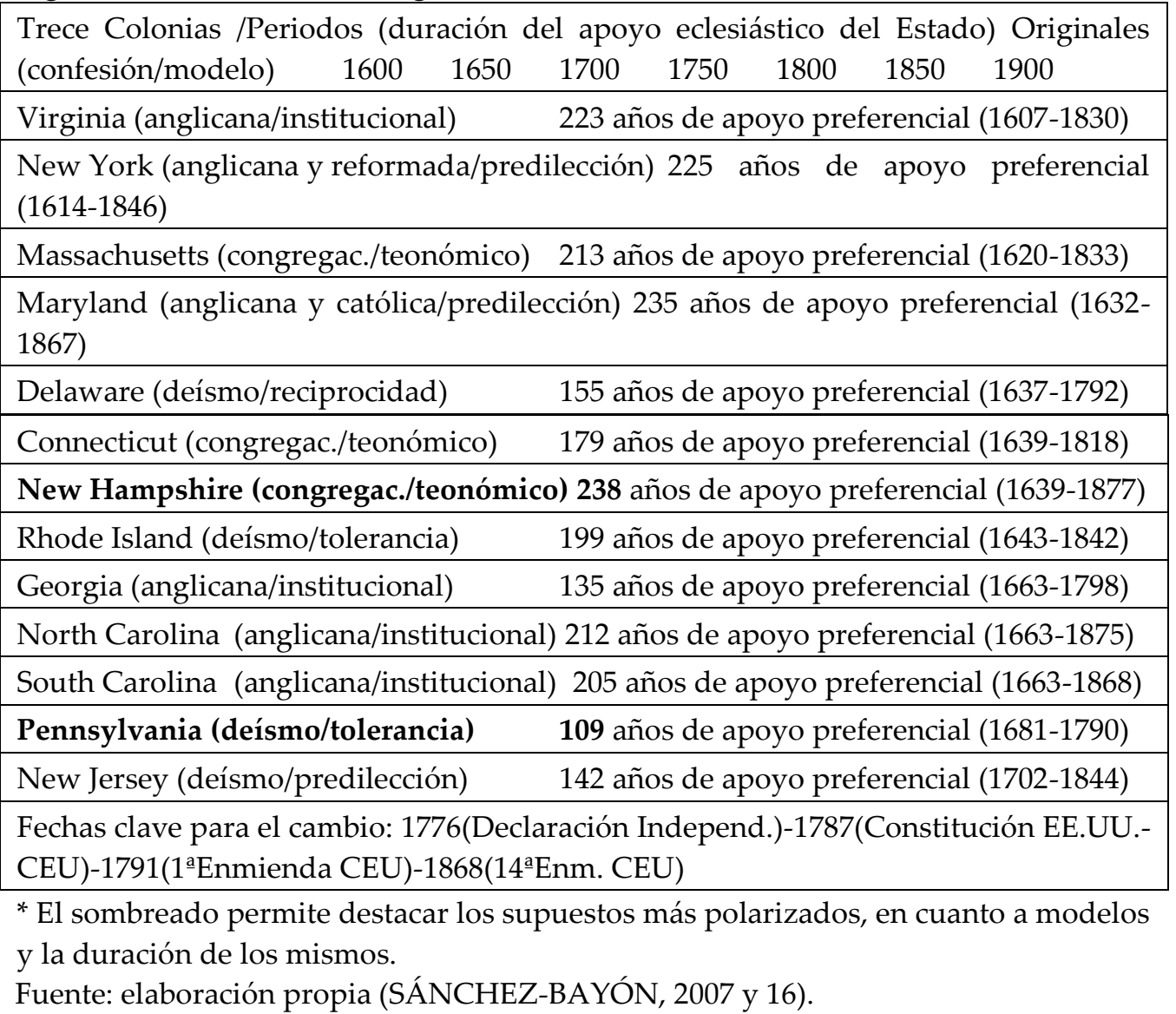


Se pone de relieve por esta vía que, según la confesión mayoritaria -que no exclusiva- de cada colonia, así ha sido su propuesta de modelos de relación (v.g. modelo institucional, teonómico, de predilección, de tolerancia), por lo que fruto del ensayo-error, se han ido fundando colonias (v.g. en las Provincias Medias, como New Jersey) y constituyendo Estados (v.g. en los Territorios del Oeste, como Transylvania, luego llamada Kentucky) cada vez más plurales y cercanos a la implantación de la libertad religiosa, que finalmente, es el modelo oficial para el conjunto de los EE.UU. (ello se logra de hecho y de derecho con la Catorce Enmienda, que mediante la control clause, se confiere la competencia última sobre la cuestión al Poder Federal).

Entre las inferencias habituales, se cuenta la fama de los colonos de Nueva Inglaterra, al considerárseles los inmigrantes pioneros de mayor status socioeconómico y grado de instrucción (v.g. con nociones de lectura y escritura, con oficios artesanales y liberales, etc.). Su única pretensión era lograr el reconocimiento religioso, que en Europa se les negaba, tratándoseles como minorías perseguibles ${ }^{209}$. En cambio, al llegar a América, asentarse y adquirir la condición de mayorías establecidas, la cuestión mutó: las víctimas se convirtieron, durante un tiempo, en victimarios (v.g. de Massachusetts tuvieron que huir cuáqueros, bautistas, judíos, católicos, etc.). Cierto es que, por entonces, había más propensión a la tolerancia (moderna) ${ }^{210}$ en la América colonial que en la Europa del momento (v.g. Maryland Toleration Act de 1649, frente a la English Toleration Act de 1689). Es predicable la

\footnotetext{
${ }^{209}$ Cabe descarse por su crudeza -y consiguiente inmigración de los vencidos y demás minorías locales-, en Gran Bretaña, la Rebelión del Norte (1569), entre católicos escoceses y anglicanos, y las Revoluciones Desmond (1569 y 1579), entre católicos irlandeses y anglicanos; en Europa central, las Guerras de Religión (1562-98), entre hugotes franceses y católicos, y la Guerra de los Treinta Años (161848), entre luteranos holandeses y católicos; etc.

${ }^{210}$ La tolerancia tradicional consiste en soportar el mal ajeno e innevitable, mientras que la moderna, tiende al respeto y reconocimiento, acercándose a la libertad.
} 
anterior afirmación, incluso, allí donde se llegó a establecer una comunión institucionalizada de Iglesia-Estado, como pasara en las Plantaciones sureñas. Ahora bien, se acometió bajo un sentido confesional moderno (utilitarista projurisdiccionalista, vid. infra figura 24 y 27). El problema, obstaculizador del tránsito de una tolerancia clásica a una moderna (y con ella, hacia la libertad), radicaba en la falta de realización efectiva de la pretendida emancipación del individuo frente a la comunidad, a la vez que el orden político-civil del religioso-cultural. Dicha falta de cristalización se debió al freno ocasionado por algunos resultados contraproducentes de la puesta en práctica del método de ensayo-error. Uno de los episodios más reaccionarios, de entre las experimentales prácticas neortodoxas del modelo teonómico, fue el sobresaliente caso de las ejecuciones por brujería de la figura siguiente.

Figura 28.- Fallas del ensayo-error en modelos relacionales ${ }^{211}$

\begin{tabular}{|c|c|c|}
\hline \multicolumn{3}{|c|}{$\begin{array}{l}\text { Condenados a la hoguera por delitos de brujería } \\
\qquad(E x 22,18 ; L v 20,27)\end{array}$} \\
\hline Condenados & Asentamientos & Año \\
\hline G. AYERS & Hartford, Connecticut & 1662 \\
\hline M. BARNES & Farmington, Connecticut & 1663 \\
\hline
\end{tabular}

${ }^{211}$ Hubo más de doscientos procesos (MATHER y su ensayo Late memorable providences relating to witchcraft and possesions, de 1689; BOULTON y su obra de dos volúmenes A compleat History of Magick, Sorcery, and Witchcraft, de 1715-16), sólo que registrados como penas de muerte por brujería, sólo constan en torno a 45 casos. Sus grandes instigadores fueron los Magistrados J. HAWTHORNE y J. CORWIN, el Gobernador T. DANFORTH, los Reverendos C. MATHER y J. COTTON. Cfr. DORSON, R.M.: America in Legend. Folklore from Colonial Period to the Present, New York: Pantheon Books, 1973, pp. 32 ss. STOKES, A.P.: Church and State in the United States (vol. 1)... op. cit., pp. 169 ss. Vid. BEHRINGER, W.: Witches and Witch Hunts: A Global History. Malden: Polity Press, 2004. BOYER, P., NISSENBAUM, S.: Salem Possessed: The Social Origins of Witchcraft, Cambridge: Harvard University Press, 1974. GODBEER, R.: The Devil's Dominion: Magic and Religion in Early New England. Cambridge: Cambridge University Press, 1994. Complement., vid. referencias de la nota anterior y anexos de HILLERS, S.: Derecho Constitucional y Régimenes Políticos: España, Gran Bretaña y EE.UU. (trad., vols. IIV), Pamplona: Aranzadi, 1993. 


\begin{tabular}{|lll|}
\hline G. BASSET & Fairfield, Connecticut & 1651 \\
\hline B. BISHOP & Salem, Massachusetts & 1692 \\
\hline G. BORROUGHS & Wells, Maine & 1692 \\
\hline M. CARRIER & Andover, Massachusetts & 1692 \\
\hline J. CARRINGTON (Joan) Wethersfield, Connecticut & 1651 \\
\hline J. CARRINGTON (John) Wethersfield, Connect. & 1651 \\
\hline M. CASTY & Topfield, Massachusetts & 1692 \\
\hline G. CORY & Salem, Massachusetts & 1692 \\
\hline M. CORY & Salem, Massachusetts & 1692 \\
\hline S. DASHTON & Boston, Massachusetts & 1692 \\
\hline Dorcas & Salem, Massachusetts & 1692 \\
\hline Elizabeth & Cambridge, Massachus. & 1647 \\
\hline M. ENGLISH & Boston, Massachusetts & 1692 \\
\hline P. ENGLISH & Boston, Massachusetts & 1692 \\
\hline A. FOSTER & Salem, Massachusetts & 1693 \\
\hline L. GILBERT & Windsor, Connecticut & 1654 \\
\hline M. GLOVER & Boston, Massachusetts & 1688 \\
\hline S. GOODE & Salem, Massachusetts & 1692 \\
\hline I. GOODE & Salem, Massachusetts & 1692 \\
\hline N. GREENSMITH & Hartford, Connecticut & 1692 \\
\hline R. GREENSMITH & Hartford, Connecticut & 1692 \\
\hline A. HIBBENS & Boston, Massachusetts & 1656 \\
\hline E. HOW & Ipswich, Massachusetts & 1692 \\
\hline G. JACOBS & Salem, Massachusetts & 1692 \\
\hline M. JOHNSON & Wethersfield, Connecticut & 1648 \\
\hline M. JONES & Charlestown, Massachus. & 1648 \\
\hline E. KNAPP & Fairfield, Connecticut & 1653 \\
\hline A. LAKE & Dorchester, Massachus. & 1651 \\
\hline S. MARTIN & Arresbury, Massachus. & 1692 \\
\hline R. NURSE & Salem, Massachusetts & 1692 \\
\hline S. OSBURNE & Salem, Massachusetts & 1692 \\
\hline M. OSGOOD & Salem, Massachusetts & 1692 \\
\hline A. PARKER & Salem, Massachusetts & 1692 \\
\hline M. PARKER & Andover, Massachus. & 1692 \\
\hline E. PROCTOR & 1692 \\
\hline J. PROCTOR & Salem, Massachusetts & 1692 \\
\hline A. PUDEATOR & Salem, & 1692 \\
\hline W. REDD & Massachets & \\
\hline
\end{tabular}




\begin{tabular}{|lll|}
\hline M. SANFORD & Hartford, Connecticut & 1662 \\
\hline M. SCOTT & Rowley, Massachusetts & 1662 \\
\hline S. WARDWELL & Andover, Massachusetts & 1662 \\
\hline S. WILDES & Topsfield, Massachusetts & 1692 \\
\hline J. WILLARD & Salem, Massachusetts & 1692 \\
\hline A. YOUNG & Windsor, Connecticut & 1647 \\
\hline \multicolumn{2}{|c|}{ Total: 33 mujeres, 10 hombres, 1 niño, 2 mascotas } \\
\hline
\end{tabular}

Fuente: elaboración propia (SÁNCHEZ-BAYÓN, 2007 y 16).

Al respecto, sólo retirar otro velo de confusión, muy extendido por los Estudios culturales sobrevenidos desde 1972 (de corte neomarxista -por ende proclive a los velos de confusión posmodernos-): es el relativo a la brujería y la Inquisición. El proceso abierto contra las brujas en el s. XVI (y que perduró hasta bien avanzado el s. XVII), es más propio del mundo protestante, y estaba dirigido contra aquellas mujeres autónomas, no sometidas a la comunidad y dispuestas a vivir fuera de la colonia correspondiente, con los riesgos que entrañaba. Sin embargo, no bastaba su ostracismo, que era visto como una amenaza a la supervivencia de la comunidad, de ahí la urgencia y necesidad de su persecución y exterminio. Así fue en las colonias de Nueva Inglaterra, donde no sólo se condenaron a muerte a adultos, sino también a niños y mascotas. Como ya se indicara (en la Parte inicial y en el cap. 4), el problema del colonialismo protestante era que no había división de poderes, sino que el colono los concentraba todos (a diferencia del modelo de conquista católico, en el que se distinguía entre el soldado, quiere era la espada y el representante del poder civil, y el religioso, que era la cruz y el representante del poder religioso). Además, desde los Estudios culturales, no se han molestado en estudiar a fondo la Inquisición, por lo que no distinguen entre la medieval (que preocupara a CALVINO) y la moderna (impulsada por los Reyes Católicos). Fue esta última la que llegó a América, y se 
basaba en un sistema jurídico muy avanzado para su tiempo (origen del moderno Derecho procesal): de un lado estaba la acusación, que solía estar representada por un dominico, y de otro la defensa, a cargo de un franciscano; se observaba el habeas corpus, pues el acusado debía estar presente y relativamente indemne, hasta la sentencia, que debía ser ejecutada por el poder civil. En definitiva, los procesos de Salem (población que recibe su nombre de Jeru-Salem [casa de paz]), conmocionaron a sus coetáneos, haciéndoles vivir en un temor reverencial a lo sobrenatural gestionado por los líderes locales, para primar la continuidad de la comunidad a toda costa-, que no se producía en Nueva España de entonces.

Por tanto, ¿qué inspiró los ensayos y errores para la consecución del tránsito de la tolerancia moderna a la libertad religiosa en los EE.UU., cambiando con ello su ICS? Sírvase a tener en consideración el siguiente mapa conceptual, con sus espectros de oscilación en el citado proceso.

Figura 29.- Dimensiones de la libertad religiosa ${ }^{212}$

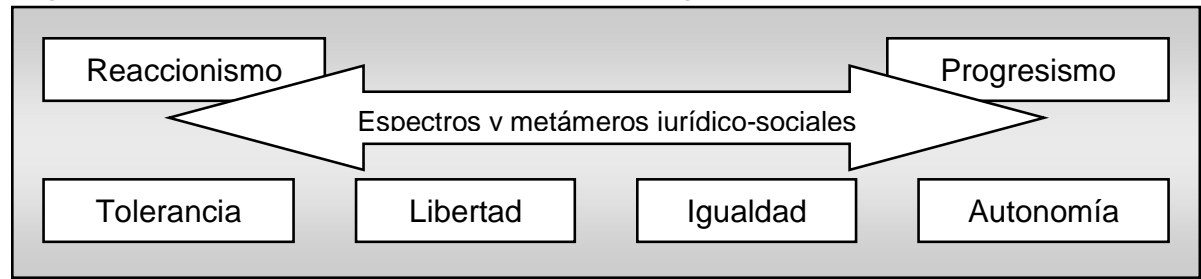

Fuente: elaboración propia (SÁNCHEZ-BAYÓN, 2007 y 16).

\footnotetext{
${ }^{212}$ Espectro en el sentido científico-natural, de distribución de ondas de un conjunto, o si se prefiere mapa de oscilación de tendencias.
} 
Entre las confesiones coloniales y sus modelos relaciones -tal y como se viene exponiendo-, se produjo un amplio espectro de propuestas, desde la obstinación dogmática del congregacionalismo heredero del calvinismo, partidario de fundar repúblicas teonómicas, hasta aquellas sectas de creencias más transgresoras, como los cuáqueros o los bautistas, defensores de la independencia entre el poder político y el religioso; sin olvidar los Church covenant [unión/pacto eclesiástico] ${ }^{213}$ del modelo institucional, que dejaba a la Iglesia Anglicana como paraguas de las diversas fórmulas locales -empero, su poder fue prácticamente testimonial, porque pronto se percibieron con recelo las directrices provenientes de su máxima autoridad, la Monarquía británica ${ }^{214}$. En términos generales, la tendencia evolutiva de todo este bagaje ha sido el largo camino hacia la tolerancia, pese a la concentración territorial según el tipo de fe (v.g. Maryland católica, Massachusetts congregacionalista, Virginia anglicana, etc.), lo que pudo ser causa de ciertos tratos de ventaja para la confesión dominante -pero por razones más culturales que políticas (a diferencia con Reino Unido de la Gran Bretaña o UK). Ahora bien, la propia transitoriedad y capacidad transformadora estadounidense (por su Americaness: con su paradoxología y su pragmatismo), ha hecho insostenible tal condición preferencial fáctica, pues se

213 Cada parroquia constituye una unidad administrativa autónoma (Parish Council [consejo parroquial]), aunque comprometida con el promotor colonial titular de la concesión, pudiendo ser incluso la propia confesión. Dicho pacto eclesiástico, resulta otra distinción con las manifestaciones europeo-continentales, pues no prima la homogeneización religiosa tradicional, ya que se trata de sectas emergentes (salvo el catolicismo, aunque también sujeto a transformación), sino que progresiva y programáticamente se busca la convivencia social basada en la tolerancia religiosa, y más tarde la libertad religiosa.

${ }^{214}$ Aunque se denomina anglicanismo, en realidad, en las colonias americanas, lo que proliferan son las main-line churches, como los presbiterianos y episcopalianos. Igualmente cierto, acerca del peculiar anglicanismo colonial es, que pese a su gran avance, gracias a la expansión colonial británica (v.g. fruto de asimilación de asentamientos vecinos, anexión de territorios de potencias europeas vencidas), tal situación es insostenible por razones materiales, ya que las colonias con mayor grado de tolerancia en la práctica, resultan las más productivas, al atraer a nueva fuerza de trabajo. 
ha plasmado, en diversas etapas, una oposición al respecto: el art. VI de la Constitución de los EE.UU. o CEU (1787, en vigor en 1788), exonerando del juramento y discriminación religiosa para el acceso a cargo público ${ }^{215}$; la Primera Enmienda (1789, en vigor en 1791), prohibiendo el reconocimiento de una religión oficial; la Catorce Enmienda (1866, en vigor en 1868), suprimiendo los preferencialismos eclesiásticos estatales por medio del control federal de la materia.

En resumidas cuentas, ante la amalgama de propuestas modélicas, es por ello que, en la figura previa, se advierte frente a la evolución acontecida: no ha sido sencillamente lineal y unívoca -sino bidireccional, tal y como señala la flecha principal-, pues ha estado sujeta a las oscilaciones coyunturales correspondientes (llegando a generarse ciclos de despertares y revitalizaciones). Eso sí, la tendencia general ha sido aperturista, hacia la consecución de un modelo respetuoso con el ámbito de autonomía interna del individuo, además de garante de la libertad religiosa, consagrada como la primera y gran libertad pública (entre su declaración de derechos o Bill of rights) del Ordenamiento estadounidense.

¿Cómo se aterrizaría la cuestión en términos y condiciones específicas? En planteamientos más concretos, relativos a las propuestas estadounidenses de modelos relacionales Iglesia-Estado (o si se prefiere, de esferas sociales: derechopolítica-religión), se ofrece a continuación una sinopsis de las seis tipologías de mayor índice de impacto en la academia estadounidense (hecho contrastado con los muestreos de ítems de las lecturas realizadas para este estudio, en las indexaciones del

\footnotetext{
${ }^{215}$ Se trata de un gesto de demostración de la superación de los vestigios británicos en las colonias, de sumisión y discriminatorios, derivados de las Act of Supremacy de Enrique VIII (1534) e Isabel I (1559).
} 
Journal of Church and State, así como, en las sugerencias complementarias a píe de página ${ }^{216}$.

a) Tipología de estructuras históricosociales (AHLSTROM, DESTRO, NOLL) ${ }^{217}$ : responde a una mirada compartimentada, según los antecedentes fundacionales (v.g. por bagaje cultural y motivos coloniales, circunstancias espacio-temporales de los asentamientos, etc.). Cabe distinguirse, al menos, tres grandes variantes modélicas. La primera, es la del teonomismo (Holy/Bible Commonwealth), en las colonias del noreste o Nueva Inglaterra. La segunda, es el institucionalismo o establecimiento oficial (confesionalismo moderno), en las colonias del sur o Plantaciones sureñas. La tercera, es el predileccionismo, con toques de reciprocidad, en las colonias del centro o Provincias medias.

b) Tipología de dinámicas transitivas (BERG, STOKES, WOOD) ${ }^{218}$ : ofrece una visión de conjunto, con diversas etapas, desde las influencias europeas, pasando por los matices coloniales y paterfundacionistas, hasta la consecución de una equidad pluralista. Se destaca, entonces, entre una fase inicial, plagada de reminiscencias europeas, por lo que se producen establecimientos y restricciones a disidentes.

\footnotetext{
216 Vid. NOONAN, J.T., GAFFNEY, E.Mc.: Religious Freedom. History, cases, and other materials on the interaction of religion and Government... op. cit. ELAZAR, D. J.: The American mosaic. The impact of space, time and culture on American politics, Bourder: Westview Press, 1994. OLSON, L.R., JELEN, T.G. (comps.): The religious dimension of political behavior. A critical analysis and annotated bibliography, Westport: Greenwood Press, 1998. OLSON, L.R., DJUPE, P.A. (comps.): Encyclopedia of American religion and politics, New York: Fact on File, 2003. TRIBE, L.H.: Constitutional choices, Cambridge: Harvard University Press, 1985.

217 Vid. AHLSTROM, S.E.: A religious History of the American people, New Haven: Yale University Press, 1972. ARIENS, M.S., DESTRO, R.A.: Religious Liberty in a Pluralistic Society, Durham: Carolina Academic Press, 1996 NOLL, M.A.: One nation under God? Christian faith and political action in America, San Francisco: Harper \& Row, 1988. - Religion and American politics. From Colonial Period to the 1980's... op. cit. - A History of Christianity in the United States and Canada... op. cit.

${ }^{218}$ Vid. BERG, T.C.: The State and Religion in a Nutshell, St. Paul: West Group, 2004. STOKES, A.P.: Church and State in the United States (vol. I-III)... op. cit. WOOD, J., et al.: Church and State in Scripture. History and Constitutional Law... op. cit. - Church and State, Waco: Baylor University Press, 1961.
} 
Seguidamente, se transcurre hacia la diversidad colonial, con sus preferencialismos, de variopintos parámetros de reciprocidad. En el periodo fundacional, por la vía constitucional, se implanta el moderno modelo de libertad (art. VI y Primera Enmienda de CEU). Finalmente, tras la Guerra Civil, se matiza el modelo actual mediante parámetros de igualdad, dando lugar a una cierta homogeneización de trato, afianzándose la pluralidad (Catorce Enmienda).

c) Tipología de horquillas tendenciales (ESBECK, SMITH) ${ }^{219}$ : es una visión de posibles escenarios según el énfasis dispuesto en cada coyuntura. Se ofrece así un intervalo de categorías relacionales interconectadas, lo que permiten oscilar entre ellas, sin causar quiebra en el sistema. El intervalo de ESBECK distingue cuatro categorías ${ }^{220}$ a) strict separtionism o independencia total, donde cada confesión tiene su propio Derecho y el Estado queda al margen; b) pluralistic separationist o autonomía plural, donde se produce una regulación estatal en materia de religión civil; c) nonpreferencialist o colaboracionismo, donde el Estado coopera de mantera general, por conceder especial atención al factor religioso, pero sin apoyar ninguna confesión concreta; d) restorationist o restauracionismo (confesional), donde tiene lugar una preferencia por una religión -la judeocristiana-, a la que concede un trato de favor, tanto en su reconocimiento de eficacia civil como en la asistencia religiosa pública. Por su parte, SMITH ofrece la siguiente posibilidad: a) theonomy o teonomía moral, donde el Derecho divino rige todos los aspectos jurídico-sociológicos de la comunidad; b) principled

\footnotetext{
${ }^{219}$ Vid. ESBECK, C.H.: "Five views of Church-State Relations in Contemporary American Thought", en Brigham Young University Law Review (vol. 2), 1986, pp. 371 ss. SMITH, G.S. (ed.): God and Politics. Four views on the reformation of civil government: Theonomy, Principled pluralism, Christian America, National confessionalism, Phillipsburg: Presbyterian and Reformed Publishing Co., 1989.

${ }^{220}$ Con arreglo a la traducción, no se atiende a un criterio de literalidad, sino de equivalencia con instituciones próximas en el Derecho Eclesiástico del Estado europeo-continental.
} 
pluralism o pluralismo ordenado, donde la diversidad asegura el mutuo respeto; c) Christian America o cristianismo secular, donde la dogmática ha desaparecido para dar paso a fórmulas pragmáticas de convivencia, basada en valores humanistas universalizables; d) Nacional confessionalism o confesionalismo nacional, donde las fórmulas religiosas tradicionales son sustituidas por un patriotismo, que dota de vigencia el discurso del compromiso social y la consecución del bienestar general.

d) Tipología de permeabilidad al cambio (BETH, CURRY) ${ }^{221}$ : se da una disponibilidad al cambio según el tipo de comunidad y su nivel de interacción (en su seno y en su proyecto exterior). En tal sentido, BETH, ofrece la siguiente propuesta: a) Complete separation of Church-State [completa separación de IglesiaEstado], como en Rhode Island; b) No established Church and laws infavorable to Catholics and non-Christians [sin iglesia oficial pero con leyes desfavorables a católicos y no cristianos], como en New Jersey, Pennsylvania, Delaware; c) Congregational Church establishments [iglesia congregacional oficial], como en Massachusetts, Connecticut, New Hampshire; d) Legal Anglican establishments [iglesia anglicana oficial], como en Virginia, the Carolinas, Georgia, New York, Maryland. Por su parte, CURRY, proporciona otra categorización, no por unidades administrativo-territoriales sino por comunidades: a) Congregacionalist Churches [iglesias congregacionalistas], como los puritanos, los bautistas, los cuáqueros, los metodistas, etc., en Nueva Inglaterra -también conocida como Bible Commonwealth; b) Church of England [iglesia de Inglaterra], como los anglicanos, los presbiterianos y los episcopalianos, en las Plantaciones sureñas y

${ }^{221}$ Vid. BETH, L.P.: The American Theory of Church and State, Gainesville: University of Florida Press, 1958. CURRY, T.J.: The First Freedoms. Church and State in America to the passage of the First Amendment, New York: Oxford University Press, 1986. 
algunas Provincias medias -de forma tardía y con fórmulas especiales de Ecclesiastical Law, como en Maryland y el reconocimiento de estatus jurídico especial a los Jesuitas, gracias al padre T. COPLEY; c) Dissidents [disidentes], como los cuáqueros, los judíos, los mormones, etc., en las colonias y demás organizaciones territoriales tardías.

e) Tipología de valores y doctrinas (EIDSMOE, REICHLEY) ${ }^{222}$ : aporta una especial atención al sistema de creencias dominante en cada colonia, pues el mismo, influye en la predisposición de los integrantes de una comunidad a la consecución de una mayor integración (v.g. modelo teonómico y autoritario) o autonomía (v.g. modelo deísta y humanista). La oferta de EIDSMOE, al respecto, consiste en: a) Calvinism [calvinismo], que habilita la instauración de la integradísima comunidad mecánica; b) Puritanism [puritanismo], que dispone hacia la cuasi-permeable comunidad semi-mecánica (menos integrada y algo más abierta a cambios progresivos y programáticos); c) Deism [deísmo], que es el antecedente inmediato de la sociedad abierta y la comunidad orgánica (mucho más autónoma y dispuesta a avances constantes). Complementariamente, REICHLEY, proporciona una categoría más centrada en el ámbito de los principios éticos (valores para la acción social): a) Egoism [egoísmo], es el valor social dominante, por el que sólo se atiende a las demandas del individuo, bajo propuestas libertarias; b) Authoritarism [autoritarismo], únicamente se reconocen las demandas del grupo, en su formato comunitarista; c) Monism [monismo], donde todo tiende hacia la transcendencia, bajo una sola cosmovisión (individuo, comunidad, religión, política, etc., se consideran un único impulso); d) Idealism

222 Vid. EIDSMOE, J.: Christianity and the Constitution. The faith of our Founding Fathers, Grand Rapids: Baker Books, 1987. REICHLEY, A.J.: Religion in American Public Life, Washington DC: The Brookings Institution, 1985. 
[idealismo], se diferencia de los demás porque la transcendencia y la comunidad están combinadas, atendiendo a posturas colectivistas; e) Personalism [personalismo], combina transcendencia e individuo, por lo que las propuestas son de corte individualista; f) Civil Humanism [humanismo cívico], pone en conexión al individuo y al grupo, siguiendo unas directrices materialistas; g) Theist-Humanism [teísmo-humanista], es la propuesta englobadora, donde se distinguen todos los elementos, aunque operan armónicamente.

f) Tipología de fuerzas e hitos (LIPPY, MELTON, WEBER) ${ }^{223}$ : constituye una percepción centrada en el impacto de los movimientos sociales, tanto en los despertares (a cargo de las bases sociales) como en las revitalizaciones religiosas (a cargo de las elites de poder). Destacan sinergias tan influyentes en el devenir estadounidense -algunas ya citadas-, como el movimiento de Gospel Propagation [propagación de los Evangelios], Holiness and Perfection [sacralidad y perfección], Millennialism and Adventism [milenarismo y adventismo], Social Reforms and Crusades/Campaigns [cruzadas y reformas sociales], Restorationism and the StoneCampbell Tradition [tradición de Stone-Campbell y restauracionismo], Communitarianism [comunitarianismo], Sabbatarianism [sabatarianismo], Nineteenth-Century Evangelicalism [evangelismo decimonónico], Christian Science and Harmonialism [ciencia cristiana y armonicalismo], Social Christianity [cristianismo social], Pentecostalism [pentecostalismo], Fundamentalism [fundamentalismo], Conservative and Charismatic Developments of the Later

\footnotetext{
${ }^{223}$ Vid. LIPPY, C.H., WILLIAMS, P.W. (eds.): Encyclopedia of the American Religion. Studies of traditions and movements (vols. I-III)... op. cit. MELTON, J.G.: The Encyclopedia of American Religions, Detroit: Gale Research Inc., 1989. QUEEN, E.L., et al.: The encyclopedia of American Religious History (vols. 1-2), New York: Facts of File, 1996. TYLER, A.F.: Freedom's ferment. Phases of American Social History to $1860 \ldots$ op. cit. WEBER, P, JONES, W.L.: U.S. Religious interest groups: institucional profiles, Westport: Greenwood Press, 1994.
} 
Twentieth-Century [conservadurismo y carismaticismo], Ecumenical Movement [movimiento ecuménico], etc.

En añadidura a las grandes tipologías marco mencionadas, desde mediados de la década de 1990, ha ido ganando reconocimiento autónomo una novedosa fórmula complementaria, que versa sobre la condensación de las anteriores, aplicando sus propuestas a la geopolítica (HUNTINGTON, WHITEHEAD) 224. Entre sus centros de investigación de alto rendimiento o think-tanks, referentes de otras muchas instituciones académicas y consultores de organismos públicos, destacan el Weatherhead Center for International Affairs-Harvard University o el J.M. Dawson Institute of Church-State Institute-Baylor University225.

Todo lo visto se codifica como sigue a continuación.

${ }^{224}$ Vid. HUNTINGTON, S.P.: El orden político en las sociedades en cambio (trad.), Barcelona: Paidos, 1996. - El choque de civilizaciones y la reconfiguración del orden mundial (trad.), Barcelona: Paidos, 1997. ¿Quiénes somos? Los desafíos a la identidad nacional estadounidense (trad.), Barcelona: Paidos, 2004. WHITEHEAD, J.W.: Iglesia y Estado en las Américas (trad.), La Paz: Instituto Rutherford, 1994.

${ }^{225}$ Son muchos más los centros (v.g. Berkley Center for Religión, Peace \& World Affairs-Georgetown University), pero los ejemplos citados son referentes regionales de consolidada trayectoria. Además, en sendos casos se ha disfrutado de una productiva experiencia en su seno. En el WCFIA, cuya labor primordial se centra en el seguimiento y mediación en conflictos internacionales -y nacionales internacionalizados-, se participó en un "Dialogue Group of International Conflict-Resolutions" (dirigido por P. SCHULTE y P. STEINER), donde se contó con la inestimable participación de académicos africanos y asiáticos, Ex altos cargos de la CIA y del Departamento de Estado de los EE.UU., negociadores e investigadores europeos, etc. En el ICSS, al disponer de la condición de VisitingScholar, la participación fue mucho más diversa y con mayor grado de iniciativa. 
Figura 30.- Principios rectores (hipostasía) del modelo relacional estadounidense ${ }^{226}$

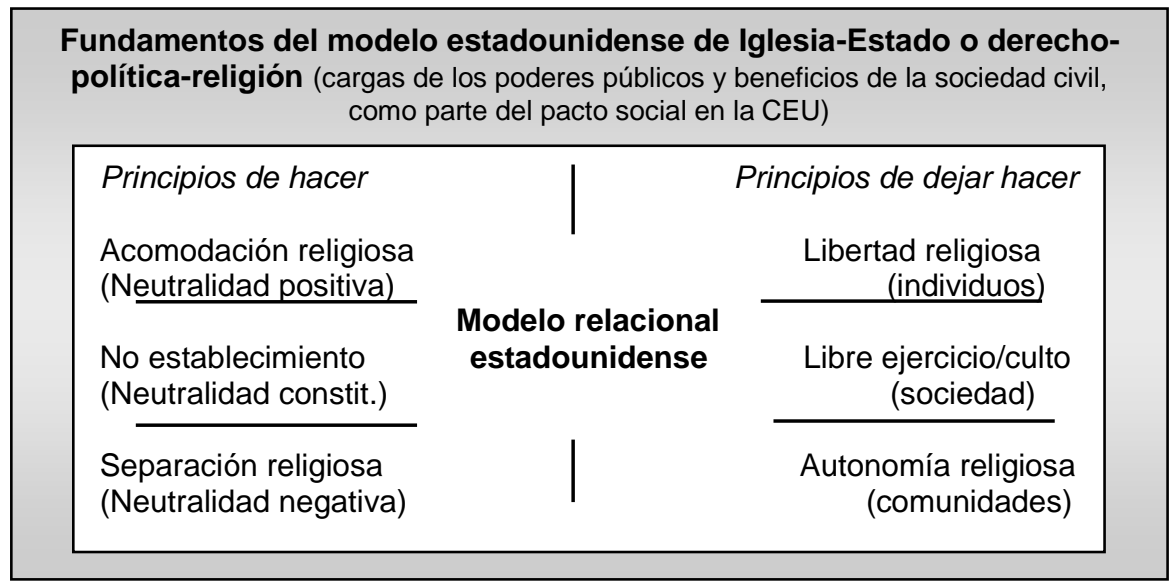

Fuente: elaboración propia (SÁNCHEZ-BAYÓN, 2007 y 16).

En realidad, dentro de los parámetros señalados, entre los estadistas de los EE.UU., se ha reconocido algún principio rector más a tener en consideración (v.g. no coerción, no discriminación, pluralidad, igualdad, refrendo). Sin embargo, los citados

226 Vid. CHOPER, J.: Securiting Religious Liberty. Principles for Judicial Interpretation of the Religion Clauses, Chicago: The University of Chicago Press, 1995. COOKSON, C.: Regulating Religion: The Courts and the Free Exercise Clause, New York: Oxford University Press, 2001. CORD, R.L.: Separation of Church and State. Crisis in the American Constitutional system, Boston: Northeastern University, 1982. CURRY, T. J.: The First Freedom. Church and State in America to the passage of the First Amendment, New York: Oxford University Press, 1986. DREISBACH, D.: Real threat and mere shadow. Religious Liberty and the First Amendment, Westchester: Crossway Books, 1987. DREISBACH, D., et al (eds.): The Founders on God and Government, Lanham: Rowman \& Littlefield, 2004. FARBER, D.A.: The First Amendment, New York: Foundation Press, 1998. GARVEY, J.H., et al.: The First Amendment. A reader, St. Paul: West Publishing Co., 1992. SMITH, S.D.: Getting Over Equality: A Critical Diagnosis of Religious Freedom in America. New York: New York University Press, 2001. VAN ALSTYNE, W.: First Amendment. Cases and Materials, New York: Foundation Press, 1990. - The American First Amendment in the Twenty-First Century. Cases and materials, New York: Foundation Press, 2002. WITTE, J.: Religion and the American Constitutional Experiment: Essential Rights and Liberties, Boulder: Westview Press, 2000. YARNOLD, B.: Religious Wars in the Courts I. The lower federal courts and the US Supreme Court in Religious Freedom cases 1970-1990, Hintington: Nova Science Publishers, 1999. - Religious Wars in the Courts II. Who were the litigants in the US Courts, Religious Freedom cases 1970-1990, Hintington: Nova Science Publishers, 2000. 
y a comentar de inmediato, son los que muestran sintéticamente las aristas elementales de la problemática relativa a la juricidad -según el nivel de libertad frente al poder- del modelo relacional estadounidense de Iglesia-Estado:

a) Acomodación religiosa: es un principio de hacer, ya que los poderes públicos están obligados a adoptar medidas para su implantación (reconocimiento, protección y promoción). Se considera de neutralidad positiva porque exige disposiciones encaminadas a la observación y ordenación de las manifestaciones religiosas sociales existentes. Se viene en identificar este principio con la metáfora del puente de comunicación entre Iglesia y Estado o derecho-políticareligión (sus referentes son MADISON y FRANKLIN) ${ }^{227}$.

b) Separación religiosa: igualmente, se trata de un principio de hacer, con similares cargas para los poderes públicos, pero de signo negativo, puesto que lo que se exige es impedir la conformación de nexos sobrevenidos y dolosos -evitando la instrumentalización para la superposición de poderes. Como metáfora, se recurre al famoso muro de separación entre Estado y religión (WILLIAMS y JEFFERSON $)^{228}$.

c) Libertad religiosa: en términos reduccionistas, se atiende como principio de dejar hacer, que informa los derechos y libertades de los individuos $\mathrm{y}$,

\footnotetext{
227 En la correspondencia entre ambos Padres fundadores y sus discusiones con otros más radicales (v.g. JEFFERSON). Vid. KURLAND, P.B., LERNER, R.(ed.): The Founders' Constitution (vols. I-V), Indianapolis: Liberty Fund, 1987. STOKES, A.P.: Church and State in the United States (vol. I)... op. cit. ${ }^{228} \mathrm{El}$ antecedente de la metáfora lo fija WILLIAMS (The bloody tenant, of persecution, for cause of conscience, discussed, in a conference between truth and Peace de 1644, más Charter of Rhode Island, 1663), aunque alcanza su máxima difusión y relevancia con JEFFERSON (ya como Presidente), en su carta a los bautistas de Connecticut ("letter to the Danbury Baptist Association", 1802). Vid. KURLAND, P.B., LERNER, R. (eds.): The Founders' Constitution (vols. I-V)... op. cit. NOONAN, J.T., et al.: Religious Freedom. History, cases, and other materials on the interaction of religion and Government... op. cit.
} 
sinalagmáticamente, las obligaciones de los poderes públicos. Su silogismo, es el bíblico sobre el libre albedrío (sus defensores son PENN y MASON) ${ }^{229}$.

d) Autonomía religiosa: se concibe como principio de dejar hacer, reconocido para personas colectivas (corporativas o no). No se prevé tanto para cualquier minoría o grupo, sino para aquellos de carácter religioso organizado, con clara vocación de asistencia social (v.g. movimientos u organizaciones de fe, de caridad, etc.). De tal modo, dichos grupos, gracias a su autonomía, disponen de la libertad suficiente de escoger el traje legal preferido (v.g. iglesia, fundación). Para este principio, el referente iconoclasta más determinante es la Magna Carta de Juan Sin Tierra (1215)230, así como, el epistolario de San Pablo (matizándose el imperativo de separación de órdenes).

e) No establecimiento y libre ejercicio/culto: son los principios constitucionales por excelencia (dando lugar a las dos cláusulas de la Primera Enmienda, (non)establishment $\mathcal{E}$ free exercise clauses), porque aportan las bases de la pluralidad del Nuevo régimen, además de fijar explícitamente los límites superior e inferior del sistema, garantizándose en consecuencia la tolerancia social y el respeto del libre examen (de conciencia). Su plasmación se vincula a la parábola cristiana del tributo César-Dios (esencia del dualismo cristiano) ${ }^{231}$.

${ }^{229}$ En sus Cartas coloniales (WILLIAMS y PENN), y en el Estatuto de Virginia (MASON). Vid. KURLAND, P.B., LERNER, R. (eds.): The Founders' Constitution (vols. I-V)... op. cit. NOONAN, J.T., et al.: Religious Freedom. History, cases, and other materials on the interaction of religion and Government... op. cit.

230 "La Iglesia de Inglaterra será libre, y disfrutará plenamente de derechos y libertades inviolables" (Capítulos 1 y 10 de la Magna Carta). Vid. NOONAN, J.T., et al.: Religious Freedom. History, cases, and other materials on the interaction of religion and Government... op. cit. STOKES, A.P.: Church and State in the United States (vol. I)... op. cit.

231 "Dad al cesar lo que es del cesar y a Dios lo que es de Dios", Mt 22:21, Mc 12:17, Lc 20:25. Vid. McCONNELL, M.W., et al.: Religion and the Constitution, Githersburg: Aspen Law \& Business, 2002. 
En suma, las disquisiciones expuestas acerca de los principios rectores del modelo relacional, encuentran su cohesión en el marco constitucional, donde se fijan los límites superior e inferior (free exercise $\mathcal{E}$ (non)establishment clauses) de una interacción evidente -casi palpable-232. Se concede, dentro de los límites tasados, un amplio margen de acción entre los criterios operativos principales de integración $v$. autonomía, y de separación v. acomodación (más algún fundamento de Teología política ya visto). En definitiva, la $\mathrm{CEU}$, por razones paradójicas, pragmáticas y posjudeocristianas, impele a la separación institucional (evitándose el establecimiento de una concreta iglesia oficial de Estado), a la vez que promueve las medidas públicas para el fortalecimiento de la fe (en la oposición abierta a los tests religiosos -reconociendo, en consecuencia, la objeción de conciencia; facilitándose el libre culto- en conexión con el resto de derechos y libertades de la declaración de derechos (Bill of rights), como la libertad de expresión, reunión, etc.). Tal mandato constitucional ha sido perfilado posteriormente por las elites de poder estadounidense, con preeminencia de sus Presidentes y Magistrados del TSEU, quiénes según las coyunturas -y cierto voluntarismo-, los menos, pensando en su legado, han dedicado sus esfuerzos a erigir un ficticio muro divisorio, para evitar presuntos conflictos sociales, mientras que la gran mayoría de estadistas, en pro de la estabilidad social y respeto por la tradición, han tendido diversos puentes de

NOONAN, J.T., et al.: Religious Freedom. History, cases, and other materials on the interaction of religion and Government... op. cit.

${ }^{232}$ Como se viene llamando la atención, las interacciones entre Estado y religión en los EE.UU. son innegables, por fehacientes en la realidad cotidiana, lo que se ha traducido jurídicamente en el reconocimiento de: a) libertades públicas y derechos fundamentales en materia religiosa, b) pluralidad y autonomía confesional social, c) un régimen especial para las organizaciones religiosas (v.g. IRS, Zoning Law), d) reconocimiento civil de la asistencia socio-religiosa prestada, etc. 
comunicación, más o menos holgados: téngase en cuenta que los argumentarios para favorecer uno $\mathrm{u}$ otro principio rector del modelo relacional sincrético estadounidense ha dependido de los intereses de la facción que esté detrás ${ }^{233}$. De ahí la exigencia de prestar mayor cuidado a la diferenciación entre la interpretación, la construcción y la traducción, desde las coloniales Blue Laws y la herencia de los padres fundadores, hasta el vigente modelo relacional.

Queda por tratar cómo ACT ha influido en los EE.UU., dando como resultado un federalismo mesiánico: ¿Cómo surge un entorno emergente basado en un sacropacto social moderno de gobierno que conduce a una mayor unión de progreso, como es el federalismo, donde cabe distinguirse entre lo individual y lo comunitario, lo civil y lo religioso, lo temporal y lo eterno, etc.? La raíz está -como se viene indicando- en la particular estadounidización (Americaness, vid. infra), que se acomete de la tradición sagrada (judeocristiana) y profana (grecorromana) mediante la teología políticojurídica autóctona, cuya expresión principal es ACT, que permite interpretar y construir la percepción general de la realidad socio-cultural y sus instituciones, además de legitimar todo ello. La ACT ha facilitado el cimiento de las bases del federalismo moderno (partiendo de planteamientos teológico-políticos, al entenderlo como pacto de gobierno del pueblo de Dios, con su bendición) $)^{234}$ : el federalismo

\footnotetext{
${ }^{233}$ Por ejemplo, desde el discurso bautista se promueve muy activamente la separación del Estado y la Iglesia, que no la religión (recuérdese que los bautistas son una confesión de corte congregacionalista -también llamados sectarians-, luego poco institucionalizada, como en cambio se suele entender de aquellas otras a las que se califican de iglesia, como los anglicanos y católicos). Aunque a diferencia del diagnóstico apriorístico a esperar, la razón se encuentra más en la voluntad de debilitar la presencia del Poder federal, que sería a quién le correspondiera la política (propia o de supervisión) de acomodación religiosa. Luego al lograr el repliegue del Estado, se procura por tal vía una mayor presencia de la religión, que es justo lo opuesto a lo predicado formalmente.

${ }^{234}$ Vid. SÁNCHEZ-BAYÓN, A.: "Revitalizaciones religiosas postmodernas en América y sus riesgos para la democracia y los derechos humanos" ... op. cit. - "<<Crimen y castigo $>>$, ¿literatura o realidad jurídica? Retos del camino hacia la democracia y la paz", en Revista de Ciencias Jurídicas-Universidad de Costa Rica (nํ 108), 2005.
} 
alude hoy a la forma del moderno Estado compuesto y descentralizado, fruto de un pacto del pueblo soberano para alcanzar una mayor unión. A la luz de la ACT es, además, el gran pacto social del pueblo, bendecido con la libertad y prosperidad, buscando una unión perfecta (vid. supra Preámbulo CEU, Pledge of allegiance). De tal suerte, lo que estaba separado (las trece colonias), quedan unidas por una entidad federal, liderada por un Presidente mesiánico (a modo de las doce tribus de Israel, cuando fundaron su gran Reino unificado y homónimo). Luego el pacto es al mismo entre los hombres, para su organización y progreso social (alianza menor), a la vez que es bendecido por Dios (alianza mayor, que es renovada periódicamente, vía despertares y revitalizaciones).

Antes de proseguir, se cree pertinente proporcionar unas mínimas consideraciones relativas a los mimbres con los que se teje el ACT, dando como resultado cestos como el federalismo estadounidense. Se pretende así ayudar a comprender mínimamente los fundamentos deductivos e inductivos de la cuestión, mientras se aclara cómo se ha ido entrelazando realidad y retórica, desde sus reminiscencias de la Antigüedad, hasta la incubación europea de la Modernidad, pasando por su recepción y transformación en la América colonial, manifestándose en su plenitud en la configuración nacional estadounidense y su novus ordo seclorum (vid. supra ACR). Tales consideraciones han de servir para comprender, en consecuencia, por qué el federalismo es entendido como el gran pacto fundacional identitario estadounidense -más allá de la configuración de su Estado-, sirviendo para reconocer, proteger y promocionar la creencia social en su bienestar interior y su liderazgo exterior. Para vislumbrar lo mencionado, se ofrece seguidamente una figura a modo de mapa conceptual sintentizador de buena parte de las nociones a desarrollar posteriormente. 
Figura 31.- Referencias articuladoras de ACT: "God's manifesto \& dispensations" 235 Un pueblo elegido y sus mesías: Pactos con Adán (Gn. 3), Noé (Gn. 6 y 9), Abraham (Gn. 12, 15 y 17), Moisés (Ex. 19), etc. * Conversión y Nueva Alianza: Jr. 31 y 32, confirmado por Mc. 14, Mt. 26, Lc. 22, 1Co. 11, Heb. 8 y 9.

Una misión: Pactos de evangelismo social (Dt. 10, Is. 1, Jr. 31, Sal. 119, etc.); Mandamientos (Ex. 19, Dt. 5), etc.

Un lugar: Paraíso terrenal o Nueva Jerusalén (Gn. 3 y 12, Sal. 122, Is. 2 y 54, Mt. 5, Lc. 6), etc.

Unas reglas (dualismo cristiano): convivencia de lo civil y lo religioso (Mc. 12; Lc. 20; Mt. 22; etc.); la doble obligación cristiana (Hch. 5 y 25, Rm. 5, etc.).

Otros Pactos (self-righteouness, civilazing sense)

Cargas y factores: temor, piedad, tolerancia, et al. (Dt. 5, Jos. 11, Sal. 34), etc.

Dispensas/dispensaciones o muestras renovadas de la gracia de Dios (para guiar a su pueblo, vid. Génesis, Éxodo, Levítico, Deuteronomio, Jueces, Reyes Eclesiastés, etc.): la inocencia con Adán en el Edén, la conciencia desde la caída hasta Noé, el gobierno humano desde Noé a Abrahán, la promesa desde Abrahán (como padre de las naciones de la tierra), la ley desde Moisés hasta Jesús, la gracia desde Jesús (y hasta su regreso), y el reino milenial o novus ordo seclorum estadounidense.

Organización: eclesiología federal de las 12 tríbus a las diócesis eclesiásticas (Génesis, Hch. 15)

Mandatos: Teología de la dominación o Dominalism (Gn. 1) * Riesgo de Teonomía.

Expresiones interconectadas:

1.- Covenant Theology o teología pactista:

a) Dispensional (renovación y continuidad del pacto según coyunturas): supone realización de la providencia y materialización del destino manifiesto de su pueblo (v.g. Destino manifiesto y Federalismo, Presidencialismo, etc.)

b) Casuístico (pacto integrador cada vez que se necesite): supone ciclos voluntaristas (v.g. Square Deal de T. ROOSEVELT, New Deal de F.D. ROOSEVELT, Fair Deal de H.S. TRUMAN, New Frontier de J.F. KENNEDY, Great Society de L. JOHNSON, New Coventant de B. CLINTON, etc.).

* Alianzas: a) Mayores (Dios con su pueblo, que en Modernidad son los estadounidenses:

235 Se trata de cuestiones que se reconocen en la formulación del Federalismo (v.g. Preámbulo de la Constitución de EE.UU.) y sirven de fundamento para estrategias derivadas de implementación, tales como Manifest Destiny y happiness pursuit, o actitudes como self-righteouness y civilazing sense. Vid. BELLAH, R.N.: Beyond beliefs, New York: Harper \& Row, 1970. - The broken covenant: American Civil Religion in the Time of Trial, New York: The Seabury Press, 1975. EIDSMOE, J.: Christianity and the Constitution. The faith of our Founding Fathers, Grand Rapids: Baker Books, 1987. HANLEY, M.Y.: Beyond a Christian Commonwealth, Chapel Hill: The University of North Carolina Press, 1994. HUGHES, R.T.: Myths America Lives By, Urbana: University of Illinois Press, 2003. NOONAN, J.T., GAFFNEY, E.Mc.: Religious Freedom. History, cases, and other materials on the interaction of Religion and Government... op. cit. WOOD, J.E. (ed.): Religion and Politics... op. cit. 
Washington como su Moisés, Adams como su Salomón, Jefferson como su profeta, Lincoln y Kennedy como sus mártires, Monroe-Polk-Roosevelt como su David, etc.); b) Menores (padres fundadores -reverendos-pastores, vid. supra 9- con su pueblo: federalism de Washington, unionims de Lincoln, new deal de Roosevelt, great society de Johnson, new frontier de Kennedy. Etc.)

2.- Teología dogmática:

a) más secular: American way of life, Federalisms, Manifest Destiny, etc.

b) menos secular: Theonomy (desde los Christian Reconstruction Movements hasta los Dominion Theology Movements)

3.- Teología cultural: histórica (providentialism), narrativa (redenptional preaching style), natural (creationism), etc.

Fuente: elaboración propia (SÁNCHEZ-BAYÓN, 2007 y 16).

Vistas las referencias hipostásicas, que fundamentan de manera variopinta el $\mathrm{ACT}$, y su proyección sobre el federalismo, cabe cuestionarse entonces -tal como se viene anunciando- su dimensión fenomenológica, relativa a: cuál fue su origen histórico; y cómo dichas referencias teológico-políticas ha ido informando su desarrollo en los EE.UU. El federalismo, en sentido moderno y como manifestación histórica, se encuentra circunscrito al periodo abierto tras la Reforma del s. XVI, en el ámbito anglo-germánico ${ }^{236}$ (frente al Contrarreformismo regalista mediterráneo) ${ }^{237}$. Tiene sus puntos de arranque en las propuestas centro-europeas sustitutivas del desgajado Sacro Imperio Romano Germano (v.g. República de los Siete Países Bajos Unidos

236 Resulta más correcto hablar de Reformas Protestantes Cristianas (cuius regio, eius religio), distinguiéndose entonces dos concepciones -que terminan entrecruzándose-, las de corte comunitarista (luteranos, calvinistas, zwinglianos, menonitas), frente a las jurisdiccionalistas (anglicanos, escandinavos).

${ }^{237}$ Vid. DE LA HERA, A.: "Evolución de las doctrinas sobre las relaciones entre la Iglesia y el poder temporal", en VV.AA.: Derecho Canónico, Pamplona: EUNSA, 1974. DE LA HERA, A., SOLER, C.: "Historia de las doctrinas sobre las relaciones entre la Iglesia y el Estado", en VV.AA.: Tratado de Derecho Eclesiástico, Pamplona: EUNSA, 1994. LOMBARDIA, P., OTADUY, J.: "La Iglesia y la comunidad política", en VV.AA.: Manual de Derecho Canónico, Pamplona: EUNSA, 1988; complement., vid. YETANO, A.: Las iglesias cristianas en la Europa de los siglos XIX y XX, Madrid: Síntesis, 1993. 
-también designada por algunos autores como Belgium Foederatum-, 1579-1795; Confederación Helvética, 1648-1798), con repercusión considerable en UK y sus colonias americanas. Sus vías de influencia, principalmente, fueron ${ }^{238}$ :

a) De intelectuales británicos en los Países Bajos (exiliados en tiempos convulsos, buscando un mayor clima de apertura), como el preeminente caso de LOCKE (componiendo su Ensayo y Carta(s) sobre la tolerancia, su La razón de ser del cristianismo según resulta de las Sagradas Escrituras, sus Tratados de gobierno civil, etc.), sirviendo de conexión entre el pensamiento Whig [liberal-conservador o conservadurismo moderno] y la Freemasonry o masonería especulativa ${ }^{239}$.

b) De confesiones progresistas puritanas británicas en los Países Bajos (ídem), como el supuesto señero de los pilgrims [(padres) peregrinos], establecidos más tarde en las colonias del área de Nueva Inglaterra, llegando a jugar un papel fundamental en el congregacionalismo estadounidense (con su aportación a la Teología política del país: dissistablishment, covenant, etc.).

\footnotetext{
238 Para una mayor profundización del tema, véase el vol. V, parte 5, en BURR, N.R., et al (eds.): A critical bibliography of religion in America, Princeton: Princeton University Press, 1961.

${ }^{239}$ Hasta el s. XVII, la masonería era de corte operativo: relativa a los oficios liberales de la época, como el de constructor de catedrales, ya que disponían de autonomía de normas y movimiento, organizándose entorno a Collegia o colegios profesionales. A partir de entonces, la masonería empieza a ser de corte especulativo: abierta al librepensamiento, especialmente de filósofos naturales o experimentales (la Nueva Filosofía comprendía los campos de la medicina, la mecánica, la navegación, la geometría, etc.), juristas, literatos (políticos y económicos), et al., organizándose ahora en el seno de Reales Sociedades/Academias -en los EE.UU., otros focos que continúan la tradición son los Colleges y sus Fraternities. Vid. BULLOCK, S.C.: Revolutionary Brotherhood. Freemasonry and the transformation of the American Social Order, 1730-1840, Chapel Hill: The University of North Carolina Press, 1996. DUCHANE, S.: The Masonery, Köln: Book Laboratory, 2007. MARTIN-ALBO, M.: La masonería. Una hermandad de carácter secreto, Madrid: LIBSA, 2003. NEWTON, J.F.: The Builders. Lexington: The Supreme Council, 1973. ROBERTS, A.E.: Freemasonry in American History, Richmond: Macoy Publishing, 1985.
} 
c) De asentamientos coloniales holandeses en América, como el caso de New York, conocido inicialmente como Novum Belgium o New Netherlands [Nuevos Países Bajos]. Sus primeros establecimientos datan de 1611-14, pasando a ser una provincia más de la República de los Siete Países Bajos Unidos, en 1624. En 1664, Carlos II de Inglaterra se anexiona los territorios, volviendo a ser parte de los Países Bajos, durante la Guerra Holandesa-Inglesa de 1672-74, a cuyo fin, regresan a la corona británica, convirtiéndose en New York. Igualmente, los holandeses Van DEN ENDEN y PLOCKHOY, en 1658 desarrollaron el proyecto utopía, sentando las bases coloniales de DELAWARE.

d) De evangélicos centro-europeos en la América colonial, como el holandés KYPNER y su doctrina del American Public Theology (que perfila la ACT y el ICS estadounidense), que tuvo una considerable repercusión en el congregacionalismo estadounidense y su peculiar Teología política. De entre sus propuestas, destacaron lemas bíblicos como Let my people go o Choosen people, y exhortos congregacionalistas del tipo Come over and help us, etc. ${ }^{240}$.

e) De doctrinas helvéticas calvinistas (v.g. Las Instituciones de CALVINO, estudiadas con ahínco por los teólogos de Princeton University) y poscalvinistas (v.g. El Contrato Social de ROUSSEAU, observado por los Federalistas); etc.

f) De asentamientos helvéticos: entre las mismos, urge distinguir entre aquellos que conformaron New Sweden y alrededores (con colonos helvéticos), y las

\footnotetext{
${ }^{240}$ La influencia de los Países Bajos y sus gentes en la América colonial, aunque históricamente obviada con excesiva frecuencia, es vital y de profunda imprenta: New York fue antes New Amsterdam, el gentilicio coloquial de los estadounidenses (específicamente del Noreste) es yankee, que proviene de un vocablo holandés, etc.
} 
colonias teonómicas de New England, fundadas por británicos, pero basadas en las doctrinas helvético-calvinistas ya mencionadas.

g) De doctrinas erasmistas (de ERASMO de ROTTERDAM y sus seguidores) filtradas por la eclesiología presbiteriana (sobre todo, aunque también presente en la episcopaliana y las congregacionalistas). Supone una percepción administrativa de la iglesia como una red integrada de comunidades, que opera de forma federal (basándose en una peculiar interpretación y construcción de Hecho de los Apóstoles 15).

h) Del posrreformismo europeo (combinado con un revivir hermético y órfico) al neognosticismo estadounidense. Se trata de corrientes que encuentran su fusión inicial en autores del tipo de HOOKER o DICKINSON (en Connecticut y en Delaware, más Pennsylvania), o fenómenos sociales catárticos precursores del de Cane Ridge (1801), hasta la formulación de expresiones autóctonas plenas, al modo de los mormones (o Iglesia de los Santos de los Últimos Días), bajo las propuestas de SMITH, YOUNG, y/o PRATT ${ }^{241}$.

i) Del pietismo centro-europeo y el metodismo británico al evangelismo estadounidense. Su resultante ha sido el periódicamente reinventado social gospel [cristianismo/evangelismo social], que ha servido para la casación de un profundo individualismo, empero, de marcado compromiso comunitario.

${ }^{241}$ Vid. BLOOM, H.: The American religion. The emergence of the Post-Christian Nation, New York: Simon \& Schuster, 1992. POWER, M.S.: Before the Convention. Religion and the Founders, Lanham: University Press of America, 1984. WRIGHT, C.: Religion in American life. Selected readings, Boston: Houghton Mifflin Co., 1972. 
j) De confesiones progresistas reformadas centro-europeas, como los menonitas, anabaptistas, etc., influyentes en los planteamientos de desinstitucionalización religiosa, tanto en el puritanismo británico, como en el congregacionalismo estadounidense; et al.

La razón de atender a las diversas líneas de penetración del federalismo es para llamar la atención sobre el hecho de que éste se constituye en piedra de toque para el tránsito al Nuevo Régimen en el mundo posreformista-convirtiéndose así, para algunos autores, en una tautología casi taumatúrgica (solucionadora de problemas por su mera mención)-. En tal sentido, ha de reconocerse que, los fundamentos del federalismo favorecen el impulso de las revoluciones y repúblicas sintomáticas del mencionado tránsito a la auténtica Modernidad occidental: a) tras las guerras civiles inglesas (1642-51, incluido el magnicidio de Carlos I), emerge la Commonwealth of England [república inglesa] o Protectorado de CROMWELL y, más tarde, tras la revolución de 1688, la British Commonwealth [república británica], suponiendo la reorganización imperial mediante las actas (leyes) de Proclamación Real y la Declaratoria $^{242}$; b) la revolución estadounidense de 1776 y su república federal vigente hasta la fecha. Por consiguiente, el interés sustancial del federalismo, como se viene señalando, radica en su habilidad para conectar la tradición sagrada (judeocristiana) y la profana (grecorromana), fusionándose al hilo de las

\footnotetext{
${ }^{242}$ En 1763, por impulso real (para integrar las adquisiciones fruto de la Guerra de los Siete Años y las Guerras Indias) se aprueba el Acta de Proclamación Real, seguida en 1766, a iniciativa parlamentaria, el Acta Declaratoria, culminando así el proceso de reformulación administrativo-territorial del imperio, anticipándose de tal forma una suerte de modelo federal entre la metrópoli y las colonias -hecho que, junto con las leyes indignas de 1774, es aprovechado tiempo después para declarar la independencia estadounidense $\mathrm{y}$, una década más tarde, implantarse un modelo federal efectivo; vid. JAMESON, J.F. (ed.): British Royal Proclamations relating to America, 1603-1783 (vols. 1-16), New York: American Historical Association, 1906-17.
} 
necesidades coyunturales angloamericanas (con sus matices, gracias al PWF). Se consigue, de tal modo, un discurso sostenido legitimador de la moderna realidad emergente: su interpretación y construcción (de dicha realidad en curso), recibe progresiva y programáticamente su justificación al hilvanar los retazos adaptados de las citadas tradiciones ${ }^{243}$.

La conjunción de la tradición sagrada y la profana, para legitimar la realidad estadounidense en marcha (novus ordo seclorum), se ha ido consiguiendo a través de una prolongada tendencia humanista secular (posjudeocristiana). La misma, no ha estado exenta de excesos divergentes en sus extremos ${ }^{244}$. Como prueba, destacan sus formas repletas de reseñas bíblicas y, sin embargo -dentro de la paradoxología y la pragmática estadounidense-, de efectos evidentemente mundanos y muy prácticos para el gobierno civil: a) virtue people o pueblo virtuoso, con bendición divina, empero, con un sistema ético público basado en los derechos naturales y la costumbre ${ }^{245}$; b) messianic covenants o pactos mesiánicos de bienestar, como los ya mencionados del New Deal de ROOSEVELT, Fair Deal de TRUMAN, New Frontier de KENNEDY, Great Society de JOHNSON, etc.; c) Sabbatharism o descanso semanal, donde al reivindicarse el mismo, se promueve el trabajo como eje ordinario del calendario; d) Pledge of Allegiance o saludo a la bandera, donde al reivindicarse el

\footnotetext{
${ }^{243}$ Estos retazos tienen el origen mítico en la fusión de la tradición sacra (pactos y mandamientos bíblicos) con la profana (ligas griegas, foedi de los romanos con pueblos fronterizos -también algunos pactos especiales internos, como los latini foederati-, ligas de ciudades italianas, federaciones holandesa y helvética, reforma imperial británica).

244 Poco secularizados, como los movimientos teonómicos (ciertos sectores de la Christian Right), o excesivamente secularizados, los movimientos laicistas (ciertos sectores de la American Civil Liberties Union).

${ }^{245}$ Yendo más allá, conectando dicha ética pública como fundamento de la democracia liberal, así vienen sosteniendo S. CARTER, J. RAWLS, J. STOUT, N. WOLTERSTORFF, F. ZAKARIA. Recientemente, vid. EBERLE, C.J.: Religious convictions in Liberal Politics, New York: Cambridge University Press, 2002. MICHAEL, J.P.: Under God: Religious faith and liberal Democracy, New York: Cambridge University Press, 2003.
} 
agradecimiento por la bendición divina de las instituciones políticas, se termina sublimando (neofetichizando) aquellas; e) In god we trust, lema de la moneda y timbre estadounidense, etc. (vid. supra).

Visto entonces que, el federalismo es el descriptor sintomático principal de la realidad estatal estadounidense, debido a que (a) engloba los otros grandes descriptores, a la vez que, (b) sirve para la legitimación de su devenir -bajo un discurso paradójico, pragmático y posjudeocristiano (vid. infra), entre destino manifiesto y/o experimento ilustrado ${ }^{246}$; además, (c) es fruto de la fusión de la tradición sagrada y profana, adaptándose a las necesidades coyunturales de los EE.UU. En consecuencia, y tras plantearse grosso modo la naturaleza del federalismo especialmente, desde el enfoque hipostásico del que se viene haciendo gala-, supone el gran pacto social constituyente del país (y de la identidad de sus gentes). Como complemento de cierre -a este conjunto de consideraciones preliminares, pues la cuestión se retoma más adelante, al analizar la ACR y sus manifestaciones, conectándose con el presidencialismo y la democracia, por ejemplo-, se propone a continuación, un retrato a grandes trazos, de la vía concreta de formulación e implementación federalista para la consecución de la vigente realidad estatal estadounidense (tal como termina plasmando el Preámbulo constitucional, vid. figura $)^{247}$.

\footnotetext{
${ }^{246}$ Vid. SCHLESINGER Jr., A.M.: The cycles of American History. New York: Houghton Mifflin Co., 1986.

${ }^{247}$ Al respecto (sin necesidad de entrar en lecturas especializadas, v.g. AHLSTROM, STOKES, PFEFFER), baste con acudir a las lecturas generalistas JENKINS, MORISON y NEVIS, más su revisión por JOHNSON. Vid. JOHNSON, P.: A History of the American People, New York: Harper \& Row, 1997.
} 
Figura 32.- Federalismo plasmado en el Preámbulo de CEU 248

Nosotros, el pueblo de los Estados Unidos, a fin de formar una Unión más perfecta, establecer la justicia, garantizar la tranquilidad nacional, tender a la defensa común, fomentar el bienestar general y asegurar los beneficios/las bendiciones de la libertad para nosotros y para nuestra posterioridad, por la presente promulgamos y establecemos esta Constitución para los Estados Unidos de América.

Fuente: elaboración propia (SÁNCHEZ-BAYÓN, 2007 y 16).

Una vez más, procurando distinguir entre retórica y realidad, pese a la llamada o vocación pactista de pueblo elegido en tierra prometida (muy presente en la Holy Commmonwealth, que es una de las denominaciones iniciales dada a Nueva Inglaterra) $)^{249}$, los fundamentos y evidencias político-jurídicas (o sea, oficializadoras de la cuestión) de una expectativa federal estadounidense se remontan a una serie de convenciones sectoriales: a) New England Confederation ${ }^{250}$ (1643) y Albany Congress (1754), con propósito defensivo; b) Stamp Act Congress (1765) y I Continental Congress (1774), para el reconocimiento de libertades y derechos; etc. ${ }^{251}$ Estas federaciones sectoriales se sustentan en los mencionados

${ }^{248}$ Traducción propia (contrastada). Vid. Programa de Información del Departamento de Estado (URL: http://usinfo.state.gov/). Programa Thomas de la Librería del Congreso (URL: http://thomas.loc.gov/).

${ }^{249}$ Tal discurso se sustenta en evidencias jurídicas coloniales, como el Mayflower Compact (1620) y las ya mencionadas Charters o cartas otorgadas. En cuanto a las denominaciones, sobre la de Holy Commonwealth, vid. AHLSTROM, S.E.: A religious History of the American people... op. cit. EIDSMOE, J.: Christianity and the Constitution. The faith of our Founding Fathers... op. cit. Otra habitual fue Biblical Commonwealth, vid. SINGER, C.G.: A theological interpretation of American History, Nutley: The Craig Press, 1964.

${ }^{250}$ Articles of Confederation for the United Colonies of New England, para Massachussetts, Plymouth, Connecticut y New Haven.

251 Otras propuestas muy atractivas e influyentes para los modelos federalistas siguientes fueron la de PENN (Penn's Plan of Union, 1697) y la de FRANKLIN (Franklin's Plan of Union, 1754). Vid. ASHLEY, R.L.: The American Federal State, New York: MacMillan, 1902. CHANNING, E; HART, A. B. (eds.): The American History Leaflets: Colonial and Constitutional (36 vols.), New York: A. Lovell \& Co., 1892-1910. WOODBURN, J.A.; MORAN, T.F.: Elementary American History and Government, Chicago: Green \& Co., 1921. 
factores (fenomenológicos) determinantes de la adhesión del individuo con el incipiente Estado (v.g. fear factor permite una integración frente a las potencias europeas y los pieles rojas, a las ansias expansivas entre colonias). Todo este bagaje va consolidándose, mediante una experiencia de método de ensayo-error (v.g. Articles of Confederation de 1777-81252, Northwest Ordinance de 1787), hasta la consecución de una "Unión más perfecta", tal y como se reconoce en la Constitución de los EE.UU. (vid. vid. infra figura 32, más supra cap. 10). Pese a su deficiencia gramatical -o se es perfecto o no-, la inclusión del "más" se debe a motivos lingüísticos empáticos, donde el discurso trasluce la vocación de compromiso total253: a) desde la tradición profana, se observa el principio jurídico elemental de pacta sum servanda (del Derecho Romano, empero, sublimado para el Derecho Común Angloamericano por BLACKSTONE, 1723-80); b) desde la tradición sacra, la participación en la federación estatal se concibe como el resultado de un convencimiento pleno, tras sentir la llamada, pues se pasa a formar parte de un pueblo bendecido (con el bienestar interior y el liderazgo exterior), luego no cabe a posteriori un derecho de anulación -explicándose de este modo, el vehemente rechazo del Norte en el intento secesionista del Sur.

\footnotetext{
${ }^{252}$ Aunque es redactada hacia 1777 , no entra en vigor -con todas sus debilidades- hasta casi cuatro años más tarde.

${ }^{253}$ Frente a fracasos ya mencionados, como el de la Confederación, cuya ley fundamental constituyente llevaba por título completo "Artículos de Confederación y Unión perpetua entre los Estados de New Hampshire, Massachussets Bay, Rhode Island and Providence Plantations, Connecticut, New York, New Jersey, Pennsilvany, Delaware, Maryland, Virginia, North Carolina, South Carolina, and Georgia".
} 


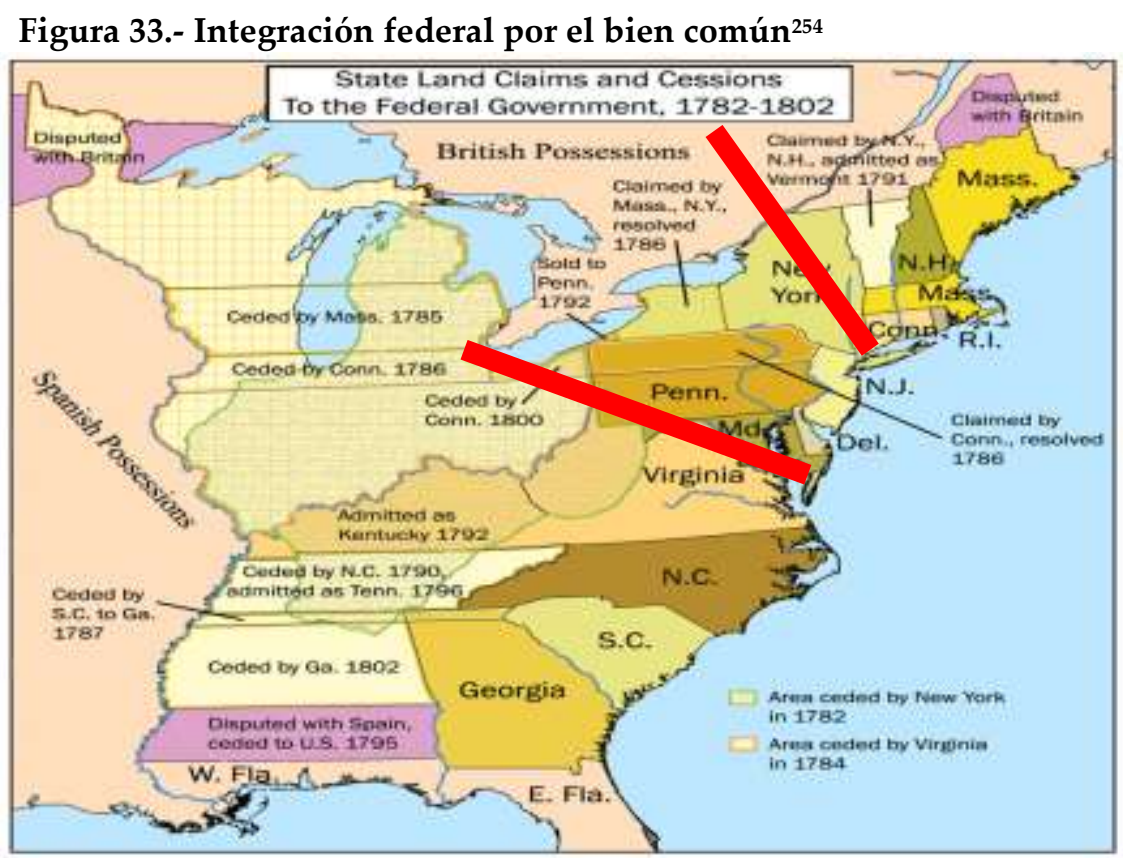

Fuente: elaboración propia (SÁNCHEZ-BAYÓN, 2007 y 16).

Pues bien, para comprender un poco más de la dimensión fenomenológica del federalismo estadounidense, en su formulación y distinción con las propuestas europeo-continentales, así como, en su desarrollo a lo largo de estos dos últimos siglos, se recurre seguidamente a una serie de figuras sintetizadoras de la abundante información existente y de sus múltiples aristas problemáticas.

Bebiendo de la tradición sacra y profana, en su lectura anglosajona (de clásicos y coetáneos, incluso, europeo-continentales), así como, de la incipiente producción intelectual autóctona (vid. supra cap. 9), tras el fracaso del ensayo

\footnotetext{
${ }^{254}$ El federalismo, como el gran pacto social estadounidense, confiere una identidad de pueblo unido, que permite, incluso, poner fin a las constantes rivalidades entre las antiguas colonias, para que la expansión al Oeste, pase a ser una cuestión de preocupación nacional, con lo que se mejora las condiciones de bienestar general. Vid. The National Atlas of the United States of America, un servicio del U.S. Department of the Interior (URL: http://nationalatlas.gov/).
} 
confederal, tiene lugar un movimiento casi homónimo impulsor del federalismo: los federalistas. Entre octubre de 1787 y mayo de 1788 (durante los debates constitucionales y de ratificación), se publican 77 ensayos, bajo el pseudónimo común de Publius, en tres periódicos de New York ("The New York Packet", "The Independent Journal", "Daily Advertiser"). Posteriormente, ya en vigor la Constitución de EE.UU., y para una mejor lectura de la misma, se editan conjuntamente todos estos ensayos de manera conjunta, más otros ocho, pero esta vez ya con el nombre de sus autores 255 : HAMILTON (ideólogo federalista, hombre de confianza de WASHINGTON y primer Secretario del Tesoro), MADISON (redactor de CEU y de la Constitución de Virginia, además de Secretario de Estado en la Adm. JEFFERSON y cuarto Presidente de los EE.UU.) y JAY (primer Presidente del TSEU); el título dado fue The Federalist Papers o El Federalista (es la traducción que finalmente se generaliza) ${ }^{256}$.

255 Existen disputas de autoría según las ediciones posteriores, aunque como criterios guía diferenciadores cabe observarse: a) el estilo clínico y estratégico de HAMILTON (el gran impulsor, pero de limitado acceso a altos cargos debido a su nacimiento antillano); b) el análisis jurídico de MADISON -mejor jurisconsulto que político; c) el estilo directo propagandístico, a favor de la Unión de JAY.

${ }^{256}$ Se debe a un criterio adoptado en las primeras traducciones (mexicanas), sin embargo, se preferiría la siguiente propuesta, por ajustada, Los ensayos federalistas o del federalismo. 


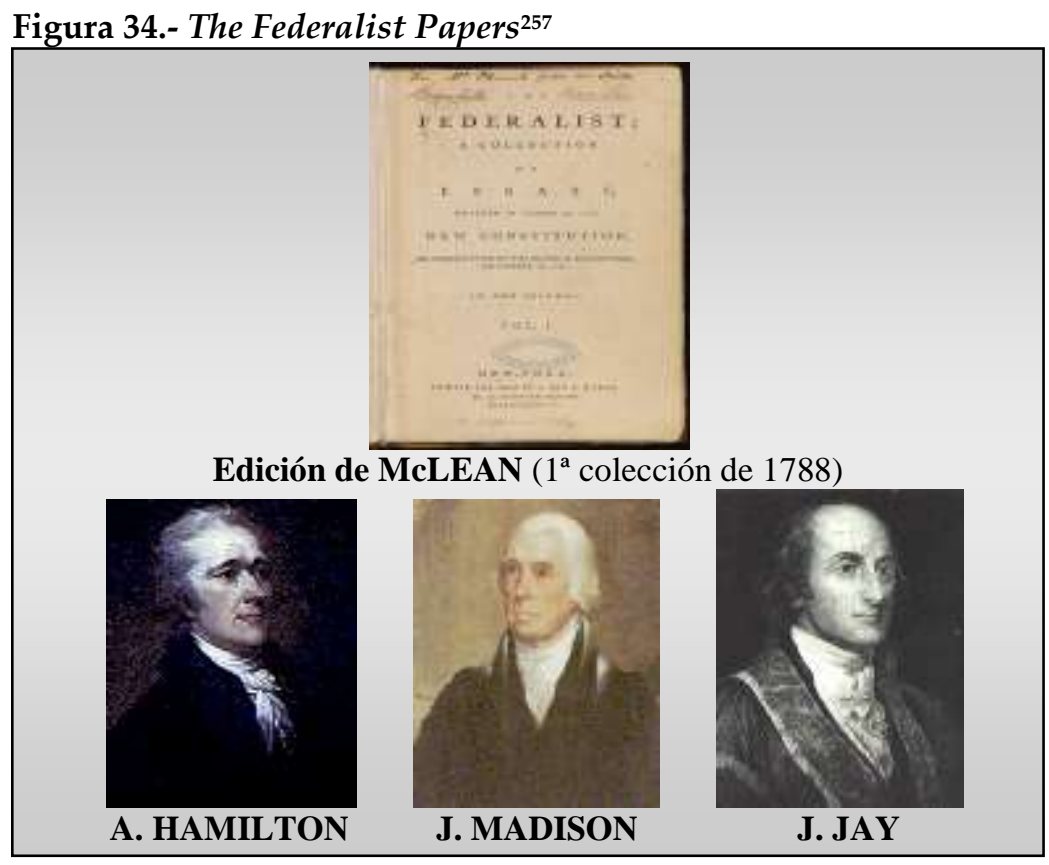

Fuente: elaboración propia (SÁNCHEZ-BAYÓN, 2007 y 16).

Las grandes aportaciones de El Federalista, además de servir como catalizador de las sinergias diacrónicas occidentales (la tradición sacra y profana), así como, de las sincrónicas (el pensamiento liberal-conservador y masón o PWF, naturalista racional y empírico, deísta, etc. $)^{258}$, también radican en su interpretación y construcción de la Unión subsiguiente ${ }^{259}$. Dicha Unión, es el resultante progresivo y programático de

${ }^{257}$ La primera publicación donde se especifican las autorías personalizadas es, la realizada por la editorial J. GIDEON en 1818 -entiéndase por ello, que desde 1787 hasta 1818, como parte de la metahistoria de El Federalista, se explica así las diferencias en la numeración, redacción y asignación de los autores. Una de las ediciones más fiables y de más fácil acceso es la McLean, ofrecida por el propio Gobierno de los EE.UU., vía el Programa de Información del Departamento de Estado o el Programa Thomas de la Librería del Congreso (URL: http://usinfo.state.gov/; http://thomas.loc.gov/).

${ }^{258}$ Vid. EIDSMOE, J.: Christianity and the Constitution. The Faith of our Founding Fathers... op. cit. HAMMER, D.: The Puritan tradition in Revolutionary, Federalist, and Whig Political Theory. A rhetoric of origins... op. cit.

${ }^{259}$ Inicialmente, se parte de una Unión, tan necesaria que se la califica de perpetua, porque se es consciente de tal necesidad vocacional para la consecución exitosa del objetivo independentista frente 
la interacción de dos macropropuestas, igualmente estadounidizadas (recibidas incipientemente, transformadas y exportadas con éxito), como son el moderno conservadurismo estadounidense (formulado por los padres fundadores, aunque su impulsor académico es EMERSON) y la religión civil (vid. supra), siendo determinantes en el devenir estratégico de los EE.UU. (vid. siguientes figuras). En cuanto al moderno conservadurismo estadounidense, el mismo, permite no perder de vista la relevancia de la gestión del bien común (tal como señalaran antecesores como BURKE o BLACKSTONE), desde parámetros operativos tan apreciados como son el common sense (el sentido común para moderar pasiones y desmontar sus discursos), los checks $\mathcal{E}$ balances (los pesos y contrapesos o sistema de distribución equilibrada de poder, tanto en su reparto vertical como horizontal), el faccionalism control (la supervisión del faccionalismo, mediante la identificación de los grupos de presión e interés, y exigiéndose una mínima pluralidad concurrente), la accountability (la posibilidad de solicitar responsabilidades a los dirigentes, incluso pudiendo llegar a procesos de repeal o impeachment [cese]), el rule of law (las reglas del Derecho o Estado de Derecho, basado en la cotidianeidad sus fuentes jurídicas: el Derecho Federal -ley suprema del lugar, art. VI de CEU.-, la tradición -la costumbre, codificada por la jurisprudencia, ídem-, y los principios -como pacta sum servanda, salus populi suprema lex est, o national interest defense -cuestión controvertida hoy tras

\footnotetext{
a UK El problema es que, aunque una confederación genera un entorno novedoso de gobierno, éste no resulta plenamente integrado, ni posee una entidad propia suficiente, pues no se trata de un Estado, sino que es una conjunción de Estados emergentes -método de ensayo y error. De ahí la designación posterior, desde el Preámbulo de la Constitución de EE.UU., para la consecución de "una Unión más perfecta" - una vez más, asumiéndose la evidente deficiencia gramatical, por recalcar un profundo significado psicosocial. En dicho devenir interpretativo y constructivo de la Unión subsiguiente, la regla general ha sido la interpretación de la Unión más perfecta como la nación integradora, y la construcción, como un cúmulo de discursos adecuados a las necesidades coyunturales, recurriendo para la consecución de la identificación con la Unión o Gobierno Federal, a la gestión interesada de los factores ya mencionados en la fenomenología.
} 
el recurso realizado por los neoconservadores y su cristalización en Homeland security), etc. Por su parte, la religión civil, hace posible la sacralización (por transferencia y/o neofetichización) del gran pacto social constituyente del país, además de determinante para la configuración del AWL (y demás manifestaciones conexas), lo que permite confiar, entonces, en la promesa de un destino interno de bienestar, y externo de liderazgo. En tal sentido, tanto el moderno conservadurismo como la religión civil, hacen prácticamente inviable la secesión o anulación de la Unión (como se ha intentado plantear fallidamente, v.g. Guerra civil). 
Figura 35.- Etapas de la implementación del federalismo

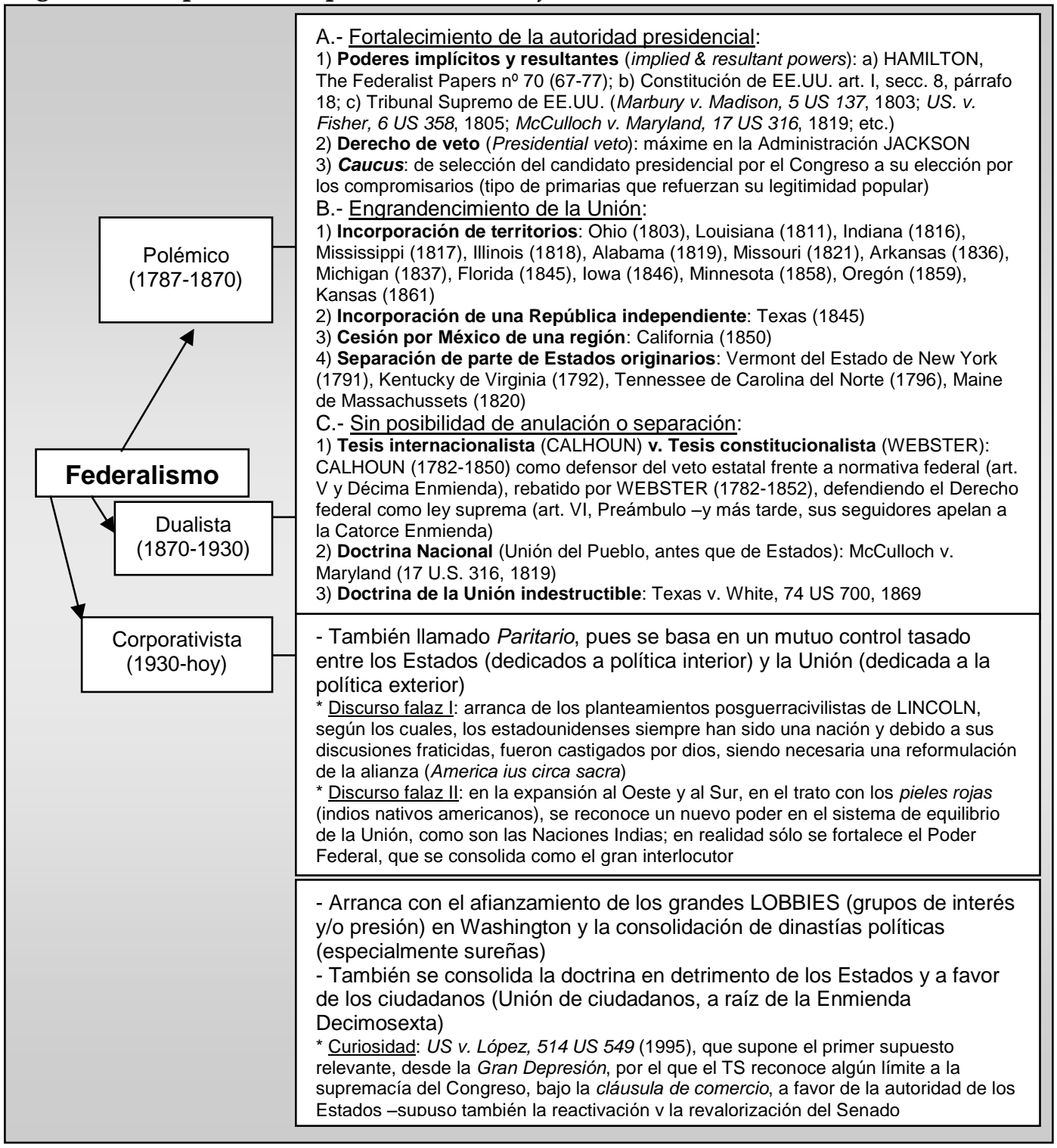

Fuente: elaboración propia (SÁNCHEZ-BAYÓN, 2007 y 16). 
Únicamente, como matiz comparado, en la línea de la paradoxología (vid. infra) obsérvese cómo los Federalistas reciben parte del discurso de la época ${ }^{260}$, lo transforman con éxito -superada la crisis guerracivilista- y es erigido luego como modelo referente.

Figura 36.- Tipos formales de federalismo

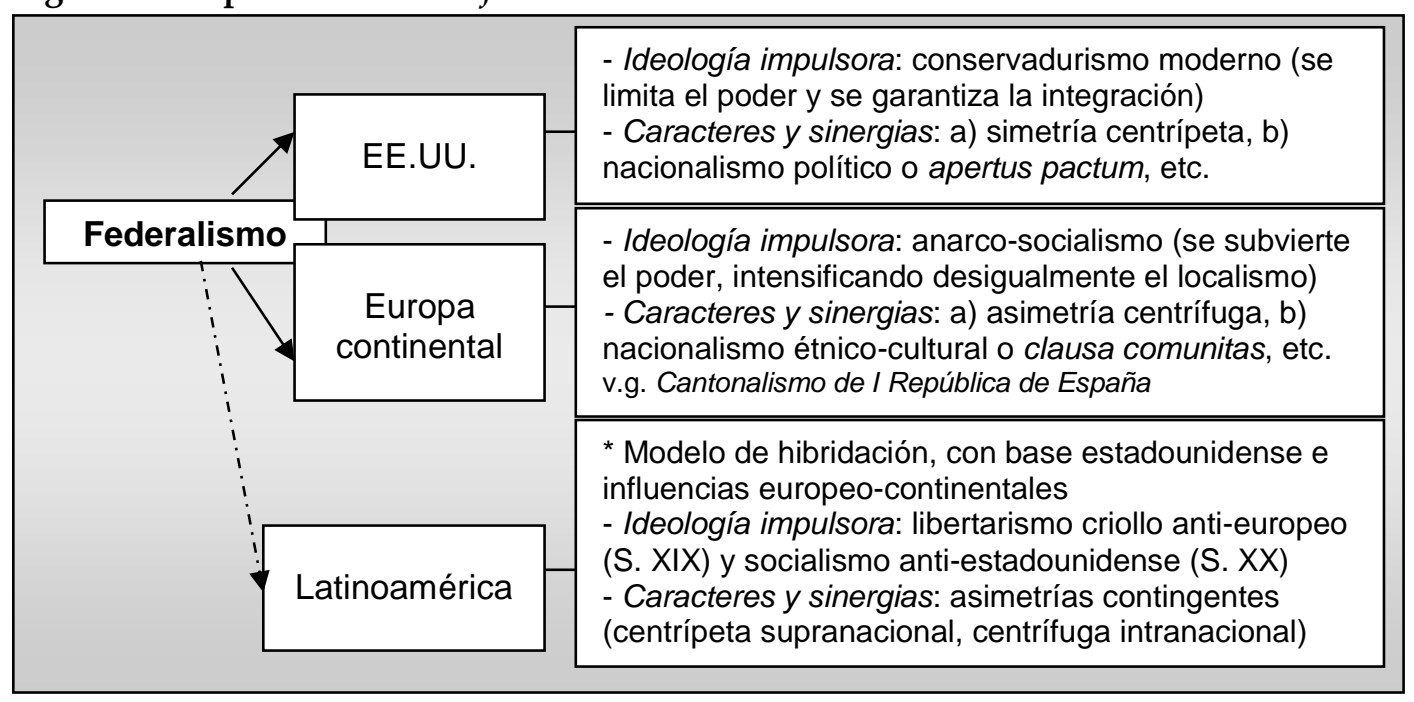

Fuente: elaboración propia (SÁNCHEZ-BAYÓN, 2007 y 16).

${ }^{260}$ Uno de los referentes habituales, en tal sentido, es MONTESQUIEU, debido a su fama del momento, que se pretende aprovechar para legitimar las directrices ofertadas en el Federalista. Para tal fin, no se duda en jugar con sus palabras e ideas, construyendo más allá de su pensamiento o proponiendo ficciones especulativas: a) MONTESQUIEU sólo aboga por la división horizontal del poder (Ejecutivo, Legislativo y Judicial), y desde el Federalista, se propone también la vertical (nivel federal, estatal y local); b) MONTESQUIEU defiende una separación total entre los poderes establecidos, mientras que el Federalista busca una política de checks $\mathcal{E}$ balances que neutralice sus abusos; c) MONTESQUIEU piensa que la idea republicana únicamente es posible para unidades de gobierno pequeñas y homogéneas (v.g. Holanda, Suiza, Norte de Italia), mientras que los Federalistas defienden sus extensión continental (apostando por una denominación expansiva americana: Estados Unidos de América); etc. 
En resumen, el federalismo, como el gran pacto social para la consecución de un novedoso entorno integrado de gobierno que es, supone: a) en términos sustanciales, la exigencia de una vocación identitaria clara (v.g. Preámbulo de CEU), comprometiéndose con el AWL y toda su teología político-jurídica posjudeocristiana sustentadora; b) en términos formales, el requerimiento de una firme unión permanente, aunque de carácter flexible y elástico para la superación de tensiones coyunturales, gracias un reparto equilibrado del poder (checks $\mathcal{E}$ balances), que ha de servir para poner límites a la corrupción y sus abusos (accountability), además de garantizar una mejor gestión del bien común, el interés general y la justicia social (v.g. DIE, CEU) ${ }^{261}$.

\title{
Figura 37.- Disonancias del discurso federalista y sus detractores
}

\begin{abstract}
- Dilema de ampliación v. profundización: El Federalismo procura un poder concentrado (identificable e integrador), a la vez que gestiona el mismo atendiendo a un serie de reglas de juego (rule of law) y un sistema distributivo de contrapesos (checks \& balances). Luego, cuando parece que se expande, por creación de agencias o incorporación de jurisdicciones, en realidad se está dispersando -y debilitando-, mientras que si se repliega, el efecto es el de profundización, concentrándose el poder existente. En consecuencia, resulta necesario analizar los discursos legitimadores.

- Dilema de forma $v$. fondo: no sólo hay que atender a qué y cómo se dice, sino también para qué se dice. Se consigue así discernir entre la retórica y realidad, pues la mayor parte de los discursos contrarios al Federalismo, telológicamente, buscan sustraer el poder del control al que está sometido en el Federalismo, pese a que el formato expositito, y su principal lema sea la libertad, en oposición a la concentración del poder (v.g. del anti-federalismo de JEFFERSON al antigubernamentalismo de REAGAN, en realidad se pretende la supresión de las instituciones intermedias limitadoras del poder -aproximándose al discurso populista).

- Dilema de main-line churches federalistas $v$. evangelical churches anti-federalist: las confesiones protestantes liberalconservadoras del Noreste son favorables al sistema federal, basándose en los principios seculares de la teología políticojurídica estadounidense, mientras que las del Sur y el Oeste (el cinturón bíblico), son contrarias, pese a su carácter más congregacionalista, pero también más conservadoras y con rasgos tradicionalistas -su discurso antiestatalista es, en realidad, prorreligioso-.
\end{abstract}

Fuente: elaboración propia (SÁNCHEZ-BAYÓN, 2007 y 16).

${ }^{261}$ La idea clave del equilibrio (y limitación) de poder arranca, remotamente (en conexión con la Teología política de la dimensión sustancial), del juego cabalístico y/o especulativo numérico (sacro) judeocristiano: el uno representa el monismo autoritario, el dos es el dualismo antagónico y el tres supone el pluralismo consensual (v.g. el Tercer Estado, frente a la nobleza y el clero; el Tercer Mundo, frente a los EE.UU. y la URSS). Por tanto, la intuición preliminar del formalismo federal, arranca de la exigencia de la división y control del poder, haciendo posible así un entorno integrado de pluralidad. 
Hasta el momento se ha prestado mayor atención a la dimensión interna del federalismo, como el gran pacto social para la consecución de un entorno integrado de gobierno que garantice el bienestar estadounidense (vid. infra figura 31, más supra cap. 10$)^{262}$. Ahora bien, también posee una notable dimensión exterior ${ }^{263}$ que, igualmente, deja traslucir su bagaje recibido de la tradición sacra (v.g. chosen people, as light/leader of nations) ${ }^{264}$ y profana (v.g. ligas y foedi), cuya fusión da lugar al American Manifesty Destiny [AMD: destino manifiesto estadounidense]. Para comprender el alcance de dicha dimensión exterior del federalismo, se recurre al análisis estratégico y a la geopolítica ${ }^{265}$.

\footnotetext{
262 Vid. SÁNCHEZ-BAYÓN, A.: Concordia Constitucional, Madrid: Delta Publicaciones, 2013. - Derecho Constitucional, Madrid: Ed. Roble, 2015. - Derecho Público General, Madrid: Delta Publicaciones, 2016. - Lecturas fundamentales de Derechos Político y Constitucional, Porto: Ed. Sindéresis, 2017. - ¿Ocaso estatal y de sus relaciones institucionales y protocolarias? Porto: Ed. Sindéresis, 2018.

${ }^{263}$ De acuerdo con la CEU y con la tradición político-jurídica estadounidense, las relaciones internacionales son una competencia clave del Poder Federal: a) el Secretario de Estado ocupa un puesto preferente en el orden de sucesión presidencial (art. II, secc.1.6 CEU); b) muchos Secretarios de Estado han sido luego Presidentes (v.g. JEFFERSON, MADISON, MONROE); c) la Secretaria de Estado es uno de los Departamento -sino el que más, según los periodos- con mayor presupuesto; d) los primeros conflictos a resolver fueron los tratados con las potencias europeas participantes en la Guerra de la Independencia, seguido de la cesión de aspiraciones territoriales de los primeros Estados de la Unión a la misma; c) el AMD ha contribuido plausiblemente a la adhesión al AWL; etc.

${ }^{264}$ De ahí que, haya sido este país, los EE.UU., el promotor -y primer desencantado- de los grandes pactos universales, como la Liga o Sociedad de Naciones y la Organización de las Naciones Unidas-ONU si hubiera sido una iniciativa de los países europeo-continentales la denominación acorde con su concepción habría sido "Sociedad de Estados (mundiales)" y "(Organización de los) Estados Unidos (del Mundo)".

${ }^{265}$ De partida, sobre los ciclos y pensadores de la geopolítica estadounidense, vid. HOFSTADTER, R.: The American political tradition and the men who made it, London: Jonathan Cape, 1967. - et al.: The structure of American History, Pretice-Hall: Englewood Cliffs, 1946. SCHLESINGER Jr., A.M.: The cycles of American History. New York: Houghton Mifflin Co., 1986. Sobre las guerras culturales y el declive hegemónico, vid. AGUIRRE, M., BENNIS, P.: La ideología neoimperial. La crisis de EE.UU. con Irak, Barcelona: Icaria, 2003. BUGNON-MORDANT, M.: América totalitaria. Los Estados Unidos y el dominio del mundo, Barcelona: Flor del Viento Ed., 1999. GUYATT, N.: Another American Century. The United States and the World sinde 9/11, New York: St. Martin's Press, 2003. KRISTOL, W., KAGAN, R.: Peligros presentes. Soluciones de la Nueva Administración Bush ante una civilización amenazada, Madrid: Almuzara,
} 
Puesto que se trata de una cuestión harto compleja y a tratar más adelante (vid. ACR), baste por el momento, para hacerse una idea de la proyección federal, con las pinceladas conceptuales y evidencias propagandísticas que se ofrecen en las figuras siguientes: de los pactos domésticos y trasatlánticos, a los panamericanos y occidentales. Se trata de la forja de una autoestima basada en la creencia de su superioridad moral, porque se está en el convencimiento de exportar un modelo bendecido por Dios; catalogándose a sus aliados como buenos, y a sus enemigos como malos; se procura responder siempre a un previo ataque que evidencia la condición maligna del enemigo; etc.

2005. NYE, J.S.: The paradox of American power. Why the World's only Superpower can't go it alone, New York: Oxford University Press, 2002. PATTERSON, J.T.: Restless gigant. The United States from Watergate to Bush v. Gore, New York: Oxford University Press, 2005. ODOM, W.E., DUJARRIC, R.: America's inadvertent empire, New Haven: Yale University Press, 2004. SEBASTIÁN, L.: Pies de barro. La decadencia de los Estados Unidos de América, Barcelona: Península, 2004. SODERBERG, N.: El mito de la superpotencia. Uso y abuso del poder (trad.), Buenos Aires: El Ateneo, 2005. Sobre las discrepancias geopolíticas entre los EE.UU. y Europa, y sus repercusiones en América Latina, vid. AMIS, S.: El hegemonismo de Estados Unidos y el desvanecimiento del proyecto europeo (trad.), León: El viejo topo, 2001. KAGAN, R.: Poder y debilidad. Europa y Estados Unidos en el nuevo orden mundial (trad.), Madrid: Santillana, 2003. KRYZANEK, M.J.: Las estrategias políticas de Estados Unidos de América en América Latina (trad.), Buenos Aires: Grupo Editor Latinoamericano, 1987. NEWSON, D.: La diplomacia y la democracia norteamericana (trad.), Buenos Aires: Grupo Editor Latinoamericano, 1989. Sobre las críticas a las estrategias adoptadas, vid. CAIRO, H., PASTOR, J. (comp.): Geopolítica, guerras y resistencias, Madrid: Trama Editorial, 2006. CALLINICOS, A.: Los nuevos mandarines del poder americano, Madrid: Alianza, 2004. NORDLINGE, E.: Isolationism reconfigured. American Foreign Policy for a new century, Princeton: Princeton University Press, 1995. 
Figura 38.- Escalada de la geopolítica (federal) estadounidense ${ }^{266}$

\begin{tabular}{|c|c|c|c|}
\hline DOCTRINAS & ESTRATEGIAS & HECHOS & PRESIDENTES \\
\hline $\begin{array}{l}\text { D. Federalista } \\
\text { (F. clásico) }\end{array}$ & $\begin{array}{l}\text { Pactos trasatlánticos } \\
\text { y vecinales }\end{array}$ & $\begin{array}{l}\text { Guerra Independencia } \\
\text { reconocimiento europeo } \\
\text { y aislacionismo estructural }\end{array}$ & $\begin{array}{l}\text { WASHINGTON } \\
\text { ADAMS }\end{array}$ \\
\hline D. Monroe & $\begin{array}{c}\text { Panamericanismo } \\
\text { Nacionalismo USA } \\
\text { Corolario (liderazgo panamericano) }\end{array}$ & $\begin{array}{l}\text { Integración de Estados } \\
\text { Guerra civil } \\
\text { Anexión de Estados }\end{array}$ & $\begin{array}{c}\text { MONROE } \\
\text { LINCOLN } \\
\text { T. ROOSEVELT }\end{array}$ \\
\hline $\begin{array}{l}\text { D. de Alianza } \\
\text { de Naciones }\end{array}$ & $\begin{array}{l}\text { Incursiones transoceánicas } \\
\text { (aseguramiento de fronteras } \\
\text { mediante jurisdicciones espe } \\
\text { en Atlántico y Pacífico) }\end{array}$ & $\begin{array}{l}\text { I Guerra Mundial } \\
\text { II Guerra Mundial } \\
\text { eciales }\end{array}$ & $\begin{array}{l}\text { WILSON } \\
\text { HOOVER } \\
\text { D. ROOSEVELT }\end{array}$ \\
\hline D. Anticomunista & $\begin{array}{c}\text { Seguridad Nacional de } \\
\text { contención (Europa occidental), } \\
\text { prevención (Latinoamérica y África), } \\
\text { y disuasión (URSS y Asia) }\end{array}$ & $\begin{array}{l}\text { Guerra Fría (MAD, SDI) } \\
\text { y focos calientes } \\
\text { (Alemania, Cuba, } \\
\text { Corea, Vietnam, etc.) }\end{array}$ & $\begin{array}{l}\text { TRUMAN } \\
\text { KENNEDY } \\
\text { REAGAN }\end{array}$ \\
\hline $\begin{array}{l}\text { D. de Liderazgo } \\
\text { (F. Corporativo) }\end{array}$ & $\begin{array}{l}\text { Neoliberalismo (geomercado) } \\
\text { Corporativismo trasnacional } \\
\text { Diplomacia y humanitarismo }\end{array}$ & $\begin{array}{l}\text { Coord. Orden Internacional } \\
\text { Paradigma cultural occidenta } \\
\text { Ataques a embajadas USA } \\
\text { e intervenciones en rogue sta }\end{array}$ & $\begin{array}{l}\text { BUSH } \\
\text { al CLINTON } \\
\text { W.BUSH } \\
\text { tates }\end{array}$ \\
\hline
\end{tabular}

Fuente: elaboración propia (SÁNCHEZ-BAYÓN, 2007 y 16).

Fue el Presidente ROOSEVELT, quien recurriendo a la libertad religiosa, diseñó una geopolítica de aliados y enemigos, convenciendo a sus compatriotas para entrar en la II Guerra Mundial. Tal estrategia, casi medio siglo después fue usada por otro demócrata, el Presidente CLINTON, para articular el sistema IRFA (de libertad religiosa internacional) $)^{267}$, con el que los EE.UU. pudiera justificar sus

266 De la escalada federal (de Federalismo clásico al corporativo), bajo el análisis estratégico, vid. SÁNCHEZ-BAYÓN, A.: "La International Religious Freedom Act of 1998 y la geopolítica estadounidense actual", en CAIRO, H., PASTOR, J. (comp.): Geopolítica, guerras y resistencias, Madrid: Trama Editorial, 2006. - "Revitalizaciones religiosas postmodernas en América y sus riesgos para la democracia y los derechos humanos", en la Revista General de Derecho Canónico y Derecho Eclesiástico del Estado-Iustel (no 11), 2006. - "Comunicación y Geopolítica estadounidense actual: de IRFA al Choque de Civilizaciones", en Historia y Comunicación Social (vol. 11), 2006.

${ }^{267}$ Vid. bibliografía de la nota previa. 
intervenciones exteriores. Sin embargo, debido a su escándalo sexual, y con la confirmación de los neoconservadores, tras los atentados terroristas del 11/S, la causa de la libertad religiosa, su geopolítica correspondiente y el federalismo mesiánico quedó seriamente comprometido y entredicho, dando lugar a buena parte del problema actual relativo al recurso del factor religioso (vid. supra epígr. 6.4 y 7.3).

Figura 39.- Salvar la libertad de culto ${ }^{268}$

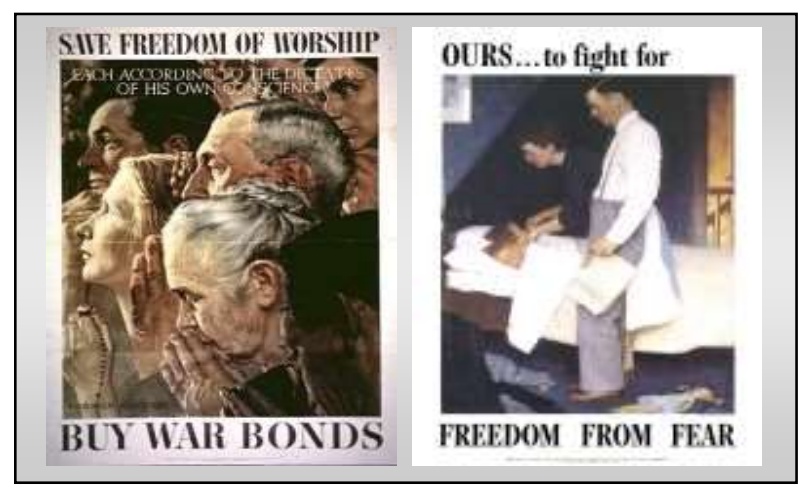

Fuente: elaboración propia (SÁNCHEZ-BAYÓN, 2007 y 16).

${ }^{268}$ Cartel diseñado por N. ROCKWELL, en la campaña propagandística Four Freedoms [cuatro libertades], para la Segunda Guerra Mundial, a raíz del Mensaje Anual al Congreso del Presidente F.D. ROOSEVELT, el 6 de enero de 1941. 


\section{4.- ACR \& AMERICAN COVENANT THEOLOGY II:}

\section{PACTISMO ESTADOUNIDENSE Y RELACIONES INTERNACIONALES ${ }^{269}$}

Los padres fundadores (vid. cap. 9) dejaron claro su interés por el Derecho Internacional o Law of nations, aludiéndolo en los grandes documentos fundaciones (v.g. DIE, CEU, vid. supra cap. 10), así como en los tratados internacionales celebrados (vid. figura siguiente). Para ellos, los tratados eran parte del pactismo menor (frente al pactismo mayor, de Dios con su pueblo), según el cual los pueblos se relacionaban, y los EE.UU. estaban llamados a liderar, conforme a su destino manifiesto (vid. ACR y AMD en Parte de desarrollo especial). En consecuencia, desde el periodo fundacional los tratados están considerados como la institucionalización del ACT exterior, para vehicular su destino manifiesto, y sólo así se entiende su paradójica inclusión en el Ordenamiento estadounidense: cierto es que se consideran los pactos internacionales como parte de la ley suprema del país (art. VI CEU), sin embargo, los jueces disponen de discrecionalidad en la observación de la regulación internacional -aplicándose sólo cuando es útil para el caso, vid. supra rasgos-. Esta aparente disonancia, es una muestra más de la paradoxología estadounidense (vid. cap. 4 y 5), y para cuya comprensión, es necesario tener en cuenta los siguientes rasgos preventivos, acerca de su cultura político-jurídica aplicable a la noción de tratado:

a) Pensamiento inductivo: para la mentalidad estadounidense, carece de sentido arreglar algo que no está roto, por lo que no parece lógico el atarse a algo que aún no ha llegado y que sin embargo se prevé en un tratado. Para los estadounidenses

\footnotetext{
${ }^{269}$ Vid. infra nota 162, más La Modernidad sin prejuicios.
} 
un pacto internacional tiene que surgir a resultas de un acontecimiento que lo justifique y no por un mero ejercicio intelectual elitista preventivo -como se considera la visión europeo-continental al respecto-.

b) Pensamiento pragmático: el respeto a los pactos internacionales no radica en el propio tratado -como sí piensan los europeo-continentales-, sino en la costumbre generada de las relaciones internacionales, por lo que únicamente se reconoce aquella parte del Derecho Internacional que afecta a los intereses y misión de los EE.UU. y sus ciudadanos (vid. supra IRFA).

c) Pensamiento mesiánico: los estadounidenses se consideran bendecidos con un sistema político-jurídico de libertad (vid. Preámbulo de CEU, Saludo a la Bandera), sintiéndose por ello obligados a exportarlo al resto del mundo, y dada su sobreautoestima, creen que los pactos internacionales han de ser instrumentos útiles para su liderazgo mundial (v.g. Discursos Presidenciales de WASHINGTON, MONROE, EISENHOWER).

d) Pensamiento liberal-moral: en el análisis político estadounidense de las relaciones internacionales, por herencia de los padres fundadores (vid. cap. 8), suele concebirse el orden internacional como la jungla, mientras que los EE.UU., con sus aliados, son el paraíso (discurso wildeness v. garden de WILLIAMS). Igualmente, se tiende a manejar un discurso religioso secularizado - un tanto maniqueo-, por el que el planeta se divide en aliados-buenos, defensores de la libertad, y enemigos-malos, de naturaleza totalitaria (vid. siguientes epígrafes).

e) Pensamiento transnacional: debido a sus intereses y misión internacional, las elites de poder estadounidense barajan periódicamente la tramitación de 
regulación doméstica con alcance exterior, justificándose por el argumento liberal-moral mencionado -así como el de su sobreautoestima-.

f) Pensamiento discrecional: los EE.UU., es un país con una doble vía para adoptar regulación internacional, según la naturaleza de la misma. La vía presidencial, para asuntos de urgencia y necesidad -así como algo turbios, v.g. pactos con dictaduras latinoamericanas durante la Guerra Fría-, y la vía parlamentaria, para asuntos públicos de buenas relaciones (v.g. comercio, defensa, etc.).

g) Pensamiento etnocéntrico: independientemente de la vía que se opte para la adopción del tratado o normativa internacional, dicha preceptiva sólo es válida cuando es incorporada por una ley o reglamento interno, además de tener que ser admitido el precepto en un caso ante los tribunales -para que goce de vigor pleno-.

Se entenderá ahora, un poco mejor, el significado y alcance que los tratados y la normativa internacional tienen para los EE.UU., y por qué poseen una naturaleza de preceptiva auxiliar, quedan a la discrecionalidad de sus elites de poder (v.g. del Presidente y/o el Congreso para su adopción, de los tribunales para su aplicación).

Se ofrece, a reglón seguido, en primer lugar, un muestrario de los tratados más destacados -al servir los citados para fijar las pautas y modelos para los siguientes-, con sus preceptos relativos a las relaciones religión-Estado. Para completar la información de la figura y descubrir sus claves, se proporciona una serie de explicaciones (repartidas entre tres grandes categorías), clarificadoras del uso que se ha llevado a cabo del discurso religioso por los EE.UU., en las relaciones internacionales, hasta encumbrarse como -el autopercibido- líder de Occidente. 
Figura 40.- Preceptos sobre religión en tratados estadounidenses ${ }^{270}$

\begin{tabular}{|c|}
\hline Tratado (precepto) \\
\hline A.- Con Europa/Antiguas Potencias (tratados de amistad y comercio) \\
\hline - Tratado con Países Bajos, 1782 (art. IV) \\
\hline - Tratado con Suecia, 1783 (art. V), \\
\hline - Tratado con Prusia, 1785 (art. XI) y 1799 (art. XII) \\
\hline - Tratado con Suecia y Noruega, 1816 (art. XII) y 1827 (art. XVII) \\
\hline - Tratado con Rusia, 1867 (arts. II y III) \\
\hline - Tratado con Francia, 1803 (art. III) \\
\hline - Negociaciones con Santa Sede, 1783 y Primera Misión en 1848 \\
\hline B.- Con América/Hemisferio Occidental (tratados de amistad y comercio) \\
\hline - Tratado con Colombia, 1824 (art. XI) \\
\hline - Tratado con Brasil, 1828 (art. XIII) \\
\hline - Tratado con Chile, 1832 (art. XI) \\
\hline - Tratado con Venezuela, 1836 (art. XIV) y 1860 (art. IV) \\
\hline - Tratado con Federación Perú-Bolivia, 1836 (art. X) \\
\hline - Tratado con México, 1848 (art. IX) \\
\hline - Tratado con El Salvador, 1850 (art. XIV) y 1870 (art. XIV) \\
\hline - Tratado con Costa Rica, 1851 (art. XII) \\
\hline - Tratado con Confederación Argentina, 1853 (art. XIII) \\
\hline - Tratado con Honduras, 1864 (art. XII) \\
\hline - Tratado con Haití, 1864 (art. VIII) \\
\hline - Tratado con Nicaragua, 1867 (art. XII) \\
\hline - Tratado con Rep. Dominicana, 1867 (art. IV) \\
\hline C.- Con Africa y Oriente Próximo (tratados de paz y amistad -antipiratería) \\
\hline - Tratado con Argelia, 1795 (art. XVII), 1815 (art. XV) y 1816 (art. XV) \\
\hline - Tratado con Trípoli, 1797 (art. XI) y 1805 (art. XIV) \\
\hline - Tratado con Irak, 1930 (art. II y IV) \\
\hline D.- Con Asia (tratados de amistad -protección de misioneros y conversos) \\
\hline - Tratado con Japón, 1858 (art. VIII), 1894 (art. I) y 1922 (art. II) \\
\hline
\end{tabular}

${ }^{270}$ Cfr. BETH, L.P.: The American Theory of Church and State, Gainesville: University of Florida Press, 1958, pp. 74. BLAKELY, W.A. (comp.): American State papers and related documents on Freedom in Religion, Washington DC: The Religious Liberty Association, 1949, pp. 311 ss. EIDSMOE, J.: Christianity and the Constitution. The Faith of our Founding Fathers, Grand Rapids: Baker Book House, 1987, pp. 413 ss. STOKES, A.P.: Church and State in the United State (vol. 1), New York: Harper \& Row, pp. 458 ss. y 497 ss. 
- Tratado con China, 1844 (art. XVII), 1858 (art. XXIX), 1868 (art. IV) y 1903 (art. XIV)

Fuente: elaboración propia (SÁNCHEZ-BAYÓN, 2007 y 16).

A grandes rasgos, se aportan las claves para la comprensión de la emersión y consolidación de la hegemonía estadounidense en el orden internacional. Para facilitar su exposición (y en coherencia con la figura anterior), se reparten las explicaciones en tres grandes bloques, de acuerdo con el tipo de discurso religioso manejado, según el interlocutor y el momento de madurez de los EE.UU. en las relaciones diplomáticas: a) Los Tratados Occidentales Judeocristianos y los lazos fraternales; b) Los Tratados Orientales Musulmanes y la convivencia con el bárbaro/infiel; c) Los Tratados Orientales Asiáticos y el comienzo de una evangelización.

a) Tratados Occidentales Judeocristianos (América y Europa): aunque se parte de un discurso religioso combativo, por una causa justa como es la de preservar la pluralidad confesional, la tolerancia social y el libre examen (de conciencia), de las colonias frente a las metrópolis, representando estas últimas la religiosidad oficial y la intolerancia (v.g. UK con el anglicanismo, Francia y España con el catolicismo, etc.); finalmente, se llega al empleo de un discurso conciliador, de mutuo respeto religioso y de los modos y/o fe de vida, con lo que se favorecen los intercambios comerciales, intelectuales, etc.

A grandes rasgos, los acontecimientos geopolíticos y su normativa internacional correspondiente, todo acontece como sigue: en 1774, UK desea reordenar sus territorios americanos, y aprueba las Intolerable Acts -así conocidas en las colonias americanas-, entre ellas, la Quebec Act. La Ley de Quebec (pese a su nombre, alcanza a todos los territorios del este de la actual Canadá, más Ohio). Se trata de 
una concesión de tolerancia, por parte del anglicanismo británico, al catolicismo local, para asegurar su lealtad. Tal acción es tomada como una ofensa por parte de las Trece Colonias, que se reúnen en un Congreso Continental y deciden mandar una misión diplomática a Canadá -a la que se invitaría, más tarde, a formar parte de los EE.UU., según el art. XI de los Artículos de Confederación. Debido a la escalada de la tensión, en 1776, los EE.UU. se presentan al mundo mediante una Declaración de Independencia. En sus Artículos de Confederación, en concreto, en su art. III, se tipifica que ninguno de los Estados parte puede ser atacado por razón de disputa religiosa, de soberanía o comercial. Antes de que UK reconozca formalmente la soberanía de los EE.UU., en 1782, se firma una Tratado con los Países Bajos, para asegurar las buenas relaciones vecinales -debido a los intereses que aún mantienen los Países Bajos en América-, donde se contempla la necesidad del respeto a la libertad religiosa. Posteriormente, el resto de grandes potencias europeas firman Tratados de amistad y comercio con los EE.UU., incorporando también un precepto sobre la relevancia del respeto a la libertad religiosa, para asegurar con ello unas relaciones cordiales. Ello no impide que, en la carrera de expansión hacia el Oeste (aprobándose por parte de los EE.UU. las Ordenanzas del Noroeste, 1787), vuelve a haber confrontaciones que desembocan en la Guerra de 1812. A partir de ahí, los EE.UU., prueba su superioridad en la zona y frente a las potencias europeas. Comienza así a centrar su atención en su expansión continental plena y hacia el sur -animando a las colonias a que se independicen, siguiendo su ejemplo. A mediados del s. XIX, los EE.UU., ha firmado Tratados de amistad y comercio con buena parte de las jóvenes Repúblicas latinoamericanas (igualmente, contemplando la necesidad de respetar la libertad religiosa). 
b) Tratados Orientales Musulmanes (África y Oriente Próximo): el discurso religioso, por pragmatismo, se dulcifica y disfraza de samaritanismo, pues hay en juego intereses y vidas de estadounidense (v.g. los miembros de las misiones diplomáticas, el transporte marítimo, etc.). Así ocurre, especialmente, en el caso del primer Tratado con Trípoli y su controvertido art. XI -ahora, de moda y esgrimido por quienes desea renunciar a la herencia judeocristiana estadounidense.

Figura 41.- Art. XI del Tratado de Paz y Amistad con Trípoli de 1797271

El Gobierno de los EE.UU. no está, en sentido alguno, fundado en la religión cristiana; como no tiene en sí mismo ningún carácter de enemistad contra las leyes, la religión o la tranquilidad de los musulmanes; y los mencionados Estados nunca han entrado en guerra o acto de hostilidad frente a ninguna nación mahometana. Se declara por las partes que el pretexto de ofensa en la opinión religiosa no será esgrimido para producir una interrupción de la armonía existente entre los dos países (...).

Fuente: elaboración propia (SÁNCHEZ-BAYÓN, 2007 y 16).

En 1796, se negocia un acuerdo de salvoconducto para los buques estadounidenses y su cuerpo diplomático en la zona, siendo firmado el documento (el 4 de noviembre) por el Cónsul para los Países Bárbaros, J. BARLOW, y el Bey/Señor de Trípoli, J. BASHAW. Posteriormente, se remite a la firma del Bey/Señor de Argel, H. BASHAW, que se produce el 3 de enero de 1797. Seguidamente, el tratado se manda a Lisboa, donde obtiene el visto bueno

${ }^{271}$ Cfr. BETH, L.P.: The American Theory of Church and State, Gainesville: University of Florida Press, 1958, pp. 74. BLAKELY, W.A. (comp.): American State papers and related documents on Freedom in Religion, Washington DC: The Religious Liberty Association, 1949, pp. 311 ss. EIDSMOE, J.: Christianity and the Constitution. The Faith of our Founding Fathers, Grand Rapids: Baker Book House, 1987, pp. 413 ss. STOKES, A.P.: Church and State in the United State (vol. 1), New York: Harper \& Row, pp. 497 ss. 
de D. HUMPHREYS, el Embajador estadounidense en Portugal (el 10 de febrero de 1797). Como valija diplomática, se da salida al documento, hacia los EE.UU., llegando al Despacho Presidencial el 10 de junio de 1787, donde por fin lo firma ADAMS. El mencionar todo este periplo, no es para poner de relieve la gran cantidad de trámites de control, sino más bien lo contrario, lo que aclararía la existencia del mencionado art. XI y su extraño contenido.

Tanto STOKES como EIDSMOE, coinciden en la hipótesis de que dicho artículo fuera una separata, para los Señores de Trípoli y Argel, pero que no debió llegar nunca a ADAMS, pues no ha quedado constancia oficial actual. Muy posiblemente, la culpa de un episodio así, con una redacción y traducción tan polémica, se pueda achacar a BARLOW y su personalidad -afectada de un cierto laicismo y pro-orientalismo, tras vivir una larga temporada en Francia.

El caso es que, nada de todo este episodio tuvo sentido, ni sirvió para mucho, ya que los piratas magrebíes no respetaron el tratado, quedando roto por parte de Trípoli en 1801 y teniendo que hacerse la guerra en 1805 (fue la primera acción de combate en el extranjero del Cuerpo de los Marines, para liberar a unos estadounidenses secuestrados). El 4 de junio de 1805, se vuelve a celebrar otro Tratado con Trípoli, donde no figura vestigio alguno del supuesto art. XI del tratado anterior -lo cual, hace dudar aún más de su existencia real, ya que la Administración JEFFERSON habría estado más predispuesta a su inclusión que la de ADAMS. Lo que se empieza a garantizar, en el art. XIX de ese tratado, y de otros siguientes, es la libertad religiosa del cuerpo diplomático dentro de los edificios oficiales estadounidenses. 
c) Tratados Orientales Asiáticos (Japón y China): la característica común de este tipo de tratados, a diferencia de los bloques anteriores, es su condición tardía, por lo que puede observarse, con más claridad, la mayor definición, consolidación y seguridad, que de sí mismos tienen los EE.UU. -ya no se trata de un aprendiz en las relaciones internacionales, ni están midiendo fuerzas con otros países, sino que se tiene constancia del propio potencial, y eso concede seguridad para marcar las relaciones diplomáticas. Así se explica el paso del uso de cláusulas de mutuo respeto y mínima intervención, a imponer prerrogativas de salvoconducto a los misioneros (y locales conversos) en aquellas tierras.

Sobre el estado reciente de la cuestión, en especial, sobre el sistema universal de la ONU para la libertad religiosa, y del que forma parte los EE.UU., tras la ratificación (por la Administración CLINTON) del Pacto de Derechos Civiles y Políticos de 1966, se remite al siguiente capítulo. 


\title{
7.- BALANCE PRAGMÁTICO SOCIO-RELIGIOSO HASTA LA GLOBALIZACIÓN:
}

\author{
INFLUJO DE ACR EN LA EMERGENCIA HEGEMÓNICA DE EE.UU. ${ }^{272}$
}

Para comprender el devenir estadounidense, ayudándose del hilo conector del factor religioso (por la misión, visión y valores aportados en la marcha de los acontecimientos), se adelanta aquí uno de los constructos vinculados a ACR y que permite periodificar dicha evolución, según una serie de ciclos y conforme a una teoría de rango panorámico, como es la teoría de despertares y revitalizaciones religiosas (TDR, vid. supra cap. 10): las crisis socio-culturales han generado despertares entre las bases sociales, afectándose a la agenda institucional (los temas de la opinión pública y plasmación en políticas públicas y regulación correspondiente), y por ende se han dado las revitalizaciones religiosas renovadoras de las elites de poder. Pues bien el origen del último ciclo de TDR, preparatorio de la globalización y sus crisis,

\footnotetext{
272 Amén de las pasadas publicaciones (citadas en el cap. 3, más la notas 3 a 5, 11, 16, 24, 55 y 68, más p. 126 ss.), el presente capítulo está sustentado por recientes artículos (publicados durante la matrícula de doctorado en la UVA y aprobados en las memorias tramitadas, vid. infra notas 137 y 138), sin olvidar otros previos clave, vid. SÁNCHEZ-BAYÓN, A.: "Revitalizaciones religiosas postmodernas en América y sus riesgos para la democracia y los derechos humanos" (pp. 1-23), en Revista General de Derecho Canónico y Derecho Eclesiástico del Estado-Iustel (n⿳0 11), mayo 2006. “Comunicación y Geopolítica estadounidense actual: de IRFA al Choque de Civilizaciones" (pp. 173198), en Historia y Comunicación Social (vol. 11), junio 2006. "Historia de la Comunicación Social Estadounidense a través de sus Movimientos Religiosos" (pp. 199-223), en Historia y Comunicación Social (vol. 13), junio 2008. “Conocer y gestionar las esferas sociales en la globalización: de las religión, la política y el derecho en las Américas del nuevo milenio" (pp. 103-146), en ICADE-Revista Cuatrimestral de las Facultades de Derecho y Ciencias Económicas y Empresariales (nº 81), sept.-dic. 2010. "Religión, Cultura y Comunicación Social en la Historia de la universidad estadounidense: de Church-State E American Studies a Cross-Cultural Studies" (pp. 6-28), en Compé, Revista Científica de Comunicación, Protocolo y Eventos, UCJC (no 2), dic. 2013. Complement., vid. infra Con el respaldo de pasadas publicaciones (citadas en el cap. 3, especialmente, La Modernidad sin prejuicios, Universidad, ciencia y religión en los Estados Unidos de América y La religión civil estadounidense), el presente capítulo está sustentado por recientes artículos (publicados durante la matrícula de doctorado en la UVA y aprobados en las memorias tramitadas).
} 
ha sido el iniciado con la llamada pérdida de inocencia estadounidense y las -ya aludidas- guerras culturales. En la década de 1960, con la perdida de inocencia (v.g. asesinato de KENNEDY, el bloqueo de Cuba, la Guerra de Vietnam, las revueltas del Congo, el triunfo contracultural en la universidad y medios) y crisis del AWL (v.g. por el aumento desmesurado de divorcios, abortos, anticonceptivos, drogas), se produce un despertar religioso, que pretende reconstruir la memoria histórica del país, para devolverle su liderazgo moral. En la década de 1980, dicha movilización ciudadana cala en las elites de poder, comenzando así la consiguiente revitalización religiosa ${ }^{273}$, con las Administraciones REAGAN. El proceso no se completa, pues la reconstrucción identitaria estadounidense se afirma frente al comunismo, pero al caer la URSS (1989-91), sólo queda una superpotencia dedicada al consumo y con un déficit idiosincrásico -agravado con la globalización-. Así, durante la primera mitad de la década de 1990, predomina la reconstrucción cultural vía lo políticamente correcto, con el apoyo de los Estudios culturales (sobrevenidos) en la universidad (vid. supra cap. 8), y mediante políticas y regulación de affirmative action o discriminación positiva y cuotas. Con tal tendencia, parece que se avanza hacia un despuntar de secularización laicista (como en la posmoderna Europa-continental, vid. infra), tal como se puede comprobar con el aumento de regulación sobre el factor religioso (vid. figura próxima), en un intento de su limitación -rayando la violación del art. VI y la Primera Enmienda de CEU-. La tendencia señalada quiebra con el escándalo sexual del Presidente CLINTON (en 1998), y su consiguiente proceso de impeachment

\footnotetext{
${ }^{273}$ Vid. SÁNCHEZ-BAYÓN, A.: “Revitalizaciones religiosas postmodernas en América y sus riesgos para la democracia y los derechos humanos", en Revista General de Derecho Canónico y Derecho Eclesiástico del Estado-Iustel (nº 11), 2006. - "Comunicación y Geopolítica estadounidense actual: de IRFA al Choque de Civilizaciones", en Historia y Comunicación Social (vol. 11), 2006. - "Idiosincrasia de la identidad nacional y del modelo socio-cultural estadounidense según el influjo de sus elites político-jurídicas (a vueltas con la religión civil)", en Las Actas del VII Congreso Español de Ciencia Política y de la Administración: Democracia y Buen Gobierno (Grupo 226: Elites de poder), 2005.
} 
(por perjurio y abuso de poder), por lo que el discurso religioso vuelve a copar el debate político (desde un énfasis moralista -produciéndose el contra-ataque cultural de la derecha-cristiana o Christian Right, en especial, de Moral Majority). Tal tendencia bélico-cultural, se acentúa a raíz de los trágicos atentados terroristas del 11 de septiembre de 2001 (cuando el discurso se vuelve mesiánico), sirviendo de reafirmación a los neoconservadores en el poder, dando lugar a una guerra mundial contra el terror (pero la identidad estadounidense como pueblo de libertad, queda en entredicho, por llevar la misma a través de la guerra). Por su parte la izquierdaliberal, tras el giro hermenéutico de la Administración CLINTON, pasa de la corrección política a un puritanismo de denuncias pro hechos diferenciales y renuncia del legado recibido. De tal suerte, se conforman dos grandes bloques que creen disponer de la superioridad moral que ha de orientar a los estadounidenses: de un lado, la derecha-cristiana (defensora de la "América real" -llamada por la otra parte, la "América profunda"- y su AWL tradicional, impulsora del originalismo y normalizadora de la ciudadanía), y de otro lado, la izquierda-liberal (contracultural y -según ellos- "bienpensante", por defender a las minorías y su memoria histórica). Tal polarización viene enconando la resolución del problema identitario relativoa a qué es ser estadounidense tras la globalización.

Dado el estancamiento actual, se considera más productivo el dar marcha atrás y procurar entender cómo se formuló, implemento y evaluó en cada ciclo de TDR la ACR: cómo se llegaron a convertir unas colonias en el país hegemónico de la Baja Modernidad o Contemporaneidad (resolviendo de paso la cuestión del funcionamiento hasta la globalización de la identidad estadounidense). Para lograrlo, se va a recurrir a una vía indirecta de aproximación (mediante contructos complementarios de ACR), analizándose primero el devenir de la misión, visión y 
valores estadounidenses, como se desprende de su AMD (y por ende, el auge de un pueblo elegido y bendecido); se continúa con la conformación de su sobreautoestima y superioridad moral o ASR (atendiendo a las principales agendas, generadoras de la solidaridad en cada periodo); se completa el análisis con la combinación de todo ello, focalizándose en la geopolítica estadounidense para Occidente (desde IRFA hasta el choque de civilizaciones y finalmente la guerra contra el terror). A lo largo de tan dilatado periodo, se va a atender a una organización espacio-temporal mediante TDR, así como a la aparición y trasformación de los ítem de ACR (cuya tópica sistematizada se trata en el cap. 10).

\section{1.- ACR \& AMERICAN MANIFEST DESTINY (AMD):}

\section{AUGE DE UN PUEBLO ELEGIDO Y BENDECIDO ${ }^{274}$}

Para conocer la idiosincrasia estadounidense en su complejidad, canalizada vía su ACR, urge saber cómo es su puesta en práctica: indagar sobre el talante estadounidense (su actitud, al realizar su visión, misión y valores), que no sólo se forja domésticamente (con cruzadas de transformación sociocultural, vid. supra epígr. 7.2), sino también en el exterior (con cruzadas para "nutrir" su Americaness, recibiendo influjos y poniéndose a prueba), en sus relaciones internacionales (conforme a un patrón de mesianismo o AMD, más cierta superioridad moral o ASR y sentido civilizatorio o ACS -recuérdese que los estadounidenses se sienten un pueblo elegido y bendecido, para guiar a los demás, v.g. pleadge of allegiance, vid.

${ }^{274}$ Vid. infra nota 162. 
supra cap. 10). Aquí se estudia cómo se relacionan los estadounidenses con dos pueblos occidentales: a) con los europeos, con los que se compite y hay que tener alejados (v.g. Despedida de WASHINGTON, Doctrina MONROE, Corolario ROOSEVELT); b) con los panamericanos/latinoamericanos ${ }^{275}$, a quienes ha de guiarse en su éxito y beneficio. Con los primeros (los europeos), el interés va cesando, a medida que el desencanto es mayor (v.g. pronto se les supera tecnológicamente -no culturalmente, pues dicho complejo permitió la fuga de cerebros y su posmodernidad-, hay que rescatarles militar y financieramente de manera periódica). En cambio, con los segundos (los americanos), no dejan de ser los vecinos del patio trasero o back-yard, o sea, parte de su configuración del hemisferio occidental (hasta que el socialismo cultural de las guerras culturales va inoculando el guerrillismo -desde la revolución de los barbudos en Cuba-, y más tarde el indigenismo -confirmándose en el Foro de Sau Paulo-, sacando así a Latinoamerica de la tradición occidental -confirmándose por intelectuales como HUNTINGTON-).

Este apartado se va a centrar en la relación mesiánica de EE.UU. con el resto de América, según el desencanto con los Europeos, y su intento de reafirmación en la región: de tal manera, se entiende que se pase de una relación fraternal, como fuera el panamericanismo inicial decimonónico (recuérdense las conferencias panamericanas, en las que participara EE.UU. como un miembro más), de países americanos frente a potencias europeas, transitándose al latinoamericanismo intervenido por $\mathrm{AMD}$, tras las guerras hispanoamericanas de 1898: pese a que

\footnotetext{
275 Durante el s. XIX convivieron dos visiones de América: la panamericana, de proto-organización internacional, con países vecinos, colaborando entre sí y frente a las potencias europeas, y la latinoamericana, inoculada por Francia, para medrar en la región. Se logró la división entre los países vecinos, insuflándoles la idea de ser potencias como las europeas, a modo de imperios regionales (v.g. La Gran Colombia -perdió Panamá-, el Imperio Mexicano -perdió Texas, Nuevo México y Arizona-, el Imperio Brasileño).
} 
EE.UU. había prometido lealtad eterna a España, por contribuir a su independencia, sin embargo, dice auxiliar un siglo después a pueblos americanos (cubanos y puertorriqueños -incluso, los filipinos-), quedando así bajo su órbita (especialmente, Puerto Rico).

¿Cómo se pasa de percibir a los países vecinos, como semejantes americanos (con ciertas diferencias socioculturales, al reducirles a un catolicismo deficiente, en comparación con el modelo WASP, vid. infra), a asumir su tutela? De tal manera, se afecta su percepción de sí mismos en el trato con los demás, confrontándose con la visión que los otros tienen de ellos - tratándose de paso una cuestión que ya ha salido a relucir, como es el mal denominado imperialismo estadounidense (un anacronismo medieval, no correspondiente con un país moderno)-276. Para no dispersarse demasiado, se centra la atención en dos cuestiones relacionadas con ACR y su proyección externa: a) el destino manifiesto (el despuntar estadounidense, frente a europeos y americanos), y b) las interacciones con Latinoamérica (la tutela e intervención frente a riesgos no-occidentales: guerrillismo e indigenismo).

\section{Destino manifiesto: herencia católica europea y su Americaness}

Dicha alocución, destino manifiesto, significa que se tiene una visión y misión claras y evidentes de lo que se está llamado a ser y a hacer; se dispone así de una guía de progreso, basada en un compromiso y confianza en las cruzadas a acometer

276 Vid. SÁNCHEZ-BAYÓN, A.: Concordia constitucional, Madrid: Delta, 2013. Derecho Constitucional, Madrid: Ed. Roble, 2014. Derecho Público General: Instituciones públicas y actores sociales, Madrid: Delta, 2016. Lecturas fundamentales de Derecho Político y Constitucional, Porto: Ed. Sindéresis, 2017. ¿Ocaso estatal y de sus relaciones institucionales y protocolarias? Porto: Ed. Sindéresis, 2018. Instituciones del Estado, Porto: Ed. Sindéresis, 2018. 
(por estar respaldadas: se cumple el designio divino, el plan de Dios para su pueblo). Su noción vigente, heredera del excepcionalismo (vid. supra cap. 8), es de corte posjudeocristiano, pues mantiene la idea de unción y salvación, más progreso y bienestar, pero adaptándola para el pueblo estadounidense, como líder de Occidente: gracias a su pactismo (recuérdese, ACT), no sólo Dios puede disponer y fijar designios, sino también el pueblo estadounidense (como pueblo elegido y bendecido), según las exigencias coyunturales. De ahí que en cada despertar religioso surjan novedosas corrientes de protestantismo misionero carismático, eso sí, cada vez más desdibujadas dichas corrientes con respecto al cristianismo original y sí con una impronta estadounidense más clara, v.g. pentecostalistas, adventistas, testigos de Jehová, mormones) $)^{277}$.

El destino manifiesto estadounidense o American manifest destiny (AMD) enraíza con la herencia del destino manifiesto católico de los españoles ${ }^{278}$, usándola justamente contra ellos, en su expansión decimonónica, a costa de las posesiones de

\footnotetext{
277 En cuestión de propaganda religiosa suele ser la Iglesia católica la receptora de la mayor parte de la crítica, sobre todo tras el Concilio de Trento, por la constitución de la Congregatio de Propaganda fide (para guardar la ortodoxia y combatir las herejías, además de expandir el evangelio); sin embargo, dicho organismo es propio de todas las iglesias del momento: la Iglesia anglicana funda la Sociedad para la Propagación del Evangelio, de gran presencia en América, así como los órganos respectivos de la Iglesia Holandesa Reformada, lo mismo con los luteranos alemanes, etc. Las evangelical churches no optan por tales organismos -por su oposición al establecimiento y la jerarquización-, lo que no impide que dispongan de sus prácticas -sólo que de manera más discrecional- (v.g. los juicios de Salem de los puritanos, los linchamientos del Ku-Klux-Klan). Entre las variantes protestantes y la católica, la principal diferencia radica en que la última exige base teológica y de proceso canónico de ahí que queden más pruebas de sus actuaciones-. Otra gran diferencia es el énfasis misionero, que los protestantes sí han mantenido, especialmente en los EE.UU., vía despertares y revitalizaciones (vid. supra cap. 10).

${ }^{278}$ Los españoles creían tener un destino de unión cristiana de vocación universal y oficial (que es lo que significa "católico", conforme al Edicto de Tesalónica de Teodosio en el año 380, vid. SÁNCHEZBAYÓN, A.: Derecho Eclesiástico Global... op. cit.). Era una llamada divina -respaldada por el Papa, con la concesión de títulos como Reyes Católicos- a unir los diversos pueblos cristianos de la Península Ibérica, expulsando a los invasores (v.g. musulmanes, judíos), dando lugar de este modo a cruzadas mesiánicas como la Reconquista primero, y la Conquista o Evangelización de América después.
} 
los mismos (desde las Floridas en 1810 y 1819, hasta Cuba, Puerto Rico y Filipinas en 1898). Se llega incluso al Americaness de su propia identidad, convirtiéndose a los viejos civilizados en neobárbaros (vid. infra) ${ }^{279}$. Luego, detrás de AMD existe una suerte de mesianismo (reconocerse como un pueblo ungido entre las naciones, para guiarlas), incorrectamente calificado de imperialismo (no sería tal en rigor, tanto por el error anacrónico, como por su sustento religioso: al buscarse evangelizar y no dominar sin más) ${ }^{280}$. Y es que, AMD resulta uno de los pilares (en conexión con AWL, ASR, etc.), para la construcción de una identidad propia fuerte y mesiánica ${ }^{281}$, de vocación expansiva (como lo hiciera de manera continental y finalmente hemisférica y occidental). Así se entiende cuándo y cómo cala la expresión (tras la reconstrucción de la Guerra civil y el despegue del nuevo influjo expansionista de la nación), atribuyéndose su popularización -o sea, su tematización en la opinión pública- al

279 Vid. SÁNCHEZ-BAYÓN, A.: Humanismo iberoamericano, Guatemala: Cara Parens, 2012. Renovación de la Filosofía Social Iberoamericana, Valencia: Tirant Lo Blanch, 2013.

${ }^{280}$ Resulta incorrecto hablar de imperialismo estadounidense, puesto que no es tal en sentido tradicional, ya que no suele producirse la ocupación física permanente, sino la dirección en la distancia, a modo de intervenciones coyunturales para salvaguardar intereses estadounidenses. Más que al Imperio romano, se podría parecer al helénico, al responder al modelo de talasocracia con colonias. Sin embargo, a los estadounidenses, a diferencia de los griegos, sí les interesa extender su cultura (americanizar/estadounidizar el mundo -hacerlo a imagen y semejanza, cosa que los griegos eran muy celosos de su cultura, pues consideraban que les proporcionaba superioridad en los intercambios-). Como pasara al comentar la posible comparativa de cesaropapismo (antiguo y moderno, vid. cap. 9), la cuestión es muy rica y compleja, por lo que se deja aquí la cuestión a expensas de nuevas consideraciones ilustrativas.

${ }^{281}$ EE.UU., resulta el único país americano que, para independizarse, ha de luchar de manera prolongada con una gran potencia hegemónica europea en auge, como UK. Por contraste, las Repúblicas hispanoamericanas eclosionadas durante el s. XIX, ni fueron colonias tratadas injustamente, ni tuvieron que luchar de manera sostenida contra potencia alguna: las provincias de ultramar eran parte de las Españas y como tales estaban reconocidas en las Constituciones y participaban en las Cortes (así reflejado desde la Constitución de 1812), y cuando decidieron secesionarse, no encontraron casi resistencia de la Corona española, que estaba en disputa entre los Borbones y los Bonaparte, además de encontrarse en declive el Imperio español (crisis completada con el desastre de 1898 y que condujo al auge de los nacionalismos periféricos, que atacarán la idea misma de España). Vid. SÁNCHEZ-BAYÓN, A.: Humanismo iberoamericano... op. cit. Renovación de la Filosofía Social Iberoamericana... op. cit. Instituciones del Estado, Porto: Ed. Sindéresis, 2018. 
escritor y periodista O'SULLIVAN (quien diera difusión en publicaciones de referencia como Democratic Review, New York Morning News, etc.) -aunque hay investigaciones actuales que se la atribuyen al Presidente J.Q. ADAMS, vid. supra-. En sus columnas, el periodista usaba apologéticamente la expresión destino manifiesto para apoyar la -según él- irrenunciable expansión estadounidense, mediante la anexión de Texas y California, la invasión y guerra con México (dando lugar a la Cesión mexicana -una compraventa forzosa, por la que México renunciaba a más de la mitad de su territorio de entonces-: Colorado, Arizona, Nuevo México, Nevada, Utah y partes de Wyoming, Kansas y Oklahoma), y finalmente el Caribe (v.g. Cuba, Puerto Rico) y el Pacífico (v.g. Filipinas, Indonesia) -a costa de España, contra la que se aplicaría una estrategia similar a la seguida contra México- ${ }^{282}$.

En términos más amplios, cabe conectar el destino manifiesto con otras alocuciones que forman parte del legado de los padres fundadores (lato sensu, incluyendo todo el panteón, con sus grandes estadistas posteriores). Para ilustrar la cuestión, baste con los siguientes ejemplos:

a) Pueblo elegido (G. WASHINGTON, apodado father of our country o padre de nuestra nación): en su discurso de despedida, esboza las bases de lo que serán los planteamientos del destino manifiesto, sólo que lo indica en clave aislacionista y de profundización (centrándose en América y evitando los conflictos europeos), al menos hasta que los EE.UU. llegue a recuperarse completamente de las heridas de guerra y sus gentes compartan su condición

\footnotetext{
${ }^{282}$ Cuestión que, por cierto, a parte de las suspicacias habituales sobre el hundimiento del Maine, podría interpretarse como traición y violación del Derecho Internacional, pues los EE.UU., un siglo antes, había prometido lealtad a España por su ayuda en la Guerra de Independencia contra UK -mutatis mutandis se podría decir de la traición a México, pues existía una presunción de pacto panamericano, tal como se desprende de la Doctrina Monroe y el Corolario Roosevelt, vid. supra-.
} 
común de ser un mismo pueblo.

b) Poderes ocultos (T. JEFFERSON, llamado el gran demócrata -aunque lo fue JACKSON-, además de habérsele atribuido incorrectamente la autoría de la Declaración de Independencia -al haber sido una comisión-): mientras estuvo en la oposición, recordó a ADAMS el deseo de WASHINGTON (de mantenerse alejado de los europeos, hasta su consagración idiosincrásica), pero al llegar a la Presidencia, inicia una estrategia expansionista (v.g. comprando territorios a europeos), articulando para ello una doctrina nueva que confiere al Presidente la condición de hombre fuerte y mesiánico, director del avance de los EE.UU.

c) Destino propio (J.Q. ADAMS, conocido como old man eloquent o anciano elocuente): tras educarse en Europa y conocer las grandes potencias de entonces (como fuera la voluntad de su padre, el Presidente ADAMS), J.Q. ADAMS regresa habiendo aprendido la importancia de la sobreautoestima de un pueblo para contar con un papel importante en el concierto de naciones de entonces. De ahí que sea de los primeros en reivindicar el legado de los colonos fundadores (especialmente los de Nueva Inglaterra, al menos, el mito que empieza a forjarse al respecto), como estrategia para dotar de una identidad propia, emancipada lo máximo posible de Europa.

d) Doctrina expansiva/Monroe (J. MONROE, cuyo mandato fue bautizado como Era of good feelings o era de las buenas sensaciones/sentimientos): EE.UU., ya se ha recuperado de las Guerras indias (de expansión hacia el oeste y norte), y está en plena colonización del lejano Oeste, aunque sigue teniendo fricciones con algunas potencias europeas (v.g. UK, Francia), de ahí que MONROE insista en 
que "América es para los americanos".

e) Anexionismo máximo (J.K. POLK, con el sobrenombre de young hickory o joven nogal): en pleno despegue industrial, EE.UU., es un país pujante, con necesidad de materias primas, luego la vía más rápida es la anexión de nuevos territorios (con los recursos naturales necesitados). A dichos territorios (hacia el oeste y el sur), se los considera tierra de frontera por civilizar. Se juega con el sentido de extender AMD, la omisión de la impronta española y mexicanos habitadores, pero tal propaganda funciona para la expansión de costa a costa (del Atlántico al Pacífico, creándose así otro mito, como es que la condición continental de EE.UU.), además de permitir la adquisición de un gran número de puertos para mejorar el comercio (como pasa con los intentos expansivos hacia el Golfo de México, y el objetivo final que es el Caribe). El caso es que, dicho giro discursivo de AMD, con los nuevos clichés del norte civilizado e industrial (ergo, superior), y el oeste y sur salvajes y rurales (inferiores), se va a volver en contra de los propios estadounidenses, sembrando las bases de la Guerra civil (que más tarde, se rebautizará como Guerra de secesión: como si los sureños bárbaros hubieran traicionado el proyecto de la Unión).

f) Última esperanza (A. LINCOLN, apodado honest Abe o Abra el honrado): tras la Guerra civil, LINCOLN logra convertir la debilidad en fortaleza, procurando defender en sus discursos, que el ciudadano estadounidense representa el prototipo del hombre nuevo y moderno, y que EE.UU., es la última y mejor esperanza (y que la guerra sólo se debió al olvido de tales cuestiones que definen en su conjunto a los estadounidenses). En definitiva se trata de un intento por revalorizar moralmente el destino manifiesto, tras el desprestigio guerracivilista vivido. 
g) Política expansiva (McKINLEY, llamado Idol of Ohio o ídolo de Ohio): su discurso es maniqueo, revistiendo con todos los vicios posibles a los competidores de los intereses estadounidenses, de modo que por contraste, EE.UU., supone un cúmulo de virtudes, viéndose obligado a intervenir, como defensor del bien. Sirva como ejemplo, la connivencia con los grandes periódicos de entonces, como los dirigidos por los afamados PULITZER (New York World) y HEARST (New York Journal), acusándose a los españoles de infanticidio y canibalismo, para despertar así el civilizing sense o sentido civilizatorio (ACS), que permitiera el apoyo del pueblo estadounidense a la Guerra hispano-cubana (también hispanoamericana, por alcanzar a Puerto Rico y Filipinas), en la que EE.UU. únicamente intervienen por obligación, en nombre del bien y como pueblo más civilizado.

h) Corolario de exclusión (T. ROOSEVELT, su apodo variaba según defensores y detractores, pero suele ser Teddy, trust buster o Teo el cautivador): tío del posterior Presidente ROOSEVELT, siendo un hombre fuerte, no resulta tan vehemente como su oponente BLAINE ${ }^{283}$ (al menos no tan abiertamente, quizá al recordar lo que le pasara a McKINLEY). Tal templanza le permite fijar el complemento de la Doctrina Monroe, con el apoyo del resto de pueblos americanos: América es para los americanos, "sin los europeos". Sin enfrentamiento directo, ROOSEVELT llega así a jugar con las palabras, pues American, en inglés es estadounidense (el gentilicio de los EE.UU.), siendo el resto Canadians, Mexicans, etc.

\footnotetext{
283 BLAINE llegó a descalificar sin tapujos el Panamericanismo y a los latinoamericanos, ya que a su entender siempre estarían sometidos a los EE.UU.
} 
i) Policía internacional (T.W. WILSON, apodado School-master in Politics o maestro de la política): de los pocos académicos que ha habido en la Presidencia estadounidense, al dedicarse al Derecho y la Política Internacional, fue uno de los principales impulsores de la Sociedad/Liga de Naciones (proyecto que partiera de su discurso de los Catorce puntos, 1918). Cometió el error de creer que, al haber sido EE.UU. el país que puso fin a la Gran Guerra (I Guerra Mundial), el resto de potencias habrían de reconocer su liderazgo, cosa que los europeos no estaban dispuestos. En consecuencia, poco a poco, el país se va desvinculando del proyecto, apostándose por la vía unilateral (de vuelta a AMD), por la que EE.UU. se convierte en el gran policía internacional.

x) Liderazgo mundial (R. REAGAN/G. BUSH, conocido el primero como The great communicator o el gran comunicador, y el otro como Poppy o amapola/adormidera -así como el apodo dado a una mascota): REAGAN defiende un destino manifiesto en mundo bipolar, en el que EE.UU. ha de liderar el bando del bien y la libertad, basado en el libre albedrío individual (visión que se intensifica tras el intento de asesinato sufrido). Mientras, BUSH padre, plantea un AMD para un mundo globalizado (estadounidizar el mundo, tal como FUKUYAMA defendiera a la postre, con la caída de la URSS y la hegemonía mundial estadounidense). No obstante, tales planteamientos estaban llamados a fracasar, pues se había reducido ACR y AMD a su oposición a los regímenes socialistas, pero no al socialismo cultural, ya instalado en el seno estadounidense y bloqueado en su revisión idiosincrásica para el nuevo periodo iniciado. 
y) Occidente y guerra contra el terror (W.BUSH): reformula AMD bajo una doctrina de corte neoconservador, de énfasis en la superioridad moral estadounidense, que ha de ser el guardián de un mundo inseguro. Dicho terror legitima la actuación exterior estadounidense en cualquier parte del mundo; incluso se acomete cierto "terror" en "agujeros negros" (instalaciones militares fuera de la jurisdicción de la justicia estadounidense, v.g. base militar en Guantánamo, fruto de un alquiler al Gobierno Cubano). El problema es que se deslegitima AMD, pues desaparece la superioridad moral, para quedar la política intervencionista del miedo.

z) Transoccidentalización (TRUMP): más que una reacción, se trata del resultado del triunfo de la posmodernidad (inoculada por la fuga de cerebros europeos en EE.UU., tras las guerras mundiales), conduciéndose a la renuncia del liderazgo occidental tradicional (basado en el mesianismo responsable de los demás pueblos, en especial, de los europeos). Se llega así a la situación de desapego con las relaciones atlánticas, por traer sólo problemas y poco agradecimiento (v.g. el problema de la OTAN y reducido presupuesto europeo en defensa -mientras prolifera la industria armamentística en Francia, España, etc.). Se produce así un giro e intensificación de las relaciones pacíficas: con Japón, Corea del Sur, Singapur y demás dragones (como se llaman a las potencias regionales), así como con los latinoamericanos a través de dicha costa, además de la Commonwealth o Mancomunidad de Naciones en Oceanía. No obstante, se está revisando dicha vía, pues una de las primeras medidas de TRUMP fue salír del Pacto Transpacífico de Cooperación en 2016, para "proteger a su clase media" -en realidad, es un indicador de un periodo aislacionista previo a otro expansionista, que bien podría ser transpacífico o no (transoccidental seguro)-. AMD ha quedado 
desarticulada, por perder su fondo y forma tradicional, pretendiéndose su reformulación total ${ }^{284}$ (vid. supra cap. 11 y 12).

En definitiva, para buena parte de los estadounidenses, hablar de destino manifiesto es hacer referencia a tres convicciones simples: a) la virtud de las normas e instituciones estadounidenses y de sus ciudadanos; b) la llamada a extender dichas normas e instituciones, con su modo de vida (AWL) al resto del mundo (la estadounidización no se ve mal, sino al contrario, pues se identifica con extender la democracia, la libertad, la meritocracia, la propiedad, etc.); c) el respaldo de Dios para lograr dicha misión (tal como reza su lema naciona annuit coeptis, vid. infra epígr. 5.3; para comprender mejor la visión, misión y valores estadounidenses, se remite a las nociones y evidencias de ACT, vid. infra cap. 5 y 6, o la Geopolítica estadounidense en el último epígrafe y en el cap. 10). Como se aclarará a continuación, las convicciones mencionadas en realidad no se cumplen en las relaciones con los vecinos latinoamericanos $-\mathrm{O}$ al menos existe una profunda disonancia entre la autopercepción estadounidense y la percepción latinoamericana en su mayoría-.

\section{Mesianismo estadounidense en Latinoamérica:}

proyección de Americaness en sus vecinos católicos

y frentre a los riesgos no-occidentales

Este apartado se ha escrito, atendiéndose a las propuestas explicativas -algo más críticas- de los Estudios culturales tradicionales, como son la sección Latin

${ }^{284}$ Vid. TRUMP, D.: Great Again: How to Fix Our Crippled America, New York: Threshold Editions, 2016. 
American Church-State Studies, Religion ands, Cross-Cultural Studies e International Affairs. En tal sentido, se tiende a percibir Latinoamérica como un conglomerado, conformado por el otro americano (el no éxitoso, al que hay que tutelar y guiar para que progrese). Luego, pese a la proximidad geográfica (como vecinos, con quienes se comparte continente -más tarde, continentes, y por ello se habla conjuntamente de hemisferio-), en cambio, en términos socioculturales, la percepción es distante, y desde los Estudios culturales además, resulta dialéctica: según los Estudios culturales tradicionales, lo que es buena vecindad e intervencionismo por el bien del otro (evitándose problemas mayores, para sí y para la región), para los Estudios culturales sobrevenidos es imperialismo depredador (se busca ventaja y evitar competidores, a la vez que se explotan los recursos naturales). Desde las guerras culturales, la visión más generalizada es que, con la excusa intervencionista del destino manifiesto no se ha dado muestra de virtuosismo y buena vecindad (back-yard policy ${ }^{285}$, sino más bien de otras políticas conocidas como "el palo y la zanahoria", "el gran dólar", "la lucha anti-comunista", o "el freno al narco-tráfico"286. Su resultado común ha sido un mayor distanciamiento entre EE.UU. y Latinoamérica: las dictaduras, el empobrecimiento, la desectructuración social, así como otros males acaecidos en Latinoamerica, y por contraste con el progreso estadounidense, han dado lugar a lecturas polarizadas: una vez más, los Estudios culturales tradicionales

\footnotetext{
${ }^{285}$ Back yard policy, literalmente significa política de patio trasero, lo cual resulta peliagudo en su interpretación por las diferencias culturales entre mediterráneos y latinoamericanos con respecto a los anglosajones: para los primeros, el patio trasero es el trastero donde acumular residuos, colgar la ropa, expulsar los humos, etc. -en definitivo, donde haces aquello que no quieres que se vea en la puerta principal-, mientras que para los segundos (los estadounidenses), se trata del jardín donde celebrar barbacoas con los vecinos. Se entenderá así que, desde Latinoamérica se traduzca con desconfianza y malestar, hablándose de Política de patio trasero, mientras que desde el punto de vista de los estadounidenses habría de traducirse como Política de buena vecindad.

286 Se trata de expresiones sacadas de discursos presidenciales, siendo uno de los más coloquiales (en sus calificaciones al respecto) el Presidente L.B. JOHNSON, o el Secretario de Estado F. DALLAS.
} 
lo achacan a la falta de entendimiento entre vecinos y el no desear orientación alguna desde la guía de AMD, mientras que los Estudios culturales sobrevenidos, responsabilizan de todos los males a AMD.

A continuación, se va a intentar exponer una revisión crítica de síntesis (entre las polarizaciones existentes en los Estudios culturales), procurándose la focalización en las manifestaciones más evidentes de ACR desde la propia sociedad civil (y no tanto la geopolítica, más próxima a la religiosidad política).

Entonces, la mencionada deriva latinoamericana (dictatorial, de empobrecimiento, fractura sociocultural, etc.), ¿cómo es interpretada en clave de ACR y AMD desde movimientos socio-religiosos estadounidenses? Por ejemplo, los pentecostalistas, en sus campañas de evangelización durante las guerras culturales, lo aprovechan para medrar a costa del catolicismo, al que culpan de los males endogámicos latinoamericanos; sin embargo, tras la globalización, en sus campañas ha habido un cambio discursivo, prestándose atención a los riesgos no-occidentales (v.g. neomarxismo, indigenismo).

Figura 42.- Mesianismo estadounidense “duro" en Latinoamérica ${ }^{287}$

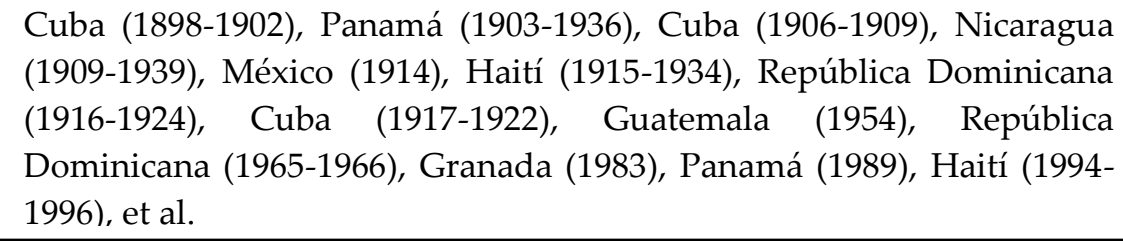

Fuente: elaboración propia (SÁNCHEZ-BAYÓN, 2007 y 16).

\footnotetext{
${ }^{287}$ Más de la mitad de las intervenciones acabaron en ocupación -aunque se hayan revestido luego a modo de arrendamientos, como el caso de Panamá con el canal, o de Cuba con Guantánamo-, manteniéndose luego un tercio de las mismas bajo régimen de protectorado (semi-democracias formales en régimen implícito de fiducia), y sólo un $10 \%$ resultó exitoso (ya que varias intervenciones tuvieron que repetirse poco después); vid. figura siguiente sobre fundamentos propagandísticos.
} 
No se pone tanto en tela de juicio las intenciones originales estadounidenses, como los resultados logrados y el tipo de campaña comunicativa y psicosocial acometida. Para comprender esta cuestión, se reconducen las explicaciones al problema original del pentecostalismo estadounidense en Latinoamérica, pues disponiendo de medios, no logra calar en las sociedades hasta que no varió su discurso y enfoque de su misión -mutatis mutandis, lo que vale para el soft-power o poder blando/cultural, es aplicable al hard-power o poder duro/militar-.

\section{Especial atención al influjo pentecostal}

Fundamentalismo, evangelismo, pentecostalismo, incluso, neopentecostalismo, son expresiones de uso corriente para referirse a movimientos relacionados, de ahí la imprecisión habitual en su manejo intercambiable, a modo de sinónimos, pese a tener significados y alcances diversos, además de corresponderse con etapas diferentes ${ }^{288}$. Sin embargo, la intuición popular que favorece tal identificación de nociones se debe a que en realidad dichos fenómenos y movimientos integran la estrategia global del protestantismo misionero y carismático, conectado con la identidad

\footnotetext{
${ }^{288}$ A modo telegráfico: a) el evangelismo se corresponde con el primer despertar (vid. cap. 6) y el periodo de implementación, de impronta pragmática (contrario al misticismo y al establecimiento oficial religioso), alimentando la llamada a la frontera (la expansión hacia el interior del continente); b) el fundamentalismo se corresponde con el segundo despertar e inicio del periodo de evaluación, cuyo objetivo es la profundización en el AG, con sus implicaciones de AWL, AD, etc.; c) el pentecostalismo eclosiona con la transición entre el segundo y tercer despertar (en el periodo de evaluación), caracterizándose por su proselitismo misionero doméstico, y poco después también exterior (v.g. Asia-Pacífico); el neopentecostalismo se corresponde con el cuarto despertar, teniendo lugar en la transición entre el periodo de evaluación y el de confusión, centrando su atención sobre todo en Latinoamérica (v.g. Centro América, Brasil).
} 
estadounidense, su destino manifiesto y el mito de la frontera ${ }^{289}$. Se trata de una estrategia expansiva mesiánica, que primero condujo a la ocupación de lo que dominaron el "Continente" (de la costa Atlántica a la Pacífica), y luego se proyectó hacia el Sur (Caribe y Norte de Sudamérica -que por cierto, pasaron a catalogarse como otro continente-, vid. infra). La cuestión resultante es que dicho protestantismo misionero y carismático ha sido una pieza clave para la expansión estadounidense: se ha tratado de su ariete, inspirado por la firme creencia de cumplir una misión divina. Sin embargo, al tratarse de una expresión de posjudeocristianismo, se comprenderá entonces que su pensamiento inspirador no sea puramente teológico, sino - el varias veces aludido- American Covenant Theology (ACT) [teología pactista estadounidense -o mejor dicho Teología política estadounidense-]: se trata de una adaptación pragmática estadounidense, por lo que no se centra tanto en el qué (Cristología) y el por qué (Salvación), sino en el cómo (no en Eclesiología tradicional, sino en comunitarismo o asambleas, v.g. Asambleas de Dios), de ahí que se sustente en nociones de tendencia emotiva y empática (vid. figura siguiente): a) la creencia en un Cristo íntimo -no un Dios de la humanidad, sino uno personal/ personalizado, que permite la redención-; b) el sustento en una escatología folklorizada o de storytelling -se transmite a modo de cuento, donde existen amenazas permanentes como los demonios, el infierno y el apocalipsis-; c) la obtención de dones del Espíritu Santo -de ahí lo de pentecostalismo-290, lo que refuerza las otras creencias y favorece el

\footnotetext{
289 Ya se ha mencionado, al abordar Americaness, se trata el fenómeno de la frontera, entendido no como espacio físico (border), sino como límite mental a superar (frontier). Se trata del estado espiritual por el que se invita a los disidentes y heterodoxos a ir hasta los confines y ensayar allí sus propuestas, y si lo logran, los demás lo aceptarán y seguirán.

290 Pentecostés o Día de las primicias/dones, proviene del griego, que significa quincuagésimo. En su origen judío se refiere a la celebración anual (a los cincuenta días de Pascua) de la Fiesta de las Semanas, para agradecer los primeros frutos de la cosecha (vid. $L v$ 23). Se refiere también a la promesa del derramamiento del Espíritu Santo (vid. Jl 2). Es así como lo han recibido los cristianos, quienes
} 
cumplimiento de su misión. Pero, ¿en qué ha consistido exactamente esta misión?, y ¿cómo ha afectado a los latinoamericanos?

Como ya se ha mencionado, al aludir al mal llamado imperialismo estadounidense, pese a su intermitencia y coyunturalidad, sí es cierto que cuenta con una constante, como es la tendencia expansionista del destino manifiesto (de ahí los ciclos de despertares y revitalizaciones, favorecedores de episodios aislacionistas e intervencionistas, debidos a los ajustes necesarios entre profundización y ampliación del sistema). El caso es que, se desea llamar la atención sobre el hecho de que el intervencionismo estadounidense sobre Latinoamérica arranca con el protestantismo misionero carismático -como ariete de soft-power-, cuya última expresión al respecto es el fenómeno del calificado como neopentecostalismo (y sus cruzadas de sanación y santidad $)^{291}$. Resumiendo bastante -quizá demasiado, pero ya se ha advertido al respecto en la Nota del autor-, dicho movimiento religioso no empieza a orientar su atención hacia Latinoamérica hasta el tercer despertar religioso, o sea, el periodo de evaluación en la Historia estadounidense (1890-1980, vid. cap. 10). Se trata de una época expansiva, de reafirmación (tras haber logrado superar la Guerra civil y la depresión rural, además de conseguir conectar el país de un extremo a otro). El estadounidense va a poner a prueba su idiosincrasia, en un ejercicio proselitista de su modo de vida (AWL), y con un giro total de la propaganda: con el primer despertar se transformaron los discursos persuasivos

celebran la concesión de dones a los Apóstoles para poder evangelizar a toda la humanidad, v.g. glosolatia o don de lenguas (vid. Hch 1, 2, 8, 10, 11 y 19).

${ }^{291}$ Muchas de las comunidades neopentecostales provienen de las Asambleas de Dios, de donde surgen los denominados Movimientos de Fe, que es una expresión dominante en el colectivo. Sus padres fundadores - por así decirlo- fueron K.E. HAGIN, D. BENNETT, D. Du PLESSIS. Otros difusores importantes han sido T. HICKS, M. CERULLO, P. FINGERMAN, R. HUMBERT, J. SWAGGART, etc.; complement., vid. nota siguiente. 
religiosos en políticos; con el segundo despertar, se convirtió la propaganda política en comunicación institucional; y con el tercer despertar, se procedió a trastocar todo lo anterior reconvirtiéndolo a marketing o propaganda comercial (vid. figura siguiente). Ergo, los movimientos religiosos en sus misiones van a enfocar su American Gospel (AG) en el intento de venta del American way of life (AWL) y su American Dream (AD), ayudándose del American manifest destiny (AMD). Es por este motivo que las primeras misiones fallan, pues desprecian lo existente (el catolicismo y el hispanismo) y pretenden que los locales consuman su producto espiritual: no comprenden cómo llegando con sobrados medios económicos y su pulcritud (física y moral), no logran calar tanto como el desaliñado cura católico, que en cambio es capaz de ir a la cantina y participar de un folklore sincrético -rayando a veces la hibridación pagana-. Como buenos pragmáticos, la solución a la que llegan es sencilla: resulta urgente y necesario intensificar la propaganda, haciendo identificar el bienestar económico, con el político y religioso, además de introducir nuevos clichés, roles y estereotipos que desbanquen a los tradicionales -por eso es propaganda, porque se exalta una parte y se impide que exista contraparte, al condicionar y desprestigiar cualquier otra opción-. De tal manera, no es hasta la Guerra fría y el aggiornamento de la Iglesia católica, circunstancias estas que favorecen el despegue del denominado neopentecostalismo, iniciando sus campañas de evangelización a fondo ${ }^{292}$, articuladas en tres fases de cuatro años cada

\footnotetext{
292 Se trata de la cruzada más conocida y referente de las siguientes (junto con el Programa Amanecer), influyendo en el resto de Misiones de Fe y en las cruzadas de CAUSA, AULA, etc. Evangelización a fondo fue lanzada en 1961 por el Rev. K. STRACHAN (Director de LAM -pretendidamente el equivalente evangélico a CELAM de la Iglesia católica; en tal sentido, son de destacar también CONELA y CLAI). Se aprovechó entonces la experiencia de la "evangelización agresiva" de las "cruzadas" del -ya citado- Rev. GRAHAM tras la II Guerra Mundial (para los nuevos inmigrantes en los EE.UU. -y la llamada a atajar la cuestión en su origen-). Los objetivos de las campañas consistían, básicamente, en su acción doméstica (en los EE.UU.), en lograr la adhesión misionera de la sociedad civil -sobre todo de estudiantes, que lo concebían como voluntariado-, y el respaldo de los poderes públicos (v.g.
} 
una (de 1961 a 1972)293, y financiadas incluso con fondos públicos -algo que a los defensores del separatismo no parece molestar-, acometiéndose bajo la excusa de cooperación al desarrollo -o sea, el freno al influjo socialista, que ha afectado a la Iglesia católica (v.g. Teología de la liberación), ha generado la proliferación de guerrillas, ha causado el aumento de la violencia organizada y la inseguridad ciudadana, la desestructuración familiar, más pobreza, etc. -294 . Frente a tal deterioro se ofrece una salvación, que pasa por un bienestar económico, pero que implica la renuncia de la herencia cultural y la aceptación de las nuevas categorías. Es así como el latinoamericano, que ha llevado a nuevas cuotas de esplendor la cultura occidental recibida de los civilizados mediterráneos (v.g. la ciudad letrada, el arielismo), renuncia a todo ello, incluso a su pasado más reciente (de repúblicas soberanas decimonónicas), para aceptar la condición de neobárbaro, de tercermundista (vid. infra $)^{295}$. Y es que, no se olvide el lector que, la religión es el mejor condensador y

\footnotetext{
visados, financiación -al canalizar a través de dichas confesiones la ayuda al desarrollo-), bajo excusa de extender el AWL y frenar el socialismo. En su acción local, se insistía en la importancia de ganarse a los personajes socialmente influyentes (v.g. facilitar el estudio a los hijos de dirigentes políticos), además de realizarse un uso masivo de los medios de comunicación, donde acometer un intenso proselitismo. En los años 80 comienzan las campañas de segunda generación, de latinoamericanos conversos, que son la auténtica base del neopentecostalismo. Sus campañas reciben denominaciones peculiares como cruzadas de sanación y santidad o guerrilla espiritual, tal como retrata la documentación pública de líderes religiosos como C. ANNACONDIA, O. CABRERA, E.H. GIMÉNEZ, Y. AVILA, D. MIRANDA, et al., vid. SÁNCHEZ-BAYÓN, A.: La Modernidad sin prejuicios (vol. 3)... op. cit.

${ }^{293}$ La etapa inicial (1961-64) se focaliza en Centro América (Nicaragua, Costa Rica -donde se establecen las oficinas principales de cooperación y desarrollo-, Guatemala y Honduras); la etapa de expansión (1965-68) hacia la zona andina (Bolivia, Venezuela, Perú y Ecuador); la etapa de consolidación (1969-72) acercándose a las dictaduras de derechas -como concesión a las exigencias del Departamento de Estado-, así como a los vecinos próximos (Paraguay, Uruguay, Chile y México).

${ }^{294}$ Se precisa que, aunque se ha mencionado su capacidad de captar los fondos públicos, ésta no es su principal fuente de financiación, sino que la misma reside en la sociedad civil, recibiendo millones de dólares de Fundaciones como la Rockefeller, y donaciones de particulares que -según los añospueden superar el presupuesto de pequeños países.

295 Se trata de una categoría de la Guerra Fría, para referirse a los países recién descolonizados, en vías de desarrollo, que se consideran el Tercer mundo, pues no está alineados ni con el Primer mundo o bloque occidental libre (EE.UU., junto con el resto de pueblos anglosajones y europeos-continentales),
} 
catalizador del capital cultural y el imaginario social, por lo que una vez que comienza a operar es difícil apagarlo, pudiendo producir grandes estragos como en este caso, que no sólo se ha usado con fines propios de la religión, sino también políticos, jurídicos, económicos, etc. De tal manera se explica la deserción del catolicismo en Latinoamérica, pues se considera que la adhesión al protestantismo es el primer paso para llegar a ser (como) un estadounidense -se recurre a técnicas psicocomunicativas diversas, desde la psicología inversa a la transferencia, vid. figura siguiente-. Como síntesis de la propaganda religiosa sobre Latinoamérica, y su confusión con otros factores y esferas sociales, se ofrecen las palabras inspiradoras de las campañas acometidas durante la Guerra fría en textos de referencia como la revista evangélica International Review Mission y la Declaración de Wheaton -espíritu de los Congresos de Misión Mundial de la Asociación Interdenominacional de Misiones extranjeras-, y los Mission Handbooks (vid. figura siguiente). También se recoge la lista de recomendaciones que los Mission Handbooks [manuales de misión] ofrecen a los nuevos misioneros estadounidenses, para que su proselitismo cale (vid. ídem). Nótese la evolución propagandística, pasándose del self-righteouness al emotivism $\mathcal{E}$ empathy (o sea, de la sobreautoestima moral al emotivismo y la empatía).

ni con el Segundo mundo o bloque oriental socialista (URSS y el resto de países socialistas independientemente de su Internacional inspiradora-). Van a ser las principales víctimas de los cfnflictos de baja intensidad de los dos primeros bloques -de ahí la expresión Guerra Fría, pues las tensiones entre el Primer mundo y el Segundo suelen disputarse en el Tercero en un sinfín de pequeños enfrentamiento-. Para saber más sobre las tergiversaciones cometidas, vid. SÁNCHEZBAYÓN, A.: Humanismo Iberoamericano, Guatemala: Cara Parens, 2012. 
Figura 43.- Fundamentos propagandísticos de la misión en Latinoamérica ${ }^{296}$

International Review Mission (1946): (...) ha llegado el tiempo para el avance de las fuerzas evangélicas en América Latina. El hemisferio tiene toda clase de atractivo: gentes amables y devotas, reservas físicas incalculables, todo, excepto algo que sólo el movimiento evangélico le puede dar como fruto maduro: el fundamento moral y espiritual de su democracia (...).

The Wheaton Declaration (1966) -se eligió Wheaton por ser la sede la universidad fundada por B. GRAHAM-: (...) Es necesario mantener el balance en el énfasis que se hace en el desafío de las necesidades de la gente. Se da la impresión de que el mensaje de salvación es únicamente para los pobres o enfermos del mundo. Otro extremo consiste en tener tanto miedo al Evangelio social que hasta se rechaza cualquier oportunidad de un trabajo médico de un misionero o todo tipo de empresas humanitarias (...).

Adenda (1968) -en un congreso posterior-: (...) El comunismo no solamente desafía los supuestos teológicos del cristianismo, sino que, en el mundo de la explosión demográfica, miseria social, lucha política y hambre total, él desafía a la Iglesia Cristiana a ser cristiana de verdad, a expresar la compasión de Cristo en una realidad comprehensiva y concreta. De esta manera, el comunismo nos lleva hacia una actualizada comprensión bíblica de la misión cristiana y su función en el mundo (...).

Recomendaciones - de misioneros locales a jóvenes estadounidenses- del Mission Handbook (edic. 1995): (...) Saca de tu cabeza tus grandes ideas estadounidenses sobre cómo tienen que ser aquí las cosas. No te sientas agradecido por haber venido a trabajar con gente no civilizada. Lee algo sobre Latinoamérica y el país al que vas. Ten más contactos con la gente, no solamente en las iglesias, sino también en tu vida social. Vive en un nivel adecuado, no más alto ni más bajo que nosotros. Adapta tu estilo de vida a la gente con quien trabajas. No te sientas superior a nosotros. Sé más diplomático en tus relaciones. Muestra que esperas amablemente mucho de nosotros sin aparecer como un jefe paternalista. Lucha honestamente en nuestras causas/batallas: en nuestra vida social, histórica, cultural, de iglesia cristiana. No nos des las respuestas capitalistas y no reduzcas problemas sociales a las simplistas respuestas espirituales. Recuerda que tenemos una manera de pensar diferente a la tuya y las soluciones de problemas van a ser distintas a las tuyas también. Lee la Biblia desde la nuestra perspectiva y de nuestra cultura. No nos impongas tus costumbres. No trates de convertirnos en pequeños estadounidenses (...).

Fuente: elaboración propia (SÁNCHEZ-BAYÓN, 2007 y 16).

296 Son extractos de traducciones propias, obtenidos durante la etapa de trabajo de campo. Por este motivo no se entrecomilla el texto ni se ofrece la cita exacta, sino aproximada. 


\section{Balance del destino manifiesto}

En definitiva, si bien se ha mencionado aspectos negativos del destino manifiesto y su expansionismo -visto por los vecinos y por los Estudios culturales sobrevenidos como imperialismo, más bien-, el mismo tiene una serie de restricciones, como es la necesidad de justificación en términos morales, más su necesario apoyo por la opinión pública. De no respetarse tales términos, entonces desaparecería la base de la superioridad moral, dejando de ser una misión de liderazgo y vecindad, para convertirse en cualquier guerra injusta (v.g. Corea, Vietnam -todos los conflictos en el sudeste asiático, que tuvieron lugar durante las guerras culturales, se perdieron antes domésticamente en EE.UU. por la falta de confianza de la opinión pública, socavada desde los medios y las universidades). Luego, es necesario que exista una agresión previa e inmerecida, de gran calado moral y causante de una injusticia, v.g. ataques a buques como el Maine y el Lusitania o a bases como Pearl Harbor (sirviendo de excusa para entrar en guerra -de ahí que costara la entrada inicial en las guerras mundiales); expropiaciones injustas de las dictaduras cubana, coreana, vietnamita o china (dando lugar a embargos). Se requiere además del respaldo de líderes de opinión (siendo muchos de ellos representantes religiosos -tanto es así que, los Presidentes, suelen invitarles a tomas de posesión o cuando tienen que hacer un anuncio importante, v.g. declaración de guerra).

Es de destacar que, la doctrina del destino manifiesto entró en reformulación con el inicio de la globalización, para ver cómo podía servir a los intereses estadounidenses por el mundo -pues la versión anti-comunista y de liderazgo del mundo libre de la Guerra fría ya estaba caducada-. En un primero momento, se optó 
por su adaptación hacia el ya citado soft-power, vía cooperación y desarrollo, donde los también citados pentecostalistas han logrado hacerse un lugar reseñable (especialmente en Latinoamérica). Sin embargo, paradójicamente, es de destacar que, los últimos en hacer uso de la doctrina y en invalidarla, han sido los neoconservadores: REAGAN se basó en la misma para afianzar la superioridad moral estadounidense en el fin de la Guerra fría, y BUSH la usó para esbozar el papel de EE.UU. en el nuevo orden mundial; en cambio, W.BUSH, pese a su gusto por el discurso moralista, con la intervención en Oriente Medio (en especial en Iraq) impugnó su recurso y su Administración se vio obligada a generar una doctrina antijurídica como la "legítima defensa preventiva" -desnaturalizadora de la institución-. Por su parte, la Adm. OBAMA dio pábulo a las críticas más extremas de los Estudios culturales sobrevenidos (vid. infra), deslegitimando así la doctrina de AMD desde sus orígenes. Y finalmente, la Adm. TRUMP, la está reformulando, pero en versión (pre)transoccidental: "America, firt" (fue el eslogan de su campaña) ${ }^{297}$, y dado que los europeos (en su posmodernidad negacionista de Occidente), siguen criticando a EE.UU. (como pasara desde la cumbre de Niza, en la Francia y Alemania veían la disminución de su poder, por la alianza de las potencias medias como España y Polonia con EE.UU., por lo que prefirieron alejarse de dicho país, para acercarse a Rusia), por lo que a la postre se está llevando a cabo un trasvase hacia el Pacífico. De tal suerte se recupera su AMD, pero vaciada de fundamento, pues estaba pensada para un mesianismo del viejo Occidente. Téngase en cuenta que, el nuevo Occidente o hemisferio occidental pacífico, carece de la tradición sagrada y profana, y sólo desde hace poco tiempo que comparte sus formas, v.g. democracia liberal, capitalismo.

\footnotetext{
297 Vid. TRUMP, D.: Great Again... op. cit.
} 
Una cuestión pendiente, que no se ha de olvidar en caso de reemergencia del destino manifiesto en las renovadas relaciones entre EE.UU. y Latinoamérica, es la exigencia de la apelación al virtuosismo y moralidad (que conlleva AMD), para reclamar respeto y rechazo a falacias, como la iniciada por el mito de la superioridad norteña (y cultivada por los historiadores de la frontera) ${ }^{298}$, causante del desprestigio de los civilizados vecinos latinoamericanos, reducidos más tarde a la condición de neobárbaros (vid. infra) ${ }^{299}$.

\section{2.- AMERICAN CRUSADES:}

\section{CRUZADAS SOCIO-RELIGIOSAS QUE HAN TRANSFIGURADO EE.UU. 300}

Con el rótulo del epígrafe se alude así a los principales movimientos socioreligiosos (vid. figura siguiente), que han influido en la configuración nacional estadounidense, o sea, en su auto-percepción y en la que otros pueblos tienen de sus gentes. Aunque la voz cruzada pueda identificarse con el cristianismo, y a episodios como los acaecidos en Europa continental, cuando saliera de su Alto Medievo, para entrar en contacto con Oriente, sin embargo, en el caso estadounidense, la cuestión

\footnotetext{
${ }^{298}$ Es una generación que se ve impelida a recuperar el orgullo nacional (tras los desastres citados). Entre sus representantes destacan: a) F.J. TURNER y su teoría de la frontera expansiva (como elemento forjador del carácter estadounidense -pues la frontera saca lo mejor de uno- y su misión colonizadora); b) J. STRONG y su teoría de la frontera misionera (se basa en la idea de mandar misiones cristianas a otros países para que la primera frontera no sea la interna); c) B. ADAMS y su ley de la civilización y la decadencia (defendía la importancia de la dispersión física y la búsqueda de nuevas fronteras para evitar los colapsos); d) A.T. MAHAN y su teoría de la potencia marítima, etc.

299 Vid. SÁNCHEZ-BAYÓN, A.: Humanismo Iberoamericano... op. cit. - Renovación de la Filosofía Social Iberoamericana... op. cit.

${ }^{300}$ Vid. infra nota 162 y 234.
} 
ha de ser matizada: en primer lugar, porque no se ha tratado de episodios de hardpower o uso de fuerza militar ${ }^{301}$, sino de soft-power o supuesta superioridad moral y cultural, vía estrategias comunicativas y psicosociales; en segundo lugar, porque los planteamientos seguidos no se identifican plenamente con el cristianismo, sino que son expresión sincrética de posjudeocristianismo, donde las diversas confesiones han competido para aportar su impronta. Son muchas más las posibles matizaciones mencionables, pero basten las aludidas para comprender que la noción empleada de cruzada, se hace en términos de gente que se siente ungida y tiene una misión, que gracias a los grupos religiosos, se transmite en el espacio y tiempo, dándose el peculiar sinónimo de convergencia causante de la identidad estadounidense. Véase ahora cómo aconteció tal cosa.

Figura 44.- Notas básicas sobre movimientos socio-religiosos estadounidenses ${ }^{302}$

\begin{tabular}{l}
$\begin{array}{l}\text { a) tipos de movimientos: de conversos y transformistas, salvíficos y carismáticos, de } \\
\text { introversión y aislacionistas, milenaristas y utópicos, cientificistas y } \\
\text { transhumanistas, de manipulación y mentalistas, taumatúrgicos, et al.; } \\
\text { regeneracionistas, reformistas, revolucionarios, colectivistas, etc. }\end{array}$ \\
\hline b) corrientes: congregationalism [congregacionalismo], propagationism \\
[propagandismo], perfectionism [perfeccionismo], millennialism [milenarismo], \\
restorationism [restauracionismo], communitarianism [comunitarismo], sabbatarianism \\
[dominicalismo], evangelicalism [evangelismo], harmonialism [armonialismo], \\
pentecostalism [pentecostalismo], fundamentalism [fundamentalismo], neortodoxa \\
[neortodoxia conservadurista], ecumenicalism [ecumenismo], judeochristianism \\
[judeocristianismo], et al. \\
\hline $\begin{array}{l}\text { c) expresiones autóctonas estadounidenses: Gospel Propagation, Holiness and } \\
\text { Perfection, Millennialism and Adventism, Social Reforms and Crusades/Campaigns (vid. } \\
\text { pto. e), Restorationism and the Stone-Campbell Tradition, Communitarianism, } \\
\text { Sabbatarianism, Nineteenth-Century Evangelicalism, Christian Science and Harmonialism, } \\
\text { Social Christianity, Pentecostalism, Fundamentalism, Conservative and Charismatic }\end{array}$
\end{tabular}

${ }^{301}$ Evidentemente, los grupos religiosos participaron en las campañas de la Guerra de independencia, las Guerras indias y la Guerra civil, pero no fueron sus instigadores ni causantes principales.

302 Vid. SÁNCHEZ-BAYÓN, A.: "Historia de la comunicación social estadounidense a través de sus movimientos religioso (...)" ... op. cit. - La Modernidad sin prejuicios (vol. 3)... op. cit. 


\author{
Developments of the Later Twentieth-Century, Ecumenical Movement, Nonviolence \\ resistence, Black religion \& Black muslim nation, et al.
}

d) hitos: New Plymouth (peregrinos y puritanos, 1620); Philadelphia (deístas, 1776-87); Cane Ridge (metodistas, 1801); Salt Lake City (mormones, 1847); Oneida Community (perfeccionistas y comunitaristas, década de 1840); Gettysburg (religión civil, 1863); New Orleans \& Harlem (santería y vudú, década de 1920); Woodstock (orientalismo y New age, 1969); New York-Washington (judeocristianos neocon, 2001), etc.

e) cruzadas de ASG y ACR (conforme a TDR): s. XVIII campañas pro-colonización, iluminismo, pro-revolución y patriotismo, etc.; s. XIX campañas anti-duelo, antivicio (anti-juego y apuestas, anti-prostitución y pro-celibato, etc.), milenaristas, antiguerracivilismo, anti-esclavitud y abolicionistas, tradicionalismo-nativista (v.g. $\mathrm{KKK}$ ), anti-poligamia (v.g. contra mormones), alfabetización, beneficencia (viudas, huérfanos, comedores sociales), etc.; s. XX campañas anti-alcohol, pro-familia, antiaborto y pro-vida, eco-pacifista, anti-pena capital, anti-socialismo (ateo), resistencia pacífica y derechos civiles (v.g. M.L. KING), pro derechos de los trabajadores y los inmigrantes, escuela doméstica, guerras culturales (v.g. posmodernos v. neocon), etc.; s. XXI campañas de castidad (v.g. anillos de virginidad), animalista, etc.

Fuente: elaboración propia (SÁNCHEZ-BAYÓN, 2007 y 16).

A continuación se exponen y explican aquellas acciones populares que han generado despertares religiosos transformadores de la idiosincrasia estadounidense, inspiradas por el American (social) gospel [ASG: evangelismo social estadounidense o su credo, en relación con ARC (vid. supra cap. 10), más otras expresiones conexas: American way of life (AWF), American dream (AD), American manifest destiny (AMD), etc. ${ }^{303}$. Para su abordaje, se han fijado las siguientes categorías o subepígrafes: a)

303 Se recuerda que (tal como se aclarara ya), con el giro hermenéutico de la Teología política estadounidense, se recupera e incide en el elemento del bien común, combinado con el de justicia social, orientándose hacia la consecución terrenal de bienestar e igualdad social (atendiendo al respeto de la costumbre generada). Se trata de una fusión estadounidense (vid. cap. 4), en su nuevo orden secular, de propuestas religiosas reformadas y políticas conservadoras modernas (v.g. common sense [sentido común], commitment [compromiso], welfare [bienestar], etc.). Su sustento parte de la confianza en la posible consecución material del adelanto (terrenal) del reino de los cielos, tal como se ha recogido en la teología político-jurídica posjudeocristiana estadounidense (y su codificación ICS), desde sus múltiples alusiones tempranas por el Redemptive-Historical Preaching Style [estilo de predicación histórico-redentora], hasta los diversos estilos de American Social Gospel [evangelismo social 
Cruzadas de opinión pública: la conformación de la superioridad moral (v.g. campañas anti-duelos, eco-pacifistas, pro-vida o anti-aborto, anti-pena capital); b) Cruzadas de publicidad y relaciones institucionales: se presta especial atención a las relaciones Iglesia-Estado, en lo tocante a la auténtica separación acomodaticia (aclarándose en qué consiste el muro de separación, la falacia BLACK, el sistema de equilibrios y balanzas o también llamado de frenos y contrapesos), además de comprender las relaciones internacionales con aquellas confesiones con dimensión política (v.g. Papado de los católicos, Patriarcados de los ortodoxos, Monarcas de protestantes anglicanos y nórdicos; c) Cruzadas y propaganda: de la prensa parroquial a los telepredicadores (aportándose las claves sobre el proselitismo, así como las técnicas más sobresalientes de los líderes religiosos y su gestión de las TIC); d) Cruzadas y partidismo: las causas y las elecciones (tratándose las conexiones entre política y religión, y cómo se ha modulado la identidad estadounidense según las coyunturas).

\footnotetext{
estadounidense]. En definitiva, ASG es el intento de realización cotidiana de las enseñanzas del Evangelio. De ahí el impulso de los despertares y revitalizaciones socio-religiosas en los EE.UU. (vid. cap. 6), dando lugar a la emergencia de movimientos comprometidos con cruzadas de transformación social, tales como la lucha contra el alcohol, las apuestas, la prostitución, etc. (vid. supra). Teológicamente hablando, el ASG es el resultado de la heteropraxis (reconducida luego hacia la ortopraxis de ACR, vid. supra), por la que las confesiones compiten por mejorar su comunidad, en el sentido milenarista de preparar la II Venida de Cristo. Políticamente, se trata del reflejo del liberalismo y del activismo de la sociedad civil. En los EE.UU., el liberalismo estuvo presente desde sus orígenes, gracias al pensamiento Whig y Freemanson, de ahí su aceptación natural y su fácil interacción religioso-civil. En cambio, en Europa continental, con los vaivenes en el tránsito del Antiguo al Nuevo Régimen, dicho reto de transformación social lo terminaron por monopolizar las ideologías (nacionalismo y socialismo). El ASG es el mestizaje y puesta en práctica de los modelos de evangelización mediterránea-católica y anglosajona-protestante (vid. infra), más orientados hacia la heteropraxis y la ordenación de la cristiandad. Hasta el s. XIX, el mestizaje de modelos y el ASG resultante es liderado por el protestantismo; sin embargo, con el cambio de siglo, pasa a tener un gran peso la doctrina social de la Iglesia católica: con el tractarianismo y la teología liberal de NEWMAN, FEBLE o PUSEY, más la teología social desde la corriente jesuita HOPKINS, o la dominica de DRANE, así como los movimientos socio-religiosos del tipo National Catholic War Council de 1919, League of Social Justice de 1932, etc. -antes de los contagios posmodernos posteriores de la teología de la liberación, vid. ídem-. En recientes revisiones de la materia, se conectan ACR y ASG, como la base del credo estadounidense, sobre el que se cimienta su identidad.
} 


\section{Cruzadas de opinión pública: la conformación de la superioridad moral}

El asunto que se enuncia en el rótulo del presente punto es de crucial importancia para conocer cuáles han sido las cuestiones que más han preocupado y ocupado a los estadounidenses en la conformación de su identidad y su código comunicativo común, o sea, el ASG (junto con ARC, AWF, AMD, etc.). En consecuencia, sus tramas, son gestionadas a través de cruzadas (fruto de despertares y revitalizaciones, vid. cap. 6), impulsadas y difundidas mediante panfletos y hojas parroquiales (durante los s. XVIII-XIX), hasta los chats [foros electrónicos] y los blogs [páginas electrónicas de opinión] (en los s. XX-XXI), todo ello ha servido para lograr materializar las demandas sociales, exigidas por las bases sociales, hasta su incorporación en las agendas institucionales de los poderes públicos. De este modo, ha sido posible tratar cuestiones tan diversas, ricas y complejas en matices, como las campañas anti-vicio y las vitalistas.

Antes de entrar en los supuestos ilustrativos de la realidad histórica estadounidense, permítase apuntar un par de matizaciones convenientes. La primera es, la relativa a la consideración de cruzadas de las campañas acometidas, pues se entienden las mismas como misiones de fe en la consecución de un mundo mejor (ideal inspirador del ASG). Esa es la esencia del ASG y su influencia en la opinión pública: de forma muy sintética, cabe afirmarse que -al menos durante el siglo y medio de construcción nacional estadounidense (desde la Guerra de Independencia de 1776, hasta las Guerras Mundiales del s. XX)-, la generación y gestión de los temas 
principales de preocupación social y debate público, han venido fijados por unos fundamentos, argumentarios y formas propias de una religiosidad posjudeocristiana ${ }^{304}$, preocupada por la realización de un paraíso terrenal ${ }^{305}$. Los EE.UU., es un país que se ha concebido a sí mismo como una tierra de oportunidades, donde a través de la observación de unos principios morales, el trabajo vocacional y un estilo de vida social responsable ${ }^{306}$-entre pactista y asociativo, como la propia Unión-, es posible así alcanzar la salvación o felicidad (tal

${ }^{304}$ Es la habilidad propia de los EE.UU., para fusionar la tradición occidental sacra (judeocristiana) y profana (grecorromana), tras pasar por filtros previos heredados (v.g. el pensamiento Whig, el Freemanson), más adaptaciones correctoras autóctonas (v.g. FRANKLIN y los deístas-patriotas, EDWARDS y los teólogo-civilistas, EMERSON y los trascendentalistas, JAMES y los pragmáticos, etc.), y todo ello para dar como resultado una novedosa visión de la religión, mucho más secular, práctica y popular (vid. infra).

${ }^{305}$ Las referencias a la América noratlántica colonial, como paradise/garden in wilderness [paraíso terrenal], (new) Zion [tierra prometida], o a city upon the hill [una ciudad en lo alto de la colina], son un conjunto de expresiones bíblicas sobre la redención terrenal (v.g. Gn. 3 y 12, Is. 54 y 60, Mt. 5, Lc. 6), así recogidas en la literatura religiosa fundacional (de corte predicamental), considerada como el comienzo de la implantación de la Teología político-jurídica estadounidense (vid. cap. 4 y 5). Uno de sus ejemplos más famosos es el sermón "A model of Christian Charity" (1630) de J. WINTHROP (recuperado con posterioridad por el Presidente REAGAN en su Discurso de despedida de 1989), junto con los igualmente ilustres casos de J. COTTON, J. ELIOT, I. MATHER, C. MATHER, T. TATCHER o J. EDWARDS. Vid. BOORSTIN, D.J. (comp.): An American Primer, Chicago: The University of Chicago Press, 1966. GAUSTAD, E. S. (ed.): A documentary History of Religion in America. To the Civil War, Grand Rapids: William B. Eerdmans Publishing Co., 1993. MARSDEN, G.M.: Religious and American Culture, Fort Worth: Harcourt Brace Jovanovich College Publishers, 1990. NOONAN, J.T., GAFNEY, E.Mc.: Religious Freedom. History, cases, and other materials on the interaction of religion and Government, New York: Foundation Press, 2001. POWER, M.S.: Before the Convention. Religion and the Founders, Lanham: University Press of America, 1984.

306 Un ferviente impulsor de dichos principios morales, como estilo de vida, para la dotación del sentido común y la brújula ética necesaria para construcción de la joven nación, es FRANKLIN, quien adapta el Libro de los Proverbios y el Libro de Job, combinándolo con las enseñanzas de SMITH (especialmente, en su obra Theory of moral sentiments), todo ello le sirve de inspiración para editar, entre 1733 y 1758, su colección de proverbios, titulada Almanaque del pobre Ricardo (siendo una colección de gran éxito, llegando a tener tres tiradas anuales de 10.000 ejemplares). Cfr. BOORSTIN, D.J.: Compendio histórico de los Estados Unidos. Un recorrido por sus documentos fundamentales (trad.), México DF: Fondo de Cultura Económica, 1997, pp. 54 ss. COMMANGER, H.S. (comp.): Benjamin Franklin. Autobiography and Selections from his other writings, New York: The Modern Library, 1944, pp. 106 ss. FRANKLIN, B.: El libro del hombre de bien (trad.), Madrid: Espasa Calpe, 1964, pp. 54 ss. 
como se expresa en la DIE). De acuerdo con esta primera precisión, se entenderá mejor la segunda, que versa sobre la distinción entre las dos grandes categorías de cruzadas: las anti-vicio (o de templanza) y las vitalistas. Las anti-vicio, son las primeras en surgir y dominan el s. XIX, poseyendo un mensaje más comunitarista, pues reivindican el compromiso del individuo con el grupo, para asegurar la convivencia -además de ser una reminiscencia de ACT-307. Entre sus ejemplos más conocidos cuentan las cruzadas anti-juego y apuestas, anti-alcohol, anti-prostitución y obscenidad, etc. En cuanto al segundo tipo de campañas, las vitalistas, estas empiezan a dominar el debate público tras la Guerra civil de los EE.UU., intensificándose su mensaje, frente a los avances tecnológicos del s. XX, al considerarse los mismos como invasivos de la intimidad humana y violentadores de la naturaleza. Entre sus cruzadas tipo, destacan las campañas anti-duelos, eco-pacifistas, pro-vida o anti-aborto, anti-pena capital. Ahora bien, la distinción apuntada, no es absoluta y confrontada, sino más bien complementaria entre sí, según el énfasis puesto en cada campaña. Véase el caso de las cruzadas anti-duelo y anti-alcohol, pues pese a nacer como campañas anti-vicio, terminan poseyendo un cariz más vitalista, en cuanto se insiste en un mensaje moral positivo pro-templanza (Temperance Movement). Además, sendos tipos de cruzadas (anti-vicio y vitalistas), se han gestado y desarrollado de modo muy similar: hechos impactantes en las bases populares, han dado lugar al

\footnotetext{
${ }^{307}$ Se trata de un conjunto de campañas llevadas a cabo, para la vigilancia de una rectitud moral en la vida cotidiana, garantizándose así una serie de reglas elementales de comportamiento social, basadas en la supresión de la lívido, a favor de una convivencia civilizada en una sociedad en formación -de ahí la importancia inicial de corrientes puritanas, pietistas, metodistas, etc. En términos freudianos (de paternalismo y lividez), se explica entonces las iniciativas de los movimientos religiosos, a través de las campañas anti-vicio, para elevar los imperativos morales a la condición de preceptos jurídicos. Ello mismo es constatado en su práctica por TOCQUEVILLE, durante el tiempo vivido en los EE.UU., y que le sirvió para redactar su famosa obra Democracy in America. Vid. FREUD, S.: The future of an Illusion, New York: Norton, 1989. TOCQUEVILLE, A.: La democracia en América (trad.), Madrid: Alianza, 1980.
} 
debate parroquial primero (plasmándose en sermons, parish-newsletters), seguido de la fundación de organizaciones (v.g. associations, clubs, coalitions, unions, leagues) sustentadoras de la causa -con sus respectivos panfletos y libros de cabecera-, hasta alcanzar el respaldo institucional, en forma de algún tipo de norma civil o penal, más programas públicos -incluso, afectándose a la organización policial y fiscal, en sus divisiones anti-vicio-. Por tanto, teniéndose en cuanta las consideraciones teoréticas expuestas, se está ya en condiciones óptimas de aprovechamiento de los supuestos prácticos más relevantes sobre las cruzadas del evangelismo social y su impacto en la opinión pública estadounidense.

a) Cruzadas anti-duelo (antidueling campaigns/crusades): los duelos se consideran expresiones de resolución alternativa de conflictos, respaldados por dos grupos marginales de población -distantes del sistema de justicia civil en consolidación, como son los aristócratas sureños (incluidos los políticos de Washington DC), más la gente de la frontera.

La oposición generalizada frente a las prácticas duelistas, arrancan en 1804, a consecuencia de un suceso que conmociona a la sociedad estadounidense, como es el desafío de honor HAMILTON-BURR, donde muere el primero, dejando intelectualmente huérfanos a los Federalistas -ya muy afectados, además, por las elecciones presidenciales. El propio HAMILTON, la noche antes de su muerte, deja constancia de su oposición a los duelos, por motivos religiosos y por la herida en la sensibilidad de quienes los presencian. Tal postura es ratificada horas después, en su lecho de muerte y ante sus amigos, entre los que se encuentran dos autoridades religiosas, como el Obispo R. CHANNING MOORE y el Rev. J. M. MASON. Estos influyentes personajes, comienzan a predicar en contra de los duelos y a exigir su ilegalización. Su ejemplo es seguido por otros 
ilustres clérigos de la época, quienes no sólo piden la penalización, sino que no se vote a aquellos candidatos que hayan estados envueltos en un duelo alguna vez: a) Rev. T. DWIGHT en Yale University, con su famoso sermón “The folly, guilt, and mischief of dueling" (del que se imprimieran miles de copias y sirviera de referencia para las main-line churches de Nueva Inglaterra); b) Rev. E. NOTT en Union College, con su sermón en la North Dutch Church; c) Rev. L. BEECHER, quien llegara a influir en la redacción de la Constitución de Connecticut de 1818, donde uno de sus preceptos establece la inhabilitación para los duelistas; d) Rev. L. BACON, quien lograra efectos similares en la legislación de Long Island, etc. Unas líneas propias, por su activismo notable, merece el Obispo J. ENGLAND, que desde la Catedral de Charleston (South Carolina), mediante la carta pastoral "On the Origin and History of Duelling" (1827), promueve la fundación de la South Carolina Anti-Duelling Association, y termina influyendo en la Constitución de 1868.

Poco a poco, tales presiones de los movimientos religiosos anti-duelo van consiguiendo sus resultados deseados, dando lugar a normativa censora, tanto estatal (v.g. Constitución de Virginia de 1819, Constitución de Alabama de 1819, Constitución de Tennessee de 1834, Constitución de Mississippi de 1868, etc.), así como federal (v.g. prohibición para Washington DC, para el ejército, etc.).

b) Cruzadas anti-juego (antilottery $\mathcal{E}$ gambling campaigns/ crusades): antes de que el Estado y su sistema recaudatorio funcionara adecuadamente, para suplir las necesidades financieras, la sociedad civil recurría a la lotería. Mediante la misma, se hace viable la sustentación de proyectos vertebradores del propio Estado, como la construcción y mejora de escuelas parroquiales y universidades confesionales en su origen, como Harvard, Yale y/o Brown; la rehabilitación de 
edificios públicos (v.g. Faneuil Hall de Boston); la captación de fondos para los soldados en el frente; la obtención de dinero para sufragar campañas de beneficencia; etc. Sin embargo, progresivamente, van surgiendo movimientos religiosos contrarios, por vincular la lotería con las apuestas, el enriquecimiento indebido, el desorden público y el vicio.

Muchos de los reverendos que clamaran contra los duelos, también aprovechan la tendencia en auge para demonizar la lotería y su impacto social. Un ejemplo de gran difusión por entonces (durante toda la década de 1820), es el del -ya citadoRev. J.M. MASON y su ensayo "Considerations of Lots".

Otro caso destacado de activismo anti-lotería, es el del prominente abogado de Filadelfia, J.R. TYSON, quien publicara el exitosísimo libro "A brief survey of the great extent and evil tendencies of the lottery system of the United States" (1833). TYSON y sus fondos, además, resultan claves para la fundación de una de las más combativas organizaciones anti-lotería y apuestas del país (sirviendo de referente para otros movimientos, en otros Estados de la Unión), como la celebérrima Pennsylvania Society for the Supression of Lotteries.

Como pasara con las campañas anti-duelo, una vez que el mensaje de los movimientos religiosos trascendiera a las elites de poder, se comienza a adoptar normativa supresora o restrictiva sobremanera de su práctica: New York en 1821, Massachusetts en 1833, Connecticut y Maryland en 1834, Virginia en 1850, etc.

c) Cruzadas anti-alcohol (temperance $\mathcal{E}$ liquor control crusades): se trata del tipo de campaña vigente en los EE.UU., desde sus orígenes hasta el día de hoy. Se presentan a continuación, por su gran valía comunicativa, las tres grandes líneas discursivas clásicas, de movimientos metodistas, cuáqueros y católicos, dando lugar 
a la adopción de la Dieciocho Enmienda -los discursos posteriores, de adventistas y pentecostalistas, no resultan tan interesantes en términos comunicativos, ya que resultan excesivamente catequéticos y sectarios.

Discurso metodista: uno de sus impulsores es B. RUSH y su "Inquiry into the effects of ardent spirits on the human body and mind" (1785). Durante tres lustros es una de las obras más vendidas en Nueva Inglaterra, gracias al respaldo para su difusión -al adoptarlo como libro de cabecera-, por parte de The Methodist General Conference, General Assembly of Presbyterian Church, Congregational Associations of Massachusetts \& Connecticut, etc. En 1826, todos estos movimientos convergen en la American Society for the Promotion of Temperance. El libro de RUSH, termina sintetizado y reconfigurado en formato de sermón panfletario - de fácil comprensión y movilizador para la acción-, vía el ya citado Rev. L. BEECHER y su aportación revisionista con "Six sermons on the nature, occasions, signs, evils and remedy of intemperance" (1827).

Discurso cuáquero: su máximo exponente es N. DOW, quien en 1837 lidera el movimiento Maine State Temperance Liquor. Se trata de una organización de gran repercusión, que logra en poco tiempo, no sólo promover el control del tráfico de alcohol, sino que desde 1851, también se vigile su destilación.

Discurso católico: aunque los antecedentes de su discurso son irlandeses, finalmente, se convierte en uno de los movimientos de mayor repercusión en los EE.UU. de la reconstrucción (tras la Guerra Civil). Todo parte del Padre T. MATHEW, quien fundara en Irlanda la Total Abstinence Society (1838), por lo que es invitado a pasar dos años en los EE.UU. (1849-51), dando conferencias sobre estrategias comunicativas y de acción, orientadas 
especialmente a las mujeres. En la década de 1870, su esfuerzo ve sus frutos en dos grandes organizaciones de presencia nacional e influencia en otras confesiones, como son Catholic Total Abstinence Union (1872), más Women's Christian Temperance Union (1874) -esta última organización, es recordada hoy en American Feminist Studies [estudios feministas estadounidenses], por el liderazgo ejercido por su carismática E. WILLARD-.

En cuanto a la repercusión de todas estas líneas discursivas confesionales, uno de sus primeros defensores, entre las elites de poder, es el Presidente LINCOLN, durante su etapa como político en Illinois (1855). Otro ejemplo de su impacto, es el cúmulo de normativa estatal que empieza a aprobarse a finales del S. XIX, con el ánimo de prohibir el tráfico del alcohol, contándose entre los primeros casos el del Estado de Maine, Vermont y New Hampshire. Finalmente, se aprueba la prohibición federal (conocida coloquialmente como la ley seca), a través de la Dieciocho Enmienda (1917), hasta su anulación por la Veintiuna Enmienda (1933).

d) Cruzadas pro-vida (pro-life crusades/campaigns): este tipo de acciones se extiende a casi todas las cuestiones relativas a la bioética y biojurídica, o sea, la protección de la vida y la salud (v.g. aborto, eutanasia, pena capital). A este respecto la confesión que más se ha significado a favor de la vida ha sido la Iglesia católica. Tal ha sido el liderazgo comunicativo ejercido a la postre por los católicos, que se ha llegado incluso a marcar, desde esta confesión, las directrices comunicativas del resto de los movimientos, superándose los discursos teológicos y catequéticos, para llegar a emplear argumentarios modernos, de 
apariencia científica y secular, como los de Bioethics $\mathcal{E}$ Human Rights [bioética y derechos humanos] $]^{308}$.

La Bioética (junto con la Biojurídica) ${ }^{309}$ es un campo en expansión -y hoy en día más contaminado de velos cientificistas, de ahí que se le preste especial atención. Empezó con temas de trasplantes y trasfusiones, continuando con la eugenesia (v.g. síndrome down), y la castración química (ídem), por la contracepción, para extenderse luego a cuestiones como la clonación, la crioestasis, la modificación genética, los bebes a la carta y/o medicamento (diseñados para curar a otros

${ }^{308}$ Sirva recordar ahora lo dicho hace lustros (vid. SÁNCHEZ-BAYÓN, A.: “Biojurídica: ¿cuestión nominalista o epistemológica? (manifiesto para la persuasión constructiva identitaria)", en MARTIN, I, et al.: Bioética, Religión y Derecho, Madrid: Fundación Universitaria Española, 2005, pp. 394-411): "téngase en cuenta que la Bioética emerge en los EE.UU. para humanizar y dotar de sentido los progresos que en la investigación de la vida y el cuidado de la salud se estaban produciendo desde la década de 1960 (v.g. trasplante de órganos, aborto selectivo, etc.); destacan de aquella época los trabajos del profesor POTTER en la Universidad de Wisconsin, y los del profesor CALLAHAN, quién fundó el "Institute of Society Ethics and the Life Sciences" (denominado coloquialmente "Hastings Center") y cuyos informes se convirtieron en referentes para la materia. Para el desarrollo científicoacadémico, propiamente (v.g. cursos, revistas, becas, etc.), hay que acudir a los referentes católicos, destacando la labor en los EE.UU. de "The Joseph and Rose Kennedy Institute for the Study of Humany Reproduction and Bioethics" (conocido como "Kennedy Institute"), que en 1978 publicó la Enciclopedia de la Bioética, o el "The Pope John XXIII Medical-Moral Research and Education Center" (o "The Pope John Center"); así como, la misión de los jesuitas en universidades como "John Hopkins University" y "The University of Georgetown". Hay que esperar a mediados de los 70 para la implementación, también católica, en Europa de los primeros centros científico-académicos, como el Instituto Borja de Bioética en Barcelona o el "Institute of Medical Ethics" (o "The Linacre Centre") en Londres. Tras los mencionados referentes, la Bioética se extiende por toda Europa, y durante la década siguiente (1980), como resultado de la revolución tecnológica biosanitaria y de gerencia hospitalaria, la materia pierde interés en cuestiones sustanciales filosóficas y demasiado teóricas, para centrarse en asuntos procedimentales cotidianos, relativos en su mayoría al desarrollo de protocolos para la incorporación de los avances técnicos a la praxis; florece así la denominación de Biotecnología. Una década más tarde (1990), bajo el influjo de las organizaciones internacionales para la promoción de los derechos humanos (con cátedras UNESCO), surge la conflictividad que subyace con la nueva denominación de Bioderecho. Dos son las posturas enfrentadas, para imponerse en el Bioderecho: a) iushumanistas, que defienden la unión entre la Bioética y los derechos humanos; b) positivistas, que meramente reconocen la ley, y en la mayoría de los casos, sólo el Derecho público nacional sin especialidad autónoma $(\ldots)^{\prime \prime}$.

309 Vid. SÁNCHEZ-BAYÓN, A.: "Biojurídica: ¿cuestión nominalista o epistemológica? (manifiesto para la persuasión constructiva identitaria)" ... op. cit. 
familiares), etc. Los problemas han ido creciendo a medida que ha ido aumentando la tecnología bio-sanitaria, pues en las fronteras es donde surgen los dilemas ético-morales de calificación (condicionándose así su reconocimiento y protección). El caso es que -por duro que suene-, no le corresponde al jurista determinar lo que está bien o mal -eso es misión del filósofo especialista en ética, sino que ha de limitarse a calificar si un supuesto es conforme a Derecho o no. Para ello es necesario que existan unas instituciones con contenido, o sea, con términos y plazos, además de derechos y obligaciones. Ahora bien, lo que sí es clara misión del jurista es denunciar la perversión que se realice del sistema de Derecho: por la transmutación de los delitos en derechos; la desaparición de los contenidos y límites (v.g. términos y plazos, causas eximentes, imputables, agravantes o atenuantes); la inadecuación entre hechos y fundamentos de derecho, etc. Todo ello es fruto de fenómenos anti-jurídicos como el activismo judicial, la ingeniería social político-jurídica, los cientificismos político-jurídicos (velos de confusión técnica e ideológica), et al.

En consecuencia con lo apuntado, es recomendable recurrir a una serie de ejemplos que ilustren bien no sólo los dilemas bioéticos de implicaciones biojurídicas, sino también cómo se está pervirtiendo el conjunto del Ordenamiento, al haberse fundamentado en supuestos de probada anti-juridicidad, como los casos Roe y Doe, basados en mentiras, para lograr que el delito del aborto se volviera un derecho; o tal vez la regulación de la Administración W.BUSH, aprobando legislación para casos concretos, además de confundir el orden moral con el jurídico -eso sí, por intereses políticos y económicos-. 
Sociología de las Relaciones Socioculturales Nortatlánticas (...) American civil religion - A. Sánchez-Bayón 
Figura 45.- Síntesis de los supuestos más ilustrativos de bioética y sus tensiones a) Disquisición de fondo (Roe y Doe): en la década de 1970 se procede a una mutación
del Ordenamiento, basándose en falsedades y excepcionalidades procesales. Bajo
falsas acusaciones de violación -pues luego se ha probado que habían sido las
respectivas parejas de las conocidas bajo los pseudónimos de Roe y Doe-, sus
abogados presionaron a sus clientes para forzar el activismo judicial -que los jueces
admitieran los casos sin base suficiente y sí por supuestas presiones sociales, o sea,
standing-, de modo que se procediera a la despenalización del aborto, para llegar
finalmente a su reconocimiento como derecho (polos opuestos del Ordenamiento y
por ello no intercambiables -como sí se ha hecho-). El problema jurídico de fondo
no se limita al bien "autonomía de la voluntad" -que sólo se reconoce a la madre,
ignorándose la del padre y la del nasciturus-, sino que afecta también al bien "vida". b) Disquisición de forma (Gobernador W.Bush v. Presidente W.Bush): mientras W.Bush fue Gobernador de Texas, por intereses económicos y de seguridad, aprobó Mexico City Policy of 2001, que financiara a organizaciones de planificación familiar en México -aunque éstas paradójicamente impulsaran el aborto como medida de planificación familiar-, además de aprobar normativa a favor de farmacéuticas y hospitales para que tomaran ellos la decisión eutanásica para los casos que quisieran -sin atender a la voluntad del paciente o su familia-; sin embargo, como Presidente, ratificó leyes como la Unborn Victims of Violence Act of 2004 o aprobó la normativa Palm Sunday Compromise of 2005 (regulación específica por el caso T. Schiavo -cuando el derecho estatutario no puede adoptarse para un caso concreto, sino en previsión general de supuestos-). Otras contradicciones sonadas fueron su empeño de imponer la jurisdicción federal sobre la estatal, para intentar en unos casos dejar sin efecto regulación estatal como la Oregon's Death With Dignity Act of 1997 -falaz denominación para referirse a la eutanasia-, y en otros casos, en cambio, procurar cambiar la calificación de los delitos en Estados como Massachusetts, donde no hay pena de muerte, y de tal modo si fuera posible dicha imputación -pues en la jurisdicción federal sí cabe-.

c) Conclusiones (EE.UU. v. Irak): el argumentario basado en el Derecho Natural y la superioridad moral que comporta cae por el peso de su contradicción, cuando se pretende que en los EE.UU. la vida es sacro-santa (salvo en caso de pena capital), mientras que en el extranjero no -son bajas colaterales para el sustento del orden internacional-. Más incomprensible aún es cuando los movimientos radicales pro-life ponen bombas que matan gente en las clínicas abortistas. En cuanto al argumentario, como última curiosidad comparada en términos comunicativos y psicosociales, resulta llamativo observar que en los EE.UU. es la Derecha Cristiana la que se abroga la superioridad moral (en los términos expuestos), mientras que en Europa continental, defendiendo el extremo contrario, son los socialistas quienes detentan dicha superioridad (defendiendo que la vida en el extranjero es sacro-santa, mientras que en sus países es discutible, de ahí su defensa del aborto, la eutanasia, la revolución armada, etc.).

Fuente: elaboración propia (SÁNCHEZ-BAYÓN, 2007 y 16). 
Son ese tipo de posturas moralistas y voluntaristas las que arruinan la misión comunicativa del resto de campañas, así como los grupos radicales, que llegan a poner bombas -¿cómo defender la vida matando?-.

Otras muchas fueron las cruzadas y controversias que surgieron con la configuración nacional: el correo dominical y el sabatarianismo, recuperando así la polémica de las Blue Laws coloniales sobre el descanso religioso semanal obligatorio -desviándose luego la polémica a otras cuestiones como la venta de alcohol ese día, incluso, llegándose a cuestionar qué día debía ser: ¿domingo o sábado?-; la cuestión del segregacionismo mormón y de los testigos de Jehová, opuestos a la idolatría del saludo a la bandera y demás adoctrinamientos nacionales -entrando en colisión con la civil religión-, de ahí su defensa de la escuela en casa, favoreciéndose con ello la continuidad de prácticas prohibidas (v.g. la poligamia); la condición femenina o women status, que empezará por reconocer la labor pública filantrópica de las mujeres, para pasar a ampliar dicha presencia social en temas como la educación, la política, etc. -curiosamente, por tal vía se establecerían las conexiones y el modelo solidario y de actuación entre los movimientos feministas y otros de liberación de minorías oprimidas o marginadas-; la lucha contra la obscenidad y la pornografía en conflicto con los supuestos defensores de la libertad, en especial, la de expresión y prensa-, etc. Las citadas controversias, junto con otras más (v.g. las teorías conspirativas del tipo hidden enemy [enemigo oculto/en las sombras], que condujeron a la aparición de grupos de presión y organizaciones enfrentadas como los católicos Knights of Columbus [Caballeros de Colón] y los protestantes Ku-Klus-Klan; la privacy protection [protección de la intimidad], frente a la invasión de poderes externos máxime los públicos- sobre los datos personales y familiares), en definitiva, gracias 
a una positiva gestión psicosocial y comunicativa, no se quedaron en meras disputas discursivas polarizantes de la sociedad, si no que sirvieron para generar un modelo de superación de disonancias cognitivas, al tiempo que se contribuía a la forja de la -supuesta- superioridad moral estadounidense (que luego se manifiesta en las relaciones internacionales, vid. cap. 10). Por ahora se deja aquí la cuestión, para poder proseguir con las otras cruzadas socio-religiosas de gran impacto psicosocial y comunicativo.

\section{Cruzadas de publicidad y relaciones institucionales}

\section{(Iglesia-Estado y la auténtica separación acomodaticia)}

En este tema (sobre las relaciones oficiales entre las confesiones privadas y los poderes públicos, junto con la comunicación existente entre ambas partes), pese a que los movimientos religiosos siguen siendo la parte más activa -gracias a su gran autonomía, a diferencia de Europa continental, donde son sometidos a una mayor fiscalización-, sin embargo han de respetar a modo de regla general una serie de preceptos constitucionales básicos, como es el sistema de equilibrios o checks' $n$ 'balances: a los movimientos les corresponde promover iniciativas periódicas de (re)interpretación del significado y alcance coyuntural de las relaciones y sus comunicaciones (siempre dentro de los límites del art. VI y las Enmiendas Primera y Catorce de CEU), para lograr así que su discurso (con sus demandas) tenga cabida en la agenda institucional de las políticas públicas de la Administración. Por tanto, mientras se respete dicha regla general, se estará en un periodo ordinario de relaciones estables y predecibles. Sin embargo, puede pasar que alguna de las partes 
decida actuar de manera especial o excepcional, por lo que se entraría en una situación extraordinaria que requeriría una revisión del sistema, pudiendo conducir a un proceso de nuevo despertar y revitalización. Sirva como ejemplo el caso de la interpretación polarizada del sistema, que se hiciera desde la década de 1940, y condujera así al despertar de los años 60 . Se alude a la doctrina separatista defendida por Magistrados del TSEU como H. BLACK (y sus acólitos, vid. epígr. 5.2.2 y cap. 7 y 8$)^{310}$, introduciendo por entonces una serie de inferencias, imposturas y falacias vulneradoras del sistema (de los preceptos citados, más el art. III y la Undécima Enmienda, donde se previene frente al construccionismo/ activismo judicial) ${ }^{311}$. Para comprender por qué el separatismo se considera una polarización del sistema, se ofrece a continuación un esbozo acerca de la lógica del sistema ${ }^{312}$ (vid. cap. 4). Sin embargo, antes de proceder, se considera pertinente recuperar una cuestión de alto

\footnotetext{
${ }^{310}$ Desde su primer gran éxito de construcción doctrinal (con su versión del wall of separation [muro de separación], en sentencias como Everson v. Bd. of Educ. (330 U.S. 1, 1947), BLACK encuentra su apoyo y continuidad (antieclesiástica) en DOUGLAS, en decisiones como Bd. of Educ. v. Allen (392 U.S. 236, 1968) -con un voto de disentimiento- y Lemon v. Kurtzman (403 U.S. 602, 1971) -con un voto concurrente con BLACK-.

311 Se trata del fenómeno de antijuridicidad por el que el juez llega a retorcer las palabras de la ley para que expresen sus propios valores y cosmovisión. Es una cuestión de lo más compleja y se remontan a la actividad del Magistrado MARSHALL, quien cambiara el sentido de una norma para lograr así el reconocimiento de unos poderes no atribuidos a la judicatura, dando así pie no sólo al control constitucional difuso, sino también al standing o apoyo a causas aún no reguladas por el Ordenamiento. A partir de ahí, surgen una serie de desviaciones fruto del amplio margen de discrecionalidad judicial y su posible construccionismo. Vid. SÁNCHEZ-BAYÓN, A.: Filosofía Político-Jurídica Glocal... op. cit. Complement., vid. SÁNCHEZ-BAYÓN, A.: “Normatividad Global: repensar las reglas de juego", en Anales de la Facultad de Derecho-Universidad de La Laguna (n-28), diciembre 2011. - "Au revoir, loi de l'État: el fin del derecho estatal", en Revista Electrónica de Pensamiento, Economía y Sociedad-Instituto Virtual de Ciencias Humanas (vol. 5), septiembre-octubre 2010; versión revisada y ampliada, en Bajo Palabra. Revista de Filosofía (no 5), 2010.

312 A diferencia de las Ciencias Naturales, que se suelen centrar en el estudio de la causalidad, en Ciencias Sociales es importante prestar atención a la intencionalidad, de modo que, si un discurso rompe con el status quo, provocando polarización en el sistema y dando lugar al recurso de las reglas de especialidad y excepción, por lo que se abandona la situación ordinaria para entrar en otra extraordinaria, entonces, se comprenderá que sea necesario buscar las conexiones e intereses ocultos.
} 
valor clarificador, al respecto de lo que se viene tratando, como es la falacia BLACK sobre su muro de separación.

\section{a) Falacia BLACK del muro}

Se trata de un caso de falacia naturalista (confusión del ser con el deber ser), pues para empezar nunca ha habido muro legal alguno -recuérdese que lo que sí existe es un sistema jurídico de equilibrios entre los límites de intervalo establecido-, sino que se trata de una metáfora extraída de un documento semiprivado de JEFFERSON -contradicho por otros suyos-, donde se hablaba de la conveniencia de un muro de separación entre la Iglesia y el Estado (refiriéndose al Poder Federal, para no tomar cartas en las disputas religiosas), y en ningún caso entre Estado y religión (relación que garantiza la Primera Enmienda de CEU). Entonces, ¿qué pasaba por la cabeza del Magistrado BLACK para acometer un argumentario tan vehemente al respecto? Para contestar a dicha pregunta, es necesario saber primero quién fue realmente BLACK y cuáles fueron sus intenciones personales.

BLACK fue un bautista sureño, o sea, antifederalista y converso (vid. cap. 5). Criado en una Alabama con reminiscencias de los Know-Nothing y del Ku-Klux-Klan, contribuye a la reavivación de esta última organización, en la década de $1920^{313}$. Una de sus aportaciones más destacadas fue, en 1921 y a petición personal de ESDALE (Grand Dragon o máxima autoridad del Klan en Alabama), la defensa del Rev.

\footnotetext{
${ }^{313}$ El propio BLACK reconoce que su entorno familiar y los amigos de su padre venían de la tradición Know-Nothing y del Ku Klux Klan. Vid. BLACK, H.T.: My Father: a remembrance, Ramdon House, New York, 1975. Pruebas de que BLACK fue un Klanman, cfr. GARNETT, R.W.: "The Theology of the Blaine Amendment", en First Amendment Law Review (vol. 2), 2003, pp. 66. HAMBURGER, P.: Separation of Church and State, Cambridge: Harvard University Press, 2002, pp. 422 ss.
} 
STEPHENSON ${ }^{314}$. Su otra gran contribución fue su peculiar doctrina de separación iglesia-Estado, en la línea anticatólica de las Enmiendas Blaine ${ }^{315}$. Para ser un Magistrado que se definía a sí mismo como a Textualist [textualista] y aplicador de un strict constructionist [construccionismo estricto], demostró poco apego al texto de la CEU y mucha manga ancha argumentativa, al montar su construcción doctrinal del muro de separación, sobre la base de la reseña (a la metáfora jeffersoniana) del Magistrado WAITE, en el caso Reynolds v. U.S. (98 U.S. 145, 1878)316, así como, en el tono argumentativo radical -anticlerical-, más acorde con el contenido de las Enmiendas Blaine de los Estados sureños -violándose con ello las dos cláusulas de la

314 Rev. STEPHENSON, un eminente Klanman de Alabama, mató de un disparo al cura católico COYLE (párroco de St. Paul), por haber casado a su hija con un puertorriqueño, P. GUSSMAN -lo cual se consideraba una doble ofensa, por tratarse de un mulato y católico. Como recompensa por su labor, el Klan le apoyó en su carrera política, como Senador de los EE.UU. (1926-37). Todo ello salió a la luz, con la propuesta de ROOSEVELT para su candidatura como Magistrado del TSEU, publicándose en el Pittsburg Post-Gazette, por R. SPRIGLE, quien ganara por su investigación el Premio Pulitzer.

315 Moción BLAINE: se trata de una propuesta de prohibición a los ministros de culto para ocupar cargos públicos, así como, a las confesiones religiosas para acceder al disfrute de fondos y espacios públicos. Su tramitación se inicia el 14 de diciembre de 1875, bajo la denominación coloquial de BLAINE Amendment [enmienda BLAINE] -debe su nombre al Congresista Republicano y candidato Presidencial, J.G. BLAINE. Llega a la Cámara de Representantes, donde es aprobada por amplia mayoría (180-7), el 4 de agosto de 1876; de ahí, pasa al Senado, donde es rechazada, el 14 de agosto, por no alcanzar los 2/3 exigidos (28-16). Tal contratiempo, no paraliza la iniciativa (fruto del movimiento Nativista) ${ }^{315}$, sino que se procede a una modificación encubierta de la CEU, a través de la enmienda de Constituciones estatales. Ello trae consigo la declaración de inconstitucionalidad de las State Sunday Laws [legislación dominical estatal], así como, el intento de implantar una política pública anticlerical. Ahora bien, dicha dinámica es frenada en seco, pues logra generar en poco tiempo un rechazo popular, que se concreta en un nuevo despertar religioso, por el que se financian a políticos muy comprometidos con la religión, así que se produce un giro de ciento ochenta grados (vid. cap. $4-5$ y 10, más Anexos y tesis 2007 y 16). Cfr. BLAKELY, W.A. (comp.): American State papers and related documents on Freedom in Religion, The Religious Liberty Association, Washington DC., 1949, pp. 260 ss. SÁNCHEZ-BAYÓN, A.: Estado y religión de acuerdo con los Estados Unidos de América... op. cit.

${ }^{316}$ El Magistrado WAITE, también realizó una interpretación un tanto peculiar, pues la metáfora de JEFFERSON, no versaba sobre la libertad de conciencia -eso es una referencia posterior, unas líneas más abajo-, sino que reivindicaba la autonomía religiosa de las confesiones y la no intervención del Poder Federal en los conflictos religiosos. 
Primera Enmienda de CEU, además de oscurecer la memoria histórica, únicamente, a favor de su legado ${ }^{317}$. Por acabar con una nota positiva, sí es de reconocer a BLACK su énfasis en la exigencia de estar alerta, para que las relaciones entre Estado y religión se mantengan, pero no se confundan.

\section{b) Sistema de equilibrios}

Para comprender cómo opera el sistema de equilibrios constitucional es necesario partir de los límites de su intervalo fijado, o sea, las dos cláusulas tasadas en la Primera Enmienda (1791) ${ }^{318}$ : establishment clause $\mathcal{E}$ free exercise clause [cláusulas de (no) establecimiento y de libre ejercicio] ${ }^{319}$. La cláusula de (no) establecimiento, representa el límite inferior, pues el mínimo del que se parte en las relaciones IglesiaEstado en los EE.UU., es la prohibición de fijar una religión tradicional como oficial (en oposición a las prácticas dominantes de la Europa continental de finales del s. XVIII, donde los Estados son confesionales o disponen de una Iglesia estatal). La cláusula de libre ejercicio, en cambio, representa el límite superior, habilitando la

\footnotetext{
317 Como ya se ha señalado, BLACK encuentra su apoyo y continuidad en el primer DOUGLAS.

318 La cláusula de la Catorce Enmienda (1866), the equal clause, es de tipo procesal: representa una garantía de igualdad de trato jurídico en cualquiera de los Estados miembros de la Unión. Su razón de ser parte de la situación previa a la Guerra Civil, donde la disparidad de cumplimiento de la Declaración de Derechos de los EE.UU. (configurada por las diez primeras enmiendas a la Constitución), daba como resultado unos derechos ciudadanos distintos según el Estado en que se residiera. Para corregir dicha desigualdad ciudadana, se impuso una observación homogénea de la Declaración de Derechos o Bill of Rights, más su supervisión, en última instancia, por parte del TSEU -o sea, por el poder federal-.

${ }^{319}$ La Primera Enmienda establece que, "Congress shall make no law respecting an establishment of religion" [El Congreso no aprobará ley alguna para el establecimiento de religión (oficial)] (Establishment Clause), "or prohibiting the free exercise thereof" [o para prohibir el libre ejercicio de credo] (Free Exercise Clause); vid. supra cap. 10.
} 
discrecionalidad de los poderes públicos para asegurar la observación de la primera de las libertades civiles del Derecho estadounidense, como es la libertad religiosa y además, de las pocas con doble cláusula garante-.

Pues bien, las indicaciones previas constituyen los fundamentos de las relaciones Iglesia-Estado en los EE.UU., y su publicidad, concretándose todo ello en un complejo sistema de checks $\mathcal{E}$ balances [frenos y contrapesos], entre los principios de separación de esferas -que no independencia, pues guardan relación entre sí-, y el de acomodación de interacciones (para una visión esquemática de los principios del sistema).

Ahora bien, frente a estos fundamentos claros y tasados en la Constitución de los EE.UU., surgen a la postre una gran diversidad interpretativa de discursos y formas: de ahí la importancia de la publicidad de una versión oficial, llamada "el legado de los padres fundadores", siendo muy útil para integrar propuestas y superar disonancias cognitivas posibles. La publicitación de dicha versión oficial, ha consistido en la promoción preferencial del discurso - de corte posjudeocristiano (su Americaness)- "religio ex machina", y de su consiguiente forma de colaboración para la realización de misiones de bienestar social ${ }^{320}$. Esto es, se ha procurado fomentar, de tal manera, un clima de conciliación en las tensiones habidas entre las main-line churches [protestantes liberales-conservadores o iglesias tradicionales jerarquizadas] y las evangelical churches [protestantismo evangélico o iglesias emergentes comunitaristas], así como, entre las religiones tradicionales entre sí, y con la religión civil -afectando a su vez al AG, AWL, etc.-; todo ello con el fin de mejorar las

\footnotetext{
${ }^{320}$ Así cabe constatarse en la codificación que de la regulación sobre la religión se ha llevado a cabo, con el paso del tiempo, concentrándose en su mayoría en el Título 42 del U.S. Code, relativo a Public Health and Welfare [bienestar y salud pública].
} 
condiciones de vida e intentar alcanzar el -ya citado- sueño estadounidense de un paraíso terrenal.

\section{c) Lecturas fraudulentas de las relaciones instituciones}

Ante tal oficialidad de fundamentos, argumentarios y formas, constitutivas del legado paterfundacionalista estadounidense, en las relaciones Iglesia-Estado, sin embargo, de forma intermitente, han ido surgiendo interpretaciones sesgadas y sin sustento real. Más bien, dichas interpretaciones han sido de corte construccionista, con un marcado voluntarismo y moralismo, cosa que facilita bastante su detección como falacias vulneradoras del sistema -como la ya apuntada de BLACK-. Entre las interpretaciones falaces sostenidas por grupos confesionales -intoxicando las relaciones institucionales Iglesia-Estado- destacan, por su repercusión, las siguientes líneas fraudulentas:

Falacias bautistas: su interpretación de los fundamentos es errónea por excesiva, porque la separación que reclama entre la iglesia y el Estado, no es tal, sino que se orienta hacia la destrucción de los puentes entre las confesiones institucionalizadas (las main-line churches) y la Unión. En realidad, lo que se pretende es la retirada del poder federal, garante de la igualdad de trato entre confesiones, para así dejar mayor campo de actuación social a las evangelical churches. Para legitimar esta impostura, se falsea la historia, convirtiendo a insignes padres fundadores en proto-bautistas (v.g. R. WILLIAMS, T. JEFFERSON), atendiéndose luego a su argumento de autoridad. Finalmente, para facilitar la adhesión a la causa, se recurre a una metáfora muy plástica y atractiva, como la 
del wall of separation [muro de separación]; empero, ni es constitucional, ni se ha manejado correctamente (vid. infra falacia BLACK) $)^{321}$.

> Falacias católicas: mientras que, hasta finales de s. XIX, el Papado rechaza los fundamentos de la Constitución de los EE.UU., en cambio, la jerarquía católica estadounidense busca la manera de conciliar posiciones, hasta el punto de ser la confesión que lidera el discurso de la acomodación. Tal circunstancia se manifiesta desde el primer Obispo católico, el jesuita J. CARROLL ${ }^{322}$, amigo íntimo de G. WASHINGTON y B. FRANKLIN -de ahí su vehemente intercesión

${ }^{321}$ R. WILLIAMS, como promotor y líder de Rhode Island (colonia de tolerancia por excelencia), recurre en varios de sus sermones y escritos a la metáfora del muro de separación (v.g. The bloody tenant, of persecution, for cause of conscience, discussed, in a conference between truth and Peace, 1644; Charter of Rhode Island, 1663), para recordar la fórmula del dualismo cristiano, frente a los casos de establecimiento y teonomía de otras colonias coetáneas de Nueva Inglaterra. En fraude flagrante de tal dato objetivo, ha habido estadistas posteriores que, según las exigencias de los movimientos, han hecho un uso incorrecto de la metáfora. Un ejemplo escandaloso, es el Presidente JEFFERSON, quien durante su mandato llega a mantener una doble postura contrapuesta, a conveniencia: para mantener el apoyo de los congregacionalistas y evangélicos, sostiene el discurso emergente bautista (v.g. Presidential Letter to Committee of the Danbury Baptist Association, in the State of Connecticut, 1802); mientras que, para obtener el respaldo allá donde las grandes iglesias están muy asentadas -máxime la católica en Maryland, Florida, Loussiana, etc.-, pasa entonces a enarbolar una postura radicalmente opuesta a la primera (v.g. Presidential Letter To Sister Marie Theresa Farjon de St. Xavier, 1804). Vid. ADAMS, A.M., EMMERICH, C.J.: A Nation dedicated to Religious Liberty. The Constitutional Heritage of Religion Clauses, Philadelphia: University of Pennsylvania Press, 1990. BLAU, J. (ed.): Cornerstones of Religious Freedom in America. Selected Basic Documents, Courts Decisions, and Public Statements, Boston: The Beacon Press, 1949. BOORSTIN, D.J. (comp.): An American Primer, Chicago: The University of Chicago Press, 1966. GAUSTAD, E.S.: Faith of the Founders. Religion and the New Nation 1776-1826, Waco: Baylor University Press, 1993. KURLAND, P.B., LERNER, R. (ed.): The Founders' Constitution (vols. I-V), Indianapolis: Liberty Fund, 1987. MacDONALD, W.: Select Charters and other documents illustrative of American History, 1606-1775, New York: The MacMillan Co., 1899. THORPE, F.N.: The Federal and State Constitutions, Colonial Charters, and other Organic Laws (vols. 1-7), Washington DC: Government Printing Office, 1909. Complement., vid. Avalon Project-Yale Law School (URL: http://www.yale.edu/lawweb/avalon/avalon.htm). From Revolution to Reconstruction Project-Univ. Groningen (URL: http://www.let.rug.nl/ usa/D/index.htm).

322 Entre sus escritos pro-acomodacionismo, destacan: Cartas al Papa Pio VI (1788-89), Discurso en nombre de los Católicos estadounidenses a George Washington (1790), Oración por los líderes nacionales (1791), contribuciones al Primer Sinodo de Baltimore (1791), Carta Pastoral (1792), etc. Vid. fuentes de consulta de la nota anterior. 
por aquel ante el Nuncio en París, para que desplazara en América al Vicario de Londres. El problema dialéctico -por otra parte, típico de los jesuitas-, se acrecienta con su proximidad al poder político, pues en vez de domesticarlo, suelen sucumbir, de modo que buena parte de sus miembros han terminado por respaldar una publicidad fraudulenta, al tiempo que incrementaban sus beneficios encubiertos (especialmente, en relación con sus centros educativos, más el sostenimiento de su posición de predominancia como elites católicas locales -hasta la intromisión de las nuevas jerarquías procedentes de una Latinoamérica post-teología de la liberación).

> Falacias episcopalianas y presbiterianas: mientras dichas confesiones se mantienen próximas al poder político, y con el respaldo civil suficiente, su argumentario resulta autocomplaciente, de self righteouness [sobre-autoestima]. Pese a sostener teóricamente el discurso de separación, con toques acomodaticias, en la práctica, se produce un preferencialismo ${ }^{323}$ (vid. cap. 4 y 5). Hoy en día, las confesiones herederas del anglicismo reformado estadounidense, al verse superadas por el empuje social de las evangelical churches, y al carecer de un discurso homogéneo e ilusionante en las relaciones Iglesia-Estado, entonces, desde su seno, se ha preferido concentrar los esfuerzos en las relaciones entre confesiones, llegando a liderar -en buena medida- el movimiento ecuménico ${ }^{324}$.

\footnotetext{
${ }^{323}$ Los Estados donde se produce una larga práctica de preferencialismo (hasta una intervención directa del poder federal), son: Virginia (1607-1830), New York (1614-1846), Maryland (1632-1867), Georgia (1663-1798), North Carolina (1663-1875), South Carolina (1663-1868).

${ }^{324}$ Entre los movimientos y sus organizaciones satélite, destacan: World Council of Churches, 1948; ETC Movement, 1994. Vid. AVIS, P.: Ecumenical Theology: and the elusiveness of doctrine, London: SPCK, 1986. BRIGGS, J., et al.: A History of the Ecumenical Movement-1968-2000 (vols. 1-3), Genova: WCC Press, 2004. LOSSKY, N., et al.: Dictionary of the Ecumenical Movement, Geneva: WCC Press, 2002. WOOD, J. (ed.): Jewish-Christian Relations in Today's World, Waco: Baylor University Press, 1971.
} 
Antes de concluir este punto, no se desea dejar pasar la oportunidad de prevenir acerca del polémico programa, vigente durante la última década, de Faithbased \& Community Organizations/Iniciatives [iniciativas/organizaciones comunitarias y de fe] (FBOs, vid. supra). Dicho programa, va más allá de las mencionadas falacias vulneradoras del legado paterfundacionalista, pues resulta un tipo de fraude al sistema estadounidense de relaciones Iglesia-Estado, de calado más hondo: se incumple la Constitución, y se tergiversa la legislación vigente ${ }^{325}$; no se trata de una propuesta fruto de demandas sociales, sino del juego de las elites de poder ${ }^{326}$; se merma el Social Gospel (recuérdose ASG, vid. infra), a favor de iniciativas de Evangelical Pastoral ${ }^{327}$;

325 Partiendo de la reforma del Estado de bienestar, iniciada por CLINTON con el conjunto de programas Charitable Choice, el Presidente W.BUSH, ha reconducido las ayudas previstas, incrementándolas, y donándolas a organizaciones locales basadas en la fe y el servicio comunitario bajo la excusa de acercar la Administración al ciudadano, sin necesidad de niveles intermedios, evitándose así un excesivo papeleo, el goteo de fondos, etc. La curiosidad radica en que, la idea original de Charitable Choice, era la de promocionar las ONGs de reciente creación, en detrimento de las confesiones tradicionales y su labor de acción social. El caso es que, tras el escándalo Lewinsky y la ola moralista consiguiente, CLINTON se vio obligado a ganarse la simpatía de los movimientos religiosos, haciéndoles partícipes de los fondos federales. Tal viraje fue aprovechado, poco después, por W.BUSH para promocionar a los movimientos del último despertar religioso (frente a los wellestablished -de ahí la denominación Faith-based iniciatives-), por constituir el grueso de su respaldo electoral.

326 Para vertebrar el sistema, se crea una oficina en la propia Casa Blanca, como parte del Ejecutivo y con rango similar -o superior- a los Departamentos/Ministerios. El Presidente W.BUSH, en el año 2001 nombra como Director de la Oficina de la Casa Blanca para FBOs a J. TOWEY -sustituido en 2006 por J.F. HEIN, quién además ocupa el cargo de Vicesecretario del Presidente-, sirviendo de enlace con unos ciento cincuenta programas en curso de otros Departamentos (v.g. Agricultura, Comercio, Educación, Salud y Servicios Sociales, Vivienda y Desarrollo Urbanístico, Justicia, Trabajo, Asuntos de Veteranos, Administración de Pequeños Negocios, etc.), y gestionando la concesión de más de mil programas de ayudas y becas (con un presupuesto de cientos de millones de dólares).

327 Para guardar las apariencias legales -de ahí el fraude y la tergiversación ya mencionadas-, todas estas ayudas están abiertas a la solicitud de cualquier organización con actividades de asistencia y promoción social (v.g. caridad, educación, salud, ayuda a minusválidos). No hay fondos exclusivos para las organizaciones basadas en la fe -salvo pequeños programas algo más específicos, como Compassion Capital Fund [Fondo de capitales para la compasión]-, sino que todas las ayudas están abiertas a cualquier organización y/o iniciativa con vocación de ayuda a los demás y contribución al 
etc.

\section{Cruzadas y propaganda: de la prensa parroquial a los telepredicadores}

En relación con este nuevo tema, se desea llamar la atención del lector sobre dos puntos del título del epígrafe. De un lado, la premisa sobre las relaciones entre los medios y los movimientos, supone un ejemplo claro de paradoja estadounidense, que es aquel tipo de aparente contradicción superada por el sentido pragmático que se aplica al dilema existente. Esto es, de partida, buena parte de las confesiones recelan de los medios, por considerarlos un instrumento de secularización excesiva, pero por otro lado, aprecian su valía para propagar su mensaje. Ello nos conduce, directamente, al segundo punto del título a comentar, que es la cuestión relativa al recurso de la propaganda. Mientras que en Europa continental, la propaganda ha recibido una significación muy negativa, próxima a la de engaño burdo en materia política y comercial, en cambio, en los EE.UU., aunque también se puede aplicar así, aún mantiene su significado original, relativo a la difusión de la fe o propagation. De ahí que, muchos movimientos religiosos, en su acción social, se autodenominen propagandistas.

Realizadas las advertencias oportunas, se procede a rendir sucinta cuenta acerca del acceso de los movimientos religiosos a las tres grandes categorías de medios de comunicación de masas tradicionales, según una prelación de modas y

\footnotetext{
bienestar general. Ahora bien, tras esa fachada, en cambio, se conceden fondos a movimientos cuyas actividades están próximas al proselitismo (v.g. campañas de salvación de almas y de abstención sexual); al mantenimiento religioso (v.g. rezos por el bienestar general); etc. Incluso, se ha llegado a aplicar estos fondos para financiar la contratación de los seguros de responsabilidad civil del clero y las iglesias.
} 
preferencias a la hora de su recurso para dar salida a su propaganda: a) la prensa del protestantismo liberal o main-line churches; b) la radio católica; c) la televisión del protestantismo evangélico o evangelical churches.

- Prensa parroquial: en la versión oficialista de la Historia estadounidense, revisada durante la Guerra Fría (en especial con la Administración REAGAN) ${ }^{328}$, se pretende hacer creer al gran público que las publicaciones en los actuales EE.UU. arrancan con el protestantismo liberal-conservador (main-line churches), por ser el primero en establecerse en la América noratlántica, además de contar sus fieles con un superior grado de instrucción (v.g. con alfabetización básica, con oficios artesanales y liberales), lo que les confería una mayor propensión al flujo de información a través de tal medio de comunicación -se trata de un revisionismo falaz al intentar ocultar la presencia hispánica, pues son los españoles los primeros en llevar y establecer permanentemente la imprenta en América (Puebla, en Nueva España, o sea, México actual), cuando siglo y medio después los colonos de Nueva Inglaterra aún continuaban llevando a la

328 Como la devastación cultural es tal a inicios de la década de 1980 -justo cuando se acercan las conmemoraciones del bicentenario-, la Administración REAGAN -tal como ya se explicará en las notas 13 y 64- solicita a reputados historiadores -aunque sean aquellos autoproclamados como críticos (v.g. HOFSTADTER)-, que asesoren en un dossier informativo de la Historia estadounidense: Reseña de la Historia de los Estados Unidos, que se entrega a las embajadas, obligándose a su traducción a las lenguas locales, y se distribuye como material de cooperación al desarrollo -para reforzar la imagen positiva- $y$, finalmente, con internet resulta la base que se ha venido manejando -con diversas modificaciones- para ofrecer la versión oficial de la historia estadounidense (usándose para educación infantil y secundaria, para los exámenes de ciudadanía, etc.). Entre las primeras imposturas a desmontar en dicho dossier destaca la relativa a los descubrimientos y las colonias, atribuyéndose a los nórdicos, en vez de a los españoles -cuestión que, tras la corrección política y el auge de los Estudios Culturales, se ha vuelto en contra de los WASP (white anglo-saxon protestants [protestantes blancos anglosajones -acrónimo que, además, en inglés significa avispa-, vid. infra]), pues se postula que los primeros descubridores fueron los asiáticos-. 
metrópoli sus obras a imprimir- ${ }^{329}$. En dicha versión oficialista se hace hincapié en la supuesta paradoja por la que la prensa religiosa de entonces, debido a su origen disidente inicial, las primeras publicaciones son más seculares, volcadas en asuntos de Church-State [Iglesia-Estado], garantes de la estabilidad social del momento, mientras que, con el paso del tiempo y el afianzamiento como confesiones predominantes, es entonces cuando surge la Denominational Press [prensa confesional], más orientada hacia planteamientos catequéticos -para desmontar tal falacia basta con citar ejemplos de literatura intolerante y de persecución (v.g. brujas, herejes) del área de Nueva Inglaterra ${ }^{330}$.

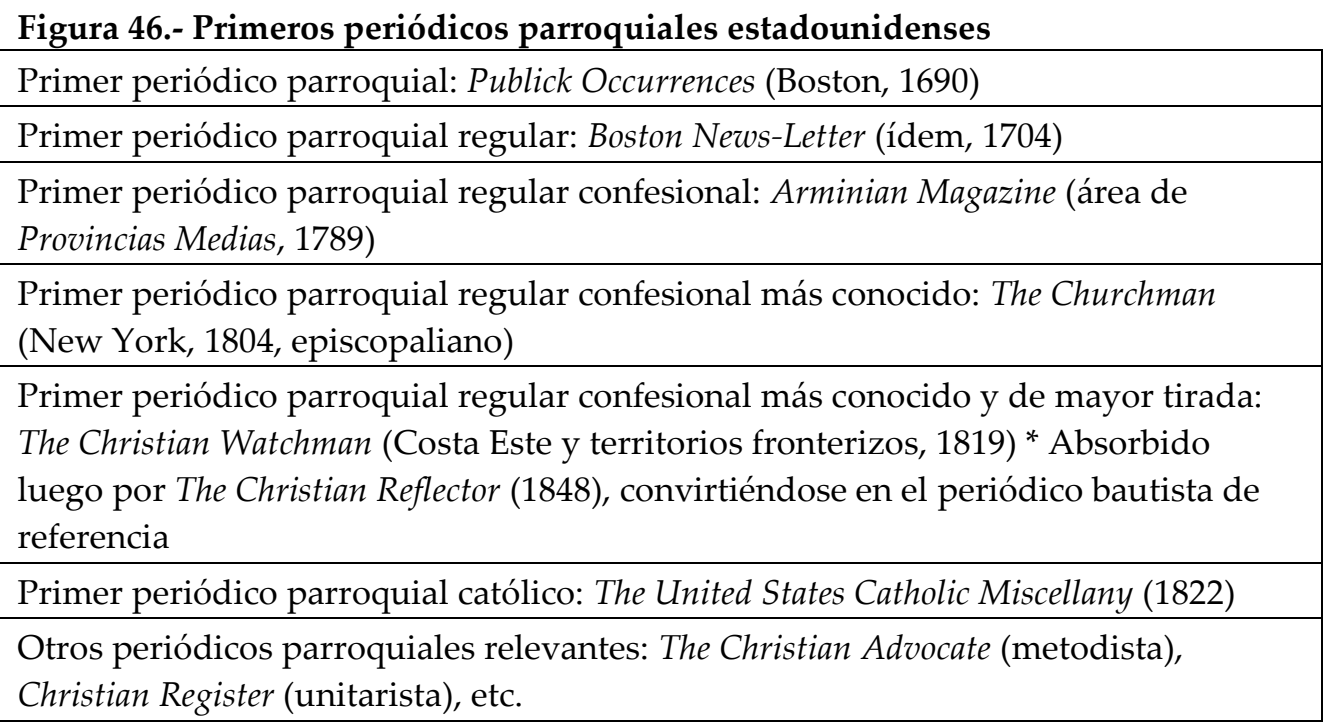

Fuente: elaboración propia (SÁNCHEZ-BAYÓN, 2007 y 16).

\footnotetext{
329 Vid. SÁNCHEZ-BAYÓN, A.: Humanismo Iberoamericano... op. cit. - Renovación de la Filosofía Social Iberoamericana... op. cit.

${ }^{330}$ En lo tocante a la brujería, cabe destacar, que hubo más de doscientos procesos (vid. C. MATHER $\mathrm{y}$ sus libelos Wonders of the invisible World y Late memorable providences relating to witchcraft and possesions, de 1689; I. MATHER y su Cases of conscience concerning evil spirits, de 1692; BOULTON y su obra de dos volúmenes A compleat History of Magick, Sorcery, and Witchcraft, de 1715-16), sólo que registrados expresamente como penas de muerte por brujería, únicamente constan unos 45 casos (vid. figura ). Sus grandes instigadores fueron los Magistrados J. HAWTHORNE y J. CORWIN, el Gobernador T. DANFORTH, los Reverendos C. MATHER y J. COTTON.
} 
Continuando con la citada -y discutible- versión oficialista, la misma destaca que, si bien, el campo de la prensa parroquial (que engloba la Church-State Press y la Denominational Press), inicialmente, había sido un coto reservado al protestantismo liberal-conservador, por exigencias del tipo de perfil requerido a su feligrés, en cambio, a medida que se fue imponiendo la tendencia de la Denominational Press (sobre la Church-State), como consecuencia de su carácter propagandístico y adoctrinador, a su vez, se ha ido incrementado la presencia en el medio de los evangélicos (evangelical churches) y los católicos: tanto es así que, hoy en día, acaparan más del $80 \%$ del medio -pese a sus propias tensiones internas- ${ }^{331}$.

- Radiopredicadores: a comienzos del s. XX, es la Iglesia católica la que domina este medio, con estrellas radiofónicas como el Padre C. COUGHLIN, con su programa estrella en la CBS (en la década de 1930, desde Detroit). Entre los logros de este radiopredicador cuentan, de un lado, su influencia para modernizar el discurso católico, a favor de la justicia social (dando lugar a la fundación de la National Union for Social Justice); por otra parte, es admirable su capacidad para movilizar políticamente a los católicos (respaldando la elección de ROOSEVELT, pero acusándole luego por apoyar a la Banca internacional). Finalmente, el Padre COUGHLIN termina cayendo en un aislacionismo institucional, debido a su discurso anti-semita -y pro-fascismos europeos-, además de por su -ya

\footnotetext{
331 Uno de los ejemplos, más claro y recurrente, de confrontación en la prensa parroquial, dentro de una misma confesión, es el de la Iglesia católica: con una sonada rivalidad de medios entre The Tablet y The Commonweal; o la díscola publicación jesuita America (de gran difusión en el periodo de entreguerras mundiales), donde se llega a denunciar la existencia de una lista negra vaticana de libros (v.g. Los miserables de HUGO, La crítica a la razón pura de KANT, El declive y caída del Imperio Romano de GIBSON), así como, la arbitraria selección de anunciantes en la prensa parroquial; etc.
} 
mencionada- oposición tardía a ROOSEVELT.

Al Padre COUGHLIN, le siguen otras estrellas mediáticas, como el Obispo F. SHEEN (de New York, en los 50 y 60), quien cosechara gran éxito predicador (tanto en radio como en televisión), además de representar el giro discursivo de la Iglesia católica para el periodo de Guerra Fría. Pero, ¿cuál ha sido dicha evolución discursiva católica en las ondas, respaldada por sus movimientos de base? Cabe distinguirse, al menos, tres grandes etapas y líneas argumentales:

> Hasta la década de 1940: el discurso manejado es triple. De un lado, se produce una marcada tendencia censora, frente a las políticas sociales seguidas (v.g. la de control de la natalidad). De otro lado, se asume la condición de vigilante socio-moral, denunciándose las corrupciones existentes. Por último, se promueve una línea reivindicativa de doctrina social -que empieza a ir más allá de las exigencias asistenciales, para exigir también las promocionales.

Durante la Guerra Fría: el discurso sigue una progresión proporcional inversa, pues cuanto más anti-comunista se vuelve, a su vez, más enarbola las banderas del patriotismo estadounidense. De este modo, comienza a salirse de una situación de aislacionismo confesional para acercarse a otras religiones (v.g. se participa en el discurso ecuménico de las main-line churches, además de reconciliarse con los judíos y los cristianos ortodoxos).

Desde la década de 1990: el argumentario principal, consta de una línea de discurso anti-difamación, y otra anti-discriminación. En el primer caso, se revelan y combaten los estereotipos anticatólicos existentes en la cultura estadounidense y manejados por los medios, siendo una de sus plataformas 
de protesta más destacadas la Catholic League (for Religious and Civil Rights)332. En el segundo caso, se denuncian los supuestos de vulneración de derechos y libertades civiles de los católicos, acudiéndose a la División especial de Derechos Civiles del Departamento de Justicia ${ }^{333}$.

Debido a su destacada impronta y revolución de fórmulas comunicativas en el medio, no puede dejarse de mencionar la labor del Rev. evangélico Billy GRAHAM, con su programa radiofónico Songs in the Night (a mediados de los años 40, en Illinois), antes de mudarse a California y triunfar como televangelista -tal y como se aborda a continuación.

- Tele-evangélicos: quienes, más y mejor, han explorado el medio televisivo, han sido los ministros de culto evangélicos, debido a su facilidad para conectar historias ejemplares bíblicas, códigos morales llanos y entretenimiento al comunicar todo ello. La televisión les ha servido para llegar al gran público, directamente en sus hogares -a diferencia de la prensa y la radio, que podían seguirse en otros ámbitos; surgen así las megachurches: grandes comunidades de fieles, que gracias a la televisión, no necesitan congregarse juntos y, aun así, se sienten parte de un grupo vivo de creyentes. Entre sus pioneros, entre 1960 y 1970, destacan -el ya citado- Rev. B. GRAHAM, el Rev. R. HUMBARD, el

\footnotetext{
332 Organización fundada por el Jesuita V.C. BLUM, en 1973-75. Dispone de su propia prensa parroquial, como las publicaciones periódicas Catalyst y (annual) Report on Anti-Catholicism. Sus campañas anti-difamatorias más conocidas y recientes, son las llevadas a cabo contra los programas de televisión South Park y The View, o las películas Priest y Dogma.

${ }_{333}$ Dicha oficina (con sus ramificaciones internas), se constituye a raíz del First Freedom Project (vid. cap. 7 y 10), una iniciativa impulsada por el Fiscal General (GONZALES). Su existencia y operatividad, bien podrían considerarse contrarias al modelo relacional estadounidense iglesiaEstado (visto en el epígrafe anterior), pero forman parte del compromiso de apoyo, del Presidente W.BUSH, a sus bases electorales.
} 
matrimonio de Pastores OSTEEN, etc. Ahora bien, la era dorada del teleevangelismo ha sido la década de 1980, cuando florecen un gran cúmulo de programas de predicación, e incluso, canales específicos para ello (tanto en abierto como de pago -como si de teletienda se tratase-) $)^{334}$ : FALWELL y su Hora del evangelio de antaño, HUMBARD y su Catedral del futuro, ROBERTSON y su Club 700, et al. El problema es que el tele-evangelismo casi muere de su propio éxito, por convertirse en una fuente de fama, dinero y poder -siendo capaz de influir en el curso de campañas electorales-. Los tele-evangélicos se vuelven cada vez más agresivos, para diferenciarse entre sí y ganar audiencia. De este modo, se explican casos dramáticos como el de la escalada de tensión difamatoria entre los Revs. SWAGGART, BAKKER y GORMAN, a finales de la década de $1980^{335}$. Otros ejemplos de escándalos posteriores han sido: TILTON (1991), HOUSTON (2000), GOODMAN (2004), HAGGARD (2006), BARNESS (2006), ROBERTS (2007), etc.

Como remedio al rápido deterioro de los tele-evangelistas, muchas confesiones han optado por aumentar el rigor en los códigos deontológico -en la línea del

\footnotetext{
334 Un buen ejemplo para ilustrar el tránsito mencionado es el de Christian Broadcasting Network (CBN), nace como un canal local de UHF de Virginia Beach, durante la década de 1960. En 1977, pasa a formar parte de un servicio de televisión por cable de la región. Tiempo después, como CBN Cable Network, se constituye como canal de cable por sí mismo. En 1988, pasa a llamarse CBN Family Channel, y al poco, Family Channel, a secas. Durante los 90, dicho canal es vendido a la Fox y a Disney, siendo hoy $A B C$ Family. Entre sus programas estrella y buque insignia del canal, durante décadas, ha sido The 700 Club, a cargo del Rev. P. ROBERTSON: transmitiendo 24h., con más de 30 millones de abonados y haciendo ganar cientos de millones de dólares, además de dar lugar al proyecto de la CBN University (para la que se elegía cada año 800 estudiantes llamados a convertirse en influyentes futuros líderes político-religiosos).

335 El Rev. SWAGGART, comenzó en 1986 una campaña de difamación de otros ministros de culto (BAKKER y GORMAN), acusándoles de mantener relaciones extramatrimoniales. Como represalia, BAKKER, contrató un detective y desveló que SWAGGART mantenía relaciones con prostitutas. En 1988, SWAGGART tuvo que pedir disculpas públicas a su familia y congregación, pero en 1991 volvió a encontrarse envuelto en otro caso de prostitución.
} 
código ético de la Nacional Religious Broadcasting, de 1949, y hoy inaplicado-, además de recurrir a una censura encubierta. En cualquier caso, aunque parece que los tele-evangélicos comienzan a recuperarse -tras la búsqueda popular de mensajes de orientación y esperanza (como consecuencia de los atentados del 11/S y los efectos devastadores del huracán Katrina), la cuestión es difícil de integrar en una misma solución para todos, ya que como afirmara MARX (en su Crítica a la Filosofía del Derecho de Hegel, 1843): con el protestantismo, cada hombre común puede ser ministro de culto e iglesia en sí mismo -luego es imposible ejercer un control sobre todo aquel que sepa interpretar la Biblia.

\section{Cruzadas y partidismo: las causas y las elecciones}

El último gran tema a abordar en este artículo, es el del electoralismo y los movimientos religiosos. A lo largo de los anteriores epígrafes, se han hecho algunas referencias de enlace con el presente apartado, puesto que el mismo sirve para matizar las zonas grises de los anteriores, por reflejar mejor que otros asuntos, las peculiares interacciones entre la política y la religión, al más puro estilo estadounidense: la religión, entra en la política, y viceversa, respetándose el modelo Iglesia-Estado, gracias a que los movimientos se limitan a respaldar aquellos discursos y a candidatos, de una fuerte impronta religiosa, pero sin identificación inmediata y oficial con ninguna confesión concreta. Se entiende así que, en términos generales, las confesiones gozan de una gran autonomía frente a los poderes públicos, porque ni se dedican a constituir partidos de alcance nacional, ni sus ministros de culto se promueven como candidatos federales. Ahora bien, toda regla 
general tiene sus especialidades y excepciones, y entre las mismas, sobremanera, destaca la actuación católica (hasta mediados del s. XX). Su especialidad radica en la discriminación de la que ha sido objeto en los EE.UU., pese a ser la confesión mayoritaria del país (en torno al 25\% de la población) ${ }^{336}$. Entre sus excepciones, resalta el caso del Padre J.R. COX y su Jobless Party, en las Elecciones Presidenciales de 1932 $2^{337}$. Pese al atractivo evidente de las especialidades y excepciones, comprenderá el lector que, por causa de las limitaciones materiales de este artículo, tan sólo es posible dedicar unas líneas a exponer los rasgos esenciales de aquellos supuestos más sobresalientes, que sí encajen en los términos de la regla general.

Luego, en los procesos de respaldo electoral, los movimientos religiosos estadounidenses se han identificado con las siguientes causas político-sociales:

a) Patriotismo v. Realismo: la causa patriótica, defensora de la independencia de los EE.UU., es respaldada por la primera oleada de confesionalismo habido en América; esto es, se hace referencia a las tres grandes corrientes originarias de las main-line churches, como son los episcopalianos, los presbiterianos y los congregacionalistas (predecesores de los evangélicos). De otro lado, los realistas o leales, son principalmente anglicanos, que no desean la independencia, porque

\footnotetext{
336 Sobre las teorías conspiratorias católicas en los EE.UU., justificadoras de la discriminación de facto sufrida, vid. DAVIS, D.B.: The fear of conspiracy. Images of un-american subversion from the revolution to the present, New York: Cornell University Press, 1971. WALLACE, J.D.: Historia no-oficial de Estados Unidos de América. El libro negro del imperio (trad.) Barcelona: Ediciones de la Tempestad, 2004. En cuanto a la estimación estadística del número de católicos a lo largo del S.XX, la cifra ha sido contrastada por diversas fuentes: U.S. Census Bureau (Current Population Reports); Survey Research Center (The Research Program in Religion and Society, SRC-University of California); Gallup International Poll and Reports; The CIA's World FactBook.

${ }^{337}$ Los bautistas -como equivalentes polémicos de los católicos entre las evangelical churches-, cuentan con supuestos algo más grises (de analizar), como el de M.L. KING y su Southern Christian Leadership Conference (en los 60), P. ROBERTSON y su Christian Coalition (1986-87), J. FALWELL y su Moral Majority (1987 y 1994).
} 
ello supondría romper también con la cabeza de su iglesia -que es el rey de Gran Bretaña, de ahí la denominación de realistas.

b) Federalismo v. Antifederalismo: la causa federalista, es impulsada por las mainline churches, que en ese momento resultan las confesiones más liberales y abiertas a la modernización. En cambio, las evangelical churches apoyan la causa antifederalista, pues radican principalmente en el Sur, donde el Estado está menos desarrollado y permite llevar un estilo de vida tradicional (más apegado a los mandatos bíblicos). Esta tensión va en escalada, superando lo político, y desembocando en el conflicto religioso-cultural de la Guerra de Independencia (que es el siguiente punto a tratar).

c) Unionismo v. Secesionismo: es la continuación de la tensión previa (entre federalistas y antifederalistas), sólo que, ex post, la política termina inhibiéndose a favor de la religión, para reivindicarse por tal medio la supremacía de una u otra identidad, con su código comunicativo propio. Se genera así, una confrontación de dos modelos religioso-culturales, en pugna por un mismo espacio vital. La cuestión, no se resuelve tanto a través de la guerra, sino de la conciliación discursiva del Presidente LINCOLN, quien sienta las bases de la moderna ACR, para la integración de ambos modelos religioso-culturales ${ }^{338}$.

\footnotetext{
${ }_{338}$ El argumentario integrador empleado por LINCOLN, parte de la premisa de que, en la Guerra Civil no ha habido ni vencedores ni vencidos, sino que, fruto de las luchas cainitas entre hermanos estadounidenses, dios ha permitido dicho castigo, por lo que es necesario trabajar unidos en la reconstrucción. Entre los discursos presidenciales de LINCOLN, destacan (en el sentido planteado): Discurso de Gettysburg, 1863; Segundo Discurso Inaugural, 1865; Discurso de Reconstrucción, 1865. Vid. ALCORIZA, J., LASTRA, A.: El Discurso de Gettysburg y otros escritos de la Unión, Madrid: Tecnos, 2005. MONTERO, I.: Abraham Lincoln, Madrid: Editorial Labor, 1991.
} 
d) Progresismo v. Conservadurismo: tras la Guerra civil, este tipo de tensión supera los roces tradicionales entre las main-line churches y las evangelical churches, puesto que, como consecuencia de sus fricciones previas, sus modelos religiosoculturales ya no son puros, sino que ambas corrientes religiosas observan, a la vez, propuestas progresistas y conservadoras. En cambio, los católicos y los judíos, hasta entonces outsiders [observadores ajenos] de la política estadounidense, comienzan a tomar posiciones. Pese a ser religiones tradicionales muy rígidas, coincide que es su momento de apertura a la modernización (v.g. doctrina social católica y sionismo judío), además de requerir su acción social en los EE.UU., para poder comenzar su promoción y dejar su Estado de marginación social. De ahí que, desde finales del S. XX, hasta comienzos de la Guerra Fría, tanto católicos como judíos, son muy progresistas, siendo vital su aportación para la elección de candidatos presidenciales como ROOSEVELT y KENNEDY. Sin embargo, a raíz del recelo emergente, frente a la acción represiva del socialismo europeo y su persecución religiosa (v.g. las purgas soviéticas, el anticlericalismo italiano y español), ello conduce al giro de posiciones. Se abandonan las filas de militancia demócrata, seguido de una revisión doctrinal durante los 70, para terminar simpatizando con el partido Republicano en la década de 1980. Nace así la corriente neoconservadora ${ }^{339}$.

\footnotetext{
339 Tanto los universitarios católicos de Washington DC, los judíos de New York, como ambos en Chicago, por diversas razones e influjos de mentores (v.g. L. STRAUSS), terminan trasvasando su pensamiento, de posturas progresistas a conservadoras, provocando con ello una alteración del conservadurismo, que se vuelve también combativo y con mayor preocupación por demandas sociales, más allá de la exigencia de seguridad. Vid. REICHLEY. FRACHON, A., VERNET, D.: La América Mesiánica. Los orígenes del neoconservadurismo y las guerras del presente, Barcelona: Paidos, 2006. SÁNCHEZ-BAYÓN, A.: "Revitalizaciones religiosas postmodernas en América y sus riesgos para la democracia y los derechos humanos", en Revista General de Derecho Canónico y Derecho Eclesiástico del Estado-Iustel (no 11), 2006. -“Comunicación y Geopolítica estadounidense actual: de IRFA al Choque de Civilizaciones", en Historia y Comunicación Social (vol. 11), 2006.
} 
Como ha podido observarse, de la exposición de tendencias generales (realizada grosso modo), el respaldo de los movimientos religiosos en política es muy importante -casi, determinante. En términos macro, es fundamental su respaldo para que prolifere una causa. En términos micro, igualmente, es fundamental su grado de involucración en unas elecciones, para respaldar a un candidato u otro, puesto que los movimientos religiosos cuentan con una significativa red de voluntariado -muy útil en campaña-, además de su alto compromiso cívico, ejerciendo su derecho al voto -como prueba la alta participación en el denominado Bible belt [cinturón bíblico o evangélico] ${ }^{340}$. Ahora bien, tal participación en los procesos electorales no puede ejercerse de cualquier modo, sino que las reglas del modelo Iglesia-Estado, exigen que, para no perder los fondos públicos recibidos: a) las confesiones no pueden patrocinar un candidato; b) si se organiza un mitin, debe ofrecerse esa oportunidad al resto de alternativas políticas, c) si se celebran debates electorales en sus instalaciones, debe invitarse a todo candidato; etc. ${ }^{341}$.

Otros temas de conocimiento, en el seno de las relaciones religión-culturacomunicación en los EE.UU., materializados a través de la acción social de los movimientos religiosos, son:

\footnotetext{
340 Se hace referencia a los dominios evangélicos, que son los siguientes Estados: Kansas, Missouri, Oklahoma, Arkansas, Tennessee, Texas, Luisiana, Mississippi, Alabama, Georgia, Florida. También cabe incluirse a aquellos Estados que han tenido normativa prohibiendo la sodomía y las prácticas homosexuales, así como otras discriminaciones con base moralista, como Arizona, Nevada, Utah, Idaho, Montana, Minnesota. Cfr. LEMARCHAND, P.: Atlas de Estados Unidos. Las paradojas del poder (trad.), Madrid: Acento Editorial, 1999, pp. 111.

${ }^{341}$ Los requisitos se fijan en el Título 26 (Internal Revenue Code) del U.S. Code, más en la normativa interna de desarrollo del Internal Revenue Service [servicio de recaudación interna -el equivalente a Hacienda].
} 
a) En lo sustancial: las propuestas artísticas musicales, como el Gospel, y cualquier variante comercial con el adjetivo "cristiano" (v.g. Christian Pop, REB, Rock, Rap -incluso hoy, Reaggeton-); las pictóricas y fotográficas (v.g. Christian American Realism); los anuncios de neón para ubicar iglesias y advertir de la cita del evangelio del día, etc. Alcanza también a los planteamientos científicos (v.g. Intelligent Design) y su impulso universitario (v.g. TRACS) $)^{342}$.

b) En lo discursivo: las propuestas revisionistas -en lo religioso-cultural y más alládel nativismo, el feminismo, la corrección política, etc.; así como las propias, de calado eminentemente moral (v.g. Moral majority), amplificadas por think-tanks [centros de investigación de alto rendimiento] tales como los Institutos Hoover, Cato, Hudson y de Empresa, o las Fundaciones Olin y Heritage -esta última, con televisión y radio propias, más línea editorial (para sus publicaciones y los programas de campañas electorales), etc.; y es que sus integrantes presumen de gestionar mejor que nadie las cuatro "m": "mission, money, management \& marketing" [misión, dinero, gestión y comercialización]-.

342 Transnational Association of Christian Colleges and Schools [Asociación Transnacional de Universidades y Facultades Cristianas]) o TRACS, es la organización que integra a los centros cristianos de educación aquellos que cumplen las exigencias de la Secretaria de Educación de los EE.UU. (el equivalente al Ministerio/Departamento de Educación en Europa continental); vid. cap. 7. No es hasta el cuarto despertar (vid. cap. 6), cuando se inicia el auge de dichos centros, que pasan de centrarse en la formación de líderes religiosos, a comprender otras áreas científico-académicas (v.g. Derecho, Política, Economía, Educación, Comunicación, Medicina, Biología). A diferencia de Europa continental donde la clase trabajadora ha tendido al socialismo, en los EE.UU., las clases más bajas, sobre todo rurales, han sido evangélicas, y debido a lo que han considerado un reparto injusto de las ayudas públicas desde ROOSEVELT hasta KENNEDY, nace así una serie de movimientos entre los descalificados "red-neck" [paletos], como serán más tarde, por ejemplo, los "anger male" [rabia masculina] (vid. cap. 10), en contra de la discriminación positiva a favor de las mujeres y las minorías étnicas que imposibilitaban su ascenso social. El caso es que se produce todo un giro, afectando a la educación, considerándose que es necesario formar a futuros profesionales cristianos que impidan tanta injusticia y actúen conforme al AG y todas sus implicaciones. Así surgen universidades de nuevo cuño -de marcado proselitismo- como Bob Jones University, Oral Roberts University, Liberty University, etc. 
c) En lo formal: destaca, principalmente, las expresiones de ACR tales como: a) Símbolos: Billetes y monedas de dólar ("in god we trust" [en Dios confiamos]); Sello nacional ("mottos \& icons: ídem"); Campana de la libertad ("Leviticus XXV:10"); Himno nacional ("The Star-Spangled Banner"); Canciones conmemorativas y del ejército (v.g. la marcha del ejercito de la Unión en la Guerra Civil decía "as Christ died to make men holy let us die to make free men" [igual que Cristo murió para hacer hombres santos, déjanos morir para hacer hombres libres]; Monumentos de los diez mandamientos en Tribunales y en Archivo Nacional; Declaración de Independencia y Constitución de los EE.UU. (textos venerados y ufanos de referencias religiosas); Arte sacro en museos y centros públicos; Templos nacionales (v.g. "Chaplains for the House and Senate", "Arlington National Cementery"); Edificaciones conmemorativas (v.g. "Washington Monument", "Jefferson Memorial", "Lincoln Memorial”, “FDR Memorial", "Veterans Memorial"). b) Ritos: Saludo a la bandera ("pledge of allegiance"); Juramentos públicos ("public oath ceremonies"); Festividades de carácter nacional ("National Holidays \& School District's Calendar: Christmas, Thanksgiving Day, St. Valentine's Day, St. Patrick's Day", etc.); Oración del Congreso al comenzar las sesiones; Misa roja (de apertura de legislatura); Día de la Oración y demás invocaciones religiosas presidenciales (desde “Thanksgiving Proclamation of 1774" hasta "Jewish Heritage Week Proclamation of 2004"; "National Day of prayer"; "Presidential Christmas Messages"; "Inaugural \& Farewell Addresses"; etc.); Día del Presidente (veneración del líder -de la nación elegida-, elementos de legitimidad teológica); Tele-evangelismo; etc. c) Creencias: Pueblo elegido, en tierra prometida, con una misión o destino 
manifiesto, siendo bendecidos, para liderar al resto de naciones, mostrando el camino de rectitud, bienestar y salvación, etc. (vid. supra cap. 10).

\section{3.- AMERICAN HERITAGE E WESTERN LEADERSHIP:}

GEOPOLÍTICA ESTADOUNIDENSE DE LA GLOBALIZACIÓN SEGÚN SU RELIGIÓN CIVIL

(DE IRFA A CLASH OF CIVILIZATIONS) ${ }^{343}$

La geopolítica hace referencia a las estrategias de política exterior, comprendidas en un tablero de juego de alcance global (World Island [isla mundial], en vocabulario de MACKINDER y MAHAN), donde se considera como Heartland [zona principal] un Occidente sometido a tensiones entre el modelo anglosajón y el europeo-continental. Desde mediados del siglo pasado, se ha impuesto el primer modelo, cuya voz cantante es la estadounidense, por lo que el epicentro hemisférico pasa a radicar en su Raum [espacio] (RATZEL y HAUSHOFER). De acuerdo con tales planteamientos, el conocimiento y dirección de las relaciones internacionales, hoy en día, se configura desde mentalidad y el suelo estadounidense, como citado epicentro. Los Rimlands [anillos exteriores] (donde se desarrolla la acción exterior), varían según las coyunturas, pues aunque buena parte de los mismos se fijan con los

\footnotetext{
${ }^{343}$ El presente epígrafe es una adaptación del artículo públicado en la Revista Historia y Comunicación Social de la Universidad Complentese de Madrid (vid. SÁNCHEZ-BAYÓN, A.: “Comunicación y Geopolítica estadounidense actual: de IRFA al Choque de Civilizaciones", en Historia y Comunicación Social (vol. 11), 2006, pp. 173-198) -de ahí el tono inspirador del fragmento, pues fue redactado originalmente en el año 2004, antes de la nueva oleada de literatura académica sobre Geopolítica. Complementariamente, vid. infra nota 300.
} 
procesos descolonizadores de África y Asia de las décadas de 1960 y 70, éstos variaron con la caída de la URSS -afectándose incluso a la Europa de los años 90-, y volviendo a variar tras los atentados terroristas del 11/S. Por tanto, ¿en qué consistiría un juego geopolítico religioso-cultural? (tal como se diseñara durante las guerras culturales y se viene implementando desde la globalización).

Con la caída de la URSS y durante buena parte de la década de 1990, en los EE.UU. se barajan diversas opciones legitimadoras de su intervención exterior (v.g. contención del narcotráfico, del terrorismo, del subdesarrollo y de la inmigración de los Estados fallidos o rogue States). De entre las mismas, finalmente, llega a destacar la promoción y protección de la libertad religiosa, entendida como un pilar de los derechos humanos y la democracia. Bajo tal argumentario, se revitaliza así un mesianismo que, tras los atentados del 11/S, da lugar a una intensificación de un juego geopolítico de carácter religioso-cultural. Pues bien, del estudio de uno de los primeros instrumentos legitimadores (la Ley de libertad religiosa internacional y su sistema operativo), y de la comprensión de la deriva hacia un juego geopolítico netamente religioso-cultural, es de lo que versa este punto, permitiendo la observación de la actual lógica de trasnacionalidad del Derecho estadounidense.

Así pues, la introducción del discurso religioso y sus dos sentidos ${ }^{344}$ en el seno de los EE.UU., se remonta al periodo colonial de este país. Es por entonces cuando

\footnotetext{
${ }^{344}$ Históricamente, para Occidente, el discurso religioso -en términos judeocristianos- se ha utilizado políticamente en dos sentidos: a) para la legitimación divina o espiritual, y b) la legitimación tradicional o temporal. El primer discurso religioso tiene por justificación principal la voluntad del Ser Supremo (referente absoluto de todo poder), que avala las pretensiones de los gobernantes o les confiere personalmente una misión. En cuanto a la segunda gran construcción del discurso religioso, éste ya más secularizado pues se orienta preferentemente hacia la ordenación social, utiliza como referente justificador la tradición y la voluntad de los antepasados. Pues bien, aunque pudieran parecer alternativos, en la actualidad y desde el marco estadounidense, se manejan sendos sentidos del discurso religioso de forma complementaria.
} 
llegan mayoritariamente a las costas de Nueva Inglaterra olas de inmigrantes huidos de Europa por motivos de persecución religiosa, viendo en América la tierra prometida y concibiéndose a ellos mismos como un pueblo elegido con un destino manifiesto para el nuevo orden secular (tal y como ya se ha explicado)-convicción estas que, paulatinamente, se va viendo reforzada con el creciente éxito y aumento de poder internacional de los EE.UU.

Ahondando en la mencionada paradoja, ésta se entiende mejor al observar la construcción nacional de los EE.UU.; en la misma, ha sido fundamental el juego interactivo entre las bases populares, de gran religiosidad tradicional, generadora de despertares periódicos en momentos de transición, y las elites político-jurídicas, cuyo filtro deísta secularizante, permitió orientar los despertares populares hacia un fortalecimiento de la religión civil (vid. infra cap. 5 y 6, más supra cap. 10), integradora de la identidad nacional y del modelo socio-cultural estadounidense. Consecuentemente, el dual discurso religioso legitimador recibido en los incipientes EE.UU., gracias al deísmo mitigador de dogmatismos y preponderancias divinas específicas -pudiendo considerarse como expresión propia (estadounidizada) e inconclusa de teodicea-, más la veneración de la escasa (por reciente) aunque eficaz tradición autóctona integradora, todo ello entonces, se va transformado en el seno estadounidense (v.g. melting pot), matizándose según los momentos históricos, y cuyo resultado ha sido el omnipresente AWL o paradigma social moderno occidental. De tal modo, en síntesis, cabe afirmarse que, se ha ido logrando la consolidación progresiva y programática de la conjugación dual, complementaria entre sí, de los sentidos del discurso religioso: Dios bendice a los EE.UU., porque tienen una misión en el mundo y, de este modo, se transmite de generación en generación -bajo una cierta violencia simbólica en la educación y demás instrumentos 
socializadores-, legitimándose así una identidad nacional y un modelo sociocultural efectivo hasta la fecha.

Aterrizando en el discurso religioso manejado por los neoconservadores estadounidenses (durante las últimas décadas, vid. supra), éste responde a unas demandas coyunturales, con antecedentes en exigencias sociales identitarias y socioculturales frente a tendencias marginales antisistema de las décadas de 1960 y 70 (v.g. underground movement, Zen \& Krishna fashion, etc.) ${ }^{345}$. Sin embargo, dichas exigencias, llegan a ser acuciantes treinta años después, tras la caída de la URSS. Ello se explica porque, durante la Guerra fría, el esfuerzo de las elites estadounidenses por configurar la identidad nacional y el modelo socio-cultural había sido escaso y, meramente, articulado en oposición al Comunismo (bajo el lema de los EE.UU. como adalid del mundo libre). Entonces, al desaparecer el elemento vertebrador, la transitoriedad del momento bien podía llevar a dos alternativas contrapuestas: a) la absoluta secularización de los EE.UU. y ensayar un multiculturalismo laicista-como el abogado por los teóricos deconstruccionistas; o b) aprovechar el despertar religioso ya iniciado en los años 60, y revitalizar así la religión civil por medio de la potenciación de la memoria histórica sobre el papel armonizador de la tradición judeocristiana en los EE.UU. ${ }^{346}$.

${ }^{345}$ Vid. HARRIS, M.: American Now: the Anthropology of a Changing Culture, New York: Simon \& Schuster, 1984.

${ }^{346}$ Con respecto a las tendencias antisistema señaladas, estás, aunque marginales en un principio, se veían como una gran amenaza causante de la perdida de la inocencia estadounidense, por promover: el uso de anticonceptivos, el aumento de los divorcios y relaciones extramatrimoniales, la aparición de familias uniparentales, el consumo público de drogas (de diseño), las manifestaciones callejeras, la derrota de Vietnam, etc.; téngase en cuenta que, incluso, se consideraban parte de las mismas a movimientos como el feminismo, el ecologismo y el de los derechos civiles, que finalmente fueron incorporados al sistema como parte de la sociedad civil organizada (v.g. agrupaciones vecinales y religiosas tradicionales); también el socialismo y el sindicalismo se vieron afectados, integrándose muchos de sus líderes en los partidos principales del sistema. Luego, como grandes amenazas 
La alternativa del multiculturalismo laicista se descartó enseguida por no viable, puesto que de un lado, sus planteamientos teóricos provenían de intelectuales neo-marxistas y, en la práctica, su ensayo había resultado un desastre virulento en los países emergentes (tras procesos descolonizadores) que habían optado por tal propuesta -especialmente, los de tradición afrancesada. Además, la segunda opción, desde planteamientos pragmáticos e historicistas, había probado en reiteradas circunstancias de crisis identitaria y socio-cultural su valía, por lo que esta vez no tenía por qué ser menos.

La gran novedad, en esta última revitalización religiosa ${ }^{347}$, radicaba en la heterogeneidad de las elites y los matices de su pensamiento, especialmente, si se es

\footnotetext{
latentes quedaron las minorías emergentes y ciertos intelectuales deconstruccionistas. Igualmente, de forma sucinta, cabe destacar que, pese a su afinidad conceptual, tales demandas identitarias se distinguen de las teorías conspirativas precedentes, puesto que las últimas sólo han sido ejercicios elitistas de carácter predominantemente público, mientras que las primeras resultan realidades populares, tanto de ámbito público como privado, a las que ofrecer unos "out puts" estatales. Vid. DAVIS, D.B.: The fear of conspiracy. Images of un-american subversion from the revolution to the present, New York: Cornell University Press, 1971. HARRIS, M.: American Now: the Anthropology of a Changing Culture, New York: Simon \& Schuster, 1984. LIPSET, S.M.; RAAB, E.: The politics of unreason, Chicago: The University of Chicago, 1978.

347 A grandes rasgos, resulta posible periodificar los "religious awakenings" o despertares religiosos (a cargo de las bases populares) y sus consiguientes "religious revivals" o revitalizaciones (a cargo de las elites político-jurídicas) de la religión civil estadounidense, quedando como sigue (vid. cap. 6): a) Periodo fundacional (1620-1770), donde el despertar supone la búsqueda de un entorno tolerante al margen de las Guerras de religión de Europa, y su revitalización conlleva la emancipación políticoreligiosa frente al Reino Unido (siendo la primera guerra civil estadounidense, aunque transcendió como la Guerra de Independencia); b) Periodo de secesión (1840-1860), donde el despertar supone la adaptación de las religiones tradicionales a las necesidades del medio estadounidense, y su revitalización conlleva el posicionamiento identitario y socio-cultural entre los norteños y los sureños (su consecuencia inmediata fue la Guerra Civil); c) Periodo expansionista (1890-1970), donde el despertar supone el proselitismo del modelo socio-cultural estadounidense, en términos mesiánicos, y su revitalización conlleva el inicio de la geopolítica de los EE.UU. y su confirmación como líder de las relaciones internacionales; d) Periodo de consolidación (1980-en adelante), donde el despertar supone la búsqueda un nuevo paradigma de identidad nacional y modelo socio-cultural posmoderno, así que la revitalización corriente corre a cargo de los neoconservadores, en los términos que se están indicando. Tal periodificación se ha revisado en el cap. 10.
} 
consciente que dentro del crisol neoconservador estadounidense estaban conviviendo desde los años 60 dos extremos hasta entonces conocidos y de tremenda carga ideológica: a) la Christian Right [Derecha cristiana]; b) los ex-comunistas (principalmente ex trotskistas) y demás heréticos de izquierdas.

Pues bien, si hasta la fecha, las elites habían sido de procedencia y pensamiento prácticamente homogéneo, de tipo liberal-conservador ${ }^{348}$ y bastante secularizado, aunque sin llegar a tocar techo (la laicidad), y habían logrado integrar el discurso religioso legitimador sin demasiada tensión ni complejidad expositiva, en cambio, es ahora, con las interacciones entre la Derecha cristiana y los excomunistas, junto con el apoyo -o al menos, sin la oposición- del resto de tendencias neoconservadoras, se abandona así la tradicional filosofía pragmática sobre la materia y se instaura una ideología blindada: ya no se pretende convencer de las virtudes y beneficios del sistema, sino que se exige la adhesión incondicional a la cosmovisión que se ofrece (Derecha cristiana), además de llevarse a cabo una campaña de deconstrucción de cualquier postura crítica (ex-comunista) -o sea, pura propaganda de una réplica de la realidad, en vez de un conocimiento consensuado de la misma.

\footnotetext{
${ }^{348}$ En contra de la tesis del prof. HARTZ (Harvard University), quién procuró en la década de los 60's clarificar la posición contradictoria de los liberales en los EE.UU., cuya confusión se debía -pese a los esfuerzos argumentativos del profesor- a que el liberalismo estadounidense no se puede explicar como el europeo-continental, sino que responde a una pragmática hibridación entre conservadurismo y liberalismo (heredero de politólogos británicos como BURKE, BETHAM o LORD ACTON), haciendo posible la conjugación de la tradición judeocristiana, la democracia, el capitalismo, etc. Como mero apunte introductoria de una idea clave a considerar, de reiterada presencia en el trabajo, es el hecho por el que la filosofía conservadora pragmática es sustituida por la ideología neoconservadora, cuya prioridad es monopolizar la interpretación de la memoria histórica estadounidense- confundiendo así su utopía milenarista con el discurso legitimador de la identidad nacional y el modelo sociocultural.
} 
La siguiente inquietud a considerar es, ¿cómo se incorpora el discurso religioso a la política internacional? Pues bien, tradicionalmente se ha hecho en términos dialécticos -tomados del judaísmo- y proselitistas -del cristianismo(articulado todo ello en los mapas conceptuales inmediatos), ya que el posicionamiento entre aliados-buenos y enemigos-malos, aunque reduccionista y falaz, ha servido para constituir la unidad interna necesaria y dar el apoyo de la sociedad civil a sus tropas (hard power [poder duro]) o a los embargos decretados por el Gobierno correspondiente (soft power [poder blando]).

Los mencionados recursos, la dialéctica y el proselitismo, en su hibridación activista del mesianismo, han resultado piezas claves para la articulación del juego geopolítico de los EE.UU., donde no sólo se ha recurrido a la interpretación del mundo en términos de buenos y malos, y el cumplimiento de una misión divina en el mundo, sino que para afianzar la adhesión de la ciudadanía, igualmente, se ha hecho uso de ansiedades colectivas, como el miedo al enemigo exterior, a las situaciones incontrolables, etc. -se podría decir, aunque la sugerencia bien podría calificarse de anacrónica y excesiva, que las autoridades estadounidenses han utilizado en su propia gente antes que en otros pueblos la incipiente guerra psicológica, al indagar y rentabilizar la mecánica del modelo socio-cultural y las ansiedades colectivas.

Visto el marco genérico, la cuestión se va concretando a medida que se especifican las líneas maestras de cada generación de elites político-jurídicas, puesto que son las que permiten ir orientando, según la coyuntura a salvar, la configuración de la identidad nacional y el modelo socio-cultural estadounidense; lacónicamente, dicha especificación, en su más alto nivel corresponde a las doctrinas presidenciales y a las estrategias implementadoras de sus analistas y gestores de confianza. Como 
se ve en el siguiente mapa conceptual, aunque la coyuntura ha oscilado, distinguiendo entre las condiciones transitorias y las confirmatorias o reiterativas, básicamente, el sentido general se ha mantenido: se instrumentalizan las tensiones internacionales para fortalecer la identidad nacional y mejorar la respetabilidad de la imagen exterior estadounidense.

Con estos mimbres (el discurso religioso y su estadounidización), véase a continuación cuáles han sido sus articulaciones para el orden internacional, especialmente, en el diseño geopolítico de los últimos años.

\section{b) Instrumentos y discursos legitimadores de intervenciones trasnacionales:}

Se introducen así los recientes y muy peculiares recursos político-jurídicos de Política exterior estadounidense, propiciadores de una Geopolítica que ha pasado de un carácter secular, centrada en los derechos humanos, a otro cariz netamente de tipo religioso-cultural: desde la International Religious Freedom Act of 1998 [Ley de libertad religiosa internacional de 1998] (IRFA); más su complejo sistema operativo, constituido por una Comisión, una Oficina, un Embajador plenipotenciario y la disposición de la red de embajadas de los EE.UU.; hasta su transformación, bajo una versión adaptada -por los think-tanks neoconservadores- del clash of civilizations [choque de civilizaciones]. Se pretende, entonces, llevar a cabo un diagnóstico de los instrumentos o instituciones político-jurídicas, además de una evaluación del proceso evolutivo del discurso legitimador (y sus recursos normativos), esperando que ello pueda ayudar a desentramar y distinguir la comunicación oficial respecto de los intereses y realidades oficiosas. 
Retomando el marco coyuntural post-soviético, de entre las diversas argumentaciones legitimadoras de la misión internacional estadounidense y de sus intervenciones exteriores, durante buena parte de la década de los años 90, se barajaron posibilidades tan variopintas como la lucha contra el narcotráfico, el terrorismo, el genocidio, etc. Finalmente, la Administración CLINTON logró fusionar todos estos riesgos emergentes bajo un mismo tratamiento, la doctrina del liderazgo $0^{349}$, cuya vía legitimadora había de basarse en el humanitarismo obligado civilizador -una revitalización peculiar del civilizing sense y self-righteousness, con un enmascaramiento progresista -de lo políticamente correcto-, conferido por el discurso combinado del derecho humanitario y los derechos humanos, además de aprovechar las estructuras de organizaciones internacionales en auge ${ }^{350}$. Por esta vía, se logra fundamentar material y formalmente la misión e intervenciones internacionales de los EE.UU., eludiéndose entrar en razones sustanciales, por debilidad argumental

349 Con antecedentes doctrinales y algún intento práctico durante la Administración BUSH precedente, y cuyos burócratas y analistas, en buen número, continuaron en sus cargos con la siguiente Administración presidencial -no se olvide el lector que fue BUSH quien remodeló los servicios de seguridad e inteligencia, cambiando incluso el perfil de los analistas de la CIA, por ejemplo.

350 Vid. NYE, J.: La paradoja del poder norteamericano (trad.), Taurus: Madrid, 2003. Como anticipo del cambio de legitimaciones, atendiendo al discurso de los derechos humanos, vid. KEOHANE, R., NYE, J.: Poder e interdependencia. La política mundial en transición (trad.), Buenos Aires: Grupo Editor Latinoamericano, 1977. SCHLESINGER Jr., A.M.: The cycles of American History, New York: Houghton Mifflin, 1986. 
del discurso habilitante ${ }^{351}$ (sobre todo por las incoherencias implementadoras de M. ALBRIGHT, ex-Secretaria de Estado ${ }^{352}$.

Pues bien, tras ciertos bandazos en la Política exterior y algunos programas públicos peregrinos, con un Congreso de los EE.UU. dominantemente republicano y una burocracia mayoritariamente neoconservadora, al fin, parece producirse el entendimiento, o al menos el beneplácito común, entre la vocación internacionalista y progresista del Presidente, y las ansiedades identitarias además de preventivas del neoconservadurismo (especialmente, de la Derecha cristiana y -los conocidos comolos Halcones). Por tanto, en términos macro, la respuesta al recurso de la libertad religiosa como primer instrumento político-jurídico trasversal (por consiguiente, operativo en cualquier tema y lugar), viene dada por la casación de la demanda presidencial y la oferta neoconservadora de los poderes públicos.

Desde planteamientos meta, se vertebra la argumentación del recurso de la libertad religiosa para la justificación de las intervenciones exteriores estadounidenses por una doble vía: a) recordando el peso tradicional que ha tenido

351 Vista la cuestión con cierta perspectiva temporal, parece ser que la política internacionalista -que no propiamente internacional, porque el epicentro sigue siendo los EE.UU.- de la Administración CLINTON fue inicialmente reactiva y de contención frente a problemas sectoriales locales, como los ya mencionados (v.g. narcotráfico en Colombia), pero ya entonces, los neoconservadores, posicionados en cargos relevantes consolidaban la teoría del intervencionismo preventivo, hasta que a la postre se dio con un tema de creciente interés y general aceptación, que bien podía servir para dicho fin, los derechos humanos; la cuestión a dilucidar es, de entre todos los múltiples derechos y libertades, por qué se fue a elegir la libertad religiosa como instrumento de promoción, incluso, por qué se hizo en unos términos ajenos a la tradición constitucional estadounidense, sino más bien, siguiendo la interpretación de las organizaciones internacionales (v.g. art. 18 del Pacto de Derechos Civiles y Políticos-ONU).

352 Acaso, cabe explicarse la cuestión por demasiado voluntarismo chocante con el estructuralismo garantizado por la anterior Administración presidencial, dando entonces una imagen en los medios de una política exterior basada en Muddling Through \& Garbage Can Policy o arte de ir tirando -en realidad, tal impresión era general a todas las políticas públicas de dicha Administración, obligando al Vicepresidente A. GORE a formular el modelo de Nueva Gestión. 
la religión en la constitución de los EE.UU., y cómo tal recuerdo ayuda a recuperar el carácter mesiánico de dicho país en las relaciones internacionales; b) promocionando y protegiendo - de forma indirecta y sui generis- la reciente normativa internacional, en especial de la ONU -y no tanto la del sistema regional interamericano-, pues según sus planteamientos, se trata de una libertad tripartita (de pensamiento, conciencia y religión) garante del resto de derechos humanos -el individuo debe ser consciente de su ámbito de autonomía interna para exigir así su protección personal.

En cuanto a la dimensión micro, centrada en los entresijos de la IRFA y de su sistema (a) acerca de la ley (tramitación y contenido); b) acerca de los órganos (la Comisión, la Oficina, el Embajador itinerante y el Asesor especial); c) acerca de sus medidas (los informes)), se aportan a continuación una serie de notas sintéticas.

\section{c) De la trasversalidad de IRFA al juego geopolítico}

\section{del Choque de civilizaciones:}

En pocas palabras, si la IRFA y su sistema supusieron una de las primigenias respuestas político-jurídicas de carácter trasversal en materia de religión y geopolítica, al llegar a dividir el mundo entre, (a) países donde se cometen graves violaciones de la libertad religiosa (por ende, del resto de derechos humanos), y los EE.UU. tienen la obligación de intervenir con firmeza; (b) países donde se cometen leves violaciones de la libertad religiosa, y los EE.UU., meramente, deben manifestar su inconveniencia al respecto e incentivar el cambio gracias al soft power [poder blando]; o (c) países no violadores de la libertad religiosa -donde hasta ahora habían 
permanecido también los que defendían un modelo multicultural laicista, aunque quizá la cosa cambie ${ }^{353}$. Consecuentemente, tras la elección de la nueva Administración presidencial y la perpetración de los citados atentados del 11/S (en Nueva York, Washington DC y en el Estado de Pennsylvania), el discurso religioso en la geopolítica orquestada por los EE.UU. se ha intensificado -de trasversal ha pasado a centrípeto-, incluso, se ha radicalizado -una parte del pensamiento neoconservador trabajó intensivamente en los meses inmediatos a los atentados para construir un sistema de diferencias (y exclusiones) que permitiera una clara distinción del "nosotros (Occidente)-ellos (Oriente)"354.

En términos especulativos, habría sido natural pensar que la Administración W. BUSH hubiera querido instrumentalizar por completo la IRFA, en cambio, ello no ha podido ser, debido a la propia naturaleza limitada de la norma y su sistema: a la norma y a su sistema les faltan sustancialidad y capacidad movilizadora global (alcance total de actuación); en cambio, si ha servido de base para introducir briosamente el discurso religioso en las relaciones internacionales, así como para generar una geopolítica elemental sobre la materia ${ }^{355}$. Todo ello es aprovechado, y en combinación con una versión reduccionista de la teoría del choque de civilizaciones

\footnotetext{
353 Vid. siguiente epígrafe, especialmente, en relación con las menciones que se hagan sobre el Informe de 2005 de la Comisión.

${ }^{354}$ El discurso distintivo al que se hace referencia, no sólo ha servido para manipular la memoria histórica estadounidense, potenciando la tradición judeocristiana y su componente WASP ("white anglo-saxon protestant" o protestante anglosajón blanco, vid. cap. 4) -de forma edulcorada y cívica con el judaísmo y el catolicismo, como muestra de un pseudo-ecumenismo de las verdaderas raíces-, sino que también se ha utilizado para fortalecer la escasa legitimidad institucional del Presidente W. BUSH (tras el incidente del controvertido recuento de votos), recurriéndose entonces a la legitimidad religiosa, en su doble sentido, y trayendo consigo el riesgo del neocesaropapismo (el poder civil controla el religioso para afianzarse).

355 Vid. la actual distribución geopolítica que proporciona la Comisión para la Libertad Religiosa Internacional (URL: http://www.uscirf.gov/countries/index.html).
} 
(generada desde el American Enterprise Institute-AEI) ${ }^{356}$-que dicho sea de paso, es introducida en varios de los documentos de la Comisión-, junto con construcciones doctrinales judeocristianas mesiánicas y la concepción realista e inestable del mundo, es el caldo de cultivo perfecto para diseñar una geopolítica en términos religioso-culturales y de tipo intervencionista preventiva o neokantianismo realista de RICE 357 .

En definitiva, el discurso religioso manejado en la geopolítica estadounidense expuesta no se corresponde con el del Antiguo Régimen, salvo en las formas de algunas facciones radicales -luego las comparaciones diacrónicas son muy limitadas. La gran mayoría de los neoconservadores aboga por una interpretación religioso-cultural que asegure un código común mínimo para la interacción y el compromiso social, de ahí la defensa de AWL y la constitución de anillos de seguridad (allá donde alcanzan los intereses estadounidenses y mediante influjos del soft power, principalmente); tales planteamientos son defendidos tanto desde posiciones conservadoras resignadas (v.g. Nueva academia y realistas) hasta las que

${ }^{356} \mathrm{El}$ AEI, es uno de los think tank buque insignia del neocorservadurismo, cuyos académicos (v.g. MURAVCHIK, GOLDWIN, KIRKPATRICK, NOVAK, etc.), han desempeñado una función crucial como ideólogos para el tránsito del viejo sistema de legitimaciones al presente, priorizando el discurso de la misión democratizadora iushumanista de los EE.UU. Siendo una versión adaptada, principalmente por el AEI, discrepante con la de HUNTINGTON (El choque de civilizaciones y la reconfiguración del orden mundial (trad.), Barcelona: Paidos, 1996. - ¿Quiénes somos? Los desafíos a la identidad nacional estadounidense (trad.), Barcelona: Paidos, 2004), al que se considera un mero rentabilizador del pensamiento precedente de BELL y BERGER (BELL, D.: El fin de las ideologías (trad.), Madrid: Tecnos, 1954. - The Radical Right, Garden City: Double-day-Anchor, 1964. BERGER, P.L.: Modernidad, pluralismo y crisis de sentido: la orientación del hombre moderno (trad.), Barcelona: Paidos, 1994. BERGER, P.L., NEUHAUS, R.J.: To empower people: from state to civil society, Washington DC: AEI, 1996). A tal respecto, se considera destacable, como ejemplo de otro punto de vista bastante generalizado, la crítica rotunda al choque de civilizaciones, al que se considera realmente como una colisión de ignorancias; vid. ODINA, M.: Europa versus USA, Madrid: Espasa, 2004.

357 Resulta muy discutible la denominación de neokantianismo realista, como han designado los medios de comunicación estadounidense a la estrategia de RICE, pues ciertamente sería más correcto hablar de un neopragmatismo -aunque sí ha tomado muchos elementos discursivos del neokantianismo. 
postulan un mesianismo intervencionista preventivo (v.g. Derecha cristiana) -este último discurso ha sido el dominante hasta ahora por la ratificación que suponen las alternativas radicales e intestabilizadoras (v.g. islamistas, indigenistas), aunque la cuestión y su tendencia a largo plazo queda pendiente de los resultados electorales del 2008.

\section{d) Acerca de IRFA (tramitación y contenido):}

La International Religious Freedom Act (IRFA) [Ley de libertad religiosa internacional], es una ley pública, comparable con las leyes orgánicas de Europacontinental, cuya introducción en el parlamento federal corrió a cargo del Congresista F.R. WOLF ${ }^{358}$, el 8 de septiembre de 1997, bajo la denominación Freedom From Religious Persecution Act [Ley de libertad a causa de la persecución religiosa].

El proyecto original de WOLF pretendía la supervisión de la libertad religiosa en el mundo, con el ánimo de proteger a los misioneros estadounidenses, y de paso, a las minorías religiosas. La idea no era tan descabellada, como clamaron algunos puristas del corriente Derecho Internacional Público -dicho sea de paso, con menos

\footnotetext{
358 Se trata de un político de larga trayectoria, con experiencia en distintos campos, aunque hace tiempo que se centró en relaciones internacionales y derechos humanos: elegido en representación del Estado de Virginia en diez ocasiones (más de veinte años en el cargo), ha repartido su tiempo entre tres áreas políticas, como son Transportes y Telecomunicaciones (perteneciendo a los Subcomités de Comercio y Justicia, el de Estado y Judicatura, etc.), así como Derechos Humanos (sirviendo en la Comisión para la Seguridad y Cooperación en Europa, además de realizar trabajos de campo en Afganistán, China, Etiopía, Sierra Leona y Sudán -acaso, tales destinos pudieron influir en el tono de civilizing sense y self-righteousness de su proyecto de ley, y que tan bien casaban con el sentir de la doctrina CLINTON del humanitarismo, además de abrir las puertas a las ansiedades preventivas neoconservadoras.
} 
de sesenta años de vigencia (la ONU)_ ${ }^{359}$, ya que no se trataba de una ley internacional aprobada por un parlamento nacional, sino más bien era una norma trasnacional: los EE.UU., como hiper-potencia planetaria tiene intereses y ciudadanos en todo el mundo, por lo que en consecuencia con dicha lógica puede regularse tal realidad -ahora bien, cuáles son los fines no oficiales que mueven a la constitución de un instrumento así, como su sistema propio, cuando existe otro vigente al que se supone se apoya, como es la figura del relator para la libertad religiosa de la ONU. Todo ello conduce a la aceptación o no del principio de buena fe, como vuelve a plantearse más adelante.

Con respecto al proceso de tramitación de la IRFA, pese a su premura ${ }^{360}$, fue arduo y laborioso, no tanto en términos sustanciales ya que había una vocación unívoca de los poderes públicos, sino en lo formal, porque los matices y sellos personales suponían prestigio y poder potencial de para su interpretación implementadora. En esto, el proyecto pasó por más de una decena de Comités y Subcomités, recibiendo tres enmiendas en la Cámara de Representantes (más dos normas de apoyo para su tramitación), a las que añadir otras tres del Senado, y una última durante la votación final; de tal modo, el 9 de octubre de 1978, el Senado aprobó la norma por abrumadora mayoría (98 votos a favor, 0 en contra, 2 en blanco) ${ }^{361}$; dieciocho días más tarde, el Presidente de los EE.UU. la firmó, adquiriendo entonces la condición de ley pública.

\footnotetext{
359 En la línea discursiva, igualmente, resulta curioso que no se proteste frente a las cláusulas abusivas -independientemente de la pretensión moral subyacente- frente a terceros que impone la UE en sus intercambios comerciales con otros países, pudiendo rescindir dicha relación discrecionalmente sino se observan aquellas.

${ }^{360}$ Un tiempo record de un año, un mes y un día, gracias a que desde su presentación recibió el mensaje de urgencia del Comité de Reglas, lo que agilizó considerablemente su tramitación, pues de otro modo se habría demorado años.

${ }^{361}$ Vid. “US Senate Roll Call Votes 105th Congress - 2nd Session: October 9, 1998, 09:51 am”.
} 
En cuanto a la estructura de la norma, la IRFA, resulta una norma relativamente larga, si se tiene en cuenta que se trata de un tema concreto y no se está ante una Omnibus Law [Ley de acompañamiento] de contenido y alcance variado. Tal y como se aclara en la figura siguiente, la IRFA consta de un preámbulo, siete títulos, dos subtítulos y cuarenta y una secciones.

Figura 47.- Estructura y contenidos de IRFA ${ }^{362}$.

\begin{tabular}{|l|}
\hline \multicolumn{1}{|c|}{ (PREÁMBULO) } \\
\hline Sección 1 (1): Título corto; contenido. \\
\hline Sección 2 (2): Resultados; política. \\
\hline Sección 3 (3): Definiciones. \\
\hline \multicolumn{1}{|c|}{ TITULO I - ACTIVIDADES DEL DEPARTAMENTO DE ESTADO } \\
\hline $\begin{array}{l}\text { Sección } 101 \text { (4): Oficinal para la Libertad religiosa internacional; Embajador } \\
\text { itinerante para la Libertad religiosa internacional. }\end{array}$ \\
\hline Sección 102 (5): Informes. \\
\hline $\begin{array}{l}\text { Sección } 103 \text { (6): Establecimiento de una página electrónica para la Libertad } \\
\text { religiosa. }\end{array}$ \\
\hline Sección 104 (7): Entrenamiento para funcionarios del Servicio Extranjero. \\
\hline $\begin{array}{l}\text { Sección } 105 \text { (8): Contactos de alto nivel con Organizaciones No Gubernamentales } \\
\text { (ONGs). }\end{array}$ \\
\hline
\end{tabular}

362 Vid. “PL 105-292, October 27, 1998, 112 Stat 2787 UNITED STATES PUBLIC LAWS 105th Congress - Second Session Convening January 27, 1998 PL 105-292 (HR 2431) INTERNATIONAL RELIGIOUS FREEDOM ACT OF 1998"; complementariamente, vid. historial legal (URL: http://www.uscirf.gov/about/authorizinglegislation.html): "Public Law 107-228: H.R. 1646 (S. 1401): HOUSE REPORTS: Nos. 107-57 (Comm. on International Relations) and 107-671 (Comm. of Conference). SENATE REPORTS: No. 107-60 accompanying S. 1401 (Comm. on Foreign Relations). CONGRESSIONAL RECORD: Vol. 147 (2001): May 16, considered and passed House. Vol. 148 (2002): May 1, considered and passed Senate, amended. Sept. 25, House agreed to conference report. Sept. 26, Senate agreed to conference report. Approved September 30, 2002. WEEKLY COMPILATION OF PRESIDENTIAL DOCUMENTS, Vol. 38 (2002): Sept. 30, Presidential statement. Public Law 105-292: H.R. 2431. HOUSE REPORTS: No. 105-480, Pt. 1 (Comm. on International Relations), Pt. 2 (Comm. on Ways and Means), and Pt. 3 (Comm. on the Judiciary).CONGRESSIONAL RECORD, Vol. 144 (1998): May 14, considered and passed House; Oct. 8, 9, considered and passed Senate, amended; Oct. 10, House concurred in Senate amendments. Approved October 27, 1998. WEEKLY COMPILATION OF PRESIDENTIAL DOCUMENTS, Vol. 34 (1998): Oct. 27, Presidential statement. Public Law 10655: S. 1546. CONGRESSIONAL RECORD, Vol. 145 (1999): Aug. 5, considered and passed Senate and House. Approved August 17, 1999. 
Sección 106 (9): Programas y asignación de fondos para las misiones de los EE.UU. en el extranjero.

Sección 107 (10): Igual acceso a las misiones de los EE.UU. en el extranjero para conducir actividades religiosas.

Sección 108 (11): Listas de prisioneros y cuestiones breves concernientes a la Libertad religiosa.

TITULO II - COMISION PARA LA LIBERTAD RELIGIOSA INTERNACIONAL

Sección 201 (12): Establecimiento y composición.

Sección 202 (13): Deberes de la Comisión.

Sección 203 (14): Informe de la Comisión.

Sección 204 (15): Aplicabilidad de otras leyes.

Sección 205 (16): Autorización de apropiaciones.

Sección 206 (17): Terminación.

TITULO III - CONSEJO DE SEGURIDAD NACIONAL

Sección 301 (18): Consejero especial para la Libertad religiosa internacional.

TITULO IV - ACCIONES PRESIDENCIALES

Subtítulo I - Respuestas apuntadas a las violaciones de la Libertad religiosa en el exterior.

Sección 401 (19): Acciones presidenciales en respuesta a las violaciones de la Libertad religiosa.

Sección 402 (20): Acciones presidenciales en respuesta a violaciones

particularmente graves de la Libertad religiosa.

Sección 403 (21): Consultas.

Sección 404 (22): Informe al Congreso.

Sección 405 (23): Descripción de acciones presidenciales.

Sección 406 (24): Efectos sobre contratos/compromisos existentes.

Sección 407 (25): Excepciones presidenciales.

Sección 408 (26): Publicación en Registro Federal.

Sección 409 (27): Terminación de acciones presidenciales.

Sección 410 (28): Preclusión de la revisión judicial.

Subtítulo II - Consolidación del Derecho existente.

Sección 421 (29): Apoyo de los EE.UU.

Sección 422 (30): Apoyo multilateral.

Sección 423 (31): Exportación de ciertos artículos usados en violaciones

particularmente graves de la Libertad religiosa.

TITULO V - PROMOCION DE LA LIBERTAD RELIGIOSA

Sección 501 (32): Apoyo para promover la Libertad religiosa.

Sección 502 (33): Difusión internacional.

Sección 503 (34): Intercambios internacionales. 
Sección 504 (35): Concesiones al Servicio Extranjero.

TITULO VI - REFUGIO, ASILO Y MATERIAS CONSULARES

Sección 601 (36): Uso del Informe Anual.

Sección 602 (37): Reforma de la política de refugio.

Sección 603 (38): Reforma de la política de asilo.

Sección 604 (39): Inadmisibilidad de funcionarios de Estados extranjeros que guarden relación con violaciones particularmente graves de la Libertad religiosa.

Sección 605 (40): Estudios sobre los efectos del retiro de provisiones en materia de peticiones de asilo.

TITULO VII - PROVISIONES MISCELÁNEAS

Sección 701 (41): Códigos de conducta en el comercio.

Fuente: elaboración propia (SÁNCHEZ-BAYÓN, 2007 y 16).

Sobre su contenido (stricto sensu), cabe destacar que pese a su carácter trasnacional, efectivamente, los EE.UU. se mantienen dentro del margen de sus intereses, así como, de la atención a sus ciudadanos y sus recursos; tanto es así, que la labor de vigilancia corresponde a las embajadas estadounidenses y las sanciones a adoptar siguen afectando a la soberanía de dicho país, porque sólo operan sobre las ayudas internacionales que los EE.UU. aprueban en sus presupuestos nacionales -la gran duda, otra vez, es acerca del respeto al principio de buena fe.

Como último apunte sobre la elaboración de la norma, únicamente, se completa la lacónica información posible -debido a los estrictos límites materiales del presente estudio-, enunciando una serie de enmiendas sobrevenidas a su aprobación: Pub. L. 106-31, May 21, 1999; Pub. L. 106-55, Aug. 17, 1999; Pub. L. 106113, Nov. 29, 1999; Pub. L. 106-246, Jul. 13, 2000; Pub. L. 107-77, Nov. 28, 2001; Pub. L. 108-6, Febr. 13, 2003; Pub. L. 108-7, Febr. 20, 2003 -la mayor parte de estas modificaciones son ajustes presupuestarios o de incorporación a instituciones afectadas por la IRFA. 


\section{d) Acerca de sus órganos: la Comisión, la Oficina, el Embajador itinerante y el Asesor especial}

Como se viene anunciando, la IRFA trae consigo todo un sistema operativo con órganos ex novo (los mencionados en el rótulo del apartado) y alguno ad hoc (máxime para las visitas in loco), además de exigir la colaboración de otros ya existentes (v.g. red de embajadas). Pues bien, el problema inicial -aparte del presupuestario ya salvado con las enmiendas citadas- fue buscar la fórmula de encaje, principalmente, con los órganos pre-existentes. Las discusiones interpretativas, para la implementación del sistema se polarizaban entre la configuración de una agencia federal autónoma y su incorporación subordinada en el seno del Departamento de Estado (equivalente a un Ministerio de Asuntos Exteriores o Relaciones Internacionales). Se acabó por imponer la segunda alternativa -por prudente y tradicional-, lo que a su vez exigió nuevas

modificaciones del Departamento de Estado, afectando a la reciente Secretaria General o Despacho del Departamento de Estado para la Democracia, los Derechos Humanos y el Trabajo (Secretaria DDHH, en adelante). Para tener una visión genérica del reparto de jurisdicciones y competencias, véase el siguiente mapa conceptual. 
Figura 48.- Organigrama operativo de la IRFA y su sistema (1998-01)

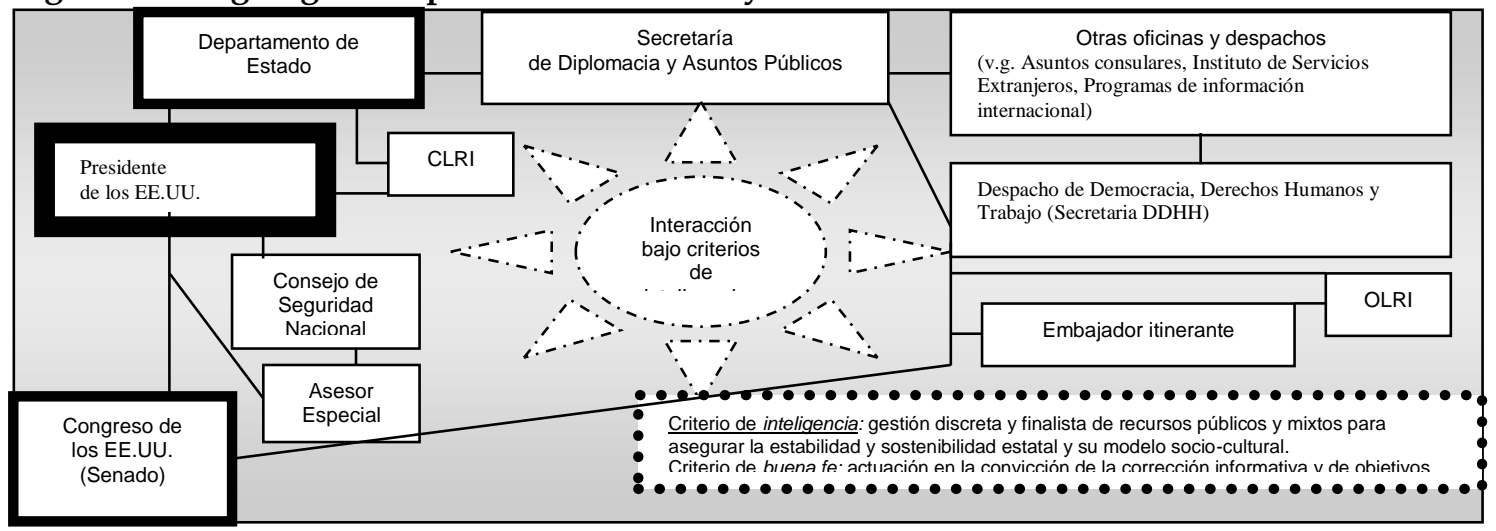

Fuente: elaboración propia (SÁNCHEZ-BAYÓN, 2007 y 16).

Nótese que se atiende a dos criterios básicos de actuación en las interacciones institucionales, de un lado el de inteligencia y, del otro, el de buena fe; ello quiere decir que cabe una cierta discrecionalidad limitada por la exigencia ética patriótica y jurídica del rule of law [reglas/principios del Derecho, según el Derecho Común Anglosajón, pues en el Derecho Civil o Europeo-continental se confunde con la expresión Estado de Derecho y/o principio de legalidad, circunscribiéndose el Derecho al marco del Estado] $]^{363}$. La afirmación precedente, seguramente, se clarifique un poco más si se traslada a la cotidianeidad de los órganos y su proceso interactivo para el ejercicio de sus funciones.

La mecánica del sistema, entonces, puede resumirse del modo siguiente, atendiendo a tres fases:

- Fase 1, de recogida y tratamiento de información: las embajadas recaban la información local (bien por denuncias recibidas o a instancia propia) para

363 Vid. SÁNCHEZ-BAYÓN, A.: Sistema de Derecho Comparado y Global, Valencia: Tirant Lo Blanch, 2012. - Introducción al Derecho Comparado y Global, Madrid: Delta Publicaciones, 2011. 
elaborar así el borrador de la agenda institucional -luego el primer sesgo proviene ya del tipo de relaciones que tenga el cuerpo diplomático con las elites político-jurídicas del lugar; seguidamente, la información es filtrada por los analistas de la Oficina, fijando entonces la agenda institucional que llega inmediatamente a la Secretaría de Derechos Humanos, e indirectamente, también a la Comisión, al Presidente y al Congreso.

- Fase 2, de formulación e implementación de programas: es ya en la Comisión cuando se fija -por discrecionalidad de su director para elegir las prioridades, siendo luego ratificadas por el resto de los comisionados- el borrador de la agenda normativa a aprobar por el gestor, que según el caso, puede ser el Secretario de Estado o el mismo Presidente, dependiendo de que se vayan a adoptar meras medidas administrativas de política exterior u otras de alcance también doméstico (v.g. un giro en las relaciones con un país).

- Fase 3, de evaluación de actividades: se hace balance de las estrategias y programas adoptados por las recomendaciones de la Comisión, incluso (según las jurisdicciones y competencias), de los otros órganos del sistema (v.g. el Embajador itinerante o el Asesor especial); atendiendo al resultado del análisis, bien se puede optar por insistir en las recomendaciones, pedir la intensificación o atenuación de medidas, o dar prioridad a nuevos objetivos $^{364}$.

\footnotetext{
${ }^{364}$ Vid. última regulación aprobada (en el marco temporal planteado desde el cap. 5) bajo el consejo de la Comisión durante la Legislatura 109th, del Congreso de los EE.UU., 2005-06 (URL: http://www.uscirf.gov/washingtonupdate/legislation/109.htm1): Belarus $\quad$ (H.Con.Res.102Condeming Human Rights Violations in Belarus). Central Asia (H.Con.Res. 31- Human Rights in Central Asia). China (S.Res.91-E.U. Arms Embargo on China). India (H.R. 160- Urging the United States to condemn all violations of religious freedom in India). Iran (H.R.282-Iran Freedom Support Act). North Korea (H.Con.Res.168-Condemning Human Rights Violations in the Democratic People's
} 
Las fases expuestas, en la realidad, no se distinguen con tanta precisión como en los tipos ideales enunciados, especialmente, entre la segunda y tercera fase, pues en su análisis, los informes de los órganos competentes sirven tanto para diagnosticar como para evaluar -se retoma la cuestión al tratar de los informes, en el apartado próximo.

Consecuentemente con los apuntes señalados sobre la mecánica del sistema, se entenderá mejor que, pese al riesgo latente permanente de instrumentalización política según las conveniencias de la Administración presidencial de turno, sus integrantes, principalmente los miembros de la Comisión -quienes no cobran por sus servicios, pues meramente reciben la cobertura de sus gastos- actúen bajo el principio de buena fe: la información y objetivos son correctos (se procede dentro de la legalidad vigente) y los fines también (se pretende dar protección frente a violaciones de derechos y garantizar la libre convivencia allí donde el Estado no interviene o es el mismo causante de problema) ${ }^{365}$.

Republic of Korea). Saudi Arabia (H.R.505- Prohibit Aid to Saudi Arabia Act). Anti-Semitism (H.Res.39- Strengthening of the fight against racism, intolerance, bigotry, prejudice, discrimination, and anti-Semitism; H.Res.54- Anti-Semitism in the United Nations).

365 Este es uno de los antecedentes político-jurídicos más relevantes, además de los discursos presidenciales de CLINTON (donde se menciona expresamente), de la variable rogue state [Estado fallido] que fundamenta las estrategias actuales del intervencionismo preventivo -una vez más, las teorías operativas de hoy llevan fraguándose y ensayándose décadas atrás, no es algo Ex novo [de nuevo] ni Ex nunc [desde ahora] atribuible a la Administración W. BUSH. 


\section{e) Acerca de sus medidas: especial atención a los informes}

Desarrollando, con un par de pinceladas más, las indicaciones de la fase tercera del mecanismo del sistema, se llama la atención sobre: a) la pluralidad de informes; b) las implicaciones de la actividad asesora o recomendaciones.

Existen, sólo en el sistema de la IRFA, al menos, tres fuentes de informes periódicos sobre la protección internacional de la libertad religiosa: los de la Oficina y los de la Comisión, complementados con los de la Secretaria de Derechos Humanos. Además, los informes pueden ser anuales o por países. Tómese como referencia los de la Comisión, como órgano con mayor peso político-jurídico y que distingue entre los informes anuales y por países; obsérvese luego cómo queda su ranking o listado de los Estados cuyas condiciones resultan las más alarmantes y exigen la adopción de medidas inmediatas: Afganistán, Cuba, Corea del Norte, Irán, Iraq... Rusia, etc. ${ }^{366}$-acaso no recuerda este listado al de los Estados tradicionalmente enemigos de los EE.UU.-.

Así pues, tal variedad de informes y la diversidad de matices entre ellos incluso, dándose discrepancia en la prioridad de objetivos, tanto sincrónica como diacrónicamente-, lleva a pensar que: más que pluralidad, se da solapamiento, lo que a su vez genera, más que hiper-cobertura, en realidad, se provoca confusión e intranquilidad (if you can't convince them, confuse them [sino puedes convencerles, confúndeles] -frase atribuida al Presidente TRUMAN, en el inicio de la Guerra fría); muchos planteamientos divergentes de una misma información, desde varias

\footnotetext{
${ }^{366}$ La lista se ha modificado en cierta medida, v.g. actualmente, Afganistán e Iraq se han sustraído porque ya hay una intervención estadounidense, igualmente, ha cesado el hostigamiento contra Rusia por razón de apoyos internacionales.
} 
fuentes, terminan provocando alarma y sensación de vivir en un mundo más inseguro de lo que ciertamente es.

En cuanto a las recomendaciones, la mayor suspicacia que despiertan, en términos generales -pues los casuísticos suponen material desbordante para múltiples publicaciones-, es la relativa a la tensión entre la instrumentalización política vs. la buena fe. El hecho de que coincidan los países con violaciones más graves de la libertad religiosa con los Estados tradicionalmente enemigos de los EE.UU., cabe justificarse porque se trata de regímenes no democráticos; pero es que tal argumento elemental se desploma cuando: a) se varía el listado, según criterios de oportunidad política internacional; b) se sustraen temas con un fuerte componente religioso identitario, como el conflicto israelí-palestino, o se marginalizan otros, como el conflicto marroquí-saharaui; etc. Todo ello resta credibilidad a la buena fe, otorgando mayor convicción a la explicación del recurso de la libertad religiosa, como discurso relacionado con los derechos humanos y con un cariz progresista, como nueva vía de justificación de intervenciones estadounidenses en el exterior.

\section{f) La generación de discursos legitimadores: comunicación oficial vs. realidades oficiosas}

La gran crítica a la IRFA y su sistema, no viene tanto por la tentación de las elites estadounidenses de recurrir a la instrumentalización política de los derechos humanos para justificar sus intervenciones exteriores, sino por el intento de

ocultarlo, y construir luego una teoría comunicativa nociva. Véase algunas de las 
argucias legitimadoras fruto de las aportaciones de los ex-comunistas al neoconservadurismo, y que han cuajado plenamente en el devenir de la IRFA y su sistema (sobre todo en la Comisión), haciendo necesaria la distinción entre la comunicación oficial y las realidades oficiosas:

a) Los órganos (del pluralismo orgánico real al monismo de imagen pluralista): la IRFA, originalmente, preveía una diversidad de órganos que habrían de interactuar, pero con el nuevo discurso, se ha pasado a ocultar la presencia de dichos órganos ${ }^{367}$, integrando parte de ellos (v.g. el Embajador itinerante), en el seno de la Comisión, pues se ha decidido que sólo ésta sea la imagen exterior/ pública del sistema; para ello, se ha modificado su estructura interna, pasando de reunir expertos profesionales sobre la materia (v.g. profesores universitarios y burócratas del Departamento de Estado) a representantes de confesiones dominantes en los EE.UU. -curiosamente, y confirmando afirmaciones anteriores sobre el catolicismo y el neoconservadurismo, en la actualidad, integran la Comisión dos Obispos.

La vía para lograr el tránsito del pluralismo orgánico real al monismo de imagen pluralista, ha sido la de la confusión interpretativa, ya que sin incurrir en manifiesta contradicción con la norma, sí se ofrece un discurso expositivo completamente distinto a la tradición operativa del sistema ${ }^{368}$.

\footnotetext{
367 De la versión que se mantuvo desde el 2000 hasta el 2003, ha desaparecido en la actualidad la publicidad de los otros órganos del sistema, quedando como única referencia la de la Comisión; vid página electrónica del Departamento de Estado de los EE.UU. (URL: http://www.state.gov/g/drl/irf/). 368 Vid. la afirmación publicitaria de la Comisión por la que se autodefine como un órgano independiente federal (URL: http://www.uscirf.gov/).
} 
b) El discurso (el abuso de lo políticamente correcto y del deconstruccionismo): como ejemplo, claramente ilustrativo, véase cómo se recurre a la diferenciación entre los musulmanes occidentalizados (buenos) y los del Oriente Próximo, África y parte de Asia (malos). La estrategia de propaganda ex-comunista neoconservadora es arremeter contra estos últimos (los musulmanes orientales) por dos vías, siendo la primera la exposición de virtudes ciudadanas de los musulmanes occidentalizados (quiénes pueden participar en la Comisión, con un comisionado y algún becario), desvelando por contraste las deficiencias de los musulmanes orientales.

Otro aspecto a destacar sobre el discurso es, la habilidad para distraer de la atención pública ha obligación que tiene dicho órgano (la Comisión) de desaparecer a los diez años de su constitución (no más tarde del 2008-09).

c) La imagen (el info-entertainment para confundir su naturaleza y fines): nuevamente, véase lo acontecido a la Comisión como ejercicio ideográfico, pues ha pasado a tener un Departamento de Comunicación (de tres responsables y sus subordinados), entre cuyos "logros" cuentan la desnaturalización del propio órgano; tal y como se ofrecen los comunicados desde la Comisión, ésta no se identifica como un órgano público estadounidense, sino como una plataforma de la sociedad civil (v.g. Amnesty International, Human Right Watch, Freedom House, etc.), así como una ramificación de la ONU y demás organizaciones internacionales de gran difusión (v.g. OSCE) ${ }^{369}$.

\footnotetext{
369 Vid. enlaces ofrecidos por la Comisión, así como, la afiliación de sus comisionados (URL: http://www.uscirf.gov/washingtonupdate/links.html).
} 
El giro acometido en los aspectos mencionados, ha permitido, finalmente, la superación de una disonancia cognitiva desestructurante como era el recurso de la libertad religiosa, desde el discurso moderno de los derechos humanos patrocinados por la ONU -con su propio sistema al que debería apoyar los EE.UU., en vez de promover alternativas solapantes-, y en conflicto con el discurso constitucional estadounidense mucho más reduccionista y sin relación expresa con la naturaleza tripartita de dicha libertad o su proyección sobre el resto de derechos humanos; curiosamente, en vez de lograrse la superación de tensiones por medio de una mayor permeabilidad nacional en relación con los derechos humanos, éstos -gracias al giro impulsado desde la Comisión-, en cambio, se conciben para el recurso internacionalista ${ }^{370}$.

\section{g) De la trasversalidad de IRFA al juego geopolítico del choque de civilizaciones}

Pues bien, observada la IRFA y su sistema, y recordando las críticas a su progresiva transformación, se enuncia sucintamente el devenir evolutivo que ha llevado al auge del juego geopolítico de carácter religioso-cultural como el actual, y así, poder continuar en el próximo epígrafe con la pronosticabilidad de todo ello, además de atender a los retos y tensiones que aguardan al discurso religioso en las relaciones internacionales -desde la orientación estadounidense, por supuesto.

\footnotetext{
${ }^{370} \mathrm{El}$ recurso de los derechos humanos que se lleva a cabo desde los EE.UU., es internacionalista, que no internacional, ya que: a) no se corresponde plenamente con el universalista de la ONU; b) se acude a órganos propios con jurisdicción trasnacional y toma de decisión unilateral; c) adolece del criterio de doble "standard" o medida (según se trate de países aliados o no); et. al.
} 
En pocas palabras, si la IRFA y su sistema supusieron una de las primigenias respuestas político-jurídicas de carácter trasversal en materia de religión y geopolítica, al llegar a dividir el mundo entre, (a) países donde se cometen graves violaciones de la libertad religiosa (por ende, del resto de derechos humanos), y los EE.UU. tienen la obligación de intervenir con firmeza; (b) países donde se cometen leves violaciones de la libertad religiosa, y los EE.UU., meramente, deben manifestar su inconveniencia al respecto e incentivar el cambio gracias al soft power; o (c) países no violadores de la libertad religiosa -donde hasta ahora habían permanecido también los que defendían un modelo multicultural laicista, aunque quizá la cosa cambie $^{371}$. Consecuentemente, tras la elección de la nueva Administración presidencial y la perpetración de los trágicos atentados del 11/S (en Nueva York, Washington DC y en el Estado de Pennsylvania), el discurso religioso en la geopolítica orquestada por los EE.UU. se ha intensificado -de trasversal ha pasado a centrípeto-, incluso, se ha radicalizado -una parte del pensamiento neoconservador trabajó intensivamente en los meses inmediatos a los atentados para construir un sistema de diferencias (y exclusiones) que permitiera una clara distinción del "nosotros (Occidente)-ellos (Oriente)"372.

\footnotetext{
371 Vid. siguiente epígrafe, especialmente, en relación con las menciones que se hagan sobre el Informe de 2005 de la Comisión.

372 El discurso distintivo al que se hace referencia, no sólo ha servido para manipular la memoria histórica estadounidense, potenciando la tradición judeocristiana y su componente WASP ("white anglo-saxon protestant" [protestante anglosajón blanco -aunque también significa avispa, como juego de palabras por parte de las minorías], vid. infra) -de forma edulcorada y cívica con el judaísmo y el catolicismo, como muestra de un pseudo-ecumenismo de las verdaderas raíces-, sino que también se ha utilizado para fortalecer la escasa legitimidad institucional del Presidente W. BUSH (tras el incidente del controvertido recuento de votos), recurriéndose entonces a la legitimidad religiosa, en su doble sentido, y trayendo consigo el riesgo del neocesaropapismo (el poder civil controla el religioso para afianzarse).
} 
Figura 49.- Indicios de neocesaropapismo por liderazgo de confesiones ${ }^{373}$

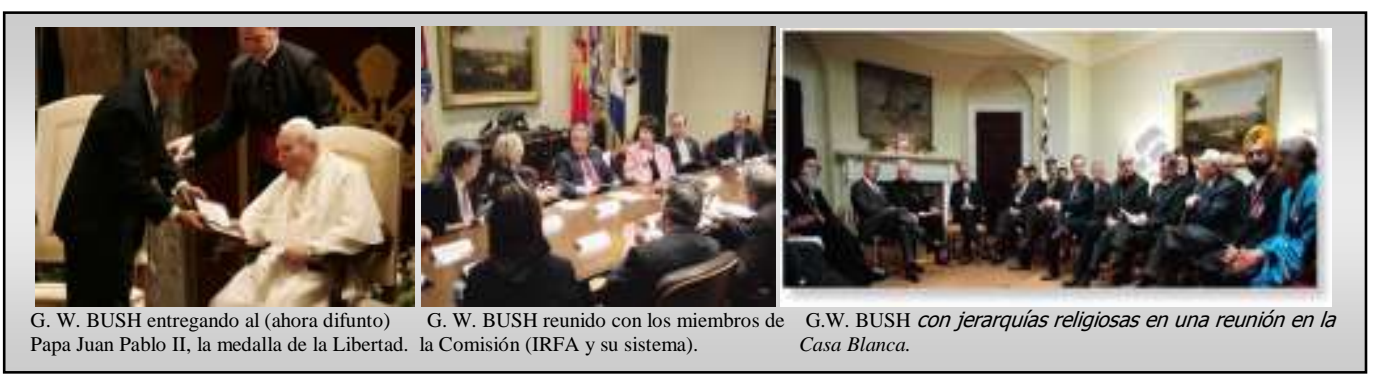

Fuente: elaboración propia (SÁNCHEZ-BAYÓN, 2007 y 16).

En términos especulativos, habría sido natural pensar que la Administración W. BUSH hubiera querido instrumentalizar por completo la IRFA y su sistema, pero en cambio no ha sido así, ya que el recurso de la misma es limitado -por la propia naturaleza de la IRFA, que no por las ganas: a la norma y a su sistema les faltan sustancialidad y capacidad movilizadora global (alcance total de actuación); en cambio, si ha servido de base para introducir briosamente el discurso religioso en las relaciones internacionales, así como para generar una geopolítica elemental sobre la materia ${ }^{374}$. Todo ello es aprovechado, y en combinación con una versión reduccionista de la teoría del choque de civilizaciones (generada desde el American Enterprise Institute-AEI) ${ }^{375}$-que dicho sea de paso, es introducida en varios de los

373 Vid. SÁNCHEZ-BAYÓN, A.: “U.S. Religious Liberty: One (secular) Nation under God. Paradox nature and explanatory hypothesis", tesina inédita de DEA (investigación realizada en Harvard University, 2002-03, y aprobada por la UCM, 2003; Programas de información de los EE.UU.-USINFO (URL: http://usinfo.state.gov/esp/); Freedom House (URL: http://www.freedomhouse.org/religion/); Sistema integral de enciclopedias electrónicas "Answers" (URL: http://www.answers.com); Gallup International Poll and Reports (URL: www.gallup.com).

374 Vid. la actual distribución geopolítica que proporciona la Comisión (URL: http://www.uscirf.gov/countries/index.html).

${ }^{375}$ Siendo una versión adaptada, principalmente por el AEI, discrepante con la de HUNTINGTON (El choque de civilizaciones y la reconfiguración del orden mundial (trad.), Barcelona: Paidos, 1996. ¿Quiénes somos? Los desafíos a la identidad nacional estadounidense (trad.), Barcelona: Paidos, 2004), al 
documentos de la Comisión-, junto con construcciones doctrinales judeocristianas mesiánicas y la concepción realista e inestable del mundo, es el caldo de cultivo perfecto para diseñar una geopolítica en términos religioso-culturales y de tipo intervencionista preventiva o neokantianismo realista de RICE ${ }^{376}$.

Figura 50.- Unidad doctrinal, dualidad estratégica y pluralidad operacional

\begin{tabular}{|c|c|c|}
\hline Doctrina presidencial & \multicolumn{2}{|c|}{ Estrategias de los Secretarios de Estado } \\
\hline$\downarrow$ & \multirow{2}{*}{$\begin{array}{l}\text { C. POWELL (Neohobbesianismo) } \\
\text { Alianza de países occidentales democráticos } \\
\text { vs. Eje del mal (estrategia de contención) } \\
{ }^{*} \text { No continuidad: a) versión oficial, motivos } \\
\text { familiares; b) versiones oficiosas, por } \\
\text { diferencias con CHENEY -aunque fue con } \\
\text { RUMSFELD y demás del Grupo B con } \\
\text { quienes chocara- o no voluntad de фesgaste }\end{array}$} & \multirow{2}{*}{$\begin{array}{l}\text { C. RICE (Neokantianismo realista) } \\
\text { Geopolítica democratizadora vs. } \\
\text { rogue states (estrategia de } \\
\text { prevención: democratización por } \\
\text { todo medio y aseguramiento de los } \\
\text { círculos de riqueza) }\end{array}$} \\
\hline $\begin{array}{c}\text { W. BUSH: } \\
\text { Manifest Destiny Revival }\end{array}$ & & \\
\hline \multicolumn{3}{|c|}{$\begin{array}{l}\text { Analistas y Gestores (del Grupo B de Seguridad Nacional con la Administración REAGAN a la Cábala de la } \\
\text { Administración W. BUSH) }\end{array}$} \\
\hline
\end{tabular}

Fuente: elaboración propia (SÁNCHEZ-BAYÓN, 2007 y 16).

El AEI, es el think tank [centro de investigación de alto rendimiento] neoconservador más relevante ${ }^{377}$, cuyos académicos han desempeñado una función

que se considera un mero rentabilizador del pensamiento precedente de BELL y BERGER (BELL, D.: El fin de las ideologías (trad.), Madrid: Tecnos, 1954. - The Radical Right, Double-day-Anchor, Garden City, 1964. BERGER, P.L.: Modernidad, pluralismo y crisis de sentido: la orientación del hombre moderno (trad.): Barcelona: Paidos, 1994. BERGER, P.L., NEUHAUS, R.J.: To empower people: from state to civil society, Washington DC: AEI, 1996). A tal respecto, se considera destacable, como ejemplo de otro punto de vista bastante generalizado, la crítica rotunda al choque de civilizaciones, al que se considera realmente como una colisión de ignorancias; vid. ODINA, M.: Europa versus USA, Espasa, Madrid, 2004.

376 Vid. nota 357

377 El AEI es uno de los think tanks más destacados, pero existen otros muchos: a) Hasta 1994, los centros de alto rendimiento más destacados, por influencia en las universidades y manejo de fondos (alrededor de 1.000 millones de dólares de presupuesto), han sido: Lynde and Harry Bradley Foundation. The Carthage Foundation. The Earhart Foundation, The Charles G. Koch, David H. Koch and Claude R. Lambe charitable foundations. The Phillip M. McKenna Foundation. The JM Foundation. The John 
crucial como ideólogos para el tránsito del viejo sistema de legitimaciones al presente, priorizando el discurso de la misión democratizadora iushumanista de los EE.UU.

Figura 51.- El bagaje del AEI en discurso democrático y iushumanista

AEI cuenta con destacados académicos y burócratas neocons, con amplio conocimiento y experiencia en materia de democracia y derechos humanos $-\mathrm{y}$ crítica al socialismo, dicho sea de paso: a) MURAVCHIK (miembro de la Comisión Estadounidense de Derechos Civiles 1985-97, destacan sus libros Heaven on Earth y The future of the United Nations), b) GOLDWIN (prof. Derecho Constitucional y Derechos Humanos, destaca su libro From Parchment to Power), c) KIRKPATRICK (miembro de la Comisión de Derechos Humanos-ONU 2003, representante permanente de los EE.UU. en ONU 1981-85, destaca su libro Right versus Might), d) FALCOFF (miembro de la Comisión de Derechos Humanos-ONU 2003, destaca su libro Cuba the morning alter), e) NOVAK (embajador de los EE.UU. en OSCE 1986, embajador de los EE.UU. en ONU -sede de Ginebra-, destacan sus libros The Universal Hunger for Liberty, Human Rights and the New Realism, Christian Capitalism or Christian Socialism?, The Spirit of Democratic Capitalism), f) WATTENBERG (delegado estadounidense en la Conferencia de Madrid (pacificación de Oriente Próximo), g) BERNS (consultor del Departamento de Estado 1983-87, representante de los EE.UU. en la Comisión de Derechos Humanos-ONU 1983, destaca su libro Alter the people vote), etc.

Fuente: elaboración propia (SÁNCHEZ-BAYÓN, 2007 y 16).

M. Olin Foundation. The Henry Salvatori Foundation. The Sarah Scaife Foundation. Smith Richardson Foundation. b) Desde finales de la década de 1990, han destacado en el ranking: American Legislative Exchange Council. Atlas Economic Research Foundation. Cato Institute. Center for Strategic and International Studies. Citizens for a Sound Economy. Competitive. Enterprise Institute. Empower America. Employment Policy Foundation. Ethics and Public Policy Center. Family Research Council. Free Congress Research and Education Foundation. Heritage Foundation. Hoover Institution. Hudson Institute. Manhattan Institute. National Center for Policy Analysis. National. Center for Public Policy Research. Progress and Freedom Foundation. Reason Foundation. Posteriormente, su número ha crecido y su proximidad a la Administración y las universidades se ha intensificado (con dotaciones presupuestarias y departamentos propios); para más información, vid. InfoUSA: Think Tanks and Public Interest Organizations (URL: http://usinfo.state.gov/usa/infousa/politics/thnktank.htm). US Conservative Think Tanks (URL: http://usconservatives.about.com/od/thinktanks/). 


\section{h) Algunas consideraciones de cierre:}

Llegado a este punto, tras tener en consideración la importancia y vigencia del discurso religioso, así como de su revitalización en las relaciones internacionales por parte de los EE.UU., que ha creado para ello un instrumento político-jurídico trasnacional como la IRFA y cuyo resultado más importante (para este trabajo) ha sido el diseño de una propuesta trasversal geopolítica en términos religiosos y de derechos humanos, aprovechable la misma luego para la política internacional en curso. Pero, entonces -y es la pregunta que falta por abordarse para completar el estudio-, ¿cuál es la situación presente y cuáles son las proyecciones, previsiones y conjeturas al respecto?

Esta pregunta, compleja por su doble formulación y por las incertidumbres que la rodean, atiende no sólo a la nueva división del mundo por razones religiosoculturales, sino que también determina el acceso a los flujos de riqueza y, por tanto, a la integración o exclusión entre los países favorecidos o los perjudicados, pues el mundo ya está maduro y sólo cabe su continuidad en los términos actuales si se aprovechan las inestabilidades de los países perjudicados -se trata de una visión peculiar de las tesis de KANT, SCHUMPETER, etc.

La gran diferencia con propuestas geopolíticas estadounidenses previas (v.g. mundo libre vs. totalitarismo), radica sobre todo en el tratamiento conferido desde la presente a los jugadores indecisos: no serán objeto de intervención por razón de seguridad (como pasara con el Tercer Mundo), sino que desde el principio han de notar las consecuencias de no ser aliados de los EE.UU. -así se manifestaron W. BUSH y RICE, 
tras la deserción de España de Iraq y la invitación de este mismo país a los demás a que le siguieran al ostracismo.

Tanto son así las previsiones para los próximos años, con las nuevas reglas geopolíticas, que países hasta ahora excluidos de sospecha, como Francia, son a día de hoy objeto de investigación por acusaciones de antisemitismo (vid. Informe del 2005 de la Comisión) ${ }^{378}$. La cuestión no es baladí, ya que la presencia en el foro internacional de tal acusación deshabilitaría a dicho país a pronunciarse en el conflicto israelípalestino, y por extensión, en cualquier otro de Oriente Próximo. Los efectos de las nuevas reglas no pararían ahí, pues se conjetura con posibles medidas de aviso frente a la Unión Europea (UE) y su excepcionalismo actual -atribuido, desde interpretaciones estadounidenses, tanto a su condición transitoria (en el proceso integrador europeo) como por su aislamiento de la realidad internacional (al defender un idealismo ni siquiera materializable en su entorno)- ${ }^{379}$. Igualmente, se espera una intervención preventiva frente al auge de regímenes de izquierda radical en Latinoamérica históricamente, el U.S. back yard [patio trasero estadounidense], donde ahora emergen tanto propuestas laicistas como indigenistas, que se interpretan desde los EE.UU. como posibles focos de inestabilidad continental a corto plazo. Como se puede observar, se está implementando el nuevo modelo geopolítico, más estricto con las posturas intermedias o no claramente definidas, además de exigir demostraciones actualizadas de posicionamiento.

\footnotetext{
378 Vid. página 82 y siguientes del Informe de la Comisión, de 2 de mayo del 2005 (URL: http://www.uscirf.gov/countries/publications/currentreport/2005annualRpt.pdf\#page=1).

379 KAGAN (Committee on the Present Danger), sostiene que si Europa goza de tal estabilidad que la mantiene al margen de la inestabilidad internacional es gracias al escudo de seguridad que los EE.UU. la ha proporcionado durante la última mitad de siglo; vid. KAGAN, R.: Poder y debilidad. Europa y EE.UU. en el nuevo orden mundial (trad.), Madrid: Taurus, 2003.
} 
En cuanto a las incertidumbres más reseñables y que se harán más relevantes a medida que se acerque el 2008, son las siguientes:

- Inestabilidad mundial, ipor iniciativa estadounidense o como consecuencia de sus respuestas en el seno de la comunidad internacional?: la posición privilegiada de los EE.UU., no sólo confiere la habilidad de ejecutar un Derecho trasnacional impensable con otras potencias, sino que también acarrea la vulnerabilidad dentro de la comunidad internacional, ya que aunque se ha intentado disfrazar la cuestión, llamando liderazgo al imperialismo moderno, ello no evita que se dirija la atribución última del malestar de los Estados insatisfechos hacia los EE.UU. -aunque buena parte de la responsabilidad originaria la tienen los europeos, tanto por los vicios colonizadores como descolonizadores, y el tratamiento dado a la inmigración. La cuestión no termina ahí, pues buena parte de los estadounidenses considera -por influjo de discursos neoconservadores y ratificándose luego su recepción con la reelección de W. BUSH en el 2004- que existe una hostilidad internacional frente a su país y que el mundo se divide entre los occidentales (judeocristianos secularizados, liderados por los EE.UU.) y los orientales (islamistas, primordialmente, de Oriente Próximo), y que es necesaria una actitud firme para evitar la escalada de conflictos - porque se achaca a la debilidad de las potencias europeas las dos guerras mundiales del s. XX.

El caso es que, el auge del neoconservadurismo y de los islamistas (considerados como mayor fuerza inestabilizadora internacional) ha sido parejo desde la década de los 60, aunque sin interacción hasta los 80, que es cuando -paradójicamente- actuaron juntos para propiciar el derrumbe de la URSS; ahora bien, una vez desaparecido el enemigo común, la confrontación 
ha resultado inevitable: provocaciones mutuas, primero en territorio islamista, y a partir del 2001, también en los EE.UU. El corolario al que se quiere llegar es -sin perder más tiempo-, que los neoconservadores y los islamistas se necesitan mutuamente, por lo que únicamente se concibe el fin de la inestabilidad mundial actual, (a) si desde los EE.UU. deja de percibirse ésta, por lo que igualmente, (b) habría de cesar toda hostilidad islamista, y además, (c) volver a considerar el conflicto israelí-palestino como local -lo que a día de hoy es un círculo vicioso, y sólo se ve viable la (a) en los términos apuntados en la sucesión presidencial estadounidense.

- Geopolítica secular, países seculares vs. los no seculares (incluidos los totalmente secularizados o laicistas ${ }^{380}$ ): si se intensifica la tendencia actual, endureciéndose las relaciones con los países indecisos -que básicamente son los laicistas-, la geopolítica previsible distinguirá, entonces, entre (a) países no secularizados o islamista (enemigos), (b) países plenamente secularizados o laicistas (posibles enemigos), y (c) países seculares (aliados); la lógica subyacente es que un país secular permite un amplio margen a la libertad religiosa (desde la no imposición de una religión oficial hasta velar por el respeto a las creencias religiosas), cosa que los islamistas y laicistas no hacen.

\footnotetext{
${ }^{380}$ Con el deconstruccionismo y la teoría crítica del discurso se ha querido dar un nuevo barniz purificador al laicismo, y hablar ahora de laicidad y laico, estadio utópico inalcanzable, pues lo que se procede realmente es a la supresión de la dimensión espiritual de la religión, imponiéndose exclusivamente la material, que normalmente viene dirigida desde el movimiento político oportuno o desde el propio Estado, si se ha llegado al poder.
} 
En definitiva, el discurso religioso manejado en la geopolítica estadounidense expuesta no se corresponde con el del Antiguo Régimen -puesto que se acomete, no desde el confesionalismo, sino desde la defensa de los derechos humanos-, salvo en las formas de algunas facciones radicales -luego las comparaciones diacrónicas son muy limitadas, v.g. neocesaropapismo-. La gran mayoría de los neoconservadores aboga por una interpretación religioso-cultural que asegure un código común mínimo para la interacción y el compromiso social, de ahí la defensa del AWL y la constitución de anillos de seguridad (allá donde alcanzan los intereses estadounidenses y mediante influjos del soft power, principalmente). Tales planteamientos son defendidos tanto desde posiciones conservadoras resignadas (v.g. Nueva academia y realistas) hasta las que postulan un mesianismo intervencionista preventivo (v.g. Derecha cristiana). Este último discurso ha sido el dominante durante la década de 2000, por la ratificación que suponen las alternativas radicales e inestabilizadoras (v.g. islamistas, indigenistas) ${ }^{381}$. La cuestión parece varíar -al menos en el discurso, basado en el cambio-, por parte de la Adm. OBAMA. Así se apunta en la campaña electoral de 2008 (con eslóganes como "Yes, we can" o "Change"), supuestamente confirmada con la obtención del Premio Nobel de la Paz en 2009 (por su apoyo discursivo al desarme nuclear y la lucha contra el cambio climático). Ahora bien, la realidad es otra: no se trata de un demócrata intervencionista en el orden mundial y pro-biopolítica, sino más bien ha sido aislacionista, focalizado en las tensiones entre minorías en el seno de los EE.UU. (además de alcanzar altas cuotas de deportaciones de inmigrantes ilegales y sancionar a confesiones que ayudaban a aquellos, vid. supra cap. 12). Resulta que,

\footnotetext{
${ }^{381}$ Vid. SÁNCHEZ-BAYÓN, A.: “Revitalizaciones religiosas postmodernas en América y sus riesgos para la democracia y los derechos humanos" (pp. 1-23), en Revista General de Derecho Canónico y Derecho Eclesiástico del Estado-Iustel (nำ11), mayo 2006.
} 
entre sus primeras medidas adoptadas, está la retirada progresiva y programática de Oriente Próximo. Igualmente, en Latinoamérica, se retira también el apoyo a Colombia y se simpatiza con los líderes neomarxistas (condenados por la Adm. W.BUSH), hasta llegar a levantar el embargo de Cuba. Ello se debe a la recuperación de parte de los asesores de la Adm. CLINTON. Con respecto a la Adm. TRUMP, no se trata aquí, pues ya se corresponde con la posglobalización, y su geopolítica es de corte transoccidental (abandonándose progresiva y programáticamente los modelos previos, dando paso a una fase de aislacionismo previa a un ulterior expansionismo, que será transpacífico o no, pero transoccidental seguro). 


\section{PARTE FinAL:}

\section{ESTUDIO DE CASOS DEL LEGADO SOCIO-CULTURAL}

DE LA RELIGIÓN CIVIL ESTADOUNIDENSE

\section{(RETROALIMENTACIONES TRASATLÁNTICAS) 382}

En esta parte, se profundiza en la multiplicidad de manifestaciones de ACR y sus complejas relaciones. Las mismas, pese a su pluralidad de conexiones (expresas, implícitas y tácitas), están bien trabadas, pues cualquier posible disonancia cognitiva es superada gracias al conjunto del sistema, orientado en el sentido integrador de la diversidad (tal como reza uno de los lemas del Gran Sello: e pluribus unum), tipificándose en forma de legado. Igualmente, para favorecer el estudio de tan rico aparato de ítems, se recurre a una técnica de estudio autóctona de los EE.UU., como es el estudio de caso.

Antes de analizar los contenidos y trayectoria de ACR en EE.UU., se ofrece a continuación un apunte sobre alguna de las técnicas más empleadas por los Estudios culturales al abordar la materia (aunque esta tesis se enmarque en las relaciones atlánticas, no se sigue tanto el tratamiento tradicional de carácter historicista de las Relaciones Internacionales, sino preferiblemente la causística y otras tantas técnicas más clarificar).

\footnotetext{
${ }^{382}$ Con el respaldo de pasadas publicaciones (citadas en el cap. 3, especialmente, La Modernidad sin prejuicios, Universidad, ciencia y religión en los Estados Unidos de América y La religión civil estadounidense), el presente capítulo está sustentado por recientes artículos (publicados durante la matrícula de doctorado en la UVA y aprobados en las memorias tramitadas); complement., vid. infra notas 3 a 5 , $11,16,24,55,68$ y 272, más p. 126 ss.
} 
La principal técnica a abordar aquí, es la procedente de los estudios de Derecho, en concreto de su disciplina de Jurisprudence (que equivaldría a Filosofía del Derecho en Europa continental). Se insiste en su carácter revelador -como se viene acometiendo-: se trata de un ejercicio de retirada de velos de confusión, de aquellos planteamientos que se han extendido, no permitiéndose así reconocer y operar con la realidad social subyacente (oculta tras dicho velo). El primer paso es partir del cuestionamiento más elemental: ¿Qué significa jurisprudence? ¿Quizá sea un false-friend ${ }^{383}$ ? No cabe una traducción sin más, al menos no tal cual se ha venido realizando. Hasta el s. XIX, como reflejo de la Ilustración (que a su vez, recuperaba el saber de los clásicos de la Antigüedad), por jurisprudencia se entendía la Ciencia del Derecho (el conocimiento propio de los juristas), resultando algo parecido tanto en la familia de Derecho Común como en la de Derecho Civil. No obstante, en Europa continental, tras los procesos de codificación y las modificaciones pertinentes del Derecho, de carácter técnico-profesional y para que considerara un atributo del Estado -y no al revés-, por jurisprudencia comenzó a entenderse las sentencias de los tribunales superiores o últimas instancias. Mientras, en el mundo anglosajón, sigue manteniendo buena parte del significado originario, pues los jueces, no es que generen derecho, sino que le dan vida, al aplicarlo a la realidad social en conflicto, en la que tienen que mediar y dirimir. En los EE.UU., además, los jueces, no sólo insuflan vida a la Ciencia Jurídica, sino que la purgan, acometiendo un control constitución y legislativo difuso, conforme a su pragmatismo (principal y más influyente corriente de pensamiento autóctono, vid. infra). Prueba de su pragmatismo es su habilidad para combinar la teoría y la práctica bajo la rúbrica de jurisprudence, que incluye: a) Historia y Filosofía del Derecho; b) Case Law [Derecho

\footnotetext{
${ }^{383}$ Término equívoco, pues suena parecido, pero significa distinto de una lengua a otra.
} 
de casos o tópica -no sentencias sin más, sino conforme a un sistema de precedentes]. Permítase una aclaración más al respecto: en el Derecho estadounidense el héroe es el juez -no el académico, como si pasa en el Derecho Civil-, quien ha estudiado Juris Doctor [Derecho -sólo que no es un Grado sino un Posgrado-], aprendiendo lo básico en los tres años que dura el programa, para luego ponerlo en práctica antes los tribunales; por el sistema de cooptación -una de las vías más frecuentes para llegar a ser juez, aunque no la única-, si se es un buen abogado, los propios compañeros te promueven para ocupar el cargo, y así se va ascendiendo. Luego, por su pragmatismo, los estadounidenses entienden que el estudiante de Derecho, no está aún listo para filosofar y apreciar el sentido de la justicia -pese a ser mayor que el europeo-continental habitual, que empieza sus estudios a los dieciocho años (sin experiencia alguna, y sin embargo se le exige la selección de una especialización profesional), mientras que el estadounidense suele hacerlo más cerca de los treinta (tras cierta experiencia académica y profesional)-; más bien, se considera que dicha preparación para el sentido de lo jurídico y la justicia se adquiere con la práctica profesional o forense, al intentar dar a cada uno lo suyo y colaborar para que funcione el sistema de justicia. Por ende, la auténtica Historia y Filosofía del Derecho son plasmadas por los jueces, según su bagaje y siempre con apego a la realidad. Es por ello, que para reflexionar y comprender la evolución del Derecho, lo que se suele hacer es acudir a las sentencias de los grandes magistrados, quienes vuelcan en sus resoluciones todo su saber; además, procuran que sus escritos sean amenos e instructivos -citando incluso a los clásicos de la Antigüedad-, pues son conscientes de que no sólo resuelven inter partes, sino erga omnes, alcanzando a los discentes y su aprendizaje mediante el estudio de caso: las sentencias guardan relación con hechos concretos, a los que se aplican fundamentos de derecho y se alcanza una calificación 
ejemplar, por lo que se comprende así el Derecho y la justicia (de manera viva, o sea, real), sin exigirles un alto nivel de abstracción, sino de relación. ¿Se entiende ahora por qué es tan importante el estudio de caso en el aprendizaje del Derecho estadounidense?

Antes de proceder a exponer y explicar el marco general de los estudios de caso -ya referenciados con anterioridad, vid. infra cap. 4 y 7-, se reiteran algunas nociones ya tratadas, conforme a las cuales, queda clara la identificación de los EE.UU. como el país pionero, de la Modernidad (lato sensu) y del Nuevo Régimen, tal como se especifica en uno de sus lemas nacionales ("novus ordo seclorum" [nuevo orden secular], vid. supra cap. 10), aunque ello no quiere decir que se desconozca la tradición occidental, tanto la sagrada (o judeocristiana) como la profana (o grecorromana) -como se acaba de evidenciar en la cita de su lema nacional, pues otros que se adoptaron en el periodo constitucional (de finales del s. XVIII), también se aprobaron en latín-. El caso es que sus padres fundadores, en concreto los Framers [constituyentes -redactores de la Declaración de Independencia hasta la Declaración de Derechos-], conocían bien la cultura grecorromana, y con ella la importancia que se daba al arte de preguntar ${ }^{384}$, mediante técnicas como la epojé (suspensión del juicio) o la mayéutica (cuestionamiento ontológico de manera dialogada). Así entró el método socrático en los estudios universitarios, cuya homogeneización comenzó casi un siglo después, usándose como referente la adaptación autóctona del Decano LANGDELL, cuestión a tratar a continuación.

El citado Socratic method o método socrático, como ya se ha señalado, consistía en la combinación de la epojé o suspensión del juicio -para evitar dar nada por

\footnotetext{
384 Vid. SÁNCHEZ-BAYÓN, A.: "Problemas epistemológicos y fenomenológicos de la Universidad actual"... op. cit. - "Galeato pro universitas humanitatis"... op. cit.
} 
sentado-, y la mayéutica o cuestionamiento del porqué de aquello que se pretende conocer -para ahondar en el análisis, hasta llegar a la razón fundamental-. Pero, ¿cómo llegó el influjo de tal método a las universidades estadounidenses, en especial a sus Escuelas de Leyes -denominación común hasta el s. XIX_385? Fue a finales de la década de 1870 cuando en Europa se produce la implementación de la red de universidades públicas (v.g. España y los antecedentes del Plan Gamazo), y con ellas la normalización -en sentido francés de tipificación- de los estudios, dando lugar a la transformación de las Facultades tradicionales, como las Escuelas de Cánones y Leyes, que pasaban a ser las Facultades de Jurisprudencia, y seguidamente, las Facultades de Derecho, donde concentrar el esfuerzo docente en enseñar el nuevo y flamante Derecho estatal, de corte estatutario codificado. Pues bien, aunque el Derecho estadounidense se corresponde con la familia de Common Law [Derecho Común -tal como se ha venido aludiendo-], en su seno, resulta algo excepcional, pues de todos los derechos integrantes, el estadounidense es el más permeable a las influencias del Civil Law / Continental Law [Derecho Civil o Europeo-continental -ídem-]. Tanto es así que, entre las pujantes universidades de Nueva Inglaterra (vid. cap. 5) -sustento del también mencionado Ivy league (o club de universidades imitadoras del estilo tradicional europeo)-, la Universidad de Harvard comienza a destacar, y en su

\footnotetext{
${ }^{385}$ Desde el s. XI, las escuelas catedralicias se convierten en auténticos studia, llamándose los primeros Escuelas de Cánones y Leyes, como el famoso caso de Bolonia (año 1088, aprox.): cánones por el estudio del Derecho Canónico -auténtico derecho vigente de entonces (de la Cristiandad) y sustento para el desarrollo de todo el derecho público y procesal-, y leyes por el estudio del Derecho Romano -base para la Ciencia Jurídica y sus disciplinas, tales como la Historia del Derecho, el Derecho Natural y de Gentes (más tarde Derecho Internacional), etc.-. El caso es que, como en Europa continental, el sistema de derecho dominante va a ser el Derecho Civil, su gran protagonista va a ser el académico (no el práctico, en concreto el juez, como sí pasa en el Derecho Común Anglosajón), de ahí que se termine prestando más atención, como formación de base a sus disciplinas, y finalmente su denominación para las Facultades resultantes: Facultades de Leyes, que en francés es Loi (para referirse al derecho objetivo, aunque más bien es específicamente el estatutario, dominante desde el s. XIX), y por influencias sobre el inglés, da lugar a Law (fonéticamente parecido).
} 
intento de convertirse en un referente para la homogenización de los estudios de Derecho -téngase en cuenta que por influencia del Derecho inglés, el método es más bien de Inn Courts, o estudio de unos rudimentos y luego aprender todo como pasante de abogados y jueces-, por su parte, el Decano de la Facultad de Derecho, el Prof. LANGDELL, empezó a poner en práctica un método, de inspiración socrática, aunque con aspiración formalista (en comparación con el tipo de estudio exegético y analítico que se venía acometiendo, de obras referenciales como Commentaries [Comentarios] de BLACKSTONE, o Jurisprudence [Jurisprudencia Ciencia Jurídica Analítica-] de AUSTIN). Se trataba de un estudio conforme a tres reglas a seguir: a) read the cases [lectura de casos]; b) distill the rule [destilar la regla]; c) apply the rule to future cases [aplicación de la regla a futuros casos]. Es curioso que dicho método triunfara, no tanto por su propia calidad, sino por la publicidad que generó la competición personal entre dos grandes juristas de su tiempo: LANGDELL V. HOLMES - una rivalidad comparable a la habida un siglo antes entre HAMILTON y JEFFERSON (vid. supra cap. 9)-. Si LANGDELL llegó a Decano de Derecho en Harvard, HOLMES lo procura también, pero sólo logra ser profesor, por lo que opta por la práctica jurídica, llegando a convertirse en Magistrado del Tribunal Supremo. Si LANGDELL promovió el Formalismo jurídico, HOLMES, patrocina la emergencia del Realismo jurídico (habrá que esperar hasta después de la I Guerra Mundial); etc. El caso es que, HOLMES, provocó el efecto contrario al pretendido desde la revista jurídica que editaba (American Law Review) y su famosa obra The Common Law (1881), que fue conceder excesiva relevancia a LANGDELL tanto lo criticó, que fue quien más lo dio a conocer-. De esta historia entre juristas, también arranca la rivalidad entre Facultades de Derecho, como la de Harvard (que continuará durante un tiempo rindiendo pleitesía a LANGDELL) y la de Yale (que 
tomará como referente a HOLMES). El caso es que tal como se enseña a los futuros operadores jurídicos (v.g. abogados, jueces, funcionarios), así se va transformando el Derecho, en su concepción y práctica. Luego, ni que decir tiene la influencia que han tenido estas dos Facultades, que siguen siendo de las más importantes en su país, pues de entre sus estudiantes han surgido un gran número de altos cargos del país (v.g. Presidentes, Magistrados del Supremo, Secretarios de Estado, Senadores, Congresistas), así como importantísimos hombres de negocios (vid. supra cap. 9).

Aunque el Derecho y su estudio han ido cambiando, la impronta de LANGDELL ha permanecido en buena medida, como el primero en ofrecer una versión autóctona del método socrático, siendo el referente para mejorar, cambiar, criticar o proponer alternativas a su método. De ahí, han ido surgiendo otras propuestas y materiales docentes, como el casebook [manual de clase] (un libro de aprendizaje mediante ejemplos de supuestos que ilustran la teoría, que ha sido reducida a sus fundamentos jurídicos y la comparación de casos). La última versión aparecida, con bastante éxito ha sido el Problem method [método de (resolución de) problemas], a resultas de las críticas vertidas contra el método LANGDELL y los casebooks, que se habían vuelto una excusa para que se trivializaran las clases -a modo del famoso juego de mesa Trivial pursuit [búsqueda de lo (conocido) trivial]-, convirtiéndose en concursos donde los alumnos tenían que memorizar las respuestas prefijadas; luego, para revitalizar el estudio del Derecho, se optó por esta vía, donde se enuncia un caso ficticio o real -según el profesor-, con diversas implicaciones jurídicas que los estudiantes han de resolver, normalmente en grupo y simulando un proceso judicial que supervisa el docente.

Por tanto, pese a que el método LANGDELL y los casebooks han servido para positivizar el Derecho estadounidense, sin embargo, también han sido los causantes 
de la tendencia reduccionista a enseñar el Derecho a través del Case Law o sentencias judiciales, cuando existen otras fuentes y ramas del Ordenamiento, tal como se retrata en la siguiente figura.

Figura 52.- Fuentes y ramas del Ordenamiento estadounidense ${ }^{386}$

\begin{tabular}{|l|}
\hline \multicolumn{2}{|c|}{ Fuentes primarias o directas } \\
\hline 1.- Regulación básica y auxiliar \\
\hline 1.1.- Constituciones ("Constitutions”): 1 Constitución de EE.UU., 50 \\
Constituciones/Leyes fundamentales estatales (Alabama, Alaska, Arizona, \\
Arkansas, California, Colorado, Connecticut, Delaware, Florida, Georgia, Hawaii, \\
Idaho, Illinois, Indiana, Iowa, Kansas, Kentucky, Louisiana, Maine, Maryland, \\
Massachusetts, Michigan, Minnesota, Mississippi, Missouri, Montana, Nebraska, \\
Nevada, New Hampshire, New Jersey, New Mexico, New York, North Carolina, \\
North Dakota, Ohio, Oklahoma, Oregon, Pennsylvania, Rhode Island, South \\
Carolina, South Dakota, Tennessee, Texas, Utah, Vermont, Virginia, Washington, \\
West Virginia, Wisconsin, Wyoming) ${ }^{387}$ \\
\hline 1.2.- Jurisprudencia/Resoluciones (“Cases”, “Reports”): a) Tribunales federales \\
(circuito judicial: corte de distrito, corte de apelación, corte suprema), b) Tribunales \\
estatales (circuito judicial: depende de cada Estado, pero similar al federal. Para \\
ciertas materias, como derechos y libertades, el último órgano es el Tribunal \\
Supremo de EE.UU.). ${ }^{*}$ ) Por esta vía se introduce la costumbre y los principios
\end{tabular}

386 Vid. FINE, T.: American Legal Systems: A resource and reference guide, Cincinnati: Anderson Publishing Co, 1997. HODES, W.: Legal research: A self-teaching guide, to the Law library, Minneapolis: The National Institute for Trial Advocacy, 1998. KELSO, J.C.: Studying Law: An introduction to legal research, New York: Matthew Bender, 1990. KLEIN, D.: Legal research materials, Dubuque: Hunt Publishing Co., 1989. KUKLIN, B., STEMPEL, J.W.: Foundations of the Law. An Interdisciplinary and Jurisprudential Primer, St. Paul: West Publishing Co., 1994. OLSON, K.: Legal information. How to find it, how to use it, Phoenix: Oryx Press, 1999. VV.AA.: Legal research illustrated. An abridgment of fundamentals of legal research, New York: Foundation Press, 1998. VV.AA.: Practical approaches to Legal research, New York: The Haworth Press, 1988. VV.AA.: Searching the Law, Arlsley: Transnational Publishers, 1999. VV.AA.: Winning research skills, New York: West Group, 1999. WREN, C.G., WREN, J.R.: The Legal research manual. A game plan for Legal research and Analysis, Rice Lake: Adams \& Ambrose Publising, 1986. Complement., vid. SÁNCHEZ-BAYÓN, A.: “U.S. Religious Liberty: One (secular) Nation under God. Paradox nature and explanatory hypothesis", tesina inédita de DEA (investigación realizada en Harvard University, 2002-03, y aprobada por la UCM, 2003). VV.AA.: The Bluebook. A Uniform System of Citation, The Columbia Law Review Association, The Harvard Law Review Association, The University of Pennsylvania Law Review, The Yale Law Journal, Cambridge, 2000 .

${ }^{387}$ Además de tener en cuenta el Estado libre asociado (Puerto Rico) y catorce jurisdicciones especiales (v.g. Virgin Islands) -sólo cinco de ellas tienen representantes en el Congreso-. 


\begin{abstract}
generales, más la normativa internacional, la religiosa y la sociológica -de ahí la importancia de interpretar, pero los recelos frente a la construcción (v.g. activismo judicial).

2.- Regulación de desarrollo

2.1.- Legislación/Estatutos ("Statutes": "Public Law", "Private Law", "Act", "Bill", "Amendment"): a) Leyes federales (aprobadas por el Congreso de EEUU), b) Leyes estatales (aprobadas por el Poder Legislativo de cada Estado: similar). Vienen recogidas en Códigos oficiales (anotados o no) y no oficiales (elaborados por asociaciones de abogados, "BAR's")
\end{abstract}

2.2.- Reglamentos/Mandatos (“Orders", “Rules", "Proclamations", “Regulations"):

a) Normativa federal (procedente del Presidente de EEUU y de agencias federales),

b) Normativa estatal (procedente del Gobernador del Estado y de agencias estatales),

c) Normativa local (Condados, Ayuntamientos).

Fuentes secundarias o indirectas

3.- Doctrina: manuales ("Handbooks" / "Manuals"), tratados ("Treatises")388, monografías ("Restatement"): elaborados por juristas, con el patrocinio de asociaciones de abogados, revistas jurídicas ("Law Reviews": editadas por las Facultades de Derecho de cada universidad, v.g. "Harvard Law Review"), enciclopedias legales (“Legal Encyclopedias”), informes de Derecho estadounidense ("American Law Reports").

4.- Otras menos frecuentes: "Comercial Looseleaf Services", "Practice guides", "Form books", "Memorandum opinion", "Amicus curia”, et al.

Fuente: elaboración propia (SÁNCHEZ-BAYÓN, 2007 y 16).

${ }^{388} \mathrm{El}$ sentido aludido de tratado, es el de obra recopilatoria científico-académica de las cuestiones más relevantes de la disciplina (por esa razón no es una enciclopedia, ni una monografía). Por tanto, no debe confundirse -ni en español ni en inglés- con tratado o acuerdo internacional ("Treaty" o "International Agreement"). Dicho tipo de texto jurídico no ha sido citado (a propósito) entre las fuentes, ni primarias ni secundarias, debido a su compleja situación dentro del Sistema formativo de los EE.UU. En principio, y según el art. VI, secc. 2 de la Constitución de EE.UU., los tratados internacionales son fuente primaria (vid. cap. 10), aunque considerada como auxiliar por el poder judicial -que puede decidir en cada caso el valor aplicable, como se desprende de las prácticas de SCALIA (contrario a su uso) y de KENNEDY (favorable al respecto); vid. cap. 4 de SÁNCHEZBAYÓN, A.: Estado y religión de acuerdo con los EE.UU... op. cit. 
Sociología de las Relaciones Socioculturales Nortatlánticas (...) American civil religion - A. Sánchez-Bayón 


\section{8.- DIMENSIÓN SISTÉMICA:}

\section{ESTUDIO CIENTÍFICO-ACADÉMICO Y DESARROLLO UNIVERSITARIO ${ }^{389}$}

Si para un no-estadounidense, la misma idea de ACR (sin siquiera entrar en su rica y compleja tópica) puede parecer una curiosa contradicción (al no haberse socializado conforme al Americaness habilitador), para un europeo-continental (quien lleva tiempo en la posmodernidad), el estudio científico-académico de la religión, posiblemente, resulte un oxímeron difícil de asumir: ¿cómo es posible tal cosa? Como ya se ha mencionado con anterioridad, la religión, es un tipo de conocimiento (con sus conceptos, teorías y formas), como lo puede ser de igual modo la ciencia o la filosofía. Actualmente se encuentran separados estos conocimientos, pero conectados por disciplinas duales (v.g. Derecho Eclesiástico, Filosofía Jurídica, Política y Moral, Teología política). También se trata de una vigorosa esfera social, con sus normas e instituciones, como pasa con la política y el derecho (con las que igualmente, pese a su distinción, comparte nexos, v.g. Ordenamientos confesionales, libertad religiosa, asistencias socio-religiosa). Incluso, cabe entenderla como un factor de transformación y/o estancamiento social, mediante movimientos y campañas, afectando al devenir de comunidades. Tal es la complejidad que subyace bajo ese iceberg al que se llama comúnmente religión, que en los EE.UU., como prototípico país moderno y autoproclamado adalid de Occidente (vid. infra), la cuestión se ha estudiado desde sus orígenes en sus universidades (al cultivarse todo conocimiento relevante, para una mejor percepción y gestión de las esferas sociales), recurriendo a diversos enfoques y disciplinas: desde los estudios de carácter

\footnotetext{
389 Vid. infra nota 382, especialmente, Universidad, ciencia y religión... op. cit.
} 
tradicional nativista, como Church-State Studies [CCS: Estudios Iglesia-Estado] -dado el prototípico modelo relacional estadounidense, vid. infra cap. 5 y 6- o American Studies [AS: Estudios Americanistas /Estadounidenses] -igualmente, una suerte de pionera filología anglo-americana-, hasta los más recientes, aperturistas y trasversales, como los (Cross)Cultural Studies [CCS: Estudios Interculturales], sin olvidar los técnico-profesionales, como First Amendment Studies [FAS: Estudios de Primera Enmienda], o Religion \& [Religión y (Derecho / Economía / Política / Relaciones Internacionales, etc.)]. Existen otros sobrevenidos -tal como se vienen previniendo-, como los Estudios culturales etnoculturales (v.g. afroamericanos, asiáticoamericanos, feministas y de genero). Lograron su impulso a raíz de la Ethnic Heritage Studies Program Act of 1972 (ley de programas de estudios culturales étnicos). Son los responsables de lecturas alternativas a la oficialmente establecida, que en lo tocante a la religión, en vez de tratarla como factor trasversal de convergencia, se ha usado la misma como elemento distintivo y de conflicto. Dada su multiplicidad particularista y contradictoria entre sí (unos Estudios chocan con otros), así como su falta de fundamentación rigurosa, ya que sus nociones proceden de hibridaciones (de corte neo y posmarxista en su mayoría) entre humanidades (sobre todo, de fuentes privadas y de ficción, como las literarias) y Ciencias Sociales (v.g. Economía, Política, Antropología, Sociología), en consecuencia, se ha dejado fuera de esta investigación -además de la imposibilidad material de su tratamiento, está la problemática deconstructiva, pues justo de estos Estudios Culturales sobrevenidos han aflorado y se han extendido buena parte de los velos de confusión que aquí se están desarticulando (vid. infra figura 3 y 4).

Volviendo a los Estudios culturales tradicionales, fruto de la especialización del conocimiento y el intento de conexión vía consenso, todos ellos han contribuido a 
expandir (ampliando y profundizando) los planteamientos sobre el estudio científico de la religión y su papel socio-cultural en las universidades estadounidenses. No obstante, su devenir no ha sido pacífico ni exento de conflictos: ¿Cómo se puede estudiar sendos conocimientos sin confundirlos? ¿Cómo es posible que pueda estudiarse la religión en centros públicos si existe una doctrina de "muro de separación" de Iglesia-Estado? etc. La dificultad y sus retos, se volvieron confusión tras la guerras culturales (iniciadas en la década de 1960, hasta la década de 1990, con el inicio de la globalización), afectándose a la esencia misma del objeto de conocimiento: cómo estudiar la religión, de manera racional (rigurosa y plausible), que no patética (en cuanto relativa a los sentimientos), cuando los Estudios culturales sobrevenidos (etnoculturales) han hecho gala de recursos híbridos, para extender falacias contra la religión, además de procurar su ocultación por medio de velos de confusión posmodernos (vid. infra cap. 1).

A continuación se ofrece una visión panorámica de evolución y evaluación acerca de la producción científico-académica estadounidense sobre el factor religioso y su influjo idiosincrásico, para proceder luego con la incursión en los Estudios culturales sobrevenidos y sus velos de confusión posmodernos.

¿Cuál ha sido el papel de la religión en la universidad estadounidense? Sin dificultad -visto lo planteado hasta ahora-, cabe observarse en el devenir estadounidense la presencia constante de la inquietud religiosa, desde su periodo fundacional, y reformulándose periódicamente a través de despertares y revitalizaciones (vid. supra cap. 10). Así se entiende que los primeros centros educativos fueran confesionales, máxime los de Nueva Inglaterra, desde donde se irradian los líderes religiosos que han de guiar en la expansión de la frontera (frontier factor), permitiendo el crecimiento del país. Sin embargo, debido a la marcha de los 
acontecimientos (v.g. Guerra civil, bancarrotas, migraciones masivas) y para asegurar la socialización homogeneizada, la educación pasa a ser un objetivo principal de la construcción nacional -no es algo distinto al resto de países de Occidente, pues lo mismo sucede en la decimonónica Europa continental-390. El caso es que, para asegurar la libertad e igualdad religiosa en los centros públicos, se fijan como parámetros los siguientes: no cabe apoyo directo a presencia religiosa específica alguna, máxime si su labor es de corte proselitista y catequético. Luego, para que la religión sea admitida en los centros públicos ha de ser introducida a instancia de parte (de los particulares) y con fines asistenciales (no proselitistas) ${ }^{391}$. Y para que su estudio sea oficial ha de responder a criterios científico-académicos, normalmente, del tipo humanista y científico-social -pues es en dichas Facultades donde han solido desenvolverse las disciplinas homónimas, que se abordan seguidamente: Church-State Studies [CCS: estudios Iglesia-Estado], Cultural Studies [CCSS: estudios culturales], Religion $\mathcal{E}$ (Law/Policy) [religión y (derecho/política)], etc.-.

Antes de proceder a conocer cuáles han sido las principales escuelas y tendencias en el estudio del factor religioso en los centros de educación superior estadounidenses, se ofrece un croquis del desarrollo de la cuestión en las universidades públicas y privadas (prestándose atención a las propias categorías de

\footnotetext{
390 Vid. SÁNCHEZ-BAYÓN, A.: Estudios de cultura político-jurídica... op. cit.

${ }^{391}$ Sí se admiten asociaciones estudiantiles de corte confesional (v.g. los clubes Newman de los católicos, las sociedades Menorah de los judios, la red YMCA de los protestantes), con espacios para sus reuniones y cierta financiación a cargo de la universidad, siempre y cuando su principal objetivo no sea el proselitismo, sino el apoyo en servicios comunitarios (v.g. campañas de beneficencia, difusión cultural, apoyo psicológico y ético) -incluso ha habido periodos en los que se les ha exigido a estos grupos la obligatoria aceptación de cualquier candidato que lo desee, aunque no sea practicante de su religión, resultando discriminatorio con respecto a las fraternities y soronities (de religiosidad grecorromana y masónica, vid. SÁNCHEZ-BAYÓN, A.: La Modernidad sin prejuicios (vol. 1)... op. cit.)-.
} 
las que se han dotado para su catalogación distintiva).

De las universidades originarias del Ivy League ${ }^{392}$, en su mayoría procedentes de colegios confesionales y seminarios teológicos (v.g. William and Mary como referente de los anglicanos, Princeton y los presbiterianos, Yale y Dartmouth con respecto a los congregacionalistas, Harvard y los unitarianistas, la actual Brown y los bautistas; King's College -hoy Columbia- a anglicanos -y luego también a episcopalianos y presbiterianos-, Philadelphia School -más tarde Universidad de Pensilvania- y los cuáqueros, Rutgers y holandeses reformados) ${ }^{393}$. Se van nutriendo así las universidades estatales, no sólo en su faculty o claustro, sino también en los planteamientos académicos, en cuanto a competitividad y excelencia -de ahí que universidades tardías y públicas, como la Universidad de California, sin embargo gocen de tanto respeto, equiparándose con las primeras del citado Ivy League-. Para reconocer una universidad pública, suele bastar con buscar en su denominación una referencia expresa a la ciudad o Estado (v.g. University of California, campus de Davis o Berkeley) en la que se halle, así como una posible mención de "State University" (v.g. Midwestern State University). Otra opción para el discernimiento es observar cómo trata el factor religioso en su ideario, pues mientras el resto de universidades privadas no han de hacer declaración expresa, en cambio las públicas sí -siguiendo,

\footnotetext{
392 De las más de tres mil quinientas instituciones de educación superior estadounidenses, se distinguen del resto un reducido grupo de universidades constitutivas de la Ivy League o Liga de hiedra. Se trata de una metáfora muy plástica, pues la exclusividad de dicho club se basa en: a) la reivindicación de la solera de sus universidades - pretendidas herederas de las más venerables europeas, donde hay hiedra en sus muros-; b) la calidad de su educación y la selección intensiva de sus alumnos y profesores -que como la hiedra, se entremezcla para ser más fuerte y elevarse-; c) la referencia social, tanto por ser parte de su comunidad como por acogerla, pues todo ello proporciona respetabilidad y posibilidad de promoción social -como la hiedra, proporciona solera y distinción a la edificación-, etc. La mayor parte de estas universidades se fundaron como centros educativos confesionales para asegurar el relevo generacional de profesiones liberales, especialmente los ministros de culto.

${ }^{393}$ Vid. SÁNCHEZ-BAYÓN, A.: La Modernidad sin prejuicios (vol. 1 y 3)... op. cit.
} 
además, la regla citada en el punto previo, sobre "instancia de parte" (solicitado por integrantes de la comunidad universitaria y no por iniciativa de la propia institución), "objetivos asistenciales" (sin fin inmediato religioso, sino de voluntariado y beneficencia) y "estudio humanista y científico-social" (como conocimiento aséptico y no adoctrinador)-.

Los primeros planes para incorporar los estudios religiosos en las universidades públicas fueron las propuestas de South Carolina [Carolina del Sur] (tras la Guerra Civil), aunque la mayor parte de los primeros Departamentos propios comenzaron a funcionar en la década de 1920, con el apoyo del National Council on Religion in Higher Education [Consejo Nacional sobre Religión en Educación Superior]. A continuación se rinde cuenta de los casos pioneros.

Todo empezó - como ya se ha adelantado- con los proyectos habidos para la Universidad de Carolina del Sur. Con motivo de la reconstrucción tras la Guerra Civil, se decidió apostar por la universidad pública, por lo que se solicitó al parlamento estatal, en la legislatura de 1864-65, una dotación presupuestaria para la constitución de un Departamento de Religión. La cuestión quedó pospuesta para mejor momento, pues se consideró que otros proyectos resultaban prioritarios en la reconstrucción. En 1873 se considera oportuno retomar la cuestión, apuntándose esta vez más bajo y solicitando por ello presupuesto para una cátedra ("Professor of Sacred Literature and Evidences of Christianity"). Hay que esperar a 1878, cuando la State University of Iowa comienza a contratar personal formado en la costa Este (académicos acostumbrados al estudio de la religión desde las humanidades). Tal ambiente favorece que para el curso de 1924-25, comience su andadura la Facultad de Religión (montada con la asesoría de diversas organizaciones religiosas, como YMCA, así como el Council of the Church Board of Education). Para lograr la financiación pública 
se decide abrir el proyecto a católicos y judíos, de modo que se logra una ayuda inicial de más de 30.000 dólares de entonces. En menos de una década se logra no sólo la autofinanciación, sino la rentabilidad, pues la media es de 400 nuevos estudiantes por curso. La senda abierta por las Universidades de Carolina del Sur e Iowa, es seguida por la Universidad de Míchigan (1923), la de Hawaii (1930), la de Oregón (que es la primera en enseñar Ciencias de la Religión más allá de las Humanidades, apostando fuerte por los diversos enfoques de las Ciencias Sociales). También nacen en la década de 1930 los Departamentos y Facultades de Religión de las Universidades de Carolina del Norte y las de Florida (Florida University, Florida State College for Women, Miami University). Tras la II Guerra Mundial arrancaran muchas iniciativas en la costa del Pacífico y el Sur.

En cuanto a las universidades privadas, la media y la moda apuntan a las confesionales cristianas, en su mayoría las agrupadas en TRACS ${ }^{394}$ (es la asociación de las mismas, que cuenta con la aprobación de sus estudios por la Secretaría de Estado de Educación). Igualmente, también se recuerda ahora que la eclosión de las universidades cristianas tiene lugar con el cuarto despertar: a las universidades confesionales tradicionales -aunque bastante aperturistas-, asimiladas al Ivy League (por antigüedad y excelencia, como las católicas jesuitas o de la orden de Paul, así como las evangélicas bautistas y metodistas, por ejemplo), se les unen otras de nuevo cuño y bastante polémicas (por su proselitismo y su tendencia a irradiar el factor

\footnotetext{
394 TRACS son las siglas de Transnational Association of Christian Colleges and Schools [Asociación transnacional de Universidades y Facultades Cristianas]. Se trata de una organización sin ánimo de lucro, constituida en 1979 y, desde 1991, con reconocimiento oficial por el U.S. Department of Education [Ministerio de Educación estadounidense], permitiéndosele la concesión de acreditaciones de estudios superiores homologados -donde se enseña con un discurso científico las doctrinas tradicionales-. Entre los centros integrados destacan los mencionados, pero existe una gran lista de aspirantes (URL: http://tracs.org/).
} 
religiosos sobre cualquier área científico-académica), como son los casos de las pioneras (en la década de 1960, aprox. -algunas son fundadas poco antes, pero no eclosionan hasta entonces-) de Wheaton College, Bob Jones University, Oral Roberts University, Liberty University, etc. Justo por tal razón, las universidades privadas comienzan a manejar categorías clasificatorias que permitan una diferenciación entre sí. Entre las más populares destacan las siguientes ${ }^{395}$ :

a) Clasificación de HAYNES (basada en la DE PACE, 1972): 1) defenders of the faith colleges (centros de raíces religiosas pero sin implicaciones jurídicas en su constitución y gestión, v.g. universidades de main-line churches), 2) non-affirming colleges (centros con denominación pero que se ha secularizado, v.g. los católicos), 3) free-Christian college (centros vinculados con una confesión pero abiertas a otras, v.g. los evangélicos), 4) Church-related university (nuevas universidades evangélicas como las ya citadas).

b) Clasificación de CUNINGGIM (1978): Consenant College (centros simpatizantes), Proclaming College (centros con denominación), Emboding College (centros integrados).

c) Clasificación de HULL (1992): Administrative control (centros bajo control administrativo-religioso), Academics components (centros con elementos religiosoacadémicos), campus ethos (centros con reglas confesionales).

\footnotetext{
395 Vid. HAYNES, S.R. (ed.): Professing in the Postmodern Academy: Faculty and the Future of ChurchRelated Colleges, Waco: Baylor University Press, 2002. Complement., vid. publicaciones periódicas como Faculty Christian Fellowship (en la década de 1950), Christian Scholar y Faculty Forum (en los 60) -los números de entonces se centran en la cuestión del establecimiento de clasificaciones diferenciales y los rankings o listados de preferencia-.
} 
Amén de lo ya apuntado con anterioridad, se especifica e insiste aquí en que, como corresponde al conocimiento científico (en contraste con otros: diacrónicamente, la sabiduría o la mística; sincrónicamente, el conocimiento religioso o el cultural), tal conocimiento ha de ser autónomo y sistémico, para poder ampliar y profundizar, conforme a una metodología propia. En consecuencia, lo que se pretende en este capítulo es cursar una Historia estadounidense de las relaciones científico-académicas con la religión y su impacto idiosincrásico, para propiciar un sistema de armonización, donde tengan cabida planteamientos aparentemente dialécticos, tratándose de manera copulativa y sintética: a) un sistema empírico y de periodificación (de tipo fáctico y tradicional, más inductivo y descriptivo fenomenológico-, con una exposición y explicación de atrás a adelante -buscando ordenación de sucesos-, con un mayor protagonismo de las bases -bien como fuentes originarias o ratificando luego-), compatible con un sistema lógico y de cronología (construido y técnico-profesional, más deductivo y prescriptivo -dogmático-, articulado de adelante a atrás -buscando coherencia-, impulsado por las elites para las bases y con el auspicio del Estado-nación); b) un sistema que comprehende fuentes (ad intra, tanto las originarias y de creación, como las derivadas y de interpretación o conocimiento, etc.) a la vez que instituciones (ad extra, públicas y privadas, simples y complejas, autónomas e interdependientes, etc.). Incluso, por observación de tendencias dominantes en la historiografía reciente estadounidense, se incluyen ciertos reflejos de story-telling o narración-motivacional, de carácter posmoderno -en especial, al destacar las relaciones interpersonales entre académicos y su legado en las disciplinas-. 
También se recuerdan y retoman ideas expuestas con anterioridad, relativas a la Historia de los EE.UU., o mejor dicho, la Historia de los estadounidenses (como prefieren llamarla ellos), que pese a ser considerada una historia breve, de un pueblo joven, sin embargo, se trata de un caso prototípico -que no excepcional (como algunos autores han pretendido narrar), de tránsito a la Modernidad, al nuevo régimen, con una sociedad plural y móvil, vid. infra cap. 5 y 6-. Luego, los estadounidenses quizá dispongan de una Historia moderna y contemporánea más rica que otros pueblos occidentales, con más experiencias sobre la convivencia de multitudes, la gestión de olas migratorias, la cultura democrática, etc., y cómo no, del recurso de la religión (de manera secularizada o separada, que no laicista o independiente). Incluso, a la hora de abordar el estudio histórico, los estadounidenses parecen mostrar una mayor sensibilidad a otros factores sociales, como hilos reveladores, conectores y narrativos, más allá del canon de la crónica oficial -dando la impresión de una preferencia por el kairós o tiempo preciso o providencial-. Por tal razón, desde esta investigación se ha incidido en un factor socio-cultural clave, al que quizá no se haya prestado la suficiente atención, pero que con la globalización se ha revalorizado (aumentando su importancia e implicaciones), como pasa con el factor religioso. Téngase en cuenta que la religión ${ }^{396}$, no sólo articula las relaciones entre el poder y lo sagrado, sino que además constituye una de las grandes esferas sociales (al igual que la política, el derecho, la economía, etc.), donde se resuelve la cuestión de la salvación y trascendencia. Pon tanto, la religión también comprende cuestiones de

\footnotetext{
396 Por religión se entiende (tal como se aclarara en la Parte de desarrollo general, y con mayor detalle en la bibliografía de la siguiente nota), toda relación estrecha y reiterada (re-ligar) con aquello que obliga a salir de uno mismo (a trascender), pudiendo ser la divinidad, la tradición, la comunidad, el legado, etc. Cierto es que en este estudio, para acotar dicha noción difusa, se centra la atención en la tradición judeocristiana, que es de las pocas que permite un conocimiento científico de la cuestión (su Teología).
} 
conectividad como la identidad, solidaridad, mentalidad, imaginario, capital simbólico, códigos comunicativos y psicosociales, mitopoiesis, et al. En definitiva, impacta severamente en la conciencia social y su idiosincrasia. En consecuencia, según opere el factor religioso, el mismo puede servir de cemento o disolvente social (tal como viene estudiando, sobre todo, la Sociología de la religión). También juega un papel crucial -como se viene señalando- como motor social, al acelerar, ralentizar o frenar la acción social, sus cambios y crisis ${ }^{397}$. En consecuencia, siendo un factor tan valioso para descubrir el devenir social y cultural, actualmente, con la globalización, parece que lo es aún más: las tecnologías de la información y la comunicación (TIC) han puesto en contacto en tiempo real gentes y culturas de todo el planeta, por lo que el factor religioso ha recobrado gran relevancia, al tener un papel crucial en el juego de las identidades y solidaridades, además de permitir el comprender cómo se articulan la normas, fuentes e instituciones sociales, cuando parece que se difuminan las fijadas por el Estado-nación, al empezar a diluirse el mismo en la rica y compleja sociedad internacional de la globalización. Dado lo valioso del factor religioso y la revitalización del mismo que ha traído consigo la globalización (para el juego social), se entenderá entonces que este estudio preste atención a la religión y su estudio científico-académico, eso sí, no tanto para el diagnóstico y pronóstico actual -salvo en lo tocante a hacer inteligible cómo se ha llegado al presente desde el pasado-398,

\footnotetext{
397 Vid. SÁNCHEZ-BAYÓN, A.: La Modernidad sin prejuicios (3 vols.)... op. cit. - Estado y religión de acuerdo con los EE.UU... op. cit. - "Historia de la Comunicación Social Estadounidense a través de sus Movimientos Religiosos"... op. cit. - "Revitalizaciones religiosas postmodernas en América y sus riesgos para la democracia y los derechos humanos"... op. cit. - “Comunicación y Geopolítica estadounidense actual: de IRFA al Choque de Civilizaciones". Complem. vid. Fuentes de consulta.

${ }^{398}$ Desde la década de 1990, con el fin de la Guerra fría y la eclosión de la globalización, parece ser que se ha abierto un nuevo ciclo histórico, con una serie de cambios socioculturales importantes. Algunos de los calificativos más famosos al respecto han sido: sociedad de riesgo (BECK o LUHMANN), líquida (BAUMAN), frágil (TALEB), corrosiva y flexible (SENNETT), digital y en red (CASTELLS o MATTELART), difusa (KOSKO), glocal y de interconexión (SÁNCHEZ-BAYÓN), entrelazada
} 
sino para llevar a cabo una evaluación de evolución, que permita (re)descubrir los hitos, conexiones y narraciones del devenir que ha traído hasta el momento actual, y todo ello gracias a que en los EE.UU. se ha venido realizando de manera científicoacadémica, y por ende, con rigor y autoridad (de manera legítima, válida y eficaz).

Como último apunte, sobre la clasificación de las principales disciplinas a tratar seguidamente, cabe distinguir:

a) Según criterios cronológicos: en términos generales, de un lado están las disciplinas tradicionales (de US/American History a US/American Studies), y de otro lado las sobrevenidas (Religion \& y (Cross)Cultural Studies). Ahora bien, algunas de ellas se han reformulado (v.g. American Studies), además de aparecer en otras Facultades de manera dispar (de la genérica y tradicional Facultad de Artes a la especializada y reciente de Comunicación).

b) Según contenidos: aunque el eje común es la religión, sin embargo, el enfoque modula y mucho lo que se estudia y cómo se hace. De ahí que, aun siendo la misma disciplina (v.g. Church State Studies), varía sensiblemente su calificación como tradicional, si se imparte en una Facultad de Derecho, a si se enseña en la Facultad de Artes o de Teología/Ciencias de las Religiones (Divinity School);

(CHEW o CAPRA), holográfica (WILBER), de retos (MANZANERO), etc. (vid. cap. 1 y 2). Los citados calificativos desvelan que se está viviendo en una época de significativas, múltiples, veloces y cada vez más frecuentes y presentes transformaciones socioculturales, donde la constante paradójicamente- es el cambio: se desdibujan las tradicionales estructuras, sin terminar de cristalizar las nuevas reglas e instituciones socioculturales. Igualmente pasa con las dinámicas sociales heredadas y sus narrativas expositivas y explicativas. Todo ello es consecuencia de la crisis y tránsito entre épocas: de una caduca y dominada por los Estados-nación y sus planteamientos oficialistas y proteccionistas, a otra emergente y aperturista con las interacciones socioculturales, conducente a una aldea-global (conforme al espíritu de San Francisco, de la Carta de la ONU de 1945, revitalizado con la globalización). 
pasando a considerarse sobrevenida si se imparte en alguna otra Facultad nueva. Además, los contenidos pueden variar y mucho debido a la libertad de cátedra, eso sí, habiendo de respetarse unos mínimos tasados y supervisados por la Administración (desde la Secretaría de Estado de Educación a la Junta de Educación Local).

c) Según centro donde se imparte: como se viene indicando, la Facultad en la que se oferta la disciplina, puede modificar su calificación de tradicional a sobrevenida, pero más aún puede alterar tal clasificación si la universidad es pública o privada, aconfesional o religiosa, etc.

En definitiva, la distinción entre disciplinas tradicionales y sobrevenidas no es algo que preocupe tanto a los académicos estadounidenses, quienes se mueven con mayor libertad científico-académica al respecto (vid. cap. 3). Más bien, la distinción es útil para esta tesis, puesto que permite distinguir entre: a) unos Estudios culturales tradicionales, de origen finisecular y novecentista, de carácter interdisciplinario, conectándose los estudios de cada Facultad con planteamientos filológicos, sociológicos y antropológicos; son los encargados de fundamentar el Americaness o estadounidización (v.g. American Studies, CCS); b) otros Estudios culturales sobrevenidos, de mediados del s. XX, impulsados por la fuga de cerebros, $\mathrm{y}$ con un sesgo neomarxista, hibridándose Ciencias Sociales con Humanidades; esencialmente, se basan en la crítica cultural, para lograr el reconocimiento de la singularidad e intereses que defienden, además de extender buena parte de los velos de confusión actuales (vid. infra cap. 1). 


\section{1.- COMPLEJIDAD SOCIO-CULTURAL Y DE PLANTEAMIENTOS:}

\section{MATERIAS INTERDISCIPLINARIAS Y EL HILO CONECTOR RELIGIOSO}

El cultivo específico de la religión, desde una perspectiva historiográfica académica -o sea, de manuales y monografías propias, más artículos de investigación periódicos- no empieza a cuajar y consolidarse hasta finales del s. XIX, pues es entonces cuando se inicia la modernización de la universidad (con sus nuevos Departamentos y planes de estudio), con una incipiente red de centros públicos, así como una supervisión administrativa de los títulos para reconocer su valía -además de asegurarse así que los graduados tengan conocimiento de la producción nacional en sus respectivos campos, v.g. que los futuros abogados sepan sobre todo de Derecho estadounidense-. Los primeros cultivadores son académicos de gran bagaje cultural, que procuran conciliar la tradición de Ecclesiastical Law de las main-line churches, las perdurables Blue Laws y Church-State Law de las evangelicalchurches, y el Cannon Law de la Iglesia católica -con el esfuerzo añadido de integrarlo todo como parte del estudio propio de los EE.UU.-. Es así como nace y se extiende la interdisciplinaria área de conocimiento, que estudia la emergencia de la libertad religiosa, las relaciones Iglesia-Estado y el impacto social de la religión, por lo que se encuentra presente (según las universidades) en las Facultades de Derecho, Teología o Artes/Humanidades, ya que en su seno se combinan los estudios de Derecho y Religión, junto con la Historia, la Política, la Economía, la Sociología, la Comunicación, etc. Su denominación resulta variable -pues influye bastante en la misma la construcción doctrinal al respecto-, aunque hasta la I Guerra Mundial suele coincidir bajo el peculiar nombre de American (Civil) Church Law [ACCL: Derecho eclesiástico estadounidense]. En tal sentido así fue cultivada desde la Costa Este por 
Profesores como COBB, FISKE, MOORE, PERRY, THOM, SCHAFF y ZOLLMANN, hasta llegar al Medio Oeste, con el grupo de docentes formado por CALHOUN, HALL, MATHEWS y MEYER. Ya las posteriores generaciones (del periodo de entreguerras y siguientes), tienden a posicionarse, eligiendo prioritariamente alguna de las corrientes que se exponen a continuación: a) línea tradicional formal, de antagonismo entre First Amendment Studies [FAS: estudios sobre la Primera Enmienda] y Church-State Studies [CSS: estudios sobre las relaciones Iglesia-Estado] cuyo cese tiene lugar con el auge de la línea de trabajo Religion $\mathcal{E}$ [religión y (derecho, política, economía, etc.)], dando paso al predominio de los Cultural Studies [estudios culturales]; b) línea moderna informal, con expresiones como Latin American Studies [LAS: estudios latinoamericanos], Cross-Cultural Studies [CCS: estudios interculturales], y Communication Studies [estudios de comunicación] -que prestan mayor atención a la cuestión comunicativa y psicosocial de la religión en la vida pública, sólo que con fuertes cargas cientificistas-.

Conforme a una inferencia asumida y predicada en casi todos los estudios actuales sobre la materia ${ }^{399}$, suele aceptarse sin discusión la explicación reduccionista e incorrecta de que, con el intento formalizador / normalizador de los estudios universitarios a finales del s. XIX, el cultivo de la interdisciplinaria área de conocimiento ACCL, se canaliza a través de dos vías consideradas antagónicas: de un lado, la vía constitucionalista, que alcanza su mayor desarrollo con los FAS, y de otro lado, la vía sociologicista, cuyo buque insignia son los CSS. Se procede a

\footnotetext{
399 Seguramente, debido a la combinación del pragmatismo estadounidense con la tendencia generalizada en todo Occidente a la desaparición en el ámbito universitario de la atención a la propedéutica de cada disciplina -dejándose de estudiar por ello lo relativo al concepto, objeto, método, fuentes (incluida la historiografía)-, para proceder casi de inmediato al estudio del Ordenamiento -sin tener que pasar por las nociones introductorias y de fundamento de la Ciencia correspondiente-.
} 
continuación a corregir las incorrecciones de tal presunción.

La citada inferencia responde a la dicotomía que se produce en los estudios de ACCL desde los años 40, debido al éxito de la doctrina del separatismo, fruto de la importación de corrientes laicistas europeas ${ }^{400}$, combinadas con planteamientos radicales propios (v.g. Know-nothing, Ku-Klux-Klan). Se impone entonces una tendencia polarizante: aquellos más propensos a la corriente de separatismo abogarán por el cultivo del constitucionalismo vía los FAS, mientras que los demás seguirán con la vía interdisciplinaria de los CSS. Luego, no se trata de una división de planteamientos por la que la línea constitucional se reserva a las Facultades de Derecho, y la sociológica a las demás, pues en cualquier curso de CSS -que por cierto, también se imparte en las Facultades de Derecho-, en su temario se estudia la regulación constitucional, incluidos los casos más sobresalientes. Y es que, cuando se pretende distinguir entre constitucionalismo y sociologismo, en realidad, se está aludiendo a la dialéctica académica de normativismo y empirismo -o si se prefiere, de estudios analíticos del deber ser, y aquellos observacionales sobre el ser-. Con suficiente perspectiva histórica se observa que las universidades más favorables a seguir la mal llamada vía del constitucionalismo -que en realidad es un intento discursivo de identificar el separatismo con la Constitución-, han sido aquellas con mayor permeabilidad a las tendencias europeas, o sea, las de la Costa Este (por proximidad geográfica) y las católicas (por ubicación de la Sede Papal -recuérdese además el problema de entonces del influjo de las ideologías nacionalistas y socialistas que pretendiera resolver poco después el Concilio Vaticano II-). Más tarde,

\footnotetext{
400 Dichas corrientes laicistas europeas habían calado en sus elites, vía fascismo y/o socialismo, incorporándolas luego a los EE.UU., como resultado de la llamada fuga de cerebros (vid. cap. 4), v.g. la recepción en universidades estadounidenses de la neomarxista Escuela de Frankfurt; vid. supra Estudios Culturales.
} 
se unen a este grupo buena parte de las universidades públicas, por el tipo de Administración acometida por los Demócratas -apoyando el separatismo (vid. infra falacia $B L A C K)-$, dificultándose la financiación de los centros si hay relación alguna con la religión -postura que bien podría considerarse contraria a la cláusula de libre ejercicio religioso o free exercise-. Con la llegada al poder de los Republicanos se produce una pendulación, sólo que en vez de financiarse directamente a las universidades, se impulsa la constitución de think-tanks o centros de alto rendimiento intelectual y comunicativo, de carácter autónomo -no necesariamente relacionados con el ámbito universitario, pero sí próximos a Washington DC-. En cualquier caso, toda la tensión mencionada termina superándose por la vía de reintegración de líneas de trabajo mediante la expresión de los estudios Religion $\mathcal{E}$.

Antes de aportar nota alguna sobre Religion \& -y cómo abrió el camino a los Cultural Studies-, o de ofrecer un directorio básico de who's who [quién es quién -un listado de académicos y centros más influyentes en la disciplina-], se considera oportuno brindar un breve repaso al devenir de los estudios de ACCL, bajo la denominación de CSS (lato sensu, incluyéndose las dos vías: constitucionalismo y sociologicismo -a retomar y profundizar en el siguiente epígrafe), pues se trata de la denominación dominante en los cursos impartidos sobre la materia en el s. XX. 


\section{2.- PAPEl de los Estudios culturales: CONSENSOS Y CONFLictos}

La genealogía de la idiosincrasia estadounidense, o sea la evolución de su visión, misión y valores propios (con sus características ideas y creencias, ritos y símbolos, relaciones Iglesia-Estado, despertares sociales y revitalizaciones elitistas, etc.), es una materia interdisciplinaria que habitualmente venía acometiéndose desde los Estudios culturales. Empero, en la actualidad, se hallan divididos y enfrentados: de un lado, los tradicionales (finiseculares y novecentistas) abogan por el consenso y la normalización ciudadana (protegiéndose el legado recibido); de otra parte, los sobrevenidos (eclosionados a raíz de la fuga de cerebros y alcanzando su cénit durante las guerras culturales), desde el conflicto social, postulan el hecho diferencial de cada comunidad. Tal es el nivel de tensión y polarización generadas, que los Estudios culturales hace tiempo que no pueden cumplir su misión propia (de gestión idiosincrásica estadounidense), y resolver el problema identitario revitalizado con la globalización y sus crisis. Para entender mejor el ejercicio de revelaciones que se viene acometiendo (frente a confusiones extendidas), y de reconciliaciones (buscándose el mínimo común denominador de la idiosincrasia estadounidense, tal como ofrecía ACR -hasta sus intentos de deconstrucción desde los Estudios culturales sobrevenidos, vid. supra epígr. 8.3). Por tanto, previamente a exponer y explicar el devenir de los Estudios culturales, según el hilo conector del factor religioso, se esquematiza a continuación una síntesis de lo ya apuntado sobre el marco coyuntural en el que tiene lugar el problema señalado.

En cuanto al contexto del problema detectado, y de vuelta al punto crucial ante la posglobalización (y la falta de una identidad estadounidense generalmente aceptada), téngase en cuenta que hasta los EE.UU., pese a su pionero modelo socio- 
cultural occidental de tránsito a la Modernidad efectiva, y de haberse incluso autoproclamado adalid de Occidente (tras la II Guerra Mundial), finalmente ha sucumbido tras décadas de desgaste, con las guerras culturales y el caballo de Troya de los Estudios culturales sobrevenidos y sus velos ${ }^{401}$. Seguidamente se proporcionan una serie de aclaraciones al respecto.

a) Guerras culturales: tienen lugar durante las décadas duras de la Guerra fría (196080), sólo que aquellas libradas en el seno del país, y su objetivo es hacerse con su mentalidad e identidad, y demás cuestiones aparejadas a la idiosincrasia estadounidense. A diferencia de las guerras militares (calientes/duras) en los países recién descolonizados o tercermundistas (no alineados o periféricos), las guerras culturales son consideradas verdaderamente frías (al modo de la Guerra fría de entonces) y blandas (dando paso al pensamiento débil), pues su principal munición empleada es la de los velos y el objetivo a batir es el sistema. Su origen está en la hibridación de planteamientos realizada por la intelligentsia europea, recibida con la fuga de cerebros (tras las guerras mundiales), y bien instalada en los medios de comunicación y universidades estadounidenses. Si ya en Europa

\footnotetext{
401 Téngase en cuenta que los EE.UU. nació con la Modernidad, combinándose en su seno la tradición occidental (sagrada y profana) recibida de viejos y nuevos civilizados. Durante casi todo el s. XIX se mantuvo prácticamente inmune a las teorías de las sospechas (v.g. NIETZSCHE, MARX, FREUD) y la eclosión ideológica europea (máxime, del socialismo y el nacionalismo). Así, mientras en el viejo mundo se daban hibridaciones (v.g. fascismo, nacional-socialismo), conduciéndolo a guerras (militares y culturales), también fue llevada Europa a la renuncia sociocultural (en pro de utopías) y a la deriva posmoderna (con sus velos -en realidad, para evitar la necesidad de autocrítica-). Tras la II Guerra Mundial, parecía que sólo EE.UU. se mantenía en la Modernidad occidental, liderando por ello el bloque del mundo libre y democrático. Sin embargo, con la fuga de cerebros, las élites intelectuales europeas (v.g. Escuela de Frankfurt, de Annales, de Birmingham), fueron cómodamente instaladas en las universidades del Ivy League y en los principales medios de comunicación de masas, desde donde iniciaron las guerras culturales, siendo los velos su munición. De tal manera comenzó el asedio a la Modernidad estadounidense: uno de sus objetivos preferentes de ataque era la religión (vid. supra prisma social), vista ya no desde el Americaness [estadounidización (proceso de adaptación americanizante)], sino desde la laïcité europea-continental.
} 
se había hibridado socialismo y nacionalismo (pese a ser dos ideologías mutuamente excluyentes), cuando dicha intelligentsia procede a su irradiación en los EE.UU., lo hace atacando a la nación, el Estado y la cultura estadounidense: desde sus planteamientos nacional-socialistas sui generis (reconvertidos a étnoculturales), se sienten exiliados en tierra de paletos venidos a ricos ( $\sin$ la Historia y la cultura de sus países de origen), por lo que se atacan los cimientos estadounidenses, y la quinta columna más accesible para ello son los medios de comunicación (imponiendo su opinión, por supuesta superioridad moral y cultural, además de generar espirales de silencio) y los Estudios culturales (revistiendo de cientificidad la ideología subyacente, aprovechándose su natural interdisciplinariedad, para hacer pasar la literatura por ciencia social, tejiéndose así los velos a extender). Sirva como ejemplo el caso de la Escuela de Frankfurt (v.g. WEIL como financiador, BLOCH como colaborador, POLLOCK y HORKHEIMER como directores en la etapa europea, ADORNO y MARCUSE como líderes en América) ${ }^{402}$, cuyo Instituto de Investigación Social se trasladó a New York y más tarde a California (periodo en el que son condenados al ostracismo autores como BENJAMIN -suicidándose en la frontera española- o FROMM -trasladándose a México-); allí, su integrantes llegan a jugar un papel crucial en las revueltas estudiantiles de los años 60 (desde la crítica literaria e ideológica se aborda la economía, la psicología, la sociología, etc., fomentándose el choque intergeneracional: lo baby-boomers, altamente ideologizados,

\footnotetext{
402 Todos ellos de origen alemán y socialistas, y muchos de familias judías, por lo que sólo cuando los nazis llegan al poder y realizan su antisemitismo, es cuando se desligan (rebautizándose como teoría crítica), exiliándose e iniciando su "blanqueo" (en dicho proceso, por cierto, se recupera a HEIDEGGER -de ahí el apoyo de ARENT, GADAMER, et al.-). Sólo permanece BENJAMÍN hasta su suicidio (fue invitado por Adorno a EE.UU., pero al contestarle que "aún quedan causas en Europa por las que luchar", queda fuera del círculo, evitándose su cita directa en los textos -una purga parecida pasa con FROMM-).
} 
desprecian a la gran generación y condicionan a los trans/odiseos).

b) Estudios culturales ${ }^{403}$ : se alude al variopinto conjunto de programas académicos en los que se han combinado disciplinas de Humanidades y Ciencias Sociales, para indagar sobre la idiosincrasia estadounidense (guardan relació con los estudios de Antropología europeos -originalmente más disciplinados y relacionados con los estudios de Arqueología, aunque en la actualidad se hallan más expuestos a los velos de confusión y su tropología-). Los Estudios culturales se van consolidando con la normalización de los programas académicos de las universidades a finales del s. XIX, desarrollándose en el seno de las Facultades de Humanidades o Liberal Arts Schools, Teología y CC. Religiones o Divinity Schools, y Derecho y CC. Jurídicas o Law Schools, en las elitistas universidades del club de la hiedra o Ivy League. Entre los primeros Estudios culturales en consagrase destaca el área de conocimiento de American Studies (también llamada en su origen American Civilization, v.g. Programa de doctorado de la Univ. Harvard desde los años 20: History and American Civilization), es el resultado del estudio combinado de Historia, sociedad y cultura estadounidense, mediante el recurso de Historia, Literatura y una incipiente Antropología, dominada entonces por dos corrientes, como eran los Estudios religiosos y folklóricos (influyentes en los Estudios culturales tradicionales, v.g. American Culture, American Social Thought, Church-State Studies, Religion E, First Amendment Studies), más la emergente Teoría crítica (clave para los Estudios culturales sobrevenidos, v.g. African American Studies, Asian American Studies, Latin American Studies, American feminist and gender -todos ellos impulsados a raíz de

${ }^{403}$ Vid. PARRINGTON, V.L.: Main Currents in American Thought (3 vols.), Norman: Univ. Oklahoma Press, 1927 (premiada en 1928: Pulitzer Prize for History). Para profundizar, vid. SÁNCHEZ-BAYÓN, A.: Universidad, ciencia y religión en los Estados Unidos de América... op. cit. 
Ethnic Heritage Studies Program Act of 1972-), añadiéndose poco después aportes de otras Ciencias Sociales y Humanidades, v.g. Economía, Política, Comunicación y Psicología Social. Para conocer la historiografía y devenir universitario de esta área de estudios, suele citarse la voluminosa y premiada obra de PARRINGTON (1871-1929), uno de los integrantes de la generación de historiadores progresistas (junto con TURNER y la historiografía de la frontera, los BEARD y la historiografía económico-social, et al.). Pues bien, así los Estudios culturales tradicionales mantuvieron como parte de su objeto de estudio la religión (como metámero socio-cultural clave), orientándola hacia el consenso facilitador de la unión (en inglés, es sinónimo de la nación, v.g. Preámbulo de la Constitución estadounidense de 1787), además de darse paso en el periodo de entreguerras a la teoría del excepcionalismo y melting pot o crisol cultural estadounidense (de la providencia divina a la autodeterminación de un pueblo con un destino manifiesto, vid. infra cap. 7, más supra epígr. 8.3 y cap. 10). En cambio, los Estudios culturales sobrevenidos (de origen neomarxista, aunque hoy autocalificados de posmarxistas, poscoloniales, subalternos, etc.), al ser proclives al conflicto y la fragmentación (al exaltar el hecho diferencial, legitimador de la violencia victimaria de comunidades supuestamente marginadas y oprimidas), procedieron a extender una tropología (preñada de velos), contraria a la tradición sagrada occidental (anti-judeocristiana y proorientalista, indigenista, etc.), y reivindicadora de reparaciones sociales para las minorías presuntamente excluidas del modelo socio-cultural dominante hasta entonces. El ataque de los Estudios culturales sobrevenidos a los Estudios culturales tradicionales se ha saldado con la inoperatividad de los mismos para reformular el cíclico problema de reajuste identitario estadounidense (y con ello, 
la pérdida de liderazgo y condición referencial para Occidente). Como honrosa excepción, aún operativa, cabe destacar la experiencia pragmática de CrossCultural Management o Gestión (inter)cultural en las Escuelas de Negocios (vid. supra).

\section{Breve recorrido historiográfico de Church-State Studies (CSS)}

\section{y su directorio base}

Como se viene recalcando, los CSS constituyen un área de conocimiento heterodoxa e interdisciplinaria, eso sí, considerada de lo más idiosincrásica, pues aclara la formulación e implementación de un pensamiento identitario (que parte de teólogos políticos, vid. infra cap. 5 y 6), así como de modelo relacional pionero, todo ello favorecedor del tránsito efectivo al Nuevo Régimen (o como reza uno de los lemas nacionales del Gran Sello: novus ordo seclorum). Los CSS gozan de larga tradición en las universidades estadounidenses (con presencia casi originaria y permanente en casi todos los centros del Ivy League, vid. infra). Sus antecedentes remotos están en las materias casi homónimas impartidas en los primeros Seminarios de Teología del s. XVII (vid. infra cap. 5 y 6), con obras compiladoras como Memorable Providences, o Magnolia Christi Americana de C. MATHER, A Survay of the Summe of Church Discipline y The way of the Congregational Churches cleared de T. HOOKER, The Churches Quarrel Espoused de J. WISE, et al. Su versión canónica se fija a finales del s. XIX (como ocurre con el resto de estudios superiores/universitarios), difiriendo ligeramente según el tipo de centro donde se enseña, ya que se encuentra a caballo 
entre: a) enfoque histórico-sociológico, presente en las Liberal Arts \& Divinity Schools [Facultades de Humanidades y Teología/CC. Religiones]; b) enfoque políticojurídico, en las Government \& Law Schools [Facultades de Ciencia Política y Derecho]. Los CSS guardan ciertas conexiones y similitudes con otros estudios europeocontinentales: el Derecho Eclesiástico del Estado en España, que bebe del Diritto Ecclesiastico en Italia, que a su vez lo hace de Staatskirschenrecht en Alemania; también es de considerar Droit civil ecclésiastique en Francia, etc.). No obstante, es de destacar que los CSS poseen un marcado carácter americanista/estadounidense, y por tanto, centrado en aclarar su idiosincrasia a través de la gestión del factor religioso. Inicialmente, los CSS se centran en una exposición y explicación doméstica, aunque desde comienzos del s. XX se aproximan también a sus vecinos del sur: Latinoamérica. Su recurso, sirve para un estudio por contraste, al atribuírseles otro fallido modelo cultural, además de mantenerse con ellos una política de patio trasero o back yard policy (vid. infra cap. 7). Tal conexión con Latinoamérica, ha supuesto también una interacción con otros Estudios Culturales -con contagios neomarxistas y demás velos posmodernos-, como los Latin-American Studies o LAS.

Los CSS han combinado diversos enfoques, como puede constatarse en las obras de mayor impacto de su campo (que se citan a continuación, así como en cap. 3 y Fuentes). En las obras del primer tipo de enfoque, el histórico-sociológico, destacan de entre el conjunto, las historicistas de AHLSTROM, OLMSTEAD y SWEET ${ }^{404 ;}$ las culturalistas de BELLAH, REICHLEY y SEWARD ${ }^{405}$; las confesionalistas de GREELY,

\footnotetext{
${ }^{404} \mathrm{Vid}$. AHLSTROM, S.E.: A religious History of the American people... op. cit. OLMSTEAD, C.E.: History of Religion in the United States... op. cit. SWEET, W.W.: Religion in the development of American culture... op. cit. - Religion in Colonial America... op. cit.

405 Vid. BELLAH, R.N.: Beyond beliefs... op. cit. - The broken covenant: American Civil Religion in the Time of Trial... op. cit. REICHLEY, A.J.: Religion in American Public Life... op. cit. SEWARD, W.: Religion in American Culture. A sociological interpretation ... op. cit. Complement., vid. BERGER, P., et al: The Sacred
} 
MAZUR y MEAD ${ }^{406}$; las estadísticas de DEMERATH, GALLUP y HUDSON ${ }^{407}$; las sociologistas de TYLER, STARK y GLOCK ${ }^{408}$. Entre las segundas, las político-jurídicas, llaman la atención por sí mismas, las contribuciones sectoriales de LIPSET, MALBIN, SANDOZ, TUVESON, etc. ${ }^{409}$, así como las constitucionalistas y procesales de ANGLIM, BASSETT, BULLIS, BURSTEIN, CHAFFEE, COUSER, EIDSMOE, ESBECK, HAMMAR, JASPER, LYNN, MAZUR, POLLACK, REMLEY, TAYLOR, et al. Y en un sentido holístico, destacan los manuales clásicos (por orden cronológico y de influencia en los especialistas) de ZOLLMANN, STOKES -reinterpretado heterodoxamente por PFEFFER-, LEGLER, DAWSON, WOOD, MANNING, et al. ${ }^{410}$. A la vez que, no cabe olvidarse de las valiosísimas compilaciones de fuentes

Canopy: Elements of a Sociological Theory of Religion... op. cit. - A rumor of angels: Modern Society and the rediscovery of the Supernatural... op. cit. CLARK, H.: The irony of American Morality ... op. cit.

406 Vid. GREELY, A.M.: The Denominational society. A sociological approach to Religion in America... op. cit. MAZUR, E.: The Americanization of Religious Minorities. Confronting the Constitutional Order... op. cit. MEAD, F.S., et al.: Handbook of Denominations in the United States... op. cit. Complement., no se olvide consultar la obra de partida de JAMES (The Varieties of Religious Experience... op. cit.).

407 Vid. DEMERATH, N.J.: Social class in American Protestantism... op. cit. HUDSON, W.S.: Religion in America. An historical account of the development of American religious life... op. cit. GALLUP, G., et al.: The people's religion. American Faith in the 90's... op. cit.

408 Vid. TYLER, A.F.: Freedom's Ferment. Phases of American Social History to $1860 \ldots$ op. cit. STARK, R., GLOCK, C.Y.: American Piety... op. cit.

409 Vid. LIPSET, S.M.: Religion and American Values in the First New Nation... op. cit. MALBIN, M.J.: Religion and politics: the intentions of the authors of the First Amendment... op. cit. SANDOZ, E.: Government of Laws. Political Theory, Religion, and the American Founding... op. cit. TUVESON, E.L.: Redeemer Nation. The Idea of America's Millennial Role... op. cit. Complement., vid. BROWN, W.A.: Church and State in contemporary America... op. cit. CORNELISON, I.A.: The relation of religion to Civil Government in the United States of America. A State without a Church, but not without a Religion... op. cit. CURRY, T.J.: The First Freedoms. Church and State in America to the passage of the First Amendment... op. cit. GREENE, E.B.: Religion and the State: the making and testing of an American tradition... op. cit. 410 Vid. ZOLLMANN, C.: American Church Law, St. Paul: West Publishing Co., 1933. STOKES, A.P.: Church and State in the United States (vol. I-III)... op. cit. PFEFFER, L.: Church, State and Freedom... op. cit. - Creeds in competition: A creative force in American culture... op. cit. LEGLER, J.: The Two Sovereignties. A study of the relationship between Church and State... op. cit. DAWSON, J.M.: America's Way of Church, State, and Society... op. cit. WOOD, J., et al (eds.): Church and State in Scripture. History and Constitutional Law... op. cit. - Church and State... op. cit. MANNING, L.F.: The Law of ChurchState Relations in a Nutshell... op. cit. 
primarias de BLAKELY, BLAU, COBBS, HAMMAR, NOONAN, GAFNEY o SCHAFF ${ }^{411} ;$ y las compilaciones de fuentes secundarias o derivadas, (de carácter bibliográfico) como SMITH y JAMISON, más BRUNKOW, HURD, etc.; (de carácter enciclopédico) como las de LIPPY y WILLIAMS, más LEVY, MELTON, etc.; y sobre todo, las colecciones de Routledge, coordinadas por LEVINSON ${ }^{412}$. Por último, se destaca la labor pionera y compiladora bibliográfica al respecto de BURR ${ }^{413}$.

Muchos son ya los nombres propios citados, y por medio de los cuales es posible seguir una evolución -bastante correcta- del estudio de la materia en los EE.UU. Sin embargo, se desea recalcar la labor de algunos, como auténticos referentes o nudos (conforme a la teoría de redes), al tratarse de aquellos más (re)nombrados -no sólo por generar y gestionar conocimiento, sino por servir de enlace (interconectando y sincronizando la labor científico-académica)-. El criterio

411 Vid. BLAKELY, W.A. (comp.): American State papers and related documents on Freedom in Religion... op. cit. COBB, S.H.: The rise of religious liberty in America... op. cit. HAMMAR, R.R.: Pastor, Church $\mathcal{E}$ Law... op. cit. 412 Vid. BRUNKOW, R.V. (ed.): Religion and society in North America. An annotated bibliography... op. cit. HURD, A.E. (ed.): Religion and Church and State: a bibliography selected from the ATLA religion database... op. cit. LIPPY, C.H., Williams, P.W. (eds.): Encyclopedia of the American Religion. Studies of traditions and movements (vol. I-III)... op. cit. MELTON, J.G.: The Encyclopedia of American Religions... op. cit. NOONAN, J.T., GAFNEY, E.Mc.: Religious Freedom. History, cases, and other materials on the interaction of religion and Government... op. cit. SMITH, J.W., JAMISON, A.L. (ed.): Religion in American Life (vol. I-IV)... op. cit. Complement., vid. BOORSTIN, D.J. (comp.): An American Primer... op. cit. DIXON, R.G., et al.: American Government: basic documents and materials... op. cit. MacDONALD, W.: Select Charters and other documents illustrative of American History, 1606-1775... op. cit. MENENDEZ, A.J.: Church-State Relations: an annotated bibliography... op. cit. - Religious conflict in America: a Bibliography... op. cit. QUEEN, E.L., et al.: The enciclopedia of American Religious History (vol. 1-2)... op. cit. SCHULTZ, J.D., et al. (eds.): Encyclopedia of Religion in American Politics... op. cit. SWATOS, W.H. (ed.): Encyclopedia of Religion and Society.. op. cit. Se invita a la lectura suplementaria de las mencionadas enciclopedias Routledge (Routledge Encyclopedias of Religion and Society: The Encyclopedia of Millennialism \& Millennial Movements. The Encyclopedia of African \& African-American Religions, The Encyclopedia of Fundamentalism, The Encyclopedia of Religious Freedom, The Encyclopedia of Protestantism, etc.). Igualmente, en su peculiariedad, se aconseja a la ojeada de DORSEY, S.P.: Early English Churches in America 1607-1807... op. cit. GLAZIER, M., SHELLEY, T.J.: The Encyclopedia of American Catholic History... op. cit. WILSON, C.R., FERRIS, W. (eds.): Encyclopedia of Southern Culture... op. cit. ${ }^{413}$ Vid. BURR, N.R.: Religion in American life... op. cit. 
observado entonces, no se limita al mero índice de impacto, sino al auténtico influjo -así constatado con otros colegas outsiders o investigadores extranjeros especialistas en los EE.UU.-. Dicho influjo se desprende, no sólo por la constitución de Programas y Centros especializados, con sus publicaciones respectivas de difusión, sino por su apertura a la comunidad científica, de manera plural -prueba de ello es que este autor ha sido académico visitante y/o ha mantenido distintos grados de colaboración con la mayoría de las instituciones aquí recogidas-. Sin más dilación, se procede a enunciar los centros y publicaciones nudo, así como un listado complementario de cultivadores actuales de la disciplina (en sus diversas asignaturas, v.g. Church-State Relations, Freedom of religión Semminar).

a) Centros y publicaciones: expresamente sobre Church-State, los más prestigiosos y antiguos -como centros, que no como programas-414, son los de las universidades privadas confesionales de Baylor (bautista, en el Sur) y de DePaul (católica, en el Medio Oeste). El centro de Baylor, J.M. Dawson Institute of ChurchState Studies, fue pionero no sólo en su constitución (a mediados del s. XX), sino también en disponer de estudios oficiales propios y una revista científica: Journal of Church and State. Recibe su nombre de uno de los primeros directores (DAWSON), al que han seguido insignes académicos, como WOOD y DAVIS quien a su vez, constituyó en la década de 2000, en MHBU el Center for Religious Liberty- ${ }^{415}$. Es una lástima el declive que vive hoy el centro, pues ha perdido

\footnotetext{
414 Pues si se evaluaran los programas, entonces sí, los pioneros serían los de la mayor parte de las universidades integrantes del Ivy League (v.g. Yale, Princeton). Complement., vid. DAVIS, D.H., HAENER, R.H.: "An examination of Church-State Curriculum in American Higher Education", en Journal of Church and State (vol. 38), 1996. WOOD, J.: "The Place of Church-State Studies in the University", en Journal of Church and State (vol. 35), 1993.

415 Proyecto malogrado, por las tensiones entre la dirección separatista de DAVIS (que además de académico ha sido colaborador de ACLU y asesor de diversas Fiscalías), frente a la visión confesional del Consejo de la Universidad -de ahí que abandonara su cargo de Decano de la Facultad de
} 
buena parte de su autonomía (v.g. pérdida de fondos, de estudios, de académicos visitantes), pasando a depender en gran medida de Keston Institute de Oxford University, que es el encargado hoy de la gestión de la revista. En cuanto al segundo centro, Center for Church-State Studies, tuvo su etapa de esplendor en la década de 1990, bajo la dirección del Prof. y Rev. MOUSIN ${ }^{416}$. Al igual que al Instituto de Baylor, también se está tratando de relanzar el centro -esperemos que con más suerte, pero se insiste en que la clave está en la apertura y apoyo a académicos visitantes de cualquier signo-.

Otros centros, en la línea de FAS, son First Amendment Center en Vanderbilt University, dirigido por el Prof. POLICINSKI y apoyando iniciativas tales como Freedom Forum (una de las conferencias periódicas más importantes e internacionales); First Amendment Studies (Program) en Ball State Universiy, con proyectos como J-IDEAS y curiosamente actuando en el seno de la Facultad de Periodismo/Comunicación. Y en la línea de Religion E, es de destacar la labor de Center for the Study of Law and Religion en Emory University, dirigido por WITTE y siendo uno de los centros clave para la recepción de profesores visitantes (sobre todo internacionales); International Center for Law and Religion Studies en Brigham Young University, dirigido durante largo tiempo por DURHAM -quien ha sabido sacar provecho personal (gracias a los fondos mormones), pero no así tanto para el propio centro-; Center for the Study of Law and the Church de Samford University,

Humanidades y volviera a Baylor antes de su retiro-. Es de destacar de este gran académico su fortaleza y templanza, pues pese al momento complicado mencionado (en 2010), fue capaz de dirigir el número 6 de la Revista Derecho y Religión (de la que este autor es Secretario). Además, a él debo mis estancias iniciales en Baylor y MHBU.

${ }^{416}$ Hombre generoso, que ha intercalador su labor académica con la misionera, sobre todo en Centro América. En la década del 2000 cambió su campo de CSS por el de inmigración, sin embargo, cuando estuve en DePaul, puso a mi disposición los fondos del centro y reajustó su agenda para que pudiéramos tener sesiones de trabajo semanales. 
bajo la dirección de DOSS; Institute for Christian Legal Studies en Regent University, con el liderazgo de SCHUTT (junto con ASH, TUSKEY, et al.); Center on Religion and Democracy de University of Virginia; Law and Religion Program en Catholic University of America; Law, Religion and Ethics (Program) de Hamline University; Pew Forum on Religion and Public Life, como red inter-universitaria; etc.

b) Profesores y universidades: al igual que está pasando con los centros, se vive ahora una etapa de transición e intento de relanzamiento, no sólo debiéndose los cambios al importante relevo generacional (jubilándose muchos de los autores más conocidos -y desapareciendo con ellos el separatismo-), sino que también se nota en la sustitución de asignaturas de la disciplina (de Church-State Relations o Freedom of Religion Semminar a Law and Religion o Religion and Public Policy incluso recuperándose otras como American Civil Religion, o emergiendo algunas novedosas relacionadas con la bioética, la geopolítica y la comunicación, así como de intensificarse su relación con los Estudios Culturales, vid. subepíg. siguiente). Entre los nombres propios a destacar -habiéndose conocido personalmente a más de la mitad de ellos-, se hace constar"17: H.J. ABRAHAM, A.E.D. HOWARD, M.R. O’NEIL (Univ. of Virginia); J. ATTANASIO (Southern Methodist Univ.); R.F. BRINAN, K.C. SANTORA (Georgetown Univ.); A.E. BROWNSTEIN, E.S. GAUSTAD (Univ. of California); L. CANIPE (Chowan Univ.); E. CHEMERINSKY (Univ. of California, Duke Univ.); D. DAVIS (MHBU, Baylor Univ.); W. DANIEL (Mercer Univ.); D.L. DEISBACH (American Univ.);

\footnotetext{
417 Se deja fuera del listado, a propósito, los investigadores y profesores de asignaturas confesionales de Derecho Canónico, Judío, Musulmán y Evangélico -incluyéndose confesiones posjudeocristianas como los mormones, por ejemplo-, así como aquellos otros de Derechos Humanos y Derecho y Política Comparada e Internacional, pues su abordaje sobre el factor religioso es más bien sectorial. Igualmente, no se incluye el gran número de profesores de universidades medias de TRACS; vid. vol. 1 y 3 de SÁNCHEZ-BAYÓN, A.: La Modernidad sin prejuicios... op. cit.
} 
R. DESTRO, W.A. KAPLIN (Catholic Univ. of America); C. DOSS (Samford Univ.); W.C. DURHAM (Brigham Young Univ.); C. ESBECK (Univ. of Missouri); B.K. FAIR (Univ. of Alabama); R.B. FLOWERS (Texas Christian Univ.); H. FRIEDMAN (Univ. of Toledo); E.M. GAFFNEY (Valparaiso Univ.); R. GARNETT (Univ. of Norte Dame); J.H. GARVEY (Boston College); S. GREEN (Willamette Univ.); K. GREENAWALT (Columbia Univ.); P. HAMBURGER (Univ. of Chicago y Columbia Univ.); M.D. HALL (George Fox Univ.); M.A. HAMILTON (Yeshiva Univ.); R.T. HUGHES (Messiah College); T. JELEN (University of Nevada); V. KARPOV (Western Michigan Univ.); D. KOEPSELL (State Univ. of New York); R.D. LINDER (Kansas State Univ.); C.H. LIPPY (Univ. of Tennessee); F.H. LITTLE (Temple Univ.); J. MANSFIELD, MARTY (Harvard Univ.); T.R. McCOY, POLICINSKI (Vanderbilt Univ.); C. MOUSIN, BLACKMAN -difunto recientemente-, TAVANTI, BUDDY (DePaul Univ.); P. PIERARD (Indiana State Univ.); M. ROGERS (Wake Forest Univ.); M. SCHUTT, R. ASH, J. TUSKEY (Regent Univ.); G.S. SMITH (Grove City College); J. WARHOLA (Univ. of Maine); J.D. WEXLER (Boston Univ.); C.M. WHELAN (Fordham Univ.); M.W. WHITTEN (Montgomery College), et al.

\section{Otros enfoques posteriores: Religion ands}

La expresión Religion ands/E [religión y (derecho, política, economía, etc.)] cuaja en la década de los años 60, con motivo del éxito del movimiento de derechos civiles. Téngase en cuenta que, hasta entonces, la disputa estaba entre la 
denominación CSS y FAS, con enfoques más formalistas que los postulados por Religion $\mathcal{E}$. Si hasta entonces, debido a la corriente del separatismo, existía una desconfianza hacia la religión, la cosa cambia, pues dos sectores fundamentales en la lucha de la causa negra -también conocida como black power, o defensa de los derechos civiles de los afroamericanos-son las iglesias evangélicas (como la del Rev. M.L. KING, vid. supra cap. 10) y la nación musulmana (en la que militaran personajes como Malcom X o M. ALI). De tal suerte, los pensadores contraculturales y la Nueva Izquierda no tienen más remedio que readmitir en su discurso el factor religioso, sólo que se hace bajo una lectura muy secularizada -incluso, ideológica-, de intenciones políticas, económicas, sociológicas, etc. (además de reconducirlo ya hacia lecturas comunitarias de exaltación del hecho diferencial, vid. infra Parte inicial). Así, los académicos que antes se oponían al estudio de CSS, ahora lo admiten gustosos si es dentro de los parámetros de Critical and Cultural Studies: se usa el factor religioso como elemento de crítica cultural a la mayoría, además de servir de elemento definitorio de minorías (oprimidas). De tal suerte, comienza a estudiarse la religión de la mujer, de los homosexuales, de la clase obrera, de las etnias (v.g. asioamericanos, afroamericanos, latinoamericanos), etc. Comienza de este modo la era de los Estudios Culturales, la extensión de velos posmodernos, el abuso de cientificismos y la entrada en la Posmodernidad -justo lo contrario de la Modernidad que representa los EE.UU., y a la que tanto ha contribuido la religión, tal como se viene explicando desde el inicio de este estudio-.

De las pocas variantes de Religion $\mathcal{E}$, sin el sesgo indicado (de Estudios culturales, bajo planteamientos híbridos neomarxistas, vid. supra), pero que no ha pasado de seminario o taller, es el caso de Religion $\mathcal{E}$ International Affairs [Religión y Relaciones Internacionales]. Un supuesto ilustrativo es el de la experiencia de este 
autor, mientras fuera académico visitante en Harvard, DePaul y Baylor, impartiendo workshops o talleres al respecto -tal como se aprendiera de los maestros de Harvard, sobre todo, combinándolo con lo aprendido en la UCM, y los syllabii o guías docentes de otras universidades estadounidenses-. En dichos talleres se enseñaban cuestiones relacionadas con las fuerzas transnacionales (que son las confesiones), Derecho Concordatario y Diplomático, regulación internacional y comparada (vid. infra figura 40, más infra cap. 7), etc.

Otra modalidad disciplinaria relacionada con Religion $\mathcal{E}$, en la misma línea excepcional (vid. infra), y heredera de CSS, es la de los cursos de American Civil Religion [religión civil estadounidense], para lo cual, se remite al cap. 5 y 6 .

\section{Recuperación y ahondamiento en el estudio constitucionalista de la materia ${ }^{418}$}

A continuación, tras la visión panorámica de las disciplinas tradicionales, se procede a profundizar específicamente en el enfoque clásico del constitucionalismo. Y es que dicha visión y sus planteamientos no han sido bien retratados -más bien, distorsionados, vid. supra-, con el tránsito a la globalización, sus trasplantes y contagios (afectando sobre todo a los nuevos estadounidenses). Tanto es así, que en

\footnotetext{
${ }^{418}$ Capítulo deudor de los siguientes artículos, vid. SÁNCHEZ-BAYÓN, A.: "Innovación docente en ciencias eclesiásticas y jurídico-sociales: estudio crítico y comparado de la metodología estadounidense" (pp. 317-349), en Cauriensia (vol. 8), 2013. - "El Derecho Eclesiástico en las universidades estadounidenses" (pp. 229-265), en Revista Española de Derecho Canónico (vol. 70, no171), 2013. - "Régimen jurídico del factor religioso en EE.UU.: teoría y praxis relativa a los ministros de culto y las confesiones" (pp. 315-340), en Cauriensia (vol. 9), 2014. - "Historia, Historiología e Historiografía de los Estudios Interculturales en EE.UU." (pp. 147-57), en Revista Banda de Moebius, Univ. Chile (nº 48), 2014.
} 
la actualidad parece que se han diluido los consensos pretéritos acerca del juego político-jurídico que se ha venido ofreciendo con respecto al sistema de separación acomodaticia estadounidense entre derecho-política-religión ${ }^{419}$. Ello puede achacarse, entre otras causas, a los contagios posmodernos, que han alcanzado incluso a los estudios científico-académicos en sus universidades, y por ende a la visión de las siguientes elites de poder y sus sucesivos relevos. Es por ello que se dedica este epígrafe a arrojar algo de luz sobre la cuestión.

${ }^{419}$ Vid. SÁNCHEZ-BAYÓN, A.: "Freedom of religion at large in American Common Law: a critical review and new topics" (pp. 35-72), en Journal for the Study of Religions and Ideologies, Univ. BabesBolyai-Rumanía (vol. 13, issue 37), Spring 2014. - "Cómo se aprende Derecho Eclesiástico del Estado en los Estados Unidos de América y su jurisprudencia: los otros estudios de casos menos conocidos" (pp. 1-43), en Revista Jurídica de la Universidad Bernardo O'Higgins Ars Boni et Aequi (vol. 9, no 2), nov. 2013. - "Regulación sobre ministros de culto y organizaciones religiosas en los Estados Unidos: estado de la cuestión y evaluación de las últimas décadas" (pp. 103-141), en Revista Jurídica de la Universidad Bernardo O’Higgins Ars Boni et Aequi (vol. 9, nº 1), junio 2013. - "Régimen jurídico estadounidense de las organizaciones religiosas y sus miembros" (pp. 221-51), en ICADE-Revista Cuatrimestral de las Facultades de Derecho y Ciencias Económicas y Empresariales (no89), sept. 2013. - "Religión, Política y Derecho en las Américas del nuevo milenio" (pp. 39-104), en Revista Jurídica de la Universidad Bernardo O'Higgins Ars Boni et Aequi (vol. 8, no 1), enero 2012. - "Mejora del aprendizaje del Derecho mediante los estudios de caso: aplicación al Derecho Eclesiástico del Estado" (pp. 49-80), en REPES: Revista Electrónica de Pensamiento, Economía y Sociedad-Instituto Virtual de Ciencias Humanas (vol. 16), sept.-oct. 2012. - “Conocer y gestionar las esferas sociales en la globalización: de las religión, la política y el derecho en las Américas del nuevo milenio" (pp. 103-146), en ICADE-Revista Cuatrimestral de las Facultades de Derecho y Ciencias Económicas y Empresariales (no 81), sept.-dic. 2010. - "Historia de la Comunicación Social Estadounidense a través de sus Movimientos Religiosos" (pp. 199-223), en Historia y Comunicación Social (vol. 13), junio 2008. - "Revitalizaciones religiosas postmodernas en América y sus riesgos para la democracia y los derechos humanos" (pp. 1-23), en Revista General de Derecho Canónico y Derecho Eclesiástico del Estado-Iustel (no 11), mayo 2006. - "Revitalizaciones religiosas postmodernas en América y sus riesgos para la democracia y los derechos humanos" (pp. 1-23), en Revista General de Derecho Canónico y Derecho Eclesiástico del Estado-Iustel (no 11), mayo 2006. - "Derecho y Religión en Estados Unidos de Norteamérica: Análisis de su relación desde diversos enfoques" (pp. 32-36), en Zalacaín Harvard Journal of Ibero-America (vol. I, nº 5), Fall 2002. - "La viabilidad de la enseñanza del Derecho Eclesiástico del Estado en la Universidad de Harvard" (pp. 13-18), en Zalacaín, Harvard Journal of Ibero-America (vol. I, no 5), Fall 2002. COLL, A., SÁNCHEZBAYÓN, A.: "The Federal Legal Framework for Religion: freedom of religion and church-state relations in the United States" (pp. 253-280), en Derecho y Religión (vol. VIII), septiembre 2013. GONZALEZ, M., SÁNCHEZ-BAYÓN, A.: "Libertades fundamentales en las Américas: devenir de la libertad religiosa en América Latina, los Estados Unidos de América y el Sistema Interamericano" (pp. 107-126), en Revista Jurídica-Universidad Autónoma de Madrid (nº 14), 2006. 
Como es sabido, el Derecho estadounidense resulta una variante excepcional de la familia jurídica del Derecho común anglosajón ${ }^{420}$. Ello se explica porque los EE.UU. fue el primer país en independizarse del Imperio Británico, consolidándose como una república soberana, con un sistema jurídico singular. Su Derecho -como el resto de su cultura- es fruto del influjo de otras familias jurídicas: Derecho Europeo-Continental o Civil en el Sureste (v.g. Luisiana), Derecho Canónico allí donde hay importantes comunidades católicas (v.g. Diócesis de Boston para Nueva Inglaterra), Derecho Germánico en el Noreste (como reminiscencia de las colonias de los pueblos bálticos, v.g. Nueva Suecia), etc. De este modo se explica que el Ordenamiento estadounidense cuente con la Constitución escrita más antigua -y aún vigente (desde 1787)-, Códigos de leyes (como el U.S. Code o los Códigos estatales de práctica forense -equivalentes a las leyes de enjuiciamiento civil del Derecho Europeo-Continental-), etc. En definitiva, sus fuentes jurídicas no son tan diferentes -como se suele pensar, sobre todo desde Europa continental-, sino que en vez de atender al instrumento por el que se vehiculan, se presta mayor atención al poder del que emanan. De ahí que, en vez de dar prioridad al Derecho estatutario del Legislativo (v.g. acts, bills [leyes]), éste sólo es uno más, como lo es también el Derecho reglamentario del Ejecutivo (v.g. orders, rules [reglamentos]), así como el Derecho casuístico o jurisdiccional del Poder Judicial (v.g. Case Law $\mathcal{E}$ sentences [derecho procesal y sentencias]). A todo ello hay que añadir el Derecho Internacional, la que la Constitución estadounidense confiere cierto reconocimiento (v.g. law of nations [Derecho Internacional, Comparado y Extranjero], treatries [tratados]). Luego las fuentes iuseclesiasticistas estadounidenses van desde la Primera enmienda (sobre libertad religiosa) y la Décimo cuarta (sobre igualdad

${ }^{420}$ Vid. Cap. 3 y 4 de SÁNCHEZ-BAYÓN, A.: Sistema de Derecho Comparado y Global... op. cit. 
jurídica ciudadana en cuanto a la Declaración de Derechos o Bill of rights, y su vigilancia por el TSEU), más preceptos como el art. VI y otras referencias constitucionales, hasta la ordenación local de las Juntas municipales en materia de educación o urbanismo, en lo tocante al factor religioso.

Advertido lo anterior, se espera resulte más fácil aclarar cómo se aprende la materia en los EE.UU., especialmente, desde el enfoque constitucionalista y vía el estudio de caso, pues todo ello ha demostrado proporcionar valiosos recursos con los que estimular el desarrollo del sentido jurídico y la habilidad de establecer analogías y articular ficciones solucionadoras de lagunas jurídicas.

\section{De las compilaciones cronológicas a la sistemática por áreas}

Como ya se ha prevenido, erróneamente suele identificarse el American Common Law con el Case Law, pero este último sólo supone una fuente y/o rama del Derecho: existen otras igualmente importantes, como el Executive Law [Derecho ejecutivo, principalmente, Derecho Administrativo], con sus reglamentos, o el Statutory Law [Derecho estatutario o legislativo, emanado del Parlamento], con sus leyes. Tal exaltación del Case Law proviene del citado método LANGDELL y los casebooks -tal como ya se ha explicado, vid. infra presentación de Parte de desarrollo especial-. No obstante, existe una relación más íntima, más allá de la cuestión de su enseñanza, esto es, se alude al hecho jurídico de que para que se produzca el perfeccionamiento del Executive Law, por ejemplo, es necesario que éste sea citado en algún juicio, luego el Case Law sirve para dar impulso y difusión a buena parte 
del Executive Law. En definitiva, tal relación es una muestra más del pragmatismo estadounidense. Es por ello que también, por dicho pragmatismo, de la amplia producción jurisprudencial, sólo se termine recordando las sentencias más recientes e impactantes -o sea, en el s. XIX aquellas que defendían la intervención del Estado (v.g. contra los mormones y testigos de Jehová, en cuanto vulneradores del American way of life [estilo de vida estadounidense]), y en el s. XX justo al contrario (v.g. la jurisprudencia de la secularizante Corte BLACK, vid. supra). En consecuencia, para conocer la regulación iusreligiosa o iuseclesiasticista estadounidense, a continuación, se ofrece no sólo el exiguo elenco de los actualmente considerados leading cases [casos clave], sino que se proporciona el listado más amplio posible.

\section{A) Compilación cronológica}

Se remite aquí a los casi trescientos casos compilados en la figura 70 (vid. cap. 5), donde se sistematizaban los supuestos más sobresalientes sobre la materia, y que deberían estudiarse en las Facultades de Derecho, para conocer la auténticca jurisprudencia sobre el modelo relacional Iglesia-Estado lato sensu -las sin embargo, muchos de estos casos y su jurisprudencia, por diversas razones, han sido olvidados, bien por superarse las temáticas, bien por no encajar con el discurso dominante en la coyuntura correspondiente, etc.-. Tales casos sistematizados resultan determinantes para conocer adecuadamente la tendencia interpretativa de las materias relativas a la regulación del factor religioso en los EE.UU., como es la implementación de la libertad y autonomía religiosa (de personas físicas y jurídicas, como las confesiones), así como la tutela de la no-discriminación por motivos 
religiosos (ídem), y demás cuestiones conexas (vid. supra), respondiendo todo ello a los fundamentos político-jurídicos y comparativa realizada a la luz del estudio de los centenares de sentencias compiladas (los casi trescientos case studies de Case Law, sistematizados por fecha y temática).

A propósito, en la figure 14 y figura 53, se corta el enunciado de casos en el año 2005 (tras la reelección de W.BUSH), pues es entonces cuando el número de casos comienza a crecer exponencialmente a la postre -requiriéndose otro estudio para su exposición y explicación al respecto- ${ }^{421}$. En definitiva, a comienzos de la década de 2010, los casos sobre la materia rebasaban ya el medio millar, evidenciando nuevas áreas temáticas, así como la urgencia y necesidad de una revisión de propuestas académicas para su enseñanza (vid. supra). Entre las muchas lecciones a extraer (de la casuística planteada), una que no se desea dejar pasar y que guarda relación con la amplia producción jurisprudencial -casi olvidada en parte-, es el hecho de que el viejo sistema del estudio de caso de tipo lineal (por criterios cronológicos), no es viable ya -por las razones aducidas-, sino que resulta más conveniente la vía sistemática por áreas (area cases), tal como se aclara seguidamente.

\section{B) Áreas temáticas}

Como se viene indicando, dada la acumulación de jurisprudencia y el creciente volumen de Derecho Estatutario y Ejecutivo (sobre todo tras las Administraciones ROOSEVELT y su New Deal o nuevo trato, para implementar el

\footnotetext{
${ }^{421}$ En principio, sirva las aproximaciones intentadas en SÁNCHEZ-BAYÓN, A.: Universidad, ciencia y religión... op. cit. - Estado y religión de acuerdo con los Estados Unidos de América... op. cit. - La Modernidad sin prejuicios. La religión en la vida pública estadounidense (vol. 2: Normativa)... op. cit.
} 
Estado social estadounidense, de corte asistencialista, soportado en gran medida por las organizaciones religiosas y su voluntariado), finalmente, a partir de la década de 1960, se produce el giro hermenéutico, y se pasa al predominio docente vía estudios de caso por áreas temáticas. Para ilustrar la cuestión se van a mostrar dos áreas temáticas consolidadas: a) régimen jurídico de ministros de culto y confesiones; b) régimen jurídico de religiones nativas amerindias ${ }^{422}$.

\section{B1) Régimen jurídico de ministros de culto y confesiones}

Las cuestiones abordadas en esta área de estudio son básicamente tres: la personalidad, la capacidad y la responsabilidad jurídica de los ministros de culto (v.g. reverendos, pastores, sacerdotes, religiosos, misioneros) y las confesiones $\mathrm{u}$ organizaciones religiosas (v.g. corporaciones, asociaciones, fundaciones). Se circunscriben los apuntes siguientes a la regulación de alcance doméstico (estadounidense), con especial atención a la generada durante las Administraciones CLINTON y W. BUSH -como ejemplo de polos que pueden llegar a tocarse-.

En el Ordenamiento estadounidense, se reconocen como conceptos jurídicos válidos, con un status propio, los términos clergy / clergyman [clérigo / religioso] y church [iglesia / organización religiosa]. Con el primero, se identifica al líder religioso, y con el segundo, la organización. Tanto en la jurisprudencia (sobre todo de las Cortes de Apelación o Segunda Instancia), como en las compilaciones normativas, The Uniform Rules of Evidence [las reglas uniformes de evidencia -ley de

\footnotetext{
${ }^{422}$ En este apartado, sólo se ofrece una mínima sinopsis, pudiendo atenderse al resto de referencias y casos relacionados en el cap. 4 .
} 
enjuiciamiento civil y penal-] y The Internal Revenue Code [el código de recaudación interna -código de Derecho financiero y tributario-], se tipifican estos términos, con sus sinónimos genéricos y específicos ${ }^{423}$.

En cuanto a su status, debido a su labor espiritual y social, tienen reconocidos una serie de privilegios:

a) Privilegios e inmunidades del clero: pese a las restricciones históricas, que datan incluso desde los primeros años de los EE.UU. (v.g. abolición de beneficios del clero por el Congreso en 1790), en la actualidad, el clero aún goza de las siguientes prerrogativas ${ }^{424}$ :

- Exención de impuestos (IRS): de ingresos, no teniendo que realizarse en muchos casos la declaración -correspondiéndole a la iglesia; de la vivienda ídem; etc.

${ }^{423}$ En el U.S. Code, The Uniform Rules of Evidence [las reglas uniformes de evidencia] y The Internal Revenue Code [el código de recaudación interna], reconocen como sinónimos genéricos de clergy [religioso], los términos minister [ministro], reverend [reverendo] y pastor [pastor], distinguiendo, eso sí, que el ministro de culto es cualquiera que haya sido ordenado o acreditado, mientras que el pastor, es el responsable local de una iglesia; y como específicos, cabe enunciarse priest [padre católico], rabbi [rabino judío], imam [imán musulmán], etc. Las iglesias, de igual manera, poseen sus sinónimos genéricos, como religious institutions/organizations [instituciones/organizaciones religiosas] -aunque de carácter expansivo, pues también comprenden hospitales o colegios religiosos; y los específicos, como parish [parroquia católica y protestante de la línea principal], congregation [congregación protestante evangélica], etc.

424 Para la realización de algunas de estas prerrogativas, algunos Estados piden además, que el religioso solicite una licencia, esté inscrito en un Registro público especial e informe de actuaciones. 
- Exención de deberes públicos: de ser jurado en un juicio ${ }^{425}$; del servicio militar ${ }^{426}$, etc.

b) Privilegios de trato por la Administración: ventajas penitenciarias ${ }^{427}$, prioridad con el servicio de inmigración ${ }^{428}$, etc. Facultades de prestación de servicios: para celebrar matrimonios ${ }^{429}$, bautizos, etc.

c) Privilegios e inmunidades de las organizaciones religiosas:

- Ventajas en urbanismo (Zoning Law \& Building Codes [Derecho urbanístico y códigos de construcción]): puede impedirse el establecimiento de licorerías a menos de dos manzanas de una iglesia. Cabe también prohibir la apertura en domingo de bares y licorerías. La cesión de terrenos para la edificación de lugares de culto - pero el propietario no sería la iglesia, sino la comunidad local; etc.

- Ventajas fiscales: las propiedades eclesiásticas están exentas o tributan a precios distintos de mercado; las donaciones a las iglesias tienen beneficios fiscales; etc.

- Ventajas de trato con la Administración: debido a su labor de asistencia y promoción social, puede solicitarse ayudas públicas -no importa si la organización es religiosa o no, sino la labor que realiza; puede disponerse de

\footnotetext{
${ }^{425}$ El clero esta excusado en muchos Estados (v.g. Hawaii Revised Statutes -612-6, Exempt when, 1987) y en los que no lo está, basta con que pida su recusación por diversas causas: prejuicios y/o familiaridad con los hechos y las partes.

${ }^{426}$ Tanto el clero como los estudiantes de teología reciben un trato especial, pues aunque la Selective Service Act, les obliga a registrarse, no son luego llamados a filas.

${ }^{427}$ Tanto el clero como el preso, no pueden ser obligados a desvelar el contenido de sus conversaciones (v.g. Alabama Rules of Evidence, Rule 505, Communications to clergymen).

${ }^{428}$ Vid. Religious Workers Act of 2000.

${ }^{429}$ Hay Estados que exigen al clero disponer de una licencia y comunicar las actuaciones (v.g. Alabama Code-30-1-7, Persons authorized to solemnize marriages, 1988).
} 
propiedades públicas para sus servicios -en algunos casos, siendo necesario pagar un alquiler mínimo; puede mostrarse símbolos propios en espacios públicos -ya que muchos de estos símbolos poseen un valor secular; puede distribuirse literatura religiosa en espacios públicos y aceras -siempre y cuando se respete el orden público; puede recibirse asistencia legal gratuita por parte de la Fiscalía (a través de The First Freedom Project, vid. cap. 10); etc.

Para iniciar el abordaje de la cuestión, sobre las vías de funcionamiento, el ACCL ofrece diversas posibilidades, siendo las principales y más recomendadas por los despachos especializados (v.g. RJEL Religious Institutions Group), la vía ex novo y la de tracto sucesivo (basada en la Ecclesiastical Corporation Sole) ${ }^{430}$ :

a) Régimen ex novo: como ya advirtiera MARX, lo atractivo del protestantismo como macrovariedad religiosa dominante en los EE.UU.-, es que cada persona común puede ser ministro de culto e iglesia. Luego, por esta vía, bastaría con constituir una entidad, que fuera reconocida como organización religiosa por un organismo público, y a sí mismo (al sujeto que constituye la entidad), como su representante legal o como su empleado (de acuerdo con la Self-Employment Constributions Act y la Federal Insurance Contributions Act). La mejor forma de lograr dicho reconocimiento es mediante el Internal Revenue Service [Servicio de recaudación interna] (IRS). Para obtener el reconocimiento del IRS, como iglesia y religioso, sólo es necesario solicitarlo por escrito en una carta, tramitar

\footnotetext{
${ }^{430}$ Entre las diversas formas legales adoptadas por las iglesias en los EE.UU., cabe distinguirse hasta una docena de opciones, desde las tradicionales ofrecidas por la vía del Ecclesiastical Corporation Sole [Fuero de corporación eclesiástica], hasta las más recientes, como aquellas bajo el régimen de la Revised Model Nonprofit Corporation Act [Ley del modelo revisado para corporaciones sin ánimo de lucro].
} 
anualmente el Formulario 990 o el 990-EZ, y cumplir los requisitos tipificados en la secc. 501(c)(3) del IRC431 (v.g. ser una organización sin ánimo de lucro, con actividades de caridad, etc.), y últimamente, además, se exige no haber hecho campaña contra ningún candidato político; vid. figura siguiente.

Figura 53.- Preceptos del IRC sobre clero e iglesia ${ }^{432}$

I.R.C. § 79 Exemption of Church Plans from Limitations on Group Term Life Insurance. I.R.C. \$74(b) Certain Exceptions for Prizes and Awards in Recognition of Religious Achievement. I.R.C. \& 107 Rental Value of Parsonages. I.R.C. \& 170(b)(1)(A) Limitations on Charitable Contributions to a Church. I.R.C. § 170(f)(6) Disallowance of Charitable Contribution Deductions. I.R.C. \& 401(a)(9)(C)(iv) Church Plan Exception to Required Distributions for Qualified Pension, Profit-Sharing and Stock Bonus Plans. I.R.C. §402(g)(7)(B) Special Rules for Certain Organizations Regarding Limitations On Exclusion for Elective Referral. I.R.C. § 403(b) Taxability of Beneficiary Under Annuity Purchase by §501(c)(3) Organization. I.R.C. $\S 404(a)(10)$ Contributions By Certain Ministers to Retirement Income Accounts. I.R.C. $\S$ 410(c)(1)(B) Application of Participation Standards to Certain Plans. I.R.C. § 410(d)(1)\&(2) Election By Church to Have Participation, Vesting, Funding, etc. Provisions Apply. I.R.C. § 411(e)(1)(B) Application of Vesting Standards to Certain Plans. I.R.C. $\S 412(h)(4)$ Exceptions to Minimum Funding Standards. I.R.C. § 414(e) Church Plan Defined. I.R.C. § 414(p)(11) Church Plan Payments Classified as Qualified Domestic Relations Order. I.R.C. § 414(q)(9) Highly Compensated Employee Definition. I.R.C. § 415(c)(7) Special Rules for Church Plans on Limitations for Defined Contribution Plans. I.R.C. $\S \S 501(c)(3)$, (d) Exemption from Taxation for Religious Organizations. I.R.C. \& 501(h)(5) Disqualified Organizations Expenditures by Public Charities to Influence Legislation. I.R.C. § 501(i) Prohibition of Discrimination by Certain Social Clubs. I.R.C. \& 501(m)(3)(D) Certain Organizations Providing Commercial-Type Insurance Not Exempt from Tax. I.R.C. §§ 508(a), (c) Exceptions to Special Rules with Respect to 501(c)(3) Organizations. I.R.C. § 509(a)(1) Churches and Religious Organizations Are Not Private Foundations. I.R.C. § 512(b)(12) Specific Church Deduction for Unrelated Business Taxable Income. I.R.C. § 514(b)(3)(E) Special Rule for Churches When Land is Acquired for Exempt use Within 10 Years. I.R.C. $\S \S 530(b)(4)(A)(i)$, $(b)(4)(A)(i i)$ Coverdell Education Savings Account Application to Religious Schools. I.R.C. $\S 642(c)(2)(B)$ Deductions Paid or Permanently Set Aside for Charitable (including religious) Purposes. I.R.C. $\S 999(b)(3)($ iii) Participation In or Cooperation With an International Boycott. I.R.C. § 1402(a)(8) Tax on Self-Employment Income for Ministers of a Church Members of a

${ }^{431}$ Complement., para saber cómo era el sistema antes de 1970, vid. COUGHLIN, B.J.: Church and State in Social Welfare, New York: Columbia University Press, 1965. ZOLLMANN, C.: American Church Law, St. Paul: West Publishing Co., 1933.

${ }^{432}$ Lista ilustrativa, que no exhaustiva, vid. Título 26 del U.S. Code; complement., para clero, vid. Títulos 20, 22, 39 y 50 del U.S. Code; para iglesia vid. Títulos 11, 20, 21 y 29 del U.S. Code. Complement., vid. Anexos y tesis de 2007 y 16. 
Religious Order. I.R.C. §§ 1402(a)(14), (j) Church Employee Income Special Rules. I.R.C. §§ 1402(c)(4),(e),(g) Self-Employment Income Definitions and Exemptions For Churches, Ministers, Members of Religious Order. I.R.C. \$2011(d) Credit for State Tax Deaths and Additional Limitations for Cases Religious Uses Under §2055. I.R.C. § 2014(f) Credit for Foreign Tax Deaths and Additional Limitations for Cases Religious Uses Under \$2055. I.R.C. $\S 2053$ Estate Tax Deduction for Death Taxes on Gifts to Churches, If Tax Savings Given to Churches. I.R.C. § 2055 Estate Tax Deduction for Religious Gifts. I.R.C. § 2106 Estate Tax Deduction for Religious Gifts by Non-Resident Decedents. I.R.C. § 2522 Gift Tax Deduction for Religious Gifts. I.R.C. $\S \S 3121(b)(8)(A),(b)(8)(B)$ Employment Definitions For Calculating Employment Tax, Does not Include Ministers, etc. I.R.C. § 3121(w) Federal Insurance Contributions Act; Exemption of Churches and Qualified Church-Controlled Organizations. I.R.C. § 3127 Exclusion of Religious Organizations and Employees from Social Security Tax Where Religious Tenants are in Opposition to Government Provided Benefits. I.R.C. § 3306 Religious Service Overseas Exempted from Employment Definition. I.R.C. §§ 3309(b)(1), (b)(2) State Law Coverage of Services Performed for Non-Profit Organizations or Governmental Entities. I.R.C. §3401(a)(9) Exclusion of Duly Ordained, Commissioned, or Licensed Minister of a Church from Wage Definition for Employment Tax Purposes. I.R.C. $\$ 4980 B$ (d) Church Plans Excluded for Failure to Satisfy Continuation Coverage Requirements of Group Health Plans. I.R.C. $\S \S 4980 D(b),(c)(2)(B)$ Failure to Meet Certain Group Health Plan Requirements. I.R.C. $\S 4980 F(f)(2)(B)$ Church Plan Excluded From Tax Imposed for Failure of Applicable Plans Reducing Benefits Accruals to Satisfy Notice Requirements. I.R.C. \& 5122(c) Occupational Tax, Limited Retailer Definition Includes Church. I.R.C. \& 6033(a)(3)(A)(i) Returns Required to Be Filed by Exempt Organizations. I.R.C. § 6043(b)(1) Exempt Organization Return Requirements Following Liquidation, etc. I.R.C. \& 6057(c) Annual Registration Concerning Pension Plans Including Church Plans. I.R.C. § 6115 Value of Intangible Religious Services Received in Exchange for Contribution Does not Reduce Charitable Contribution Deduction. I.R.C. § 7611 Restrictions on Church Tax Inquiries and Examination. I.R.C. § 7701(a)(19)(v) Definitions of Savings and Loan Association Included if 60 Percent of the Total Asset is Loans Primarily for church Purposes. I.R.C. § 7702(j) Certain Church Self-Funded Death-Benefit Plans Treated As Life Insurance. I.R.C. § 9802(c) Special Rules for Church Plans Regarding Prohibiting Discrimination Against Individuals and Beneficiaries Based on Health Status; et al.

Fuente: elaboración propia (SÁNCHEZ-BAYÓN, 2007 y 16).

b) Régimen de tracto sucesivo: es la vía más recurrente, pues se aprovecha la estructura y trayectoria consolidada de familias confesionales, donde existe un sistema tasado de formación y acreditación interna, pudiendo llevarse a cabo por ordenación, como comisionado o bajo licencia, según se trata de una iglesia o una congregación. Proceso de selección de clero por las iglesias (v.g. católica, ortodoxa, anglicana): lo habitual es que el candidato, primero se forme en los 
seminarios correspondientes, y luego sea seleccionado por la jerarquía de su organización para encargarse de una delegación local. Proceso de selección de clero por las congregaciones (v.g. bautista, metodistas): normalmente, suele ser la congregación la que oferta el puesto y elige al candidato. A este respecto, las disputas que puedan surgir de la selección del candidato, no suelen ser admitidas por los tribunales civiles. Otra cosa es, las posibles responsabilidades derivadas de la elección del candidato y sus actuaciones, cuestiones que sí entran a ser conocidas por los jueces. Como última regla general al respecto, lo habitual es que la relación entre el religioso y la iglesia sea por vía contractual, por lo que se aplica la teoría general de los contratos, eso sí, observándose las especialidades de la materia.

En lo tocante a los litigios, responsabilidades e indemnizaciones, desde mediados de la década de 1810, surge la doctrina Church Authonomy [doctrina de la autonomía religiosa], lo que supone un cierto distanciamiento del poder civil respecto del religioso. Los tribunales civiles, en aplicación estricta de las cláusulas de la Primera Enmienda (de CEU), renuncian a conocer de las disputas internas eclesiásticas y de los litigios planteados contra las organizaciones religiosas, sustentándose en la figura de la Charitable immunity [inmunidad caritativa] -se trata de un privilegio cuyo origen se remonta al Derecho medieval ${ }^{433}$. Esta situación perdura hasta la década de 1940, comenzando a variar cuando algunos tribunales estatales emprenden un cierto cuestionamiento de los fundamentos de dicho

${ }^{433}$ Cuatro son las teorías que lo sustentan y que han sido desmontadas progresivamente por los tribunales estadounidenses, cfr. MAZUR, C., BULLIS, R.: Legal Guide for Day-to-Day Church Matters. A Handbook for Pastors and Church Members, Cleveland: The Pilgrim Press, 2003, 3 ss. 
privilegio. A finales de la década de 1970, con el pistoletazo de salida del caso Barr y otros análogos, los tribunales empiezan a flexibilizar los criterios de admisión de causas contra el clero y las iglesias ${ }^{434}$. A raíz del caso Barr v. United Methodist Church (90 Cal. App. 3rd 259, 1979) y demás jurisprudencia continuadora de la tendencia (Chellew v. Hope Lutheran Church 1980, Frank Tyler Allen v. Presbyterian Housing Program Inc. 1982, Bozeman Deaconess Foundation v. Yellowstone Conference of the United Methodist Church 1981, Minor v. Southern Baptist Convention 1981), de este modo, arranca una normalización (por aceptación como condición general y ordinaria), de la admisión de litigios frente al clero y las iglesias (más otros entes dependientes sin ánimo de lucro), pudiéndose exigir responsabilidades e indemnizaciones, cada vez más copiosas, obligando en consecuencia a tener que contratar seguros ${ }^{435}$ (por causas como las de la figura 54).

Para compensar el posible desequilibrio financiero de las iglesias y sus entes dependientes, en la década de 1990, los tribunales, igualmente, comenzaron a admitir la posibilidad de recepción de fondos públicos por parte de las iglesias, para el desempeño de funciones sociales (educativas, sanitarias, etc.) y mejora del bienestar general. Ello explica la constitución y consolidación de las Faith-based iniciatives (vid. supra), programa directamente dependiente de la Casa Blanca, y cuya significación y alcance se expone a reglón seguido.

Otra cuestión clave en esta área temática es lo tocante a los seguros en el ámbito eclesiástico, ya no se hace referencia a los tradicionales seguros contra

\footnotetext{
${ }^{434}$ Para poder estudiar dicha evolución y reciente tendencia, es necesario recurrir a las decisiones de Cortes de Apelación Estatales y alguna del Federal, pero aún queda tiempo para que el Tribunal Supremo de EE.UU. (TSEU) entre a casar la materia.

435 Vid. GAFFNEY, E.M.: Ascending Liability in Religious and Other Nonprofit Organizations, Macon: Mercer University Press, 1984.
} 
incendios, robos o desastres naturales, que meramente protegían las propiedades. Hoy en día, con la decadencia de la doctrina de autonomía religiosa y la pérdida del privilegio de caridad -ambas figuras eran el escudo judicial del clero y las iglesias frente a posibles reclamaciones de propios y terceros ante los tribunales civiles-, entonces, para poder desarrollar sus actividades sociales con cierta normalidad, resulta necesario destinar parte del presupuesto a la contratación de un seguro de responsabilidad civil. Dicho seguro, viene a cubrir casi todos los tipos y causas que se abordan con inmediatez (vid. supra), facilitando la cobertura jurídica debida que necesite el asegurado y llegando a pagar por éste la indemnización pertinente, si se diera el caso.

Los contratos de seguros más atractivos, son los de las mutuas de las iglesias aseguradas de una misma familia confesional (v.g. Church Mutual Insurance Co., Brotherhood Mutual). En otro caso, es necesario buscar aquel seguro que ofrezca la cobertura más amplia y con cuotas asumibles. Tal como está el mundo actuarial (de seguros), resulta prácticamente imposible lograr un contrato donde ambas partes negocien cada una de las cláusulas, pero sí existen una serie de cláusulas tipo que todo seguro debe contemplar: a) provide full cooperation in the defense [dar plena cooperación para la defensa] ${ }^{436}$; b) provide timely notice [dar constancia periódica] ${ }^{437}$;

\footnotetext{
436 Plena cooperación: el asegurado está obligado a colaborar en la investigación y defensa del caso, debiendo incluso permitir la consulta de documentos internos, si fuera preciso. La obstaculización en dicho sentido, libera a la compañía de seguros de sus obligaciones.

${ }^{437}$ Constancia periódica: la parte asegurada ha de notificar periódicamente acerca de aquellos hechos que podría considerarse posible causa de litigio.
} 
c) duty to defend the insured [obligación de defender al asegurado] ${ }^{438}$; d) legal demonstration of liability [demostración jurídica de la responsabilidad] ${ }^{439}$; etc.

Por último, se mencionan, a continuación, una serie de notas básicas acerca de los litigios contra y en defensa del clero y las iglesias, conforme a las acusaciones más frecuentes, por los que se rinde cuenta de los ejemplos más representativos y arraigados de tort o litigios civiles derivados de ilícito ${ }^{440}$-que alguno puede, por su gravedad y alcance social, acabar como litigio penal o crime_$^{-441}$, cuya responsabilidad puede acarrear el pago de indemnizaciones copiosas, además de las costas del juicio. De ahí que, en la actualidad, el clero (y sus iglesias) han de prestar especial atención a las reclamaciones de responsabilidad, por el servicio prestado, debido al riesgo de acusaciones de: a) fraud [fraude, estafa, defraudación]; b) defamation [difamación e injurias]; c) negligence [negligencia y malpráctica]; d) abuse [abuso y acoso].

\footnotetext{
${ }^{438}$ Obligación de defensa: la aseguradora, antes de indemnizar, tiene el deber de proveer de la mejor defensa posible al indemnizado -pues la credibilidad de su asegurado es muy importante. Los tribunales, suelen interpretar de forma favorable al asegurado la covertura del contrato, pues sólo quedan excluidas de protección aquellas causas que se indican expresamente, v.g. Evangelical Lutheran Church in America v. Atlantic Mutual Insurance, Co. (169 F. 3rd 947, 5th Cir. 1999).

${ }^{439}$ Demostración jurídica: la aseguradora sólo ha de responder cuando el daño causado no sea por un acto deliberado y posea causa legal suficiente.

${ }^{440}$ Se observa al respecto, la influencia derivada de las categorías y reglas de BLACKSTONE y sus Comentarios (op. cit.). En cuanto a los litigios civiles derivados de incumplimiento de contrato, por lo general, si es un caso entre un clérigo y un seglar, se aplica la teoría general de los contratos y su máxima genérica pacta sum servanda; si el contrato es entre un clérigo y su iglesia, se suele seguir respetando el principio de autonomía religiosa, permitiéndose que se dirima el asunto por sus vías internas (v.g. tribunales eclesiásticos).

${ }^{441}$ Las causas y los tipos gozan de la suficiente amplitud de margen como para posibilitar la disponibilidad de parte de los cargos a juzgar. Ahora bien, si se opta por la vía penal, la Fiscalía, aún cuando las partes hayan llegado a un acuerdo por la vía civil, puede disponer de la causa, por razón de representación ciudadana (ya que el caso tiene la necesaria gravedad y alcance social, la Fiscalía interviene en nombre de la comunidad y para preservar el orden público). Por regla general, si la causa es civil, el tipo se regula por el Título 29 (Labor [trabajo]) y el 42 (Public Health $\mathcal{E}$ Welfare [salud pública y bienestar]), del U.S. Code. Pero si la causa es penal, al tipo se le aplican los preceptos del Título 18 (Crimes \& Criminal Procedure [delitos y proceso penal]) y el Apéndice (Rules of Evidence $\mathcal{E}$ Criminal Procedure [reglas de prueba y de procedimiento penal]).
} 
Figura 54.- Disputas civiles y/o penales sobre religión más relevantes

\begin{tabular}{|c|}
\hline Litigios en contra del clero y las iglesias: \\
\hline Fraud (fraude, estafa, defraudación). \\
\hline Defamation (difamación e injurias). \\
\hline $\begin{array}{l}\text { Negligence (negligencia): común: own liability (responsabilidad propia); especial: clergy } \\
\text { malpractice (malpráctica clerical). }\end{array}$ \\
\hline $\begin{array}{l}\text { * Regla de imputación: vicarious liability \& respondent superior (responsabilidad del vicario } \\
\text { y respuesta del superior). }\end{array}$ \\
\hline $\begin{array}{l}\text { - Abuse (abuso): Child abuse (abuso infantil y personas vulnerables). Sexual misconduct } \mathcal{E} \\
\text { sexual harassment (conducta sexual indebida y acoso sexual). Brainwashing (lavado de } \\
\text { cerebro/pseudoconversión). }\end{array}$ \\
\hline Litigios a favor del clero y las iglesias: \\
\hline $\begin{array}{l}\text { - Religious Discrimination (discriminación religiosa): education, employment, housing, } \\
\text { landing, public acomodation, public facilities (educación, empleo, vivienda, urbanismo, } \\
\text { asistencia pública y facilidades). }\end{array}$ \\
\hline $\begin{array}{l}\text { - Religious Bias Crimes (delitos religiosos): crimes against persons and property based on } \\
\text { religion (delitos contra personas y propiedad de carácter religioso). }\end{array}$ \\
\hline $\begin{array}{l}\text { - Protecting Religious Freedom (protección de la libertad religiosa): religious land use, } \\
\text { institutionalized persons (uso religioso del suelo, personas institucionalizadas/bajo } \\
\text { supervisión institucional) }\end{array}$ \\
\hline
\end{tabular}

Fuente: elaboración propia (SÁNCHEZ-BAYÓN, 2007 y 16).

Antes de entrar a conocer las causas y los tipos de litigación, se enuncian algunas de sus reglas procesales elementales (con su terminología técnica y jerga habitual), aplicables para la determinación de la responsabilidad. En cuanto a las modalidades de responsabilidad, cabe su clasificación según el sujeto responsable y el alcance de sus actos, así como, por el tipo de organización religiosa de que se trate. 
a) Sujeto responsable:

- Direct or own liability [responsabilidad directa]: es la responsabilidad directa e inmediata del sujeto acusado. De dicha responsabilidad puede acusarse, por ejemplo, al clero, a los religiosos, a los trabajadores (v.g. abogados, médicos, profesores, técnicos de limpieza y mantenimiento), a los voluntarios, etc.

- Ascending or derivate liability [responsabilidad derivada]: es la responsabilidad de los sujetos acusados, hecha extensible a su iglesia, por ser la que les contratara o en nombre de la que se actuara. En los casos de las entidades derivadas (v.g. colegios o centros de salud religiosos), cabe prolongar la responsabilidad a la iglesia de la que dependan.

- (Respondent) superior liability [responsabilidad del superior]: es la responsabilidad achacable al superior directo del acusado, si existiera obligación de rendirle cuentas y hubiera dispuesto de indicios. También se conoce la institución como vicarious liability $\mathcal{E}$ respondent superior [responsabilidad del vicario y respuesta del superior].

b) Organización religiosa:

- Iglesias jerárquicas (v.g. católicos, ortodoxos, anglicanos): debido a su estructura interna (de corte tipo piramidal), cabe exigirse la superior liability, quedándose en el nivel del Obispo o Vicario, pues el responsable de zona ello explica, que en los casos de acusación de pederastia a curas de la diócesis de Bostón, sólo se exigiera la responsabilidad de su superior, el Obispo de Boston (cabeza de su diócesis), y no se pudiera ascender en la escala de mandos hasta el mismísimo Papa-. 
- Iglesias congregacionalistas (v.g. bautistas, metodistas): su organigrama es más bien horizontal, por lo que las iglesias locales gozan de gran autonomía, siendo difícil extender la responsabilidad, pues la coordinate liability es muy difícil de probar y de escasa repercusión.

En lo tocante a las vías de indagación de responsabilidad, en primer lugar, para determinar la imputación de responsabilidad y posible extensión de la misma, a la iglesia local y/o a su superior, han de comprobarse los registros públicos y los documentos internos de gobierno. Si no quedase clara la relación, puede seguirse la pista de la denominación (el nombre de la iglesia local, que la vincule a una familia religiosa de alcance regional o nacional) y los folletos informativos.

En cuento a las causas y tipos de litigios (desarrollándose la figura previa), cabe destacar:

a) Fraud [fraude, estafa, defraudación]: se trata de cualquier intento deliberado de engañar a otro, sacando un provecho. Sus requisitos son el engaño, el conocimiento del engaño, el intento de obtener beneficio, causar un daño y el nexo entre todo ello. Uno de los casos más emblemáticos, es U.S. v. Ballard (322 U.S. 78, 1944), por los puntos que toca (fraude y estafa) y su condición precursora $^{442}$. Se plantea, entonces, una causa de fraude religioso y otra de estafa postal, por parte de I Am Movement [movimiento soy yo]. En cuanto al fraude religioso, relativo a la falsedad de sus creencias, aunque el tribunal decide no

\footnotetext{
${ }^{442}$ Hubo otros casos antes, sólo que en niveles inferiores y con menor repercusión, como New v. U.S. (245 F. 710, 9th Cir. 1917), donde la Corte de Apelación consideró que el Dr. NEW era un impostor, pero el TSEU lo rechaza.
} 
entrar a conocer, en cambio, sí sirve el caso para iniciar un cierto criticismo frente a los nuevos movimientos religiosos (cults [sectas]), cuyo apogeo está en la década de 1970.

Sobre la estafa postal, basada en el envío de literatura y solicitud de fondos, el error de la Fiscalía fue permitir a la Defensa conectar la estafa postal con el fraude religioso, haciendo imposible determinar la falsedad de las promesas por ser materia religiosa. La lección de BALLARD fue aprendida, como prueban los casos U.S. v. Kuch (288 F. Supp. 439, DDC 1968) y Thomas v. Review Bd. Employment Service Div. (450 U.S. 707, 1981). En el primero, sobre la Neo-American Church, constituida para el consumo de mariguana, se consideró un timo. En el segundo, se consideró que si la causa principal del litigio no era religiosa, no cabía la protección de la Primera Enmienda (de CEU). Otros casos donde las doctrinas religiosas, sin ser juzgadas directa y expresamente, sí son valoradas por los jueces, por guardar un papel crucial en la consecución de la confianza de los demandantes, que más tarde se sienten engañados. Así se desprende de: a) Marcus v. Jewish Nacional Fund (557 NYS 2nd 886, App. Div. 1990), siendo un caso de donaciones de caridad, donde se recaudaban fondos para financiar reclamaciones territoriales en Israel, pero no se llevó a cabo; b) Tilton v. Marshall (125 S.W. 2nd 672, Tex. 1996), donde el Rev. R. TILTON prometía (en su programa de televisión) leer, tocar y rezar con sus donantes, no haciéndolo luego; c) Safsten v. LDS Social Services, Inc. (942 P. 2nd 949, Utah App. 1997), una mujer se sintió engañada, presionada para dar en adopción a su hijo, lo que el tribunal entendió que fue por mala fe de la congregación mediante; etc. Recientemente, uno de los casos más polémicos es el del curandero, ya que se 
trata de un sujeto que ejerce de médico-sacerdote, sin tener licencia para ninguna de estas dos profesiones.

Antes de concluir la actual causa de litigio, otra dimensión que comprende y a apuntar de inmediato, es la defraudación fiscal. La misma consiste en recurrir a las formas religiosas para obtener los beneficios y excepciones reservadas a las iglesias, o no comunicar debidamente los cambios sustanciales. Así se resolvió en los siguientes casos: a) Church of Chosen People v. U.S. (548 F. Supp. 1247, D. Minn. 1982), donde un grupo homosexual pretendía ser reconocido como iglesia para obtener sus ventajas fiscales; b) National Association of American Churches v. Commissioner (82 T.C. 18, 1984) $)^{443}$, ídem, pero para una familia que pretendía obtener para sí las ventajas fiscales de las iglesias; c) Mutual Aid Association of the Church of Brethren v. U.S. (578 F. Supp. 1451, D.C. Ks. 1983), donde la iglesia perdió su exención fiscal por exceder su límite estatutario de fondos, superior a 150.000 dólares, sin la comunicación debida; etc.

Una figura fraudulenta típica, para la que el IRS tiene unos protocolos de actuación específicos ${ }^{44}$, es la del mail-order ministries [ministros ordenados por correo] que desde 1978 son objeto de investigación prioritaria y sometidos a auditoría periódica.

Finalmente, sólo se apunta por encima, el supuesto de missappropiation of funds [apropiación indebida de fondos], por combinar la dimensión de fraude, estafa

\footnotetext{
${ }^{443}$ Se trata de una resolución muy peculiar, porque proviene del Tax Court o Tribunal Fiscal del IRS. De igual modo y en un sentido similar, cabe citarse otros supuestos previos: a) Presbyterian and Reformed Publishing Co. v. Commissioner (79 T.C. 1070, 1982); b) Bethel Conservative Mennonite Church v. Commissioner (80 T.C. 352, 1983); etc.

${ }_{444}$ Vid. Illegal Tax Protesters Threaten Tax System Report by the Comptroller General of the United States, 1981.
} 
y defraudación, más apuntar maneras en la línea de la malpráctica clerical como se aclara al tratar la negligencia específica, más adelante-. Un caso ilustrativo, por ejemplo, es el de Commonwealth $v$. Nichols (206 Pa. Super 352, 213 A.2nd 105, 1965), donde el Obispo NICHOLS, a través de unas cuentas, desvió fondos de la African Methodist Episcopal Church de Filadelfia, vulnerando entre otros preceptos, la Sección 827 del Código Penal de Pennsylvania.

b) Defamation [difamación e injurias]: es una comunicación dañosa, que vulnera la reputación de un individuo, negocio, grupo o gobierno, con la única intención de afectar a su buena opinión y fama. Puede tratarse de una ofensa hablada y transitoria (slander), o escrita y permanente (libel). Sus requisitos son, la ofensa pública, el daño en la fama y el nexo entre ambos. La difamación religiosa debe ser cometida por una persona vinculada a la iglesia, principalmente, el clérigo. Ha de tratarse de una acusación relativa al incumplimiento de fe o bajeza moral del afectado (v.g. hipocresía, adulterio, etc.), lo que acarrearía una sanción ostracista de la comunidad. Entre los casos más sobresalientes, de gran popularidad en su momento y generador de la doctrina excesive publication [excesiva publicidad], se llama la atención sobre Gorman v. Swaggart (524 So. 2nd 915, 1988). En 1986, el televangelista J. SWAGGART, en su programa, acusó a otro ministro de culto (M. GORMAN) de haber cometido inmoralidades con una mujer. GORMAN renunció a su posición como pastor de su iglesia y fue revocada su condición de ministro de culto de su confesión. Aun así, SWAGGART siguió difamando, hasta que GORMAN le demandó. SWAGGART pretendió defenderse apelando al libre ejercicio religioso y la figura del privilegio del foro -creada para los periodistas y la libertad de prensa-. 
El tribunal entendió que, como clérigo tenía un cierto privilegio de comunicación pública, aunque restringido al interés de su iglesia; empero, la excesiva publicidad dada acababa con dicho privilegio -máxime porque GORMAN era ya un seglar más-.

En cuanto a los temas tabú de estrecha relación con la difamación, el que más ha evolucionado en los últimos tiempos ha sido la blasfemia. Ésta ha sido retirada ya, como tipo especial, de la protección penal de los Derechos estatales, aunque perdura su observación como causa de desorden público (v.g. la ofensa religiosa que provoca una pelea en la calle). Los otros temas tabú vigentes son el antisemitismo y el racismo con las iglesias negras.

c) Negligence [negligencia]: se hace referencia al descuido o falta de atención debida, por actos involuntarios u omisiones, que terminan provocando un daño. Para que la negligencia tenga cabida, es necesario probar que el acusado era el responsable, así como, que su falta de atención debida -y no mero accidente-, originó la causa del daño. Se distingue en este apartado entre la negligencia común y la específica (o malpráctica clerical):

- Negligencia común: una iglesia tiene la misma responsabilidad de ofrecer la seguridad debida al público, como cabe exigírsele a cualquier institución civil. Así se apunta en: a) Glorioso v. YMCA of Jackson (540 So. 2nd 638, Miss. 1989), donde un niño de nueve años murió en el desarrollo de una actividad juvenil (amparada por YMCA, que es la organización de jóvenes cristianos estadounidenses con mayor arraigo del país); b) Logan v. Old Enter Farms, ltd. (544 N.E. 2nd 998, 1989), donde un adolescente de quince años se cayó de un 
árbol, quedando tetrapléjico, durante una fiesta organizada para los monaguillos; etc.

Ahora bien, una tendencia como la ejemplificada, podría llegar a acabar con las actividades de caridad o la prestación de propiedades eclesiásticas para actividades recreativas y de ocio; de ahí que haya cierto recelo a indemnizar, como regla general, para casos así: a) Malaere v. Peachtree City Church of Christ, Inc. (253 Ga. App. 593, 1994), donde un niño se lesionó en una piscina de la iglesia; b) Harmon v. St. Joseph's Catholic Church (11 Cal. App. 4th 1071, 1992), donde un niño se lesionó al montar en bicicleta en el parking de la iglesia; etc. Para completar la exposición sobre los supuestos de negligencia común, por un servicio social como es la educación, un caso muy revelador es el de Smith v. Archbishop of St. Louis (32 S.W. 2nd 516, 1982), donde se puede observar con cierta claridad la extensión de responsabilidad al superior. Los hechos probados son, que una profesora de un colegio religioso, sin advertir del riesgo a sus alumnos, ponía una vela encendida (durante el mes de mayo) en su escritorio, hasta que un niño se quemó con ella; por ser la diócesis la responsable superior del centro y de la contratación de su profesorado, ello hizo posible la extensión de la responsabilidad al Arzobispo.

- Negligencia específica (mala praxis o malpráctica clerical): el presupuesto es que cualquier profesión liberal y de trato directo con el público, dispone de un código deontológico y unos baremos de competencia, a los que está sujeta la obtención y mantenimiento de la licencia de ejercicio profesional, ¿pero todo ello es predicable del clero? El problema radica en que, aunque ciertas prácticas (v.g. celebración de matrimonio), sí se puede exigir licencia por parte de los poderes públicos, en cambio, no resulta posible fijar unos 
baremos comunes y unas licencias generales para la profesión, porque se vulneraría el derecho de libre ejercicio (free exercise clause) y la igualdad religiosa (pues a las iglesias congregacionalistas se les pediría tener un nivel de establecimiento similar al de las iglesias jerárquicas). El hecho es que, algún tribunal ha sugerido ya positivamente la fijación de un test/examen judicial capaz de medir la malpráctica clerical, v.g. Bird v. Faber (565 N.E. 2nd 584, 1991). Sin embargo, hasta que se institucionalice de forma generalizada una técnica así, la cuestión sigue quedando en manos del construccionismo judicial y sus riesgos correspondientes.

En todo caso, por aportar una sistematización entre la más de una veintena de casos tramitados sobre la materia, cabe distinguirse entre cuatro categorías (citando para cada una de ellas dos ejemplos, aunque muchos de ellos-como se ha dicho- guardan íntima relación, pudiéndose mencionar en las otras categorías):

Malpráctica y suicidio (cases concerning suicides): Nally v. Grace Community Church (47 Cal. 3rd 278, 763 P. 2nd 948, 253 Cal. Rptr. 97, 1988). Handley v. Richards (518 So. 2nd 682, Ala. 1987).

> Malpráctica y consejo/confidencia (cases involving breach of confidence): Hester v. Barnett (723 S.W. 2nd 544, Mo. 1987). Amato v. Greenquist (679 N.E. 2nd 446, III App. 1997).

Malpráctica y catarsis de fe (cases involving faith healing): Baumgartner v. First Church of Christ, Scientist (141 III. App. 3rd 898, 96 III Dec 114, 490 N.E. 2nd 1319, 1986); Lundman v. McKown (530 N. W. 2d 807, 827 Minn. App. 1995). 
> Malpráctica y sexualidad (cases involving sexual misconduct): Jones v. Trane (153 Misc. 2nd 822, 591 N.Y.S. 2nd 927, 1992). E.J.M. v. Archdiocese of Philadelphia (424 Pa. Super. 449, 622 A. 2nd 1388, 1993), etc.

Dichas categorías no están desconectadas entre sí, sino que guardan una relación intensa entre ellas, por lo que resulta una práctica habitual de los demandantes, tanto el solicitar indemnizaciones por varias de las citadas causas, como el fundamentar y pedir también por otros tipos ya citados (v.g. fraude) o por tratar (v.g. abuso), y en cualquier caso, siempre añadir una petición de compensación por daños emocionales (severe emotional distress). Como comentario de cierre, se apunta un par de aporías sobre el tema más polémico y actual -aún por resolver y muy conectado en sus resultados con la difamación-, como es el supuesto de invasion of privacy [invasión de la intimidad], por el que el clero puede ser acusado de: a) divulgar la vida privada de alguien, habiendo recibido la información a través de confidencia; b) suplantar o utilizar la identidad de algún feligrés para obtener ventajas; etc.

d) Abuse (abuso): se trata de un tipo agravado, que va más allá de la malpráctica clerical, pues se comete un atropello de autoridad, aprovechándose para ello de la confianza que tienen los fieles en las funciones clericales.

Entre la amalgama posible, destacan dos categorías, por ser las más execrables, ya que no sólo suponen un abuso de la confianza de los fieles, sino que resultan una violación de los votos o compromisos adquiridos por los clérigos, como se produce con el abuso infantil/discapacitados, así como, con la conducta sexual 
inadecuada (que incluye las relaciones extramaritales y el acoso sexual). Se reserva para el final, una categoría en avance, como es la propiciada por la aparición de cults [sectas], acusándose a dichos movimientos de brainwashing o lavado de cerebro.

- Abuso infantil/discapacitados: es el atropello físico, mental y/o moral de un niño y/o persona adulta desvalida, por parte de un adulto revestido de autoridad, que se aprovecha de su posición para actuar cruelmente.

Entre su tipología, cabe observar:

> Menores: varía según los Derechos estatales, pero por regla general, se entiende por tal toda aquella persona que no haya cumplido los diecisiete años y sin emanciparse. En el ámbito del Derecho federal y para prevenir los casos de abuso a menores, se aprueba en 1993 la National Child Protection Act [ley de protección nacional del niño] (reforzando el resto de normativa ya existente al respecto y compilada en el Título 42 del U.S. Code $)^{445}$. Entre sus medidas más destacadas cuentan la constitución de agencias especializadas ${ }^{446}$, junto con la imposición ciudadana de notificar supuestos de posibles abusos a menores ${ }^{447}$. ¿Cómo afecta dichos mandatos al clero? La práctica procesal, permite al clero, poder denunciar los hechos sin tener que revelar la fuente, de modo que no se vulnera el

\footnotetext{
${ }_{445}$ Así como otras posteriores, que enmiendan disposiciones relativas al voluntariado y a las actividades caritativas con menores, como por ejemplo, Volunteers for Children Act of 1998 [Ley de voluntarios para los niños].

${ }_{446}$ National Center for Child Abuse and Neglect [Centro nacional para (evitar) la negligencia y el abuso infantil]; National Center for Missing and Exploited Children [Centro nacional para niños desaparecidos y explotados]; National Center for the Prosecution of Child Abuse [Centro nacional para la persecución del abuso infantil]; operando todas estas agencias federales con los organismos estatales.

${ }^{447} \mathrm{Si}$ no se colabora en las investigaciones de abusos a menores, puede castigarse al culpable con prisión de seis meses a un año, y/o multa de 500 a 1.000 dólares.
} 
secreto de confesión o consejo/confidencialidad. Un ejemplo ilustrativo, previo a la normativa adoptada desde 1993, es el de Schmidt v. Bishop (779 F. Supp. 321, 1991), donde una mujer madura acusó a un clérigo de haber abusado de ella cuando tenía 12 años. El tribunal rechazó la solicitud ya que habían pasado 31 años de aquello.

Otro tema candente es el de las acusaciones a curas católicos de abusos sexuales a niños, como en el caso Kennedy v. Roman Catholic Diocese of Burlington (921 F. Supp. 231, D. Vt. 1996) -así como el de la Diócesis de Boston, donde se extendió la responsabilidad al Obispo, quién presuntamente trató de tapar el tema con una serie de compensaciones económicas, causándose la bancarrota de la diócesis-.

Discapacitados: existe una amplia regulación estatal al respecto, aunque el gran impulso proviene de la normativa federal, como la Sección 504 de la Rehabilitation Act of 1973 [Ley de rehabilitación], o la American with Disabilities Act of 1992 [Ley sobre estadounidenses con discapacidades], donde la nueva doctrina no exige que se creen programas especiales para discapacitados, pero si éstos son admitidos, entonces, debe prestarse especial atención a sus necesidades. Incluso, existe normativa religiosa en esta línea, como la católica, Pastoral Statement of U.S. Catholic Bishops on Handicapped People (1978) [Carta pastoral a los Obispos católicos de los EE.UU. sobre la gente con discapacidades].

- Conducta sexual inapropiada: abarca todo comportamiento sexual del clero con adultos. Se distingue, a continuación, entre las relaciones extramaritales y el acoso sexual. La presente categoría, se subdivide además, entre: 
> Relaciones extramaritales: entre la malapráctica y el abuso de confianza, cabe citarse aquellos casos en los que el clérigo, al impartir sesiones de consejo prematrimonial y/o matrimonial, finalmente, viola sus votos o compromisos adquiridos y mantiene relaciones con alguna de las partes: a) F.G. v. MacDonell (150 N.J. 550, 696 A.2nd 697, 1997); b) Sanders v. Casa View Baptist Church (134 F. 3rd. 331, Tex. 1998); c) Destefano v. Grabrian (763 P. 2nd 275, Col. 1988); etc.

Acoso sexual: constituye una serie de agresiones, desde molestias leves (v.g. insinuaciones y gestos obscenos) a violaciones serias (v.g. tocamientos y propuestas sexuales), que en cualquier caso, vuelven hostil el entorno laboral. Se considera el acoso sexual como un tipo de discriminación ilegal, además de una forma de intimidación, pues su oposición puede acarrear consecuencias negativas (v.g. participación en proyectos, promoción interna). Su tipificación más destacada se encuentra en el Título VII y IX de la Civil Rights Act of 1964 [Ley de derechos civiles] $]^{448}$ y, más recientemente, en la Equal Employment Opportunity Act [Ley de igualdad en la oportunidad de empleo], con su agencia principal, la Equal Employment Opportunity Commision [Comisión para la igualdad en la oportunidad de empleo]. Caso ilustrativo, del tránsito de la tradicional normativa sobre la materia y la más reciente (desde la década de 1990), cabe destacar el de Jane Doe v. Special School District of St. Louis County (901 F. 2nd. 642, 8th Cir. 1990).

\footnotetext{
${ }^{448}$ El Título VII exige el mantenimiento del lugar de trabajo libre de acoso sexual, enumerándose como conductas reprobables y a evitar, por ejemplo, las proposiciones sexuales, las insinuaciones y gestos obscenos, etc. El Título IX exige programas de educación preventiva al respecto.
} 
> Lavado de cerebro: se trata de una pseudoconversión o programación, como algunos autores han calificado a esta categoría de abuso ${ }^{449}$. Consiste en la captación de personas, privándoseles de su ámbito de autonomía interna del individuo (AAII), provocándose con ello trastornos mentales (v.g. depresión, estrés), incluso, en algunos casos, hasta la muerte.

Su tipificación, se ha ido incorporando progresivamente a los Códigos Penales estatales, quedando a su vez, completada con normativa federal, como la Occupational Health and Safety Act [Ley de salud y seguridad profesional], más otras tantas, compiladas en el Título 29 del U.S. Code. Sus requisitos son, la captación de adeptos vulnerables psicológicamente (v.g. se les buscan en funerales, en grupos de apoyo frente a drogodependencias o enfermedades) y ser cultos de captación coercitiva. Son muchísimos los casos, por lo que se han elegido cuatro, que representan los supuestos más típicos y a los cultos más demandados:

- Katz v. Superior Court (73 Cal. App. 3rd 952, 141 Cal. Rptr. 234, 1977): la corte, frente al alegato de libertad religiosa, dio la razón a unos padres que secuestraron a sus hijos para frenar su proceso de

\footnotetext{
${ }^{449}$ Se califica de pseudoconversión, ya que no se ajusta al proceso individual y voluntario del renacido o converso, sino que se trata un proceso agresivo contra el ámbito de autonomía interna del individuo -para ello, se impide al sujeto que tenga contacto con familiares y amigos, mientras dura el brainwashing. La visión más completa al respecto, es la que aporta BASSETT, quién establece una categoría más amplia, deceptive recruiting practices [prácticas engañosas de reclutamiento], donde distingue entre la responsabilidad por brainwashing [lavado de cerebro] y deprogramming [desprogramación]. Vid. BASSETT, W.W.: Religious organizations and the Law (vol. 2), Danvers: West Group, 2002, pp. 8:8, 8:9 y 8:10.
} 
pseudoconversión de la Unification Church, ya que se consideraba que los niños habían perdido su escasa autonomía ${ }^{450}$.

- Moroni v. Holy Spirit Association (119 A.D. 2nd, 506 N.Y.S. 2nd 174, 1986): un padre denuncia al culto del que formó parte su hijo, quién murió debido al estrés emocional causado por el agresivo proceso de pseudoconversión.

- George v. International Society for Krishna Consciousness of California (262 Cal. Rptr. 217, 1989): una madre y su hija demandaron a los krishna por el rapto y lavado de cerebro de la hija. En 1983, un jurado de California condenó a los krishna a pagar 32,5 millones de dólares, que tras su apelación, la indemnización quedó en 2,9 millones. Para su pago, los krishna tuvieron que vender cinco de sus templos y oficinas principales en Los Angeles.

- Wollersheim v. Church of Scientology (212 Cal. App. 3rd 872, 1989): ídem, pero la condena fue de 30 millones de dólares, que tras la apelación, la indemnización por daños psicológicos de 5 millones, se redujo a 500.000 dólares, y pago punitivo de 25 millones, quedando en 2 millones.

Como visión de conjunto final, de litigios contra el clero y las confesiones, se aporta un ejemplo de caso omnibus [que da cabida y conecta todos los tipos expuestos], y una serie de reflexiones sobre la gravedad de los tipos y las dudas

450 Otros casos contra la Unification Church son: Turner v. Unification Church (602 F. 2nd 458, 1st Cir. 1979); Schuppin v. Unification Church (435 F. Supp. 603, D. Vt. 1977), etc. 
procedimentales que suscitan a los tribunales. El citado ejemplo de caso que reúne en su seno casi todos los tipos por los que se puede reclamar responsabilidad al clero y exigir copiosas indemnizaciones, es Hester v. Barnett (723 S. W. 2nd 544, Mo. 1987), donde un marido y su mujer demandaron a su pastor por defamation, ministerial malpractice, alienation of affections, intencional infliction of emotional distress, invasion of privacy, and interferente with contract [difamación, malpráctica ministerial/clerical, alineación afectiva, provocación voluntaria de daños emocionales, invasión de la intimidad e interferencia de contrato]. Todo ello porque, habiendo pedido consejo pastoral, luego el clérigo le contó al diácono/sacristán y a algún miembro más de la comunidad, que ellos eran unos padres abusivos, deshonestos, etc. Cuando los afectados objetaron dichos comentarios, el pastor lo hizo público desde el púlpito. La corte decidió que el pastor no tenía derecho a su privilegio de comunicaciones, demostrando malicia en sus actos.

De entre los tipos vistos (fraude, difamación, negligencia y abuso), el más peliagudo, es este último, pues medra significativamente la confianza y autoridad que requiere el clero para cumplir sus funciones en la comunidad (breach of fiduciary duty). Además, procesalmente hablando, es el tipo que ocasiona más situaciones de indefensión -limitando la prueba a una mera duda razonable, y no más allá de toda duda razonable, como exigen las Rules of Evidence \& Criminal Procedure-, a la vez que, adolece de mayores lagunas jurídicas -cuya integración está en manos del construccionismo voluntarista judicial. Entre las múltiples dudas que se suscitan en su admisión de causa, los tribunales discrepan acerca de: ¿cuál es el plazo, si lo hay, 
para presentar una reclamación así? ${ }^{451}$ ¿Hasta qué punto los supuestos que se plantean son debidos a la descomposición del sistema por el abuso de privilegios del clero (breach of fiduciary duty) o, por el contrario, resultan un choque cultural generacional fruto de la corrección política? ¿Dónde está el límite entre una observación sobre la vestimenta, por razón de pudor para ámbitos religiosos (o el uniforme para centros sociales), frente a una causa de abuso? et al.

A diferencia de los tipos y causas vistos hasta ahora (casos contra el clero y las iglesias), se ofrece para terminar una serie de casos relativos a litigios en defensa de dichos sujetos jurídicos: son supuestos en los que ya no se va judicialmente contra el clero y las iglesias, sino que éstos son objeto de protección jurídica, reconociéndose así su importante labor social y espiritual. Otra diferencia es, que ya no resulta necesario un seguro de responsabilidad que se haga cargo de la defensa legal, sino que esta misma la asume el Ministerio Fiscal (con políticas como The First Freedom Project [Proyecto Primera Libertad], vid. infra epígr. 4.4 y 7.3). Para simplificar la exposición, se sintetiza la miscelánea eclesiasticista existente -cuyo incremento de figuras ha llevado un ritmo muy intenso, tanto por parte del Congreso como por la Presidencia-, repartiéndose dicha nueva preceptiva entre tres bloques básicos, según el tipo de litigio resultante: a) los casos de discriminación religiosa; b) los casos de delitos religiosos; c) los casos de protección de la autonomía religiosa.

\footnotetext{
${ }^{451}$ Existen tres teorías al respecto: a) Discovery theory [teoría del descubrimiento], donde los plazos no empiezan a correr hasta que el demandante no se da cuenta de que ha sido objeto de abusos; b) Tolling of the statutory period during the child's minority [instrumentalización durante el periodo de minoría de edad], donde los plazos corren desde que ocurren los hechos hasta un margen oscilante entre los 18 años y los 21, que ya se es completamente adulto; c) Equitable (or fairness) theory [teoría de la razonabilidad], donde los dependen de la gravedad de los hechos y sus consecuencias. Vid. TAYLOR, T.F.: 7 Deadly Lawsuits. How Ministers can avoid litigation and regulation, Nashville: Abingdon Press, 1996, o. c.. 59 ss.
} 
a) Casos de discriminación religiosa: se trata de aquellos supuestos ya abordados al estudiar la normativa de desarrollo para la protección y garantía del AAII, a través de la libertad religiosa (en conexión con el resto de derechos y libertades). Entre los casos a los que el Fiscal General, en su Proyecto Primera Libertad, ha prestado un especial cuidado, han sido la discriminación religiosa en materia educativa, laboral, de vivienda, crediticia y de acceso a facilidades públicas, etc.

b) Casos de delitos religiosos: no son tipos penales autónomos -como lo pudiera ser años atrás la blasfemia-, sino que se trata de causas de especialidad de tipos comunes, operando en buena parte de los casos como agravante del delito. Dicha condición de agravante, no es fruto de la propia naturaleza religiosa por sí misma, sino por la valía concedida por la Fiscalía, que puede alegar obstrucción a la justicia, al vulnerarse una prioridad de objetivos (vid. supra The First Freedom Project, más cap. 10 ${ }^{452}$-esto es, los delitos contra personas y propiedades de carácter religioso, no lo son tanto por su naturaleza religiosa, sino porque se trata de un objetivo prioritario actual de las Fiscalías (Federal y Estatales), junto con la Sección Criminal de la División de Derechos Civiles del Departamento de Justicia. Pues bien, entre los casos más recientes y notables ${ }^{453}$ acerca de crimes against persons and property based on religion [delitos contra personas y propiedades de carácter religioso -en Europa continental se califica de delitos de odio o contra los sentimientos religiosos-], la Sección Criminal de la División de Derechos Civiles ha impulsado la tramitación de los siguientes:

\footnotetext{
${ }^{452}$ Cfr. Título 18, seccs. 241 y 245, del U.S. Code.

${ }^{453}$ De ahí que aún carezcan de las notas de registro de otros casos ya compilados, pues algunos están pendientes de resolución firme.
} 
- U.S. v. Ried (2007), donde una mujer mandó una nota de amenazas a su supervisora, por ser musulmana, solicitándose por ello un año de prisión y 100.000 dólares de fianza.

- U.S. v. Laskey, et al. (D.Or. 2006), donde un grupo de supremacía blanca, lanzó rocas a una sinagoga durante la celebración de un servicio, pidiéndose quince meses de cárcel por ello.

- U.S. v. Nunez-Flores (W.D. Tex. 2005), donde un hombre lanzó un cóctel molotov a una mezquita de El Paso, pidiéndose contra él una pena de prisión de 171 meses.

- U.S. v. Dropik (E.D. Wis., W.D. Mich., 2005), donde un sujeto, por odio a los afroamericanos, quemó dos de sus iglesias, por lo que se pidieron 63 años de condena.

- U.S. v. Bryant and Martin (W.D. Va. 2004), donde dos hombres fueron acusados de vandalismo contra dos iglesias históricas afroamericanas, recibiendo por ello una condena de 27 y 21 meses respectivamente; etc.

c) Casos de autonomía religiosa: se entiende por tales, ya no aquellos supuestos en los que se defendía la independencia de esferas para la resolución de conflictos en los que se hallara inmerso un clérigo o una iglesia -donde un tribunal civil renunciaba a conocer, por considerarse competencia de uno eclesiástico o por aplicación del privilegio de caridad; se hace referencia ahora, a los supuestos actuales de protección de la libertad religiosa cualificada del clero y las iglesias, en relación con el uso del suelo y las relaciones con organismos públicos de internamiento (v.g. cárceles, sanatorios psiquiátricos). Como se viene señalando, 
desde la década de 1990, se ha producido un aumento considerablemente en el número de leyes orgánicas sobre la religión (v.g. Restauration Act, MOMA, IRFA). Entre ellas, a la que ha apelado la Fiscalía, para sus fundamentar sus intervenciones, ha sido la Religious Land Use and Institutionalized Persons Act of 2000 [Ley sobre el uso religioso del suelo y para las personas internadas], distinguiéndose dos tipos de actuaciones realizadas:

- Sobre la libertad religiosa en el uso del suelo: la línea de actuación seguida por la Sección de Vivienda y Promoción Civil (de la División de Derechos Civiles), tras revisarse más de ciento treinta casos e investigar más de treinta, ha sido la de promover los derechos de las minorías religiosas para que también puedan disponer de sus espacios públicos. Así se desprende de Albanian Associated Fund v. Township of Wayne (New Jersey 2006); U.S. v. City of Hollywood (Florida 2005); U.S. v. Village of Airmont (New York 2005); etc.

- Sobre la libertad religiosa en las personas internadas: la línea de actuación seguida por la Sección Especial de Litigación (de la División de Derechos Civiles), en aplicación de la Religious Land Use and Institutionalized Persons Act y la Civil Rights Institucionalized Persons Act, ha sido la de priorizar el respeto de la libertad religiosa de aquellas personas internadas, frente a las políticas de gobierno de dichas instituciones (v.g. prisiones, psiquiátricos, centros de menores). Los últimos casos tramitados -conforme al corte temporal aclarado sobre la jurisprudencia en el epígr. 5.2.2 y en este capítulo- han sido U.S. v. State of Mississippi (por los abusos en Oakley and Columbia Training Schools, en 2005); U.S. v. State of Arkansas (por los abusos en Alexander Youth Services Center, en 2005); etc. 


\section{B2) Régimen jurídico de religiones nativas amerindias}

Cuando se alude a nativos amerindios o indios americanos, se hace referencia -conforme a documentos oficiales históricos estadounidenses- a indios nativos continentales -también naciones indias o pieles rojas (denominación última suprimida por considerarse políticamente incorrecta, vid. cap. 4)-454, más los indios nativos insulares (de Hawái) y peninsulares (de Alaska). Tal concepción se mantuvo hasta el censo de 1990, no representando los nativos amerindios más del 1,2 \% de la población estadounidense, variando a partir del año 2000, con las ayudas por reparación, y desde el año 2010 se ha dejado la elección de categoría al ciudadano (no basándose tanto en criterios raciales, sino por inclusión en prácticas religiosoculturales, vid. supra) -dicha práctica correctiva se ha extendido a otros grupos de población como los latinos (descendientes de latinoamericanos en los EE.UU.), quienes dejaran de ser hispanic, para poder optar entre diversas expresiones racionales-. De igual manera -y tal como ya se aclarara en el cap. 4-, es de destacar la falta de reconocimiento jurídico específico de los indios nativos (pese a los tratados de paz y reserva con las Naciones Indias y la Federación en el s. XIX), siendo necesario el esperar hasta la década de 1960, y sobre todo a partir de la década de 1990 para que se produzca una regulación propia de la singularidad india, con sus derechos y libertades, incluida la religiosa (que se proyecta a casi todos sus derechos políticos y civiles, así como económicos y sociales). Tal mérito, de influjo en la

\footnotetext{
${ }^{454}$ Entre las naciones indias históricas, cabe destacarse: a) zona de bosques, Delawares, Iroqueses, Creek, Cherokees, etc.; b) zona de praderas, Dakota Siux, Cheyenes, Comanches, Crow, Iowa, etc.; c) zona de llanuras del sur, Navajos, Apaches, Navajos, etc.; d) zona rocosa, Ute, Salinan, Modoc, etc.; e) zona norpacífica, Chinook, Nootka, etc. Vid. LEMARCHAND, P. (dir.): Atlas de Estados Unidos. Las paradojas del poder (trad.), Madrid: Acento Editorial, 1999. YAPP, N.: El milenio norteamericano. Mil años memorables de logros y acontecimientos (trad.), Colonia: Könemann, 2000.
} 
opinión pública y a la postre en la agenda institucional (con sus políticas públicas y regulación correspondiente) se lo han atribuido desde la universidad los propios Estudios Culturales reformulados tras las guerras culturales. Dicha nueva variante de Estudios Culturales, sin ser necesariamente de corte neomarxista, sí ha potenciado un giro hermenéutico contracultural: de la integración racional ilustrada, a la diferenciación emocional poscolonial (vid. infra cap. 4). Se pasa así de la atención racial, como minoría reprimida, a la exaltación de una supuesta singularidad religioso-cultural -por tal razón, sólo se presta atención al periodo de eclosión, puesto que la regulación correspondiente, como pasara con las sentencias relativas al factor religioso (vid. infra figuras de este capítulo), ha aumentado el volumen con el reconocimiento de las iglesias de amerindios-. Para un mayor ahondamiento en la cuestión se remite a lo visto en la Parte de desarrollo general.

\section{Revisión de las áreas temáticas}

La áreas temáticas elegidas, no han sido tratadas de modo exhaustivo, sino esquemático e ilustrativo (remitiéndose para un mayor ahondamiento al cap. 10). Se proporciona seguidamente el conjunto de rudimentos necesarios para conocer cómo se revisan y reformulan las áreas temáticas, a modo de una red de redes de cuestiones entrelazadas, de carácter interdisciplinario y de gran complejidad, de ahí que se recurra a un tipo de estudio de caso holístico y difuso -así se definen las nuevas áreas revisadas-: se trata de combinar desde la epojé y la mayéutica, pasando por la analítica política y la crítica cultural, hasta llegar a la polemología social 
(problem method), sin dejar de prestar atención al enfoque prioritario, que es el jurídico (conforme a unos fundamentos de derecho, que guían el resto de la argumentación y evidenciación del caso correspondiente).

\section{A) Estudios domésticos: libertad religiosa y políticas federales}

Téngase en cuenta que la religión en los EE.UU. (debido a su concepción más secular, vid. infra cap. 5 y 6) pasa a ser la clave para lograr la salvación a través del mundo, lo que contribuye al impulso de un Estado social de base particular o social gospel [evangelismo social -algo así como la versión protestante de la doctrina social católica-]. La idea es que la asistencia social comunitaria la proporcionen asociaciones locales, en su mayoría religiosas -siguen siendo las únicas que prestan un servicio de voluntariado, que a diferencia del cooperante de ONG, es gratuito-. Por tal motivo, buena parte de la regulación sobre la materia está compilada en el Título 42 del U.S. Code, cuyo rótulo es de la Salud y Bienestar Público. Así se constata del listado de más de cien actividades que en tal sentido vienen desarrollando el clero, los religiosos, las iglesias y sus entes dependientes, de entre las que se destacan las siguientes (por ser la más populares): a) actividades y servicios (v.g. adopción y acogida, orfanatos, centros de asistencia, programas de alimentación a indigentes); b) organizaciones y actividades patrocinadas (v.g. colegios, institutos, universidades, bibliotecas); c) bienes y productos ofrecidos por las iglesias (v.g. libros, revistas, documentales); d) actividades recreativas y sociales (v.g. grupos de 
teatro, clubes de hombres y de mujeres, campamentos de verano); e) organizaciones afiliadas (v.g. tiendas de objetos religiosos, conventos, cementerios); et al.

Por tanto, debido al gran peso que tienen las confesiones en la implementación local de las políticas sociales, se entenderá que se haya seleccionado el tratamiento de los dos siguientes supuestos, por su amplio alcance de cuestiones socio-religiosas comprendidas, además de mostrar cómo interactua el Ejecutivo Federal con los poderes locales y la sociedad civil, a través de un entramado de Sector Público tanto institucionalizado propio (caso de la Fiscalía General), como por vía delegada (caso de FBO). Ambos supuestos evidencia igualmente una lectura de inversión de las interpretaciones clásicas de las cláusulas de la Primera enmienda de la CEU sobre libertad religiosa (free exercise $\mathcal{E}$ (no)establishment, vid. infra cap. 6, más supra cap. 10) -causando con ello, no sólo cierta discriminación, sino además una creciente brecha en el tan cacareado muro de separación (wall of separation), vid. idem-.

Se insiste en que aquí sólo se ofrece un avance esquemático de los contenidos que se detallan posteriormente.

\section{A1) Estudio de caso 1: Organizaciones basadas en la comunidad y la fe (Faith-based \& Community Organizations/Iniciatives - FBOs)}

Consideraciones preliminares: la política social de las Administraciones W.BUSH -como ya se mencionara- es heredera del impulso intervencionista 
federal de los programas iniciados por CLINTON (v.g. Charitable choice, International Religious Freedom Monitoring, No child left behind) ${ }^{455}$, sólo que con un sesgo discursivo neoconservador. En términos más específicos, ello aclara la paradoxología manifiesta en torno a las políticas públicas de W.BUSH, pues pese a tratarse de un republicano y evangélico converso, sus programas federales de intervención comunitaria, en realidad, son vías de financiación de Faith-based $\mathcal{E}$ Community Organizations/Iniciatives [organizaciones/iniciativas basadas en la fe y (el servicio a) la comunidad] (FBOs). Con esta denominación eufemística, se está haciendo referencia a las organizaciones e iniciativas religiosas, especialmente, a aquellas variedades surgidas del último despertar religioso (frente a las well-established) ${ }^{456}$, y cuyos fieles conforman buena parte de la base electoral de W.BUSH. Formuladas las debidas aclaraciones preventivas y contextualizadoras, a continuación, se procede a una breve y expeditiva presentación de las FBOs, abordándose cuestiones como: a) ¿en qué consiste y qué relación se tiene con la Casa Blanca?; b) ¿qué regulación le atañe?; c) polémicas y aporías.

\footnotetext{
455 Como se ha mencionado con anterioridad, los programas de organizaciones basadas en la fe de W.BUSH, parten de la Welfare Reform [reforma del Estado de bienestar] de las Administraciones CLINTON, a través de la Charitable Choice (implantada por leyes como The Personal Responsability and Work Opportunity Reconciliation Act of 1996, así como, programas del tipo de Temporary Assistence to Needy Families, Community Services Block Grant, etc.). La diferencia estriba en que, mientras el objetivo inicial de la primera etapa de las políticas públicas de CLINTON, se pretendía dotar de fondos públicos a las ONGs -haciendo la competencia excluyente a las iglesias-, con W.BUSH, se eliminan las restricciones tradicionales, al acceso a fondos públicos, para las organizaciones de fe con actividades de promoción comunitaria. Vid. DAVIS, D., HANKINS, B. (eds.): Welfare reform \& Faithbased organizations, Waco: Baylor University Press, 1999. EDWARDS, G.C.: Governing by campaigning. The politics of the Bush Presidency, New York: Pearson, 2007.

456 Por faith groups [grupos de fe], se entienden aquellas variedades religiosa más recientes e informales, surgidas del último despertar religioso en los años 1960. Dicha terminología se adopta en oposición a las well-established religious denominations [confesiones religiosas bien establecidas criterio parecido al notorio arraigo en España-], que refiere al resto de organizaciones religiosas.
} 
Significado y alcance: FBOs constituye un conjunto de programas de actuación social, calificado por el propio Presidente W.BUSH como "una de mis más importantes iniciativas (...) para ensalzar la gran compasión estadounidense, mediante unos EE.UU. con un corazón, un alma, y una conciencia al mismo tiempo"457. Partiendo de la reforma del Estado de bienestar iniciada por CLINTON con el conjunto de programas Charitable choice, el Presidente W.BUSH, recondujo las ayudas previstas, incrementándolas, y donándolas a organizaciones locales basadas en la fe y el servicio comunitario -bajo la excusa de acercar la Administración al ciudadano, sin necesidad de niveles intermedios, evitándose así una excesiva burocracia y su papeleo, el llamado goteo de fondos, etc. Para vertebrar el sistema, el Presidente W.BUSH, en el año 2001 nombra como Director de la Oficina de la Casa Blanca para FBOs a J. TOWEY sustituido en 2006 por J.F. HEIN, quién además ocupa el cargo de Vicesecretario del Presidente-, sirviendo de enlace con unos ciento cincuenta programas en curso de otros Departamentos (v.g. Agricultura, Comercio, Educación, Salud y Servicios Sociales, Vivienda y Desarrollo Urbanístico, Justicia, Trabajo, Asuntos de Veteranos, Administración de Pequeños Negocios, etc.), y gestionando la concesión de más de mil programas de ayudas y becas (con un presupuesto de cientos de millones de dólares). Todas estas ayudas están abiertas a la solicitud de cualquier organización con actividades de promoción social y bienestar general (v.g. caridad, educación, salud, ayuda a minusválidos). No hay fondos exclusivos para las organizaciones basadas en la fe -salvo pequeños programas algo más específicos, como Compassion Capital Fund [Fondo de capitales para la

\footnotetext{
${ }^{457}$ Cfr. VV.AA., Guidance to Faith-based and Community Organizations on Partnering with the Federal Government, Washington DC: White House, 2001, pp. 2.
} 
compasión]-. El conjunto de las ayudas está abierto a la solicitud de cualquier organización y/o iniciativa con vocación de ayuda a los demás o contribución al bien común, por lo que igualmente podrían postularse las ONG -tal como se preveía originalmente, para desplazar a las confesiones, sólo que las ONG y su supuesta profesionalización, con su burocracia correspondiente, complican el acceso a los fondos-. La fiscalización de las ayudas concedidas se realiza a través de un procedimiento de cinco pasos: (1) Paso 1, informes financieros: se exige cumplimentar el Standard Form 269 [formulario tipo 269], que asegura estar al corriente de los pagos tributarios y de la adecuada situación financiera. (2) Paso 2, co-patrocinio: no es un requisito obligatorio para todas las ayudas, pero sí bastante frecuente. Consiste en pedir datos de las otras organizaciones que también contribuyen a financiar el proyecto. (3) Paso 3, custodia de documentación: se pide al receptor de la ayuda, que guarde la documentación presentada, así como las facturas de los gastos, durante un periodo aproximado de tres años (v.g. si se recibe la ayuda en 2003, hasta 2006, entonces, es necesario guardar la documentación hasta 2009). (4) Paso 4, notificación periódica: mientras se reciba la ayuda, existe el deber de informar periódicamente, en los plazos fijados para cada convocatoria, dando detalle de la evolución del proyecto, con sus gastos, sus resultados, etc. (5) Paso 5, auditoría: por la recepción de los fondos públicos, la Administración se reserva el derecho de auditoría. Normalmente, para fondos inferiores a 500.000 dólares, se suele permitir la auto-auditoría de la organización receptora de la ayuda; para más de 500.000, habitualmente, se solicita a la organización que contrate a un auditor externo; para cuantías mayores, es la propia Administración la que audita. 
$>$ Regulación: ésta es una regulación de desarrollo de rango diverso (vid. cap. 5 y 10), ya que comprende desde Órdenes/Decretos Ejecutivos Presidenciales, pasando por Leyes Parlamentarias y Reglamentos Departamentales / Ministeriales, hasta Órdenes de Agencias autónomas: (1) Executive Orders [Órdenes / Decretos Ejecutivos Presidenciales] (E.O.): E.O. 13397, para la creación de un nuevo centro para FBOs en el Departamento de Seguridad Nacional (7 de marzo de 2006); E.O. 13280, para exigir una igual protección para FBOs (12 de diciembre de 2002); E.O. 13199, para la creación de la Oficina de la Casa Blanca para FBOs (29 de enero de 2001); E.O. 13198, para la creación de cinco centros para FBOs (29 de enero de 2001); etc. (2) Public Acts/Bills [Leyes orgánicas y ordinarias]: Charity Aid, Recovery, and Empowerment Act of 2002 [Ley de ayuda a la caridad, la recuperación y su vinculatoriedad]; Savings for Working Families Act of 2002 [Ley de ahorros para las familias trabajadoras]; etc. (3) Final Rules [Reglamentos Departamentales / Ministeriales] (F.R.): a) F.R. del Departamento de Educación: Participation in Education Department Programs by Religious Organizations; Providing for Equal Treatment of All Education Program Participants [Programas de participación en educación por las organizaciones religiosas; dándose un tratamiento igualitario a todos los participantes en los programas de educación] (4 de junio de 2004); b) F.R. del Departamento de Asuntos de Veteranos: Homeless Providers Grant and Per Diem Program; religious organizations [ayudas proporcionadas a los sintecho y programas diarios (de asistencia)] (8 de junio de 2004); c) F.R. del Departamento de Agricultura: Equal opportunity for religious organizations [igualdad de oportunidades para las organizaciones religiosas] (9 de julio de 2004); etc. 
> Polémicas: resulta de dudosa constitucionalidad el uso que a veces se ha hecho de los fondos concedidos, para actividades próximas al proselitismo (v.g. campañas de salvación de almas y de abstención sexual); al mantenimiento religioso (v.g. rezos por el bienestar general); etc. Incluso, se ha llegado a aplicar estos fondos para financiar la contratación de los seguros de responsabilidad civil, para ministros de culto e iglesias. ¿En qué afecta todo esto a la interpretación de las citadas cláusulas de la Primera Enmienda sobre la libertad religiosa? ¿Podría haber conflicto con el estudio de caso A2?

\section{A2) Estudio de caso 2: Proyecto Libertad Primera/Principal}

(The First Freedom Project)

Consideraciones preliminares: el 20 de febrero de 2007, el Fiscal General, A. R. GONZALES, pone en conocimiento de los medios de comunicación una de las iniciativas clave de su mandato, como es The First Freedom Project [Proyecto Libertad Primera/Principal]. En sus propias palabras, consiste en: "una iniciativa para preservar la libertad religiosa, lo que requiere un avanzado compromiso para proteger la más básica libertad para la gente de todo tipo de fe".

Significado y alcance: entre las medidas iniciales a adoptar, en el seno de este proyecto, el Fiscal General priorizó las siguientes: a) La presentación de un informe sobre el impulso para el cumplimiento de leyes protectoras de la libertad religiosa (con la actividad del Ministerio Fiscal, entre los años 2001 y 2006), donde se pone de manifiesto que, pese al empeño mostrado, es necesario 
dotar de más recursos, lo que conduce a la segunda medida; b) Se propone la constitución de un Departamento dependiente, cuyo director sería el ayudante del Fiscal General para la División de Derechos Civiles; c) Se enuncian una serie de primeras actuaciones complementarias de concienciación, como la celebración de seminarios regionales, la implantación de un servicio de consulta sobre discriminaciones religiosas, etc.; d) Los objetivos: Los temas prioritarios marcados, para dar un impulso "pro-activo" de la libertad religiosa y combatir la discriminación a través de "sinergias", son: a) la discriminación en la educación; b) la discriminación en el empleo; c) la discriminación en vivienda; d) la discriminación crediticia; e) la discriminación en la asistencia pública; e) Discriminación religiosa en Educación: dentro de la División de Derechos Civiles, la Sección de oportunidades educativas, en aplicación del Título IV y IX de la Ley de Derechos Civiles de 1964, se dedica a promover casos ante los tribunales para evitar discriminaciones en las aulas públicas por razón de raza, color, religión, sexo u origen nacional. Los litigios más habituales, así como sus ejemplos más recientes -de ahí que aún carezcan de las notas de registro de otros casos ya compilados-, son: (1) Harassment [acoso]: se vigilan casos de acoso religioso, especialmente, de profesores a alumnos (v.g. En Delaware School District, en marzo de 2005, hubo que proteger a estudiantes musulmanes de cuarto grado). (2) Student Religion Expressions [expresiones religiosas estudiantiles]: se vigila la discriminación en iniciativas de los propios estudiantes (v.g. un grupo de estudiantes de instituto en Massachusetts fueron suspendidos de clases por entregar caramelos con mensaje religioso) y las patrocinadas por los centros educativos (v.g. un concurso de talentos musicales, en un colegio de New Jersey, censuró una canción por ser cristiana). (3) Religious 
dress [vestimenta religiosa]: no cabe discriminación, por ejemplo, por el uso de pañuelo para la cabeza (v.g. Muskogee Public School District, fue denunciado por no permitir a una estudiante musulmana asistir a clases con el velo). (4) Equal access [acceso en igualdad (de condiciones)]: los centros públicos deben permitir a los grupos religiosos desarrollar actividades extraescolares en igualdad de oportunidades (v.g. Good News Clubs [agrupaciones de buenas noticias], son asociaciones estudiantiles que realizan actividades benéficas y para la mejora social, pero debido a su cariz religioso, no es reconocida su labor y no se les conceden espacios para sus reuniones, ni financiación, etc.). (5) Exclusion from Higher Educational Opportunities Based on Belief [exclusiones por creencias para oportunidades de educación superior]: ídem (v.g. Texas Tech University, un profesor de biología se negaba a hacer cartas de recomendación para Facultades de Medicina si el estudiante no prometía antes creer firmemente en la teoría de la evolución). (6) Religious Holidays [festividades religiosas]: deben respetarse las festividades, especialmente, si existe autorización paterna (v.g. en Indiana, un chico fue suspendido de clases por faltar varias veces al centro, debido a celebraciones religiosas, y su madre fue demandada por negligencia, por parte de las autoridades locales); f) Discriminación religiosa en el empleo: igualmente, dentro de la División de Derechos Civiles, existe una Comisión para la igualdad de oportunidades laborales, que en aplicación del Título VII de la Ley de Derechos Civiles de 1964, se dedica a promover casos ante los tribunales para evitar discriminaciones de trabajadores en instituciones públicas o de centros religiosos a sus trabajadores. Entre los litigios más recientes llevados por la Comisión (entre los años 2005 y 2006), destacan dos casos: a) U.S. v. Los Angeles County Metropolitan Transit Authority, por exigir en sus formularios de empleo 
plena disposición de horario, sin tener en cuenta el descanso sabático de los judíos o el dominical de los cristianos, etc.; b) U.S. v. State of Ohio, donde su agencia de protección ambiental no empleaba trabajadores que, por motivos religiosos, alegaban objeción de conciencia al pago obligatorio de las tasas sindicales (ya que el sindicato era pro-aborto, pro-matrimonio homosexual, etc.); g) Discriminación religiosa en vivienda: otra entidad, en el seno de la División de Derechos Civiles, es la Sección de Vivienda y Promoción Civil, en aplicación de la Fair Housing Act o Ley de vivienda digna -competencia compartida con el Departamento de Vivienda y Desarrollo Urbanístico-, que se dedica a promover casos ante los tribunales para evitar discriminaciones religiosas en la obtención de casa. Igualmente, entre los litigios más recientes, llevados por la Sección, destacan tres casos, donde los afectados, bien no pudieron adquirir su vivienda o ésta fue atacada, por razón de su fe y raza, porque se logran indemnizaciones al respecto: a) U.S. v. Hillman Housing Corporation, en New York; b) U.S. v. Altmayer, en Chicago; c) U.S. v. San Francisco Housing Authority, en San Francisco; h) Discriminación religiosa en créditos: la Sección de Vivienda y Promoción Civil, también se dedica a dar cumplimiento a la Equal Credit Opportunity Act o Ley de igualdad de oportunidades crediticias -competencia compartida con otras agencias, como el Internal Revenue Service [servicio de recaudación interna]-, dedicándose a promover casos ante los tribunales para evitar discriminaciones religiosas en la concesión o devolución de créditos (v.g. causas habituales en la práctica son: la denegación del crédito, la incorporación de cláusulas abusivas, etc. $)^{458}$; h) Discriminación religiosa en servicios públicos: una

\footnotetext{
${ }^{458}$ Tras la crisis crediticia-hipotecaria (antecedente de la crisis financiera global de 2008), esta medida del proyecto ha quedado muy difuminada. Téngase en cuenta que fue ROOSEVELT, otro Presidente demócrata y nada sospechoso de acometer recortes sociales, quien tipificara un límite al
} 
vez más, otra tarea de la Sección de Vivienda y Promoción Civil, en aplicación del Título II de la Ley de Derechos Civiles de 1964, es velar por el cumplimiento del respeto religioso en servicios públicos, como restaurantes, cines, etc. Uno de los últimos casos llevados por la Sección fue, la discriminación sufrida por un Sikh, en un restaurante de Virginia, donde le exigían quitarse el turbante para poder acceder al restaurante; i) Discriminación religiosa en asistencia pública: sin una unidad específica, la División de Derechos Civiles, de acuerdo con el Título III de la Ley de derechos civiles de 1964, puede tramitar todo caso relacionado con la falta de igualdad de trato en el acceso a las prestaciones públicas. Un buen caso ilustrativo de la materia, es el de Blanch Springs (Texas), donde un bando municipal de 2003, prohibía toda actividad religiosa en los Centros de Recreo de Mayores, no pudiendo los jubilados bendecir la mesa, cantar himnos bíblicos, etc.

Regulación: vid. fundamentos de derecho citados, más los sistematizados en los cap. 5 y 10.

Polémicas: cierto es que corresponde a los poderes públicos promover el libre ejercicio, pero no así una actitud proselitista en materia religiosa. ¿Existen indicios de discrecionalidad y/o activismo jurídico-administrativo? (vid. cap. 5 y 10).

endeudamiento familiar (en su caso, para evitar la especulación bursátil). Cuando CLINTON deroga la regulación, retirando la limitación de endeudamiento familiar, entonces es cuando se acentua la burbuja inmobiliaria. 


\section{B) Estudios foráneos: factor religioso y geopolítica}

En la década de 1990, con la Administración CLINTON se procede por fin a ratificar el Pacto de Derechos Civiles y Políticos de 1966 -uno de los principales convenios de derechos humanos de la ONU, del que los EE.UU. había sido su máximo valedor durante la Guerra Fría, y sin embargo, nunca había incorporado plenamente a su Ordenamiento interno-. De este modo, los EE.UU., pasa a ser un país de pleno derecho y participación en el sistema de la ONU para el reconocimiento, protección y promoción de los derechos humanos. Especialmente destacada es su actuación en la Relatoría de Libertad Religiosa. Sorprendentemente, es la misma Administración CLINTON la que empieza a constituir un sistema paralelo, a través de sus embajadas, nutriéndolo de recursos, hasta que de pronto, salta el escándalo sexual, se termina la legislatura y comienza su andadura la Administración W.BUSH, que hará un excesivo uso del sistema IRFA -se trata de una reproducción del mismo problema que tuvo lugar con el ámbito doméstico con el sistema FBOs, por ejemplo-.

\section{B1) Estudio de caso 3: Ley de libertad religiosa internacional}

(The International Religious Freedom Program - IRFA, vid. infra cap. 4 y 7)

Consideraciones preliminares: como se viene señalando, con la caída de la URSS y durante buena parte de la década de los 90, en los EE.UU. se barajan diversas opciones legitimadoras de su intervención exterior (v.g. contención del narcotráfico, del terrorismo, del subdesarrollo y de la inmigración de los Estados 
fallidos). De entre las mismas, finalmente, llega a destacar la promoción y protección de la libertad religiosa, entendida como un pilar de los derechos humanos y la democracia. Bajo tal argumentario, se revitaliza así un mesianismo que, tras los atentados del 11/S, da lugar a una intensificación de un juego geopolítico de carácter religioso-cultural. Pues bien, del estudio de uno de los primeros instrumentos legitimadores (la Ley de libertad religiosa internacional y su sistema operativo), y de la comprensión de la deriva hacia un juego geopolítico netamente religioso-cultural, es de lo que versa este punto, permitiendo la observación de la actual lógica de transnacionalidad del Derecho estadounidense.

Significado y alcance: se trata de una ley pública, comparable con las leyes orgánicas de Europa-continental, cuya introducción en el parlamento federal corrió a cargo del Congresista F.R. WOLF459, el 8 de septiembre de 1997, bajo la denominación Freedom From Religious Persecution Act [Ley de libertad a causa de la persecución religiosa]. El proyecto original de WOLF pretendía la supervisión de la libertad religiosa en el mundo, con el ánimo de proteger a los misioneros estadounidenses, y de paso, a las minorías religiosas. La idea no era tan descabellada, como algunos puristas del corriente Derecho Internacional Público -dicho sea de paso, con menos de sesenta años de vigencia (la ONU)-

\footnotetext{
459 Se trata de un político de larga trayectoria, con experiencia en distintos campos, aunque hace tiempo que se centró en relaciones internacionales y derechos humanos: elegido en representación del Estado de Virginia en diez ocasiones (más de veinte años en el cargo), ha repartido su tiempo entre tres áreas políticas, como son Transportes y Telecomunicaciones (perteneciendo a los Subcomités de Comercio y Justicia, el de Estado y Judicatura, etc.), así como Derechos Humanos (sirviendo en la Comisión para la Seguridad y Cooperación en Europa, además de realizar trabajos de campo en Afganistán, China, Etiopía, Sierra Leona y Sudán -acaso, tales destinos pudieron influir en el tono de civilizing sense y self-righteousness de su proyecto de ley, y que tan bien casaban con el sentir de la doctrina Clinton del humanitarismo, además de abrir las puertas a las ansiedades preventivas neoconservadoras.
} 
clamaron ${ }^{460}$, ya que no se trataba de una ley internacional aprobada por un parlamento nacional, sino más bien era una norma trasnacional: los EE.UU., como hiper-potencia planetaria tiene intereses y ciudadanos en todo el mundo, por lo que en consecuencia con dicha lógica puede regularse tal realidad -ahora bien, cuáles son los fines no oficiales que mueven a la constitución de un instrumento así, como su sistema propio, cuando existe otro vigente al que se supone se apoya, como es la figura del relator para la libertad religiosa de la ONU; todo ello conduce a la aceptación o no del principio de buena fe, como vuelve a plantearse más adelante. Con respecto al proceso de tramitación de la IRFA, pese a su premura ${ }^{461}$, fue arduo y laborioso, no tanto en términos sustanciales ya que había una vocación unívoca de los poderes públicos, sino en lo formal, porque los matices y sellos personales suponían prestigio y poder potencial de para su interpretación implementadora. En esto, el proyecto pasó por más de una decena de Comités y Subcomités, recibiendo tres enmiendas en la Cámara de Representantes (más dos normas de apoyo para su tramitación), a las que añadir otras tres del Senado, y una última durante la votación final; de tal modo, el 9 de octubre de 1978, el Senado aprobó la norma por abrumadora mayoría (98 votos a favor, 0 en contra, 2 en blanco) ${ }^{462}$; dieciocho días más tarde, el Presidente de los EE.UU. la firmó, adquiriendo entonces la condición de ley pública. En cuanto a la estructura de la norma, la IRFA, resulta una norma

\footnotetext{
${ }^{460}$ En la línea discursiva, igualmente, resulta curioso que no se proteste frente a las cláusulas abusivas, v.g. cláusula democrática -independientemente de la pretensión moral subyacente- frente a terceros que impone la Unión Europea (UE) en sus intercambios comerciales con otros países, pudiendo rescindir dicha relación discrecionalmente sino se observan aquellas.

${ }^{461}$ Un tiempo record de un año, un mes y un día, gracias a que desde su presentación recibió el mensaje de urgencia del Comité de Reglas, lo que agilizó considerablemente su tramitación, pues de otro modo se habría demorado años.

${ }^{462}$ Vid. “US Senate Roll Call Votes 105th Congress - 2nd Session: October 9, 1998, 09:51 am”.
} 
relativamente larga, si se tiene en cuenta que se trata de un tema concreto y no se está ante una Omnibus Law [Ley de acompañamiento] de contenido y alcance variado. La IRFA consta de un preámbulo, siete títulos, dos subtítulos y cuarenta y una secciones (vid. pto. siguiente) ${ }^{463}$. Sobre el contenido stricto sensu de IRFA, cabe destacar que pese a su carácter transnacional, efectivamente, los EE.UU. se mantienen dentro del margen de sus intereses, así como de la atención a sus ciudadanos y sus recursos. Su labor de vigilancia corresponde a las embajadas estadounidenses y las sanciones a adoptar siguen afectando a la soberanía de dicho país, porque sólo operan sobre las ayudas internacionales que los EE.UU. aprueban en sus presupuestos nacionales -la gran duda, otra vez, es acerca del respeto al principio de buena fe y el de soberanía nacional-.

Regulación: IRFA ${ }^{464}$ y sus modificaciones ${ }^{465}$ (vid. infra figuras del cap. 7).

${ }^{463}$ Vid. "PL 105-292, October 27, 1998, 112 Stat 2787 UNITED STATES PUBLIC LAWS 105th Congress - Second Session Convening January 27, 1998 PL 105-292 (HR 2431) INTERNATIONAL RELIGIOUS FREEDOM ACT OF 1998": Public Law 107-228: H.R. 1646 (S. 1401): HOUSE REPORTS: Nos. 107-57 (Comm. on International Relations) and 107-671 (Comm. of Conference). SENATE REPORTS: No. 107-60 accompanying S. 1401 (Comm. on Foreign Relations). CONGRESSIONAL RECORD: Vol. 147 (2001): May 16, considered and passed House. Vol. 148 (2002): May 1, considered and passed Senate, amended. Sept. 25, House agreed to conference report. Sept. 26, Senate agreed to conference report. Approved Sept. 30, 2002. WEEKLY COMPILATION OF PRESIDENTIAL DOCUMENTS, Vol. 38 (2002): Sept. 30, Presidential statement. Public Law 105-292: H.R. 2431. HOUSE REPORTS: No. 105480, Pt. 1 (Comm. on International Relations), Pt. 2 (Comm. on Ways and Means), and Pt. 3 (Comm. on the Judiciary).CONGRESSIONAL RECORD, Vol. 144 (1998): May 14, considered and passed House; Oct. 8, 9, considered and passed Senate, amended; Oct. 10, House concurred in Senate amendments. Approv. October 27, 1998. WEEKLY COMPILATION OF PRESIDENTIAL DOCUMENTS, Vol. 34 (1998): Oct. 27, Presidential statement. Public Law 106-55: S. 1546. CONGRESSIONAL RECORD, Vol. 145 (1999): Aug. 5, considered and passed Senate and House. Approv. August 17, 1999.

${ }^{464}$ Vid. “PL 105-292, October 27, 1998, 112 Stat 2787 UNITED STATES PUBLIC LAWS 105th Congress - Second Session Convening January 27, 1998 PL 105-292 (HR 2431) INTERNATIONAL RELIGIOUS FREEDOM ACT OF 1998".

465 Pub. L 105-292, October 27, 1998, 112 Stat 2787 UNITED STATES PUBLIC LAWS 105th Congress Second Session Convening January 27, 1998 PL 105-292 (HR 2431) INTERNATIONAL RELIGIOUS FREEDOM ACT OF 1998. Pub. L. 106-31, May 21, 1999; Pub. L. 106-55, Aug. 17, 1999; Pub. L. 106-113, 
> Polémicas: varios son los puntos oscuros. Desde cuestiones procedimentales, como es el hecho de la prescripción y caducidad previstas para el Sistema IRFA (que deberían haber desaparecido buena parte de sus organismos a comienzos de la presente década), hasta otros temas de mayor fondo y calado, como es la legitimidad, validez y eficacia de la transnacionalidad del Derecho estadounidense - ¿por qué y cómo pueden los estadounidense legislar y hacer cumplir su Derecho más allá de sus fronteras? ¿Su regulación puede llegar hasta donde alcancen sus intereses y haya un estadounidense?-.

A estas áreas temáticas señaladas habría que añadir otras pujantes como las actuales, relativas a la protección de las minorías, de la bioética, etc. De modo telegráfico, se ofrecen a continuación una serie de apuntes al respecto -dejando para mejor ocasión su estudio pormenorizado-.

En cuanto a la cuestión de las minorías, es una temática peliaguda, pues supone salir del régimen de los derechos generales para todos, para entrar en la justificación de por qué un grupo se merece un trato especial. Cierto es que la noción tradicional de democracia es la del gobierno de la mayoría respetando a las minorías, sin embargo, bajo tal premisa se esconde una trampa, porque cualquier integrante de la mayoría, en realidad, se halla en desventaja frente a las minorías, que a su vez diluyen sus obligaciones y responsabilidades (como cruz de la cara de los derechos especiales propios) vía la persona moral que representa al grupo. La cuestión es que, para poder otorgar un régimen especial a las minorías, ha de responder el mismo a

Nov. 29, 1999; Pub. L. 106-246, Jul. 13, 2000; Pub. L. 107-77, Nov. 28, 2001; Pub. L. 108-6, Febr. 13, 2003; Pub. L. 108-7, Febr. 20, 2003 -la mayor parte de estas modificaciones son ajustes presupuestarios o de incorporación a instituciones afectadas por IRFA-. 
una exigencia de subsistencia del mismo grupo, y que su existencia suponga una contribución al bien común -en principio, la pluralidad es buena, pero la división y la confrontación no, luego habrá que valorar los fines y medios de dichas minorías: ¿aportan riqueza o generan tensión?-. Sin ánimo de desviarse hacia campos de la Filosofía Social (Filosofía Político-Jurídica y Moral) ${ }^{466}$, se procede a aterrizar la cuestión relativa a por qué sí se protege a unas minorías y no a otras. El estudio de caso que mejor ilustra toda esta problemática es la polémica de comienzos de la globalización: peyote v. pollo. Por motivo religioso, se permitió el consumo de estupefaciente para los indios nativos, mientras que los afro-americanos no podían sacrificar animales; para evitar un doble rasero y seguir garantizando la supremacía de la libertad religiosa, finalmente, se aceptaron sendas prácticas.

Con respecto a la bioética, se trata de un campo de por sí en expansión ${ }^{467}$. Comenzó con temas de trasplantes y trasfusiones, continuando con la eugenesia (v.g. Síndrome de Down, comenzando con casos de retraso mental severo hasta ampliarse a malformaciones), y la castración química (ídem), por la contracepción, para extenderse luego a cuestiones como la clonación, la crioestasis, la modificación genética, los bebes a la carta y/o medicamento (diseñados para curar a otros familiares), etc. Los problemas relacionados con esta área temática crecen a medida que aumenta la tecnología bio-sanitaria, pues en las fronteras es donde surgen los dilemas ético-morales. El caso es que -por duro que suene-, no le corresponde al jurista determinar lo que está bien o mal -eso es misión del filósofo especialista en ética y moral-, sino que ha de limitarse a calificar si un supuesto es conforme a

\footnotetext{
${ }^{466}$ Vid. SÁNCHEZ-BAYÓN, A.: Renovación de la Filosofía Social Iberoamericana, Tirant lo Blanch, Valencia, 2013. - Filosofía Político-Jurídica Glocal, EAE, Saarbrücken, 2012.

${ }^{467}$ Vid. SÁNCHEZ-BAYÓN, A.: “Biojurídica: ¿cuestión nominalista o epistemológica? (manifiesto para la persuasión constructiva identitaria)" (pp. 394-411), en MARTÍN, I., et al.: Bioética, Religión y Derecho, Madrid: Fundación Universitaria Española, 2005.
} 
Derecho o no. Para ello es necesario que existan unas instituciones con contenido, o sea, con términos y plazos, además de derechos y obligaciones. Ahora bien, lo que sí es clara misión del jurista es denunciar la perversión que se realice del sistema de derecho, bien por la transmutación de los delitos en derechos, la desaparición de los límites (con los términos y plazos, con sus causas eximentes, imputables, agravantes o atenuantes), todo ello fruto de fenómenos anti-jurídicos como el activismo judicial, la ingeniería social político-jurídica, los cientificismos político-jurídicos (velos de confusión técnica e ideológica), et al. En consecuencia, una buena propuesta de estudio de caso sería Casos Roe \& Doe v. W.Bush y su regulación. Con tanta amalgama, se busca la evidenciación no sólo de los dilemas bioéticos de implicaciones biojurídicas ${ }^{468}$, sino también las perversiones que se están acometiendo contra el Ordenamiento, al articularse desde una flagrante antijuridicidad (v.g. falsas acusaciones, activismo legislativo y judicial) ${ }^{469}$.

\footnotetext{
468 Vid. nota previa, más SÁNCHEZ-BAYÓN, A.: Derecho Eclesiástico Global... op. cit. - Manual de Sociología Jurídica Estadounidense... op. cit.

${ }^{469}$ Los casos Roe y Doe -pseudónimos dados a las supuestas víctimas de violación-, que sirvieran de base para la legalización del aborto en EE.UU., en la década de 1970, están basados en falsedades en ambos casos se probó con el tiempo que no hubo violaciones de extraños, ni las embarazadas estaban en peligro, si acaso por las presiones de sus abogados, más preocupados en hacer historia y apoyar causas que en el bienestar de sus defendidas-; b) la regulación de W.BUSH, tanto como Gobernador como Presidente, ha sido a resultas de casos concretos y recurriéndose habitualmente a vías excepcionales de tramitación (v.g. caso T. SHIAVO), de ahí que luego se hayan usado para otros fines (v.g. Texas Advanced Directives Act in 1999, Partial Birth Abortion Act in 2003, Unborn Victims of Violence Law in 2004). Complement., sobre activismo judicial y legislativo, vid. SÁNCHEZ-BAYÓN, A.: "Au revoir, loi de l'État: el fin del derecho estatal de bienestar", Bajo Palabra (no5), 2010, p. 143162.
} 


\section{Estudios sobrevenidos: de Cultural Studies a Cross-Cultural Studies}

Se plantea aquí la paradójica transición entre disciplinas modernas y autóctonas, de corte cultural, como los CSS y los American Studies [estudios de cultura estadounidense $]^{470}$, suplantadas hoy por autodenominados Estudios culturales, de corte posmoderno y origen exterior (sobre todo europeo-continental y latinoamericano), que nada tienen que ver con la cultura, sino con la ideología, o en su caso -como cada vez es más frecuente-, con las teorías débiles -o sea, los retazos ideológicos, combinados a modo de collage-. La paradoja se acentúa con la condición que se provoca: los Estudios culturales (sobrevenidos, tras las guerras culturales) no sirven para conocer la cultura, sino la crítica que se hace a la misma, además de darse impulso a la dispersión de lecturas marginales de la misma, por lo que al final cada cual pretende disponer de su cultura (v.g. cultura feminista, cultura afroamericana), a la vez que se niega su expresión común dominante (ni cultura vitae, ni cultus animi). Luego, al reincorporar los Estudios culturales su atención por el factor religioso, no lo hacen para conocer su impacto cultural, sino como fuerza subversiva (un poder social opuesto a cualquier otro establecido -incluso, unos pocos, pretenden recuperar y distorsionar el argumento inicial de la relación modular entre lo sagrado y lo profano-).

\footnotetext{
470 Tanto los American Studies como los CSS, han contribuido a dar forma y continuidad a la idiosincrasia estadounidense, pero como todo lo sometido a su paradoxología adaptativa (vid. vol. 1, sobre su capacidad de absorción y transformación de lo ajeno en propio), es de destacar que sendas disciplinas no dejan de ser una copia de los English Studies [Filosofía e Historia Inglesa], que a su vez son una imitación de los Humanae Studia o Departamentos de Humanidades/Filosofía y Letras Hispánicas, presentes en las principales universidades del mundo -pues la cultura hispánica, como su imperio, comprendía el marco occidental hasta el s. XVIII-. Siguiendo con la idea de paradoja, resulta curioso que los Humanae Studia estadounidenses hayan quedado reducidos hoy Estudios Latinoamericanos, en el mejor de los casos, o meros Programas de Lenguas Extranjeras Modernas.
} 
En cuanto a los Estudios Latinoamericanos y su sección Church-State patterns [asuntos Iglesia-Estado], es necesario distinguir entre la labor acometida en las universidades de los EE.UU. y en las de Latinoamérica.

a) Estudios Latinoamericanos desde los EE.UU.: sus primeros cultivadores los hacen para conocer la realidad de sus vecinos y la cultura que importan (en su inmigración). Es de destacar la labor acometida hasta mediados del s. XX, imitándose los CSS. En tal sentido sobresalen MECHAM y su Church and State in Latin America (Chapel Hill: University of North Carolina Press, 1934, revisado y ampliado 1966), o HOWARD y su Religious Liberty in Latin America? (Philadelphia: The Westminster Press, 1944). Más tarde, con la Guerra Fría y el cuarto despertar (lo que para los protestantes supone el neopentecostalismo y para los católicos la teología de la liberación y los movimientos carismáticos), comienza una labor discursiva (con velos posmodernos y cientificismos), ya en la línea de los Estudios Culturales propiamente. Entre los impulsores del giro destacan BOFF y su Church: charism and power. Liberation theology and the Institutional Church (Minneapolis: Winston Press, 1986), o las ediciones de KEOGH y Church and Politics in Latin America (New York: St. Martin's Press, 1990), PATINAYAK y Organized religion in the Political transformation of Latin America, (New York: University Press of America, 1984), PIKE y The conflict between Church and State in Latin America (New York: Alfred A. Knopf Inc., 1964), así como la colección ofrecida por Orbis Books, cuyas publicaciones mejores son las anteriores a finales de la década de 1990471. El estado actual de los Estudios

${ }^{471}$ Vid. BERRYMAN, P.: Religious roots of rebellion, Maryknoll: Orbis Books, 1984. CLEARY, E.: Crisis 
Latinoamericanos estadounidenses es el paradójico - una vez más- conforme a la expresión popular de morir de propio éxito. Esto es, gracias al boom de los Estudios Culturales (que a su vez se vieron favorecidos por la corrección política y la discriminación positiva de los años 90), aumentó exponencialmente tanto el propio contenido posible de los mismos, como el número de sus programas y su cuerpo docente, por lo que hoy existe una gran dispersión y dificultad para encontrar salida a su oferta -de ahí que para asegurar su supervivencia hoy se oriente hacia la enseñanza idiomática-. Por otra parte, es de destacar que, tras el fin de la Guerra Fría y con la globalización, tiene lugar una intensificación de relaciones con la línea de Estudios Latinoamericanos de Latinoamérica, recibiéndose profesores y obras de corte, ya no neomarxista, sino meramente posmoderno de teorías débiles. De tal suerte, en la actualidad, casi todos los manuales que se publican al respecto son readings ${ }^{472}$.

b) Estudios Latinoamericanos (desde Latinoamérica): al rechazar su propia herencia cultural, los latinoamericanos renuncian a su identidad, aceptando en su lugar las categorías fijadas por otros (v.g. clichés, roles) ${ }^{473}$. Así lo civilizados

and Social conflict, Maryknoll: Orbis Books, 1982; y un largo etcétera hasta KLAIBER, J.: The Chuches, Dictatorships, and Democracy in Latin America, Maryknoll: Orbis Books, 1998 -es una traducción, cuyo original fue publicado en español por la Pontificia Universidad Católica de Perú-.

472 Readings o lecturas, no son ya aquellas ediciones de textos selectos (fragmentos de textos clásicos para suscitar la reflexión sobre los fundamentos de la disciplina). Se trata de obras colectivas, que suelen comprender una serie de países representativos, y cuya preparación se encarga más por criterio nepótico que de auctoritas. Así se explica la relación inversa que se produce entre el aumento de estas obras y el descenso de su calidad científico-académica -tienden a compilar todos los tópicazos habidos, a un nivel de wikipedia, pues muchos de sus redactores ni siquiera han vivido en país del que tratan. Como intento compensador de tal mal-praxis, es por ello que los organismos evaluadores de la calidad científico-académica hayan dejado de valorar la elaboración de los readings y/o handbook [manuales] -lo que en realidad ha causado una aceleración del deterioro, pues es raro que hoy los grandes maestros se dediquen a dicha labor crucial-.

473 Vid. SÁNCHEZ-BAYÓN, A.: Humanismo Iberoamericano... op. cit. - Renovación de la Filosofía Social Iberoamericana... op. cit. 
decimonónicos de repúblicas igualmente soberanas -considerados incluso dandies: hombres de mundo, con capital cultural y patrimonial-474, pasan a convertirse durante la Guerra fría en países tercemundistas -algo erróneo, pues no acaban de ser descolonizados, como sí ocurre en buena parte de Africa y Asia, y su población se compone de afro-indígenas pobres y bárbaros -en vez de dandies ahora son pandilleros y guerrilleros-. Se trata de una reducción al absurd $0^{475}$, pero es que es en dicho tono y con tales estereotipos cómo se construye la producción posmoderna de los Estudios Latinoamericanos procedentes de Latinoamérica ${ }^{476}$ : una combinación de neomarxismo (heredero -en el mejor de

\footnotetext{
${ }^{474}$ Se recuerda que, dicho cliché de dandies se mantuvo hasta las guerras culturales (v.g. el adinerado personaje Ricky Ricardo del programa televisimo con más éxito de la década de 1950, como fue I Love Lucy. Durante las guerras culturales y el influjo posmoderno de los Estudios culturales latinoamericanos, se abandona la tradición occidental recibida de la Península Ibérica, para aceptar la etiqueta indigenista, favorecedora del discurso segregador de las Américas: la anglosajona protestante, de éxito, y la mediterránea católica de fracaso, vid. infra.

${ }^{475}$ Evidentemente, el tono es de denuncia, pero los elementos y discursos están sacados de la realidad cotidiana: claro que habrá excepciones notables y honorables, el problema es que sus casos ya no son la regla general, sino la excepción. Para ahondar en las paradojas y confusiones, vid. Humanismo Iberoamericano... op. cit., Renovación de la Filosofía Social Iberoamericana... op. cit.

476 Se pasa de las últimas iniciativas humanistas autóctonas -que ya empiezan a demostrar contagios ideológicos (v.g. socialismo, nacionalismo)-, las cuales aún buscan dotar de un significado y sentido propio para Latinoamérica, tal como intentaron los grandes maestros regionales modernistas: a) mexicanos como J. VASCONCELOS, A. CASO, A. REYES, A. NERVA, S. RAMOS, P. HENRÍQUEZ UREÑA -aunque de origen dominicano-, L. ZEA, influidos todos ellos por J. SIERRA y G. BARREDA); b) venezolanos como P.E. COLL, M. DÍAZ, C. ZUMETA, R. GALLEGOS, M. PICÓNSALAS, J.R. POCATERRA, A. USLAR-PIETRÍ); c) rioplatenses y sureños como A. ARDAO, C.O. BUNGE, D.F. SARMIENTO, E. MARTÍNEZ ESTRADA, J.F. RODÓ, A. ROA BASTOS); d) centroamericanos y caribeños como E.M. de HOSTOS, J. MARINELLO, R. DARÍO, A.C. SANDINO); -y el foco más tardío- e) peruanos como J.C. MARIÁTEGUI, M. GONZÁLEZ PRADA, F. MIRÓ, A. SALAZAR BONDY). Sin embargo, por renuncia de aquello, termina imponiéndose el influjo neomarxista -y por tanto, el triunfo de los neobárbaros-, tal como se irradia desde iniciativas como el Grupo Hiperión (Facultad de Filosofía y Letras de la UNAM), la Unión de Universidad de América Latina o el Centro de Estudios Latinoamericanos Rómulo Gallegos (en los años 60 y 70), los nuevos centros y estudios latinoamericanos reconocidos por la UNESCO (desde 1977, supervisándose desde la UNAM y su Centro Coordinador y Difusor de Estudios Latinoamericanos), etc. Hoy es un totum revolutum de teorías débiles sin dirección compartida.
} 


\section{los casos- de la Escuela de Frankfurt, Normale-Annales y Birmingham) ${ }^{477}$ y crítica}

${ }^{477}$ Se alude así a la fuga de cerebros resultante de las Guerras mundales, que encontraron su acomodo en los medios de comunicación y la universidad estadounidense, creyéndose que convendría su crítica posmoderna a Europa (fortaleciéndose así el liderazgo estadounidense), cuando el resultado ha sido la extensión de la posmodernidad a EE.UU. Entre las escuelas citadas, cabe destacar los siguientes aportes relacionales: 1.- Escuela de Frankfurt, en realidad, Instituto de Investigación Social (1923, asociado a la Univ. Frankfurt y financiado por la familia WEIL), que con el auge nazi y durante la II Guerra mundial se traslada a EE.UU. (como Nueva Escuela de Investigación Social-NEIS), vinculándose a la Univ. Columbia (1934), para trasladarse en los años 40 a la de California (patrocinados por Scientific Division of the American Jewish Committee y su edificio de Pacific Palisades fue llamado por T. MANN la California alemana dada la fuga de cerebros recibido y reubicados), hasta su regreso en 1951; en ese periodo, su revista sigue escribiéndose básicamente en alemán (bloqueándose así el Americaness), y despuntan HORKHEIMER (investigador en varias universidades estadounidenses y think-tanks, compaginando luego su cargo de Rector de Frankfurt con la posición de profesor visitante en la Univ. Chicago), ADORNO (investigador de Princeton y colaborador de OSS/CIA -con el austriaco LAZARSFELD y su programa de propaganda y control social-, y en los años de California se proyecta sobre Hollywood, gracias a su amistad con otros exiliados, v.g. CHAPLIN, LANG, EISLER), y MARCUSE (igualmente, investigador de varias universidades -en Columbia fue muy amigo de WRIGHT MILLS-, colaborador de OSS/CIA, y ya como profesor en California, influyó en los líderes de New Left, v.g. BROWN, DAVIS, MOORE, HOFFMAN, RUBIN); de pensamiento neomarxista (conectando filosofía y psicología, más sociología y comunicación), se critica la democrática sociedad capitalista (por su condición de masa y consumista), trasplantándose la lucha de clases a la de generaciones (baby-boomers v. great gen.). 2.Normale-Annales: toma su nombre de dos instituciones que vertebran su pensamiento, como son la Escuela Normal Superior-ENS y la revista Annales (v.g. BRAUDEL, FEBVRE, LEVI-STRAUSS, SARTRE, MORIN, DERRIDA, BOURDIEU), donde se combinó nacionalismo y socialismo, para inculcar una formación de cuadros e intelectuales públicos con un sentido progresista de la historia francesa (BRAUDEL consiguió la financiación de las fundaciones Rockefeller y Ford para repatriar la fuga de cerebros y constituir así la sección VI de École pratique des hautes études/PSLU: primero en New York como Escuela Libre de Altos Estudios, 1941-46, posteriormente en París como Escuela de Altos Estudios en CC. Sociales, manteniendo secciones en las universidades de New York, Columbia, California, etc.); se tejen por esta vía velos de confusión diversos (v.g. existencialistas, estructuralistas, posestructuralista, posmodernos), aprovechándose sucesos como mayo del 68, guerras del Sudeste asiático (la vieja Indochina: Corea, Vietnam, Laos, Camboya -de ahí la firma del tratado de paz en París). 3.- Birmingham, en realidad, Centro de Estudios Culturales Contemporáneos (1964, en Univ. Birmingham), liderado por HALL, WILLIAMS, HOGGART y THOMPSON, todos ellos autores entre el neomarxismo y posmarxismo, preocupados por la hegemonía cultural (focalizándose en GRAMSCI, combinado con la Escuela de Frankfurt, vid. infra), así como medios de comunicación y la cultura popular, influyendo en gran medida en los ECS, Dptos. Antropología, Comunicación, etc. 4.- Otras escuelas diversas (formadas con la fuga de cerebros): Escuela Psicosocial (Gestalt), con el polaco-alemán K. LEWIN en la Univ. Iowa y MIT, y el checo-alemán M. WERTHEIMER (colaborador de la Escuela de Frankfurt en NEIS, vid. infra), junto con sus discípulos KÖHLER y KOFFKA (también de origen alemán y nacionalizados estadounidenses), monopolizaron durante los años 50 y 60 la American Psicologist Asociation-APA; Escuela de Palo Alto (o Colegio invisible), con el científico 
literaria-ergo, prima la ideología y la poética sobre la realidad-. Así se genera un confuso glosario, basado en un neolenguaje críptico -o sea, de velos posmodernos y cientificismos-, con expresiones tales como: estudios poscoloniales, otredad, la raza, etnicidad, deconstrucción, indigenismo, literatura testimonial, memoria histórica, boom y post-boom, etc. En cuanto al tratamiento del factor religioso, durante la época neomarxista (en la Guerra Fría), se acometió en oposición abiertamente hostil- a la religión, en especial, con respecto a la Iglesia Católica, salvo una línea que brotó de la misma, como fuera la teología de la liberación -un cristianismo contagiado de ideología (socialista y nacionalista), vid. infra cap. 5 y 6-. En la actualidad, cuando sólo subsisten las teorías débiles, la lectura religiosa se hace en clave anti-occidental, o sea, pro-islamista, indigenista, etc. En cuanto a la situación de los Estudios, es aún más problemática que en los EE.UU., pues las lecturas son tremendamente personalistas -ni siquiera hay intentos de readings, sino que se atiende a modas, y cada cual da su opinión en el momento; sin embargo, en esa capacidad creadora de opinión radica su oportunidad de subsistencia, por encontrar acomodo en ciertos gobiernos -478 .

social británico BATESON (uno de los maestros del movimiento transpersonalista del austriaco y residente en EE.UU., CAPRA y el psicólogo WILBER), junto con el psicólogo austriaco WATZLAWICK, más el psiquiatra estadounidense JACKSON (uno de los primeros de EE.UU., integrante de Mental Research Institute y colaborador de agencias gubernamentales en programación neuroconductual), el antropólogo estadounidense HALL (próximo a la Escuela de Birmingham, impulsor de Estudios Nativo-americanos) y el sociólogo canadiense GOFFMAN (heredero del interaccionismo simbólico, vid. infra); sin olvidar los Orientalistas -o mejor dicho los poscolonialistas y anti-occidentalistas- como el británico-palestino E. SAID (impulsor de Estudios árabe-americanos, quien se aprovechara del pensamiento descolonizador de F. FANON, como lo hiciera SARTRE en París) y la británica-india G.C. SPIVAK (ambos formados en universidades de Ivy League y profesores en Columbia), el británico-indio H.K. BHABHA (profesor en Princeton, Chicago y Harvard -donde dirige el Centro de Humanidades, pese a que sus discursos son robóticos), R. TAKAKI (hawaiano de origen japonés, impulsó los Estudios asiático-americanos en California-Berkeley -con profundos problemas mentales, que provocaron su suicidio-), et al.

${ }^{478}$ Vid. SÁNCHEZ-BAYÓN, A.: “Revitalizaciones religiosas postmodernas en América y sus riesgos 


\section{Nuevas tendencias: (Cross-) Cultural Communication Studies (CCS)}

\section{(Cross-) Cultural Communication Studies o Estudios de Comunicación (inter-)}

Cultural resultan una suerte de estudios pluridisciplinarios, menos teoréticos que la mayor parte de los Estudios Culturales, y sí más inductivos, tal como fueran los pretéritos estudios de corte cultural (v.g. American Studies, CSS): luego, no parten de una cosmovisión interpretativa de la realidad, sino más bien al contrario, buscan descubrir las conexiones ocultas que afectan a los procesos de culturización y los transculturales.

Para acometer tales descubrimientos, en su seno se combinan enfoques y técnicas de investigación de diversas Ciencias Sociales y Humanidades, aunque finalmente se reconduce todo ello al campo de las pujantes Ciencias de la Información, Comunicación, Cibernética y Redes ${ }^{479}$. En su estudio, se presta atención al juego de múltiples interacciones (en una sociedad-masa/masiva de redes telemáticas, como es la estadounidense), acaecidas entre la religión, la cultura y la comunicación, y su

para la democracia y los derechos humanos", en Revista General de Derecho Canónico y Derecho Eclesiástico del Estado-Iustel (nº 11), mayo 2006.

${ }^{479}$ El número de Departamentos de Periodismo y Comunicación en las universidades estadounidenses va en aumento, de forma progresiva en la última década y media, como reflejo de una creciente demanda formativa en temas sobrevenidos de comunicación sociocultural e intercultural. A comienzos de la década de 2000, ofertaban tales estudios -de manera seria y continuada- más de ciento veinte universidades públicas y cincuenta privadas - pertenecientes a la ya citada Ivy League (y sus aspirantes más serios). Por entonces se encontraban en evaluación, al respecto, buena parte de los centros académicos integrantes de TRACS, procediendo en la segunda mitad de la década pasada a su incorporación en la materia, de manera vigorosa, pues se considera la misma una cuestión clave para la creación de opinión pública -y por tanto un objetivo a dominar por sus think-tanks, donde se gestan buena parte de los discursos actuales-. 
proyección en los medios ${ }^{480}$. Entre las diversas propuestas más recientes -al menos, en su revisión de fórmulas- ${ }^{481}$, destacan por sus sugerentes temáticas los trabajos de CLARK y HOOVER (sobre la gestión, por los medios, de las manifestaciones de la religiosidad moderna) ${ }^{482}$; HANGEN, HENDERSHOT, MORGAN, NORD y SCHMALZBAUER (acerca del recurso religioso-propagandístico de los medios) ${ }^{483}$;

480 Dichas relaciones (entre religión, cultura y comunicación), versan sobre macro-áreas de conocimiento, como la generación y la difusión civilizatoria occidental, además de abordar una serie de micro-áreas, del tipo de: a) el papel de la comunicación social en la promoción del diálogo interreligioso (la multiculturalidad y la geopolítica); b) el rol y usos de los medios para la promoción del conocimiento religioso (más allá del mero proselitismo); c) las interacciones entre la religión y la comunicación (desde la construcción sociocultural hasta la propaganda); d) el papel de la religión y sus expresiones en la cultura y sus estrategias de comunicación (los procesos de socialización y la gestión social); e) la introducción de nuevos tópicos sociales, aprovechándose el know-how [saber hacer] de comunicación socio-religiosa (afectándose así a la agenda política y los programas públicos); etc.

${ }^{481}$ La revisión -que aquí se recoge- se concentra en los estudios monográficos, puesto que el número de artículos sobre la materia resulta excesivo y sumamente heterodoxo, superando las limitaciones materiales del presente epígrafe de Parte inicial. Ahora bien, lo que sí es factible, es mencionar aquellas publicaciones periódicas especializadas de mayor impacto sobre la materia: a) revistas interdisciplinarias, como Journal of Media and Religion; Journalism Quaterly; Newspaper Research Journal; Journalism and Mass Communication Educator; Journal of Communication and Religion; etc.; b) publicaciones periódicas sectoriales, como Journal of Church \& State, del J.M. Dawson Institute of Church-State Studies-Baylor University, o Religion and the Public Order. An annual review of Church and State and of Religión, Law, and Society, del Institute of Church and State Villanova University School of Law, publicado por The University of Chicago Press (1963-67), luego por Cornell University Press (desde 1968), etc.; c) los informes oficiales anuales, como los Annual Reports on International Religious Freedom, del U.S. Bureau of Democracy, Human Rights and Labor (con apoyo de la CIRF y la OIRF); et al.

${ }^{482}$ Vid. CLARK, L.S.: From Angels to Aliens: Teenagers, the Media, and the Supernatural. New York: Oxford University Press, 2003. - Religion, Media, and the Marketplace, Piscataway: Rutgers University, 2007. HOOVER, S.M., CLARK, L.S. (eds.): Practicing Religion in the Media Age, New York: Columbia University Press, 2002. HOOVER, S.M., LUNDBY, K. (eds.): Rethinking Media, Religion, and Culture, Thousand Oaks: SAGE, 1997.

483 Vid. HANGEN, T.J.: Redeeming the Dial: Radio, Religion, and Popular Culture in America, Chapel Hill: University of North Carolina Press, 2002. HENDERSHOT, H.: Shaking the World for Jesus: Media and Conservative Evangelical Culture, Chicago: The University of Chicago Press, 2004. MORGAN, D.: The Sacred Gaze: Religious Visual Culture in Theory and Practice, Berkeley: University of California Press, 2005. - Visual Religion: A History of Visual Media in the United States, London: Routledge, 2007. - The Visual Culture of American Religions, Berkeley: University of California Press, 2001. NORD, D.P.: Faith in Reading: Religious Publishing and the Birth of Mass Media in America, New York: Oxford University Press, 2004. SCHMALZBAUER, J.: People of Faith: Religious Conviction in American Journalism and Higher Education, Ithaca: Cornell University Press, 2003. 
GINSBURG, McCLOUD, De VRIES y WEBER (sobre la comprensión del pensamiento religioso en una sociedad de masas mediática $)^{484}$; (en torno a la relación de ciertas confesiones con los medios y su impacto cultural) ${ }^{485}$; EMERY, MEYER, MOORS, PETERS, SIMONSON, et al. (de la moralidad y el impacto social de las relaciones entre la religión y los medios) ${ }^{486}$. Por último -al igual que se hiciera al referenciar los Estudios de Iglesia-Estado-, se destaca la labor pionera y compiladora bibliográfica al respecto de TATE y McCONNELL ${ }^{487}$.

Sin embargo, el bache discursivo de los Estudios Culturales no está del todo superado, pues existen reminiscencias que podrían conducir a los CCS a la zona común de hibridación. Se está haciendo referencia a la cuestión de la narratología (narrative identity $\mathcal{E}$ story-telling approach) ${ }^{488}$. Entre los trabajos a destacar, se han seleccionado las contribuciones procedentes del ámbito universitario y de mayor impacto (al guiar las olas de finales de los 80 y mediados de los 90), como son los de BRODSKY, CARR, COHAN, DOLAN, HANNE, MITCHELL, PECORA, ROE y WHITEBROOK (así como los de entornos anglosajones) ${ }^{489}$.

${ }^{484}$ Vid. GINSBURG, F.D., et al (eds.): Media Worlds: Anthropology on New Terrain, Berkeley: University of California Press, 2002. De VRIES, H., WEBER, S. (eds.): Religion and Media. Stanford: Stanford University Press, 2001. McCLOUD, S.: Making the American Religious Fringe: Exotics, Subversives, and Journalists, 1955-1993, Chapel Hill: University of North Carolina Press, 2004.

${ }^{485}$ Vid. EICKELMAN, D.F., et al. (eds.): New Media in the Muslim World, Bloomington: Indiana University Press, 1999. HORSFIELD, P., et al. (eds): Belief in Media: Cultural Perspectives on Media and Christianity, Burlington: Ashgate, 2004.

486 Vid. MEYER, B., MOORS, A.: Religion, Media, and the Public Sphere, Bloomington: Indiana University Press, 2006. PETERS, J.D., SIMON, P. (eds.): Mass Communication and American Social Thought. Key text, 1919-1968, Lanham: Rowman \& Littlefield Publishers, 2004. VV.AA.: Religious, morality and communication between peoples: religion in public life (vol. 1), New York: Book News, 2005.

487 Vid. TATE, E.D., McCONNELL, K.: Religion and Communication: a selected, annotated basic bibliography, Annandale: Speech Communication Association, 1988.

488 Vid. SÁNCHEZ-BAYÓN, A. (coord.): Innovación docente... op. cit.

489 Vid. BRODSKY, C.J.: The imposition of form. Studies in narrative representation and knowledges, Princeton: Pirnceton University Press, 1987. CARR, D.: Time, narrative and History, Bloomington: Indiana University Press, 1986. COHAN, S., SHIRES, L.M.: Telling stories. A theoretical analysis of 


\section{3.- ¿QUÉ HA QUEDADO DEL MELTING POT TRAS LAS GUERRAS CULTURALES? ${ }^{490}$}

Hasta las guerras culturales, el consenso identitario proporcionado por los Estudios culturales tradicionales, había transitado de la providencia divina con su pueblo hasta una autodeterminación del mismo en forma pragmática, incluso excepcional, postulándose reformulaciones del modelo socio-cultural en forma de melting pot o crisol cultural (vid. supra). No obstante, vía velos de confusión de pensamiento débil de los Estudios culturales sobrevenidos, no sólo se volvió conflictivo el consenso previo (por no retratar a las minorías reprimidas supuestamente-), sino que se procedió a la deconstrucción de su sustento: se cuestionó el legado recibido, buscándose sus puntos débiles y su falta de sensibilidad con el hecho diferencial de las comunidades (tanto etnoculturales, como la femenina), hasta retrotraerse al periodo fundacional y alterar asi la matriz mitopoiética -afirmándose (en una tropología muy polémica), que los padres fundadores, en especial los framers o constituyentes (vid. supra cap. 9), sólo tenían en común y así articularon la república como un gobierno de hombres blancos anglosajones protestantes (WASP), además de heterosexuales y capitalistas-.

narrative fiction, New York: Routledge, 1988. DOLAN, F.: Allegories of America. Narratives-metaphysicspolitics, Ithaca: Cornell University Press, 1994. HANNE, M.: The power of the story, Oxford: Berghaslin Books, 1994. MITCHELL, T. (ed.): On narrative, Chicago: The University of Chicago Press, 1987. PECORA, V.P.: Self and form in modern narrative, Baltimore: The John Hopkins University Press, 1989. ROE, E.: Narrative policy analysis: theory and practice, Durham: Duke University Press, 1994. WHITEBROOK, M.: Identity, narrative and politics, New York: Routledge, 2001. Entre los entornos próximos (brítanico y canadiense), cabe citar las obras de BURKE, P.: Varieties of cultural History, Cambridge: Cambridge University Press, 1997. NASH, C. (ed.): Narrative in cultura: the uses of storytelling in the Sciences, Philosophy and Literature, London: Routledge, 1994. RANDALL, W.L.: The stories we are: an essay on self-creation, Toronto: University of Toronto Press, 1995.

${ }^{490}$ Vid. infra nota 382. 
Como la revelación (o retirada de velos), sobre las vulneraciones a la matriz mitopoiética y su legado, excedería con mucho el objeto de este epígrafe, se ofrece a continuación el punto de partida, en el que se acabó con el último gran consenso impulsado por los Estudios culturales tradicionales, como fue el excepcionalismo y su melting pot (que fue aprovechado por los Estudios culturales sobrevenidos para iniciar su andadura desde la exaltación del multiculturalismo e interculturalidad). En consecuencia, a continuación, se aborda el ascenso del pensamiento débil y sus propuestas híbridas (vía velos y deconstrucción), centrándose en la desarticulación del melting pot y sus ataques como brown culture.

\section{¿Cuáles eran las propuestas religadoras de los Estudios culturales tradicionales? De frontier factor hasta melting pot}

En los Estudios culturales tradicionales se han usado una serie de recursos expositivos para explicar la emergencia y fundación de los EE.UU. Entre dichos recursos han destacado, y aquí se han seleccionado (por su relación con el factor religioso), los siguientes: el mesianismo y el excepcionalismo, la frontera y la misión, el factor llamada y la condición pionera.

Como se viene indicando, entre las muchas propuestas que se han manejado para intentar exponer y explicar la evolución expansiva y hegemónica de los EE.UU., procurando al mismo tiempo poner de manifiesto la singularidad de dicho país y sus gentes -dicho sea de paso, se trata de algo común entre las propuestas historiográficas de la Contemporaneidad: ¿qué Estado-nación no ha sido objeto de 
intentos legitimadores de tal índole por sus historiadores oficialistas?-. En el caso estadounidense, según sus generaciones de historiadores identitarios (como intelectualidad establecida desde el s. XIX, máxime desde la normalización de los estudios universitarios), no difiere del resto de casos occidentales, haciéndose gala de propuestas diversas: pasándose de la singularidad legitimadora, a la crítica revisionista, para llegar a los dos polos extremos, como son la singularidad nacional del excepcionalismo (Estudios culturales tradicionales, v.g. American Studies), y el hecho diferencial comunitario del relativismo (Estudios culturales sobrevenidos de corte neomarxista -incluso hoy autocalificados de posmarxistas y poscoloniales-, v.g. feministas y de género -no heredero de los Women Studies, que bien podrían considerarse parte de los Estudios culturales tradicionales, al completar el pensamiento idiosincrásico estadounidense-, latinomaericanos, afroamericanos, asiático-americanos y orientalistas).

A continuación, se esboza el devenir de la historiografía estadounidense común a los estudios culturales tradicionales (su rama compartida de Historia estadounidense), pues la especializada se trata más adelante (aunque ya se adelanta que es calidoscopio de difícil sistematización). Sírvase ahora a considerar las revelaciones y tendencias entre historiógrafos estadounidenses agrupados por generaciones:

a) Las generaciones nativistas y legitimadoras, decimonónicas y novecentistas, de tono literario y casi enciclopédico (románticos homogeneizadores por la épica): se alude a los Revival historians (v.g. PRESCOTT, METLEY, BANCROFT, PARKMAN); los Frontier historians (v.g. TURNER, JOHNSON, MENHAN); más 
el resto de los Golden Age -o Gilded Age ${ }^{491}$, según las siguientes generaciones, sobre todo por los impulsores de los Estudios culturales estadounidenses, como el Prof. PARRINGTON-; cabe distinguir, a su vez: 1o generación (BANCROFT, HILDRETH, FROTHINGHAM, FISKE, MCMASTER, etc.), y 2og generación (CHANNING, HART, etc. $)^{492}$. Para todos ellos no hubo tensiones idiomáticas y de imaginario social, sino una visión y misión compartida de progreso -eso sí, construida frente a otros pueblos, o a costa de los mismos-. Sientan las bases de la homogeneización socializadora WASP, como sustento del melting pot o crisol cultural estadounidense (vid. supra).

Las generaciones de crítico-contestatarios y revisionistas, de las grandes guerras del s. XX (I y II Guerra Mundial y Guerra fría), influidos en cierto modo por el socialismo (bien a favor, bien en contra) y con pretensiones científico-sociales: comprende los Progressive historians (1ํ generación: los BEARD, CHARLES, PARRINGTON, MILLER, SPILLER, SMITH, SIMONS, etc., con sus dialécticas democratic-popular v. business-interest, $2^{\underline{o}}$ generación: JENSEN, MORISON,

${ }^{491}$ En vez de generación dorada, la generación de PARRINGTON Les llaman de oro chapado, pues el barniz triunfalista de su narrativa poco se sostenía si se profundizaba en las tensiones sociales. 492 Se les llama así, no sólo porque hacen despegar brillantemente el nivel académico estadounidense, sino porque además son los padres de la (re)construcción histórica propiamente estadounidense -al modo nacionalista aprendido en Europa, como da buena muestra BANCROFT y su monumental obra de 10 volúmenes History of the United States, from the Discovery of the American Continent (1854-78)-. Y es que el calificativo dorado se debe también a que son los padres de la leyenda dorada estadounidense: proporcionan una narrativa fluida y armónica de una ejemplar colonización del Este y conquista del Oeste, a modo de una aventura de superación humana, donde nunca hubo fricciones (ni raciales, ni económicas, ni religiosas, ni lingüísticas, etc.). Ante tal incipiente ficcionamiento -que no falsificación aún-, brota el característico espíritu crítico, tanto histórico como cultural -ya aludido-, que acompañará a la Historia social estadounidense. Entre la segunda generación, destacan con firma propia, aunque aún con estilo enciclopédico y algún apunte romántico, CHANNING, E.: A History of the United States (7 vols.), New York: ed. priv., 1905-12, o HART, B. (ed.): The American Nation. A History (10 vols.), New York: ed. priv., 1904-05, et al.; dichas obras están disponibles (como facsímil) en las bases de datos citadas en la parte introductoria del estudio. 
COMMANGER, DODD, BARKER, HACKER, etc.) ${ }^{493}$; los Critical historians (1o generación: HOFSTADTER -líder de su generación, con gran giro ideológico y muy admirador de PARRINGTON-, HIGHAM, CONKIN, WRIGHT MILLS, JENSEN, CROWL, POOL, 2o generación: KELLEY -y sus discípulos en el extranjero-, SCHLESINGER JR., LIPSET, etc. ${ }^{444}$; sin olvidar a la otra gran

${ }^{493}$ Son los autores que impulsan el crecimiento de los American Studies o estudios estadounidenses, al haber vivido la gran crisis de posguerra civil, así como la quiebra económica y ruina de la democracia agraria (dando lugar a la eclosión generalizada del mundo urbano e industrializado -que atrajo más gentes aún de Europa, donde el socialismo ya había calado-), no es de extrañar entonces que sean receptivos al análisis económico y sociológico socialista de comienzos del s. XX. Tal es el atractivo socialista para esta generación -no tanto desde un anhelo revolucionario, sino comprensivo, para corregir desigualdades- que BEARD, SMITH y SIMONS fundan la American Socialist Society en New York (1905). En esta generación el gran libro canónico -y gran éxito de ventas además- es The rise of American civilization (1927), escrito por el matrimonio BEARD -donde se observa el influjo economicista de la obra previa (solo de Charles) An economic interpretation of the Constitution of the United States (1913)-. Es de destacar también el cierto paralelismo entre los historiadores progresistas y la Escuela de Frankfurt: ambas corrientes coinciden en su propensión al análisis crítico-cultural, con elementos economicistas -sólo que la Escuela de Frankfurt es marcadamente neomarxista-, además de contar en su seno con dos generaciones (entre los representantes de dicha continuación destacan JENSEN -discípulo directo de BEARD-, junto con MORISON, que con el joven COMMAGER escriben The growth of the American Republic (1930) -reescrito varias veces, con la participación de NEVINS (entre otros, y con reorientación hacia las propuestas neo-whig), hasta llegar a nosotros como el archiconocido manual $A$ concise History of the American Republic-. Otro título relevante de COMMAGER, junto con DODD y BARKER es Our nation's development, New York: Row, Peterson \& Co., 1934. En la misma línea y de la época destacan las siguientes obras: HACKER, L.M.: The shaping of the American tradition (2 vols.), New York: Columbia University Press, 1947. HUBERMAN, L.: We, The People, New York: Monthly Review Press, 1964 (1ª edic. 1932). STEPHENSON, N.W.: A History of the American People (2 vols.), New York: Charles Scribner's Sons, 1934. WIRTH, F.P.: Forman's our Republic. A brief History of the American people, New York: Appleton-Century Co., 1935 (original es de 1922).

${ }^{494}$ Vid. HOFSTADTER, R., et al.: The structure of American History, Pretice-Hall: Englewood Cliffs, 1946. - The American political tradition and the men who made it, London: Jonathan Cape, 1967. - The progressive historians, New York: Vintage Books, 1970 (tesis respaldada por sus coetáneos, vid. HIGHAM, J., CONKIN, P.K. (eds.): New directions in American intellectual History, Baltimore: The John Hopkins University Press, 1979. KELLEY, R.: The cultural pattern in American politics. The first century, New York: Alfred A. Knopf, 1979. WRIGHT MILLS, C.: The New Men of Power: America's Labor Leaders, New York: Harcourt, Brace \& co, 1948. - White Collar: The American Middle Classes, New York: Oxford University Press, 1951. HIGHAM, C.: New directions in American intellectual History, Baltimore: The John Hopkins University Press, 1979. SCHLESINGER JR., A.: The cycles of American History. New York: Houghton Mifflin Co., 1986. LIPSET, M.S.: Political Man: The Social Bases of Politics, New York: Doubleday, 1960. - The First New Nation: The United States in Historical and Comparative 
corriente, como son los revisionistas o Reviewers historians, destacando los newwhig/republicans (1ำ generación: MORISON, HANDLIN, BAILYN, HARTZ, MORGAN, NEVINS, etc., $2^{\underline{0}}$ generación: POCOCK, WOOD, SKINNER, ACKERMAN, HUNTINGTON, et al.) ${ }^{495}$; más la nueva manualística (desde los primeros impulsores, como ALLEN, BARCK, BOORSTIN, DEGLER, etc., hasta los más recientes, tipo HUNTINGTON, NASH, DIVINE, etc. $)^{496}$.

b) Las generaciones discursivas de la globalización, presentes en la Historiografía general, pero sobre todo en los Estudios culturales sobrevenidos y sus readings $\mathcal{E}$

Perspective, New York: W.W.Norton, 1979. - Revolution and Counterrevolution: Change and Persistence in Social Structures, New York: Basic Books, 1968. - The Politics of Unreason: Right Wing Extremism in America, 1790-1970, New York: Harper \& Row, 1970.

495 Vid. BAILYN, B.: The ideological origins of the American revolution, Cambridge: Harvard Univ. Press, 1967. HANDLIN, O.: America. A History, Boston: Henry Holt \& co, 1968. MORGAN, E.S.: The Birth of the Republic, Chicago: The University of Chicago, 1956. NEVINS, MORRIS, R.B., GREEALEAF, W.: The History of a Nation (2 vols.), Chicago: Rand MacNally \& Co., 1969.

${ }^{496}$ De la $1^{\circ}$ generación, vid. ALLEN, F.L.: America transforms itself, New York: Harper \& Row, 1952. BARCK, O.T.: Since 1900: A History of the United States in our times, New York: Ronald Press Co., 1964. BARCK, O, LEFLER, H.: A History of the United States (2 vols.), New York: Ronald Press Co., 1968. BOORSTIN, D.: The Americans (3 vols.), New York: Random House, 1958-73. DEGLER, C.N.: Out of our past. The forces that shaped modern America, New York: Harper \& Row, 1970. - The democratic experience: a short American History, New York: Harper \& Row, 1973. GARRATY, J.A.: The American Nation: a history of the United States, New York: Harper, 1971. - A short history of the American Nation, New York: Harper, 1973. WHITE, P.L., et al.: A History of the American people, New York: McGrawHill, 1970. PARKES, H.B.: The United States of America, New York: Alfred A. Knopf, 1968. De la 20 generación, vid. NASH, G.B.: The American people: creating a nation and a society, New York: Longman, 1996. DIVINE, R.A.: America, past and present, New York: Harper, 1987 - quien se ha reciclado en el estilo story-telling (vid. supra)-. HUNTINGTON, S.: Who Are We? The Challenges to America's National Identity, New York: Simon \& Schuster, 2004. Cabría hablar de una 3ª generación, compuesta por John M. MURRIN y James M. McPHERSON (Princeton University), Alice FAHS y Emily ROSENBERG (Univ. California), Gary GERSTLE (Vanderbilt Univ.), Norman ROSENBERG (Macalester College), et al., reunidos todos ellos en obras tipo Liberty, Equality, and Power: A History of the American People, Boston: Thomson, 2008. Igualmente, ha de destacarse la revitalización del interés británico por la Historia estadounidense, vid. JOHNSON, P.: A History of the American People, New York: Harper \& Row, 1997. GRANT, S.: A concise History of the United States of America, Cambridge: Cambridge Univ. Press, 2012. 
voices [lecturas -ediciones ensayísticas (usualmente, coordinando autores o reagrupando artículos, v.g. CAMPBELL y KEAN ${ }^{497}$ ), con técnicas tropológicas de narrativa motivacional como story-telling y literatura testimonial-], con visiones alternativas (de otredad, subalternidad, etc.) -y un tanto conflictivas-, destacándose la labor universitaria del dramaturgo ZINN (posmarxista), o el ensayista TAKAKI (etnoculturalista), más otros autores mediáticos y polémicos, como los comunicadores DAVIS, LASN, DIVINE, et al., y en materia de factor religioso HACKETT ${ }^{498}$-se llama la atención sobre la profunda crisis que dichas corrientes han traído consigo, reseñándose las críticas de referentes académicos como FRITZE y HARLAN ${ }^{499}$.

497 Vid. CAMPBELL, N., KEAN, A.: American Cultural Studies. An introduction to American Culture, New York: Routledge, 1997.

498 Vid. ZINN, H.: A People's History of the United States, New York: Harper \& Row, 1980. - Voices of a people's History of the United States, New York: Seven Stories Press, 2004. - A people's History of American empire, New York: Metropolitan Books, 2008. ZINN, H., ARNOVE, A.: Voices of a People's History of the United States, New York: Seven Stories Press, 2004. TAKAKI, R.: A different mirror. A History of multicultural America, New York: Little Brown, 2008). - Debating diversity: clashing perspectives on race and ethnicity in America, New York: Oxford University Press, 2002. Otros autores y obras a considerar son: BEDERMAN, G.: Manliness and Civilization: A Cultural History of Gender and Race in the United States, 1880-1917. Chicago: University of Chicago Press, 1995. BRINKLEY, A.: The unfinished nation: a concise history of the American people, New York: McGraw-Hill, 1997. DAVIS, K.C.: America's hidden History: untold tales of the first Pilgrims, fighting women, and forgotten Founders who shaped a Nation, Washington: Smithsonian, 2008. - A Nation Rising: Untold Tales of Flawed Founders, Fallen Heroes, and Forgotten Fighters from America's Hidden History, Washington DC: Smithsonian, 2010. DENNING, M.: The Cultural Front: The Laboring of American Culture in the Twentieth Century. New York: Verso, 1996. KASSON, J.F.: Houdini, Tarzan, and the Perfect Man: The White Male Body and the Challenge of Modernity in America. New York: Hill and Wang, 2001. GILES, P.: Virtual Americas: Transnational Fictions and the Transatlantic Imaginary. Durham: Duke University Press, 2002. LASN, K: Culture Jam. The Uncooling of America, Eaglebrook: William Morrow, 1999. DIVINE, R.A.: The American story, New York: Longman, 2002. HACKETT, D.: Religion and American Culture: A Reader, New York: Routledge, 2003.

${ }^{499}$ Vid. FRITZE, R.: Invented Knowledge... op. cit. HARLAN, D.: The degradation of American History, Chicago: The University of Chicago Press, 1997. En cuanto al revisionismo crítico de la disciplina, cabe destacar las aportaciones de FISHER, P.: The New American Studies: Essays from Representations. Berkeley: University of California Press, 1991. KROES, R.: Predecessors: Intellectual Lineages in American Studies. Amsterdam: VU University Press, 1999. LIPSITZ, G.: American Studies in a Moment of Danger. 
En cuanto a la historiografía especializada, relativa a la evolución del pensamiento identitario estadounidense, esta viene muy ligada al factor religioso, pues los primeros en reflexionar al respecto fueron teólogos políticos, seguidos de los filósofos sociales (sobre todo pragmáticos) y, finalmente, los científicos socioculturales (máxime, los de los Estudios culturales). En tal sentido, se reseñan las siguientes aportaciones (articulándose también por generaciones):

a) Entre los proto-historiadores estadounidenses, preocupados por vincular las colonias con la continuidad de historia sagrada occidental, cabe citar los escritos fundacionales (desde pilgrins hasta framers, recogidos en su mayoría en los anales compiladores del s. XVII: New England Primer) ${ }^{500}$, tales como los comentarios locales al Book of Common Prayer y demás escritos de evangelización colonial de los Rev. HUNT, WHITAKER y DAVIS -llamados los primeros apóstoles americanos- en las plantaciones sureñas (Jamestown, 1607-24); los líderes y pastores CAVER, BRADFORD y MERTON (Mayflower compact, New Plymouth, 1620; Of Plymouth Plantation, Cabe Cod, 1647; New England's Memorial, London, 1669 -edición que incluía su original New English Canaan, acerca de su fundación de Merrymount-), el Gobernador WINTHROP (A modell of Christian charity, Plymonth Bay-, 1630), los Rev. COTTON y los MATHER

\footnotetext{
Minneapolis: University of Minnesota Press, 2001. MADDOX, L.: Locating American Studies: The Evolution of a Discipline. Baltimore: Johns Hopkins University Press, 1999.

${ }^{500}$ Vid. BOORSTIN, D. (comp.), An American Primer, Chicago: The University of Chicago Press, 1966. GAUSTAD, E.S. (ed.), A documentary History of Religion in America. To the Civil War, Grand Rapids: William B. Eerdmans Publishing Co., 1993. KENNEDY, D., et al., The American Pageant, Boston: Houghton Mifflin, 2006. MARSDEN, G.M.: Religious and American Culture, Fort Worth: Harcourt Brace Jovanovich College Publishers, 1990. NOONAN, J.T., GAFNEY, E.Mc.: Religious Freedom. History, cases, and other materials on the interaction of religion and Government, New York: Foundation Press, 2001.
} 
(Memorable Providences y Magnolia Christi Americana, publicados tardíamente en 1702), los Rev. HOOKER (The Covenant of Grace Opened, 1645), y WILLIAMS (The Bloudy Tenent Truth Peace, 1652), más el juez PHIPPS (Witchcraft, 1692), en Nueva Inglaterra; los PENN (Primitive Christianity Revived, 1696) en las provincias medias. En dichos escritos se mezclaba teología, política, historia y geografía, v.g. comparándose América con paradise/garden in wilderness [paraíso terrenal], (new) Zion [tierra prometida], o a city upon the hill [una ciudad en lo alto de la colina, $M t 5: 14])$.

b) Otras generaciones posteriores de fundadores, preocupados por la materia, fueron -telegráficamente aquí apuntados-: a) Enlightenments [ilustrados]: Benjamin FRANKLIN y su The Autobiography (1784-88), más Poor Richard's Almanac (1732-57); John ADAMS y su A dissertation on the Canon and the Feudal Law (1765), más sus Letters (to Samuel Adams, October 18, 1790; to Thomas Jefferson, Nov. 15, 1813, April 19, 1817 -no se citan, aunque resultan de los más esclarecedoras las cartas a su mujer y su hijo, el futuro Presidente J.Q. ADAMS); Thomas PAINE y su Common Sense (1776); Thomas JEFFERSON y su borrador de The Declaration of Independence (1776), más su Notes on the State of Virginia (1787), y sus Letters (to John Adams, Oct. 28, 1813; to Benjamin Rush, April 21, 1803; to Thomas Law, June 13, 1814), etc. b) Evangelical democratics [democráticoevangélicos]: Charles Grandison FINNEY y su What a revival of religion is (1815); John Humphrey NOYES (teólogo de Yale e impulsor de la comuna Oneida), con su The Berean (1847) y Bible Comunism (1848); William LEGGETT y sus Political writings (1834); George BANCROFT y su The Office of the People in Art, Government, and Religion (1835); Catharine BEECHER y A treatise on Domestic Economy (1841); Henry C. CAREY y su Of wealth (1858), et. al. c) Romantics $\mathcal{E}$ 
reformists [reformistas y románticos]: Ralph Waldo EMERSON y su The Divinity School Address (1838), más Self-reliance (1841); Margaret FULLER (sufragista, olvidada por los Estudios de género) y su The great lawsuit: man versus men, woman versus women (1843), más Women in the nineteenth century (1855); Henry David THOREAU y Resistance to Civil Government (18491849 -más tarde conocido como Civil desobedience), o su Walden (1854 -como guiño a su mentor EMERSON); Herman MELVILLE y Hawthorne and his Mosses (1850). d) Unionists [unionistas]: Presidente A. LINCOLN y su Speech at Peoria (1854) o su Gettysburg Address (1863); H.G. SPAFFORD, prominente abogado y activista socioreligioso, produjo el popular himno It is well with my soul (1873 -basado en el Evangelio de San Juan y a raíz del incendio de Chicago, en el que perdió a su hijo y se arruinó; terminó en Jerusalén, en una colonia estad ounidense, pionera de lo que será la cooperación y desarrollo durante la Guerra fría); H.E. BEECHER STOWE ${ }^{501}$, otra destacada activista socio-religiosa y sufragista -igualmente, olvidada por los Estudios de género- (The Amercian woman's home, 1869, Lady Byron vindicated, 1870, o Woman in Sacred History, 1873), además de profesora de Hartford Female Seminary y autora de la popular novela abolicionista Uncle Tom's cabin (1852 -difundida por Semi-Colon Club, en el que participaran relevantes personajes como S.P. CHASE: Gobernador de Ohio y Secretario del Tesoro de la Adm. LINCOLN), etc.

La posterior historiografía especializada (sobre pensamiento identitario estadounidense y factor religioso, de la que se nutrirán los primeros Estudios

\footnotetext{
${ }^{501}$ Descendiente directa del rev. L. BEECHER, redactor de la Constitución de Connecticut (1818), más su Six sermons on the nature, occasions, signs, evils and remedy of intemperance (1827); además de familiar de la libre-pensadora y sufragista ya citada C. BEECHER, vid infra.
} 
culturales) llega primero a los seminarios teológicos (sobre todo de Nueva Inglaterra), y poco después a las primeras universidades estadounidenses herederas de aquellos ${ }^{502}$. De tal manera, comienza a cultivarse la disciplina referencial para esta investigación como es (American) Church-State Studies. La razón de ser, por la que dicha disciplina resulta idiosincrásica es porque, a diferencia de Europa, EE.UU. va a ser el primer país occidental en reconocer oficialmente (y a nivel constitucional) la separación entre instituciones (Iglesia y Estado), a la vez que se favorece el libre ejercicio religioso (tal como fija la Primera enmienda y sus dos cláusulas); luego, de cómo EE.UU. resulta pionero y referente del resto de Occidente, es algo que ha movido a la reflexión idiosincrásica de su intelectualidad y científicos académicos. Se destaca también que, en el ámbito de esta disciplina, han surgido y despuntado (apareciendo en casi todas las guías docentes de las asignaturas relacionadas y derivadas, v.g. American Civil Religion), más de un millar y medio de obras monográficas (entre la década de 1950 y 2010) 503 , agrupadas por bloques temáticos y enfoques (v.g. Church-State Relations, Political Theology, Religion \& [Relaciones IglesiaEstado, Teología política, Religión y/con]: se trata de disciplinas y asignaturas con un fuerte enfoque en Historia y Sociología de la Religión, más Eclesiología aplicada,

\footnotetext{
502 El Ivy League o club de la hiedra (vid. supra), cabe recordar la relación directa de la religión y las universidades estadounidenses: William and Mary para los anglicanos, Princeton para los presbiterianos, Yale y Dartmouth para los congregacionalistas, Harvard para los unitarianistas, la actual Brown para los bautistas, King's College -hoy Columbia- para los anglicanos -y luego también para episcopalianos y presbiterianos-, Philadelphia School -más tarde Universidad de Pensilvania- para los cuáqueros, Rutgers para holandeses reformados, et al.

${ }^{503}$ Amén de sus publicaciones periódicas más acreditadas y de mayor índice de impacto: a) las revistas, del tipo de Journal of Church \& State, del J.M. Dawson Institute of Church-State Studies-Baylor University, o Religion and the Public Order. An annual review of Church and State and of Religión, Law, and Society, del Institute of Church and State Villanova University School of Law, publicado por The University of Chicago Press (1963-67), luego por Cornell University Press (desde 1968), etc.; b) los informes, como los Annual Reports on International Religious Freedom, del U.S. Bureau of Democracy, Human Rights and Labor (con apoyo de la CIRF y la OIRF).
} 
en los EE.UU., cursadas en Facultades de Teología y CC. Religiosas, junto con las de Artes y Humanidades; idem, pero desde Facultades de Derecho y Ciencias Sociales; First Amendment Studies, Political \& Social Thougth [Estudios sobre la Primera Enmienda, Pensamiento Político y Social]: por esta vía, desde cualquier Facultad, se confiere una especial atención a las ideas, formas y movimientos, que mejor han contribuido al avance sostenible y armónico de las relaciones entre el poder, lo sagrado y la libertad, en el novus ordo seclorum de los EE.UU., codificándose en su American Civil Religion \& American Social Gospel), y de cuya selección (ilustrativa, que no exhaustiva, de las más citadas), se ha rendido cuenta en otros trabajos publicados ${ }^{504}$.

Como secuencia lógica evolutiva de la historiografía especializada, quedaría por apuntar la de los Estudios culturales sobrevenidos, pero como ya se indicara, resulta un all that jazz o miscelánea tan diversa como difícil de integrar sistemáticamente. Ello se debe a su burbuja, iniciada a raíz de la Ley de Estudios Etnoculturales de 1972 y el apoyo de la Adm. CARTER (1977-81), recibiendo de manera preferente fondos y posiciones en centros educativos, de ahí su rápida expansión académica (sustentada a su vez por un neopuritanismo articulado desde los velos de confusión extendidos por la fuga de cerebros). Su historiografía sobre el pensamiento e identidad estadounidense es caleidoscópica y tan diversa, como

\footnotetext{
504 Vid. SÁNCHEZ-BAYÓN, A.: “Evolución y evaluación de la ciencia iuseclesiasticista en los EE.UU.”, Anuario de Derecho Eclesiástico del Estado - Ministerio de Justicia (vol. XXXI), 2015. - "Freedom of religion at large in American Common Law", Journal for the Study of Religions and Ideologies (v. 13, n. 37), 2014. - "Historia, Historiología e Historiografía de los Estudios Interculturales en EE.UU.", Rev. Banda de Moebius (no 48), 2014. -“Innovación docente en Ciencias Eclesiásticas y Jurídico-Sociales”, Cauriensia (v. VIII), 2013. - "Cómo se aprende Derecho Eclesiástico del Estado en los Estados Unidos de América y su jurisprudencia", Ars Boni et Aequi (v. 9, no 2), 2013. - "Religión, Política y Derecho en las Américas del nuevo milenio", Ars Boni et Aequi (v. 8, no 1), 2012. - "Historia de la Comunicación Social Estadounidense a través de sus Movimientos Religiosos", Historia y Comunicación Social (v. 13), 2008.
} 
comunidades reivindican su hecho diferencial, así como su reparación por su marginación previa. Incluso, aquellos manuales que pretenden la compilación de corrientes, siguen la lógica caleidoscópica, a modo de readings $\mathcal{E}$ voices (lecturas ediciones ensayísticas (usualmente, coordinando autores o reagrupando artículos), con técnicas tropológicas de narrativa motivacional como story-telling y literatura testimonial-], con visiones alternativas (de otredad, subalternidad, poscolonialidad, etc., basadas en el conflicto y el hecho diferencial). En tal sentido, se destaca la labor universitaria del dramaturgo ZINN (posmarxista), más otros autores mediáticos y polémicos, como los comunicadores DAVIS, LANS, DIVINE, et al. Como se viene señalando, dada la galaxia de propuestas de los Estudios culturales sobrevenidos (requerirían de una publicación de varios volúmenes), sólo cabe insistir que su única conexión es la articulación desde el pathos $\mathcal{E}$ mithos para dar impulso a identidades comunitarias posmodernas y neofeudales, deconstructoras de la moderna identidad ciudadana estadounidense.

Vista la principal historiografía estadounidense (tanto de la Historia general como de las especialidades de Estudios culturales), se ofrece a continuación una síntesis de sus aportes relativos a recursos expositivos y explicativos del impacto del factor religioso en la fundación de los EE.UU. -acometiéndose desde una lectura de revelaciones frente a las inferencias del Americaness-. Entre los primeros recursos en manejarse destacan el factor llamada (relacionado con el de la misión) y la condición pionera (igualmente conectado con la frontera), completándose todo ello con el excepcionalismo (que es la gran teoría autóctona de la singularidad estadounidense o American uniqueness). 
En cuanto al factor llamada y misión, se alude al énfasis dado por las primeras generaciones de historiadores estadounidenses (vid. infra), priorizando el modelo de colonización de Nueva Inglaterra sobre el resto de modelos. Se forja así el mito fundacional de los EE.UU. como tierra prometida, acogiendo a los más preparados y por ello perseguidos, quienes encontraran en las colonias su hogar y el reconocimiento pretendido. Se trataba de gentes con una marcada llamada o vocación ${ }^{505}$, para acometer una misión, resultando así pioneros (con unas creencias que otorgan confianza para llegar donde otros no se atreven): con la Reforma protestante no sólo se profesa la religión (stricto sensu), sino que la misma se proyecta sobre el resto de facetas sociales (surgiendo así la profesión laboral, y demás empresas a acometer), pues si se tiene éxito y beneficio en vida, ello es muestra de la predestinación. Se trata de la concreción del destino que se tiene en vida: de tal manera se reconcilia el más allá o vida eterna y el más acá o vida temporal, ya que la salvación espiritual se logra por medio de lo material -en el catolicismo, tal noción se aplica sobre todo a los laicos, quienes han de participar en los asuntos terrenales y dirigirlos según la voluntad de Dios-. Como ejemplos usados para fundamentar dicho mito, cabe citar entre otros, el influjo evangelizador para la colonización por parte de las sagas de reverendos como los ELIOT, MAYHEWS, COTTON, MASON, TOPPER, SHEPARD, RAWSON, WILLIAMS, SERGEANT, EDWARDS, etc. Sin embargo, dicho mito dista bastante de la realidad acaecida, introduciendo un sesgo habilitador de la leyenda dorada fundacional de los peregrinos religiosos

\footnotetext{
${ }^{505}$ La noción de profesión, parte de la de vocación (del latín vocare, como deseo de realizar una misión o emprender un proyecto, relacionado con la saludatio o salvación, ergo de inspiración divina, y que para los protestantes, además de significar "ir al cielo", guarda relación con "redención" -recomprar o ganarse la salvación-). Así se proyecta en los vocablos calling (ingles) y beruf (alemán). Véase la interpretación que de dichos términos hace WEBER ( La ética protestante y el espíritu del capitalismo (trad.), Madrid: Alianza, 1986), así como, la de autores hipercríticos (con el modelo WASP), del tipo de ORTEGA Y MEDINA, J.A.: La evangelización puritana en Norteamérica... op. cit.
} 
(perseguidos por su religión, encontrando la libertad en América), cosa que fue cuestionada por las siguientes generaciones críticas y revisionistas, quienes pusieron de manifiesto los episodios de intolerancia de entonces. Sirva de ejemplo, a nivel macro, las teocracias de Nueva Inglaterra; a nivel meso, juicios de Salem y alrededores (Boston, Andover, etc.) de mediados a finales del s. XVII; a nivel micro, los delitos por razón religiosa y/o moral de las Blue Laws. También procedió la citada generación de autores a reivindicar los otros modelos coloniales, como el de las Plantaciones sureñas. Ahora bien, tampoco fueron excesivamente críticos, pues idealizaron la fórmula de Virginia, ocultándose sus episodios oscuros, como el canibalismo en la llamada "época del hambre" durante el tercer invierno de Jametown (1609-10), al no llegar ayuda alguna ${ }^{506}$ y no disponer de útiles para la agricultura, pues lo que se buscaba originalmente era el oro -se critica a los españoles, pero se genera el mismo mito de Pizarro con el Capitán J. Smith ${ }^{507}$. De igual manera se obvia el origen como colonia militar y penitenciara de Georgia, con sus penas excesivas. Tampoco prestaron atención crítica a los otros modelos, como los de las Provincias medias -sin aclarar el debido origen de las mismas a la labor colonial de otras potencias, v.g. Holanda, Suecia-, y los laboratorios sociales, como Pennsylvania, donde los cuáqueros o amigos de Penn introdujeron las celdas celulares

\footnotetext{
${ }^{506}$ La ayuda debía llegar con la expedición de Gate, que naufragó por culpa de un huracán. Este episodio inspiró la última gran obra de Shakespeare, su The Tempest, 1612 -igualmente, es clave para entender la visión que de los indios tenían los ingleses, consolidándose así el arquetipo de Calibán (acrónimo de caribeño y caníbal), vid. Isaac Asimov, The shaping of North America. From Earliest times to 1763, Boston: Houghton Mifflin, 1973.

${ }^{507}$ Autores como HOFSTADTER o ASIMOV afianzan dicho mito fundacional de Virginia, con el personaje carismático de John Smith, al que atribuyen el matrimonio con la princesa indígena Pocahontas (hija del Jefe indio Powhatan), para salvar la fundación de Jamestown. Sin embargo, en la tradición anglosajona, la denominación John Smith se utiliza para referir a aquella persona de nombre incierto (Juan Algo), equivaliendo en castellano a expresiones tipo Pedro Pérez, Fulanito De Tal o Menganito De Cual. La nueva historiografía defiende otro líder salvador de Virginia, otro Capitán llamado John Rolfe, igualmente amigo de los indios y quien introdujera la explotación del tabaco.
} 
(de aislamiento de los presos), etc.

En relación al factor frontera, se recuerda lo ya apuntado, que en inglés, la frontera física es bourder, mientras que la mental es frontier, o sea, la delimitación de lo establecido o retos a superar, para seguir progresando (se trata de llegar a los límites y atravesarlos, de ahí el papel de la religión, para fijar los mínimos morales, que separen la civilización de la barbarie, tal como coinciden los historiadores de la frontera, vid. supra). Por tanto, todo aquel que tuviera diferentes propuestas a lo ya establecido, había de ir a la frontera para ensayar, y si tenía éxito y beneficio, dichas propuestas quedarían integradas en el acervo común. Así se fundaron las nuevas colonias periféricas y del interior (v.g. Rhode Island, Pennsylvania, Ohio), con los disidentes irradiados de las teocracias de Nueva Inglaterra; o se dio impulso a la conquista del Oeste, estimulando a lo naciente y no consolidado, bajo lemas como go West, young man, go West [ve al Oeste, joven, ve al Oeste], que igualmente sirviera para recientes confesiones, como los mormones, con su éxodo hasta Salt Lake City. La frontera del progreso está presente en la Historia estadounidense, incluso en las políticas públicas, como la de New Frontier [nueva frontera] de la Administración Kennedy en la década de 1960 (para consolidar el Estado de bienestar estadounidense, así como dar impulso a la carrera especial, que llevaría a la colonización de la luna en 1969). La generación de historiadores que consagró el estudio del factor fronterizo para explicar la evolución estadounidense fue la TURNER y sus coetáneos (vid. infra).

Todas estas propuestas (y muchas más) fueron integradas por el constructo intelectual decimonónico, y tesis académica posterior, de American excepcionalism o excepcionalismo estadounidense. Se postula de este modo la singularidad radical estadounidense (desde sus raíces fundacionales), resultando distinto este país al 
resto de pueblos occidentales -al menos, así se han autopercibido quienes han sostenido dicha tesis, especialmente en los Estudios culturales (vid. supra)-. Según la propuesta historiológica de integración del excepcionalismo, el caso estadounidense es diferente por haberse conformado ajeno a los grandes conflictos y problemas de otras potencias, máxime las europeas. Según el excepcionalismo, en los EE.UU. ha habido diversidad religiosa sin guerras de religiones; ha habido prosperidad popular sin necesidad de ideologías ni revoluciones sociales; ha habido democracia sin dictaduras, etc. Todo ello ha tenido como resultado una visión conciliadora de los EE.UU. como melting pot o crisol cultural ${ }^{508}$. No obstante, en los EE.UU., sí ha habido:

a) Persecución religiosa: de las main-line churches o iglesias jerárquicas y establecidas contra las evangelical o iglesias comunitarias y emergentes durante los s. XVII y XVIII; contra los indios hasta el s. XIX y su reducción en reservas; contra los católicos, judíos y protestantes afro-americanos hasta finales del s. XX (con políticas de segregación), etc.

b) Conflictos ideológicos: no se han dado exactamente las mismas expresiones ideológicas (acaecidas en la Europa coetánea), pero sí ha habido ciertos brotes, tales como los múltiples casos de anarco-colectivismo agrario (de comunidades religiosas en su mayoría, en zonas fronterizas) hasta finales del s. XIX y su milenarismo; el nacionalismo étnico-cultural de nativistas (v.g. Know-nothing movement), milicias y KKK hasta finales del s. XX (v.g. caso de Davidianos

\footnotetext{
508 Se recuerda aquí las menciones previas al respecto: melting pot, es una expresión coloquial para referirse al caldero donde se prepara una especie de potaje, por lo que cuanto mayor es la diversidad de sus componentes, más sabroso se estima el plato cocinado. De tal manera y gracias al excepcionalismo, así se ven los estadounidenses, como crisol cultural, donde todos pueden traer componentes de sus culturas de procedencia, pero ello sólo es para mejorar el sabor civilizatorio occidental que en los EE.UU. se cuece.
} 
Adventistas del Séptimo Día y la masacre de la comunidad de Waco en 1993 muriendo 86 personas, incluidos niños-, al enfrentarse a tiros con agencias federales como la ATF y el FBI). Igualmente destacable, en la línea que se viene señalando, cierto es que la ideología socialista ha sido minoritaria (reconocida por la mismísima hija de MARX en su viaje a los EE.UU., y aclarado académicamente por SOMBART (y ya en los EE.UU., por LIPSET) -además de denunciado por activistas, como el líder comunista estadounidense LOVESTONE, y académicos de la línea crítica del excepcionalismo, vid. supra-), cabe destacar entre otros hitos -menores, pero sangrientos- la revuelta de Haymarket en Chicago (1886), con sus disturbios obreros y ahorcamiento de los responsables, etc.

c) Debilidades democráticas: tampoco ha habido dictaduras propiamente, pero ha tenido lugar en el seno estadounidense una guerra civil, así como episodios dudosamente democráticos. Sirvan de ejemplo, los procesos anticomunistas en la década de 1950 impulsados por el Director del FBI, HOOVER, y Senador de Wisconsin, McCARTHY; el espionaje electoral del Watergate, cuyo máximo responsable fue el Presidente NIXON, provocando su dimisión en 1974; la polémica doctrina neoconservadora de legítima defensa preventiva, más los procesos contrarios al habeas corpus en la base militar de Guantánamo, y las contrataciones de los mercenarios de Blackwater -actualmente Academi- por parte de la Administración W.BUSH en la década del 2000, et al.). 
Téngase en cuenta que, si el pragmatismo ${ }^{509}$ fue la gran corriente filosófica autóctona de los EE.UU., el excepcionalismo estadounidense es su ideología distintiva: es su concreción aconfesional de construcción nacional (patriótica), más allá de su singularidad histórica, su dimensión continental, sus instituciones modernas y su cultura democrática, etc., el excepcionalismo ha permitido a los estadounidenses articular su auto-imagen (self-image) y dotar de sentido su evolución como país (con una visión y misión propias). Todo parte de los planteamientos de ACR, con sus derivados del evangelismo social estadounidense o American (social) gospel, el destino manifiesto o American manifest destiny, la sobreautoestima moral o American self-righteousness, el sueño estadounidense o American dream, etc. (vid. infra). La noción original parte de la visión y misión fundacional de los estadounidenses, autopercibiéndose como pueblo elegido por la gracia de Dios para alcanzar un progreso y bienestar terrenal (v.g. la ciudad en lo alto de la colina, del discurso A model

\footnotetext{
509 Se dice que la única aportación estadounidense a la filosofía ha sido el pragmatismo, como propuesta de segundo nivel, basada en una aplicación de la teoría de la evolución al mundo de las ideas, por lo que sólo prevalecen aquellas aportaciones plausibles y pedagógicas, o sea, fáciles de entender, comunicar y llevar a la acción entre las mayorías... nada más lejos de la realidad: se trata de una desnaturalización del pragmatismo, para reconvertirlo en pensamiento débil etnocultural, como se viene procurando por parte de los filósofos posmodernos y los Estudios culturales sobrevenidos. Si se revisa el origen y desarrollo del pragmatismo, antes de la llegada de la fuga de cerebros, entonces, queda claro que es una filosofía moderna analítico-empírica de preocupación social (o filosofía social racio-vital: un nuevo pensamiento intuitivo (como fuera definido por sus fundadores del club trascendentalista/metafísico), divergente del positivismo europeo coetáneo, y a la postre antagónico de idealismos emergentes antipositivistas (máxime de origen germano y próximos a las ideologías, v.g. vitalismo, materialismo). Se busca comprender y gestionar el novus ordo seclorum (otro de los lemas nacionales del Gran Sello, 1782), y para ello, se posee una base metafísica (de ontología y axiología con conceptos y valores generalmente admitidos y relacionados con la experiencia), siempre aplicable a la rica, compleja y voluble realidad social estadounidense (no se piensa en abstracto ni deductivamente, sino inductivamente, para solucionar problemas concretos de interés general y/o a favor del bien común, base de la unidad original predicada). Luego, para entender mejor el pragmatismo, retirándose además velos de confusión, lo que se requiere hoy es de una revisión crítica de autenticidad (verificándose si ocurrió y cómo, junto con sus relaciones): cuáles fueron sus antecedentes (v.g. deísmo, unitarismo, trascendentalismo), y cuáles sus continuaciones (v.g. interaccionismo simbólico, democracia simbólica y de liderazgo); vid. infra nota 31.
} 
of Christian charity de WINTHROP, 1630). Todo ello fue tipificado por los padres fundadores en su legado de la religión civil, secularizándose progresiva y programáticamente hasta dar lugar al planteamiento decimonónico del excepcionalismo estadounidense. De este modo, los estadounidenses dejan de depender directamente de la gracia de Dios, para confiar más en sí mismos -eso sí, aún sintiéndose bendecidos por Dios-, concibiéndose como un pueblo diverso, fuerte y noble, capaz de ser referente para otros y dirimir problemas internacionales.

En definitiva, a modo de elemental síntesis histórica-historiológicahistoriográfica, el excepcionalismo estadounidense aparece por primera vez (como expresión acuñada, generalmente aceptada y con una tesis aparejada) con el jornalism o literatura de viajes y proto-periodismo, destacando el apunte realizado por Tocqueville en su Democracia en América (1835 y 1840), al describir en dichos términos el país que visita: siendo excepcional, por nuevo y por su mestizaje (han participado de la rica tradición de viajeros observadores del excepcionalismo estadounidense personajes tales como H.G. WELLS, G.K. CHESTERTON, H. BELLOC, et al.). La expresión se hace célebre durante la Guerra civil, siendo usada por los periódicos de la época en su sentido redentor (v.g. The New York Times), de ahí su alusión al describir la naturaleza estadounidense (como una nación únicaAmerican uniqueness-, concebida en libertad y que pretende la igualdad de los hombres) en el célebre discurso presencial Gettysburg Address de LINCOLN (1863). A finales del s. XIX, gracias al sustento de académicos como EMERSON (y sus seguidores del Metaphisical $(\mathrm{Club}$ ) o de literatos como WHITMAN, la expresión y su significado relativo al carácter estadounidense se consolida, incluso se normaliza en términos científico-académicos en los trabajos de Historia estadounidense y en los emergentes Estudios culturales. La expresión del excepcionalismo va a tener dos acepciones o 
vertientes contrapuestas: a) una connotativa y autóctona de legitimación (sustentadora de su patriotismo y basada en el consenso y carácter compartido), relativa a la singularidad estadounidense, su articulación nacional y su misión ejemplar -incluso salvífica- (presente en los Estudios culturales tradicionales); b) otra denotativa y foránea de crítica (sobre la rareza estadounidense, insistiéndose en sus supuestas debilidades y los conflictos soterrados), impulsada desde Europa (adhiriéndose la URSS) y consolidada con la fuga de cerebros (a raíz de las Guerras Mundiales del s. XX) que permea la universidad estadounidense (impulsándose en los Estudios culturales sobrevenidos). La simbiosis académica de ambas corrientes (con predominio de la opción a), encuentra su vehículo de irradiación en movimientos del Ivy League ${ }^{510}$ como liberal consensus (también conocido como Consensus History, cuya época de esplendor fue la década de 1950 y 1960, hasta su desbancamiento por New Left Review) ${ }^{511}$. Entre sus representantes más conocidos, destacan los profesores de Historia estadounidense y especializada (v.g. Historia del Derecho y de las Instituciones o Historia Política -incluida Historia de las Relaciones

\footnotetext{
${ }^{510}$ De los millares de centros universitarios reconocidos en los EE.UU., existe un reducido y exclusivo grupo denominado Ivy League o liga/club de la hiedra. Se trata de una metáfora muy plástica, pues la exclusividad de dicho club se basa en: a) la reivindicación de la solera de sus universidades pretendidas herederas de las más venerables europeas, donde hay hiedra longeva en sus muros-; b) la calidad de su educación y la selección intensiva de sus alumnos y profesores -que como la hiedra, se entremezcla para ser más fuerte y elevarse, de ahí la intensificación educativa en seminarios o almuerzos de estudio, por ejemplo-; c) la referencia social, tanto por ser parte de su comunidad como por acogerla, pues todo ello proporciona respetabilidad y posibilidad de promoción social -como la hiedra, proporciona solera y distinción a la edificación-, etc. La mayor parte de estas universidades se fundaron como centros educativos confesionales para asegurar el relevo generacional de profesiones liberales, especialmente los ministros de culto (quienes debían impulsar la colonización de la Costa Atlántica primero, y del Oeste después); sirva como ejemplo el caso de Princeton y los presbiterianos, Yale y los congregacionalistas, Harvard y los unitarianistas, la actual Brown y los bautistas, et al.

511 Liberal, en los EE.UU., bebe del pensamiento Whig (proto-liberalismo) y Free-mason (librepensadores), por lo que alcanza a comprender tanto a liberales-conservadores (próximos a la derecha tradicional europea), como a liberales-progresistas (cercanos a la izquierda).
} 
Internacionales-, Historia Económica y Social, Historia Cultural e Intelectual), en universidades tales como Harvard (v.g. L. HARTZ, B. BAILYN, P. MILLER, S.P. HUNTINGTON, S.M. LIPSET), Yale y Standford (v.g. D.M. POTTER, A.P. STOKES, E.S. MORGAN, -también LIPSET-), Columbia (v.g. R. HOFSTADTER, H.S. COMMAGER, A. NEVINS -nuevamente LIPSET-), Chicago (v.g. D.J. BOORSTIN), Michigan y Cornell (v.g. P.C. ROSSITER), et al. De entre los prestigiosos historiadores citados, diversos entre sí (new-whigs, uniqueness theorists, reviewers, etc.) cabe dedicar un breve apunte sobre el Prof. LIPSET (1922-2006), por tratarse del más heterodoxo y evolucionado de entre todos ellos: hijo de inmigrantes rusos y judíos -y por ende, de fuertes convicciones socialistas, de las que participaba el sionismo-, se crio durante la era ROOSEVELT (años 30 y 40), en el intercultural Bronx (uno de los barrios con mayor inmigración y deprimidos de la ciudad de New York). Comienza su docencia en la Univ. Columbia, mientras prepara su doctorado, que logra en 1949 en Sociología (su tesis, Agrariam socialism, ratifica empíricamente las tesis de SOMBART, vid. infra $)^{512}$. Resulta que la Sociología es una ciencia pujante en los EE.UU. de mitad del s. XX (hasta entonces dicho conocimiento se acometía desde Estudios culturales como Amercian Studies). Dicha ciencia se nutría de la -ya aludidafuga de cerebros procedente de Europa y la URSS. Por el influjo de sus maestros, así se explica el primer viraje de LIPSET, quien sigue liderando el frente de juventudes socialistas (Young People's Socialist League), pero se vuelve anti-Stanlinista (por el influjo de sus maestros), marchando a enseñar a la Universidad de Toronto (Canadá), para descubrir la corriente de la social-democracia. Regresa a los EE.UU.,

\footnotetext{
512 Profundiza y concreta más en su tesis en otras publicaciones como LIPSET, S.M.: "Why no socialism in the United States", en BIALER, S, SLUZAR, S. (ed.), Sources of contemporary radicalism, Bouder: Westview Press, 1977. LIPSET, S.M., MARKS, G.: It didn't happen here: why socialism failed in the United States, New York: W.W. Norton \& co., 2000.
} 
como docente en las universidades de Standford, Harvard, Mason, etc. Se intensifican sus publicaciones sobre el excepcionalismo ${ }^{513}$. Dado el influjo de sus colegas, sobre todo en Harvard, entra en contacto con el movimiento liberal consensus, lo que provoca un nuevo cambio en su trayectoria intelectual, llegando a volverse en un referente de los neoconservadores hacia el final de la Guerra fría. En su interpretación del American excepcionalism reconoce un importante papel al factor religioso y el modelo cultural WASP. Este legado es recibido tiempo después por otro profesor de Harvard (ya citado al inicio de este estudio): HUNTINGTON.

De vuelta al movimiento liberal consensus, el mismo cuenta en su haber con el logro de aglutinar en su seno diversas lecturas del American excepcionalism, además de extender y afianzar la imagen de los EE.UU. como melting pot. De tal suerte, se consolida el excepcionalismo estadounidense como fórmula expositiva y explicativa dominante en la historiografía autóctona de la Guerra fría. Y es que, el excepcionalismo permite articular una Historia estadounidense basada en unos valores de consenso e integración (v.g. libertad ciudadana, republicanismo y democracia, oportunidades y meritocracia), con un credo común y un legado compartido (v.g. padres fundadores y patriotismo, sueño estadounidense y crisol cultural), además de llegarse a fijar por esta vía las grandes etapas del desarrollo estadounidense (el gran hito de referencia fue el manual de divulgación desde las embajadas estadounidenses, durante la Administración REAGAN, supervisado por

\footnotetext{
513 Vid. LIPSET, S.M.: The first new nation: the United States in Historical and comparative perspective, New York: Basic Books, 1963. - Continental divide: the values and institutions of the United States and Canada, New York: Routledge, 1989. - American excepcionalism. A double-edged sword, New York: W.W. Norton \& co., 1996. LIPSET, S.M., LOWENTHAL, L. (ed.): Culture and Social Character, New York: The Free Press, 1961. LIPSET, S.M., et al.: The paradox of American Unionism: why Americans like unions more than Canadians do, but join much less, Ithaca: Cornell Univ. Press, 2004
} 
el Prof. HOFSTADTER $)^{514}$. Así se vino cultivando en los Estudios culturales tradicionales (v.g. American Studies, Church-State Studies), mientras que en los sobrevenidos (impulsados desde la década de 1970 y de gran auge con la globalización), el excepcionalismo estadounidense pasó a ser altamente cuestionado y muy denostado: de los citados planteamientos críticos (sobre las contradicciones internas del complejo y pionero sistema social estadounidense), se pasó a vincular el excepcionalismo con la decadencia de una singularidad que nunca fue tal -más bien existió un tabú imposibilitador del tratamiento de las cuestiones-. Finalmente, se llegó a un reduccionismo desconstruccionista, según el cual, el excepcionalismo ha terminado por vincularse con un doble rasero, y su melting pot se ha calificado primero de naif, y más tarde de una gran impostura. Entre las críticas más sobresalientes -a tratar seguidamente-, cabe señalar denominational pot, salad bowl, pizzaland, brown culture, etc.

\section{¿Cuáles han sido las principales críticas, velos y deconstrucciones de los Estudios culturales sobrevenidos a la última propuesta de consenso (como fuera melting pot)?}

Como se viene advirtiendo, se plantea aquí el secular problema occidental de la hibridación ${ }^{515}$. Se trata del castigo divino (por sobervia e impiedad), en forma de

\footnotetext{
514 Vid. VV.AA.: Reseña de la Historia de los Estados Unidos... op. cit.

515 Tal como se ha mencionado ya y seguidamente se clarifica algo más, la hybris, para los clásicos, era el castigo divino a los humanos soberbios, enajenándolos de modo que quedadaran marginados a la postre. Por tanto, cuando aquí se denuncia el problema de hibridación se alude así al incorrecto mestizaje de reglas e instituciones, y sobre todo de discursos dado que existen unos intereses ocultos
} 
confusión y desprecio humano, presente tanto en la tradición sagrada o judeocristiana, como en la tradición profana o greco-romana: cuando los dioses (tanto el judeocristiano como los grecorromanos) pretendían castigar a humanos soberbios, entonces, les confundían el juicio, que es el síndrome de Babel (v.g. pueblos antediluvianos, NABUCODONOSOR, ZACARÍAS) o la hybris (v.g. EDIPO, ORFEO, PROMETEO), de modo que el resto de humanos les excluyeran. Por tanto, se está aludiendo así a la confusión interesada, impuesta por unos pocos (quienes desean acceder o mantenerse en el poder), por la que se intenta sustituir la realidad por modelos soberbios, que sólo devienen en fracaso y caos; dicho problema se agudiza cuanto más ideologizado y utópico es el modelo ${ }^{516}$. En el caso estadounidense,

que dificultan reconocer la realidad. Vid. SÁNCHEZ-BAYON, A.: Filosofía Político-Jurídica Glocal... op. cit. - Renovación de la Filosofía Social Iberoamericana... op. cit.

${ }^{516}$ Las utopías, son cultismos usados por la patrística cristiana (v.g. San Agustín y su La ciudad de Dios, adaptando el mensaje de Jesús sobre el Reino de los Cielos), con un desarrollo medieval orientado a la consecución del comunitarismo dominante de aquel periodo -distorsionador del dualismo cristiano-. Mediante las utopías se recupera la dialéctica de lo terrenal imperfecto y temporal frente a lo celestial perfecto y eterno, mostrándose así el camino entre el ser (lo cotidiano corrupto) y el deber ser (el modelo a seguir). Quien consagra el término es Tomás MORO con su obra Utopía (De optimo reipublicae statu, deque nova insula Vtopiae, 1516), pudiendo referir tanto a un no-lugar (ou-topos), como a un feliz-lugar (eu-topos). Sin embargo, desde ideologías decimonónicas como el socialismo, el concepto de utopía se ha deformado -ignorándose los planteamientos del dualismo cristiano-, llegando a confundir el fin con el medio, además de predicarse una tanatofilia o deseo de destrucción de lo presente (del hombre, la sociedad, la cultura, etc.), articulándose desde el resentimiento (malinterpretándose la metafísica y los enunciados del materialismo dialéctico e histórico), para exigir a la postre a las bases sociales la renuncia de la realidad y seguir los dictados mesiánicos de los líderes (vid. artículos de MARX en DFJ, de LENIN en Iskra, o de CASTRO en Granma). En consecuencia, la utopía ya no es el modelo a seguir y alcanzar, sino los dictados convenientes de quienes pretenden llegar y mantenerse en el poder. Ideológicamente, se articula nutriendo un malestar social, y alentando un victimismo revanchista. De este modo, una vez ha calado la utopía ideológica, se impide el libre desarrollo de la autonomía individual, en pro de una seguridad e igualdad colectiva (primando el supuesto bienestar dado frente a felicidad personal buscada). Este autor acometió tiempo atrás otro planteamiento actual de utopía, como los no-lugares (clónicos y de tránsito), donde no se desea estar y que, sin embargo, son requeridos para llegar al destino pretendido (más bien, impuesto por el sistema), como son los ascensores, las estaciones de autobús o tren, los aeropuertos, etc. Además de las utopías, existen las distopías, dorotopías, ontopías, et. al.; frente a todas estas expresiones, desde el humanismo (máxime el hispánico) se aboga por la realidad con ilusión: sin perder contacto con el mundo y la cultura, se trata de buscar la felicidad, a través de una luz guía 
aunque posee la capacidad (como rasgo distintivo) de recibir y combinar pragmáticamente las influencias de diversos orígenes, haciéndolas propias, incorporándolas a su exitoso y beneficioso modelo de Modernidad, sin embargo, tras las pasadas guerras culturales (vid. siguiente párrafo), se han logrado extender una serie de velos de confusión (que ocultan la realidad, que es la piedra de toque del modelo moderno estadounidense), un sinfín de propuestas híbridas. Dichos velos (y sus consiguientes hibridaciones), pueden clasificarse ilustrativamente -que no exhaustivamente- del siguiente modo: corrección política, discriminación positiva, política de cuotas, relativismo, pensamiento débil, etc.

Las mencionadas guerras culturales -una vez más- versan sobre los conflictos relativos a la percepción y gestión del capital simbólico, que en el caso estadounidense es el legado de los padres fundadores y su matriz idiosincrática. Si los padres fundadores han logrado su expresión máxima de racionalidad ilustrada, fijando así el paradigma de la Modernidad estadounidense; sin embargo, existen grupos minoritarios o antisistema que se oponen al mismo. Mientras que en ocasiones anteriores, dichos grupos antisistema eran reducidos y excepcionales, marchándose a la frontera (frontier factor) 517 , en cambio, en la década de 1960, los grupos antisistema alcanzan al grueso de la población, pues se nutren de

de las vocaciones (cada uno la suya e interconectadas todas), para lograr la mejor versión posible de la imagen referente de la perfección. Vid. SÁNCHEZ-BAYÓN, A.: Humanismo Iberoamericano... op. cit. - Renovación de la Filosofía Social Iberoamericana... op. cit.

517 Frontier factor o factor fronterizo fue el recurso usado por los historiadores de la generación decimonónica de TURNER, para articular su teoría de Frontier cultura: téngase en cuenta que la frontera geográfica en inglés es border, pero la psicosocial, como movilización o frente pionero para la realización del sueño -y/o fe- estadounidense (AD y AWL) es frontier. En su seno se da cabida a los disidentes o no-conformistas (dissidents \& non-conformist), además de forjarse el nativismo o nativism (se considera que, el individualismo y la laboriosidad anglosajona protestante, son las condiciones que aseguran la colonización, por dura que ésta pueda ser, ya que existe una llamada o vocación para tal fin). 
inmigrantes postbélicos y afecta a buena parte de la generación de los baby-boomers (son el relevo generacional de entonces, y uno de los más numerosos de la Historia). De este modo, hibridan y hacen un frente común de crítica y resistencia las corrientes juveniles contraculturales o underground, más los tradicionales grupos anarcocomunitarios -que, incluso (a diferencia de los europeos), pueden tener tintes religiosos, v.g. Ku-Klux-Klan o KKK, American militia-, y los discursos neomarxistas (de inmigrantes, especialmente, con la brain drain o fuga de cerebros en las universidades y los medios de comunicación). Tal combinación, más el desgaste bélico de las Guerras Mundiales, y las posteriores Guerra fría y guerras pacíficas y/o indochinas (v.g. Corea, Laos, Vietnam), junto con las impopulares intervenciones de entonces en las guerras civiles latinoamericanas, magrebíes y mashrekíes, todo ello es el caldo de cultivo perfecto para la extensión de las hibridaciones anteriormente citadas. Su resultado son las guerras culturales (de 1960 hasta 1990), que terminan con la inocencia estadounidense y confunden su autopercepción. Se cuestiona cualquier visión integradora de los EE.UU., al tiempo que se fomenta la dispersión y fragmentación de visiones. Para ello es clave las aportaciones que se realizan desde los Estudios culturales, pues se impulsan así lecturas contrarias a la Ilustración estadounidense, al descalificarla de racista, machista, imperialista, etc.; en su lugar se ofrecen contradictorias lecturas étnico-culturales (v.g. afroamericanas, asiáticoamericanas, indoamericanas o americanas nativas, feministas y de género). Tales guerras culturales han traído consigo oscilaciones, desde la tendencia posmoderna de la primera Administración CLINTON, hasta su pendulación -y sin embargo tocante en muchos puntos- neoconservadora Administración BUSH (vid. infra cap. 7, más supra cap. 9). 
Frente a la disolución de las guerras culturales, ha de resaltarse el papel jugado de las muchas propuestas de integración -que no de asimilación, como las europeo-continentales decimonónicas, al modelo francés-, todas ellas manejadas por los estadounidenses, para entender y explicar su matriz idiosincrásica: qué les une en la diversidad, que es uno de los lemas nacionales (e pluribus unum, vid. infra cap. 5 y 6, más supra cap. 10). Cabe mencionar entre dichas propuestas integradoras, desde la decimonónica de frontier factor o factor fronterizo (el disidente encuentra su lugar en la frontera), hasta la más reciente del crisol cultural o melting pot (EE.UU. es como un caldero donde caben y se mezclan todos los ingredientes, vid. supra). Esta última propuesta (melting pot), vigente durante las guerras culturales, fue objeto de sus críticas, recibiendo las siguientes contestaciones o contra-propuestas -aunque puedan parecer algo naif, sin embargo dividieron a la academia en legitimarios y contestatarios-518:

a) denominational pot o caldero congregacionalista: se considera que la mezcla entre las nacionalidades de origen se da en el seno de grupos religiosos relativamente homogeneizados (protestantes, católicos, judíos), y los que no encajan, entonces quedan silenciados (y por ende, sin participación en la Historia estadounidense).

b) transmuting pot o caldero de maceración: no ha habido fusión real, sino imposición de asimilación, pues las características culturales de los inmigrantes

\footnotetext{
518 Entre las principales revisiones y contestaciones (propias y extranjeras) al melting pot, vid. FAIRCHILD, H.P.: The melting-pot mistake, Boston: Little Brown \& Co., 1926. GORDON, M.: Assimilation in American Life: The role of race, religion and national origins, New York: Oxford Univ. Press, 1964. HORSMAN, R.: Race and Manifest Destiny. The origins of American racial Anglo-Saxonism... op. cit. LEMARCHAND, P.(dir.): Atlas de Estados Unidos. Las paradojas del poder... op. cit. LEWIS, E.R.L.: America, nation or confusion. A study of our inmigration problems, New York: Harper \& Bro., 1928. ORTEGA Y MEDINA, J.A.: La evangelización puritana en Norteamérica... op. cit. PORTES, J.: Estados Unidos hoy. ¿Los amos del mundo? (trad.), Madrid: Larousse, 2003. RODRÍGUEZ, R.: Brown: The last discovery of America, New York: Viking, 2002.
} 
recién llegados han de someterse a un proceso de adecuación al acervo WASP, que es el único referente cultural que permanece.

c) salad bowl o cuenco de ensalada: cada grupo étnico conserva su legado cultural, sin desnaturalizarse ni mezclarse plenamente, por lo que cada comunidad, en realidad, vive segregada localmente de las demás, aunque federalmente de la impresión de ser una ensalada bien aliñada.

d) pizzaland o tierra de pizza: se incoa un multiculturalismo (encuentro de culturas), con variedad pero sin mezcla, donde la base WASP es el soporte de la identidad estadounidense.

La crítica más incisiva, lesiva y desmitificadora ha sido la de brown culture o cultura marrón/mestiza. Se califica con dicho color, pues el mismo es el resultante de la combinación desordenada de colores; además de tratarse del descalificativo genérico usado contra los mestizos. Se plantea así la visión de los EE.UU. como país de mestizaje impropio (o sea, híbrido), pues en realidad, en su seno nada es autóctono, sino resultado de la combinación de elementos, de manera excepcional. De este modo se articula una idiosincrasia estadounidense, que niega cualquier matriz fruto de la racionalidad, sino que se debe al azar y necesidad de la convivencia de comunidades. Gracias a dicho planteamiento, de gran calado durante las guerras culturales (desde la década de 1960) e imperante tras la globalización (desde la década de 1990) en los Estudios culturales, ello ha favorecido la extensión de los citados velos de confusión, consolidándose la hibridación dominante, además de agudizarse así la crisis idiosincrásica estadounidense recuérdese lo mencionado al inicio de esta tesis (vid. infra cap. 1) sobre la confusión 
indentitaria introducida por los Estudios culturales en lo tocante al descubrimiento y desarrollo cultural de los EE.UU., ya que cada variante de dichos estudios postulan su versión sesgada e interesada-. 


\section{9.- DIMENSIÓN SUBJETIVA:}

\section{PAPEL DE LOS FOUNDING FATHERS EN LA CONSTITUCIÓN Y LEGADO DE ACR 519}

Hablar de los founding fathers o padres fundadores en EE.UU. es algo de carácter sagrado: al igual que existe la patrística en la tradición sagrada occidental, al pasarse por su Americaness, en el novus ordo seclorum estadounidense, aparece un patrística de su ACR. La misma, ha venido tratándose con gran respeto y devoción (incluso, siendo objeto de culto), además de alcanzar un grado de santidad (por su ejemplaridad de vida atribuida), tipificándose todo ello en su ACR y su legado. Tal es el nivel referencial (hierático), salvífico y trascendente conferido a los padres fundadores, que no sólo custodian el acervo socio-cultural idiosincrásico de los EE.UU., sino que disponen del mismo, para contribuir a su legado: influyen en sus ritos, símbolos, creencias, instituciones, etc., tanto comunes (de los padres fundadores en conjunto) como personalizadas (de cada uno de ellos). En la construcción de la realidad social llegan a contar incluso con sus días festivos, v.g. Día del Presidente (el tercer lunes de febrero, con especial conmemoración de G. WASHINGTON y A. LICOLN); Día de los Patriotas (el tercer lunes de abril); Día del Memorial (el último lunes de mayo, dedicado a los sacrificados por la patria); Día de la Independencia (el 4 de julio, sobre todo, para el recuerdo de los revolucionarios y constituyentes), etc. La patrística estadounidense bien puede equipararse con la original de la tradición sagrada occidental, como son los profetas judeocristianos y

\footnotetext{
519 Vid. infra nota 382, en especial, vid. SÁNCHEZ-BAYÓN, A.: “Estudio de la idiosincrasia estadounidense desde su Teología política y Ciencias Eclesiásticas" (p. 165-204), Estudios Eclesiásticos, v. 93, no 364, 2018. - "Revelaciones sobre los padres fundadores estadounidenses y su legado en materia de relaciones Iglesia-Estado, libertad religiosa y asistencia socio-religiosa" (p. 383-438), Anuario de Derecho Eclesiástico del Estado-Ministerio de Justicia (nº33), 2018.
} 
otros ungidos por Dios (v.g. reyes, jueces, libertadores). En realidad, se trata de una prolongación de aquella, según su ACR (al sintetizarse la tradición occidental sagrada con la profana, más el pensamiento whig o liberal-conservador y freemanson o librepensador o PWF520, así como otros planteamientos de su Americaness o estadounidización) $)^{521}$.

520 Apuntes sobre el pensamiento whig \& freemason (PWF): Whig proviene del gaélico escocés y norirlandés y puede traducirse por villano, pues aludía a los pequeños propietarios de los minifundios del Norte, en concreto a los covenanters o pactistas presbiterianos (futuros puritanos), quienes durante las guerras civiles británicas del s. XVII (marcharon sobre Edimburgo y luego hacia la capital para reclamar derechos (sobre todo, libertad religiosa, de asociación y de comercio), además de oponerse a la Monarquía absoluta. También se les conoció como los dissenters [disidentes] y Kirk party [partido eclesiástico], por oponerse a la oficialidad del anglicanismo (y cuando llegaron al poder, también se enfrentaron al catolicismo, vid. Exclusión bill, 1678). Darán lugar al partido liberal, tanto en Gran Bretaña-UK como en los EE.UU., dominante durante el s. XIX. Freemason es la adaptación de una expresión traída del continente, de los territorios británicos en la Bretaña francesa (causa de disputa en la Guerra de los cien años), y alude al constructor de casas, quien disponía de los pocos oficios libres del Medievo, pues no dependía de gremios ni talleres que le limitaran, sino de su conocimiento y se desplazaba allá donde hubiera trabajo (construcción de catedrales, palacios, etc.). En síntesis (sobre el cambio de concepción acaecido en los EE.UU., y por ende, qué se entiende desde entonces por freemason), hasta el S. XVII, la masonería era de corte operativo: relativa a los oficios liberales de la época, como el de constructor de catedrales, ya que disponían de autonomía de normas y movimiento, organizándose en torno a Collegia o colegios profesionales. A partir de entonces, la masonería empieza a ser de corte especulativo: abierta al librepensamiento, especialmente de filósofos naturales o experimentales (la Nueva Filosofía comprendía los campos de la medicina, la mecánica, la navegación, la geometría, etc.), juristas, literatos (políticos y económicos), et al., organizándose ahora en el seno de Reales Sociedades/Academias -en los EE.UU., otros focos que continúan la tradición son los Colleges y sus Fraternities. Vid. infra nota 1. Sobre Whig, vid. HAMMER, D.: The Puritan Tradition in Revolutionary, Federalist, and Whig Political Theory. A rhetoric of origins, New York: Peter Lang, 1998. RICHARD, C.J.: The Founders and the Classics. Greece, Rome, and the American Enlightement, Cambridge: Harvard University Press, 1994. WILTSHIRE, W.: The Usefulness of Classical Learning in the Eighteenth Century, New York: American Philological Association, University Press, 1976. - Greece, Rome, and the Bill of Rights, Norman: University of Oklahoma Press, 1992. Sobre Freemason, vid. BULLOCK, S.C.: Revolutionary Brotherhood. Freemasonry and the transformation of the American Social Order, 1730-1840, Chapel Hill: The University of North Carolina Press, 1996. NEWTON, J.F: The Builders, Lexington: The Supreme Council, 1973. ROBERTS, A.E.: Freemasonry in American History, Richmond: Macoy Publishing, 1985.

${ }^{521}$ Proceso de conversión en estadounidense (vía socialización, trasplante, etc.). En este caso, se alude a la capacidad estadounidense de recibir y transformar constructos socioculturales de todo el mundo, revistiéndolos de éxito y beneficio, con los que se socializa a sus ciudadanos, además de servir para 
¿Quiénes son los padres fundadores? Se trata de aquel conjunto de hombres sobresalientes, las nuevas elites americanas (cooptadas por sus méritos y compromiso -y no hereditarias-), caracterizándose por su renovación cíclica, para dirigir y/o legar algo clave a su pueblo en momentos cruciales, influyendo en su idiosincrasia. Por tanto, la categoría de padres fundadores no se restringe a quienes fundaron las colonias e hicieron la Revolución de Independencia o firmaron la Constitución, sino que trasciende a quienes han ido sentando las bases constitucionales de la nación, refundándola cuando ha sido necesario. Han sido los encargados de guiar al pueblo y/o transmitirles la renovación del mensaje pactista (American Covenant Theology o ACT) ${ }^{522}$. Sirva como adelanto delimitador de la

\footnotetext{
dar impulso a su soft-power o poder blando, también llamado por los Estudios culturales sobrevenidos como neo-colonialismo cultural.

${ }^{522}$ Conforme a la teología positiva (máxime la Teología política manejada por los primeros padres fundadores, v.g. J. WINTHROP, J. COTTON, J. ELIOT, I. MATHER, C. MATHER, T. TATCHER, J. EDWARDS), consiste en el conocimiento de Dios mediado por el hombre, y se centra en el pueblo elegido para su salvación. Entre sus clasificaciones, cabe distinguir entre una teología positiva común, focalizada en el estudio de los pactos y las Escrituras, y una teología positiva particular, de cada una de las tradiciones teológicas, v.g. ortodoxos, católicos romanos y orientales, protestantes. Pues bien, la ACT (teología político-jurídica estadounidense pactista) es la principal manifestación de Teología política estadounidense, combinando la teología positiva moderna, tanto común como particular, pues permite observar los pactos (de salvación) de Dios con su pueblo, atendiéndose a las tradiciones recibidas y desarrolladas en su seno, incluso aquellas posjudeocristianas como las decimonónicas mormona y de los testigos de Jehová, o las del s. XX de los cienciólogos o los davidianos, et al. Sirvan como muestra, en forma de apuntes telegráficos, de las referencias articuladoras de ACT ("God's manifesto"): Un pueblo elegido y sus mesías: Pactos con Adán (Gn. 3), Noé (Gn. 6 y 9), Abraham (Gn. 12, 15 y 17), Moisés (Ex. 19), etc. Conversión y Nueva Alianza (Jr. 31 y 32, confirmado por Mc. 14, Mt. 26, Lc. 22, 1Co. 11, Heb. 8 y 9). Una misión: Pactos de evangelismo social (Dt. 10, Is. 1, Jr. 31, Sal. 119, etc.); Mandamientos (Ex. 19, Dt. 5), etc. Un lugar: Paraíso terrenal o Nueva Jerusalén (Gn. 3 y 12, Sal. 122, Is. 2 y 54, Mt. 5, Lc. 6), etc. Unas reglas (dualismo cristiano): convivencia de lo civil y lo religioso (Mc. 12; Lc. 20; Mt. 22; etc.); la doble obligación cristiana (Hch. 5 y 25, Rm. 5, etc.). Otros Pactos (selfrighteouness, civilazing sense): cargas y factores tipo temor, piedad, tolerancia, et al. (Dt. 5, Jos. 11, Sal. 34), etc. Organización tipo eclesiología federal (Hch. 15). Mandatos tipo Teología de la dominación o Dominalism (Gn. 1), et al. En cuanto a sus expresiones interconectadas: 1.- Covenant Theology o teología pactista: a) Dispensional (continuidad del pacto según coyunturas): supone linealidad estructural (v.g. Federalismo y Destino Manifiesto); b) Casuístico (pacto integrador cada vez que se necesite): supone ciclos voluntaristas (v.g. Square Deal de T. ROOSEVELT, New Deal de F.D. ROOSEVELT, Fair Deal de H.S. TRUMAN, New Frontier de J.F. KENNEDY, Great Society de L. JOHNSON, New Coventant de B.
} 
cuestión sobre quiénes son los padres fundadores o patrística estadounidense, la siguiente enunciación clasificatoria por ciclos: a) pilgrims [peregrinos (fundacionales)] y leaders [líderes (coloniales)] del periodo colonial; b) rebels [rebeldes (independentistas)] y framers [constituyentes (redactores de la Constitución de los EE.UU. o CEU y la Declaración de Independencia o DIE)] en el periodo nacional; c) Statemen [estadistas] en los periodos refundaciones (bien como pastores, bien como reverendos, vid. supra).

Volviéndose a la cuestión preliminar de las elites de poder (conforme a ACT), se atiende aquí a la dimensión más subjetiva de los ciclos de despertares y revitalizaciones (American awakenings $\mathcal{E}$ revivals o AAR $)^{523}$, lo que precisa a su vez de

CLINTON, etc.). 2.- Teología dogmática: a) más secular: American way of life, Federalisms, Manifest Destiny, etc.; b) menos secular: Theonomy (desde los Christian Reconstruction Movements hasta los Dominion Theology Movements). 3.- Teología cultural: histórica, narrativa, natural, etc. Vid. infra bibliografía de nota 1. Vid. BELLAH, R.N.: Beyond beliefs, New York: Harper \& Row, 1970. - The broken covenant: American Civil Religion in the Time of Trial, New York: The Seabury Press, 1975. EIDSMOE, J.: Christianity and the Constitution. The faith of our Founding Fathers, Grand Rapids: Baker Books, 1987. HANLEY, M.Y.: Beyond a Christian Commonwealth, Chapel Hill: The University of North Carolina Press, 1994. HUGHES, R.T.: Myths America Lives By, Urbana: University of Illinois Press, 2003. Vid. infra cap. 5 y 6.

${ }^{523}$ AAR se entiende como un juego de interacciones socioculturales (sacro-profanas), dinamizadoras de la vida nacional (aquellos episodios determinantes de su idiosincrasia), además de evidenciadoras de una serie de ciclos sociales (v.g. expansionistas-aislacionistas), que conforman a su vez de una pauta de desarrollo (hacia un supuesto progreso bendecido). Téngase en cuenta que, la aludida vida nacional ha de entenderse de manera distinta al sentido europeo-continental, pues en el caso estadounidense, no ha sido monopolizada por el Estado-nación, sino que su dinamización principal ha procedido de la sociedad civil, con sus múltiples comunidades, entre las que destacan las confesiones y su preocupación por mejorar el mundo (como parte de la Teología política aplicada, como es el evangelismo social, vid. cap. 5). Volviéndose a la TDR y las interacciones que incluye, resulta que el arranque de la mayor parte de tales interacciones suele provenir de la eclosión de movimientos sociales demandantes de reformas del sistema, propiciándose una incorporación de nuevos discursos regeneradores, así como la renovación de las elites de poder, hasta su adopción por las consiguientes elites sensibles a la regeneración, bajo una suerte de revitalización sociocultural del proyecto nacional, y a la postre, además, procurándose el plasmar todo ello en su contribución al legado nacional. Una vez más de manera esquemática, cabe discernir al menos cuatro grandes etapas de "religious awakenings" o despertares religiosos (a cargo de las bases populares y dando lugar a sincretismos), junto con sus correlativas "religious revivals" o revitalizaciones religiosas (de sus elites 


\section{un recurso cimentador de: a) los estudios sobre elites de poder; b) los estudios} interpretativos.

de poder para reorientar la religión civil estadounidense): a) Periodo de formulación (de las colonias a la nación, 1620-1790): su despertar es la búsqueda de un entorno de tolerancia (y fe necesaria para la colonización), en contraste con las guerras de religión europeas. Su revitalización conlleva la emancipación político-religiosa frente a UK. De ahí, el auge de confesiones reformadas del anglicanismo (v.g. episcopalismo, presbiterianismo), permitiéndose así romper en todos los sentidos con la monarquía -que era el cenit institucional del Estado, la Iglesia y sus relaciones-. Su crisis culmina con la Guerra de Independencia (1776-81) -o la primera guerra civil stricto sensu, de patriotas (reformados) $v$. realistas/lealistas (anglicanos)-, dando paso a los ensayos de confederación y federación. b) Periodo de implementación adaptativo (de la nación a la hegemonía continental, 1790-1890, con el lapso de la secesión, 1860-1864): el despertar supone la adaptación de las religiones tradicionales a las necesidades del medio estadounidense en ampliación y profundización (v.g. guerras indias, conquista del oeste), y su revitalización conlleva el posicionamiento identitario y sociocultural entre norteños (protestantes liberales) y sureños (protestantes evangélicos) -aunque en realidad se trató de un choque de mentalidades colectivas y de sus acciones sociales, o sea, la dialéctica entre modernos sureños y contemporáneos norteños (que por una excesiva secularización de los norteños, reemerge la cuestión desde la década de 1960)-. c) Periodo de implementación expansionista (de la hegemonía continental a la internacional, 1890-1960): su despertar es el empuje proselitista del modelo sociocultural estadounidense, en términos mesiánicos (basados en su sobrestima, al considerarse como pueblo predilecto y herramienta de Dios). Su revitalización, es la consolidación del modelo geopolítico estadounidense, basado en el liderazgo (no en el imperialismo tradicional, sino en un destino manifiesto) y los parámetros de alianza del bien (aliados) contra eje del mal (enemigos) -en este periodo, los conflictos armados, sirven para unir aún más a los estadounidenses, fortaleciéndose el American way of life o AWL, hasta que se produce la Guerra Fría (1956-1989), y con ella, una serie de derrotas y quiebras (máxime, en el sudeste asiático, con el apoyo de la contracultura estadounidense). d) Periodo de evaluación y de confusiones (1960-en adelante, pues es cuando estallan las guerras culturales, que dan lugar al auge de la corrección política y demás velos de confusión de 1990, y al neoconservadurismo de 2000): dado el malestar interno estadounidense tras su pérdida de inocencia, el despertar que acontece es dual, nuevamente diferenciándose el modo sureño (de interior y neortodoxo, al reivindicar un fundamentalismo o vuelta a los orígenes fundacionales), y el modo norteño (de costa y sincrético, con reformulaciones socio-religiosas: neopaganas, orientalistas, etc.). Sendos despertares ponen de manifiesto la urgente necesidad de la renovación del paradigma identitario nacional y su modelo sociocultural. En consecuencia, la revitalización resultante también es dual, pues de un lado, los contagios posmodernos y las crisis de la globalización, dan lugar a respuestas relativistas de la intelectualidad establecida y al servicio de la Administración en el poder, mientras que de otro lado, brotan movimientos contestatarios y regeneradores, v.g. Tea party movement. Actualmente, se estaría viviendo el despertar de un quinto ciclo, muy posiblemente (vid. infra ciclos de despertares y revitalizaciones en la Parte de desarrollo general). 
a) Estudios sobre elites de poder 524 : ayudan a entender las redes y los juegos de las elites de poder, así como, la causalidad e intencionalidad de sus contribuciones. En el caso estadounidense es de destacar que, se trata de un auténtico supuesto moderno, pues cíclicamente ha tenido lugar una cierta renovación de las elites de poder -en vez del problema estamental y endogámico del Antiguo Régimen-, en cuyo proceso ha influido de manera significativa el factor religioso, v.g. como ascensor social; como revulsivo de la agenda institucional; como conductor de creencias, causas, discursos, etc.

b) Estudios interpretativos: sirven para conocer cómo han entendido y transmitido el legado recibido los padres fundadores, y cómo ha sido tratado el mismo por generaciones posteriores. Sirva como ejemplo el caso eclosionado en la década de 1980 con la corriente del originalismo y los primeros neocon (dominantes luego

524 Vid. BONNELL, J.S.: Presidential Profiles. Religion in the life of American Presidents, Philadelphia: The Westminster Press, 1971. BRADFORD, M.E.: Founding Fathers: Brief Lives of the Framers of the United States Constitution, Lawrence: University Press of Kansas, 1994. COUSINS, N. (ed.): The Republic of Reason. The personal philosophies of the Founding Fathers, New York: Harper \& Row., 1988. DREISBACH, D.L., HALL, M.D.: The Founders on God and Government, New York: Rowman \& Littlefield Pub., 2004. EIDSMOE, J.: Christianity and the Constitution. The Faith of our Founding Fathers, Grand Rapids: Baker Book House, 1987. FOWLER, R.B., HERTZKE, A.D.: Religion and Politics in America: Faith, culture and strategic choices, Boulder: Westview Press, 1995. HARTZ, L.: The Liberal tradition in America. An interpretation of American Political Thought since the Revolution, New York: HBJ Books, 1955. HOFSTADTER, R.: The American political tradition and the men who made it, London: Jonathan Cape, 1967. - et al.: The structure of American History, Prentice-Hall: Englewood Cliffs, 1946. KIRK, R.: The conservative mind, Chicago: Henry Regnery Co., 1955. HYNEMAN, C., LUTZ, D.S. (eds.): American Political Writings during the Founding Era, 1760-1805 (vols I-II), Indianapolis: Liberty Press, 1983. KRAMNICK, I., MOORE, R.L.: The Godless Constitution. A moral defence of the Secular State, New York: W. W. Norton \& Co., 2005. NASH, G.H.: The conservative intellectual movement in America, New York: Basic Books, 1976. NOVAK, M.: On two wings. Humble faith a common sense at the American founding, Washington DC: AEI, 2001. OLSON, L.R.: Filled with spirit and power. Protestant clergy in politics, Albany: State University of New York Press, 2000. SMITH, G.S.: Faith and the Presidency. From George Washington to George W. Bush, New York: Oxford University Press, 2006. 
en la década del 2000), por la que los estatistas de entonces (políticos y jueces, sobre todo), pretendían realizar una anacrónica lectura original del legado fundacional, sin atender al acervo posterior. En definitiva, gracias a los estudios interpretativos, cabe distinguir entre la interpretación (stricto sensu), la construcción y la traducción, además de permitir la detección de falacias, fraudes e imposturas, junto con sus falsarios. Propedéuticamente, resulta sugerente la lectura de GRAFTON ${ }^{525}$, quien sugiere las siguientes reglas en la interpretación del papel y legado de los padres fundadores:

- Evaluación de motivos: a) ambición social (se pretende medrar, alagando al poderoso y/o ganándose la simpatía de la mayoría) y profesional (se sustentan tesis revolucionarias, para dar cabida los propios planteamientos); b) vanidad y malevolencia (se escriben textos apócrifos deliberados para probar el ingenio y desacreditar a otros, v.g. los libelos revolucionarios y guerracivilistas).

- Valoración de medios: se trata de saber distinguir los documentos oficiales (sobre todo políticos y jurídicos) de los privados (v.g. epístolas, testamentos), detectando de entre todos ellos aquellos textos de tipo espurio y apócrifo, casualmente perdidos y encontrados, y con imposturas y falacias contestatarias o legitimadoras de la causa correspondiente (v.g. el abuso de las Escrituras por parte de leaders coloniales, los statemen guerracivilistas o los neocon tras el 11/S). Entre las adulteraciones interpretativas frecuentes, en términos formales, destacan las especulativas (v.g. modus ponens, modus tallens), las transitivas (v.g. silogismos erróneos, correlaciones accidentales), las generalistas (v.g. inferencias, idealizaciones) y las ambiguas (v.g. indeterminaciones, polisemias). En términos

\footnotetext{
525 Vid. GRAFTON, A.: Forgers and Critics. Creativity and Duplicity in Western Scholarship, Princeton Univ. Press, Princeton, 1990.
} 
sustanciales, figuran habitualmente las falacias ad hominen (se ataca a la persona y su credibilidad), ad ignorantiam (se sustenta en la incertidumbre o dificultad de prueba), ad baculum (se amenaza, especialmente, con la fuerza), ad populum (se apela a las emociones de las masas), ad verecumdiam (se apela a la autoridad de otros), petitio principii (hay petición de principio o círculo vicioso), etc.

- Apreciación de circunstancias: los padres fundadores, como los rabinos antiguos, la patrística clasicotardía o las órdenes religiosas bajomedievales, no consideraban que sus reinterpretaciones de la tradición sacra y profana occidental fuera algo inmoral o amoral, tan sólo atendían a las exigencias de momentos constituyentes y de crisis coyunturales, en los que era esencial fijar la verdad y la autoridad, apuntalándose así los fundamentos del sistema -tal y como se desprende de los Preámbulos de la DIE y la CEU, por ejemplo-.

Además de las técnicas y recursos de estudio planteados, dado que se trata de una interdisciplinaria sobre los padres fundadores y su legado, se deja constancia del empleo igualmente de las herramientas científico-académicas propias del Derecho Eclesiástico (como base del estudio, v.g. exégesis, hermenéutica), junto con aquellas otras aportaciones de refuerzo, provenientes de CC. Sociales (v.g. Sociología, con estadística y semblanzas) y Humanidades (v.g. Filosofía, con análisis crítico).

Tras esta introducción (de nociones y recursos de estudio) se está ya en disposición de profundizar al respecto. 


\section{1.- REVELACIONES SOBRE LOS PADRES FUNDADORES:}

MÁS ALLÁ DE LA VIDA EJEMPLAR DE SANTOS

¿Quiénes son los padres fundadores? En sentido laxo, se trata de una macrocategoría de cultura político-jurídica estadounidense, que incluye a medio millar de personalidades (aprox.), representativas de las elites de poder de las generaciones más relevantes en la configuración del American way of life [modo de vida/de ser estadounidense] o AWL (entre la emergencia colonial y la puesta en marcha del sistema constitucional federal, sobre todo). Si transcendieron estos personajes, es debido a su capacidad visionaria, su destreza de mando y su predisposición para anteponer el bien común al bienestar personal -jugándose la vida y el patrimonio, en muchos de los casos y en diversas ocasiones-. Ahora bien, en puridad, por padres fundadores resulta conveniente distinguir entre las cinco grandes subcategorías (pilgrims, leaders, rebels, framers, Statemen -aunque en los últimos años se ha ido imponiendo otra clasificación, discutible en sus denominaciones y en sus contenidos, vid. supra figura final de epígrafe-. Las citadas subcategorías (las propias), son las que conforman el conjunto de la expresión padres fundadores, clarificándose con ello la lógica motora del tránsito al Nuevo Régimen, y la implantación en el mismo de la libertad religiosa, y su influjo en el avance del resto de derechos civiles y políticos.

a) Pilgrims [peregrinos: llamados así por el éxodo que les tocara vivir, hasta su llegada a Nueva Sión (la bahía de Plymouth)-] E puritans [puritanos: son todas las variantes reformadas del protestantismo, que incluyen a los peregrinos, absorbiéndoles a la postre (con el predominio de la gran Colonia de la Bahía de 
Massachusetts]: en su conjunto, representan el referente del primer estereotipo de estadounidense, quién ha de ser una persona con un sueño y con la tenacidad suficiente para lograr su cumplimiento ${ }^{526}$. Los pilgrims, en concreto, eran unas familias congregacionalistas, huidas a Holanda y retornadas a U.K. (a Plymouth -al menos, para los contactos con la compañía homónima que sufragara la fundación colonial-), para partir definitivamente a América (llegando a Nueva Plymouth, vid. supra). Los cuarenta cabezas de familia de la expedición (representantes de los 101 peregrinos, de acuerdo con los anales de MORTON basados a su vez en Of Plymouth Plantation de BRADFORD) ${ }^{527}$, para consagrar su misión (la búsqueda de la tierra prometida: Nueva Sión/Jerusalén), tras el

\footnotetext{
526 Por descontado que hubo otros colonos antes -muchos abandonados a su suerte (JOHNSON); pero a diferencia de la conquista española (que exigía pureza de sangre y cierta hidalguía para viajar a América; vid. Leyes de Indias), la colonización británica alentaba a las clases más bajas -incluso a impagadores y delincuentes (vid. Agencia de Comunicación de las Embajadas Estadounidenses)- a dejar la metrópoli, de ahí que, los pilgrims resulten el referente más próximo a la hidalguía. Vid. JOHNSON, P.: Estados Unidos. La Historia (trad.), Buenos Aires: Ediciones B, 2001. KRAMNICK, I., MOORE, R.L.: The Godless Constitution. A moral defense of the Secular State, New York: W.W. Norton \& Co., VV.AA.: Reseña de la Historia de los Estados Unidos (trad.), Washington DC: Agencia de Comunicación de las Embajadas Estadounidenses, 1975. WALLACE, J.D.: Historia no-oficial de Estados Unidos de América. El libro negro del imperio (trad.), Barcelona: Ediciones de la Tempestad, 2004. Debido a la prevención que se viene haciendo, relativa a la importancia de distinguir entre la interpretación, la construcción y la traducción, o sea, entre la retórica y la realidad, se incide entonces en la reseña de la publicación reflejo de la cruda sinceridad de la década de 1970- de la Agencia de Comunicación de las Embajadas Estadounidenses -antes de su reconfiguración, bajo la revitalización judeocristiana, quedando como el ya citado servicio propagandístico de Programas de información de los EE.UU.-USINFO (URL: http://usinfo.state.gov/esp/). En el citado texto, en su página 5, se reconoce que "los capitanes de barco, que recibían jugosas recompensas a cambio de los contratos de trabajo de inmigrantes pobres, recurrían a todo tipo de métodos, desde promesas extravagantes hasta secuestros, para embarcar en sus naves tantos pasajeros como cabían. Se estimulaba a los jueces y autoridades carcelarias para que ofrecieran a los condenados la oportunidad de emigrar a América en lugar de cumplir sus sentencias".

527 Vid. BRADFORD, W.: Of Plymouth Plantation, Cabe Cod, 1647 (fue recuperado y reeditado siglos después: Boston: Wright \& Potter Printing Co., 1898). MORTON, N.: New England's Memoral, 1669 (facsimile en bases universitarias: JSTOR-Princeton Univ., Humanities Text Collection-Making of AmericaUniv. Michigan, Perseus Project-Tufts Univ., Project Gutenberg-Benedictine College; y bases de instituciones públicas, v.g. World Digital Library-WDL (UNESCO con la biblioteca nacional estadounidense Library of Congress -más su proyecto Thomas-).
} 
desembargo, procedieron a la firma del Mayflower Compact [Pacto del Mayflower (nombre del buque en el que se acometió la travesía)], sentando así las bases del ius circa sacra (ICS) estadounidense, o sea, los antecedentes de su American Church Law (ACL): cómo se regulan sus relaciones Iglesia-Estado lato sensu (comprendiendo las relaciones derecho-política-religión, los avances hacia la libertad religiosa, la asistencia socio-religiosa, etc.).

Entre los nombres más sobresalientes destacan (por sus raíces entre los pilgrims y su posterior liderazgo en fundaciones sucesivas): CARVER, BRADFORD, HOWLAND, HOPKINS, WINSLOW, TINKER, FULLER, WILLIAMS, BROWN, TILLY, CLARK, COOKE, EATON, etc. ${ }^{528}$.

b) Leaders [líderes]: es una subcategoría aún más amplia que la anterior, ya que atañe y ensalza el estereotipo del dirigente carismático colonial -no autoritario, como es el jefe europeo-mediterráneo-. Se trata de gentes capaces de organizar y dirigir grupos, confiriéndoles un sentir identitario y una misión común. Entre dichos líderes locales, sobresalen los casos de referentes políticos y socioreligiosos como WINTHROP (Gobernador colonial) y STODDARD (abuelo de EDWARDS), junto con los MATHER en el área actual de Massachusetts; o los CALVERT (descendientes del pilgrim) en Maine y Maryland. Incluso, comienzan a surgir los líderes heterodoxos, impulsores del avance hacia la frontera y la transición hacia la Modernidad, tal como resultan referentes socio-religiosos

\footnotetext{
${ }^{528}$ Lista de los cuarenta y un varones adultos (representantes de familias), que firman el Mayflower Compact -el 11 de noviembre de 1620, conforme al calendario juliano, de ahí que la celebración del día de acción de gracias se traslade al tercer jueves de noviembre-, y que el sobrino de BRADFORD compiló (fijando la prelación que ha subsistido hasta hoy) en su obra New England's Memorial, 1669 (vid. nota previa).
} 
disidentes de la talla de la Sra. HUTCHINSON y el Rev. HOOKER, para los congregacionalistas reformados en Connecticut; el Rev. WILLIAMS, para los bautistas en Rhode Island; los PENN, para los cuáqueros o amigos en Pennsylvania, junto con los WESLEY (pietistas fundadores del metodismo estadounidense) en Bethlehem (Pennsylvania); el Rev. DAVIS, para los presbiterianos en Virginia y Delaware; el Rev. ROGERS, para los rogerenes en Massachusetts ${ }^{529}$; etc. Otros referentes a recordar, impulsores del pensamiento guía del ICS (con su Teología política) son los teólogos, filósofos y docentes proto-pragmáticos (impulsores de despertares y movimientos del tipo trascendentalismo o nativismo), como son los casos de HARVARD en Cambridge, los EDWARDS en Princeton, EMERSON (y el resto del Club metafísico) en Cambridge y Concord, WHITEFIELD (y el Club Sagrado) con sus fundaciones de Connecticut a Georgia, CHANNING en Boston, BACKUS en Middleborough, et al.

c) Rebels [rebeldes]: conforman el conjunto de figuras emblemáticas, de personajes apasionados y transgresores, de verbo fácil, encendido y progresista, cuyo marco temporal transcurre entre la Guerra de la Independencia y la de 1812. Inspiran el primer referente del antihéroe estadounidense, pues se trata de sujetos de buen status socio-económico y cultural (de familias acomodadas y profesiones liberales), que forman parte de las elites de poder y, en cambio, luchan contra el sistema. Sus exponentes más claros y populares son P. HENRY (1736-99) y T. PAINE (1737-1809). El primero, es conocido por interrumpir a gritos en la

\footnotetext{
529 Es una de las primeras expresiones de la variedad religiosa autóctona estadounidense, nacida en el entorno académico de Harvard Univ.
} 
Convención Constitucional de Virginia (1775) con la famosa soflama give me liberty or give me death [dame libertad o dame muerte]; igualmente, escribe el panfleto Religious Tolerance [Tolerancia religiosa] (1776), con cierta repercusión en la Bill of Rights o Declaración de Derechos del citado Estado -incluso, influirá en la futura declaración francesa de 1789, además de gozar de gran eco entre sus coetáneos gracias a PAINE y a JEFFERSON-. El segundo, redacta las obras Common Sense [Sentido común] (1776), Rights of Man [Derechos del hombre] (1791), Dissertation on the First Principles of Government [Tesis sobre los principios fundamentales del Gobierno] (1795). Ambos (HENRY y PAINE), siendo vástagos de familias acomodadas británicas, forman parte de los alzamientos locales frente a la metrópoli (Virginia y Massachusetts, respectivamente), y contribuyen a dar amplia publicidad a la DIE. En su línea disidente, pese a participar en las discusiones de la redacción de la CEU, finalmente, deciden no firmar el documento. Asimismo, aunque formalmente son episcopalianos (de familia), predican un deísmo radical, que en el caso de PAINE llega a rayar cierto anticlericalismo ${ }^{530}$. Cabría incorporar al grupo de rebeldes a JEFFERSON (aunque también puede ser considerado framer y Statemen según los periodos), pues cumple con la mayoría de las condiciones enunciadas (v.g. de familia acomodada, de discurso vehemente y progresista, participa en las discusiones constitucionales pero no firma el texto final y su deísmo es muy radical), ahora bien, todo cambia cuando es proclamado Presidente.

\footnotetext{
530 "I am a sect by myself" [soy una confesión por mi mismo] o "I consider myself in the hands of my Creator" [me considero en manos de mi creador -no en las de una iglesia], son expresiones atribuidas a PAINE, en su manifiesta oposición a los poderes establecidos, pues las iglesias oficiales mataban la verdadera religiosidad. Vid. COUSINS, N. (ed.): The Republic of Reason. The personal philosophies of the Founding Fathers, New York: Harper \& Row., 1988.
} 
d) Framers [constituyentes]: se trata del selecto grupo de delegados firmantes de los documentos cardinales en la construcción jurídica de los EE.UU. En primer lugar, la DIE, rubricada por cincuenta y seis delegados, representantes de aproximadamente una docena de confesiones distintas -en correlación directa con el número de Estados emergentes y su preferencialismo ${ }^{531}$.. En segundo lugar, los Artículos de la Confederación, aprobados por cuarenta y ocho delegados, con un número creciente (en progresión aritmética) de representatividad religiosa por Estado -síntoma del tránsito a la tolerancia moderna y cercanía de la noción de libertad religiosa. Finalmente, la CEU, con treinta y nueve delegados, más el Secretario (de la Comisión), quienes firmaron a favor, y dieciséis delegados en contra $^{532}$; todos ellos representantes de una rica variedad religiosa ${ }^{533}$-no tanto por el despertar confesional en sentido tradicional (de emergencia de nuevas sectas autóctonas), sino por el auge del deísmo (preconizado por los leaders y los rebels), garante de la autonomía individual frente a poderes establecidos.

Entre los firmantes de sendos textos (DIE, Arts. Confederación y CEU), cabe destacar los apellidos siguientes: WASHINGTON, ADAMS, CARROLL,

\footnotetext{
531 Uno de los modelos de Iglesia-Estado, consistente en el reconocimiento privado de otras confesiones, favoreciendo la de mayor arraigo desde el periodo colonial. Indirectamente siguió este modelo en algunos Estados hasta la aprobación de la Catorce enmienda de CEU.

532 Rhode Island no mandó delegado alguno. Vid. FERRAND, M. (ed.): Records of the Federal Convention of 1787, New Haven: Yale Univ. Press, 1911.

${ }^{533}$ La razón de insistir en la correlación entre las firmas y la religiosidad de los delegados, es por su valía para traslucir el avance del proceso secularizador, con sus implicaciones en el aumento de la pluralidad religiosa, lo que a su vez supone el tránsito a la moderna tolerancia y, finalmente, su plasmación en la libertad constitucional. Luego, téngase en cuenta que de las 143 firmas totales (DIE, Artículos de la Confederación y CEU), aproximadamente, un $54 \%$ es de episcopalianos, un $18 \%$ presbiterianos, un $16 \%$ congregacionalistas, un $4 \%$ cuáqueros, un $3 \%$ reformados holandeses y alemanes, un 2,5\% luteranos, un $1 \%$ católicos, un $1 \%$ hugonotes, un $1 \%$ unitaristas, un $1 \%$ metodistas y un $0,5 \%$ calvinistas.
} 
FRANKLIN, et $\mathrm{al}^{534}$. Y aunque no firmaran todos los documentos, sí contribuyeron al debate con publicaciones periódicas (v.g. Federalist Papers) personajes de la talla de JAY, MADISON, HAMILTON, JEFFERSON, PAIN, et al.

e) Statemen [estadistas]: son grandes personalidades públicas que ponen en marcha el Federalismo previsto para el Nuevo Régimen. Entre los mismos, resulta prioritario el papel que juegan los Magistrados (y Presidentes) del Tribunal Supremo de los EE.UU. o TSEU, JAY y MARSHALL, ambos Federalistas (uno nombrado por WASHINGTON, y el otro por ADAMS) y de main-line churches o iglesias establecidas -como se viera en la teoría del denominalismo ${ }^{535}$, la confesión influye considerablemente en la integración en las elites de poder. Con JAY, se comienza a consolidar -con muchas dificultades- ${ }^{536}$ un órgano judicial como el

\footnotetext{
${ }^{534}$ De las trece colonias originales hubo cincuenta y cinco delegados, de los cuales, sólo firmaron los tres principales documentos fundacionales (DIE, Artículos de la Confederación y CEU) y son considerados padres fundadores -aunque menores- SHERMAN y MORRIS.

535 Teoría del denominalismo (confesionalismo establecido), versa sobre la afiliación religiosa y sus repercusiones en el status y rol social (v.g. movilidad social vertical -ascendente o descendente- y horizontal -distribución territorial). Se trata de una teoría sociológica (en auge en la década de 1950), de tipo cualitativo: intenta aportar una serie de hipótesis expositivas y explicativas sobre las directrices estructurales (la significación del establecimiento religioso) y de las actitudes sociales (la significación de las interacciones, roles y clichés), donde se pone de relieve que, la pertenencia a una u otra confesión no es de carácter inocuo, sino que influye significativamente en el status social y las posibilidades de movilidad, tanto vertical como horizontal. Para clarificar alguno de los pormenores de la presente teoría, sírvase a observar primero los datos de la siguiente figura, donde se atiende a oportunidades educativas, laborales, etc., según la pertenencia a un tipo de grupo religioso. Los Estudios culturales sobrevenidos la descartaron por discriminatoria -a la vez que, paradójicamente, promovían la diferenciación étnico-cultural, prefiriendo su comunidad sobre las demás y el resto de la sociedad-.

${ }^{536}$ Cuesta conferirle al TSEU el prestigio y crédito que hoy tiene. Prueba de las dificultades iniciales es su falta de atractivo para grandes personalidades, como HAMILTON, que rechazara ser Presidente del órgano, o el Magistrado RUTLEDGE, que prefirió ejercer en un tribunal inferior.
} 
TSEU, que únicamente es mencionado en la CEU y cuyo desarrollo arranca con la Judiciary Act of 1787 [Ley de judicatura/sistema judicial de 1787] -derogada dicha versión con posterioridad por su sucesor en el cargo, el Magistrado MARSHALL, aduciendo que es por el bien y continuidad del sistema. Por su parte, MARSHALL, logra incorporar con eficacia al Ordenamiento estadounidense una serie de correcciones sobrevenidas -que rayan la impostura, como son el stare decisis o la judicial review [regla del precedente y revisión o control judicial] $]^{537}$, basadas en instituciones prestadas de otros Derechos, intensificándose con ello la condición de utrumque ius [de uno y otro derecho o Derecho Comparado] y potenciándose la Jurisprudence [jurisprudencia o Ciencia del Derecho] $]^{538}$.

${ }^{537}$ La revisión judicial, aunque bebe de la mencionada obra El Federalista, debe su fama al caso Marbury v. Madison (5 U.S. 137, 1803), donde el Presidente del TSEU, MARSHALL, hizo gala de un ejercicio de checks $\mathcal{E}$ balances o frenos y contrapesos -y cierto construccionismo: la Administración ADAMS, tras perder las elecciones presidenciales, y para asegurarse una cierta afinidad judicial, nombra con celeridad a una serie de jueces (los llamados jueces de medianoche), entre ellos MARSHALL. Alguno de estos cargos, como el del banquero MARBURY (como Juez de Paz de la capital), no habían sido efectivos -seguramente, por culpa de MARSHALL al abandonar la Secretaria de Estado para ser Presidente del TSEU-, y el subsiguiente responsable, MADISON, no quería ejecutar unos nombramientos que consideraba ilegales y de última hora. Para completar la polémica, MARSHALL, aunque Federalista, era familiar de JEFFERSON (Presidente de los EE.UU., por entonces). Pues bien, pese a todo, MARSHALL conoció del asunto, que dejaba en pésimo lugar al nuevo sistema político-jurídico estadounidense: a) si MARSHALL fallaba a favor del MARBURY, parecería nepotismo claro y sería muy difícil obligar a MADISON a cumplir con el mandato, debilitando la autoridad del TSEU; b) si se daba la razón a MADISON, implícitamente, se reconocerían las ilegalidades y fraudes de la Administración ADAMS -incluyéndose el nombramiento del mismísimo MARSHALL- y el TSEU parecería débil frente al Ejecutivo. MARSHALL salvó la situación, renunciando a algunas aspiraciones federalistas (como la lista no efectiva de jueces afines) para fortalecer el diseño federal, especialmente, el papel del TSEU (con competencias sobrevenidas, como la revisión judicial, en sentido de legislador negativo). Se declaró inconstitucional la Judiciary Act, evitándose con ello el tener que entrar a conocer en la disputa de Marbury v. Madison.

538 Vid. SÁNCHEZ-BAYÓN, A.: Sistema de Derecho Comparado y Global, Valencia: Tirant lo Blanch, 2012. 
Figura 55.- Otra clasificación de generaciones de elites estadounidenses

a) Puritan vision [visión puritana]: John Winthrop y su "A Modell of Christian Charity", 1630; Samuel Willard y "A compleat body of divinity", 1688; Anne Hutchinson y "The examination of Mrs. Anne Hutchinson at the Court at Newtown", 1637; Roger Williams y "Christenings make not Christians", 1645; Cotton Mather "Bonifacious", 1710; Jonathan Edwards y "The Justice of God in the damnation of sinners", 1734, más "A Treatise Concerning Religious Affections", 1746.

b) Enlightenment vision [vision ilustrada]: Benjamin Franklin y "The Autobiography", 1784-88, más "Poor Richard's Almanac", 1732-57; John Adams y "A dissertation on the Canon and the Feudal Law", 1765, más "Letters" (to Samuel Adams, October 18, 1790; to Thomas Jefferson, Nov. 15, 1813, April 19, 1817 -no se citan, aunque resultan de los más esclarecedoras las cartas a su mujer y su hijo, el futuro Presidente J.Q. Adams); Thomas Paine y "Common Sense", 1776; Thomas Jefferson y "The Declaration of Independence", 1776, más "Notes on the State of Virginia", 1787, y "Letters" (to John Adams, Oct. 28, 1813; to Benjamin Rush, April 21, 1803; to Thomas Law, June 13, 1814)

c) Evangelical democratic vision [visión democrática evangélica]: Charles Grandison Finney y "What a revival of religion is", 1815; John Humphrey Noyes y "The Berean", 1847; William Leggett y "Political writings", 1834; George Bancroft y "The Office of the People in Art, Government, and Religion" (1835); Catharine Beecher y "A treatise on Domestic Economy", 1841; Henry C. Carey y "Of wealth", 1858.

d) Romantic and reformist vision [vision reformista y romántica]: Ralph Waldo Emerson y "The Divinity School Address", 1838, más "Self-reliance", 1841; Margaret Fuller y "The great lawsuit: man versus men, woman versus women", 1843; Henry David Thoreau y "Resistance to Civil Government", 1849; Herman Melville y "Hawthorne and his Mosses", 1850.

e) Unionist vision [vision unionista/nacional]: John C. Calhoun y "A disquisition on Government", 1840; George Fitzhugh y "Sociology for the South", 1854; Frederick Douglass y "What to the slave is the fourth of July", 1852; Abraham Lincoln y "Speech at Peoria", 1854, más "Address before the Wisconsin State Agricultural Society", 1859, y "Address delivered at the dedication of the cemetery at Gettysburg", 1863, o "Second inaugural Address", 1865.

Fuente: elaboración propia (SÁNCHEZ-BAYÓN, 2007 y 16). 


\section{Algunas semblanzas sobresalientes}

De los personajes citados, se han seleccionado los siguientes por su alto impacto y trascendencia, además de haber quedado ligados por su legado, tal como se estudia en los EE.UU.

Entre los fundadores coloniales (pilgrims-puritans $\mathcal{E}$ leaders), se recuerda como rasgos comunes, que la mayor parte de ellos son europeos excepcionales, pues se trata de disidentes y pioneros en la experiencia de la movilidad social (tanto vertical como horizontal). En cuanto a su disidencia, la misma se debe a su formación, ya que son los primeros profesionales, o sea, protestantes con preparación, cuya lectura de la religión, no les aleja de lo mundano y de la riqueza, sino que la persiguen como vía de agrado a Dios (y prueba de su predestinación) ${ }^{539}$. No son ni católicos (bien establecidos en el continente) ni anglicanos (bien establecidos en las islas), sino que se trata de reformistas que combinan planteamientos diversos (v.g. CALVINO,

\footnotetext{
${ }^{539}$ A diferencia de la versión oficial, o sea católica, dominante durante diez siglos (desde el s. IV hasta el s. XIV), que postula una renuncia al más acá para alcanzar el más allá -y cuya distorsión del dualismo cristiano termina derivando en un comunitarismo probrista, atribuyéndose a la pobreza virtudes que nada tienen que ver-. No obstante, tras la Reforma Protestante, se produce un giro hermenéutico que favorece la profesionalización y el enriquecimiento: ya no se rinde cuenta de la fe sólo en la vida religiosa, pues se extiende también a lo cotidiano, como es el trabajo (de ahí la nueva noción de profesión: se profesa la fe en todas las esferas sociales). Tal concepción va unida a la idea de predestinación: el creyente ha de esforzarse en el más acá para alcanzar el más allá, y cómo sólo Dios sabe si nos vamos a salvar, la única pista posible es esforzarse en el día a día, y si se alcanza éxito, ello supone evidencia de predestinación -luego, de un lado se gana al abandonar planteamientos pobristas, pero se pierde al renunciarse al libre albedrío y al poner en el centro de la vida social el trabajo y el dinero-. Pues bien, tal lectura fue reducida al absurdo por M. WEBER, en su famosa obra La ética protestante y el espíritu del capitalismo; ahora bien, a diferencia de lo que postula el autor en el texto, el mismo no es fruto de su esfuerzo, sino de un alumno, en su tesina para completar sus estudios universitarios. Y su tesis sobre la superioridad de los países protestantes sobre los católicos se desmontan con los datos de entonces, ya que a finales del s. XIX y principios del s. XX, no todos los países protestantes son ricos, ni los católicos pobres, más aún, uno de los más prósperos era la católica Bélgica.
} 
LUTERO, ZWINGLIO), de ahí su autodiferenciación y autoexclusión, lo que les motiva en la realización de su segundo rasgo: la movilidad. Se trata de algo nada habitual en el mundo medieval y sus estamentos, pues la persona se mantenía allí donde nacía, tanto física como socialmente. En cambio, los peregrinos, puritanos y líderes coloniales, son gente que ya no responde a fórmulas estamentales, sino de clases, dando buena muestra de su movilidad: a) vertical, ya que gracias a su profesionalidad, no dependen de gremio alguno, sino de su vocación y esfuerzo, buscando en consecuencia su prosperidad; b) horizontal, viajando entre las islas británicas y el continente europeo, así como yendo a América, y dentro de la misma. En la movilidad horizontal también influyó la religión, no sólo por concebir América como tierra prometida (incluso, paraíso terrenal o nuevo Jerusalén), sino porque la condición de disidente, en muchas ocasiones motivó los desplazamientos y fundación de nuevos asentamientos, para poder ejercer su religión libremente.

Para ilustrar todo lo apuntado, se ofrecen una serie de semblanzas, de los artífices de las primeras comunidades precursoras de las trece colonias originadoras de los actuales EE.UU.:

- CARVER y BRADFORD (Massachusetts -línea peregrina-): dos de los principales pilgrims (peregrinos), quienes fueron a su vez los dos primeros Gobernadores y líderes religiosos de la colonia de Plymouth (llamada más tarde la vieja colonia o New Plymouth, en honor a la población del Condado de Devon, en el sudoeste de Inglaterra, donde radicaba tanto el puerto como la compañía financiadora del viaje a América; incluso, según las relecturas de los Estudios culturales $^{540}$, se ha identificado con la legendaria Vindland, así como uno de los

\footnotetext{
540 Se alude al variopinto conjunto de programas académicos en los que se han combinados disciplinas de Humanidades y Ciencias Sociales, para indagar sobre la idiosincrasia estadounidense. Los
} 
primeros descubrimientos de los RALEIGH -en especial, de GILBERT-, y del Cap. J. SMITH -antes de Jamestown-). Destacan ambos caracteres por su tenacidad y vocación de subsistencia: CARVER, político expansionista, buscando alianzas con los indios, para sobrevivir a los duros inviernos (en especial, cuando no llegaban los víveres supuestamente enviados por la compañía); y BRADFORD, político aislacionista, protector de la continuidad de la colonia a toda costa (incluso, gráficamente, convirtiéndose en el primer historiador estadounidense).

Estudios culturales se van consolidando con la normalización de los programas académicos de las universidades a finales del s. XIX, desarrollándose en el seno de las Facultades de Humanidades o Liberal Arts Schools, Teología y CC. Religiones o Divinity Schools, y Derecho y CC. Jurídicas o Law Schools, en las elitistas universidades del club de la hiedra o Ivy League. Entre los primeros Estudios culturales en consolidarse destaca el área de conocimiento de American Studies (también llamada en su origen American Civilization, v.g. Programa de doctorado de la Univ. Harvard desde los años 20: History and American Civilization), es el resultado del estudio combinado de Historia, sociedad y cultura estadounidense, mediante el recurso de Historia, Literatura y una incipiente Antropología, dominada entonces por dos corrientes, como eran los Estudios religiosos y folklóricos (influyentes en los Estudios culturales tradicionales, v.g. American Culture, American Social Thought, Church-State Studies, Religion E, First Amendment Studies), más la emergente Teoría crítica (clave para los Estudios culturales sobrevenidos, v.g. African American Studies, Asian American Studies, Latin American Studies, American feminist and gender -todos ellos impulsados a raíz de Ethnic Heritage Studies Program Act of 1972-), añadiéndose poco después aportes de otras Ciencias Sociales y Humanidades, v.g. Economía, Política, Comunicación y Psicología Social. Para conocer la historiografía y devenir universitario de esta área de estudios, suele citarse la voluminosa y premiada obra de PARRINGTON (1871-1929), uno de los integrantes de la generación de historiadores progresistas (junto con Turner y la historiografía de la frontera, los BEARD y la historiografía económico-social, et al.). Pues bien, así los Estudios culturales tradicionales mantuvieron como parte de su objeto de estudio la religión, orientándola hacia el consenso facilitador de la unión (en inglés, es sinónimo de la nación, v.g. Preámbulo de la Constitución estadounidense de 1787), además de darse paso en el periodo de entreguerras a la teoría del excepcionalismo y el crisol cultural estadounidense (de la providencia divina a la autodeterminación de un pueblo con un destino manifiesto, vid. infra). En cambio, los Estudios culturales sobrevenidos (de origen neomarxista, aunque hoy autocalificados de posmarxistas, poscoloniales, subalternos, etc.), al ser proclives al conflicto y la fragmentación, procedieron a extender una tropología (preñada de velos), contraria a la tradición sagrada occidental (antijudeocristiana y pro-oriental e indigenista), y reivindicadora de reparaciones sociales para las minorías supuestamente excluidas. Vid. infra nota 1. 
John CARVER (Nottinghanshire 1576-Plymouth 1621) fue un rico mercader de Londres, que hacia 1607, debido a la persecución religiosa, se vio obligado a emigrar a Leiden (Países Bajos). En 1617, con el apoyo del líder religioso de los reformistas-separatistas (J. ROBINSON), se convirtió en el representante legal de los pilgrims -llamados así por su éxodo-, preparando su viaje a América. El 11 de noviembre de 1620, el centenar de colonos a su cargo desembarcaron en América y firmaron el Pacto del Mayflower (nombre de su embarcación). Fue el primero en firmar dicho pacto, al ser ratificado además como Gobernador. También logró una alianza con la tribu vecina Wampanoag (con la que se inició la festividad de Acción de gracias, vid supra cap. 10). Lamentablemente, murió de un infarto, siendo sucedido por BRADFORD.

William BRADFORD (Austerfield 1590-Plymouth 1657), sucedió a CARVER como Gobernador de los peregrinos -rompiendo la regla democrática original, pues su elección fue a raíz del supuesto infarto de CARVER y superó claramente el año de mandato-. De vida paralela a CARVER (de origen inglés, Condado de Devon, vivió igualmente en Leiden, Holanda, ganándose la vida como tejedor), pero de carácter muy distinto. Al llegar a América, fue el segundo en firmar el Pacto del Mayflower. También fue el primer historiador de Nueva Inglaterra ( $O f$ Plymouth Plantation, 1647). Se casó dos veces y tuvo cuatro hijos. Su mayor logro fue conseguir la subsistencia de la colonia (a diferencia de otras que se extinguieron en aquel periodo), incluso ampliándola a todo el Cabo de Cod, a la vez que frenó durante un tiempo los avances de colonias vecinas, como la poderosa Colonia de la Bahía de Massachusetts. Lo logró al permitir la explotación privada de tierras (en vez de comunitaria -lo que sirvió de aliciente para la colonización), cambiando el criterio de relación con los indios -practicó el 
dominalismo-541, además de expulsar a los disidentes (v.g. MORTON en 1628, WILLIAMS en 1630).

- WINTHROP y ENDECOTT/ENDICOTT (Massachusetts -línea puritana-): ambos son ingleses puritanos, que se disputan hoy la condición de primer Gobernador de la Colonia de Bahía de Massachusetts -en realidad, WINTHROP gobernó la colonia resultante del asentamiento fijado por ENDECOTT-. El primero fue un político y teólogo (conocido por discurso Un modelo de caridad cristiana, basado en el sermón de la montaña), y el segundo un magistrado, además de noble y militar, y sin embargo un beligerante reformista religioso (conocido por sus ejecuciones a disidentes religiosos y a indios, además de fundar el polémico asentamiento de Salem). Ambos son un claro ejemplo de cómo las víctimas pueden convertirse en victimarios, cuando dejan de representar una minoría y se convierten en mayoría. Pese a sus planteamientos puritanos reformistas (de renovación moral), sin embargo, practicaron: a) el dominalismo o sometimiento de la creación; b) la esclavitud, tanto de negros como de indios (en especial, tras la Guerra -contra los indios-Pequot); c) la intolerancia, condenando de herejes a los disidentes y opositores políticos (así lo sufrieron HUTCHINSON, HOOKER, etc.).

\footnotetext{
${ }^{541}$ Corriente teológico-política protestante, muy presente en la América colonial (y mantenida en planteamientos como American manifest destiny, American self-righteousness, etc.), basada en el mandato divino de Gen. 1: "(...) y Dios indicó al hombre que dominara la creación"; de tal manera, el hombre tiene la empresa de someterlo todo (recuérdese el lema nacional: annuit coeptis), lo que justifica la colonización y conquista impulsora de los EE.UU. Vid. BROWN, D.: Bury My Heart at Wounded Knee: An Indian History of the American West, New York: Rinehart and Winston, 1971. HORSMAN, R.: Race and Manifest Destiny. The origins of American racial Anglo-Saxonism, Cambridge: Harvard University Press, 1981. ORTEGA Y MEDINA, J.A.: La evangelización puritana en Norteamérica, México DF: Fondo de Cultura Económica, 1976. PRUCHA, F.P.: The Great Father. The United State Government and the American Indians (vols. 1-2), Lincoln: University of Nebraska Press, 1984.
} 
- MORTON (Maine -Merry Mount-, 1624), BALTIMOR (Maryland, 1634), HUTCHINSON y HOOKER (Connecticut, 1635), WILLIAMS (Rodhe Island Providence-, 1636), más PENN y WESLEY (Pennsylvania, 1682): no se trata de pilgrims (peregrinos), sino de puritans (puritanos -incluidos cuáqueros como PENN y metodistas como WESLEY-), o sea, unos reformistas protestantes algunos historiadores les consideran incluso los padres de las iglesias evangélicas o evangelicals-. Se distinguen de los primeros por no ser tan radicales (más bien disidentes reformistas: ética e institucionalmente), y por mantener ciertos canales de comunicación con la religiosidad oficial europea (que les avala en la fundación de nuevos asentamientos -máxime tras sus choques con otros líderes locales-, como los casos de MORTON, PENN, etc.). Además, se les considera a estos personajes como padres fundadores de las colonias mencionadas entre paréntesis (v.g. Maine, Rhode Island), de ahí que también se les pueda ubicar en la categoría de leaders (líderes). Casi todos proceden de familias aristocráticas (v.g. PENN, BALTIMOR) y/o acomodadas (v.g. MORTON, WILLIAMS), caídas en desgracia en Europa, bien por pertenecer a minorías religiosas (v.g. PENN, BALTIMOR), bien por participar en conspiraciones fallidas (v.g. MORTON, WILLIAMS). En su mayoría, estos líderes coloniales fueron relevantes por abrir nuevos espacios de convivencia, donde realmente sí se avanzó para lograr el tránsito de la vieja tolerancia (según la cual es necesario soportar el mal ajeno hasta que exista amenaza, que es causa justa para la violencia) hacia la nueva (conducente hacia la libertad religiosa, que 
conlleva un respeto reconocido tanto a miembros de la comunidad, como a los visitantes y vecinos). Baste consultar las actas fundaciones y Blue Laws $^{542}$.

De entre todos los líderes mencionados, pese al atractivo de todos ellos (v.g. Lord BALTIMOR como referente para los católicos, tan reprimidos en el mundo anglosajón, dada su condición minoritaria -en realidad, su condición no oficial, pese a su nombre-), el caso más sobresaliente y del que se están haciendo más relecturas en clave posmoderna, es el caso de la Sra. A. HUTCHINSON: líder religiosa y fundadora de diversos asentamientos, máxime tras su condena por herejía y orden de destierro; fue clave en la construcción de la Teología política estadounidense, en especial, en su variante de ACT -simpatizante de los planteamientos de pactismo de COTTON-.

Entre los fundadores nacionales (rebels $\mathcal{E}$ framers), se plantea, como rasgos comunes y de entrelazamientos entre generaciones, que los principales conflictos influyentes en su devenir son los tocantes a su configuración idiosincrásica como nación. Si los anteriores padres fundadores eran disidentes que buscaban su lugar, para ensayar su forma de vida, diferente a la establecida (vid. infra), en cambio, los rebeldes y constituyentes, tiene la misión de armonizar en la diversidad (como reza el lema nacional e pluribus unum, vid. infra epígr. 5.3), para lo cual se ayudan de la Teología política: la noción de pueblo de Dios es muy útil para romper lazos

\footnotetext{
${ }_{542}$ Nombre metafórico (en relación al cielo, dada su condición socio-religiosa), que bien se puede traducir como Derecho dominical de las colonias (regulador de cualquier materia, pública o privada, siempre y cuando afectara a la continuidad del asentamiento). A la postre, sirvió para transitar de la tolerancia tradicional (soportar el mal ajeno) a la moderna (próxima a la libertad religiosa, v.g. Maryland Toleration Act of 1649). Finalmente, devino en el decimonónico American Civil Church-State Law o Derecho eclesiástico estadounidense
} 
políticos con la Monarquía británica y con cualquier otra europea-continental. La nación es articulada desde las bases sociales, gracias a las comunidades y al menos un siglo antes de que lo haga el decimonónico Estado-nación: de ahí que sea un proceso libre de integración y no una imposición de asimilación. En tal sentido, el factor religioso es clave, pues se identifica a lo largo del s. XVIII a los traidores con los anglicanos realistas (los fieles al monarca británico, cabeza de su iglesia), mientras que los patriotas son los herederos de los disidentes, quienes a su vez, pasan de formar parte de main-line churches o iglesias establecidas y jerárquicas (v.g. anglicanos, presbiterianos, episcopalianos), a ser integrantes de evangelical churches o iglesias comunitaristas (cuya eclosión final se produce en el s. XIX, expandiéndose por el sur y oeste de los EE.UU.), incluso, entre sus líderes, se extiende la creencia deísta (según la cual, cada hombre es una iglesia en sí mismo, vid. supra semblanzas de ADAMS y FRANKLIN).

Entre los casos más sobresalientes de rebeldes y constituyentes, se ofrecen semblanzas de aquellos que combinan las dos condiciones, además de haber mantenido entre sí relaciones personales cruciales (mientras que los anteriores padres fundadores coincidieron en su actitud vital -pero no por ello tuvieron que hacerlo física y personalmente-, estos nuevos padres fundadores vivieron episodios intensos, como la guerra, la redacción de textos constituyentes, etc.). Los casos más conocidos y bien trabajados por la historiografía estadounidense son las semblanzas de los fundadores nacionales procedentes de Nueva Inglaterra (v.g. BASSETT, GORHAM, SHERMAN), incluso de las Provincias Medias (v.g. CARROLL, HAMILTON, JAY, PAINE) y las Plantaciones Sureñas (v.g. HENRY, JEFFERSON, WASHINGTON). Sin embargo, de todos ellos, se han seleccionado dos casos, por estar ambos íntimamente relacionados entre sí y con el resto de padres fundadores 
(con vínculos de amistad y/o familiares), siendo sendos referentes de autoridad para todos (por su sentido racional y moral, siendo ejemplos de la Ilustración estadounidense), y con una gran proyección internacional (igualmente, ambos fueron embajadores en Europa y mediaron para evitar conflictos exteriores). Se alude así a los casos de los deístas ADAMS y FRANKLIN.

J. ADAMS (1735 en Baintree/Quincy ${ }^{543}$, MA -1826): fue el mayor de tres hermanos de una familia puritana (de origen calvinista y corte congregacionalista americano, configurándose más tarde como unitarista, aunque ADAMS ha sido calificado por la historiografía reciente como deísta $)^{544}$. Su padre le transmitió el valor del legado (familiar) ${ }^{545}$ y un alto sentido de la responsabilidad, de ahí que, pese a su falta de dotes sociales - a diferencia de su primo lejano S. ADAMS-, gracias a su vocación y mucho esfuerzo (especialmente, como jurista), fue reconocido y apreciado por sus coetáneos. Ahora bien, tal sentido del servicio comunitario repercutió negativamente en su familia, de la que tuvo que estar separado durante

\footnotetext{
${ }^{543}$ Originalmente, dicha población de Massachusetts se llamaba como el pueblo británico del que procedía su abuelo paterno, pero más tarde cambió su nombre en honor a este Presidente y su hijo, pues ambos tenían dicho segundo nombre.

$544 \mathrm{Su}$ deísmo, entendido como un cristianismo muy secularizado y panteísta, basado en el amor a Dios y su creación, lo recibió durante sus años de estudio universitario en Harvard -donde casi se hace clérigo, por deseo de su padre-, y lo plasmó especialmente en sus cartas a JEFFERSON y RUSH (ambos padres fundadores, y gracias al último, se reconcilió con el primero, manteniendo a la postre un epistolario de casi tres lustros -curiosamente, ambos murieron el mismo día, en el $50^{\circ}$ aniversario de la Declaración de Independencia, de la que fueron co-autores-).

${ }^{545}$ En sus memorias así dejó constancia, recordando lo que decía su padre al respecto: “(...) [el legado de los primeros colonos, quienes] creían en la vida según la Biblia. La Inglaterra bajo los Estuardo era como Egipto, y ellos eran Israel huyendo (...) para establecer un refugio de piedad, una ciudad sobre la colina" (traducción propia). ADAMS, J.: Autobiography (primera parte "John Adams", 1802-07), se trata de manuscritos microfilmados (en 1954), de consulta abierta on-line: Adams Family Papers: An Electronic Archive (URL: http://www.masshist.org/digitaladams/archive/autobio/). Complement., vid. nota 10 .
} 
años (por la guerra, el Congreso Continental, el servicio diplomático, etc.), y que su hijo, el sexto Presidente de los EE.UU., dejó constancia en su epistolario.

ADAMS fue conocido de casi todos los delegados constituyentes, por ser uno de los escribanos entre ellos, y amigo de los más relevantes, con quienes compartió servicio a la nación: luchó con WASHINGTON (siendo los dos parte de la Junta de Guerra -ADAMS fue clave para la ratificación de WASHINGTON como Comandante en Jefe-), siendo más tarde su Vicepresidente, además de embajador (confiando en él para lograr financiación externa, alianzas con potencias europeas y evitar guerras). Fue miembro del Comité redactor de la Declaración de Independencia, con JEFFERSON y FRANKLIN. JEFFERSON siempre sucedió en los cargos a ADAMS (como embajador de Francia, luego como Vicepresidente y por último como Presidente), por lo que su relación fue algo difícil y voluble: pese a respetarse intelectualmente, resultaban polos opuestos, pues ADAMS era más introvertido, trabajador y coherente (entre sus ideas y acciones), mientras que JEFFERSON era más apasionado, y tras su paso por Francia, además, se volvió altamente ideológico. El ego de JEFFERSON, quien no deseaba seguir la estela de ADAMS y llegar por su designación a la Presidencia de los EE.UU., prefirió romper y constituir su propio partido - usando una campaña demagógica y de descalificación contra los federalistas (aprovechando la división interna entre los seguidores de ADAMS y los de HAMILTON, además de atraer a su causa a MADISON), hasta que llegó a la presidencia con el partido Demócrata-Republicano, y fue más allá, creando la doctrina de los poderes implícitos-. Finalmente, por mediación de RUSH (otro padre fundador, firmante de casi todos los documentos, y de los últimos en fallecer), ADAMS y JEFFERSON se reconciliaron y mantuvieron un epistolario de casi tres lustros (llegando a morir el mismo día: en el veinticinco aniversario de la DEI). En cuanto a 
la relación de ADAMS con FRANKLIN, fue de lo más cordial, remontándose al periodo pre-revolucionario (ADAMS fue observado de cerca por FRANKLIN en los juicios a los casacas rojas, que defendiera el primero, ya que nadie lo hacía recomendándole más tarde para diversos cargos, como el de embajador en Francia); su relación se intensificó a raíz del nombramiento de ambos para la Comisión redactora de la DEI (en la que también estuvo JEFFERSON -y que más tarde logró casi monopolizar su autoría, eclipsando al resto-). Tal fue su sintonía y la brillantez de su trabajo en común, que ambos fueron elegidos para negociar la paz con el General HOWE, el 11 de septiembre de 1776 en New York; sin embargo, pese a ser los dos padres fundadores grandes negociadores, ambos se negaron a aceptar de partida la exigencia de derogar la DEI. ADAMS, a su vez, fue quien nombró a J. MARSHALL Presidente del TSEU. Igualmente, ADAMS, fue conocido de alguno de los grandes intelectuales y académicos de su tiempo, tras su paso por la Univ. Harvard, tanto por los estudios de Teología, como los de Derecho. Quizá, el mayor problema de ADAMS para la política fue su rectitud moral y su sentido de la justicia -de ahí que el reconocimiento de sus logros ha venido principalmente de los historiadores posteriores, al estudiar las fuentes oficiales de la época-; sin embargo, quien lidió mejor con todo ello fue FRANKLIN, tal como se aclara a continuación.

B. FRANKLIN (Boston, 17 de enero de 1706-Filadelfia, 17 de abril de 1790), fue un personaje polifacético, conocido como referente de artistas, intelectuales, políticos, periodistas, escritores, científicos e inventores estadounidenses -la encarnación de la Ilustración de su país-, fue además el veterano de los padres fundadores. FRANKLIN fue el decimoquinto hijo (de diecisiete hermanos), de un segundo matrimonio. FRANKLIN, además de trabajar en la fábrica de velas y jabones de la familia, probó diversos oficios, decantándose por el periodismo, en el 
primer diario independiente de las colonias: New England Courant (propiedad también de la familia). Viajó a Inglaterra para conocer mejor el oficio de impresor y editor, lo que le permitió publicar sus ensayos de filosofía y política (v.g. Disertación sobre la libertad y la necesidad, sobre el placer y el dolor, 1726), entrando así en círculos masones, de modo que regresó a América, como responsable de la emisión del papel moneda en las colonias británicas. Se le atribuye la fundación de la primera biblioteca pública en Filadelfia (1731), del primer cuerpo de bomberos (Union Fire Company, 1736), del primer hospital y de la Univ. Pensilvania (1749), etc. También mejora el servicio postal entre las Provincias Medias (v.g. New Jersey, Maryland) cuestión que le llevó a viajar por todas ellas, y que aprovechaba para sus contactos con otros masones e ir preparando los ánimos revolucionarios-. Como científico e inventor es recordado por el pararrayos, las lentes bifocales, el hornillo, el cuentakilómetros, las aletas de nadador, etc.; además de haber sido miembro de diversas academias y sociedades de su época (v.g. Sociedad Filosófica Estadounidense, Sociedad/Academia Real Británica, Sociedad Lunar). Como político, fue un gran negociador: como miembro de la Asamblea General de Filadelfia, fue el responsable de pactar con los indios (en la década de 1740), con los británicos (en la década de 1750 y 60), y con los franceses (en la década de 1770 -fue quien logró el apoyo de Francia a la Guerra de la Independencia-). Precedió a ADAMS y a JEFFERSON, como embajadores en Francia, y participó con ellos en la redacción de la DEI y la CEU. En 1785 fue elegido Gobernador de Pensilvania. Entre sus últimas causas defendidas estuvo el movimiento abolicionista, llegando a influir en el pensamiento de LINCOLN (vid. supra). En lo tocante a sus creencias religiosas, como ya se mencionara, al igual que ADAMS, es deísta, articulando su credo entorno a trece grandes virtudes (Almanaque del pobre Ricardo, 1733-57, y La vida privada de Benjamín 
Franklin, 1791) -que pretendía, más que observaba, como él mismo reconociera (recuérdese, además, la obesidad mórbida que alcanzó)-: templanza, silencio, orden, determinación, frugalidad / sostenibilidad, diligencia, sinceridad, justicia, moderación, limpieza, tranquilidad, castidad y humildad. En realidad, sus principales virtudes fueron su insaciable inquietud, y su capacidad para conectar gente valiosa (al modo masónico). Sirva como ejemplo su capacidad para mediar entre los delegados del Congreso Continental, evitando los conflictos religiosos entre las diversas sectas protestantes, y éstas con los católicos (uno de sus mejores amigos fue el representante de Maryland, Daniel CARROLL, hermano del Primer Arzobispo estadounidense -nombramiento que logró gracias en buena medida a las influencias de FRANKLIN, en detrimento de los franceses-).

En definitiva, si se aplicara la teoría de comunicación de los seis grados de separación, tanto ADAMS como FRANKLIN resultarían el nodo de conexión entre los padres fundadores de su época, y un gran referente para las siguientes.

Entre los grandes estadistas, custodiadores del legado estadounidense (o sea de su matriz idiosincrásica), destacan como padres fundadores (conectados los unos con los otros), enlazados con las generaciones precedentes, desde: Secretarios de Estado y Presidentes del TSEU, como JAY, MADISON y MARSHALL; pasando por Secretarios de la Federación y Gobernadores, como DICKINSON, FRANKLIN, LANGDON o RUTLEDGE; hasta Presidentes mesiánicos como MONROE, McKINLEY o ROOSEVELT; et al. No obstante, de todas las semblanzas posibles, se desea prestar especial atención a dos casos sobresalientes, como los Presidentes sacrificados o mártires: LINCOLN y KENNEDY.

Según la Teología política estadounidense, y la teoría de despertares y revitalizaciones, la cosmogonía estadounidense responde a una serie de ciclos en los que 
se recalibran cuestiones tales como las relaciones entre lo sagrado y lo profano. Para ello es necesaria la aparición de personajes mesiánicos, cuya unción bien puede legitimar para reconducir al pueblo elegido (a modo de pastor o reverendo, vid. supra), o cabe -como en este caso- que tengan que ser sacrificados, para redimir al pueblo y renovar así el pacto con Dios -no se quiere decir, que tal cosa sea así, sino que la historiografía termina presentándolo de esa manera (de ahí los claroscuros a formular con las semblanzas)-. Conforme a dicho planteamiento, se entenderá entonces que, pese a que fueron varios los Presidentes de los EE.UU. fallecidos durante su mandato (ocho muertos) ${ }^{546}$, sin embargo, han trascendido dos casos como símbolo de holocausto y redención: en el s. XIX fue LINCOLN, y en el s. XX KENNEDY.

A. LINCOLN (Hodgenville-Kentucky, 12 de febrero de 1809-Washington DC, 15 de abril de 1865), fue el decimosexto Presidente de los EE.UU. (1861-65), y primero por el partido Republicano (por entonces, el más liberal -procedía del partido Whig-, y apoyado por las clases medias, en zonas urbanas, industrializadas y del norte). Se trata de uno de los padres fundadores más importantes, considerado en la Teología política estadounidense a la altura de su homónimo en el judeocristianismo: Abrahán -sólo que en vez de recibir la llamada de Dios para sacrificar a su hijo, fue él el sacrificado, en el teatro Ford, asesinado de un tiro por BOOTH-. El féretro de LINCOLN fue llevado en tren en procesión por varios Estados, alimentándose así su fama póstuma: pese a sus claroscuros, LINCOLN ha pasado a la Historia estadounidense, como el Presidente que acabó con la Guerra Civil -en realidad, de Secesión de los Estados sureños-; quien aprobó la abolición de la esclavitud -asegurándose así la incorporación a filas en su bando de los

\footnotetext{
${ }^{546}$ Ocho han sido los Presidentes fallecidos durante su mandato: cuatro de manera natural o por enfermedad (HARRISON, TAYLOR, HARDING, ROOSEVELT), y cuatro de manera violenta o asesinados (LINCOLN, GARFIELD, McKINLEY, KENNEDY).
} 
afroamericanos-; defendió los derechos de las minorías -desde los Estudios Culturales de la década de 2000, se viene defendiendo la tesis de la homosexualidad de LINCOLN y su apoyo a la causa- ${ }^{547}$. En cualquier caso, LINCOLN fue una persona muy sacrificada, pues nada le fue fácil (ni en lo personal, con pérdidas de prometidas e hijos -dos de ellos siendo aún niños-, ni en lo político, con extinción de partidos, contiendas para nombramientos, etc.); sin embargo, sus discursos no son victimistas ni revanchistas, sino de reconciliación. Como presbiteriano que era aunque haya corrientes doctrinales actuales que afirman su condición de bautista (algo difícil, pues esa es una confesión dominante en el sur, no en el centro del país, aunque sí ha habido cierto desplazamiento en los últimos treinta años), LINCOLN creía firmemente en la democracia (a modo de presbiterios -en el sentido protestante, v.g. CALVINO, KNOX-: con la elección de representantes mayores, que en asambleas gobernaran la comunidad y eligieran otros delegados para uniones mayores), citando la Biblia como fuente de referencia moral y guía de la vida social (a su Administración se debe la inclusión en las monedas del lema in God we trust [en Dios confiamos], así como la acuñación de la expresión under God [bajo/ante

\footnotetext{
${ }_{547}$ Pese a haber estado casado con M. TODD, con quien tuvo cuatro hijos, además de haber sido novio formal de M. OWENS y A. RUDLEDGE, desde los Estudios Culturales (financiados por el lobby gay, especialmente, por el guionista L. KRAMER), basándose en fuentes indirectas privadas, se viene postulando que LINCOLN fue homosexual, debiendo crear una fachada cuando se saltó a la política, concertándose un matrimonio de conveniencia. Entre quienes sostienen tales tesis, cabe destacar BORITT, G.: The Lincoln Enigma: The changing faces of an American Icon, New York: Oxford Univ. Press, 2001. ERIC, M.: Making Gay History, New York: HarperCollins Publishers, 2002. TRIPP, C.A.: The intimate World of Abraham Lincoln, New York: Free Press, 2005. Tal dato de la biografía de LINCOLN no es relevante, pues pertenece a su vida privada, sin proyección social; sin embargo, con el relativismo y demás velos de confusión posmodernos, se ha distorsionado la política, que debería encargarse de temas relativos al bien común y por tanto públicos, para sustituirlos por temas personales, produciéndose así una inversión entre lo público y lo privado. Curiosamente, estos mismos autores defienden que LINCOLN carecía de creencias religiosas y que las mismas no son relevantes socialmente, por reducirse al fuero interno.
} 
Dios], casi un siglo después así enseñada en el pledge of allegiance o saludo a la bandera (incluyéndose por la Adm. EISENHOWER).

J.F. KENNEDY (Brookline, Massachusetts, 29 de mayo de 1917-Dalla, Texas, 22 de noviembre de 1963), fue el treinta y cinco Presidente de los EE.UU., y el segundo más joven (con 43 años) y de perfil académico (con muchos asesores reclutados de la universidad), y al igual que le pasara al Presidente WILSON (el otro demócrata académico -y con el que se renueva el partido-), su mandato fue de lo más controvertido (v.g. Bahía de Cochinos y crisis de los misiles en Cuba, muro de Berlín y tensión nuclear con la URSS, recrudecimiento bélico en Vietnam, armar a opositores en África, Asia y América Latina). KENNEDY, además, resulta el primer Presidente católico, logrando así la normalización de los mismos. Téngase en cuenta que, desde finales del s. XIX, los católicos venían sufriendo cierta exclusión social, siendo objeto de teorías de la conspiración (v.g. por prestar obediencia a poderes extranjeros como el Papa, formar parte de partidos socialistas). Con KENNEDY, se ofrece al pueblo estadounidense un modelo social dorado -como discurso, no como realidad-, llamado la Gran Sociedad. Tanto es así que se llega a comparar la Casa Blanca con Camelot (la corte del Rey Arturo). Con su magnicidio, junto con el resto de conflictividades sociales en curso (v.g. movimiento de libertades civiles, comunas hippies, panteras negras, rebelión feminista), se produce el fin de una era: la pérdida de inocencia estadounidense, o el despertar del sueño estadounidense. Se inician las denominadas guerras culturales $^{548}$, y con ellas el cuarto gran despertar religioso, cuya

\footnotetext{
548 Tienen lugar durante las décadas duras de la Guerra fría (1960-80), sólo que aquellas tienen lugar en el seno del país, y su objetivo es hacerse con su mentalidad e identidad, y demás cuestiones aparejadas a la idiosincrasia estadounidense. A diferencia de las guerras militares (calientes/duras) en los países recién descolonizados o tercermundistas (no alineados o periféricos), las guerras culturales son consideradas verdaderamente frías (al modo de la Guerra fría de entonces) y blandas (dando paso al pensamiento débil), pues su principal munición empleada es la de los velos y el objetivo
} 
revitalización tiene lugar desde la década de 1980, trayendo consigo la ola neoconservadora. Al igual que LINCOLN, KENNEDY es considerado como un sacrificio para apaciguar a un pueblo dividido y enfrentado, que sólo así vuelve a reconciliarse.

De las similitudes entre LINCOLN y KENNEDY se han dicho muchas cosas, pero quizá las más interesantes son las siguientes: a) ambos procedían de familias de clase media, siendo los segundos hijos, y promocionaron socialmente gracias al ejercito; b) los dos habían sido congresistas previamente (tomando posesión en el año 46 de su siglo correspondiente), y propuestos para vicepresidentes (igualmente, en el año 56 de su propio siglo); c) en sendos casos fueron elegidos Presidentes en los años sesenta y fueron asesinados justo en su proceso de reelección (bien un poco antes, bien un poco después); d) los dos fueron asesinados en viernes, por disparos en la cabeza y en presencia de sus cónyuges, en actos públicos; e) sus respectivos asesinos murieron antes de ir a juicio; f) los dos fueron sucedidos en la Presidencia por sureños demócratas apellidados Johnson y nacidos en el año 8 de su respectivo siglo; g) sendos Presidentes se preocuparon por la población afroamericana,

\footnotetext{
a batir es el sistema. Su origen está en la hibridación de planteamientos realizada por la intelligentsia europea, recibida con la fuga de cerebros (tras las guerras mundiales), y bien instalada en los medios de comunicación y universidades estadounidenses. Si ya en Europa se había hibridado socialismo y nacionalismo (pese a ser dos ideologías mutuamente excluyentes), cuando dicha intelligentsia procede a su irradiación en los EE.UU., lo hace atacando a la nación, el Estado y la cultura estadounidense: desde sus planteamientos nacional-socialistas sui generis, se sienten exiliados en tierra de paletos venidos a ricos (sin la Historia y la cultura de sus países de origen), por lo que se atacan los cimientos estadounidenses, y la quinta columna más accesible para ello son los Estudios culturales, dada su natural interdisciplinariedad (ergo, el laboratorio perfecto para tejer los velos a extender). Sirva como ejemplo el caso de la Escuela de Frankfurt (v.g. WEIL como financiador, BLOCH como colaborador, POLLOCK y HORKHEIMER como directores en la etapa europea, ADORNO y MARCUSE como líderes en América), cuyo Instituto de Investigación Social se traslado a New York y más tarde a California, jugando su integrantes un papel crucial en las revueltas estudiantiles de los años 60 (desde la crítica literaria se aborda la economía, la psicología, la sociología, etc., fomentándose el choque intergeneracional).
} 
firmando LINCOLN la Proclamación de emancipación en 1863, y KENNEDY presentó al Congreso sus propuestas de regulación sobre derechos civiles en 1963; et al. 


\section{2.- LEGADO PATRÍSTICO: DE PILGRIMS A STATEMEN}

¿Cuál ha sido su papel y su influencia? El legado de los padres fundadores procede en gran medida de la combinación de: a) su condición alcanzada de élites (reconocidos así por las bases sociales) y sus puestos detentados (bien como líderes comunitarios, bien como cargos públicos electos); b) su coherente ejercicio de libre examen (de conciencia), pues no se trata tanto de un proselitismo confesional concreto, sino de vivir conforme a unas virtudes y valores aplicables a cualquier faceta de la vida social; c) su vocación de contribuir al bien común y ser recordado por ello (propiamente su legado -que en la Teología política protestante se llama también alianzas menores: de los líderes con su pueblo). En tal sentido (y para aterrizar algo más la cuestión), se desarrolla a continuación la lógica inspiradora de los principios rectores del sistema estadounidense de Iglesia-Estado, tal como los padres fundadores pretendieron fijar como su legado.

El principio de libertad de conciencia y el argumentario sobre la tolerancia social (leaders WILLIAMS y PENN): aunque el discurso sobre la tolerancia viene de largo, reconocible en el ideario de los pilgrims en Nueva Inglaterra y de Lord Baltimore en las Provincias Medias en cuanto gozaran de la ventaja suficiente, se preveía volver -en algún tipo de recreación neortodoxa-al caduco y anacrónico sistema confesional (de naturaleza exclusiva y excluyente), como en ciertos episodios asamblearios locales ya mencionados (v.g. expulsiones de BRADFORD, juicios de Salem). Este fraude discursivo era un vicio de la época, salpicando incluso a insignes pensadores Whigs-Freemansons (PWF) como LOCKE, a quién le costó media vida y un sinfín de tribulaciones la consecución del tránsito de la tolerancia tradicional a la moderna desde el Ensayo sobre la Tolerancia en 1667, hasta la(s) Carta(s), a partir de 1689. Ahora 
bien, una vez más, la América colonial se adelanta a la europea de su tiempo en la puesta en práctica de ideales, en forma de un modo de vida (un proto-AWL). Los ejemplos de partida -más populares- son los de WILLIAMS en Rhode Island (la colonia de tolerancia) y PENN en Pennsylvania (el santo experimento), quienes dejan de ejecutar un modelo de tolerancia negativo y de mínimos (como corresponde a la concepción tradicional), apostando por la implantación de la formulación moderna -gracias a su alto cargo y libre examen, cuya coherencia fue premiada con un prolongado liderazgo. Se reconoce una mínima libertad y ciertos destellos de igualdad religiosa, incluso, a las confesiones más perseguidas (v.g. judíos, católicos, bautistas, cuáqueros, etc. ${ }^{549}$, o aquellas ignoradas por entonces -en cuanto no reconocidas jurídicamente- (v.g. indios nativos, africanos esclavos). Prueba de ello es, que pese a contar con la concesión real, además, se compran los terrenos colindantes a las tribus vecinas, como acto de respeto -en los términos mencionados sobre el reconocimiento de alteridad, pero sin la exigencia de conversión-, se logra así evitar los conflictos identitarios posteriores.

Al igual que LOCKE, WILLIAMS y PENN ${ }^{550}$, creen firmemente en la distinción entre lo civil y lo religioso, por razón de conciencia: a la iglesia le

\footnotetext{
${ }^{549}$ En el caso de PENN, resulta más comprensible su predisposición favorable hacia una minoría tan polémica como la de los cuáqueros, pues el mismo lo era, así como, conocido de sus fundadores (amigos de su padre, el Almirante PENN). En el supuesto de WILLIAMS, aunque la impostura actual afirma que fue bautista, en realidad, resultó un congregacionalista bastante abierto y progresista para su época. Dicho rasgo de su personalidad (la predisposición al reconocimiento de la alteridad), se evidencia incluso, en sus años universitarios (University of Cambridge, 1624-27), donde mantuvo un intercambio tutorial con MILTON, a quién le enseñaba holandés a cambio de hebreo.

550 Para conocer mejor el argumentario y del principio rector, se remite a las siguientes lecturas -de corte apologético-: a) de WILLIAMS y su obra El inquilino maldito, de persecución, por causa de conciencia, objeto debatido, en una conferencia entre la verdad y la paz de 1644, su epistolario con el Rev. COTTON (164452), y en la Carta otorgada de Rhode Island de 1663; b) de PENN y su escrito La gran causa de la conciencia de 1670, La verdadera libertad espiritual de 1681, Tempranos escritos cuáqueros de 1682, Una Clave de 1692 y la Carta de Privilegios de Pennsylvania de 1701. Vid. nota 10.
} 
corresponde la administración de las cuestiones del alma, y a los magistrados civiles las del bienestar terrenal. En tal sentido, consideran inútil a largo plazo el desear contravenir dicha separación, pues sólo se logran discriminaciones injustas. Ahora bien, LOCKE, se vio tentado por el poder, traicionando su argumentario y su principio rector ${ }^{551}$-pagando con el exilio señalado, en Holanda-, mientras que los leaders fueron mucho más firmes y coherentes en su albedrío, permaneciendo más tiempo en el poder.

El principio de neutralidad y separación entre Iglesia-Estado y su argumentario (framers JEFFERSON y MADISON): al respecto, se ha alimentado la gran impostura en los últimos años, sobredimensionándose el pensamiento de JEFFERSON, en detrimento de MADISON. Ambos fueron eminentes estadistas de Virginia, Secretarios de Estado y Presidentes de los EE.UU., pero como suele pasar con la Historia Política -especialmente, la estadounidense se reinterpreta a través de los escritos y no tanto por los acontecimientos cotidianos en vida. JEFFERSON, fijó él mismo, mediante escritos proto-populistas ${ }^{552}$, las bases de su propaganda favorable -lejos de toda coherencia vital-553, mientras que MADISON, de escritos más

\footnotetext{
551 Algo habitual entre los intelectuales, que creen poder cambiar al poder y luego sucumben al mismo. LILLA llama a esta debilidad de los pensadores el síndrome de Siracusa. Vid. LILLA, M.: The reckless mind. Intellectuals in Politics, New York: The New York Review of Books, 2001. Complement., SÁNCHEZ-BAYÓN, A.: Estudios de cultura político-jurídica, Madrid: Delta, 2010.

${ }^{552}$ Son textos de corte emotivo, vehemente, progresista y directo al pueblo (obviando las instituciones democráticas intermedias, moduladoras del poder y garantes de la libertad, pues sin ellas se estaría ante un despotismo ilustrado como el de la Europa continental de entonces) -ahondando en tal sentido, recuérdese que JEFFERSON se hizo apodar, en su Monticello residencial, con el sobrenombre Man of the People [hombre del pueblo].

553 Entre las múltiples incoherencias y disonancias entre la retórica y la realidad jeffersoniana, destacan: a) su vehemente defensa de la libertad e igualdad, tal y como se afirma en su (auto)atribuida- DIE "all men are equal and independent", mientras que era propietario de un centenar de esclavos; b) su firme defensa de la separación iglesia-Estado, como en su carta a la Asociación Bautista de Danbury, a la vez que funda con fondos públicos la Universidad de Virginia, que ha de formar a ministros de culto, para el Sur y los territorios del Oeste; c) su apasionado alegato
} 
complejos (sesudos) y elitistas -por tanto de menor repercusión popular-, fue desdeñado por la academia, bien como castigo por su abandono del bando Federalista, bien por engrandecer más aún el mito de JEFFERSON. En realidad, el problema de MADISON fue su juventud (uno de los delegados más jóvenes de la Convención), quedando atrapado entre dos grandes personalidades del momento, HAMILTON y JEFFERSON.

En cualquier caso, la idea de defender la conciencia, y con ella, separar lo civil de lo religioso, metafóricamente, vía un muro divisorio, es tomada de WILLIAMS554. Así como el formato epistolar es copiado de WASHINGTON (Letter to the Religious Society called Quakers, 1789). Sin embargo, una vez más, la gloria y la fama les son reconocidas a JEFFERSON y su Carta a la Asociación Bautista de Danbury ("the legitimate powers of the Government reach actions only, and not opinions (...) thus building a wall of separation between Church and State") [los legítimos poderes del Gobierno (Federal) alcanzan acciones sólo, y no opiniones (...) por tanto es construido un muro de separación entre Iglesia y Estado]-cuyas afirmaciones son enmendadas dos años después en su epistolario con la Hermana Ma la Orden de las Ursulinas en New Orleans.

Otro episodio similar (de impostura), tiene lugar en relación con la regulación de la libertad religiosa y demás libertades y derechos naturales. Popularmente, se identifica tal hito con JEFFERSON, seguramente por su auto-atribución en su

\footnotetext{
a favor de los derechos naturales y la intimidad de la persona, mientras promovía moralistas leyes antisodomía y antipoligamia (como su borrador del Código Penal de Virginia de 1779), a la par que abusaba de su esclava -y presunta hermanastra- S. HEMINGS; et al.

${ }^{554}$ Vid. GARMAN, G.: America's real religion, Pittsburg: Pittsburg State University Press, 1989. GAUSTAD, E.S.: Faith of the Founders. Religion and the New Nation 1776-1826, Waco: Baylor University Press, 1993. GEY, S.C.: Religion and the State, San Francisco: LexisNexis, 2001. McCONNELL, M.W., et al.: Religion and the Constitution, Gaithersburg: Aspen Publishers, 2002. WRIGHT, C. (ed.): Religion in American Life. Selected readings, Boston: Houghton Mifflin Co., 1972.
} 
epitafio $^{555}$, pero fueron otros los auténticos artífices. Sucintamente, el juego de influencias y autorías fue como sigue: G. $\mathrm{MASON}^{556}$ fue el redactor del borrador enmendado por LEE y MADISON- de la Declaración de Derechos de Virginia (1776), influenciado por la Declaración de Derechos Inglesa (1689), a su vez bajo el influjo doctrinal de LOCKE y de la Magna Carta (1215). La Declaración de Derechos de Virginia inspiró a MADISON -ya desde sus enmiendas- para la redacción de la Declaración de Derechos de los EE.UU. (1789). En todo este proceso, la participación real de JEFFERSON fue modesta. Fue uno de los cinco integrantes de la Comisión para la redacción de la DIE (1776) 557 , que sirviera de base para la Declaración de Derechos, además de participar indirectamente en los grupos de trabajo para la misma (a través de MADISON, por encontrase JEFFERSON de embajador en Europa).

En cuanto a la polémica Ley para fijar la libertad religiosa, aprobada por la Asamblea de Virginia en 1786, cierto es que, el proyecto nace de JEFFERSON, para medirse con el otro gran estadista (igualmente Gobernador) de Virginia, P. HENRY, y su propuesta de Ley para dotar de profesorado de religión cristiana, 1784. Ahora bien,

${ }^{555}$ En Monticello, puede leerse en la tumba de JEFFERSON (por mandato testamentario) “aquí yace Thomas Jefferson, autor de la Declaración de Independencia estadounidense, del Estatuto de Virginia para la Libertad Religiosa y Padre de la Universidad de Virginia". Llama poderosamente la atención que, JEFFERSON, prefiriera omitir cuestiones objetivas fácilmente constatables, como sus cargos de Presidente y Vicepresidente de los EE.UU., de Secretario de Estado, etc., mientras que su deseo expreso estaba en ser recordado por méritos discutibles y, en cualquier caso, siempre compartidos. Tal predilección, parece poner de manifiesto la poca confianza de JEFFERSON por la Unión.

${ }^{556}$ Vid. DAVIDOW, R.P. (ed.): Natural Rights and Natural Law: The Legacy of George Mason, Fairfax: The George Mason University Press, 1986. JENSEN, M.: The Making of the American Constitution, Malabar: Krieger Publishing Co., 1979. SHUMATE, T.D.: The First Amendment: The Legacy of George Mason, Fairfax: The George Mason University Press, 1985.

${ }_{557}$ Cierto es que resultó su ponente defensor, por haber rechazado dicho encargo FRANKLIN y ADAMS. Su borrador fue enmendado (especialmente, por FRANKLIN y MADISON), tanto en lo sustancial para convertir su estilo político en jurídico, y en lo formal para evitar incorrecciones gramaticales y sintácticas. Vid. (cualquier edición de) Notes of Debates in the Federal Convention of 1787 reported by James Madison. RODELL, F.: Fifty-five Men: The Story of the Constitution, Harrisburg: Stackpole Books, 1986. 
JEFFERSON, acepta el cargo -dejado por FRANKLIN- de embajador en Francia, y es MADISON quien se queda sólo defendiendo el proyecto, motivo por el cual redacta su célebre Recuerdo y oposición frente a las asignaciones religiosas, 1785. En lo tocante a la elaboración de la Declaración de Derechos estadounidense, también es cierto que JEFFERSON influyó relativamente mediante su epistolario con MADISON -tal y como ya se ha mencionado-, mientras estuvo en Francia (1785-89). De París volvió con un discurso más radicalizado y asumiendo autorías como las criticadas, creyendo que le ayudarían a ganar la campaña por la Presidencia de los EE.UU. -lo que más bien despertó un buen número de antipatías, sólo que sacó ventaja de la división interna entre los Federalistas (v.g. la muerte de WASHINGTON, las disputas entre ADAMS y HAMILTON, el abandono de MADISON, etc.).

Debido a la experiencia francesa (como representante de los incipientes EE.UU.), se explica así el incremento de radicalismo doctrinal de JEFFERSON, postulando por un aislacionista muro de separación, mientras que en su mayor profundidad de pensamiento y complejidad técnica de políticas públicas, MADISON558, abogaba por una separación comunicada con un puente de anchura y tránsito variable, según las necesidades coyunturales ${ }^{559}$.

\footnotetext{
558 A diferencia de JEFFERSON, su apodo -fruto de un amplio consenso, generalizado y no de autopromoción- fue el de The Great Legislator [el gran legislador], rivalizando en todo caso con HAMILTON -quién, por cierto, pese a su gran capacidad y prestigio, no pudo ser Presidente de los EE.UU. por su origen antillano.

559 Para conocer algo más, de primera mano, el pensamiento de estos dos insignes estadistas, consúltese los siguientes escritos: a) de JEFFERSON, su Visión sumaria sobre los Derechos en la América Británica (1774), su Notas sobre el Estado de Virginia (1781), su versión de la Biblia (1820), más su Autobiografía (1821); b) de MADISON, su Memorial (1785), su Notas de los debates en la Convención Federal (1787), sus Memorandos en materias políticas -especialmente, su Monopolios, perpetuidades, cooperación y cargas eclesiásticas (1817); vid. nota 10. Cabe señalar además, que entre los muchos memorandos, destaca por su modulación de la metáfora del puente y por haber sido redactado justo
} 
El principio de acomodación y el argumentario sobre el deísmo (FRANKLIN y CARROLL): hasta el momento, los casos representativos citados guardan un cierto equilibrio entre el peso de sus cargos públicos ejercidos y la realización de su visión del libre examen. Ahora bien, en las siguientes semblanzas, sobresale con creces la personalidad mediadora de los sujetos: entre el pueblo y las elites de poder (y de éstas entre sí) $)^{560}$, entre la sociedad civil y la religiosa, entre la esfera pública y la privada, etc. Cierto es que ambos fueron constituyentes (uno de pleno derecho, como fue FRANKLIN, y el otro invitado a sesiones, tanto por su hermano CARROLL, como por su amigo FRANKLIN), pero son mucho más reconocidos por su labor de cohesión social, como canales de comunicación: FRANKLIN como editor y CARROLL como Arzobispo católico. El sustento de su capacidad conciliadora se basa en su tendencia secular hacia el deísmo (al menos en el primero, vid. infra): una fórmula de religiosidad vigorosa y muy vital, abierta a la tolerancia social y proclive

antes de morir -como prueba de la dificultad de un tema así-, aquel sobre el polémico asunto de las capillas en el Congreso y la asistencia religiosa en las fuerzas armadas. Otras expresiones de su vigilancia constante de la materia, por ejemplo, fueron sus vetos presidenciales: a) el de 21 de febrero de 1811, contra una ley que pretendía financiar la construcción de una iglesia episcopaliana en Alexandria ("governments are limited by the essential distinction between civil and religious functions"); b) el de 28 de febrero de 1811, contra una ley que donaba terrenos para una iglesia bautista de Mississippi ("comprises a principle and precedent for the appropriation of funds of the United States for the use and support of religious societies"). Vid. RICHARDSON, J.D. (comp.): Compilation of the Messages and Papers of the Presidents (vols. I-X y Suplemento), US Congress, Washington DC, 1902-04; de forma gratuita y académica (con el reconocimiento de seis prestigiosas universidades), Project Gutenberg (URL: http://onlinebooks.library.upenn.edu/webbin/metabook?id=mppresidents).

${ }^{560}$ FRANKLIN y CARROLL eran dos personajes que gozaban de gran auctoritas entre los Framers, por ser de los más instruidos, ancianos e íntimos amigos de las más carismáticas personalidades del momento (y sucesivos Presidentes de los EE.UU.), como WASHINTON, ADAMS, JEFFERSON, etc. Incluso, en lo relativo a la amistad, la más profunda y sincera era la que se profesaban entre FRANKLIN y los hermanos CARROLL, pues gracias a las insistentes recomendaciones de FRANKLIN, al Nuncio del Papa en París, para que el destacado jesuita CARROLL supliera las funciones del Vicario de Londres, pasando a ocupar el cargo de Superior de Misiones en América del Norte (los EE.UU. y Canadá) -evidentemente, se instaló en Maryland. Complementariamente, para saber algo más acerca de los nexos entre los EE.UU., Canadá y CARROLL. 
al libre examen maduro, permitiéndose así la coexistencia pacífica de lo material y lo espiritual, lo tradicional y lo moderno, lo teológico y lo científico, etc.

El deísmo, es una de las expresiones autóctonas más relevantes de la estadounidización del pensamiento Whig [liberal-conservador] y Freemasonry [masón] (PWF), ya que supone la máxima abstracción teológica, lo que facilita el tránsito periódico -y no convulso- de unos despertares y revitalizaciones religiosas a otras. Dicha característica cohesionadora del deísmo, por el que se fijan unos mínimos y los matices interpretativos corresponden a la privacy o intimidad, es incorporada por FRANKLIN y CARROLL al espíritu constituyente, durante las sesiones de la Convención, plasmándose en el texto de la CEU, y la campaña divulgativa posterior para su implantación. En tal sentido, FRANKLIN da difusión en la American Philosophical Society [Sociedad filosófica estadounidense] ${ }^{561}$ y en sus publicaciones periódicas, mientras que CARROLL lo hacía en los sínodos y en los púlpitos.

Entre sus aportaciones más interesantes y clarificadoras de su visión y misión acomodaticia y de discurso deísta, destacan: a) de FRANKLIN, su panfleto Una disertación sobre la libertad y la necesidad, el placer y el dolor (1725), sus Artículos de fe y actos de religión (1728), su Almanaque del pobre Ricardo (1733-58), su Sermón del Padre Abrahán (1758), su Breviario del Libro de la Oración Común (1773), su Discurso ante la Convención Constitucional (28 de junio de 1787), etc.; b) de CARROLL, sus Cartas al Papa Pio VI (1788-89), su Discurso en nombre de los Católicos estadounidenses a George Washington (1790), su Oración por los líderes nacionales (1791), sus contribuciones al Primer Sínodo de Baltimore (1791), su Carta Pastoral (1792), etc.

\footnotetext{
${ }^{561}$ Equivalente estadounidense a la Royal Society o Real Sociedad británica, donde se formulaba el ideario del PWF.
} 


\section{¿Cuál ha sido el uso del legado patrístico?}

Los Founding fathers [padres fundadores o patrística] -tal y como se viene indicando-, trabajaron por y para la estadounidización del PWF (obteniendo logros autóctonos como el deísmo, el Federalismo, etc. ${ }^{562}$. En su adelanto a la Ilustración europea-continental, los Founders confirieron carta de naturaleza a la armonización plausible y realizable de la tradición sacra y profana occidental. Aterrizando sus logros en la concreción de un modelo relacional Iglesia-Estado de libertad religiosa, ello se consiguió gracias a su profundo convencimiento en la necesidad de oponerse al establecimiento de una religión oficial, con su correspondiente Derecho eclesiástico (como el caso anglicano, y su expresión americana de las Blue Laws), a la vez que, se considera indispensable una defensa del libre culto desde las instituciones públicas. Tales planteamientos se constitucionalizaron (en la Primera Enmienda de CEU), dejando clara la secularización frente a las iglesias, aunque no así frente a la religión, cuyo papel en la vida pública sigue siendo el reto a asumir y vislumbrar por los estadistas posteriores.

Por tanto, los padres fundadores -en un ejercicio sacralizador, incluso fetichizador- son vistos, para el Nuevo orden, como la versión estadounidense de la patrística judeocristiana (los padres de la iglesia primitiva, junto con los patriarcas

\footnotetext{
562 Vid. ADAMS, A.M., EMMERICH, C.J.: A Nation dedicated to Religious Liberty. The Constitutional Heritage of the Religion Clauses, Philadelphia: University of Pennsylvania Press, 1990. HART, B.: Faith $\mathcal{E}$ Freedom. The Christian roots of American Liberty, Dallas: Lewis and Stanley Publishers, 1988. WOOD, G.: The Creation of the American Republic 1776-1787, The Chapel Hill: University of North Carolina Press, 1969.
} 
bíblicos), cuyo novedosísimo testamento (alianza y/o) social ${ }^{563}$ es la DIE, la CEU y su Bill of rights o Declaración de derechos. A diferencia de la patrística tardoantigua, que procuraba discernir la ortodoxia de lo apócrifo, sin evidenciar su personalismo al hacerlo -por primar aún la comunidad frente al individuo-, los padres fundadores quiénes sí han procurado dejar su propia huella para las generaciones venideras-, seleccionaron los pilares del AWL, dejando su legado para el resto de estadistas posteriores, que han de probar su valía como tales, sabiendo interpretar adecuadamente dicho bagaje, para lograr en cada momento la revitalización requerida de la auto-percepción y misión de los EE.UU.: un pueblo elegido con un destino manifiesto (American manifest destiny o AMD).

Pues bien, la herencia de los padres fundadores es un reto que ha sido asumido sobre todo por los poderes más voluntaristas, o sea, aquellos sujetos con un constatado deseo de plasmar su impronta personal en la interpretación coyuntural del legado recibido. Entre dichos poderes, ocupan un lugar destacado los Presidentes de los EE.UU. y los Magistrados del TSEU, cuyas contribuciones a la herencia fundacional son sistematizadas a continuación, y analizadas desde la teoría de las élites de poder.

Como regla general de roles al respecto, cabe afirmar que -tal y como se viene indicando periódicamente-, los Presidentes y Magistrados estadounidenses, a lo largo de su trayectoria de altos cargos públicos, se hallan en la tesitura de optar por priorizar unos principios $\mathrm{u}$ otros: a) bien en sus primeros años de mandato -y para los menos, en los últimos, debido a la urgencia de dejar impronta-, como expresión

\footnotetext{
${ }^{563}$ Como ya se indicara al tratar la ACT, el uso del término "testamento", proviene del hebreo berit (alianza o disposiciones contractuales) a través del griego diathéké (legado, entre otros significados) y, más tarde, del latín testamentum. De ahí que su significado original sea el de Nueva Alianza y/o Testamento/Legado.
} 
de su vocación mesiánica y deseo de dejar legado, es habitual la preferencia por los principios de separación y autonomía frente a los principios de acomodación e integración; b) el resto de su trayectoria, suele estar más orientada por razones prácticas de estabilidad social -antes que preferencias personales- hacia los principios de acomodación e integración.

Entre Presidentes y Magistrados, cabe distinguir las siguientes categorías, según sus actitudes para el acceso al cargo, a la par que para su implementación del libre examen, una vez ya en el puesto. Se ofrece a renglón seguido una serie de consideraciones críticas acerca de la relevancia de la confesionalidad, tanto para el acceso y representatividad de sensibilidades en dichos cargos públicos, como en la gestión del argumentario para dejar su legado personal.

a) Representatividad de sensibilidades: en un inicio, los puestos públicos relevantes son copados por fieles de main-line churches, ya que las elites de poder son, en su mayoría, episcopalianos y presbiterianos. En cambio, con el paso del tiempo y la sucesión de despertares y revitalizaciones religiosas, la potenciación de la idiosincrasia estadounidense va cristalizándose a través de los fieles de las evangelical churches, quienes son considerados algo más autóctonos (natives) -a representar nuevas sensibilidades y territorios, más allá de la Costa Este. Incluso, de forma paulatina, los católicos, vistos bajo sospecha durante largo tiempo, terminan incorporándose a las elites de poder de los EE.UU., disparándose su acceso a los altos cargos públicos tras la década de 1960 (recuérdese el impulso que trajo consigo el Presidente KENNEDY). 
b) Confesionalidad presidencial564: aproximadamente, los representantes de las mainline churches han sido cerca de un $47 \%$ (episcopalianos $29 \%$, presbiterianos $16 \%$, etc.); de las evangelical churches, sobre el 51\% (bautistas 9\%, cuáqueros 4,5\%, etc.); más un $2 \%$ católico -cuantitativamente ínfimo, pero muy significativo cualitativamente (vid. figura siguiente). Tales resultados estadísticos han de ser interpretados de acuerdo con las causalidades e intencionalidades tratadas en las diversas teorías sobre la religión y la secularización (v.g. teoría del denominalismo, teoría de la conversión, etc.).

Figura 56.- Profesión religiosa de los Presidentes estadounidenses

\begin{tabular}{|lll|}
\hline Presidente & Periodo (toma de posesión) & Confesión \\
\hline G. WASHINGTON & $1789-97$ & Episcopaliano \\
\hline J. ADAMS & $1797-01$ & Unitarista \\
\hline T. JEFFERSON & $1801-09$ & Episcopaliano \\
\hline J. MADISON & $1809-17$ & Episcopaliano \\
\hline J. MONROE & $1817-25$ & Episcopaliano \\
\hline J. Q. ADAMS & $1825-29$ & Unitarista \\
\hline A. JACKSON & $1829-37$ & Metodista \\
\hline M. VAN BUREN & $1837-41$ & Holandés reformado \\
\hline W. H. HARRISON & $1841-41$ & Episcopaliano \\
\hline J. TYLER & $1841-45$ & Episcopaliano \\
\hline J. K. POLK & $1845-49$ & Metodista \\
\hline Z. TAYLOR & $1849-50$ & Episcopaliano \\
\hline M. FILLMORE & $1850-53$ & Unitarista \\
\hline F. PIERCE & $1853-57$ & Episcopaliano \\
\hline J. BUCHANAN & $1857-61$ & Presbiteriano \\
\hline A. LINCOLN & $1861-65$ & Presbiteriano/Bautista \\
\hline A. JOHNSON & $1865-69$ & Metodista \\
\hline
\end{tabular}

${ }^{564}$ Vid. BONNELL, J.S.: Presidential profiles. Religion in the life of American Presidents, Philadelphia: The Westminster Press, 1971. HUTCHESON, R.G.: God in the White House. How religion has changed the modern presidency, New York: MacMillan, 1988. SÁNCHEZ-BAYÓN, A.: "La religión civil estadounidense: análisis de la configuración de la realidad socio-cultural y su identidad social", en Revista General de Derecho Canónico y Derecho Eclesiástico del Estado-Iustel (no 10), 2006. 


\begin{tabular}{|c|c|c|}
\hline U.S. GRANT & $1869-77$ & Metodista \\
\hline R. B. HAYES & $1877-81$ & Metodista \\
\hline J. A. GARFIELD & $1881-81$ & Discípulo de Cristo \\
\hline C. A. ARTHUR & 1881-85 & Episcopaliano \\
\hline G. CLEVELAND & $1885-89 / 93-97$ & Presbiteriano \\
\hline B. HARRISON & $1889-93$ & Presbiteriano \\
\hline W. McKINLEY & $1897-1901$ & Metodista \\
\hline T. ROOSEVELT & 1901-09 & Holandés reform. \\
\hline W. H. TAFT & 1909-13 & Unitarista \\
\hline W. WILSON & 1913-21 & Presbiteriano \\
\hline W. G. HARDING & 1921-23 & Bautista \\
\hline C. COOLIDGE & 1923-29 & Congregacionalist. \\
\hline H. HOOVER & 1929-33 & Amigo/Cuáquero \\
\hline F. D. ROOSEVELT & $1933-45$ & Episcopaliano \\
\hline H. S. TRUMAN & $1945-53$ & Bautista \\
\hline D. D. EISENHOWER & 1953-61 & Presbiteriano \\
\hline J. F. KENNEDY & 1961-63 & Católico \\
\hline L. B. JOHNSON & $1963-69$ & Discípulo de Cristo \\
\hline R. M. NIXON & $1969-74$ & Amigo/Cuáquero \\
\hline G. R. FORD & 1974-77 (20 ene.) & Episcopaliano \\
\hline J. CARTER & 1977-81 (ídem) & Bautista \\
\hline R. W. REAGAN & $1981-89 "$ & Presbiteriano \\
\hline G. H. W. BUSH & $1989-93 “$ & Episcopaliano \\
\hline W. CLINTON & 1993-01 “ & Bautista \\
\hline G.W. BUSH & 2001-09 “ & Metodista(antes episcopal.) \\
\hline \multicolumn{3}{|c|}{$\begin{array}{l}\text { mayor peso en gestión del factor religioso ha sido su Vicepresidente BIDEN, quier } \\
\text { moviera el voto católico-. }\end{array}$} \\
\hline $\begin{array}{l}\text { D. TRUMP } \\
\text { M. PENCE, es evangél }\end{array}$ & $\begin{array}{l}\text { 2017-en adelante } \\
\text { co (de los nuevos } n\end{array}$ & $\begin{array}{l}\text { Presbiteriano -su Vicepresidente, } \\
\text { ientos carismáticos)-. }\end{array}$ \\
\hline
\end{tabular}

Fuente: elaboración propia (SÁNCHEZ-BAYÓN, 2007 y 16). 
c) Confesionalidad judicial565: con una complejidad superior a la vista para la Presidencia, puesto que se trata de un órgano colegiado donde sus integrantes gozan de un gran personalismo, ello ha generado una serie de prácticas garantes de un mayor grado de representatividad y posibilidad de trasvases de mayorías, como por ejemplo, la institución del asiento católico y/o judío ${ }^{566}$. Pues bien, según las estadísticas, las proporciones habidas han sido de, entre los ciento diez Magistrados, noventa y uno correspondían a denominaciones protestantes (33\% episcopalianos, $18 \%$ presbiterianos, $9,5 \%$ unitaristas, $5 \%$ metodistas, 3\% bautistas -recuérdese el polémico BLACK, etc.), once a católicos (más MINTON, que se convirtió tras abandonar el cargo), siete a judíos. De entre los diecisiete Presidentes del TSEU, diez han sido protestantes y tres católicos, mientras que los judíos sólo han tenido la fallida propuesta de FORTAS.

565 Vid. GRAHAM, F.: Wall of controversy. Church-State conflict in America (the Justices and their opinions), Malabar: Robert \& Krieger Publishing Co., 1986. SEKULOW, A.: Witnessing Their Faith: Religious Influence on Supreme Court Justices and Their Opinions, New York: Rowman \& Littlefield Publishers, 2006.

${ }^{566}$ Los asientos para las minorías, especialmente, para católicos y judíos, es una práctica cuya institucionalización busca preservar la diversidad suficiente como para que el grueso de la ciudadanía se sienta mínimamente representada -entre católicos y judíos, siempre han supuesto cerca de una cuarta parte de la población de los EE.UU. Sírvase ahora a recibir algunas de las notas más esclarecedoras de dichos asientos: a) el asiento católico: surge en 1836, con TANEY, propuesto por la Administración JACKSON, consolidándose con el nombramiento de WHITE, en 1894; b) el asiento judío: arranca en 1916, con el nombramiento de BRANDEIS, que llegó a coincidir con CARDOZO, desde 1932, lo que provocó una gran controversia -frenada gracias a la gran cualificación de CARDOZO, lo que sirvió para fijar el asiento judío, heredándole en el puesto, FRANKFURTER. 
Figura 57.- Religiosidad de Magistrados de TSEU en la década de $2000^{567}$

\begin{tabular}{|llcc|}
\hline Confesión & Magistrados & \% Tribunal Supremo & \% Población \\
\hline Protestantes & $\begin{array}{l}\text { STEVENS, SOUTER -sustituido } \\
\text { por SOTOMAYOR en 2009-, STEVENS }\end{array}$ & $22 \%$ \\
& -sustituido por KAGAN en 2010- & \\
\hline Católicos & $\begin{array}{l}\text { KENNEDY, SCALIA, THOMAS } \\
\text {--converso-, ROBERTS, ALITO, SOTOMAYOR }\end{array}$ & $28 \%$ \\
\hline Judíos & BREYER, GINSBURG, KAGAN & $22 \%$ & $2 \%$ \\
\hline
\end{tabular}

Fuente: elaboración propia (SÁNCHEZ-BAYÓN, 2007 y 16).

d) Gestión del argumentario: muy posiblemente, la presente, sea la cuestión que encaja más imposturas en su haber. Esto es, por tratarse de poderes tan voluntaristas -ávidos de dejar su impronta en el legado estadounidense-, su polarización vital en el desempeño del puesto ha sido superior a la de otros altos cargos. Tanto es así que, según su evolución personal (su visión e implementación del libre examen), los titulares del cargo correspondiente han expresado un cúmulo de planteamientos contrapuestos tan diversos que, de la selección de fragmentos, bien puede nacer una impostura no pretendida -y los que sí las han generado con avidez, ya se han tratado, v.g. BLACK-. En resumidas cuentas, antes de analizar los textos, resulta muy recomendable estudiar los perfiles de los Presidentes y Magistrados, así como, clasificar sus manifestaciones según su jerarquía preceptiva (v.g. documentos públicos antes que los privados, la ratio decidendi conjunta antes que los obiter dicta personales, tendencias

\footnotetext{
567 Actualmente, el Presidente TRUMP está tratando de proponer Magistrados realistas (contrarios a affirmative action $\mathcal{E}$ identity politics, y más próximos al originalismo de otros Magistrados como SCALIA, quien falleciera en 2016): Neil GORSUCH (ya confirmado por el Senado en julio de 2018), y Brett KAVANAUGH (por confirmar y acusado sin pruebas de presunto acoso sexual hace más de 20 años -la defensa de la ahora denunciante declina el comparecer ante el Senado, sin embargo, tendrá que hacerlo finalmente, ya no por coherencia, sino por posible delito).
} 
dominantes antes que los exabruptos coyunturales, etc.). Según lo cual, obsérvense las siguientes categorías.

- Discurso presidencial: según el tipo de personalidad y desempeño del cargo, cabe distinguirse entre Presidentes predicadores (v.g. MONROE, EISENHOWER, REAGAN, W.BUSH) y pastores (v.g. LINCOLN, KENNEDY, CARTER, CLINTON). Los predicadores son aquellos más impetuosos y vehementes, movilizadores para la acción, por confiar en una misión de la que se creen custodios: el AMD -suelen llegar al poder tras los despertares religiosos populares, dando lugar a las revitalizaciones elitistas-. Los pastores, por su parte, resultan mucho más conciliadores en su discurso, por lo que éste es más abierto a la interpretación personal de la ciudadanía. En ambos casos, el recurso del argumentario religioso es polémico y preocupante, ya que oculta intereses político-jurídicos de legitimación de poder y de movilización socio-cultural, lo que implica, a su vez, riesgos latentes de neocesaropapismo (vid. figura final del pto.).

- Discurso judicial: algunos apuntes al respecto, se vieron al tratar la definición y semiología político-jurídica u oficial estadounidense de la religión, donde se advertía del uso construccionista de las notas a píe de página y de los votos particulares, para procurar dejar constancia por tales vías de la visión personal sobre una cuestión, considerada en los EE.UU., tan polémica como identitaria. De igual forma, también se ha llamado la atención ya sobre el recurso de los principios rectores, implementados según el momento profesional y personal de cada Magistrado -afectándose así, también, a su nivel de compromiso social. 
A continuación se recogen unas pocas muestras de técnicas y tácticas interpretativas jurisprudenciales para invitar a la reflexión comparada entre el cesaropapismo de la Antigüedad y el supuesto neocesaropapismo estadounidense exacerbado sobre todo, bajo el influjo neocon (neoconservador), con la Administración W.BUSH-568.

Figura 58.- Cesaropapismo: comparación entre Roma y EE.UU.

\begin{tabular}{|l|}
\hline \multicolumn{1}{|c|}{ Similitudes } \\
\hline DATOS GENERALES: \\
\hline $\begin{array}{l}\text { 1.- Se trata de potencias expansivas internacionales, donde los elementos religiosos } \\
\text { arquetípicos se consideran instrumentos necesarios de cohesión entre la diversa } \\
\text { población integrada (Occidentalismo) }\end{array}$ \\
\hline $\begin{array}{l}\text { 2.- Existe un deseo de extender su modelo de vida a todo el mundo (ecumenismo y } \\
\text { globalización) }\end{array}$ \\
\hline $\begin{array}{l}\text { 3.- El gobernante afianza su poder político por medio del respaldo religioso (retorno } \\
\text { a la Teología política tradicional, en detrimento de la secularización democrática) }\end{array}$ \\
\hline $\begin{array}{l}\text { 4.- Existe una situación de diversidad religiosa, cuya cabeza visible coordinadora es } \\
\text { el gobernante (monolatría y multiculturalismo integrado -vía religiones tradicionales } \\
\text { privadas y religión civil pública) }\end{array}$ \\
\hline DATOS ESPECIFICOS: \\
\hline $\begin{array}{l}\text { 1.- Normas para supervisar los elementos religiosos arquetípicos: a) Roma: Edicto de Nicea } \\
\text { (Galerio, 311); Edicto de Milán (Constantino, 313); Edicto de Tesalónica (Teodosio, }\end{array}$
\end{tabular}

${ }^{568}$ Cfr. SÁNCHEZ-BAYÓN, A.: “La religión civil estadounidense: análisis de la configuración de la realidad socio-cultural y su identidad social", en Revista General de Derecho Canónico y Derecho Eclesiástico del Estado-Iustel (no 10), 2006, pp. 14 y 15. La tendencia a la comparación de las elites anglosajonas con Roma es más frecuente de lo que se suele imaginar (especialmente desde Europa continental -donde se cree disponer del monopolio sobre dicha conexión-). Baste recordar los harto conocidos ejemplos (con sus reseñas) de la producción de HOBBES (y su Leviatán), HUME (y su Historia de Inglaterra desde la invasión de Julio César hasta la Revolución de 1688), LOCKE (y sus Dos tratados de Gobierno Civil), y otros tantos como BACON, T. MORO, etc., todos de gran influjo en los padres fundadores estadounidenses. Igualmente, son de destacar las iniciativas propagandísticas de las Catto Letters (para la Revolución Inglesa y la reforma estatal), que condicionaran los libelos coloniales, y más tarde los panfletos estadounidenses, como los enfrentados documentos de Federalist Papers y las Publio Letters. No se olvide además que el segundo libro más vendido y leído en el periodo fundacional estadounidense (después de la Biblia) fue La Historia del Declive y Caída del Imperio Romano de GIBBON; o que de los libros de cabecera de M. STANDISH, Capitán del Mayflower, figura (amén de la Biblia) La guerra de las Galias de J. CESAR. 
380), etc.; b) EE.UU.: PL. 103-141, November 16, 1993, Religious Freedom Restoration Act; PL. 103-344, October 6, 1994, American Indian Religious Freedom Act Amendment; PL. 105-183, June 19, 1998, Religious Liberty and Charitable Donation Protection Act; etc.

2.- Actos religiosos organizados por el poder político: a) Roma: Concilio de Nicea 325; Concilio de Constantinopla 381; Concilio de Éfeso 431, etc.; b) EE.UU.: servicios religiosos y funerales en honor de las víctimas del once de septiembre de 2001, bajo la convocatoria presidencial y con el respaldo de todos los líderes religiosos estadounidenses; Discurso sobre el estado de la Nación (W. BUSH, enero 2003); celebración de matrimonios de integrantes del ejército de los EE.UU. (durante las operaciones en Oriente próximo, febrero 2003); etc.

\section{Diferencias}

* Son muchas (temporales, materiales y espaciales), empero, las más destacadas son: a) en el fuero exterior, los EE.UU. es un país con vocación expansiva de su modo de vida, pero no de forma imperial (por ocupación), sino desde el liderazgo (por referencias); b) en el fuero interno, donde se reconoce y garantiza constitucionalmente el ámbito de autonomía interna del individuo, por lo que se justifica así la relegación paulatina de las religiones tradicionales (de carácter totalizante o absorbente de toda faceta humana) al ámbito de lo privado, y la religión civil, al público (sólo se pide identificación con el proyecto social para su desarrollo, confiriendo autonomía interpretativa en su ejercicio cotidiano).

Fuente: elaboración propia (SÁNCHEZ-BAYÓN, 2007 y 16).

Como ya se ha advertido, se trata de un ejercicio de comparación muy dudoso y polémico, pues aunque resulta difícil la evidenciación plena, al menos sus interpretaciones y discursos correlativos sí han encontrado cabida en el mundo universitario, incluso más allá de las disciplinas académicas dedicadas a la materia, para ser sus máximos defensores politólogos y científicos sociales de la talla de DAHL, HUNTINGTON, LIPSET, etc. ${ }^{569}$.

\footnotetext{
569 Vid. DAHL, R.: Congress and foreign policy, New Haven: Yale Institute of International Studies, 1949. - After the revolution; authority in a good society, New Haven: Yale University Press, 1970. - How democratic is the American Constitution? New Haven: Yale University Press, 2003. HUNTINGTON, S.P.: The Common Defense: Strategic Programs in National Politics, New York: Columbia University Press, 1961. - American Politics: The Promise of Disharmony, Cambridge: Harvard University Press, 1983. - Culture Matters How Values Shape Human Progress, New York: Basic Books, 2000. - Who Are We? The Challenges to America's National Identity, New York: Simon \& Schuster, 2004. LIPSET, S.M.: Political Man: The Social Bases of Politics, New York: Doubleday, 1960. - The First New Nation: The United States
} 
La esencia de este capítulo radica en la capacidad de percepción acerca de la rica experiencia americana/estadounidense para la consecución de un modelo de libertad en las relaciones Iglesia-Estado lato sensu. Frente a las fórmulas ideales europeo-continentales, de realización tardía y excesiva, la experiencia americana demuestra que, pese a los traspiés de la ejecución del método ensayo-error, ello ha sido conveniente para ir descubriendo el camino hacia la implantación de la tolerancia social y el libre examen, que son los cimientos de la libertad religiosa vigente. En analogía con la célebre máxima -ya aludida- de EDISON (el gran inventor decimonónico estadounidense) y aplicándola al vigente modelo relacional de Iglesia-Estado (lato sensu): ha sido necesario más de un millar de ensayos y errores para descubrir un modelo funcional a largo plazo, y sin cuyo bagaje, habría sido prácticamente imposible llegar al modelo vigente.

Entre los aspectos más concretos y técnico-jurídicos del capítulo, es conveniente recordar lo relativo a las fórmulas relacionales y la regulación colonial. Además de enunciarse las tipologías más reputadas sobre los modelos de relación y sus tendencias, se ha prestado especial atención a sus evidencias históricas más interesantes y valiosas, las Blue Laws [Derecho dominical de tránsito de la tolerancia tradicional a la moderna durante la época colonial]. Se trata de un cuerpo de preceptos socio-religiosos, proto-sistema precursor del American Civil Church LawACL (una suerte de Derecho Eclesiástico Estadounidense o DEE) ${ }^{570}$, que prueba la

\footnotetext{
in Historical and Comparative Perspective, New York: W.W. Norton, 1979. - Revolution and Counterrevolution: Change and Persistence in Social Structures, New York: Basic Books, 1968. - The Politics of Unreason: Right Wing Extremism in America, 1790-1970, New York: Harper \& Row, 1970.

570 Cuestión polémica, cuya comparación por la doctrina iuseclesiasticista española suele ser rechazada (al considerarse una disciplina eminentemente europeo-continental, no obstante, también existe con sus especialidades en el mundo anglosajón y latinoamericano). La denominación ACL procede de la relevante obra del Prof. ZOLLMANN. Vid. ZOLLMANN, C.: American Church Law, St. Paul: West Publishing Co., 1933. En cuanto a la visión comparada iuseclesiasticista en América, vid.
} 
condición de Derecho común de la regulación religiosa en la época colonial y la nacional emergente de entre guerras (Guerra de la Independencia, Guerra de 1812 y Guerra de Secesión $)^{571}$, hasta que con su secularización, ha ido conformándose como rama autónoma del Derecho público -tal como se viene aclarando-.

Como último apunte, recuérdese también que, las Blue Laws son el reflejo de la integración de diversas propuestas de legislación eclesiástica del momento posreformista (v.g. Derecho eclesiástico holandés y suizo en las Provincias Medias, Derecho eclesiástico calvinista y luterano en Nueva Inglaterra, etc.), armonizadas paulatinamente por el Derecho eclesiástico anglicano, a medida que iba conformándose su imperio colonial americano (vid. criterio de supremacía). La idiosincrasia del ACCL, frente al Derecho Eclesiástico Británico o English Ecclesiastical Law (una vez integradas otras propuestas eclesiásticas de territorios colonizados, más las revisiones puritanas de la metrópoli), se manifiesta en los siguientes rasgos ${ }^{572}$.

GONZÁLEZ, M., SÁNCHEZ-BAYÓN, A.: “Libertades fundamentales en las Américas: devenir de la libertad religiosa en América Latina, los Estados Unidos de América y el Sistema Interamericano", Rev. Jurídica-UAM (nº 14), 2006. - Derecho Eclesiástico de las Américas, Madrid: Delta, 2009. - Regulación Iberoamericana de Derecho Eclesiástico del Estado, Madrid: Delta, 2011. Para profundizar en el devenir de dicha disciplina, vid. nota 1; complement., puede consultarse entre las publicaciones más recientes SÁNCHEZ-BAYÓN, A.: "Freedom of religion at large in American Common Law", Journal for the Study of Religions and Ideologies, Univ. Babes-Bolyai-Rumanía (vol. 13, issue 37), Spring 2014. "Historia, Historiología e Historiografía de los Estudios Interculturales en EE.UU.", Rev. Banda de Moebius-Univ. Chile (no 48), 2014. - "Enseñanzas del Prof. Navarro-Valls para comprender el "aggiornamento" del Ordenamiento global: aplicación a las Américas" (vol. 1), en MARTíNEZTORRÓN, et al.: Religión, Matrimonio y Derecho ante el siglo XXI, Madrid: Iustel, 2013. - "Cómo se aprende Derecho Eclesiástico del Estado en los Estados Unidos de América y su jurisprudencia", Ars Boni et Aequi-Univ. Bernardo O'Higgins (vol. 9, no 2), 2013. - “El Derecho Eclesiástico en las universidades estadounidenses", Rev. Española de Derecho Canónico (vol. 70, no171), 2013, et al.

571 Tanto por su valoración de la tradición, como por la dimensión generalista conferida a la materia, vid. SÁNCHEZ-BAYÓN, A.: Sistema de Derecho Comparado y Global, Valencia: Tirant Lo Blanch, 2012. 572 Vid. KRAMNICK, I; MOORE, R.L.: The Godless Constitution. A moral defence of the secular State, New York: W. W. Norton \& Co., 2005, pp. 49 ss. 
Aunque ambos casos, son ejemplos de confesionalismo moderno, al imponerse tributos a favor de la Iglesia Anglicana (se sea fiel o no), al exigirse para el reconocimiento de derechos civiles y políticos el cumplimiento del juramento de supremacía, más la observación de leyes dominicales y moralistas, etc., en el caso del emergente ACCL, la imagen de la Corona británica como cabeza religiosa es cada vez más difusa y su pérdida de significado va en aumento -hasta dar lugar a una hostilidad justificadora de la Guerra de la Independencia ${ }^{573}$.

Las especificidades del incipiente ACCL, se ven más claras en rasgos genuinos anticipatorios al resto Ordenamientos occidentales, como son, por regla general, a) la no concesión de cargos públicos a los ministros de culto por su mera condición; b) el no reconocimiento de cortes eclesiásticas con jurisdicciones especiales; c) los cargos eclesiásticos son elegidos por la comunidad (teniendo cada vez menos que decir la Corona británica); etc.

\section{Relevancia del Presidente de EE.UU.: vocación mesiánica y riesgo cesaropapista}

Se trata de una cuestión compleja y de hondo calado, pues el césar ha de ser y parecer honrado: al mismo tiempo que el Presidente ha de mediar salomónicamente en el complejo sistema relacional estadounidense (v.g. entre

\footnotetext{
${ }^{573}$ Tanto es así que, en el ánimo de marcar diferencias desde un origen, a la producción de DEE en América, para distinguirla de aquella claramente inglesa, en vez de utilizar la expresión "Ecclesiastical Law", se recurre a acuñaciones autóctonas como "Church Law" (ACCL). Así lo llegan a sistematizar y a enseñar en las universidades desde finales del s. XIX, como destacan los ejemplos de los profesores HALL y MATHEWS en The University of Chicago; MOORE y ZOLLMANN, en Columbia University.
} 
esferas sociales: derecho, política y religión; entre instituciones públicas y civiles: ejecutivo federal y estatal, legislativo idem, lobbies), igualmente, dispone de la capacidad interpretativa para hacer oscilar la tendencia relacional hacia un límite $\mathrm{u}$ otro del intervalo fijado en el marco constitucional (establishment clause v. free exercise clause). Y es que, como parte de los poderes implícitos -institucionalizados por JEFFERSON, pese a su denuncia cuando estaba en la oposición-, mediante tal recurso no sólo no se limita a intervenir en las relaciones entre las religiones tradicionales y la religión-política -incluso, con tal actuación acrecienta la religión civil, a la vez que se fortalece su figura, pasando al acervo del legado-. La institución presidencial estadounidense es una de las más ricas, puesto que observa las principales facetas de su gran líder: el máximo dirigente de la nación, de la Jefatura de Estado, del Ejecutivo, de los Ejércitos, de su partido, etc. Resulta tan importante porque encarna el mesianismo estadounidense, que en el imaginario colectivo se identifica con la figura del padre ${ }^{574}$ : se trata del elegido para ser continuador de la misión de los padres fundadores, siendo quien recibe, gestiona y transmite su legadocuestión en la que se vuelcan todos los Presidentes, máxime en su segundo mandato-. Si será importante la figura presidencial que, al igual que se celebra el día del padre, también hay un día del Presidente. Tanto es el poder y responsabilidad presidencial, que en la rendición de cuentas (para evitar el riesgo de cesaropapismo, vid. infra figura previa) se mezcla lo jurídico con lo moral, pues la mentira puede ser causa de impeachment o destitución presidencial (v.g. NIXON).

En relación con la idea anterior (relativa a la relevancia del patriarca en la

\footnotetext{
574 Se llama la atención sobre la capacidad de reinventarse de los EE.UU., pues se ha pasado de la predominancia y práctico monopolio del varón WASP (white anglo-saxon protestant o protestante anglosajón protestante), dando cabida periódica a algún candidato católico, hasta llegar a la situación de 2008, donde se postularan mujeres (H. CLINTON como candidata a Presidente, o PALIN para Vicepresidenta), incluso un afroamericano (OBAMA). Vid. figura siguiente.
} 
tradición occidental sagrada), cabe destacar como elemento objetivo fácilmente contrastable, el hecho de que todo Presidente de los EE.UU. ha sido cristiano (lato sensu -quizá sería mejor decir posjudeocristiano, incluyéndose así el deísmo y restantes movimientos autóctonos, v.g. mormones, testigos de Jehová, cienciólogos, vid. figura siguiente). Cabe reseñar como caso especial, el supuesto de KENNEDY, quien además fue católico y "mártir" -aunque no ha sido el único Presidente en morir en el cargo-. Otro elemento objetivo demostrable es la presencia de los valores y expresiones cristianas (v.g. Dios bendiga a los EE.UU., con la ayuda de Dios) en sus discursos y actos públicos, los cuales resultan constitutivos de regulación administrativa y orientan las políticas públicas. También es conocida la liturgia por la que los Presidentes estadounidenses, desde WASHINGTON, juran su cargo sobre una biblia-salvo JOHNSON, quien lo hiciera mediante un misal católico, por ser el único libro sacro a mano tras el magnicidio de KENNEDY-. Ahora bien, gracias a la ACR se logra una fórmula ecuménica, como la Red Mass o misa roja (una suerte de servicio pluriconfesional) en St. Matthew's Cathedral (Catedral de Washington DC, dedicada a San Mateo evangelista, patrón de los funcionarios), tras la toma de posesión presidencial o por funerales de Estado (incluso, en otras partes del país, también se celebran misas rojas para el cuerpo jurídico-administrativo con la apertura de curso, v.g. jueces, profesores y estudiantes de Derecho). Volviéndose al tema que ahora ocupa, el problema radica, no tanto en el encaje de relaciones entre el factor religioso y la institución presidencial (dentro del sistema), sino en la gestión que se acometa al respecto en su seno, pues ha habido casos polémicos de cierto activismo religioso -y la ya citada amenaza de cesaropapismo-: se alude a las actitudes frente a la religión y todo lo que comprehende, pues su recurso puede servir, por ejemplo, para favorecer la legitimación presidencial en medidas concretas, pues se 
busca el refuerzo por vía divina, carismática y tradicional.

De tan peculiar relación entre religión y Presidencia, surge la distinción entre los Presidentes reverendos y pastores, tal como se aborda en el siguiente punto (después de la figura inmediata).

Figura 59.- Devenir y peso confesional entre Presidentes

Episcopalianos: variante de la Iglesia de Inglaterra, con influencias calvinistas y luteranas, siendo de las primeras en defender su emancipación -contribuyendo así al germen independentista estadounidense-; han pertenecido a la misma doce Presidentes (29\% aprox.: WASHINGTON, JEFFERSON, MADISON, MONROE, HARRISON, TYLER, TAYLOR, PIERCE, ARTHUR, ROOSEVELT, FORD, BUSH y W.BUSH -hasta el 2000-). Presbiterianos: variante de la Iglesia de Escocia, fundada por KNOX, con rasgos puritanos; han pertenecido a la misma siete Presidentes (16\% aprox.: BUCHANAN, LINCOLN, CLEVELAND, HARRISON, WILSON, EISENHOWER y REAGAN).

Metodistas: variante de la Iglesia de Escocia y Gales, fundada por WESLEY e influida por pietismo; han pertenecido a la misma seis Presidentes (14\% aprox.: JACKSON, POLK, JOHNSON, GRANT, HAYES, McKINLEY y W.BUSH -desde el 2000-).

Otras denominaciones: Bautistas y Unitaristas con cuatro Presidentes (9\% aprox.), respectivamente; Holandeses reformistas, Cuáqueros, Congregacionalistas y Discípulos de Cristo con dos Presidentes (4,5\% aprox.) cada confesión.

Fuente: elaboración propia (SÁNCHEZ-BAYÓN, 2007 y 16).

\section{Roles presidenciales: reverendos y pastores}

Hablar de reverendos y pastores es atender a los supuestos rasgos definitorios de los ministros de culto protestantes: los reverendos suelen corresponderse con las main-line churches [iglesias tradicionales], luego tienen una concepción establecida y jerárquica, con un tipo de discurso de corte paternalista -de arriba abajo, estando ellos en un plano superior al de sus interlocutores-, moralista - 
al partir de una sobre-autoestima de su ser y con una visión algo maniquea de lo circundante-, y voluntarista -anteponen su fe a todo-; en cambio, los pastores, al guardar relación con las evangelical churches [iglesias emergentes], su visión es más informal y comunitaria, luego su discurso en más fraternal -de hermano a hermano, en plano de igualdad-, siendo más empático y comprensivo con el interlocutor. Cuando se aplican a los Presidentes dichas categorías, con sus cualidades, ello permite distinguir entre aquellos (los reverendos), que son más duros y exigentes con su pueblo, dando prioridad a la misión, y con una vocación expansiva, frente a los otros (los pastores) que operan justo al contrario. Si se contextualizan todas estas premisas, cabe destacar que hasta el s. XX, los Presidentes reverendos eran intervencionistas (ejecutando su poder y ampliando su jurisdicción y competencia), mientras que los pastores resultaban aislacionistas (centrándose en el pueblo estadounidense y dejándole hacer). El problema es que desde la década de 1990, con la exposición en la globalización a los contagios posmodernos, resulta difícil el recurso de las categorías ilustrativas que aquí se exponen: tanto CLINTON como W. BUSH -como propiciadores de la corrección política y el neoconservadurismo-podrían parecer pastores en sus discursos -máxime, en los de sus primeros mandatos- (v.g. registro coloquial, atención a problemáticas y demandas sociales), sin embargo, en realidad actuaban como reverendos (v.g. intervencionismo por el bien de los demás y contra el mal: ex Yugoslavia, Oriente Próximo; identificación de su postura con el bien y cualquier crítica con el mal -al ser ellos quienes fijaban los marcos del debate, en vez de recoger los servidos por la opinión pública-). Con OBAMA ha seguido el desconcierto, pero quizá su papel -si se compara con J. CARTER- haya estado más próximo al del pastor. Conforme a la $\mathrm{ACR}$, es posible que, lo más conveniente para los EE.UU., sea tener un Presidente pastor, que atienda a las demandas de la 
sociedad civil (a través de sus despertares), al que luego suceda un Presidente reverendo (favorecedor de una revitalización), de modo que en su intervencionismo expansionista de self-righteouness pueda devolver la confianza a los estadounidenses en su identidad y misión -y quizá así también resulte posible recuperar un modelo social de referencia-.

\section{Selección de fragmentos de discursos presidenciales}

Se han seleccionado una serie de muestras ilustrativas del tipo de interpretación que los Presidentes han llevado a cabo del factor religioso, y por ende, del sistema relacional Iglesia-Estado. Se han extraído dichas muestras de los discursos oficiales, en su mayoría los de apertura de mandato inicial o los de despedida/clausura del último término -salvo CARTER, por ejemplo, que procede de uno de sus discursos a la nación (vía radiofónica)-. Se evita así el recurso de fuentes privadas (v.g. cartas, memorias), pues su nivel de contradicción es alto, al darse prioridad a la comunicación con el interlocutor correspondiente, y no a la fijación de la postura institucional con respecto a la materia. Se recomienda, por tanto, la lectura de los extractos traducidos (vid. figura inmediata), teniendo en cuenta las indicaciones anteriormente facilitadas sobre el posible cesaropapismo y el activismo religioso, así como, sobre las categorías de Presidentes reverendos y pastores sin olvidar el análisis de intencionalidad y coherencia del legado, tal como se advirtiera ya al inicio de este texto-. 
Figura 60.- Discursos presidenciales sobre el factor religioso ${ }^{575}$

\begin{abstract}
G. WASHINGTON (1789-97, 1er. Presidente): (...) religión y moral son sostenes indispensables. En vano reclamaría el título de patriota aquel que trabajara para subvertir estos grandes pilares de la felicidad humana, pues son los puntales más firmes de los deberes del hombre y el ciudadano.
\end{abstract}

J. ADAMS (1797-1801, 2o. Presidente): (...) si el amor por la ciencia y las letras y el deseo de patrocinar cualquier esfuerzo racional para fomentar las escuelas, colegios, universidades, academias, y cada institución para propagar el conocimiento, la virtud y la religión entre todas las clases del pueblo, ello se debe no sólo por su influencia benigna en la felicidad de la vida en todas sus etapas y clases, y de la sociedad en todas sus formas, sino que también se trata del único medio para preservar la Constitución de sus enemigos naturales, del espíritu sofista, partidista y de intrigas, los despilfarros de la corrupción, y la pestilencia de la influencia extranjera, que es el ángel de la destrucción a los gobiernos electivos.

T. JEFFERSON (1801-09, 3er. Presidente): (...) justicia igual y exacta para todos los hombres, cualquiera que sea su creencia religiosa o política (...) No habrá hombres que sufran a causa de sus opiniones o creencias religiosas, pues todos los hombres serán libres de profesar y mantener su opinión en asuntos de religión (...) Nuestros gobernantes no pueden tener autoridad sobre (...) los derechos naturales, sólo como nosotros se los hemos sometido a ellos. Los derechos de credo nunca fueron sometidos, pues no podíamos. Sólo daremos respuesta de ellos a nuestro Dios. Los poderes legítimos de nuestro Gobierno se extienden a nuestros actos sólo cuando resulten perjudiciales para otros. Pero no es una lesión que mi vecino diga que hay veinte dioses o ninguno. [Que diga esto] no me quita dinero de mi bolsillo ni me rompe una pierna.

J.Q. ADAMS (1825-29, 6o. Presidente): Apareco, mis conciudadanos, ante su presencia y la del Cielo para comprometerme conforme a las solemnidades de la obligación religiosa para rendir fe de las obligaciones asumidas con mi puesto y las que he sido llamado de precepto religioso para el fiel cumplimiento de los deberes asignados a mí en la estación a la que he sido llamado (...) [entre los compromisos] que los militares han de mantenerse en estricta subordinación al poder civil, que la libertad de prensa y de opinión religiosa debe ser inviolable.

W.H. HARRISON (1841-41, 9o. Presidente): Considero esta ocasión lo suficientemente importante y solemne como para justificar, expresando a mis conciudadanos, mi profundo respeto por la religión cristiana y el convencimiento acerca de la importancia del sentido moral, la libertad religiosa, y la responsabilidad religiosa, que están esencialmente conectados

575 Vid. SÁNCHEZ-BAYÓN, A.: “La religión civil estadounidense: análisis de la configuración de la realidad socio-cultural y su identidad social", en Revista General de Derecho Canónico y Derecho Eclesiástico del Estado-Iustel (n⿳0 10), 2006. VV.AA.: La libertad religiosa como un derecho humano, en Temas de la Democracia (n², vol. 6), Departamento de Estado, 2001. Complement., vid. FEDERER, W.: "America's God and Country", en Encyclopedia of Quotations, Coppell: Fame Publishing, 1994. RICHARDSON, J.D.: A Compilation of the Messages and Papers of the Presidents, edic. priv., 1902-04 (actualmente disponible en version electronica $\mathrm{u}$ on-line: Project Gutenberg, URL: http://www.gutenberg.org/files/11314/11314-h/11314-h.htm; más Onlinebooks, URL: http://onlinebooks.library.upenn.edu/webbin/metabook?id=mppresidents); más referencias de cap. 3. 
entre sí y con verdadera y definitiva felicidad, así como con ese Ser bueno que nos ha bendecido con los dones de la libertad civil y religiosa, que velara por la prosperidad del trabajo de nuestros padres y las instituciones que hasta ahora se han conservado para nosotros, dando muestra de ser superiores en la excelencia a las de cualquier otro pueblo, luego unámonos para mantener con fervor estos intereses para el futuro de nuestro querido país.

J.K. POLK (1845-49, 11o. Presidente): (...) gracias a Dios, bajo nuestra Constitución no hay unión entre Iglesia y Estado, y en mi actuación como Presidente de los EE.UU., no reconocí distinción de credos en mis declaraciones oficiales (...) El derecho de libertad de credo en los EE.UU. permite la protección del Estado, de cada hombre que vive en nuestra tierra, ya lo sea de nacimiento o extranjero nacionalizado, de todas las sectas religiosas, en su adoración del Todopoderoso conforme a los dictados de su propia conciencia (...).

M. FILLMORE (1850-53, 13o. Presidente): (...) soy tolerante con todos los credos. Aun así, si alguna confesión se sintiera utilizada por causas políticas, lo resolvería oponiéndome. En mi opinión Iglesia y Estado deben estar separados, no sólo de forma, sino también de hecho. La religión y la política no deben ser mezcladas.

J. BUCHANAN (1857-61, 15o. Presidente): (...) humildemente, siento una confianza en la Providencia que inspirara a nuestros padres, dándoles el marco de sabiduría para lograr la forma de gobierno y la unión más perfecta jamás ideada por el hombre, donde nadie pudiera sufrir, por ejemplo, por disfrutar pacíficamente de la libertad civil y religiosa.

A. LINCOLN (1861-65, 16o. Presidente): [refiriéndose a estadounidenses de los dos bandos] Ambos leen la misma Biblia y oran al mismo Dios, y cada uno invoca su ayuda contra el otro (...) Las oraciones de ambos no podían ser contestadas (...) El Todopoderoso tiene sus propios fines (...) Si vamos a suponer que la esclavitud estadounidense es una de las infracciones que, en la providencia de Dios, tiene que castigarse con la guerra (...) Cariñosamente lo esperamos, oramos con fervor, que este flagelo poderoso de la guerra rápidamente pueda pasar. Pero, si Dios quiere que continúe hasta que toda la riqueza acumulada durante doscientos cincuenta años de trabajo indebido se desvanezca, y hasta que cada gota de sangre fruto del látigo sea pagada con espada (...) como se dijo hace tres mil años, por lo que aún hoy se puede decir que "los juicios de Jehová son verdad, todos justos" (...) Con malicia hacia nadie, con caridad para todos, con firmeza en el derecho que Dios nos da a ver el Derecho, esforcémonos en terminar la obra en la que estamos, para vendar las heridas de la nación (...) para hacer todo lo que puede permitir lograr y apreciar una paz justa $y$ duradera entre nosotros y con todas las naciones.

J.F. KENNEDY (1961-63, 35o. Presidente): (...) sea cual sea la religión que se siga en la vida privada, para el funcionario, nada afecta a su juramento para respetar la Constitución y todas sus partes -incluida la Primera Enmienda y la separación de Iglesia y Estado-. Creo en unos EE.UU. donde la separación de la Iglesia y del Estado sea absoluta, que ningún prelado católico pueda decir al Presidente (siendo católico) cómo actuar, y que ningún ministro de culto protestante pueda decir a sus feligreses a quién deben votar -donde ni Iglesia ni colegio religioso sea mantenido con fondos públicos o preferencias políticas- y donde a ningún hombre se le deniegue el acceso a puestos públicos meramente porque su religión difiere de la del Presidente que fuera a nombrarle o respecto de la gente elegida por él.

J.E. CARTER (1977-81, 39o. Presidente): (...) el año pasado estaba en el espectáculo de Pat Robertson, y nosotros discutimos sobre nuestra fe cristiana -en concreto, la separación de 


\begin{abstract}
Iglesia y Estado. Es contrario a mis creencias intentar exaltar el Cristianismo concediéndole un estatus preferencial in EE.UU. Esto viola la Constitución. No estoy a favor del rezo obligatorio en la escuela o de usar fondos públicos para financiar el educación religiosa.

W. CLINTON (1993-01, 42o. Presidente): (...) tenemos que comprender esto bien. Y tenemos que mantener este equilibrio. Este país necesita ser un lugar donde la religión crezca y florezca. ¿No creen ustedes que si cada chico en cada vecindario difícil de Estados Unidos se encontrase en una institución religiosa durante los fines de semana, en la sinagoga los sábados, en una iglesia los domingos, en una mezquita los viernes, no creen realmente que la tasa de drogas, la tasa de delincuencia, la tasa de violencia, el sentido de autodestrucción se reduciría mucho y la calidad del carácter de este país aumentaría mucho? ¿Pero no creen también ustedes que si en los últimos 200 años hubiéramos tenido un Estado gobernado por la religión la gente estaría aburrida de ella, y pensarían que ha sido comprometida por los políticos, recortada en los bordes, impuesta por gente que realmente no se ajustaba a ella, y no tendríamos 250.000 casas de culto en EE.UU.? Quiero decir, no las tendríamos. Es posible que la Primera Enmienda sea imperfecta, pero es lo más aproximado a la perfección que haya sido creado jamás por sociedad humana alguna para la promoción de la religión y de los valores religiosos.

G.W. BUSH (2001-09, 43o. Presidente): (...) la libertad religiosa es una piedra angular de nuestra república, un principio básico de nuestra Constitución y un derecho humano fundamental. Muchos de los que primero se asentaron en Norteamérica, como los Peregrinos, vinieron por la libertad de culto y credo que prometía esta tierra nueva. Y cuando las colonias británicas se convirtieron en los EE.UU. nuestros Fundadores limitaron constitucionalmente la capacidad de nuestro gobierno federal de interferir con el credo religioso, al prohibir al Congreso aprobar cualquier ley "respecto al establecimiento de una religión, o que prohíba el libre ejercicio de la misma". Estos límites constitucionales permitieron el florecimiento de la fe en todo nuestro país, lo que bendice enormemente a nuestra tierra.
\end{abstract}

Fuente: elaboración propia (SÁNCHEZ-BAYÓN, 2007 y 16).

Luego, ¿qué cabe esperar del papel presidencial ante el factor religioso? Pues que la religión está suficientemente secularizada como para incluir a todos, pero no tanto como para no satisfacer su función de cemento social. De ahí que, aquellos Presidentes que han pretendido ir más allá del intervalo fijado para las relaciones religión-Estado, han terminado mal, viéndose obligados a rectificar (v.g. CLINTON). 


\section{Balance sobre la patrística ante la posglobalización}

El gran problema que han tenido los padres fundadores es que casi han muerto de su propio éxito. Téngase en cuenta que en vez de quedar retratados como inadaptados (que tuvieron que migrar), traidores (a la Corona Británica) o arrogantes (autodeclarados adalides de occidental), en cambio, han pasado a la Historia como santos: ello ha ido provocando un cierto temor reverencial, indisposición personal y distancia emocional, que ha sido aprovechado por los sobrevenidos Estudios culturales y sus velos de confusión. Al respecto, durante las guerras culturales, para deconstruir y deponer el tradicional panteón de padres fundadores, primero se les rehumaniza con la revisión histórica, incidiendo en sus defectos y contradicciones; posteriormente se les relativiza, ninguneando su papel y legado, además de confundir todo ello con renovados panteones (ficcionados, multifragmentados y enfrentados entre sí), pues cada versión procede de una corriente de Estudios culturales sobrevenidos (v.g. feministas y de género, étnicoculturales: afroamericanos, latinoamericanos, nativoamericanos, et al.). Finalmente, gracias a la anti-historia posmoderna (que confunde History con story, especialmente en su vertiente de memoria histórica y literatura testimonial), se procede a la inhabilitación del conocimiento disponible sobre los padres fundadores y su contribución a la configuración idiosincrásica estadounidense -tildándoles de grandes censores y represores de su época, sin posibilidad de contrastación, al haberse pervertido las fuentes, v.g. al darse más peso a una novela histórica o historiografía de la década de 1960, que a la regulación oficial de la década de 1860, sobre la Guerra civil y la emancipación-. 
Desde este estudio, se ha intentado revisar el sentido y alcance del conocimiento disponible y sus límites, aprovechándose para retirar velos de confusión extendidos, de modo que quepa plantear como resultados de la investigación y su discusión los siguientes:

- Existe una religión civil estadounidense, fruto de la combinación de la tradición occidental (sagrada y profana, fusionada con PWF y demás elementos de Americaness), que integra las religiones tradicionales recibidas y adaptadas, más la nueva religión-política configuradora de la nación. En definitiva, se trata de un sistema de plurilealtades integrado como rezan los lemas oficiales del Gran Sello nacional: novus ordo seclorum, e pluribus unum, etc.

- Los padres fundadores son aquellos referentes de los mejores hombres de cada generación, que han tenido que afrontar el reto de redefinir la idiosincrasia estadounidense (desde su fundación colonial y revolución de independencia, pasando por su refundación tras la Guerra civil, etc.). Por tanto -como se ha dicho ya-, los padres fundadores -en un ejercicio sacralizador y de fetiche- son vistos, para el Nuevo orden de los tiempos, como la versión estadounidense de la patrística judeocristiana (los padres de la Iglesia primitiva, junto con los patriarcas bíblicos), cuyo novedosísimo testamento/alianza/legado social puede constatarse en la DIE, la CEU y su Bill of rights (o declaración de derechos), la carta emancipatoria, la regulación anti-segregación, etc. A diferencia de la patrística tardoantigua, que procuraba discernir la ortodoxia de lo apócrifo, sin evidenciar su personalismo al hacerlo (por primar aún la comunidad sobre el individuo), los padres fundadores (quiénes sí han procurado dejar su propia huella para las generaciones venideras), han ido seleccionando los muros de carga y nuevas plantas del edificio del AWL y su melting pot, dejando su legado para el resto de estadistas 
posteriores, que han de probar su valía como tales, sabiendo interpretar adecuadamente dicho bagaje (manteniendo el complejo skyscraper o rascacielos en pie), para lograr en cada momento la revitalización requerida de la autopercepción y misión de los EE.UU.: un pueblo elegido con un destino manifiesto (American manifest destiny o AMD). ¿Pero tal misión es posible si se olvida el árbol genealógico y se sucumbe al adanismo y tabula rasa de los Estudios culturales sobrevenidos?

- La relevancia presidencial, como el mesías de los tiempos (de cada coyuntura), plantea en la actualidad más incertidumbres que seguridades, hasta el punto de llegar a cuestionarse su papel de padre de la nación. Posiblemente, la corrección de tal deriva (que no es la popularización de la institución -pues siempre ha sido así-, sino la vulgarización de la misma -cualquiera puede ser Presidente, sin los méritos debidos ni el compromiso probado-), bien pueda proceder de un nuevo ciclo de despertares y revitalizaciones (American awakenings $\mathcal{E}$ revivals o AAR): el quinto despertar en la posglobalización y el Tecno Evo en ciernes ${ }^{576}$; empero, ¿es posible ante un proyecto idiosincrásico huérfano? ¿Qué padres fundadores podrían inspirar el revulsivo social necesario?

\footnotetext{
576 Dado el impacto negativo de los Estudio culturales sobrevenidos y sus velos, imposibilitando la reconfiguración idiosincrásica estadounidense (más allá del reconocimiento o no de los padres fundadores) ante el reto de la posglobalización, entonces, es posible que se esté ante el fin del tiempo estadounidense (iniciado con su autoproclamación como adalid de Occidente tras la II Guerra Mundial). Incluso, bien puede tratarse de algo más que un cambio de ciclo y liderazgo occidental (sin relevo aún y con los no-occidentales en ciernes, cuestionándose hasta la sostenibilidad civilizatoria de Occidente): cabe especular con una regresión a un estadio calificable de Medio Evo prossimo venturo (tal como hiciera Eco y otros en 1973); una suerte de Tecno Evo o nuevo Medievo de corte tecnológico y virtual, hasta que se defina algo más el siguiente periodo y su líder. Vid. ECO, U. et al.: Documenti su il nuovo Medioevo, Milano: Casa Ed. Valentino Bompiani, 1973.
} 
Sociología de las Relaciones Socioculturales Nortatlánticas (...) American civil religion - A. Sánchez-Bayón 


\section{0.- DIMENSIÓN OBJETIVA:}

\section{CASUÍSTICA RELEVANTE DE ACR Y SU LEGADO SOCIO-CULTURAL 577}

Haciendo balance de lo visto hasta ahora, se recuerdan nociones circulares relativas a ACR (y clarificadoras, para comprender su tópica, que se analiza en este capítulo). La religión civil, sobre todo para los europeos, puede parecer a simple vista una contradictio in terminis, que en realidad ha dado lugar a un oxímoron: no se trata de la mera unión de conceptos contrapuestos, sino que su combinación ha dado lugar a una figura plena de sentido y alcance (que en EE.UU., además, forma parte de su idiosincrasia, al recibir y adaptar la tradición vía proceso de Americaness o estadounidización, con el resultado identitario de ACR). Gracias a la secularización moderna (que libera a la religión de la Iglesia) y su Teología política (que organiza de manera participativa las relaciones entre los fieles), se logra así una religión práctica (liberada del monopolio de élites y dogmas, además de estar orientada a la asistencia social: a resolver los problemas terrenales). Tal novedosa religión práctica, resulta operante conforme a unas reglas de libre competencia (cada cuál decide cómo y cuánto involucrarse, según el nivel de salvación que desee, y con respeto a los demás). De tal suerte, comienzan a convivir las religiones tradicionales establecidas (hierocráticas y relacionadas con el poder civil) y recibidas (v.g. judíos, católicos, protestantes, ortodoxos), con la recién conformada ACR (basada en un panteísmo colector, para la integración social): en un sistema de plurilealtades o multi-identidades, de modo que se puede ser un judío de Rhode Island, un católico

\footnotetext{
577 Vid. infra nota 382, 519 y 568. Uno de los primeros textos en español sobre la materia fue SÁNCHEZ-BAYÓN, A.: "La religión civil estadounidense: análisis de la configuración de la realidad socio-cultural y su identidad social" (pp. 1-36), en Revista General de Derecho Canónico y Derecho Eclesiástico del Estado-Iustel (no 10), febrero 2006.
} 
de Maryland, un budista de California, un mormón de Utah, etc., pero en última instancia, todos convergen en la misma creencia: I'm American (soy estadounidense). Para comprender mejor, es necesario revisar el origen y desarrollo de dicha figura (ACR), que en la actualidad incluso ha alcanzado la condición de metámero (por ser un poderoso conector de factores y esferas sociales, además de condensador de capital socio-cultural, logrando reproducir de manera muy fidedigna la compleja y voluble realidad social, sin incurrir en un alto coste al hacerlo). Téngase en cuenta que, para acometer dicho ejercicio de profundidad comprensiva, además de requerirse de la retirada de velos de confusión extendidos (durante las guerras culturales), urge remontarse al hito que cambió el devenir de europeos y americanos: pese a contar con la misma tradición occidental sagrada y profana, en las colonias americanas se combinará el racionalismo humanista de la Alta Modernidad hispánica (que de la libertas christiana pone el énfasis en la libertad) y el racionalismo protestante o profesional de la Baja Modernidad nórdico-anglosajona (que de la libertas christiana pone el acento en el modo de vida mesiánico), dándose lugar así al deísmo laxo de ACR. Ahora bien, para alcanzar a entender más, resulta conveniente el abordar cuestiones preliminares como qué se entiende por religiosidad en EE.UU. (ya que la religión se ha desarrollado en un novedoso estadio de secularización moderna, facilitador de la aparición de novedosas manifestaciones -tal como explicara James, uno de los padres del pragmatismo), y cuál ha sido su Teología política de partida (centrada en la organización social de un pueblo predestinado y/o mesiánico), lo que ha permitido la formulación e implementación de una categoría de integración social de multitudes como es ACR (generando con ello una idiosincrasia: el ser propio estadounidense -relacionado con los europeos, pero diferente de ellos). 
Como se viene señalando, ACR es una categoría de integración social del Nuevo régimen, debiéndose concebir a modo de protonoción moderna de nación (construida desde las interacciones religión-política, desde los planteamientos de la secularización moderna y su Teología política) ${ }^{578}$. Dicha noción es previa a la dialéctica contemporánea europeo-continental de nacionalismo liberal-patriótico (o nacionalismo incluyente) y el étnico-cultural (o nacionalismo excluyente), causante de múltiples conflictos -debido a la confusión interesada en forma de Estado-nación y su correspondiente religión política (Dios es sustituido por el Estado, el sujeto mesiánico es la nación, el credo es la ideología, etc.). No obstante, en EE.UU., gracias a su ACR, se mantiene el sentido original de pueblo (no específico de gens o tribu, sino extenso de pueblo de Dios: integrándose las gentilitas, y organizándose como ecclesia o asamblea participada -de ahí la vocación federal, democrática, etc). En definitiva, ACR, hace posible el exponer y explicar cómo en la Modernidad se pasa de la propaganda religiosa a la política, permitiéndose la gestión de identidades sociales, pero desde la propia sociedad civil, sin el monopolio estatal (como sí pasa en Europa continental de entonces -de ahí que resulte una religión civil y no política): la religión civil responde a una fórmula adaptativa propia (vía Americaness), hábil para casar las disonancias del nuevo orden secular (vid. infra lemas nacionales), del tipo de: a) integración v. autonomía; b) religiones tradicionales (privadas) v. religiosidad pública; c) éxito y beneficio (personal) v. bienestar común (con su plus social); etc. En definitiva, la religión civil es-como mínimo- aquel vínculo

\footnotetext{
${ }^{578}$ La Teología política permite centrarse en el estudio de la ordenación del pueblo de Dios, tal como se acomete en el periodo fundacional estadounidense, plasmándose en sus lemas nacionales del Gran Sello (1782): novus ordo seclorum (nuevo orden de los siglos/Nuevo Régimen), annuit coeptis (-Dios/la providencia- favorece (el) entendimiento/aprueba (nuestra) empresa -algunos autores lo traducen como "favorece la causa estadounidense"-), y e pluribus unum (de muchos, uno/unidos en la diversidad); más el último en institucionalizarse (1956), ya en inglés: in God we trust (en Dios confiamos -y nos bendice por ello); vid. infra epígr. 5.3.
} 
moral y sacro, común a todas las comunidades y predicable del conjunto de la sociedad, en el que el individuo, como ser sociable y trascendental, necesita para dar sentido a su entorno y su papel en el mismo. Se trata del cemento y levadura social de las sociedades modernas, donde hay madurez racional, pero falta paridad emocional y social -pues ese tipo de inteligencia suele quedar menguada por la desproporción con el progreso científico-técnico-. La religión civil, aún con todas las aristas de su problemática denominación (al sintetizar dos constructos supuestamente antitéticos -al menos para los europeos contemporáneos-, como es lo religioso y lo civil-, sin olvidar las inconveniencias de su tratamiento -al no quedar claro si es causa y/o resultado del sincretismo moderno, especialmente el estadounidense, con su Americaness-, en cambio, guarda una relación directa e influyente con otros constructos, tipo AMD, ASG, AD, AWL, ASR, ACS, et al. (ya citado).

Con la religión civil, se cierra el círculo evolutivo occidental, ya que se combina la tradición occidental profana o greco-romano, con la sagrada o judeocristiana, que tras pasar por el tamiz de Americaness, se define como: a) universalista (por influjo cristiano: abierto a todo hombre y/o mujer, joven y/o anciano, rico y/o pobre, etc.); b) vocacional (exige un convencimiento responsable); c) se basa en la libertad y la pluralidad (propia de una sociedad de hombres libres, con conciencia propia y, que sin embargo, sienten una llamada común, además de comprometerse con un pacto de prosperidad y salvación); d) secular (hay distinción de órdenes: la religión interactúa con la política, pero no hay confusión, pues la política gestiona los bienes y servicios terrenales y la religión la convivencia y salvación de las almas); etc. La noción de religión civil de la que parten los autores ilustrados europeos -con influjo suficiente en EE.UU.-, es la constantiniana (antes de 
la corrupción teodosiana), con ciertos toques comprensivos de autores tipo CALVINO, LUTERO, VICO, LOCKE, et al. Así, de manera generalmente aceptada, se atribuye el bautizo de la idea moderna de religión civil a ROUSSEAU (Libro IV de El contrato social, con ciertos matices apuntados en el Emilio, 1762). Más tarde, son otros francófonoes quienes devuelven a los europeos la expresión apreciada en EE.UU. (tras su Americaness): CRÈVECOEUR (Cartas a un granjero americano, 1782) y TOCQUEVILLE (La democracia en América, 1835-40). Al respecto, existe una rica tradición de viajeros observadores de la identidad estadounidense (v.g. H.G. WELLS, G.K. CHESTERTON, H. BELLOC), vinculándola ya con cierto excepcionalismo (cultivándose así por los últimos Estudios culturales tradicionales, vid. infra cap. 8). Durante la Guerra civil y su posterior reconstrucción, los periódicos estadounidenses (v.g. New York Post, 1801, Chicago Tribune, 1847, New York Times, 1851), empiezan a popularizar (con un sentido redentor) la expresión American uniqueness (singularidad estadounidense), como nación concebida en libertad y que pretende la igualdad de los hombres (parafraseándose el célebre discurso presencial Gettysburg Address de LINCOLN, 1863). A finales del s. XIX, gracias al sustento de académicos como EMERSON y literatos como WHITMAN, la expresión y su significado relativo al carácter estadounidense se consolida, incluso se normaliza en términos científico-académicos en los trabajos de Historia estadounidense $\mathrm{y}$ en los emergentes Estudios culturales finiseculares y novocentistas. Así se consagra, la última gran aportación de consenso, sobre la identidad estadounidense, como es American excepcionalism \& melting pot. Dicha propuesta posee dos acepciones o vertientes contrapuestas: a) una connotativa y autóctona de legitimación (sustentadora de su patriotismo y basada en el consenso y carácter compartido), relativa a la singularidad estadounidense, su articulación 
nacional y su misión ejemplar -incluso salvífica- (presente en los Estudios culturales tradicionales); b) otra denotativa y foránea de crítica (sobre la rareza estadounidense, insistiéndose en sus supuestas debilidades y los conflictos soterrados), impulsada desde Europa (adhiriéndose la URSS) y consolidada con la fuga de cerebros (a raíz de las Guerras mundiales del s. XX), que permea la universidad estadounidense (impulsándose en los Estudios culturales sobrevenidos). La simbiosis académica de ambas corrientes (con predominio de la opción a), encuentra su vehículo de irradiación en movimientos del Ivy League 579 como liberal consensus o consensus history (compuesto de new-whigs, uniqueness theorists, reviewers, etc., cuya época de esplendor fue la década de 1950 y 1960, hasta su desbancamiento por New Left, reforzada por la fuga de cerebros y los Estudios culturales sobrevenidos).

Volviendo a ACR, durante el s. XIX y principios del XX, la semiología estadounidense de la religión civil se sustenta en aportaciones de teólogo-políticos, filósofos sociales (sobre todo, pragmáticos) y académicos sociales (vid. infra). Ahora bien, con la fuga de cerebros, cambia la visión de consenso, volviéndose crítica y deconstructiva durante las guerras culturales, y de ahí su rebrote universitario: tras

\footnotetext{
579 De los millares de centros universitarios reconocidos en los EE.UU., existe un reducido y exclusivo grupo denominado Ivy League o liga/club de la hiedra. Se trata de una metáfora muy plástica, pues la exclusividad de dicho club se basa en: a) la reivindicación de la solera de sus universidades pretendidas herederas de las más venerables europeas, donde hay hiedra longeva en sus muros-; b) la calidad de su educación y la selección intensiva de sus alumnos y profesores -que como la hiedra, se entremezcla para ser más fuerte y elevarse, de ahí la intensificación educativa en seminarios o almuerzos de estudio, por ejemplo-; c) la referencia social, tanto por ser parte de su comunidad como por acogerla, pues todo ello proporciona respetabilidad y posibilidad de promoción social -como la hiedra, proporciona solera y distinción a la edificación-, etc. La mayor parte de estas universidades se fundaron como centros educativos confesionales para asegurar el relevo generacional de profesiones liberales, especialmente los ministros de culto (quienes debían impulsar la colonización de la Costa Atlántica primero, y del Oeste después); sirva como ejemplo el caso de Princeton y los presbiterianos, Yale y los congregacionalistas, Harvard y los unitarianistas, la actual Brown y los bautistas, et al.
} 
los intentos de los sociólogos BELL y BERGER (por redescubrir la religión y lo sagrado y su influjo en las identidades colectivas), finalmente, destaca la propuesta de BELLAH y su signatura homónima de ACR en 1966 (heredera, a su vez, del funcionalismo de PARSONS y el interaccionismo de MEAD, con la religión republicana $)^{580}$, hasta las propuestas matizadas y tentadoras de LUCKMANN y su religión invisible (construccionista), NOVAK y su religión cívica (electivista), ROBERTSON y su religión americana (excepcionalista), LONG y su religión secular (comparativista), CASANOVA y su religión política (aunque esta es más predicable de Europa), et al. También se llama la atención sobre otras lecturas relacionadas, como: a) fundamentos de la religión civil (propedéutica), con BALITZER, LINDER, RICHEY, SMITH o WEST; b) religión civil, estadistas y sociedad (principios y movimientos), con DAVIS, JEWETT, LAWRENCE, LITTLE, et al.; c) diagnóstico y evaluación de la religión civil (críticas y previsiones), BALDWIN, HUGHES, LIPSET o HUNTINGTON.

En cuanto a las manifestaciones de $\mathrm{ACR}$, que mejor condensan la idiosincrasia estadounidense (soportando su identidad y dando prueba de su singular capacidad de recepción y transformación de la tradición occidental sagrada y profana, otorgando una novedad propia), cabe destacar:

a) Símbolos: monedas y billetes de dólar (con el Gran Sello y sus lemas nacionales, v.g. in God we trust, en monedas desde 1864 -para reactivar al confianza tras la

\footnotetext{
580 BELLAH fue un discípulo destacado de PARSONS, al igual que recibió ciertas influencias de MEAD (quien bebiera de los pragmáticos JAMES, DEWEY y PEIRCE, sucesores de EMERSON y el trascendentalismo). Indirectamente, también se vio influido por las propuestas previas de Herberg y su civic faith, en 1955. La publicación que dio fama a Bellah fue su artículo en la revista Daedalus (96 (1967): 1-21); más tarde vería la luz ampliada como libro (algo habitual como le pasara a Lipset con excepcionalismo estadounidense, FUKUYAMA y fin de la historia, HUNTINGTON -maestro de FUKUYAMA y en respuesta a su tesis- con choque de civilizaciones, etc.). BELLAH, R.: The Broken Covenant: American Civil Religion in a Time of Trial, Chicago: Univ. Chicago Press, 1992.
} 
Guerra civil- y en billetes desde 1935 -ídem, tras Crac y Gran depresión); Gran Sello nacional (mottos $\mathcal{E}$ icons); campana de la libertad (tallada en 1751 y papel en 1776, Levitico 25:10); himno nacional (The Star-Spangled Banner, letra de 1773 y oficializada por ley en 1987); etc.

b) Ritos: saludo a la bandera (pledge of allegiance, versión original de 1892 y última gran revisión en 1954); juramentos públicos (public oath ceremonias, tanto en tomas de posesión o declaraciones ante tribunales, con el recurso de la Biblia y/o la Constitución de EE.UU.); festividades de carácter nacional (National Holidays E School District's Calendar, ley de 1870 y modificaciones de 1968 y 71: Christmas, Thanksgiving Day, St. Valentine's Day, St. Patrick's Day, etc.); oración del Congreso al comenzar las sesiones; Día de la Oración y demás invocaciones religiosas presidenciales (desde Thanksgiving Proclamation of 1789 hasta Jewish Heritage Week Proclamation of 2004, National Day of prayer, Presidential Christmas Messages; Inaugural \& Farewell Addresses, etc.); red-mass en la Catedral de Washington DC (para inaugurar año judicial), blue-mass (ídem, para cuerpos y fuerzas de seguridad), etc.; Día del Presidente (veneración del líder -de la nación elegida-, elementos de legitimidad teológica); discursos políticos con invocación a Dios (v.g. God bless America, God bless you) y citas bíblicas; tele-evangelismo; etc.

c) Creencias: tierra prometida y pueblo elegido (promise land or New Jerusalem; pilgrims \& founding fathers; American's creed; sentencias del Tribunal Supremo declarando los orígenes judéo-cristianos de los EE.UU.); Destino manifiesto y mesianismo (manifest destiny $\mathcal{E}$ messianism); vidas ejemplares de los padres fundadores (founding fathers tales); etc.

d) Valores: valores democristianos (American values forman parte del American way of life, bajo las tensiones interpretativas del self-righteousness); sistema no jurídico 
sino de justicia (v.g. pena de muerte, juramento sobre la biblia); uso de la religión como justificante de intervenciones internacionales (v.g. IRFA, clash of civilizations); etc.

e) Normas: Declaración de Independencia (1776), Constitución de EE.UU. (1787) y Declaración de Derechos o Bill of Rights (1791), son textos ufanos de referencias religiosas, además de venerados como nuevas escrituras sagradas, custiodados en NARA (vid. supra); Blue Laws o derecho dominical/eclesiástico (conducente de la tolerancia a la libertad religiosa, y aún vigente alguna norma en los Ordenamientos locales); etc.

f) Instituciones: Church-State relations o relaciones Iglesia-Estado ((non)establishment clause, free exercise clause, wall of separation); pactismo y federalismo, más democracia y presidencialismo (American covenantism-ACT); patrística y su legado (founding fathers $\mathcal{E}$ heritage: pilgrims, puritans, leaders, rebels, framers, statemen); influjo en parlamentarismo, constitucionalismo, federalismo, et al.

g) Arte: obras y piezas del Instituto Smithsonian (con sus exposiciones y colecciones); compilaciones de NARA; arte sacro en museos y centros públicos (v.g. diez mandamientos en los tribunales de justicia); capillas, pinturas y esculturas en edificios públicos (parlamentos, ayuntamientos, universidades, etc., v.g. Chaplains of the US Senate \& House of Representatives); ídem, instituciones privadas (v.g. Jacob's Dream o escalera de Jacob en campus de Abilene Christian Univ.); medio centenar de catedrales católicas, protestantes y ortodoxas, y millares de templos, etc. 
h) Monumentos: homenajes a padres fundadores (v.g. Washington Memorial, Jefferson Memorial, Lilcoln Memorial) en explanada nacional o National mall \& West Potomac Park; Monumento Nacional Monte Rushmore; Cristo de los Ozarks; monumentos de los diez mandamientos en Tribunales; Memorial de Guerra del Cuerpo de Marines de EE.UU. (Marine Corps War Memorial o Iwo Jima Memorial: en Arlington, Newington, Quantico, etc.); monumentos conforme a Antiquities Act of 1906 y Servicio de Parques Nacionales (más de 100 en 2010, v.g. Monumento nacional de la torre del diablo, salina Pueblo Missions, Washington Birthplace), et al.

i) Floclore: toponimia y gentilicios (v.g. Jerusalem/Salem y Hope son nombres frecuentes de poblaciones en casi la mitad de los Estados de la Unión); estilos musicales (v.g. góspel, soul, R\&B -incluso el subestilo Underground railroad: canciones con clave para fuga de esclavos y abolicionistas), canciones populares (v.g. God bless America, Jingle bells, Amazing grace, Hallelujah! -fusionando HANDEL, soul, etc.-, When the saints go marching in -usado en actos oficiales, v.g. funerales de Estado) y musicales (v.g. Jesus Christ Superstar, Sister Act), et al. 


\section{1.- CONSIDERACIONES PRELIMINARES: CRITERIOS DE SELECCIÓN Y EXPOSICIÓN}

La ACR ${ }^{511}$-como se viene señalando- resulta un constructo de la Modernidad occidental ${ }^{582}$ : gracias a la diferenciación efectiva entre religión y política (creciendo cada esfera social en su ámbito), con el impulso de la secularización moderna y su Teología política (vid. infra cap. 5 y 6), surgen así las religiones políticas (con más éxito en Europa) y civiles (como el modelo prototípico estadounidense). La religión civil, permite conciliar las religiosidades tradicionales comunitarias, introduciéndolas en un sistema de plurilealtades, que culmina con una fórmula sincrética de integración social. Es el resultado, además, de la combinación de la tradición occidental sagrada y profana recibidas, revisadas por propuestas de PWF, así como otros filtros de Americaness ${ }^{583}$, dándose lugar a un metámero de gestión de

\footnotetext{
${ }^{581}$ Buena parte de los planteamientos y evidencias que aquí se sistematizan fueron avalados por la comunidad científico-académica hace más de un década, tanto en publicaciones como congresos. Sirva como ejemplo, y en español, vid. SÁNCHEZ-BAYÓN, A.: "La religión civil estadounidense: análisis de la configuración de la realidad socio-cultural y su identidad social", en Revista General de Derecho Canónico y Derecho Eclesiástico del Estado-Iustel (no 10), 2006. - La Modernidad sin prejuicios (vol. 1)... op. cit. - La religión civil estadounidense... op. cit.

582 Eso quiere decir que, pese a posibles inspiraciones sobrenaturales, la ACR es ante todo un producto cultural, de un entorno dominando por el cristianismo, llamado por entonces Cristiandad. De ahí que, pese a las procedencias diversas, las bases socioculturales son muy similares, por lo que se aprovecha tal circunstancia para fomentar fórmulas de integración como la ACR: gracias a la secularización moderna, lo común de la religión es usado para facilitar el tránsito hacia un nuevo orden secular o Nuevo Régimen (vid. infra cap. 5 y 6 ).

583 Con la religión civil, en cierto modo, se cierra el círculo evolutivo, ya que en buena medida se vuelve al modelo greco-romano, con las discrepancias con aquel, en cuanto que: a) es universalista (por influjo cristiano), así que está abierta a todo hombre y/o mujer, joven y/o anciano, rico y/o pobre, etc.; b) es vocacional, lo que exige un convencimiento responsable; c) se basa en la libertad y la pluralidad (propia de una sociedad de hombres libres, con conciencia propia y, que sin embargo, sienten una llamada común, además de comprometerse con un pacto de prosperidad y salvación); d) es secular (hay distinción de órdenes), pues la religión interactúa con la política, pero no hay confusión (la política gestiona los bienes y servicios terrenales y la religión la convivencia y salvación de las almas); etc. La noción de religión civil de la que parten los autores ilustrados europeos -con influjo suficiente en los EE.UU.-, es la constantiniana (antes de la corrupción teodosiana), con ciertos
} 
multitudes, previo al de nación, como es el de pueblo (en el sentido posjudeocristiano). De ahí, que mientras los europeo-continentales decimonónicos estaban enfrascados en el debate entre nacionalismo liberal y el etnocultural, los estadounidenses ya estaban viendo la democracia popular jacksoniana, expansiva hacia el Oeste. Para tejer un país tan reciente (iniciando su andadura internacional en 1776, pero su régimen político-jurídico vigente es de 1787), extenso (de alcance continental) y diverso (al haberse nutrido de oleadas migratorias), la ACR y su legado han sido cruciales, para condensar el ser idiosincrásico estadounidense, además de guiarlo en su devenir, hasta convertirse en una gran potencia hegemónica, autoproclamada adalid de Occidente tras la II Guerra Mundial. El

toques comprensivos de autores previamente mencionados (v.g. CALVINO, VICO, TOCQUEVILLE). Así, de manera generalmente aceptada, se atribuye el bautizo de la idea moderna de religión civil a ROSSEAU (Libro IV de El contrato social, más ciertos matices apuntados en el Emilio). Más tarde, es otro francófono quién devuelve a los europeos la expresión apreciada en los EE.UU.: TOCQUEVILLE (La democracia en América). Durante el S. XIX y principios del XX, la semiología estadounidense de la religión civil se circunscribe al ámbito estrictamente político-jurídico, concibiéndose como el instrumento para lograr la sublimación de la nación, la democracia y el Estado de Derecho (neofetichizándose así sus instituciones y adquiriendo, entonces, legitimidad moral y sacra). Empero, tras la crisis de los 1960 (y las guerras culturales), con la consiguiente reformulación del AWL, comienzan a barajarse diversas propuestas académicas para su estudio: desde la dominante de BELLAH y su signatura de 1966, la religión civil (que es heredera del funcionalismo de PARSONS y el interaccionismo de MEAD, con la religión republicana), hasta las propuestas matizadas y tentadoras de LUCKMANN y su religión invisible (construccionista), NOVAK y su religión cívica (electivista), ROBERTSON y su religión americana (excepcionalista), LONG y su religión secular (comparativista), et al. En realidad, si se quiere llegar al meollo de la cuestión, donde se produce la auténtica paradoxología (la transformación exitosa de la propuesta para el nuevo orden secular), además de tener en cuenta las influencias del ya señalado pensamiento Whig y Freemason (PWF) en las elites político-jurídicas estadounidenses (con el pulimiento coyuntural por parte de sus grandes Estadistas), es imprescindible resaltar la significativa aportación de elites intelectuales, como los trascendentalistas: su promotor fue el ministro de culto unitarista CHANNING -padre, igualmente, de la pseudo-teodicea estadounidense-, cuyos herederos naturales fueron, el también ministro unitarista y ya mencionado EMERSON (Naturaleza), ALCOTT (Reflexiones en torno al Evangelio), THOUREAU (Desobediencia civil), FULLER (directora del periódico "The Dial”), et al. Su lema fue "a cada uno su propio dios" (recuérdese lo dicho sobre un nivel de secularización tocante incluso a la denominación y tratamiento de la divinidad, vid. infra), o sea, una fe sin dogmas, una iglesia abierta, una religión cultural, una relación interna con Dios (y con la naturaleza, porque guarda una relación inmanente con la misma), etc. 
problema actual al respecto, no es tanto la crisis y caducidad del Estado-nación tras la globalización (de lo que adolecen sobre todo los europeo-continentales), pues los EE.UU., se ha articulado -como se viene señalando- vía su adaptativo ACR ${ }^{584}$, estando en manos de las bases sociales, encargadas de los despertares socioreligiosos, para dar cauce a las preocupaciones de los estadounidenses e ir reformulando su idiosincrasia periódicamente (vid. supra epígr. 10.3). Ahora bien, para dar apoyo a tal labor, a finales del s. XIX fueron apareciendo los Estudios culturales, en lo que, por razones obvias, se fueron integrando académicos venidos de todo el mundo, pensándose que ayudarían a fortalecer el estudio de la idiosincrasia estadounidense. Sin embargo, tras las guerras mundiales del s. XX, se produjo la gran fuga de cerebros, que trajo elites de conocimiento (sobre todo europeas), cuyos planteamientos posmodernos fueron muy celebrados al inicio, al atacar los cimientos europeos y favorecer así el ascenso cultural estadounidense. No obstante, su crítica no se limitó a Europa, sino que siguió con EE.UU., extendiéndose velos de confusión al respecto e iniciándose las llamadas guerras culturales. Su resultado fue la proyección de la posmodernidad sobre los EE.UU., deconstruyéndose su ACR y legado integrador, remontándose incluso al periodo fundacional, De tal manera, se terminaba con el universo ciudadano (articulado

\footnotetext{
${ }^{584}$ La ACR responde a una fórmula adaptativa propia (al más puro estilo Americaness: paradoxológica, pragmática y posjudeocristiana), hábil para casar las disonancias del nuevo orden secular, del tipo de: a) integración v. autonomía; b) religiones tradicionales (privadas) v. religiosidad pública; c) éxito y beneficio (personal) v. bienestar común (con su plus social); etc. En definitiva, la ACR es aquel vínculo moral y sacro, que el individuo, como ser social y trascendental, necesita para dar sentido a su entorno y su papel en el mismo. Se trata del cemento y levadura social de las sociedades modernas, donde hay madurez racional, pero no emocional y social -ese tipo de inteligencia queda menguada por la desproporción con el progreso científico-técnico-. La ACR, aún con todas las aristas de su problemática denominación -sintetizando dos constructos históricamente antitéticos, como lo religioso y lo civil-, así como, de su tratamiento -al no quedar claro si es causa y/o resultado del sincretismo estadounidense-, en cambio, cabe ser identificada con el AWL, AD, et al. (en cuanto que articula la fe y/o el modo de vida estadounidense, su sueño, etc.).
} 
mediante ethos), para promover un multiverso de comunidades (vía pathos). Luego, antes de asumir el fin de ACR y su legado, se va a revisar todo ello a continuación, prestándose especial atención a sus elementos integradores y sus manifestaciones cotidianas (tal como ya se avanzaran en la figura 21). 


\section{2.- PRINCIPALES ADVOCACIONES DEL LEGADO ${ }^{585}$}

Se ha logrado extraer de la realidad cotidiana de los EE.UU. una serie de muestras de ACR (símbolos, ritos, creencias e instituciones), elegidas por su gran popularidad (su recurso socializador y su amplia difusión). Son claras muestras de la secularización moderna, impulsora de su Teología política, capaz de dotar de una común visión y misión a gentes de diversas procedencias, además de dar viabilidad a una diferenciación de esferas sociales, sin perder sus conexiones (de modo que el conjunto de las normas e instituciones sociales tengan un sentido profundo compartido, que no provoque tensiones sociales y ni personales en su observación). Todo ello se aborda conforme a la concepción de los padres fundadores y su legado (qué influencias recibieron y cómo lo vehicularon para las siguientes generaciones), además de aprovecharse para adelantar cuestionamientos acerca de los riesgos de un uso y abuso desnaturalizado de la materia (tal como ha tenido lugar con las guerras culturales de las últimas décadas), y cuyo resultado ha sido la puesta en peligro de la matriz idiosincrásica estadounidense (vid. supra).

\footnotetext{
${ }^{585}$ La mayor parte de los elementos a estudiar a continuación, proceden de anteriores publicaciones, como SÁNCHEZ-BAYÓN, A.: La Modernidad sin prejuicio... op. cit. - Estado y religión de acuerdo con los Estados Unidos de América... op. cit. - Manual de Sociología Jurídica Estadounidense... op. cit. - Religión civil estadounidense... op. cit.
} 


\subsection{1.- SÍMBOLOS Y RITOS}

\section{A.- Símbolos}

Se alude a aquel elemento que trasciende su significado propio y atribuye otro que conecta a una comunidad, al compartir dicho significado añadido entre los miembros. Por tanto, el símbolo evoca un sentido y alcance que trasciende al objeto simbolizado (v.g. una bandera no sólo es un trapo, sino que representa a toda una comunidad, que se siente comprendida así). El símbolo además, suele hacer tangible aquellas nociones intangibles (relativas al ethos, pathos, sanctum, etc.), al facilitar la conexión de diversas asociaciones (v.g. la citada bandera represente a su vez la patria, la unidad de la ciudadanía, etc.).

Entre los elementos a abordar aquí, como parte de la ACR, destacan: a) billete de dólar; b) sello nacional; c) campana de la libertad; d) himno bandera de estrellas; y e) sagradas escrituras de ACR (DIE, CEU y BR).

\section{a) Monedas y billetes de dólar}

Los billetes de dólar son mundialmente reconocidos y gozan de gran crédito como instrumento de intercambio generalmente aceptado para las operaciones mercantiles cotidianas. De entre su oferta ordinaria, que va desde el billete de 1 dólar, pasando por el de 2, 5, 10, 20, 50, y hasta el de 100 dólares (existiendo otras variantes extraordinarias, de cuantías muy superiores, aunque fuera del comercio 
habitual), destaca principalmente y aún a día de hoy -pese a la inflación-, el billete de 1 dólar, por lo que se toma como referente para las explicaciones siguientes.

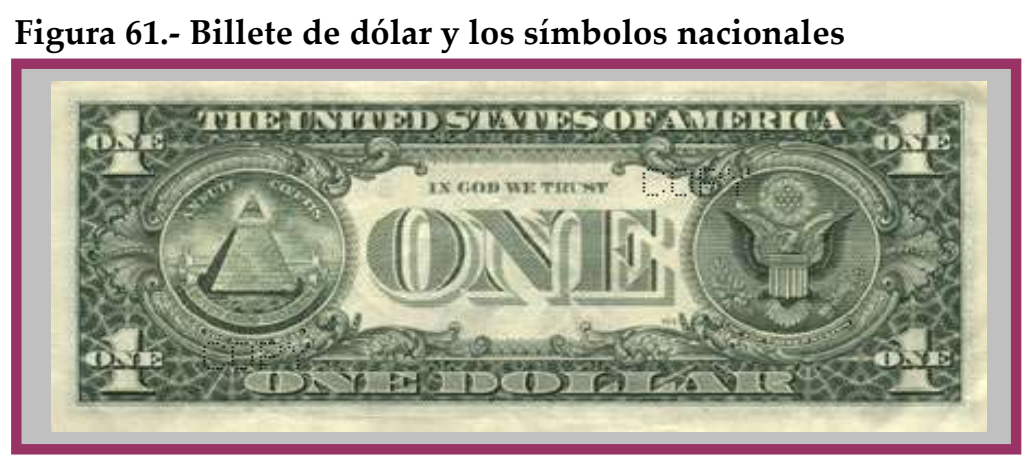

Fuente: elaboración propia (SÁNCHEZ-BAYÓN, 2007 y 16).

A efectos de este estudio, cabe destacar el aumento de poder simbólico del dinero de curso legal estadounidense a lo largo de su evolución -según su progresivo y programático proceso de fetichización o neosacralización, como elemento integrador de la tradición sacra y profana, además de instrumento cimentador del sistema-. Entre sus hitos y episodios más reseñables, figura la integración del lema in god we trust [en Dios confiamos], cuyos momentos clave han sido 586 :

a) en 1864, a consecuencia de la guerra civil y para reactivar la economía, a través de la restauración de la confianza -gracias al único credo común entre los bandos-, se incorpora el lema a las monedas de dos centavos;

b) posteriormente, se va extendiendo el lema al resto de monedas y billetes -de acuerdo con el grado de confianza popular, observable en su demanda para las

\footnotetext{
586 Vid. MOONEY, C.: Religion and the American dream. The search for Freedom under God, Philadelphia: The Westminster Press, 1977.
} 
transacciones;

c) en 1935, entre las medidas para reactivar la economía tras la crisis de 1929-33, la Administración ROOSEVELT remodela y fija el diseño actual del billete de dólar, incorporando las dos caras del Gran Sello nacional -el reverso (la imagen de la pirámide y el ojo que todo lo ve)- hacía mucho que no se mostraba públicamente, teniendo que ser un masón como ROOSEVELT, quien diera a conocer la obra de otros masones como los diseñadores originales (WASHINGTON, FRANKLIN, ADAMS, JEFFERSON, etc.);

d) en 1956, la Administración EISENHOWER, tras la última guerra mundial y en ciernes de la Guerra fría, promueve el fortalecimiento de la confianza en el dólar, elevando a rango de lema nacional la poderosa afirmación -en términos simbólicos (y esta vez en inglés)- "en Dios confiamos" (consolidando la letra del himno nacional "The Star-Spangled Banner", vid. supra).

El caso es que el diseño del billete de dólar es un claro ejemplo de posjudeocristianismo, pues contiene signos y símbolos de la tradición sagrada occidental, combinándolos con otros de la tradición profana (v.g. las ramas de olivo y las flechas), incluso yéndose más allá, al incorporar referencias gnósticas (v.g. el águila, que vuela entre los mundos: el natural y el sobrenatural) y herméticas (de la antigua religión egipcia, y otros orientalismos, v.g. la pirámide), y todo ello dando muestra del influjo Whig y Freemason (v.g. las trece estrellas -por los trece Estados originales de la unión, así como el número de la perfección masona-, que conectadas forman un pentagrama, y traspuesto sobre los lemas que bordean la pirámide, sus puntas señalan las letras de la palabra "masón"). 
Es esta una buena oportunidad para centrar la atención sobre el billete de dólar y el significado que entraña su diseño. Las disquisiciones generadas al respecto son:

a) Sobre el valor del lema: tras una afirmación tal, "en dios confiamos" -un dios que va más allá del judeocristiano (pues procede de la expresión anglo-germana), y tan secularizado que cabe su tratamiento en minúsculas-, y sin mucho esfuerzo, puede interpretarse dialécticamente su significado entre la bendición divina del dinero vs. deificación del dinero; luego: ¿dios confiere su gracia a dicho instrumento y así se materializa como prueba de predestinación, o más bien, bajo dicha fórmula se transfiere al dinero las condiciones fetichistas (de sacralización), presentes en los símbolos religiosos tradicionales y necesarias para generar la confianza colectiva -y el significado mágico- predicable de dicho medio de transacción? El dinero de curso legal estadounidense, ¿sigue poseyendo rasgos fetichistas tradicionales (con referentes externos y/o subyacentes) o ha mutado hacia una idolatría plena (con referente acabado en sí mismo)?

b) Sobre la significación de las distribuciones: si el billete más popular estadounidense presenta un diseño donde, entre las dos caras del Gran Sello nacional, claramente centrado y de forma rotunda impacta la rúbrica de "one" [uno], ello invita a meditar acerca del monismo planteado: teniéndose en cuenta que, uno de los rasgos idiosincrásicos de las religiones tradicionales judía y cristiana, es el monoteísmo y la concepción paternalista de la divinidad, entonces, cabe desprenderse que todos (los creyentes) están llamados a la integración bajo dios, confiriendo dicha unidad el imperativo solidario necesario para el correcto funcionamiento de la sociedad. Por lo que parece ser -dándose 
una respuesta a la pregunta anterior-, que se persigue así la legitimación imprescindible para que la sociedad confíe en su sistema de producción, de modo que se logre un desarrollo sostenible, como muestra del paraiso terrenal pretendido.

\section{b) Gran Sello nacional}

El Gran Sello de los Estados Unidos de América -que es su nombre oficial-, resulta el símbolo que autentifica los documentos oficiales estadounidenses -los EE.UU. no tienen escudo, por ser un país nacido con la Modernidad, entre cuyas primeras leyes federales fue la abolición de títulos nobiliarios, confirmándose así la igualdad jurídica tipificada en CEU-. Su custodia corresponde al Secretario de Estado, y figura su reproducción en las entradas de las embajadas y consulados estadounidenses a lo largo del mundo. Fue elaborado mediante una serie de Comisiones (con relevantes artistas de la época, como BARTON o THOMSON, y donde prestaron sus servicios los principales framers o constituyentes: WASHINGTON, FRANKLIN, ADAMS, JEFFERSON, etc., vid. infra cap. 9). Fue adoptado en 1782, pasando a ser reconocido por el Congreso como símbolo oficial de la nación (15 de septiembre de 1789). 


\section{Figura 62.- Caras del Gran Sello nacional}

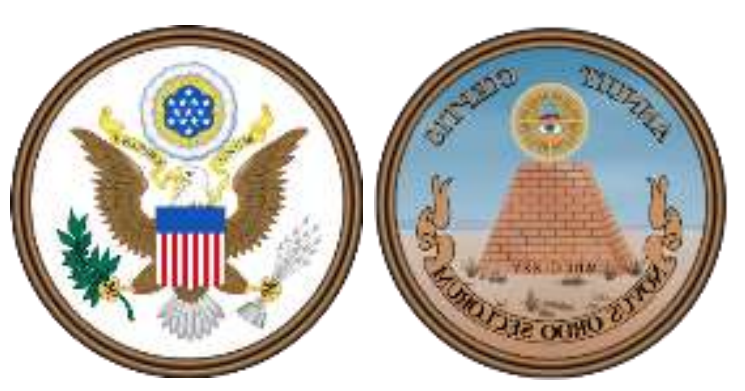

Fuente: elaboración propia (SÁNCHEZ-BAYÓN, 2007 y 16).

Los componentes de su diseño poseen una gran riqueza alegórica de dual naturaleza -al menos-, pudiendo observarse con claridad, tanto sus referencias bíblicas y como las deístas (con tintes herméticos y masones británicos o Freemasons -marcadamente diferente de la masonería europea-continental posterior-):

a) Componentes bíblicos: se trata de alegorías y referencias a pasajes de los textos sagrados y tradiciones comunes judeocristianas, como se desprende de: el cielo rasgado con haces de luz y el ojo que todo lo ve, que son representaciones de Dios (posteriormente copiadas por los masones europeo-continentales); la constelación de estrellas y los rayos de luz entre nubes (imágenes de la gloria y providencia divina sobre las trece colonias); la rama de olivo (símbolo de paz terrenal concedida por Dios, por ejemplo, tras el diluvio universal); etc. 
b) Componentes deístas: entre dibujos y lemas ${ }^{587}$, tales como el águila (símbolo masónico, heráldico y judeocristiano ${ }^{588}$; dada su condición de ave carroñera, FRANKLIN objetó -pese a ser masón- y propuso en su lugar el pavo -al considerarla un ave más noble y dado su valor en las celebraciones familiares, vid. supra Ritos-); la pirámide (símbolo masónico, tomado del hermetismo, que representa la fortaleza y la duración, además de los trece escalones del perfeccionamiento -como los trece Estados originales-); las fechas y el escudo (elementos heráldicos clásicos -eso sí, siempre cifrándose con el mencionado número trece, que es una cantidad masónica para representar el cambio o revolución-); etc.

En cuanto a los lemas que contiene el Gran Sello (vid. infra epígr. 5.3), estos son:

- e pluribus unum (de muchos, uno): se alude a los trece Estados originales llamados a formar la Unión (o Estado federal). También se entiende, conforme al sistema de plurilealtades estadounidense (vid. infra figura 6), por el que se reconoce la convivencia de multitud de comunidades en lo privado, siempre y cuando se integren en su cúspide nacional -así se articula ACR-.

\footnotetext{
${ }^{587}$ Dichos lemas fueron tomados de la obra de Virgilio, por razones que se explican seguidamente; empero, previa incorporación al Gran Sello nacional, sufrieron algunas modificaciones gramaticales de interés: el verbo "annue" se conjugó en tercera persona de singular para referirse a Él (Dios, que figura bajo la forma del ojo de la providencia u ojo que todo lo ve: delta luminoso), la contracción de "saeculorum" por "seclorum", et al.

${ }^{588}$ Como ya se ha mencionado, el evangelista San Juan es representado con el águila, ya que es el ave que se mueve entre los dos mundos: el terrenal y el celestial. Posteriormente, desde los Estudios culturales sobrevenidos se ha empezado a vincular el águila con los pueblos nativos (pero no hubo representante alguno durante los Congresos Continentales del s. XVIII, cuando se adoptaron todos los elementos que ahora se estudian).
} 
Igualmente, se le atribuye el significado relativo al origen diverso de sus gentes (imigrantes de toda Europa, sobre todo), que finalmente se vuelven ciudadanía estadounidense. Este lema, se aprobó al mismo tiempo que el de annuit coeptis y novus ordo seclorum, pero se le dio prioridad al mismo, hasta que fue desplazado por el de in god we trust (30 de julio de 1956, vía Ley Pública 851, en el 84ํㅡㄹ Congreso de EE.UU., recogida en el Título 36, Parte A, Capítulo 3, Sección 302 del Código de EE.UU., vid. infra cap. 4).

- annuit coeptis (favorece entendimiento): literalmente significa "(Dios) asiente (nuestros) comienzos", pudiéndose traducir también como "favorece / legitima nuestros inicios / empresa", incluso, "confirma lo que hacemos". La referencia a dios, no sólo se justifica por el uso de la tercer persona, sino por el dibujo que acompaña, que es delta luminoso o el ojo que todo lo vé (proviene del hermetismo egipcio, pero lo hizo suyo el judeocristianismo, y más tarde la masonería). En cuanto a los comienzos o proyecto, es tanto el general del nuevo orden secular, como el específico de la nación estadounidense. Desde 1935, se incorporó al reverso del dólar.

- novus ordo seclorum (nuevo orden temporal/terrenal/de los tiempos): el nuevo periodo o ciclo que se abre, es el del tránsito efectivo a la Modernidad, con su Nuevo Régimen (en oposición a los vaivenes europeos -con sus retrocesos por las monarquías absolutas y las guerras de religiones-), y que está llamado a ser liderado por los EE.UU. (en sintonía con constructos relacionados con ACR, como AMD). 
Se trata de lemas tomados del poeta clásico Virgilio. Se emula así la técnica de dicho autor para conectar el poder humano con el divino: como pasara en su Eneida, poema que sirviera para vincular el linaje del Emperador romano Octavio Augusto con el del gran Patriarca romano y Príncipe troyano Eneas y, el de éste, con las divinidades olímpicas -se raya así el cesaropapismo de la figura presidencial, vid. infra-589.

Pensando en su conjunto, la propuesta (que encaja con eficacia las reseñas bíblicas, los elementos heráldicos europeos y herméticos egiptológicos, así como las insinuaciones masónicas -en la línea adaptativa y de mestizaje apuntada ya, vía Americaness-), se expresa de tal modo, la fuerza y duración del proyecto social que se pretende en la conformación de los EE.UU. y su confirmación como potencia hegemónica.

\section{c) Campana de la libertad}

Este símbolo estadounidense, ubicado en Filadelfia (que fuera la protocapital, donde se reunió el Congreso Continental y se declaró la independencia), fue mandado tallar en 1751 por R. CHARLES (Agente colonial de la Provincia de Pensilvania, con apoyo de la Asamblea), con motivo de la celebración del cincuenta

\footnotetext{
589 Se alude al riesgo de vulneración del modelo estadounidense de separación acomodaticia en las relaciones Iglesia-Estado (vid. infra figuras del cap. 4 y 6), en caso de que el Presidente (como máximo representante del poder civil), se exceda (en su mesianismo) y busque dirigir también el poder religioso (malogrando el legado de los padres fundadores y poniendo el riesgo la ACR y su relación con el resto de religiones tradicionales existentes).
} 
aniversario de la Carta de Derechos de W. PENN 590 (vid. infra cap. 4 y 6). Fue fabricada en Londres y en 1752 es trasladada a Filadelfia, a su Capitolio. Fue usada por el Coronel J. NIXON para dar a conocer la Declaración de Independencia (DIE) y llamar a la revolución. También se utilizó durante el Primer Congreso Continental, y en la década de 1880 estuvo viajando por las ciudades estadounidenses proclamando la libertad.

Figura 63.- La campana de la libertad y su inscripción

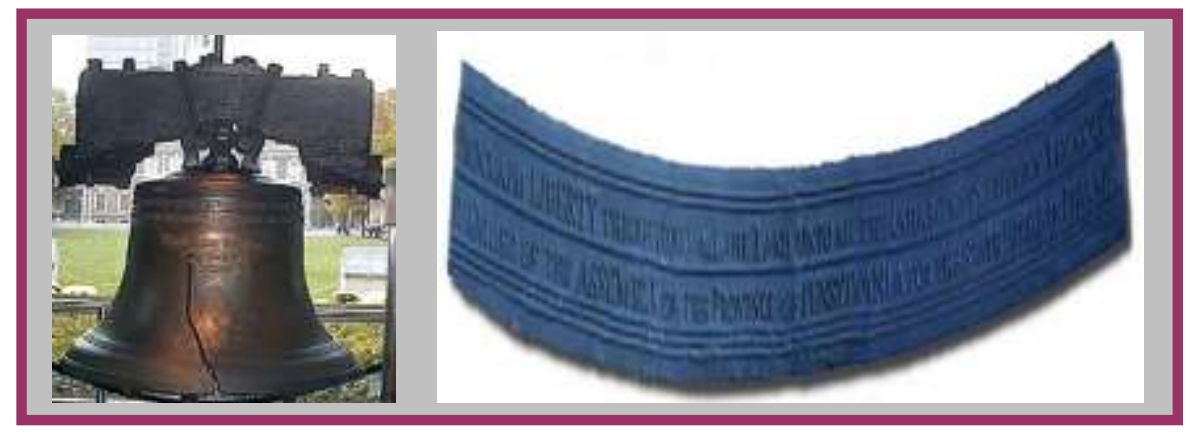

Fuente: elaboración propia (SÁNCHEZ-BAYÓN, 2007 y 16).

La campana, aunque no muy conocida fuera de los EE.UU. -en comparación con otros símbolos- en territorio patrio está considerada como uno de los más grandes emblemas nacionales, ya que ha servido a diversas causas cruciales en la configuración de la identidad estadounidense (v.g. la independencia, el antiesclavismo). A parte de las razones formales por las que la campana se considera una de las insignias más esgrimidas de la ACR (al ser la figura retórica y artística de

\footnotetext{
590 Se trata de la "Charter of Privileges" (1701), considerado como el primer documento oficial que reconoce la libertad religiosa, más allá del cristianismo; se comienza a superar así el concepto de tolerancia iniciado con el Pacto del Mayflower de 1620 y se camina hacia la noción moderna de libertad, que exige la igualdad de condiciones para toda religión no cristiana.
} 
las "cruzadas" mencionadas), se da la circunstancia esencial que aclara aún más la cuestión, puesto que el origen de su función social viene justificada por el lema que tiene grabado: "Proclaim Liberty throughout all the land unto all the inhabitants thereof" (propagad la libertad por toda la tierra y a sus moradores, Levítico 25:10).

La campana, en relación con el apartado último sobre Arte, monumentos y folclore (vid. supra epígr. 10.2.4), dispone de una marcha propia.

\section{d) Himno Bandera de Estrellas}

The Star-Spangled Banner (Bandera de estrellas centelleantes) es el himno nacional de los EE.UU. (que no debe confundirse con The Stars and Stripes Forever: oficialmente, es la marcha nacional desde una Ley federal de 1987). Pese a la dificultad en la entonación de sus notas, goza de una omnipresencia en la vida cotidiana estadounidense, abriendo actos multitudinarios de todo tipo: mítines políticos, acontecimientos deportivos, etc. Su melodía original se atribuye a J.S. SMITH (1773 -basada en una popular canción inglesa Anacreontic song-), y la letra se corresponde con un poema de F. SCOTT KEY, quien la compuso durante un enfrentamiento entre estadounidenses y británicos en la Guerra de 1812-14 (también llamadas Guerras Indias, por los territorios del Oeste). Más tarde, fue usada para sus actos oficiales por la Armada (1889) y por la Adm. WILSON (1916). Tiempo después, en 1931 y bajo la Adm. HOOVER, se declara la canción himno nacional de los EE.UU., mediante Ley federal de 3 de marzo de 1931. 

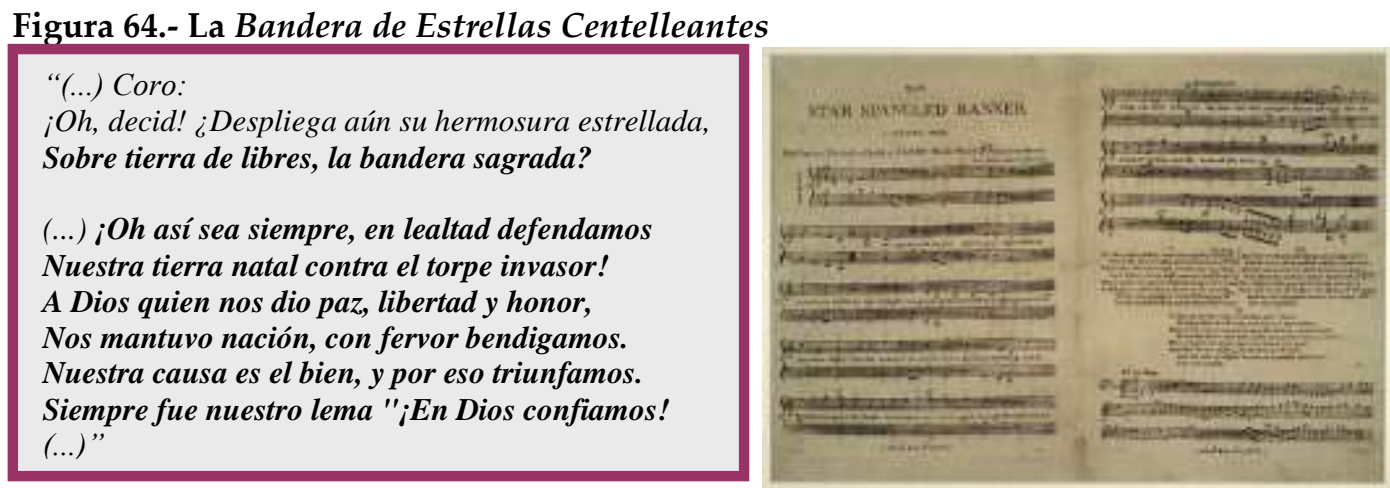

Fuente: elaboración propia (SÁNCHEZ-BAYÓN, 2007 y 16).

Interesa destacar, como objeto de reflexión, los siguientes fragmentos de la letra del himno:

a) Del coro: resulta aconsejable resaltar la conexión entre la expresión "sobre tierra de libres" y las creencias de tierra prometida, pueblo elegido y destino manifiesto (vid. supra Creencias). Tal planteamiento será recuperado y encumbrado después por el gran poeta nacional del s. XIX, Walt WHITMAN. Estrofas más adelante, se alude a la "bandera sagrada", lo que inspirará también ritos como el pledge of allegiance (vid. supra Ritos).

b) De la última estrofa: está cargada la misma de referencias religiosas tradicionales aunque con un sentido matizado por el proceso secularizador (como se viene aclarando, vid. infra cap. 5 y 6). Es de destacar la presencia del lema nacional in god we trust (vid. infra Gran Sello). 


\section{e) Sagradas escrituras de ACR (DIE, CEU y BR).}

Si la tradición sagrada occidental tiene su gran texto sagrado, como es la Biblia, en su caso, la ACR tiene sus propias escrituras: la Declaración de IndependenciaDIE (4 de julio de 1776), la Constitución de los EE.UU.-CEU (17 de septiembre de 1787) y la Declaración de Derechos (o primeras diez enmiendas)-BR (15 de diciembre de 1791). El análisis del contenido de dichos textos sagrados de ACR se pospone al apartado sobre normas e instituciones (vid. supra epígr. 10.2.3), abordándose aquí su concreción física en documentos de gran valor, que reciben peregrinaciones multitudinarias cada año (hay una copia del borrador en la Biblioteca Nacional del Congreso y el resto se exponen en la agencia de Archivos Nacionales-NARA en Washington DC, a abordar en Arte, monumentos y folclore, vid. supra epígr. 10.2.4).

Figura 65.- Sagradas escrituras de ACR
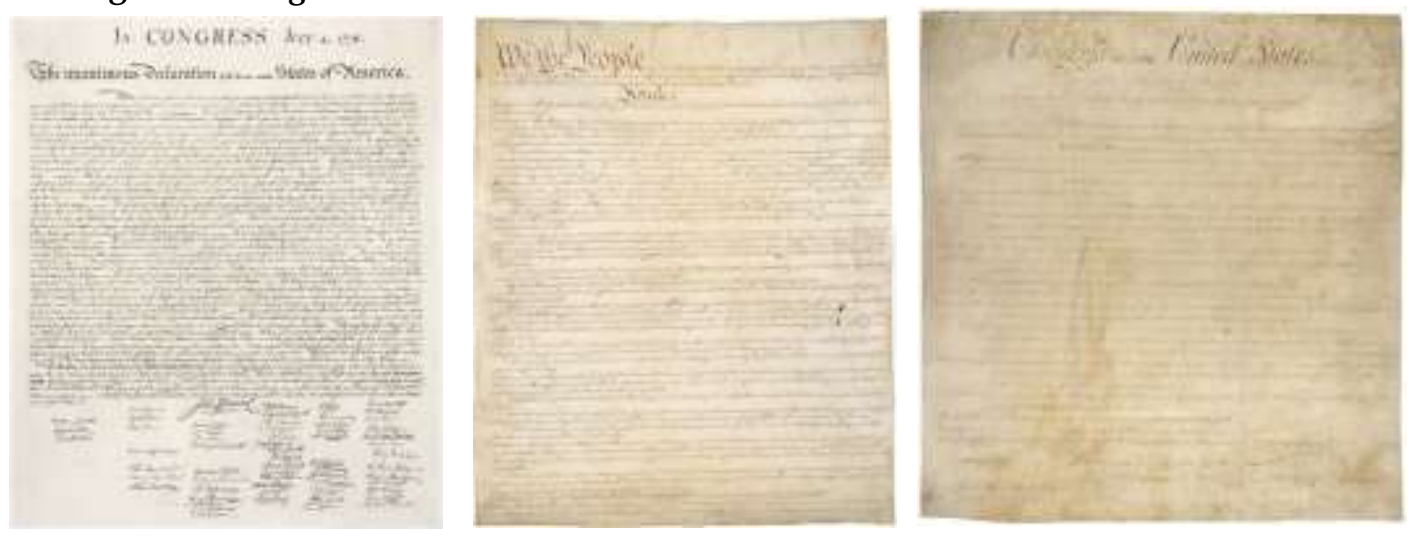

Fuente: elaboración propia (SÁNCHEZ-BAYÓN, 2007 y 16). 


\section{B.- Ritos}

$\mathrm{Al}$ ser una nación joven y de origen diverso en tierra considerada virgen, ya desde el periodo colonial se le da importancia a las celebraciones comunitarias, para consolidar las relaciones sociales e institucionalizarse, configurándose así la requerida identidad integradora (recuérdese lo visto sobre Blue Laws y la obligación jurídica de participar en los servicios confesionales de la colonia, vid. infra Parte de desarrollo general). De tal suerte, surge un gran compendio de efemérides a diversos niveles: de lo local a lo nacional (en el sentido del sistema de plurilealtades, vid. infra figura 6). Como llega a afirmar el gran literato -ya citado- W. WITHMAN, se trata de un ejercicio de canto a celebrar la vida, la comunidad y a uno mismo ("Canto a mi mismo" en Hojas de Hierba, 1855) -no se trata de un planteamiento idolátrico, sino deísta, tal como se reconvirtió WITHMAN desde su formación familiar cuáquera-. Tanto es así (el cambio de la religiosidad tradicional a la de ACR), que va dejándose de celebrar las lejanas honomásticas de los santos, para empezar a festijarse lo cercano, como los nacimientos y cumpleaños: sólo se es auténticamente estadounidense, si estás orgulloso de serlo (ASR) y si pruebas tu éxito y beneficio mediante una celebración popular, vid. supra folclore).

Entre los diversos hábitos de ACR (para configurar la nación estadounidense), se han seleccionado los siguientes elementos: a) saludo a la bandera; b) festividades nacionales; c) celebraciones populares; d) ceremonias inaugurales (Red mass et al.); e) juramentos públicos; f) oraciones de apertura de sesiones, et al. 


\section{a) Saludo a la bandera}

El presente ejemplo, es un rito de complejo calibrado, ya que posee a su vez, tanto los mencionados rasgos simbólicos, como otros aún más sobresalientes, típicos de los elementos administrativos (o institucionales, vid. supra), pues entra en juego la relación Iglesia-Estado (vid. infra cap. 4 y 6). Pese a que se ha ido dando con soluciones para las tensiones pasadas, respecto de supuestos muy parecidos, como la lectura de la Biblia o las oraciones cristianas en los colegios públicos, las referencias religiosas tradicionales en los libros de texto (v.g. teoría del creacionismo) o el destino preferencial del cheque escolar hacia los colegios religiosos (sobre todo católicos), no así, se ha conseguido una solución definitiva apaciguadora de las fricciones cíclicas para el rito de pledge of allegiance o saludo a la bandera de los EE.UU.

Se trata de una composición breve, que suele recitarse en la mayoría de los colegios de los EE.UU., y su función es enseñar al niño a rendir pleitesía a la bandera de su nación -logrando que se identifique desde pequeño con ella-. Su aparición en las escuelas arranca a finales del s. XIX, como tributo a los padres fundadores, y su recital terminó generalizándose a la totalidad del país. Su texto original de 1892, no planteaba problema alguno -salvo para los testigos de Jehová, y alguna otra confesión más reciente, que lo consideraba un ejercicio de idolatría y toma de dios ${ }^{591}$ en vano (al jurar)-. La fórmula recitada decía así: “juro lealtad a mi bandera, y a la República a la cual ampara: una nación indivisible, con libertad y justicia para todos". El

\footnotetext{
${ }^{591}$ Recuérdese lo aclarado ya, sobre el grado de secularización de ACR, que permite hablar de dios en minúsculas y para todos, vid. infra Parte de desarrollo general.
} 
contenido de dicho juramento y su alcance, fue viéndose modificado tras sucesivos retoques (en 1923 y 1924), pero el más destacado y polémico fue el introducido por el Congreso de los EE.UU. en 1954, al incorporar la expresión "ante dios" (tendencia que sigue la Administración EISENHOWER al remodelar el billete de dólar e incorporar "en dios confiamos", vid. infra). Actualmente, no sólo se recita un texto, ciertamente modificado respecto del original, sino que además, cuando se hace se le acompaña de una serie de explicaciones que ayudan a comprender la dimensión de cada verso, tal y como se recoge en la siguiente figura.

Figura 66.- Actual texto del recital "pledge of allegiance" y sus comentarios Saludo / Mi compromiso de lealtad: prometo ser fiel y sincero (promesa de lealtad). A la bandera: el emblema que nos comprende/soporta y representa.

De los Estados Unidos: todos, los cincuenta Estados, cada uno de ellos individualmente, representados en la bandera.

De América: constituida en una UNION de una Nación.

Y a la República: y también mi compromiso de lealtad al Gobierno de la República, a una forma de Gobierno donde el PUEBLO es soberano.

Que comprende: este Gobierno también está representado por la bandera a la que prometo lealtad.

Una Nación ante/bajo Dios: estos cincuenta Estados individuales están unidos como una sola República bajo la divina providencia de Dios, "nuestro más poderoso recurso" (según las palabras del Presidente Eisenhower).

Indivisible; y no puede ser separada (esta parte del compromiso es de la versión original que fue escrita apenas cincuenta años después de la Guerra Civil y demuestra la unidad alcanzada en los años posteriores al periodo de división de nuestra historia).

Con Libertad: el pueblo de esta Nación está llamado a la consecución de la "vida, libertad y felicidad".

Y Justicia: y cada persona tiene derecho a ser tratada justa, adecuadamente y según la ley y los principios apropiados.

Para todos: y estos principios afectan a todo norteamericano sin importar la raza, religión, color, credo, o cualquier otro criterio. Así como la bandera representa a cincuenta Estados que no pueden ser divididos, esta Nación representa a millones de personas que no pueden ser separadas o divididas.

Fuente: elaboración propia (SÁNCHEZ-BAYÓN, 2007 y 16). 
Las suspicacias que ya desde sus orígenes levantaba el recital "pledge of allegiance" hicieron que la cuestión estuviera en los tribunales ${ }^{592}$ en la década de 1930 y 1940 ("Minersville School District vs. Gobitis", 1940; “West Virginia State Board of Education vs. Barnette", 1943), puesto que por aquel entonces, el recitar la composición era una obligación escolar y -como ya se mencionara-, algunas confesiones, como los testigos de Jehová, lo consideraban un acto de idolatría que vulneraba su libertad religiosa ${ }^{593}$-además, se estaba expulsando de los colegios públicos a los niños de dicha confesión por negarse a repetir la composición como los demás estudiantes-. Reiteradamente, desde las primeras interpretaciones jurisprudenciales sobre la cuestión, se falló en contra de los testigos de Jehová, pues se consideraba que el texto era un elemento nacional y no religioso (ACR estaba ya por encima de cualquier religión comunitaria). La cuestión ha recuperado su conflictividad y vigencia, al volver a los tribunales a principios del año 2002, cuando un padre de la ciudad de Sacramento denunció el sentido religioso del recital de pledge of allegiance, haciendo un destacado inciso en el verso "one nation under god" (una nación ante/bajo Dios) y su posible inconstitucionalidad; tras conseguir un fallo favorable, el mismo fue modificado por la Corte de Apelación ${ }^{594}$, que consideró, una vez más, que la composición es un rito nacional carente de significado religioso tradicional.

\footnotetext{
592 Vid. CURTIS, M.K (ed.): The Constitution and the flag (vol. I: The Flag salute cases; vol. II: The flag burning cases), New York: Garland Publishing, 1993.

593 Vid. ALBANESE, C.L.: American Religions and Religion, Belmont: Wadsworth Publishing Co, 1992.

${ }^{594}$ Caso conocido por el nombre breve de "Newdow vs. U.S. Congress", 2002, que ha enfrentado a Michael A. NEWDOW contra: el Congreso de los EE.UU., el Presidente de la Nación, el Estado de California, Elk Grove Unified School District, David W. GORDON (Superintendente EGUSD), Sacramento City United School District, y Jim SWEENEY (Superintendente SCUSD); se presentó la apelación el 14 de marzo de 2002 y la decisión fue pública el 26 de junio de ese mismo año, donde el Magistrado O'SCANNLAIN no consideró inconstitucional el "pledge of allegiance", y finalmente, el Magistrado FERNANDEZ denegó la revisión de la decisión.
} 
Antes de proceder con el próximo rito, se llama la atención sobre los cambios en la ejecución del saludo, pues hasta la II Guerra Mundial, se realizaba de manera marcial (imitando el saludo legionario). Para distanciarse del Nacionalsocialismo alemán y del Fascismo italiano, el saludo a la bandera pasó a realizarse con la mano puesta en el corazón (tal como también se canta el himno nacional).

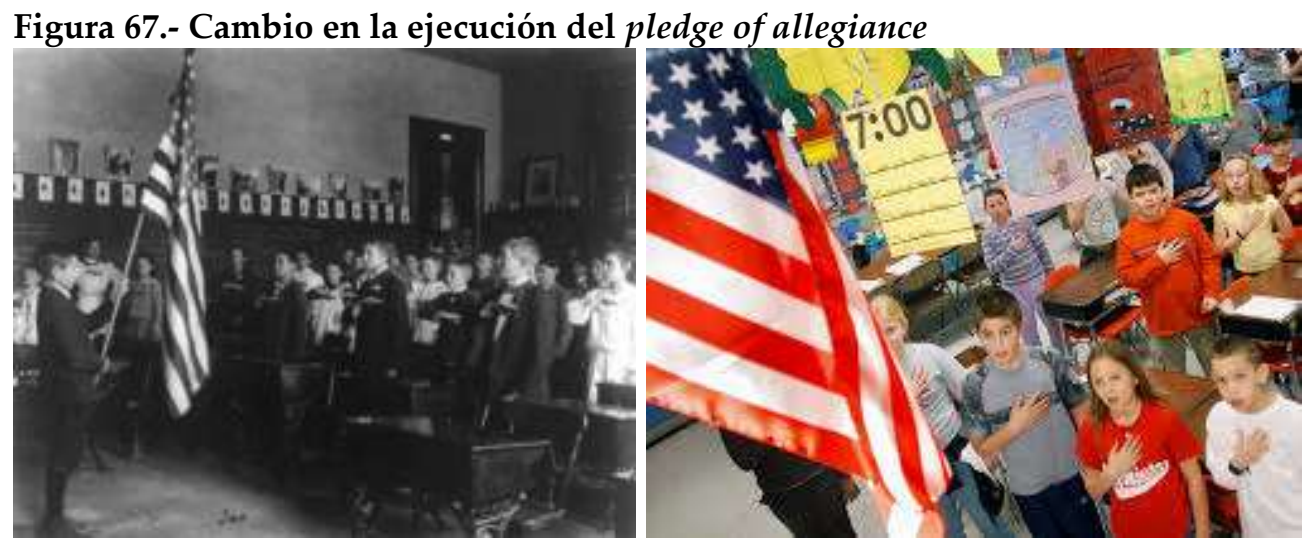

Fuente: elaboración propia (SÁNCHEZ-BAYÓN, 2007 y 16).

\section{b) Festividades nacionales}

En los EE.UU., a resultas de su Americaness y su incorporación a ACR, se ha generado un legado que tiene hasta una dimensión temporal, marcando celebraciones, conmemoraciones, festividades, etc. Fruto de la combinación de la tradicción occidental sagrada y profana, adaptada al marco estadounidense, convive así un tiempo social con celebraciones de las religiones tradicionales más las sobrevenidas integradoras de religión civil. En este punto se van a tratar algunas muestras de sus celebraciones oficiales federales (las más populares y tipificadas por la regulación, v.g. Monday Holiday Act of 1968; Uniform Federal Holidays Act of 1971). 
Se reparte su exposición en dos bloques ${ }^{595}$ : a) de consenso (correspondiente a las más consolidadas y en su mayoría con días fijos en el calendario); y b) polémicas (aquellas más recientes, con días móviles en el calendario y salpicadas por los velos de confusión). Se reserva para el siguiente punto aquellas conmemoraciones más oficiosas, pues aunque están presentes en todo el país, sus expresiones dependen de cada manifestación local (viviéndose con mayor o menor intensidad, según el éxito y beneficio alcanzado, etc.).

a) Fiestas oficiales federales de consenso: comienza su reconocimiento con una Ley de 1870, que habilita al Congreso para fijar las fiestas nacionales (incluso, para crearlas). En 1875, otra ley del Congreso fija como vacaciones obligatorias para los funcionarios el día de año nuevo, el día de la independencia, Acción de Gracias y Navidad. Posteriormente, han ido surgiendo nuevas fiestas, entre las que cabe destacar (por su mayor consenso):

- New Year's day (año nuevo, 1 de enero): comienza con la cuenta regresiva de tránsito entre el 31 de diciembre y el 1 de enero, seguido de saludos afectuosos y un brindis, pidiendo prosperidad para el año recién inaugurado. Según la tradición occidental profana, era la fiesta del dios Jano (divinidad de los inicios y las puertas: entradas y salidas -de ahí su representación con dos caras-), en la que se regalaban ramas de árbol y se deseaba el mejor comienzo de año, seguido de prácticas carnavalescas. En el s. I aC, se pasó la fiesta del tránsito de primavera a la fecha actual y por ello en el mundo anglosajón el mes de enero se llama January o tiempo de Jano

\footnotetext{
${ }^{595}$ Existe una fiesta federal (que no encaja en ninguno de los bloques): es Inauguration day o día de comienzo de mandato, que se celebra sólo cada cuatro años, aproximadamente. Tiene luegar tras las elecciones presidenciales, cuando se inaugura nueva Administración, celebrándose el 20 de enero, salvo que caiga en domingo, pasándose entonces al día 21.
} 
(de comienzos). En el s. VI dC, la Iglesia logró refrenar los excesos y reconvertir la fiesta en una práctica familiar, de ahí que según la tradición occidental sagrada, en año nuevo se celebra la circuncisión del niño Jesús (a la semana de su nacimiento, como parte de la alianza de Dios con Abrahán -Gn. 16:10, Lc. 2:21-, vid. infra cap. 5 y 6). En el mundo protestante, además, trasladado a ACR, esta festividad supone el fin del periodo vacacional de Navidad.

- Washington's birthday (día del cumpleaños de WASHINGTON, o coloquialmente dia del Presidente -por extenderse a otros Presidentes-, tercer lunes de febrero): es una de las fiestas de la patrística estadounidense (vid. infra cap. 9), elegido ese día por ser el aniversario del primer Presidente de la Unión, G. WASHINGTON (quien naciera el 22 de febrero de 1722). También se quiso conmemorar al Presidente que fue asesinado por defender la Unión, A. LINCOLN (quien naciera el 12 de febrero de 1809), por lo que la Ley de 1971 fijó que esta festividad tuviera lugar entre sendos aniversarios, haciéndolo coincidir con el tercer lunes de febrero (de modo que resulte un fin de semana largo).

- Memorial day (día de recuerdo a los caídos, el último lunes de mayo): tradicionalmente, se celebraba el 30 de mayo, en honor de los compatriotas falledidos durante la Guerra civil, pero desde la Ley de 1971, no sólo se cambió la fecha, sino que se le dio un sentido más extenso, en honor a todos los que han dado su vida sirviendo en el Ejercito de los EE.UU. Igualmente, esta conmemoriación marcaba el inicio de la temporada de verano (llamándose también Decoration day), cerrándola el día del trabajo (vid. supra Labor day). Lo habitual este día es ir con la familia a los cementarios 
nacionales a presentar respeto a los difuntos.

- Independence day (día de la independencia, 4 de julio): durante el II Congreso Continental, en Filadelfía, el 2 de julio se aprobó la decisión de independizarse de Gran Bretaña, pero la adopción de la declaración oficial (vid. DIE) y su lectura pública no fue hasta el 4 julio. Su redacción se realizó en tiempo record y corrió a cargo del Comité de los cinco (JEFFERSON, ADAMS, FRANKLIN, SHERMAN, LIVINGSTON, vid. infra cap. 9), dándose a conocer el día 4 por la tarde. En su Preámbulo, se aclara su legitimidad, que está expresamente en el Derecho Natural y la Ley divina (además de usarse la teoría del tiranicidio de la Escuela de Salamanca, vid. supra).

- Veterans day (día del veterano, 11 de noviembre): originalmente, se conmemoraba el fin de la I Guerra Mundial (llamándose por entoces Armistice Day), pues se supone que a las 11h del día 11 del mes 11 de 1918 cesaron las hostilidades, firmándose el armisticio que puso final al conflicto (aunque luego Francia impulsara el Tratado de Versalles, imponiéndole una condiciones abusivas y de perdedora a Alemania -fijándose así el caldo del cultivo de la II Guerra Mundial-). En 1954 se cambió el nombre de la fiesta para que alcanzara a rendir honores a los veteranos de la II Guerra Mundial y de Corea. Hoy en día se entiende como el día de homenaje para todos los soldados que han luchado por EE.UU. (como ya se ha dicho, se trata de la otra cara de Memorial day: en este caso es la fiesta para lo supervivientes y el fin de la temporada de verano e inauguración del otoño, desde la perspectiva de ACR). 
- Thanksgiving (Acción de gracias, el cuarto jueves de noviembre -entre el 22 y el 28-): su origen está en la Reforma protestante inglesa, pues Enrique VIII, pretendió acabar con las festividades de la Iglesia e instaurar días de acción de gracia a la Providencia. De tal modo llegarón a América estas celebraciones, concretándose en la conmemoración del día del desembarco y constitución de la nueva colonia correspondiente (tanto católicos como protestantes actuaban igual, buscando un lugar apacible y con un árbol para celebrar una misa o servicio en agradecimiento a dios). Ahora bien, la actual celebración y la fecha elegida se atribuye al episodio -ya mencionado- de CARVER (líder religioso y primer Gobernador de los peregrinos). A raíz de su llegada a New Plymouth, y con la firma de una alianza con la tribu vecina Wampanoag, eso les salvó de los duros inviernos, pues pudieron compartir alimentos con aquellos, dándose así inicio a la versión más autóctona de la fiesta (de ahí que en las representaciones teatrales en los colegios estadounidenses los niños de disfracen de peregrinos e indios). Se trata de una de las celebraciones más familiares (junto con Navidad), produciéndose una gran movilidad por todo el país -algunas personas, por la tradición de comer pavo esa noche, también llaman a la festividad el día del pavo-.

- Christmas (Navidad, 25 de diciembre): se conmemora el nacimiento del niño dios (es la contracción de Christ o mesías y mass o misa, o sea, eucaristía por el nacimiento del mesías). Algunas familias se entregan regalos en la noche del 24, y la gran mayoría en la mañana del 25. Es típico de estas fechas las reuniones familiares, cantar villancicos, el árbol de Navidad, etc. Actualmente, está siendo muy atacada desde los Estudios culturales sobrevenidos, y el Partido Demócrata está a favor de sustituirla por otras 
fiestas alternativas (según comunidades)-aunque no se ajustan exactamente en fechas, por adelantarse o retrasarse- como Hanukkah (judíos), Posadas (latinoamericanos), Kwanzaa (afroamericanos), etc.

b) Fiestas oficiales federales (polémicas): no sólo porque en su mayoría son días móviles en el calendario, sino porque resultan de las más recientes (en su reconocimiento), y se han visto distorsionadas por velos de confusión (de los Estudios culturales, vid. infra cap. 2 y 8 ).

- Birthday of Martin Luther King Jr. (día de Martín Lutero King, tercer lunes de enero -entre el día 15 y 21-): se conmemora el nacimiento de uno de los personajes de la sociedad civil más importante en el s. XX, quien fuera asesinado (1968), por su defensa pacífica de los derechos de los afroamericanos. Fue doctor, reverendo y activista del movimiento de derechos civiles, además de asesor del Presidente KENNEDY (quien también fuera asesinado, en 1963, vid. infra cap. 9). Su festividad fue fijada por la Adm. REAGAN en 1983, aunque no se generalizó hasta tres años después. Inicialmente, se celebraba esta fiesta con servicios religioso y realizándose acciones comunitarias (favorecedoras de la integración social). La polémica actual viene dada por la desnaturalización de la fiesta, pues aún el Rev. King era el líder de nonviolence movement, es aprovechada por radicales para acometer protestas raciales (basándose en velos extendidos por algunos de los Estudios culturales afroamericanos).

- Mother's day (domingo de mayo, entre el día 8 y el 14): tradicionalmente se celebraba en familia, yendo al servicio religioso y posteriormente a un 
restaurante. Recientemente, desde Estudios feministas y de género, se pretende asimilar con la celebración del 8 de marzo de la mujer trabajadora (establecido en los últimos tiempos de la URSS y, actualmente, se conmemora como cita para manifestaciones feministas, de género y hembristas, donde se reivindica -paradójicamente- el derecho al aborto).

- Día de la bandera (14 de junio): la bandera fue adoptada el 14 de junio de 1777 (durante la Guerra de independencia). El Ejército celebraba su festividad anual, extendiéndose al conjunto de la ciudadanía y oficializándose mediante decreto de WILSON en 1916 (durante la I Guerra Mundial). En 1937, el Estado de Pennsylvania declaró este día como festivo y, finalmente, en 1946 el Congreso aprobó la National Flag Day Act y el Presidente lo confirmó como día festivo, aunque no de manera definitiva, por lo que depende del diseño del calendario oficial cada año (aunque sí hay Estados que lo tienen tipificado de manera permanente).

- Labor day (día del trabajo, primer lunes de septiembre -entre el día 1 y 7-): se celebra el trabajo, como uno de los valores de ACR (vid. supra), con un largo fin de semana de descanso, realizándose desfiles y barbacoas familiares (para muchos supone el fin del verano) -además de ser un día de rebajas, equiparable a Black Friday, con el que se inauguran las compras de Navidad, vid. supra-. La historia oficial (tras la Adm. CLEVELAND), fija como impulsora de esta festividad a la organización masónica (aunque respaldada por la Iglesia católica local) de Noble and Holy Order of the Knights of Labor (la Noble y Sagrada Orden de los Caballeros del trabajo). Surgió en Filadelfia (1869), expandiéndose por el resto de grandes urbes del Este (llegando a tener cerca de 800.000 integrantes -a diferencia de los sindicatos de la época, 
desde 1878, en sus asambleas locales se admitieron mujeres y afroamericanos; eso sí, los asiático siguieron excluidos-). Su mayor desarrollo lo tuvo en la ciudad de New York, donde se celebro la gran manifestación de Union Square (1882), cuyo resultado fue la aprobación de la primera regulación laboral generalizada (v.g. Contract Labor Act of 1885), con medidas como el establecimiento de la jornada laboral de ocho horas, la prohibición del trabajo infantil, la promoción del trabajo de mujeres y afroamericanos, etc. El primer Estado en reconocer esta fiesta oficialmente fue Oregón (1887), pasando a ser una celebración nacional en 1894 (aunque a día de hoy, sólo se celebra en treinta de los cincuenta Estados de la Unión: el resto celebran fiestas alternativas locales). La polémica, suscitada por los velos de los Estudios culturales sobrevenidos (sobre todo los de clase, herederos de la Escuela de Birminghan, vid. infra cap. 8), tiene que ver con el revisionismo histórico y el intento de asimilar el día del trabajo a las celebraciones en otras partes del mundo y celebrarlo el 1 de mayo (así se celebra en Europa, por el influjo socialista: curiosamente, se eligió esa fecha en conmemoración de las protestas en Chicago en 1886, donde fueron represaliados los líderes sindicalistas y del partido socialista en EE.UU., pasando a denominarles los "mártires de Chicago" -en realidad, el 4 de mayo de 1886, explotó una bomba en la plaza de Haymarket, dando paso a días de revueltas callejeras-).

- Columbus day (día de Colón, 12 de octubre): de todas las fiestas federales, es hoy la más polémica y prácticamente está desapareciendo. Se fijó en , en honor del descubridor de América (el 12 de octubre de 1492, vid. infra cap. 1 y 2). No obstante, como los Estudios culturales sobrevenidos defienden 
una diversidad de descubrientos (por cada una de las comunidades) o, incluso, la negación de tal acontecimiento, al tiempo que lo tildan de racista (por basarse en el destino manifiesto, primero de la Corona español, y luego de los propios estadounidense, introduciéndose así superioridad de los occidentales sobre otros pueblos); en su lugar, vienen promoviéndose celebraciones de fiestas alternativas, sobre todo en Estados como Hawaii, Alaska, Oregón y South Dakota (donde hay mayor población indígena, con cuotas de representación en los gobiernos locales), v.g. Native American Day (oficialmente ya, en South Dakota), La Raza (es la denominación popular dada por organizaciones latinoamericanas, con desfiles en ciudades como New York, Chicago, etc.).

Actualmente (sobre todo, desde el Partido Demócrata), se está promoviendo la incorporación de nuevas fiestas oficiales (algunas ya están reconocidas en determinados Estados de la Unión, otras vendrían a completar -incluso a suplir- las ya existentes), tales como: Susan B. Anthony day (famosa sufragista, promovida por las feministas, que se celebraría como alternativa al cumpleaños de WASHINGTON); Cesar Chavez day -ya pasado por Americaness, sin los acentos correspondientes- (el 31 de marzo, en honor al líder síndical y de derechos civiles de hispanos -iniciativa apoyada por el Presidente OBAMA-); Malcom X day (el 19 de mayo o el tercer domingo de mayo, en honor al activista de los derechos civiles de afroamericanos -el problema es que tuvo un pasado delictivo, además de haber sido parte de Hermanos musulmanes-); Native American Awareness Week (del 15 al 21 de septiembre, como muestra del orgullo indio y en compensación por los males ocasionados; el día festivo ya existe en algunos Estados, pero sería la primera vez 
que se celebrara toda una semana de vacaciones para todo el país -las diversas iniciativas presentadas al Congreso no han prosperado hasta ahora por considerarse de difícil integración en su ACR-), etc.

\section{c) Celebraciones populares}

Son la muestra de transformación de celebraciones tradicionales (hierocráticas) en religiosidad popular (con un cambio de relaciones entre lo sagrado y lo profano, v.g. algunas transfieren la liturgia de los tempos a los centros comerciales, y las procesiones a las manifestaciones y desfiles):

- Entre las fiestas claramente de origen religioso tradicional, pasadas por el Americaness, cabe destacar San Valentín (14 de febrero, con múltiples actividades en los colegios, regalándose tarjetas, bombones y flores); San Patricio (17 de marzo, sobre todo en grandes ciudades como New York, Boston, etc., donde se celebran desfiles y se tiñen los ríos locales de verde); Pascua (la tradicional Semana Santa se sigue celebrando ${ }^{596}$, sólo que reducida por el protestantismo al Domingo de resurrección, más la inclusión de la tradición nórdica -incluidos centroeuropeos, vid. infra Parte inicial- del conejo de pascua y la búsqueda de huevos -los conejos representaban la fertilidad y los huevos la prosperidad-; últimamente, dicha festividad está siendo superada

\footnotetext{
${ }^{596}$ Hay viacrucis y procesiones en grandes diócesis (v.g. Boston, Chicago, Los Ángeles). Es de destacar las tradiciones de los Estados fronterizos (v.g. Texas, New Mexico), y el caso de Florida, donde las celebraciones tienen un especial significado local, por haber sido descubierta el Domingo de Ramos en 1512.
} 
por otras celebraciones como Spring break y Mardi Gras -que sería el equivalente al entierro de la sardina en New Orleans, con el fin del carnaval, dando paso al miércoles de ceniza de cuaresma), etc.

- Fiestas sincréticas, del tipo Halloween (se celebra el 31 de octubre; es fruto de la fusión de la tradición de fiesta de todos los santos y difuntos católica, con la indígena del día de muertos, añadiéndose después la pagana de los druidas; incluso, recientemente, desde Estudios culturales sobrevenidos, en especial los feminista y de género, la llaman también noche de brujas -pese al pasado polémico colonial, vid. infra Parte de desarrollo general; ha pasado de ser una fiesta familiar, en la que los niños se disfrazaban e iban pidiendo dulces por las casas del vecindario -bajo la consigna truco/susto o trato/caramelos-, a una fiesta nocturna adolescente con alcohol -pese a estar prohibido su consumo hasta los veintiún años, y en ningún caso admisible en público-).

Figura 68.- Símbolo de Halloween

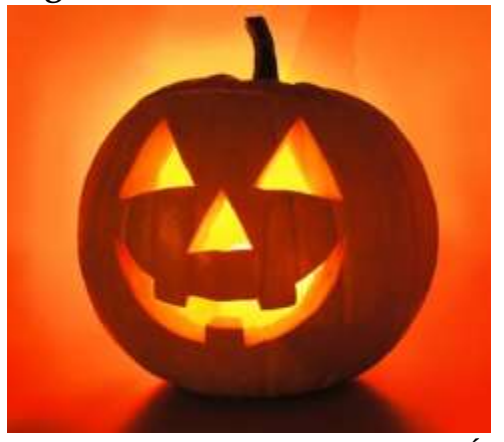

Fuente: elaboración propia (SÁNCHEZ-BAYÓN, 2007 y 16).

- Otras fiestas propiamente de religiosidad popular son Homecoming (con celebraciones diversas, según comunidades e instituciones, sobre todo en 
institutos y universidades); Black Friday (con el que se inician las rebajas, justo después de la cena de Acción de gracias, vid. infra; se llama así por razones contables anglosajonas: se cuadraban balances semanalmente, por lo que si el viernes se estaba en números rojos, se empezaban a realizar descuentos hasta volver a cuadrar los números y que volvieran a estar en números negros); temporada de deportes (el curso estadounidense se reparte entre otoño de fútbol americano, invierno de baloncesto y primavera de béisbol; en todas estas actividades se involucran las familias, pues no sólo participan los jugadores, también los animadores, la banda, la mascota, los ex alumnos, etc., y hay grandes celebraciones si se gana la competición de la semana), et al.

\section{d) Ceremonias inaugurales (Red Mass et al)}

La misa roja, originalmente, consistía en la fiesta de inauguración del curso académico y judicial, celebrada por jueces, profesores y alumnos de Derecho. Procedía del tardo-medievo, y se llamaba así por el color de las lenguas de fuego de Pentecostés: se pretendía invocar al Espíritu Santo, para que iluminara la comprensión a lo largo de cada periodo de actividad (tanto el curso académico, como el año judicial). Dicha tradición se ha mantenido (incluso el color rojo, como representación de los Estudios de Derecho). En los EE.UU. se instauró la Red Mass en círculos académicos en 1877 (en University of Detroit Mercy), oficiándose en la Iglesia de San Pedro y San Pablo (extiéndose luego a Boston College en la Iglesia de la Inmaculada Concepción, seguido del resto de universidades católicas de la costa 
Este y más tarde también a buena parte del Ivy League); y en círculos judiciales hacia 1928 (en la jurisdicción de Foley Square Courthouse -donde están sitas la Corte de Apelación del $2^{\underline{0}}$ Circuito Federal, la Corte de Justicia del Estado de New York, la Corte Internacional de Comercio, etc.-, oficiándose la ceremonia en próxima Iglesia de San Andrés. En la actualidad, destaca el servicio ecuménico ofrecido en la Catedral de San Mateo Apostol (Washigton DC), al que acuden normalmente el Presidente de los EE.UU., su Gabinete, el Fiscal General, el Presidente y demás Magistrados del TSEU, etc.

$\mathrm{Al}$ igual que se celebra la misa roja, también se dan otras variantes posteriores, como la Blue Mass (para los cuerpos y fuerzas de seguridad, oficiándose en la Catedral de Washington todo los años desde 1934, el 29 de septiembre: día del Arcángel Miguel, patrón de los policías); White Mass (impulsada por la Asociación católica de médicos desde la década de 1930, celebrándose en las capillas hospitalarias); Rose Mass (desde la década de 1990, para dentistas, enfermeras y otras profesiones bio-sanitarias); Gold Mass (para los científicos, celebrándose en latín, y alcanzando tal relevancia, que desde 2016, se incluye entre las actividades del curso académico en instituciones tan prestigiosas como el MIT).

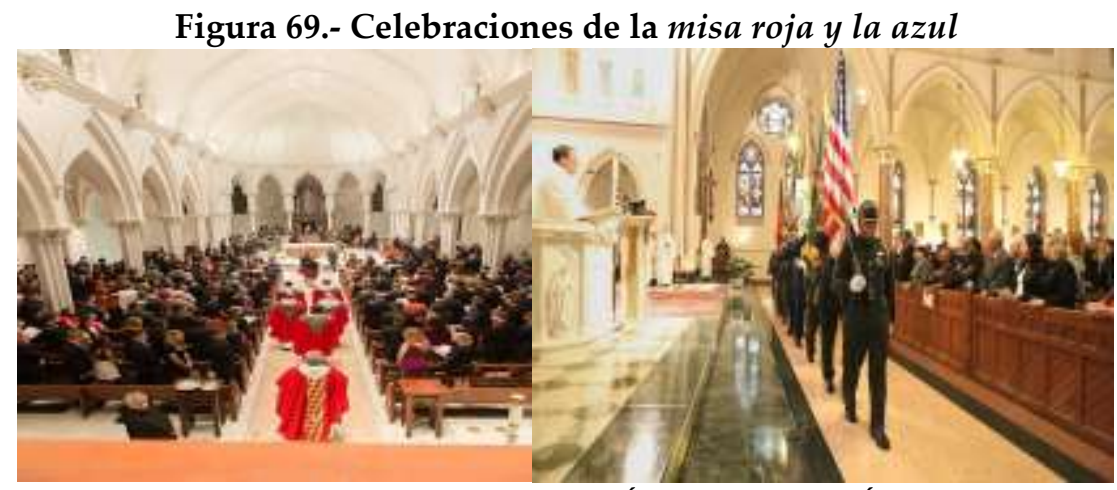

Fuente: elaboración propia (SÁNCHEZ-BAYÓN, 2007 y 16). 


\section{e) Juramentos públicos}

Pese a que el art. 6 de la Constitución de los EE.UU. (CEU), prohíbe la exigencia de declaración de creencias religiosas, así como de los juramentos, en cambio, por tradición, voluntariamente la mayor parte de las tomas de posesión de altos funcionarios y cargos de la Administración, incluido el Presidente de los EE.UU., se realiza bajo dicha fórmula (además de ayudarse de una Biblia y/o una copia de CEU -una excepción fue el Presidente JOHNSON, quien uso un catecismo católico, por ser el único texto sagrado a mano, tras el asesinato del Presidente KENNEDY, que era católico, vid. infra cap. 9).

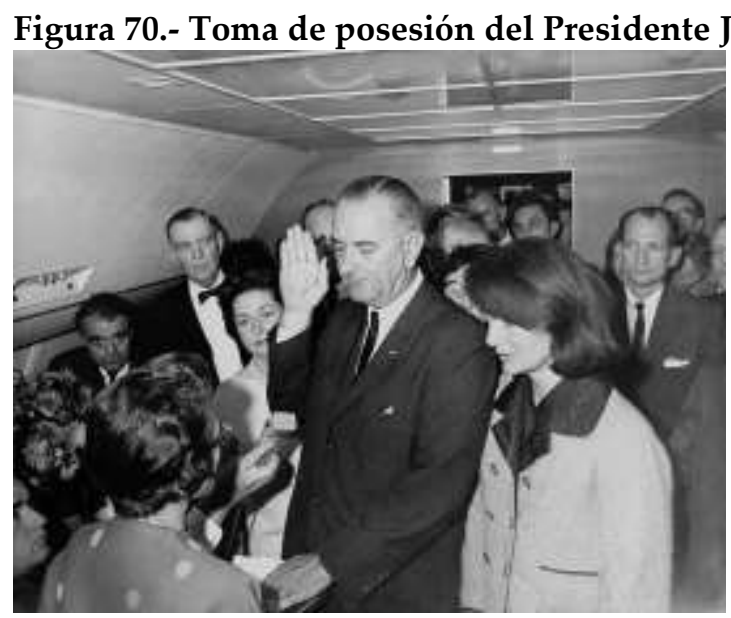

Fuente: elaboración propia (SÁNCHEZ-BAYÓN, 2007 y 16).

La Ley del Poder Judicial o Judiciary Act of 1789 tipificó como fórmula para la toma de posesión de los jueces: "I do solemnly swear (or affirm), that I will administer justice without respect to persons, and do equal right to the poor and to 
the rich, and that I will faithfully and impartially discharge and perform all the duties incumbent on me, according to the best of my abilities and understanding, agreeably to the Constitution, and laws of the United States. [So help me God.]". De ahí que luego, en los juzgados se considere normal el tomar juramento a los testigos en los juicios, con una fórmula similar (usándose también para ello una Biblia y/o una CEU) -y el inclumplimiento supone un grave delito de desacato y obstrucción a la justicia-.

Uno de los últimos juramentos públicos en revisarse y tipificarse por ley (Public Law 89-554, Sept. 6, 1966, en Tit. 5 U.S. Code § 3331 - Oath of office), ha sido el de Congresistas y Senadores, quedando como sigue: “I, (name), do solemnly swear (or affirm) that I will support and defend the Constitution of the United States against all enemies, foreign and domestic; that I will bear true faith and allegiance to the same; that I take this obligation freely, without any mental reservation or purpose of evasion; and that I will well and faithfully discharge the duties of the office on which I am about to enter. So help me God".

\section{f) Oraciones de apertura de sesiones}

Hasta las guerras culturales (1960-80), resultaba frecuente la inauguración de sesiones públicas con una oración de apertura, o una invocación de la gracia divina para guiar en la labor de la sesión (tanto en el Congreso, las Cámaras estatales, los ayuntamientos, etc.). Aún hay Cámaras estatales que lo siguen realizando (aún con las restricciones de la Sentencia del Tribunal Supremo de 1983: Marsh v. Chambers, 
463 US 783, sobre los capellanes de la Cámara de Nebrasca o Nebraska Legislature), por razón de Protocolo, pese al riesgo de demandas por organizaciones contrarias y autodeclaradas defensoras de los derechos civiles (v.g. ACLU). Actualmente, el Senado de EE.UU., no sólo mantiene la oración de apertura, sino que dispone de un capellán que la realiza (normalmente, suelen ser capellanes del ejercito, sobre todo, de la marina). También el Congreso dispone de su capellán. El rango de dichos capellanes es de nivel IV entre las autoridades del Estado.

Como curiosidad (de la integración de $\mathrm{ACR}$ ), cabe señalar la figura del capellán invitado o Guess Chaplain: en 1948 fue la primera mujer encargada de la oración inaugural (W. ROWLAND SMITH); en 1992 fue el primer musulmán (W. DEEN MOHAMMED); en 2007 fue el primer hindú (R. ZED); en 2014 fue el primer budista (T. GYATSO), etc.

Figura 71.- Oración de apertura de sesión del Senado de EE.UU. (1939).

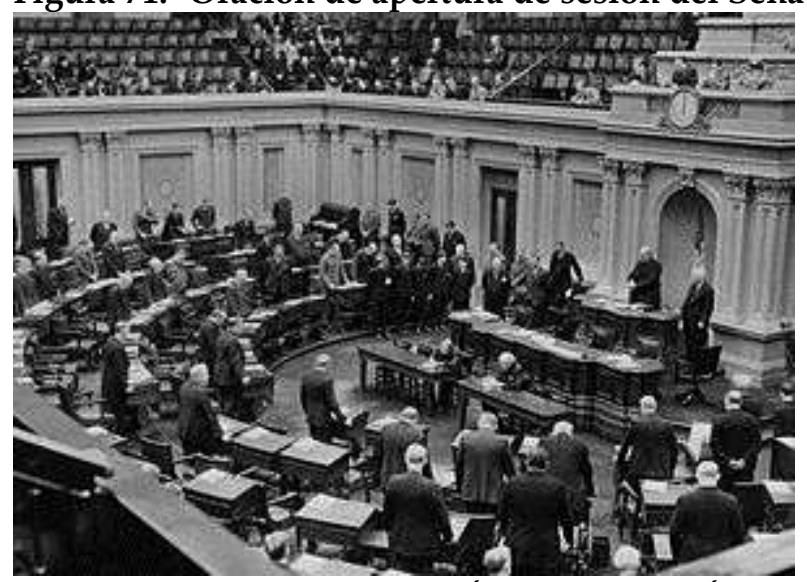

Fuente: elaboración propia (SÁNCHEZ-BAYÓN, 2007 y 16). 


\subsection{2.- CREENCIAS Y VALORES}

Para lograr el tránsito efectivo a la Modernidad fue necesario aprender a discernir y discriminar entre ideas y creencias, individuo y comunidad, religión y política, Iglesia y Estado, etc., sabiendo cuál era cual, su sentido y alcance, así como su relación con los otros constructos (favoreciéndose así el surgimiento de una sociedad abierta de Nuevo Régimen). En lo tocante a la relación entre ideas y creencias, baste señalar que las primeras (las ideas), son tenidas por nosotros (de ahí que evolucionen con nuestro pensamiento y puedan intercambiarse sin problemas), mientras que las segundas (las creencias), nos sostienen a nosotros (no las elaboramos, sino que las recibimos y aceptamos, sin cuestionamiento, pues de otro modo se provocaría una crisis que vulneraría la personalidad). Entre las creencias, tradicionalmente se ha distinguido también, desde la Modernidad, entre aquellas religiosas (creencias stricto sensu) y las políticas (convicciones) -el problema está con las ideologías, pues muchas de ellas son falsas religiones políticas, implantadas como falsa conciencia, mediante un sistema de creencias total sobre cómo vivir, qué pensar, decir y hacer, exigiendo la renuncia de la individualidad en pro de un bien común no disponible-. En cuanto a los valores, es la manera de referirse a las virtudes clásicas tras la Reforma protestante, pues los criterios de toma de decisión van cambiando (en la Antigüedad eran el bien y la belleza, en el Medievo las virtudes teologales y cardinales, y en la Modernidad el éxito y beneficio). Desde la Reforma protestante, el centro de la vida social deja de ser dios y el hombre, para serlo el trabajo y el dinero, que requieren de cuantificación, de ahí la denominación como valores (siendo las creencias para la acción, que pueden ser medidas en sus resultados -así entendido, al menos, por el ACR-). Por tanto, este apartado, se va a 
dedicar a señalar aquellas creencias y valores de origen religioso tradicional, que tras pasar por el Americaness, han pasado a formar parte del ACR, marcando la idiosincrasia estadounidense, con su visión, misión y valores propios. Entre los elementos a estudiar, se llama la atención sobre: a) tierra prometida y pueblo elegido; b) destino manifiesto y mesianismo; c) valores democristianos; d) American creed (el credo estadounidense).

\section{a) Tierra prometida y pueblo elegido:}

Bajo el presente rótulo se da cabida a tres propuestas clave a analizar (las dos primeras de tipo estructural y la última más dinamizadora y voluntarista): a) los referentes literarios, tomados en su mayoría de la Biblia; b) los referentes biográficos (y hagiográficos) de la patrística estadounidense (incluidos grandes estadistas posteriores), de sus experiencias personales; c) los referentes jurisprudenciales, de los magistrados del TSEU, quienes actualizan periódicamente el significado y alcance de la materia.

a) Referentes literarios: en el periodo fundacional de los EE.UU., los ministros de culto protestantes escudriñaron las Sagradas Escrituras para encontrar y explicar a sus feligreses el paralelismo entre su situación y el éxodo bíblico en busca de la Tierra prometida -hasta el punto de bautizar con nombres bíblicos las colonias de entonces, vid. infra-. Algunas de las citas elegidas para tales explicaciones, además de las más célebres y literales, como el compromiso de Dios con ABRAHAM (Libro del Génesis) y con MOISÉS (Libro del Éxodo), también 
tuvieron su repercusión aquellas otras como Ap 21:1; Is 65:17, y 66:22; Mt 3:2; Mc $1: 14 ;$ Lc 10:8; etc.

Los conceptos de Pueblo elegido en Tierra prometida, así como Nueva Jerusalén o Nuevo Israel, fueron manejados tanto por partidarios como detractores. En el primer caso, resultaron relevantes los sermones de reverendos tan ilustres como J. WINTHROP (líder protestante de la colonia de la Bahía de Massachusetts), destacando su celebérrimo -y ya citado- sermón "A Modell of Christian Charity" $(1630)^{597}$. Frente a tales propuestas, y manejando los mismos conceptos desde una perspectiva más aperturista (no exclusiva para protestantes), fue fundamental la actuación del igualmente reverendo y señalado estadista, R. WILLIAMS (fundador de la colonia de Rhode Island) y la publicación de su obra "The bloody tenant, of persecution, for cause of conscience, discussed, in a conference between truth and Peace" (1644).

b) Referentes biográficos: muchos son los referentes de padres fundadores, lato sensu (incluidos grandes estadistas posteriores), quienes en su mayoría han sido cristianos, ejerciendo cierto activismo político orientado por sus valores (como se estudia más adelante). Entre los mismos, destacan: A. HUTCHINSON (15911643) y T. HOOKER (1586-1647), congregacionalistas ambos; LORD BALTIMORE (1605-75) y J. CARROLL (1735-1815), católicos; R. WILLIAMS (1603-82), J. CLARKE (1609-76), I. BACKUS (1724-1806), y J. LELAND (17541811), bautistas; S. DAVIS (1724-61) y J. WITHERSPOON (1723-94), presbiterianos; B. FRANKLIN (1706-90), G. MANSON (1725-92), P. HENRY

597 Dicho sermón gira entorno a la idea principal de América como "Ciudad sobre la colina" (Mateo 5:14), o sea, la oportunidad de ensayar un paraíso terrenal o Nueva Sión. 
(1736-99), S. LIVERMORE (1732-1803) y C. PINCKNEY (1757-1824), episcopalianos; et al.

Pese a la afirmación anterior, de vinculación abierta y conocida de los padres fundadores con alguna confesión cristiana (vid. infra cap. 9), sin embargo, tal como ya se anunciara, la ACR y su sistema de plurilealtades ha facilitado que algunos fueran además deístas, masones, etc. -de ahí que se hable del rasgo posjudeocristiano-.

\section{Figura 72.- Deísmo de los padres fundadores ${ }^{598}$}

Germen de la religión civil estadounidense, pues hizo posible la comunión de variadas tendencias elitistas ilustradas (v.g. racio-naturalistas y pseudo-masónicas), y promover para su fin la secularización de elementos propios de la religiosidad tradicional popular (básicamente judeo-cristiana o también denominada bíblica), logrando con ello que las religiones mayoritarias en el periodo constitutivo de los EE.UU., se sintieran -por igualidentificadas con los textos nacionales (Declaración de Independencia, Constitución de los EE.UU., etc.), logrando el necesario fervor ciudadano.

Fuente: elaboración propia (SÁNCHEZ-BAYÓN, 2007 y 16).

Hecha la aclaración y recuperando la cuestión del "American Israel theme" [EE.UU. como Nueva Jerusalén] -en relación estrecha con el punto siguiente (destino manifiesto y mesianismo)-, el tema en su dimensión laxa ha perdurado entre los estadistas estadounidenses hasta días recientes, bajo doctrinas actuales, como La Nueva Frontera de KENNEDY, La Gran Sociedad de JOHNSON o El

\footnotetext{
598 Cfr. "The Founding Fathers "religion" did essentially have one meaning: The beliefs and practices associated with the worship of God, whether the Christian God, the Jewish God, Nature's God, or Divine Providence" (pp. 129), en GOLDBERG, G.: Church, State and the Constitution, Washington DC: Regnery Gateway, 1987. Vid. PFEFFER, L.: Church, State and Freedom, Boston: Beacon Press, 1967. EIDSMOE, J.: Christianity and the Constitution. The Faith of Our Founding Fathers, Grand Rapids: Baker Book House, 1987.
} 
humanitarismo de CLINTON.

c) Referentes jurisprudenciales: con sus sentencias, los magistrados del TSEU, logran ajustar en cada momento e impulsar periódicamente la noción de religión civil y su relación con las religiones tradicionales. En concreto, y debido al tema de este punto, se enuncian a continuación aquellas sentencias que han reconocido el origen judeocristiano de los EE.UU., así como la regla secular, por la que transcurrido un tiempo del recurso de elementos arquetípicos de las religiones tradicionales, éstos pasan a poseer una naturaleza identitaria nacional, engrosando así la lista de componentes de la ACR (bajo cita coloquial -no formal de Case Law-) $)^{599}$ : LYNCH vs. DONNELLY; ABINGTON SCHOOL DIST. vs. SCHEMPP; ENGEL vs. VITALE; ZORACH vs. CLAUSON; etc.

Como disquisición concluyente de este punto, cabe observarse, que los padres fundadores (lato sensu), no sólo se relacionan con la religión civil por su contribución a la formación de la misma, sino que a día de hoy, ellos mismos son una parte más de ésta, por lo que igualmente, como pasa con el resto de elementos arquetípicos vistos, gozan de un aura sacramental -bien por transferencia, fetichismo de nuevo cuño, etc.-.

Como aporía, se recuerda la ya reiterada intriga, sobre el alcance del proyecto neoconservador (durante la Administración W.BUSH), para influir en la memoria histórica y reconfigurar así el paradigma identitario estadounidense -suplantándolo

\footnotetext{
${ }^{599}$ La cita jurídicamente correcta es: LYNCH, MAYOR OF PAINTUCKET vs. DONNELLY, 465 US 668 (1984) at 673; ABINGTON SCHOOL DIST. vs. SCHEMPP, 374 US 203 (1963) at 203; ENGEL vs. VITALE, 370 US 421 (1962) at 421; ZORACH vs. CLAUSON, 343 US 306 (1952) at 313.
} 
por uno lineal simplista y homogéneo, de impronta únicamente judeocristiana-.

\section{b) Destino manifiesto y mesianismo:}

De tal modo se conectan dos creencias identitarias estadounidenses, como son la predestinación y el mesianismo, pudiendo sintetizarse todo ello, sucintamente, como el celo apostólico cristiano, que se ve revitalizado periódicamente en los EE.UU., al sentirse (self-understanding) como el pueblo elegido por Dios para liderar -y en cierto modo, liberar del mal terrenal- al resto de las naciones (recuérdese el pledge of allegiance, entre otras muestras, en tal sentido), además de creerse en deuda por la bendición divina que supone su democracia y libertad.

Figura 73.- Representación del destino manifiesto estadounidense (GAST, 1872)

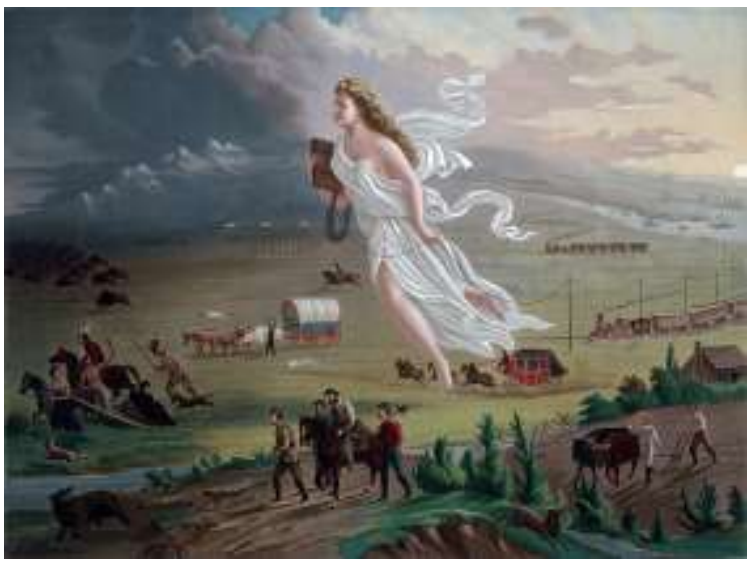

Fuente: elaboración propia (SÁNCHEZ-BAYÓN, 2007 y 16). 
Desarrollando la idea del párrafo anterior, se explica así la pretensión estadounidense (proselitista) de extender al resto del mundo su modelo de vida o AWL (más su AD), pero al hacerlo se suele incurrir en una serie de fricciones procedimentales y actitudes generadoras de hostilidades no cesadas -e íntimamente relacionadas con las ansiedades y disonancias cognitivas de la mentalidad estadounidense-:

a) Tensiones procedimentales:

- Unilateralismo (para toma de decisiones de repliegue o isolationism, y de expansionismo o expanding/intervencionism) y liderazgo (hegemonía sin responsabilidad tradicional imperial -aunque sí, desde los parámetros de la sobreestima o self-righteouness y su moralismo, vid. supra-).

- Doble rasero (double standard) en la implementación del modelo de vida estadounidense en otras partes del mundo, o al calificar las acciones de aliados y enemigos (v.g. en materia de derechos humanos, seguridad y defensa).

b) Tensiones psicológicas:

- Condescendencia (obliging sense E civilizing process) y estrés de vigilancia (control).

- Cierta arrogancia y autoconvicción de superioridad moral (self-righteouness $\&$ selfunderstanding), por la -supuesta- supremacía del American way of life o AWL: los EE.UU., es un país que recibe influencias de todo el mundo, las transforma y las exporta al planeta con un formato abierto y expansivo.

- Moralismo y pietismo (fruto del deísmo, que permite fijar unos valores morales de vocación universal, pero para el ejercicio particular cotidiano). 
En cuanto a las dos primeras ideas, éstas se expresan con claridad al tratar el mesianismo, pero para ilustrar la última (moralismo y pietismo), se recurre a los siguientes ejemplos:

a) Moralismo: téngase en cuenta las campañas contra el vicio (v.g. anti-duelos, antiprostitución, anti-alcohol), a favor del descanso dominical, pro y contra la esclavitud (dependiendo de la confesión y zona de los EE.UU.), etc. ${ }^{600}$; todas ellas de carácter socio-político, pero que suelen terminar poseyendo consecuencias jurídicas (v.g. Dieciocho enmienda de CEU, 1919: "Section 1. After one year from the ratification of this article the manufacture, sale, or transportation of intoxicating liquors within, the importation thereof into, or the exportation thereof from the United States and all territory subject to the jurisdiction thereof for beverage purposes is hereby prohibited"; dicho mandato fue abolido con la Veintiuna enmienda de CEU, 1933).

b) Pietismo: reflexiónese sobre la exigencia histórico-social de la participación del buen hombre libre en la política estadounidense -noción que combina la exigencia protestante del hombre de fe, y la católica del buen padre de familia-. Dicha visión

\footnotetext{
${ }^{600}$ Vid. VV.AA.: Religion in America, San Diego: Greenhaven Press, 1989. Al igual que la versión de STOKES, A.P.: Church and State in the United States (vol II)... op. cit., donde se distingue entre: "The Antidueling campaign", "The Sunday mail controversy", "The Antimasonic campaign", "The Antilottery campaign", "Religious journalism", "Temperance and liquor control", "The Mormon Theocracy and Independence", "Nonsectarian Public Education", "The Annexation of Texas", etc. Otras cuestiones objeto de campañas moralistas con vocación político-jurídica realizadas por organizaciones religiosas, han sido: Campañas anti-militaristas y pacifistas ("The role of Religious organizations in the Peace Moviments between the Wars", Capítulo 4 de YARNOLD, B (ed.). The role of religious organizations in social movements, New York: Praeger, 1991); Los Derechos de los homosexuales ("The role of Religious organizations in the Gay and Lesbian Rights Movement", Capítulo 5 de YARNOLD, B (ed.). The role of religious organizations in social movements... op. cit.). FELT TYLER, A.: Freedom's Ferment. Phases of American social History to 1860, Minneapolis: University of Minnesota Press, 1944. VV.AA.: Religious and Secular Reform in America. Ideas, beliefs, and social change, New York: New York University Press, 1999.
} 
del proto-ciudadano, a quién se le exige un alto grado de integridad y honradez, pues no sólo ha de ejercer como gobernante, sino también como modelo de virtudes, referente para la educación de los niños. En tal sentido, como hombre político por excelencia, recuérdese la importancia que tiene el símbolo del Presidente y su día ritual (vid. infra), así como el hecho, de que los impeachments (procesos de control de la actividad presidencial) formulados han tenido el fundamento en causas morales más que jurídicas.

Sobre el mesianismo, se llama la atención en relación con dos ideas clave de su noción para comprender luego la dimensión práctica del mismo en los mapas conceptuales relativos a la geopolítica estadounidense:

a) El mesianismo como acción social: puede considerarse el mesianismo como un movimiento religioso de tendencia secular porque busca la salvación terrenal como el adelanto del reino de Dios, ya mencionado al tratar la predestinación-, proyectándose en todas las facetas humanas; se trata de un proceso liberalizador diseñado y ejecutado por los hombres para los hombres, aunque con la ayuda de $\operatorname{Dios}^{601}$.

b) El mesianismo como liderazgo: la superioridad moral y el favor divino del que creen gozar los estadounidense, les habilita, desde su autopercepción, a intentar hacer el bien en el mundo, por lo que no consideran su intervencionismo de corte imperialista -una de las fallas de tal discurso legitimador es la dudosa objetividad para seleccionar los problemas a atajar y el escaso espíritu

${ }^{601}$ Para el desarrollo de la noción y tipos de mesianismo, vid. FIERRO, A.: Hecho religioso, Barcelona: Salvat, 1981, pp. 33. 
comunicativo en dichas intervenciones.

Figura 74.- Juego geopolítico estadounidense: escenarios y jugadores
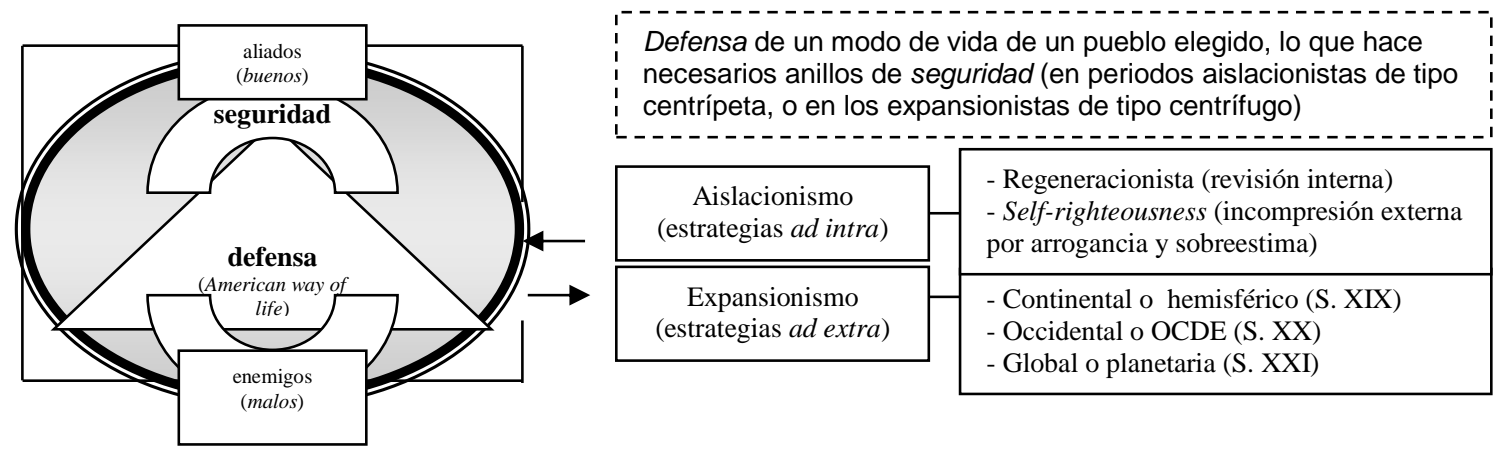

Fuente: elaboración propia (SÁNCHEZ-BAYÓN, 2007 y 16).

Figura 75.- Juego geopolítico estadounidense (de influjo neocon): niveles o fases
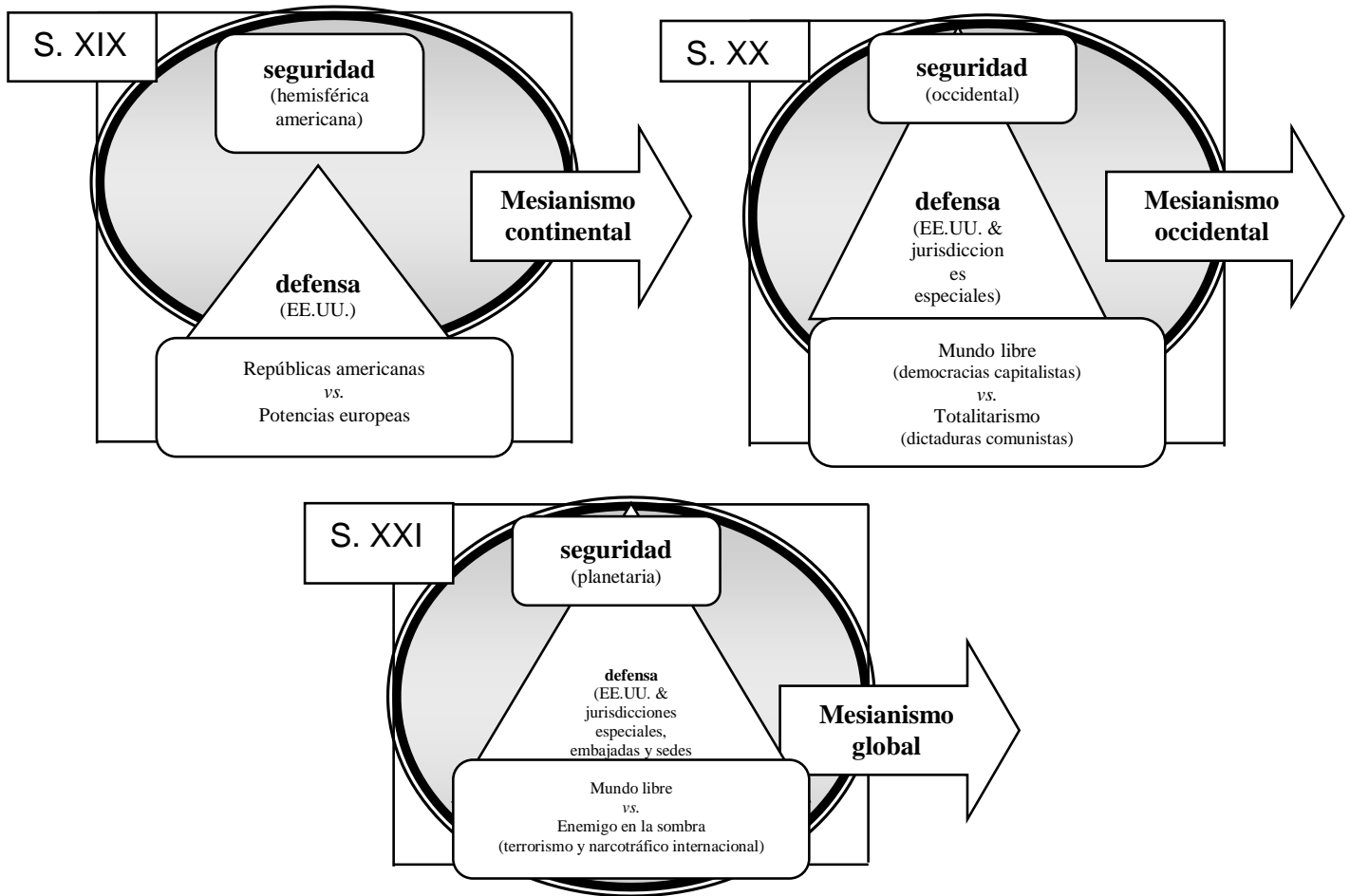

Fuente: elaboración propia (SÁNCHEZ-BAYÓN, 2007 y 16). 


\section{c) Valores democristianos:}

Algunos de los valores cristianos que formaron parte inicialmente de la ética estadounidense o American civic piety (ACP) de los colonos, posteriormente, se vieron recogidos en el Derecho estadounidense, logrado así contribuir a la configuración del AWL. A día de hoy se mantienen, casi inalterados y con bastante empuje, la mayoría de estos valores, que tal y como recoge la siguiente figura, siguen teniendo una gran importancia para los jóvenes estadounidenses.

Figura 76.- Valores del American civic piety según los jóvenes ${ }^{602}$

\begin{tabular}{|llc|}
\hline \multicolumn{2}{|c|}{ Porcentaje de jóvenes que consideran “muy importantes" los siguientes valores } \\
\hline Honestidad: $89 \%$ & Responsabilidad 89\% & Autorrespeto $87 \%$ \\
\hline Trabajo duro/Constancia 70\% & Independencia/Libertad 65\% & Paciencia 61\% \\
\hline Obediencia 60\% & Fervor religioso 44\% & \\
\hline
\end{tabular}

Fuente: elaboración propia (SÁNCHEZ-BAYÓN, 2007 y 16).

Dichos valores, suelen interpretarse de forma interrelacionada, especialmente en su dimensión más abstracta, como pasa con:

a) verdad y libertad: "la verdad os hará libres" (Jn. 8:32), de ahí que existan Comisiones de la verdad, un juramento religioso en tribunales civiles (vid. infra), etc.

${ }^{602}$ Cfr. VVAA.: The People's Religion. American Faith in the 90's, MacMillan Publishing Co, New York, 1989, pp. 130 (son datos obtenidos de 1.000 entrevistas personales celebradas en 1986, con un margen estimado de error del $4 \%$ ). 
b) justicia y equidad: para los protestantes parece evidente y posible que se pueda hacer justicia en el mundo terrenal (como consecuencia de la "anticipación del reino de Dios"), admitiéndose incluso, la pena de muerte o pena capital (en alusión tropológica de la Biblia, sobre todo del Antiguo Testamento: realmente, no se considera que la comunidad ordene la muerte, sino que se limita a reconocer la sanción que ha buscado el mismo individuo, cumpliéndose así la voluntad de Dios para el respeto de la comunidad).

Otra dimensión analítica que sustenta la cuestión de los valores democristianos y el modelo de vida a seguir es el fenómeno social estadounidense del denominalismo, ya que afecta al rol social del individuo, fijando el estereotipo del feligrés y su posición en la jerarquización social de facto. A título ilustrativo, véase la siguiente figura.

Figura 77.- Denominalismo y tipo de vida según religión tradicional ${ }^{603}$

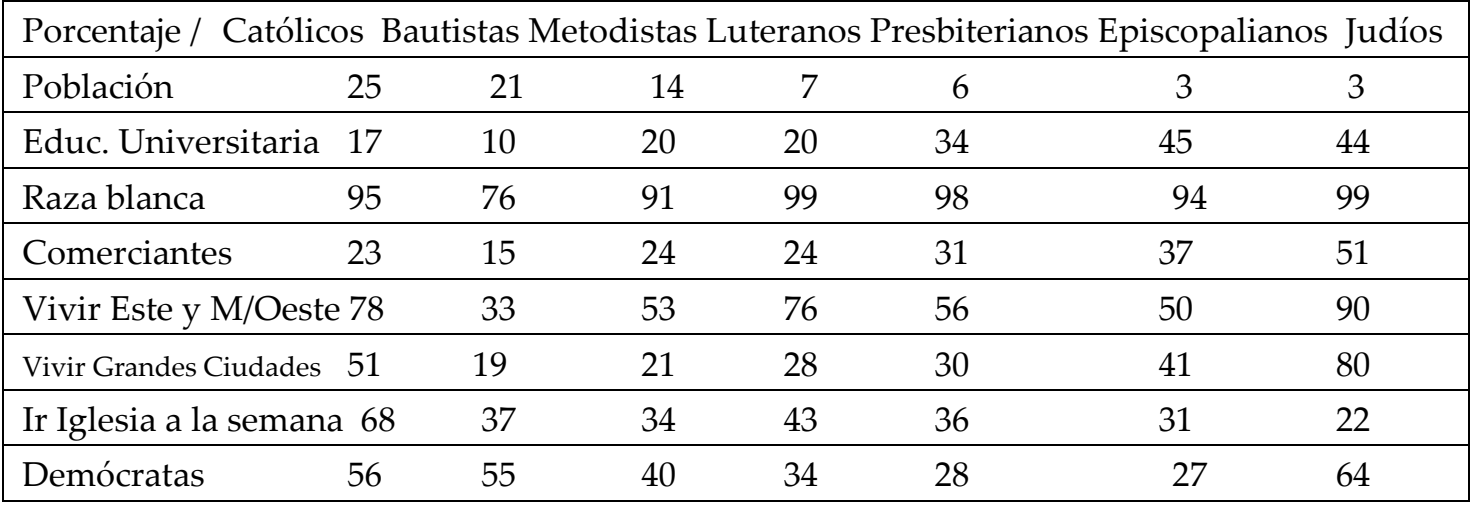

Fuente: elaboración propia (SÁNCHEZ-BAYÓN, 2007 y 16). ${ }^{603}$ Cfr. VVAA.: The Denominational society. A sociological approach to Religion in America, Scott Foresman
and Co., Glenview, 1972. United States census sample of 1957. 
Para poner fin a este punto sobre valores democristianos - previos a cualquier formulación europea-continental, pues habrá que esperar más de un siglo para ver manifestaciones similares en Alemania e Italia, por ejemplo-, así como, al análisis de las creencias en general, se invita al lector a la observación de las inmediatas figuras con datos históricos y actuales de afiliación religiosa en los EE.UU., lo que seguramente, irá permitiendo intuir cuál es la jerarquización social de facto en dicho país y el porqué del acceso al poder y a la configuración del modelo de vida, como después se comenta con alguna que otra disquisición y aporía.

Figura 78.- Estimaciones históricas sobre denominaciones cristianas en EE.UU. ${ }^{604}$

\begin{tabular}{|c|c|c|c|c|}
\hline Denominaciones (congregaciones o procedencias predominantes) / & $1780 /$ & $320 /$ & $860 /$ & 1900 \\
\hline Anglicana (episcopalianos) & 14,8 & 5,5 & 4,1 & 3,8 \\
\hline Calvinista (congregacionalistas, presbiterianos, "puritanos") & 50,2 & 30,1 & 18,6 & 14,3 \\
\hline Evangélica (metodistas, baptistas) & 16,7 & 49,4 & 61,2 & 63,7 \\
\hline Luterana (de Suecia, Suiza, Alemania) & 8,7 & 7,3 & 4,1 & 6,6 \\
\hline Católica (de Latinoamérica, Irlanda) & 2,1 & 1,1 & 4,9 & 6,3 \\
\hline
\end{tabular}

Fuente: elaboración propia (SÁNCHEZ-BAYÓN, 2007 y 16).

Figura 79.- Denominaciones protestantes en los EE.UU. (1967-1987)605

\begin{tabular}{|lrrrrrr|}
\hline Años / Iglesias: & Bautistas & Metodistas & Luteranos & Presbiterianos & \multicolumn{2}{c|}{ Espiscopalianos } \\
\hline 1967 & $21 \%$ & $14 \%$ & $7 \%$ & $6 \%$ & $3 \%$ \\
\hline 1969 & $20 \%$ & $14 \%$ & $7 \%$ & $6 \%$ & $3 \%$ \\
\hline 1974 & $21 \%$ & $14 \%$ & $7 \%$ & $6 \%$ & $3 \%$ \\
\hline 1976 & $21 \%$ & $11 \%$ & $7 \%$ & $5 \%$ & $3 \%$ \\
\hline 1980 & $19 \%$ & $10 \%$ & $6 \%$ & $4 \%$ & $2 \%$ \\
\hline 1984 & $20 \%$ & $9 \%$ & $7 \%$ & $2 \%$ & $3 \%$ \\
\hline
\end{tabular}

${ }^{604}$ Se trata de estimaciones acerca del crecimiento de dichas denominaciones, agrupadas según directrices religiosas dominantes (v.g. los puritanos son anglicanos reformados con componentes calvinistas) en relación con la inmigración recibida; vid. WITTE, J.: Religion and the American Constitutional Experiment. Essential Rights and Liberties... op. cit.

${ }^{605}$ Datos tomados de VV.AA.: The People's Religion. American Faith in the 90's, New York: MacMillan Publishing Co, 1989, pp. 25 (son datos obtenidos de 14.147 entrevistas personales celebradas en 1987, con un margen estimado de error del $2 \%)$. 


\begin{tabular}{|llllll|}
\hline 1987 & $20 \%$ & $9 \%$ & $6 \%$ & $3 \%$ & $2 \%$ \\
\hline
\end{tabular}

Fuente: elaboración propia (SÁNCHEZ-BAYÓN, 2007 y 16).

Figura 80.- Religiones tradicionales en los EE.UU. de 1947-1987606

\begin{tabular}{|lcccccccccc|}
\hline Religiones / Años: & 1947 & 1952 & 1957 & 1962 & 1967 & 1972 & 1976 & 1980 & 1984 & 1987 \\
\hline Protestantes & $69 \%$ & $67 \%$ & $66 \%$ & $70 \%$ & $67 \%$ & $63 \%$ & $61 \%$ & $61 \%$ & $57 \%$ & $57 \%$ \\
\hline Católicos & $20 \%$ & $25 \%$ & $26 \%$ & $23 \%$ & $25 \%$ & $26 \%$ & $27 \%$ & $28 \%$ & $28 \%$ & $28 \%$ \\
\hline Judíos & $5 \%$ & $4 \%$ & $3 \%$ & $3 \%$ & $3 \%$ & $2 \%$ & $2 \%$ & $2 \%$ & $2 \%$ & $2 \%$ \\
\hline Otras & $1 \%$ & $1 \%$ & $1 \%$ & $2 \%$ & $3 \%$ & $4 \%$ & $4 \%$ & $2 \%$ & $4 \%$ & $4 \%$ \\
\hline Ninguna & $6 \%$ & $2 \%$ & $3 \%$ & $2 \%$ & $2 \%$ & $5 \%$ & $6 \%$ & $7 \%$ & $9 \%$ & $9 \%$ \\
\hline
\end{tabular}

Fuente: elaboración propia (SÁNCHEZ-BAYÓN, 2007 y 16).

\section{Figura 81.- Religiones tradicionales en los EE.UU. hasta la globalización} Iglesias, confesiones y grupos religiosos en los EE.UU. (\% de la población)

Cristianos-protestantes: $56 \%$ población ( $16 \%$ baptistas, $9 \%$ metodistas, $6 \%$ luteranos, $3 \%$ pentacostalistas, $3 \%$ presbiterianos, $2 \%$ episcopalianos, $1 \%$ Iglesia de Cristo, $1 \%$ mormones, $15 \%$ otros).

Cristianos-católicos: $28 \%$ población (número creciente debido a la inmigración latinoamericana, que en el año 2010 se estima como minoría más relevante en EEUU).

Cristianos-ortodoxos: 0,4\% población (descendientes de inmigrantes griegos, Europa del Este y Rusia).

Otras religiones abrahámicas: $4,5 \%$ población ( $2 \%$ judíos, $2 \%$ musulmanes, $0,7 \%$ bahais \& ahmadíes, $0,2 \%$ santería y otros sincretismos).

Religiones populares: $1,5 \%$ población $(0,7 \%$ budistas, $0,3 \%$ hinduistas, $1 \%$ sintoístas \& taoístas, $0,5 \%$ animistas y otros).

Descreídos y neopaganos: 9,6\% población (7\% agnósticos \& ateos -como fórmula contracultural, de discrepancia con el modelo religioso tradicional de Occidente, aunque sí se organizan como comunidad y venían participando en la religión civil pública-, $2 \%$ neopaganos -extraterrestres y sobrenatural-, $0,6 \%$ otros).

Fuente: elaboración propia (SÁNCHEZ-BAYÓN, 2007 y 16).

606 Datos tomados de VV.AA.: The People's Religion. American Faith in the 90's... op. cit., pp. 24 (son datos obtenidos de 14.147 entrevistas personales celebradas en 1987, con un margen estimado de error del $2 \%)$. 
Ahora sí, como últimas consideraciones sobre el devenir estadounidense de los valores democristianos, se llama la atención sobre dos de las aristas a pulir conceptualmente:

a) Hasta qué punto se han secularizado los vigentes valores democráticos y los derechos humanos, si su cimiento y muro de carga de su edificio intelectual sigue siendo la salvaguardia de la dignidad humana -aún reconocida, por reminiscencia judeocristiana, como la condición propia de quién es hijo de Dios, en vez de hablar de una protección de la humanidad, como condición racional potencial de toda persona.

b) Dichos valores, como creencias movilizadoras - ¿realmente?-impulsaron la auténtica revolución estadounidense (porque los dos grandes conflictos armados, en realidad fueron una guerra de independencia, y luego, una guerra civil), consistente la misma en la consolidación de una cultura cívica novedosa hasta entonces, soporte del modelo democrático a implementar (ALMOND y VERBA); por tanto, ¿a día de hoy los EE.UU. sigue siendo una república democrática cristiana?; ¿pero lo ha sido alguna vez en sentido estricto o desde el ecumenismo propio del neocesaropapismo emergente?.

Sobre las historias ejemplares de los padres fundadores (founding father tales) y las bendiciones al inicio y final de sus discursos (God bless America, God bless you, etc.), se remite al cap. 9 y a otros trabajos ${ }^{607}$.

${ }^{607}$ Vid. SÁNCHEZ-BAYÓN, A.: La Modernidad... op. cit. - Estado y religión... op. cit. 


\section{d) American's creed}

El credo estadounidense, no es una mera propuesta doctrinal, basada en unos valores rectores como la democracia, la libertad e igualdad, el individualismo, etc. (vid. supra), tal como plantearan ilustres viajeros, v.g. CRÈVECOUR en el s. XVIII, TOCQUEVILLE en el s. XIX, CHESTERTON en el s. XX; o prestiosos académicos estadounidenses de sus Estudios culturales, v.g. HOFSTADTER, LIPSET, HUNTINGTON (vid. infra cap. 8). En realidad, se trata de una norma homónima de soft-law o derecho dispositivo (con atecedentes en el Preámbulo de DIE, el Discurso de Gettysburg de LINCOLN, etc.). Resulta que el 3 de abril de 1918, el Congreso de los EE.UU. aprobó una resolución homónima, basada en el texto de William Tyler PAGE (congresista de Virginia y Letrado del Congreso nacional). El texto, de dos páginas, dice: "I believe in the United States of America as a government of the people, by the people, for the people; whose just powers are derived from the consent of the governed; a democracy in a republic; a sovereign Nation of many sovereign States; a perfect union, one and inseparable; established upon those principles of freedom, equality, justice, and humanity for which American patriots sacrificed their lives and fortunes. I therefore believe it is my duty to my country to love it, to support its Constitution, to obey its laws, to respect its flag, and to defend it against all enemies. The American's Creed is a summing up, in one hundred words, of the basic principles of American political faith. It is not an expression of individual opinion upon the obligations and duties of American citizenship or with

respect to its rights and privileges. It is a summary of the fundamental principles of American political faith as set forth in its greatest documents, its worthiest traditions and by its greatest leaders". 
Figura 82.- PAGE y su redacción original de American's creed

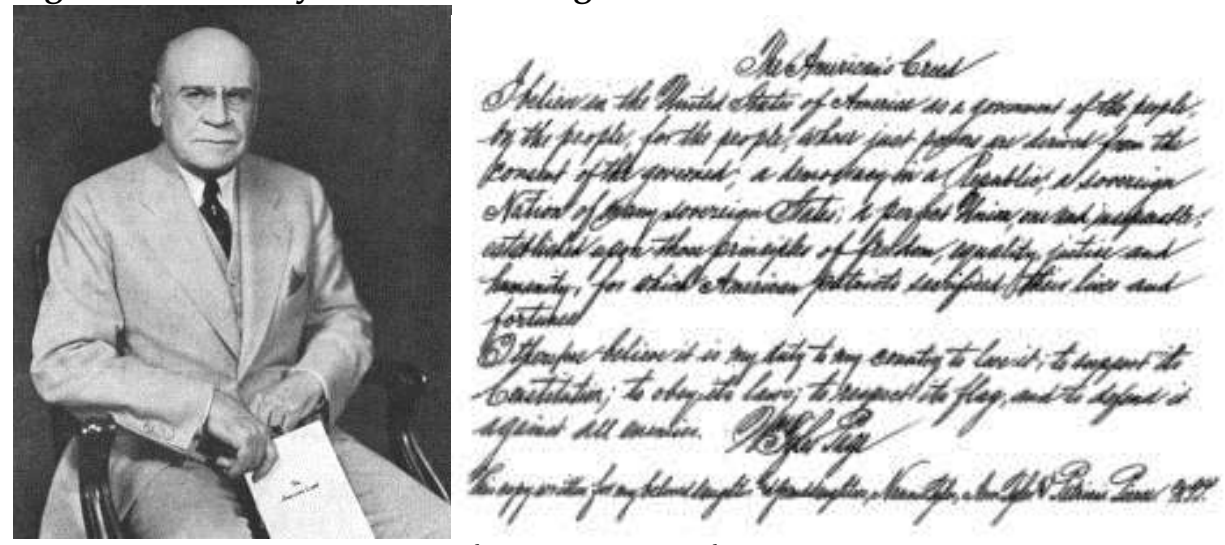

Fuente: elaboración propia (SÁNCHEZ-BAYÓN, 2007 y 16).

Para concluir este apartado, sólo destacar que, la idea de valores, tras pasar por su Americaness, sí alcanzó también su realización como "valor" financiero, pues en cada ocasión que la nación ha necesitado financiación extra, se han emitido valores patrióticos (vid. figura siguiente):

Figura 83.- Los otros valores estadounidenses (Liberty bounds)

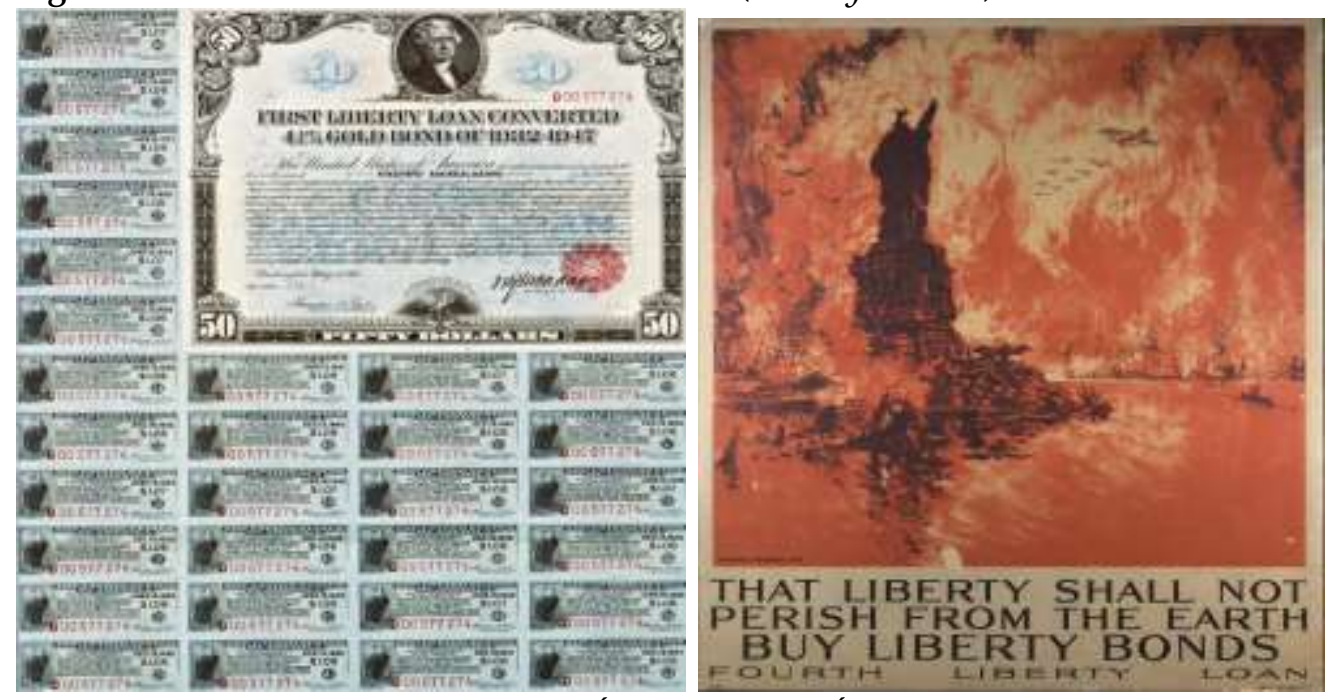

Fuente: elaboración propia (SÁNCHEZ-BAYÓN, 2007 y 16). 


\subsection{3.- NORMAS E INSTITUCIONES}

Se alude a las dos principales herramientas para poner orden social: de un lado, las normas, que son imperativos en forma de regla; y de otro, las instituciones, que son las normas entrelazadas, dando lugar a una figura de ordenación y relación social compleja. Más aún, desde los Estudios político-jurídicos ${ }^{608}$, tiende a simplificarse la cuestión, y reducir en consecuencia, por lo que por norma se entiende las fuentes de regulación (aunque propiamente, cada una de dichas fuentes, en sí, sería una institución), y las instituciones como órganos de gobierno y administración, Por tanto, aquí se va a rendir cuenta, de manera combinada (y ajustada a ACR), de: a) instituciones político-administrativas (nociones básicas de organización político-jurídica: federalismo, democracia, presidencialismo, parlamentarismo y constitucionalismo); b) instituciones jurídicas y socio-religiosas (Blue Laws, Escrituras sagradas de ACR y jurisprudencia actualizadora).

\section{a) Instituciones político-administrativas: federalismo, democracia, presidencialismo, parlamentarismo y constitucionalismo}

Son las tres expresiones organizativas idiosincrásicas estadounidenses por excelencia. Se basan en un racionalismo lógico moderno propiciador del nuevo orden secular (lema del Gran Sello nacional, vid. infra), que parte de la Teología política manejada por los padres fundadores (vid. infra cap. 5, 6 y 9).

${ }^{608}$ Vid. SÁNCHEZ-BAYÓN, A.: Estudios de cultura político-jurídica... op. cit. 
a) Federalismo: tal como se ha apuntado en el epígrafe anterior, el federalismo responde a la lógica de la Teología política sobre el pactismo (de la unión del pueblo de Dios, en tierra prometida, bajo su providencia y para su prosperidad y salvación). En términos tropológicos, los padres fundadores, reciben una herencia por la que, mediante el ensayo y error llegan a una fórmula de federalismo inspirada en una concepción tripartita del poder ${ }^{609}$ : en sentido horizontal se distingue el Legislativo, Ejecutivo y Judicial (o sea, el gobierno de escribas, reyes y jueces); y verticalmente, se conforma del Estado Federal, Estados Federados y Entes Locales (el gran reino o reino unido, los reinos históricos y sus casas). Así se entiende la preocupación por alcanzar la unión de las diversas colonias (como si de las doce tribus de Israel se tratara), formando un gran Estado (Israel), de vocación continental (como refleja la denominación oficial, vid. infra). En términos epistemológicos, el federalismo bebe de la tradición judeocristiana, pasada por el PWF, y cuyo mejor respresentante de referencia para los padres fundadores es LOCKE (y sus Ensayos sobre el gobierno civil, 1660-62), quien fija las reglas del Estado federal, con su división de poderes y contrapoderes, la necesidad de pluralidad y tolerancia, etc.

b) Democracia: su significado sustancial, marcadamente determinado por la Teología política, presume la condición de los estadounidenses como pueblo elegido, y por tanto soberano, que sólo rinde cuentas a Dios (a través de pactos ${ }^{610}$. En consecuencia, su sistema de gobierno resulta participativo, libre,

\footnotetext{
${ }^{609}$ Conforme a la cábala, se atribuye al número tres la pluralidad y consenso; según el cristianismo, representa la trinidad divina (cuyas personas se aman y fruto de ese amor desbordante brota la creación).

${ }^{610}$ Ya no se trata de subditos medievales (que en Europa perdurará, debido al Absolutismo), sino de ciudadanos: como hijos de Dios, resultan libres e iguales, para alcanzar su progreso y salvación, unidos voluntariamente como pueblo elegido. Incluso, como tipifica la DIE, tal suerte de ciudadano
} 
bendecido y con la misión de expandir el mismo -dicha presunción, para sus gentes, se confirma con el éxito de la geopolítica de los EE.UU., fortaleciéndose así las creencias citadas-. Formalmente, la organización de la democracia estadounidense guarda profundas similitudes con el gobierno de las iglesias protestantes: con las iglesias emergentes y comunitarias o evangelicals, en el ámbito local (basándose en un poder directo y participativo); y con las establecidas y jerárquicas o main-line, en el ámbito federal (basándose en un poder indirecto y delegado).

c) Presidencialismo: la Teología política ha influido en la religión civil para dar lugar a una concepción mesiánica del poder. El Presidente es aquella persona predestinada por Dios y ratificada por su pueblo para dirigirlo, mostrando el camino a seguir para su progreso y salvación. Como ya se ha indicado, el Presidente es el gran líder (el patriarca - pues hasta ahora sólo ha sido un cargo ocupado por hombres, pese a su democracia-), quien resulta a su vez jefe de Estado, del Gobierno, de los Ejércitos, de su partido... hasta tiene su día de celebración (vid. infra).

d) Parlamentarismo y constitucionalismo: para comprender la cuestión, se requiere de un breve apunte sobre el conciliarismo, como movimiento clave en la posibilitación del tránsito a la Modernidad y su Nuevo Régimen. Tradicionalmente, se trataba de una temática presente en casi todos los manuales de Historia de las Ideas Políticas, Historia de las Instituciones, incluso de Historia del Derech $0^{611}$. Sin embargo, en la actualidad, a duras penas sobrevive la temática en

del nuevo orden secular, goza de derechos naturales, puede y debe participar en política, cabe el tiranicidio (si está justificado), etc.

611 Vid. SABINE, G.H.: A History of Political Theory, New York: Henry. Holt \& Co., 1937. TOUCHARD, J., et al.: Histoire des idées politiques (2 vols.), París: Presses universitaires de France, 1959. 
disciplinas como Historia eclesiástica o Church-State Studies, incluso en algunas corrientes de Derecho Canónico y Eclesiástico612. Tal desaparición progresiva, no sólo ha empobrecido el conocimiento disponible de la época, sino que además dificulta la comprensión de cómo se corrigió la deriva teocrática papal y de cierto sector protestante (v.g. el calvinismo influyente en la Nueva Inglaterra colonial del s. XVII ${ }^{613}$. Pues bien, el conciliarismo tiene su apogeo con el Gran Cisma, entre los concilios y cónclaves de 1378 y de 1431-45614. Originalmente, los concilios son asambleas extraordinarias de representantes eclesiásticos, para resolver problemas dogmáticos (sobre todo heréticos) y de elección papal. La consolidación del hierocratismo (el dominio de la autoridad religiosa sobre el poder civil), con Bonifacio VIII y su Bula Unam Sanctam (1302) autoproclamándose vicario de Cristo $\mathrm{y}$, por ende, poder supremo de la Cristiandad-, trae consigo una creciente tensión frente al emperador (del Sacro Imperio) y las principales Coronas de entonces (v.g. Castilla, Aragón, Inglaterra, Francia). Para superar con éxito tal tensión, el Papa requiere del máximo apoyo dentro de la Iglesia, por lo que los concilios comienzan a normalizarse, y con ello se ratifica su competencia en la producción político-jurídica, mediante el Derecho Canónico, que a su vez vive su era dorada con el impulso de las universidades

${ }^{612}$ Vid. CESAREA, E.: Historia Eclesiástica (2 vols.), Madrid: BAC, 1973. LLORCA, B., et al., Historia de la Iglesia Católica, Madrid: BAC, 1964. ORLANDIS, J.: Historia de la Iglesia (vol. 1), Madrid: Pelícano, 1979. STOKES, A.P. - Church and State in the United States (3 vols.), New York: Harper \& Bro., 1950. ${ }^{6} 13$ Vid. SÁNCHEZ-BAYÓN, A.: La Modernidad sin prejuicios... op. cit.

${ }^{614}$ En concreto y de manera telegráfica, cabe destacar: a) Conclave de 1378, en el que es elegido el Papa Urbano VI (con sede en Roma y su sucesor Gregorio XII); mientras que Clemente VII, lo es en Aviñón (sucedido en 1394 por Benedicto XIII -conocido también como Papa Luna-, pero dado su apoyo por las Coronas ibéricas e itálicas, Francia se lo retira y apoya a su candidato); b) Concilio y conclave de 1409, siendo elegido Alejandro V (sucedido por Juan XXIII); c) Concilio Constanza de 1414-18, se depone a los antipapas y se reconoce como único Papa a Martín V; d) Concilio Basilea de 1431-45, con el que toca techo las aspiraciones conciliaristas, ocasionando la reacción papal de su calificación de "conventículo" y la proscripción de su doctrina. 
(Corpus Iuris Canonici). El conciliarismo va a convertirse en el gran movimiento que, no sólo va a frenar los excesos papales, sino que además va a sentar las bases de la proto-cultura democrática occidental, su parlamentarismo moderno y su Derecho Constitucional ulterior. Entre los cimientos que establece el conciliarismo (que deja de fundamentarse en Teología para hacerlo propiamente en Derecho Canónico y sus títulos justos), cabe señalar a modo ilustrativo: a) reglas sustantivas (v.g. regla dominium ${ }^{615}$; regla agere licere $^{616}$; regla manus ${ }^{617}$ ); b) reglas procedimentales (v.g. regla concilium o QOT618; regla liberum veto ${ }^{619}$ ); c) garantías (inmunidades, procedimientos, etc.), et al.

La aporía de cierre de este apartado, es la relativa al supuesto abuso neoconservador de la Teología política y de la religión civil (por la Adm. W.BUSH), lo que podría haber devenido en un debilitamiento, desafección y en última instancia, un descrédito del federalismo, la democracia, el presidencialismo, el parlamentarismo y el constitucionalismo, hoy tildado de "originalista" (vid. infra), dándose lugar a un efecto pendular (como ha parecido ser la Adm. OBAMA, proclive a institucionalizar los velos de los Estudios culturales sobrevenidos), y por

\footnotetext{
${ }^{615}$ Regla dominium o de soberanía: todo creyente en gracia goza de dignidad y soberanía, base del auténtico señorío real y no servidumbre (sustento de la moderna libertad e igualdad jurídica).

${ }^{616}$ Regla agere licere: los poderes sólo pueden hacer lo que expresamente tengan permitido, mientras que los particulares pueden hacer todo aquello que no esté expresamente prohibido. Con esta regla se potencia el principio de legalidad y de separación de poderes.

${ }^{617}$ Regla manus: el criterio de oficio permite justificar un mandato dispositivo, confiriéndose un alto grado de autonomía al representante de diócesis en el concilio.

${ }^{618}$ Regla QOT: quod omnes tangit, ab omnibus approbari debet. Mientras que en Derecho Romano, se trataba de una regla de Derecho privado (de Derecho de familia), gracias al Derecho Canónico, pasa a ser de Derecho público (base de la votación consensual de medidas relativas al bien común).

${ }^{619}$ Regla liberum veto: libre veto y exigencia de mayorías (distinguiéndose entre mayoría simple y absoluta, así como el requerimiento de unanimidad para ciertas cuestiones).
} 
ende agravándose la crisis de la identidad y misión estadounidense (vid. Conclusiones).

\section{b) Instituciones jurídicas y socio-religiosas}

\section{b1) Blue Laws: de la regulación colonial, revolucionaria y nacional, más la falacia neocon}

Como ya se ha clarificado previamente, bajo la denominación coloquial de Blue Laws, que literalmente significa leyes azules (relativas al color del cielo) ${ }^{620}$, se está haciendo referencia al difuso (por amplio y variado) sistema normativo autóctono de rectitud vigente durante el periodo fundacional en los EE.UU., y que aquí se ha traducido con la expresión de leyes espirituales o Derecho dominical/eclesiástico. Se atribuye la paternidad de la expresión al Rev. PETERS y su General History of Connecticut (London, 1792). En dicho proto-sistema de Derecho Eclesiástico del Estado de los EE.UU., cada colonia (según el margen de actuación conferido por su modelo relacional Iglesia-Estado, vid. infra), podía fijar las leyes fundamentales y los mandatos aprobados por el Gobernador y/o la Asamblea local, con la intención de instrumentalizar la religión como herramienta de integración social (religio ex machina), garantizándose así la supervivencia del asentamiento (al fijarse claramente un ideario, un código ético, un sistema de derechos y deberes, más ritos y símbolos a observar por la comunidad $)^{621}$. Los ítems más destacados y objeto de regulación de

\footnotetext{
${ }^{620}$ La significación de dicha denominación es de tipo metafórico, ya que para la nueva ordenación social americana se fija un referente celestial o de máximos, con el ánimo de conseguir la realización de un paraíso terrenal.

${ }^{621}$ Pese al origen heterogéneo de las colonias (como se ha visto: siendo unas constituidas por propia
} 
las Blue Laws solían referirse al desarrollo de tres grandes aspectos, con desarrollos diversos: a) grados de reconocimiento de tolerancia; b) grados de sometimiento al juramento de supremacía u oath of supremacy; c) grados de observación de las leyes dominicales o Sabbath/Sunday Laws.

Yéndose más allá de la regulación fundacional, si se estudia adecuadamente el Ordenamiento estadounidense, puede constatarse que: a) su sistema de Derecho Común -entendido en oposición al Derecho Civil o europeo-continental-, no sólo consta de jurisprudencia, sino que también cuenta con una abundante regulación (incluso estatutaria y codificada de la misma); b) entre dicha regulación, además, el factor religioso es observado con interés (v.g. evitar la implantación de una religión tradicional como oficial, proteger el libre culto).

Figura 84.- Referencias reguladoras de la "gestión" de la religión en los EE.UU.

\begin{tabular}{|l|}
\hline \multicolumn{1}{|c|}{ Textos históricos (periodos colonial y revolucionario) } \\
\hline 1.- The First Chapter of Virginia (1606). \\
\hline 2.- The Mayflower Compact (1620). \\
\hline 3.- Chapter of Rhode Island and Providence Plantations (1643). \\
\hline 4.- The Maryland Toleration Act (1649). \\
\hline 5.- Virginia Declaration of Rights (1776). \\
\hline 6.- Declaration of Independence (1776) \\
\hline
\end{tabular}

iniciativa real, otras por concesión a compañías o familias destacadas, etc.), todas ellas comparten la misma preocupación intelectual por una problemática de la realidad, como es (en ese momento histórico), la disquisición en torno a la posibilidad de alcanzar un entorno de tolerancia y progreso social. Dicha posibilidad comienza a tomar un cuerpo común, gracias al plan de supremacía británica, pues aunque su aportación al respecto fue más bien formal, en cambio, su contribución para el impulso de las Blue Laws, como Derecho común colonial, fue decisivo. De ahí que las Blue Laws compartan una similitud de fuentes y tipologías de normas: desde la normativa real y las ordenanzas eclesiásticas de las potencias europeas (v.g. UK, Holanda, etc.), quedando tras el plan de supremacía únicamente es English Ecclesiastical Law [Derecho Eclesiástico Inglés/Anglicano] como referentes, pasando por las aportaciones de la normativa puritana, el Derecho eclesiástico calvinista (o Las Instituciones) y luterano; hasta llegar a las leyes fundamentales coloniales (de las Cartas Otorgadas a las Constituciones), más las ordenanzas coloniales (Sunday Laws, Moral Laws, etc.). 
7.- Constitution of the Commonwealth of Massachusetts (1780).

8.- Articles of the Confederation -and perpetual Union between the states of New Hampshire, Massachusetts-bay Rhode Island and Providence Plantations, Connecticut, New York, New Jersey, Pennsylvania, Delaware, Maryland, Virginia, North Carolina, South Carolina and Georgia- (1781).

9.- Ordinances passed by Continental Congress for the Government of the Northwest Territory (1787).

Textos presentes (periodo nacional)

A.- Constitución y enmiendas

1.- Constitution of the United States of America (1787, entrada en vigor en 1789).

2.- Bill of Rights: First Amendment: free exercise clause; (no)establishment clause (1789, entrada en vigor en 1791).

3.- Fourteenth Amendment (defines citizenship): privileges/immunities clause, due process clause, equal protection clause (1866, entrada en vigor en 1868).

B.- Leyes públicas federales orgánicas

1.- PL 103-141, November 16, 1993, 107 Stat. 1488 UNITED STATES PUBLIC LAWS 103rd Congress - First Session Convening January 5, 1993 PL 103-141 (HR 1308) RELIGIOUS FREEDOM RESTORATION ACT OF 1993.

2.- PL 103-344, October 6, 1994, 108 Stat. 3125, UNITED STATES PUBLIC LAWS 103rd Congress - Second Session Convening January 25, 1994 PL 103-344 (HR 4230) AMERICAN INDIAN RELIGIOUS FREEDOM ACT AMENDMENTS OF 1994.

3.- PL 105-54, October 6, 1997, 111 Stat 1175 UNITED STATES PUBLIC LAWS 105th Congress - First Session Convening January 7, 1997 PL 105-54 (S 1198) EXTENSION OF IMMIGRATION DEADLINES FOR RELIGIOUS WORKERS, CHARITABLE SERVICE WORKERS, AND PAPERWORK CHANGES IN EMPLOYER SANCTIONS OF 1997.

4.- PL 105-292, October 27, 1998, 112 Stat 2787 UNITED STATES PUBLIC LAWS 105th Congress - Second Session Convening January 27, 1998 PL 105-292 (HR 2431) INTERNATIONAL RELIGIOUS FREEDOM ACT OF 1998.

5.- PL 105-183, June 19, 1998, 112 Stat 517 UNITED STATES PUBLIC LAWS 105th Congress - Second Session Convening January 27, 1998 PL 105-183 (S 1244) BANKRUPTCY-RELIGIOUS LIBERTY AND CHARITABLE DONATION PROTECTION ACT OF 1998.

6.- PL 106-55, August 17, 1999, 113 Stat 401 UNITED STATES PUBLIC LAWS 106th Congress - First Session Convening January 27, 1999 PL 106-55 (S 1546) INTERNATIONAL RELIGIOUS FREEDOM ACT AMENDMENTS, 1999.

7.- PL 106-274, September 22, 2000, 114 Stat 803 UNITED STATES PUBLIC LAWS 106th Congress - Second Session Convening January 24, 2000 PL 106-274 (S 2869) RELIGIOUS LAND USE AND INSTITUTIONALIZED PERSONS ACT OF 2000.

8.- PL 106-409, November 1, 2000, 114 Stat 1787 UNITED STATES PUBLIC LAWS 106th Congress - Second Session Convening January 24, 2000 PL 106-409 (HR 4068) RELIGIOUS WORKERS ACT OF 2000.

C.- Leyes públicas federales ordinarias

1.- PL 103-196 (SJRes 154), Religious Freedom Day-Proclamation.

2.- House bill (H.R. 5155), Native American Sacred Lands Act of 2002, to save Indian sacred 
lands.

\begin{tabular}{l} 
D.- Reglamentos federales \\
\hline 1.- President Clinton's executive order on Native American Sacred Sites, 1996. \\
\hline 2.- Permissible Accommodation of Sacred Sites, a memorandum opinion by the Office of Legal \\
Counsel of the Department of Justice for the Secretary of the Interior, Sept. 18, 1996. \\
\hline $\begin{array}{l}\text { 3.- President Clinton's memorandum on Religious Exercise on Religious Expression in the } \\
\text { Federal Workplace, 1997. } \\
\text { 4.- President Clinton's Guidelines on Religious Exercise and Religious Expression in the } \\
\text { Federal Workplace, } 1997 .\end{array}$ \\
\hline
\end{tabular}

Fuente: elaboración propia (SÁNCHEZ-BAYÓN, 2007 y 16).

\section{Figura 85.- Fragmentos de la Declaración de Independencia-DIE}

“(...) Se hace necesario para un pueblo disolver los vínculos políticos que lo han ligado a otro y tomar entre las naciones de la tierra el puesto separado e igual a que las leyes de la naturaleza y el Dios de esa naturaleza le dan derecho (...) Todos los hombres son creados iguales; que son dotados por su Creador de ciertos derechos inalienables; que entre éstos están la vida, la libertad, y la búsqueda de la felicidad; que para garantizar estos derechos se instituyen entre los hombres los gobiernos, que derivan sus poderes legítimos del consentimiento de los gobernados; que cuando quiera que una forma de gobierno se haga destructora de estos principios, el pueblo tiene el derecho a reformarla o abolirla e instituir un nuevo gobierno que se funde en dichos principios (...) Por lo tanto, los Representantes de los Estados Unidos de América, convocados en Congreso General, apelando al Juez Supremo del mundo por la rectitud de nuestras intenciones, en nombre y por la autoridad del buen pueblo de estas Colonias, solemnemente hacemos público y declaramos: Que estas Colonias Unidas son, y deben serlo por derecho, Estados Libres e Independientes (...) Y en apoyo de esta Declaración, con absoluta confianza en la protección de la Divina Providencia, empeñamos nuestra vida, nuestra hacienda y nuestro sagrado honor (...)”.

Fuente: elaboración propia (SÁNCHEZ-BAYÓN, 2007 y 16).

Figura 86.- Primera Enmienda de la Constitución de los EE.UU. (CEU)

"El Congreso no podrá aprobar ley alguna para el establecimiento de una religión oficial, o la prohibición del libre ejercicio de culto; o para limitar la libertad de expresión o de prensa; o el derecho del pueblo a reunirse pacíficamente, y a pedir al Gobierno la reparación de agravios".

Fuente: elaboración propia (SÁNCHEZ-BAYÓN, 2007 y 16).

La cuestión de las Blue Laws y al devenir histórico de la regulación sobre tolerancia religiosa en los EE.UU., resulta un tema candente, tras la extensión del velo neoconservador: existe aún una falacia neoconservadora acerca del estrecho 
vínculo entre el judaísmo y el cristianismo (en cualquiera de sus expresiones) en los EE.UU., así como, la presunción ecuménica actual, que no es más que un disfrazamiento necesario para reconstruir la identidad nacional estadounidense. Para entender el proceso real, ha de tenerse en cuenta la paradoxología, el pragmatismo y el posjudeocristianismo estadounidense (vid. infra), que ayuda a clarificar el hecho de que los primeros colonos, víctimas de la intolerancia religiosa en Europa, por pertenecer a minorías allá, en cuanto se instalan en América y forman mayorías, se convierten en victimarios de las minorías locales, al aprobar leyes muy estrictas de tolerancia religiosa en sentido tradicional (soportar el mal ajeno). Afortunadamente, en relativamente poco tiempo (si se compara con Europa), comienza a reconocerse en las Constituciones de las Mancomunidades coloniales una noción de tolerancia moderna basada en el respeto mutuo. Desde el periodo revolucionario, se empieza a acuñar la idea de libertad -siendo la libertad religiosa la primera en reconocerse en su declaración de derechos o Bill of Rights- como seña de identidad estadounidense frente a las antiguas potencias coloniales europeas.

Como aporías destacables sobre las cuestiones planteadas, cabe señalar:

a. En cuanto a las Blue Laws y los riesgos de la falacia neocon: ¿pueden considerarse superados por fin los vestigios de las Blue Laws, sin amenazas de revitalizaciones anacrónicas o revivals (como la citada falacia)? Téngase en cuenta que, gracias a la moderna secularización y su teología resultó posible el ensayo y error acometido en América, para el tránsito al Nuevo Régimen. La rica experiencia fundacional estadounidense habilitó la consecución de un modelo de libertad en las relaciones de Iglesia-Estado, y la ordenación del factor religioso. Frente a las fórmulas ideales europeo-continentales, de realización tardía y excesiva -por lo 
que adolecen de un riesgo creciente de entropía social-, en cambio, la experiencia estadounidense demuestra que, pese a los traspiés de la ejecución del citado método ensayo-error, ello ha sido conveniente para ir descubriendo el camino efectivo hacia la implantación de un auténtico entorno de tolerancia social y un tasado respeto al libre examen (de conciencia), que son los cimientos de la libertad religiosa vigente. En analogía con la célebre máxima de EDISON -el gran inventor estadounidense del s. XIX-al concebir la bombilla, entonces, los modelos coloniales puestos en práctica no resultaron un rotundo fracaso (como los primeros intentos de EDISON), sino mil maneras diferentes de descubrir cómo no debía ser un modelo funcional a largo plazo, y sin cuyo bagaje, habría sido prácticamente imposible llegar al modelo vigente. Por tanto, cualquier intento de retrotraerse anacrónicamente a los modelos fundacionales (como la falacia neocon, en su variante del originalismo de SCALIA, Magistrado del Tribunal Supremo de EE.UU.-TSEU), sin tener en cuenta sus sucesivas adaptaciones coyunturales, no sólo supone una traición al legado de los padres fundadores, sino que también resulta una desnaturalización del Ordenamiento vigente (un tipo de activismo judicial pernicioso) $)^{622}$.

b. En cuanto al reciente incremento de la regulación en materia religiosa (máxime en las primeras décadas de la globalización: años 1990 y 2000), inicialmente en Derecho Legislativo o Statutory Law, seguido del Derecho Administrativo o Executive Law, y poco después también el Derecho Judicial o Case Law (ídem),

\footnotetext{
${ }^{622}$ Se retuerce el sentido de la ley hasta que exprese las propias creencias, además de dar causa a aquello no regulado, incurrir en prevaricación, etc. Vid. SÁNCHEZ-BAYÓN, A.: Filosofía JurídicoPolítica Glocal... op. cit.
} 
todo ello supone un riego de hiperinflación normativa ${ }^{623}$, contraria a la confianza en el pueblo estadounidense y su autonomía. Igualmente, representa la amenaza de quiebra de la coherencia entre la normatividad de los diversos órdenes o esferas sociales (o sea, que las leyes y los mandatos ético-morales, por ejemplo, siguieran un mismo sentido). Tal coherencia, hasta ahora ha venido dada gracias al papel mediador entre órdenes de ACR; sin embargo, una hiperinflación supondría la amenaza de su necrosación, por pérdida de capacidad de adaptación, además de generar otros problemas, como los aluviones de objeción de conciencia y desobediencia civil (como ya se ha conocido en otros tiempos, dando lugar a conflictos sociales, v.g. Guerra Civil, Gran Depresión).

\section{b2) Las Escrituras sagradas de ACT: DIE, CEU \& BR}

Como ya se ha mencionado, al menos tres son los grandes textos políticojurídicos estadounidenses, piedra angular del sistema vigente (no sólo de su ACR, sino del mismísismo sistema de orden, vid. infra cap. 4), resultando parte de la principal muestra del legado de los padres fundadores. Si han alcanzado dicha condición ha sido gracias al cambio de mentalidad habilitado por la secularización moderna, y sobre todo por el influjo de la Teología política, al facilitar la

${ }^{623} \mathrm{El}$ boom regulatorio de la globalización sobre libertad religiosa (iniciado por los laicistas de la Administración CLINTON, y aprovechado luego por los neocon de la Administración W.BUSH), ha resultado justo lo contrario: un intento de limitar la figura e instrumentalizarla para reconstruir la identidad estadounidense y el sentido de su misión y visión del mundo (v.g. sistema IRFA), así como para su gestión doméstica en las interacciones ciudadanas (v.g. The First Freedom Project, FBOs); vid. infra cap. 4 y 7. 
transferencia de la sacralidad tradicional, propiamente religiosa, hacia la sacralidad moderna o civil (o sea, de la veneración de la Biblia a la de la Constitución).

¿Cómo ha tenido lugar tal transferencia y conversión en Escrituras Sagradas de ACT? Para responder, se acomete seguidamente un estudio clínico de CEU (como ordenación primigenia que inspira el resto del Derecho) y DIE (su complemento interpretativo), mediante el recurso de técnicas tales como la exégesis, la hermenéutica (incluida la jurisprudencia) y la heurística. Por tanto, lo primero en abordarse, en las páginas siguientes, es el estudio originario de CEU, seguido de su actualización jurisprudencial, para terminar con el complemento interpretativo germinal que supone la DIE. Como se puede apreciar, todo un sistema de fuentes político-jurídicas, de naturaleza dual, como pasa con las fuentes de los Ordenamientos confesionales (por su parte civil y su parte de ACR). 


\section{CEU: ordenación primigenia ${ }^{624}$.}

Tres son los puntos básicos a tratar en este apartado, sobre cómo se ha codificado la regulación constitucional acerca del factor religioso (cimiento del resto del Ordenamiento): a) las notas contextualizadoras del proceso constituyente, relativas a la Convención Constitucional de Filadelfia, con sus tribulaciones y documentos de trabajo; b) los preceptos constitucionales aprobados (explícitos e implícitos, sobre el factor religioso), analizados clínicamente, con ciertas

${ }^{624}$ No se tratan aquí los preceptos constitucionales estatales por varias razones, que atañen, principalmente, a la lógica analítica y sistemática de la distribución aplicada a la materia en el estudio: para evitarse innecesarias complejidades expositivas (al requerirse entonces de una distinción entre la normativa histórica y la presente), y debido a que el sistema de libertades civiles en los EE.UU. es claro tras la aprobación de la Decimocuarta Enmienda, consagradora del control Federal en la materia, entonces, los preceptos constitucionales estatales resultan -más bien- un complemento de los preceptos de la CEU (siempre dentro de sus límites). Por tanto, se ha considerado más conveniente para facilitar la comprensión de la red normativa, el remitir a lo dicho previamente al tratar los modelos relacionales de Iglesia-Estado (con las Declaraciones y Constituciones citadas). En cualquier caso, los avances de la citada regulación histórica han quedado integrados en la CEU, y su complemento, como es la DIE (al ser ambos textos modélicos). Para la consulta de preceptiva histórica y su influjo en la CEU y DIE, vid. ADAMS, A.M., EMMERICH, C.J.: A Nation dedicated to Religious Liberty. The Constitutional Heritage of Religion Clauses, Philadelphia: University of Pennsylvania Press, 1990. COGAN, N.H. (ed.): The complete Bill of Rights. The Drafts, Debates, Sources, and Origins, New York: Oxford University Press, 1997. GAUSTAD, E.S.: Faith of the Founders. Religion and the New Nation 1776-1826, Waco: Baylor University Press, 1993. KURLAND, P.B., LERNER, R. (eds.): The Founders' Constitution (vols. I-V), Indianapolis: Liberty Fund, 1987. PATRICK, J.J., LONG, G.P. (eds.): Constitutional debates on Freedom of Religion. A documentary History, Westport: Greenwood Press, 1991. THORPE, F.N.: The Federal and State Constitutions, Colonial Charters, and other Organic Laws (vols. 1-7), Washington DC: Government Printing Office, 1909. Complement., vid. Avalon Project-Yale Law School (URL: http://www.yale.edu/lawweb/avalon/avalon.htm). From Revolution to Reconstruction Project-University of Groningen (URL: http://www.let.rug.nl/ usa/D/index.htm). Sobre la preceptiva presente, vid. ANTIEUS, C.J., et al.: Religion under the State Constitutions, New York: Brooklyn, 1965. VV.AA.: Religious Liberty and State Constitutions, Buffalo: Prometheus Books, 1993. Igualmente, para conocer las más recientes versiones adoptadas, basta con consultar las páginas electrónicas oficiales de cada uno de los Estados de la Unión. 
observaciones heurísticas y exegéticas; c) los preceptos tramitados y no ratificados, o sea, las enmiendas coyunturales que no vieron la luz.

a) Notas contextualizadoras: en los anteriores apartados, se ha explicado el devenir de las colonias americanas, nacidas de asentamientos de diverso origen y entidad, que progresiva y programáticamente habían sido incorporadas al Imperio Británico y cuya integración consistía en un formalismo identitario anglicano (v.g. juramento de supremacía), bastante relajado, pues los verdaderos intereses eran los comerciales y los tributarios. Tales condiciones (junto con la herencia del PWF y el ICS, vid. infra), favorecieron la afloración de alianzas internas desde época temprana. Como ya se ha mencionado, para encontrar los cimientos claros del constitucionalismo estadounidense, su proto-experiencia está en el Primer Congreso Continental de 1774, en Filadelfia, donde se aprobaron los Artículos de Asociación, así como, otras tantas normas domésticas y transnacionales, frente las Leyes intolerables de ese mismo año, aprobadas por el Parlamento Británico, en su programa de remodelación administrativa del Imperio (en lo tocante a América, tras las incorporaciones de territorios gracias a las Guerras de Sucesión Española, de los Siete Años, y las Indias). Surge así, también, el primer proto-gobierno nacional estadounidense, el Segundo Congreso Continental, actuando más dicho sentido (con una política y ejército común frente a UK), que como un foro de debate colonial. El Congreso, igualmente, reunido en Filadelfia, desde mayo de 1775, se mantiene así durante catorce años. Durante este periodo, se redactan y aprueban -con vocación nacional- la DIE (4 de julio de 1776), los Artículos de Confederación (1777-81), el Tratado de París (firmado en septiembre de 1783 y ratificado por el Congreso en enero de 1784), la Ordenanza 
de los Territorios del Noroeste (14 de julio 1787) y, finalmente, la CEU (firmada en septiembre 1787 y ratificada por los Congresos estatales en junio 1788).

Llegándose este punto, al de la tramitación de la CEU, y como sobre los Framers o Constituyentes ya se ha rendido cuenta -desmontándose algunas de las imposturas más frecuentes sobre sus contribuciones y autorías-, se dedican las líneas siguientes a esbozar sucinta y expeditivamente las propuestas constitucionales manejadas acerca del modelo relacional Iglesia-Estado. Se distinguen así tres bloques: en primer lugar, las propuestas de la Convención, de donde se extrae el borrador definitivo, que una vez firmado, se manda a los Estados para su ratificación. Consecuentemente, las propuestas de enmienda de los Estados en sus ratificaciones, manifestándose la necesidad de incorporar una Bill of rights o declaración de derechos a la Constitución (son las diez primeras enmiendas de CEU). Por último, las propuestas tramitadas por el Congreso (la Cámara de Representantes y el Senado), para la adopción de la Primera Enmienda $a^{625}$.

${ }^{625}$ Cfr. ARIENS, M.S., DESTRO, R.A.: Religious Liberty in a Pluralistic Society... op. cit, pp. 74 ss. GAUSTAD, E.S.: Faith of the Founders. Religion and the New Nation 1776-1826, Waco: Baylor University Press, 1993, pp. 156. KURLAND, P.B., LERNER, R.: The Founders' Constitution (vol. V)... op. cit., pp. 11 ss. MALBIN, M.J.: Religion and Politics: The intentions of the Authors of the First Amendment, Washington DC: AEI, 1978, pp. 3 ss. McCONNELL, M.W., et al.: Religion and the Constitution, Gaithersburg: Aspen Publishers, 2002, pp. 71 ss. STOKES, A.P.: Church and State in the United States (vol. 1)... op. cit., pp. 519 ss. WITTE, J.: Religion and the American Constitutional Experiment. Essential Rights and Liberties... op. cit., pp. 241 ss. Vid. ELLIOT, J (ed.): The debates in the several State Conventions on the adoption of the Federal Constitution (vols. 1-5), New York: Burt Franklin, 1888. VV.AA.: Annals of Congress. The debates and proceedings in the Congress of the United States (vols. 1-42), Washington DC: Gales \& Seaton, 2000. 
- Las propuestas de la Convención:

$>$ "El Parlamento de los EE.UU. no pasará ley alguna en materia de religión", propuesta de C. PINCKNEY (29 de mayo de 1787), sin éxito y por tanto, sin condición de moción, ni debate en el Comité.

> "No podrá ser requerido test/examen religioso alguno como una cualificación para detentar cargo o negocio público bajo la autoridad de los EE.UU.", moción de C. PINCKNEY (30 de agosto de 1787), aprobada sin oposición.

$>$ "El Congreso tendrá poder para establecer una Universidad, donde no quepa preferencias o distinciones por razón religiosa", moción de C. PINCKNEY y J. MADISON (14 de septiembre de 1787), con oposición de MORRIS, siendo desestimada finalmente (seis votos en contra, frente a cuatro a favor y uno dudoso).

- Las propuestas de los Estados (al ratificar la CEU): Maryland se adelanta en el proceso, con un borrador emitido por un grupo minoritario (6 de mayo de 1788), pero no obtiene el respaldo necesario de la mayoría, por lo que ha de esperarse hasta 1789 para mandar la propuesta. En cambio, entre las proposiciones que sí se tramitan a tiempo, se han elegido los siguientes ejemplos, por tratarse de aquellas presentadas por los Estados que mostraron una mayor oposición a la ratificación de la CEU, si no se incorporaba una Bill of rights o declaración de derechos.

$>$ “El Congreso no podrá aprobar leyes en lo tocante a la religión, o infringir los derechos de conciencia", propuesta de New Hampshire (21 de junio de 1788). 
> “La religión, la obligación con nuestro creador, y la manera de rendirle culto, puede ser sólo dirigida por la razón y la convicción, no por la fuerza o la violencia, por consiguiente todos los hombres tienen igual, natural e inalienable derecho al libre ejercicio de la religión de acuerdo con los dictados de la conciencia, y que ninguna secta o sociedad religiosa puede ser favorecida o establecida por ley en preferencia sobre otras", propuesta de Virginia (27 de junio de 1788) -sirve de referencia para North Carolina (1 de agosto de 1788) y Rhode Island (16 de junio de 1790).

> "La gente tiene un igual, natural e inalienable derecho al libre y pacífico ejercicio de su religión, de acuerdo con los dictados de la conciencia; y que ninguna secta o sociedad religiosa puede ser favorecida o establecida por ley en preferencia sobre otras", propuesta de Nueva York (26 de julio de 1788).

> "Cualquier persona con escrúpulos religiosos de portar armas puede quedar liberada, para su cumplimiento basta con emplear a otra persona de su confianza que lo haga (...) La religión, la obligación con nuestro creador, y la manera de rendirle culto, puede ser sólo dirigida por la razón y la convicción, no por la fuerza o la violencia, por consiguiente todos los hombres tienen igual, natural e inalienable derecho al libre ejercicio de la religión de acuerdo con los dictados de la conciencia, y que ninguna secta o sociedad religiosa puede ser favorecida o establecida por ley en preferencia sobre otras", propuesta de North Carolina (1 de agosto de 1788). 
- Las propuestas para la Primera Enmienda ${ }^{626}$ : el 8 de junio de 1789, MADISON compilando las propuestas estatales recibidas-, presenta al Congreso dos borradores de enmienda ${ }^{627}$, cuyo debate genera la conformación de un Comité especial (21 de julio) -donde también interviene MADISON. Dicho Comité elabora un informe con tres propuestas autónomas ${ }^{628}$, siendo presentado el 28 de julio y aprobándose sin debate el 13 de agosto, puesto que habría de ser objeto de discusión, desde el 15 de agosto, en la Cámara de Representantes donde también figuraría MADISON-.

Debate en la Cámara de Representantes: a) “El Congreso no aprobará leyes en lo tocante a la religión, o para infringir los derechos de conciencia", propuesta de C. LIVERMORE (15 de agosto), que pasa a ser una moción de la Cámara; b) “La igualdad en los derechos de conciencia, de libertad de expresión y prensa, y del derecho a un proceso con jurado en casos criminales", propuesta por F. AMES (20 de agosto) e, igualmente, adoptada como moción de la Cámara. El 22 de agosto se manda al Senado una moción conjunta, “El Congreso no aprobará ley alguna para establecer una religión,

${ }^{626}$ Vid. Madison's proposed Amendments (June 8, 1789), Report of the House Committee of Eleven (July 28, 1789), Amendments passed bay the House (Aug. 24, 1789), Amendments passed by the Senate (Sept. 9, 1789), Amendments passed by Congress and sent to States (Sept. 25, 1789),

627 Propuesta A: “Los derechos civiles de nadie podrán ser limitados de manera alguna en las creencias y credos religiosos, ni podrá ser establecida ninguna religión nacional, ni podrán ser infringidos, de ninguna manera o pretesto, los derechos protectores de una plena e igual libertad de conciencia". Propuesta B: "Ningún Estado podrá violar la igualdad en los derechos de conciencia, o de libertad de prensa, o de proceso con jurado en los casos criminales".

${ }^{628}$ Propuesta A: "Ninguna religión será establecida por ley, ni será infringida la igual en los derechos de conciencia". Propuesta B: "Ninguna persona con escrupulos religiosos podrá ser obligado a portar armas". Propuesta C: "Ningún Estado podrá infringir la igualdad en los derechos de conciencia, de libertad de expresión o prensa, o de proceso con jurado en los casos criminales". 
o para prohibir su libre ejercicio al respecto, ni podrán ser infringidos los derechos de conciencia".

Debate en el Senado: a) "El Congreso no aprobará ley alguna para el establecimiento de religión, o para prohibir el libre ejercicio de culto" (3 de septiembre); b) “El Congreso no aprobará ley alguna para el establecimiento de artículos de fe o un modo de credo, o para prohibir el libre ejercicio de la religión" (9 de septiembre). Finalmente, el 24 de septiembre, se adopta la versión definitiva “El Congreso no aprobará ley alguna para el establecimiento de religión, o para prohibir el libre ejercicio al respecto", que al día siguiente es elevada (conjuntamente con la Cámara de Representantes) a la condición de moción para la Primera Enmienda.

b) Preceptos constitucionales ${ }^{629}$ : antes de proceder pormenorizadamente con la preceptiva de la CEU, se invita a recordar y tener presente las soluciones de armonización (vistas en las consideraciones preliminares de esta parte del estudio). Ello ha de permitir entender, con algo más de claridad, el criterio empleado de categorización jerarquizada (de acuerdo con la misma CEU y la práctica del ACL), lo que supone que, en primer lugar, y con preferencia, se tratan las normas expresas sobre el factor religioso y su reconocimiento de eficacia civil (e.g. relaciones Iglesia-Estado, libertad religiosa, asistencia socio-

${ }^{629}$ Vid. BLAU, J. (ed.): Cornerstones of Religious Freedom in America, Boston: The Beacon Press, 1949. BOORSTIN, D.J. (comp.): An American Primer, Chicago: The University of Chicago Press, 1966. COGAN, N.H. (ed.): The complete Bill of Rights. The Drafts, Debates, Sources, and Origins, New York: Oxford University Press, 1997. KURLAND, P.B., LERNER, R. (eds.): The Founders' Constitution (vols. I-V), Indianapolis: Liberty Fund, 1987. LEVY, L.W. (ed.): Encyclopedia of the American Constitution (vol. 1-4), New York: MacMillan, 1986. WITTE, J.: Religion and the American Constitutional Experiment. Essential Rights and Liberties... op. cit. 
religiosa); seguidas del bloque de reflejos del ICS; y, por último, las relativas al desarrollo de las libertades civiles (que operan en conjunto con la libertad religiosa y garantizan la intimidad).

- Regulación explícita: abarca los dos preceptos que regulan expresa y sustancialmente la religión (art. VI y Primera Enmienda), más aquel que fija las reglas procesales al respecto (Decimocuarta o Catorce Enmienda) ${ }^{630}$. Las disquisiciones principales que se abordan, son las relativas al test/prueba religiosa, el juramento, la cláusula de (no)establecimiento, la cláusula de libre ejercicio (religioso), la cláusula de igualdad (y control/supervisión), y la (santificación de la) propiedad.

$>$ Art. VI ${ }^{631}$ : religious test $\mathcal{E}$ oath [prueba religiosa y juramento].

Contenido: "The Senators and Representatives before mentioned, and the Members of the several State Legislatures, and all executive and judicial Officers, both of the United States and of the several States, shall be bound by Oath or Affirmation, to support this Constitution; but no religious Test shall ever be required as a Qualification to any Office or public Trust under the United States" [Los Senadores y Congresistas anteriormente mencionados, los miembros de las diversas legislaturas estatales, y todos los funcionarios ejecutivos y judiciales, tanto de los Estados Unidos de América

\footnotetext{
${ }^{630}$ En el inglés de los EE.UU. existe una tendencia a simplificar (para facilitar la comunicación), prefiriéndose las denominaciones numerales a las nominales, la fórmula arábiga a la romana, y los números ordinarios a los ordinales (v.g. no es habitual la expresión "Decimononic Century", ni "XIX Century", sino "19th Century" o directamente "19 c."). De ahí que en este estudio se use indistintamente las traduciones ordinales y ordinarias para las enmiendas constitucionales, pues se pretende combinar el respeto por lo original (el inglés estadounidense), pero acercándolo al receptor lector (en español).

${ }^{631}$ Precepto aprobado el 17 de septiembre de 1787 y ratificado el 21 de junio de 1788.
} 
como de los diversos Estados, se obligarán mediante juramento o promesa, para sostener esta Constitución; pero nunca se exigirá una prueba religiosa como condición para ocupar cargo o mandato público en los Estados Unidos], en art. VI, pto. 3.

Comentarios: pese a tratarse de dos instituciones autónomas, la prueba religiosa y el juramento, sin embargo guardan entre sí una íntima relación, pues ambas previenen del mismo ámbito, que es el Derecho Eclesiástico Británico (v.g. Ecclesiastical Licences Act 1533) y sus reflejos coloniales en las Blue Laws (vid. infra) -además, en su realización, toda prueba religiosa requiere de cierto juramento, a la vez que, todo juramento resulta en buena medida una prueba religiosa ${ }^{632}$.

La prueba religiosa es una herencia de la época de los asentamientos, cuando -para asegurar la continuidad y el orden del grupo- había que declarar públicamente el compromiso con la comunidad y el rechazo de otras identidades colectivas -ello quiere significar que, el individuo puede optar entre adoptar públicamente la religión dominante o constituir un asentamiento propio (vid. infra). El juramento, por su parte, proviene del oath of supremacy o juramento de supremacía, por el que el compromiso se adquiriría con el monarca, al que se le aseguraba lealtad poniendo como testigo a Dios. Ahora bien, con este artículo y otros concordantes (v.g. arts. I y II, más Cuarta y Decimocuarta Enmiendas), se pretende poner fin a tal práctica invasiva de la intimidad, gracias a una libertad garante de la diversidad

\footnotetext{
${ }^{632}$ Esta interdependencia y cierta fusión se constata mejor hoy en día en polémicas vivas y abiertas como el Pledge of Allegiance [compromiso de lealtad o saludo a la bandera], o el juramento en Corte (vid. infra); ahí radica la habilidad del posjudeocristianismo, por no ser exclusivo y excluyente.
} 
religiosa tradicional, pero manteniendo un compromiso común con la religión civil estadounidense: de ahí que no se pueda exigir prueba religiosa alguna -pues se entiende que, cada cual, ha de ser fiel a la religión tradicional que decida, a la vez que se jura compromiso a la CEU y al AWL.

La materia, máxime la cuestión del juramento (vid. infra), ha evolucionado considerablemente -como se ve en los preceptos concordantes citados-, adoptando diversas modalidades de alcance fluctuante (v.g. liberalización en formas hasta 1850, intensificación de garantías de lealtad durante la Guerra Civil, generalización para casi cualquier acto público tras las Guerras Mundiales -aunque de forma leida o dirigida). Para el presente punto, se ha decidido tratar el proceso de recepción de este rito posjudeocristiano por aquellas confesiones minoritarias que han conseguido algún representante entre los más altos cargos del país (como los citados por el art. VI): a) los cuáqueros, lograron desde los primeros años de la entrada en vigor del juramento, la incorporación de una opción complementaria de ejecución, como es to affirm [prometer] (en vez de to swear [jurar]), tal y como hizo HOOVER en su momento; b) los católicos, que en el caso de KENNEDY, éste utilizó una versión propia de la Biblia (distinta de las protestantes, usadas por otros Presidentes); c) los budistas, como los Congresistas HIRONO (Hawaii) y JONSON (Georgia), prometiendo la primera sin la Biblia -pese a haberla usado con anterioridad para la toma de posesión de su cargo como Gobernadora-, y siguiendo el rito habitual el otro -por respeto a la tradición; d) los musulmanes, que con ELLISON, es la primera vez que tienen un Congresista, quien suscitó una tremenda polémica al pretender jurar su cargo con una copia del Corán; etc. 
$>$ Primera Enmienda633: (no) establishment clause $\mathcal{E}$ free exercise clause [cláusula de (no) establecimiento y cláusula de libre ejercicio].

Contenido: "Congress shall make no law respecting an establishment of religion, or prohibiting the free exercise thereof" [El Congreso no aprobará ley alguna para el establecimiento de religión [oficial], o para prohibir el libre ejercicio de credo], en Primera Enmienda, $1^{\underline{a}}$ y $2^{\underline{a}}$ línea.

Comentarios: En términos generales, existe una larga tradición judeocristiana en la distinción entre lo material y lo espiritual, como desvela la ya mencionada máxima del dualismo cristiano, "al césar lo que es del césar, y a Dios lo que es de Dios" (Mt 22:15-22; Mc 12:13-17; Lc 20:20-26; vid. infra). En términos más específicos, y ya así lo quisieron los padres fundadores al fijar una doble regulación sobre la materia, distinguiéndose en consecuencia entre dos cláusulas: a) la (no) establishment [(no) establecimiento]; b) la free exercise [libre ejercicio].

Respecto a la cláusula de (no) establecimiento, resulta necesario precisar que, no es lo mismo que disestablishment o desestablecimiento -como algunos autores han pretendido argumentar y confundir desde la década de 1980. Se trata de una impostura de traducción o lingüística, pues el (no) establecimiento, meramente, limita a los poderes públicos a no fijar una religión oficial, mientras que el desestablecimiento, supondría que: a) existe una religión oficial común a extinguir -supuesto que ni durante el anglicanismo colonial se produjo, por tratarse de un confesionalismo formal para asegurar funciones públicas más seculares, como el comercio y la recaudación de

${ }^{633}$ Precepto aprobado el 25 de septiembre de 1789 y ratificado el 15 de diciembre de 1791. 
impuestos; b) los poderes públicos, no tendrían una obligación de no hacer, sino de hacer, con lo que dicha función entraría en disonancia con la otra cláusula; c) el desestablecimiento supondría la extinción de los principios de integración y acomodación -quedando sólo operativos los de autonomía y separación; etc.

En cuanto a la cláusula de libre ejercicio, ésta si es una obligación de hacer, por parte de los poderes políticos, que deben promover la pluralidad religiosa, la tolerancia social y el libre examen individual.

$>$ Decimocuarta o Catorce Enmienda ${ }^{634}$ : equal clause, property \& oath [cláusula de igualdad, (santificación de) propiedad y juramento].

Contenido: "No State shall make or enforce any law which shall abridge the privileges or immunities of citizens of the United States; nor shall any State deprive any person of life, liberty, or property, without due process of law; nor deny to any person within its jurisdiction the equal protection of the laws" [Ningún Estado podrá dictar ni dar efecto a cualquier ley que limite privilegios e inmunidades de los ciudadanos de los Estados Unidos; tampoco podrá Estado alguno privar a cualquier persona de la vida, la libertad o la propiedad sin el debido proceso legal; ni negar a cualquier persona que se encuentre dentro de sus límites jurisdiccionales la igual protección de las leyes], en la Decimocuarta Enmienda, secc. 1.

Comentarios: la idea más relevante de esta sección, es la relativa a la equal ( $\mathcal{E}$ control) clause [cláusula de igualdad (y supervisión)]. La primera dimensión de esta única cláusula -a diferencia de la Primera Enmienda y sus dos

${ }^{634}$ Precepto aprobado el 13 de junio de 1866 y ratificado el 9 de julio de 1868. 
cláusulas expresas sobre religión-, es la relativa a la igualdad, mientras que la segunda, de tipo procesal, versa sobre la supervisión de las libertades civiles por el Poder Federal. En cuanto a la noción de igualdad, ésta es la recibida de la tradición judeocristiana (Gn 1:26-27), que tras su estadounidización, es tipificada en la DIE, como el reconocimiento de que todos los hombres son creados iguales, con unos derechos y libertades inalienables ${ }^{635}$. Otra muestra de tipificación, en la propia CEU, es el art. I, secc. 10, pto. 1, que desautoriza los títulos nobiliarios. Para garantizar el cumplimiento de tal premisa del sistema estadounidense de libertades civiles, y armonizar la dispersión posible a través de las Novena y Décima Enmiendas, se hace necesario que el TSEU se convierta en el referente último de la materia, vigilando que en todo momento cualquier ciudadano estadounidense sea igual ante la ley.

Ahora bien, expuesta la teoría, la realidad es tozuda, puesto que a los Estados de la Unión les cuesta ir extinguiendo las prácticas de preferencialismo religioso, la no discriminación de las minorías, etc. Debido a que el proceso de homogeneización de las libertades civiles, para todos los EE.UU., es lento y tortuoso, llegando a necesitarse un siglo, para que en la década de 1960, tenga lugar el Movimiento de Derechos Civiles, gracias al cual, se acortan distancias entre la retórica jurídica y su realidad sociológica.

Sobre la santificación de la propiedad, ésta es otra herencia judeocristiana más (Ex 20:15; Dt 5:19), que se ve con mayor detalle en la Quinta Enmienda.

\footnotetext{
635 También es conocidísima y fundamental la difusión -como Derecho Ejecutivo e impulsor de políticas públicas-, que de la igualdad entre estadounidense (como hijos de dios y detentores de derechos inalienables) acomete el Presidente LINCOLN, en el Discurso de Gettysburg (1863).
} 
Contenido: "No person shall be a Senator or Representative in Congress, or elector of President and Vice President, or hold any office, civil or military, under the United States, or under any State, who, having previously taken an oath, as a member of Congress, or as an officer of the United States, or as a member of any State legislature, or as an executive or judicial officer of any State, to support the Constitution of the United States, shall have engaged in insurrection or rebellion against the same, or given aid or comfort to the enemies thereof. But Congress may by a vote of two-thirds of each House, remove such disability" [Ninguna persona podrá ser Senador o Representante en el Congreso, ni elector del Presidente y Vicepresidente, o ocupar cargos, civiles o militares, en los EE.UU., o en cualquiera de los Estados, si habiendo prestado previamente juramento, como miembro del Congreso, o como oficial/funcionario de los EE.UU., o como miembro de cualquier legislatura de alguno de los Estados, o como oficial/funcionario del Poder Ejecutivo o Judicial, para defender la Constitución de los EE.UU., hubiera incurrido en insurrección o rebelión contra la misma (la CEU), o hubiera dado auxilio o consuelo a los enemigos. Pero el Congreso puede votar por dos tercios de cada Cámara, para remover tal inhabilidad], en la Decimocuarta Enmienda, secc. 3.

Comentarios: una vez más se aborda la cuestión del juramento, pero esta vez, sin revocar del todo el Ironclad Test Oath [juramento de hierro] ${ }^{636}$, en cambio, se pretende la reconciliación de las elites de poder tras la Guerra Civil. De ahí se deriva la última sentencia de la sección, donde la traición de los

\footnotetext{
636 Vid. Ironclad Test Oath, adoptado el 2 de julio de 1862, por el 37º Congreso, en $2^{\text {a }}$ Sesión, en el Capítulo 128, en la Ley de juramentos o Act to Prescribe and Oath of Office and for other purposes.
} 
funcionarios sureños puede quedar perdonada. El juramento de hierro, igualmente, resulta interesante, pues introduce la expresión final so help me god [con la ayuda de Dios], reforzándose aún más si cabe la sacralidad del juramento de lealtad exigido.

- Regulación implícita: se compilan en este apartado los preceptos constitucionales sin mención expresa, pero sí relacionados con la ordenación del factor religioso y sus reflejos del ICS. Se trata de aquellas reglas que aprovechan las fórmulas y figuras de la tradición sacra occidental (pasadas por el filtro de la secularización), dando lugar así a valiosas neofetichizaciones de las instituciones más relevantes de la sociedad moderna, con lo que se salvaguardan las mismas y la propia CEU incrementa su sacralidad -pues dicha condición, por la que la CEU se valora como la Sagrada Escritura del Nuevo Régimen, es también un reflejo más del ICS-. Los reflejos a comentar, extraídos de la CEU, son las neofetichizaciones de pueblo, unión, bienestar, contratos, propiedad, deshonra, buen comportamiento, etc., más ciertas prácticas secularizadas, como la excepción dominical, el juramento, el Derecho Natural y de Gentes, la corrupción sanguinea, el testimonio, la plena fe, etc.

> Preámbulo637: People, Union (Secular Covenant) \& blessines of liberty [pueblo, unión (alianza secular) y bendiciones de la libertad].

"We the People of the United States, in Order to form a more perfect Union, establish Justice, insure domestic Tranquility, provide for the common defence, promote the general Welfare, and secure the Blessings of Liberty to

${ }^{637}$ Precepto aprobado el 17 de septiembre de 1787 y ratificado el 21 de junio de 1788. 
ourselves and our Posterity, do ordain and establish this Constitution for the United States of America" [Nosotros el pueblo de los EE.UU., a fin de formar una Unión más perfecta, para establecer justicia, asegurar la tranquilidad interior, proveer la defensa común, promover el bienestar general y asegurar para nosotros mismos y nuestros descendientes las bendiciones de la libertad, ordenamos e instituimos esta Constitución para los EE.UU.].

Contenido: "We the People of the United States" [Nosotros el pueblo de los Estados Unidos], en el Preámbulo, 1ํa línea.

Comentarios: en tan pocas palabras no podría condensarse mejor la esencia del ICS, puesto que, al mismo tiempo, se logra fijar una identidad común discurso judío del nosotros v. demás- y su unanimidad -del discurso ecuménico cristiano-, además de reconocerse su dignidad como pueblo elegido- y su condición de vehículo de legitimidad secular del poder. Se trata de ejercicios de neofetichización de tal calibre, que cabe preguntarse hoy en día, ¿hasta qué punto estaban autorizados los delegados estatales, en del Congreso Continental, para hablar en nombre de todos y no sólo en representación de sus Estados correspondientes? (vid. art. VII, junto con DIE).

Contenido: "in Order to form a more perfect Union (...) do ordain and establish this Constitution for the United States of America" [a fin de formar una Unión más perfecta (...) ordenamos e instituimos esta Constitución para los EE.UU.], en el Preámbulo, $2^{a}$ y última línea.

Comentarios: la idea de la unión como alianza (de origen bíblico), ya se trató con detalle al abordar la ACT y el Federalismo (vid. infra). En lo relativo a su 
redacción, se llama la atención sobre dos cuestiones: a) su incorrección gramatical ("more perfect" [más perfecta] -o es perfecta o no lo es), se explica por el ánimo de superar las deficiencias de intentos previos ${ }^{638}$; b) su pompa ("do ordain and establish this Constitution for the United States of America" [ordenamos e instituimos esta Constitución para los EE.UU.]), sigue la ritualística de los pactos bíblicos (vid. infra), como forma de sacralizar el documento -de ahí que, se prive a los Estados de la posibilidad de celebrar otras alianzas así (art. I, secc. 10, pto. 1).

Contenido: "establish justice, insure domestic tranquility, provide for the common defense, promote the general welfare" [para establecer justicia, afianzar la tranquilidad interior, proveer la defensa común, promover el bienestar general], en el Preámbulo, $3^{\underline{a}}$ y $4^{\underline{a}}$ línea.

Comentarios: se trata de la descripción del paraíso terrenal, tal y como se considera a America ("a city upon de hill" [una ciudad en lo alto de la colina], WINTHROP; “New Zion” [Nuevo Sión/Jerusalem], COTTON; “a garden in the wilderness" [un jardin en la jungla], WILLIAMS, etc.). En tal sentido, y sirviendo de referencia el art. III de los Artículos de Confederación, se enuncian y constitucionalizan aquellas condiciones mínimas definitorias del Nuevo régimen que se pretende alcanzar con los EE.UU.

\footnotetext{
${ }^{638}$ Quizá el referente más inmediato que los Framers tenían en sus cabezas, era el del Preámbulo de los Artículos de Confederación, donde su tipificación de "perpetual Union" [unión perpetua] careció de éxito, incluso, tras la enmienda de la CEU, pues no se pudo evitar las tensiones estatales previas a la Guerra de 1812 y la de Secesión (o Civil). Vid. SÁNCHEZ-BAYÓN, A.: Lecturas fundamentales de Derecho Político y Constitucional, Porto: Ed. Sindéresis, 2017. - ¿Ocaso estatal y de sus relaciones insitucionales y protocolarias? Porto: Ed. Sindéresis, 2018.
} 
Contenido: "the blessines of liberty to ourselves and our posterity" [las bendiciones de la libertad para nosotros mismos y nuestros descendientes], en el Preámbulo, 4ํํำea.

Comentarios: se habla de bendiciones, pues la libertad y demás mecanismos del Ordenamiento estadounidense, se consideran regalos de la divinidad protectora -en el mencionado sentido abierto y difuso posjudeocristiano. Ello guarda relación con la noción de Derecho Natural y de Gentes, junto con el reconocimiento de derechos y libertades inalienables, tal y como se tipifica a lo largo de la CEU (vid. siguientes puntos), y de manera más explícita, en la DIE, junto con las Declaraciones de libertades civiles en las Constituciones estatales (vid. supra). Tal consideración es el fundamento de la sobreautoestima estadounidense o ASR, que sirve, a su vez, para articular el American way of life y el American manifest destiny. Se puede observar también en fórmulas de lealtad pública ya mencionadas, como el Pledge of Allegiance, o en Discursos Presidenciales, igualmente citados, como el de LINCOLN en Gettysburg (1863).

Art. I639: impeachment-oath, Sundays excepted, Law of Nation $\mathcal{E}$ contracts [deshonra-juramento, excepción dominical, Derecho Natural y de Gentes, contratos].

Contenido: "the sole Power of Impeachment (...) on oath (...) and disqualification to hold and enjoy any Office of honor" [el poder de [incoar un proceso de exigencia de responsabilidades por] deshonra (...) [requiere, por parte del funcionario acusado, que esté] bajo juramento (...) [pudiendo

${ }^{639}$ Precepto aprobado el 17 de septiembre de 1787 y ratificado el 21 de junio de 1788. 
quedar] inhabilitado para detentar cualquier cargo de honor/público], en art. I, secc. 2, pto. 5, más secc. 2, ptos. 6 y 7.

Comentarios: este punto responde a la observación que se viene reiterando a lo largo del estudio, sobre el cariz tanto liberal como moral del Ordenamiento estadounidense, pues los funcionarios deben ser y parecer moralmente correctos, ya que en ellos se descansan las funciones de administrar la res publica. Hasta la fecha, tres han sido los Presidentes sometidos al proceso de exigencia de responsabilidades por deshonra -no tanto por el supuesto delito cometido, sino por mentir para intentar ocultarlo a la opinión pública-, JOHNSON (que lo ganó en la votación, al no alcanzarse el quorum). NIXON (que dimitió, antes de producirse la votación) y CLINTON (que pidió disculpas al pueblo estadounidense, con lo que se frenó el procedimiento). De entre los tres casos, el más interesante, a los efectos de este estudio, es el de CLINTON, que a resultas de la conmoción sufre una peculiar reconversión y gestión del discurso religioso.

Contenido: "[bill passed] (Sundays excepted)" [[trámite legislativo] “(Domingos exceptuados)], en art. I, secc. 7, pto. 2.

Comentarios: en la tramitación de las leyes, el Presidente puede vetar un proyecto, que se devuelve al Congreso, y si las dos Cámaras lo aprueban, el Presidente tiene un plazo de diez días para firmarlo, o igualmente entrará en vigor, sólo que bajo la condición de bill en vez de act. Pues bien, en ese plazo de diez días, se exceptúan los domingos, por herencia judeocristiana del descanso por Sabbath o día del Señor (Ex 20,8-10), tal y como se tipificara en las Blue Laws coloniales -el problema está en que hay confesiones que consideran otro el día dedicado a Dios, pues para los musulmanes es el 
viernes, para los judíos y algunos protestantes es el sábado, etc. Además, la cuestión engarza directamente con uno de los grandes dilemas jurídicosociales del s. XIX estadounidense (aunque procede del Primer Despertar Religioso de la década de 1740), como es el Sabbatharism y las Sunday (closing) Laws [leyes (de cierre) dominicales].

Contenido: "offenses against the Law of Nations" [ofensas contra el Derecho de las Naciones/Derecho Natural y de Gentes], en art. I, secc. 8, pto. 10.

Comentarios: como se viene advirtiendo, en los EE.UU., tiene lugar un proceso de fusión entre la tradición sacra y profana occidental, y éste es uno de los mejores casos para ilustrar tal unión, pues permite poner de manifiesto la casación de las interpretaciones romanistas y escolásticas acerca del ius naturales et gentium, aplicándose sus resultados a la noción manejada del Derecho Internacional y la regulación de las libertades civiles ${ }^{640}$. En tal sentido, explícitamente, se tipifica en la DIE y en buena parte de las Constituciones estatales, mientras que en la Constitución se reconoce de forma implícita -para evitar interpretaciones erróneas iusteistas, en vez de iusnaturalistas racionales.

Contenido: "or Law impairing the obligation of contracts" [o ley alguna que menoscabe la obligación de los contratos], en art. I, secc. 10, pto. 1.

Comentarios: de antecedente bíblico (Mat. 18:18), se conoce también este precepto, en los EE.UU., como contract tie [atadura contractual], siendo una iniciativa impulsada por HAMILTON, para que no se violaran los créditos

\footnotetext{
${ }^{640}$ Las vías de penetración e influencia generalizada han sido, sobre todo, en los años coloniales, los Comentarios de BLACKSTONE, y en revitalizaciones posteriores, las Universidades Católicas (especialmente, las Jesuitas).
} 
asumidos antes y durante la Revolución (la Guerra de la Independencia), pues preveía que su incumplimiento mediaría la confianza en el proyecto en marcha. Esta filosofía perduró hasta 1934, cuando la Administración ROOSEVELT introdujo una serie de excepciones debido a la crisis económica y financiera -desde entonces, los Presidentes han actuado con cierta discrecionalidad al respecto.

Art. II ${ }^{641}:$ oath, pardon, faithfully clause \& impeachment [juramento, perdón, cláusula de plena fe, y (responsabilidad por) deshonra].

Contenido: "(Presidential) Oath: I do solemne swear that I will faithfully excute the Office of President of the United States, and will to the best of my Ability, preserve, protect and defend the Constitution of the United States" [Juramento (Presidencial): juro (o prometo) solemnemente que de plena fe desempeñaré el cargo de Presidente de los EE.UU. y con el máximo empeño de mis facultades, preservaré, protegeré y defenderé la CEU], en art. II, secc. 1, pto. 8 .

Comentarios: en el art. VI, se expuso en líneas generales el juramento del funcionariado público; en la Decimocuarta Enmienda, se aclaró parte de la evolución del mismo; en el art. I, se conectó con el proceso de impeachment. En las líneas siguientes, se procede a completar todo lo visto hasta el momento -pues aún queda ver el juramento en las investigaciones, en la Cuarta Enmienda-, ofreciéndose ahora un par de consideraciones sobre la celebración del juramento presidencial. En su ejecución, que por costumbre, se realiza con una Biblia, más la presencia de algún ministro de culto, el

${ }^{641}$ Precepto aprobado el 17 de septiembre de 1787 y ratificado el 21 de junio de 1788. 
Presidente ha de repetir la fórmula tasada en el precepto constitucional, a la que se le ha añadido el broche final, con la ayuda de Dios ${ }^{642}$. Resulta propio del posjudeocristianismo que, a diferencia de otros juramentos de lealtad, no se haga éste respecto de la nación u otros símbolos más plásticos y fácilmente identificables, sino que opera en relación con la CEU, pues según el mismo WASHINGTON (el primer Presidente en jurar el cargo), el primer derecho de un pueblo es el de darse una Constitución, para establecer su orden y comprometerse con él y el documento que lo representa.

Contenido: "he shall have power to grant reprevies and pardons for offenses against to the United States, except in cases of impeachment" [(el Presidente) estará facultado para suspender la ejecución de las sentencias y para conceder indultos en delitos contra los EE.UU., salvo en los casos de acusación por responsabilidades oficiales], en art. II, secc. 2, pto. 1.

Comentarios: al respecto, lo más interesante, amén de la consabida noción de gracia, perdón e indulto en la tradición judeocristiana (Dt 30,15-16), es uno de los episodios más relevantes para la conformación de la noción jurídica estadounidense. Se está haciendo referencia al caso Biddle v. Perovich (274 U.S. 480, 1927), donde el Magistrado HOLMES dejó claro que, pese a la voluntad del condenado, el Presidente puede conceder el indulto y éste ha de ejecutarse, porque no es un acto privado de gracia, sino que es un poder constitucional de la máxima autoridad en la política, responsable del bienestar general.

\footnotetext{
${ }^{642}$ Así es desde el 5 de mayo de 1950, al adoptarse por ley, en el 81ํㅡㄹ Congreso, 2ª Sesión, registrándose en el Capítulo 169, como Ley Pública/Orgánica 506
} 
Contenido: "impeachment" [proceso de exigencia de responsabilidades por deshonra del cargo], en art. II, secc. 2 y secc. 4.

Comentarios: vid. art. I, secc. 2, pto 5, más secc. 2, ptos 6 y 7

Contenido: "he shall take Care that the Laws be faithfully executed" [cuidará del cumplimiento de plena fe de la ley], en art. II, secc. 3.

Comentarios: se trata de una neofetichización de la ley, con fundamento judeocristiano (Provs. 3:1 y 21). Vid. art. IV.

$>$ Art. III ${ }^{633}$ : good behavior, witnesess \& corruption of blood [buen comportamiento, testigos y transmisión de delitos].

Contenido: "The Judges, both of Supreme and inferior Courts, shall hold their Offices during good behavior" [Los jueces, tanto los del TSEU como los de cortes inferiores, cumplirán sus funciones mientras muestren buena conducta], en art. III, sect. 1.

Comentarios: exigencia moral judeocristiana, que guarda relación con lo dicho sobre los funcionarios y su deber de ser y parecer correctos en el cargo, bajo riesgo de impeachment (vid. art. I, secc. 2, pto 5, más secc. 2, ptos 6 y 7).

Contenido: "No person shall be convicted of treason unless on the testimony of two Witnesess to the same overt act, or on confession in open Court" [ninguna persona podrá ser condenada de traición, si no es sobre la base de la declaración de dos testigos que hayan presenciado el mismo acto perpetrado abiertamente o de una confesión en sesión pública en un tribunal], en art. III, secc. 3, pto. 1.

${ }^{643}$ Precepto aprobado el 17 de septiembre de 1787 y ratificado el 21 de junio de 1788. 
Comentarios: se tipifica el imperativo bíblico acerca de cómo ha de ser un testimonio para que sea válido (Dt 17:6; $M c$ 14:55-59). Complementariamente, vid. Quinta Enmienda y su prohibición contra la autoincriminación.

Contenido: "no attainder of treason shall work corruption of blood, or forfeiture except during the life of the person attained" [ninguna condena por traición podrá privar del derecho de heredar o de transmitir bienes por herencia, ni producirá la confiscación de sus bienes excepto en vida de la persona expropiada], en art. III, secc. 3, pto. 2.

Comentarios: se está ante otra evidente influencia bíblica, como es la exclusión de la corrupción de sangre (Dt 24:16), que consiste en que cada hombre ha de responder de sus propios pecados, sin que los hijos se vean afectados por los padres, ni los padres por los hijos. En cambio, en el Derecho inglés medieval y moderno, bajo la acusación de alta traición o lexa maiesta, era excesivamente habitual un uso discrecional de dicha acusación para aplicar la corrupción de sangre, con lo que los bienes del acusado revertían a la Corona. En la América colonial prerrevolucionaria existía un profundo rechazo hacia la Monarquía y sus prácticas abusivas, de ahí el reconocimiento de la exclusión de la corrupción de sangre, tanto por motivos religiosos como políticos -sin embargo, ésta sí tuvo lugar para castigar a los realistas o leales a la Corona, que fueron objeto de expropiaciones.

En lo tocante a las expropiaciones, se trata de una excepción al mandato de (santificación de) la propiedad del art. I y la Quinta Enmienda. 
Como última reflexión -más en la línea de aporía-, ¿no podría considerarse la ley aprobada por la Administración W.BUSH para el caso T. SCHIAVO (en el año 2003), como un supuesto reciente de expropiación para bienes jurídicos tan relevantes como la vida y la intimidad?

Art. IV ${ }^{644}$ faithfully clause [cláusula de fe plena].

Contenido: "Full faith and credit shall be given in each State to the Public Acts, Records, and Judicial Proceedings shall be proved, and the Effect thereof" [Se dará plena fe y crédito en cada Estado a las actas/actos públicos, registros y procedimientos judiciales de todos los demás Estados], en art. IV, secc. 1.

Comentarios: la plena fe, es un acto de religiosidad total, ya que se deposita la confianza en otro, lo que aplicado a la labor de las instituciones públicas, supone su neofetichización.

En lo tocante a la presente sección, se está ante un trasvase claro del art. IV, pto. 3, de los Articulos de Confederación; empero, en el presente caso, no se ha dejado para el final, sino que se ha partido de la cláusula de plena fe, como premisa de las cordiales y fluidas relaciones entre Estados, además de extender su protección los actos de cualquier funcionario. Ello es fundamental, a efectos de este estudio, para garantizar los efectos del Derecho de familia (v.g. reconocimiento de licencias matrimoniales y/o testamentos) $)^{645}$.

${ }^{644}$ Precepto aprobado el 17 de septiembre de 1787 y ratificado el 21 de junio de 1788.

${ }^{645}$ A este respecto y como desarrollo del mandato constitucional, recientemente, se han aprobado las siguientes leyes: Uniform Interstate Family Support Act (1993), Full Faith and Credit for Child Support Orders Act (1994 y enmendada en 1996), etc. 
$>$ Art. VII ${ }^{646}$ : unanimous consent $\mathcal{E}$ year of our Lord [consentimiento unánime y año de nuestro Señor]

Contenido: "Done in Convention by the Unanimous consent" [hecha en convención por consentimiento unánime], en art. VII, pto. 2.

Comentarios: hasta los documentos más sagrados contienen falacias, como en este caso, pues la afirmación de la existencia de consentimiento unánime, no es más que la priorización del discurso sobre la realidad. Al buscarse una vía de neofetichización de la CEU, que legitimara su condición -pues la unanimidad es un rasgo excepcional en la naturaleza humana y prácticamente imposible de materializar-, ello sirvió justo para lo contrario, o sea, poner de manifiesto la falta de la misma. No hubo unanimidad entre todo el pueblo, ni entre los Estados originales, y aún menos entre sus elites de poder, pues para la ratificación hubo divisiones y exigencias de enmiendas con declaraciones de derechos.

Figura 87.- Ratificaciones estatales de la Constitución (CEU)

\begin{tabular}{|lll|}
\hline \multicolumn{1}{|c}{ Estado } & Fecha & Proporciones \\
\hline 1.- Delaware & 7 dic 1787 & $30-0(100 \%)$ \\
\hline 2.- Pennsylvania & 12 dic 1787 & $46-23(67 \%)$ \\
\hline 3.- New Jersey & 18 dic 1787 & $38-0(100 \%)$ \\
\hline 4.- Georgia & 2 ene 1788 & $26-0(100 \%)$ \\
\hline 5.- Connecticut & 9 ene 1788 & $128-40(76 \%)$ \\
\hline 6.- Massachuss. & 6 febr 1788 & $187-168(53 \%)$ \\
\hline 7.- Maryland & 28 abril 1788 & $63-11(85 \%)$ \\
\hline 8.- South Carolina & 23 mayo 1788 & $149-73(67 \%)$ \\
\hline 9.- New Hampshire 21 junio 1788 & $57-47(55 \%)$ \\
\hline 10.- Virginia & 25 junio 1788 & $89-79(53 \%)$ \\
\hline 11.- New York & 26 julio 1788 & $30-27(53 \%)$ \\
\hline
\end{tabular}

${ }^{646}$ Precepto aprobado el 17 de septiembre de 1787 y ratificado el 21 de junio de 1788. 


\begin{tabular}{|ll|}
\hline 12.- North Carolina 21 nov 1789 & $194-77$ (72\%) \\
\hline 13.- Rhode Island 29 mayo 1790 & $34-32(52 \%)$ \\
\hline
\end{tabular}

Fuente: elaboración propia (SÁNCHEZ-BAYÓN, 2007 y 16).

Contenido: "the Year of our Lord" [el año de nuestro Señor], en art. VII, pto. 2.

Comentarios: la mención a Dios, también se reconoce como una muestra aséptica posjudeocristiana, casi en tono meramente formalista -pomposa-, pues mucho más explícitas -y sirviendo para comparar- son las referencias que figuran en las Constituciones estatales ${ }^{647}$.

\section{Cuarta Enmienda ${ }^{648}$ oath [juramento]}

Contenido: "and no warrants shall issue, but upon probable cause, supported by oath or affirmation, and particularly describing the place to be searched, and the persons or things to be seized" [y no se expedirán al efecto mandamientos que no se apoyen en un motivo posible, corroborándose mediante juramento o promesa, y describan con particularidad el lugar a registrar, y las personas a detener o las cosas a incautar], en Cuarta Enmienda, últimas líneas.

Comentarios: para evitar las pesquisas y aprehensiones arbitrarias, se exige este juramento en las investigaciones, con la carga moral y consecuencias de

${ }^{647}$ Casi todas las Constituciones estatales recogen una mención sobre dios en sus Preámbulos, siguiendo la fórmula de la Constitución de Pennsylvania (1776): "We, the people of Pennsylvania, grateful to Almighty God for the blessings of civil and religious liberty" [nosotros, el pueblo de Pensilvania, agradecidos a dios todopoderoso por su bendición de libertad civil y religiosa].

${ }_{648}$ Precepto aprobado el 25 de septiembre de 1789 y ratificado el 15 de diciembre de 1791. 
exigencia de responsabilidades ya vistas (vid. arts. I, II y VI, más la Catorce Enmienda).

$>$ Quinta Enmienda ${ }^{649}$ : limb, witness against himself, property [miembro/limbo, no autoincriminación, (santificación de) propiedad].

Contenido: "nor shall any person be subject for the same offence to be twice put in jeopardy of life or limb" [tampoco ninguna persona podrá ser encausado por la misma ofensa, afectándose su vida o sus miembros/o quedar su proceso en el limbo], en Quinta Enmienda, últimas líneas.

Comentario: limb (miembro), entendido como castigo extremo del quid pro quo, es propio de los Derechos confesionales. La idea parte de la incipiente noción retributiva de justicia, que ya no es venganza (pues sólo le corresponde a los poderes públicos su ejecución), ni castigo (propio del Derecho natural), sino que se está ante los cimientos del moderno Derecho positivo penal; donde, y sólo para los casos más graves, previa tipificación por el Ordenamiento, si uno decide violar las reglas más básicas de la convivencia (identificadas, por la tradición judeocristiana, con los diez mandamientos bíblicos), entonces, cabe imponer una pena ejemplar, pudiendo llegar a responder con la propia vida o la integridad: si quitas una vida violentamente, la comunidad puede quitarte la tuya, para que no se repita; si robas, la comunidad puede amputarte la mano con la que cometiste el delito; etc. El caso es que, como Derecho moderno, el ACL va mitigando tales previsiones legales, a medida que el individuo prima antes que la comunidad.

${ }_{649}$ Precepto aprobado el 25 de septiembre de 1789 y ratificado el 15 de diciembre de 1791. 
Otra posible acepción -más difícil de probar y, por tanto, más próxima a la especulación-, es la de limb como limbo; o sea, aquel lugar indeterminado a la espera del juicio, se corresponde con la construcción bíblica aplicable a la condición en la que se hallan las almas de los santos y patriarcas precedentes a Jesús, hasta su regreso, con el juicio final.

En la actualidad, ¿podría considerarse Guantánamo como un limbo para procesos penales? Así parece que lo ha interpretado el TSEU, que ha ordenado su desmantelamiento.

Contenido: "nor shall be compelled in any criminal case to be a witness against himself" [ni se le compelerá a declarar contra sí mismo en ningún proceso penal].

Comentario: la salvedad tipificada, parte de la noción judeocristiana por la que se rechaza la idea de la autoincriminación, por considerarse una vía conducente al suicidio -mandato más rígido entre los judíos que entre los cristianos, y que como toda regla general tiene su gran excepción, como fue su inobservacia por el Sanedrín en el proceso contra Jesús, Jn 18,19-21). Sobre los demás aspectos del testimonio, vid. art. III.

Igualmente, otra reminiscencia judeocristiana es, la composición del Grand Jury o jurado, que consta de doce hombres justos (número cabalístico, que en el cristianismo representa a los doce apóstoles).

Contenido: "nor be deprived of life, liberty, or property (...) nor shall private property be taken for public use, without just compensation" [ni se puede privar de la vida, la libertad o la propiedad (...) ni será confiscada la propiedad privada para uso público, sin una debida compensación] 
Comentarios: vid. Decimocuarta Enmienda.

$>$ Catorce Enmienda650: vid. infra regulación explícita.

Dieciocho Enmienda ${ }^{651}$ : intoxicating liquors prohibited [bebidas alcohólicas prohibidas]

Contenido: "After one year from the ratification of this article the manufacture, sale, or transportation of intoxicating liquors within, the importation thereof into, or the exportation thereof from the United States and all territory subject to the jurisdiction thereof for beverage purposes is hereby prohibited" [tras un año desde la ratificación de este artículo, la manufactura, venta o transporte de licores de intoxicación/con alcohol, la importación o la exportación al respecto, en los EE.UU. y todo territorio sujeto su jurisdicción, queda terminantemente prohibido], en Dieciocho Enmienda, secc. 1.

Comentarios: mandato coyuntural -por razón de orden y moral pública-, revocado por la Veintiuna Enmienda, el 5 de diciembre de 1933 -pero la cuestión no cesó ahí, pues tuvo un resurgir más virulento en sus intenciones, con la moción de enmienda de 1938.

- Regulación tácita: la expresión político-jurídica fundamental estadounidense -por ende, oficializadora- de su moderno modelo relacional Iglesia-Estado (o dicho de otro modo: modelo derecho-política-religión, vid. infra), es su consagración de la libertad religiosa (como informadora del resto de derechos y libertades del Ordenamiento): a) en términos macro, porque

\footnotetext{
${ }_{650}$ Precepto aprobado el 13 de junio de 1866 y ratificado el 9 de julio de 1868.

${ }^{651}$ Precepto aprobado el 18 de diciembre de 1917 y ratificado el 16 de enero de 1919.
} 
aclara cuál es la variable modular en las relaciones poder-sacralidad-libertad (la libertad es la variable de contención y moderación entre las otras dos); b) en términos micro, porque es la primera libertad civil en ser reconocida y bajo una doble cláusula; c) en términos meta, porque es considerada como el motor fundacional de los EE.UU. (América como el paraíso terrenal bendecido por Dios -según el American way of life: lugar de oportunidades, tolerancia social y libre examen-); además, sin la libertad religiosa es imposible concebir la intimidad (o autonomía de la voluntad individual), y sin este figura, no se puede tener conciencia de uno mismo y del resto de derechos propios y de los demás. Luego, la libertad religiosa, intrínsecamente, supone la autonomía religiosa (establishment clause), la libertad de creencia y de culto (free exercise clause), etc., y de forma extrínseca, se conecta con la libertad de expresión, derecho de reunión, y demás libertades civiles de la Primera Enmienda, del resto de enmiendas de la Declaración de derechos (Bill of rights), así como, de otras muchas más libertades públicas del Ordenamiento (en la Declaración de Independencia, en Declaraciones y Constituciones Estatales y/o por la práctica ciudadana, según las Novena y Décima Enmiendas) ${ }^{652}$.

652 Sobre propuestas de estudio conjunto de libertades civiles, vid. COHEN, W., KAPLAN, J.: Constitutional Law. Civil Liberty and Individual Rights, New York: Foundation Press, 1982. DARSEN, N (ed.): The Rights of Americans. What they are-what they should be, New York: Pantheon Books, 1971. EMERSON, T.I., et al.: Political and Civil Rights in the United States, Boston: Little Brown \& Co., 1967. KONVITZ, M.R.: Fundamental liberties of Free People: religión, speech, press, assembly, Binghamton: Vail Ballou Press, 1957. De forma más sectorial (conectándose la libertad religiosa con prácticas y costumbres administrativas, o con geopolítica), vid. JACOBS, J.B.: Individual Rights and Institutional Authority: Prisons, Mental Hospitals, Schools and Military. Cases and Materials, New York: The BobbsMerrill Co., 1972. NOVAK, M.: Human Rights $\mathcal{E}$ the New Realism. Strategic Thinking in a New Age, New York: Freedom House, 1986. 
Entre los antecedentes más destacados en la conformación del sistema de libertades civiles estadounidense, destacan algunos documentos politicojurídicos elementales ya mencionados -y ahora compilados por razones de facilidad heurística y hermenéutica-, como son: The Charter of Liberties of Henry I (1100), The Oxford Charter of Stephen (1136), The Charter of Henry II (1154), Magna Carta (1214-15), Letters Patent to Sir Humphrey Gilbert (1573), First Charter of Virginia (1606), The Mayflower Compact (1620), Laws and Orders concluded by the Virginia General Assambly (1624), Petition of Rights (England, 1628), Charter of Massachusetts Bay (1629), The Charter of Maryland (1632), Pilgrim Code of Law (1636), An Act for the Liberties of the People (Maryland, 1638), Maryland Act Concerning Religion (1639), Fundamental Orders of Connecticut (1639), Massachussetts Body of Liberties (1641), Articles of Confederation for the United Colonies of New England (1643), The Laws and Liberties of Massachussetts (1647), The Toleration Act (Maryland, 1649), Acts and Orders (Rhode Island, 1647), Connecticut Code of Laws (1650), An Act concerning our liberties (Massachussetts, 1661), The Charter of Connecticut (1662), The Charter of Rhode Island and Providence Plantations (1663), General Laws and Liberties of Massachussetts (1672), Habeas Corpus Act (England, 1679), Laws and Liberties of New Hampshire (1682), Penn's Charter of Liberties (1682), New York Charter of Liberties (1683), Bill of Rights (England, 1689), Charter of Privileges of Pennsylvania (1701), The Charter of Delawer (1701), The Charter of Georgia (1732), Articles of Association (1774), Appeal to the Inhabitants of Quebec (1774), Declaration and Resolves of First Continental Congress (1774), Rights of the Colonist (1774), Second Declaration of the Continental Congress (1775), Virginia Declaration of Rights (1776), Pennsylvania Declaration of Rights (1776), Maryland 
Declaration of Rights (1776), Declaration of Independence (1776), Pennsylvania Declaration of Rights (1776), Delaware Declaration of Rights (1776), Articles of Confederation (1777-81), North Caroline Declaration of Rights (1780), Massachusetts Declaration of Rights (1780), New Hampshire Declaration of Rights (1784), Northwest Ordinance (1787), Constitution of the United States of America (1787), U.S. Bill of Rigths (1791) ${ }^{653}$.

Una vez constituida la Unión y consolidada tras la Guerra Civil, la exigibilidad de las libertades civiles se ha llevado a trámite mediante las Civil Rights Acts [leyes de derechos civiles] ${ }^{654}$. Tal es su relevancia para el sistema que, en el Departamento/Ministerio de Justicia Estadounidense, existe una

${ }^{653}$ Cfr. LUTZ, D.S.: A prefac to American Political Theory, University Press of Kansas, Lawrence, 1992, pp. 79 ss. Vid. BLAKELY, W.A. (comp.): American State papers and related documents on Freedom in Religion, The Religious Liberty Association, Washington DC., 1949. CHANNING, E; HART, A. B. (eds.): The American History Leaflets: Colonial and Constitutional (36 vols.), A. Lovell \& Co., New York, 1892-1910. KURLAND, P.B., LERNER, R. (eds.): The Founders' Constitution (vols. I-V), Liberty Fund, Indianapolis, 1987. LEVY, L.W. (ed.): Encyclopedia of the American Constitution (vol. 1-4), MacMillan, New York, 1986.

${ }^{654}$ Vid. Civil Rights Act of 1866 (Apr. 9, 1866, ch. 31, 14 Stat. 27); Civil Rights Act of 1957 (Pub. L. 85-315, Sept. 9, 1957, 71 Stat. 634); Civil Rights Act of 1960 (Pub. L. 86-449, May 6, 1960, 74 Stat. 86); Civil Rights Act of 1964 (Pub. L. 88-352, July 2, 1964, 78 Stat. 241); Civil Rights Act of 1968 (Pub. L. 90-284, Apr. 11, 1968, 82 Stat. 73); Civil Rights Act of 1991 (Pub. L. 102-166, Nov. 21, 1991, 105 Stat. 1071). Enmiendas y complementos, Civil Liberties Act of 1988 (Pub. L. 100-383, title I, Aug. 10, 1988, 102 Stat. 904 (50 App. U.S.C. 1989b et seq.)); Civil Rights Restoration Act of 1987 (Pub. L. 100-259, Mar. 22, 1988, 102 Stat. 28); Civil Liberties Act Amendments of 1992 (Pub. L. 102-371, Sept. 27, 1992, 106 Stat. 1167); Civil Obedience Act of 1968 (Pub. L. 90-284, title X, Apr. 11, 1968, 82 Stat. 90 (18 U.S.C. 231 et seq.)); Civil Rights Commission Authorization Act of 1976 (Pub. L. 94-292, May 27, 1976, 90 Stat. 524); Civil Rights Commission Authorization Act of 1977 (Pub. L. 95-132, Oct. 13, 1977, 91 Stat. 1157); Civil Rights Commission Authorization Act of 1979 (Pub. L. 96-81, Oct. 6, 1979, 93 Stat. 642); Civil Rights Commission Authorization Act of 1980 (Pub. L. 96-447, Oct. 13, 1980, 94 Stat. 1894); Civil Rights Commission Act of 1983 (Pub. L. 98-183, Nov. 30, 1983, 97 Stat. 1301 (42 U.S.C. 1975 et seq.)); Civil Rights Commission Reauthorization Act of 1989 (Pub. L. 101-180, Nov. 28, 1989, 103 Stat. 1325); Civil Rights Commission Amendments Act of 1994 (Pub. L. 103-419, Oct. 25, 1994, 108 Stat. 4338); Civil Rights of Institutionalized Persons Act (Pub. L. 96-247, May 23, 1980, 94 Stat. 349 (42 U.S.C. 1997 et seq.)); Civil Rights Remedies for Gender-Motivated Violence Act (Pub. L. 103-322, title IV, subtitle C (\$40301 et seq.), Sept. 13, 1994, 108 Stat. 1941 (42 U.S.C. 13981)); etc. 
División de Derechos Civiles. Dicha agencia, bajo la supervisión del actual Fiscal General de los EE.UU., GONZALES, ha vuelto a intensificar su labor de promoción de las libertades civiles, a través de la libertad religiosa -en previsión de constituir un Sub-Departamento específico (vid. The First Freedom Project en cap. 10).

Como apunte de cierre sobre la cuestión, se sistematiza a continuación, una propuesta ordenadora de la Declaración de derechos, en el sentido en el que se viene abordando.

\section{Figura 88.- Sistema estadounidense de libertades civiles}

Intimidad: Primera Enmienda (freedom of speech, of press, right to assemble, right to petition), Tercera y Cuerta Enmienda (rights to privacy: in their persons, houses, papers, effects), Novena Enmienda (rights retained by the people), Catorce Enmienda (civil rights $\mathcal{E}$ equality clause)

Libertades civiles procesales: Cuarta Enmienda (search $\mathcal{E}$ arrest warrants), Quinta Enmienda (rights in criminal cases), Sexta Enmienda (rights to a fair trial), Séptima Enmienda (rights in civil cases), Octava Enmienda (nor cruel and unusual punishments inflicted)

Libertades civiles idiosincrásicas: Segunda Enmienda (right to keep and bear arms), Trece Enmienda (abolition of slavery), Quince-Diecinueve-Veintitrés-Veintiseis Enmiendas (black suffrage, woman suffrage, suffrage in DC, suffrage of 18 years old)

Exigibilidad de libertades civiles: Civil Rights Acts (vid. nota inmediata); Equal Acces Act (TITLE VIII, Pub. L. 98-377, 1984)

Fuente: elaboración propia (SÁNCHEZ-BAYÓN, 2007 y 16). 
c) Preceptos tramitados y no ratificados ${ }^{655}$ : en primer lugar, se enuncian las propuestas más relevantes (por superar los procesos iniciales y alcanzar la condición de moción), pero que, a la postre, no alcanzaron su objetivo de convertirse en enmiendas de la CEU. En segundo lugar, se presenta la moción Blaine, que pese a no lograr su objetivo inicial, sí continuó su curso en las instancias estatales, conviertiéndose allí en enmienda constitucional.

- Mociones no ratificadas: a) el reconocimiento constitucional de Dios y Jesucristo como sumas autoridades de los asuntos humanos (1894) -es una reacción a las Enmiendas Blaine; b) la prohibición del alcoholismo y la drogadicción en los EE.UU. (1938) -es una reacción a la derogación de la Dieciocho Enmienda por la Veintiuna Enmienda; c) la protección de las expresiones religiosas en los espacios públicos (1995) -son dos propuestas, de HYDE y de ISTOOK, como reacción frente a la Religious Freedom Restauration Act; d) la protección del matrimonio frente a las uniones del mismo sexo (desde 1996) -es una reacción, según la Derecha Cristiana, frente al incremento de presión del Lobby Gay y la irrupción de los registros de parejas de hecho en algunos Estados (v.g. Vermont, Massachusetts, California).

- Moción BLAINE: se trata de una propuesta de prohibición a los ministros de culto para ocupar cargos públicos, así como, a las confesiones religiosas para acceder al disfrute de fondos y espacios públicos. Su tramitación se inicia el 14 de diciembre de 1875, bajo la denominación coloquial de Blaine Amendment

${ }^{655}$ Cfr. JORDAN, T.: The U.S. Constitution and fascinating facts about it, Naperville: Oak Hill Publishing Co., 2003, pp. 58. Vid. DAVIS, D.H.: "A commentary on the proponed "religious equality/liberties" Amendment", en Journal of Church and State (vol. 38), 1996. 
[enmienda Blaine] -debe su nombre al Congresista Republicano y candidato Presidencial, J.G. BLAINE. Llega a la Cámara de Representantes, donde es aprobada por amplia mayoría (180-7), el 4 de agosto de 1876; de ahí, pasa al Senado, donde es rechazada, el 14 de agosto, por no alcanzar los 2/3 exigidos (28-16). Tal contratiempo, no paraliza la iniciativa (fruto del movimiento Nativista) ${ }^{656}$, sino que se procede a una modificación encubierta de la CEU, a través de la enmienda de Constituciones estatales (adoptándose mociones como las aludidas). Ello trae consigo la declaración de inconstitucionalidad de las State Sunday Laws [legislación dominical estatal], así como, el intento de implantar una política pública anticlerical. Ahora bien, dicha dinámica es frenada en seco, pues logra generar en poco tiempo un rechazo popular, que se concreta en un nuevo despertar religioso, por el que se financian a políticos muy comprometidos con la religión, así que se produce un giro de ciento ochenta grados ${ }^{657}$.

656 Un nacionalismo postguerracivilista, de entre cuyos rasgos característicos destaca su anticatolicismo, poniéndolo bajo sospecha por obediencia a un poder extranjero, el Papa.

657 Se aprueba legislación federal para el cierre dominical, se fija el logo "In God We Trust" para las monedas, etc. Cfr. BLAKELY, W.A. (comp.): American State papers and related documents on Freedom in Religion, The Religious Liberty Association, Washington DC., 1949, pp. 260 ss. 
Figura 89.- Enmiendas (estatales) BLAINE ${ }^{658}$

Ningún Estado aprobará ley alguna para el establecimiento de religión, o para prohibir el libre ejercicio al respecto; y ningún dinero recaudado por impuestos estatales, para el mantenimiento de los colegios públicos, así como, ningún fondo público o espacio público, nunca estarán en manos de grupo religioso alguno.

Fuente: elaboración propia (SÁNCHEZ-BAYÓN, 2007 y 16).

\section{Jurisprudencia: desarrollo y actualización de CEU}

$\mathrm{Al}$ igual que en el apartado previo (sobre CEU, en su versión originaria), en el presente también se abordan tres puntos básicos: a) las extracciones teoréticas, a modo de hilo conductor, sirviendo para la superación de las disonancias cognitivas acasionadas por las tensiones entre la abundante casuística; b) las clasificaciones manejadas, poniéndose de manifiesto los parámetros habituales aplicados por la academia, seguido de una ordenación cronológica y por materias; c) el desmantelamiento de imposturas, acerca de la casuística, del construccionismo y sus riesgos, más la falacia del muro de separación, evidenciándose de este modo la valía de las propuestas precedentes.

658 Propuesta que bebe de la original federal (Blaine Amendment), sustituyéndose únicamente el comienzo, y donde decía "El Congreso no aprobará", ahora figura en las enmiendas estatales (Blaine Amendments) "Ningún Estado aprobará". Cfr. BLAKELY, W.A. (comp.): American State papers and related documents on Freedom in Religion, Washington DC: The Religious Liberty Association, 1949, pp. 255. McCONNELL, M.W., et al.: Religion and the Constitution, Gaithersburg: Aspen Publishers, 2002, pp. 451 ss. VAN ALSTYNE, W.W.: First Amendment. Cases and Materials, New York: Foundation Press, 1995, pp. 858 ss. Vid. GARNETT, R.W.: "The Theology of the Blaine Amendment", en First Amendment Law Review (vol. 2), 2003. 
a) Extracciones teoréticas: con respecto a la labor de los jueces, ésta no sólo es la de juzgar (aplicando la ley y la equidad, como exige la CEU), sino también la de codificar la costumbre y los principios generales del ACL, así como, ser capaces de generar una teoría jurídica para el Ordenamiento ${ }^{659}$. Se comprende, entonces, que no resulte tan relevante dar con la lógica de continuidad interna permanente entre los múltiples obiter dicta de su creciente casuística -pues esa es la parte más construccionista de la Jurisprudencia y frente a la que recela la CEU-, sino que se presume más acertado, plausible y valioso, la consecución de la extracción de la ratio decidendi, justificadora del stare decisis en el seno de dicha amalgama; además de permitirse, a su vez, la puesta en evidencia de los fundamentos, argumentarios y formas de referencia. Pues bien, se presentan a continuación, aquellas extracciones teoréticas más significativas, por ser las más generalizables al conjunto de la casuística:

- La tendencia general es la del posjudeocristianismo, que -como ya se aclarara- supone una corriente aperturista de humanismo judeocristiano secular estadounidense, aunque a veces haya estado salpicado de episodios extremos (bien de integrismo religioso, bien de laicidad civil). En tal sentido, al evaluarse la trayectoria global de la producción jurisprudencial del TSEU, cabe observarse con más facilidad y claridad (que en la casuística

\footnotetext{
${ }^{659}$ Así se desprende de los Comentarios de BLACKSTONE y la Jurisprudencia de AUSTIN, además de los diccionarios jurídicos de BLACK y WEBSTER. En tal sentido, la Jurisprudencia ha de ser: a) Theory of Law [teoría del Derecho], que es el estudio de la naturaleza del Derecho y sus cuestiones morales; b) Theory of Legal Interpretation [teoría de la interpretación jurídica], que es el estudio de la autoridad y las técnicas jurídicas; c) Theory of Adjudication [teoría de la adjudicación], que es el estudio del impacto del precepto, según el comportamiento de los actores procesales, los factores sociales, las políticas públicas en curso, etc.
} 
coyuntural), como se ha ido generando una compatibilidad sostenible entre las diversas formas de religión tradicional y la de la religión civil.

- Las decisiones de los Magistrados se han movido entre la autonomía y la integración, así como, entre la separación y la acomodación (vid. infra), de acuerdo con sus circunstancias, que se corresponden con su predisposición psicológica (v.g. nivel de religiosidad), sociológica (v.g. círculos de amistades) y coyuntural (v.g. periodos de crisis identitaria). En todo caso, en la aplicación de dichos principios del modelo relacional Iglesia-Estado, cabe destacarse las siguientes reglas como generales: a) los estudiantes, en colegios públicos, pueden rezar y distribuir literatura religiosa, si lo hacen de forma voluntaria y sin coacción alguna; b) puede realizarse discursos religiosos en la calle, así como, distribuirse folletos, siempre y cuando no se altere el orden público; c) pueden portarse símbolos religiosos, incluso en espacios públicos, guardándose un mínimo decoro; d) las iglesias pueden organizar debates electorales, pero no apoyar abiertamente a un candidato del que reciben ventajas; e) las iglesias tienen ventajas fiscales, especialmente, si su labor está relacionada con la mejora del bienestar social; etc.

- La labor de interpretación del Poder Judicial es esencial para dar vitalidad al Derecho, tal y como previene la CEU, pero también advierte de la necesaria vigilancia de la labor de los Magistrados, para evitar excesos de voluntarismo 
y de predisposición al activismo judicial -por ser esa la parte más oscilante e insegura del Ordenamiento ${ }^{660}$.

- Desde su configuración y consolidación, en el TSEU ha habido diversas corrientes jurisprudenciales (vid. figura siguiente), divergentes sobre todo en su interpretación de la gestión preceptiva, lo que ha suscitado la aparición de múltiples métodos y técnicas de diagnóstico, tal y como se refleja en la figura inmediata. Ahora bien, aunque la oscilación ha sido considerable, en la interpretación de los principios básicos del modelo relacional Iglesia-Estado (v.g. autonomía v. integración, separación v. acomodación), sí ha habido una tendencia continuista, consolidadora de libertades.

Figura 90.- Técnicas de diagnóstico jurisprudencial ${ }^{661}$

\begin{tabular}{|ll|}
\hline Técnicas & \multicolumn{1}{c|}{ Supuestos ilustrativos } \\
\hline Establishment & Lemon test (Lemon vs. Kurtzman, 403 U.S. 602, 1971) \\
clause tests & Lemon test redux (Agostini vs. Felton, 521 U.S. 203, 1997) \\
& Religious clubs test (Westside Bd. of Ed. vs. Mergens, 496 \\
& U.S. 226, 1990) \\
\hline
\end{tabular}

${ }^{660}$ Pese a la prevención de la Once Enmienda, advirtiendo de los riesgos del construccionismo, el Presidente del TSEU, el Magistrado MARSHALL, en Marbury v. Madison (5 U.S. 137, 1803), logra argumentar una cosa y establecer otra: se aduce en la decisión que el TSEU no tiene competencia para conocer, y en cambio, se aprovecha la ocasión para institucionalizar el stare decisis y la judicial review. Vid. Statemen en el cap. 8, más imposturas de este subepígrafe.

${ }^{661}$ Meramente a título ejemplificativo de la gran variedad existente de recursos técnicos de los que dispone y hace uso la Jurisprudencia estadounidense. Vid. CONKLE, D.O.: Constitutional Law: The Religion Clauses, New York: Foundation Press, 2003. FLOWERS, R.B.: That Godless Court: Supreme Court Decisions on Church-State Relationships, Louisville: Westminster John Knox Press, 1994. MANNING, L.F.: The Law of Church-State Relations, St. Paul: West Publishing Co., 1981. YARNOLD, B.: Religious Wars in the Courts I. The lower federal courts and the US Supreme Court in Religious Freedom cases 1970-1990, Hintington: Nova Science Publishers, 1999. - Religious Wars in the Courts II. Who were the litingants in the US Courts, Religious Freedom cases 1970-1990, Hintington: Nova Science Publishers, 2000. Resulta curioso el juego de palabras y las dinámicas entorno al religious test, ya que según el art. VI de la CEU, está prohibido practicarlo para impedir el acceso a cargo público, mientras que es aplicado en los tribunales para evaluar los casos -además de exigirse jurar a todo aquel que declare en el proceso correspondiente. 


\begin{tabular}{|c|c|}
\hline $\begin{array}{l}\text { Free exercise } \\
\text { clause tests }\end{array}$ & $\begin{array}{l}\text { Sherbert test (Sherbert vs. Verner, } 372 \text { U.S. 398, 1963) } \\
\text { Conscientious objector exemption test (U.S. vs. Specer, } 380 \text { U.S. } \\
\text { 163, 1965) } \\
\text { Compelling interest test (Employment Div. vs. Smith, } 494 \text { U.S. } \\
872,1990 \text { ) }\end{array}$ \\
\hline $\begin{array}{l}\text { Establishment } \\
\text { clause standards }\end{array}$ & $\begin{array}{l}\text { Coercion (Allegheny County vs. ACLU, } 492 \text { U.S. 573, 1989) } \\
\text { Endorsement (Lynch vs. Donnelly, } 465 \text { U.S. 668, 1984) } \\
\text { Neutrality (Mitchell vs. Helms, } 530 \text { U.S. 793, 2000) } \\
\text { Separation (Everson vs. Board of Education, } 330 \text { U.S. 1, 1947) } \\
\text { Accommodation (Harris vs. Forklift Systems } 510 \text { U.S. 17, 1993) }\end{array}$ \\
\hline $\begin{array}{l}\text { Free exercise } \\
\text { clause standards } \\
\text { 1987) }\end{array}$ & $\begin{array}{l}\text { Strict Scrutiny (Wisconsin vs. Yoder } 406 \text { US 205, 1972) } \\
\text { Intermediate Scrutiny (Edwards vs. Aguillard, } 482 \text { U.S. 578, } \\
\text { Rational Basis Review (O'lone vs. Estate of Shabazz, } 482 \text { U.S. } 3 \\
\text { 342, 1987) } \\
\text { Skeptical Scrutiny (Jensen vs. Quaring, } 472 \text { U.S. 478, 1985) }\end{array}$ \\
\hline Standing levels & $\begin{array}{l}\text { Flast v. Cohen ( } 392 \text { U.S. 83, 1968) } \\
\text { Valley Forge Christian College v. Americans United for } \\
\text { Separation of Church and State (454 U.S. 464, 1982) }\end{array}$ \\
\hline
\end{tabular}

Fuente: elaboración propia (SÁNCHEZ-BAYÓN, 2007 y 16).

b) Clasificaciones manejadas: tan amplia como la propia casuística es la diversidad de propuestas clasificadoras de la misma. Durante el último tercio del s. XX, en la academia estadounidense, se vino a implantar, de manera más o menos generalizada, un criterio clasificador un tanto artificial y forzado, imbrincado en la influencia de la labor del Magistrado BLACK, por el que se distinguía entre casos sobre la cláusula de no establecimiento y la de libre ejercicio. Ahora bien, con el ejercicio revisionista doctrinal crítico, acometiéndose desde las universidades y think-tanks, en los años recientes, además de desmontarse buena parte de las inferencias, imposturas y falacias asumidas hasta hace poco, vuelve a florecer una rica variedad de propuestas clasificadoras ${ }^{662}$-el inconveniente es, que la

${ }^{662}$ Por ejemplo, desde parámetros económicos, la clasificiación de ROTUNDA, que detingue entre el apoyo financiero a la religión, el apoyo no financiero y las excepciones a las cargas estatales de las organizaciones religiosas. Vid. ROTUNDA, R.D.: Modern Constitutional Law. Cases and notes, West 
orientación sesgada y polarizada que están alcanzando hace que sean incompatibles y excluyentes las clasificaciones (elaboradas y enarboladas para sus propias campañas), de la American Civil Liberties Union (ACLU) y de la Alliance Defense Fund (ADF)-.

Para no superar los límites materiales de este trabajo, se remite a la síntesis y sistematización de los más de trescientos casos resueltos por el TSEU, relativos a la ordenación del factor religioso ${ }^{663}$. Tal riqueza (tanto en casos como en temáticas conexas), no deja de ser una evidencia de su secularización, así como, de la alta consideración que se tiene de la intimidad y de la libertad religiosa, como epicentros del vórtice de las relaciones Iglesia-Estado lato sensu, de acuerdo con los EE.UU. (vid. infra figura 14 y 15).

Publishing, St. Paul, 1997. Se pretenden recuperar clasificaciones clásicas y más ricas en matices sociales, como la de STOKES o BLAKELY (vid. infra).

${ }_{663}$ Supuestamente, de entre los primeros casos regionales cabe destacar Van Hornes Lessee v. Dorranze (2 Dallas 304, 1795), o el de Carder v. Bull (2 Dallas 386, 1798). Entre los casos de mayor impacto de aquella época, tras la aprobación de la ley federal de judicatura y las reformas posteriores del sistema, es de reseñar el de People v. Phillips (New York City of General Sessions, 1813), donde se juzgó la autonomía religiosa y la comunicación religiosa, al darse instrucciones al jurado acerca del secreto de confesión de un cura católico. A este caso, le siguió una plétora relativa a propiedades eclesiásticas, como fue Terrett $v$. Taylor (13 U.S. 43, 1815) -curiosamente, poco conocido este y el resto de casos relacionados en el ámbito universitario, pero sí claves en la práctica forense, máxime en la asesoría jurídica especializada de confesiones- En definitiva, los supuestos compilados en otros trabajos (y donde se remite desde aquí), son los juzgados por el TSEU cristalizando en la jurisprudencia que hoy se conoce, o debería conocerse. Cfr. ADAMS, A.M., EMMERICH, C.J.: A Nation dedicated to Religious Liberty. The Constitutional heritage of Religion Clauses, Philadelphia: University of Pennsylvania Press, Philadephia, 1990, pp. 122 ss. ESBECK, C.H.: “Table of United States Supreme Court Decisions relating to Religious Liberty 1789-1994", en Journal of Law and Religion (vol.10, n²), 1994, pp. 573 ss. MILLER, R.T., FLOWERS, R.B.: Towards benevolent neutrality: Church, State, and the Supreme Court, Waco: Baylor University Press, 1992 (supplement of 1993). NUSSBAUM, L.M. (ed.): "Decision of the Court", en Rothgerber Johnson $\mathcal{E}$ Lyons (URL: http://www.churchstatelaw.com/). WITTE, J.: Religion and the American Constitutional Experiment. Essential Rights and Liberties... op. cit., pp. 251 ss. Complement., vid. fuentes electrónicas de J.M. Dawson Institute of Church State Studies (URL: http://www3.baylor.edu/Church State/). En cuanto a las compilaciones previas aludidas, vid. SÁNCHEZ-BAYÓN, A.: La Modernidad... op. cit. - Estado y religión... op. cit. - Universidad, ciencia y religión ... op. cit. - “Evolución y evaluación (...)” ... op. cit. 
c) Desmantelamiento de incorrecciones (inferencias, imposturas y falacias): tres son los supuestos sometidos a análisis crítico. El primero, es una inferencia sobre la excesiva identificación del ACL con el Case Law, confundiéndose así una parte con el todo (inferencia LANGDELL, vid. infra presentación de Parte de desarrollo especial). El segundo ejercicio de reflexión versa sobre los riesgos del construccionismo en el ACL, máxime si se asume la inferencia anterior (inferencia MARSHALL). El tercer caso aborda la falacia naturalista del muro de separación entre Iglesia y Estado, pues éste no es tal, sino un exceso de la conjunción de los supuestos previos (falacia BLACK).

- Inferencia LANGDELL: la identificación del ACL con el Case Law. El Case Law [jurisprudencia] sólo es una parte del ACL, pues igualmente importante es el Executive Law [reglamentos] o el Statutory Law [legislación]. Tal exaltación del Caso Law proviene de los primeros programas de estudio de Derecho en los EE.UU., cuando en la década de 1870 en Harvard, el Decano LANGDELL, implanta un método de instrucción legal más formalista que el de los planes previos, basados en conferencias y exégesis de obras de culto, como los Comentarios de BLACKSTONE o la Jurisprudencia de AUSTIN. La dinámica del nuevo método se articula en tres pasos: a) read the cases [lectura de casos]; b) distill the rule [destilar la regla]; c) apply the rule to future cases [aplicación de la regla a futuros casos].

Si dicha inferencia triunfó, ello se explica por la competición entre los dos grandes juristas de la época, LANGDELL y HOLMES -tensión comparable a la habida entre HAMILTON y JEFFERSON. Si LANGDELL llegó a Decano de Derecho en Harvard, HOLMES lo procura también, pero sólo llega a profesor, 
por lo que opta por la práctica jurídica, llegando a convertirse en Magistrado del TSEU. Si LANGDELL promovió el Formalismo, HOLMES, patrocina el Realismo; etc. El caso es que, HOLMES, provocó el efecto contrario al pretendido desde la revista jurídica que editaba (American Law Review) y su famosa obra The Common Law (1881), que fue conceder excesiva relevancia a LANGDELL -hasta el punto de que, él también, asumío la inferencia, aunque sólo fuera para criticarla-.

Así se generaliza la inferencia, gracias a los licenciados de Harvard, que nutren las nuevas Facultades de Derecho del país, y destacan en la práctica jurídica, llegando a desempeñar luego los cargos de Magistrados, y desde esas atalayas continúan la difusión.

La inferencia continua hasta hoy, pues la selección de los casos para su estudio en las Facultades de Derecho estadounidense, dependen del criterio voluntarista académico, ya que no se atiende a parámetros objetivos como la ratio de votos (v.g. ni priman los casos de decisión per curiam [decisión adoptada por unanimidad], ni los pluralities [decisión adoptada con diversidad de votos], ni los que han requerido el voto de calidad, etc.) -entre los más de doscientos casos del TSEU sobre el modelo relacional Estadoreligión, se constata la hipótesis planteada sobre la selección voluntarista, pues depende de modas basadas en la generalización de incorrecciones como las abordadas en este punto del estudio.

Como ventaja a las aportaciones de LANGDELL (y HOLMES), es que su labor sirvió para positivizar el Derecho estadounidense y estructurar modernos planes de estudio -pero, recuérdese que el $\mathrm{ACL}$, en especial para la rama 
especial de ACCL, es mucho más que el Case Law, como prueba la complicación de preceptos (de diversa naturaleza) de este volumen.

- Inferencia MARSHALL: los riesgos del construccionismo judicial. En el Case Law, los jueces pretenden hacer justicia, haciendo vivir el Derecho, para lo que recurren a la regulación escrita (CEU, legislación, reglamentos, etc.), la costumbre, los principios generales y la equidad. De su práctica, surgen instituciones como stare decisis o precedent [precedente], judicial review [control de legalidad], fallo ex aequo et bono [según lo adecuado y lo bueno], etc., pero que abren las puertas a un construccionismo voluntarista del Derecho, frente al que previene la propia CEU (art. III y Once Enmienda).

Como ya se aclarara (y se volverá a tratar en en capítulos como el 8 y 10), fue MARSHALL, en una muestra de paradoxología asombrosa, quien introdujo buena parte de las figuras citadas, desconocidas por la CEU y cuya vía de incorporación al sistema chocaba con sus preceptos, pero que, sin embargo, iban encaminadas a afianzar el Federalismo y la misma CEU. Ahora bien, una vez superada la fase de consolidación del TSEU y del Case Law, la herencia de MARSHALL ha dado lugar a otras figuras nuevas, reflejo de un construccionismo voluntarista, justo opuesto a las intenciones de MARSHALL, como son el judicial activism \& standing [activismo judicial y apoyo de causa] (v.g. ripeness, mootness, political question) ${ }^{664}$. Se trata de figuras

\footnotetext{
${ }^{664}$ Aunque ha habido ejemplos diversos de contruccionismo voluntarista, por parte de los jueces estadounidenses, a lo largo de toda su historia institucional (iniciándose el proceso con MARSHALL), la figura del activismo judicial, stricto sensu, arranca con el bautismo de SCHLESINGER en un artículo de 1947, donde distinguía entre los jueces más voluntaristas (judicial activism), como BLACK, DOUGLAS, MURPHY y RUTLEDGE, frente a los más restrictivos (judicial restraint), como FRANKFURTER, JACKSON y BURTON. Vid. SCHLESINGER, A.M.: "The Supreme Court: 1947", en Fortune (no 35), 1947. Complement., vid. FINE, T.: American Legal Systems: A resource and reference guide, Cincinnati: Anderson Publishing Co., 1997. KMIEC, K.D.: "The origin and current meaning of
} 
jurídicas que permiten a los jueces llevar a cabo una aplicación más discrecional del Derecho, e incluso, oponerse a las políticas públicas del Ejecutivo y del Legislativo ${ }^{665}$. En principio, esta práctica se justificó a si misma para dar cabida a las libertades civiles sin tipificar, pero pronto se expandió trasversalmente a tantas materias, que al verse desbordado, el propio TSEU tuvo que declinar su labor en la revisión de decisiones presidenciales sobre concesiones de perdón, reconocimiento de credenciales diplomáticas, etc.

Como se ha dicho, la ventaja de un cierto construccionismo voluntarista es aconsejable para que los jueces flexibilicen la aplicación del Derecho y lo hagan más permeable a las demandas sociales. Ahora bien, su exceso de discrecionalidad atenta contra la seguridad del Ordenamiento, y ello no es admisible por la mera intención del juez correspondiente de dejar su legado como pasa con BLACK, a continuación:

- Falacia BLACK: la perversión del muro. Se trata de un rotundo caso de falacia naturalista donde se confunde el deber ser con el ser. Negando la premisa mayor, pues nunca ha habido muro legal alguno (vid. infra), sino una

\footnotetext{
"Judicial Activism"”, en California Law Review (no 92), 2004. HARWOOD, S.: Judicial Activism. A restrained defense, San Francisco: Austin \& Winfield, 1996. LEVIN, M.R.: Men in Black: How the Supreme Court is destroying America, Washington DC: Regnery, 2005.

${ }^{665} \mathrm{~A}$ grandes rasgos, el activismo judicial, queda definido como la fórmula que tienen los jueces para llevar a cabo ingenieria social a través de un uso discrecional del Derecho, ya que no aplican el contenido real de las normas vigentes, sino que construyen sentencias según el sentido que, personalmente, creen que deberían tener dichas normas. Por su parte, el apoyo de causa, es la admisión que los jueces hacen de casos que carecen de sustento legal, por razón de oposición a las políticas públicas en curso, para lo que siguen diversas estrategias: a) ripeness o madurez de la cuestión (hay suficientes casos y la causa debe ser tratada); b) mootness o sentir de la cuestión (es un tema relevante para la mayoría y por ello debe ser tratado); c) political question o duda política (se consideran desacertadas la política públicas en curso y es una manera de valorarlas). De este modo, se vulnera la separación de poderes, además de atentarse contra la legalidad y legitimidad del Legislativo y del Ejecutivo.
} 
metáfora al respecto, en un documento semiprivado de JEFFERSON, contradicho por otros tantos, donde se hablaba de la conveniencia de un muro de separación entre la Iglesia y el Estado (refiriéndose al Poder Federal, para no tomar cartas en las disputas religiosas), y en ningún caso entre el Estado (en cualquiera de sus niveles) y la religión, tal como se garantiza en la Primera Enmienda de CEU. Entonces, ¿qué pasaba por la cabeza del Magistrado BLACK para acometer un argumentario tan vehemente al respecto? Para contestar a dicha pregunta, es necesario saber primero quién fue realmente BLACK y cuáles fueron sus problemas personales.

BLACK fue un bautista sureño, o sea, antifederalista y converso. Criado en una Alabama con reminiscencias de los Know-Nothing y del Ku-Klux-Klan (KKK o Klan) -dicho sea de paso, contribuye a la reavivación de esta última organización, en la década de $1920^{666}$. Una de sus aportaciones más destacadas fue, en 1921 y a petición personal de ESDALE (Grand Dragon o máxima autoridad del Klan en Alabama), la defensa del Rev. STEPHENSON ${ }^{667}$. Su otra gran contribución fue su peculiar doctrina de

${ }^{666}$ El propio BLACK reconoce que su entorno familiar y los amigos de su padre venían de la tradición Know-Nothing y del Ku Klux Klan. Vid. BLACK, H.T.: My Father: a remembrance, Ramdon House, New York, 1975. Pruebas de que BLACK fue un miembro de KKK o Klanman, cfr. GARNETT, R.W.: “The Theology of the Blaine Amendment", en First Amendment Law Review (vol. 2), 2003, pp. 66. HAMBURGER, P.: Separation of Church and State, Cambridge: Harvard University Press, 2002, pp.422 ss.

${ }^{667}$ Rev. STEPHENSON, un eminete Klanman de Alabama, mató de un disparo al cura católico COYLE (párroco de St. Paul), por haber casado a su hija con un puertorriqueño, P. GUSSMAN -lo cual se consideraba una doble ofensa, por tratarse de un mulato y católico-. Como recompensa por su labor, el Klan le apoyó en su carrera política, como Senador de los EE.UU. (1926-37). Todo ello salío a la luz, con la propuesta de ROOSEVELT para su candidatura como Magistrado del TSEU, publicándose en el Pittsburg Post-Gazette, por R. SPRIGLE, quien ganara por su investigación el Premio Pulitzer. 
separación Iglesia-Estado, en la línea anticatólica de las Enmiendas Blaine (vid. infra).

Para ser un Magistrado que se definía a sí mismo como a Textualist [textualista], y aplicador de un strict constructionist [construccionismo estricto], demostró poco apego al texto de la CEU y mucha manga ancha argumentativa, al montar su construcción doctrinal del muro de separación, sobre la base de la reseña (a la metáfora jeffersoniana) del Magistrado WAITE, en el caso Reynolds v. U.S. (98 U.S. 145, 1878)668, así como, en el tono argumentativo radical -anticlerical-, más acorde con el contenido de las Enmiendas Blaine de los Estados sureños -violándose con ello las dos cláusulas de la Primera Enmienda, las exigencias de la Decimocuarta Enmienda (sirviendo de inspiración a la postre para la doctrina de la segregación), además de oscurecer la memoria histórica al respecto, únicamente, a favor de su propio legado-.

Como pasara con LANGDELL, y su apoyo indirecto por HOLMES, BLACK encuentra su apoyo y continuidad (antieclesiástica) en DOUGLAS, en decisiones como Bd. of Educ. v. Allen (392 U.S. 236, 1968) -con un voto de disentimiento- y Lemon v. Kurtzman (403 U.S. 602, 1971) -con un voto concurrente con BLACK-.

${ }^{668}$ El Magistrado WAITE, también realizó una interpretación un tanto peculiar, pues la metáfora de JEFFERSON, no versaba sobre la libertad de conciencia -eso es una referencia posterior, unas líneas más abajo-, sino que reivindicaba la autonomía religiosa de las confesiones y la no intervención del Poder Federal en los conflictos religiosos. 
La única ventaja reseñable, ha sido el énfasis de BLACK en la necesidad de estar alerta, para que las relaciones entre Estado y religión se mantengan, pero no se confundan.

Otro problema añadido frente a las imposturas y falacias desmontadas, acerca de los abusos del voluntarismo en el construccionismo judicial, es el desprecio hacia la justicia que se está dando en los sectores religiosos más tradicionalistas, que si bien aún creen en la misma, en cambio, desconfían bastante de sus funcionarios: "ya que él mismo Satanás se disfrazará de ángel de luz. Pues no es asombroso si sus Ministros también se disfrazan de Ministros de Justicia" (2 Co 11:14-15).

Ahora bien, no toda producción construccionista del TSEU ha sido tan voluntarista, sino que su judicial review o control de legalidad, ha garantizado el cumplimiento de las Novena y Catorce Enmiendas, como se desprende de la declaración de inconstitucionalidad y consiguiente derogación de normativa diversa contraria a la intimidad.

a) Normativa religiosa derogada: canonística católica, en Cannon v. U.S. (116 U.S. 55, 1885); preceptiva mormona (El Libro de los Mormones), en Reynolds v. U.S. (98 U.S. 145, 1878); mandatos de los testigos de jehová (Ordenanzas de los testigos), en Jones v. Opelika (319 U.S. 579, 1942); etc.

b) Normativa civil derogada: legislación estatal, en Joseph Burstyn, Inc. v. Wilson (343 U.S. 495, 1952); ordenanzas locales, en Novell v. City of Griffin (303 U.S. 444, 1938); etc. 
Los casos de derogación más polémicos de los últimos tiempos (hasta la globalización -pues la década 2010, especialmente tras la gran crisis financiera global de 2008, pude considerarse ya como posglobalización o salida de la misma para transitar un nuevo periodo histórico), cabe destacar: a) la supresión de la prohibición del uso de anticonceptivos en los matrimonios, en Griswold v. Connecticut (381 U.S. 479, 1965); b) la limitación del poder estatal para prohibir el aborto, en Roe v. Wade (410 U.S. 113, 1973); c) la derogación de normativa estatal antisodomía y antihomosexualidad, en Lawrence. Texas (539 U.S. 558, 2003).

\section{DIE: las declaraciones como normativa auxiliar}

La sistematización y análisis de los contenidos del presente punto, permite prestar la atención debida a un tipo de regulación que, normalmente, suele pasarse por alto -en buena medida, por la creciente discrecionalidad judicial al respecto (v.g. aperturismo conveniente de KENNEDY v. originalismo restrictivo de SCALIA, vid. infra)-, pese a ser reconocida la misma, por la propia CEU, como un complemento fundamental de la Ley suprema del país (vid. art. VI, más Novena y Décima Enmiendas).

En el caso de las declaraciones de libertades civiles, se centra la atención en DIE, pues acerca de las cincuenta Declaraciones estatales de derechos, sólo se harán las oportunas referencias y remisiones básicas.

En cuanto a DIE, este colosal documento jurídico, resulta clave, no sólo por las razones esgrimidas acerca de la teoría del Estado y el surgimiento de los EE.UU. 
(vid. infra), sino que, además, constituye un valioso acopio de derechos civiles y políticos, a la vez que recopila indicadores clave de la cultura político-jurídica estadounidense. Se entiende así que, la DIE, pese a ser preconstitucional, sea estudia en las Facultades de Derecho de los EE.UU., pues entre sus argumentos favorables más relevantes y frecuentes (considerándola parte esencial del Ordenamiento estadounidense), destacan los siguientes:

a) Así lo entiende el TSEU en sus decisiones, tales como Gula v. Ellis (165 U.S. 150, 1897), Butchers' Union v. Crescent City (111 U.S. 746, 1884), U.S. v. Will (449 U.S. 200, 1980), Dames \& Moore v. Reagan (453 U.S. 654, 1981), etc.

b) El documento está incluido en el U.S. Code Annotated, en la categoría titulada "The Organic Laws of the United States of America" [Leyes orgánicas de los EE.UU.].

c) Es mencionada como parte básica del Derecho estadounidense, que todo Estado de la Unión ha de respetar -al menos, en sus principios y libertades civiles-, tal y como se suele establecer en las "Enabling Acts" [leyes de incorporación a la Unión]; valga como ejemplo el de la Oklahoma Enabling Act of 1906.

d) La propia CEU, deja la puerta abierta a la DIE a través de las Novena y Décima Enmiendas.

Como se hiciera con los preceptos constitucionales (y a cuyas aclaraciones se remite), a continuación, y para completar las explicaciones, se enuncian los reflejos de ICS y ACT más memorables de la DIE:

a) “One People" [un pueblo], en la Presentación/Exposición de motivos: vid. Preámbulo de CEU (vid. infra). 
b) "The Laws of Nature and of Nature's God" [las leyes de la naturaleza y del Dios de esta naturaleza], en la Presentación/Exposición de motivos: vid. art. I, secc. 8, pto. 10, más las referencias a BLACKSTONE.

c) "We hold these thruths (...) all men are created equal" [nosotros sostenemos estas verdades (...) todos los hombres son creados iguales], en el Preámbulo: vid. Preámbulo de la CEU, art. I, secc. 10, pto. 1 y Decimocuarta Enmienda ${ }^{669}$.

d) "All men are endowed by their creador with certain inalienable rights, that among these are life, liberty and pursuit of happiness" [todos los hombres son dotados por su creador con ciertos derechos inalienables, entre los cuales destacan la vida, la libertad y la búsqueda de la felicidad], en el Preámbulo: vid. Preámbulo de la CEU, Quinta y Decimocuarta Enmiendas ${ }^{670}$.

e) "While evils are sufferable" [mientras los males sean soportables/tolerables], en el Preámbulo: vid. (indirectamente) art. I, secc. 8, pto. 10, más las referencias al PWF.

${ }^{669}$ En cuanto a las verdades, igualmente, se trata de un constructo judeocristiano relativo a una atribución divina, que se proyecta en la realidad humana, para sacralizar instituciones sociales. De ahí que, se conecte con las explicaciones dadas sobre la cláusula de plena fe, el juramento, etc., por tratarse de rituales que garanticen su respeto.

${ }^{670}$ La búsqueda de la felicidad, se sospecha que fue una mala transcripción en las copias del documento, pues la herencia del PWF promovía la protección de vida, libertad y propieadad, tal y como tipifican la Quinta y Decimocuarta Enmiendas. En cuanto a qué entendían los padres fundadores por la búsqueda de la felicidad, de acuerdo con su epistolario y demás documentación complementaria, para ADAMS consistía en la realización del bienestar general a través de la virtud y racionalidad en las decisiones; para JEFFERSON, resultaba la posibilidad de participar en la vida pública; etc. Vid. KURLAND, P.B., LERNER, R. (eds.): The Founders' Constitution (vols. I-V)... op. cit. 
f) "With a firm reliance on the protection of divine providence" [con absoluta confianza en la protección de la divina providencia], en Conclusiones: vid. (indirectamente) art. I, secc. 8, pto. 10, más las referencias al PWF.

g) "We mutually pledge to each other our lives, our fortunes, and our sacred honor" [nosotros mutuamente comprometemos cada una de nuestra vidas, nuestras fortunas y nuestro sagrado honor], en Conclusiones: vid. (indirectamente) Preámbulo de la CEU, art. I, secc. 8, pto. 10, Quinta y Decimocuarta Enmiendas.

En lo tocante a las Declaraciones estatales de derechos -como ya se mencionara con anterioridad-, tras las reformas constitucionales posguerracivilistas (en favor de la Unión), las Declaraciones estatales de derechos, se vieron afectadas. Pese a que las libertades civiles pasaron a ser competencia última del Poder Federal (Decimocuarta Enmienda), los Estados aún podían reconocer derechos y libertades dentro de los límites de la CEU (Novena y Décima Enmiendas). En consecuencia, las Declaraciones de derechos fueron incorporadas a las partes dogmáticas de las respectivas leyes fundamentales estatales. Igualmente, es conveniente recordar que los límites de la Constitución sobre el modelo relacional Iglesia-Estado, son ciertamente amplios, por lo que, para aligerar la carga expositiva y facilitar la comprensión, se han sintetizado las reglas generales y comunes de los cincuenta sistemas estatales de libertades civiles entorno a la religión ${ }^{671}$ a) prohibiciones tipificadas, como la no financiación de la educación religiosa (objeción reflejo de la Enmienda Blaine, vid. infra); b) cláusulas suplementarias, como la de no preferencia religiosa (ídem); c) reflejos de

\footnotetext{
${ }^{671}$ Síntesis acometida basándose en el estudio de WITTE. Cfr. WITTE, J.: Religion and the American Constitutional Experiment. Essential Rights and Liberties, Boulder: Westview Press, 2000, pp. 245 ss.
} 
ICS y ACT, como las referencias a Dios y el lenguaje de origen sacramental; $d$ ) otras hierofanías y hierocracias tipificadoras (vid. infra); et al.

Como se ha podido apreciar, existen abundantes manifestaciones que no sólo revelan una realidad social normalizada e institucionalizada, sino que además permiten una hipostasía de fundamentación ontológica, epistemológica y axiológica solvente -incluso plausible, si se le dedica el estudio especializado y prospectivo debido, y no panorámico, como aquí se acomete-. 


\subsection{4.- ARTE, MONUMENTOS Y FOLCLORE}

En este último apartado, se da muestra variada de aquellos otros aspectos más secularizados, en los que la religión, prácticamente, resulta cultura (vid. supra cap. 11): lo sagrado es transferido del más allá al más acá, volviéndolo disponible, por lo que lo hierocrático se vuelve popular, participándose así en la fijación compartida del acervo cultural relativo a saberes y supersticiones, costumbres y tradiciones, historias y mitos, gustos y modas, fiestas y celebraciones, artesanía, bailes y música, etc. (tal como postulara en su momento la Reforma protestante, devolviéndose la religión al pueblo -pero quedándose sin respaldo teológico, por lo que resulta méramente cultural). Dada la sobreabundancia del folclore estadounidense (al comprender la recepción de otros folclores y su Americaness, más el sobrevenido propio, combinándose todo ello y regenerándose periódicamente, con los grandes saltos generacionales de los ciclos de despertares y revitalizaciones, vid. infra Parte de desarroll general); incluso, para no reiterar lo visto en otros apartados de esta investigación (v.g. toponimia y gentilicios, vid. infra figura 23); por tanto, únicamente se ofrece aquí una serie de notas ilustrativas de algunas de las manifestaciones al respecto (seleccionadas por su índice de popularidad y oficialización -amén de dar buena muestra de su singularidad identitaria-, v.g. US Census Bureau, Smithsonian Institution, National Heritage Areas-Department of Interior).

Se inicia la ilustración (de tanta creatividad, riqueza y densidad artística y folclórica), con algunas notas de arte popular (pictórico, musical, etc.), más ciertas menciones a monumentos (entre los más visitados del país), y alguna expresión de religiosidad popular (complementaria del ACR, conectándolo con lo local). 
En cuanto al arte, igualmente, cuestión de hondo y complejo calado -pues ha variado, y mucho, su comprensión y clasificación en el devenir occidental-, por lo que refiere al conjunto de técnicas, estilos y/o actividades creativas, estéticas y comunicativas, que reproducen la cultura de una sociedad (según los Clásicos, cada arte tenía su musa: pintura, escultura, música, danza y teatro, literatura, arquitectura, etc.). Tras pasar por el filtro de Americaness, el arte se estudia en la universidad según tres grandes bloques (o maneras de crear): Bellas Artes (pintura, escultura, etc.), Artes Liberales (literatura, teatro, etc.), y Artes Técnicas (arquitectura, fotografía y cinematografía, etc. -hoy incluso diseño gráfico y videojuegos-). Incluso, se generan nuevas artes de mestizaje (entremezclando todas), estudiadas como Performing Arts o artes escenográficas. También, gracias al Americaness, empiezan a incorporarse otras artes más populares (alejadas de la visión elitista europea de cultus animi, y más próximas a cultura vitae) como: gastronomía, perfumería, moda, organización de eventos, etc. En definitiva, lo más relevante al respecto, es que EE.UU. es la cuna del arte popular: no sólo cualquiera puede producir arte, sino que éste se genera para el consumo masivo, pues se hace asequible para todos (conforme a gustos y modas populares); además, el mestizaje de expresiones artísticas resulta espontáneo y movido por las bases sociales, y no tanto por la experimentación elitista, aunque con la transición a la posmodernidad la cuestilnón ha empezado a cambiar.

Aterrizándose en manifestaciones artísticas concretas, sobre la pintura y escultura, se llama la atención (en relación con ACR), cómo se pasa del tradicional arte sacro occidental, recibido con cada oleada migratoria y sufragado por las comunidades religiosas, al boom comercial acopiado en los museos estadounidenses, aprovechándose las tendencias laicistas y guerras del s. XX en Europa (v.g. varias 
salas del Metropolitan Museum de New York contienen obras procedentes de iglesias españolas, tras la guerra civil y el contrabando de los años 70 -resultado de una errónea implementación del Concilio Vaticano II) ${ }^{672}$. En los EE.UU., gracias a su secularización, dicho arte sacro occidental, pronto se populariza, con mayor libertad de expresión, incluso de combinación de elementos y diversidad de expresiones artísticas. Como muestra del sincretismo alcanzado en el seno de los EE.UU. (combinándose el judeocristianismo, el indigenismo y el tribalismo), se destacan los elementos artísticos, ornamentales y de protección de santería y vudú, como se exhibe en las calles de New Orleans, Los Angeles o Miami. Otra manifestación muy frecuente a lo largo del país, combinándose el arte sacro y el arte pop (con diversidad de técnicas y materiales), va desde la nueva imaginaría hasta los letreros luminosos y cartelería variada de las iglesias, reclamando la visita de posibles fieles (además de involucrarse en asuntos públicos del vecindario). Sin olvidar una gran industria, como son las tradicionales postales de festividades religiosas (v.g. Pascua, Navidad).

Figura 91.- Del tradicional arte sacro occidental al pop sincrético
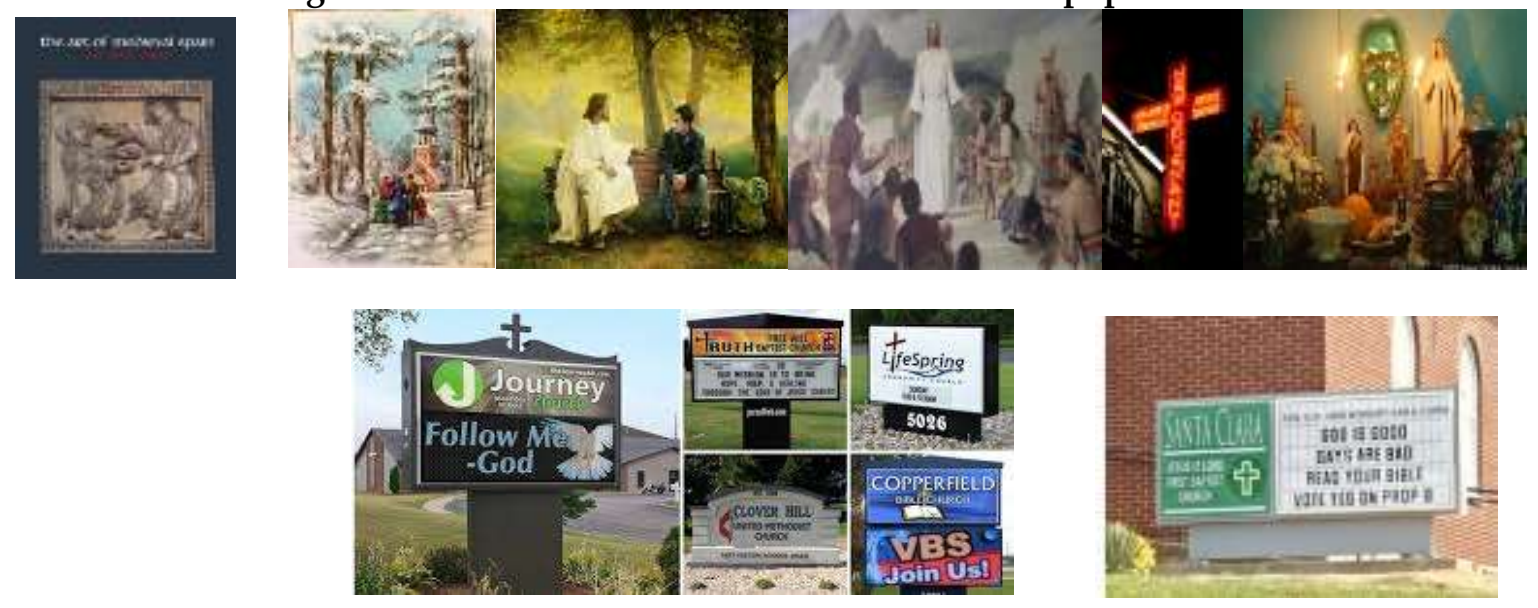

Fuente: elaboración propia (SÁNCHEZ-BAYÓN, 2007 y 16).

672 Más de ciento ciencuenta piezas declaradas por el propio museo (URL: https://www.metmuseum.org/art/metpublications/The Art of Medieval Spain AD 500 1200). 
Con respecto a la literatura (pasada por Americaness), pronto trasciende su soporte papel (v.g. audio-libro, ebook), así como su medio de difusión limitada (como es el libro), para combinarse con otros medios de comunicación (v.g. radio, cine, televisión, videojuegos). Téngase en cuenta que, EE.UU., es el país donde más literatura (lato sensu) se produce y consume popularmente (acuñándose la expresión best-seller), y es el tercero más premiado con el Nobel de Literatura (once ganadores). Son demasiados lo títulos de grandes obras estadounidenses a destacar, incluso acotándolo a aquellas relativas a ACR, donde se contiene la idiosincrasia estadounidense: suelen ser, predominantemente, de corte realista y moral (para una mayor identificación con los personajes y el argumento, además de poder transmitir así su ACR, AWL, AD, etc.), a modo de novelas históricas (recreaciones de Americaness), con crítica social y dilemas morales (dando lugar al género drama). Cierto es, que hay otros géneros populares (v.g. aventuras), relacionados con ACR (con el subgénero de la Conquista del Oeste y el Lejano Oeste), pero se va a centrar la atención en el drama, al ser el más relacionado con el folclore y el dominante en las listas de lecturas obligatorias en Educación Secundaria (además de codificar el AWL y demás dimensiones relacionadas con ACR).

Entre las grandes obras estadounidenses, donde se retrata su folclore y su idiosincrasia, cabe destacar:

- Textos coloniales: producidos en el periodo fundacional y reportando su incipiente $\mathrm{AWL}$, con un estilo entre lo real y lo sobrenatural, puede citarse The Day of Doom (1662) de WIGGLESWORTH, con su escatología del juicio final ambientado en Nueva Inglaterra; Las maravillas del mundo oculto (1693) o Magnolia Christi Americana (1702) de MATHER, con referencias a la citada 
escatología y el folclore en América. Se trata de una temática recurrente, revisitada en épocas posteriores, sólo que ya más centrada en los aspectos psicológicos y morales del periodo fundacional, como La letra escarlata (1850) de HAWTHORN (sobre el puritanismo colonial y el castigo a una adultera), o Las brujas de Salem (1953) de MILLER (en analogía con el neopuritanismo macarthista). Como compilación de la religiosidad y folclore fundacional, destaca el varias veces reeditado Chap-books of the Eighteenth Century de ASHTON en 1882 (a punto de completarse la conquista continenal del país, gracias a los avances tecnológicos, se compila en este libro lo legendario y sobrenatural de sus orígenes, v.g. apariciones del demonio, brujas, milagros).

- Textos decimonónicos: aunque son obras costumbristas, también retratan los profundos cambios en el país, manteniendo su realismo crítico moral, v.g. $L a$ cabaña del tío Tom (1852) de H. BEECHER. STOWE (quien fuera alumna y maestra en Hartford Female Seminary, de familia muy religiosa -recuérdese las aportaciones de los BEECHER en Nueva Inglaterra- y cuya tesis era que el amor cristiano terminaría con las injusticias de la esclavitud). En su polo opuesto, Mose among the Britishers; or, The b'hoy in London (1850) de GUNN (sobre las vivencias de un gangster neoyorkino, con su novedosa religiosidad popular). Como estudios entre la etnología y la literatura, cabe citar La vida en el Mississippi (1883) de TWAIN, o Las bostonianas (1886) de JAMES; incluso best-sellers (y más tarde películas, series de televisión e internet, etc.), impulsoras del género drama, con recreaciones históricas (v.g. post-guerra civil, gran recesión y depresión, dustbowl) y geográficas (v.g. sur profundo o Deep South, cinturón bíblico o Bible belt), con reflexiones sobre la naturaleza del mal y la lucha del bien y del libre albedrío, además de abundante épica, dilemas morales e injusticias sociales (de raza, 
pobreza, etc.), como Lo que el viento se llevó (1936) de MITCHEL (periodista olvidada por los Estudios de género); De ratones y hombres (1937), Las uvas de la ira (1939) y Al este del Edén (1952) del premio Pulitzer (1940) y Nobel (1962) STEINBECK; Ve y pon un centinela (de la cita de Isaías 21, 6, escrita en 1955 aprox., y publicada en 2015) y Matar a un ruiseñor (1960) de la ganadora del Pulitzer HARPER LEE -igualmente olvidada por los Estudios de género-.

La citada tendencia hacia la novela histórica y el realismo social (transmitiéndose así su $\mathrm{ACR}, \mathrm{AWL}, \mathrm{AD}$, etc.), termina con la generación beat y la perdida (inspiradoras de los baby-boomers y su conversión contracultural -transitando del judeocristianismo al socialismo y al orientalismo), al abandonarse los retratos costumbristas y la denuncia de problemas sociales y dilemas morales, para dar cabida a estilos contestatarios y alternativos a AWL (siendo los primeros velos de confusión extendidos): baste citar como muestra, al germano-estadounidense H.C. BUKOWSKY, máximo referente del realismo sucio, cuyo eje literario es el alcohol y el sexo, y su sentido de lo religioso está entre la crítica de la religión tradicional y la curiosidad por lo exotérico -no pretende la denuncia social, sino el escándalo del lector-.

Entre los literatos estadounidenses (y al efecto de indagar sobre su relación con ACR), si un nombre ha de recordarse, ese es el del considerado poeta nacional, W. WITHMAN, y su canto a América, a su gente y a sí mismo. Se recuerda -de lo mencionado ya-, en cuanto a su aporte para el folclore estadounidense, que su obra se trata de un ejercicio de canto a celebrar la vida, la comunidad y a uno mismo ("Canto a mi mismo" en Hojas de Hierba, 1855): no es un planteamiento idolátrico, sino deísta (tal como se reconvirtiera WITHMAN desde su formación familiar 
cuáquera), pues Dios ama a su pueblo y a cada uno de sus integrantes, por lo que todos tenemos algo de divino que celebrar, y en consecuencia, hemos de homenajearnos. Tanto es así (el cambio de la religiosidad tradicional a la de ACR), que va dejándose de festejar las lejanas honomásticas de los santos, para empezar a celebrar lo cercano, como los nacimientos y cumpleaños (es el triunfo del individualismo: uno importa y es quién decida ser): sólo se es auténticamente estadounidense, si se está orgulloso de serlo (ASR) y si se prueba el propio éxito y beneficio mediante una fiesta de lo más popular (en cuanto conocida y seguida), que te convierta en celebridad (no importa la antigüedad ni quién organice la fiesta, sino lo celebrada que sea), como en El Gran Gatsby (1925), de SCOTT FITZGERALD.

Como detalle complementario (sobre la relevancia del factor religioso en el mundo de las letras), téngase en cuenta que, aún a día de hoy, la obra que sigue manteniendo record de ventas en los EE.UU., desde el periodo fundacional, es la Biblia (seguida de lejos por Historia de la decadencia y caída del Imperio romano, 177689, de GIBBON).

En EE.UU., la música, el teatro y la danza, se fusionan vía Americaness, generándose Performing Arts (vid. infra), con sus expresiones más populares, como son los musicales y los festivales. Al respecto, se invita a reflexionar sobre los siguientes aspectos: es parte de su ACR, la demanda popular (en cualquier población que se precie) de un theater (anfiteatro o gran auditorio donde celebrar actuaciones multitudinarias con precios asequibles), para representaciones diversas, v.g. Lincoln Center for the Performing Arts en New York, John F. Kennedy Center for Performing Arts en Washington DC; incluso, los hay nacionales, v.g. American National Theater en Washington DC. Ahora bien, con la crisis vigente de ACR, puede comprobarse la misma con el cambio de denominaciones de dichos centros, 
sustituyéndose el nombre de padres fundadores y otros hitos de ACR, por marcas comerciales, v.g. Kodak Theatre, 2001-12, y Dolby Theatre, desde 2013, de los Angeles, donde se celebran los premios Óscar de la Academia de las Artes y las Ciencias Cinematográficas. En cuanto a las temáticas de las representaciones, son de lo más diversas, aunque al igual que en la literatura, abundan los retratos histórico-sociales y las preocupaciones morales, dejándose constancia de la evolución de su AWL, formando parte de su ACR. También hay que llamar la atención sobre la crisis en las representaciones: hasta las guerras culturales, las obras más frecuentes en los colegios (amén de los centros comunitarios y confesionales), eran las escenas de Acción de gracias y de Navidad, además de alguna alusiva a los padres fundadores y Presidentes de EE.UU. Actualmente, sobre todo en los colegios públicos, se han sustituido por celebraciones políticamente correctas y de exaltación de la diversidad (sin filtro de Americaness y con ánimo deconstructor de ACR, v.g. el día de la naturaleza, de los nativos americanos, del orgullo LGTBI), por lo que las representaciones suelen reducirse a números musicales próximos a los video-clips.

Como muestra de sincretismo total, se llama la atención sobre un tipo de musical, que más se ha popularizado y ha provocado la fusión de géneros musicales (vid. supra): se alude a dos obras representadas en Brodway en 1971 (sin olvidar la ayuda precursora de El violinista en el tejado de 1964, ganadora de varios Premios Tony y llevada al cine en 1971), con estética hippie, como son la famosa opera-rock Jesucristo Superstar de WEBBER y RICE (sobre la Pasión de Cristo), y el musical de pop-cristiano Godpell de SCHAWARTZ y TEBELAK (con pasajes del Evangelio de San Mateo, incluyéndose también la Pasión), cuyo éxito inspiró la aparición de otros musicales de fusión (v.g. Sister Act y el blues \& soul, The Passion y la música étnica, The Book of Mormon y remixes, además de su elevado tono satírico). 
Específicamente, en cuanto a la música, ésta es una de las artes y expresiones folclóricas de mayor desarrollo y relación con ACR: a diferencia del mundo europeo, en el que la música se profesionaliza y es considerada parte del cultus animi (cuyo sujeto activo o generador es una minoría cualificada, mientras que el resto resulta sujeto pasivo u oyente) -casi hasta la revolución punk, durante las guerras culturales-, en cambio, en EE.UU., gracias a su proceso de Americaness, se considera parte de su cultura vitae, convirtiéndose en una herramienta popular de configuración idiosincrásica, que ayuda a cantarse a sí mismo y a la comunidad (vid. infra WHITMAN). En EE.UU., se mantiene vigente el gusto por la música religiosa (himnos, salmos, villancicos, etc.), los cuales llegan a popularizarse y convertirse en himnos nacionales oficiosos, v.g. Amazing grace, fue compuesto en 1773, para el sermón de Año Nuevo del rev. NEWTON, difundiéndose gracias a la colección de Himnos de Olney y penetrando en EE.UU. como canción predilecta del Segundo Gran Despertar (vid. infra). Fue usado por el movimiento abolicionista y un siglo después, también por el movimiento de derechos civiles (incluso, lo adoptaron los hippies y rockeros, sonando en el mítico festival de Woodstock en 1969). Actualmente, se usa incluso en actos públicos, como en funerales de Estado. Algo parecido ha pasado con otros himnos, como When the saints go marching in, usado en funerales de Estado como el de 2015 (varias veces repetido con la Adm. OBAMA); Nearer, My God, to Thee (basado en el Génesis), e interpretado en los funerales de los Presidentes de EE.UU.: GARFIELD, HARDING, FORD, etc.; Hallelujah!, et al.

Entre los villancicos (que en EE.UU. se llaman Christmas (songs): como la fiesta, las felicitaciones, etc.), de los más conocidos y parte de su ACR, cabe citar: $O$ Christmas tree (de origen alemán), O Holy nigth (de origen francés), et al.; de los villancicos más antiguos y autóctonos destaca Jingle bells (desde Nueva Inglaterra, 
hacia mediados del s. XIX); el gran boom se produjo durante la Gran Depresión, convirtiéndose en grandes éxitos de la radio y de venta de discos: Santa Claus is coming to town, Rudolph the red-nosed reindeer, Whit Christmast, etc.

La popularización de la música religiosa en EE.UU. ha dado lugar a novedos estilos musicales, tanto mayores (v.g. gospel, soul, blues, $R^{\prime} n^{\prime} B$ ) como menores (v.g. underground railroad, mission). Se ofrece una síntesis evolutiva: desde el periodo colonial, en el que la música para los puritanos casi se reduce a los salmos y villancicos (vid. infra), hasta el Primer despertar religioso (antes de la independencia), en el que se consolida el estilo Gospel o música espiritual (con himnos sobre el amor de Dios y su castigo a las injusticias), animándose así la revolución en marcha (y con el segundo despertar se focaliza en los afroamericanos). Hacia el segundo despertar religioso (previo a la Guerra civil), del Gospel derivará el Christian country music y, sobre todo, se consagra el Blues: la causa abolicionista encontrará gran paralelo con la liberación del pueblo de Israel (además de añadirse rutas secretas de fuga en sus canciones: underground railroad). En el s. XX, la fusión es total, dándose lugar al $R^{\prime} n^{\prime} B$ o Rhythm and Blues, Bluegrass, (new/California) Soul y Contemporary Christian music o CCM (también llamado inspirational music), que englobal Christian pop, Christian rock, Christian ballades, etc.

Sobre otros aspectos y manifestaciones artísticas, atravesadas por el factor religioso, popularizándose y formando parte de su ACR, cabe seguir planteando un sinfín de ejemplos; sin embargo, por la natural limitación material del trabajo, se cesa aquí, no sin antes remitir a la labor compiladora y divulgadora por parte de dos agencias estadounidenses, como son el Instituto Smithsonian (con sus exposiciones y colecciones), así como su National Archives and Records Administration-NARA. 
A continuación se procede con una serie de consideraciones telegráficas acerca de la arquitectura, los monumentos, y algún aspecto más del folclore estadounidense, relacionados todos ellos con su ACR. Si se viajara por EE.UU., por la mítica ruta 66 (también llamada Main Street of America o the Mother Road, que une el país de California a Ilinois y prácticamente New York, y fragmento está el National Museum of American History, además de aparecer en un sinfín de novelas, películas, series de televisión, etc.), podría comprobarse la impronta de la tradición sagrada occidental (pasada por su Americaness), tanto en las denominaciones de las poblaciones (v.g. Jerusalem/Salem y Hope son nombres frecuentes de poblaciones en casi la mitad de los Estados de la Unión, vid. infra cap. 5 y 6), así como en su arquitectura local (incluidos monumentos): resulta recurrente la representación de los diez mandamientos en los tribunales de justicia, capitolios y parlamentos estatales (v.g. frontispicio del Tribunal Supremo -con representaciones además de Moisés, Salomón, Confucio, etc.-, Capitolio de Texas); capillas, pinturas y esculturas en edificios públicos (v.g. Prayer Room of the US Senate \& House of Representatives); ídem, instituciones privadas (v.g. Jacob's Dream o escalera de Jacob en campus de Abilene Christian Univ.); casi doscientas catedrales católicas, más de doscientas protestantes, medio centenar ortodoxas y millares de templos (v.g. iglesias, sinagogas, mezquitas), etc. Entre los principales monumentos nacionales (reconocidos por la Ley de antigüedades, la Ley de patrimonio y el Servicio de Parques Nacionales), se llama la atención sobre los más sincréticos de ACR, como son: Monumento Nacional Monte Rushmore; Cristo de los Ozarks; Memorial de Guerra del Cuerpo de Marines de EE.UU. (Marine Corps War Memorial o Iwo Jima Memorial: en Arlington, Newington, Quantico, etc.); Monumento nacional de la torre del diablo, salina Pueblo Missions, Washington Birthplace, et al. Un lugar de máxima concentración de 
arquitectura y monumentos de ACR dedicados a los padres fundadores es la llamada explanada nacional o National mall \& West Potomac Park, que incluyen en su haber: Washington Memorial, Jefferson Memorial, Lilcoln Memorial, etc.

Figura 92.- Representaciones de los diez mandamientos en edificios oficiales
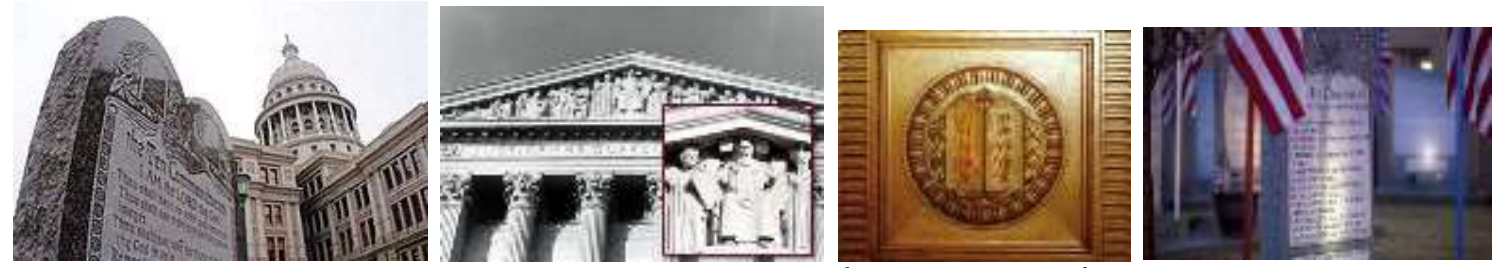

Fuente: elaboración propia (SÁNCHEZ-BAYÓN, 2007 y 16).

Figura 93.- Capitol E Congressional Prayer Room
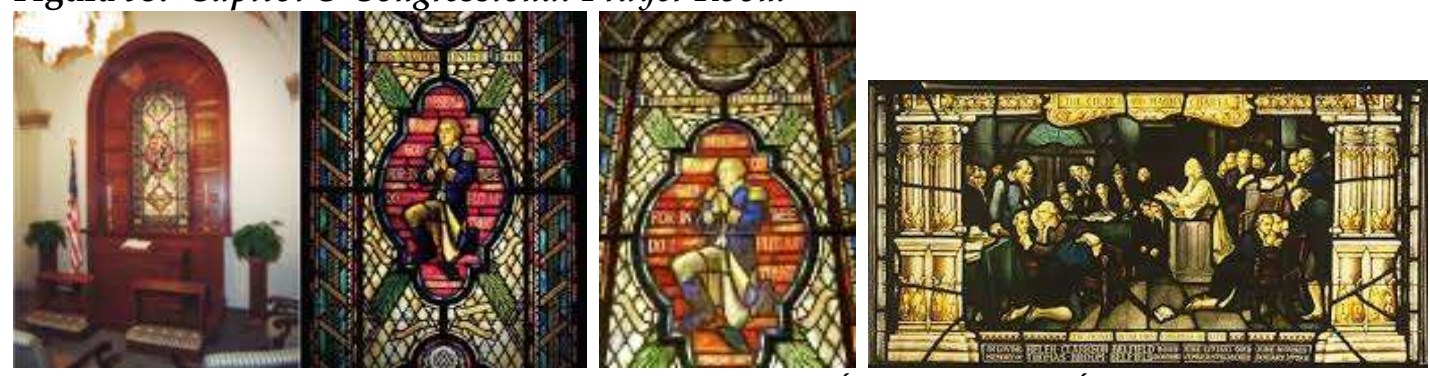

Fuente: elaboración propia (SÁNCHEZ-BAYÓN, 2007 y 16).

Figura 94.- Jacob's Dream statue en ACU campus (Gn. 28:10-22) o Ozark Christ College (Lc. 8: 5-11)
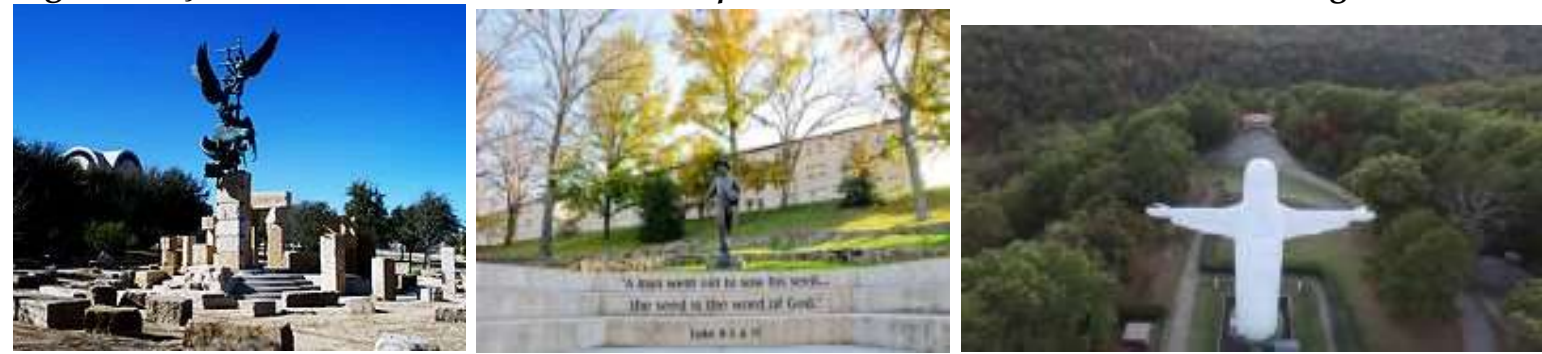

Fuente: elaboración propia (SÁNCHEZ-BAYÓN, 2007 y 16).

Figura 95.- National mall \& West Potomac Park.
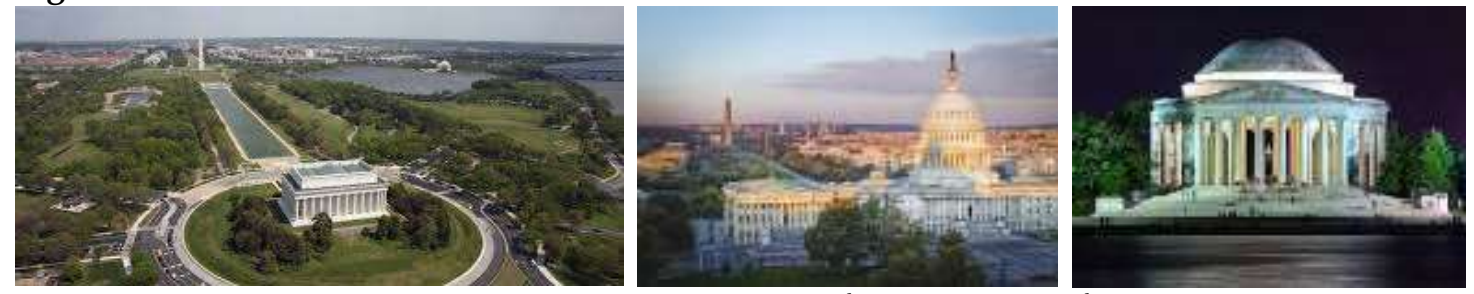

Fuente: elaboración propia (SÁNCHEZ-BAYÓN, 2007 y 16). 


\section{3.- EVOLUCIÓN Y EVALUACIÓN DE SU GESTIÓN Y ESTADO ACTUAL:} CICLOS DE DESPERTARES Y REVITALIZACIONES (SEGÚN RELACIONES ATLÁNTICAS).

Se retoma aquí lo planteado con anterioridad (vid. infra cap. 1 y 8), sobre la Historia estadounidense y su dimensión participativa y vocación popular (con su juego de palabras History of $U S$ ), que sin embargo ha sido distorsionada con velos de confusión extendidos desde los Estudios culturales sobrevenidos: no sólo promovieron la memoria comunitaria frente a la Historia social, sino que además, procuraron deconstruir cualquier consenso integrador (recuérdense los ataques al excepcionalismo y su melting pot), llegando incluso a afectar al periodo fundacional, violentándose la matriz mitopoiética estadounidense y su legado (y con ello su $\mathrm{ACR})$, para intentar llenar ese vacio con su tropología exaltadora del hecho diferencial de cada supuesta comunidad marginada (v.g. afroamericanos, latinoamericanos, asiáticoamericanos, feministas y género). Todo ello llevó al enfrentamiento y polarización de los Estudios culturales, los cuales siguen aún hoy sin cumplir con su cometido científico-académico de reformular la identidad estadounidense, para adaptarla a cada época (en este caso, al periodo posglobalizatorio).

Desde este estudio se pretende ofrecer una novedosa propuesta historiológica estadounidense, basada en sus ciclos de despertares y revitalizaciones (CDR). A diferencia de las propuestas historiológicas antecedentes (v.g. factor llamada, frontera), la de CDR se ofrece como una suerte de teoría evolutiva lato sensu (combinando evolucionismo científico-natural, desarrollismo científico-social, 
emanatismo/emanantismo filosófico, etc. $)^{673}$. Dicha condición evolutiva afecta tanto a la propia religión (en su secularización moderna y su apertura al Nuevo Régimen o como reza el lema nacional estadounidense: novus ordo seclorum, vid. infra cap. 5), como a su impacto en el devenir sociocultural estadounidense (dado su evangelismo, su mesianismo, su moralidad, etc., reflejándose todo ello desde las bases sociales en su folclore y misiones o cruzadas sociales, además de llegar a la agenda institucional de las elites de poder, vid. infra). Igualmente, otro rasgo definitorio de la propuesta de CDR es su vocación holística, entre otras razones, para procurar la integración de las diversas aportaciones historiológicas precedentes (rasgo a aclarar algo más en breve). De tal suerte, además, se pretende por esta vía el detectar y aglutinar pautas y patrones de tendencias, según las coyunturas más marcadas del devenir sociocultural estadounidense, según las tensiones de acción-reflexión, ampliación-profundización, intervención-aislacionismo, éxito-fracaso, moral-inmoral, etc. En consecuencia, CDR da juego a la combinación de dualidades y dialécticas históricas tradicionales (casi coincidentes con la mayoría de las europeas coetáneas

${ }^{673}$ Las voces mencionadas son aceptadas por la doctrina científico-académica, atendiendo a la siguiente diferenciación generalmente aceptada: dado el pretendido monopolio de la voz evolution o evolución por los científicos naturales (atribuyendo su epistemología a Darwing -quien refiere en sus estudios otros conceptos como capacidad de adaptación, selección natural, etc.-, en vez de reconocérsela al sociólogo SPENCER), ello ha provocado que para las Ciencias Sociales se reserve la voz development o desarrollo. En la Filosofía (y resto de Liberal Arts o Humanidades), se maneja la dualidad emanatismo/emanantismo; la primera voz suele ser usada por aquellos autores que trabajan de manera comparada con planteamientos filosófico-religiosos protestantes (anglosajones y nórdicos), además de orientales y gnósticos, mientras que la segunda se corresponde con las líneas de pensamiento clásico, medieval y moderno católico. Además de las expresiones citadas, desde los Estudios culturales se viene recurriendo también a otras voces como genealogía o raíces. Tal diferenciación, con su correspondiente tensión y pretendida jerarquización de las ciencias es parte del problema del cientificismo (velo posmoderno de confusión, por el que la ciencia es ocultada por la tecnología, con ayuda de otros velos, como el pensamiento débil, la corrección política, etc.), y todo ello aflora con los citados Estudios culturales sobrevenidos, como se aclara más adelante (ídem). Vid. SÁNCHEZBAYÓN, A.: "Problemas epistemológicos y fenomenológicos de la Universidad actual", Miscelánea Comillas (v. 71, no 139), 2013. - “Galeato pro universitas humanitatis”, REPES (v. 20), 2013. 
-de ahí la aceptación de parte de la crítica a los planteamientos del excepcionalismo estadounidense, pues su singularidad no se basa tanto en lo extraordinario de lo acaecido, sino en el tipo de percepción y gestión acometida y generalizada al respecto-): relaciones campo-ciudad, manufactura-industria, guerra-paz, Iglesia-Estado, elites-bases sociales, etc., junto con la rica amalgama de nuevas cuestiones apuntadas por la Historia sociocultural estadounidense (reincorporándose al análisis factores y esferas sociales reactivadas con la globalización, como la religión), con relaciones del tipo: a) realistas-patriotas: los primeros, en su mayoría anglicanos (y por ende leales a la Corona), y los otros, profesan nuevas corrientes protestantes (incluso, el deísmo); de ahí la lógica unitaria del I despertar y su revitalización, que condujera al trascendentalismo (y al pragmatismo), además de abonar las condiciones sociales para el II despertar y revitalización, con el interludio de la Guerra civil (vid. supra); b) terratenientes-industriales: los unos anglicanos del sur, y los otros reformados autóctonos del norte (main-line churches y evangelical churches); su tensión va más allá del dominio de los medios de producción, pues afecta al modelo socio-cultural dominante (la Guerra civil puede entenderse también como un conflicto por la superioridad moral y el influjo sobre el alma de la nación); c) blancos-negros: pudiendo ser ambos, por ejemplo, bautistas (iglesias bautistas blancas -centradas en la heteropraxis-y negras -definidas por la heropatía, máxime a través de los cánticos espirituales, v.g. soul, gospel-), pero sin mezclarse realmente, evidenciándose aristas sociales a pulir mediante sucesivas cruzadas (v.g. la corrección política podría considerarse una suerte de neopuritanismo, como lo fuera el abolicionismo decimonónico); d) santos/apolíneos-pecadores/dionisiacos: una muestra, entre las múltiples cruzadas sociales acometidas desde el s. XIX (y presente hasta la fecha), es la relación abstemios-bebedores, siendo más beligerantes los evangélicos, quienes han 
articulado como su némesis a los católicos (en sus cruzadas anti-alcohol, anti-vicio, etc.). Actualmente, como resultado de las guerras culturales, tal relación se ha trasplantado a republicanos-demócratas; e) nativos-inmigrantes: los protestantes se imponen frente al resto (con su modelo socio-cultural WASP), por ser según ellos nuevos inmigrantes y/o sujetos de derecho (v.g. religiones afroamericanas, indoamericanas, asiático-pacíficas); et al.

En definitiva, la CDR es una suerte de propuesta de bootstraps o entrelazamientos, en la que no se da preferencia a hitos, discursos, personajes y/o movimientos, sino que se presenta todo ello conectado (cuyo hilo argumental es el impacto sociocultural del factor religioso en la construcción idiosincrásica estadounidense). Además, es posible de tal modo el entender los avances y retrocesos (en realidad, apertura y cierre de ciclos, en forma de espirales, más bien), que aparentemente suelen tener lugar en el transcurrir histórico sobre el que se fundamenta la forja identitaria. Se comprenden así los tiempos de acción y reacción, profano y sagrado, aislacionismo e intervencionismo, et al. Se nutren por esta vía los ciclos de un plan de progreso, que puede leerse a la par en clave de predestinación y de autoderminación, incluso de kairología.

La propuesta de CDR que aquí se presenta -aún a modo de teoría en ciernes, que no de tesis dogmática acabada (pues aún hoy sigue sometida a revisión y reformulación)-, bebe de las nociones que se manejan en disciplinas de Estudios culturales tradicionales (vid. infra cap. 8), siendo recibidas durante las estancias de investigación en universidades estadounidenses (v.g. Harvard, DePaul, Baylor, $M H B U)$. Se basa dicha propuesta en los procesos históricos y su lógica sistémica, según la cual el desarrollo estadounidense, aunque ha sido tendente hacia el progreso (entendido como un mayor bienestar generalizado), ha tenido etapas de 
fluctuación (entre el crecimiento, su aceleración y desaceleración, el estancamiento, la recesión, incluso la contracción), pero en cualquier caso, corrigiéndose a la postre gracias a los despertares sociales y revitalizaciones elitistas acaecidas en su seno. Con tales nociones se formuló una primera teoría al respecto, validada ante la academia a mediados de la década del 2000 (siendo revisada a la postre). Antes de dar a conocer los rasgos del sistema CDR, así como las diversas versiones manejadas al respecto, se ofrece un mínimo esbozo de las lecturas originales que inspiraran la propuesta: a) Rev. y Prof. EMERSON (líder del trascendentalismo, padre del pragmatismo, vinculado a la Divinity School de Harvard y formado en parte en Prusia, además de amigo de la intelectualidad británica de entonces, v.g. STUART MILL, CARLYLE, WORDSWORTH, COLERIDGE), con su teoría de la rivalidad acción-reflexión (Conservative, 1841); b) ADAMS (ex Presidente y con cargos en Europa, además de admirador de EMERSON) y su teoría de las pendulaciones entre nacionalismo-localismo (History of the United States of America during the Administrations of Thomas Jefferson and James Madison, 2 vols., 1889-91); c) SOROKIN (ruso y primer director del Departamento de Sociología en Harvard) y su teoría de mentalidades culturales (Social and Cultural Dynamics, 4 vols., 1937-43); d) LUBELL/LUBELSKY (polaco y primer demógrafo electoral, además de periodista y colaborador de varias universidades, v.g. Columbia) y su teoría de los modelos de realineamiento (The future of American politics, 1952); e) los SCHLESINGER (ambos profesores de Historia de Harvard, además de asesores políticos), tanto el padre (Paths to the Present, 1949) como el hijo (The cycles of American History, 1986); f) Rev. y Prof. STOKES (además de capellán de Yale) y su monumental Church and State in the United States (3 vols., 1950), revisada por PFEFFER (judío austro-húngaro y prof. Derecho Constitucional en la Univ. New York) y versionada una década después (Church, State and Freedom, 
1963); g) STRAUSS y HOWE (historiadores y consultores -colaboradores de BANNON, quien es el principal consejero del Presidente TRUMP) con su teoría generacional -entre la historia, la psicología (con sus arquetipos) y la profecía(Generations, 1991 y The Fourth Turning, 1997), et al. Sin más dilación, se esquematiza CDR del siguiente modo (sabiéndose de su necesaria reformulación de matizaciones, con reajustes en ciertos aspectos cronológicos, cliométricos, generacionales y kairológicos).

Antes de ofrecer el esqueva evolutivo de CDR, se retoma la cuestión de su vocación holística: ello supone una aspiración de un mayor conocimiento de conjunto, basado en interconexiones, que dé cabida a las teorías y lecturas precedentes (v.g. frontera, excepcionalismo), intentando su conciliación en la medida de lo posible (incluso con sus críticas), procurándose así el arrojar más luz, de manera global, sobre el devenir estadounidense. En cuanto a su articulación holística, como sistema integrador interdisciplinar, supone que se procura el ofrecer un estudio armonizador de conocimientos interconectados, tanto el científico stricto sensu (tal conocimiento ha de ser autónomo y sistémico, para poder ampliar y profundizar, conforme a una metodología propia) ${ }^{674}$, como otros conocimientos influyentes en el objeto de estudio (diacrónicamente, la sabiduría o la mística; sincrónicamente, el conocimiento religioso o el cultural). En consecuencia, lo que se pretende en esta investigación y bajo la propuesta CDR, es el dar cabida a planteamientos tanto históricos, como historiológicos, además de historiográficos, aparentemente dialécticos, tratándose de manera copulativa y sintética:

\footnotetext{
${ }^{674}$ Se debe mucho a multitud de autores, citado todo ello en diversas obras, máxime, en SÁNCHEZBAYÓN, A.: Estudios de cultura política-jurídica, Madrid: Delta, 2010. - Innovación Docente en los nuevos estudios universitarios, Valencia: Tirant Lo Blanch, 2014.
} 
a) Un sistema empírico y de periodificación (de tipo fáctico y tradicional, más inductivo y descriptivo -fenomenológico-, con una exposición y explicación de atrás a adelante -buscando ordenación de sucesos-, con un mayor protagonismo de las bases -bien como fuentes originarias o ratificando luego-), compatible con un sistema lógico y de cronología (construido y técnico-profesional, más deductivo y prescriptivo -dogmático-, articulado de adelante a atrás -buscando coherencia-, impulsado por las elites para las bases y con el auspicio del Estado-nación).

b) Un sistema ad intra-ad extra, que comprende fuentes (ad intra, tanto las originarias y de creación, como las derivadas y de interpretación o conocimiento, etc.) a la vez que instituciones (ad extra, públicas y privadas, simples y complejas, autónomas e interdependientes, etc.).

c) Un sistema de ciclos de progreso (con sus etapas de crecimiento y recesión), atendiéndose a planteamientos analíticos y kairológicos, dándose así cabida a un juego de lo sagrado y lo profano (según la recepción y adaptación de las tradiciones occidentales judeo-cristiana -irrepetible, trascendente y de predestinación- y greco-romana -cíclica, inmanente y de ensayo y error-). A su vez, se combina dicho juego con aportaciones empíricas y cliométricas, relativas a las relaciones entre las bases sociales y sus élites de poder en su búsqueda de un mayor bienestar. Así, la presunta lectura evolutiva estadounidense responde a una expectativa de progreso, conforme a la providencia divina, y matizándose con la revolución correctora, frente a desviaciones humanas de la empresa nacional. Luego, se asume por ello que hay crisis y transiciones (periodos emocionales e irracionales de reconfiguración, frente a los racionales de expansión, dando lugar a episodios de expansionismo o de aislacionismo, etc.). La cuestión se intenta aclarar mejor, más adelante, con la revisión de CDR que aquí se propone. 
Por tanto, la propuesta de CDR, no sólo atiende a la evolución en sentido laxo, sino que ella misma ha pasado por un proceso evolutivo de formulación, revisándose periódicamente (a medida que ha ido aumentado el conocimiento al respecto). Téngase en cuenta que, por despertares y revitalizaciones se alude al juego de interacciones socioculturales (sacro-profanas), dinamizadoras de la vida nacional (aquellos episodios determinantes de su idiosincrasia), además de evidenciadoras de una serie de ciclos sociales (v.g. expansionistas-aislacionistas), que conforman a su vez de una pauta de desarrollo (hacia un supuesto progreso bendecido). Recuérdese que, la aludida vida nacional ha de entenderse de manera diferente al sentido europeo-continental (tal como predica el excepcionalismo), pues en el caso estadounidense, no ha sido monopolizada por el Estado-nación, sino que su dinamización principal ha procedido de la sociedad civil, con sus múltiples comunidades, entre las que destacan las confesiones y su preocupación por mejorar el mundo. Volviéndose a la propuesta de CDR y las interacciones que incluye, resulta que el arranque de la mayor parte de tales interacciones suele provenir de la eclosión de movimientos sociales demandantes de reformas del sistema, propiciándose una incorporación de nuevos discursos regeneradores, así como la renovación de las elites de poder, hasta su adopción por las consiguientes elites sensibles a la regeneración, bajo una suerte de revitalización sociocultural del proyecto nacional, y a la postre, además, procurándose el plasmar todo ello en su contribución al legado nacional.

Se formuló al respecto una periodificación rudimentaria en 2005 (tras unas entrevistas con expertos de las universidades de DePaul, Chicago y Northwestern), presentándose ese mismo año en el Congreso de la Asociación Española de Ciencia Política y de la Administración-AECPA en la Univ. Complutense de Madrid-UCM 
(publicándose en sus actas, así como en un libro colectivo dirigido por los Prof. Pastor y Cairo ${ }^{675}$. Esa periodificación, más alguna noción fundamentadora, se sometió a revisión, para su matización y ampliación, durante la estancia de investigación en Baylor (2006), defendiéndose en la tesis doctoral de Derecho por la UCM (2007), y dándose a conocer en una serie de publicaciones en $2008^{676}$. Más tarde, tras reiteradas estancias de investigación posteriores, se revisó y amplió la propuesta de CDR (con matizaciones de reajuste en ciertos aspectos cronológicos, cliométricos y kairológicos) para la tesis doctoral en Humanidades (especialidad en Teología) por la Univ. Murcia (2016). La última vez que se ha revisado la cuestión, ha sido durante la estancia de investigación en IPB (Braganza, Portugal), impartiéndose un seminario, más una publicación de impacto (índice Scopus/SJR) ${ }^{677}$, ofreciéndose el siguiente planteamiento de CDR:

a) Periodo fundacional I (nacimiento) o independentista (CDR 1, 1730-60/1770-90): en cuanto a su pensamiento idiosincrásico, predomina la teología política, combinada con la ilustración propia, y comprende el problema civilizatorio y de frontera, con sus respuestas nativista e independentista. El CDR 1 afecta a la genealogía colonial (de pilgrims, puritans \& leaders), y sus hierofanías y hierocracias de Plantaciones sureñas (donde domina un confesionalismo moderno

\footnotetext{
${ }^{675}$ Vid. SÁNCHEZ-BAYÓN, A.: “Idiosincrasia de la identidad nacional y del modelo socio-cultural estadounidense según el influjo de sus elites político-jurídicas", Actas del VII Congreso Español de Ciencia Política y de la Administración, 2005. - "International Religious Freedom Act of 1998 y la evolución de la geopolítica estadounidense reciente", idem. - "La International Religious Freedom Act of 1998 y la geopolítica estadounidense actual", en CAIRO, H., PASTOR, J. (comp.): Geopolítica, guerras y resistencias, Madrid: Trama Editorial, 2006.

${ }^{676}$ Vid. SÁNCHEZ-BAYÓN, A.: “Historia de la Comunicación Social Estadounidense a través de sus Movimientos Religiosos" (pp. 199-223), en Historia y Comunicación Social (vol. 13), junio 2008. Complement., vid. infra nota 373, 419, 468, 504, 519, etc.

677 Vid. SÁNCHEZ-BAYÓN, A., et al.: “Una historia filosófica de la identidad estadounidense: Balance de propuestas y su crisis actual", en Bajo Palabra (II Época), no 18, 2018, p. 209-36. Complement., vid. infra notas 3 a 5, 11, 16, 24, 55, 68 y 272, más p. 126 ss.
} 
-más formal que de fondo-, matizado por el espíritu empresarial -ese es el formato de asentamiento: adventures $\mathcal{E}$ settlement-), Nueva Inglaterra (denominalismo -reformista y puritano-, bajo formato de colonias -autárquicas en su mayoría, salvo por políticas fiscales desde la metrópoli), y Provincias Medias (experimentos socio-religiosos -incluso con contendencias deístas y fórmulas de comunitarismos agrarios-, y con formato dominante de misiones y concesiones). Viven el I despertar y revitalización: una llamada a la unión (e pluribus unum) como pueblo (American people) con un destino manifiesto (American manifest destiny$A M D$ ), para liderar al resto de naciones en el nuevo orden mundial (novus ordo seclorum).

b) Periodo fundacional II (auge) o nacionalista (CDR 2, 1800-1840/1850-60): se transita de la teología política a la filosofía pragmática, atendiéndose al problema moral de estilo de vida y su respuesta guerracivilista, así como la reconciliación posterior. El CDR 2 atiende a la genealogía nacional (framers), dividida entre la Confederación (expuesta al síndrome de Babel: sin una unión real, y por tanto con división a la postre), y la Federación (reformulando la tradición occidental, entre Jerusalén y Roma). Empieza a haber movimientos milenaristas (más otros posjudeocristianos), máxime con conflictos fronterizos (secesionistas y de conquista del Oeste). Viven el II despertar y revitalización: una llamada a compartir un estilo de vida (American way of life- $A W L$ ) moralmente comprometido con una sociedad mejor (inspiradora del American dream- $A D$ o sueño estadounidense).

c) Periodo (re)fundacional (cénit) o hegemónico (CDR 3, 1870-90/1900-1950): siguen conviviendo la teología política y la filosofía pragmática, además de aparecer los Estudios culturales tradicionales. Inicialmente, se circunscribe al problema milenarista y apocalíptico (guerracivilismo y gran recesión), con su respuesta 
mesiánica y renovación de pactos sociales para el progreso. El CDR 3 se centra en la genealogía regional (statemen), distinguiendo el tipo de mesianismo y redención entre las gentes del Este-Oeste y del Norte-Sur. También alcanza a la genealogía guerracivilista y reconciliadora (redeemers), con su secesionismo (por (pseudo)nativismos y milenarismos) y su guerracivilismo (cainismo y reconciliación); completándose con las nuevas alianzas, inspiradoras de la gran expansión de bienestar y áreas de influencia socio-cultural. Se trata de un periodo preñado de movimientos milenaristas y múltiples cruzadas. Viven el III despertar y revitalización: una llamada a participar en un adelanto del reino de los cielos, debiéndose combatir el mal existente que lo amenaza (lo que supone la combinación de metámeros sociales y propuestas del tipo American gospel-AG, American self-righteouness-ASR, etc.).

d) Periodo (post)fundacional (declive) o imperial (CDR 4, 1960-90/2000-2010): a medida que EE.UU. tiene una mayor presencia internacional, también recibe más influjos, que el Americaness tarda en adaptar, escapándose buena parte de la crítica generada por la fuga de cerebros (instalados cómodamente en medios de comunicación y universidades), que a modo de caballo de Troya, extienden velos anti-europeístas, más tarde anti-americanos y finalmente anti-occidentales (tal como se cultiva desde los Estudios culturales sobrevenidos). Tienen lugar las llamadas guerras culturales (entre las élites progresista del Ivy League y las bases tradicionalistas del Bible belt), a raíz de la pérdida de inocencia (cuestionándose AMD, AD, AWL, AS, ASR, etc.), transitándose hacia la posmodernidad estadounidense (pasándose del ethos al pathos, del consenso al hecho diferencial, además de inhabilitarse el diálogo intergeneracional, al polarizarse la discusión de la decadencia cultural y moral). En cuanto a la genealogía comprendida, es 
transcontinental de corte pop, comprendiéndose, de un lado, los etnoculturales, de influjo crítico-contestatario (herederos de la Escuela de Frankfurt, NormaleAnnales y Birmingham, influyentes en los baby-boomers, así como los posestructuralistas en la generación $x$ y los poscoloniales en la generación y); de otro lado, los originalistas, tanto fundamentalistas (en centros TRACS) ${ }^{678}$ como los conversos o neoconservadores (en universidades más allá del Ioy League y think-tanks). La identidad estadounidense queda escindida, pues en lo económico e internacional parece haberse impuesto el bando neocon, mientras que lo sociocultural y doméstico ha quedado en manos etnoculturales. Durante las guerras culturales se vive el $I V$ despertar y revitalización: una llamada por la memoria histórica y la conciencia moral del país y sus comunidades.

Tal como se ha señalado, actualmente se sigue trabajando en la materia para su mejora (además de atender al $V$ despertar y revitalización, sobre la extinción estadounidense, a raíz de su Americaless y su transoccidentalización: la renuncia a su ser y su relación con Occidente tradicional, para reinterpretarlo en una focalización Asia-pacífico, vid. supra) ${ }^{679}$. La versión en curso pretende integrar todo lo apuntado

\footnotetext{
${ }^{678}$ Transnational Association of Christian Colleges and Schools, es la organización que integra a los centros cristianos de educación aquellos que cumplen las exigencias de la Secretaria de Educación de los EE.UU. No es hasta el IV despertar, cuando se inicia el auge de dichos centros, que pasan de focalizarse en la formación de líderes religiosos, a comprender otras áreas científico-académicas (v.g. Derecho, Política, Economía, Educación, Comunicación, Medicina, Biología). Así surgen universidades de nuevo cuño -de marcado proselitismo- como Bob Jones, Oral Roberts, Liberty, etc.

${ }^{679}$ Según la Teología política estadounidense, y la teoría de despertares y revitalizaciones, la cosmogonía estadounidense responde a una serie de ciclos en los que se recalibran cuestiones tales como las relaciones entre lo sagrado y lo profano, el aislamiento y el intervencionismo, etc. Para ello es necesaria la aparición de personajes mesiánicos, cuya unción bien puede legitimar para reconducir al pueblo elegido (a modo de pastor o reverendo), o cabe -como en los casos de LINCOLN o KENNEDY - que tengan que ser sacrificados, para redimir al pueblo y renovar así el pacto con Dios -no se quiere decir, que tal cosa sea así, sino que la historiografía termina presentándolo de esa manera (a modo de vidas ejemplares de santos, revisadas por los Estudios culturales sobrevenidos)-.
} 
hasta ahora, yendo más allá, y prestando una mayor atención a las fluctuaciones acaecidas y sus patrones. La pretensión es llegar a establecer un sistema holístico basado en unas oleadas de despertares y revitalizaciones según oportunidades, urgencias y necesidades sociales -pero tal cosa ya resulta materia de otras publicaciones futuras-. Ahora se aterriza en los mimbres de los que se ha partido y que han conformado las múltiples manifestaciones de la filosofía identitaria estadounidense.

Finalmente, la propuesta queda como sigue (desarrollándose en la tesis de Historia de la Filosofía en curso):

e) Periodo fundacional I y sus ciclos de despertares y revitalizaciones (CDR 1, 173050/1770-80): comprende el problema civilizatorio y de frontera, con sus respuestas nativista e independentista. El CDR 1 afecta a la genealogía colonial (de pilgrims, puritans \& leaders), y sus hierofanías y hierocracias de Plantaciones sureñas (donde domina un confesionalismo moderno -más formal que de fondo, matizado por el espíritu empresarial -ese es el formato de asentamiento: adventures \& settlement-), Nueva Inglaterra (denominalismo -reformista y puritano-, bajo formato de colonias -autárquicas en su mayoría, salvo por políticas fiscales desde la metrópoli-), y Provincias Medias (experimentos socioreligiosos -incluso con contendencias deístas y fórmulas de comunitarismos agrarios-, y con formato dominante de misiones y concesiones).

f) Periodo fundacional II y sus ciclos de despertares y revitalizaciones (CDR 2, 1790-1830/1840-60): atañe al problema moral de estilo de vida y su respuesta guerracivilista. El CDR 2 atiende a la genealogía nacional (framers), dividida entre 
la Confederación (expuesta al sindrome de Babel: sin una unión real, y por tanto con división a la postre), y la Federación (reformulando la tradición occidental, entre Jerusalén y Roma). Empieza a haber movimientos milenaristas, máxime con las guerras y conflictos fronterizos.

g) Periodo (re)fundacional y sus ciclos de despertares y revitalizaciones (CDR 3, 1860-80/1890-1950): se circunscribe al problema apocalíptico (guerracivilismo y depresión) y su respuesta mesiánica. El CDR 3 se centra en la genealogía regional (statemen), distinguiendo el tipo de mesianismo y redención entre las gentes del Este-Oeste y del Norte-Sur. También alcanza a la genealogía guerracivilista y reconciliadora (redeemers), con su secesionismo (por (pseudo)nativismos y milenarismos) y su guerracivilismo (cainismo y reconciliación). Se trata de un periodo preñado de movimientos milenaristas y múltiples cruzadas.

h) Periodo (post)fundacional y sus ciclos de despertares y revitalizaciones (CDR 4, 1960-90/2000-2010): con su problema de decadencia cultural y moral (guerras culturales), destacando entre sus respuestas la neoconservadora. En cuanto a la genealogía comprendida, ésta es transcontinental $(p o p(s))$, afectándose a las relaciones domésticas (en temas como el cinturón bíblico y otras Américas), y las relaciones exteriores (con sus cruzadas en patio trasero y Tierra santa).

Tal como se ha señalado, actualmente se sigue trabajando en la materia para su mejora. La versión en curso pretende integrar todo lo apuntado hasta ahora, yendo más allá, y prestando una mayor atención a las fluctuaciones acaecidas y sus patrones (procurándose un mayor ajuste con el análisis generacional). La pretensión es llegar a establecer un sistema holístico basado en unas oleadas de despertares y 
revitalizaciones, conforme a una matriz DAFO adaptada (atendiéndose a debilidades o fallos-riesgos, amenazas y urgencias sobrevenidas, fortalezas o apoyos institucionales y sociales, y oportunidades de demandas sociales y práctica de ensayo-error de fórmulas -pero tal cosa ya resulta materia de otras publicaciones futuras-). 
Sociología de las Relaciones Socioculturales Nortatlánticas (...) American civil religion - A. Sánchez-Bayón 


\section{CONCLUSIONS}

In the USA, the religious factor and religious social sphere, also the freedom of religion is extensively sense, it is not just as a foundational milestone, because it is part of the American way of life, from colonial experiences for those who were prosecuted for their religion and culture, and it has been for several communities until the great wars and mass exterminations of the 20th century (i.e. Jewish People, Armenians, Baha'is), and all of them, they could be part of American melting pot (at least until the current identity politics, as a result of post-modern veils and the deconstruction by recent Cultural Studies). So, the religion (under the American way), it is such a key issue that it is the very first of the liberties recognized, and even in a double doubly fashion (with two protective clauses). What is more, a great part of US doctrine considers that it is the cornerstone through which the rest of civil freedoms have been construed, as has been observed in the cases studied. As a consequence, freedom of religion is deeply acknowledged, protected and furthered in the USA, and in its relations with other countries (idem). Nonetheless, the last Administrations (CLINTON and G.W.BUSH) have prompted a crisis due to postmodern contagion. There has been a manipulation of meanings in the traditional scope of words, and language has been used politically and selfishly in order to legitimize public policies. What then has happened to the much-quoted "wall of separation"? It is crucial to draw a clear separation between Church and State (not an independization): the Church is an institution pertaining to the religious sphere, and the State is the political sphere, so each one has its own competences (but linked in social problems and public issues). Although both issues have an impact on society they are not mutually exclusive, especially in other mix issues as American 
civil religion or ACR (to build the American identity and its heritage). It is so important to highlight this notion because otherwise the result could be: a) identification, like in Middle East regimes (confessionalism), or b) exclusion, like in continental European countries (secularism / laicité). Politics and religion have their own social spheres, but they overlap in areas like social assistance or identity issues (like ACR). That is the reason why it is so urgent in the West (under the revival of identity trouble and religious identity around the World), to recover an accommodating separation model to lead to a rational system of checks and balances. Regarding the final assessment of the U.S. social order its treatment of the religious factor, such regulation ranges from basic rules (Constitution and jurisprudence), to auxiliary ones (Executive Law, Statutory and International Treaties, especially in human rights). Traditionally, in the first third of the 20th century, the weight of organization was in the hands of the law, but statutory law took on more prominence beginning in the inter-war period, and it has been the instrument chosen to implementthe welfare state. However, with the onset of globalization, Executive Law has become particularly relevant, although its short expirationand rather discursive load are serious problems. The question now is how to articulate the Ordinance, which is the current major factor to regulate this issue. The religious factor in the U.S. is crucial, because as mentioned before, it has been considered a corner stone of identity, cultural background, social power, and solidarity. And the U.S. model is still a reference point for other Western countries.

In conclusion, after the whole review of the state of the ACR (which was attacked by recent Cultural Studies), it is expected to have showed the objectives set out at the beginning of this thesis, having offered the articulation of a critical review and authenticity analysis, on the ACR evolution and its influence on the US 
idiosyncratic configuration (after receiving and adapting the western tradition, singularizing it by Americaness, to end up becoming western leader of the last period). In this analysis, in addition to deepening the evolution and evaluation of its sociocultural dimension, it is expected to have contributed enough comparative perspective (not only diachronic, but also synchronous in the North Atlantic relations). In this way, equally, it is expected to have achieved the disclosure:

- The essence and manifestation of ACR (as sociocultural metamer of integration prior to the nineteenth-century category of nation), as well as to investigate its evolution (with its advances and drifts, with its cycles and transitions), according to its influence on the American articulation of its identity and collective mentality, its social imaginary and its symbolic capital, etc.

- The North Atlantic relations in the emergence, development and decline of the ACR, finding out how the relations occurred and how much depth had the feedback between the two coasts (the awakening as the American people, thanks to the integration of people from all over Europe, prior it passed through its Americaness, until the most recent incorporation of the post-war brain drain, which brought with it postmodernity and the Americaless).

- The balance of the current situation of the ACR, its crisis and translation to the current trance of idiosyncratic American failure, not only from the crisis of globalization (due to the expiration of norms and institutions linked to the nationstate), but also by the previous, during the cultural wars (in the middle of the Cold War), which have been projected on past eras, going back even to the foundational period and its mitopoietic matrix and its consequent legacy (causing a set-up corruption). 
- The complementary constructs to ACR (with their corresponding mid-range theories), of type AG / ASG, AMC, AD, AWL, AC, ASR, et al., Up to one of the most recent manifestations -and of the most criticized by the cultural studies that have taken place - such as American exceptionalism \& melting pot.

As such objectives are very rich and complex, it is offered a sistematic balance and some complementary corollaries. 


\section{PARTE FinAl: BALANCE}

(DECLIVE DE ACR, REALIZACIÓN DE APP-SET

Y FIN DE LAS RELACIONES ATLÁNTICAS Y DE OCCIDENTE)

Se sintetizan a continuación las principales y más llamativas ideas expuestas y explicadas, poniéndose énfasis en aquellas relativas al modelo sociocultural estadounidense y su idiosincrasia, según el papel jugado por ACR al respecto. También se condensan los resultados validantes de la investigación y su discusión a lo largo de la tesis, máximo en lo referente a la deconstrucción de ACR, mediante velos de confusión, soportados por los Estudios culturales sobrevenidos, durante las guerras culturales, provocándose la imposibilidad de una reformulación identitaria en la globalización, pese a su urgencia y necesidad prioritaria. Finalmente, se procede a su sistematización de clausura, en forma de teorema, en el que se ensamblan las hipótesis de trabajo, con las tesis desarrolladas, siguiendo un patrón y unos planteamientos de inteligibilidad, que den lugar a un comprensible modelo relacional sobre la compleja realidad sociocultural estadounidense. Todo ello se completa con unos corolarios, sobre las cuestiones aún en curso y que se siguen investigando (formando las futuras líneas de indagación, que dan continuidad a esta tesis), como son aquellas relativas a la desnaturalización estadounidenses: de un lado el riesgo de Americaless y transoccidentalización de EE.UU. (con la pérdida de la tradición occidental y su ruptura de relaciones atlánticas), y de otro lado la persecución religiosa de inmigrantes (algo totalmente contrario al ser estadounidense y clave en su genética identitaria). 
Sociología de las Relaciones Socioculturales Nortatlánticas (...) American civil religion - A. Sánchez-Bayón 


\section{1.- RESULTADOS DEL ESTUDIO Y SU DISCUSIÓN}

En el marco de un estudio sociológico como este (aunque muy conectado e incorporando planteamientos y técnicas de los multidisciplinares Estudios culturales estadounidenses), en el que se ha abordado el análisis crítico y prospectivo (de revisión de conocimiento, su autenticidad y revelaciones al respecto), para sistematizar cuáles han sido las relaciones socioculturales noratlánticas y su influjo en la idiosincrasia estadounidense, al recibir y transformar vía Americaness la tradición sagrada y profana occidental, hasta convertirse en en su custodio tras la II Guerra Mundial y hasta la globalización (con el emergente riesgo de transoccidentalización). El vehículo de indagación ha sido ACR, como metámero de integración y configuración ciudadana del pueblo estadounidense, junto con su legado revisado y ampliado por cada generación de su patrística. A continuación se acomete un balance general de las ideas más destacadas del estudio, así como una articulación del teorema probado a lo largo del mismo (en forma de pentalema). 


\section{1.- BALANCE GENERAL}

Como se ha aclarado a lo largo de la tesis, resulta muy difícil de cuestionar incluso para los Estudios culturales sobrevenidos- que los EE.UU., ha sido un país pionero de la Modernidad, mezclando en su seno planteamientos de la racionalidad humanista mediterránea (de la Alta Modernidad) y de la racionalidad técnicoprofesional anglonórdica (de la Baja Modernidad), recibiéndose así influjos de todas partes, en especial del mundo atlántico, acometiéndose un proceso de estadounidización o Americaness, que ha ayudado a su adaptación exitosa (incorporándose a su propio acervo), y exportándose posteriormente al resto del planeta. Así, los EE.UU., ha sido un país pionero en la realización de una secularización y aplicación de una teología política facilitadoras de la implantación del Nuevo Régimen (con su democracia, federalismo, presidencialismo, etc.), siendo tres de sus lemas inspiradores, los que forman parte del Gran Sello nacional: novus ordo seclorum, annuit coeptis et e pluribus unum; tiempo después se añadiría uno completamente autóctono, como es in God we trust. Luego, la religión, en su nuevo estadio ha sido un gran motor social, operando también de cemento y levadura de la construcción identitaria del país; eso sí, sin religión oficial del Estado, sino facilitándose el libre ejercicio religioso, lo que ha posibilitado la intensa acción social citada, sobre todo en forma de despertares de movimientos de bases sociales, con los que se ha ido conformando la agenda institucional estadounidense, permitiéndose a su vez la renovación de élites de poder, que acometieran luego las revitalizaciones, cuyos resultados formarían parte de su legado de ACR. Y es que en los EE.UU., las confesiones procedentes de todo el mundo, trajeron consigo el acervo cultural de su origen, que gracias al Americaness, se adaptó todo ello y se integró en 
un sistema identitario de plurilealtades compatibles, permitiéndose así la convivencia de diversidad de comunidades integradas en la cúspide mediante un metámero como se manifiesta ACR. No se trata de religión política alguna, para fortalecer el Estado-nación y normalizar la producción de ciudadanos, con códigos no disponibles, pero sí presentes en cualquier faceta de su vida social, sino que se trata de la experiencia del ensayo y error de las múltiples combinaciones realizadas en el periodo fundacional estadounidense. De tal suerte, ACR es una religión civil que integra a las demás tradicionales, permitiendo la convergencia hacia la configuración identitaria estadounidense y su producción sociocultural, que no ha dejado de estar en manos de las bases sociales, para la contestación social y para su reformulación identitaria periódica, de modo que los poderes públicos sólo han intervenido para su institucionalización final, canalizando todas esa energía social hacia el legado a transmitir a la siguientes generaciones, como parte del espíritu compartido del pueblo estadounidense.

En tal sentido, se ha acometido un recorrido panorámico del devenir estadounidense, cuyo hilo conector ha sido el influjo del factor religioso, con el que se ha tejido su ACR, que ha favorecido la necesaria integración en la diversidad, dotándose de una compartida visión, misión y valores, con rico capital simbólico e imaginario sociocultural sustendador de todo ello, dando así lugar al gran consenso estadounidense. Y para volver inteligible lo planteado, surgieron a final del s. XIX los Estudios culturales tradicionales, consagrándose en el periodo de entreguerras del s. XX. Sin embargo, y dadas las fluidas relaciones atlánticas hasta entonces, se dio cabida a las posmodernas élites intelectuales europeas o intelligentsia (quienes habían coqueteado con la hibridación de dos religiones políticas o ideologías, como fueran el nacionalismo y el socialismo), acogiéndolas en sus medios de 
comunicación de masas y sus universidades (y dentro de estas, sobre todo en los programas de los Estudios culturales). Se presumía entonces que tal medida iba a ser doble: de un lado, gracias a su demoledora crítica -ya en sentido posmoderno, de contestación y ataque- ayudarían en la deconstrucción de la superioridad sociocultural mantenida hasta entonces por la vieja Europa; de otro lado, facilitarían el relevo estadounidense de dicha superioridad sociocultural, con el correspondiente liderazgo occidental. Ahora bien, tal presunción duró lo que tardó en arraigar la citada intelligentsia, que tras demoler a la vieja Europa, continuó con la joven América. Las élites intelectuales tradicionales estadounidenses, no se preocupaban de la cuestión sociocultural, por dar por sentadas las bases y reglas de juego, que pasaba por la aplicación del Americaness, para cualquier influjo exterior, de modo que resultara compatible con el ser estadounidense. Sin embargo, al haber sido un tipo de inmigración extraordinaria (una fuga de cerebros captada tras la guerra), no operó su Americaness, lo que posibilitó el tejimiento de velos de confusión, que poco a poco, no sólo cuestionarían el $\mathrm{AWL}, \mathrm{AD}$, etc., sino que atacarían su ASG, ASR, etc., hasta llegar a la deconstrucción de su ACR. Y no sólo se realizó sincrónicamente, durante las guerras culturales, sino también diacrónicamente, alcanzándose al periodo fundacional y violentándose la matriz mitopoiética estadounidense y el origen de su legado integrador (dando paso al proceso de Americaless o desestadounidización: la desnaturalización del ser estadounidense, provocándose su transoccidentalización, vid. supra). De tal suerte, al influir esa intelectualidad posmoderna en los medios y las universidades, condicionaron a la generación de baby-boomers, quienes ya en el poder (con la renovación de élites acometida por la Adm. KENNEDY y su proyecto Camelot), terminarían aprobando leyes como la de 1972 y un ingente volumen de ayudas 
públicas para el impulso de los Estudios culturales sobrevenidos, relativos a la exaltación del hecho diferencial de comunidades supuestamente oprimidas y a las que había que compensar, pero que a su vez, terminaban con cualquier consenso posible e intensificaban el conflicto sociocultural. De tal manera, los Estudios culturales quedaron divididos y muy polarizados, no siendo capaces de asumir su específica misión científico-académica de reformular la identidad estadounidense, para nuevos periodos como el de la globalización, con sus crisis, preparándose así para la posglobalización (iniciada tras la gran crisis de valores de 2008). El resultado ha sido una profunda desconfianza -algo poco estadounidense, quienes eran considerados por los europeos como ingenuos, por no haber pasado por siglos de violencia histórica e institucional-, lo que ha conducido al desentendimiento del mundo atlántico, por considerarse que de ahí procede el origen de la tensión social actual. Se considera que, quizá, la solución esté en una reafirmación como hemisferio occidental (sin necesidad de Europa), dando paso a un viraje de Americaless y transoccidentalización, tal como se aclara más adelante (vid. supra cap. 12); sin embargo, tal solución, muy posiblemente conduciría a un agravamiento del problema, como es la falta de una identidad compartida estadounidense, conduciéndose no sólo a la desnaturalización estadounidense, sino al declive occidental y la deriva de la humanidad hacia una sociedad masa global consumista (si se opta por aproximarse al corporativismo himenóptero asiático).

En definitiva, lo que está en riesgo, no sólo es la identidad estadounidense, sino la continuidad o declive total occidental, al perder a su adalid, sin relevo alguno a la vista (pues Europa está aún más perdida en el laberinto posmoderno -y expuesta a una islamización de nuevo cuño, sencillamente por tasa de natalidad-). El caso es que está a punto de caer el último bastión de la Modernidad occidental, referente de 
su realismo, racionalidad, autenticidad, eticidad, etc. Independientemente del cuándo acontezca (a lo largo del Horizonte 2030: tiempo para la consolidación de la posglobalización), lo que sí ha quedado de manifiesto con la globalización y sus crisis, es que se ha cerrado un ciclo histórico y se está abriendo otro (un TecnoEvo, que según se gestiones, puede conducir a la sociedad del conocimiento y su civilización tipo I, o a la distopía de una sociedad masa global consumista). Ello afecta no sólo a las relaciones atlánticas (como se ha mencionado $-y$ en seguida se profundiza algo más-), sino también a la propia Sociología (inspiradora de este estudio), que surgiera como ciencia social para comprender dicho periodo de la Modernidad, con su Nuevo Régimen y todos los cambios sociales que trajo consigo su implementación ${ }^{680}$. Como se vé, los efectos de la crisis identitaria estadounidense

680 Actualmente, tal es el desdibujamiento de la Sociología, que se la define como el estudio de las sociedades humanas (lato sensu), de modo que cada cual luego pone el énfasis en aquellos aspectos que desea recalcar: conflicto, intercambio, estructuras, fenómenos, factores, acción, etc. Pues bien, la Sociología, nace como filosofía social, para entender las nuevas sociedades modernas emergentes en Occidente. Más aún, también la Antropología se ha desdibujado, llegando a definirse como el estudio del ser humano de manera integral. Se entenderá entonces que sea urgente y necesaria una revisión de fundamentos, que ahonde en los cimientos. Sirva como adelanto la siguiente noción clarificadora y deslindadora: en el s. XIX, cuando la Sociología y la Antropología comienzan a balbucear, ambas se diferencian claramente, pues la Sociología sirve para comprendernos los occidentales a nosotros mismos (con todas las transformaciones de nuestras sociedades y modos de vida: el tránsito del campo a la ciudad, de la artesanía a la industria, etc.), mientras que la Antropología se encarga de comprender a los otros pueblos (cuyo encuentro se había intensificado con el colonialismo). Evidentemente, la Sociología ha pasado por múltiples transformaciones de paradigmas y corrientes de pensamiento (v.g. positivismo, estructuralismo, funcionalismo, conductivismo, interaccionismo simbólico, teoría crítica, poscolonialismo -dependencia, liberación, desarrollismo, otredad, etc.-), pero quede claro que: a) se trata de un concepto tridimensional (alude a una realidad histórica de producción socio-cultural, a la vez que a las teorías y formas propuestas para su estudio, así como la literatura científicoacadémica al respecto); b) no ha existido siempre, sino que responde a unas coordenadas espaciotemporales y materiales (las sociedades occidentales modernas: aquellas abiertas del Nuevo Régimen) -de tal manera cabe delimitar el conocimiento propio y distinto de la Antropología, la Arqueología, la Etnología, etc. Téngase en cuenta que, si las sociedades occidentales modernas dejan de existir, entonces, para el estudio de lo que venga se requerirá de otra ciencia: de ahí la urgencia aquí apuntada de prestar atención a la posglobalización y su punto crucial, por si la teoría social ha de conducir a otra ciencia (quizá CCM o TecnoEvoLogía). En definitiva, si la Sociología desea seguir siendo la disciplina que aclare la realidad social, sus cambios y modus vivendi en las sociedades 
tienen un gran alcance y calado, de ahí la importancia de acometer al menos un balance de sus relaciones socioculturales.

\section{2.- TEOREMA SOBRE EL INFLUJO IDENTITARIO DE ACR, SU VULNERACIÓN Y DECLIVE,} Y LOS RIESGOS DE REALIZACIÓN DE APP-SET

Todo lo visto se reduce a la siguiente isometría: Identidad estadounidense $=$ $f\left(A C R\right.$, legado, progreso -providencia/(auto)determinación-) ${ }^{C D R}$. ACR y su legado, suponen una visión, misión y valores compartidos y orientadores, que han ido materializándose en símbolos y ritos, creencias y valores, normas e instituciones, arte y folclore, etc. Ahora bien, si se desea contravenir esas evidencias tangibles y demostrables, se requiere de unos velos de confusión que procuren ocultarlas (impidiendo su reconocimiento, aunque esté delante), además de deslegitimar a sus autores (con un ataque ad hominem contra todos y cada uno de los padres fundadores estadounidenses, de modo que no quepa vida ejemplar alguna de referencia). Con todo ello, se logra la introducción en un limbo posmoderno, en el que no cabe sentido (no de ethos y su historicidad, sólo de pathos y mithos -intensificándose gracias a la virtualidad propiciada por las TIC-), y menos aún en forma progreso (ni como predestinación de la tradición sagrada, ni como autodeterminación de la tradición profana).

modernas occidentales (si es que estas perviven -pues EE.UU. ha renunciado a su liderazgo y no parece que haya relevo dentro de Occidente, más bien fuera-), urge el recuperar las aportaciones del humanismo. En concreto, aquí se aboga por la recuperación y actualización del humanismo hispánico, que operara para la globalización de su tiempo (el descubrimiento del Nuevo Mundo y el intento de transitar al Nuevo Régimen desde la ilusión). Vid. SÁNCHEZ-BAYÓN, A.: , Eduser, 2018. VALERO-MATAS, J., SÁNCHEZ-BAYÓN, A.: Balance de la globalización... op. cit. 
Por tanto, conforme a lo planteado, analizado y evidenciado a lo largo de esta tesis, cabe condensar las hipótesis y tesis de rango medio propuestas, para dar lugar a los siguientes axiomas sintéticos y entrelazados, constitutivos del teorema relativo a las relaciones socioculturales en el marco noratlántico influyentes en la identidad estadounidense, cuya vulneración, conlleva el declive (estadounidense y occidental), por la aceleración del riesgo de Americaless y transoccidentalización.

Los axiomas sintéticos y entrelazados resultantes constituyen el siguiente pentalema de entrelazamientos:

I.- Sincretismo occidental estadounidense en su Nuevo Régimen: se ha logrado gracias a la formulación e implementación del metámero de ACR y su configuración idiosincrásica. Desde sus orígenes, EE.UU., ha recibido influencias de todo el mundo, en especial, de sus relaciones noratlánticas europeas, dándose en su seno la combinación de la Modernidad hispánica y su racionalismo humanista (v.g. derechos naturales, libertades, tiranicidio), y la Modernidad anglo-nórdica y su racionalismo técnico-profesional (v.g. capitalismo, democracia liberal). De tal suerte, la Cristiandad se transformó en América en Occidente, recibiéndose la tradición sagrada o judeocristina y la profana o grecorromana, para mezclarse con pensamiento whig $\mathcal{E}$ free-mason, y demás corrientes (algunas posteriores y autóctonas, como el pragmatismo, el excepcionalismo, etc.), que pasado todo ello por su Americaness, ha permitido la realización del lema nacional (del Gran Sello): e pluribus unum. La clave del éxito ha estado en el abandono de la oficialidad religiosa (presente en Europa desde la Constitición de Tesalónica del 380 hasta la Paz de Westfalia de 1648), para dar rienda a una religión secularizada (próxima a la cultura abierta del Nuevo Régimen) y civil (en manos de los laicos o bases sociales). Así, ha operado como valioso cemento y levadura social, con despertares y revitalizaciones, que han 
arrancado con los movimientos religiosos (sus cruzadas, demandas, etc.), favorecedores de la renovación de la agenda institucional y las élites de poder, y cuando ha cristalizado, se ha generado un legado de integración y conformación idiosincrásica (reactualizándose periódicamente). Luego su ACR ha perfilado a un pueblo, con una patrística preocupada por aportar un legado, con el que se ha ido formando a las siguientes generaciones, que a su vez han deseado ir dejando su impronta en dicho legado (revisado con cada CDR).

II.- Relevancia de ACR y su legado: la configuración idiosincrásica estadounidense, desde su independencia hasta su consolidación como potencia hegemónica $\mathrm{y}$, finalmente, líder occidental. Aunque la Teología política y la idea de religión civil surgen en Europa (donde sólo son disquisiciones de élites -visionarias del Nuevo Régimen, pero sin su implementación-), en América se transforman en una realidad, permitiéndose el ensayo pionero del Estado contemporáneo, no vinculado a una nación, sino a un pueblo. Ya en el s. XVIII, se transita del Estado-dinástico al Estadopopular o democrático (generalizado occidentalmente en el s. XX), sin necesidad de pasar previamente por el Estado-nación, tal como sí les ocurre a los europeos, con su polémica nacionalista: nacionalismo-político o liberal (mediterráneo) v. nacionalismo étnico-cultural (anglosajón-nórdico). En consecuencia, gracias a la secularización moderna y la Teología política implementada en la fundación de EE.UU., se tiene claro que no debe haber religión oficial (evitándose las religiones políticas o ideologías del nacionalismo y/o socialismo), a la vez que existe el compromiso de remover cualquier obstáculo para el libre ejercicio de la libertad religiosa (facilitándose la convivencia de gran diversidad de confesiones). La manera de acomodar estos dos límites del sistema ha sido mediante el metámero de ACR: cualquier religión comunitaria o confesión/denominación que desee ser 
respetada y prosperar, basta con que se acoja al amparo de un paraguas lo suficientemente secularizado, que admite aportaciones para su sincretismo (Americaness), posibilitándose así la configuración ciudadana, a modo de un pueblo elegido para la realización de la moderna empresa estadounidense de progreso occidental: el guiar al resto de los pueblos en la senda del respeto de derechos inalienables como son la vida, la libertad, y búsqueda de la felicidad (DIE, uno de los textos sagrados de ACR y con los que nace EE.UU., rindiéndose cuenta de su misión, visión y valores).

Su ACR de ciudadanos diversos, integrados por un sistema de plurilealtades, en el que ya pueden ser bautistas de Rhode Island o Texas, católicos de Maryland o Florida, episcopalianos de Connecticut, judíos de California, etc., que a la postre, todos son estadounidenses, compartiendo por todo el país (gracias a su legado tipificador) los mismos símbolos y ritos, creencias y valores, normas e instituciones, artes, monumentos y floclores, et al.

III.- Ataques a ACR y su legado: los velos de confusión extendidos y las confrontaciones entre Estudios culturales. Su ACR (tal como se viene señalando), como metámero condensador y vehiculizador de la idiosincrasia estadounidense, para facilitar la convivencia e integración de multitud de comunidades, conformándose así una misma sociedad plural, que a la postre comparten todos sus integrantes una identidad y solidaridad común, más una mentalidad y códigos comunicativos propios, además de un capital simbólico y un imaginario sociocultural enriquecido por las aportaciones de todos, previo filtro del Americaness. Por tanto, su ACR ha sido clave para implementar el pionero modelo relacional estadounidense entre el poder, lo sagrado y la libertad, conforme a los lemas del Gran Sello (v.g. e pluribus unum, annuit coeptis, novus ordo seclorum, in God we trust). Ello tiene su origen en el papel jugado por la Teología política recibida, 
adaptada y desarrollada en el periodo fundacional. La misma estuvo centrada en la ordenación terrenal del pueblo de Dios conforme a su providencia y la vocación de advenimiento del Reino de los cielos, materializándose su muestra en la vida cotidiana (como señal de predestinación, a diferencia de buena parte de Europa, que había vivido un Medievo de negación de lo terrenal en favor de lo eterno). Dichos planteamientos, se van materializando en una búsqueda del bien común, según el uso de los talentos personales, guiados por fórmulas de socialización como ACR y ASG, combinándose con otras complementarias, como AMD, AWL, AD, AC, ASR, et al. Todo ello, que diera lugar a pioneras fórmulas modernas de Nuevo Régimen, con un gobierno civil basado en la participación popular y el pactismo (de corte federal, democrático, presidencialista, etc.), con un fuerte sistema de libertades civiles y tolerancia social, más un claro sentido vital ético, racional y realista, sin embargo, tal sistema, que lograra resistir a crisis, recesiones, guerras y otros males sociales, finalmente sucumbio a una quinta columna, gustosamente instalada en el seno del país. Se alude así a la fuga de cerebros cómodamente instalada en universidades y medios de comunicación a raíz de las guerras mundiales del s. XX. Las mismas, dada su excepcionalidad (que aún a día de hoy se mantiene, como es la concesión acelerada de la nacionalidad por altas capacidades), arribaron con su acervo posmoderno y sin pasar por el filtro de Americaness. Por lo que primero extendieron sus velos sobre las relaciones atlánticas, dificultando el entendimiento entre estadounidenses y europeos, para terminar extendiendo sus velos sobre el propio pueblo estadounidense que les acogiera, sembrando su Americaless o desestadounidización: se trata de una crítica más allá de la contestación, pues pretende la deslegitimación y la confrontación. Se cuestiona el sistema de vida y el legado recibido, sembrándose dudas y desconfianzas sobre el mismo, además de 
moverse a su renuncia y revisión, no desde el ethos (con su racionalidad y realismo, además de sentido de misión, visión y valores), sino desde el pathos (el sentimiento del wishful-thinking y superioridad moral, sustentados en mithos contraculturales de revancha). Para extender la desconfianza y confrontación entre las jóvenes generaciones de élites de poder (sobre todo los baby-boomers), en forma de velos y sustentada por los sobrevenidos Estudios culturales (de corte etnocultural y de género), alineados con el socialismo cultural (su IV Internacional, hoy autocalificados como poscoloniales y descoloniales), ello fue posible gracias a las guerras culturales, aprovechándose el telón de fondo de la Guerra fría: mediante el pathos, se convenció a los baby-boomers para que rechazaran a los padres fundadores (calificándolos primero de aburridos y atacándoles luego como malignos WASP esclavistas, reprimidos y represores), aceptándose en su lugar el mithos del buen guerrillero no-occidental (v.g. desde los pioneros TROTSKI y Mao ZEDONG, hasta los contemporáneos CASTRO, Ché GUEVARA y Pol POT). De tal suerte, los Estudios culturales dejaron de cumplir su misión de revisar y actualizar la identidad estadounidense, para asegurar su integración y funcionalidad como pueblo, hallándose divididos y polarizados desde entonces y sin visos de solución próxima (con el riesgo añadido de la transoccidentalización, vid. supra).

IV.- Vulneración y crisis de ACR y su legado: daño de su matriz miotopoiética o corrupción de setup, más deslegitimación y desafección institucional y sistémica, y urgencia de mind-reset. ¿Qué quiere decirse con todas estas expresiones? Las mismas han surgido tras el balance de las crisis de la globalización. Recuérdese el cuestionamiento al inicio de este estudio, por el que sorprendía que EE.UU. no se uniera al reavivado interés planetario por el factor religioso, dado su importante papel para comprende la cuestión identitaria reabierta con la crisis de la nación como 
categoría superada (al caducar el Estado-nación y su sistema rígido). Y es que tras el devastador efecto de las guerras culturales, con los velos de confusión extendidos por los Estudios culturales sobrevenidos, no sólo se ha procurado minar el consenso ciudadano previo, sino que también se ha procurado deconstruir su ACR, y volver la religión como un elemento de represión personal y de conflicto entre comunidades. De tal manera, se desnaturaliza la tendencia habitual estadounidense tratar con normalidad la religión (como conocimiento, factor y esfera social), tan presente en la vida pública estadounidense (nunca exclusiva del Estado-nación, sino más bien propia de la sociedad civil). Resulta que, durante las guerras culturales, se ha atacado tanto sincrónicamente su ACR, como diacrónicamente, procurándose su deslegitimación y desafección desde el propio periodo fundacional, quedando el mismo desdibujado y de difícil acceso en la actualidad: la memoria histórica extendida impide su disponibilidad revisora, pues al articularse desde la hibridación de un pathos y mithos de superioridad moral (al "empoderar" a minorías supuestamente reprimidas -terrible expresión gramatical ya aclarada-), ello dificulta su crítica de autenticidad, pues contravenir tal pensamiento débil extendido, es atacado como delito de odio (acusándose al crítico -como mero detector de incoherencias, contradicciones, etc.- de machista, racista, homófobo, et al.). Tal actitud hostil de la acomoda intelligentsia (heredera de la fuga de cerebros y formada por los Estudios culturales sobrevenidos), más su incoherencia de autodefinirse como antisistema, a la vez que se detenta el poder y se fija la oficialidad en los medios de masas, universidades, agencias estatales, etc., ello ha provocado movimientos de contestación y reivindicación de mind-reset o reinicio de mentalidad. Cabe destacar, por ejemplo (y en orden inverso de aparición), frente a los neoconservadores, el teaparty; frente a los defensores de género, los anger-male y los men-apart; frente a los 
defensores de la corrección política, se ha producido una reaparición de los supremacistas, etc. - de todos modos, esto no es exclusivo de EE.UU., pues en Europa también se está produciendo, calificándose el fenómeno de reauge de la "extrema derecha", que en realidad es un nuevo tipo de "nacional-socialismo" aún más populista-. En definitiva $-\mathrm{y}$ de vuelta a EE.UU.-, se trata de una división y polarización social mayor a la de épocas pasadas, pues alcanza a casi todas las dimensiones socioculturales del sistema, evidenciándose su caducidad y la falta de alternativas claras de solución. Cada vez que ha ocurrido algo así en EE.UU., se ha dado un episodio de gran violencia correctora (v.g. entre patriotas y realistas la Guerra de independencia de 1776, entre abolicionistas y esclavistas la Guerra de secesión de 1861); ahora bien, en el presente caso, se ha ido retrasando el episodio guerracivilista por las Guerras mundiales, la Guerra fría y la Guerra contra el terror. Como únicas alternativas viables al citado episodio de violencia doméstica es la realización del $V$ Gran despertar religioso o la transoccidentalización -y parece tener más visos de acontecer esta última-.

V.- Riesgo de transoccidentalización: de la realización de Americaless y APP-set. Antes de dictaminar sobre la transoccidentalización (con la consiguiente desnaturalización estadounidense, se recuerdan los principales ítems de la red de confusiones de APP-set:

- APP stricto sensu: con las TIC, ha quedado interconectado el mundo, pudiendo entrar en contacto cualquier cultura con otra, de ahí que con la globalización se haya reabierto el debate identitario, recuperándose para ello el recurso de la religión. Al mismo tiempo que esto pasa en todo el planeta (la revitalización religiosa), llama la atención que en los EE.UU., donde la religión siempre ha tenido una gran presencia socio-cultural, en cambio, se encuentra en declive, por 
los velos posmodernos de confusión extendidos sobre ella, dejando de servir para religar o unir estrechamente con la divinidad, la comunidad, la tradición, etc., sino para convertirse en instrumento de diferenciación y conflicto entre comunidades. El impacto de APP no sólo alcanza al periodo actual de transición (entre la época dominada por el Estado-nación y la supuesta emergencia de la aldea global y la sociedad del conocimiento), sino que desde las guerras culturales (1960-80), viene sirviendo para deconstruir la ACR y su articulación de la idiosincrasia estadounidense, remontándose incluso al periodo fundacional, y atacando directamente a la matriz mitopoiética y su legado.

- Paradoja identitaria de los Estudios culturales: si los Estudios culturales encuentran su lugar en la universidad estadounidense (en el periodo de entreguerras), es para dotar de entidad científica y académica a su articulación idiosincrática nacional. Tales estudios sirvieron para alcanzar los consensos de integración doméstica y la entidad para que el país tuviera una condición de potencia hegemónica mundial. Ahora bien, todo ello se distorsionó durante las guerras culturales, pues frente a los Estudios culturales tradicionales (basados en el citado consenso) surgieron los sobrevenidos (de corte etnocultural y socialista), focalizados en el conflicto y la exaltación del hecho diferencial. El resultado ha sido una polarización entre los Estudios culturales, enfrentados entre sí, e imposibilitados para reformular el ACR y la idiosincrasia estadounidense para el nuevo periodo en curso (por lo que la amenaza de entropía y/o armagedón nacional va tomando carta de naturaleza).

- Paradoja dogmática de los velos posmodernos: pese a nacer de la supuesta crítica y resultar de lo más diversos entre sí, los velos encuentran su unión en su finalidad de desunión, atacando el consenso previo. Resulta que niegan 
cualquier posible noción universal o intento generalizador, salvo sus propios postulados e intereses, los cuales no se articulan desde la realidad y la racionalidad del ethos, sino desde la narrativa y la emocionalidad del pathos. De tal suerte, los velos, que supuestamente venían a aportar pluralidad, pretendiendo atacar los dogmatismos anteriores (con su etnocentrismo y moralismo), se han convertido en aquello a combatir, imponiendo un pensamiento débil único, con espirales de silencio, incluso con condenas de delito de odio (frente a las posibles críticas de aquello que debería serlo).

- Paradoja regresiva y desnaturalizadora de los Estudios culturales y sus velos (o la corrupción del set-up): si desde los EE.UU. se estimuló la recepción de fuga de cerebros (sobre todo europeos), para ayudar a impulsar sus Estudios culturales, responsables de la articulación de su idiosincrasia, sin necesidad de depender de avales exteriores (apartándose así la sombra fundacional europea y su supuesta superioridad socio-cultural -o sea, para que dejara de ser la madre y, en todo caso, quedara como una relación de hermanos-), hasta llegar incluso a liderar el mundo occidental (tras la II Guerra Mundial). Sin embargo, la labor de deconstrucción occidental acometida (durante las guerras culturales), no sólo desmarcó a EE.UU. de Europa (y su tradición occidental sagrada y profana), sino que además causó la desnaturalización estadounidense, al vulnerarse su matriz mitopoiética y su legado (corrompiéndose su set-up), al renunciarse a su condición moderna y perderse su realismo y racionalidad (propio de su pragmatismo). De tal suerte, con su transición posmoderna (de carácter regresivo), los EE.UU. han dejado de ser inmunes a las ideologías, volviéndose con ello un pasí anti-moderno y anti-occidental (abandonando así EE.UU. la órbita atlántica para orientarse hacia la pacífica, presentándose como una 
intensificación hacia el Oeste y el fortalecimiento del hemisferio occidental -que en realidad es sería un giro oriental asiático-pacífico-, pero ya sin la tradición occidental como sustento).

Pues bien, tal conjunto de paradojas, ha estimulado y agravado la condición caduca del sistema sociocultural estadounidense (como modelo pionero de la Modernidad occidental), el cual, al perder su Americaness, suplantado por el Americaless de los velos de confusión y los Estudios culturales sobrevenidos, ello ha provocado una acelerada desnaturalización estadounidense en cascada: hoy en día, se están produciendo fenómenos socioculturales antes ni imaginables, por vulnerar los principios fundacionales, como son el respeto a la libertad religiosa, la integración de la inmigración, la confianza en la meritocracia y la autonomía de la voluntad, etc. (algunas de estas cuestiones se abordan en el siguiente capítulo). En definitiva, no sólo se está provocando la desnaturalización estadounidense, por violentarse señas identitarias fundacionales, sino también por promover el abandono de su bagaje y el papel jugado hasta ahora, como adalid occidental, para proceder a reinventarse, sin la tradición occidental ni las relaciones atlánticas, pudiéndose focalizar así en el mundo pacífico. Por ahora, con la Adm. TRUMP, se ha ralentizado el proceso, al salirse en 2016 del sistema del Pacto Transpacífico de Cooperación y de otras iniciativas convergentes, para dar paso a un nuevo episodio transitorio de aislacionismo estadounidense (por lo que habrá que esperar al segundo mandato o la siguiente Administración presidencial, para constatar cómo se va a materializar el nuevo ciclo expansivo estadounidense: transpacífico o no, pero transoccidental seguro). 
A la postre, se espera haber satisfecho los objetivos planteados al inicio de esta tesis, habiendo ofrecido la articulación de un análisis revisor crítico y de autenticidad, sobre el devenir de la ACR y su influencia en la configuración idiosincrasia estadounidense (tras recibir y adaptar la tradición occidental, singularizándola vía Americaness, para terminar convirtiéndose en líder occidental del último periodo). En dicho análisis, además de profundizarse en la evolución y evaluación de su dimensión sociocultural, se espera haber aportado suficiente perspectiva comparada (no sólo diacrónica, sino también sincrónica en las relaciones noratlánticas). De tal suerte, igualmente, se espera haber logrado el dar a conocer:

- Cuáles han sido las esencias y manifestación de ACR (como metámero sociocultural de integración anterior a la categoría decimonónica de nación), además de indagar en su devenir (con sus avances y derivas, con sus ciclos y transiciones), según su influjo en la articulación estadounidense de su identidad y mentalidad colectiva, su imaginario social y su capital simbólico, etc.

- Cuáles han sido las relaciones noratlánticas en el surgimiento, desarrollo y declive de su $\mathrm{ACR}$, averiguándose cómo se produjeron y qué calado tuvieron las retroalimentaciones entre sendas costas (tanto su despertar como pueblo estadounidense, gracias a la integración de gentes de toda Europa, previo paso por su Americaness, hasta la más reciente incorporación de la fuga de cerebros de posguerra, que trajo consigo la posmodernidad y el Americaless).

- Cuál es el balance de la situación actual de ACR, su crisis y traslación al trance vigente de fallo idiosincrásico estadounidense, no sólo desde las crisis de la globalización (por la caducidad de normas e instituciones vinculadas al Estadonación), sino por las previas, durante las guerras culturales (en medio de la Guerra fría), que se han proyectado sobre épocas pasadas, remontándose 
incluso al periodo fundacional y su matriz mitopoiética y su legado consiguiente (causándose una corrupción de set-up).

- Cuáles son y cómo interactúan los constructos complementarios a ACR (con sus correspondientes teorías de rango medio), del tipo AG/ASG, AMC, AD, AWL, AC, ASR, et al., hasta una de las manifestaciones más recientes -y de las más criticadas por los Estudios culturales sobrevenidos- como ha sido American excepcionalism $\mathcal{E}$ melting pot.

Como tales objetivos son bien ricos y complejos, se prefiere concluir este estudio con un par de corolarios más concretos, llamados a alumbrar la continuación de este estudio. 
Sociología de las Relaciones Socioculturales Nortatlánticas (...) American civil religion - A. Sánchez-Bayón 


\section{2.- COROLARIOS Y OTRAS LÍNEAS DE INVESTIGACIÓN RELACIONADAS}

Entre las posibles consecuencias de lo estudiado en las páginas anteriores, se introduce un par de temáticas en las que ya se viene trabajando, para dar cierta continuidad a esta tesis.

\section{1.- Fin DE LA MODERNIDAD, DE LAS RELACIONES ATLÁNTICAS Y DE OCCIDENTE: MÁS ALLÁ DEL ESTUDIO SOCIOLÓGICO Y EL RIESGO DE TRANSOCCIDENTALIZACIÓN ${ }^{681}$}

Ha quedado claro que, con la entrada de EE.UU. en la posmodernidad (tras las guerras culturales, con sus velos de confusión y el papel deconstructor jugado por los Estudios culturales sobrevenidos), actualmente, ya no quedan bastiones de Modernidad occidental (por lo que no hay relevos serios para su liderazgo mundial). Luego, muy posiblemente, el tiempo occidental ha llegado a su fin, ya que su líder hasta ahora (EE.UU.), ha dejado de ser moderno (y por ende, racional, realista, auténtico, ético, etc.), para ser un país más perdido en el laberinto de la posmodernidad; incluso, a punto de iniciar el camino sin retorno de la transoccidentalización. Antes, claro está, ha de terminar de desnaturalizarse, perdiendo toda capacidad de Americaness, y con ella, la viabilidad de integración mediante ACR y su legado. Además, ha de rechazarse la tradición occidental

681 Cuestión ya anunciada en SÁNCHEZ-BAYÓN, A.: La Modernidad sin prejuicios... op. cit. Universidad, ciencia y religión... op. cit. La religión civil estadounidense... op. cit. Problemas y retos para alcanzar la sociedad del conocimiento... op. cit. Balance de la globalización... op. cit. "Balance de la Sociología tras la globalización"... op. cit.; complement., vid. nota 3 a 6. 
interiorizada, y su relación con el resto de occidentales, sobre todo, con los europeos (quienes a su vez, también vienen sufriendo dicho proceso de desnaturalización). Por añadidura, ha de desarrollarse una nueva noción de Occidente, que parta del denominado hemisferio occidental o las Américas, focalizándose hacia su ocaso. Resulta curiosa tal reinterpretación, pues en realidad, bien podría considerarse una conducción hacia la orientalización estadounidense, si no fuera por el papel de la Oceanía anglosajona (que nunca tuvo un gran arraigo occidental, salvo por las directrices en la Commonwealth).

En definitiva, y complementariamente a lo visto, cabe anunciar que la posmodernización estadounidense y su riesgo de transoccidentalización, no sólo traen efectos transformadores para los propios estadounidenses y sus relaciones atlánticas y pacíficas, sino que además se pone fin a un tipo de sociedad y su conocimiento: con tales cambios, ¿tendría sentido la continuidad de los estudios de Sociología y de Estudios culturales? ¿Sería preferible una profunda reformulación o su desarrollo de nuevas ciencias y disciplinas? 


\section{2.- ARISTAS SOBREVENIDAS DE APP-SET: PERSECUCIÓN DEL INMIGRANTE RELIGIOSO}

Y EL ACOGIMIENTO A SAGRADO EN LA POSGLOBALIZACIÓN ${ }^{682}$

Obsérvese que, EE.UU., se fundó como país occidental moderno basado en una serie de principios: el respeto a la vida, la libertad y la búsqueda de la felicidad de todos los seres humanos; la protección y disfrute de derechos de nacimiento e inalienables como la libertad religiosa y de circulación; la pluralidad de sus gentes (dada la tradición migratoria, de orígenes y comunidades diversas) en un convivencia pacítica e integrada, etc. (vid. infra DIE 1776, su CEU 1787 y su BR 1791). Dichos principios han informado la idiosincrasia estadounidense y su estilo de vida (AWL), contribuyéndose así al enriquecimiento de su acervo sociocultural, además de ofrecerse un modelo pionero de integración. Sin embargo, tras las crisis de la globalización, y la reapertura del debate identitario, en vez de reformularse la idiosincrasia estadounidense según sus principios fundacionales, se ha fomentado su deconstrucción posmoderna (negándose su condición de nación moderna y occidental), dando lugar a situaciones paradójicas de un Tecno-Evo en curso, como son las persecuciones religiosas y migratorias, tal como aquí se aclara.

Resulta que, los principios vulnerados hoy, vienen inspirados ya desde la época colonial por los founding fathers o padres fundadores, como los pilgrims o peregrinos, llamados así, por ser inmigrantes perseguidos por motivos religiosos. Tan importante ha sido la libertad religiosa en los EE.UU., que fue el primer derecho reconocido en las cartas de derechos estatales y en la mencionada Declaración de

\footnotetext{
${ }^{682}$ Fragmento basado en tres artículos en coautoría y ya aceptados para su publicación en las revistas SJR Lurralde (2020) y Migraciones (2019), más otro en evaluación.
} 
derechos nacional (BR), en cuya Primera enmienda se tipifica una doble cláusula (la nooficialidad religiosa y el libre ejercicio). Más aún, ilustres viajeros (desde TOCQUEVILLE, pasando por la hija de MARX, hasta WEBER o CHESTERTON), han coincidido en la relevancia de la defensa de la libertad religiosa y de circulación de los estadounidenses, como elemento idiosincrásico del país y sus gentes. Hasta el punto de plasmarse en regalos oficiales, como el obsequiado por el Gobierno francés en forma de la -coloquialmente llamada- estatua de la libertad (La Liberté éclairant le mondel Liberty Enlightening the World, 1886), en cuya base puede leerse el poema de LAZARUS "El nuevo coloso": (...) "¡Guardaos, tierras antiguas, vuestra pompa legendaria!" grita ella. "¿Dadme a vuestros rendidos, a vuestros pobres. Vuestras masas hacinadas anhelando respirar en libertad. El desamparado desecho de vuestras rebosantes playas. Enviadme a estos, los desamparados, sacudidos por las tempestades a mí. ¡Yo elevo mi faro detrás de la puerta dorada!"683.

Para asegurar que los citados principios fundacionales pasaran de generación en generación (a modo de legado de la idiosincrasia estadounidense), muchos han sido los recursos de su religión civil o ACR, destacando el caso del saludo a la bandera o pledge of allegiance (vid. infra cap. 10), que recitan todos los niños en las escuelas del país. Fue escrito por el Rev. bautista F. BELLAMY (1892, con motivo del IV Centenario del descubrimiento de América): "juro lealtad (...) a una nación ante Dios, indivisible, con libertad y justicia para todos", añadiéndose en su posterior versión extensa "para liderar al resto de naciones del mundo" (versión actual, propuesta por el Rev. presbiteriano G. DOCHERTY, y aprobada por la Administración

${ }^{683}$ Poema redactado por la conmemoración del centenario del país y grabado en la base del monumento; sobre este y otros elementos de American civil religion, junto con complementarios planteamientos de Sociología estadounidense y su tratamiento de la religión y la migración, vid. SÁNCHEZ-BAYÓN, A.: Manual de Sociología Jurídica Estadounidense... op. cit. La Modernidad sin prejuicios... op. cit. Estado y religión de acuerdo con los EE..UU... op. cit.; complement., vid. notas 3 a 6. 
EISENHOWER en 1954). De tal comprensión procede el sentido civilizatorio y mesiánico de los estadounidenses o AMD, con su polémica superioridad moral identitaria o ASR, y demás manifestaciones a considerar. Pero lo más relevante ha sido su respeto reverencial por la libertad religiosa y migratoria, considerando sendas cuestiones como identificativas del modo de ser estadounidense o AWL.

Tal entendimiento se ha mantenido hasta el fin de la Guerra fría (llevando a pactos con pueblos religiosos de Oriente Próximo frente a los ateos soviéticos y concediéndose preferentemente el asilo por persecución religiosa). Incluso, con la globalización y bajo la Administración CLINTON, para justificar las intervenciones exteriores estadounidenses, se creó un sistema propio de geopolítica basado en la protección de la libertad religiosa: The International Religious Freedom Act of 1998 o IRFA (vid. infra cap. 4 y 7); el mundo quedó dividido entre naciones aliadas defensoras de la libertad religiosa y demás derechos humanos, y naciones enemigas, represoras de libertades y a cuyos gobiernos había que sancionar, acogiendo a su población migrante ${ }^{684}$. Dicho sistema fue corregido y aumentado por la Administración W.BUSH, tanto en sus sesgos discursivos y de trato, como en su financiación, interviniendo también domésticamente (aprovechándose otros programas conexos de la Adm. CLINTON, v.g. Faith-based iniciatives).

A la vez que los poderes políticos llevaban a cabo políticas y regulaciones desnaturalizadoras de los principios fundacionales (sobre todo, la Adm. OBAMA, con mayor índice de conflictos religiosos y deportaciones en EE.UU., vid. supra figura), por su parte, los Estudios culturales (desde los clásicos, como American Studies, hasta los sobrevenidos con la Ley de 1972, v.g. Feminist $\mathcal{E}$ Gender Studies,

${ }^{684}$ Vid. nota previa, más 59, 60, 381, 382, etc. 
Afro-American Studies, Latin-American Studies), históricamente encargados de redefinir la identidad estadounidense en cada coyuntura, no podían acometer su función, por hallarse en conflicto desde las guerras culturales (1960-80): mientras que los Estudios culturales tradicionales buscaban el consenso y la integración de un pueblo (v.g. melting pot), los sobrevenidos perseguían la exaltación del hecho diferencial de cada comunidad (v.g. identity politics). Dada la mayor financiación a estos últimos, hoy en día son los dominantes en el ámbito universitario estadounidense, así como en los medios de comunicación de masas, y de ahí el giro hermenéutico posmodernos (antes que el enfoque occidental ilustrado de análisis uniformizador de la realidad, su racionalidad y su ethos, ahora prima la atención al calidoscopio de los discursos y pathos, extendiéndose velos posmodernos al respecto).

De tal fortuna, como se viene indicando, con la globalización y sus crisis, se está produciendo una gran paradoja (de cambio de época) ${ }^{685}$ : mientras que en el resto del mundo se está avivando el factor religioso (como parte del debate identitario), en los EE.UU., que tradicionalmente había sido un país defensor del factor religioso y de la inmigración, en cambio, ahora se halla aplicando políticas públicas con regulación restrictiva, incluso de prohibición y persecución. Ello ha provocado la

${ }^{685}$ La globalización es un poliédrico proceso de crisis y tránsito de una época en agonía, de corte rígido y dominada por el Estado-nación, a otra emergente, flexible y orientada hacia la aldea global (vid. Preámbulo de la Carta de la Organización de Naciones Unidas, San Francisco, 1945). Al final de dicho proceso, se espera y desea alcanzar finalmente la sociedad del conocimiento mundial (aunque existe el riesgo permanente de resultar una sociedad masa de consumo global). Mientras, con la caducidad de normas e instituciones (sin relevo aún), ello ha provocado la calificación de nuestras sociedades de riesgo, líquidas, difusas, etc., provocándose una suerte de Tecno-Evo: un Medievo tecnológico, previo a un rebrote humanista conducente a dicha sociedad del conocimiento -salvo que se derive a un New Brave World o sociedad masa global de consumismo y segregaciones-; vid. SÁNCHEZ-BAYÓN, A.: Humanismo Iberoamericano... op. cit. Problemas y retos para alcanzar la sociedad del conocimiento... op. cit. VALERO-MATAS, J., SÁNCHEZ-BAYÓN, A.: Balance de globalización ... op. cit. 
aparición de fenómenos aparentemente anacrónicos (de origen medieval europeo), como son la red de santuarios, el acogimiento a sagrado y la movilización de las iglesias frente al poder civil. Aquí se estudia dicho fenómeno, aterrizándolo en el caso de la inmigración hispana ${ }^{686}$ (mayoritariamente católica, aunque también protestante).

Ahondando en el problema detectado en las últimas décadas, como es la recurrente amenaza política (desde la Adm. W.BUSH hasta OBAMA -bautizado con el juego de palabras Deporter in Chief-, vid. supra) al inmigrante indocumentado o dreamer ${ }^{677}$ (corrección política alusiva American dream o AD). La singularidad de este tipo migrante radica en su confesionalidad cristiana y el recurso en consecuencia de las iglesias para su integración en el país, incluso para sortear las persecuciones (v.g. Sección $287(\mathrm{~g})$ de la Ley federal de Inmigración, que habilita a la policía a detener a cualquiera que parezca inmigrante ilegal; Ley SB1070 de Arizona, que considera delito llevar en el coche a un inmigrante ilegal).

\footnotetext{
${ }^{686}$ Categoría polémica, transformada en los primeros censos de la globalización, aunque mantenida como línea de investigación por los organismos oficiales dada su relevancia (con un peso estadístico superior al 10\% de la población estadounidense -mayor al de los afroamericanos, cuyo número ha caído con la altísima tasa de abortos-).

${ }^{687}$ Hace referencia al sueño estadounidense o American dream, aplicándose a los jóvenes hispanos menores de edad no acompañados que llegaron a los EE.UU. entre el fin de la Guerra fría y el inicio de la globalización.
} 
Figura 96.- Inmigrantes deportados desde la globalización

\begin{tabular}{|l|c|c|c|}
\hline Año/Adm. & $\begin{array}{c}\text { Indocumentados } \\
\text { (millones) }\end{array}$ & Deportaciones & Porcentaje(\%) \\
\hline 1989 | H. W. Bush & 2.00 & 34,427 & 1.7 \\
\hline 1990 | H. W. Bush & 3.50 & 30,039 & 0.8 \\
\hline 1991 | H. W. Bush & 4.10 & 33,189 & 0.8 \\
\hline 1992 | H. W. Bush & 4.60 & 43,671 & 0.94 \\
\hline 1993 | Clinton & 4.90 & 42,542 & 0.86 \\
\hline 1994 | Clinton & 5.30 & 45,674 & 0.86 \\
\hline 1995 | Clinton & 5.70 & 50,924 & 0.89 \\
\hline 1996 | Clinton & 6.30 & 69,680 & 1.1 \\
\hline 1997 | Clinton & 6.80 & 114,432 & 1.6 \\
\hline 1998 | Clinton & 7.10 & 174,813 & 2.4 \\
\hline 1999 | Clinton & 7.80 & 183,114 & 2.3 \\
\hline 2000 | Clinton & 8.60 & 188,467 & 2.1 \\
\hline 2001 | W. Bush & 9.30 & 189,026 & 2.03 \\
\hline 2002 | W. Bush & 9.40 & 165,168 & 1.75 \\
\hline 2003 | W. Bush & 9.70 & 211,098 & 2.1 \\
\hline 2004 | W. Bush & 10.40 & 240,665 & 2.3 \\
\hline 2005 | W. Bush & 11.10 & 246,431 & 2.2 \\
\hline 2006 | W. Bush & 11.60 & 280,974 & 2.4 \\
\hline 2007 | W. Bush & 12.20 & 319,382 & 2.6 \\
\hline $\mathbf{2 0 0 8}$ | W. Bush & $\mathbf{1 1 . 7 0}$ & $\mathbf{4 6 3 , 9 4 6}$ & 4.0 \\
\hline 2009 | Obama & 11.30 & 296,713 & 2.6 \\
\hline 2010 | Obama & 11.40 & 381,962 & 3.3 \\
\hline 2011 | Obama & 11.50 & 388,409 & 3.3 \\
\hline 2012 | Obama & 11.20 & 419,384 & 3.7 \\
\hline $\mathbf{2 0 1 3}$ | Obama & $\mathbf{1 1 . 3 0}$ & $\mathbf{4 3 5 , 4 9 8}$ & 3.8 \\
\hline 2014 | Obama & 11.30 & 414,481 & 3.6 \\
\hline
\end{tabular}

Fuente: DHS \& OIS, 2014

Con la actual Adm. TRUMP, parece ser que las políticas contra la inmigración indocumentada, especialmente la hispana, se van intensificando ${ }^{688}$. Sirva como

${ }^{688}$ Según declaraciones oficiales y el plan anunciado de decretos o Executive Orders (Whitehouse, 2018): Border Security and Immigration Enforcement Improvements (Jan. 25); Enhancing Public Safety in the Interior of the United States (Jan. 25), etc. 
ilustración de la violencia simbólica en aumento, las declaraciones genéricas contra inmigrantes mexicanos (y el muro en la frontera) o contra los salvadoreños (y las deportaciones masivas). Ahora bien, en relación al objeto de este corolario y su estudio, se desea ofrecer una mínima muestra de casos recientes por todo el país (se acogieron a sagrado: un inmigrante hispano con leucemia en Shadow Rock United Church of Christ de Phoenix en febrero de 2018, un mexicano en Methodist Church de Philadelphia en octubre de 2017, un salvadoreño en First Unitarian Church de Austin en septiembre de 2017, una guatemalteca en Iglesia de Dios Pentecostal de New Haven en agosto de 2017, etc., vid. supra ${ }^{689}$, para introducir en el contexto del asunto concreto a tratar aquí: cómo los inmigrantes hispanos encuentran auxilio en las iglesias del triángulo federal frente a políticas de persecución, bajo la firme creencia religiosa de estar dando cumplimiento al sermón de las bienaventuranzas, y la convicción civil de dar continuidad al muro de separación entre Iglesia y Estado (atribuido a JEFFERSON, vid. infra cap. 9).

\footnotetext{
${ }^{689}$ Incluso, ha surgido un cúmulo de movimientos religiosos de auxilio organizado mediante internet, v.g. The Interfaith Movement for Human Integrity is part of the National Sanctuary Movement (dando cobertura desde su web, URL: www.sanctuarynotdeportation.org), o Sanctuary Movement (URL: https://action.groundswell-mvmt.org/efforts/sanctuary2014). Sin olvidar las diversas páginas electrónicas donde cuentan sus experiencias, del tipo Made into America: inmigrants stories archive (URL: http://madeintoamerica.org).
} 


\section{Figura 97.- Sanctuary movement (iglesias y centros socio-religiosos)}

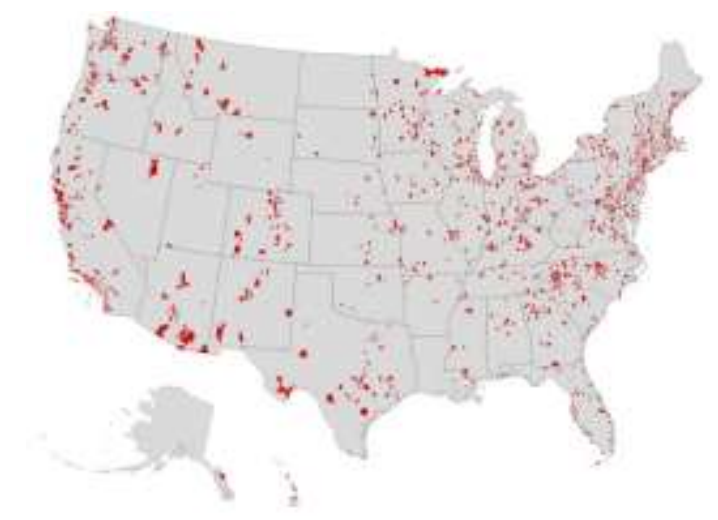

Fuentes: Church World Service \& Groundswell, 2017

El papel de la religión, como factor social, es muy importante en la integración de los inmigrantes. A su vez, la inmigración revitaliza el factor religioso y ayuda a dar dinamismo y forma a las sociedades receptoras, impactando profundamente en su economía, su política, su cultura, etc. Tal es su relevancia, que la vida social se ve afectada por la demografía de la inmigración; máxime en EE.UU., donde su historia es la de la inmigración (recuérdese el poema de LAZARUS, vid. infra). Muchas de las instituciones públicas y privadas, religiosas y seculares, comparten la responsabilidad de ayudar a los inmigrantes e incorporarles a la sociedad estadounidense. No obstante, una singularidad estadounidense es que, tradicionalmente, han sido los grupos religiosos quienes han jugado un papel central en ayudar a los nuevos inmigrantes a asentarse y convivir en el país. Los grupos religiosos (o iglesias, si se prefiere) ayudan a los inmigrantes a realizar sus derechos económico-sociales: encontrar vivienda y empleo; ofrecer formación para la integración (enseñando el idioma, el sistema legal, etc.); incluso, preparar para actuar ante una urgencia médica, policial, etc. Su labor es hasta intergeneracional, al 
ayudar también a negociar entre generaciones de origen inmigrante (ante problemas como el desarraigo, el choque cultural, etc.). En definitiva, las iglesias (como comunidades religiosas) asisten a los inmigrantes para buscar su camino de integración en una sociedad compleja (llena de contrastes y mezclas de identidades étnico-culturales en permanente competición), brindándose así ayuda de toda índole (desde alimentación y alojamiento, hasta clases idiomáticas y de cultura estadounidense, y asesoramiento jurídico sobre inmigración). Además del conjunto de ayudas mencionadas, las iglesias y sus organizaciones se convierten en instrumentos fundamentales para el mantenimiento de los valores culturales de los inmigrantes, pero también sirven de instrumento de canalización entre los valores culturales de la sociedad de origen y los valores de la sociedad de acogida. Ahora bien, el problema se plantea con la crisis identitaria estadounidense (acelerada e intensificada con la globalización), dado el agravamiento por los velos posmodernos y la deconstrucción de los Estudios culturales sobrevenidos, impidiéndose el ofrecer un modelo viable de integración; además, los vestigios que sobreviven del viejo modelo de integración, están siendo desnaturalizados (Americaless), igualmente, por los citados velos y los Estudios culturales sobrevenidos, dando lugar a situaciones tan sorprendentes como las planteadas: la persecución religiosa y migratoria en EE.UU. Tal es el grado de desnaturalización en curso, que buena parte de las generaciones trans (gen y) y los milenios (tanto gen w como gen $\mathrm{z}$ ), pese a haber sido socializados como cristianos, ya no asisten a la iglesia (ni servicios ni actividades comunitarias), ni se involucran socialmente. Esto está conduciendo al declive de las creencias que sustentaron la misión, visión y valores de EE.UU. No obstante, frente a la desnaturalización planteada, cabe aún una corrección, conducente a un V Gran despertar religioso, y todo ello gracias a las últimas oleadas migratorias, 
especialmente las de los hispanos de Mesoamérica y Centroamérica, quienes vienen con una profunda defensa de su fe. Lo que ha supuesto una revitalización en la sociedad estadounidense de los valores cristianos (no sólo católicos, de los hispanos inmigrantes, sino de otras confesiones que les han acogido). A pesar de la pérdida de fe de los WASP (especialmente, de los correspondientes a las main-line churches autóctonas, v.g. anglicanos, episcopalianos, presbiterianos), la fe cristiana está asegurada en EE.UU., gracias a los nuevos peregrinos hispanos (en su versión católica y evangélica).

Antes de concluir este corolario, se ofrece una breve reseña del diseño de la investigación que se está acometiendo (como continuación de los resultados logrados en esta tesis). Y es que, dada la importancia del problema detectado (fenómenos anacrónicos fruto de la desnaturalización estadounidense), se ha previsto una investigación a largo plazo (inter-décadas), contrastándose los datos oficiales (v.g. censo de EE.UU.), con los oficiosos (v.g. iglesias y ONG), más el trabajo de campo del propio investigador (vid. infra cap. 3). Tras la recogida de información y rastreo de ítems (desde inicios de la globalización), con su análisis de fuerza bruta y su consiguiente minería de datos (desde mediados de la década de 2000), se puedo así diseñar mejor las encuestas, entrevistas y grupos de discusión. Están ya disponibles los resultados del último periodo de investigación (curso 2017-18), focalizado en el triángulo federal ${ }^{690}$ : como se ha indicado ya, se ha centrado la atención en la inmigración hispana cristiana (tanto católica como protestante), y su desarrollo en la capital federal (Washington DC), y el área estatal vecina (Maryland y Virginia

\footnotetext{
${ }^{690}$ Su ecología humana difiere de otras áreas urbanas del país, como Chicago (con larga tradición chicana), donde La villa, sigue en expansión y prosperidad, invadiendo otras zonas, v.g. Little Italy, Guetto. Sin embargo, se ha centrado la atención en el triángulo federal, por su influjo en el diseño de la agenda institucional del país (según su visión, así se formulan e implementan las políticas públicas nacionales y su regulación).
} 
-que originalmente cedieron parte de su territorio para la constitución del Distrito de Columbia).

\section{Figura 98: District of Columbia}

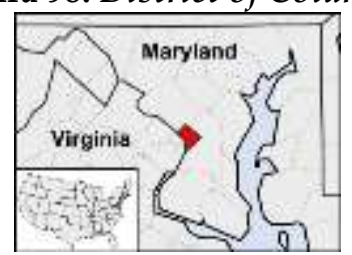

Fuente: US Census, 2018

La recolección de la muestra se ha realizado en centros de reunión aconfesional (no necesariamente vinculados a una comunidad religiosa específica, sino abierta a todas) y espacios de culto religioso de los hispanos, diferenciando entre los administrativamente regulados y no regulados (excluyéndose a los hispanos nacionalizados, puesto que su situación es muy diferente por ser ciudadanos estadounidenses). La muestra ha sido seleccionada de manera aleatoria, buscando la mayor representatividad de las nacionalidades hispanas en el triángulo federal. Las personas participantes respondieron a un cuestionario de manera anónima y conforme a los estándares de cualquier investigación sociológica. Se seleccionaron personas mayores de 18 años. Prácticamente ha sido el mismo porcentaje de mujeres $(n=104 ; 49,76 \%)$ y varones $(n=105 ; 50,24 \%)$. Por etapas educativas, estudios primarios $(58,13)$, secundarios $(30,14 \%)$, bachillerato $(5,74 \%)$ y universitarios $(5,74 \%)$, ninguno ha manifestado carecer de estudios, o ser analfabeto. En cuanto a la práctica religiosa, los porcentajes han sido, ateo, agnóstico o no identificado con ninguna religión (3,8\%), católicos (69,38\%), evangélicos $(14,83 \%)$ y protestante de main-line -desde luteranos a presbiterianos- (11,96\%). Finalmente, también se ha atendido a la situación administrativa, discerniendo entre los 
migrantes hispanos que se encuentran en situación regular e irregular, diferenciándose a su vez entre quienes poseen el visado o Green Card, y aquellos que van logrando su regularización de hecho, vía trabaja legal. Los porcentajes fueron, administrativamente, irregular (70,81\%), con Green Card (9,09\%), y con trabajo legal $(20,10 \%)$. En consecuencia, tres instrumentos se han utilizado en esta investigación. Uno, el cuestionario de recogida de información sobre su situación social global (laboral, familiar, periodo de estancia en los EE.UU., situación administrativa, práctica religiosa, etc.), con un total de 25 preguntas, 20 abiertas, mientras las otras cinco venían acompañadas de una frase corta donde los consultados debían responder a una escala de LIKERT de cinco puntos (1 a 5) expresando su grado de acuerdo o desacuerdo con la cuestión. El segundo instrumento, la entrevista semiestructurada, donde se preguntaba a los entrevistados por 20 cuestiones similares a las aparecidas en el cuestionario (permitiendo una mejor perfilación). Por último, se llevó a cabo un grupo de discusión con ocho personas, cuatro varones y cuatro mujeres, de diferentes países hispanoamericanos. Tanto el cuestionario como la entrevista se han elaborado teniendo presente los diferentes análisis desarrollados por diversos think-thank como Pew Research Center $\mathcal{E}$ Migration Policy Institute (vid. infra) y los estudios desarrollados anteriormente por VALERO-MATAS y SÁNCHEZ-BAYÓN. La investigación abarca diferentes cuestiones, aunque intenta centrarse en la averiguación de la auténtica relación del inmigrante hispanoamericano con las diferentes confesiones cristianas en EE.UU., ahondándose en sus sinergias y retroalimentaciones. En cambio, se deja para otros estudios posteriores, la indagación sobre las relaciones entre las iglesias de origen y receptoras de dicha migración. Por tanto, se han analizado los diferentes ítems, inicialmente desde un punto de vista descriptivo, estableciéndose después 
diferenciaciones entre los segmentos mediante análisis estadísticos bivariantes y multivariantes, extrayendo las diferencias (criterio de significación $\mathrm{p}<.05, \mathrm{y}$ comparando los diferentes subgrupos mediante un análisis de varianza (anova), a modo de determinar si los grupos son todos parte de una población más grande o poblaciones separadas con características diferentes. De manera que el estadístico de la desviación típica permitirá cuantificar e interpretar la magnitud de la diferencia. Y se ha utilizado el estadístico de Chi cuadrado como prueba de contraste para las variables categóricas. Finalmente, se ha recurrido a un análisis de correspondencias múltiples, pues esta técnica estadística permite analizar las relaciones de dependencia e independencia de un conjunto de variables categóricas. Todo ello saldrá publicado a lo largo del curso 2018-19 y 2019-20 (vid. infra).

Difícilmente se puede terminar aquí una tarea aún en curso, pues se trata de una investigación a largo plazo (inter-décadas). Lo que sí se puede es confirmar las hipótesis de partida, que van tomando forma de teorías de rango medio (y que pronto serán publicadas en revistas SJR, v.g. Lurralde, Migraciones), como son:

- La paradoja posmoderna estadounidense: mientras que en el resto del mundo, con las crisis de la globalización, se ha reabierto la migración planetaria y el debate identitario, además de revitalizarse el factor religioso, como hilo conector de sendas cuestiones, en cambio, en los EE.UU., donde tradicionalmente las cuestiones citadas han gozado de gran relevancia, considerándose parte de sus principios fundacionales, han pasado a ser ocultadas por velos de confusión, deconstruyéndose e incluso desnaturalizándose (vid. supra).

- Desnaturalización de los principios fundacionales estadounidenses: EE.UU. se articuló como país basándose en principios como la libertad y la búsqueda de la felicidad, así como el reconocimiento y protección de derechos de nacimiento e inalienables, 
como la libertad religiosa y la libre circulación, así como la pluralidad integrada de sus gentes (e pluribus unum: uno de los lemas nacionales de los EE.UU., presente en el Gran sello nacional).

- Triunfo de la posmodernidad vía los Estudios culturales sobrevenidos: tras las guerras culturales (durante la Guerra fría), emergieron los Estudios culturales focalizados en el conflicto social y la exaltación del hecho diferencial de diversas comunidades. Gracias a las políticas públicas y la regulación favorecedora de dichos programas (v.g. Ley de 1972), actualmente son los dominantes en EE.UU., imponiéndose así su visión posmoderna (propia de fin de ciclo histórico de EE.UU. como potencia hegemónica tras la II Guerra mundial). Dicha visión supone la deconstrucción de cualquier principio fundacional estadounidense.

- Efecto pendular de la deconstrucción de principios fundacionales: mientras que la visión de consenso de los Estudios culturales tradicionales, que favorecían metáforas de integración como American dream o melting pot (consagrándose así la libertad religiosa y la riqueza migratoria como parte del legado fundacional estadounidense), en la posglobalización actual, con los velos de confusión posmodernos, se ha logrado el efecto contrario. Aquellos que vengan buscando un país occidental moderno, van a encontrar una nación avocada hacia un Tecno-Evo, en el que la sociedad abierta y de oportunidades se está destejiendo, dando paso a un patchwork de las comunidades por cuotas, privilegios de grupo, discursos y memoria propia, etc.

- Persecución religiosa y migratoria y acogimiento a sagrado: dado el triunfo de los discursos posmodernos etnoculturales, se tiende al proteccionismo de aquellos ya integrados en las comunidades reivindicadoras, pero no cabe el otro nuevo (el inmigrante), al que se acusa de todos los males en curso. Frente a tal derivada 
(contraria a la esencia identitaria estadounidense), han reaccionado las iglesias y sus grupos comunitarios, generando una red de santuarios, que dan asilo e integración a las personas que lo requieran.

En próximos trabajos se espera poder profundizar en todas las teorías de rango medio planteadas, más otras conexas, ofreciéndose así un teorema válido para la posglobalización estadounidense, su biopolítica y su iushumanismo correspondiente (al afectarse además a Latinoamérica, así como al resto de Occidente, dado el gran cambio de ciclo y la falta de relevo y pronóstico claro, salvo los riesgos apuntados del Tecno-Evo transitorio). 
Sociología de las Relaciones Socioculturales Nortatlánticas (...) American civil religion - A. Sánchez-Bayón 


\section{REFERENCE SOURCES}

\section{3.- BIBLIOGRAPHY}

ADAMS, A.M., EMMERICH, C.J.: A Nation dedicated to Religious Liberty. The Constitutional Heritage of Religión Clauses, Philadelphia: University of Pennsylvania Press, 1990.

AHLSTROM, S.E.: A religious History of the American people, New Haven: Yale University Press, 1972.

ALBANESE, C.L.: American Religions and Religion, Belmont: Wadsworth Publishing Co, 1992.

AGUIRRE, M., BENNIS, P.: La ideología neoimperial. La crisis de EE.UU. con Irak, Barcelona: Icaria, 2003. ALGERMISSEN, K.: Konfessionskunde, Hannover: Giesel, 1939.

ALCORIZA, J., LASTRA, A.: El Discurso de Gettysburg y otros escritos de la Unión, Madrid: Tecnos, 2005.

ALLEN, F.L.: America transforms itself, New York: Harper \& Row, 1952.

ALVARO, J.L., GARRIDO, A.: Psicología social. Perspectivas psicológicas y sociológicas, Madrid: McGrawHill, 2003.

ANTIEUS, C.J., et al.: Religion under the State Constitutions, New York: Brooklyn, 1965.

ARGYLE, M.: Religious behavior, Glencoe: The Free Press, 1958. 
ARIENS, M.S., DESTRO, R.A.: Religious Liberty in a Pluralistic Society, Durham: Carolina Academic Press, 1996.

ASHLEY, R.L.: The American Federal State, New York: MacMillan, 1902.

AUSTIN, E.W.: Political fact of the United States since 1789, New York: Columbia University Press, 1986.

AVIS, P.: Ecumenical Theology: and the elusiveness of doctrine, London: SPCK, 1986.

BAILYN, B.: The ideological origins of the American revolution, Cambridge: Harvard Univ. Press, 1967.

BAIRD, R.: Religion in the United States of America, New York: The New York Times, 1969.

BALDWIN, J.: The fire next time, New York: Vintage, 1993.

BALITZER, A.: "Some thoughts about civil religion", en Journal of Church and State (n⿳⺈ 16), 1974, pp. 31-50.

BARCK, O.T.: Since 1900: A History of the United States in our times, New York: Ronald Press Co., 1964.

BARCK, O.T., LEFLER, H.:A History of the United States (2 vols.), New York: Ronald Press Co., 1968.

BASSETT, W.W.: Religious organizations and the Law (vol. 2), Danvers: West Group, 2002.

BATES, M.S.: Religious Liberty. An inquiry, New York: International Missionary Council, 1945.

BAUMAN, Z.: Modernidad líquida (trad.), México: Fondo de Cultura Económica, 
2003.

BECK, U.: La sociedad del riesgo (trad.), Barcelona: Paidos, 1998.

BECKER, H.: Through values to social interpretation, Durham: Duke University Press, 1950.

BEDERMAN, G.: Manliness and Civilization: A Cultural History of Gender and Race in the United States, 1880-1917. Chicago: University of Chicago Press, 1995.

BEHRINGER, W.: Witches and Witch Hunts: A Global History. Malden: Polity Press, 2004.

BELL, D.: El fin de las ideologías (trad.), Madrid: Tecnos, 1954. - The Radical Right, Garden City: Double-day-Anchor, 1964. - "The return of the sacred", en British Journal of Sociology (XXVIII, 4), 1977.

BELLAH, R.N.: Beyond beliefs, New York: Harper \& Row, 1970. - The broken covenant: American Civil Religion in the Time of Trial, New York: The Seabury Press, 1975 (más ed. Chicago: The University of Chicago Press, 1992).

BERG, T.C.: The State and Religion in a Nutshell, St. Paul: West Group, 2004.

BERGER, P.L.: The Sacred Canopy: Elements of a Sociological Theory of Religion, New York: Garden City, 1967. - A rumor of angels: Modern Society and the rediscovery of the Supernatural, New York: Garden City, 1970. - The social reality of religion, London: Penguin Books, 1973. - Modernidad, pluralismo y crisis de sentido: la orientación del hombre moderno (trad.), Barcelona: Paidos, 1994.

BERGER, P.L. (ed.): The secularization of the World. Resurgent religion and World politics, Grand Rapids: Williams B. Eerdmans Publishing Co., 1999. 
BERGER, P.L., NEUHAUS, R.J.: To empower people: from state to civil society, Washington DC: AEI, 1996.

BERNSTEIN, R.B., RICE, K.S.: Are we to be a Nation? The making of the Constitution, Cambridge: Harvard University Press, 1987.

BETH, L.P.: The American Theory of Church and State, Gainesville: University of Florida Press, 1958.

BIRD, D.L., SMITH, S.G. (eds.): Theology and Religious Studies in Higher Education, London: Continuum, 2009.

BLAKELY, W.A. (comp.): American State papers and related documents on Freedom in Religion, Washington DC: The Religious Liberty Association, 1949.

BLAU, J. (ed.): Cornerstones of Religious Freedom in America, Boston: The Beacon Press, 1949.

BLOOM, H.: The American religion. The emergence of the Post-Christian Nation, New York: Simon \& Schuster, 1992.

BOLT, J.: A free church, a holy nation. Abraham Kuyper's American Public Theology, Grand Rapids: Eerdmans Publishing Co., 2001.

BONNELL, J.S.: Presidential Profiles. Religion in the life of American Presidents, Philadelphia: The Westminster Press, 1971.

BORITT, G.: The Lincoln Enigma: The changing faces of an American Icon, New York: Oxford Univ. Press, 2001.

BOORSTIN, D.J. (comp.): Compendio histórico de los Estados Unidos. Un recorrido por sus documentos fundamentales (trad.), México DF: Fondo de Cultura Económica, 1997. 
BOORSTIN, D.J. (comp.): An American Primer, Chicago: The University of Chicago Press, 1966.

BOORSTIN, D.: The Americans (3 vols.), New York: Random House, 1958-73.

BOYER, P., NISSENBAUM, S.: Salem Possessed: The Social Origins of Witchcraft, Cambridge: Harvard University Press, 1974.

BRADFORD, M.E.: Founding Fathers: Brief Lives of the Framers of the United States Constitution, Lawrence: University Press of Kansas, 1994.

BRADFORD, W.: Of Plymouth Plantation, Cabe Cod, prívate edition, 1647 (recuperado y reeditado por Boston: Wright \& Potter Printing Co., 1898).

BRIGGS, J., et al.: A History of the Ecumenical Movement-1968-2000 (vols. 1-3), Genova: WCC Press, 2004.

BRINKLEY, A.: The unfinished nation: a concise history of the American people, New York: McGraw-Hill, 1997.

BRODSKY, C.J.: The imposition of form. Studies in narrative representation and knowledges, Princeton: Pirnceton University Press, 1987.

BROWN, D.: Bury My Heart at Wounded Knee: An Indian History of the AmericanWest, New York: Rinehart and Winston, 1971.

BROWN, W.A.: Church and State in contemporary America, New York: Charles Scribner's Sons, 1936.

BRUNKOW, R.V. (ed.): Religion and society in North America. An annotated bibliography, Santa Bárbara: ABC-Clio Press, 1983.

BUDDE, M., BRIMLOW, R.: Christianity incorporated. How big business is buying the church, Grand Rapids: Baker Books, 2002. 
BUGNON-MORDANT, M.: América totalitaria. Los Estados Unidos y el dominio del mundo, Barcelona: Flor del Viento Ed., 1999.

BULLOCK, S.C.: Revolutionary Brotherhood. Freemasonry and the transformation of the American Social Order, 1730-1840, Chapel Hill: The University of North Carolina Press, 1996.

BURKE, P.: Varieties of cultural History, Cambridge: Cambridge University Press, 1997.

BURR, N.R.: Religion in American Life, New York: Meredith Corp., 1971.

BURR, N.R., et al (eds.): A critical bibliography of religion in America, Princeton: Princeton University Press, 1961.

BURSTEIN, A.: Laws concerning religion in the United States, Dobbs: Oceana Publications, 1966.

BUZZARD, L.R., BRANDON, T.S.: Church Discipline and the Courts, Tyndale: Carol Stream, 1987.

CAIRO, H., PASTOR, J. (comp.): Geopolitica, guerras y resistencias, Madrid: Trama Editorial, 2006.

CALLINICOS, A.: Los nuevos mandarines del poder americano, Madrid: Alianza, 2004.

CAMPBELL, N., KEAN, A.: American Cultural Studies. An introduction to American Culture, New York: Routledge, 1997.

CARR, D.: Time, narrative and History, Bloomington: Indiana University Press, 1986.

CASTELLS, M.: La Era de la información (3 vols.), México: Siglo XXI, 2001-02.

CAVANAUGH, W.: Theopolitical Imagination, New York: T\&T Clark Ltd., 2002. 
CHANNING, E.: A History of the United States (7 vols.), New York: ed. priv., 1905-12. CHANNING, E; HART, A. B. (eds.): The American History Leaflets: Colonial and Constitutional (36 vols.), New York: A. Lovell \& Co., 1892-1910.

CHEVALIER, J (dir.): Las religiones (trad.), Bilbao: Ediciones Mensajero, 1976.

CHOPER, J.: Securiting Religious Liberty. Principles for Judicial Interpretation of the Religion Clauses, Chicago: The University of Chicago Press, 1995.

CLARK, H.: The irony of American Morality, New Haven: College \& University Press, 1971.

CLARK, L.S.: From Angels to Aliens: Teenagers, the Media, and the Supernatural. New York: Oxford University Press, 2003. - Religion, Media, and the Marketplace, Piscataway: Rutgers University, 2007.

CLAYTON, C.: Radical political theology, New York: Columbia University Press, 2011.

COBB, S.H.: The rise of religious liberty in America, New York: MacMillan, 1902.

COGAN, N.H. (ed.): The complete Bill of Rights. The Drafts, Debates, Sources, and Origins, New York: Oxford University Press, 1997.

COHAN, S., SHIRES, L.M.: Telling stories. A theoretical analysis of narrative fiction, New York: Routledge, 1988.

COHEN, W., KAPLAN, J.: Constitutional Law. Civil Liberty and Individual Rights, New York: Foundation Press, 1982.

COLL, A., SÁNCHEZ-BAYÓN, A.: “The Federal Legal Framework for Religion: freedom of religion and church-state relations in the United States", en Derecho y Religión (vol. VIII), septiembre 2013, p. 253-280. 
COMMANGER, H.S. (comp.): Benjamin Franklin. Autobiography and Selections from his other writings, New York: The Modern Library, 1944.

CONKLE, D.O.: Constitutional Law: The Religion Clauses, New York: Foundation Press, 2003.

COOKSON, C.: Regulating Religion: The Courts and the Free Exercise Clause, New York: Oxford University Press, 2001.

CORD, R.L.: Separation of Church and State. Crisis in the American Constitutional system, Boston: Northeastern University, 1982.

CONKIN, P.K.: Puritans and Pragmatist: Eight Eminent American Thinkers, Waco: Baylor University Press, 2006.

CORNELISON, I.A.: The relation of religion to Civil Government in the United States of America. A State without a Church, but not without a Religion, New York: Da Capo Press, 1970.

COUGHLIN, B.J.: Church and State in Social Welfare, New York: Columbia University Press, 1965.

COUSINS, N. (ed.): The Republic of Reason. The philosophies of the Founding Fathers, New York: Harper \& Row., 1988.

COX, H.: The Secular City: Secularization and Urbanization in Theological Perspective, New Haven, Yale Univ. Press, 1965. - The Feast of Fools: A Theological Essay on Festivity and Fantasy, Cambridge: Harvard Univ. Press, 1969.

CURRY, T.J.: The First Freedoms. Church and State in America to the passage of the First Amendment, New York: Oxford University Press, 1986. 
CURTIS, M.K (ed.): The Constitution and the flag (vol. I: The Flag salute cases; vol. II: The flag burning cases), New York: Garland Publishing, 1993.

DAHL, R.: Congress and foreign policy, New Haven: Yale Institute of International Studies, 1949. - After the revolution; authority in a good society, New Haven: Yale University Press, 1970. - How democratic is the American Constitution? New Haven: Yale University Press, 2003.

DARSEN, N (ed.): The Rights of Americans. What they are-what they should be, New York: Pantheon Books, 1971.

DAVIS, D.: "Religious pluralism and the quest for unity in American life", en Journal of Church and State ( $\mathrm{n}^{\mathrm{o}}$ 36), 1994, pp. 245-259. - "Civil religion as a Judicial Doctrine", en Journal of Church and State (no 40), 1998, pp. 7-24.

DAVIS, D.B.: The fear of conspiracy. Images of un-American subversion from the revolution to the present, New York: Cornell University Press, 1971.

DAVIS, K.C.: America's hidden History: untold tales of the first Pilgrims, fighting women, and forgotten Founders who shaped a Nation, Washington: Smithsonian, 2008. - A Nation Rising: Untold Tales of Flawed Founders, Fallen Heroes, and Forgotten Fighters from America's Hidden History, Washington DC: Smithsonian, 2010.

DAVIS, D.H., HAENER, R.H.: "An examination of Church-State Curriculum in American Higher Education", en Journal of Church and State (vol. 38), 1996.

DAVIS, D., HANKINS, B. (eds.): Welfare reform \& Faith-based organizations, Waco: Baylor University Press, 1999.

DAVIDOW, R.P. (ed.): Natural Rights and Natural Law: The Legacy of George Mason, Fairfax: The George Mason University Press, 1986. 
DAWSON, J.M.: America's Way of Church, State, and Society, New York: MacMillan, 1953.

DEGLER, C.N.: Out of our past. The forces that shaped modern America, New York: Harper \& Row, 1970. - The democratic experience: a short American History, New York: Harper \& Row, 1973.

DEMERATH, N.J.: Social class in American Protestantism, Chicago: Rand McNally, 1965.

DEMERATH, N.J., et al.: Sacred Companies, New York: Oxford University Press, 1997.

DENNING, M.: The Cultural Front: The Laboring of American Culture in the Twentieth Century. New York: Verso, 1996.

DIEZ DE VELASCO, F.: La historia de las religiones: métodos y perspectivas, Madrid: Akal, 2005.

DIVINE, R.A.: America, past and present, New York: Harper, 1987 - quien se ha reciclado en el estilo story-telling. - The American story, New York: Longman, 2002.

DIXON, R.G., et al.: American Government: basic documents and materials, New York: D. van Nostrand Co., 1950.

DOLAN, F.: Allegories of America. Narratives-metaphysics-politics, Ithaca: Cornell University Press, 1994.

DORSEY, S.P.: Early English Churches in America 1607-1807, New York: Oxford University Press, 1952.

DORSON, R.M.: America in Legend. Folklore from Colonial Period to the Present, New York: Pantheon Books, 1973. 
DREISBACH, D.: Real threat and mere shadow. Religious Liberty and the First Amendment, Westchester: Crossway Books, 1987.

DREISBACH, D.L., HALL, M.D. (ed.): The Founders on God and Government, New York: Rowman \& Littlefield Pub., 2004.

DUCH, LL.: Religión y mundo moderno. Introducción al estudio de fenómenos religiosos, Madrid: PPC, 1995. - Antropología de la religión, Barcelona: Herder, 2001.

DUCHANE, S.: The Masonery, Köln: Book Laboratory, 2007.

DUE, A.: Atlas histórico del Cristianismo (trad.), Madrid: San Pablo, 1998.

DUSSEL, E.: Las metáforas teológicas de Marx (trad.), Estella: Verbo Divino, 1993.

EBERLE, C.J.: Religious convictions in Liberal Politics, New York: Cambridge University Press, 2002.

EICKELMAN, D.F., et al. (eds.): New Media in the Muslim World, Bloomington: Indiana University Press, 1999.

EIDSMOE, J.: Christianity and the Constitution. The Faith of our Founding Fathers, Grand Rapids: Baker Book House, 1987.

ELAZAR, D. J.: The American mosaic. The impact of space, time and culture on American politics, Bourder: Westview Press, 1994.

EDWARDS, A.M.: Comparative occupational statistics for the United States, 1870 to 1940, Washington DC: Bureau of the Census, 1943.

EDWARDS, G.C.: Governing by campaigning. The politics of the Bush Presidency, New York: Pearson, 2007.

ELIADE, M.: El mito del eterno retorno, Alianza: Madrid, 1972. 
ELLIOT, J (ed.): The debates in the several State Conventions on the adoption of the Federal Constitution (vols. 1-5), New York: Burt Franklin, 1888.

EMERSON, T.I., et al.: Political and Civil Rights in the United States, Boston: Little Brown \& Co., 1967.

ERIC, M.: Making Gay History, New York: HarperCollins Publishers, 2002.

ESBECK, C.H.: "Table of United States Supreme Court Decisions relating to Religious Liberty 1789-1994", en Journal of Law and Religion (vol.10, n²), 1994, p. 573 ss.

ESBECK, C.H.: "Five views of Church-State Relations in Contemporary American Thought", en Brigham Young University Law Review (vol. 2), 1986, p. 371 ss.

ESTRUCH, J.: La innovación religiosa. Ensayo teórico de Sociología de la Religión, Barcelona: Ariel, 1972.

EVERETT, W.J.: God's Federal Republic. Reconstructing our Governing Symbol, New York: Paulist Press, 1988.

FAIRCHILD, H.P.: The melting-pot mistake, Boston: Little Brown \& Co., 1926.

FARBER, D.A.: The First Amendment, New York: Foundation Press, 1998.

FEDERER, W.: "America's God and Country", en Encyclopedia of Quotations, Coppell: Fame Publishing, 1994.

FELT TYLER, A.: Freedom's Ferment. Phases of American social History to 1860, Minneapolis: University of Minnesota Press, 1944.

FERRAND, M. (ed.): Records of the Federal Convention of 1787, New Haven: Yale University Press, 1911. 
FERRAROTTI, F.: Una fedesenzadogmi, Roma: Laterza\&Figli Spa, 1990.

FEUERBACH, L.: La esencia del cristianismo (trad.), Salamanca: Ed. Sígueme, 1975.

FIERRO, A.: Hecho religioso, Barcelona: Salvat, 1981.

FINE, T.: American Legal Systems: A resource and reference guide, Cincinnati: Anderson Publishing Co., 1997.

FINKE, R., STARK, R.: The Churching of America, 1776-1990. Winners and losers in our religious economy, New Brunswick: Rutgers University Press, 1992.

FISHER, P.: The New American Studies: EssaysfromRepresentations. Berkeley: University of California Press, 1991.

FLORIDO, F.L.: “La controversia entre filósofos y teólogos en el pensamiento de Duns Escoto", en Augustinus (vol. 51, no200-201), 2006, p. 53-77. - "El escepticismo de la teología medieval a la filosofía moderna", en Revista Española de Filosofía Medieval (nำ13), 2006, p. 181-89.

FLOWERS, R.B.: That Godless Court: Supreme Court Decisions on Church-State Relationships, Louisville: Westminster John Knox Press, 1994.

FOWLER, R.B., HERTZKE, A.D.: Religion and Politics in America: Faith, culture and strategic choices, Boulder: Westview Press, 1995.

FRANKLIN, B.: El libro del hombre de bien (trad.), Madrid: Espasa Calpe, 1964.

FREUD, S.: The future of an Illusion (trad.), New York: Norton, 1989.

FRISCH, M.J., STEVENS, R.G.: American political thought. The Philosophic dimension of American statesmanship, New York: Charles Scribner's Sons, 1971. 
FRITZE, R.H.: Invented Knowledge. False History, Fake Science and Pseudo-Religions, London: Reaktion Books, 2009.

FUKUYAMA, F.: "The End of History?", en The National Interest (16), 1989: 3-18. - The end of History and the last man, New York: Free Press, 1992.

GAFFNEY, E.M.: Ascending Liability in Religious and Other Nonprofit Organizations, Macon: Mercer University Press, 1984.

GALLUP, G., et al.: The people's religion. American Faith in the 90's, New York: MacMillan, 1989.

GARCIA, J.M. (coord.): Diccionario del Filosofía, Mileto Ediciones, Madrid, 2001.

GARCIA, P.: Diccionario Filosófico. Manual de materialismo filosófico. Una introducción analítica (revisión de G. BUENO), Ovideo: Biblioteca Filosófica en Español, 1999.

GARÍN, P.Mà.: Temas de Derecho Eclesiástico del Estado. La "Religión" en la comunidad política desde la libertad, Bilbao: Universidad de Deusto, 2000.

GARMAN, G.: America's real religion, Pittsburg: Pittsburg State University Press, 1989.

GARNETT, R.W.: "The Theology of the Blaine Amendment", en First Amendment Law Review (vol. 2), 2003.

GARRATY, J.A.: The American Nation: a history of the United States, New York: Harper, 1971. - A short history of the American Nation, New York: Harper, 1973.

GAUSTAD, E.S.: Faith of the Founders. Religion and the New Nation 1776-1826, Waco: Baylor University Press, 1993.

GAUSTAD, E. S. (ed.): A documentary History of Religion in America. To the Civil War, Grand Rapids: William B. Eerdmans Publishing Co., 1993. 
GARVEY, J.H., et al.: The First Amendment. A reader, St. Paul: West Publishing Co., 1992.

GELLNER, E.: Posmodernism, reason and religión, New York: Routledge, 1992.

GEY, S.C.: Religion and the State, San Francisco: LexisNexis, 2001.

GILES, P.: Virtual Americas: Transnational Fictions and the Transatlantic Imaginary. Durham: Duke University Press, 2002.

GLAZIER, M., SHELLEY, T.J.: The Encyclopedia of American Catholic History, Collegeville: The Liturgical Press, 1983.

GODBEER, R.: The Devil's Dominion: Magic and Religion in Early New England. Cambridge: Cambridge UniversityPress, 1994.

GOLDBERG, G.: Church, State and the Constitution, Washington DC: Regnery Gateway, 1987.

GOMEZ CAFFARENA, J., MARTIN VELASCO, J.: Filosofía de la Religión, Madrid: Revista Occidente, 1973.

GÓMEZ, L., SÁNCHEZ-BAYÓN, A.: “Enseñar ética en las Ciencias Jurídicas y Sociales", en CARRIÓN, D. (coord.): Claves docentes en el Espacio Europeo de Educación Superior, Madrid: Demiurgo Comunicación, 2010, p. 71-86.

GONZÁLEZ, M., SÁNCHEZ-BAYÓN, A.: RIDE. Regulación Iberoamericana de Derecho Eclesiástico, Madrid: Delta Publicaciones, 2011. - Derecho Eclesiástico de las Américas: Fundamentos Socio-Jurídicos y Notas Comparadas (Prólogo del Prof. Dr. I. MARTÍN, Director del Área de Derecho Eclesiástico - UAM), Madrid: Delta Publicaciones, 2009. - “Libertades fundamentales en las Américas: devenir de la libertad religiosa en América Latina, los Estados Unidos de América y el Sistema 
Interamericano", en Revista Jurídica-Universidad Autónoma de Madrid (nº 14), 2006, p. $107-126$.

GONZÁLEZ-CARVAJAL, L: Ideas y creencias del hombre actual, Santander: Sal Terrae, 1991.

GONZALEZ DEL VALLE, J.M.: Derecho Eclesiástico español, Ovideo: Universidad de Oviedo, 1997.

GORDON, M.: Assimilation in American Life: The role of race, religion and national origins, New York: Oxford Univ. Press, 1964.

GOTI, J.: Sistema de Derecho Eclesiástico del Estado, edición privada, San Sebastián, 1994. - Sistema de Derecho Eclesiástico del Estado (Parte general), Donostia: Kursaal, 1991.

GUERRA, M.: Diccionario enciclopédico de las sectas, Madrid: Biblioteca de Autores Cristianos, 1998, pp. 268.

GUINN, D.E.: Faith on trial. Communities of faith, the First Amendment, and the Theory of deep diversity, Lanham: Lexington Books, 2002.

GRAHAM, F.: Wall of controversy. Church-State conflict in America (the Justices and their opinions), Malabar: Robert \& Krieger Publishing Co., 1986.

GREELY, A.M.: The Denominational society. A sociological approach to Religion in America, Glenview: Scott Foresman\& Co., 1972.

GREENAWALT, K.: Religious convictions and political choice, New York: Oxford University Press, 1988.

GREENE, E.B.: Religion and the State: the making and testing of an American tradition, Ithaca: Cornell University Press, 1959. 
GRIGORIEFF, V.: El gran libro de las religiones del mundo (trad.), Barcelona: Ediciones Robinbooks, 1995.

GRIGORIEFF, V.: Religions du Monde entier, Bruselas: Marabut, 1989.

GUYATT, N.: Another American Century. The United States and the World sinde 9/11, New York: St. Martin's Press, 2003.

HACKER, L.M.: The shaping of the American tradition (2 vols.), New York: Columbia University Press, 1947.

HAMBURGER, P.: Separation of Church and State, Cambridge: Harvard University Press, 2002, pp.422 ss

HAMMAR, R.R.: Pastor, Church \& Law, Springfield: Christian Ministry Resources, 1983 (revision con Matthews: Christian Ministry Resources, 2000).

HAMMER, D.: The Puritan Tradition in Revolutionary, Federalist, and Whig Political Theory. A rhetoric of origins, New York: Peter Lang, 1998.

HANDLIN, O.: America. A History, Boston: Henry Holt \& co, 1968.

HANGEN, T.J.: Redeeming the Dial: Radio, Religion, and Popular Culture in America, Chapel Hill: University of North Carolina Press, 2002.

HANNE, M.: The power of the story, Oxford: Berghaslin Books, 1994.

HARLAN, D.: The degradation of American History, Chicago: The University of Chicago Press, 1997.

HANLEY, M.Y.: Beyond a Christian Commonwealth, Chapel Hill: The University of North Carolina Press, 1994. 
HARRIS, M.: American Now: the Anthropology of a Changing Culture, New York: Simon \& Schuster, 1984.

HART, B. (ed.): The American Nation. A History (10 vols.), New York: ed. priv., 190405.

HARTZ, L.: The Liberal tradition in America. An interpretation of American Political Thought since the Revolution, New York: HBJ Books, 1955.

HARWOOD, S.: Judicial Activism. A restrained defense, San Francisco: Austin \& Winfield, 1996.

HATCH, N.O.: Thesacred cause of Liberty. Republican Thought and the Millennium in Revolutionary New England, New Haven: Yale University Press, 1977.

HAYNES, S.R. (ed.): Professing in the Postmodern Academy: Faculty and the Future of Church-Related Colleges, Waco: Baylor University Press, 2002.

HENDERSHOT, H.: Shaking the World for Jesus: Media and Conservative Evangelical Culture, Chicago: The University of Chicago Press, 2004.

HENSEL, J.B. (ed.): Church, State, and Politics, Washington DC: The Roscoe Pound, 1981.

HIGHAM, J., CONKIN, P.K. (eds.): New directions in American intellectual History, Baltimore: The John Hopkins University Press, 1979.

HILLERBRAND, H.J. (ed.): The Encyclopedia of Protestantism (vol. 1-4), New York: Routledge, 2004.

HILLERS, S.: Derecho Constitucional y Régimenes Políticos: España, Gran Bretaña y EE.UU. (trad., vols. I-IV), Pamplona: Aranzadi, 1993.

HODES, W.: Legal research: A self-teaching guide, to the Law library, Minneapolis: The 
National Institute for Trial Advocacy, 1998.

HOFSTADTER, R.: The American political tradition and the men who made it, London: Jonathan Cape, 1967. - La tradición política norteamericana y los hombres que la formaron, México DF: Fondo de Cultura Económica, 1988.

HOFSTADTER, R., et al.: The structure of American History, Pretice-Hall: Englewood Cliffs, 1946. - The American political tradition and the men who made it, London: Jonathan Cape, 1967. -The progressive historians, New York: Vintage Books, 1970.

HOOVER, S.M., CLARK, L.S. (eds.): Practicing Religion in the Media Age, New York: Columbia University Press, 2002.

HOOVER, S.M., LUNDBY, K. (eds.): Rethinking Media, Religion, and Culture, Thousand Oaks: SAGE, 1997.

HORSFIELD, P., et al. (eds.): Belief in Media: Cultural Perspectives on Media and Christianity, Burlington: Ashgate, 2004.

HORSMAN, R.: Race and Manifest Destiny. The origins of American racial AngloSaxonism, Cambridge: Harvard University Press, 1981.

HOUTART, F. (coord.): Religiones: sus conceptos fundamentales (trad.), México DF: Siglo XXI, 2002.

HUBERMAN, L.: We, The People, New York: Monthly Review Press, 1964 (1a. ed. 1932).

HUDSON, W.S.: Religion in America. An historical account of the development of American religious life, New York: Charles Scribner's Sons, 1973.

HUGHES, R.T.: Myths America Lives By, Urbana: University of Illinois Press, 2003. 
HUGHES, R.T. (ed.): The American quest for the Primitive Church, Chicago: University of Illinois Press, 1988.

HUISMAN, D.: Diccionario de las mil obras clave del pensamiento (trad.),Madrid: Tecnos, 1997.

HUNTINGTON, S.P.: The Common Defense: Strategic Programs in National Politics, New York: Columbia University Press, 1961. - American Politics: The Promise of Disharmony, Cambridge: Harvard University Press, 1983. - "The Clash of Civilizations?", en Foreign Affairs (72, 3), 1993: 22-49. - The Clash of Civilazations and the Remaking of World Order. New York: Simon \& Schuster. 1996. - Culture Matters How Values Shape Human Progress, New York: Basic Books, 2000. - Who Are We? The Challenges to America's National Identity, New York: Simon \& Schuster, 2004. - El orden político en las sociedades en cambio (trad.), Barcelona: Paidos, 1996. - El choque de civilizaciones y la reconfiguración del orden mundial (trad.), Barcelona: Paidos, 1997. ¿Quiénes somos? Los desafíos a la identidad nacional estadounidense (trad.), Barcelona: Paidos, 2004.

HURD, A.E. (ed.): Religion and Church and State: a bibliography selected from the ATLA religion database, Chicago: American Theological Library Association, 1986.

HUTCHESON, R.G.: Church, State and Chaplaincy: essays and statements on the American Chaplaincy System, Washington DC: General Commission on Chaplains and Armed Forces Personnel, 1969. - God in the White House. How religion has changed the modern presidency, New York: MacMillan, 1988.

HYNEMAN, C., LUTZ, D.S. (eds.): American Political Writing during the Founding Era, 1760-1805 (vols I-II), Indianapolis: Liberty Press, 1983. 
JACOBS, J.B.: Individual Rights and Institutional Authority: Prisons, Mental Hospitals, Schools and Military. Cases and Materials, New York: The Bobbs-Merrill Co., 1972.

JAMES, W.: The Varieties of Religious Experience. A study in Human Natures, New York: The Modern Library, 1902.

JAMESON, J.F. (ed.): British Royal Proclamations relating to America, 1603-1783 (vols. 1-16), New York: American Historical Association, 1906-17.

JASPER, M.C.: Religion and the Law, Dobbs: Oceana Publications, 1998.

JENSEN, M.: The Making of the American Constitution, Malabar: Krieger Publishing Co., 1979.

JEWETT, R., LAWRENCE, J.S.: Captain America and the Crusade against Evil: The Dilemma of Zealous Nationalism, Grand Rapids: Wm. B. Eerdmans, 2004.

JOHNSON, P.: A History of the American People, New York: Harper \& Row, 1997. Estados Unidos. La Historia (trad.), Buenos Aires: Ediciones B, 2001.

JONES, M.A.: The limits of Liberty. American History 1607-1992, New York: Oxford University Press, 1930.

JORDAN, T.: The U.S. Constitution and fascinating facts about it, Naperville: Oak Hill Publishing Co., 2003, pp. 58. Vid. DAVIS, D.H.: "A commentary on the proponed "religious equality/liberties" Amendment", en Journal of Church and State (vol. 38), 1996.

JUERGENSMEYER, M. (ed.): The Oxford Handbook of Global Religions, New York: Oxford University Press, 2006.

KAGAN, R.: Poder y debilidad. Europa y EE.UU. en el nuevo orden mundial (trad.), Madrid: Taurus, 2003. 
KAHN, P.W.: Political Theology. Four new chapters on the concept of sovergignty, New York: Columbia University Press, 2011.

KAPPLER, C.J. (comp.): Indian Treaties, 1778-1883, New York: Interland Publishing Co., 1973.

KASSON, J.F.: Houdini, Tarzan, and the Perfect Man: The White Male Body and the Challenge of Modernity in America. New York: Hill and Wang, 2001.

KAUPER, P.G.: Religion and the Constitution, Baton Rouge: Louisiana State University Press, 1964.

KEILLOR, S.L.: This Rebellious House. American History \& the Truth of Christianity, Downers: InterVarsity Press, 1996.

KELLEY, R.: The cultural pattern in American politics. The first century, New York: Alfred A. Knopf, 1979.

KELSO, J.C.: Studying Law: An introduction to legal research, New York: Matthew Bender, 1990.

KENNEDY, D., et al.: The American Pageant, Boston: Houghton Mifflin, 2006.

KEOHANE, R., NYE, J.: Poder e interdependencia. La política mundial en transición (trad.), Buenos Aires: Grupo Editor Latinoamericano, 1977.

KEPEL, G.: La Revanche de Dieu: Chrétiens, juifs et musulmans à la reconquête du monde, París: Le Seuil, 1991. - A l'ouestd'Allah, París: Le Seuil, 1994. Complement., vid. - Le Prophète et le Pharaon. Auxsources des mouvementsislamistes, París: Le Seuil, 1984. - Les banlieues de l'islam. Naissanced'unereligion en France, París: Le Seuil, 1987. - Du jihad à la fitna, París: Bayard, 2005. - La revancha de dios. Cristianos, judíos y musulmanes a la reconquista del mundo (trad.), Madrid: Alianza, 2005. 
KIRK, R.: The conservative mind, Chicago: Henry Regnery Co., 1955.

KLEIN, D.: Legal research materials, Dubuque: Hunt Publishing Co., 1989.

KLINEBERG, F.A.: A free Church in a free State, Gainesville Indianapolis: National Foundation Press, 1947.

KMIEC, K.D.: "The origin and current meaning of "Judicial Activism"”, en California Law Review (n-9 92), 2004.

KOHUT, A., et al.: The diminishing divide. Religion's changing role in American politics, Washington: Brookings Institution Press, 2000.

KONVITZ, M.R.: Fundamental liberties of Free People: religión, speech, press, assembly, Binghamton: Vail Ballou Press, 1957.

KOSKO, B.: El futuro borroso o el cielo en un chip (trad.), Madrid: Crítica, 2006.

KRAMNICK, I., MOORE, R.L.: The Godless Constitution. A moral defense of the secular State, New York: W.W. Norton \& Co., 2005.

KRISTOL, W., KAGAN, R.: Peligros presentes. Soluciones de la Nueva Administración Bush ante una civilización amenazada (trad.), Madrid: Almuzara, 2005.

KROES, R.: Predecessors: Intellectual Lineages in American Studies. Amsterdam: VU University Press, 1999.

KRYZANEK, M.J.: Las estrategias políticas de Estados Unidos de América en América Latina (trad.), Buenos Aires: Grupo Editor Latinoamericano, 1987.

KUKLIN, B., STEMPEL, J.W.: Foundations of the Law. An Interdisciplinary and Jurisprudential Primer, St. Paul: West Publishing Co., 1994. 
KURLAND, P.B., LERNER, R. (eds.): The Founders' Constitution (vols. I-V), Indianapolis: Liberty Fund, 1987.

LASN, K: Culture Jam. The Uncooling of America, Eaglebrook: William Morrow, 1999.

LEGLER, J.: The Two Sovereignties. A study of the relationship between Church and State, New York: Gainesville Philosophical Library, 1952.

LEMARCHAND, P. (dir.): Atlas de Estados Unidos. Las paradojas del poder (trad.), Madrid: Acento Editorial, 1999.

LENOIR, F.: Las metamorfosis de dios. La nueva espiritualidad occidental (trad.), Madrid: Alianza, 2005.

LEONARD, V.G.: Histoire Générale du Protestantisme (vols. I-IV), París: Presses Universitaires de France, 1961.

LERNER, R (ed.): The Founders'Constitution (vols. I-V), Indianápolis: Liberty Fund, 1987.

LEVIN, M.R.: Men in Black: How the Supreme Court is destroying America, Washington DC: Regnery, 2005.

LEVY, L.W. (ed.): Encyclopedia of the American Constitution (vol. 1-4), New York: MacMillan, 1986.

LEWIS, E.R.L.: America, nation or confusion. A study of our inmigration problems, New York: Harper \& Bro., 1928.

LEWIS, J.R. (ed.): The Oxford Handbook of New Religious Movements, New York: Oxford University Press, 2004.

LILLA, M.: The reckless mind. Intellectuals in Politics, New York: The New York Review of Books, 2001. 
LINDER, R.: "Civil religion in historical perspective: the reality that underlies the concept", en Journal of Church and State (n⿳0 17), 1975, pp. 399-422.

LINDGREN, A.J.: Foundations for purposeful Church Administration, Nashville: Abingdon Press, 1981.

LIPPY, C.H., WILLIAMS, P.W. (eds.): Encyclopedia of the American religious experience. Studies of traditions and movements (vols. I-II), New York: Charles Scribner's Sons, 1988.

LIPSET, S.M.: "Religion and American Values", en ENGEMAN, T.S., ZUCKERT, M.P. (ed.): Protestantism and the American Founding, Notre Dame: University of Notre Dame Press, 2004. - LIPSET, M.S.: Political Man: The Social Bases of Politics, New York: Doubleday, 1960. - Religion and American Values in the First New Nation, New York: Basic Books, 1964. - The First New Nation: The United States in Historical and Comparative Perspective, New York: W.W.Norton, 1979. - Revolution and Counterrevolution: Change and Persistence in Social Structures, New York: Basic Books, 1968. - The Politics of Unreason: Right Wing Extremism in America, 1790-1970, New York: Harper \& Row, 1970. - American Excepcionalism: A double-edged sword, New York: W.W. Norton \& Co., Inc. 1996.

LIPSET, S.M.; RAAB, E.: The politics of unreason, Chicago: The University of Chicago, 1978.

LIPSITZ, G.: American Studies in a Moment of Danger. Minneapolis: University of Minnesota Press, 2001.

LITTLE, D.: "American civil religion and the rise of pluralism", en Union Seminary Quaterly Review (nํ 38), 1984, pp. 401-413. 
LOCKE, J.: A letter concerning toleration, London: ed. privada, 1689. BRAVO, P (ed.): Carta sobre la tolerancia. John Locke, Madrid: Tecnos, 1994.

LOSSKY, N., et al.: Dictionary of the Ecumenical Movement, Genova: WCC Press, 2002.

LUHMANN, N.: Sociología del riesgo (trad.), México: Universidad Iberoamericana, 1998.

LYNN, B., et at.: The Right to Religious Liberty, The Basic ACLU Guide to Religious Rights, Edwardsville: Southern Illinois University Press, 1995.

MacDONALD, W.: Select Charters and other documents illustrative of American History, 1606-1775, New York: MacMillan Co., 1899.

MALBIN, M.J.: Religion and politics: the intentions of the authors of the First Amendment, Washington DC: American Enterprise Institute, 1978.

MANNING, L.F.: The Law of Church-State Relations in a Nutshell, West Publishing Co., St. Paul, 1981.

MANZANERO, D., et al.: Philosophicalchallenges of plurality in a global World, Cambridge: Cambridge Scholars Publishing, 2014.

MARANELL, G.: Responses to Religion. Studies in the social psychology of religious belief, Lawrence: University Press of Kansas, 1974.

MARTIN, D.: The religious and the secular, New York: Routledge, 1969.

MARTY, M.: The Public Church, New York: Crossroad, 1989.

MAY, H.: Ideas, Faith, and Feelings. Essays on American Intellectual and Religious History 1952-1982, New York: Oxford University Press, 1983. 
MAZUR, E.: The Americanization of Religious Minorities. Confronting the Constitutional Order, Baltimore: The Johns Hopkins University Press, 1990.

MEACHAM, J.: American Gospel: God, the Founding Fathers and the Making of a Nation, New York: Random House, 2006.

MEAD, F.S., et al.: Handbook of Denominations in the United States, Nashville: Abingdon Press, 1985.

MELTON, J.G.: The Encyclopedia of American Religions, Detroit: Gale Research Inc., 1989.

MENÉNDEZ, A.J.: Church-State Relations: an annotated bibliography, New York: Garland, 1976. - Religious conflict in America: a Bibliography, Garland: New York, 1985.

MERK, F.: Manifest Destiny and Mission in American History, Cambridge: Harvard University Press, 1995.

MONTERO, I.: Abraham Lincoln, Madrid: Editorial Labor, 1991

MOONEY, C.: Religion and the American dream. The search for Freedom under God, Philadelphia: The Westminster Press, 1977. - Public Virtue. Law and the Social Character of Religion, Notre Dame: University of Notre Dame Press, 1986.

MORENO, M (dir): Diccionario del Pensamiento Contemporáneo, San Pablo, Madrid, 1997.

MORGAN, R.E.: The Politics of religious conflict: Church and State in America, Washington DC: University Press of America, 1980.

MURRAY, A.V.: The State and the Church in a Free Society, Cambridge: Cambridge University Press, 1958. 
NOLL, M.A.: A History of Christianity in the United States and Canada, Grand Rapids: William B. Eerdmans Publishing Co., 1992.

NOLL, M.A. (ed.): Religion and American Politics. From the Continental Period to the 1980s, New York: Oxford University Press, 1990.

NOVAK, M.: Human Rights \& the New Realism. Strategic Thinking in a New Age, New York: Freedom House, 1986.

NOONAN, J.T., GAFNEY, E.Mc.: Religious Freedom. History, cases, and other materials on the interaction of religion and Government, New York: Foundation Press, 2001.

NORTH, G.: Political Polytheism. The myth of pluralism, Tyler: Institute for Christian Economics, 1989.

OAKS, D.H.: Trust Doctrines in Church Controversies, Macon: Mercer University Press, 1984.

ODINA, M.: Europa versus USA, Madrid: Espasa, 2004.

OLDHAM, J.H.: Church, Community, and State, New York: Harper \& Row., 1935.

OLMSTEAD, C.E.: History of Religion in the United States, Englewood: Prentice-Hall, 1960.

OLSON, L.R., JELEN, T.G. (comps.): The religious dimension of political behavior. A critical analysis and annotated bibliography, Westport: Greenwood Press, 1998.

OLSON, L.R., DJUPE, P.A. (comps.): Encyclopedia of American religion and politics, New York: Fact on File, 2003.

ORTEGA Y MEDINA, J.A.: La evangelización puritana en Norteamérica, México DF: Fondo de Cultura Económica, 1976. 
PELÁEZ, M., SÁNCHEZ-BAYON, A.: Diccionario de Canonistas y Eclesiasticistas Europeos y Americanos. Tomo I, Saarbrücken: LAP LAMBERT Academic Publishing GmbH \& Co./EAE, 2012.

PERRY, J.: The pretenses of Loyalty: Locke, liberal theory, and American political theology, New York: Oxford University Press, 2011.

PERSONS, S.: Free religion: an American faith, New Haven: Yale University Press, 1947.

PFEFFER, L.: Church, State and Freedom, Boston: Beacon Press, 1953 (corregida en 1967). - Creeds in competition: A creative force in American culture, New York: Harper \& Row., 1958.

PHILLIPS, E.: Political theology. A guide for the perplexed, New York: T\&T Clark, 2012. PIERARD, R.V., LINDER, R.D.: Civil religion and the Presidency, Grand Rapids: Academia Books, 1988.

POWEL DAVIS, A.: American Destiny. A faith for America, Boston: Beacon Press, 1942. POWER, M.S.: Before the Convention. Religion and the Founders, Lanham: University Press of America, 1984.

PRUCHA, F.P.: The Great Father. The United State Government and the American Indians (vols. 1-2), Lincoln: University of Nebraska Press, 1984.

QUEEN, E.L., et al.: The encyclopedia of American Religious History (vols. 1-2), New York: Facts of File, 1996.

REICHLEY, A.J.: Religion in American Public Life, Washington DC: The Brookings Institution, 1985. 
RICHEY, R.E., JONES, D.G. (eds.): American Civil Religion, New York: Harper \& Row., 1974.

ROBERTSON, R. (ed.): Sociology of Religion, New York: Penguin Books, 1969.

ROBBINS, J.W.: Radical democracy and political theology, New York: Oxford University Press, 2011.

ROBBINS, T., ROBERTSON, R.: Church-State Relations. Tensions and transitions, New Brunswick: Transaction Books, 1987.

ROBERTSON, R. (comp.): Sociology of religion, London: Penguin Books, 1969.

SANDOZ, E.: A Government of Laws. Political Theory, Religion, and the American Founding, Sabon: Louisiana State University Press, 1990.

SÁNCHEZ-BAYÓN, A.: “Estudio de la idiosincrasia estadounidense desde su Teología política y Ciencias Eclesiásticas" (p. 165-204), Estudios Eclesiásticos, v. 93, nº 364, 2018. "Balance de la Sociología tras la globalización" (pp. 49-68), en EduserRevista de Educação, IPB (S.1., v. 10, n. 1), july 2018. “Revelaciones conceptuales y lingüísticas de la posglobalización". Carthaginensia, 33(64), 411-458, 2017. "Historia cultural estadounidense desde el factor religioso: fallos de Americaness y sus velos", Cauriensia, 12: 627-59, 2017. "Prisma holístico para una teoría social posglobalizatoria: papel de la religión y su relación con el resto de esferas sociales" (pp. 675-96), en Cauriensia - Revista Anual de Ciencias Eclesiásticas-Ftad. Teología de Cáceres (vol. XI), 2016. Religión civil estadounidense, Porto: Ed. Sindéresis, 2016. Universidad, Ciencia y Religión en los Estados Unidos de América: ¿separación, colaboración o confusión?, Porto: Ed. Sindéresis, 2015. - "Evolución y evaluación de la ciencia iuseclesiasticista en los EE.UU.", en Anuario de Derecho Eclesiástico del Estado Ministerio de Justicia (vol. XXXI), 2015, p. 637-729. - “Régimen jurídico del factor 
religioso en EE.UU.: teoría y praxis relativa a los ministros de culto y las confesiones", en Cauriensia. Revista Anual de Ciencias Eclesiásticas - Instituto Teológico de Cáceres (UPSA) - Universidad de Extremadura (vol. IX), 2014, p. 313-340. - “Freedom of religion at large in American Common Law: a critical review and new topics", en Journal for the Study of Religions and Ideologies, Univ. Babes-Bolyai-Rumanía (vol. 13, issue 37), Spring 2014, p. 35-72. - “Historia, Historiología e Historiografía de los Estudios Interculturales en EE.UU.", en Revista Banda de Moebius, Univ. Chile (no 48), ene. 2014, p. 147-57. - Innovación docente en los nuevos estudios universitarios, Valencia: Tirant Lo Blanch, 2014. - "Global System in a Changing Social Reality: How to Rethink and to study it" (pp. 196-209), en Beijing Law Review (no 5), 2014. - La Modernidad sin prejuicios. La religión en la vida pública estadounidense (3 vols.), Madrid: Delta, 2008-13. - “Enseñanzas del Prof. Navarro-Valls para comprender el "aggiornamento" del Ordenamiento global: aplicación a las Américas" (vol. 1 Religión y Derecho, secc. 5 Derecho Comparado), en MARTÍNEZ-TORRÓN, et al.: Religión, Matrimonio y Derecho ante el siglo XXI. Estudios en homenaje al Profesor Rafael Navarro-Valls (2 vols.), Madrid: Iustel, 2013, p. 1719-53. - Renovación de la Filosofía Social Iberoamericana, Valencia: Tirant lo Blanch, 2013. - "Examen de las principales fuentes e instituciones originarias de Derecho canónico pluriconfesional: Una historia crítica para la revelación de falacias y fundamentos", en Revista de DerechoValparaiso/Revista de Derecho de la Pontificia Universidad Católica de Valparaiso (n⿳ำ XLI), $2^{\text {o }}$ Semestre 2013, p. 605-637. - “Régimen jurídico estadounidense de las organizaciones religiosas y sus miembros", en ICADE-Revista Cuatrimestral de las Facultades de Derecho y Ciencias Económicas y Empresariales (no89), sept. 2013, p. 22151. - "El Derecho Eclesiástico en las universidades estadounidenses", en Revista Española de Derecho Canónico (vol. 70, n¹71), junio 2013, p. 229-265. - “Innovación 
docente en Ciencias Eclesiásticas y Jurídico-Sociales: estudio crítico y comparado", en Cauriensia - Revista Anual de Ciencias Eclesiásticas (vol. 8), 2013, p. 317-349. - “Cómo se aprende Derecho Eclesiástico del Estado en los Estados Unidos de América y su jurisprudencia: los otros estudios de casos menos conocidos", en Revista Jurídica de la Universidad Bernardo O'Higgins Ars Boni et Aequi (vol. 9, no 2), nov. 2013, p. 1-43. "Regulación sobre ministros de culto y organizaciones religiosas en los Estados Unidos: estado de la cuestión y evaluación de las últimas décadas", en Revista Jurídica de la Universidad Bernardo O'Higgins Ars Boni et Aequi (vol. 9, no 1), junio 2013, p. 103-141. - "Problemas epistemológicos y fenomenológicos de la Universidad actual”, en Miscelánea Comillas (vol. 71, no 139), nov. 2013, p. 359-380. - “Galeato pro universitas humanitatis", en REPES: Revista Electrónica de Pensamiento, Economía y Sociedad-Instituto Virtual de Ciencias Humanas (vol. 20), mayo-jun. 2013, p. 19-36. “Religión, Política y Derecho en las Américas del nuevo milenio", en Revista Jurídica de la Universidad Bernardo O'Higgins Ars Boni et Aequi (vol. 8, no 1), enero 2012, p. 39104. - Sistema de Derecho Comparado y Global, Valencia: Tirant Lo Blanch, 2012. - Estado y religión de acuerdo con los Estados Unidos de América, Saarbrücken: EAE, 2012. Derecho Eclesiástico Global. Cuestiones y materiales de trabajo para Derecho Eclesiástico y Canónico, Madrid: Biblioteca Universitaria de CC. Jurídicas, Económicas y Sociales UCJC/Delta, 2012. - Filosofía Político-Jurídica Glocal, Saarbrücken: EAE, 2012. Humanismo Iberoamericano, Guatemala: Cara Parens, 2012. - "Religión, Política y Derecho en las Américas del nuevo milenio", en Revista Jurídica de la Universidad Bernardo O'Higgins Ars Boni et Aequi (vol. 8, no 1), enero 2012, p. 39-104. - “Mejora del aprendizaje del Derecho mediante los estudios de caso: aplicación al Derecho Eclesiástico del Estado", en REPES: Revista Electrónica de Pensamiento, Economía y Sociedad-Instituto Virtual de Ciencias Humanas (vol. 16), sept.-oct. 2012, p. 49-80. - 
"Normatividad Global: repensar las reglas de juego", en Anales de la Facultad de Derecho-Universidad de La Laguna (n²8), diciembre 2011. - “Au revoir, loi de l’État: el fin del derecho estatal", en Revista Electrónica de Pensamiento, Economía y SociedadInstituto Virtual de Ciencias Humanas (vol. 5), septiembre-octubre 2010; versión revisada y ampliada, en Bajo Palabra. Revista de Filosofía (no 5), 2010.- Estudios de cultura político-jurídica, Madrid: Delta, 2010. - "Conocer y gestionar las esferas sociales en la globalización: de las religión, la política y el derecho en las Américas del nuevo milenio", en ICADE-Revista Cuatrimestral de las Facultades de Derecho y Ciencias Económicas y Empresariales (no 81), sept.-dic. 2010, p. 103-146.- Manual de Sociología Jurídica Estadounidense, Madrid: Delta, 2009 (2o edic.). - Manual de Sociología Jurídica Estadounidense. Del poder, lo sagrado y la libertad en la Modernidad Occidental, Madrid: Delta, 2008. - “Historia de la comunicación social estadounidense a través de sus movimientos religiosos", en Historia y Comunicación Social (vol. 13), 2008, p. 199-223. - “La International Religious Freedom Act of 1998 y la geopolítica estadounidense actual", en CAIRO, H., PASTOR, J. (comp.): Geopolítica, guerras y resistencias, Madrid: Trama Editorial, 2006, p. 121-140. - “Comunicación y Geopolítica estadounidense actual: de IRFA al Choque de Civilizaciones", en Historia y Comunicación Social (vol. 11), junio 2006, p. 173-198. - "Revitalizaciones religiosas postmodernas en América y sus riesgos para la democracia y los derechos humanos", en Revista General de Derecho Canónico y Derecho Eclesiástico del EstadoIustel (n⿳⺈ 11), mayo 2006, p. 1-23. - “La religión civil estadounidense: análisis de la configuración de la realidad socio-cultural y su identidad social", en Revista General de Derecho Canónico y Derecho Eclesiástico del Estado-Iustel (no 10), febrero 2006, p. 136. - “Biojurídica: ¿cuestión nominalista o epistemológica? (manifiesto para la persuasión constructiva identitaria)", en MARTIN, I, et al.: Bioética, Religión y 
Derecho, Madrid: Fundación Universitaria Española, 2005, p. 394-411. "Idiosincrasia de la identidad nacional y del modelo socio-cultural estadounidense según el influjo de sus elites político-jurídicas (a vueltas con la religión civil)”, en Actas del VII Congreso Español de Ciencia Política y de la Administración: Democracia y Buen Gobierno (Grupo 26: Elites de poder), 2005, p. 265-281. - “International Religious Freedom Act of 1998 y la evolución de la geopolítica estadounidense reciente (tras el discurso religioso neoconservador)", en Actas del VII Congreso Español de Ciencia Política y de la Administración: Democracia y Buen Gobierno (Grupo 27: Geopolítica, guerras y democracias), 2005, p. 152-176. - "La libertad religiosa en el Sistema Interamericano de Derechos Humanos", en Revista General de Derecho Canónico y Derecho Eclesiástico del Estado-Iustel (n⿳0 6), octubre 2004, p. 1-62. - “U.S. Religious Liberty: One (secular) Nation under God. Paradox nature and explanatory hypothesis", tesina inédita de DEA (investigación realizada en Harvard University, 2002-03), Madrid: UCM, 2003. - “Derecho y Religión en Estados Unidos de Norteamérica: Análisis de su relación desde diversos enfoques", en Zalacaín Harvard Journal of Ibero-America (vol. I, n⿳0 5), Fall 2002, p. 32-36. - “La viabilidad de la enseñanza del Derecho Eclesiástico del Estado en la Universidad de Harvard", en Zalacaín, Harvard Journal of Ibero-America (vol. I, nº 5), Fall 2002, p. 13-18.

SÁNCHEZ-BAYÓN, A.: Humanismo iberoamericano, Guatemala: Cara Parens, 2012. Renovación de la Filosofía Social Iberoamericana, Valencia: Tirant Lo Blanch, 2013. Concordia constitucional, Madrid: Delta, 2013. Derecho Constitucional, Madrid: Ed. Roble, 2014. Derecho Público General: Instituciones públicas y actores sociales, Madrid: Delta, 2016. Lecturas fundamentales de Derecho Político y Constitucional, Porto: Ed. Sindéresis, 2017. ¿Ocaso estatal y de sus relaciones institucionales y protocolarias? Porto: Ed. Sindéresis, 2018. Instituciones del Estado, Madrid: Delta Publicaciones, 2018. 
SÁNCHEZ-BAYÓN, A., et al.: “¿Revitalización o inhabilitación religiosa en la realidad social posglobalizada? El caso estadounidense y sus problemas" (pp. 1-27), en Journal of Sociology and Theory of Religion-JSTR Loyola Univ. E Univ. Valladolid (vol. 7), 2018. “Una historia filosófica de la identidad estadounidense: Balance de propuestas y su crisis actual", en Bajo Palabra (II Época), no 18, 2018, p. 209-36. "Revelaciones sobre la religión civil estadounidense: influjo en su configuración nacional y crisis postglobalizatoria" (pp. 1-29), en Journal of Sociology and Theory of Religion-JSTR Loyola Univ. \& Univ. Valladolid (vol. 6), 2017. "Historia cultural estadounidense desde el factor religioso: fallos de Americaness y sus velos" (pp. 62759), en Cauriensia - Revista Anual de Ciencias Eclesiásticas-Ftad. Teología de Cáceres (vol. XII), 2017. "Vindicatio Historia Philosophiae: estudio de caso de los programas culturales estadounidenses”, en Bajo Palabra (II Época), no 17, 2017, p. 457-76. “Glocal Politics and Law: why scholars do not understand each other and what are the veils of confusion" (Chapter 2), en MANZANERO, D., et al. (eds.): Philosophical Changes of Plurality in a Global World, Cambridge: Cambridge Scholars Publishing, 2014, p. 25-53. “The Federal Legal Framework for Religion: freedom of religion and churchstate relations in the United States" (pp. 253-280), en Derecho y Religión (vol. VIII), septiembre 2013.

SCHAFF, P.: Church and State in the United States or the American idea of religious liberty and its practical effects with official documents, New York: American Historical Association, 1888.

SCHMALZBAUER, J.: People of Faith: Religious Conviction in American Journalism and Higher Education, Ithaca: Cornell University Press, 2003.

SCHLESINGER, A.M.: "The Supreme Court: 1947", en Fortune (nº 35), 1947. Complement. 
SCHNEIDER, H.: Religión in 20th-Century America, Cambridge: Harvard University Press, 1952, pp. 228.

SCHWEIKART, L., DOUGHERTY, D.: A Patriot's History of the Modern World, From America's Exceptional Ascent to the Atomic Bomb, 1898-1945. New York: Sentinel, 2012. - A Patriot's History of the Modern World, Vol. II, From the Cold War to the Age of Entitlement, 1945-2012. New York: Sentinel, 2013.

SCHULTZ, J.D., et al. (edits.): Encyclopedia of Religion in American Politics, Phoenix: Oryx Press, 1999.

SHUMATE, T.D.: The First Amendment: The Legacy of George Mason, Fairfax: The George Mason University Press, 1985.

SENNETT, R.: La corrosión del carácter (trad.), Barcelona: Anagrama, 1998.

SEKULOW, A.: Witnessing Their Faith: Religious Influence on Supreme Court Justices and Their Opinions, New York: Rowman \& Littlefield Publishers, 2006.

SHELDON, G.W.: Religion and Politics. New York: Peter Lang Publishing Inc., 1990.

SINGER, C.G.: A theological interpretation of American History, Nutley: The Craig Press, 1964.

SMITH, E.A.: "The civil religion: is it a viable concept?", en Journal of Ecumenical Studies (no 14), 1977, pp. 113-124.

SMITH, E.A. (ed.): The Religion of the Republic, Philadelphia: Fortress Press, 1971.

SMITH, G.S.: God and politics, Philipsburg: Prebyterian and Reformed Publishing Co., 1987. -Faith and the Presidency. From George Washington to George W. Bush, New York: Oxford University Press, 2006. 
SMITH, J.W., JAMISON, A.L. (ed.): Religion in American Life (vol. I-IV, con especial atención a la bibliografía seleccionada por BURR para el vol. IV), Princeton: Princeton University Press, 1961.

SOKAL, A.: Beyon the hoax: Science, Philosophy and Culture, New York: Oxford University Press, 2008. - "Transgressing the boundaries: towards a transformative hermeneutics of quantum gravity", en Social Text, no 46-47, 1996, pp. 217-52.

SOKAL, A., BRICMONT, J.: Fashionable nonsense: postmodern intellectuals'abuse of science, New York: Picador, 1998.

SONTAG, F., ROTH, J.K.: God and America's future, Wilmington: Consortium Books, 1977.

STARK, R., GLOCK, C.: American piety: the nature of religious commitment, Berkeley: University of California Press, 1970.

STEPHENSON, N.W.: A History of the American People (2 vols.), New York: Charles Scribner's Sons, 1934.

STOKES, A.P.: Church and State in the United States (vols. I-III), New York: Harper \& Row., 1950.

SWATOS, W.H. (ed.): Encyclopedia of Religion and Society, Walnut Creeck: Altamira Press, 1998.

SWEET, W.W.: Religion in the development of American culture, New York: Charles Scribner's Sons, 1952. - Religion in Colonial America, Charles Scribner's Sons, New York, 1942. 
TAKAKI, R.: A different mirror. A History of multicultural America, New York: Little Brown, 2008). - Debatting diversity: clashing perspectives on race and ethnicity in America, New York: Oxford University Press, 2002.

TALEB, N.N.: Antifrágil (trad.). Barcelona: Paidos, 2013.

TATE, E.D., McCONNELL, K.: Religionand Communication: a selected, annotated basic bibliography, Annandale: Speech Communication Association, 1988.

TAYLER, M.L.: Religion, Politics and the Christian Right, Minneapolis: Forterpress Press, 2005.

TAYLOR, C.: Varieties of Religion Today, Cambridge: Harvard University Press, 2002.

TAYLOR, T.F.: 7 Deadly Lawsuits. How Ministers can avoid litigation and regulation, Nashville: Abingdon Press, 1996.

TOCQUEVILLE, A.: La democracia en América (trad.), Madrid: Alianza, 1980.

TORPEY, W.G.: Judicial doctrines of religious rights in America, Chapel Hill: The University of North Carolina Press, 1948.

THORPE, F.N.: The Federal and State Constitutions, Colonial Charters, and other Organic Laws (vols. 1-7), Washington DC: Government Printing Office, 1909.

THORPNING, J.F.: Religious liberty in transition, Washington DC: The Catholic University of America Press, 1931.

TRIBE, L.H.: Constitutional choices, Cambridge: Harvard University Press, 1985.

TRIPP, C.A.: The intimate World of Abraham Lincoln, New York: Free Press, 2005.

TRUMP, D.: Great Again: How to Fix Our Crippled America, New York: Threshold Editions, 2016. 
TURNER, B.S.: La religión y la Teoría social. Una perspectiva materialista (trad.), México DF: Fondo de Cultura Económica, 1985.

TUVESON, E.L.: Redeemer Nation. The Idea of America's Millennial Role, Chicago: University of Chicago Press, 1968.

TYLER, A.F.: Freedom's Ferment. Phases of American Social History to 1860, Minneapolis: The University of Minnesota Press, 1944.

VALERO-MATAS, J.A., SÁNCHEZ-BAYÓN, A.: Balance de la globalización y teoría social de la posglobalización. Madrid: Dykinson, 2018.

VAN ALSTYNE, W.: First Amendment. Cases and Materials, New York: Foundation Press, 1990. - The American First Amendment in the Twenty-First Century. Cases and materials, New York: Foundation Press, 2002.

VERA, F.P.: Derecho Eclesiástico I. Cuestiones fundamentales de Derecho Canónico, relaciones Estado-Iglesias y Derecho Eclesiástico del Estado, Madrid: Tecnos, 1990. VIDAL, C.: Enciclopedia de las Religiones, Barcelona: Ed. Planeta, 1997.

VOLOKH, E.: The First Amedment. Problems, cases and policy arguments, New York: Foundation Press, 2001.

VV.AA.: American State Papers. Indians Affairs (vol. 1), Washington DC: Gales \& Seaton, 1832.

VV.AA.: Annals of Congress. The debates and proceedings in the Congress of the United States (vols. 1-42), Washington DC: Gales \& Seaton, 2000.

VV.AA.: Derecho Canónico, Pamplona: EUNSA, 1974.

VV.AA.: Diccionario Espasa Religiones y Creencias, Madrid: Espasa, 1997. 
VV.AA.: The Enduring Vision. A History of the American people, Boston: Houghton Mifflin Co., 2002.

VV.AA.: Guidance to Faith-based and Community Organizations on Partnering with the Federal Government, Washington DC: White House, 2001, pp. 2.

VV.AA.: Handbook of Denominations in the United States, Nashville: Abingdon Press, 1985.

VV.AA.: Legal research illustrated. An abridgment of fundamentals of legal research, New York: Foundation Press, 1998.

VV.AA.: Practical approaches to Legal research, New York: The Haworth Press, 1988.

VV.AA.: ¿Qué pueden ofrecer las tradiciones religiosas a las sociedades del S. XXI?, Barcelona: CETR Editorial, 2005.

VV.AA.: Religion in America, San Diego: Greenhaven Press, 1989.

VV.AA.: Religious and Secular Reform in America. Ideas, beliefs, and social change, New York: New York University Press, 1999.

VV.AA.: Religious Liberty and State Constitutions, Buffalo: Prometheus Books, 1993.

VV.AA.: Reseña de la Historia de los Estados Unidos (trad.),Washington DC: Agencia de Comunicación de las Embajadas Estadounidenses, 1975.

VV.AA.: Tratado de Antropología de lo Sagrado (vols. 1-3), Madrid: Trotta, 1995-97.

VV.AA.: Tratado de Derecho Eclesiástico, Pamplona: Eunsa, 1994.

VV.AA.: The People's Religion. American Faith in the 90's, New York: MacMillan Publishing Co, 1989.

VV.AA.: Searching the Law, Arlsley: Transnational Publishers, 1999. 
VV.AA.: Winning research skills, New York: West Group, 1999.

WAAL, A.: Introducción a la Antropología de la Religión, Estella: Verbo Divino, 1975.

WACQUANT, L (dir.): Repensar los Estados Unidos. Para una Sociología del Hiperpoder (trad.), Barcelona: Anthropos Editorial, 2005.

WALLACE, J.D.: Historia no-oficial de Estados Unidos de América. El libro negro del imperio (trad.) Barcelona: Ediciones de la Tempestad, 2004.

WEBER, M.: Sociología de la Religión (trad.), Madrid: Istmo, 1997. La ética protestante y el espíritu del capitalismo (trad.), Madrid: Alianza, 1998.

WEBER, P, JONES, W.L.: U.S. Religious interest groups: institucional profiles, Westport: Greenwood Press, 1994

WEINBERG, A.K.: Manifest Destiny. A study of nationalist expansionism in American History, Baltimore: The Johns Hopkins Press, 1935.

WEST, E.M.: "A proposed neutral definition of civil religion", en Journal of Church and State (n⿳⺈ 22), 1980, p. 23-40.

WIEMAN, H.N., MELAND, B.E.: American Philosophies of Religion, Chicago: Willett, Clark \& Co., 1936.

WILLIAMS, W.A.: Empire as a way of life. An essay on the causes and character of America's present predicament along with few thoughts about an alternative, New York: Oxford University Press, 1980.

WILSON, C.R., FERRIS, W. (edits.): Encyclopedia of Southern Culture, Chapel Hill: The University of North Carolina Press, 1989.

WIRTH, F.P.: Forman's our Republic. A brief History of the American people, New York: Appleton-Century Co., 1935. 
WHITE, P.L. et al.: A History of the American people, New York: McGrawHill, 1970.

WHITEBROOK, M.: Identity, narrative and politics, New York: Routledge, 2001.

WHITEHEAD, J.W.: Iglesia y Estado en las Américas (trad.), La Paz: Instituto Rutherford, 1994.

WIENER, P.P.: Evolution and the Founders of Pragmatism, Cambridge: Harvard University Press, 1949.

WILTSHIRE, W.: The Usefulness of Classical Learning in the Eighteenth Century, New York: American Philological Association, 1976. - Greece, Rome, and the Bill of Rights, Norman: University of Oklahoma Press, 1992.

WILKINS, D.E.: American Indian Sovereignty and the U.S. Supreme Court. The Masking of Justice, Austin: University of Texas Press, 1997.

WITTE, J.: Religion and the American Constitutional Experiment: Essential Rights and Liberties, Boulder: Westview Press, 2000.

WOLF, R., MOORE, B., MARCUSE, H.: Crítica a la tolerancia pura (trad.), Madrid: Editorial Nacional, 1969.

WOOD, J.E.: "The Place of Church-State Studies in the University", en Journal of Church and State (vol. 35), 1993. - Church and State in Historical Perspective: A Critical Assessment and Annotated Bibliography (Bibliographies and Indexes in Religious Studies), Westport: Praeger Publishers, 2005.

WOOD, J.E. (ed.): Jewish-Christian Relations in Today's World, Waco: Baylor University Press, 1971.

WOOD, J.E., et al: Church and State in Scripture History and Constitutional Law, Waco: Baylor University Press, 1958. - Church and State, Waco: Baylor University Press, 
1961. - Religion and the State. Essays in Honor of Leo Pfeffer, Waco: Baylor University Press, 1985.

WOOD, R.C. (ed.): Civil Religion and transcendent experience, Macon: Mercer University Press, 1988.

WOODBURN, J.A.; MORAN, T.F.: Elementary American History and Government, Chicago: Green \& Co., 1921.

WREN, C.G., WREN, J.R.: The Legal research manual. A game plan for Legal research and Analysis, Rice Lake: Adams \& Ambrose Publising, 1986.

WRIGHT MILLS, C.: The New Men of Power: America's Labor Leaders, New York: Harcourt, Brace \& co, 1948. - White Collar: The American Middle Classes, New York: Oxford University Press, 1951.

WRIGHT, C. (ed.): Religion in American Life. Selected readings, Boston: Houghton Mifflin Co., 1972.

YAPP, N.: El milenio norteamericano. Mil años memorables de logros y acontecimientos (trad.), Colonia: Könemann, 2000.

YARNOLD, B.: Religious Wars in the Courts I. The lower federal courts and the US Supreme Court in Religious Freedom cases 1970-1990, Hintington: Nova Science Publishers, 1999. - Religious Wars in the Courts II. Who were the litigants in the US Courts, Religious Freedom cases 1970-1990, Hintington: Nova Science Publishers, 2000. YARNOLD, B. (ed.). The role of religious organizations in social movements, New York: Praeger, 1991.

YINGER, J.M.: The Scientific study of Religión, New York: McMillan, 1990.

YONG, A.: In the days of Caesar. Pentecostalism and political theology, Grand Rapids: 
William B. Eerdmas Publishing Co., 2009.

ZINN, H.: A People's History of the United States, New York: Harper \& Row, 1980. Voices of a people's History of the United States, New York: Seven Stories Press, 2004. A people's History of American empire, New York: Metropolitan Books, 2008.

ZINN, H., ARNOVE, A.: Voices of a People's History of the United States, New York: Seven Stories Press, 2004.

ZOLLMANN, C.: American Church Law, St. Paul: West Publishing Co., 1933. 


\section{4.- MULTIMEDIA SOURCES}

Adams Family Papers: An Electronic Archive

(URL: http://www.masshist.org/digitaladams/archive/autobio/).

Avalon Project-Yale Law School

(URL: http://www.yale.edu/lawweb/avalon/avalon.htm).

Comisión para la Libertad Religiosa Internacional

(URL: http://www.uscirf.gov/countries/index.html).

Comisión durante la Legislatura 109th, del Congreso de los EE.UU., 2005-06

(URL: http://www.uscirf.gov/washingtonupdate/legislation/109.htm1).

Comisión IRFA y sus comisionados

(URL: http://www.uscirf.gov/washingtonupdate/links.html).

Department of Homeland Security (2014): Yearbook of Inmigration Stadistics. Washington

DC: DHS (URL: https://www.dhs.gov/immigration-statistics/yearbook).

First Amendment Cyber Tribune

(URL: $\underline{\text { http://w3.trib.com/FACT/index.html) }}$

Freedom House

(URL: http://www.freedomhouse.org/religion/).

From Revolution to Reconstruction Project-University of Groningen

(URL: http://www.let.rug.nl/ usa/D/index.htm).

Gallup International Poll and Reports 
(URL: $\underline{w w w . g a l l u p . c o m})$.

Groundswell (2017): “We pledge to resist deportation and discrimination through sanctuary". Groundswell (URL: https://action.groundswell-mvmt.org/petitions/wepledge-to-resist-deportation-and-discrimination-through-sanctuary).

InfoUSA: Think Tanks and Public Interest Organizations

(URL: http://usinfo.state.gov/usa/infousa/politics/thnktank.htm).

Informe de la Comisión, de 2 de mayo del 2005

(URL: http://www.uscirf.gov/countries/publications/currentreport/2005annualRpt.pdf\#page=1).

Dawson Institute of Church State Studies

(URL: http://www3.baylor.edu/Church State/).

Kappler Project: Indian Affairs. Law \& Treaties-Oklahoma State University

(URL: $\underline{\text { http://digital.library.okstate.edu/kappler/index.htm). }}$.

LexisNexis

(URL: www.lexisnexis.com).

NUSSBAUM, L.M. (ed.): “Decision of the Court", en Rothgerber Johnson $\mathcal{E}$ Lyons

(URL: http://www.churchstatelaw.com/).

Office of Legal Counsel, U.S. Department of Justice

(URL: http://www.usdoj.gov/olc/).

Onlinebooks

(URL: http://onlinebooks.library.upenn.edu/webbin/metabook?id=mppresidents). 
Pew Research Center (2017): "Hispanic/Latino demographics". PRC (URL: http://www.pewresearch.org/topics/hispaniclatino-demography/).

Programas de información de los EE.UU.-USINFO

(URL: $\underline{\text { http://usinfo.state.gov/esp/). }}$

Programa de Información del Departamento de Estado

(URL: http://usinfo.state.gov/).

Programa de Información de la Secretaría de Estado de los EE.UU.

(URL: http://usinfo.state.gov/esp/home/topics/us society values/national symbols.html).

Project Gutenberg

(URL: http://www.gutenberg.org/files/11314/11314-h/11314-h.htm).

Project of Civic Impulse: GovTrack.US

(URL: https://www.govtrack.us/).

RICHARDSON, J.D.: A Compilation of the Messages and Papers of the Presidents, edic. priv., 1902-04 (actualmente disponible on-line: Project Gutenberg, URL: http://www.gutenberg.org/files/11314/11314-h/11314-h.htm; Onlinebooks, URL: http://onlinebooks.library.upenn.edu/webbin/metabook?id=mppresidents).

Sistema integral de enciclopedias electrónicas "Answers"

(URL: http://www.answers.com).

The American Presidency Project

(URL: www.presidency.ucsb.edu/index.php).

The National Atlas of the United States of America, un servicio del U.S. Department of the Interior 
(URL:http://nationalatlas.gov/).

Thomas-The Library of the Congress

(URL: http://thomas.loc.gov/).

U.S. Census Bureau (censo de 2010)

(URL: $\underline{\text { http://factfinder.census.gov/home/saff/main.html? lang=en). }}$

U.S. Code (historial legal)

(URL: http://www.uscirf.gov/about/authorizinglegislation.html).

U.S. Conservative Think Tanks

(URL: $\underline{\text { http://usconservatives.about.com/od/thinktanks/). }}$

U.S. Department of Education [Ministerio de Educación estadounidense], \& TRACS

(URL: $\underline{\text { http://tracs.org/). }}$

U.S. Department of Justice

(URL: https://www.justice.gov/jmd/ls/church-arson-prevention-act-1996-pl-104-155).

WestLaw

(URL: $\underline{\text { www.westlaw.com). }}$. 